


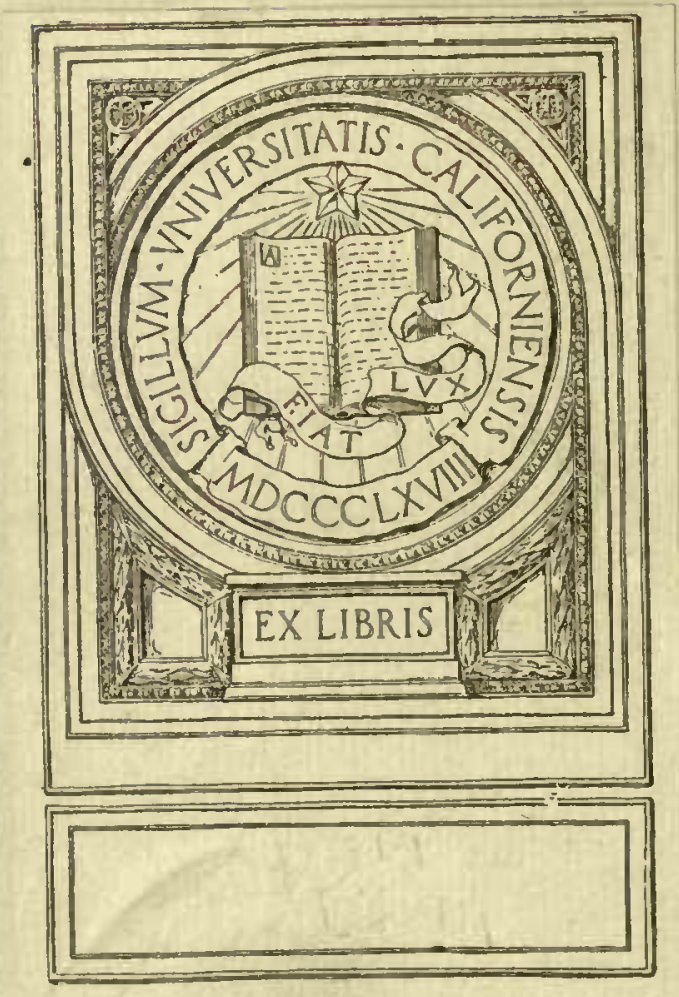





.




\section{PARADISI IN SOLE}

\section{PARADISUS TERRESTRIS}


अ.JOZ VI IEICA TA9

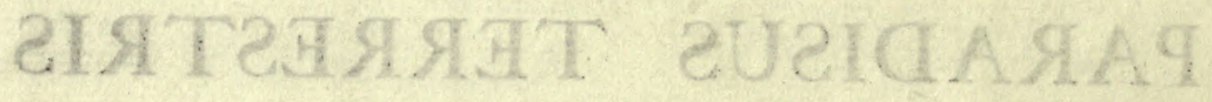




\section{PARADISI IN SOLE}

\section{PARADISUS TERRESTRIS}

BY JOHN PARKINSON

FAITHFULLY REPRINTED

FROM THE EDITION

OF $\quad$ I 629

METHUEN \& CO.

LONDON

I 904 


\section{AIOZ ИI ILIOAЯA}

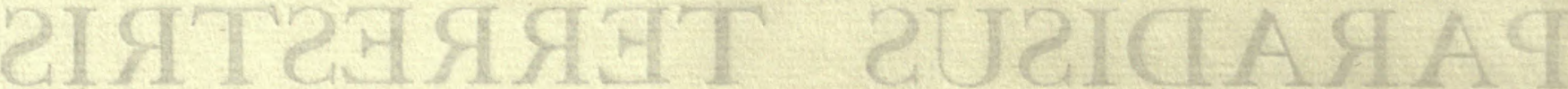

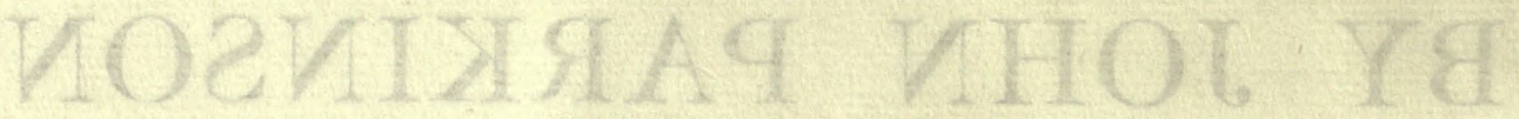

\section{बATИISGMЯ YIIUMHTIA}

\section{ИOITICI HHT MOSA}

\section{esd सं०}

THE ABERDEEN UNIVERSITY PRESS LIMITED

$\because \quad \because \vdots$

a $\because$

$.00 \quad 3$ IAHUHTMM

$100 \times 1 \times 1$ 


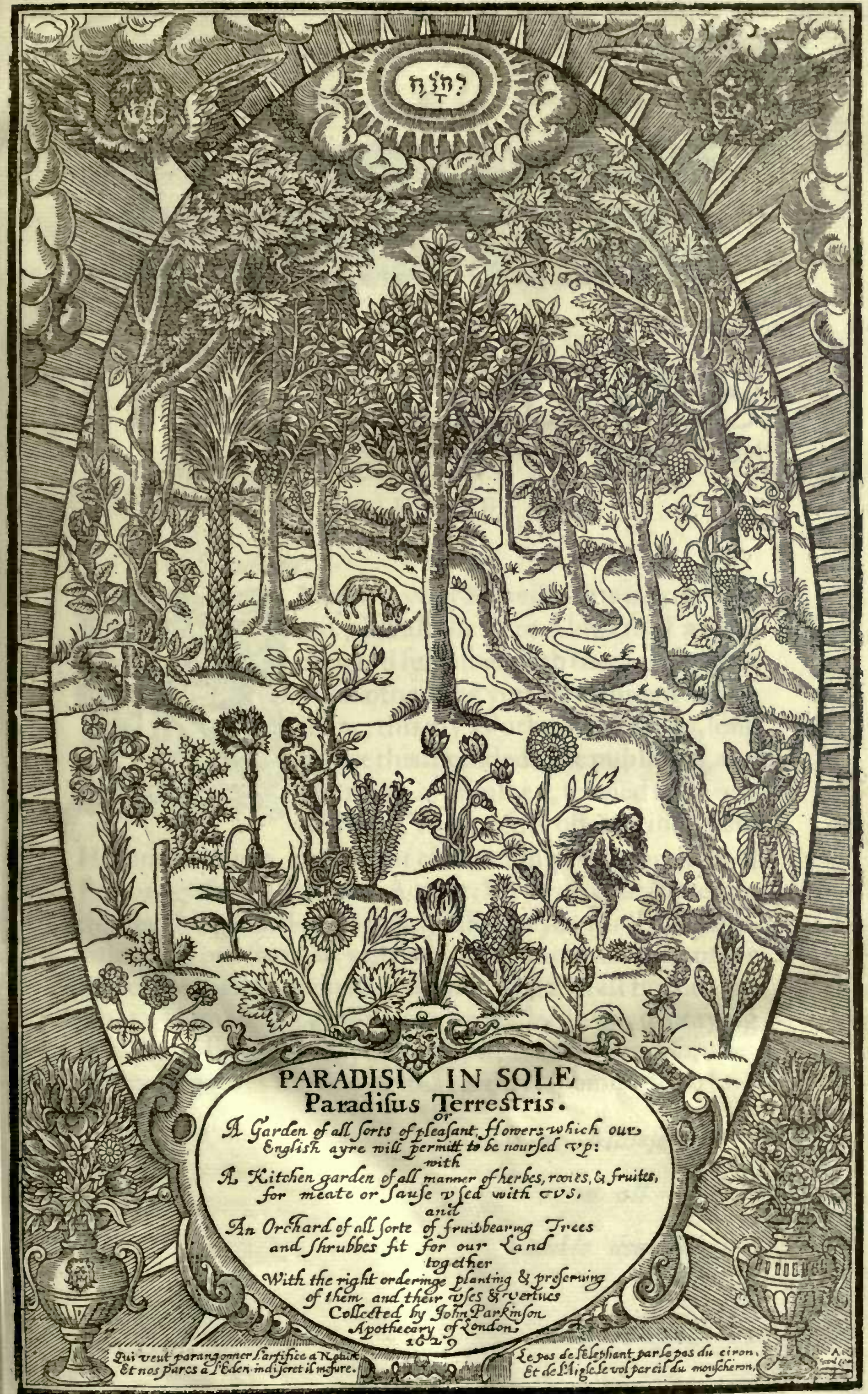




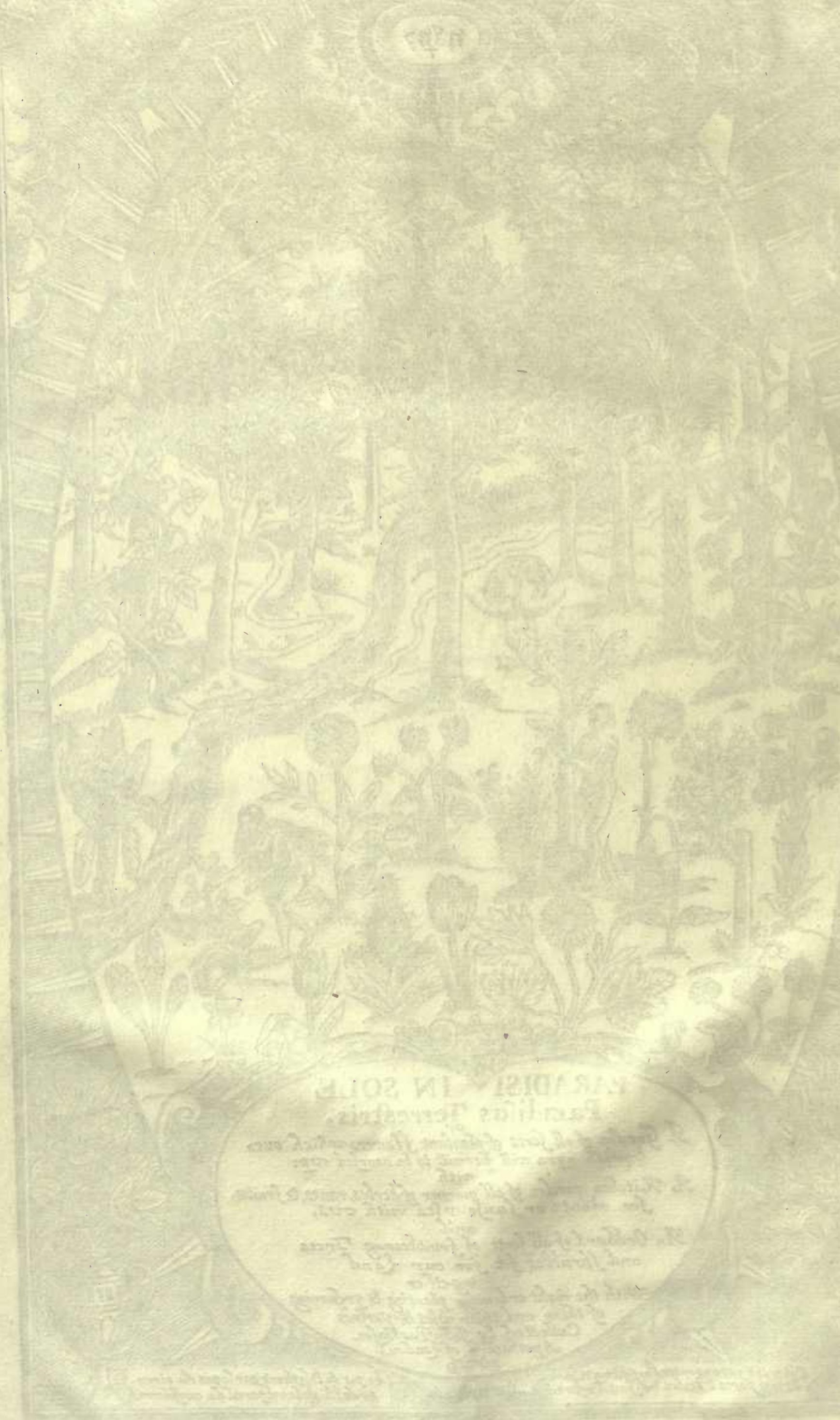




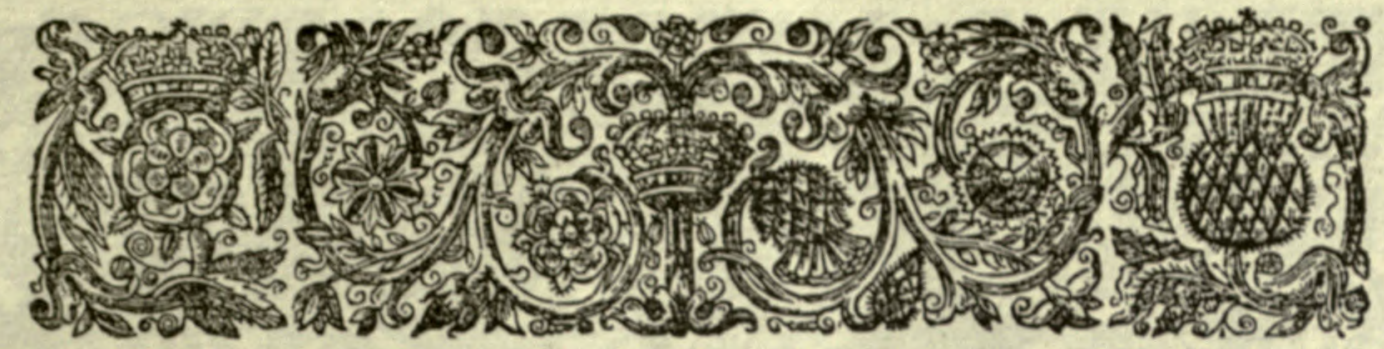

$\mathrm{TO}$

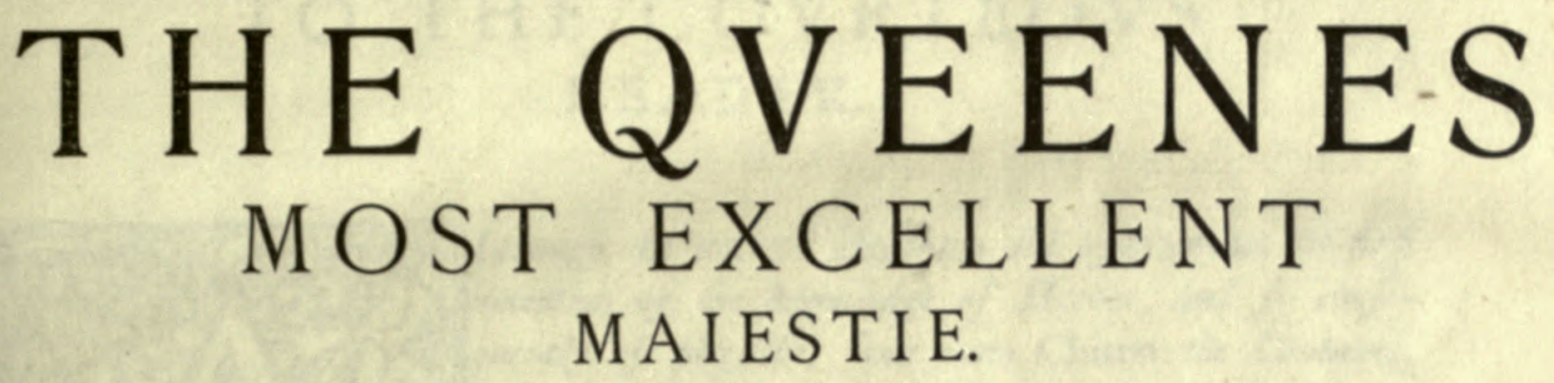

Madame,

Nowing your Maieftie fo much deligh-
ted with all the faire Flowers of a Gar-
den, and furnifhedwith them as farrebe-
yond others, as you are eminent before
them; this my Worke of a Garden, long
beforethisintended to be publifhed, and
but now only finifhed, feemed as it were
deftined, to bee firt offered into your Highneffe hands, as of right challenging the proprietie of Patronage fromall others. Accept, I befeech your Maieftie, this fpeaking Garden, that may informe you in all the particulars of your ftore, as well as wants, when you cannot fee any of them freth vpon the ground: and it thall further encourage him to accomplifh the remainder; who, in praying that your Highneffe may enioy the heauenly Paradife, after the many yeares fruition of this earthly, fubmitteth to be

\section{rour Maiefties \\ in all}

bumble deuotion, 

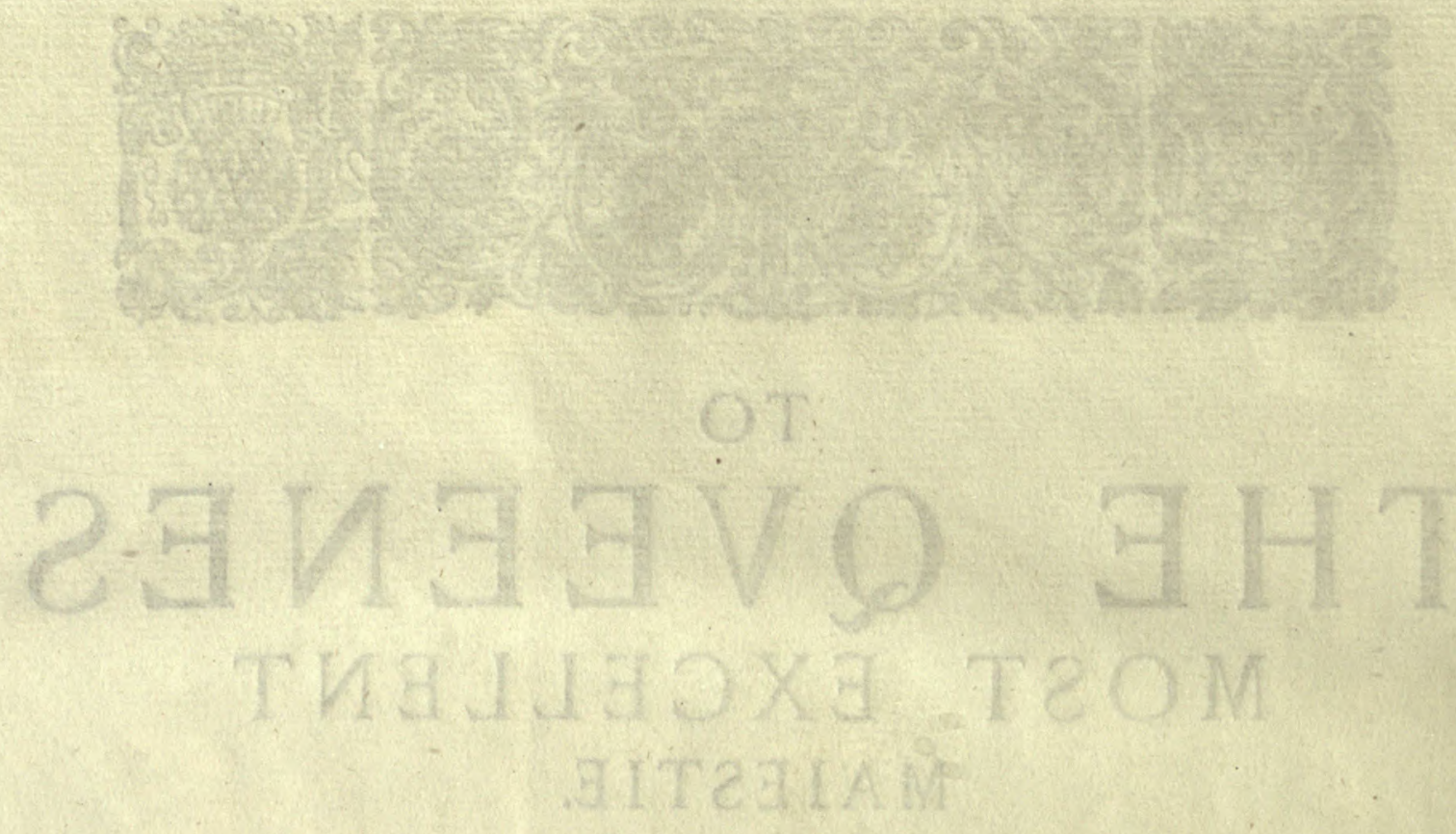

sestahisilves

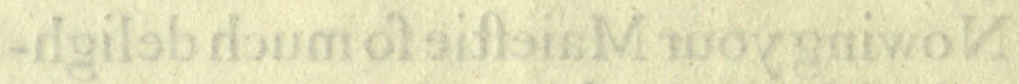

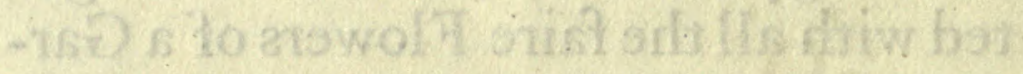

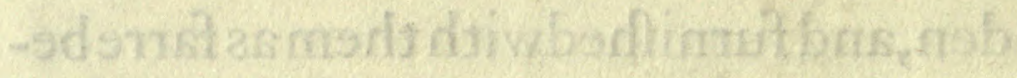

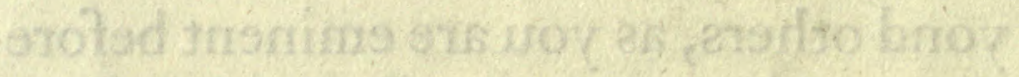

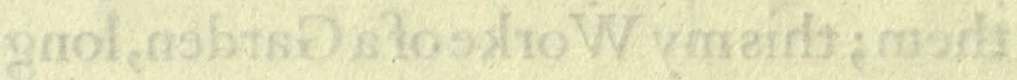

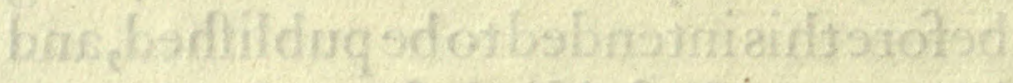

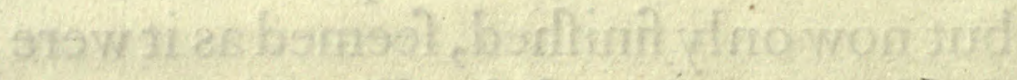

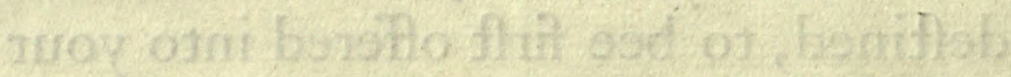

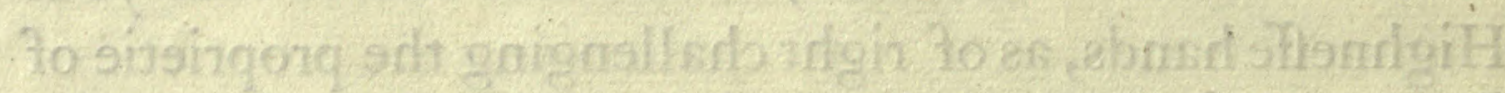

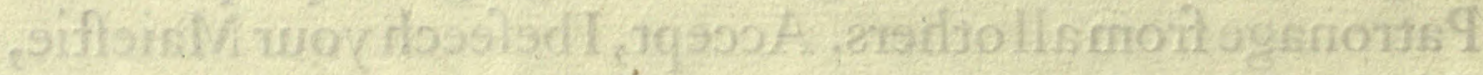

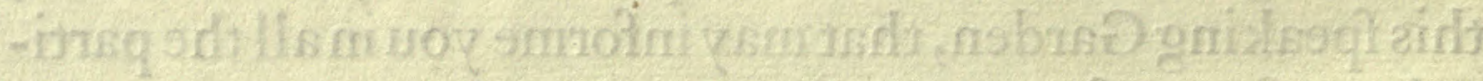

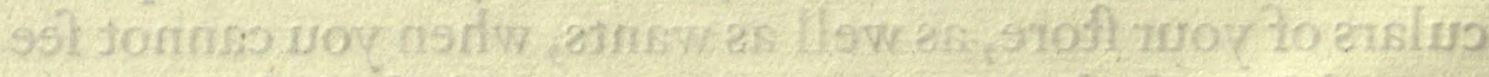

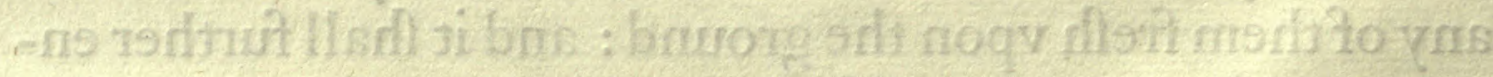

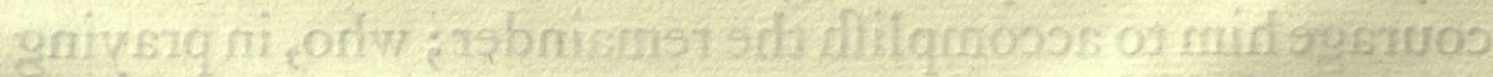

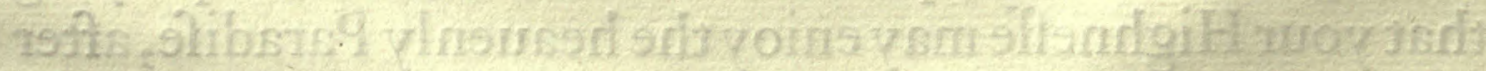

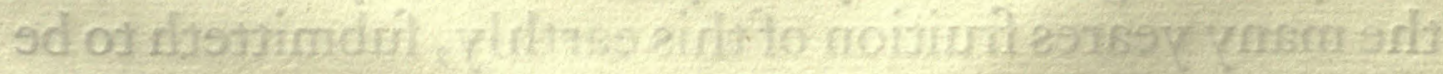

25iflosin: $=00$

Nov sín

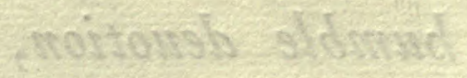




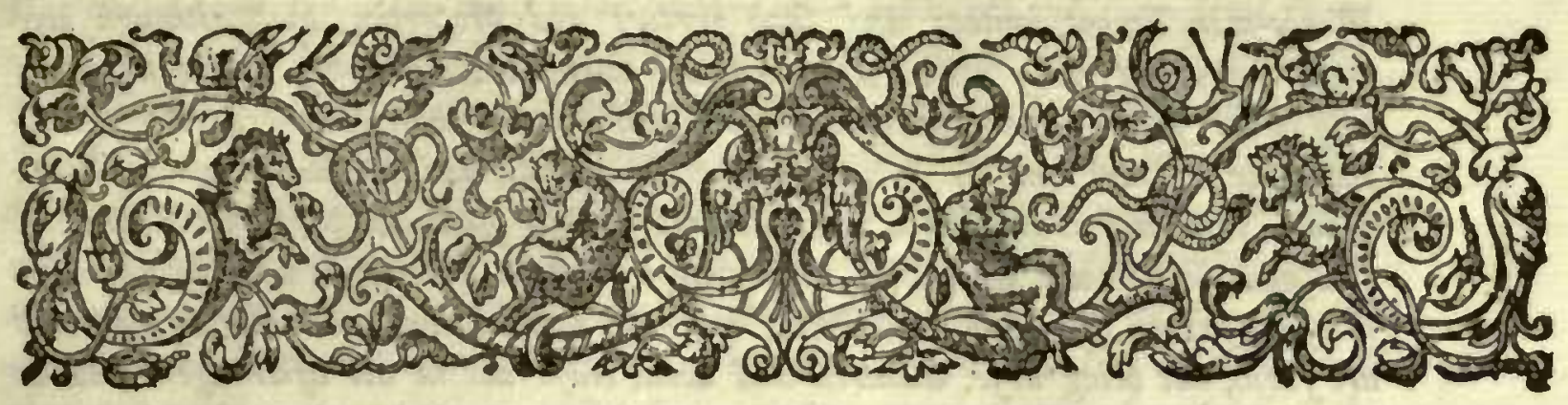

\title{
TO THE COVRTEOVS
}

\author{
R E A D E R.
}

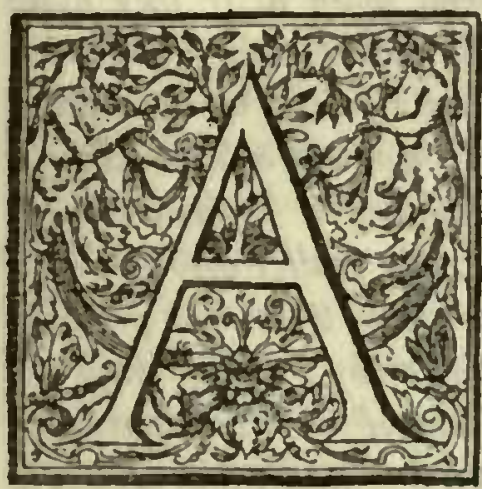

Lthough the ancient Heathens did appropriate the firf inuention of the knowledge of Herbes, and fo confeguently of phyficke, fome vnto Chiron the Centaure, and others vnto Apollo or Efculapius his Jonne; yet wee that are Chriftians haue out of a better Schoole learned, that God, the Greator of Heauen and Earth, at the beginning when he created Adam, infpired him with the knowledge of all naturall things (which fuccefsiuely defcended to Noah afterwardes, and to his Poferity): for, as he was able to giue names to all the liuing Creatures, according to their fenerall natures; fo no doubt but hee had alfo the knowledge, both what Herbes and Fruits were fit, eyther for Meate or Medicine, for V Je or for Delight. And that Adam might exercife this knowledge, God planted a Garden for him to liue in, (wherein euen in his innocency he was to labour and Spend his time) which hee fored with the beft and choyfeft Herbes and Fruits the earth could produce, that he might haue not onely for nece/sitie whereon to feede, but for pleafure alfo; the place or garden called Paradife importing as much, and more plainly the words Set downe in Genefis the fecond, which are the fe; Out of the ground the Lord God made to grow euerie tree pleafant to the fight and good for meate; and in the 24. of Numbers, the Parable of Balaam, mentioning the Aloe trees that God planted; and in other places if there were neede to recite them. But my purpofe is onely to foew you, that Paradife was a place (whether you will call it a Garden, or Orchard, or both, no doubt of Some large extent) wherein Adam was firft placed to abide; that God was the Planter thereof, hauing furnißed it with trees and herbes, as well pleafant to the fight, as good for meate, and that hee being to dreffe and keepe this place, muft of necefsity know all the things that grew therein, and to what ves they ferued, or elfe his labour about them, and knowledge in them, had been in vaine. And although Adam lost the place for his tranfgrefsion, yet he lof not the naturall knowledge, nor $v$ fe of them: but that, as God made the whole world, and all the Creatures therein for Man, fo hee may vje all things as well of pleafure as of nece/sitie, to bee helpes vnto him to Jerue his God. Let men therefore, according to their fir $\beta$ infitution, fo vfe their Seruice, that they alfo in them may remember their Seruice to God, and not (like our Grand-mother Eve) fet their affections fo frongly on the pleafure in them, as to deferue the lofje of them in this Paradife, yea and of Heauen alfo. For truly from all forts of Herbes and Flowers we may draw matter at all times not only to magnifie the Creator that hath giuen them fuch diuerfities of formes, fents and colours, that the mof cunning 
Worke-man cannot imitate, and fuch vertues and properties, that although wee know many, yet many more lye hidden and vnknowne, but many good infructions alfo to our felues: That as many herbes and flowers with their fragrant fweete Smels doe comfort, and as it were reuiue the Spirits, and perfume a whole houfe; euen fo fuch men as liue vertuoufly, labouring to doe good, and profit the Church of God and the Common wealth by their paines or penne, doe as it were fend forth a pleafing fauour of fweet infructions, not only to that time wherein they liue, and are fre乃, but being drye, withered and dead, ceaje not in all after ages to doe as much or more. Many herbes and flowers that haue fmall beautie or fauour to commend them, haue much more good vfe and vertue: fo many men of excellent rare parts and good qualities doe lye hid vnknown and not respected, vntill time and vee of them doe fet forth their properties. Againe, many flowers haue a glorious hew of beauty and brauery, yet finking in fmell, or elfe of no other v/e: fo many doe make a glorious oflentation, and flourifh in the world, when as if they finke not horribly before God, and all good men, yet furely they haue no other vertue then their outfide to commend them, or leaue behind them. Some alfo rife vp and appear like a Lilly among Thornes, or as a goodly Flower among many Weedes or Grafle, eyther by their honourable authoritie, or eminence of learning or riches, whereby they excell others, and thereby may doe good to many. The frailty alfo of Mans life is learned by the foone fading of them before their flowering, or in their pride, or foone after, being either cropt by the hand of the Spectator, or by a Judden blaft withered and parched, or by the reuolution of time decaying of it owne nature: as aljo that the faireft flowers or fruits firfl ripe, are fooneft and firft gathered. The mutabilitie alfo of flates and perfons, by this, that as where many goodly flowers E fruits did grow this yeare and age, in another they are quite pulled or digged vp, and eyther weedes and grafje grow in their place, or fome building erected thereon, and their place is no more known. The Ciuill respects to be learned from them are many alfo: for the delight of the varieties both of formes, colours and properties of Herbes and Flowers, hath euer beene powerfull ouer dull, vnnurtured, ruficke and fauage people, led only by Natures infinct; how much more powerfull is it, or Bould be in the mindes of generous perfons? for it may well bee faid, he is not humane, that is not allured with this obiect. The fudy, knowledge, and trauel in them, as they haue been entertained of great Kings, Princes and Potentates, without difparagement to their Greatnefle, or hinderance to their more ferious and weighty Affaires: So no doubt unto all that are capable thereof, it is not onely pleafant, but profitable, by comforting the minde, Jpirits and Jenfes with an harmeleffe delight, and by enabling the iudgement to conferre and apply helpe to many dangerous difeafes. It is alfo an Inftructer in the verity of the genuine Plants of the Ancients, and a Correcter of the many errours whereunto the world by continuance hath bin diuerted, and almo $\Omega$ therein fixed, by eradicating in time, and by degrees, the pertinacious wilfulnefle of many, who becaufe they were brought wp in their errours, are moft vnwilling to leaue them without confideration of the good or euill, the right or wrong, they draw on therewith. And for my selfe I may well fay, that had not mine owne paines and fudies by a naturall inclination beene more powerfull in mee then any others helpe (although fome through an euill difpofition and ignorance haue fo far traduced me as to fay this was rather another mans worke then mine owne, but I leaue them to their folly) I had neuer done fo much as I here publifb; nor been fit or prepared for a larger, as time may fuddenly (by Gods permifsion) bring to light, if the maleuolent difpofitions of degenerate Spirits doe not hinder the accomplifsment. 
The Epiftle to the Reader.

But perfwading my felfe there is no Bowore that produceth not fome fruit, or no word but worketh fome effect, eyther of good to perfwade, or of reproofe to ewince; $I$ could not but declare my minde herein, let others iudge or fay what they pleafe. For I haue alwaies held it a thing vnfit, to conceale or bury that knowledge God hath given, and not to impart it, and further others therewith as much as is conuenient, yet without ofentation, which I haue euer hated. Now further to informe the courteous Reader, both of the occafion that led me on to this worke, and the other occurrences to it. Firf, hauing perufed many Herbals in Latine, I obferwed that moft of them have eyther neglected or not knowne the many diverfities of the flower Plants, and rare fruits are known to vs at this time, and (except Clufius) haue made mention but of a very few. In Englifh likewife we haue fome extant, as Turner and Dodonxus tranflated, who have. Said little of Flowers, Gerard who is laf, hath no doubt given vs the knozvledge of as many as he attained vnto in his time, but fince his daies we haue had many more varieties, then he or they ewer heard of, as may be perceived by the fore I haue here produced. And none of them haue particularly feuered those that are beautifull fowver plants, fit to fore a garden of delight and pleafure, from the wilde and onfit: but haue enterlaced many, one among another, whereby many that hawe defored to have faire flowers, hawe not known eyther what to choose, or what to defire. Diuers Bookes of Flowers alfo haue been fet forth, fome in our owne Countrey, and more in others, all which are as it wire but handfuls fnatched from the plentifull Treafury of Nature, none of them being willing or able to open all Jorts, and declare them fully; but the greateft hinderance of all mens delight was, that none of them had giuen any defcription of them, but the bare name only. To fatisfie therefore their defires that are louers of fuch Delights, I took vpon me this labour and charge, and haue here felected and fet forth a Garden of all the chiefeft for choyce, and fairef for Bew, from among all the Seuerall Tribes and Kindreds of Natures beauty, and haue ranked them as neere as I could, or as the worke would permit, in affinity one vnto another. Secondly, and for their fakes that are fudious in Authors, I haue fet down the names haue bin formerly giuen onto them, with fome of their errours, not intending to cumber this worke with all that might bee faid of them, because the deciding of the many controuterfes, doubts, and quefions that concerne them, pertaine more fitly to a generall Hifory: yet I haue beene in fome places more copious and ample then at the fir $f$ I had intended, the occafion drawing on my defire to informe others with what I thought was fit to be known, referuing what elfe might be faid to another time $E^{\circ}$ worke; wherein (God willing) I will inlarge my felfe, the fubiect matter requiring it at my hands, in what my fmall ability can effeet. Thirdly, I haue alfo to embellifh this Worke fet forth the figures of all such plants and flowers as are materiall and different one from another: but not as fome others haue done, that is, a number of the figures of one fort of plant that haue nothing to difinguifs them but the calour, for that I hold to be fuper fuous and wafee. Fourthly, I haue alfo fet down the $V e r t u e s$ and Properties of them in a briefe manner, rather defiring to giue you the knowledge of a few certaine and true, then to relate, as others haue done, a needless and false multiplicitie, that fo there might as well profit as pleafure be taken from them, and that nothing might be wanting to accomplifs it fully. And fo, much for this firf part, my Garden of pleafant and delightfull Flowers. My next Garden confifteth of Herbes and Rootes, fit to be eaten of the rich and poor as nourifbment and food, as fawce or condiment, as fallet or refreßhing, for pleafure or profit; where I doe as well play the Gardiner, to Bew you (in briefe, but not at large) the times 
and manner of forwing, fetting, planting, replanting, and the like (although all the fe things, and many more then are true, are fet down very largely in the feuerall bookes that others haue written of this fubiect) as alfo to Bew Jome of the Kitchen veses (becaufe they are Kitchen herbes $\mathcal{E}^{2} c$.) although I confefje but very Sparingly, not intending a treatife of cookery, but briefly to giue a touch thereof; and alfo the Phyficall properties, to Bew fomewhat that others haue not fet forth; yet not to play the Empericke, and giue you receipts of medicines for all difeajes, but only to berw in fome fort the qualities of Herbes, to quicken the minds of the fudious. And lafly an Orchard of all forts of domefticke or forraine, rare and good fruits, fit for this our Land and Countrey, which is at this time better ftored and furnißhed then euer in any age before. I haue herein endeauoured, as in the other Gardens, to fet forth the varieties of euery fort in as briefe a manner as po/sibly could be, without Juperfluous repetitions of defcriptions, and onely with efpeciall notes of difference in leaues, flowers and fruits. Some ferw properties allo are fet downe, rather the chiefeft then the moft, as the worke did require. And moreouer before euery of the fe parts I haue giuen Treatifes of the ordering, preparing and keeping the feuerall Gardens and Orchard, with what foeuer I thought was conuenient to be known for euery of them.

Thus haue I fbewed you both the occafion and Scope of this Worke, and herein haue Spent my time, paines and charge, which if well accepted, I ßall thinke well employed, and may the fooner haften the fourth Part, A Garden of Simples; which will be quiet no longer at home, then that it can bring his Mafer newes of faire weather for the iourney.

Thine in what he may,

IOHN PARKINSON.

Ioanni 


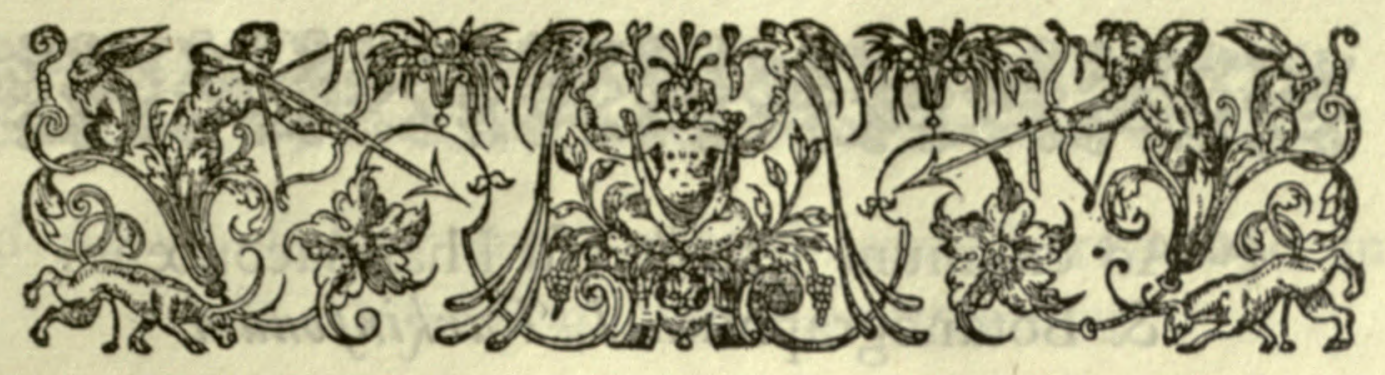

\section{Ioanni Parkinfono Pharmacopoeo Londinenfi folertif- fimo Botanico confummatifsimo \\ T.D.M. S.P.D.}

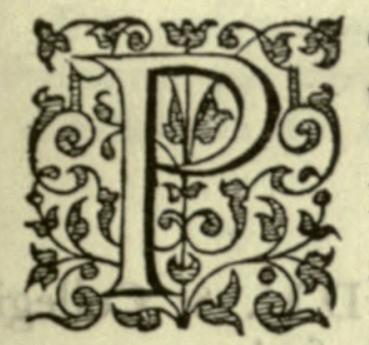

Oema panegyricum Opus tuum indefeffi laboris, vtilitatis eximiæ poftulat, \& meriti iure à me extorqueret (mi Parkinfone) fi fauentibus Mufis, \& fecundo Apolline in bicipiti fomniare Parnaffo, \& repentè Poetæ mihi prodire liceret. In fœetus tui bonis auibus in lucem editi, \& prolixiorem nepotum feriem promittentis laudes, alii Deopleni Enthufiaftæ carmine fuos pangant elenchos; quos fub figmentis ampullata hyperbolicarum vocum mulcedine, vates ferè auribus mentibufue infinuant. Veritas nuditatis amans, fuco natiuum candorem obumbranti non illuftranti perpetuum indixit bellum : In fimplicitate, quam affertionum neruofa breuitas exprimit, exultat. Audi quid de te fentiam, Tu mihi fis in pofterum Crateuas Brittannus; inter omnes quotquot mihi hic innotuerunt, peritifsimus, exercitatifsimus, oculatiffimus, \& emunctifsimæ naris Botanicus: Cuius opera in fortunata hac Infula rem herbariam tractari, emendari, augeri, \& popularibus tuis vernaculo fermone ad amufsim tradi, non decentiæ modo, fed etiam necefsitatis eft. Macte tua fedulitate (Vir optime) neque te laborum tam arduis lucubrationibus datorum hactenus pœniteat, vel deinceps impendendorum pigeat. Difficilia quæ pulchra. Leniet debitæ laudis dulcedo vigiliarum acerbitatem, \& Olympicum ftadium cito pede, à carceribus ad metas alacriter decurrentem nobile manet Bpaßeiov. Sed memento Artem longam,

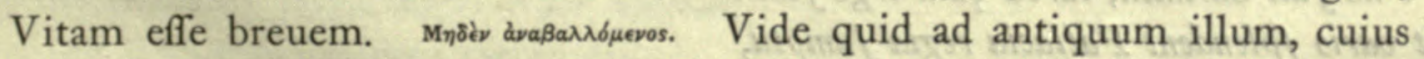
fi non animam, faltem genium induift, Crateuam fcribat Hippocrates,

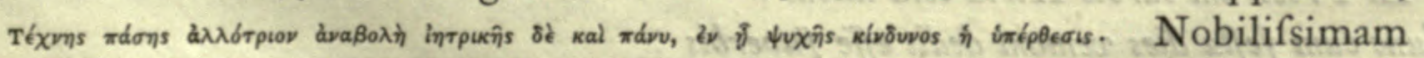
Medicinæ partem Botanicam effe reputa. Floræ nunc litafti \& Pomonæ, Apollini vt audio propediem Horto Medico facturus. Amabò integræ Veftæ facra conficito, eiufque variegatum multis fimplicium morbifugorum myriadibus finum abfolutè pandito, quem fine velo nobis exhibeas. Nulla dies abeat fine linea. Sic tandem fructus gloriæ referes vberrimos, quos iuftè fudoribus partos, vt in cruda \& viridi fenectute decerpas diu, iifque longum fruaris opto. Vale. Datum Londini Galendas Octobris anno falutis 1629 . 


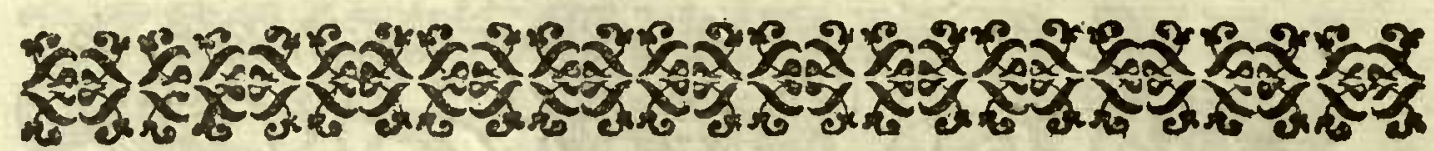

\section{Ad eximium arte \&.vfu Pharmacopoum \& Botanographum I. Parkinfonum.}

\author{
Gu. Turne- \\ rus. M.D. \\ Io. Gerar- \\ dus Chirur-

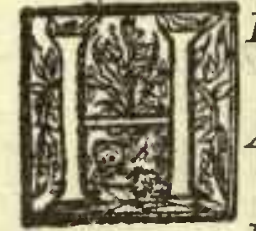 \\ Erbarum vires, primus te (magne Britanne) \\ Edocuit medicas, inclytus arte fophus. \\ Atque cluens herbis alter, Chironis alumnus, \\ Defcripfit plantas, neu cadat volla Jalus. \\ Fortunate fenex, fis tu nunc tertius Heros \\ Hortos qui referas, deliciafque foli, \\ Et flores Veneris latos, herba que virentes, \\ Arboreos fatus, pharmacum $\mathcal{E}$ arte potens. \\ Pofteritas iuftos pofthac tibi folvet honores, \\ Laudabitque tuce dexteritatis opus.
}

Ottuellus Meuerell. D.M. \& Collegii Med. Lond. focius.

\section{Amico fuo Ioanni Parkinfono.}

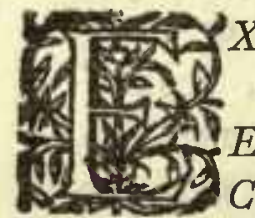
Xtollunt alij quos (Parkinfone) labores

Da mihi iam veniam comminuiffe tuos.

Extremos poteris credi migrafe per Indos:

Cum liber haud aliud quam tuus hortus hic eft :

IpJe habitare Indos tecum facis, haud petis Indos

I nunc, \&o tua me comminuifje refer.

Eft liber Effigies, tuus hic qui pingitur hortus,

Digna manu facies hac, facieque manus !

Vidi ego Splendentem varigatis vndique gemmis.

$V$ na fuit Salomon, turba quid ergo fuit?

$V t$ vario Splendent Pallacia regia fumptu,

Et Procerum turbis Atria tota nitent:

Tunc cum fefta dies veniam dedit efe fuperbis

Quofque ficus texit, nunc tria rura tegunt:

Plena tuo pariter Spectatur Curia in Horto,

Hic Princeps, Dux hic, Spon Saque pulchra Ducis.

Quaque dies eft fefta dies, nec parcius vnquam

Luxuriant, lauta hac; Quotidiana tamen.

Ecce velut Patrice Paradifi haud immemor Exul,

Hunc naturali pingit amore fibi.

Pingit Es ad vivum fub eodem nomine, EJ hic eft

Fronticuli fudor quem cerebrique dedit :

Aftat Adam medius Paradifo nofter in ifto

Et Species nomen cuique dat ipse fuum.

Hos cape pro meritis, qui florem nomine donas

Aternum florens tu tibi Nomen habe.

Guilielmus Atkins. 


\section{F/(x) (N)}

\section{Ad Amicum Ioannem Parkinfonum Pharmacopœum, \& Archibotanicum Londinenfem.}

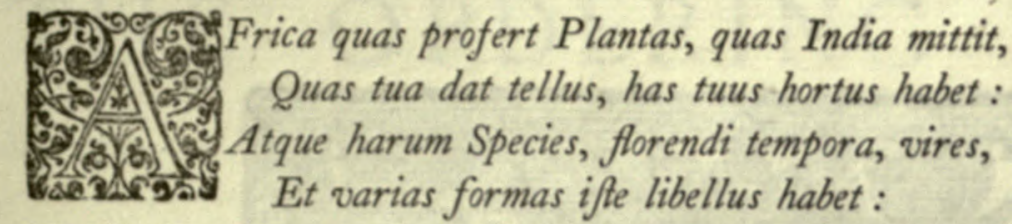

Nefcio plus librum talem mirabor, an hortum

Totus ineft horto mundus; at ifte libro.

Parkinfone tuus liber, \& labor, \& tua fit laus,

Herbas dum nobis das; datur herba tibi.

Guilielmus Brodus Pharmacopœus ac Philobotanicus Londinenfis.

\section{Ad Amicum Ioannem Parkinfonum Pharmacopœum \& Botanicum infignem. Carmen.}

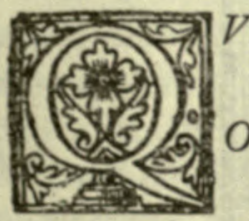

am magno pandis Flore penetralia nixu Atque facis calo liberiore frui?

Omnibus vt placeas, 6 quam propen fa voluntas,

Solicitufque labor nocte dieque premit?

Quam magno cultum fudio conquirere in hortum

Herbarum quicquid mundus in orbe tenet,

Immen fus fumptus, multofque extenfus in annos

Te labor afficiunt? E data nulla quies.

Talia quarenti, furgit novus ardor habendi,

Nec tibi tot foli munera magna petis;

Defcriptos viva profers fub imagine flores,

Tum profers menfa quicquid \& hortus alit,

Laudatos nobis fructus \& promis honores,

Profers, quas celebrant nullibi fcripta virum,

Herbarum species, quibus eft quoque grata venuftas :

Sic nos multiplici munere, Amice, beas.

Hoc cape pro meritis, florum dum gratia floret,

Suntque herbis vires; en tibi Nomen erit.

In Jerum femper tua gloria floreat avum,

Gloria qua in longum non peritura diem.

Thomas Iohnfon vtriufque

Societatis confors. 


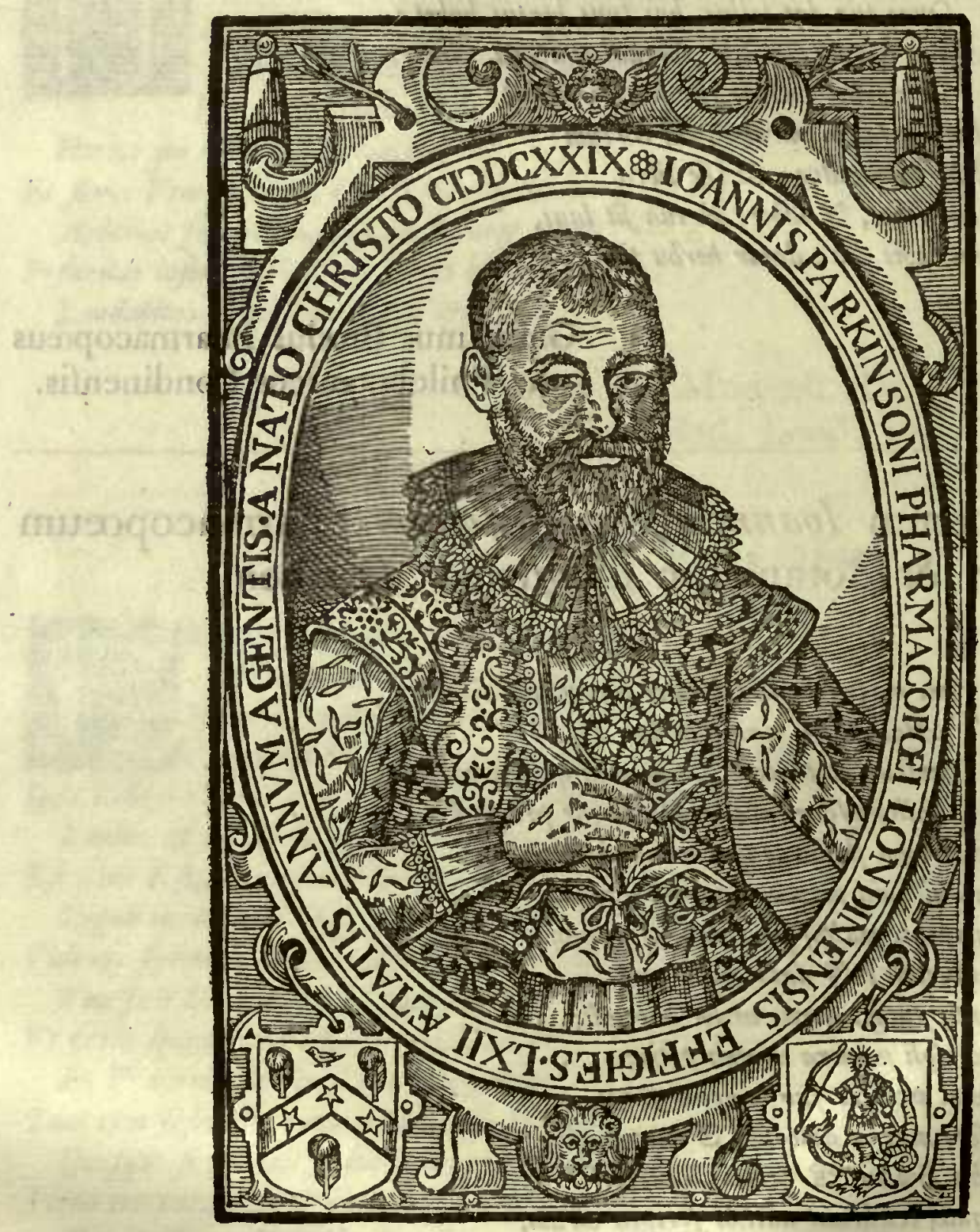




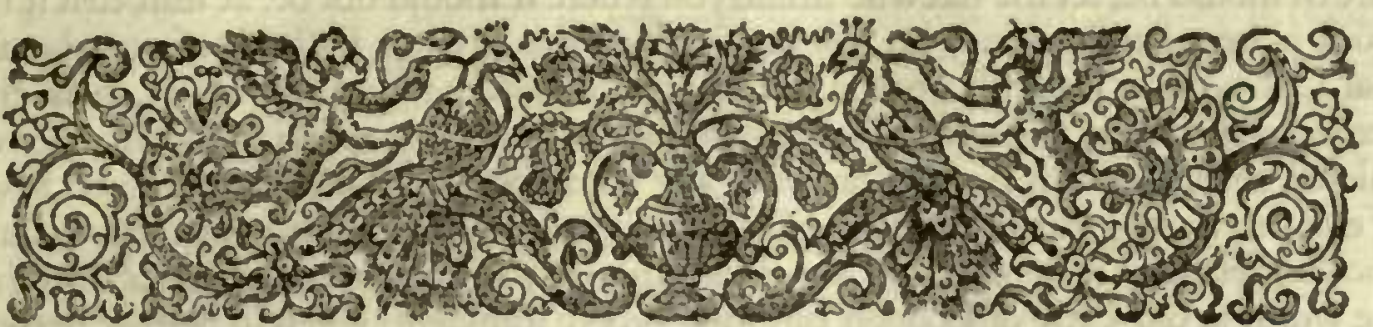

\section{THE ORDERING OF THE GARDEN OF PLEASVRE.}

\section{C н А Р. I.}

The fotuation of a Garden of pleafure, with the nature of foyles, and how to amend the defects that are in many forts of fotuations and grounds.

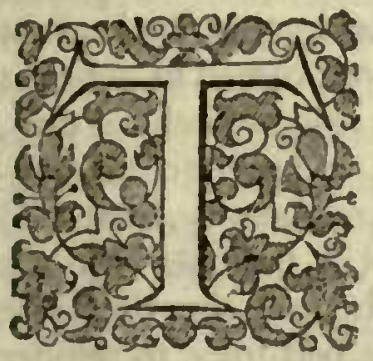

HE feuerall fituations of mens dwellings, are for the moft part vnauoideable and vnremoueable; for moft men cannot appoint forth fuch a manner of fituation for their dwelling, as is moft fit to auoide all the inconueniences of winde and weather, but murt bee content with fuch as the place will afford them; yet all men doe well know, that fome fituations are more excellent than others : according therfore to the feuerall fituation of mens dwellings, fo are the fituations of their gardens alfo for the moft part. And although diuers doe diuerly preferre their owne feuerall places which they haue chofen, or wherein they dwell; As fome thofe places that are neare vnto a river or brooke to be beft for the pleafantneffe of the water, the eafe of tranfportation of themfelues, their friends and goods, as alfo for the fertility of the foyle, which is feldome bad neare vnto a riuers fide; And others extoll the fide or top of an hill, bee it fmall or great, for the profpects fake; And againe, fome the plaine or champian ground, for the euen leuell thereof : euery one of which, as they haue their commodities accompanying them, fo haue they alfo their difcommodities belonging vnto them, according to the Latine Prouerbe, Omne commodum fert fium incommodum. Yet to thew you for euerie of thefe fituations which is the fitteft place to plant your garden in, and how to defend it from the iniuries of the cold windes and frofts that may annoy it, will, I hope, be well accepted. And firt, for the water fide, I fuppore the North fide of the water to be the beft fide for your garden, that it may haue the comfort of the South Sunne to lye vpon it and face it, and the dwelling houfe to bee aboue it, to defend the cold windes and frofts both from your herbes, and flowers, and early fruits. And ro likewife I iudge for the hill fide, that it may lye full open to the South Sunne, and the houfe aboue it, both for the comfort the ground fhall receive of the water and raine defcending into it, and of defence from winter and colds. Now for the plaine leuell ground, the buildings of the houre thould be on the North fide of the garden, that fo they might bee a defence of much fufficiency to fafeguard it from many iniurious cold nights and dayes, which elfe might fpoyle the pride thereof in the bud. But becaufe euery one cannot fo appoint his dwelling, as I here appoint the fitteft place for it to be, euery ones pleafure thereof thall be according to the fite, colt, and endeauours they beftow, to caufe it come neareft to this proportion, by fuch helpes of bricke or ftone wals to defend it, or by the helpe of high growne and well fpread trees, planted on the North fide thereof, to keepe it the warmer. And euery of thefe three fituations, hauing the faireft buildings of the houfe facing the garden in this manner before fpecified, befides the benefit of thelter it fhall haue from them, the buildings and roomes abutting thereon, Thall haue reciprocally the beautifull profpect into it, and haue both fight and fent of whatfoeuer is excellent, and worthy to giue content out from it, which is one of the greateft pleafures a garden can yeeld his Mafter. Now hauing thewed you the beft place where this your 
garden fhould be, let me likewife aduife you where it hould not be, at leaft that it is the worft place wherein it may be, if it be either on the Weft or Eaft fide of your houfe, or that it ftand in a moorifh ground, or other vnwholsome ayre (for many, both fruits, herbes, and flowers that are tender, participate with the ayre, taking in a manner their chiefeft thriuing from thence) or neare any common Lay-ftalles, or common Sewers, or elfe neare any great Brew-houfe, Dye-houfe, or any other place, where there is much fmoake, whether it be of ftraw, wood, or efpecially of fea-coales, which of all other is the worft, as our Citie of London can giue proofe fufficient, wherein neither herbe nor tree will long profper, nor hath done euer fince the vfe of fea-coales beganne to bee frequent therein. And likewife that it is much the worfe, if it bee neare vnto any Barnes or Stackes of corne or hey, becaufe that from thence will continually with the winde bee brought into the garden the ftrawe and chaffe of the corne, the duft and feede of the hey to choake or pefter it. Next vnto the place or fituation, let mee: fhew you the grounds or foyles for it, eyther naturall or artificiall. No man will deny, but the naturall blacke mould is not only the fatteft and richeft, but farre exceedeth any other either naturall or artificiall, as well in goodneffe as durability. And next thereunto, I hold the fandy loame (which is light and yet firme, but not loofe as fand, nor ftiffe like vnto clay) to be little inferiour for this our Garden of pleafure ; for that it doth caufe all bulbous and tuberous rooted plants to thriue fufficiently therein, as likewife all other flower-plants, Rofes, Trees, \&cc. which if it thall decay by much turning and working out the heart of it, may foone be helped with old ftable manure of horfes, being well turned in, when it is old and almoft conuerted to mould. Other grounds, as chalke, fand, grauell, or clay, are euery of them one more or leffe fertill or barren than other; and therefore doe require fuch helpes as is moft fit for them. And thofe grounds that are ouer dry, loofe, and duftie, the manure of ftall fedde beafts and cattell being buried or trenched into the earth, and when it is thorough rotten (which will require twice the time that the ftable foyle of horfes will) well turned and mixed with the earth, is the beft foyle to temper both the heate and drineffe of them. So contrariwife the ftable dung of horfes is the beft for cold grounds, to giue them heate and life. But of all other forts of grounds, the ftiffe clay, is the very worft for this purpose; for that although you should digge out the whole compaffe of your Garden, carry it away, and bring other good mould in the ftead thereof, and fill vp the place, yet the nature of that clay is fo predominant, that in a fmall time it will eate out the heart of the good.mould, and conuert it to its owne nature, or very neare vito it: fo that to bring it to any good, there muft bee continuall labour beftowed thereon, by bringing into it good ftore of chalke, lime, or fand, or elfe afhes eyther of wood or of fea-coales (which is the beft for this ground) weil mixed and turned in with it. And as this ftiffe clay is the worf, fo what ground foeuer commeth neareft vnto the nature thereof, is neareft vnto it in badneffe, the fignes whereof are the ouermuch moyfture thereof in Winter, and the much cleauing and chapping thereof in Summer, when the heate of the yeare hath confumed the moyfture, which tyed and bound it faft together, as alfo the ftiffe and lard working therein: but if the nature of the clay bee not too ftiffe, but as it were tempered and mixed with fand or other earths, your old ftable foyle of horfes will helpe well the fmall rifting or chapping thereof, to be plentifully beftowed therin in a fit feafon. Some alfo do commend the cafting of ponds and ditches, to helpe to manure thefe ftiffe chapping grounds. Other grounds, that are ouermoift by fprings, that lye too neare, the vpper face of the earth, befides that the beds thereof had neepd to be laid vp higher, and the allies, as trenches and furrowes, to lye lower, the ground it felfe had neede to have fome good iftore of chalke-ftones beftowed thereon, fome certaine yeares, if it may be, before it be laid into a Garden, that the Winter frofts may breake the chalke Imall, and the Raine, diffolue it into mould, that fo they may bee well mixed together; than which, there is not any better manure to foyle fuch a moift ground, to helpe to dry vp the moyfture, and to give heate and life to the coldnefle thereof, which doth alwayes accompany thefe moift grounds, and alfo to caufe it abide longer in heart than any other. For the fandy and grauelly grounds, although I know the well mollified manure of beafts and cattell to be excellent good, yet I know alfo, that fome commend a white Marle, and fome a clay to be wellifpread thereon, and after turned thereinto: and for the chalkie ground, ì conuer fo, I commend fatte clay to helpe it. You muft vnderitand, that the leffe rich or more barren that your ground is, there nee- 
deth the more care, labour, and coft to bee beftowed thereon, both to order it rightly, \& fo to preferue it from time to time : for no artificiall or forc't ground can endure good any long time, but that within a few yeares it muft be refrefhed more or leffe, according as it doth require. Yet you thall likewife vnderttand, that this Garden of pleafure ftored with thefe Out-landifh flowers; that is, bulbous and tuberous rooted plants, and other fine flowers, that I haue hereafter defcribed, and affigned vnto it, needeth not fo much or fo often manuring with foyle, \&cc. as another Garden planted with the other forts of Englifh flowers, or a Garden of ordinary Kitchin herbes doth. Your ground likewife for this Garden had neede to bee well cleanfed from all annoyances (that may hinder the well doing or profpering of the flowers therein) as ftones, weedes, rootes of trees, buthes, \&c. and all other things cumberfome or hurtfull; and therefore the earth being not naturally fine enough of it felfe, is vfed to bee fifted to make it the finer, and that either through a hurdle made of fticks, or lathes, or through fquare or round fieues platted with fine and ftrong thin ftickes, or with wyers in the bottome. Or elfe the whole earth of the Garden being courfe, may be caft in the fame manner that men vfe to try or fine fand from grauell, that is; againft a wall ; whereby the courfer and more ftony, falling downe from the fine, is to be taken away from the foote of the heape, the finer fand and ground remaining ftill aboue, and on the heape. Or elfe in the want of a wall to caft it againft, I haue feene earth fined by it felfe in this manner: Hauing made the floore or vpper part of a large plat of ground cleane from ftones, \&c. let there a reafonable round heape of fine earth be fet in the midft thereof, or in ftead thereof a large Garden flowerpot, or other great pot, the bottome turned vpwards, and then poure your courfe earth on the top or head thereof, one fhouell full after another fomewhat gently, and thereby all the courfe ftuffe and ftones will fall downe to the bottome round about the heape, which muft continually be carefully taken away, and thus you may make your earth as fine as if it were caft againft a wall, the heape being growne great, feruing in itead thereof. Thofe that will not prepare their grounds in fome of thefe manners aforefaid, thall foone finde to their loffe the neglect thereof : for the trafh and ftones fhall fo hinder the encreafe of their roots, that they will be halfe loft in the earth among the ftones, which elfe might be faued to ferue to plant wherefoeuer they pleafe.

\section{C н A P. I I. \\ The frame or forme of a Garden of delight and pleafure, with the feuerall varieties thereof:}

A Lthough many men muft be content with any plat of ground, of what forme or quantity foeuer it bee, more or leffe, for their Garden, becaufe a more large or conuenient cannot bee had to their habitation: Yet I perfwade my felfe, that Gentlemen of the better fort and quality, will prouide fuch a parcell of ground to bee laid out for their Garden, and in fuch conuenient manner, as may be fit and anfwerable to the degree they hold. To prefcribe one forme for euery man to follow, were too great prefumption and folly: for euery man will pleafe his owne fancie, according to the extent he defigneth out for that purpofe, be it orbicular or round, triangular or three fquare, quadrangular or foure fquare, or more long than broad. I will onely thew you here the feuerall formes that many men haue taken and delighted in, let euery man chufe which him liketh beft, or may moft fitly agree to that proportion of ground hee hath fet out for that purpofe. The orbicular or round forme is held in it owne proper exiftence to be the moft abfolute forme, containing within it all other formes whatfoeuer; but few I thinke will chufe fuch a proportion to be ioyned to their habitation, being not accepted any where I think, but for the generall Garden to the Vniuerfity at Padoa. The triangular or three fquare is fuch a forme alfo, as is feldome chofen by any that may make another choife, and as I thinke is onely had where another forme cannot be had, neceffitic conftraining them to be therewith content. The foure fquare forme is the moft vfually accepted with all, and doth beft agree to any mans dwelling, being (as I faid before) behinde the houfe, all the backe windowes thereof opening into it. Yet if it bee longer than the breadth, or broader than the length, the proportion of walkes, fquares, and knots may be foon brought to the fquare forme, and be fo caft, as the beauty thereof may 


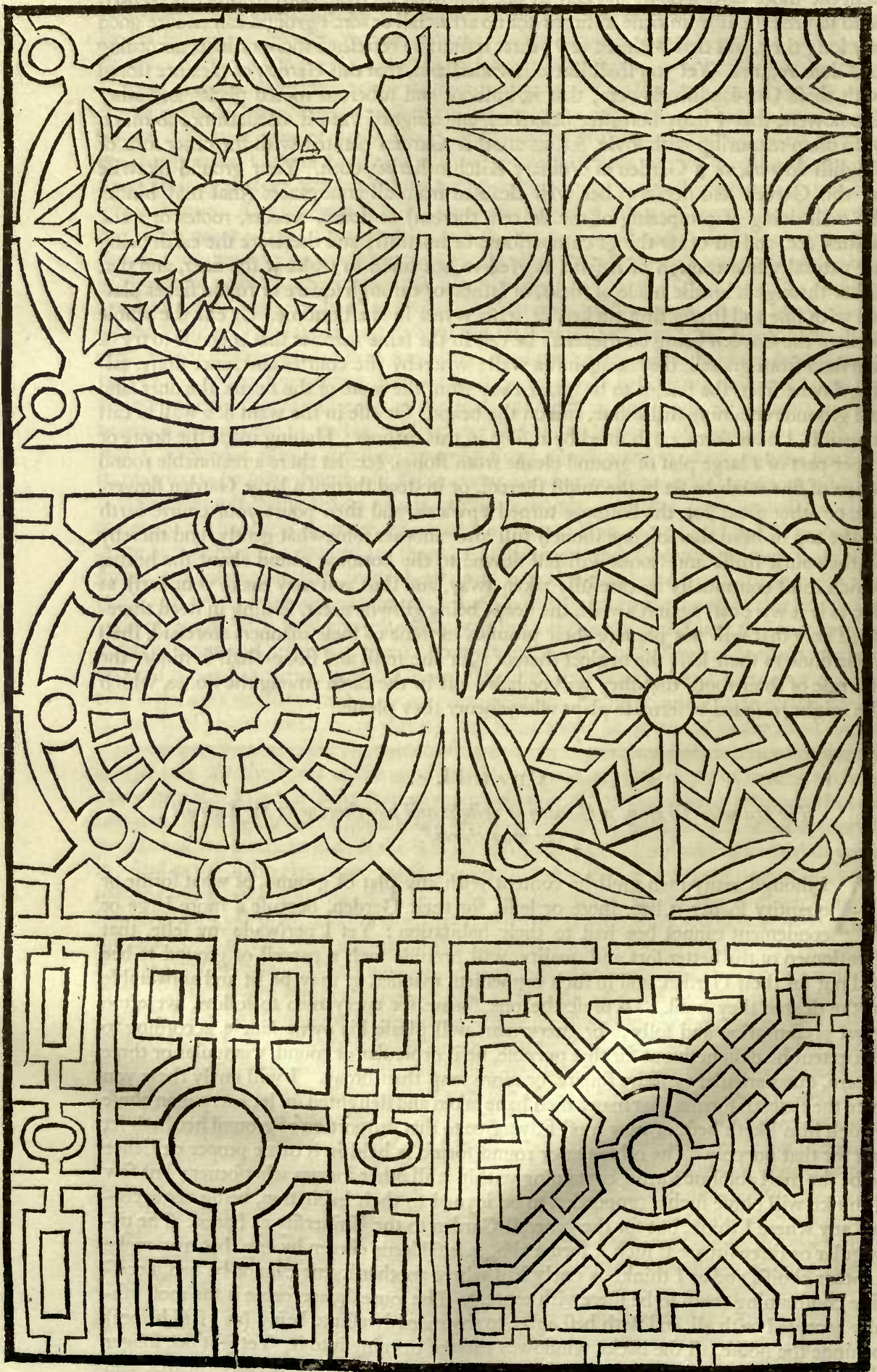


bee no leffe than the foure fquare proportion, or any other better forme, if any be. To forme it therfore with walks, croffe the middle both waies, and round about it alfo witl lsedges, with fquares, knots and trayles, or any other worke within the foure fquare parts, is according as euery mans conceit alloweth of it, and they will be at the charge: For there may be therein walkes eyther open or clofe, eyther publike or priuate, a maze or wilderneffe, a rocke or mount, with a fountaine in the midit thereof to conuey water to euery part of the Garden, eyther in pipes vnder the ground, or brought by hand, and emptied into large Cifternes or great Turkie Iarres, placed in conuenient places, to ferue as an eafe to water the neareft parts thereunto. Arbours alfo being both gracefull and neceflary, may be appointed in fuch conuenient places, as the corners, or elfe where, as may be inoft fit, to ferue both for fhadow and reft after walking. And becaufe many are defirous to fee the formes of trayles, knats, and other compartiments, and becaufe the open knots are more proper for thefe Out-landifh flowers; I haue here caufed fome to be drawne, to fatisfie their defires, not intending to cumber this worke with ouer manie, in that it would be almoft endleffe, to expreffe fo many as might bee conceiued and fet downe, for that euery man may inuent others farre differing from thefe, or any other can be fet forth. Let euery man therefore, if hee like of thefe, take what may pleafe his mind, or out of thefe or his own conceit, frame any other to his fancy, or caufe others to be done as he liketh beft, obferuing this decorum, that according to his ground he do caft out his knots, with conuenient roome for allies and walkes; for the fairer and larger your allies and walkes be, the more grace your Garden fhall haue, the leffe harme the herbes and flowers fhall receiue, by paffing by them that grow next vnto the allies fides, and the better fhall your Weeders cleanfe both the beds and the allies.

\section{Ch A P. I I I.}

The many forts of herbes and other things, wherewith the beds and parts of knots are bordered to fet out the forme of them, with their commodities and difcommodities.

$\mathrm{I}^{1}$ $T$ is neceffary alfo, that I thew you the feuerall materials, wherewith thele knots and trayles are fet forth and bordered; which are of two forts: The one are liuing herbes, and the other are dead materials; as leade, boords, bones, tyles, \&cc. Of herbes, there are many forts wherewith the knots and beds in a Garden are vfed to bee fet, to thew forth the forme of them, and to preferue them the longer in their forme, as allo to be as greene, and fweete herbes, while they grow, to be cut to perfume the houfe, keeping them in fuch order and proportion, as may be moft conuenient for their feuerall natures, and euery mans pleafure and fancy: Of all which, $I$ intend to give you the knowledge here in this place ; and firt, to begin with that which hath beene moft anciently receiued, which is Thrift. This is an euerliuing greene herbe, which many take to border their beds, and fet their knots and trayles, and therein much delight, becaufe it will grow thicke and bufhie, and may be kept, being cut with a paire of Garden theeres, in fome good handfome manner and proportion for a time, and befides, in the Summer time fend forth many fhort ftalkes of pleafant flowers, to decke vp an houfe ainong other fweete herbes: Yet thefe inconueniences doe accompany it; it will not onely in a finall time ouergrow the knot or trayle in many places, by growing fo thicke and buthie, that it will put out the forme of a knot in many places : but alfo much thereof will dye with the frofts and fnowes in Winter, and with the drought in Summer, whereby many voide places will be feene in the knot, which doth much deforme it, and muft therefore bee yearely refrefhed : the thickneffe alfo and bufhing thereof doth hide and thelter fnayles and other fmall noyfome wormes fo plentifully, that Gilloflowers, and other fine herbes and flowers being planted therein, are much fpoyled by them, and cannot be helped without much induftry, and very great and daily attendance to deftroy them. Germander is another herbe, in former times alfo much vfed, and yet alfo in many places; and becaufe it will grow thicke, and may be kept alfo in fome forme and proportion with cutting, and that the cuttings are much vfed as a ftrawing herbe for houfes, being pretty and fweete, is alfo much affected by diuers : but this alfo will often dye and grow out of forme, and befides that, the ftalkes will grow too great, hard and ftubby, the rootes doe fo farre fhoote vnder ground, that vpon a little continuance thereof, will 
fpread into many places within the knot, which if continually they be not plucked vp; they will fpoile the whole knot it felfe; and therefore once in three or foure yeares at the molt, it muft be taken vp and new fet, or elfe it will grow too roynifh and cumberfome. Hyffope hath alfo been vfed to be fet about a knot, and being fweete, will ferue for ftrewings, as Germander: But this, although the rootes doe not runne or creep like it, yet the ftalkes doe quickly grow great aboue ground, and dye often after the firft yeares fetting, whereby the grace of the knot will be much loft. Marierome, Sauorie, and Thyme, in the like manner being fweete herbes, are vfed to border vp beds and knots, and will be kept for a little while, with cutting, into fome conformity; but all and euery of them ferue moft commonly but for one yeares $v f e$, and will foone decay and perifh : and therefore none of thefe, no more than any of the former, doe I commend for a good bordering herbe for this purpofe. Lauander Cotton alfo being finely flipped and fet, is of many, and thofe of the higheft refpect of late daies, accepted, both for the beauty and forme of the herbe, being of a whitifh greene mealy colour, for his fent imelling fomewhat ftrong, and being euerliuing and abiding greene all the Winter, will, by cutting, be kept in as euen proportion as any other herbe may be. This will likewife foone grow great and ftubbed, notwithftanding the cutting, and befides will now and then perifh in fome places, efpecially if you doe not Atrike or put off the fnow, before the Sunne lying vpon it diffolue it: The rarity \& nouelty of this herbe, being for the moft part but in the Gardens of great perfons, doth caufe it to be of the greater regard, it muft therfore be renewed wholly euery fecond or third yeare at the most; becaufe of the great growing therof. Slips of Iuniper or Yew are alfo receiued of fome \& planted, becaufe they are alwayes green, and that the Iuniper efpecially hath not that ill fent that Boxe hath, which I will prefently commend vnto you, yet both Iuniper and Yew will foon grow too great and ftubbed, and force you to take vp. your knot fooner, than if it were planted with Boxe. Which laftly, I chiefly and aboue all other herbes commend vnto you, and being a fmall, lowe, or dwarfe kinde, is called French or Dutch Boxe, and ferueth very well to fet out any knot, or border out any beds: for befides that it is euer greene, it being reafonable thicke fet, will eafily be cut and formed into any fafhion one will, according to the nature thereof, which is to grow very flowly, and will not in a long time rife to be of any height, but thooting forth many fmall branches from the roote, will grow very thicke, and yet not require fo great tending, nor fo much perifh as any of the former, and is onely receiued into the Gardens of thofe that are curious. This (as I before faid) I commend and hold to bee the beft and fureft herbe to abide faire and greene in all the bitter ftormes of the fharpeft Winter, and all the great heates and droughts of Summer, and doth recompence the want of a good fweet fent with his frefh verdure, euen proportion, and long lafting continuance. Yet thefe inconueniences it hath, that befides the vnpleafing fent which many millike, and yet is but fmall, the rootes of this Boxe do fo much fpread themfelues into the ground of the knot, and doe draw from thence fo much nourifhment, that it robbeth all the herbes that grow neare it of their fap and fubftance, thereby making all the earth about it barren, or at leaft leffe fertile. Wherefore to thew you the remedy of this inconuenience of fpreading, without either taking vp the Boxe of the border, or the herbes and flowers in the knot, is I thinke a fecret knowne but 'vnto a few, which is this: You fhall take a broad pointed Iron like vnto a Slife or Cheffill, which thruft downe right into the ground a good depth all along the infide of the border of Boxe fomewhat clofe thereunto; you may thereby cut away the fpreading rootes thereof, which draw fo much moifture from the other herbes on the infide, and by this meanes both preferue your herbes and flowers in the knot, and your Boxe alfo, for that the Boxe will be nourifhed fufficiently from the reft of the rootes it fhooteth on all the other fides. And thus much for the liuing herbes, that ferue to fet or border vp any knot. Now for the dead materials, they are alfo, as I faid before diuers : as firft, Leade, which fome that are curious doe border their knots withall, caufing it to be cut of the breadth of foure fingers, bowing the lower edge a little outward, that it may lye vnder the vpper cruft of the ground, and that it may ftand the fafter, and making the vpper edge either plain, or cut out like vnto the battlements of a Church: this fafhion hath delighted fome, who haue accounted it ftately (at the leaft coftly) and fit for their degree, and the rather, becaufe it will be bowed and bended into any round fquare, angular, or other proportion as one lifteth, and is not much to be mifliked; in that the Leade: 
doth not eafily breake or fpoile without much iniury, and keepeth vp a knot for a very long time in his due proportion : but in my opinion, the Leade is ouer-hot for Summer, and ouer-cold for Winter. Others doe take Oaken inch boords, and fawing them foure or fiue inches broad, do hold vp their knot therewith : but in that thefe boordes cannot bee drawne compaffe into any finall fcantling, they muft ferue rather for long outright beds, or fuch knots as haue no rounds, halfe rounds, or compaffings in them. And befides, thefe boordes are not long lafting, becaufe they ftand continually in the weather, efpecially the ends where they are faftened together will fooneft rot and perilh, and fo the whole forme will be fpoyled. To preuent that fault, fome others haue chofen the fhanke bones of Sheep, which after they haue beene well cleanfed and boyled, to take out the fat from them, are ftucke into the ground the fmall end downewards, and the knockle head vpwards, and thus being fet fide to fide, or end to end clofe together, they fet out the whole knot therewith, which heads of bones although they looke not white the firft yeare, yet after they haue abiden forne frolts and heates will become white, and prettily grace out the ground : but this inconuenience is incident to them, that the Winter frofts will raife them out of the ground oftentimes, and if by chance the knockle head of any doe breake, or be ftrucke off with any ones foot, Scc. going by, from your ftore, that lyeth by you of the fame fort, fet another in the place, hauing firt taken away the broken peece : although thefe will laft long in forme and order, yet becaufe they are but bones many minlike them, and indeed I know but few that vfe them. Tyles are alfo vfed by fome, which by reafon they may bee brought compaffe into any fafhion many are pleafed with them, who doe not take the whole Tyle at length, but halfe Tyles, and other broken peeces fet fomewhat deepe into the ground, that they may ftand faft, and thefe take vp but little roome, and keepe $\mathrm{vp}$ the edge of the beds and knots in a pretty comely manner, but they are often out of frame, in that many of them are broken and fpoiled, both with mens feete paffing by, the weather and weight of the earth beating them downe and breaking them, but efpecially the frofts in Winter doe fo cracke off their edges, both at the toppes and fides that ftand clofe one vnto another, that they muft be continually tended and repaired with frefh and found ones put in the place of them that are broken or decayed. And laftly (for it is the lateft inuention) round whitifh or blewifh pebble stones, of fome reafonable proportion and bigneffe, neither too great nor too little, haue beene vfed by fome to be fet, or rather in a manner but laide vpon the ground to.fafhion out the traile or knot, or all along by the large grauelly walke fides to fet out the walke, and maketh a pretty handfome fhew, and becaufe the ftones will not decay with the iniuries of any time or weather, and will be placed in their places againe, if any fhould be thruft out by any accident, as alfo that their fight is fo confpicuous vpon the ground, efpecially if they be not hid with the ftore of herbes growing in the knot; is accounted both for durability, beauty of the fight, handfomneffe in the worke, and eafe in the working and charge, to be of all other dead materials the chiefert. And thus, Gentlemen, I haue thewed you all the varieties that I know are vsed by any in our Countrey, that are worth the reciting (but as for the fafhion of Iawe-bones, vfed by fome in the Low Countries, and other places beyond the Seas, being too groffe and bafe, I make no mention of them) among which euery one may take what pleafeth him beft, or may moft fitly be had, or may beft agree with the ground or knot. Moreouer, all thefe herbes that ferue for borderings, doe ferue as well to be fet vpon the ground of a leuelled knot; that is, where the allies and foot-pathes are of the fame leuell with the knot, as they may ferue alfo for the raifed knot, that is, where the beds of the knot are raifed higher than the allies; but both Leade, Boordes, Bones, and Tyles, are only for the raifed ground, be it knot or beds. The pebble ftones againe are onely for the leuelled ground, becaufe they are so fhallow, that as I faid before, they rather lye vpon the earth than are thruft any way into it. All this that $I$ haue here fet downe, you muft vnderftand is proper for the knots alone of a Garden. But for to border the whole fquare or knot about, to ferue as a hedge thereunto, euery one taketh what liketh him belt; as either Priuet alone, or fweete Bryer, and white Thorne enterlaced together, and Rofes of one, or two, or more forts placed here and there amongt them. Some alfo take Lauander, Rofemary, Sage, Southernwood, Lauander Cotton, or fome fuch other thing. Some againe plant. Cornell Trees, and plafh them, or keepe them lowe, to

forme 
forme them into an hedge. And fome againe take a lowe prickly fhrubbe, that abideth alwayes greene, defcribed in the end of this Booke, called in Latine Pyracantha, which in time will make an euer greene hedge or border, and when it beareth fruit, which are red berries like vnto Haw.thorne berries, make a glorious fhew among the greene leaues in the Winter time, when no other thrubbes haue fruit or leaues.

\section{C н A P. IV.}

The nature and names of diuers Out-landifh flowers, that for their pride, beauty, and earlinefe, are to be planted in Gardens of peafure for delight.

$\mathrm{H}$ Auing thus formed out a Garden, and diuided it into his fit and due proportion, with all the gracefull knots, arbours, walkes, \&c. likewife what is fit to keepe it in the fame comely order, is appointed vnto it, both for the borders of the fquares, and for the knots and beds themselues; let vs now come and furnifh the inward parts, and beds with thofe fine flowers that (being ftrangers vnto vs, and giuing the beauty and brauery of their colours fo early before many of our owne bred flowers, the more to entice vs to their delight) are moft befeeming it ; and namely, with Daffodils, Fritillarias, Iacinthes, Saffron-flowers, Lillies, Flowerdeluces, Tulipas, Anemones, French Cowflips, or Beares eares, and a number of fuch other flowers, very beautifull, delightfull, and pleafant, hereafter defcribed at full, whereof although many haue little fweete fcent to commend them, yet their earlineffe and exceeding great beautie and varietie doth fo farre counteruaile that defect (and yet I muft tell you with all, that there is among the many forts of them fome, and that not a few, that doe excell in fweetneffe, being fo ftrong and heady, that they rather offend by too much than by too little fent, and fome againe are of fo milde and moderate temper, that they fcarce come thort of your moft delicate and daintieft flowers) that they are almoft in all places with all perfons, efpecially with the better fort of the Gentry of the Land, as greatly defired and accepted as any other the moft choifeft, and the rather, for that the moft part of thefe Out-landifh flowers, do fhew forth their beauty and colours fo early in the yeare, that they feeme to make a Garden of delight euen in the Winter time, and doe fo giue their flowers one after another, that all their brauery is not fully fpent, vntil that Gilliflowers, the pride of our Englifh Gardens, do fhew themfelues: So that whofoeuer would haue of euery fort of thefe flowers, may haue for euery moneth feueral colours and varieties, euen from Chriftmas vntill Midfommer, or after; and then, after fome little refpite, vntill Chriftmas againe, and that in fome plenty, with great content and without forcing; fo that euery man may haue them in euery place, if they will take any care of them. And becaufe there bee many Gentlewomen and others, that would gladly haue fome fine flowers to furnifh their Gardens, but know not what the names of thofe things are that they defire, nor what are the times of their flowring, nor the skill and knowledge of their right ordering, planting, difplanting, tranfplanting, and replanting; I haue here for their fakes fet downe the nature, names, times, and manner of ordering in a briefe manner, referring the more ample declaration of them to the worke following. And firft of their names and natures: Of Daffodils there are almoft an hundred forts, as they are feuerally defcribed hereafter, euery one to be diftinguished from other, both in their times, formes, and colours, fome being eyther white, or yellow, or mixt, or elfe being fmall or great, fingle or double, and fome hauing but one flower vpon a ftalke, others many, whereof many are fo exceeding fweete, that a very few are fufficient to perfume a whole chamber, and befides, many of them be fo faire and double, eyther one vpon a ftalke, or many vpon a ftalke, that one or two ftalkes of flowers are in ftead of a whole nofe-gay, or bundell of flowers tyed together. This I doe affirme vpon good knowledge and certaine experience, and not as a great many others doe, tell of the wonders of another world, which themselues neuer faw nor euer heard of, except fome fuperficiall relation, which themselues haue augmented according to their owne fanfie and conceit. Againe, let me here alfo by the way tell you, that many idle and ignorant Gardiners and others, who get names by ftealth, as they doe many other things, doe call 
fome of thefe Daffodils Narciffes, when as all know that know any Latine, that Narciffus is the Latine name, and Daffodill the Englinh of one and the fame thing; and therefore alone without any other Epithite cannot properly diftinguifh feuerall things. I would willingly therefore that all would grow iudicious, and call euery thing by his proper Englin name in fpeaking Englifh, or elfe by fuch Latine name as euery thing hath that hath not a proper Englifh name, that thereby they may diftinguifh the feuerall varicties of things and not confound them, as alfo to take away all excufes of miftaking; as for example: The fingle Englifh baftard Daffodill (which groweth wilde in many Woods, Groues, and Orchards in England.) The double Englinh baitard Daffodill. The French fingle white Daffodill many wpon a iftalke. The French double yellow Daffodill. The great, or the little, or the leaft Spanifh yellow baftard Daffodill, or:the great or little Spanifh white Daffodill. The Turkie fingle white Daffodill, or, The Turkie fingle or double white Daffodill many ivpon a ftalke, '\&c. . Of Fritillaria, or the checkerd Daffodill, there are halfe a fcore feuerall iforts, both white and red, both yellow and blacke, which are a wonderfull :grace and ornament to a Garden in regard of the Checker like fpots are in the flowers. Of Iacinthes there are aboue halfe an hundred forts, as they are fpecified hereafter; ifome like vnto little bells or ftarres, others like vnto little bottles or pearles, both white and blew, sky+coloured and blufh, and fome ftarlike of many pretty various formes, and all to giue delight to them that will be curious to obferue them. Of Crocus or 'Saffron flowers, there are alfo twenty forts; fome of the Spring time, others flowring onely in the Autume or Fall, earlier or later than another, fome whereof abide'but a while, others indure aboue a moneth in their glorious'beauty. The Colchicum or Medowe Saffron, which fome call the fonne before the father, but not properly, is of many forts alfo; Ifome flowring in the. Spring of the yeare, but the moft in Autume, whereof fome haue faire double flowers very delightfull to behold, and fome partly coloured both Ifingle and double fo variable, that it would make any one admire the worke of the Creatour in the various fpots and: Atripes of thefe flowers. Then haue wee of Lillies itwenty feuerall forts and colours, among whom I muft reckon the Crowne Imperiall, that for his ftately forme deferueth fome fpeciall place in this Garden, as alfo the Martagons, both white and red, both blufh and yellow, that require to be fet by themfelues apart, as it were in a ifmall round or fquare of a knot, without many other, or tall flowers growing neare them. But to tell you of all the forts of Tulipas (which are the pride of delight) they arefo many, and as I may fay, almoft infinite, doth both paffe my ability, and as I beleeue the skill of any other. They are of two efpeciall forts, fome flowring earlier, and othersilater than their fellowes, and that naturally in all grounds, wherein there is fuch a wonderfull variety and mixture of colours, that it is almoft impolfible for the wit of man to defcipher them thoroughly, and to giue names that may be true \& f feuerall diftinctions to euery flower, threefcore feuerall forts of colours fimple and mixed of each kind I can reckon vp that I haue, and of ofpeciall note, and yet'I doubt not, but for euery one of them there are ten others differing from them, which may be feen at feuerall times, and in feuerall places: \& befides this glory of variety in colors that thefe flowers haue, they carry fo ftately \& $\&$ delightfull a forme, \& do abide fo long in their brauery (enduring aboue three whole moneths from the firft unto the latt) that there is no Lady or Gentlewoman of any worth that is not caught with this delight, or not delighted with thefe flowers. The Anemones likewife or Windeflowers are fo full of variety and fo dainty, fo pleafant and fo delightfome flowers, that the fight of them doth enforce an earneft longing defire in the ininde of any one to be a poffeffour of fome of them at the leaft: For without all doubt, this one kinde of flower, fo variable in colours, to differing in forme (being almoft as many forts of them double as ifingle) fo plentifull in bearing flowers, and fo durable in lafting, and alfo fo eafie both to preferue and to encreafe, is of it lelfe alone almoft fufficient to furnith a garden with their flowers for almolt halfe the yeare, as I I hall thew you in a fit and conuenient place. The Beares eares or French Cowflips muft not want their deferued commendations, feeing that their flowers, being many fet together vpon a ftalke, doe feeme euery one of them to bee a Nofegay alone of it felfe : and befides the many differing colours that are to: be feene in them, as white, yellow, blufh, purple, red, tawney, murrey, haire colour, \&cc. which encreafe much delight in all forts of the Gentry of the Land, they are not vnfurnihed with a pretty fweete fent, 
which doth adde an encreafe of pleafure in thofe that make them an ornament for their wearing. Flowerdeluces alfo are of many forts, but diuided into two efpeciall kindes; the one bearing a leafe like a flagge, whofe roots are tuberous, thicke and Thort (one kinde of them being the Orris rootes that are fold at the Apothecaries, whereof fweete powders are made to lye among garments) the other hauing round rootes like vnto Onions, and narrow long leaues fomewhat like graffe: Of both thefe kindes there is much variety, efpecially in their colours. The greater Flagge kinde is frequent enough and difperfed in this Land, and well doth ferue to decke vp both a Garden and Houfe with natures beauties: But the chiefe of all is your Sable flower, fo fit for a mourning habit, that I thinke in the whole compaffe of natures ftore, there is not a more patheticall, or of greater correfpondency, nor yet among all the flowers I know any one comming neare vnto the colour of it. The other kinde which hath bulbous or Onion like rootes, diuerfifieth it felfe alfo into fo many fine colours, being of a more neate fhape and fuccinct forme than the former, that it muft not bee wanting to furnifh this Garden. The Hepatica or Noble Liuerwoort is another flower of account, whereof fome are white, others red, or blew, or purple, fomewhat refembling Violets, but that there are white threads in the middeft of their flowers, which adde the more grace vnto them; and one kinde of them is fo double, that it refembleth a double thicke Dafie or Marigold, but being fmall and of an excellent blew colour, is like vnto a Button: but that which commendeth the flower as much as the beauty, is the earlineffe in flowring, for that it is one of the very firft flowers that open themfelues after Chriftmas, euen in the midft of Winter. The Cyclamen or Sowebread is a flower of rare receipt, becaufe it is naturally hard to encreafe, and that the flowers are like vnto red or blufh coloured Violets, flowring in the end of Summer or beginning of Autumne: the leaues likewife hereof haue no fmall delight in their pleafant colour, being fpotted and circled white vpon greene, and that which moft preferreth it, is the Phyficall properties thereof for women, which I will declare when I thall thew you the feuerall defcriptions of the varieties in his proper place. Many other forts of flowers there are fit to furnifh this Garden, as Leucoium or Bulbous Violet, both early and late flowring. Mufcari or Muske Grape flower. Starre flowers of diuers forts. Phalangium or Spiderwort, the chiefe of many is that fort whofe flowers are like vnto a white Lilly. Winter Crowfoote or Wolfes bane. The Chriftmas flower like vnto a fingle white Rofe. Bell flowers of many kindes. Yellow Larkes fpurre, the prettieft flower of a fcore in a Garden. Flower-gentle or Floramour. Flower of the Sunne. The Maruaile of Peru or of the world. Double Marfh Marigold or double yellow Buttons, much differing and farre exceeding your double yellow Crowfoote, which fome call Batchelours Buttons. Double French Marigolds that fmell well, and is a greater kinde than the ordinary, and farre furpaffeth it. The double red Ranunculus or Crowfoote (farre excelling the moft glorious double Anemone) and is like vnto our great yellow double Crowfoote. Thus hauing giuen you the knowledge of fome of the choifeft flowers for the beds of this Garden, let me alfo thew you what are fitteft for your borders and for your arbours. The Iafmine white and yellow. The double Honyfockle. The Ladies Bower, both white, and red, and purple fingle and double, are the fitteft of Outlandifh plants to fet by arbours and banqueting houfes, that are open, both before and aboue to helpe to couer them, and to giue both fight, fmell, and delight. The forts of Rofes are fitteft for ftandards in the hedges or borders. The Cherry Bay or Laurocerafus. The Rofe Bay or Oleander. The white and the blew Syringa or Pipe tree, are all gracefull and delightfull to fet at feuerall diftances in the borders of knots; for fome of them giue beautifull and fweete flowers. The Pyracantha or Prickly Corall tree doth remaine with greene leaues all the yeare, and may be plafhed, or laid downe, or tyed to make a fine hedge to border the whole knot, as is faid before. The Wilde Bay or Laurus Tinus, doth chiefly defire to be fheltered vnder a wall, where it will beft thriue, and giue you his beautifull flowers in Winter for your delight, in recompence of his fenced dwelling. The dwarfe Bay or Mefereon, is moft commonly either placed in the midft of a knot, or at the corners thereof, and fometimes all along a walke for the more grace. And thus to fit euery ones fancy, I haue fhewed you the variety of natures ftore in fome part for you to difpofe of them to your beft content.

C H A P. 


\section{CIA P. V.}

The nature and names of thofe that are called vfually Englifs flowers.

$\mathrm{T}$

Hole flowers that haue beene vfually planted in former times in Gardens of this Kingdome (when as our forefathers knew few or none of thofe that are recited before) liaue by time and cuftome attained the name of Englifh flowers, although the moft of them were neuer naturall of this our Land, but brought in from other Countries at one time or other, by thofe that tooke pleafure in them where they firft faw them: and I doubt not, but many other forts than here are fet downe, or now knowne to vs, haue beene brought, which either haue perifhed by their negligence or want of skill that brought then, or elfe becaufe they could not abide our cold Winters; thofe onely remaining with vs that have endured of themfelues, and by their encreafing haue beene diftributed ouer the whole Land. If I thould make any large difcourfe of them, being fo well knowne to all, I doubt I fhould make a long tale to fmall purporc: I will therefore but briefly recite them, that you may haue them together in one place, with fome little declaration of the nature and quality of them, and fo paffe to other matters. And firft of Primrofes and Cownlips, whereof there are many prettie varieties; fome better knowne in the Weft parts of this Kingdome, others in the North, than in any other, vntill of late being obferued by fome curious louers of varieties, they haue been tranfplanted diverny, and fo made more common : for although we haue had formerly in thefe parts about London greene Primrofes vfually, yet we neuer faw or heard of greene Cowflips both fingle and double but of late dayes, and to likewife for Primrofes to be both fingle and double from one roote, and diuers vpon one ftalke of diuers fafhions, I am fure is not vfuall: all which defire rather to bee planted vnder fome hedge, or fence, or in the fhade, than in the Sunne. Single Rofe Campions, both white, red, and blufh, and the double red Rofe Campion alfo is knowne fufficiently, and will abide moderate Sunne as well as the fhade. The flower of Briftow or None-fuch is likewife another kinde of Campion, whereof there is both white flowring plants and blum as well as Orange colour, all of them being fingle flowers require a moderate Sunne and not the Thadow: But the Orange colour Nonefuch with double flowers, as it is rare and not common, fo for his brauery doth well deferue a Mafter of account that will take care to keepe and preferue it. Batchelours Buttons both white and red, are kindes of wilde Campions of a very double forme, and will reafonably well like the Sunne but not the fhade. Wall-flowers are common in euery Garden, as well the ordinary double as the fingle, and the double kinde defireth no more fhade than the fingle, but the greater kindes both double and fingle muft haue the Sunne. Stock-Gilloflowers likewife are almoft as common as Wall-flowers, efpecially the fingle kindes in euery womans Garden, but the double kindes are much more rare, and poffeffed but of a few, and thofe onely that will bee carefull to preferuc them in Winter; for befides that the moft of them are more tender, they yeeld no feede as the fingle kindes doc to preferue them, although one kinde from the fowing of the feed yeeld double flowers: They will all require the comfort of the Sunne, efpecially the double kindes, and to be defended from cold, yet fo as in the Summer they doe not want water wherein they much ioy, and which is as it were their life. Queenes Gilloflowers (which fome call Dames Violets, and fome Winter Gilloflowers, are a kinde of Stock-Gilloflower) planted in Gardens to ferue to fill vp the parts thereof for want of better things, hauing in mine opinion neither fight nor fent much to commend them. Violets are the Springs chiefe flowers for beauty, fmell, and vfe, both fingle and double, the more thadie and moift they ftand the better. Snapdragon are flowers of much more delight, and in that they are more tender to keep, and will hardly endure the fharpe Winters, vnleffe they ftand well defended, are fcarce feene in many Gardens. Columbines fingle and double, of many forts, fafhions, and colours, very variable both fpeckled and party coloured, are flowers of that refpect, as that no Garden would willingly bee without them, that could tell how to haue them, yet the rarer the flowers are, the more trouble to keepe; the ordinary forts on the con- 
trary part will not be loft, doe what one will. Larkes heeles, or fpurres, or toes, as in feuerall Countries they are called, exceed in the varietie of colours, both fingle and double, any of the former times; for vntill of late dayes none of the moft pleafant colours were feene or heard of: but now the fingle kindes are reafonable well difperft ouer the Land, yet the double kindes of all thofe pleafant colours (and fome other alfo as beautifull) which ftand like little double Rofes, are enioyed but of a few : all of them rife from feed, and muft be fowne euery yeare, the double as. well as the fingle: Panfyes or Hartes eafes of diuers colours, and although without fent, yet not without fome refpect and delight. Double Poppies are flowers: of a great and goodly proportion, adorning: a Garden with their variable colours to the delight of the beholders, wherein there is fome fpeciall care to be taken, left they turne fingle; and that is, if you fee them grow.vp too thicke, that you muft pull them vp, and not fuffer them to grow within leffe than halfe a yard diftance, or more one from another. Double Daifies are flowers not to be forgotten, although they: be common enough in euery Garden, being both white and red, both blufh and fpeckled, or party coloured, befides that which is called Iacke an Apes on horfebacke, they require a moift and fhadowie place; for they are: fcorched away, if they ftand in the Sunne in any dry place. Double Marigolds alfo are the moft common in all Gardens. And fo are the French Marigolds that haue a ftrong heady, fent, both fingle and double, whofe glorious thew for colour would caufe any to beleeue there were fome rare goodneffe or vertue in them. Thefe all are fometimes preferued in the Winter, if they bee well defended from the cold. But what Shall I fay to the Queene of delight and of flowers, Carnations and Gilloflowers, whofe brauery, variety, and fweete Imell ioyned together, tyeth euery ones affection with great earneftneffe, both to like and to haue them ? Thofe that were knowne, and enioyed in former times: with much acceptation, are now for the moft part leffe accounted of, except a very few : for now there are fo many other varieties of later inuention, that troubleth the other both in number, beauty, and worth: The names: of them doe differ very variably, in that names are impofed and altered as euerie ones fancy will haue them, that carryed or fent them into the feuerall Countries from London, where their trueft name is to be had, in mine opinion. I will here but giue you the names of fome; and referre you to the worke enfuing for your further knowledge. The red and the gray. Hulo. The old Carnation, differing from them both. The Gran Pere. The Camberfiue. The Sauadge. The Chriftall. The Prince. The white Carnation, or Delicate. The ground Carnation. The French Carnation. The Douer. The Oxford. The Briftow. The Weftminter. The Daintie. The Granado, and many other Gilloflowers too tedious to recite in this place, becaufe I haue amply declared them in the booke following. But there is another fort of great delight and varietie, called the Orange tawny Gilloflower, which for the molt part hath rifen from feed, and doth giue feed in a more plentifull manner than any of the former forts; and likewife by the fowing of the feed; there hath been gained fo many varieties of that excellent worth and refpect, that it can hardly. be expreffed or beleeued, and called by diuers names according to the marking of the flowers; as The Infanta. The Stript Tawny. The Speckled Tawny. The Flackt Tawny. The Grifeld Tawny, and many others; euery one to bee diftinguifhed from others: Some alfo haue their flowers more double and large than others, and fome from the fame feed have fingle flowers. like broad fingle Pinkes: the further relation of them, viz. their order to fowe, encreafe and preferue them, you thall have: in the fubfequent difcourfe in a place by it felfe. Pinkes likewife both fingle and double are of much variety, all of them very fweete, comming neare the Gilloflowers. Sweete Williams. and Sweete Iohns, botb fingle and double, both white, red, and fpotted, as they are kindes of wilde Pinkes, fo for their grace and beauty helpe to furnifh a Garden, yet defire not to ftand fo open to the Sunne as the former. Double and fingle Peonies are fit flowers to furnifh a Garden, and by reafon of their durability, giue out frefh pleafure euery yeare without any further trouble of fowing. And lantly, Hollihocks both fingle and double, of many and fundry colours, yeeld out their flowers like Rofes on their tall branches, like Trees, to fute you with flowers, when almoft you haue no other to grace out your Garden: the fingle and double doe both yeeld feed, and yet doe after their feeding abide many yeares. Thus haue I thewed you moft of the Englifh, as well as (I did before) the Out- 
landifh flowers, that are: fit to furnith the knots, trailes, beds, and borders of this: Garden. Rofes onely, as. I faid before, I referue to circle or encompaffe all the reft, becaufe that for the moft part they are planted in the euter borders, of the quarters, and fometimes by themfelues in the middle: of long beds, the forts or kindes. whereof are many, as they are declared in their proper place : but the White Rofe, the Red, and the Damaske, are the molt ancient Standards in England, and therefore accounted naturall.

\section{CHAP. V I:}

The order and manner to plant and replant all the forts of Out-landiff flowers fpoken of before, as well thofe with bulbous rootes, as othiers with fringie rootes.

W Hereas it is the vfuall cuftome of moft in this Land, to turne vp their Gardens, and to plant them againe in the Spring of the yeare, which is the beft time that may bee chofen for all Englifh flowers; yet it is not fo for your Out-landifh flowers. And herein indeede hath beene not onely the errour of a great many to hinder their rootes, from bearing out their flowers as they fhould, but alfo to hinder many to take delight in them, becaure as they fay they: will not thriue and profper with them, when as the whole fault is in the want of knowledge of the fit and conuenient time wherein they fhould bee planted. And becaufe our Englifh Gardiners are all or the moft of them vtterly ignorant in the ordering of thefe Out-landifh flowers, as not being trained vp to know them, I baue here taken vpon mee the forme of a new Gardiner, to giue instructions to thofe that will take pleafure in them, that they may be the better enabled with thefe helpes I fhall thew them, both to know how they thould be ordered, and to direct their Gardiners, that are ignorant thereof, rightly to difpofe them according to their naturall qualities. And $I$ doe wilh all Gentlemen and Gentlewomen, whom it may concerne for their owne good, to bee as carefull whom they truft with the planting and replanting of thefe fine flowers, as they would be with fo many lewels; for the rootes of many of them being fmall, and of great var lue, may be foone conueyed away, and a cleanly tale faire told, that fuch a roote is rotten, or perifhed in the ground if none be feen where it Ahould be; or elfe that the flower bath changed his colour, when it hath been taken away, or a counterfeit one hath beene put in the place thereof; and thus: many haue been deceiued of their daintieft flowers, without remedy or true knowledge of the defect. You Thall therefore, if you will take the right courfe that is proper for thefe kindes of flowers, not fet or plant them among your Englinh flowers; for that when the one may be remoued, the other may not be ftirred: but plant thofe rootes that are bulbous, or round like Onions, eyther in knots or beds by themfelues which is the beft, or with but very few Englifh or Out-landifh flower plants that haue fringie rootes: For you muft take this for a generall rule, that all thofe rootes that are like Lillies or Onions, are to bee plantedin in the moneths of Iuly ar Auguft, or vnto the middle or end of September at the furthert, if you will haue them to profper as they fhould; and not in the Spring of the yeare, when other gardening is vfed. Yet I muft likewife giue you to vnderftand, that if Tulipas, and Daffodils, and fome other that are firme and hard rootes, and not limber or fpongie, being taken vp out of the ground in their fit feafon, that is, in Iune, Iuly, and Augurt, and likewife kept well and dry, may be referued out of the ground vntill Chriftmas or after; and then (if they could not be fet fooner) being fet; will thriue reafonable well, but not altogether fo well as the former, being fet long before: but if you fhall remoue thefe bulbous, rootes againe, either prefently after their planting, hauing thot their fmall fibres vnder the round rootes, and fprung likewife vpwards, or before they be in flower at the fooneft (yet: Tulipas, Daffodils, and many other bulbous, may be fafely remoued being in flower, and tranfplanted into other places, fo as they be not kept too long out of the ground) you thall much endanger them either vtterly to perin, or to be hindered from bearing out their-flowers they then would haue 
borne, and for two or three years after from bearing flowers againe. For the order of their planting there are diuers wayes, fome whereof I will fhew you in this place: Your knot or beds being prepared fitly, as before is declared, you may place and order your rootes therein thus, Eyther many rootes of one kind fet together in a round or clufter, or longwife croffe a bed one by another, whereby the beauty of many flowers of one kinde being together, may make a faire nhew well pleafing to many; Or elfe you may plant one or two in a place difperfedly ouer the whole knot, or in a proportion or diameter one place anfwering another of the knot, as your ftore will fuffer you, or your knot permit: Or you may alfo mingle thefe rootes in their planting many of diuers forts together, that they may giue the more glorious thew when they are in flower; and that you may fo doe, you muft firft obferue the feuerall kindes of them, which doe flower at one and the fame time, and then to place them in fuch order and fo neare one vnto another, that their flowers appearing together of feuerall colours, will caufe the more admiration in the beholders: as thus, The Vernall Crocus or Saffron flowers of the Spring, white, purple, yellow, and ftript, with fome Vernall Colchicum or Medow Saffron among them, fome Dens Caninus or Dogges teeth, and fome of the fmall early Leucoium or Bulbous Violet, all planted in fome proportion as neare one vnto another as is fit for them, will giue fuch a grace to the Garden, that the place will feeme like a peece of tapeftry of many glorious colours, to encreafe euery ones delight: Or elfe many of one fort together, as the blew, white, and blufh Grape flowers in the fame manner intermingled, doe make a maruellous delectable fhew, efpecially becaufe all of them rife almoft to an equall height, which caufeth the greater grace, as well neare hand as farre of. The like order may be kept with many other things, as the Hepatica, white, blew, purple, and red fet or fowne together, will make many to beleeue that one roote doth beare all thofe colours: But aboue and beyond all others, the Tulipas may be fo matched, one colour anfwering and fetting of another, that the place where they ftand may refemble a peece of curious needle-worke, or peece of painting; and I haue knowne in a Garden, the Mafter as much commended for this artificiall forme in placing the colours of Tulipas, as for the goodneffe of his flowers, or any other thing. The diuers forts and colours of Anemones or Winde-flowers may be fo ordered likewife, which are very beautifull, to haue the feuerall varieties planted one neare vnto another, that their feuerall colours appearing in one place will be a very great grace in a Garden, or if they be difperfed among the other forts of flowers, they will make a glorious thew. Another order in planting you may obferue; which is this, That thofe plants that grow low, as the Aconitum Hyemale or Winter-wolues bane, the Vernall Crocus or Saffron-flowers of diuers forts, the little early Leucoium or Bulbous Violet, and fome fuch other as rife not vp high, as alfo fome Anemones may be very well placed fomewhat neare or about your Martagons, Lillies, or Crownes Imperiall, both becaufe thefe little plants will flower earlier than they, and fo will bee gone and paft, before the other greater plants will rife vp to any height to hinder them; which is a way may well be admitted in thofe Gardens that are fmall, to faue roome, and to place things to the moft aduantage. Thus hauing fhewed you diuers wayes and orders how to plant your rootes, that your flowers may giue the greater grace in the Garden, let mee fhew you likewife how to fet thefe kindes of rootes into the ground; for many know not well eyther which end to fet vpwards or downewards, nor yet to what depth they. fhould be placed in the ground. Daffodils if they be great rootes, will require (as muft bee obferued in all other great plants) to bee planted fomewhat deeper than the fmaller of the fame kinde, as alfo that the tops or heads of the rootes be about two or three fingers breadth hid vnder ground. The Tulipas likewife if you fet them deepe, they will be the fafer from frofts if your ground be cold, which will alfo caufe them to be a little later before they be in flower, yet vfually if the mould be good, they are to be fet a good hand breadth deep within the ground, fo that there may be three or foure inches of earth at the leaft aboue the head, which is the fmaller end of the roote: for if they thall lye too neare the vpper face or cruft of the earth, the colds $\&$ frofts will pierce and pinch them the fooner. After the fame order and manner muft Hyacinthes, whether great or fmall, and other fuch great rootes be planted. Your greater rootes, as Martagons, Lillies, and Crownes Imperiall, muft be fet much deeper than any other bulbous roote, becaufe they are greater rootes than others, and by themfelues alfo, as 
is moft vfuall either in fome fquare, round, triangle, or other fmall part in the Garden, becaufe they fpread and take vp a very great deale of ground. All of them likewife are to be fet with the broad end of the roote downewards, and the fmall end vpwards, that is, both Lillies, Daffodils, Hyacinthes, and Tulipas, and all other forts of round rootes, which thew one end to bee finaller than another. But the Colchicum or Medow-Saffron onely requireth an exception to this generall rule, in regard the roote thereof hath a fmall eminence or part on the one fide thereof, which inut bee fet or planted downeward, and not vpward; for you fhall obferue, if the roote lye a little moift out of the ground, that it will hoote fibres out at the fmall long end thereof, although you may perceiue when you take it vp, that the fibres were at the other broad end or fide of the roote. As for the Crowne Imperiall, which is a broad round roote and flat withall, hauing a hole in the middle, for the moft part quite thorow, when it is taken vp in his due time out of the ground, you fhall perceiue the fcales or cloues of the rootes to bee a little open on the vpperfide, and clofe and flat on the vnderfide, which will direct you which part to fet vpward; as alfo that the hole is bigger aboue then it is below. The Perfian Lilly is almoft like unto the Crowne Imperiall, but that the roote thereof is not fo flat, and that it hath a fmaller head at the one part, whereby it may be difcerned the plainer how to be fet. The Fritillaria is a fmall white root diuided as it were into two parts, fo that many haue doubted, as formerly in the Crowne Imperiall, what part to fet vppermoft; you fhall therefore marke, that the two parts of the roote are ioyned together at the bottome, where it Thooteth out fibres or fmall Atringie rootes, as all other forts of bulbous rootes doe, and withall you fhall fee, that betweene the two parts of the roote a fmall head will appeare, which is the burgeon that will fpring vp to beare leaues and flowers. In the rootes of Anemones there are fmall round fwelling heads, eafie enough to be obferued if you marke it, which muft be fet vpwards. All other forts of Atringie rooted plants (and not bulbous or tuberous rooted) that lofe their greene leaues in Winter, will fhew a head from whence the leaues and flowers will fpring, and all others that keepe their greene leaues, are to bee planted in the fame manner that other herbes and flower-plants are accuftomed to be. But yet for the better thriuing of the ftringie rooted plants, when you will plant them, let me informe you of the beft way of planting, and the moft fure to caufe any plant to comprehend in the ground without failing, and is no common way with any Gardiner in this Kingdome, that euer I heard or knew, which is thus: Prefuming that the ftringie rooted plant is frefh and not old gathered, and a plant that being remoued will grow againe, make a hole in the ground large enough where you meane to fet this roote, and raife the earth within the hole a little higher in the middle then on the fides, and fet the roote thereon, fpreading the ftrings all abroad about the middle, that they may as it were couer the middle, and then put the earth gently round about it, preffing it a little clofe, and afterwards water it well, if it be in Summer, or in a dry time, or otherwife moderately: thus fhall euery feuerall ftring of the roote haue earth enough to caufe it to fhoote forth, and thereby to encreafe farre better than by the vfuall way, which is without any great care and refpect to thruft the rootes together into the ground. Diuers other flower plants are but annuall, to bee new fowne euery yeare; as the Maruaile of the world, the Indian Creffes, or yellow Larkes heeles, the Flower of the Sunne, and diuers others: they therefore that will take pleafure in them, that they may enioy their flowers the earlier in the yeare, and thereby haue ripe feede of them while warme weather lafteth, muft nurfe vp their feedes in a bed of hot dung, as Melons and Cowcumbers are, but your bed mut be prouided earlier for thefe feeds, than for Melons, \&c. that they may haue the more comfort of the Summer, which are to be carefully tended after they are tranfplanted from the hotbed, and couered with ftraw from colds, whereby you hall not faile to gaine ripe feed euery yeare, which otherwife if you hould miffe of a very kindly \& hot Summer, you fhould neuer haue. Some of thefe feedes neede likewife to be tranfplanted from the bed of dung vnder a warme wall, as the Flower of the Sunne, and the Maruaile of the world, and fome others, and that for a while after their tranfplanting, as alfo in the heate of Summer, you water them at the roote with water that hath ftood a day or two in the Sunne, hauing firt laid a round wifpe of hay or fuch other thing round about the roote, that fo all helpes may further their giuing of ripe feede. One or two rules more I will giue you concerning 
thefe dainty flowers, the firft whereof is this, That you fhall not bee carefull to water any of your bulbous or tuberous rooted plants at any time; for they all of them do better profper in a dry ground than in a wet, onely all forts of tuberous rooted Flowerdeluces vpon their remouall had neede of a little water, and fome will doe to alfo to fuch Tulipas and other bulbous rootes as they tranfplant, when they are in flower, and this is I grant in fome fort tolerable, if it bee not too much, and done onely to caufe the ftalke and flower to abide fometime the longer before they wither, but elfe in no other cafe to be permitted. The fecond rule is, That I would aduife you to water none of your dainty flowers or herbes, with any water that bath prefently before tbeen idrawne out of a well or pumpe, but onely with fuch water that hath iftood open in the iSunne in forme cifterne, itubbe, or pot for a day at the leaft, if more the better: for that water which is prefently drawne out of a well, \& $\mathrm{c}$. is fo cold, that it prefently chilleth \& killeth any dainty plant be it younger or elder grown, whereof I haute had fufficient proofe: and therfore I give you this caution by mine cown experience. Thus haue I directed you from point to point, in all the particulars of preparing $\&$ planting that belong to this Garden, fauing onlyt that yet I would further enforme you, of theitime of the flowring of thefe Out-landifh plants, according to thelfeuerall moneths in the yeare, that euery one may know what flowers euery moneth yeeldeth, and may chufe what them liketh beft, in that they may fee that there is no moneth, but glorieth in Ifome peouliar forts of rare flowers. I would likewife rather in this place fhew you, the true and beft manner \& order to encreafe and preferue all forts of Gilloflowers \& Carnations, then ioyne it with the Chapter of Gilloflowers in the worke following, becaufe it would in that place táke :vp too much roome. And laftly, I muft of neceffity oppofe three fundry errours, that haue poffeffed the mindes of many both in former and later itimes, which are, that any flower may be made to grow double by art, that was but fingle before by inature: And that ione may by art caufe any flower to grow of what colour they will: And that any plants may be forced to flower out of their due feafons, either earlier or later, bysan:art which fome can $v$ fe. All which lbeing declared, I then fuppore enough is f poken for an introduction to this worke, referring many other things to the feuerall directions in the Chapters of the booke.

\section{CH AIP. VII.}

\section{The feuerall times of the flowring of the fe: Out-landifs flowers, according to the feuerall moneths of the yeare.}

$\mathrm{I}$ Intend in this place onely to give you'briefly, the niames of fome of the chiefeft of thefe Out-landifh flowers, according to the feuerall moneths: of "the yeare wherein they flower, that every one feeing what forts of flowers euery moneth yeeldeth, may take of them which they like beft. I begin with Ianuary, as the firf moneth of the yeare, wherein if the frofts be not extreme, you fhall haue the fe: flowers of plants; the Chriftmas flower or Helleborus niger verus, 'Winter wolues bane or Aconitum hyemale, Hepatica or Noble Liuer wort blew andred, and of flrnbbes, the Laurus Tinus or Wilde Bay tree, and Mefereon or the dwatfe Bay: but becaufe Ianuarie is oftentimes' too deepe in frofts and fnow, I therefore referre the Hepaticas vnto the moneth following, which is February, wherein the weather beginneth sto be a little rmilder, and then they will flower much better, as alfo diuers forts of Crocus or Saffron Hower will appeare, the little early Summer foole or Leucoium bulbofum, and Itowards the latter 'end thereof the Vernall Colchicum, the Dogges tooth Violet or Dens Caminus, and fome Anemones, both fingle and double, which in fome places will flower all the Winter long. 'March will yeeld more varieties; for befides that it holdeth fome of the flowers of the former moneth, it will yeeld you both the double lblew $\mathrm{He}$ patica, and the white and the blufh fingle: then alfo you fhall have diuers other forts of Crocus or Saffron flowers, Double yellow Daffodils, !Orientall IIacinths and iothers, the Crowne Imperiall, diuers forts of early' Tulipas, fome forts of French Cownlips, both tawney, murry, yellow, and blufh, the early Fritillaria or checkerd Daffo- 
dill, and fome other forts of early Daffodils, and many forts of Anemones. In Aprill commeth on the pride of thefe ftrangers; for herein you may behold all the forts of Auricula Vrfi or Beares Eares, many forts of Anemones, both fingle and double, both the forts of Tulipas, the earlier vntill the middle of the moneth, and the later then beginning; which are of fo many different colours, that it is almoft impofible to expreffe them, the white, red, blacke, and yellow Fritillarias, the Mufcari or Muske Grape flower, both afh colour and yellow. Diuers other forts of Iacinths and Daffodils, both fingle and double, the fmaller forts of Flowerdeluces, the Veluet Flowerdeluce and double Honyfuckles, with diuers others. May likewife at the beginning feemeth as glorious as Aprill, although toward the end it doth decline, in regard the heate of the Sunne hath by this time drawne forth all the ftore of natures tendereft dainties, which are vfually fpent by the end of this moneth, and then thofe of ftronger conftitution come forward. Herein are to bee feene at the beginning the middle flowring Tulipas, and at the end the later forts : fome kindes of Daffodils, the Day Lillies, the great white Starre flower, the Flowerdeluce of Conftantinople or the mourning Sable flower, the other forts of Florverdeluces. Single and double white Crowfoote, and fingle and double red Crowfoot, the glory of a Garden : the early red Martagon, the Perfian Lilly, the yellow Martagon, the Gladiolus or Corne flagge, both white, red, and blufh : the double yellow Rofe, and fome other forts of Rofes. In Iune doe flower the white and the bluih Martagon, the Martagon Imperiall, the mountaine Lillies, and the other forts of white and red Lillies, the bulbous Flowerdeluces of diuers forts, the red flowred Ladies bower, the fingle and double purple flowred Ladies bower, the white Syringa or Pipe tree, for the blew Pipe tree flowreth earlier, the white and the yellow Iarmin. Iuly holdeth in flower fome of the Ladies bowers and Iafmines, and befides doth glory in the Female Balfame apple, the Indian Creffes or yellow Larkes fpurres, the purple Flower-gentle and the Rofe Bay. In Augut begin fome of the Autumne bulbous flowers to appeare, as the white and the purple Colchicum or Medow Saffron, the purple mountaine Crocus or Saffron flower, the little Autumne Leucoium and Autumne Iacinth, the Italian Starrewort, called of fome the purple Marigold, the Meruaile of Peru or of the world, the Flower of the Sunne, the great blew Bell-flower, the great double French Marigold. September flourifheth with the Flower of the Sunne, the Meruaile of the world, the purple Marigold, and blew Bell-flower fpoken of before, and likewife the other forts of Medow Saffron, and the double kinde likewife, the filuer Crocus, the Autumne yellow Daffodill, Cyclamen alfo or Sowbread thew their flowers in the end of this moneth. October alfo will thew the flowers of Cyclamen, and fome of the Medow Saffrons. In Nouember, as alfo fometimes in the moneth before, the party coloured Medow Saffron may bee feene, that will longeft hold his flower, becaufe it is the lateft that meweth it felfe, and the afh coloured mountaine Crocus. And euen December it felfe will not want the true blacke Hellebor or Chriftmas flower, and the glorious fhew of the Laurus Tinus or wilde Bay tree. Thus haue I thewed you fome of the flowers for euery moneth, but I referre you to the more ample declarion of them and all the others, vnto the work following.

\section{C н А P. V III.}

The true manner and order to encreaje and preferwe all forts of Gilloflowers, as well

by jlippes as jeedes.

$\mathrm{B}$ Ecaure that Carnations and Gilloflowers bee the chiefeft flowers of account in all our Englifh Gardens, I haue thought good to entreate fomewhat amply of them, and that a part by it felfe, as I faid a little before, in regard there is fo much to be faid concerning them, and that if all the matters to be entreated of thould haue beene inferted in the Chapter of Gilloflowers, it would haue made it too tedious and large, and taken vp too much roome. The particular matters whereof I mean in this place to entreate are thefe: How to encreafe Gilloflowers by planting and by 
fowing, and how to preferue them being encreafed, both in Summer from noyfome and hurtfull vermine that deftroy them, and in Winter from frofts, fnowes, and windes, that fpoile them. There are two wayes of planting, whereby to encreafe thefe faire flowers; the one is by flipping which is the old and ready vfuall way, beft knowne in this Kingdome; the other is more fure, perfect, ready, and of later inuention, videlicet, by laying downe the branches. The way to encreafe Gilloflowers by flipping, is fo common with all that euer kept any of them, that I think moft perfons may thinke me idle, to fpend time to fet downe in writing that which is fo well known vnto all: Yet giue me leaue to tell them that fo might imagine, that (when they haue heard or read what I haue written thereof, if they did know fully as much before) what I here write, was not to informe them, but fuch as did not know the beft, or fo good a way as I teach them: For I am affured, the greateft number doe vfe, and follow the moft vfuall way, and that is not alwaies the beft, efpecially when by good experience a better way is found, and may be learned; and therefore if fome can doe a thing better than others, I thinke it is no fhame to learne it of them. You fhall not then (to take the fureft courfe) take any long (pindled branches, nor thofe branches that haue any young fhootes from the ioynts on them, nor yet liue or teare any flippe or branch from the roote; for all thefe waies are vfuall and common with moft, which caufeth fo many good rootes to rot and perifh, and alfo fo many flippes to be loft, when as for the moft part, not the one halfe, or with fome, not a third part doth grow and thriue of thofe flippes they fet. And although many that haue ftore of plants, doe not fo much care what hauocke they make to gaine fome, yet to faue both labour and plants, I doe wifh them to obferue thefe orders: Take from thofe rootes from whence you intend to make your encreafe, thofe fhootes onely that are reafonable ftrong, but yet young, and not either too fmall and flender, or hauing any hootes from the ioynts vpon them; cut thefe flippes or hootes off from the Itemme or roote with a knife, as conueniently as the fhoote or branch will permit, that is, either clofe vnto the maine branch, if it be fhort, or leauing a ioynt or two behinde you, if it be long enough, at which it may thoote anew: When you haue cut off your flippes, you may either fet them by and by, or elfe as the beft Gardiners vfe to doe, caft them into a tubbe or pot with water for a day or two, and then hauing prepared a place conuenient to fet them in, which had neede to bee of the fineft, richeft, and beft mould you can prouide, that they may thriue therein the better, cut off your flippe clofe at the ioynt, and hauing cut away the loweft leaues clofe to the ftalke, and the vppermoft euen at the top, with a little fticke make a little hole in the earth, and put your flippe therein fo deep, as that the vpper leaues may be wholly aboue the ground, (fome vfe to cleaue the ftalke in the middle, and put a little earth or clay within the cleft, but many good and skilfull Gardiners doe not vfe it) ; put the earth a little clole to the flippe with your finger and thumbe, and there let it reft, and in this manner doe with as many flippes as you haue, fetting them fomewhat clofe together, and not too farre in funder, both to faue ground and coft thereon, in that a fmall compaffe will ferue for the firft planting, and alfo the better to giue them thadow: For you muft remember in any cafe, that thefe flippes new fet, haue no fight of the Sunne, vntill they be well taken in the ground, and fhot aboue ground, and alfo that they want not water, both vpon the new planting and after. When thefe lippes are well grown vp, they muft be tranfplanted into fuch other places as you thinke meete; that is, either into the ground in beds, or otherwife, or into pots, which that you may the more fafely doe, after you haue well watered the ground, for halfe a day before you intend to tranfplant them, you thall feparate them feuerally, by putting down a broad pointed knife on each fide of the flippe, fo cutting it out, take euery one by it felfe, with the earth cleauing clofe vnto the root, which by reafon of the moifture it had formerly, and that which you gaue prefently before, will be fufficient with any care had, to caufe it to hold faft unto the roote for the tranfplanting of it: for if the earth were dry, and that it fhould fall away from the roote in the tranlplanting, it would hazzard and endanger the roote very much, if it did thriue at all. You muft remember alfo, that vpon the remouing of thefe fips, you fhadow them from the heate of the Sunne for a while with fome fraw or other thing, vntill they haue taken hold in their new place. Thus although it bee a little more labour and care than the ordinary way is, yet it is furer, and will giue you plants that 
will be fo ftrongly growne before Winter, that with the care hereafter fpecified, you fhall haue them beare flowers the next yeare after, and yeeld you encreafe of lippes alfo. To giue you any fet time, wherein thefe llippes will take roote, and begin to thoote aboue ground, is very hard to doe; for that euery flip, or yet euery kinde of Gilloflower is not alike apt to grow; nor is euery earth in like manner fit to produce and bring forward the flippes that are fet therein : but if both the flippe be apt to grow, and the earth of the beft, fit to produce, I thinke within a fortnight or three weekes, you thall fee them begin to put forth young leaues in the middle, or elfe it may be a moneth and more before you thall fee any fpringing. The beft time likewife when to plant, is a fpeciall thing to be knowne, and of as great confequence as any thing elfe : For if you flippe and fet in September, as many vfe to doe, or yet in Auguft, as fome may thinke will doe well, yet (vnleffe they be the moft ordinary forts, which are likely to grow at any time, and in any place) the moft of them, if not all, will either affuredly perifh, or neuer profper well : for the more excellent and dainty the Gilloflower is, the more tender for the moft part, and hard to nurfe vp will the flippes be. The beft time therefore is, that you cut off fuch flippes as are likely, and fuch as your rootes may fpare, from the beginning of May vntill the middle of I une at the furtheft, and order them as I haue fhewed you before, that fo you may haue faire plants, plenty of flowers, and encreafe fufficient for new fupply, without offence or loffe of your ftore. For the enriching likewife of your earth, wherein you fhall plant your flippes, that they may the better thriue and profper, diuers haue vfed diuers forts of manure; as ftable foyle of horfe, beafts or kine, of theepe, and pigeons, all which are very good when they are thoroughly turned to mould, to mixe with your other earth, or being fteeped in water, may ferue to water the earth at times, and turned in with it. And fome haue likewife proued Tanners earth, that is, their barke, which after they haue vfed, doth lye on heapes and rot in their yards, or the like mould from wood-ftackes or yards; but efpecially, and beyond all other is commended the Willow earth, that is, that mould which is found in the hollow of old Willow trees, to be the moft principall to mixe with other good earth for this purpofe. And as I haue now giuen you directions for the firt way to encreafe them by flipping, fo before I come to the other way, let mee give you a caueat or two for the preferuing of them, when they are beginning to runne vtterly to decay and perifh : The one is, that whereas many are ouer greedy to haue their plants to giue them flowers, and therefore let them runne all to flower, fo farre fpending themfelues thereby, that after they haue done flowring, they grow fo weake, hauing out fpent themfelues, that they cannot poffibly be preferued from the iniuries of the fucceeding Winter; you thall therefore keepe the kinde of any fort you are delighted withall, if you carefully looke that too many branches doe not runne vp and fpindle for flowers, but rather either cut fome of them downe, before they are run vp too high, within two or three ioynts of the rootes; or elfe pluck away the innermoft leaues where it Springeth forwards, which you fee in the middle of euery branch, before it be runne vp too high, which will caufe them to breake out the fafter into flips and fuckers at the ioynts, to hinder their forward luxurie, and to preferue them the longer: The other is, If you thall perceiue any of your Gilloflower leaues to change their naturall frefh verdure, and turne yellowifh, or begin to wither in anie part or branch thereof, it is a fure figne that the roote is infected with fome cancker or rottenneffe, and will foon thew it felfe in all the reft of the branches, whereby the plant will quickly be loft : to preferue it therefore, you fhall betime, before it be runne too farre, (for otherwife it is impoffible to faue it) either couer all or moft of the branches with frefh earth, or elfe take the faireft nippes from it, as many as you can poffibly, and caft them into a pot or tubbe with water, and let them there abide for two or three daies at the leaft: the firft way hath recouered many, being taken in time. Thus you thall fee them recouer their former ftiffeneffe and colour, and then you may plant them as you haue beene heretofore directed; and although many of them may perifh, yet thall you haue fome of them that will grow to continue the kinde againe. The other or fecond way to encreafe Gilloflowers by planting, is, as I faid before, by in-laying or laying downe the branches of them, and is a way of later inuention, and as frequently vfed, not onely for the tawney or yellow Gilloflower, and all the varieties therof, but with the other kinds of Gilloflowers, whereof experience hath fhewed 
that they will likewife take if they be fo vfed; the manner whereof is thus: You muft choofe out the youngeft, likelieft, and loweft branches that are neareft the ground (for the vpper branches will fooner breake at the ioynt, than bend downe fo low into the earth, without fome pot with earth raifed vp vnto them) and cut it on the vnderfide thereof vpwards at the fecond ioynt next vnto the roote, to the middle of the branch, and no more, and not quite thorough in any cafe, and then from that fecond ioynt vnto the third, flit or cut the branch in the middle longwife, that fo it may be the more eafily bended into the ground, the cut ioynt feeming like the end of a flippe, when you haue bended downe the branch where it is cut into the ground (which muft bee done very gently for feare of breaking) with a little fticke or two thruft flopwife, croffe ouer it, keepe it downe within the earth, and raife vp fufficient earth ouer it, that there it may lye and take roote, which commonly will be effected within fixe weekes or two moneths in the Summer time, and then (or longer if you doubt the time too fhort for it to take fufficient roote) you may take or cut it away, and tranfplant it where you thinke good, yet fo as in any cafe you hadow it from the heate of the Sunne, vntill it haue taken good hold in the ground. The other way to encreafe Gilloflowers, is by fowing the feede: It is not vfuall with all forts of Gilloflowers to giue feede, but fuch of them as doe yeeld feede may be encreafed thereby, in the fame manner as is here fet downe. The Orange tawney Gilloflower and the varieties thereof is the moft vfuall kinde, (and it is a kinde by it felfe, how various foeuer the plants be that rife from the feede) that doth giue feede, and is fowne, and from thence arifeth fo many varieties of colours, both plaine and mixt, both fingle and double, that one can hardly fet them downe in writing: yet fuch as I haue obferued and marked, you fhall finde expreffed in the Chapter of Gilloflowers in the worke following. Firft therefore make choife of your feede that you intend to fowe (if you doe not defire to haue as many more fingle flowers as double) that it bee taken from double flowers, and not from fingle, and from the beft colours, howfoeuer fome may boaft to haue had double and fript flowers from the feede of a fingle one; which if it were fo, yet one Swallow (as we fay) maketh no Summer, nor a thing comming by chance cannot bee reckoned for a certaine and conftant rule; you may be affured they will not vfually doe fo: but the beft, faireft, and moft double flowers come alwaies, or for the moft part, from the feede of thofe flowers that were beft, faireft, and moft double; and I doe aduise you to take the beft and moft double: for euen from them you thall haue fingle ones enow, you neede not fowe any worfer fort. And againe, fee that your feede bee new, of the laft yeares gathering, and alfo that it was full ripe before it was gathered, left you lofe your labour, or miffe of your purpofe, which is, to haue faire and double flowers. Hauing now made choife of your feede, and prepared you a bedde to fowe them on, the earth whereof muft be rich and good, and likewife fifted to make it the finer; for the better it is, the better thall your profit and pleafure bee: hereon, being firt made leuell, plaine, and fmooth, fowe your feede fomewhat thinne, and not too thicke in any cafe, and as euenly as you can, that they be not too many in one place, and too few in another, which afterwards couer with fine fifted earth ouer them about one fingers thickneffe; let this be done in the middle of Aprill, if the time of the yeare be temperate, and not too cold, or elfe ftay vntill the end of the moneth: after they are fprung vp and growne to be fomewhat bigge, let them bee drawne forth that are too clofe and neare one vnto another, and plant them in fuch place where they thall continue, fo that they ftand halfe a yard of ground diftance af under, which after the planting, let be fhadowed for a time, as is before fpecified; and this may bee done in the end of Iuly, or fooner if there be caufe. I haue not fet downe in all this difcourfe of planting, tranfplanting, fowing, fetting, \&cc. any mention of watering thofe llips or plants, not doubting but that euery ones reafon will induce them to thinke, that they cannot profper without watering: But let this Caueat be a fufficient remembrance vnto you, that you neuer water any of thefe Gilloflowers, nor yet indeede any other fine herbe or plant with cold water, fuch as you haue prefently before drawne out from a pumpe or Well, \&c. but with fuch water as hath ftood open in the aire in a cifterne, tubbe, or pot, for one whole day at the leaft; if it be two or three daies it will be neuer the worfe, but rather the better, as I haue related before : yet take efpeciall heede that you doe not giue them too much to ouer-glut them at any time, but temperately to ir- 
rorate, bedew or fprinkle thein often. From the feedes of thefe Gilloflowers hath rifen both white, red, blufh, ftamell, tawny lighter and fadder, marbled, fpeckled, ftriped, flaked, and that in diuers manners, both fingle and double flowers, as you fhall fee them fet downe in a more ample manner in the Chapter of Gilloflowers. And thus much for their encreafe by the two wayes of planting and fowing: For as for a third way, by grafting one into or vpon another, I know none fuch to be true, nor to be of any more worth than an old Wiues tale, both nature, reafon, and experience, all contefting againf fuch an idle fancy, let men make what oftentation they pleafe. It now refteth, that we allo hew you the manner how to preferue them, as well in Summer from all noyfome and hurtfull things, as in the Winter and Spring from the fharp and chilling colds, and the fharpe and bitter killing windes in March. The hurtfull things in the Summer are efpecially thefe, too much heate of the Sunne which fcorcheth them, which you muft be carefull to preuent, by placing boughes, boords, clothes or mats, \&rc. before them, if they bee in the ground; or elfe if they bee in pots, to remoue into them into the fhadow, to giue them refrefhing from the heate, and giue thein water alfo for their life : too much water, or too little is another annoyance, which you muft order as you fee there is iuft caufe, by withholding or giuing them water gently out of a watering pot, and not caft on by difhfuls: Some alfo to water their Gilloflowers, vfe to fet their pots into tubbes or pots halfe full of water, that fo the water may foake in at the lower holes in each flower pot, to giue moifture to the roots of the Gilloflowers onely, without cafting any water vpon the leaues, and affuredly it is an excellent way to moiften the rootes fo fufficiently at one time, that it doth faue a great deale of paines many other times. Earwickes are a moft infeftuous vermine, to fpoyle the whole beauty of your flowers, and that in one night or day ; for thefe creatures delighting to creepe into any hollow or Thadowie place, doe creepe into the long greene pods of the Gilloflowers, and doe eate away the white bottomes of their leaues, which are fweete, whereby the leaues of the flowers being loofe, doe either fall away of themfelues before, or when they are gathered, or handled, or prefently wither within the pods before they are gathered, and blowne away with the winde. To auoide which inconuenience, many haue deuifed many waies and inuentions to deftroy them, as pots with double verges or brimmes, containing a hollow gutter betweene them, which being filled with water, will not fuffer thefe fmall vermine to paffe ouer it to the Gilloflowers to fpoile them. Others haue vfed old fhooes, and fuch like hollow things to bee fet by them to take them in : but the beft and moft vfuall things now vfed, are eyther long hollow canes, or elfe beafts hoofes, which being turned downe vpon ftickes ends fet into the ground, or into the pots of earth, will foone drawe into them many Earwickes, lying hid therein from funne, winde, and raine, and by care and diligence may foone bee deftroyed, if euery morning and euening one take the hoofes gently off from the ftickes, and knocking them againft the ground in a plain allie, thake out all the Earwicks that are crept into them, which quickly with ones foot may be trode to peeces. For fodain blafting with thunder and lightening, or fierce tharp windes, \&rc. I know no other remedy, vnleffe you can couer them therefrom when you firt forefee the danger, but patiently to abide the loffe, whatfoeuer fome haue aduifed, to lay litter about them to auoide blafting; for if any ntall make tryall thereof, I am in doubt, he thall more endanger his rootes thereby, being the Summer time, when any fuch feare of blafting is, than any wife faue them from it, or doe them any good. For the Winter preferuation of them, fome haue aduifed to couer them with Bee-hives, or elfe with fmall Willow ftickes, prickt croffewife into the ground ouer your flowers, and bowed archwife, and with litter laid thereon, to couer the Gilloflowers quite ouer, after they haue beene fprinkled with fope afhes and lyme mixt together: and this way is commended by fome that haue written thereof, to be fuch an admirable defence vnto them in Winter, that neither Ants, nor Snailes, nor Earwickes thall touch them, becaufe of the fope afhes and lyme, and neyther frofts nor ftorms thall hurt them, becaufe of the litter which fo well will defend them; and hereby alfo your Gilloflowers will bee ready to flower, not onely in the Spring very early, but euen all the Winter. But whofoeuer fhall follow thefe directions, may peraduenture finde them in fome part true, as they are there fet downe for the Winter time, and while they are kept clofe and couered; but let them bee affured, 
that all fuch plants, or the moft part of them, will certainely perifh and dye before the Summer be at an end : for the fope afhes and lyme will burne vp and fpoile any herbe ; and againe it is impoffible for any plant that is kept fo warme in Winter, to abide eyther the cold or the winde in the Spring following, or any heate of the Sun, but that both of them will fcorch them, and carry them quite away. One great hurt vnto them, and to all other herbes that wee preferue in Winter, is to fuffer the fnow to lye vpon them any time after it is fallen, for that it doth fo chill them, that the Sunne afterward, although in Winter, doth fcorch them and burne them vp: looke therefore vnto your Gilloflowers in thofe times, and Thake or ftrike off the fnow gently off from them, not fuffering it to abide on them any day or night if you can; for affure your felfe, if it doth not abide on them, the better they will be. The frofts likewife is another great annoyance vnto them, to corrupt the rootes, and to caufe them to fwell, rot, and break: to preuent which inconuenience, I would aduife you to take the ftraw or litter of your horfe ftable, and lay fome thereof about euery roote of your Gilloflowers (efpecially thofe of the beft account) clofe vnto them vpon the ground, but be as carefull as you can, that none thereof lye vpon the greene leaues, or as little as may be, and by this onely way haue they been better defended from the frofts that fpoile them in Winter, then by any other that I haue feen or knowne. The windes in March, and Sunnefhine dayes then, are one of the greateft inconueniences that happeneth vnto them; for they that haue had hundreds of plants, that haue kept faire and greene all the Winter vntill the beginning or middle of March, before the end thereof, haue had fcarce one of many, that either hath not vtterly perifhed, or been fo tainted, that quickly after haue not been loft; which hath happened chiefly by the neglect of thefe cautions before fpecified, or in not defending them from the bitter tharpe windes and funne in this moneth of March. You thall therefore for their better preferuation, befides the litter laid about the rootes, which I aduife you not to remoue as yet, fhelter them fomewhat from the windes, with eyther bottomleffe pots, pales, or fuch like things, to keep away the violent force both of windes and fun for that moneth, and for fome time before \& after it alfo: yet fo, that they be not couered clofe aboue, but open to receiue ayre \& raine. Some alfo vfe to wind withes of hey or ftraw about the rootes of their Gilloflowers, and faften them with ftickes thruft into the ground, which ferue very well in the ftead of the other. Thus haue I thewed you the whole preferuation of thefe worthy and dainty flowers, with the whole manner of ordering them for their encreafe : if any one haue any other better way, I thall be as willing to learne it of them, as I haue beene to giue them or any others the knowledge of that I haue here fet downe.

\section{CH A P. I X.}

That there is not any art whereby any flower may be made to grow double, that was naturally fingle, nor of any other fent or colour than it firft had by nature; nor that the fowing or planting of herbes one deeper than other, will caufe them to be in flower one after another, ewery moneth in the yeare.

T He wonderfull defire that many haue to fee faire, double, and fweete flowers, hath tranfported them beyond both reafon and nature, feigning and boafting often of what they would haue, as if they had it. And I thinke, from this defire and boafting hath rifen all the falfe tales and reports, of making flowers double as they lift, and of giuing them colour and fent as they pleafe, and to flower likewife at what time they will, I doubt not, but that fome of thefe errours are ancient, and continued long by tradition, and others are of later inuention: and therefore the more to be condemned, that men of wit and iudgement in thefe dayes fhould expofe themfelues in their writings, to be rather laughed at, then beleeued for fuch idle tales. And although in the contradiction of them, I know I thall vndergoe many calumnies, yet notwithftanding, I will endeauour to fet downe and declare fo much, as I hope may by reafon 
perfwade many in the truth, although I cannot hope of all, fome being fo ftrongly wedded to their owne will, and the errours they have beene bred in, that no reafon may alter them. Firft therefore I fay, that if there were any art to make fone flowers to grow double, that naturally were fingle, by the fame art, all forts of flowers that are fingle by nature, may be made to grow double: but the forts of flowers that are fingle by nature, whereof fome are double, were neuer made double by art ; for many forts abide ftill fingle, whereof there was neuer feene double: and therefore there is no fuch art in any mans knowledge to bring it to paffe. If any man fhall fay, that becaufe there are many flowers double, whereof there are fingle alfo of the fame kinde, as for example, Violets, Marigolds, Daifyes, Daffodils, Anemones, and many other, that therefore thofe double flowers were fo made by the art of man: viz. by the obferuation of the change of the Moone, the conftellations or coniunctions of Planets, or fome other Starres or celeftiall bodies. Although I doe confeffe and acknowledge, that I thinke fome conftellations, and peraduenture changes of the Moone, \&c. were appointed by the God of nature, as conducing and helping to the making of thofe flowers double, that nature hath fo produced, yet I doe deny, that any man hath or fhall euer be able to proue, that it was done by any art of man, or that any man can tell the true caufes and feafons, what changes of the Moone, or conftellations of the Planets, wrought together for the producing of thofe double flowers, or can imitate nature, or rather the God of nature, to doe the like. If it flall bee demanded, From whence then came thefe double flowers that we haue, if they were not fo made by art ? 1 anfwer, that afturedly all fuch flowers did firft grow wilde, and were fo found double, as they doe now grow in Gardens, but for how long before they were found they became double, no man can tell; we onely haue them as nature hath produced them, and fo they remaine. Againe, if any thall fay, that it is likely that thefe double flowers were forced fo to be, by the often planting and tranfplanting of them, becaufe it is obferued in moft of them, that if they ftand long in any one place, and not be often remoued, they will grow ftill lefre double, and in the end turne fingle. I doe confeffe, that Facilior eff defcenfus quam afcenfus, and that the vnfruitfulneffe of the ground they are planted in, or the neglect or little care had of them, or the growing of them too thicke or too long, are oftentimes a caufe of the diminifhing of the flowers doubleneffe; but withall you fhall obferue, that the fame rootes that did beare double flowers (and not any other that neuer were double before) haue returned to their former doubleneffe againe, by good ordering and looking vnto: fingle flowers haue only beene made fomewhat fairer or larger, by being planted in the richer and more fruitfull ground of the Garden, than they were found wilde by nature; but neuer made to grow double, as that which is naturally fo found of it felfe: For I will thew you mine owne experience in the matter. I haue been as inquifitiue as any man might be, with euery one I knew, that made any fuch report, or that I thought could fay any thing therein, but I neuer could finde any one, that could affuredly refolue me, that he knew certainly any fuch thing to be done: all that they could fay was but report, for the obferuation of the Moone, to remoue plants before the change, that is, as fome fay, the full of the Moone, others the new Moone, whereupon I haue made tryall at many times, and in many forts of plants, accordingly, and as I thought fit, by planting \& tranSplanting them, but I could neuer fee the effect defired, but rather in many of them the loffe of my plants. And were there indeed fuch a certaine art, to make fingle flowers to grow double, it would haue beene knowne certainly to fome that would practife it, and there are fo many fingle flowers, whereof there were neuer any of the kinde feene double, that to produce fuch of them to be double, would procure both credit and coyne enough to him that fhould vfe it; but Vlira pofe non eft e fe: and therefore let no man beleeue any fuch reports, bee they neuer fo ancient; for they are but meere tales and fables. Concerning colours and fents, the many rules and directions extant in manie inens writings, to caufe flowers to grow yellow, red, greene, or white, that neuer were fo naturally, as alfo to be of the fent of Cinamon, Muske, \&cc. would alinoft perfwade any, that the matters thus fet downe by fuch perfons, and with fome fhew of probability, were conftant and affured proofes thereof : but when they come to the triall, they all vanifh away like finoake. I will in a few words thew you the matters and manners of their proceedings to effect this purpofe: Firt (they fay) if you thall fteepe 
your feedes in the lees of red Wine, you thall haue the flowers of thofe plants to be of a purple colour. If you will have Lillies or Gilloflowers to be of a Scarlet red colour, you Thall put Vermillion or Cynaber betweene the rinde and the fmall heads growing about the roote: if you will haue them blew, you thall diffolue Azur or Byfe between the rinde and the heads : if yellow, Orpiment : if greene, Vardigreare, and thus of any other colour. Others doe aduife to open the head of the roote, and poure into it any colour diffolued, fo that there be no fretting or corroding thing therein for feare of hurting the roote, and looke what colour you put in, iuft fuch or neare vnto it thall the colour of the flower bee. Some againe doe aduife to water the plants you would haue changed, with fuch coloured liquor as you defire the flower to be of, and they fliall grow to be fo. Alfo to make Rofes to bee yellow, that you fhould graft a white Rofe (fome fay a Damaske) vpon a Broome ftalke, and the flower will be yellow, fuppofing becaufe the Broome flower is yellow, therefore the Rofe will be yellow. Some affirme the like, if a Rofe be grafted on a Barbery bufh, becaufe both the bloffome and the barke of the Barbery is yellow, \&cc. In the like manner for fents, they haue fet downe in their writings, that by putting Cloues, Muske, Cinamon, Benzoin, or any. other fuch fweete thing, bruifed with Rofe water, betweene the barke and the body of trees, the fruit of them will fmell and tafte of the fame that is put vnto them; and if they bee put vnto the toppe of the rootes, or elfe bound vnto the head of the roote, they will caufe the flowers to fmell of that fent the matter put vnto them is of : as alfo to fteep the feeds of Rofes, and other plants in the water of fuch like fweet things, and then to fowe them, and water them morning and euening with fuch like liquor, vntill they be growne vp; befides a number of fuch like rules and directions fet downe in bookes fo confidently, as if the matters were without all doubt or queftion: whenas without all doubt and queftion I will affure you, that they are all but meere idle tales $\&$ fancies, without all reafon or truth, or thadow of reafon or truth : For fents and colours are both fuch qualities as follow the effence of plants, euen as formes are alfo ; and one may as well make any plant to grow of what forme you will, as to make it of what fent or colour you will; and if any man can forme plants at his will and pleafure, he can doe as much as God himfelfe that created them. For the things they would adde vnto the plants to give them colour, are all corporeall, or of a bodily fubftance, and whatfoeuer fhould give any colour vnto a liuing and growing plant, muft be fpirituall : for no folide corporeall fubftance can ioyne it felfe with the life and effence of an herbe or tree, and the fpirituall part of the colour thereof is not the fame with the bodily fubftance, but is a meere vapour that rifeth from the fubftance, and feedeth the plant, whereby it groweth, fo that there is no ground or colour of reafon, that a fubitantiall colour fhould giue colour to a growing herbe or tree: but for fent (which is a meere vapour) you will fay there is more probability. Yet confider alfo, that what fweete fent foeuer you binde or put vnto the rootes of herbes or trees, muft be either burie.1, or as good as buried in the earth, or barke of the tree, whereby the fubftance will in a fmall time corrupt and rot, and before it can ioyne it felfe with the life, fpirit, and effence of the plant, the fent alfo will perifh with the fubftance: For no heterogeneall things can bee mixed naturally together, as Iron and Clay; and no other thing but homogeneall, can be nourifhment or conuertible into the fubftance of man or beaft: And as the ftomach of man or beaft altereth both formes, fents, and colours of all digeftible things; fo whatfoeuer fent or colour is wholfome, and not poyfonfull to nature, being receiued into the body of man or beaft, doth neither change the bloud or skinne into that colour or fent was receiued: no more doth any colour or fent to any plant; for the plants are onely nourihed by the moifture they draw naturally vnto them, be it of wine or any other liquor is put vnto them, and not by any corporeal fubftance, or heterogeneall vapour or fent, becaufe the earth like vnto the ftomach doth foone alter them, before they are conuerted into the nature and fubftance of the plant. Now for the laft part I vndertooke to confute, that no man can by art make all flowers to fpring at what time of the yeare hee will; although, as I haue here before thewed, there are flowers for euery moneth of the yeare, yet I hope there is not any one, that hath any knowledge in flowers and gardening, but knoweth that the flowers that appeare and fhew themfelues in the feuerall moneths of the yeare, are not one and the fame, and fo made to flower by art; but that they are feuerall forts of plants, which 
will flower naturally and conftantly in the fame moneths one yeare, that they vfe to doe in another, or with but little alteration, if the yeares proue not alike kindly: As for example, thofe plants that doe flower in Ianuary and February, will by no art or induftry of man be caufed to flower in Summer or in Autumne; and thofe that flower in Aprill and May, will not flower in Ianuary or February ; or thofe in Iuly, Auguft, \&c. either in the Winter or Spring: but euery one knoweth their owne appointed naturall times, which they conftantly obferue and keepe, according to the temperature of the yeare, or the temper of the climate, being further North or South, to bring them on earlier or later, as it doth with all other fruits, flowers, and growing greene herbes, \&cc. except that by chance, fome one or other extraordinarily may be hindered in their due feafon of flowring, and fo give their flowers out of time, or elfe to giue their flowers twice in the yeare, by the fuperaboundance of nourinment, or the mildneffe of the feafon, by moderate fhowers of raine, \&rc. as it fometimes alfo happeneth with fruits, which chance, as it is feldome, and not conftant, fo we then terme it but Lufus naturce: or elfe by forcing them in hot ftoues, which then will perin, when they haue given their flowers or fruits. It is not then, as fome haue written, the fowing of the feedes of Lillies, or any other plants a foote deepe, or halfe a foote deepe, or two inches deepe, that will caufe them to be in flower one after another, as they are fowne euery moneth of the yeare ; for it were too groffe to thinke, that any man of reafon and iudgement would fo beleeue. Nor is it likewife in the power of any man, to make the fame plants to abide a moneth, two, or three, or longer in their beauty of flowring, then naturally they vfe to doe; for I thinke that were no bumane art, but a fupernaturall worke. For nature ftill bendeth and tendeth to perfection, that is, after flowring to giue fruit or feede; nor can it bee hindered in the courfe thereof without manifeit danger of deftruction, euen as it is in all other fruit-bearing creatures, which ftay no longer, then their appointed time is naturall vnto them, without apparent damage. Some things I grant may be fo ordered in the planting, that according to that order and time which is obferued in their planting, they fhall thew forth their faire flowers, and they are Anemones, which will in that manner, that I haue fhewed in the worke following, flower in feuerall moneths of the yeare; which thing as it is incident to none or very few other plants, and is found out but of late, fo likewife is it knowne but vnto a very few. Thus haue I thewed you the true folution of thefe doubts: And although they haue not beene amplified with fuch Philofophicall arguments and reafons, as one of greater learning might haue done, yet are they truely and fincerely fet downe, that they may ferue tanquan galeatum, againt all the calumnies and obiections of wilfull and obdurate perfons, that will not be reformed. As firf, that all double flowers were fo found wilde, being the worke of nature alone, and not the art of any man, by planting or tranfplanting, at or before the new or full Moone, or any other obferuation of time, that hath caufed the flower to grow double, that naturally was fingle: Secondly, that the rules and directions, to caufe flowers to bee of contrary or different colours or fents, from that they were or would be naturally, are meere fancies of men, without any ground of reafon or truth. And thirdly, that there is no power or art in man, to caufe flowers to thew their beauty diuers moneths before their naturall time, nor to abide in their beauty longer then the appointed naturall time for euery one of them. 


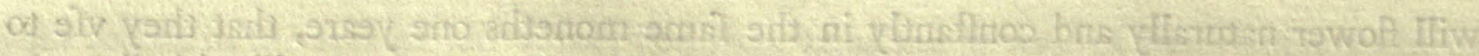

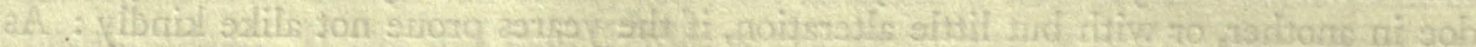

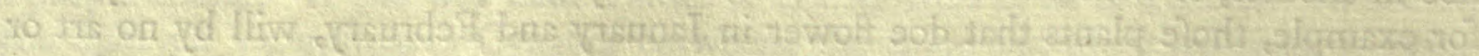

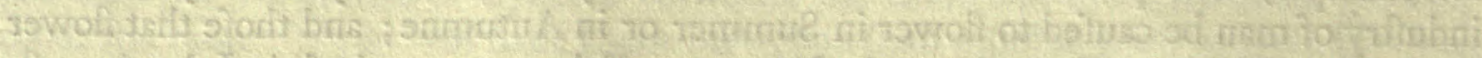

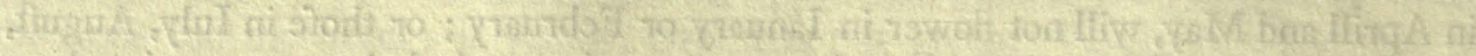

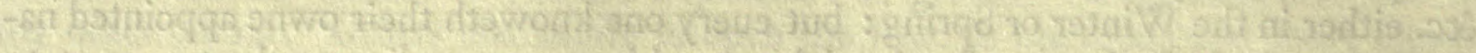
5wis

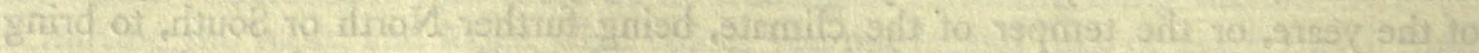

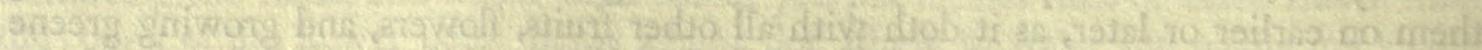

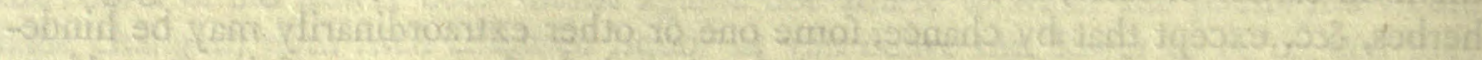

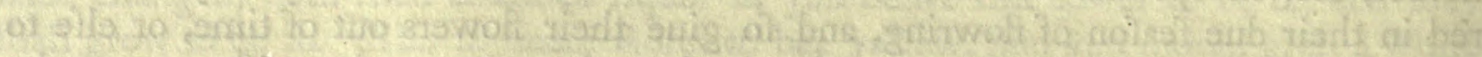

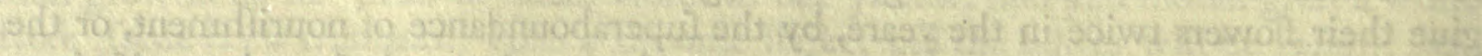

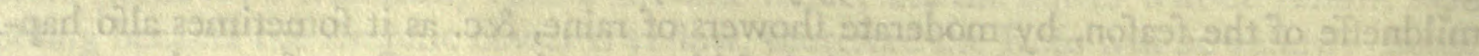

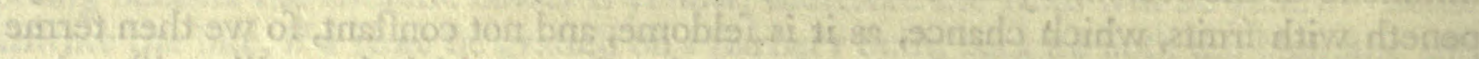

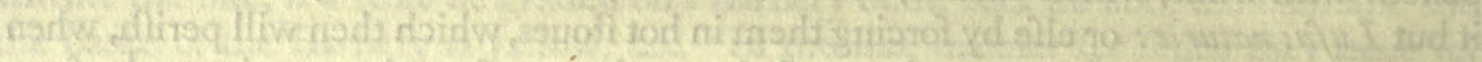

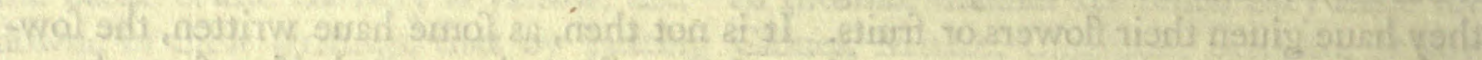

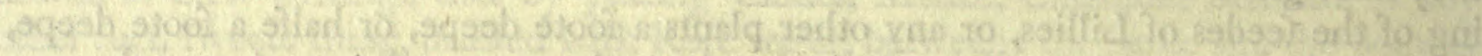

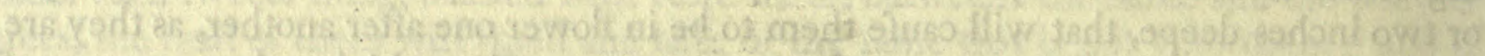

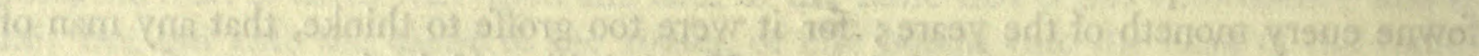

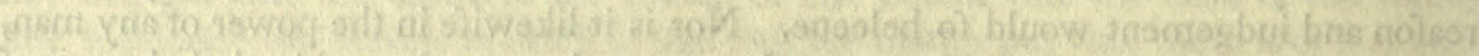

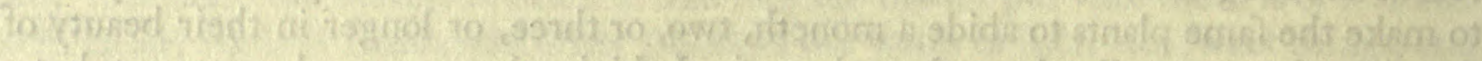

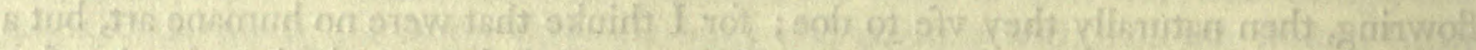

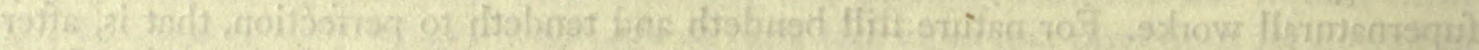

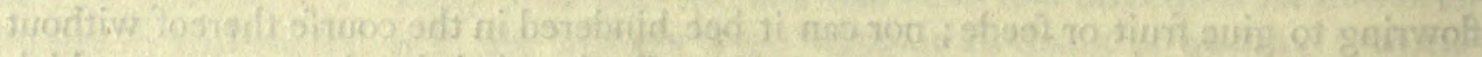

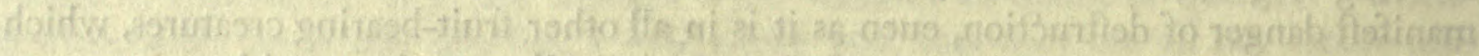

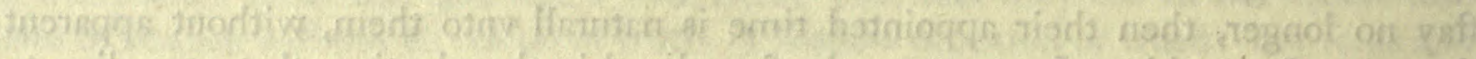

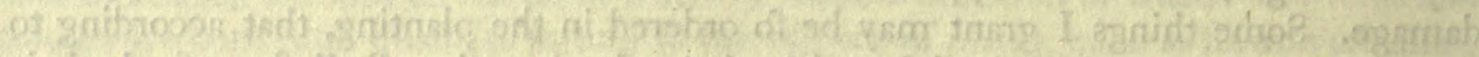

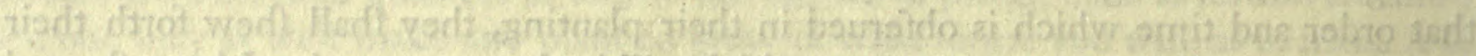

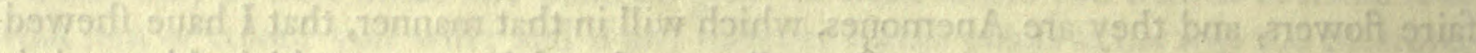

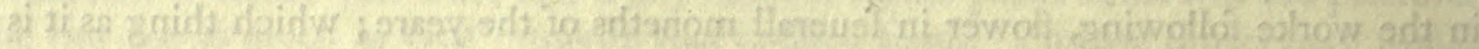

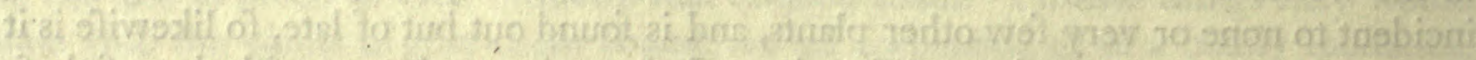

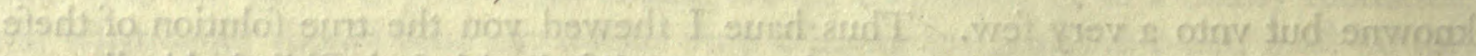

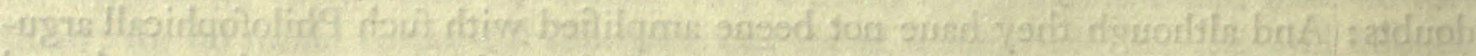

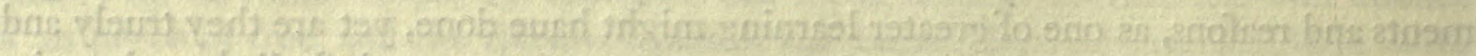

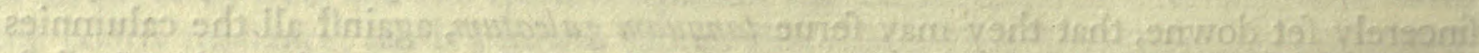

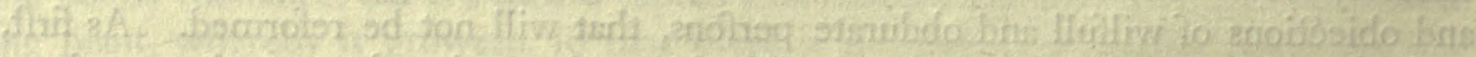

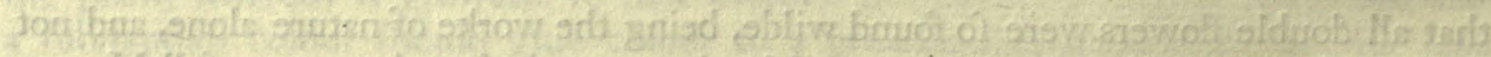

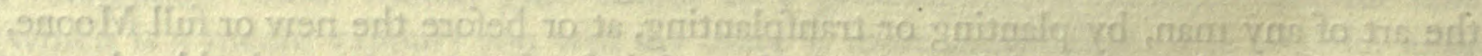

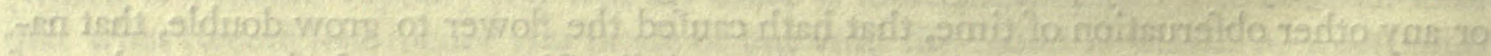

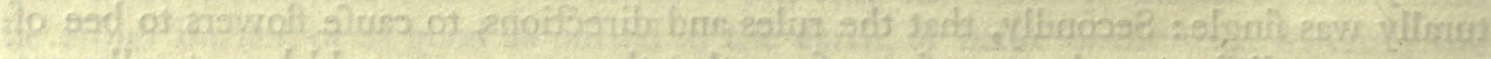

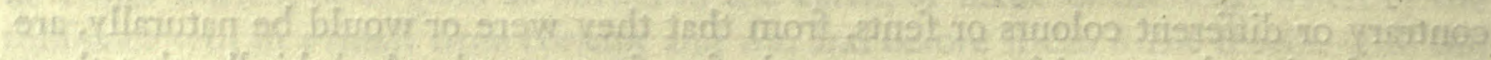

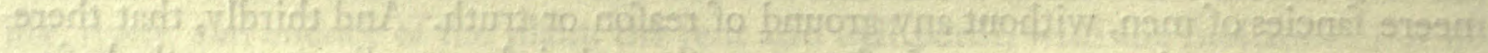

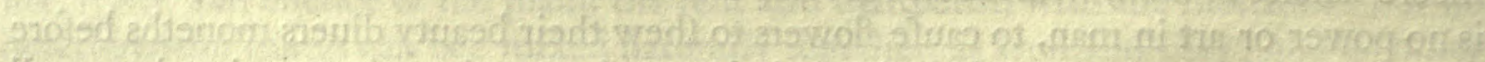

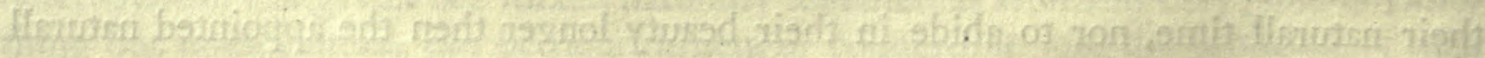

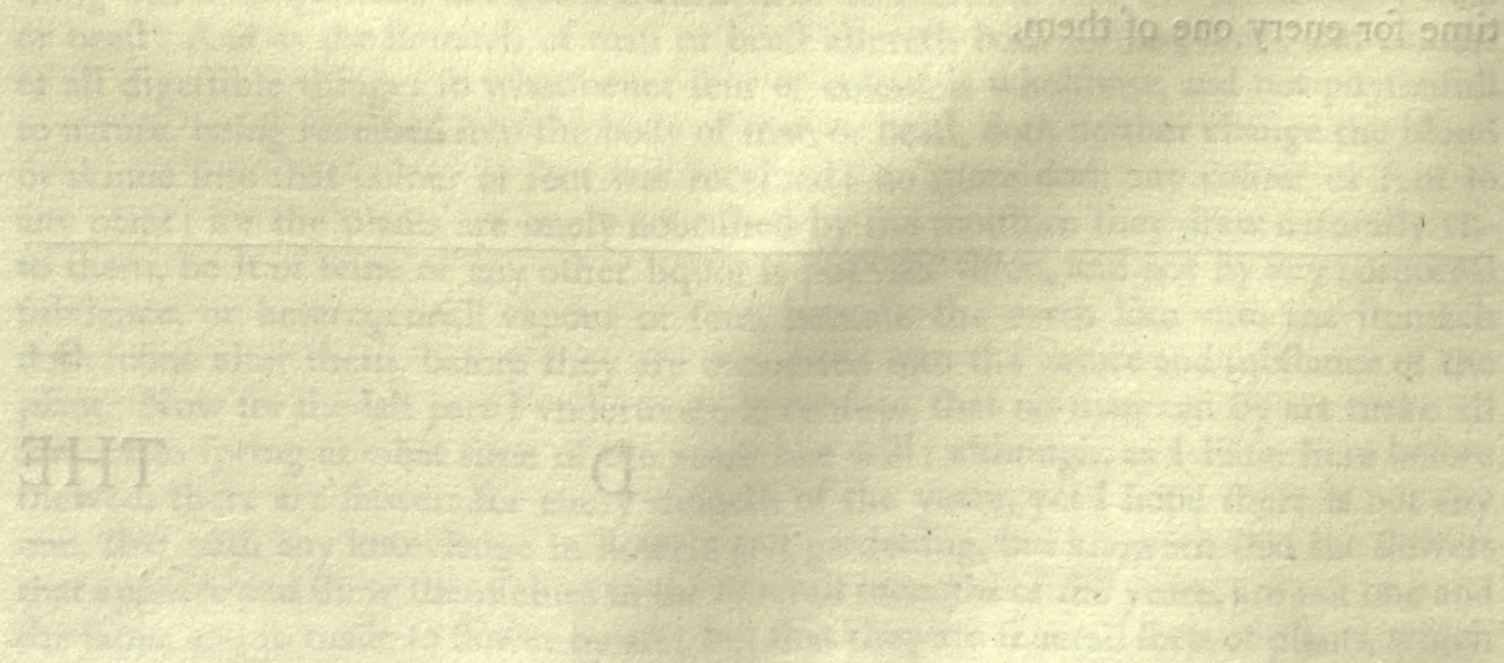



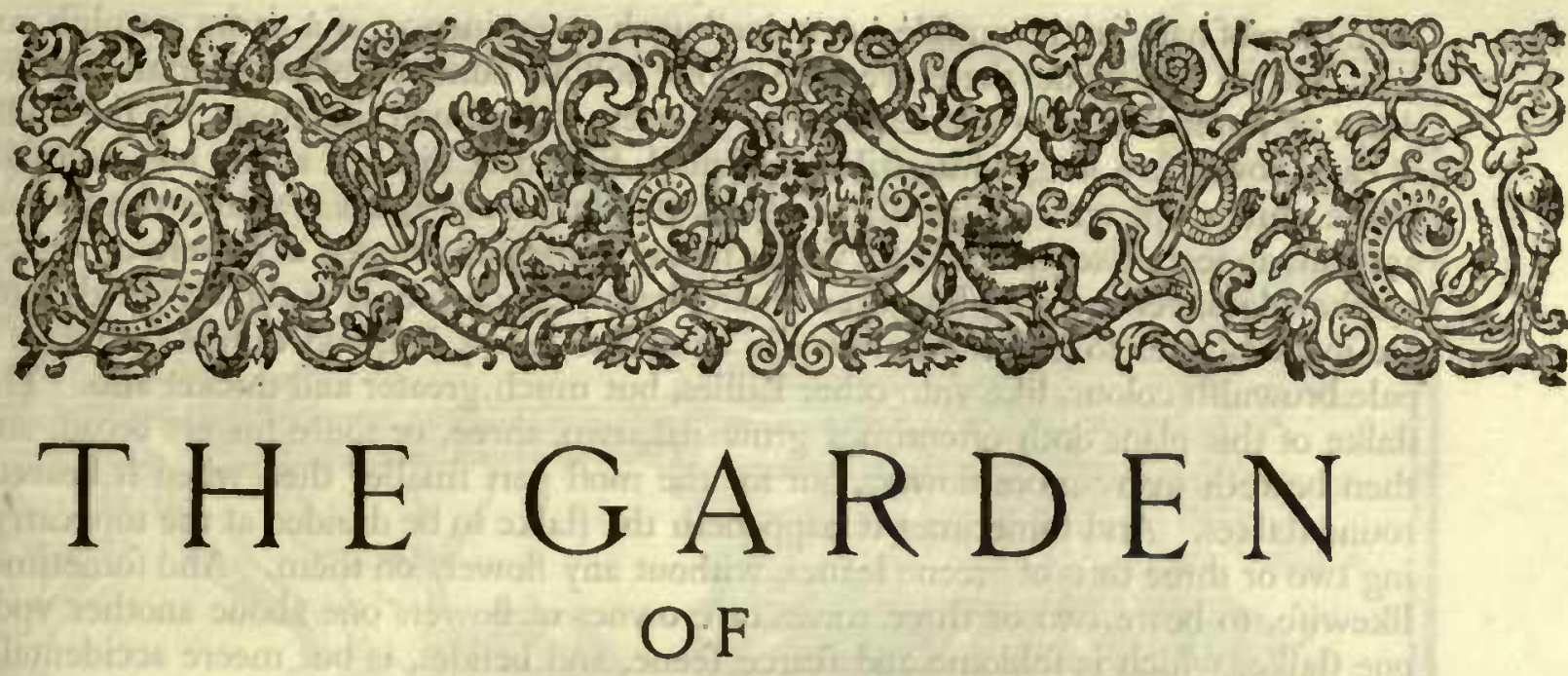

\section{PLEASANT FLOWERS.}

\section{CH A P. I.}

\section{Corona Imperialis. The Crowne Imperiall.}

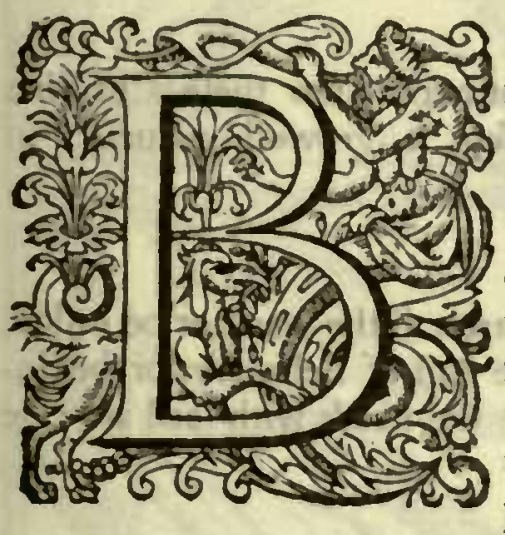

Ecaufe the Lilly is the more ftately flower among manie : and amongt the wonderfull varietie of Lillies, knowne to vs in thefe daies, much more then in former times, whereof fome are white, others blufh, fome purple, others red or yellow, fome fpotted, others without fpots, fome ftanding vpright, others hanging or turning downewards, The Crowne Imperiall for his ftately beautifulnefs, deferueth the firft place in this our Garden of delight, to be here entreated of before all other Lillies; but becaufe it is fo well knowne to moft perfons, being in a manner euery where common, I thall neede onely to give you a relation of the chiefe parts thereof (as I intend in fuch other things) which are thefe: The roote is yellowifh on the outfide, compofed of fewer, but much thicker fcales, then any other Lilly but the Perfian, and doth grow fometimes to be as great as a pretty bigge childes head, but fomewhat flat withall, from the fides whereof, and not from the bottome, it hooteth forth thicke long fibres, which perith euery yeare, hauing a hole in the midit thereof, at the end of the yeare, when the old ftalke is dry and withered, and out of the which a new ftalke doth fpring againe (from a bud or head to be feen within the hollowneffe on the one fide) the yeare following: the ftalke then filling vp the hollowneffe, rifeth vp three or foure foote high, being great, round, and of a purplinh colour at the bottome, but greene aboue, befet from thence to the middle thereof with many long and broad greene leaues, very like to the leaues of our ordinary white Lilly, but fomewhat Thorter and narrower, confuredly without order, and from the middle is bare or naked without leaues, for a certaine fpace vpwards, and then beareth foure, fixe, or tenne flowers, more or leffe, according to the age of the plant, and the fertility of the foyle where it groweth: The buddes at the firt appearing are whition, Itanding vpright among a bufh or tuft of greene leaues, fmaller then thofe below, and ftanding aboue the flowers, after a while they turne themselues, and hang downewards euerie one vpon his owne footeftalke, round about the great ftemme or ftalke, fometimes of an euen depth, and other while one lower or higher than another, which flowers are neare the forine of an ordinary Lilly, yet fomewhat leffer and clofer, confifting of fixe leaues of an Orange colour, ftriped with purplifh lines and veines, which adde a great grace to the flowers: At the bottome of the flower next vnto the ftalke, euery 
leafe thereof hath on the outfide a certaine bunch or eminence, of a darke purplifh colour, and on the infide there lyeth in thofe hollow bunched places, certaine cleare drops of water like vnto pearles, of a very fweete tafte almoft like fugar: in the midft of each flower is a long white ftile or pointell, forked or diuided at the end, and fixe white chiues tipt with yellowifh pendents, ftanding clore about it : after the flowers are paft, appeare fixe fquare feede veffels ftanding vpright, winged as it were or welted on the edges, yet feeming but three fquare, becaufe each couple of thofe welted edges are ioyned clofer together, wherein are contained broad, flat, and thinne feedes, of a pale brownifh colour, like vnto other Lillies, but much greater and thicker alfo. The ftalke of this plant doth oftentimes grow flat, two, three, or foure fingers broad, and then beareth many more flowers, but for the moft part fmaller then when it beareth round ftalkes. And fometimes it happeneth the ftalke to be diuided at the top, carrying two or three tufts of greene leaues, without any flowers on them. And fometimes likewife, to beare two or three rowes or crownes of flowers one aboue another vpon one ftalke, which is feldome and fcarce feene, and befides, is but meere accidentall: the whole plant and euery part thereof, as well rootes, as leaues and flowers, doe fmell fomewhat ftrong as it were the fauour of a Foxe, fo that if any doe but come neare it, he cannot but fmell it, which yet is not vnwholfome.

I haue not obferued any variety in the colour of this flower, more then that it will be fairer in a cleare open ayre, and paler, or as it were blafted in a muddy or fmoakie ayre. And although fome haue boafted of one with white flowers, yet I could neuer heare that any fuch hath endured in one vniforme colour.

The Place.

This plant was firft brought from Conftantinople into thefe Chriftian Countries, and by the relation of fome that fent it, groweth naturally in Perfia.

The Time.

It flowereth moft commonly in the end of March, if the weather be milde, and fpringeth not out of the ground vntill the end of February, or beginning of March, fo quicke it is in the fpringing: the heads with feed are ripe in the end of May.

The Names.

It is of fome called Lilium Perficum, the Perfian Lilly: but becaufe wee haue another, which is more vfually called by that name, as thall be fhewed in the next Chapter, I had rather with Alphonfus Pancius the Duke of Florence his Phyfitian, (who firft fent the figure thereof vnto $M^{\text {fr }}$. Iohn de Brancion) call it Corona Imperialis, the Crowne Imperiall, then by any other name, as alfo for that this name is now more generally receiued. It hath been fent alfo by the name $\mathcal{T} u f a i$, and $\mathcal{T} u f c h a i$, and $\mathcal{T} u r f a n i$, or $\mathcal{T} u r-$ fanda, being, as it is like, the Turkifh names.

\section{The Vertues.}

For any Phyficall Vertues that are in it, I know of none, nor haue heard that any hath been found out: notwithftanding the ftrong fent would perfwade it might be applyed to good purpofe.

\section{H A P. I I.}

Lilium Perficum. The Perfian Lilly.

$\mathrm{T}$ He roote of the Perfian Lilly is very like vnto the root of the Crowne Imperiall, and lofing his fibres in like maner euery yeare, hauing a hole therin likewife where the old ftalke grew, but whiter, rounder, and a little longer, fmaller, and not ftinking at all like it, from whence fpringeth vp a round whitifh greene ftalke, not much 


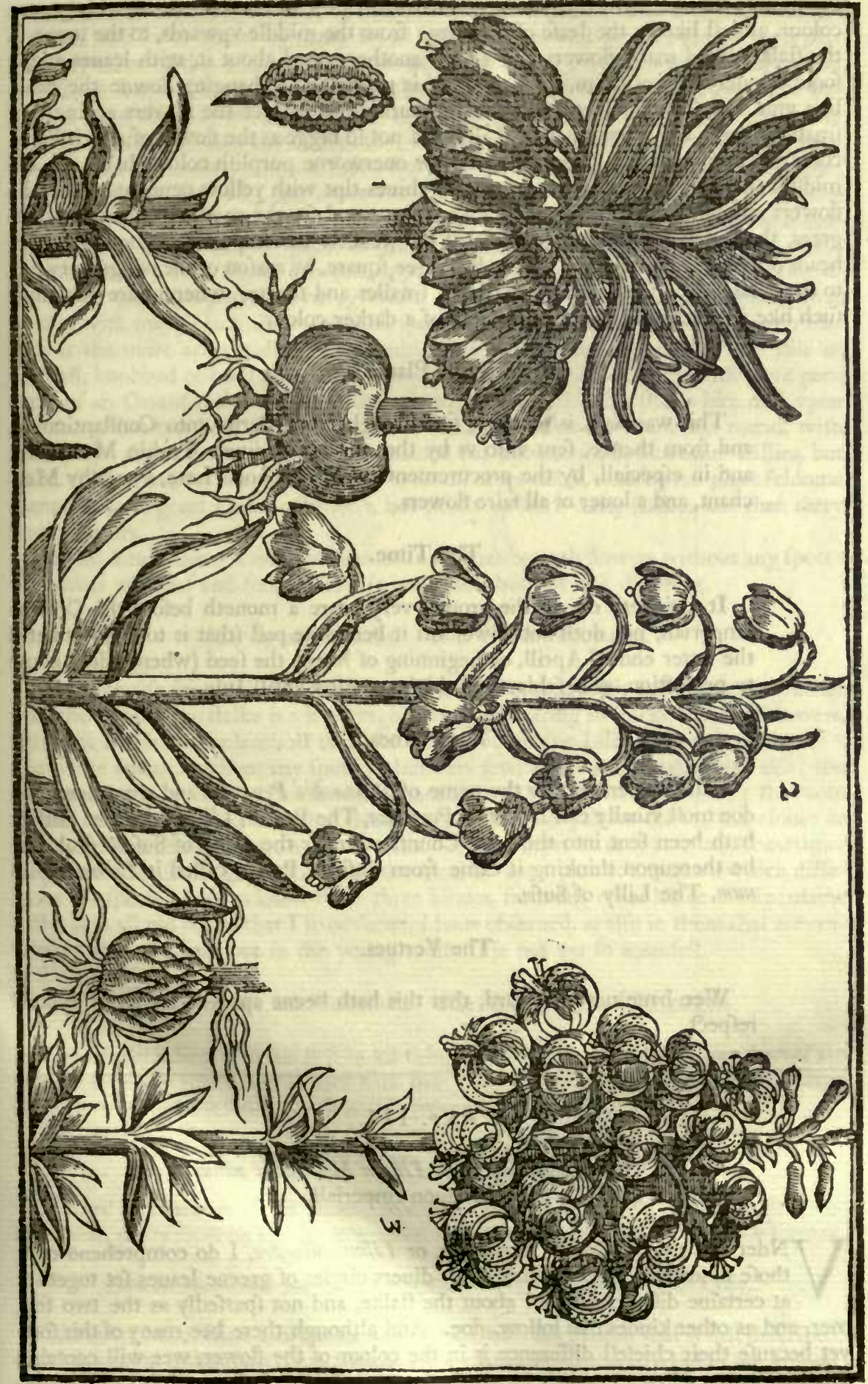

I Corona Imperialis. The Crown Imperiall. 2 Lilium Perfucum. The Perfian Lilly. 3 Marlagon Imperialc. The Martagon Imperiall. 
much lower than the Crowne Imperiall, but much fmaller, befet from the bottome to the middle thereof, with many long and narrow leaues, of a whitifh or blewifh greene colour, almoft like to the leafe of a Tulipa: from the middle vpwards, to the toppe of the ftalke, ftand many flowers one aboue another round about it, with leaues at the foote of euery one of them, each whereof is pendulous or hanging downe the head, like vnto the Crowne Imperiall, and not turning vp any of the flowers againe, but fmaller than in any other kinde of Lilly, yea not fo bigge as the flower of a Fritillaria, confifting of fixe leaues a peece, of a dead or ouerworne purplifh colour, hauing in the midft a fmall long pointell, with certaine chiues tipt with yellow pendents: after the flowers are paft (which abide open a long time, and for the moft part flower by degrees, the loweft firft, and fo vpwards) if the weather be temperate, come fixe fquare heads or feede veffels, feeming to be but three fquare, by reafon of the wings, very like to the heads of the Crowne Imperiall, but fmaller and horter, wherein are contained fuch like flat feed, but fmaller alfo, and of a darker colour.

The Place.

This was, as it is thought, firft brought from Perfia vnto Conftantinople, and from thence, fent vnto vs by the meanes of diuers Turkie Merchants, and in efpeciall, by the procurement of $\mathrm{M}^{\mathrm{r}}$. Nicholas Lete, a worthy Merchant, and a louer of all faire flowers.

The Time.

It fpringeth out of the ground very neare a moneth before the Crowne Imperiall, but doth not flower till it bee quite paft (that is to fay) not vntill the latter end of Aprill, or beginning of May: the feed (when it doth come to perfection, as it feldome doth) is not ripe vntill Iuly.

The Names.

It hath been fent by the name of Pennachio Perfiano, and wee thereupon doe moft vfually call it Lilium Perficum, The Perfian Lilly. Clufius faith it hath been fent into the Low Countries vnder the name of Sufam giul, and he thereupon thinking it came from Sufis in Perfia, called it Lilium Sufianum, The Lilly of Sufis.

The Vertues.

Wee have not yet heard, that this hath beene applyed for any Phyficall refpect.

\section{Сна P. III.}

Martagon Imperiale, fiue Lilium Montanum maius, The Martagon Imperiall.

$\mathrm{V}$

Nder this title of Lilium Montanum, or Lilium Silueftre, I do comprehend only thofe kindes of Lillies, which carry diuers circles of greene leaues fet together at certaine diftances, round about the ftalke, and not fparfedly as the two former, and as other kindes that follow, doe. And although there bee many of this fort, yet becaufe their chiefeft difference is in the colour of the flower, wee will containe them all in one Chapter, and begin with the moft ftately of them all, becaufe of the number of flowers it beareth vpon one ftalke. The Imperiall Lilly hath a fcaly roote, like vnto all the reft of the Lillies, but of a paler yellow colour, clofely compact or fet together, being fhort and fmall oftentimes, in comparifon of the greatneffe of the 
ftemme growing from it. The ftalke is brownifh and round at the bottome, and fometimes flat from the middle vpwards, three foote high or more, befet at certaine diftances with rondles or circles of many broad leaues, larger and broader for the inoft part than any other of this kinde, and of a darke green colour : It hath two or three, and fometimes foure of thefe rondles or circles of leaues, and bare without any leafe betweene ; but aboue toward the tops of the ftalkes, it hath here and there fome leaues vpon it, but fmaller than any of the other leaues: at the toppe of the ftalke come forth many flowers, fometime three or foure fcore, thicke thruft, or confufedly fet together, and not thinne or fparfedly one aboue another, as in the leffer of this kinde of Mountaine Lilly. It hath been fometimes alfo obferued in this kinde, that it hath borne manie flowers at three feuerall fpaces of the ftalke, one aboue another, which hath made a goodly thew ; each flower whereof is pendulous, hanging downe, and each leafe of the flower turning vp againe, being thicke or flefhy, of a fine delayed purple colour, fpotted with many blackifh or brownifh fpots, of a very pleasant fweet fent, which maketh it the more acceptable : in the middle of the flower hangeth downe a ftile or pointell, knobbed or buttoned at the end with fixe yellow chiues, tipt with loore pendents of an Orient red or Vermillion colour, which will eafily fticke like duft vpon any thing that toucheth them : the heads or feede veffels are fmall and round, with fmall edges about them, wherein is contained flat browne feede like other Lillies, but leffer. This root is very apt to encreafe or fet of, as we call it, wherby the plant feldome commeth to fo great a head of flowers, but rifeth vp with many ftalkes, and then carry fewer flowers.

Of this kinde there is fometimes one found, that beareth flowers without any fpots: Marragon the leaues whereof and ftalke likewife are paler, but not elfe differing. Imperiale

\section{Martagon flore albo. The White Martagon.}

We haue alfo fome other of this kind, the firt wherof hath his ftalke \& leafe greener than the former, the ftalke is a little higher, but not bearing fo thicke a head of flowers, although much more plentifull than the leffer Mountaine Lilly, being altogether of a fine white colour, without any fpots, or but very few, and that but fometimes alfo: the pendents in the middle of this flower are not red, as the former, but yellow; the roote of this, and of the other two that follow, are of a pale yellow colour, the cloues or fcales of them being brittle, and not clofely compact, yet fo as if two, and fometimes three fcales or cloues grew one vpon the head or vpperpart of another; which difference is a fpeciall note to know thefe three kindes, from any other kinde of Mountaine Lilly, as in all old rootes that I haue feene, I haue obferued, as alfo in them that are reafonably well growne, but in the young rootes it is not yet fo manifeft.

\section{Martagon flore albo maculato. The White fpotted Martagon.}

The fecond is like vnto the firf in all things, faue in this, that the flowers hereof are not altogether fo white, and befides hath many reddifh fpots on the infide of the leaues of the flower, and the falke alfo is not fo greene but brownifh.

\section{Martagon flore carneo. The bluh Martagon.}

A third fort there is of this kinde, whofe flowers are wholly of a delayed flefh colour, with many fpots on the flowers, and this is the difference hereof from the former.

\section{Lilium Montanum fiue filueftre minus. The leffer Mountaine Lilly.}

The leffer Mountaine Lilly is fo like in root vnto the greater that is firf defcribed, that it is hard to diftinguifh them afunder; but when this is fprungvp out of the ground, which is a moneth after the firf: it alfo carrieth his leaues in rondles about the ftalke, although not altogether fo great nor fo many. The flowers are more thinly fet on the ftalkes one aboue another, with more diftance betweene each flower than the former, and are of a little deeper flefh colour or purple, fpotted in the fame manner. The buds 


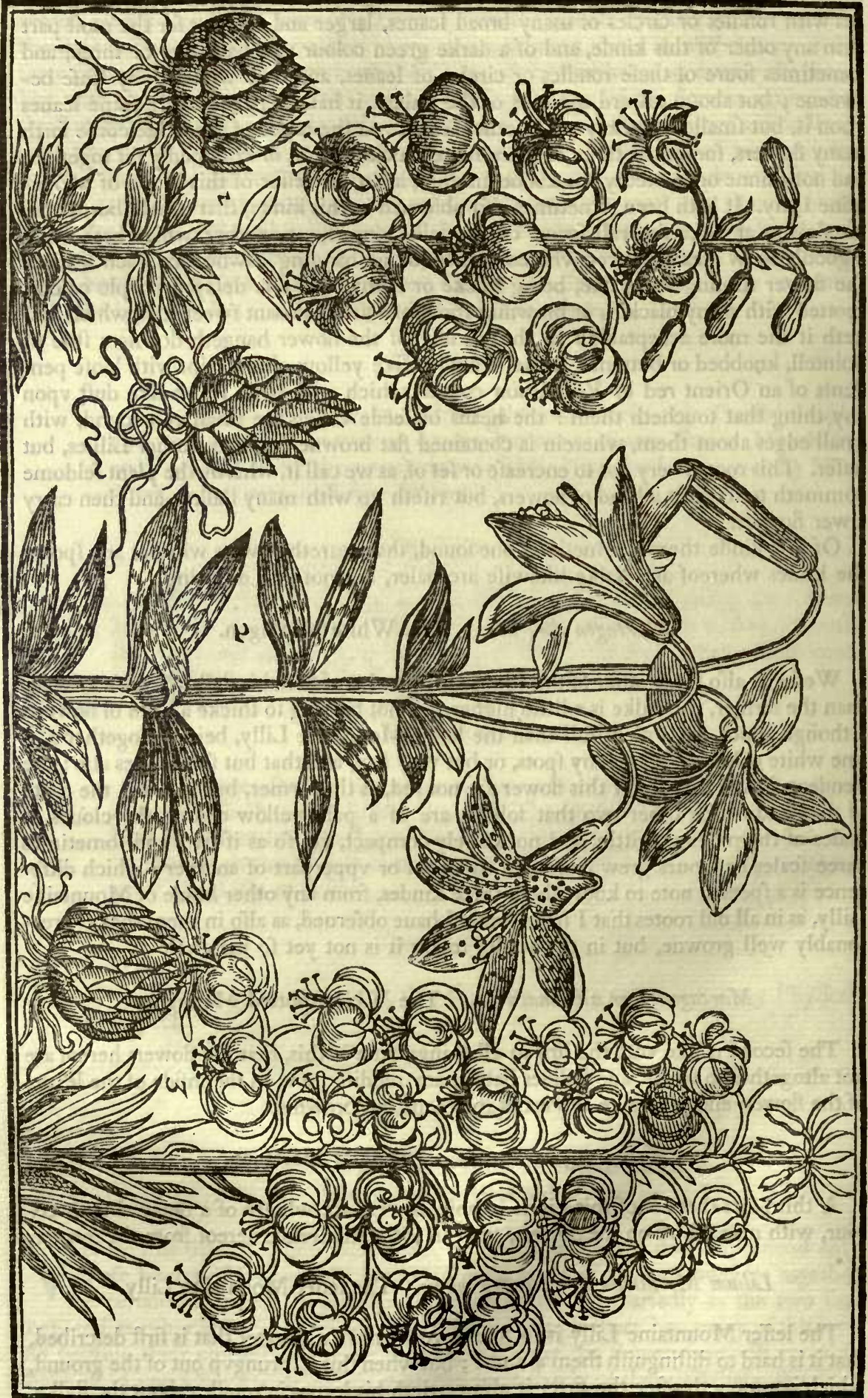

I. Martagon flore albo. The white Martagon. 2 Martagon fiue, Lilium Canadenfe maculatum. The fpotted Martagon, or Lilly of Canada. 3 Martagon Pomponesm. The Martagon Pompony, or early red Martagon. 
or heads of flowers, in fome of thefe before they be blowne, are hoary white, or hairie, whereas in others, there is no hoarineffe at all, but the buddes are fmooth and purplifh : in other things this differeth not from the former.

Of this fort alfo there is one that hath but few fpots on the flowers, whofe colour is Lilium Monfomewhat paler than the other,

\section{Martagon Canadenfe maculatum. The fpotted Martagon of Canada.}

Although this ftrange Lilly hath not his flowers hanging downe, and turning vp again, as the former kinds fet forth in this Chapter; yet becaufe the green leaues ftand at feuerall ioynts as they do, I muft needs infert it here, not knowing where more fitly to place it. It hath a fmall fcaly roote, with many fmall long fibres thereat, from whence rifeth vp a reafonable great ftalke, almoft as high as any of the former, bearing at three or foure diftances many long and narrow greene leaues, but not fo many or fo broad as the former, with diuers ribbes in them: from among the vppermoft rundle of leaues breake forth foure or fiue flowers together, euery one ftanding on a long flender foote ftalke, being almoft as large as a red Lilly, but a little bending downewards, and of a faire yellow colour, fpotted on the infide with diuers blackifh purple fpots or ftrakes, hauing a middle pointell, and fixe chiues, with pendents on them.

\section{The Place.}

All thefe Lillies haue been found in the diuers Countries of Germany, as Auftria, Hungaria, Pannonia, Stiria, \&cc. and are all made Denifons in our London Gardens, where they flourifh as in their owne naturall places. The laft was brought into France from Canada by the French Colonie, and from thence vnto vs.

The Time.

They flower about the later end of Iune for the moft part, yet the firft fpringeth out of the ground a moneth at the leaft before the other, which are moft vfually in flower before it, like vnto the Serotine Tulipas, all of them being early vp, and neuer the neere.

\section{The Names.}

The firf is vfually called Martagon Imperiale, the Imperiall Martagon, and is Lilium Montanum maius, the greateft Mountaine Lilly; for fo it deferueth the name, becaufe of the number of flowers vpon a head or ftalke. Some haue called it Lilium Sarafenicum, and fome Hemerocallis, but neither of them doth fo fitly agree vnto it.

The fecond is Lilium Montanum maius flore albo, and of fome Martagon Imperiale flore albo, but moft vfually Martagon flore albo, the white Martagon. The fecond fort of this fecond kinde, is called Martagon flore albo maculato, the fpotted white Martagon. And the third, Martagon flore carneo, the blufh Martagon.

The third kinde is called Lilium Montanum, the Mountaine Lilly, and fome adde the title minus, the leffer, to know it more diftinctly from the other. Some alfo Lilium Silueftre, as Clufius, and fome others, and of Matthiolus Martagon. Of diuers women here in England, from the Dutch name, Lilly of Nazareth. The laft hath his title Americanum \& Canadenfe, and in Englifh accordingly. 


\section{C н А P. IV.}

\section{Martagon Pomponeum fiue Lilium rubrum pracox, vel Lilium Macedonicum.} The early red Martagon, or Martagon Pompony.

1. Martagon Pomponeum angusti folium praecox:

2. Martagon angusti folium magis ferotinum. 3. Martagon Pomponeum latifolium pra $\cos$.

4. Martagon flore phaeniceo.

$\mathrm{A}^{\mathrm{i}}$ $S$ in the former Chapter we defcribed vnto you fuch Lillies, whofe flowers being pendulous, turne their leaues backe againe, and haue their greene leaues, fet by fpaces about the ftalke : fo in this wee will fet downe thofe forts, which carry their greene leaues more fparfedly, and all along the ftalke, their flowers hanging downe, and turning vp againe as the former, and begin with that which is of greateft beauty, or at leaft of moft rarity.

I. This rare Martagon hath a fcaly root clofely compact, with broader and thinner fcales than others, in time growing very great, and of a more deepe yellow colour then the former, from whence doth fpring vp a round greene ftalke in fome plants, and flat in others, two or three foote high, bearing a number of fmall, long, and narrow greene leaues, very like vnto the leaues of Pinkes, but greener, fet very thicke together, and without order about the ftalke, vp almoft vnto the toppe, and leffer by degrees vpwards, where ftand many flowers, according to the age of the plant, and thriuing in the place where it groweth; in thofe that are young, but a few, and more fparfedly, and in others that are old many more, and thicker fet: for I haue reckoned threefcore flowers and more, growing thicke together on one plant with mee, and an hundred flowers on another: thefe flowers are of a pale or yellowifh red colour, and not fo deep red as the red Martagon of Conftantinople, hereafter fet down, nor fully fo large : yet of the fame fafhion, that is, euery flower hanging downe, and turning vp his leaues againe. It is not fo plentifull in bearing of feede as the other Lillies, but when it doth, it differeth not but in being leffe.

There is another, whofe greene leaues are not fo thicke fet on the ftalke, but elfe differeth not but in flowring a fortnight later.

There is another alfo of this kind, fo like vnto the former in root, ftalk, flower, \& maner of growing, that the difference is hardly difcerned; but confifteth chiefly in thefe two points: Firft, that the leaues of this are a little broader and fhorter then the former; and fecondly, that it beareth his flowers a fortnight earlier than the firf. In the colour or forme of the flower, there can no difference bee difcerned, nor (as I faid) in any other thing. All thefe Lillies doe fpring very late out of the ground, euen as the yellow Martagons doe, but are fooner in flower then any others.

A fourth kinde hereof hath of late been knowne to vs, whofe leaues are broader and fhorter than the lait, and the flowers of a paler red, tending to yellow, of fome called a golden red colour : but flowreth not fo early as they.

\section{Lilium rubrum Byzantinum, fue Martagon Conftantinopolitanum.}

The red Martagon of Conftantinople.

I. The red Martagon of Conftantinople is become fo common euery where, and fo well knowne to all louers of thefe delights, that I thall feeme vnto them to lofe time, to beftow many lines vpon it; yet becaufe it is fo faire a flower, and was at the firft fo highly efteemed, it deferueth his place and commendations, howfoeuer encreafing the plenty hath not made it dainty. It rifeth out of the ground early in the fpring, before many other Lillies, from a great thicke yellow fcaly root, bearing a round brownifh ftalke, befet with many faire greene leaues confufedly thereon, but not fo broad as the common white Lilly, vpon the toppe whereof ftand one, two, or three, or more flowers, vpon long footeftalkes, which hang downe their heads, and turne vp their leaues againe, of an excellent red crimfon colour, and fometimes paler, hauing a long pointell in the middle, compaffed with fixe whitifh chiues, tipt with loofe yellow pendents, of a reafonable good fent, but fomewhat faint. It likewife beareth feede in heads, like vnto the other, but greater. 


\section{Martagon Conftantinopolitanum maculatum.}

The red fpotted Martagon of Conftantinople.

We haue another of this kinde, that groweth fomewhat greater and higher, with a larger flower, and of a deeper colour, fpotted with diuers blacke fpots, or ftrakes and lines, as is to be feene in the Mountaine Lillies, and in fome other hereafter to be defcribed; but is not fo in the former of this kinde, which hath no fhew of fpots at all. The whole plant as it is rare, fo it is of much more beauty than the former.

\section{Martagon Pannonicum, fiue Exoticum flore Spadiceo.}

The bright red Martagon of Hungarie.

Although this Martagon or Lilly bee of another Countrey, yet by reafon of the neereneffe both in leafe and flower vnto the former, may more fitly be placed next vnto them, then in any other place. It hath his roote very like the other, but the leaues are fomewhat larger, and more fparfedly fet vpon the ftalke, elfe not much vnlike : the flowers bend downe, and turne vp their leaues againe, but fomewhat larger, and of a bright red, tending to an Orenge colour, that is, fomewhat yellowifh, and not crimfon, like the other.

\section{Martagon Luteum punctatum. The Yellow fpotted Martagon.}

I. This Yellow Martagon hath a great fcaly or cloued roote, and yellow, like vnto all thefe forts of turning Lillies, from whence springeth vp a round greene ftrong ftalke, three foote high at the leaft, confufedly fet with narrow long greene leaues, white on the edges vp to the very toppe thereof almoft, hauing diuers flowers on the head, turning vp againe as the former doe, of a faint yellowifh, or greenifh yellow colour, with many blacke fpots or ftrakes about the middle of the leafe of euery flower, and a forked pointell, with fixe chiues about it, tipt with reddifh pendents, of a heauie ftrong fmell, not very pleafant to many. It beareth feede very plentifully, in great heads, like vnto the other former Lillies, but a little paler.

\section{Martagon Luteum non maculatum. The Yellow Martagon without fpots.}

The other yellow Martagon differeth in no other thing from the former, but onely that it hath no fpots at all vpon any of the leaues of the flowers; agreeing with the former, in colour, forme, height, and all things elfe.

\section{Martagon Luteum ferotimum. The late flowring Yellow Martagon.}

There is yet another yellow Martagon, that hath no other difference then the time of his flowring, which is not vntill Iuly, vnleffe in this, that the flower is of a deeper yellow colour.

\section{The Place.}

The knowledge of the firf kindes of thefe early Martagons hath come from Italy, from whence they haue bin fent into the Low-Countries, and to vs, and, as it feemeth by the name, whereby they haue bin fent by fome into thefe parts, his originall fhould be from the mountaines in Macedonia.

The fecond fort is fufficiently knowne by his name, being firft brought from Conftantinople, his naturall place being not farre from thence, as it is likely. But the next fort of this fecond kinde, doth plainly tell vs his place of birth to be the mountaines of Pannonia or Hungarie.

The third kindes grow on the Pyrenæan mountaines, where they haue been fearched out, and found by diuers louers of plants, as alfo in the Kingdome of Naplès. 
The Time.

The firft early Martagons flower in the end of May, or beginning of Iune, and that is a moneth at the leaft before thofe that come from Conftantinople, which is the fecond kinde. The two firft yellow Martagons flower fomewhat more early, then the early red Martagons, and fometimes at the fame time with them. But the third yellow Martagon, as is faid, flowreth a moneth later or more, and is in flower when the red Martagon of Conftantinople flowreth. And although the early red and yellow Martagons, fpring later then the other Martagons or Lillies, yet they are in flower before them.

\section{The Names.}

The firt early red Lillies or Martagons haue beene fent vnto vs by feuerall names, as Martagon Pomponeum, and thereafter are called Martagon of Pompony, and alfo Lilium or Martagon Macedonicum, the Lilly or Martagon of Macedonia. They are alfo called by Clufius Lilium rubrum pracox, the one angustiore folio, the other latiore folio. And the laft of this kinde hath the title flore phaniceo added or giuen vnto it, that is, the Martagon or Lilly of Macedonia with gold red flowers.

The Martagons of Conftantinople haue beene fent by the Turkifh name Zufiniare, and is called Martagon, or Lilium Byzantinum by fome, and $\mathrm{He}_{e-}$ merocallis Chalcedonica by others; but by the name of the Martagon of ConItantinople they are moft commonly receiued with vs, with the distinction of maculatum to the one, to diftinguifh the forts. The lant kinde in this clafsis, hath his name in his title, as it hath been fent vnto vs.

The Yellow Martagons are diftinguifhed in their feuerall titles, as much as is conuenient for them.

\section{CH A P. V.}

\section{Lilium Aureum E Lilium Rubrum. The Gold and Red Lillies.}

T Here are yet fome other kindes of red Lillies to bee defcribed, which differ from all the former, and remaine to be fpoken of in this place. Some of them grow high, and fome lowe, fome haue fmall knots, which wee call bulbes, growing vpon the ftalkes, at the ioynts of the leaues or flowers, and fome haue none: all which thall be intreated of in their feuerall orders.

Lilium pumilum cruentum. The dwarfe red Lilly.

The dwarfe red Lilly hath a fcaly roote, fomewhat like vnto other Lillies, but white, and not yellow at all, and the cloues or fcales thicker, fhorter, and fewer in number, then in moft of the former: the ftalke hereof is not aboue a foote and a halfe high, round and greene, fet confufedly with many faire and fhort greene leaues, on the toppe of which doe ftand fometimes but a few flowers, and fometimes many, of a faire purplifh red colour, and a little paler in the middle, euery flower ftanding vpright, and not hanging downe, as in the former, on the leaues whereof here and there are fome blacke fpots, lines or markes, and in the middle of the flower a long pointell, with fome chiues about it, as is in the reft of thefe Lillies.

Lilium rubrum This kinde is fometimes found to yeeld double flowers, as if all the fingle flowers muliplicififore. fhould grow into one, and fo make it confift of many leaues, which notwithftanding 


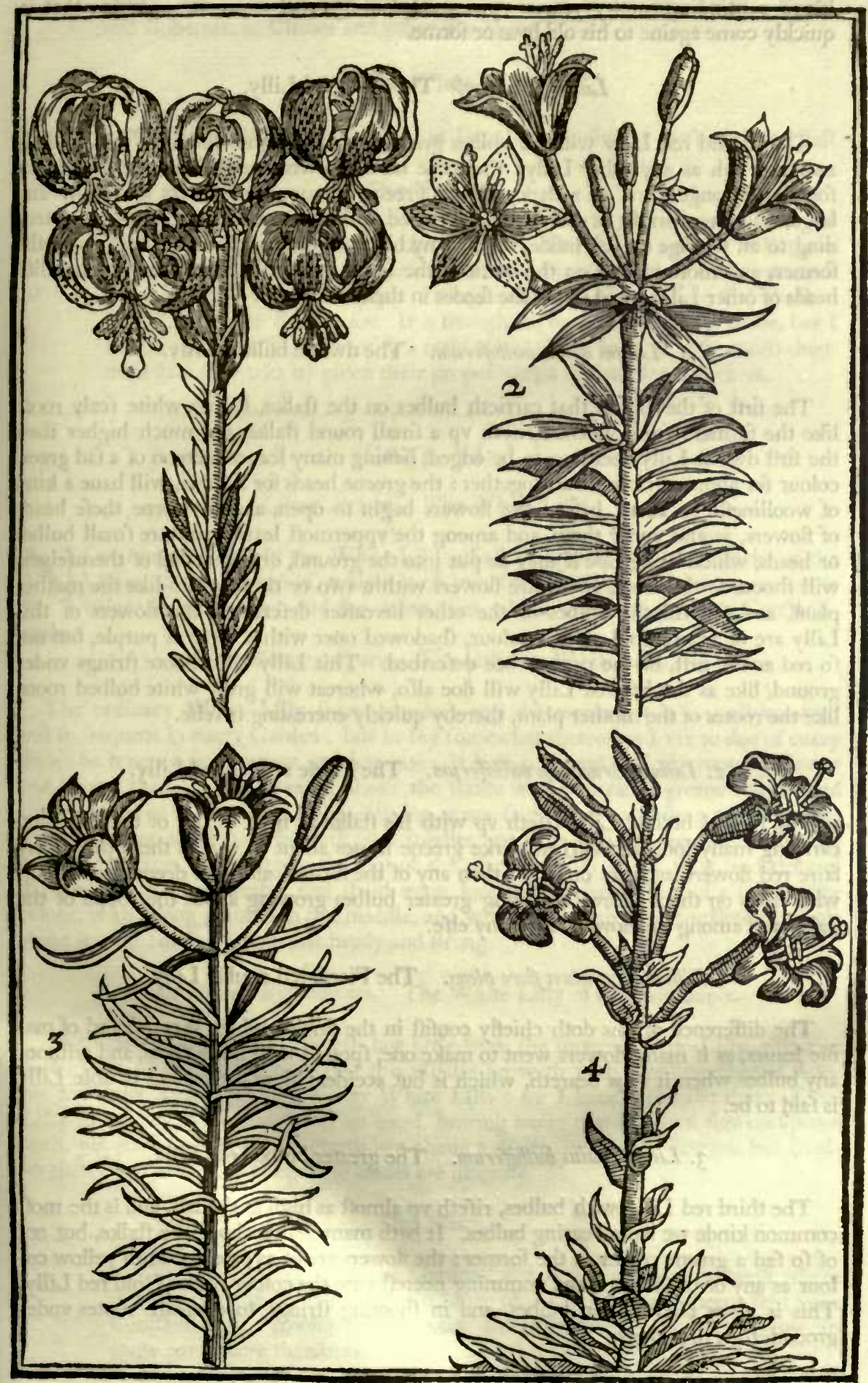

1 Martagon rubrum fiue luleum. The red or the yellow Martagon. 2 Lilium Bulbijerum. The red bulbed Lilly. 3 Lilium anroum. The gold red Lilly. 4 Lilium album. The white Lilly. 
his fo continuing fundry yeares, vpon tranfplanting, will redire ad ingenium, that is, quickly come againe to his old byas or forme.

\section{Lilium Aureum. The Gold red Lilly.}

The fecond red Lilly without bulbes groweth much higher then the firft, and almoft as high as any other Lilly: the roote hereof is white and fcaly, the leaues are fomewhat longer, and of a darke or fad greene colour; the flowers are many and large, ftanding vpright as all thefe forts of red Lillies doe, of a paler red colour tending to an Orenge on the infide, with many blacke fpots and lines on them, as in the former, and more yellow on the outfide: the feede veffels are like vnto the roundifh heads of other Lillies, and fo are the feedes in them likewife.

\section{Lilium minus bulbiferum. The dwarfe bulbed Lilly.}

The firft of the Lillies that carrieth bulbes on the ftalke, hath a white fcaly roote like the former; from whence rifeth vp a fmall round ftalke, not much higher then the firft dwarfe Lilly, feeming to be edged, hauing many leaues thereon of a fad green colour fet about it, clofe thruft together: the greene heads for flowers, will haue a kind of woollineffe on them, before the flowers begin to open, and betweene thefe heads of flowers, as alfo vnder them, and among the vppermoft leaues, appeare fmall bulbes or heads, which being ripe if they be put into the ground, or if they fall of themfelues, will fhoote forth leaues, and beare flowers within two or three yeares like the mother plant, and fo will the bulbes of the other hereafter defcribed: the flowers of this Lilly are of a faire gold yellow colour, fhadowed ouer with a thew of purple, but not fo red as the firft, or the next to bee defcribed. This Lilly will thoote ftrings vnder ground, like as the laft red Lilly will doe alfo, whereat will grow white bulbed roots, like the rootes of the mother plant, thereby quickly encreafing it felfe.

\section{Lilium Cruentum bulbiferum. The Fierie red bulbed Lilly.}

The fecond bulbed Lilly rifeth vp with his ftalke as high as any of thefe Lillies, carrying many long and narrow darke greene leaues about it, and at the toppe many faire red flowers, as large or larger then any of the former, and of a deeper red colour, with fpots on them likewife, hauing greater bulbes growing about the toppe of the ftalke and among the flowers, then any elfe.

\section{Lilium Cruentum flore pleno. The Fierie red double Lilly.}

The difference of this doth chiefly confift in the flower, which is compofed of manie leaues, as if many flowers went to make one, fpotted with black fpots, and without any bulbes when it thus beareth, which is but accidentall, as the former double Lilly is faid to be.

\section{Lilium maius bulbiferun. The greater bulbed red Lilly.}

The third red Lilly with bulbes, rifeth vp almoft as high as the laft, and is the moft common kinde we haue bearing bulbes. It hath many leaues about the ftalke, but not of fo fad a greene colour as the former: the flowers are of as pale a reddifh yellow colour as any of the former, and comming neereft vnto the colour of the Gold red Lilly. This is more plentifull in bulbes, and in fhooting ftrings, to encreafe rootes vnder ground, then the others.

\section{The Place.}

Thefe Lillies doe all grow in Gardens, but their naturall places of growing is the Mountaines and the Vallies neere them in Italy, as Matthiolus 
faith : and in many Countries of Germany, as Hungarie, Auftria, Stiria, and Bohemia, as Clufius and other doe report.

\section{The Time.}

They flower for the moft part in Iune, yet the firft of thefe is the earlieft of all the reft.

The Names.

All thefe Lillies are called Lilia Rubra, Red Lillies: Some call them Lilium Aureum, Lilium Purpureum, Lilium Puniceum, \& Lilium Cruentum. Some alfo call them Martagon Chimifarum. Clufius calleth thefe bulbed Lillies Martagon Bulbiferum. It is thought to be Hyacinthus Poetarum, but I referre the difcuffing thereof to a fitter time. Wee haue, to diftinguifh them moft fitly (as I take it) giuen their proper names in their feuerall titles.

\section{CH A P. VI.}

Lilium Album. The White Lilly.

$\mathrm{N}$ Ow remaineth onely the White Lilly, of all the whole family or ftocke of the Lillies, to bee fpoken of, which is of two forts. The one is our common or vulgar White Lilly ; and the other, that which was brought from Conftantinople.

\section{Lilium Album vulgare. The ordinary White Lilly.}

The ordinary White Lilly fcarce needeth any defcription, it is fo well knowne, and fo frequent in euery Garden ; but to fay fomewhat thereof, as I vfe to doe of euery thing, be it neuer fo common and knowne; it hath a cloued or fcaly roote, yellower and bigger then any of the red Lillies : the ftalke is of a blackifh greene colour, and rifeth as high as moit of the Lillies, hauing many faire, broad, and long greene leaues thereon, larger and longer beneath, and fmaller vpon the ftalke vpwards; the flowers are many or few, according to the age of the plant, fertility of the foile, and time of ftanding where it groweth : and ftand vpon long greene footftalkes, of a faire white colour, with a long pointell in the middle, and white chiues tipt with yellow pendents about it ; the fmell is fomewhat heady and ftrong.

\section{Lilium Album Byzantinum. The White Lilly of Conftantinople.}

The other White Lilly, differeth but little from the former White Lilly, either in roote, leafe, or flower, but only that this vfually groweth with more number of flowers, then euer we faw in our ordinary White Lilly: for I haue feene the ftalke of this Lilly turne flat, of the breadth of an hand, bearing neere two hundred flowers vpon a head, yet moft commonly it beareth not aboue a dozen, or twenty flowers, but fmaller then the ordinary, as the greene leaues are likewife.

\section{The Place.}

The firft groweth onely in Gardens, and hath not beene declared where it is found wilde, by any that I can heare of. The other hath beene fent from Conftantinople, among other rootes, and therefore is likely to grow in fome parts neere thereunto.

The Time.

They flower in Iune or thereabouts, but fhoote forth greene leaues in Autumne, 
Autumne, which abide greene all the Winter, the ftalke fpringing vp betweene the lower leaues in the Spring.

The Names.

It is called Lilium Album, the White Lilly, by moft Writers; but by Poets Rofa Iunonis, Iuno's Rofe. The other hath his name in his title.

\section{The Vertues.}

This Lilly aboue all the reft, yea, and I thinke this onely, and none of the reft is vfed in medicines now adayes, although in former times Empericks vfed the red; and therefore I haue fpoken nothing of them in the end of their Chapters, referuing what is to be faid in this. This hath a mollifying, digefting, and cleanfing quality, helping to fuppurate tumours, and to digeft them, for which purpofe the roote is much vfed. The water of the flowers diftilled, is of excellent vertue for women in trauell of childe bearing, to procure an eafie deliuery, as Matthiolus and Camerarius report. It is vfed alfo of diuers women outwardly, for their faces to cleanfe the skin, and make it white and frefh. Diues other properties there are in thefe Lillies, which my purpofe is not to declare in this place. Nor is it the fcope of this worke; this that hath been faid is fufficient : for were it not, that I would giue you fome tafte of the qualities of plants (as I faid in my Preface) as I goe along with them, a generall worke were fitter to declare them then this.

\section{C н A P. V I I.}

\section{Fritillaria. The checkerd Daffodill.}

$\Lambda$

Lthough diuers learned men do by the name giuen vnto this delightfull plant, thinke it doth in fome things partake with a Tulipa or Daffodill, and haue therefore placed it betweene them; yet I, finding it moft like vnto a little Lilly, both in roote, ftalke, leafe, flower, and feede, haue (as you fee here) placed it next vnto the Lillies, and before them. Hereof there are many forts found out of late, as white, red, blacke, and yellow, befides the purple, which was firft knowne ; and of each of them there are alfo diuers forts : and firt of that which is moft frequent, and then of the reft, euery one in his place and order.

\section{Frillaria vulgaris. The common checkerd Daffodill.}

The ordinary checkerd Daffodill (as it is vfually called, but might more properly be called the fmall checkerd Lilly) hath a fmall round white roote, and fomewhat flat, made as it were of two cloues, and diuided in a maner into two parts, yet ioyning together at the bottome or feate of the roote, which holdeth them both together: from betweene this cleft or diuifion, the budde for the ftalke \&c. appeareth, which in time rifeth vp a foote, or a foote and a halfe high, being round and of a brownifh greene colour, efpecially neere vnto the ground, whereon there ftandeth difperfedly foure or fiue narrow long and greene leaues, being a little hollow : at the toppe of the ftalke, betweene the vpper leaues (which are fmaller then the loweft) the flower fheweth it felfe, hanging or turning downe the head, but not turning vp againe any of his leaues, as fome of the Lillies before defcribed doe; (fometimes this ftalke beareth two flowers, and very feldome three) confifting of fixe leaues, of a reddifh purple colour, fpotted diuerly with great fpots, appearing like vnto fquare checkers, of a deeper colour; the infide of the flower is of a brighter colour then the outfide, which hath fome greenneffe at the bottome of euery leafe : within the flower there appeare 


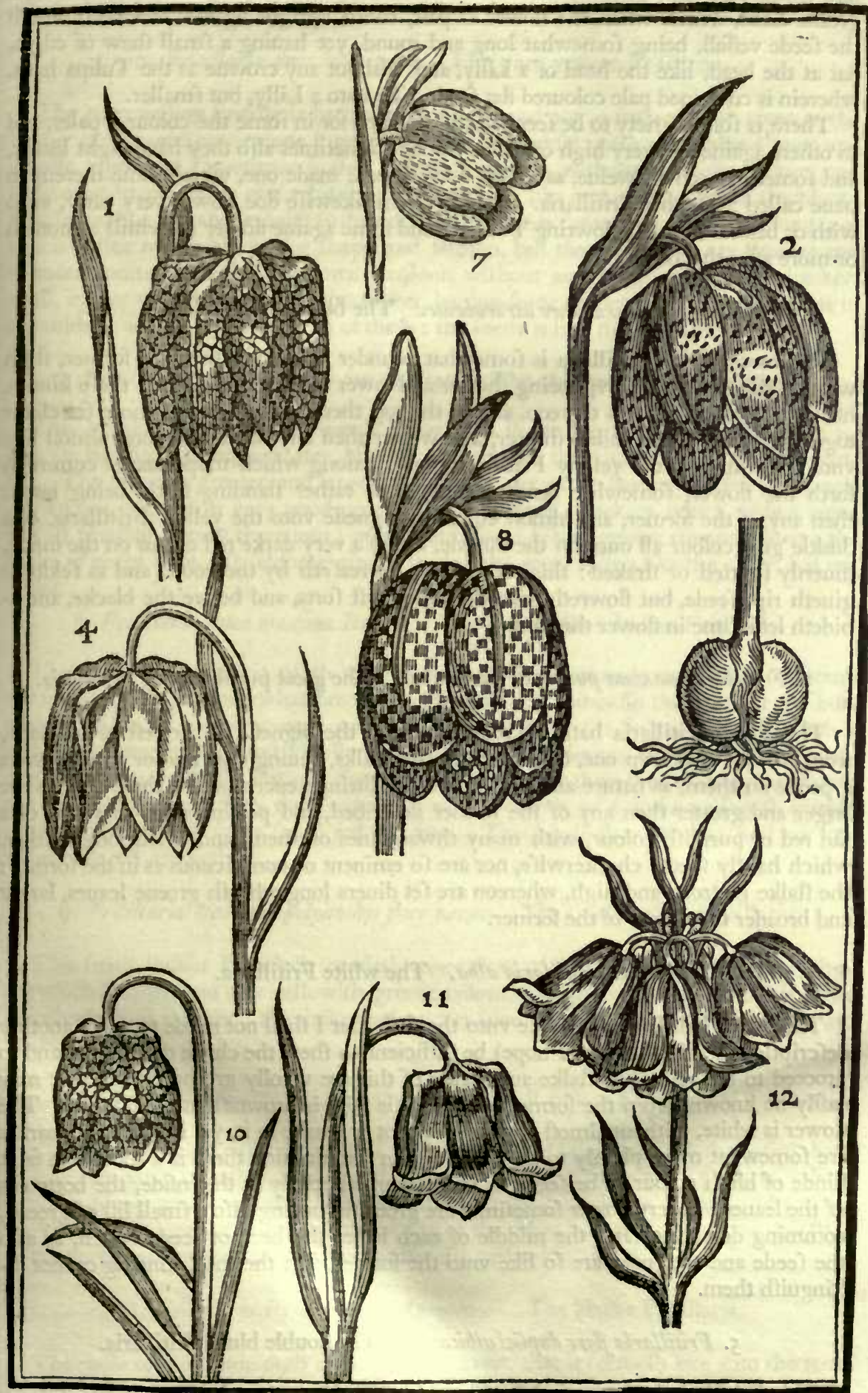

IFritllaria vulgaris. The common Fritillaria. 2 Frilillaria flore alrorwbenle. The darke red Fritillaria. 4Fritllaria alba. The white Fritillaria. 7 Frifillarin latea puncfata. The yellow checkerd Fritillaria. 8: Fritillaria lwiea Italica. The great yellow Italian Fritillaria. Io Frifillaria lutea Lufitanica. The fmall yellow Fritillaria of Portugall. II Fritillaria Pyrenae. The blacke Fritillaria. 12 Fritillaria embollifera. The Spanith blacke Fritillaria. 
fixe chiues tipt with yellow pendents, and a three-forked ftile or pointell compaffing a greene head, which when the flower is paft, rifeth vpright againe, and becommeth the feede veffell, being fomewhat long and round, yet hauing a fmall thew of edges, flat at the head, like the head of a Lilly, and without any crowne as the Tulipa hath, wherein is contained pale coloured flat feede, like vnto a Lilly, but fmaller.

Fritillaria vul- There is fome variety to be feene in this flower; for in fome the colour is paler, and garis pallidior, in others againe of a very high or deepe colour: fometimes alfo they haue eight leaues, praccox, $\mathfrak{F}^{\prime} \mathrm{fe}_{\mathrm{e}}$ and fometimes ten or twelue, as if two flowers were made one, which fome thereupon
rotime haue called a Double Fritillaria. Some of them likewife doe flower very early, euen with or before the early flowring Tulipas; and fome againe flower not vntill a moneth or-more after the former.

\section{Fritillaria flore atrorubente. The bloud red Fritillaria.}

The roote of this Fritillaria is fomewhat rounder and clofer then the former, from whence the ftalke rifeth vp, being fhorter and lower then in any other of thefe kindes, hauing one or two leaues thereon, and at the top thereof two or three more fet clofer together, which are broader, fhorter, and whiter then any of them before, almoft like vnto the leaues of the yellow Fritillaria, from among which toppe leaues commeth forth the flower, fomewhat bending downe, or rather ftanding forth, being larger then any of the former, and almoft equall in bigneffe vnto the yellow Fritillaria, of a duskie gray colour all ouer on the outfide, and of a very darke red colour on the infide, diuerlly fpotted or Atraked: this very hardly encreafeth by the roote, and as feldome giueth ripe feede, but flowreth with the other firft forts, and before the blacke, and abideth leffe time in flower then any.

\section{Fritillaria maxima purpurea fiue rubra. The great purple or red Fritillaria.}

This great Fritillaria hath his roote equall to the bigneffe of the reft of his parts, from whence rifeth vp one, \& oftentimes two ftalks, hauing one, two or three flowers a peece on them, as nature and the feafons are fitting: euery one of thefe flowers are larger and greater then any of the former defcribed, and pendulous as they are, of a fad red or purplinh colour, with many thwart lines on them, and fmall long markes, which hardly feeme checkerwife, nor are fo eminent or confpicuous as in the former: the ftalke is ftrong and high, whereon are fet diuers long whitifh greene leaues, larger and broader then thofe of the former.

\section{Fritillaria alba. The white Fritillaria.}

The white Fritillaria is fo like vnto the firlt, that I fhall not neede to make another defcription of this: it thall (I hope) be fufficient to thew the chiefe differences, and fo proceed to the reft. The ftalke and leaues of this are wholly greene, whereby it may eafily be knowne from the former, which, as is faid, is brownin at the bottome. The flower is white, without almoft any thew of fpot or marke in it, yet in fome the markes are fomewhat more plainly to be feene, and in fome againe there is a thew of a faint kinde of blufh colour to be feene in the flower, efpecially in the infide, the bottomes of the leaues of euery flower fometimes are greenifh, hauing alfo a fmall lift of greene, comming downe towards the middle of each leafe: the head or feede veffell, as alfo the feede and the roote, are fo like vnto the former, that the moft cunning cannot diftinguifh them.

\section{Fritillaria flore duplici albicante. The double blufh Fritillaria.}

This Fritillaria hath a round flattifh white roote, very like vnto the laft Fritillaria, bearing a ftalke with long greene leaues thereon, little differing from it, or the firft ordinary Fritillaria : the flower is faid to be conftant, compofed of many leaues, being ten at the leaft, and moft vfually twelue, of a pale whitifh purple colour, fpotted like vnto the paler ordinary Fritillaria that is early, fo that one would verily thinke it were 
but an accidentall kinde thereof, whereas it is (as is faid before) held to bee conftant, continuing in this manner.

\section{Fritillaria flore luteo puro. The pure yellow Fritillaria.}

The pure yellow Fritillaria hath a more round, and not fo flat a whitifh roote as the former kindes, and of a meane bigneffe; from the middle rifeth vp a ftalke a foote and a halfe high, and fometimes higher, whereon are fet without order diuers long and fomewhat broad leaues of a whitith greene colour, like vnto the leaues of the blacke Fritillaria, but not aboue halfe fo broad : the flower is fomewhat fmall and long, not much vnlike to the blacke for thape and fafhion, but that the leaues are finaller and rounder pointed, of a faint yellowilh colour, without any thew of rpots or checkers at all, eyther within or without the flower, hauing forne chiues and yellow pendents in the middle, as is to be feene in all of them : the feede is like the firt kinde.

\section{Fritillaria flore luteo vario fuc punctato. The checkerd yellow Fritillaria.}

This Fritillaria groweth not much lower then the former, and brownifh at the rifing vp, hauing his leaues whiter, broader, and fhorter then it, and almoft round pointed. The flower is greater, and larger fpread then any other before, of a faire pale yellow colour, fpotted in very good order, with fine fmall checkers, which adde a wonderfull pleafing beauty thereunto : it hath alfo fome lifts of greene running downe the backe of euery leafe. It feldome giueth feede; the roote alfo is like the other, but not fo flat.

\section{Fritillaria lutea maxima Italica. The great yellow Italian Fritillaria.}

This kinde of Fritillaria rifeth vp with a round and browne greene ftalke, whereon are fet diuers leaues fomewhat broad and hort, which compaffe the ftalke at the bottome of them, of a darke greene colour; at the toppe of the ftalke, which bendeth a little downewards, doe moft vfually ftand three or foure leaues, betweene which commeth forth moft vfually but one flower, which is longer then the laft, hanging downe the head as all the others doe, confifting of fixe leaues, of a darke yellowinh purple colour, fpotted with fome fmall red checkers. This kinde flowreth late, and not vntill all the reft are paft.

\section{Fritillaria Italorum polyanthos flore parno. The fmall Italian Fritillaria.}

This fmall Italian Fritillaria carrieth more ftore of flowers on the ftalke, but they are much fmaller, and of a yellowifh greene colour, fpotted with long and fmall darke red checkers or markes: the ftalke hath diuers fmall fhort greene leaues thereon, vnto the very toppe.

\section{Fritillaria Iutea Iuncifolia Lufitanica. The fmall yellow Fritillaria of Portugall.}

The leaues of this Fritillaria are fo fmall, narrow and long, that it hath caufed them to take the name of ruthes, as if you thould call it, The rufh leafed Fritillaria, which ftand on a long weake round ftalke, fet without order : the flower is Imall and yellow, but thicker checkerd with red Spots then any of the other yellow Fritillaria's; the ftalk of the flower, at the head thereof, being alfo of a yellowifh colour.

\section{Fritillaria Pyrenan fue Apenninea. The blacke Fritillaria.}

The roote of this kinde doth often grow fo great, that it feemeth like vnto the roote of a finall Crowne Imperiall : the ftalke is ftrong, round, and high, fet without order, with broader and whiter greene leaues then any of the former, bearing one, two, or three flowers ; fometimes at the toppe, being not fo large as thofe of the ordinary purple Fritillaria, but finaller, longer, and rounder, fometimes a little turning vp the brims or edges of the leaues againe, and are of a yellowith thining greene colour on 
the infide, fometimes fpotted with red fpots almoft through the whole infide of the flower, vnto the very edge, which abideth of a pale yellow colour, and fometimes there are very few fpots to be feene, and thofe from the middle onely on the infide (for on the outfide there neuer appeareth any fpots at all in this kinde) and fometimes with no thew of fpots at all, fometimes alfo of a more pale greene, and fometime of a more yellow colour: the outfide of the flowers doe likewife vary, for in fome the outfide of the leaues are of a darke fullen yellow, \&c. elfe more pale yellow, and in other of a darke purplifh yellow colour, which in fome is fo deepe, and fo much, that it rather feemeth blacke then purple or yellow, and this efpecially about the bottome of the flower, next vnto the ftalke, but the edges are ftill of a yellowifh greene: the head of feede, and the feede likewife is like vnto the former, but bigger in all refpects.

\section{Fritillaria Hispanica umbellifera. The Spanifh blacke Fritillaria.}

This Fritillaria is no doubt of kindred to the laft recited, it is fo like, but greater in all parts thereof, as if growing in a more fruitfull foile, it were the ftronger and luftier to beare more ftore of flowers: the flowers grow foure or fiue from the head together, hanging downe round about the ftalke, like vnto a Crowne Imperiall, and are of a yellowifh greene colour on the infide, fpotted with a few red fpots, the outfide being blackin as the former.

\section{The Place.}

The firft of thefe plants was firf brought to our knowledge from France, where it groweth plentifully about Orleance; the other forts grow in diuers other Countries, as fome in Portugall, Spaine, Italy, \&c. as their names doe import, and as in time they have been obferued by thofe that were curious fearchers of thefe rarities, haue been fent to vs.

\section{The Time.}

The early kindes doe flower in the beginning of Aprill or thereabouts, according to the mildeneffe or tharpeneffe of the precedent Winter. The other doe flower after the firft are paft, for a moneths fpace one after another, and the great yellow is very late, not flowring vntill about the middle or end of May.

\section{The Names.}

This hath receiued diuers names: fome calling it Flos Meleagridis, the Ginny Hen Flower, of the variety of the colours in the flower, agreeing with the feathers of that Bird. Some call it Narcifius Gaparonius, of the name of the firft inuentor or finder thereof, called Noel Caperon, an Apothecary dwelling in Orleance, at the time he firft found it, and was fhortly after the finding thereof taken away in the Maffacre in France. It is now generally called Fritillaria, of the word Fritillus, which diuers doe take for the Cheffe borde or table whereon they play, whereunto, by reafon of the refemblance of the great fquares or fpots fo like it, they did prefently referre it. It is called by Lobel Lilionarciffus purpureus variegatus, Es seffulatus, making it a kinde of Tulipa; but as I faid in the beginning of the Chapter, it doth moft neerely refemble a fmall pendulous Lilly, and might therefore rightly hold the name of Lilium variegatum, or in Englifh, the checkerd Lilly. But becaufe the errour which firft referred it to a Daffodill, is growne ftrong by cuftome of continuance, I leaue to euery one their owne will, to call it in Englifh eyther Fritillaria, as it is called of mot, or the checkerd Daffodill, or the Ginnie Hen flower, or, as I doe, the checkerd Lilly. I fhall not neede in this place further to explaine the feuerall names of euery of them, hauing giuen you them in their titles. 
The Vertues.

I have not found or heard by any others of any property peculiar in this plant, to be applied either inwardly or outwardly for any difeafe : the chiefe or onely vfe thereof is, to be an ornament for the Gardens of the curious louers of thefe delights, and to be worne of them abroad, which for the gallant beauty of many of them, deferueth their courteous entertainment, among many other the like pleafures.

\section{Ch A P. VIII.}

\section{Tulipa. The Turkes Cap.}

$\mathrm{N}$

Ext vnto the Lillies, and before the Narciffi or Daffodils, the difcourfe of Tulipas deferueth his place, for that it partaketh of both their natures; agreeing with the Lillies in leaues, flowers, and feede, and fomewhat with the Daffodils in rootes. There are not onely diuers kindes of Tulipas, but fundry diuerfities of colours in them, found out in thefe later dayes by many the fearchers of natures varieties, which haue not formerly been obferued : our age being more delighted in the fearch, curiofity, and rarities of thefe plearant delights, then any age I thinke before. But indeede, this flower, aboue many other, deferueth his true commendations and acceptance with all louers of thefe beauties, both for the ftately afpect, and for the admirable varietie of colours, that daily doe arife in them, farre beyond all other plants that grow, in fo much, that I doubt, although I hall in this Chapter fet downe the varieties of a great many, I thall leaue more vnfpoken of, then I thall defcribe; for I may well fay, there is in this one plant no end of diuerfity to be expected, euery yeare yeelding a mixture and variety that hath not before been obferued, and all this arifing from the fowing of the feede. The chiefe diuifion of Tulipas, is into two forts: Precoces, early flowring Tulipas, and Serotine, late flowring Tulipas. For that fort which is called Medice or Dubia, that is, which flower in the middle time betweene them both, and may be thought to be a kinde or fort by it felfe, as well as any of the other two: yet becaufe they doe neerer participate with the Serotina then with the Pracoces, not onely in the colour of the leafe, being of the fame greenneffe with the Serotina, and moft vfually alfo, for that it beareth his ftalke and flower, high and large like as the Serotina doe ; but ef pecially, for that the feede of a Media Tulipa did neuer bring forth a Precox flower (although I know Clufius, an induftrious, learned, and painfull fearcher and publifher of thefe rarities, faith otherwife) fo farre as euer I could, by mine owne care or knowledge, in fowing their feede apart, or the affurance of any others, the louers and fowers of Tulipa feede, obferue, learne, or know : and becaufe alfo that the feede of the Serotina bringeth forth Medias, and the feede of Medias Serotina, they may well bee comprehended vnder the generall title of Serotince: But becaufe they haue generally receiued the name of Media, or middle flowring Tulipas, to diftinguifh between them, and thofe that vfually doe flower after them; I am content to fet them downe, and fpeake of them feuerally, as of three forts. Vnto the place and ranke likewife of the Pracoce's, or early flowring Tulipas, there are fome other feuerall kinds of Tulipas to be added, which are notably differing, not onely from the former Pracox. Tulipa, but euery one of them; one from another, in fome fpeciall note or other: as the Tulipa Bolonien/is flore rubro, the red Bolonia Tulipa. Tulipa Bolonienfis flore lutes, the yellow Bolonia Tulipa. Tulipa Perfica, the Perfian Tulipa. Tulipa Cretica, the Candie Tulipa, and others : all which thall bee defcribed and entreated of, euery one apart by it felfe, in the end of the ranke of the Pracoces, becaufe all of them flower much about their time. To begin then with the Pracox, or early flowring Tulipas, and after them with the Medias and Serotinas, I hall for the better method, diuide their flowers into foure primary or principall colours, that is to fay, White, Purple, Red, and Yellow, and vnder euery one of thefe colours, fet downe the feuerall varie- 
ties of mixtures we haue feene and obferued in them, that fo they may be both the better defcribed by me, and the better conceiued by others, and euery one placed in their proper ranke. Yet I hall in this, as I intend to doe in diuers other plants that are variable, giue but one defcription in generall of the plant, and then fet downe the varietie of forme or colour afterwards briefly by themfelues.

\section{Tulipa.pracox. The early flowring Tulipa.}

The early Tulipa (and fo all other Tulipas) fpringeth out of the ground with his leaues folded one within another, the firft or loweft leafe rifeth vp firft, tharpe pointed, and folded round together, vntill it be an inch or two aboue the ground, which then openeth it felfe, fhewing another leafe folded alfo in the bofome or belly of the firft, which in time likewife opening it felfe, theweth forth a third, and fometimes a fourth and a fifth: the lower leaues are larger then the vpper, and are faire, thicke, broad, long, and hollow like a gutter, and fometimes crumpled on the edges, which will hold water that falleth thereon a long time, of a pale or whitifh greene colour, (and the Medice and Serotince more greene) couered ouer as it were with a mealineffe or hoarineffe, with an eye or fhew of redneffe towards the bottome of the leaues, and the edges in this kinde being more notable white, which are two principall notes to know a Pracox Tulipa from a Media or Serotina: the ftalke with the flower rifeth vp in the middle, as it were through thefe leaues, which in time ftand one aboue another, compaffing it at certaine vnequall diftances, and is often obferued to bend it felfe crookedly downe to the ground, as if it would thruft his head thereinto, but turning vp his head (which will be the flower) againe, afterwards ftandeth vpright, fometimes but three or foure fingers or inches high, but more often halfe a foote, and a foot high, but the Medias, and Serotinas much higher, carrying (for the moft part) but one flower on the toppe thereof, like vnto a Lilly for the forme, confifting of fixe leaues, greene at the firft, and afterwards changing into diuers and fundry feuerall colours and varieties, the bottomes likewife of the leaues of thefe fometimes, but moft efpecially of the Medice, being as variable as the flower, which are in fome yellow, or green, or blacke, in others white, blew, purple, or tawnie; and fometimes one colour circling another: fome of them haue little or no fent at all, and fome haue a better then others. After it hath been blowne open three or foure dayes or more, it will in the heate of the Sunne fpread it felfe open, and lay it felfe almoft flat to the ftalke : in the middle of the flower ftandeth a greene long head (which will be the feed veffell) compaffed about with fixe chiues, which doe much vary, in being fometimes of one, and fometimes of another colour, tipt with pendents diuerfly varied likewife : the head in the middle of the flower groweth after the flower is fallen, to be long, round, and edged, as it were three fquare, the edges meeting at the toppe, where it is fmalleft, and making as it were a crowne (which is not feen. in the head of any Lilly) and when it is ripe, diuideth it felfe on the infide into fixe rowes, of flat, thinne, brownifh, griftly feede, very like vnto the feede of the Lillies, but brighter, ftiffer, and more tranfparent : the roote being well growne is round, and fomewhat great, fmall and pointed at the toppe, and broader, yet roundifh at the bottome, with a certaine eminence or feate on the one fide, as the roote of the Colchicum hath; but not fo long, or great, it hath alfo an hollowneffe on the one fide (if it haue borne a flower) where the ftalke grew, (for although in the time of the firft fpringing $v p$, vntill it thew the budde for flower, the ftalke with the leaues thereon rife vp out of the middle of the roote; yet when the ftalke is rifen vp, and fheweth the budde for flower, it commeth to one fide, making an impreffion therein) couered ouer with a brownifh thin coate or skin, like an Onion, hauing a little woollineffe at the bottome ; but white within, and firme, yet compored of many coates, one folding within another, as the roote of the Daffodils be, of a reafonable good tafte, neyther very fweete, nor yet vnpleafant. This defcription may well ferue for the other Tulipas, being Medias or Serotimas, concerning their fpringing and bearing, which haue not any other great variety therein worth the note, which is not expreffed here; the chiefe difference refting in the variety of the colours of the flower, and their feuerall mixtures and markes, as I faid before : fauing onely, that the flowers of fome are great and large, and of others finaller, and the leaues of fome long 


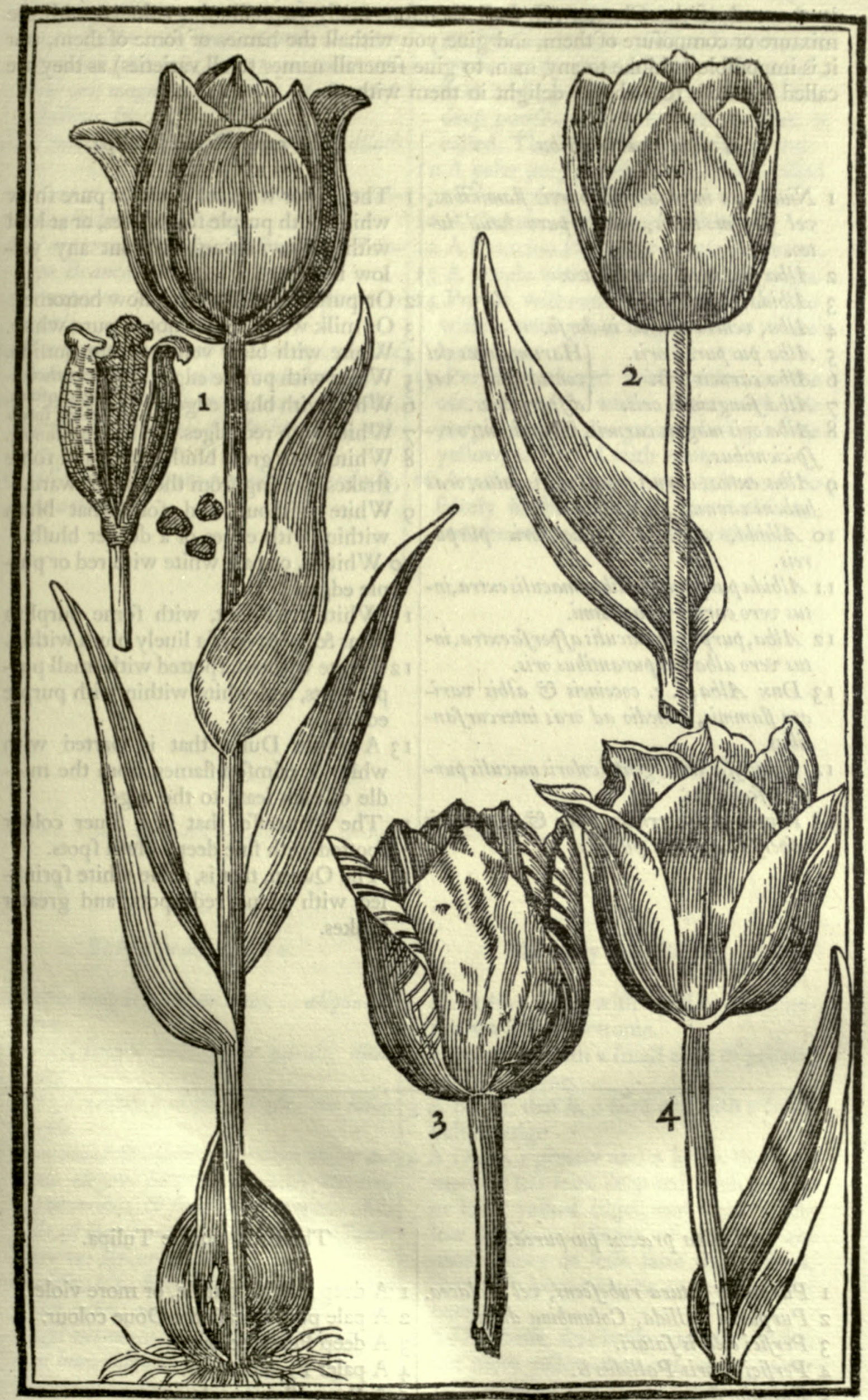

I Tulipa pracox alba fue rubra, Ecc. vnius coloris. The early white or red Tulipa, \&c. being of one colour. 2 Tulipa pracox purpurea oris albis. The early purple Tulipa with white edges, or the Prince. 3 Tulipa pracox variegata. The early ftript Tulipa. A Tulipa pracox rubra oris luteis. The early red Tulipa with yellow edges, or the Duke. 
and pointed, and of others broad and round, or bluntly pointed, as fhall bee fhewed in the end of the Chapter: I thall therefore onely expreffe the colours, with the mixture or compofure of them, and giue you withall the names of fome of them, (for it is impoffible I thinke to any man, to giue feuerall names to all varieties) as they are called by thore that chiefly delight in them with vs.

\section{Tulipa pracox Alba.}

I Niuea tota interdum purpureis faminibus, vel Saltem luteis, fundo puro haud luteo.

2 Alba fiue niuea fundo luteo.

3 Albida.

4 Alba, venis caruleis in dorfo.

5 Alba purpureis oris.

6 Alba carneis oris.

7 Alba fanguineis oris.

Harum flores vel constantes, vel

8 Alba oris magnis carneis, Eै venis intro reSpicientibus.

9 Alba extra, carnei vero coloris intus, oras habens carneas faturatiores.

Io Albida, oris rubris, vel oris purpureis.

I I Albida purpurafcentibus maculis extra, intus vero carnei viuacissimi.

I 2 Alba, purpureis maculis afperfaextra, intus vero alba purpurantibus oris.

I 3 Dux Alba, i. e. coceineis Eo albis variata flammis, à medio ad oras intercurfantibus.

14 Princeffa, i.e.argenteicoloris maculispurpurafcentibus.

I 5 Regina pulcherrima, albis EJ fanguineis a/perfa radijs E़ punctis.
The early White Tulipa.

I The flower whereof is either pure fnow white, with purple fometimes, or at leaft with yellow chiues, without any yellow bottome.

2 Or pure white with a yellow bottome.

3 Or milk white that is not fo pure white.

4 White with blew veines on the outfide.

5 White with purple edges. Some of there a-

6 White with blufh edges. biding conftant,

White with red edger others fprea-

8 White with great blufh edges, and fome ftrakes running from the edge inward.

9 White without, and fomewhat blum within, with edges of a deeper blurh.

Io Whitifh, or pale white with red or purple edges.

I I Whitifh without, with fome purplifh veins \& fpots, \& of a liuely blufh within.

I 2 White without, fpotted with fmall purple fpots, and white within with purple edges.

I 3 A white Duke, that is, parted with white \& crimfon flames, from the middle of each leafe to the edge.

I 4 The Princeffe, that is, a filuer colour potted with fine deepe blun fpots.

I 5 The Queen, that is, a fine white fprinkled with bloud red fpots, and greater ftrakes.
Tulipa pracox purpurea.

I Purpurea fatura rubefcens, vel violacea.

2 Purpurea pallida, Columbina dicta.

3 Perfici coloris faturi.

4 Perfici coloris Pallidioris.

5 Paeonia floris coloris.

6 Rolea.

7 Chermefiua peramana.

8 Chermefiua parum friata.
The early purple Tulipa.

I A deep reddifh purple, or more violet.

2 A pale purple, called a Doue colour.

3 A deep Peach colour.

4 A paler Peach colour.

5 A Peony flower colour.

6 A Rofe colour.

7 A Crimfon very bright.

8 A Crimfon ftript with a little white. 
9 Princeps, i.e. purpurea faturatior vel dilutior, oris albis magnis vel paruis, fundo luteo, vel albo orbe, qua multum variatur, $\mathcal{E}^{2}$ colore, $\mathcal{E}^{2}$ oris, ita vt purpurea elegans oris magnis albis, dicta est, Princeps excellens, \&5

1o Princeps Columbina, purpurea dilutior.

I I Purpurea Chermefina, rubicandioris coloris, albidis vel albis oris.

I 2 Purpurea, vel obfoleta albidis oris Princeps Brancion.

I3 Purpurea diluta, oris dilutioris purpurei coloris.

14 Purpurea in exterioribus, carnei vero ad medium intus, oris albis, fundo luteo.

I 5 Purpurea albo plumata extra, oris albis, purpurafcens intus, fundo luteo, vel orbe albo.

I6 Alia, minus elegans plumata, minoribu/g, oris albidis.
A Prince or Bracklar, that is, a deepe or pale purple, with white edges, greater or fmaller, and a yellow bottome, or circled with white, which varieth much, both in the purple $\&$ edges, fo that a faire deep purple, with great white edges, is called, The beft or chiefe Prince, and

Io A paler purple with white edges, called a Doue coloured Prince.

I I A Crimfon Prince or Bracklar.

I 2 A Brancion Prince, or purple Brancion.

I 3 A purple with more pale purple edges.

I 4 Purple without, and blufh halfe way within, with white edges, and a yellow bottome.

I 5 Purple feathered with white on the out fide, with white edges, and pale purple within, the ground being a little yellow, or circled with white.

I 6 Another very neere vnto it, but not fo fairely feathered, being more obfcure, and the edges not fo great or whitifh.
Tulipa pracox rubra.

I Rubra vulgaris fundo luteo, aliquando nigro.

2 Rubra fatura oris luteis paruis, dicta Roan.

3 Baro, i. e. rubra magis intenfa, oris luteis paruis.

4 Dux maior \&5 minor, i.e. rubra magis aut minus elegans fatura, oris luteis maximis vel minoribus, Eे fundo luteo magno. Alia alijs eft magis amona, in alijs etiam fundo nigro vel obfcuro viridi.

5 Duciffa, i. e. Duci firmilis, at plus lutei quàm rubri, oris magnis luteis, है rubore magis aut minus intus in gyrum acto, fundo item luteo magno.

6 Testamentum Brancion, i.e. rubra fanguinea fatura, aut minus rubra, oris pallidis, magnis vel paruis : alia alijs magis aut minus elegans diuer fimodo.
The early red Tulipa.

An ordinary red, with a yellow, \& fometimes a blacke bottome.

2 A deep red, with a fmall edge of yellow, called a Roane.

3 A Baron, that is, a faire red with a fmall yellow edge

4 A Duke, a greater and a leffer, that is, a more or lefs faire deep red, with greater or leffer yellow edges, and a great yellow bottome. Some of this fort are much more or leffe faire then others, fome alfo haue a blacke or darke greene bottome.

5 A Dutcheffe, that is like vnto the Duke, but more yellow then red, with greater yellow edges, and the red more or leffe circling the middle of the flower on the infide, with a large yellow bottome.

6 A Teftament Brancion, or a Brancion G

Duke, 
7 Flambans, ex rubore $\&$ flauedine radiata, vel friata fundo luteo.

8 Mali Aurantij coloris, ex rubore, E flauedinè integre, non feparatim mixta, oris luteis paruis, vel ab $\int_{g}$, oris.

9 Minij, fuue Cinabaris coloris, i.e. ex purpurea, rubedine, Es flanedine radiata, vnguibus luteis, E๐ aliquando oris.

Io Rex Tuliparum, i.e.ex Janguineo $\mathcal{E}^{\circ}$ aureo radiatim mixta, à flammea diuer $\int a$, fundo luteo, orbe rubro.

I I Tunica Morionis, i.e. ex rubore Eु aureo Jeparatim diuerfa.
Duke, that is, a faire deepe red, or leffe red, with a pale yellow or butter coloured edge, fome larger others fmaller: and fome more pleafing then others, in a very variable manner.

A Flambant, differing from the Dutcheffe; for this hath no fuch great yellow edge, but ftreaks of yellow through the leafe vnto the very edge.

8 An Orenge colour, that is, a reddifh yellow, or a red and yellow equally mixed, with fmall yellow edges, and fometimes without.

9 A Vermillion, that is, a purplifh red, ftreamed with yellow, the bottome yellow, and fometimes the edges.

Io The Kings flower, that is, a crimfon or bloud red, ftreamed with a gold yellow, differing from the Flambant, the bottome yellow, circled with red.

I I A Fooles coate, parted with red and yellow guardes.
Tulipa pracox lutea.

I Lutea fiue flaua.

2 Pallida lutea fiue ftraminea.

3 Aurea, oris rubicundis.

4 Straminea, oris rubris.

5 Aurea, rubore perfusa extra.

6 Aurea, vel magis pallida, rubore in gyrum aEta fimillima Duciffa, nifi minus rubedinis habet.

7 Aurea, extremitatibus rubris, dici poteft, Morionis Pilaus pracox.
The early yellow Tulipa.

I A faire gold yellow without mixture.

2 A ftrawe colour.

3 A faire yellow with reddifh edges.

4 A ftrawe colour, with red edges.

5 A faire yellow, reddifh on the out fide onely.

6 A gold or paler yellow, circled on the infide a little with red, very like the Dutcheffe, but that it hath leffe red therein.

7 A gold yellow with red toppes, and may be called, The early Fooles Cap.
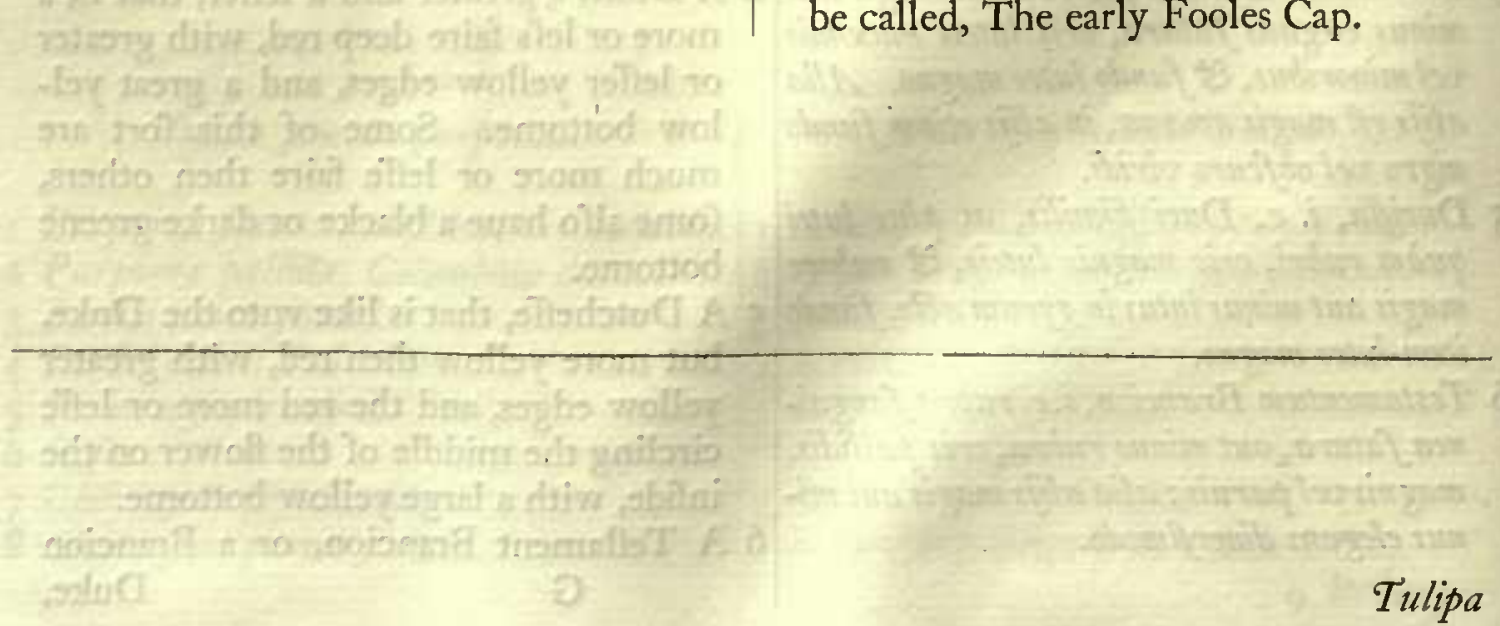


\section{Tulipa de Caffa. The Tulipa of Caffa.}

There is another fort or kinde of early Tulipa, differing from the former, whofe pale greene leaues being as brond and large as they, and fometimes crumpled or waued at the edges, in fome haue the edges onely of the faid leaues for a good breadth, of a whitifh or whitill yellow colour, and in others, the leaues are lifted or parted with whitifh yellow and greene: the ftalke rifeth not vp fo high as the former, and beareth a flower at the toppe like vnto the former, in fome of a reddifh yellow colour, with a ruffet coloured ground or bottome, and in others, of other feuerall colours: the feede and roote is fo like vnto others of this kinde, that they cannot be diftinguifhed.

There is (as I doe heare) of this kinde, both Pracoces, and Serotine, early flowring, and late flowring, whereof although wee haue not fo exact knowledge, as of the relt, yet I thought good to f peake fo much, as I could hitherto vnderftand of them, and give others leaue (if I doe not) hereafter to amplifie it.

\section{Tulipa Bolonienfis, fue Bombycina fore rubro major. \\ The greater red Bolonia Tulipa.}

There are likewife other kindes of early Tulipas to bee fpoken of, and firt of the red Bolonia Tulipa; the roote whereof is plainly difcerned, to be differing from all others: for that it is longer, and not hauing fo plaine an eminence at the bottome thereof, as the former and later Tulipas, but more efpecially becaufe the toppe is plentifully iftored with a yellowifh filke-like woollineffe: the outfide likewife or skinne is of a brighter or paler red, not fo eafie to be pilled away, and runneth vnder ground both downeright and fidewife (efpecially in the countrey ground and ayre, where it will encreafe aboundantly, but not either in our London ayre, or forc't grounds) fomewhat like vnto the yellow Bolonia Tulipa next following. It thooteth out of the ground with broad and long leaues, like the former; but neither fo broad, nor of fo white or mealy a greene colour as the former, but more darke then the late flowring Tulipa, fo that this may bee eafily difcerned by his leafe from any other Tulipa aboue the ground, by one that is skilfull. It beareth likewife three or foure leaues vpon the ftalke, like the former, and a flower alfo at the toppe of the fame fafhion, but that the leaues hereof are alwayes long, and fomewhat narrow, hauing a large blacke bottome, made like vnto a cheuerne, the point whereof rifeth vp vnto the middle of the leafe, higher then any other Tulipa ; the flower is of a pale red colour, nothing fo liuely as in the early or late red Tulipas, yet fweeter for the moft part then any of them, and neereft vnto the yellow Bolonia Tulipa, which is much about the fame fent.

\section{Tulipa pumilio rubra, fuue Bergomenfis rubra media \& minor.}

The dwarfe red Bergomo Tulipa, a bigger and a leffer.

There are two other forts hereof, and becaufe they were found about Bergomo, do carry that name, the one bigger or leffer then another, yet neither fo great as the former, hauing very little other difference to bee obferued in them, then that they are fmaller in all parts of them.

\section{Tulipa Bolonienfis fore luteo. The yellow Bolonia Tulipa.}

The roote of this Tulipa may likewife bee knowne from the former red (or any other Tulipa) in that it feldome commeth to bee fo bigge, and is not fo woolly at the toppe, and the skinne or outfide is fomewhat paler, harder, and fharper pointed : but the bottome is like the former red, and not fo eminent as the early or late Tulipas. This beareth much longer and narrower leaues then any (except the Perfian $\&$ dwarfe yellow Tulipas) and of a whitifh greene colour : it beareth fometimes but one flower on a ftalke, and fometimes two or three wholly yellow, but fmaller, \& more open then the other kinds, and (as I faid) fmelleth fweete, the head for feede is fmaller then in others, and hath not that crowne at the head thereof, yet the feed is like, but fmaller. 


\section{Tulipa Narbonenfis, fue Monspelienfis vel pumilio.}

The French or dwarfe yellow Tulipa.

This Tulipa is very like vnto the yellow Bolonia Tulipa, both in roote, leafe, and flower, as alfo in the colour thereof, being yellow: the onely difference is, that it is in all things leffer and lower, and is not fo apt to beare, nor fo plentifull to encreafe by the roote.

\section{Tulipa Italica maior \& minor. The Italian Tulipa the greater and the leffer.}

Both thefe kindes of Tulipas doe fo neere refemble the laft kinde, that I might almoft fay they were the fame, but that fome difference which I faw in them, maketh mee fet them apart; and confifteth in thefe things, the ftalkes of neither of both thefe rife fo high, as of the firt yellow Bolonia Tulipa: the leaues of both forts are writhed in and out at the edges, or made like a waue of the fea, lying neerer the ground, and the flower being yellow within, is brownifh or reddifh on the backe, in the middle of the three outer leaues the edges appearing yellow. Both thefe kindes doe differ one from the other in nothing, but in that one is bigger, and the other fmaller then the other which I faw with Iohn Tradefcante, my very good friend often remembred.

\section{Tulipa Lufitanica, fiue pumilio verficolor. The dwarfe ftript Tulipa.}

This dwarfe Tulipa is alfo of the fame kindred with the three laft defcribed; for there is no other difference in this from them, then that the flower hath fome red veins running in the leaues thereof.

There are two other forts of dwarfe Tulipas with white flowers, whereof Lobel hath made mention in the Appendix to his Aduerfaria; the one whereof is the fame that Clufius fetteth forth, vnder the title of Pumilio altera : but becaufe I have not feen either of them both, I fpeake no further of them.

\section{Tulipa pumilio alba. The white dwarfe Tulipa.}

But that white flower that Iohn Tradefcante fhewed me, and as hee faith, was deliuered him for a white Pumilio, had a ftalke longer then they fet out theirs to haue, and the flower alfo larger, but yet had narrower leaues then other forts of white Tulipas haue.

\section{Tulipa Bicolor. The fmall party coloured Tulipa.}

Vnto thefe kindes, I may well adde this kinde of Tulipa alfo, which was fent out of Italy, whofe leaues are fmall, long, and narrow, and of a darke greene colour, fomewhat like vnto the leaues of an Hyacinth: the flower is fmall alfo, confifting of fixe leaues, as all other Tulipas doe, three whereof are wholly of a red colour, and the other three wholly of a yellow.

\section{Tulipa Perfica. The Perfian Tulipa.}

This rare Tulipa, wherewith we haue beene but lately acquainted, doth moft fitly deferue to be defcribed in this place, becaufe it doth fo neerely participate with the Bolonia and Italian Tulipas, in roote, leafe, and flower : the roote hereof is fmall, couered with a thicke hard blackifh fhell or skinne, with a ycllowifh woollineffe both at the toppe, and vnder the thell. It rifeth out of the ground at the firft, with one very long and fmall round leafe, which when it is three or foure inches high, doth open it felfe, and thew forth another fmall leafe (as long almoft as the former) breaking out of the one fide thereat, and after it a third, and fometimes a fourth, and a fift; but each fhorter then other, which afterwards be of the breadth of the dwarfe yellow Tulipa, or fomewhat broader, but much longer then any other, and abiding more hollow, and of the colour of the early Tulipas on the infide: the ftalke rifeth vp a foot and a halfe 


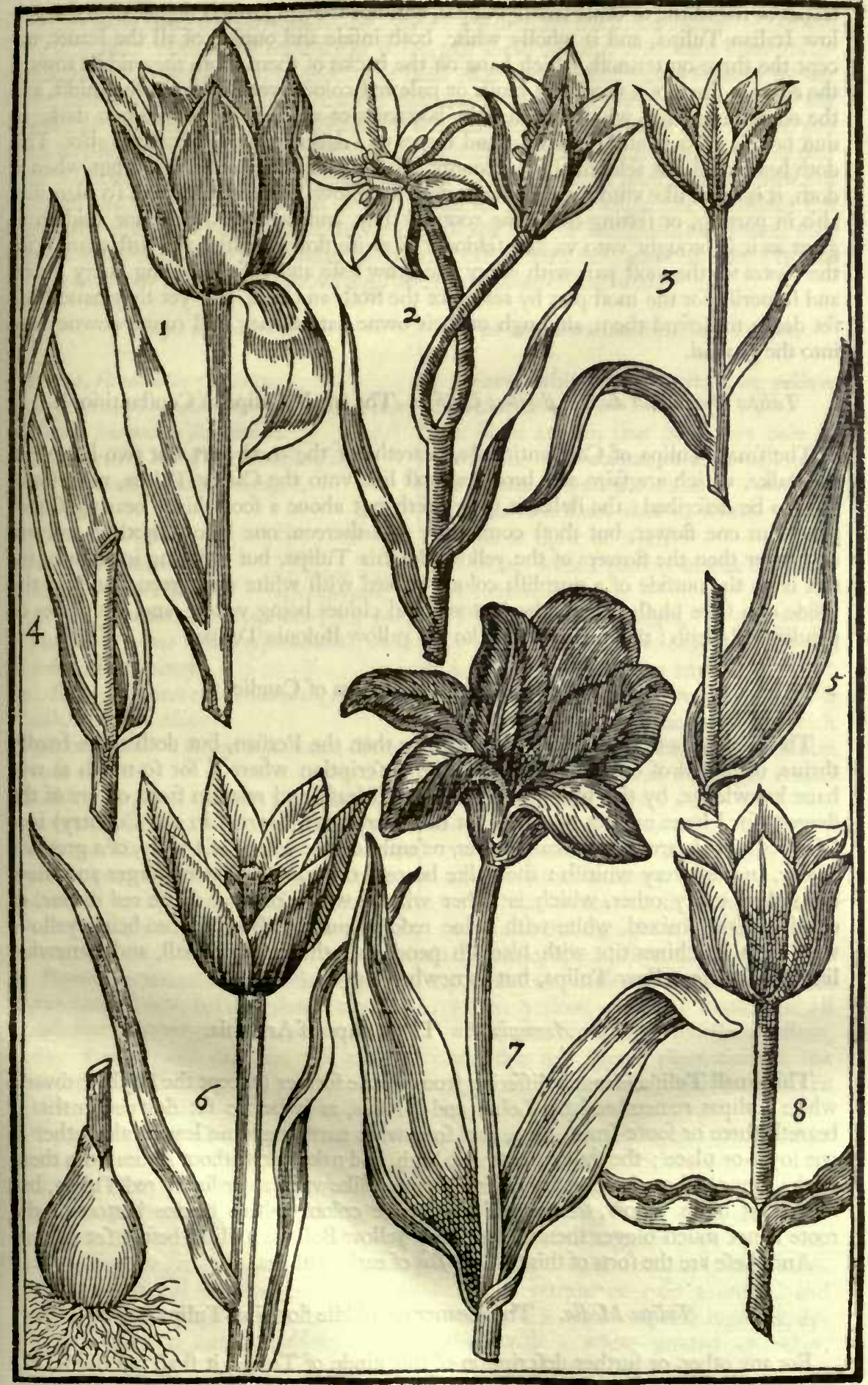

1 Tulipa Bombycina forerubro. Thered Bolonia Tulipa. 2 Tulipa Bolonienfis fore Iutco. The yellow Bolonia Tulipa. 3 Tulipa pumilio rubra fixe lutea. The red or yellow dwarfe Tulipa. 4 Folium Tulisa de Caffa per lotum firiatum. The leafe of the Tulipa of Caffa ltriped throughout the whole leafe. 5 Folium Tulipa de Caff a per oras firialum. The leafe of the Tulipa of $\mathrm{C}_{2}$ fif ftriped at the edges onely: 6 Tulipa Perfica. The Perfian Tulipa. 7 Tulifa Crelica. The Tolipa of Candie. 8 Tulifa Armeniaca. The Tulipa of Amenia. 
high fometimes, bearing one flower thereon, compofed of fixe long and pointed leaues of the forme of other fmall Tulipas, and not fhewing much bigger then the yellow Italian Tulipa, and is wholly white, both infide and outfide of all the leaues, except the three outtermont, which haue on the backe of them, from the middle toward the edges, a fhew of a brownifh blufh or pale red colour, yet deeper in the midft, and the edges remaining wholly white: the bottomes of all thefe leaues are of a darke or dun tawnie colour, and the chiues and tippes of a darkinh purple or tawnie alfo. This doth beare feed but feldome in our country, that euer I could vnderftand, but when it doth, it is fmall like vnto the Bolonia or dwarfe yellow Tulipas, being not fo plentifull alfo in parting, or fetting of by the roote as they, and neuer groweth nor abideth fo great as it is brought vnto vs, and feldome likewife flowreth after the firft yeare : for the rootes for the moft part with euery one grow leffe and leffe, decaying euery yeare, and fo perifh for the moft part by reafon of the frofts and cold, and yet they haue been fet deepe to defend them, although of their owne nature they will runne downe deep into the ground.

\section{Tulipa Byzantina duobus floribus Clufij. The fmall Tulipa of Conftantinople.}

The fmall Tulipa of Conftantinople, beareth for the moft part but two leaues on the ftalke, which are faire and broad, almoft like vnto the Candy Tulipa, next hereunto to be defcribed: the ftalke it felfe rifeth not aboue a foote high, bearing fometimes but one flower, but moft commonly two thereon, one below another, and are no bigger then the flowers of the yellow Bolonia Tulipa, but differing in colour; for this is on the outfide of a purplifh colour, mixed with white and greene, and on the infide of a faire blufh colour, the bottome and chiues being yellow, and the tippes or pendents blackifh : the roote is very like the yellow Bolonia Tulipa.

\section{Tulipa Cretica. The Tulipa of Candie.}

This Tulipa is of later knowledge with vs then the Perfian, but doth more hardly thriue, in regard of our cold climate; the defcription whereof, for fo much as wee haue knowledge, by the fight of the roote and leafe, and relation from others of the flower, (for I haue not yet heard that it hath very often flowred in our Country) is as followeth. It beareth faire broad leaues, refembling the leaues of a Lilly, of a greenifh colour, and not very whitifh : the ftalke beareth thereon one flower, larger and more open then many other, which is either wholly white, or of a deepe red colour, or elfe is variably mixed, white with a fine reddifh purple, the bottomes being yellow, with purplifh chiues tipt with blackifh pendents : the roote is fmall, and fomewhat like the dwarfe yellow Tulipa, but fomewhat bigger.

\section{Tulipa Armeniaca. The Tulipa of Armenia.}

This fmall Tulipa is much differing from all the former (except the fmall or dwarfe white Tulipas remembred by Lobel and Clufius, as is before fet downe) in that it beareth three or foure fmall, long, and fomewhat narrow greene leaues, altogether at one ioynt or place ; the ftalke being not high, and naked or without leaues from them to the toppe, where it beareth one fmall flower like vnto an ordinary red Tulipa, but fomewhat more yellow, tending to an Orenge colour with a blacke bottome : the roote is not much bigger then the ordinary yellow Bolonia Tulipa, before fet downe.

And thefe are the forts of this firf Cla/sis of early Tulipas.

\section{Tulipa Media. The meaner or middle flowring Tulipa.}

For any other, or further defcription of this kinde of Tulipa, it thall not neede, hauing giuen it fufficiently in the former early Tulipa, the maine difference confifting firft in the time of flowring, which is about a moneth after the early Tulipas, yet fome more fome leffe : for euen in the Pracoces, or early ones, fome flower a little earlier, and later then others, and then in the colours of the flowers; for wee have obferued many 
colours, and mixtures, or varieties of colours in the Medias, which we could neuer fee in the Precoces, and fo alfo fome in the Pracoces, which are not in the Medias : yet there is farre greater varieties of inixture of colours in thefe Midias, then hath been obferued in all the Prrecoces, (although Clufius faith otherwife) eyther by my felfe, or by any other that I haue conuerfed with about this matter, and all this hath happened by the fowing of the feede, as I faid before. I will therefore in this place not trouble you with any further circumftance, then to diftinguin them, as I haue done in the former early Tulipas, into their foure primary colours, and vnder them, giue you their feuerall varieties and names, for fo much as hath come to my knowledge, not doubting, but that many that have trauelled in the fowing of the feed of Tulipas many yeares, may obferue each of them to haue fome variety that others haue not: and therefore I thinke no one man can come to the knowledge of all particular diftinctions.

Tulipa media alba.

I Niuea, fundo albo vel luteo.

2 Argentea, quafi alba cineracea fundo lutefcente, purpureis faminibus.

3 Margaritina alba, carneo dilutifsima.

4 Alba, fundo caruleo vel nigro.

5 Albida.

6 Alba, oris rubris.

7 Alba, purpureis oris.

8 Alba, oris coccineis.

(Hectria genera in aliguibus confianter tenent oras, in alijs difpergunt.

9 Albida primum, deinde albidior, oris purpureis, \& venis intrò refpicientibus, dizza mobis Hackquenay.

Io Alba, fanguineo colore variata, fundo vel albifsimn, vel alio.

I I Alba, radiatim difpofita flammis, $\mathcal{E}$ maculis coccineis.

12 Alba, purpurea rubedine plumata, diuerfarum Specierum, qua cum fuperiore, vel albo, vel liuteo, vel paruo caruleo constant fundo, qua conftanter tenent punczatos colares, \& non difpergunt, fed poft trium aut quatuor dierum $\int p a t i u m$ pulchriores apparent.

13 Panni argentei coloris, i.e. alba, plumata, puncanta, friata, vel diuer fimodè variata, rubedine dilutiore, vel faturatiore purpurea, interius vel exterius, vel vtrings, diuerfarum Specierum.

14 Tunica morionis alba varia, i.e. ex albo \& purpureo friata diuer fimode, fundo albo vel alio.

I 5 Holias alba vel albida, ab $\int \dot{8}$, fiundo, vel fundopurpureocaruleo, vel caruleoalbocircundato, diuersè fignata, vel variata intus ad medietatem foliorum, furfum in orbem vt plurimum, vel ad oras pertingens amplas E albas. Ha species tantoperè multiplicantur, vt vix fint explicabiles.
The white meane flowring Tulipa.

I A fnow white, with a white or yellow bottome.

2 A filuer colour, that is, a very pale or whitifh ante colour, with a yellowif? bottome and purple chiues.

3 A Pearle colour, that is, white, with a walh or fhew of blufh.

4 A white, with a blew or blacke bottome.

5 A Creame colour.

6 A white, with red edges. Therfe three fores

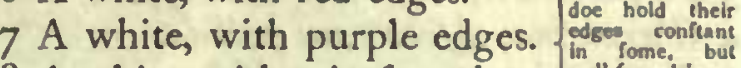

8 A white, with crimfon edges. $\begin{aligned} & \text { well forpend in a } \\ & \text { inerp, }\end{aligned}$

9 A pale or whitifh yellow, which after a few dayes groweth more white, with purplifh red edges, and fome ftreakes running inward from the edge, which we call an Hackney.

10. A white mixed with a bloud red very variably, and with a pure white, or other coloured bottome.

I A white, Atreamed with crimfon flames, and fpots through the whole flower.

I2 A white, Speckled with a reddifh purple, more or leffe, of diuers forts, with white, yellow, or blew bottomes, all which doe hold their markes conftant, and doe not Spread their colours, but thew fairer after they haue food blown three or foure dayes.

13 A cloth of filuer of diuers forts, that is, a white fpotted, ftriped, or otherwife marked with red or purple, in fome paler, in fome deeper, either on the infide, or on the outfide, or on both.

I 4 A white Fooles coate of diuers forts, that is, purple or pale crimfon, and white, as it were empaled together, eyther with a white ground or other, whereof there is great variety.

I 5 A white Holias, that is, a faire white, or paler white, eyther without a bottome, or with a blewifh purple bottome, or blew and white circling the bottome, 
Tanta eft buius varietas, vel multitudine,
vel friarum paucitate $E$ diffinctione, fundis variantibus, vt ad tadium effet perfribere. and from the middle vpwards, fpeckled and ftraked on the infide for the moft part, with bloud red or purplifh fpots and lines vnto the very edges, which abide large and white. Of this kinde there are found very great varieties, not to be expreffed.

Of this fort there is fo much variety, fome being larger or fairer marked then others, their bottomes alfo varying, that it is almoft impoffible to exprefs them.
Tulipa media purpurea.

I Purpurea fatura.

2 Purpurea dilutior, diuer farum Specierum, quarum Rofea vna, Carnea fit altera.

3 Perficicoloris, duarum aut trium specierum.

4 Chermefina, obfcura aut pallida.

5 Stamela, intenfior aut remifsior.

6 Xerampelina.

7 Purpurea, Ariata.

8 Perfici faturi, vel diluti coloris, vndulata, vel radiata.

9 Columbina, oris $\mathcal{E}^{2}$ radijs albis.

Io Purpurearubra, oris, albis, fimilis Pracoci, dicta Princeps.

I Ghermefina, vel Heluola, lineis albis in medio, Ev verfus or as, fundo caruleo, vel albo, items, albo orbe.

I2 Purpurea remissior, aut intenfior, oris albis, paruis aut magnis, vt in Principe pracoci, fundò vel caruleo orbe albo, vel albo orbe caruleo amplo.

I 3 Holias Heluola, fanguineis guttis intus à medio furfum in orbem, fundo caruleo.

14 Tunica Morionis purpurea rubra fatura, albido friata, quam in alba faturatior, fundo ex caruleo EO albo.

${ }_{5}$ Purpurea rubra faturavel diluta, albovel albedine, punctata vel friata diuerfimodè, dicta Cariophyllata.
The meane flowring purple Tulipa.

I A faire deep purple.

2 A paler purple, of many forts, whereof a Rofe colour is one, a Blufh another.

3 A Peach colour of two or three forts.

4 A Crimfon, deepe, or pale.

5 A Stamell, darke or light.

6 A Murrey.

7 A purple, ftript and Cpotted.

8 A Peach colour, higher or paler, waued or ftript.

9 A Doue colour, edged and ftraked with white.

10 A faire red purple, with white edges, like vnto the early Tulipa, called a Prince.

I A faire crimfon, or Claret wine colour, with white lines both in the middle, and towards the edges, moft haue a blew bottome, yet fome are white, or circled with white.

I 2 A light or deepe purple, with white edges, greater or fmaller, like the early Prince, the bottomes eyther blew circled with white, or white circled with a large blew.

I 3 A purple Holias, the colour of a pale Claret wine, marked and fpotted with bloud red rpots, round about the middle of each leafe vpward on the infide onely, the bottome being blew.

14 A Crimfon Fooles Coate, a darke crimfon, and pale white empaled together, differing from the white Fooles Coate, the bottome blew and white.

I 5 A deeper or paler reddifh purple, fpotted or ftriped with a paler or purer white, of diuers forts, called the Gilloflower Tulipa.

Tulipa 


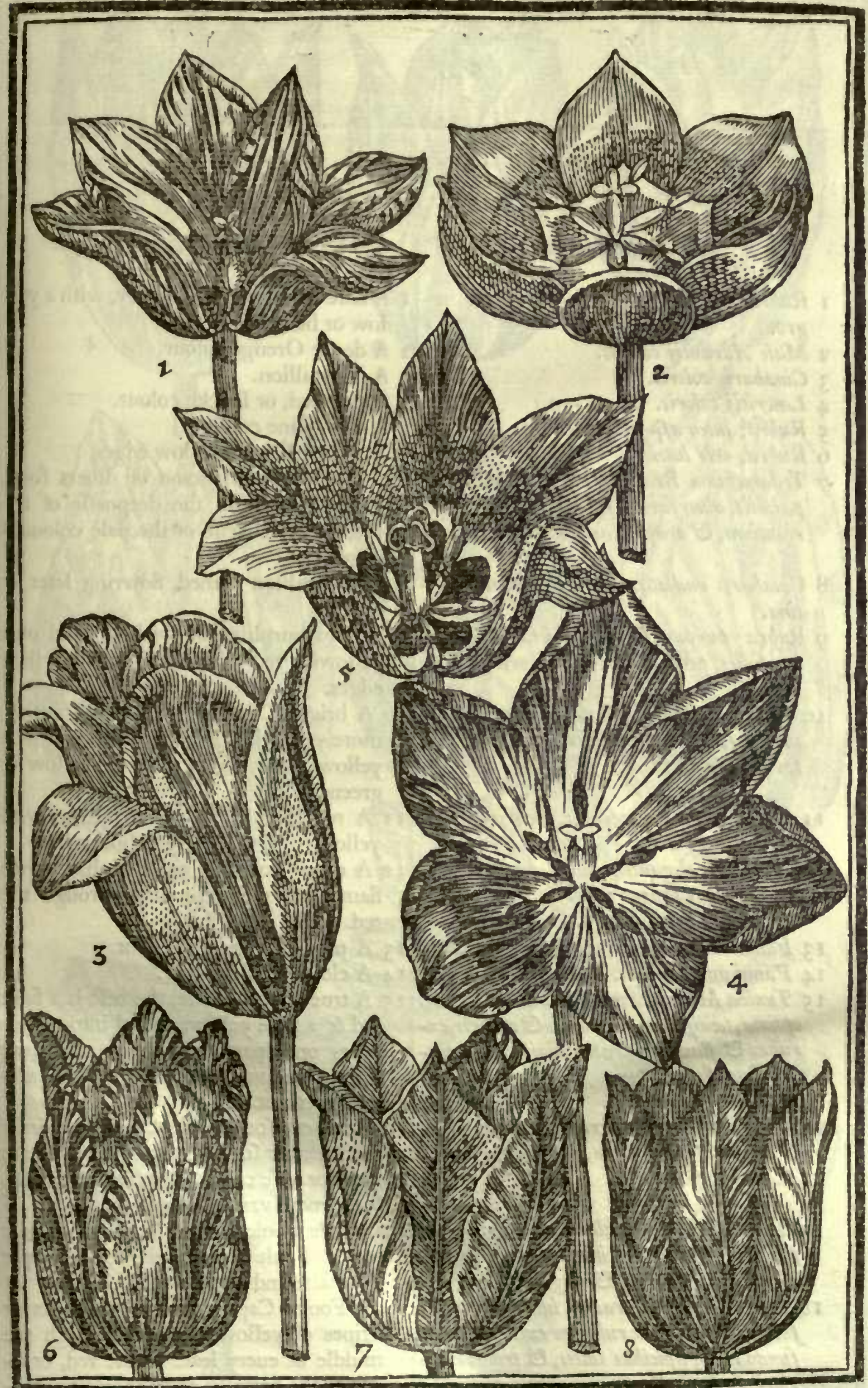

I Tulipa rubra \& luea varia. The Fooles Coate red andyellow. a Tulipa Haleas alba abfg. fundo. The white Holeas without a botsome. 3 Twlipa argensea, rel'punctata, Es. The cloth of filuer, or other fpotted Tulipa. 4 Twlipa alba Aammis coccineis. The white Fooles Coate. 5 Twlipa Holeas alla, Goc. fmudo purpureo, Ex. A white Holeas, \&c. with a purple bottome, \&c. 6 Tulipa Tulipa. 8 Tulitu alecra variata, \&. Another vasiable Tulipa. 
Tulipa media rubra.

I Rubra communis, fundo luteo, vel nigro.

2 Mali Aurantij coloris.

3 Cinabaris coloris.

4 Lateritij coloris.

5 Rubra, luteo afperfa.

6 Rubra, oris luteis.

7 Tefamentum Brancion rubra fatura, oris pallidis, diuerfarum Specierum, rubore variantium, ED orarum amplitudine.

8 Cinabaris radiata, magis aut minus ferotina.

9 Rubra purpurafcens obfoleta exteriori- 9 bus folijs, perfufa luteo intus, oris pallidis luteis.

10 Rubra purpurafcens elegans extra ED intus lutefcens, oris pallidis luteis, fundo luteo vel viridi.

I I Rubra flambans coccinea, crebris maculis huteis abj $\dot{g}_{\mathrm{s}}$ fundo.

I2 Flambans elegantior rubra, i.e. radijs luteis intercurfantibus ruborem.

13 Flambans remifsior vtrogs colore.

I4 Panni aurei coloris.

I 5 Tunica Morionis verior, Jeu Palto du Sot. optima, tanijs amplis amoenis $\mathcal{E}$ crebris, exrubro Es flauo feparatim diuifis Eo excurrentibus, flos conftans.

I6 Tunica Morionis altera, tanijs minoribus Es minus frequentibus, magis aut minus alia alijs inconftans.

I7 Tunica Morionis pallida, i.e. tanijs vel Arijs frequentioribus in virogis colore pallidis, flos eft conftans $E^{\circ}$ elegans.

18 Pileus Morionis, radijs luteis, in medio foliorum latis, per ruborem excurrentibus, fundo luteo, apicibus luteis, Eo tribus exterioribus folijs luteis oris rubris, vel $a b / \dot{g}_{s}$ oris.
The meane flowring red Tulipa.

I A faire red which is ordinary, with a yellow or blacke bottome.

2 A deepe Orenge colour.

3 A Vermillion.

4 A pale red, or Bricke colour.

5 A Gingeline colour.

6 A red with fmall yellow edges.

7 A Teftament Brancion of diuers forts, differing both in the deepneffe of the red, and largeneffe of the pale coloured edges.

8 A Vermillion flamed, flowring later or earlier.

9 A dead purplifh red without, and of a yellowinh red within, with pale yellow edges.

Io A bright Crimfon red on the outfide, more yellowifh on the infrde, with pale yellow edges, and a bottome yellow or greene.

i I A red Flambant, fpotted thicke with yellow fpots without any bottome.

I 2 A more excellent red Flambant, with flames of yellow running through the red.

I 3 A pale coloured Flambant.

I 4 A cloth of gold colour.

I 5 A true Fooles Coate, the beft is a faire red \& a faire yellow, parted into guards euery one apart, varied through euery leafe to the very edge, yet in moft abiding conftant.

I6 Another Fooles Coate, not fo fairely marked, nor fo much, fome of thefe are more or leffe conftant in their marks, \& fome more variable then others.

I7 A pale Fooles Coate, that is, with pale red, and pale yellow guardes or ftripes very faire and conftant.

I 8 A Fooles Cappe, that is, with lifts or ftripes of yellow running through the middle of euery leafe of the red, broader at the bottome then aboue, the bottome being yellow, the three outer leaues being yellow with red edges, or without. 


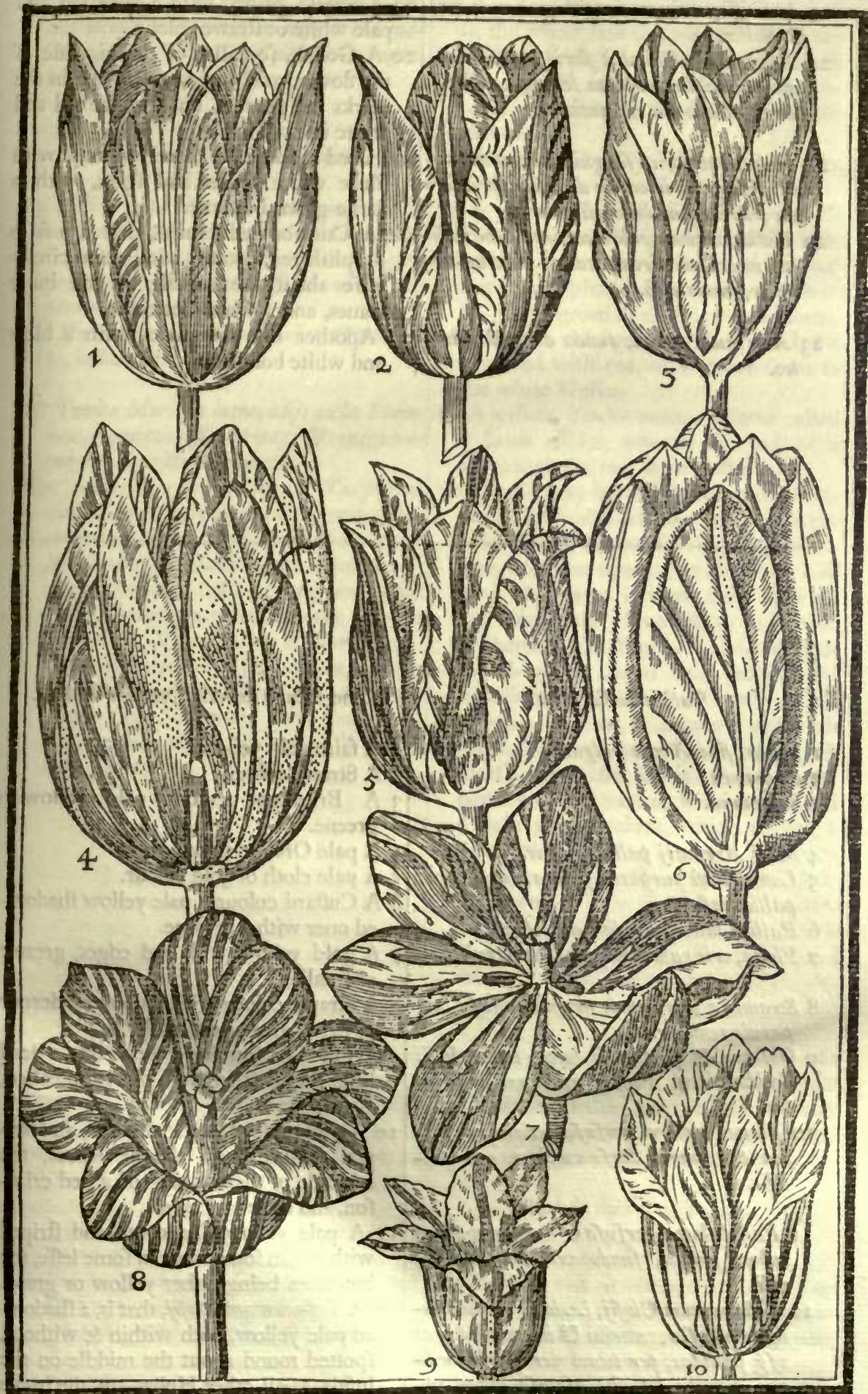

1 Tulipa tricolor. A Tulipa of three colours. 2 Tulipa Macedonica, fue de Caffa varia. The Tulipa of Cafia parple, with pale white ftripes. 3 Tulipa Hsinola chermefina verficolor. A pure Claret wine colour variable. 4 Tulipa Caryophyllata Wilmeri. Ar. Wilmers Gilloflower Tulipa. S Tulipa Chermefiwn Alammis albis. A Crimfon with white flames. 6 Twlipa Golinh. A white Flambant or Fooles Coate. 9 Tulipa Cinnabarina albo fammata. The Vermillion flamed. 10 Twlipa plumala nubra E Iutea. The feathered Tulipa red and yellow. 
19 Le Suife, tanijs radiata magnis ex rubore E pallore.

20 Altera dicta Goliah à floris magnitudine, tanijs radiata fimillima le Suife, nifi rubor Eं albedo fint elegantiores.

2 I Holias rubra, i.e. Sanguinea argenteis $r a-$ dijs, E guttis in orbem dispofitis, prafertim interius, fundo viridi faturo.

22 Holias coccinea, rubra coccinea, albo radiata in orbem, circa medium foliorum interiùs, fundo albo.

23 Alia huic fimilis, fundo albo Es cartleo.
I 9 A Swiffe, pained with a faire red and pale white or ftrawe colour.

20 A Goliah, fo called of the bigneffe of the flower, moft like to the Swiffe in the marks and guardes, but that the red and white is more liuely.

2 I A red Holias. A bloud red ftript with filuer white veines and fpots, with a darke green bottome.

22 A Crimfon red Holias, that is, a faire purplifh red, fpotted with white circlewife about the middle of the inner leaues, and a white bottome.

23 Another like thereunto, with a blew and white bottome.
Tulipa media lutea.

I Lutea, fiue Aurea vulgaris.

2 Straminea.

3 Sulphurea.

4 Mali Aurantij pallidi coloris.

5 Lutea dilutè purpurea friata, aurei pami pallidi inftar.

6 Pallide lutea fufcedine adumbrata.

7 Flaua, oris rubris magnis, aut paruis.

8 Straminea oris rubris magnis intenfis, vel paruis remis sis.

9 Obfcura Es fuliginofa lutea, inftar Folij decidui, ideog Folium mortuum appellatur.

Io Flaua, rubore perfufa, etiamque friata per totum, dorfo coccineo, oris pallidis.

I I Pallide lutea, perfufa $\mathcal{E}$ magis aut minus rubore friata, fundo vel luteo, vel viridi.

I 2 Teftamentum Clufij, i.e. lutea pallida fuligine obfufca, exterius E़ interiùs ad oras $v \int \dot{g}_{s}$ pallidas, per totum vero floris medium, maculis interiùs asperfa inftar ommium aliarum Holias, dorfo obfcuriore, fundo viridi.
The meane flowring yellow Tulipa.

I A faire gold yellow.

2 A Strawe colour.

3 A Brimftone colour pale yellowifh greene.

4 A pale Orenge colour.

5 A pale cloth of gold colour.

6 A Cuftard colour a pale yellow fhadowed ouer with a browne.

7 A gold yellow with red edges, greater or fmaller.

8 A Strawe colour with red edges, deeper or paler, greater or fmaller.

9 A fullen or fmoakie yellow, like a dead leafe that is fallen, and therefore called, Fucille mort.

Io A yellow thadowed with red, and friped alfo through all the leaues, the backfide of them being of a red crimfon, and the edges pale.

I I A pale yellow, fhadowed and ftriped with red, in fome more in fome leffe, the bottomes being either yellow or green.

I 2 A Tefamentum Glu/ij, that is, a hadowed pale yellow, both within \& without, fpotted round about the middle on the infide, as all other Holias are, the backe of the leaues being more obfcure or thadowed with pale yellow edges, and a greene bottome.

13 Flam- 
13 Flambans lutea, diuerfimode intus magis 113 aut minus friata, vel in alijs cxtra maculata rubore, funds vt plurimum migro, sel in ulijs luter.

\section{Flambans pallidior E elegantior.}

15 Holius lutea intenfior vel remifsior diuerfimode, in orbem radiata interius, rubris maculis ad fupremas of 8 oras, aliguties crebri, aliès parce, fundo viridi, vel tumetto obfcuro.

16 Holias flraminea rubore /lriata Es punctaw, infur alba Holias.

17 Tunica Morionis luten, alijs diEta Flammea, in qua color favus magis \& con/picuus rubore, diuerfinode radiata.

Huc reddenda efet viridarum Tuliparum clafsis, que diuerfarum etiam constat specierum. Vma viridis intenfior, cuius fos fimper ferè ferniclaufus manet faminibus fimbriatis. Altera remifsior, infar $P$ fittacipennarum viridium, luteo variata oris albis. Tertia adhuc dilutiori viriditate oris purpureis. Quarta, cujus folia requaliter purpura diluta, $\mathcal{E}^{2}$ viriditate diuifa funt. Quinta, folijs longissimis pellemods expanfis, ex rubore EO viridiunte concta.
3 A yellow Flambant of diuers forts, that is, the whole flower more or leffe Atreamed or fpotted on the infide, and in fome on the outfide with red, the bottome in moft being blacke, yet in fome yellow.

I 4 A paler yellow Flambant more beautifull.

I 5 A yellow Holias, paler or deeper yellow very variable, fpotted on the infide round about the middle, with red fometimes plentifully, or elfe fparingly, with a green or dark tawny bottome. I6 A ftrawe coloured Holias, fpotted and ftreamed with red, as is to bee feene in the white Holias.

I7 A yellow Fooles coate, of fome called a flame colour, wherein the yellow is more then the red, diuerly ftreamed.

Vnto thefe may be added the greene Tulipa, which is alfo of diuers forts. One hauing a great flower of a deepe green colour, feldome opening it felfe, but abiding alwaies as it were halfe thut vp and clofed, the chiues being as it were feathered. Another of a paler or yellowith green, paned with yellow, and is called, The Parret, \&c. with white edges. A third of a more yellowifh green, with red or purplifh edges. A fourth, hath the leaues of the flower equally almoft parted, with greene and a light purple colour, which abiding a long time in flower, groweth in time to be fairer marked: for at the firft it doth not thew it felfe fo plainely diuided. Some call this a greene Swiffer. A fifth hath the longeft leaues ftanding like a ftarre, confifting of greene and purple.

Tulipa Serotina. The late flowring Tulipa.

The late flowring Tulipa hath had his defcription expreffed in the precedent difcourfe, fo that I thall not neede to make a repetition of what hath already beene fet downe. The greateft matter of knowledge in this kinde is this, That it hath no fuch plentifull variety of colours or mixtures in his flowers, as are in the two former forts, but is confined within thefe limits here expreffed, as farre as hath come to our knowledge.

\section{Tulipa Serotina.}

Rojea intenfior, aut remifsior.

Rubra vulguris, aut faturatior, E' quafi nigricans, fundo luteo vel nigro, vel nigin orbe, aureo inclujo, dicka Oculus Sa lis.

Lutea communis.

Luten oris rubris.

Lutea guttis fanguineis, fundo nigro vel vario.
The late flowring Tulipa.

A Rofe colour deeper or paler.

An ordinary red, or elfe a deeper red like blacke bloud, with a blacke or yellow bottome, or backe circled with yellow, called the Suns eye.

An ordinary yellow.

A yellow with red edges.

A yellow with red fpots and veines, the bottome blacke or difcoloured. 
There yet remaine many obferuations, concerning thefe beautifull flowers, fit to be knowne, which could not, without too much prolixity, be comprehended within the body of the defcription of them; but are referued to bee intreated of a part by themfelues.

All forts of Tulipas beare vfually but one ftalke, and that without any branches: but fometimes nature is fo plentifull in bearing, that it hath two or three ftalkes, and fometimes two, or more branches out of one ftalke (euery ftalke or branch bearing one flower at the toppe) but this is but feldome feene; and when it doth happen once, it is hardly feene againe in the fame roote, but is a great figne, that the roote that doth thus, being an old roote, will the fame yeare part into diuers rootes, whereof euery one, being of a reafonable greatneffe, will beare both his ftalke and flower the next yeare, agreeing with the mother plant in colour, as all the of-fets of Tulipas doe for the moft part: for although the young of-fets of fome doe vary from the maine roote, euen while it groweth with them, yet being feparated, it will bee of the fame colour with the mother plant.

There groweth oftentimes in the Medias, and fometimes alfo in the Pracoces, but more feldome, a fmall bulbe or roote, hard aboue the ground, at the bottome of the ftalke, and betweene it and the lower leafe, which when the ftalke is dry, and it ripe, being put into the ground, will bring forth in time a flower like vnto the mother plant, from whence it was taken.

The flowers alfo of Tulipas confift moft commonly of fixe leaues, but fometimes they are feene to haue eight or tenne, or more leaues; but vfually, thofe rootes beare but their ordinary number of fixe leaues the next yeare: the head for feede then, is for the moft part foure fquare, which at all other times is but three fquare, or when the flower wanteth a leafe or two, as fometimes alfo it doth, it then is flat, hauing but two fides.

The forme of the flower is alfo very variable; for the leaues of fome Tulipas are all fharpe pointed, or all blunt and round pointed, and many haue the three outer leaues fharpe pointed, and the three inner round or pointed, and fome contrariwife, the three outermoft round pointed, and the three inner tharpe pointed. Againe, fome haue all the leaues of the flowers long and narrow, and fome haue them broader. and fhorter. Some Precoces alfo haue their flowers very large and great, equall vnto eyther the Media, or Serotina, which moft commonly are the largeft, and others have them as fmall as the Bolonia Tulipa.

The bottomes of the leaues of the flowers are alfo variably diuerfified, and fo are both the chiues or threeds that ftand vp about the head, and the tips or pendents that are hanging loofe on the toppes of them; and by the difference of the bottomes or chives, many flowers are diftinguifhed, which elfe are very like in colour, and alike alfo marked.

For the fmell alfo there is fome diuerfity; for that the flowers of fome are very fweete, of others nothing at all, and fome betweene both, of a fmall fent, but not offenfiue : and yet fome I haue obferued haue had a ftrong ill fent; but how to fhew you to diftinguifh them, more then by your owne fenfe, I cannot: for the feedes of fweete fmelling Tulipas doe not follow their mother plant, no:more then they doe in the colour.

And laftly, take this, which is not the leaft obferuation, worth the noting, that I haue obferued in many: When they haue beene of one entire colour for diuers yeares, yet in fome yeare they haue altered very much, as if it had not beene the fame, viz. from a purple or ftamell, it hath beene variably either parted, or mixed, or ftriped with white, eyther in part, or through the whole flower, and fo in a red or yellow flower, that it hath had eyther red or yellow edges, or yellow or red fpots, lines, veines, or flames, running through the red or yellow colour, and fometimes it hath happened, that three leaues haue been equally parted in the middle with red and yellow, the other three abiding of one colour, and in fome the red had fome yellow in it, and the yellow fome red fpots in it alfo; whereof $I$ haue obferued, that all fuch flowers, not hauing their originall in that manner, (for fome that haue fuch or the like markes from the beginning, that is, from the firft and fecond yeares flowring, are conAtant, and doe not change) but as I faid, were of one colour at the firft, doe thew the 
weakneffe and decay of the roote, and that this extraordinary beauty in the flower, is but as the brightnefie of a light, vpon the very extinguifhing thereof, and doth plainly declare, that it can doe his Mafter no more feruice, and therefore with this iollity doth bid him good night. I know there is a common opinion among many (and very confidently maintained) that a Tulipa with a white flower, hath changed to beare a red or yellow, and fo of the red or yellow, and other colours, that they are likewife inconitant, as though no flowers were certaine: but I could never either fee or heare for certaine any fuch alteration, nor any other variation, but what is formerly expreffed. Let not therefore any iudicious be carried away with any fuch idle conceit, but rather fufpect fome deceit in their Gardeners or others, by taking vp one, and putting in another in the place, or elfe their owne miftaking.

Now for the fowing, planting, tranfplanting, choife, and ordering of Tulipas, which is not the leaft of regard, concerning this fubiect in hand, but (as I think) would be willingly entertained; What I haue by my beft endeauours learned, by mine owne paines in almoft forty yeares trauell, or from others informations, I am willing here to fet downe; not doubting, but that fome may adde what hath not come to my knowledge.

Firf, in the fowing of feedes of Tulipas, I haue not obferued (whatfoeuer others haue written) nor could of certainty learne of others, that there doth arife from the feedes of Pracoces any Medias or Serotime Tulipas, (or but very feldome) nor am certainly affured of any: but that the feedes of all Pracoces (fo they be not doubtfull, or of the laft flowring forts) will bring Pracoces: And I am out of doubt, that I neuer faw, nor could learne, that euer the feede of the Medias or Serotines haue giuen Pracoces; but Medius or Serotines, according to their naturall kinde. But if there Thould bee any degeneration, I rather incline to thinke, that it fooner commeth to paffe (d meliore an pelus, for facilis eff defcenfus, that is) that Pracoces may giue Medias, then that Medias or Serotimes thould giue Pracoces.

For the choife of your feede to fowe. Firft, for the Pracoces, Clufius faith, that the Pracox Tulipa, that beareth a white flower, is the beft to giue the greateft variety of colours. Some among vs haue reported, that they haue found great variety rife from the feede of the red Precox, which I can more hardly beleeue : but Clufius his experience hath the greater probabilty, but efpecially if it haue fome mixture of red or purple in it. The purple I haue found to be the beft, next thereunto is the purple with white edges, and fo likewife the red with yellow edges, each of them will bring moft of their owne colours. Then the choife of the bett Medias, is to take thofe colours that are light, rather white then yellow, and purple then red; yea white, not yellow, purple, not red : but thefe againe to be fpotted is the beft, and the more the better; but withall, or aboue all in thefe, refpect the ground or bottome of the flower, (which in the Precox Tulipa cannot, becaufe you thall feldome fee any other ground in them but yellow) for if the flower be white, or whitifh, fpotted, or edged, and Araked, and the bottome blew or purple (fuch as is found in the Holias, and in the Cloth of filuer, this is beyond all other the moft excellent, and out of queftion the choifeft of an hundred, to haue the greateft and moft pleafant variety and rarity. And fo in degree, the meaner in beauty you fowe, the leffer fhall your pleafure in rarities be. Beftowe not your time in fowing red or yellow Tulipa feede, or the diuers mixtures of them; for they will (as I haue found by experience) feldome be worth your paines. The Serotina, or late flowring Tulipa, becaufe it is feldome feene, with any efpeciall beautifull variety, you may eafily your felues gheffe that it can bring forth (euen as I haue alfo learned) no raritie, and little or no diuerfity at all.

The time and inanner to fowe thefe feedes is next to be confidered. You may not fowe them in the fpring of the yeare, if you hope to haue any good of them; but in the Autumue, or prefently after they be thorough ripe and dry: yet if you fowe them not vntill the end of October, they will come forward neuer the worfe, but rather the better; for it is often feene, that ouer early fowing caufeth them to fpring out of the ground ouer early, fo that if a fharp fpring chance to follow, it may go neere to fpoile all, or the moft of your feede. Wee vfually fowe the fame yeares feede, yet if you chance to keepe of your owne, or haue from others fuch feed, as is two years old, they will thriue and doe well enough, efpecially if they were ripe and well gathered: 
You muit not fowe them too thicke, for fo doing hath loft many a pecke of good feede, as I can tell; for if the feede lye one vpon another, that it hath not roome vpon the fprouting, to enter and take roote in the earth, it perifheth by and by. Some vfe to tread downe the ground, where they meane to fowe their feede, and hauing fowne them thereon, doe couer them ouer the thickneffe of a mans thumbe with fine fifted earth, and they thinke they doe well, and haue good reafon for it: for confidering the nature of the young Tulipa rootes, is to runne downe deeper into the ground, enery yeare more then other, they thinke to hinder their quicke defcent by the faftneffe of the ground, that fo they may encreafe the better. This way may pleafe fome, but I doe not vfe it, nor can finde the reafon fufficient; for they doe not confider, that the ftiffeneffe of the earth, doth caufe the rootes of the young Tulipas to bee long before they grow great, in that a ftiffe ground doth more hinder the well thriuing of the rootes, then a loofe doth, and although the rootes doe runne downe deeper in a loofe earth, yet they may eafily by tranfplanting be holpen, and raised vp high enough. I haue alfo feene fome Tulipas not once remoued from their fowing to their flowring; but if you will not lofe them, you muft take them vp while their leafe or ftalk is freeh, and not withered: for if you doe not follow the ftalke downe to the roote, be it neuer fo deepe, you will leaue them behinde you. The ground alfo muft be refpected; for the finer, fofter, and richer the mould is, wherein you fowe your feede, the greater thall be your encreare and varietie : Sift it therefore from all ftones and rubbinh, and let it be either fat naturall ground of it felfe, or being muckt, that it bee thoroughly rotten : but fome I know, to mend their ground, doe make fuch a mixture of grounds, that they marre it in the making.

After the feede is thus fowne, the firlt yeares fpringing bringeth forth leaues, little bigger then the ordinary graffe leaues; the fecond yeare bigger, and fo by degrees euery yeare bigger then other. The leaues of the Pracoces while they are young, may be difcerned from the Medias by this note, which I haue obferued. The leaues of them doe wholly ftand $\mathrm{vp}$ aboue the ground, fhewing the fmall footftalkes, whereby euerie leafe doth ftand, but the leaues of the Medias or Serotines doe neuer wholly appeare out of the ground, but the lower part which is broad, abideth vnder the vpper face of the earth. Thofe Tulipas now growing to bee three yeares old, (yet fome at the fecond, if the ground and ayre be correfpondent) are to bee taken vp out of the ground: wherein yee thall finde they haue runne deepe, and to be anew planted, after they haue been a little dryed and cleanfed, eyther in the fame, or another ground againe, placing them reafonable neare one vnto another, according to their greatneffe, which being planted and couered ouer with earth againe, of about an inch or two thickneffe, may be left vntaken vp againe for two yeare longer, if you will, or elfe remoued euery yeare after, as you pleafe; and thus by tranfplanting them in their due feafon (which is ftill in the end of Iuly, or beginning of Auguft, or thereabouts) you thall according to your feede and foyle, haue fome come to bearing, in the fifth yeare after the flowring, (and fome haue had them in the fourth, but that hath beene but few, and none of the beft, or in a rich ground) fome in the fixth and feuenth, and fome peraduenture, not vntill the eighth or tenth yeare: but ftill remember, that as your rootes grow greater, that in re-planting you giue them the more roome to be diftant one from another, or elfe the one will hinder, if not rot the other.

The feede of the Pracoces, doe not thriue and come forward fo faft as the Medias or Serotines, nor doe giue any of-fets in their running downe as the Medias doe, which vfually leaue a fmall roote at the head of the other that is runne downe euery yeare; and befides, are more tender, and require more care and attendance then the Medias, and therefore they are the more refpected.

This is a generall and certaine rule in all Tulipas, that all the while they beare but onc leafe, they will not beare flower, whether they bee feedlings, or the of-fets of elder rootes, or the rootes themfelues, that haue heretofore borne flowers; but when they thew a fecond leafe, breaking out of the firft, it is a certaine figne, that it will then beare a flower, vnleffe fome casualty hinder it, as froft or raine, to nip or fpoile the bud, or other vntimely accident befall it.

To fet or plant your beft and bearing Tulipas fomewhat deeper then other rootes, I hold it the beft way; for if the ground bee either cold, or lye too open to the cold

Northerne 
Northerne ayre, they will be the better defended therein, and not fuffer the frofts or cold to pierce them fo foone: for the deepe frofts and fnowes doe pinch the Prrecoces chiefly, if they bee too neare the vppermoft cruft of the earth; and therefore many, with good fucceffe, coner ouer their ground before Winter, with either frefh or old rotten dung, and that will maruelloully preferue them. The like courfe you may hold with feedlings, to caufe them to come on the forwarder, fo it bee after the firf yeares fowing, and not till then.

To remoue Tulipas after they haue fhot forth their fibres or fmall ftrings, which grow vnder the great round rootes, (that is, from September vntill they bee in flower) is very dangerous; for by remouing them when they haue taken faft hold in the ground, you doe both hinder them in the bearing out their flower, and befides, put them in hazzard to perifh, at leaft to bee put backe from bearing for a while after, as oftentimes I haue proued by experience: But when they are now rifen to flower, and fo for any time after, you may fafely take them vp if you will, and remoue them without danger, if you haue any good regard vnto them, vnleffe it be a young bearing roote, which you finall in fo doing much hinder, becaufe it is yet tender, by reafon it now beareth his firt flower. But all Tulipa roots when their ftalke and leaues are dry, may molt fafely then be taken vp out of the ground, and be fo kept (fo that they lye in a dry, and not in a moift place) for fixe moneths without any great harme: yea I haue knowne them that haue had them nine moneths out of the ground, and haue done reafonable well, but this you muft vnderftand withall, that they haue not been young but elder rootes, and they haue been orderly taken vp and preferued. The dryer you keep a Tulipa roote the better, $f_{0}$ as you let it not lye in the funne or winde, which will pierce it and fpoile it.

Thus Gentlewomen for your delights, (for thefe pleafures are the delights of leafure, which hath bred your loue \& liking to them, and although you are herein predominant, yet cannot they be barred from your beloued, who I doubt not, wil fhare with you in the delight as much as is fit) haue I taken this paines, to fet downe, and bring to your knowledge fuch rules of art, as my fmall skill hath enabled mee withall concerning this fubiect, which of all other, feemed fitteft in this manner to be enlarged, both for the varietie of matter, and excellency of beautie herein, and alfo that there rules fet forth together in one place, might faue many repetitions in other places, fo that for the planting and ordering of all other bulbous rootes, and the fowing the feedes of them, you may haue recourfe vnto thefe rules, (tanquam ad norman $\mathfrak{E}$ examen) which inay ferue in generall for all other, little diuerfitie of particulars needing exception.

\section{The Place.}

The greater Tulipas haue firft beene fent vs from Conftantinople, and other parts of Turkie, where it is faid they grow naturally wilde in the Fields, Woods, and Mountaines; as Thracia, Macedonia, Pontus about the Euxine Sea, Cappadocia, Bithynia, and about Tripolis and Aleppo in Syria alfo: the leffer haue come from other feuerall places, as their names doe decipher it out vnto vs; as Armenia, Perfia, Candye, Portugall, Spaine, Italy, and France. They are all now made denizens in our Gardens, where they yeeld vs more delight, and more encreafe for their proportion, by reafon of the culture, then they did vnto their owne naturals.

\section{The Time.}

Thefe doe flower fome earlier, fome later, for three whole moneths together at the leaft, therein adorning out a Garden moft glorioufly, in that being but one kinde of flower, it is fo full of variety, as no other (except the Daffodils, which yet are not comparable, in that they yeeld not that alluring pleafant variety) doe the like befides. Some of the Pracoces haue beene in flower with vs, (for I Speake not of their owne naturall places, where the Winters are milder, and the Spring earlier then ours) in the moneth of Ianuary, when the Winter before hath beene milde, but many in February, 
and all the Pracoces, from the beginning to the end of March, if the yeare be kindly : at what time the Medias doe begin, and abide all Aprill, and part of May, when the Serotines flower and fade; but this, as I faid, if the yeare be kindly, or elfe each kinde will be a moneth later. The feede is ripe in Iune and Iuly, according to their early or late flowring.

\section{The Names.}

There haue beene diuers opinions among our moderne Writers, by what name this plant was knowne to the ancient Authors. Some would haue it be Cofmofandatos, of the Ancient. Dodonæus referreth it to $\pi v \pi \hat{\omega} \nu$ of Theophraftus, in his feuenth Booke and thirteenth Chapter: but thereof he is fo briefe, that befides the bare name, wee cannot finde him to make any further relation of forme, or quality. And Bauhinus, vpon Matthiolus Commentaries of Diofcorides, and in his Pinax allo, followeth his opinion. Camerarius in his Hortus Medicus is of opinion, it may be referred to the Helychryfum of Crateua. Gefner, as I thinke, firft of all, and after him Lobel, Camerarius, Clufius and many others, referre it to the Satyrium of Diofcorides: and furely this opinion is the moft probable for many reafons. Firft, for that this plant doth grow very frequent in many places of Greece, and the leffer Afia, which were no doubt fufficiently knowne both to Theophraftus, and Diofcorides, and was accounted among bulbous rootes, although by fundry names. And fecondly, as Diofcorides fetteth forth his Satyrium, fo this moft commonly beareth three leaues vpon a ftalke (although fometimes with vs it hath foure or fiue) like vnto a Lilly, whereof fome are often feen to be both red, in the firft fpringing, and alfo vpon the decaying, efpecially in a dry time, and in a dry ground: the flower likewife of fome is white, and like a Lilly; the roote is round, and as white within as the white of an egge, couered with a browne coate, hauing a fweetifh, but not vnpleafant tafte, as any man without danger many try. This defcription doth fo liuely fet forth this plant, that I thinke wee fhall not neede to be any longer in doubt, where to finde Diofcorides his Satyrium Triphyllum, feeing wee haue fuch plenty growing with vs. And thirdly, there is no doubt, but that it hath the fame qualities, as you fhall hereafter heare further. And laftly, that plant likewife that beareth a red flower, may very well agree with his Erythronium; for the defcriptions in Diofcorides are both alike, as are their, qualities, the greateft doubt may be in the feede, which yet may agree vnto Lin or Flaxe as fitly, or rather more then many other plants doe, in many of his comparifons, which yet wee receiue for currant. For the feede of Tulipas are flat, hard, and fhining as the feede of Linum or Flaxe, although of another colour, and bigger, as Diofcorides himfelfe fetteth it downe. But if there fhould be a miftaking in the writing of $\lambda_{i \nu \gamma}$ for Xipry, in the Greeke Text, as the flippe is both eafie and likely, it were then out of all queftion the fame : for the feede is very like vnto the feede of Lillies, as any man may eafily difcerne that know them, or will compare them. It is generally called by all the late Writers, Tulipa, which is deriued from the name Tulpan, whereby the Turkes of Dalmatia doe entitle their head Tyres, or Caps; and this flower being blowne, laide open, and inuerted, doth very well refemble them. We haue receiued the early kinde from Conitantinople, by the name of Cafa lale, and the other by the name of Cauala lale. Lobel and others doe call it Lilio-narciffus, becaufe it doth refemble a Lilly in the leafe, flower, and feede, and a Daffodill in the roote. We call it in Englifh the Turkes Cap; but moft vfually Tulipa, as moft other Chriftian Countries that delight therein doe. Dalefchampius calleth it Oulada.

The Vertues.

Diofcorides writeth, that his firf Satyrium is profitable for them that 
haue a convulfion in their necke, (which wee call a cricke in the necke) if it be drunke in harfh (which we call red) wine.

That the roots of Tulipas are nourifhing, there is no doubt, the pleafant, or at leaft the no vnpleafant tafte, may hereunto perfwade; for diuers haue had them fent by their friends from beyond Sea, and miftaking them to bee Onions, haue vfed them as Onions in their pottage or broth, and neuer found any caufe of minlike, or any fenfe of euill quality produced by them, but accounted them fwcetc Onions.

Further, I haue made tryall of them my felfe in this manner. I haue preferued the rootes of thefe Tulipas in Sugar, as I have done the rootes of Eringus, Orchis, or any other fuch like, and haue found them to be almoft as pleafant as the Eringus rootes, being firme and found, fit to be prefented to the curious; but for force of Venereous quality, I cannot fay, either from my felfe, not hauing eaten many, or from any other, on whom I haue beftowed them: but furcly, if there be any fpeciall propertie in the rootes of Orchis, or fome other tending to that purpofe, I thinke this may as well haue it as they. It thould feeme, that Diof corides doth attribute a great Venereous faculty to the feede, whereof I know not any hath made any efpeciall experiment with vs as yet.

\section{Cн A P. I X.}

\section{Narcifjus. The Daffodill.}

$\mathrm{T}$

Here hath beene great confufion among many of our moderne Writers of plants, in not diftinguifhing the manifold varieties of Daffodils; for euery one almoft, without confideration of kinde or forme, or other fpeciall note, giueth names fo diuerfly one from another, that if any one thall receiue from feuerall places the Catalogues of their names (as I haue had many) as they fet them down, and compare the one Catalogue with the other, he fhall fcarce haue three names in a dozen to agree together, one calling that by one name, which another calleth by another, that very few can tell what they meane. And this their confufion, in not diftinguifhing the name of Narcifius from P Seudonarciffus, is of all other in this kinde the greateft and groffeft errour. To auoide therefore that gulfe, whereof I complaine that fo manie haue bin endrenched; and to reduce the Daffodils into fuch a methodicall order, that euery one may know, to what Clafsis or forme any one doth appertaine, I will firft diuide them into two principall or primary kindes: that is, into Narcifos, true Daffodils, and P.endonarciffos, baftard Daffodils : which diftinction I hold to be moft necerfarie to be fet downe firt of all, that euery one may be named without confufion vnder his owne primary kind, and then to let the other parts of the fubdiuifion follow, as is proper to them, and fitteft to expreffe them. Now to caufe you to vnderftand the difference betweene a true Daffodill and a falre, is this; it confifteth onely in the flower, (when as in all other parts they cannot bee diftinguifhed) and chiefly in the middle cup or chalice; for that we doe in a manner onely account thofe to bee Pfeudonarcifos, baftard Daffodils, whofe middle cup is altogether as long, and fometime a little longer then the outter leaues that doe encompaffe it, fo that it feemeth rather like a trunke or long nofe, then a cup or chalice, fuch as almoft all the Narcifsi, or true Daffodils haue; I fay almoft, becaufe I know that fome of them have their middle cup fo fmall, that we rather call it a crowne then a cup; and againe, fome of them haue them rolong, that they may feem to be of the number of the P Peudonarcifsi, or baftard Daffodils: but yet may eafily be knowne from them, in that, although the cup of fome of the true Daffodils be great, yet it is wider open at the brim or edge, and not fo long and narrow all alike as the baftard kindes are; and this is the chiefe and onely way to know how to feuer thefe kindes, which rule holdeth certaine in all, except that kinde which is called Narcifius Iuncifolius reflexo flore, whofe cup is narrow, and as long as the leaues that turne vp againe. 
Secondly, I will fubdiuide each of thefe again apart by themfelues, into foure forts; and firt the Narcifos, or true Daffodils into

Latifolios, broad leafed Daffodils.

Anguftifolios, narrow leafed Daffodils.

Iuncifolios, Rufhe Daffodils, and

Marinos, Sea Daffodils.

Thefe forts againe doe comprehend vnder them fome other diuifions, whereby they may the better be diftinguifhed, and yet ftill bee referred to one of thofe foure former forts: as

Monanthos, that is, Daffodils that beare but one flower, or two at the moft vpon a ftalke, and

Polyanthos, thore that beare many flowers together vpon a ftalke: as alfo

Simplici flore, thofe that beare fingle flowers, and

Multiplici flore, or flore pleno, that is, haue double flowers.

Vernales, thofe that flower in the Spring, and among them fome that are earlier; and therefore called

Pracoces, early flowring Daffodils, and

Autumnales, thofe that flower in Autumne onely.

And laftly, with the Pfeudonarciffos, or baftard Daffodils, I will keepe the fame order, to diftinguifh them likewife into their foure feuerall forts; and as with the true Daffodils, fo with thefe falfe, defcribe vnder euery fort: firt, thofe that beare fingle flowers, whether one or many vpon a ftalke; and then thofe that beare double flowers, one or many alfo. As for the diftinctions of maior and minor, greater and leffer, and of maximus and minimus, greateft and leaft, they doe not onely belong to thefe Daffodils; and therefore muft be vfed as occafion permitteth, but vnto all other fort of plants. To begin therefore, I thinke fittelt with that ftately Daffodill, which for his excellency carrieth the name of None fuch.

1. Narcifus latifolius omnium maximus, amplo calice fauo, fuue Nompareille. The great None fuch Daffodill, or Incomparable Daffodill.

This Narciffus Nompareille hath three or foure long and broad leaues, of a grayith greene colour, among which rifeth vp a ftalke two foote high at the leaft, at the toppe whereof, out of a thinne skinnie huske, as all Daffodils haue, commeth forth one large fingle flower, and no more vfually, confifting of fixe very pale yellow large leaues, almoft round at the point, with a large cuppe in the middle, fomewhat yellower then the leaues, the bottome whereof next vnto the ftalke is narrow and round, rifing wider to the mouth, which is very large and open, and vneuenly cut in or indented about the edges. The cup doth very well refemble the chalice, that in former dayes with vs, and beyond the Seas is ftill vfed to hold the Sacramentall Wine, that is with a narrower bottome, and a wide mouth. After the flower is paft, fometimes there commeth (for it doth not often) a round greenc head, and blacke round feede therein, like vnto other Daffodils, but greater. The roote is great, as other Daffodils that beare large flowers, and is couered ouer with a brownifh coate or skinne. The flower hath little or no fent at all.

Flore geminato. This doth fometimes bring forth a flower with ten or twelue leaues, and a cup much larger, as if it would be two, euen as the flower feemeth.

2. Narcifus omnium maximus flore E calice fluus.

The great yellow Incomparable Daffodill.

This other kinde differeth neither in forme, nor bigneffe of leafe or flower from the former, but in the colour of the circling leaues of the flower, which are of the fame yellow colour with the cup.

Flore geminato. This doth fometimes degenerate and grow luxurious alfo, bringing forth two flowers vpon a ftalke, each diftinct from other, and fometimes two flowers thruft together, as if they were but one, although it be but feldome; for it is not a peculiar kinde that is conftant, yearly abiding in the fame forme. 
3. Narciffus maximus grifeus calice flauo. The gray Peerleffe Daffodill.

This Peerleffe Daffodill well deferueth his place among thefe kindes, for that it doth much refemble them, and peraduenture is but a difference raifed from the feede of the former, it is fo like in leafe and flower, but that the leaues feeme to be fomewhat greater, and the fixe outer leaues of the flower to be of a gliftering whitifh gray colour, and the cup yellow, as the former, but larger.

\section{Narciffus latifolius flaus flore amplo calice, fue Matteneffe.}

The leffer yellow Nompareille, or the Lady Matteneffes Daffodill.

The leaues of this Daffodill, are fomewhat like vnto the leaues of the firft kind, but not altogether fo long or broad: the ftalke likewife rifeth not vp fully fo high, and beareth one flower like the former, but leffer, and both the cuppe and the leaues are of one colour, that is, of a pale yellow, yet more yellow then in the former: the cup of this alfo is leffer, and a little differing; for it is neither fully fo fmall in the bottome, nor fo large at the edges, nor fo crumpled at the brimmes, fo that all thefe differences doe plainly fhew it to be another kinde, quite from the former.

The Place.

The places of none of thefe are certainly knowne to vs where they grow naturally, but we haue them onely in our Gardens, and haue beene fent, and procured from diuers places.

\section{The Time.}

They flower fometimes in the end of March, but chiefly in Aprill.

The Names.

The firft and fecond haue been fent vs by the name of Narciffe Nompareille, as it is called in French; and in Latine, Narciffus omnium maximus amplo calice flauo, and Narcifus Incomparabilis, that is, the Incomparable Daffodill, or the greateft Daffodill of all other, with a large yellow cuppe: but affuredly, although this Daffodill doth exceed many other, both in length and bigneffe, yet the great Spanifh baftard Daffodill, which thall be fpoken of hereafter, is in my perfwafion oftentimes a farre higher and larger flower; and therefore this name was giuen but relatiuely, we may call it in Englifh, The great None fuch Daffodill, or the Incomparable Daffodill, or the great Peerleffe Daffodill, or the Nompareille Daffodill, which you will: for they all doe anfwer either the French or the Latine name; and becaufe this name Nompareille is growne currant by cuftome, I know not well how to alter it. The third kinde may paffe with the title giuen it, without controule. The laft is very well knowne beyond the Seas, efpecially in the Low Countries, and thofe parts, by the Lady Matteneffe Daffodill, becaufe Clufius receiued it from her. We may call it in Englifh, for the correfpondency with the former, The leffer yellow Nompareille, or Peerleffe Daffodill, or the Lady Matteneffe Daffodill, which you will.

\section{Narciffus Indicus flore rubro, dictus Iacobaus.}

The Indian Daffodill with a red flower.

This Indian Daffodill is fo differing, both in forme, not hauing a cuppe, and in colour, being red, from the whole Family of the Daffodils (except the next that followeth, and the Autumne Daffodils) that fome might iuftly queftion the fitneffe of his place here. But becaufe as all the plants, whether bulbous or other, that come from 
the Indies, either Eaft or Weft (although they differ very notably, from thofe that grow in thefe parts of the world) muft in a generall furuey and mufter be ranked euery one, as neere as the furueiours wit will direct him, vnder fome other growing with vs, that is of neereft likeneffe; Euen fo vntill fome other can direct his place more fitly, I fhall require you to accept of him in this, with this defcription that followeth, which I muft tell you alfo, is more by relation then knowledge, or fight of the plant it felfe. This Daffodill hath diuers broad leaues, fomewhat like vnto the common or ordinary white Daffodill, of a grayifh greene colour; from the fides whereof, as alfo from the middle of them, rife vp fometimes two ftalkes together, but moft vfually one after another (for very, often it flowreth twice in a Summer) and often alfo but one ftalke alone, which is of a faint reddifh colour, about a foote high or more, at the toppe whereof, out of a deepe red skinne or huske, commeth forth one flower bending downewards, confifting of fixe long leaues without any cup in the middle, of an excellent red colour, tending to a crimfon; three of thefe leaues that turne vpwards, are fomewhat larger then thofe three that hang downewards, hauing fixe threads or chiues in the middle, tipt with yellow pendents, and a three forked ftile longer then the reft, and turning vp the end thereof againe: the roote is round and bigge, of a brownifh colour on the outfide, and white within. This is fet forth by Aldinus, Cardinall Farnefius his Phyfitian, that at Rome it rofe vp with ftalkes of flowers, before any leaues appeared.

\section{The Place, Time, and Names.}

This naturally groweth in the Weft Indies, from whence it was brought into Spaine, where it bore both in Iune and Iuly, and by the Indians in their tongue named Azcal Xochits, and hath beene fent from Spaine, vnto diuers louers of plants, into feuerall parts of Chriftendome, but haue not thriued long in thefe tranfalpine colder Countries, fo far as I can heare.

\section{Narciffus Trapezunticus flore luteo pracocifsimus.}

The early Daffodill of Trebizond.

Becaufe this Daffodill is fo like in flower vnto the former, although differing in colour, I thought it the fittert place to ioyne it the next thereunto. This early Daffodill hath three or foure fhort very greene leaues, fo like vnto the leaues of the Autumne Daffodill, that many may eafily bee deceiued in miftaking one for another, the difference confifting chiefly in this, that the leaues of this are not fo broad or fo long, nor rife vp in Autumne: in the midft of thefe leaues rifeth vp a fhort green ftalke, an handfull high, or not much higher vfually, (I fpeake of it as it hath often flowred with mee, whether the caufe be the coldneffe of the time wherein it flowreth, or the nature of the plant, or of our climate, I am in fome doubt; but I doe well remember, that the ftalkes of fome plants, that haue flowred later with me then the firft, haue by the greater ftrength, and comfort of the Sunne, rifen a good deale higher then the firft) bearing at the top, out of a whitifh thinne skinne ftripped with greene, one flower a little bending downewards, confifting of fixe leaues, laid open almoft in the fame manner with the former Indian Daffodill, whereof fome doe a little turne vp their points againe, of a faire pale yellow colour, hauing fixe white chiues within it, tipt with yellow pendents, and a longer pointell : the roote is not very great, but blackifh on the outfide, fo like vnto the Autumne Daffodill, but that it is yellow vnder the firft or outermoft coate, that one may eafily miftake one for another.

\section{The Place.}

It was fent vs from Conftantinople among other rootes, but as wee may gheffe by the name, it fhould come thither from Trapezunte or Trebizond.

The Time.

It flowreth fometimes in December, if the former part of the Winter 


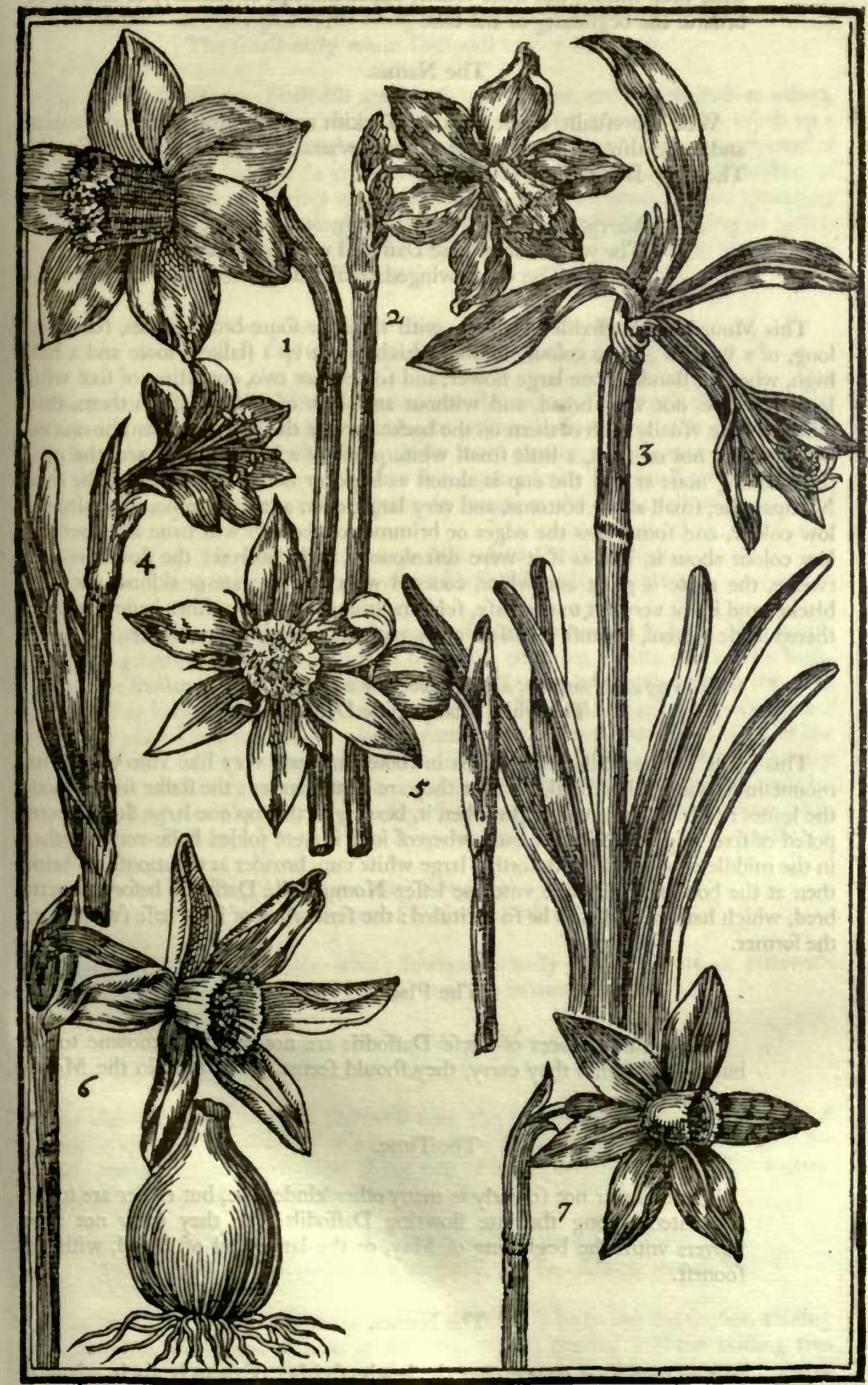

1.Narciffus Nonfarcille. The incomparable Daffodill. 2 Narciffus Maltenefe. The lefler yellow Nomparelle Daffodill. 3 Narriffus Jacobaus flore rubro. The red Indian Daffodill. 4 Narriffus Trapesunticus. The early Daffodill of Trabefond. 5 Nar-

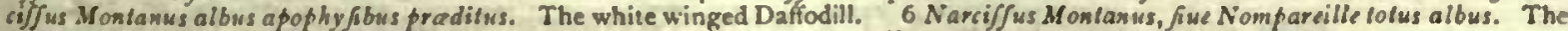
white Nompareille, or Peerleffe Daffodill. 7 Narciffus albus oblongo calice. The white Daffodill with a long cup. 
haue been milde; but moft vfually about the end of Ianuary, or elfe in $\mathrm{Fe}$ bruarie the beginning or the end.

\section{The Names.}

Wee doe vfually call it from the Turkifh name, Narcifus Trapezunticus, and fome alfo call it Narcifus vernus pracox, as Clufius doth, in Englifh, The early Daffodill of Trebizond.

\section{Narcifus Montanus albus apophyfibus praditus.}

The white Mountaine Daffodill with eares, or The white winged Daffodill.

This Mountaine Daffodill rifeth vp with three or foure broad leaues, fomewhat long, of a whitifh greene colour, among which rifeth vp a ftalke a foote and a halfe high, whereon ftandeth one large flower, and fometimes two, confifting of fixe white leaues a peece, not very broad, and without any thew of yellowneffe in them, three whereof haue vfually each of them on the backe part, at the bottome vpon the one fide of them, and not on both, a little fmall white peece of a leafe like an eare, the other three hauing none at all: the cup is almoft as large, or not much leffe then the fmall Nompareille, fmall at the bottome, and very large, open at the brimme, of a faire yellow colour, and fometimes the edges or brimmes of the cup will have a deeper yellow colour about it, like as if it were difcoloured with Saffron: the flower is verie fweete, the roote is great and white, couered with a pale coate or skinne, not verie blacke, and is not very apt to encreafe, feldome giuing of-fets; neither haue I euer gathered feede thereof, becaufe it paffeth away without bearing any with me.

\section{Narciffus Montanus, fue Nompareille totus albus amplo calice.}

The white Nompareille Daffodill.

This white Nompareille Daffodill, is in roote and leafe very like vnto the former mountain or winged Daffodill, but that they are a little larger: the ftalke from among the leaues rifeth vp not much higher then it, bearing at the top one large flower, compofed of fixe long white leaues, each whereof is as it were folded halfe way together, in the middle whereof ftandeth forth a large white cup, broader at the mouth or brims then at the bottome, very like vnto the leffer Nompareille Daffodill before remembred, which hath caufed it to be fo entituled : the fent whereof is no leffe fweete then the former.

The Place.

The naturall places of thefe Daffodils are not certainly knowne to vs; but by the names they carry, they fhould feeme to bee bred in the Mountaines.

\section{The Time.}

Thefe flower not fo early as many other kindes doe, but rather are to bee accounted among the late flowring Daffodils; for they thew not their flowers vntill the beginning of May, or the latter end of Aprill, with the fooneft.

\section{The Names.}

The names fet downe ouer the heads of either of them be fuch, whereby they are knowne to vs: yet fome doe call the firt Narciffus auriculatus, that is to fay, The Daffodill with eares: and the other, Narcifius Nompareille totus albus, that is to fay, The white Nompareille, or Peerleffe Daffodill. 
1. Narciffus albus oblongo calice luteo precox minor.

The fmall early white Daffodill with a long cup.

The leaues of this early Daffodill are broad, very greene, and not whitifh as others, three or foure ftanding together, about a foote long or better, among which rifeth vp a greene ftalke, not full fo high as the leaues, bearing one flower at the toppe thereof of a reafonable bigneffe, but not fo great as the later kindes that follow are, confifting of fix whitifh leaues, but not perfect white, hauing a fhew of a Creame colour appearing in them; in the middle is a long round yellow cup, about halfe an inch long or better. The fmell of this flower is reafonable fweete, the roote is of a reafonable bigneffe, yet leffer then the rootes of the later kindes.

2. Narciffus pallidus oblongo calice flaus pracox.

The early Strawe coloured Daffodill with a long cup.

The leaues of this Daffodill are as greene as the former, but much narrower; and the leaues of the flower are more enclining to yellow, but yet very pale, as if it were a light ftrawe colour, and feeme to bee a little more narrow and pointed then the forner : the cup of this, is as long and yellow as the precedent. The fmell whereof is very like the former, yet neither of them being fo fweete as thofe that follow.

\section{Narciffus albus oblongo calice luteo ferotinus maior.}

The great late flowring white Daffodill with a long cup.

This later flowring Daffodill hath his leaues fomewhat narrow \& long, of a grayifh or whitifh greene colour, among which the ftalke rifeth vp a foote and a halfe high, bearing one flower at the toppe, made of fix white leaues, hauing the cup in the middle thereof as long as the former, and of a deepe yellow: the edges of this cuppe are fometimes plaine, and fometimes a little crumpled; they are often alfo circled at the brimmes with a Saffron colour, and often alfo without it, the fmell whereof is very pleafant, and not heady: the roote hereof is reafonable bigge, and couered ouer rather with a pale then blackifh skinne. This flower doth fometimes alter his forme into eight leaues, which being narrow and long, feeme like a white ftarre, compaffing a yellow trunke.

4. Narciffus totus pallidus oblongo calice ferotinus minor.

The late pale coloured Daffodill with a long cup.

There is another of this kinde, whore flowers is wholly of a pale white, or yellowifh colour, differing neither in leafe nor roote from the former.

\section{Narcifus pallidus oblongo calice flauo ferotinus.}

The Strawe coloured late flowring Daffodill with a long yellow cup.

The chiefe difference of this Daffodill from the former, confifteth in the colour of the top of the flower, which is of a more yellow colour, and a little larger then the former, and the brimmes or edges of the cup of a deeper yellow, or Saffron colour. The finell of this is no leffe fweete then in the former.

\section{Narcifus albus oblongo calice flaus ferotinus, dusbus floribus in caule.}

The late white Daffodill with a long cup, and two flowers on a ftalke.

This Daffodill is furely a kinde of it felfe, although it be fo like the former, abiding conftant in his forme and manner of flowring, vfually bearing without miffing two flowers vpon a ftalke, very like vnto the former great white kinde, that one cannot know any greater matter of difference betweene them, then that it beareth two flowers on a ftalke: the cuppes whereof are foldome touched with any fhew of Saffron colour on them at the brimmes or edges, as fome of the former have. 


\section{The Place.}

All thefe Daffodils doe grow on the Pyrenæan mountaines, and haue been fought out, and brought into thefe parts, by thofe curious or couetous fearchers of thefe delights, that haue made vs partakers of them.

The Time.

The former kindes flower earlier by a fortnight then the later, the one in the later end of March, and the other not vntill the middle of Aprill.

The Names.

Their names are giuen to euery one of them in their feuerall titles, as fitly as may beft agree with their natures; and therefore I fhall not neede to fpeake any further of them.

Narciffus medioluteus vulgaris.

The common white Daffodill called Primrore Peerleffe.

This Daffodill is fo common in euery Countrey Garden almoft through England, that I doubt I fhall but fpend my time in vaine, to defcribe that which is fo well knowne, yet for their fakes that know it not, I will fet downe the defcription of it in this manner. It hath long limber and broad leaues, of a grayifh greene colour, among which rifeth vp a ftalke, bearing at the toppe out of a skinnie huske fometimes but one flower, but moft commonly two flowers, and feldome three or more, but larger for the moft part, then any that beare many flowers vpon a ftalke, of a pale whitifh Creame colour, tending fomewhat neare vnto the colour of a pale Primrofe (which hath caufed our Countrey Gentlewomen, I thinke, to entitle it Primrofe Peerleffe) with a fmall round flat Crowne, rather then a cup in the middle, of a pale yellow colour, with fome pale chiues ftanding therein, being of a fweete, but ftuffing fent : the roote is reafonable great, and encreafing more then a better plant.

\section{Narciffus mediocroceus Jerotinus. The late flowring white Daffodill.}

This Daffodill hath much fmaller leaues, and fhorter then the laft, the ftalke alfo rifeth not fo high by much, and beareth but one flower thereon, of a pure white colour, made of fix fmall leaues, and fomewhat narrow, ftanding feuerally one from another, and not fo clofe together as the former, but appearing like a ftarre: the cup is fmall and round, of a pale yellow colour, but faffrony about the brims, hauing fix fmall pale chiues in the middle, the fmell whereof is much fweeter then in the former.

The Place.

The firft is thought to grow naturally in England, but I could neuer heare of his naturall place. I am fure it is plentifull enough in all Country Gardens, fo that wee fcarce giue it place in our more curious parkes. The fecond liueth onely with them that delight in varieties.

The Time.

The firft Daffodill flowreth in the middle time, being neither of the earlieft, nor of the lateft; but about the middle, or end of Aprill. The other flowreth with the lateft in May.

The Names.

I hall not neede to trouble you with further repetitions of names, they hauing been fet downe in their titles, which are proper to them. 


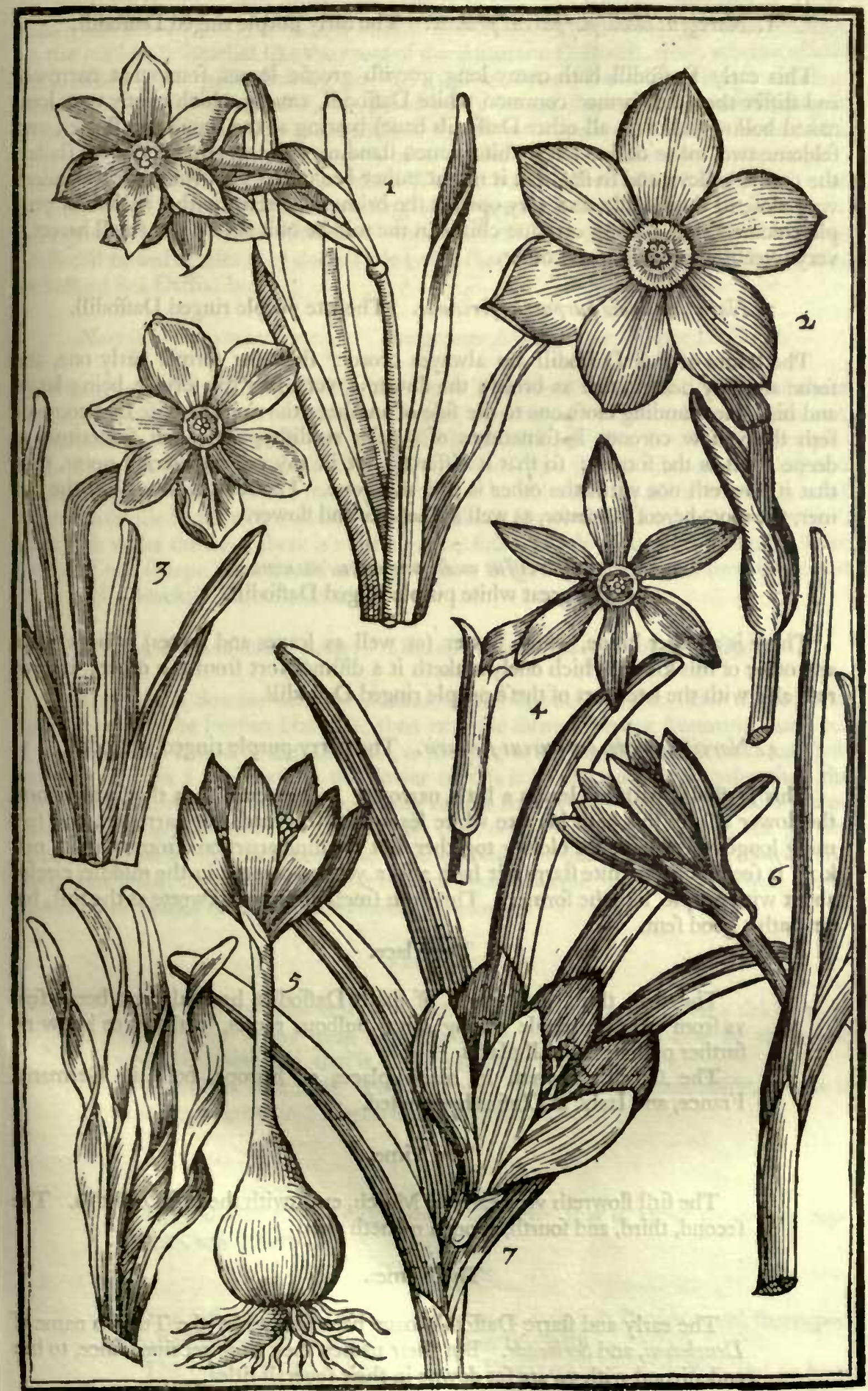

1. Narcifus aulgaris medio luleus. The common while Daffodill, or Primrofe Peerleffe. 2 Narcifjus medio purpureus maximus. The oreat white purple ringed Dafiodill. 3 Narciffus medio purpureus pracox. The early purple ringed Daffodill. 4 Narciffus acdio purfurcus flellatus. The ftarry purple ringed Daffodill. 5 Narciffus Parficus. The Perfian Daffodill. 6 Norciffus Axtumnalis minor. The leffer Winter Daffodill. 7 Narciffus Autumualis moior. The greater Winter Daffodill. 
I. Narcifus medio purpureus pracox. The early purple ringed Daffodill.

This early Daffodill hath many long grayith greene leaues, fomewhat narrower and ftiffer then the former common white Daffodill, among which rifeth vp a long naked hollow ftalke (as all other Daffodils haue) bearing at the toppe one flower, and feldome two, made of fixe long white leaues, ftanding clofe together about the ftalke; the cup is yellow, and fo flat, that it might rather bee called a crowne: for it Ptandeth very clofe to the middle, and very open at the brimmes, circled with a reddifh or purple coloured ring, hauing certaine chiues in the middle of it alfo. The fmell hereof is very fweete, exceeding many other.

\section{Narci] us medio purpureus ferotinus. The late purple ringed Daffodill.}

The leaues of this Daffodill are alwayes broader then the former early one, and fome are very neare twice as broad: the flower is very like the former, being large, and his leaues ftanding clofe one to the fide of another; the ring likewife that comparfeth the yellow coronet, is fometimes of a paler reddifh purple, and fometimes as deepe a red as the former: fo that it differeth not in any other materiall point, then that it flowreth not vntill the other is paft and gone. The fent of this is like the former, the roote hereof is greater, as well as the leafe and flower.

\section{Narcifus medio purpureus maximus.}

The great white purple ringed Daffodill.

There is another kinde, whore flower (as well as leaues and rootes) is larger then any other of this kinde, which onely maketh it a diftinct fort from the other: it flowreth alfo with the later fort of thefe purple ringed Daffodils.

\section{Narcifus medio purpureus ftellaris. The ftarry purple ringed Daffodill.}

This Daffodill hath his leaues a little narrower and greener then the former forts, the flower alfo of this hath his fixe white leaues not fo broad, but narrower, and feeming longer then they, not clofing together, but ftanding apart one from another, making it feeme like a white ftarre: it hath alfo a yellow coronet in the middle, circled about with purple, like the former. This doth fmell nothing fo fweete as the firft, but yet hath a good fent.

\section{The Place.}

The firft, third, and fourth of there Daffodils, have alwayes beene fent vs from Conftantinople among other bulbous rootes, fo that wee know no further of their naturall places.

The fecond groweth in many places of Europe, both in Germany, France, and Italy, as Clufius hath noted.

\section{The Time.}

The firt flowreth very early in March, euen with the firft Daffodils. The fecond, third, and fourth, about a moneth after.

\section{The Names.}

The early and ftarre Daffodils, haue been fent vs by the Turkifh name of Deuebohini, and Serincade. But their names, they haue receiued fince, to bee endenizond with vs, are fet downe in their feuerall titles.

\section{Narcifus Perficus. The Perfian Daffodill.}

This Perfian Daffodill differeth from all other kindes of Daffodils in his manner of growing, 
growing, for it neuer hath leaues and flowers at one time together, wherein it is like vnto a Colchicum, yet in roote and leafe it is a Daffodill. The roote is a little blackifh on the outfide, fomewhat like the roote of the Autumne Daffodill, from whence rifeth up a naked foote ftalke, bearing one pale yellow flower, breaking through a thinne skinne, which firt enclofed it, compofed of fix leaues, the three outermoft being a little larger then the reft, in the middle of the flower there are fix fmall chiues, and a longer pointell. The whole flower is of an vnpleafant fent: After the flower is paft, come vp the leaues, fometimes before Winter, but moft vfually after the deepe of Winter is paft with vs, in the beginning of the yeare, which are broad, long, and of a pale greene colour, like the leaues of other Daffodils, but not greene as the Autumne Daffodill is, and befides they doe a little twine themfelues, as fome of the Pancratium, or baftard Sea Daffodils doe.

\section{Narciffus Autumnalis maior. The greater Autumne or Winter Daffodill.}

The greater Autumne Daffodill rifeth vp with three or foure faire broad and fhort leaues at the firft, but afterwards grow longer, of a very deepe or darke greene colour, in the middle of which rifeth $\mathrm{vp}$ a fhort, ftiffe, round footeltalke, bearing one faire yellow flower on the head thereof (inclofed at the firft in a thinne skinne, or huske) and confifteth of fix leaues as the former, with certaine chiues in the middle, as all or moft other Daffodils haue, which paffeth away without fhew of any feed, or head for feed, although vnder the head there is a little greene knot, which peraduenture would beare feede, if our tharpe Winters did not hinder it. The roote is great and round, couered ouer with a blackifh skinne or coate.

\section{Narcifus Autumnalis minor. The leffer Autumne or Winter Daffodill.}

Clufius fetteth downe, that the manner of the flowring of this leffer Daffodill, is more like vnto the Perfian Daffodill, then vnto the former greater Autumne kind; but I doe finde that it doth in the fame fort, as the greater kinde, rife vp with his leaues firf, and the flowers a while after: the flower of this is leffer, and a little paler then the flower of the greater kinde, but confifting in like fort of fix leaues, narrow and tharpe pointed; the greene leaues alfo are almoft of as deepe a greene colour, as the greater kinde, but fmaller and narrower, and a little hollow in the middle. The roote is alfo alike, but leffer, and couered with a blackifh skinne as the former. This hath fometimes borne blacke round feede in three fquare heads.

\section{The Place.}

The Perfian Daffodill hath beene fent fometimes, but very feldome, among other rootes from Conftantinople, and it is probable by the name whereby it was fent, that it fhould naturally grow in Perfia.

The other two have likewife beene fent from Conftantinople, and as it is thought, grow in Thracia, or thereabouts.

\section{The Time.}

They all doe flower much about one time, that is, about the end of September, and in October.

The Names.

The firt hath been fent by the name of Serincade Perfiana, and thereupon is called Narcifus Perficus, The Perfian Daffodill.

The other two haue been thought by diuers to be Colchica, and fo haue they called them, vpon no other ground, but that their flower is in forme and time fomewhat like Colchicum, when as if they had marked them better, they might plainly difcerne, that in all other things they did refemble Daffodils; but now the names of Colchicum luteum maius, Ev mimus, is quite 
loft, time hauing worne them out, and they are called by moft Herbarifts now adayes, Narciffus Autumnalis maior $\mathbb{E}$ minor, The greater and the leffer Autumne Daffodill.

Thus farre have I proceeded with thofe Daffodils, that hauing broad leaues, beare but one fingle flower, or two at the moft vpon a ftalke: And now to proceed with the reft, that haue broad leaues, and beare fingle flowers, but many vpon a ftalke.

\section{Narcifus Africanus aureus maior. The great yellow Daffodill of Africa.}

This braue and ftately Daffodill hath many very long and broad leaues, of a better greene colour, then many others that are grayifh, among which appeareth a ftalke, not rifing to the height of the leaues, bearing at the toppe out of a skinnie hofe many faire, goodly, and large flowers, to the number of ten or twelue, if the roote bee well growne, and ftand in a warme place, euery one being larger then any of the French, Spanifh, or Turkie Daffodils, that beare many fingle flowers vpon a ftalke, and commeth neere vnto the bigneffe of the Englifh Daffodill, called Primrofe Peerleffe, before defcribed, or that French kinde hereafter defcribed, that beareth the largeft flowers, many vpon a ftalke (which fome would make to bee a kinde of that Englifh Daffodill, but bearing more flowers) and of a faire thining yellow colour, hauing large, round, and open cups or boules, yellower then the outer leaues; and is of fo exceeding fweete a fent, that it doth rather offend the fenfes by the aboundance thereof: the roote is great, and couered with a blackifh browne coate or skinne.

\section{Narcifus Africanus aureus minor. The leffer Barbary Daffodill.}

This leffer kinde is very neere the fame with the former, but that it lacketh fomewhat of his ftatelineffe of height, largeneffe of flower and cup (being of a paler yellow) and beauty of colour, for it beareth neither of thefe equall vnto the former, but is in them all inferiour. And thus by this priuatiue, you may vnderftand his pofitiue, and that thall be fufficient at this time.

\section{Narcifus Byzantinus totus luteus. The yellow Turkie Daffodill.}

Whereas the laft defcribed, came fhort of the beauty of the former, fo this lacketh of that beauty is in the laft; for this, although it haue very long leaues, and a high ftalke, yet the flowers are neither fo many, as not being aboue foure or fiue, nor fo large, being not much greater then the ordinary French Daffodill hereafter defcribed, nor the colour fo faire, but much paler, and the cup alfo fmaller; and herein confifteth the chiefert differences betweene this, and both the other, but that the fent of this is alfo weaker.

The Place.

The firft and the fecond grow in Barbary, about Argiers, and Fez, as by the relation of them, that haue brought them into thefe parts, wee haue been enformed.

The laft hath been often brought from Conftantinople among other varieties of Daffodils, but from whence they receiued them, I could neuer learne.

\section{The Time.}

Thefe Daffodils do flower very early, euen with the firft fort of Daffodils, I meane after they have been accuftomed vnto our climate: for oftentimes vpon their firft bringing ouer, they flower in Ianuary or February, efpecially if they be preferued from the frofts, and kept in any warme place; for they are very tender, and will foone perifh, being left abroad.

\section{The Names.}

The firft is called by diuers in French, Narciffe $d$ Algiers, and in many 
places of the Low Countries, Narciffen van Heck, or Narcifus Heckius; by diuers others Narcifus Africamus aureus maior, we may call it in Englifh, The great African Daffodill, or the great Barbary Daffodill, or the great yellow Daffodill of Argiers, which you pleafe.

The fecond hath no other variation of name, then a diminutiue of the former, as is fet downe in the title.

The third is no doubt the fame, that Clufius fetteth downe in the twelfth Chapter of his fecond Booke of the Hiftory of more rare plants, and maketh the fourth fort, which came from Conftantinople, and may alfo be the fame, which he maketh his fifth, which (as he faith) he receiued from Doctour Simor Touar of Seuill in Spaine. Wee call it, from the place from whence we receiued it, Narcifus Byzantinus, with the addition of totus luteus, to put a difference from other forts that come from thence alfo : in Englifh, The yellow fingle Daffodill of Turkie.

\section{Narciffus Sulphureus maior. The greater Lemon coloured Daffodill.}

The greater of thefe Daffodils, beareth three or foure greene and very long leaues, a foote and a halfe long at the leaft, among which rifeth vp a round, yet crefted ftalke, not fo high as the leaues, bearing fiue or fixe fingle flowers thereon, euery one of them being greater then the ordinary French or Italian Daffodils, with many flowers vpon a ftalke; of a faint, but yet pleafant yellow colour at the firft, which after they haue been in flower a fortnight or thereabouts, change into a deeper, or more fullen yellow colour : the cup in the middle is likewife larger, then in thofe formerly named, and of a deeper yellow colour then the outer leaues, hauing onely three chiues within it. The fmell is very pleafant.

\section{Narciffus Sulphureus minor. The lefler Lemon coloured Daffodill.}

This leffer Daffodill hath broader and fhorter leaues then the former, of the colour of other Daffodils, and not greene like the former: the ftalke of this rifeth vp higher then the leaues, bearing foure or fiue flowers vpon fhorter footeftalkes, and no bigger then the French Daffodill, of a pale yellow, which moft doe call a Brimftone colour, the cup or rather crowne in the middle, is fmall, and broad open, of a little deeper yellow, hauing many chiues within it, and is as it were fprinkled ouer with a kinde of mealineffe. The fmell of this is not full fo pleafant as the former.

The Place.

Both thefe haue been gathered on the Pyrenæan Mountaines, and both likewife haue been fent out of Italy.

The Time.

They both flower in the middle time of the Daffodils flowring, that is, in Aprill.

The Names.

They haue their Latine names expreffed in their titles, and fo are their Englifh alfo, if you pleafe fo to let them paffe; or elfe according to the Latine, you may call them, The greater and the leffer Brimftone coloured Daffodils; fome haue called them Narciffus Italicus, but the Italians themfelues haue fent them by the name of Narcifo Solfarigno.

Narcifus totus albus polyanthos. The milke white Daffodill many vpon a ftalke.

The leaues of this Daffodill are of a meane fize, both for length and breadth, yet fomewhat greener then in the ordinary forts, that haue fome whiteneffe in them: the 
flowers are many vpon the ftalke, as fmall for the moft part, as any of thefe kindes that beare many together, being wholly of a milke, or rather fnow white colour, both the cuppe, which is fmall, and the outer leaues that compaffe it ; after which come fmall heads, wherein is contained round blacke feede, as all other Daffodils doe, although fome greater, and others leffer, according to the proportion of the plants : the roote is couered ouer with a blackifh skinne or coate ; the fmell is very fweete.

There are two other forts more of this kinde, the differences whereof are, that the one hath his leaues fomewhat broader, and the flowers greater then the former : And the other fmaller leaues and flowers alfo, whofe cups being fmall, are neuer feene fully open, but as it were halfe clofed at the brimmes.

\section{Narcifus latifolius totus albus, mediocri calice reflexus.}

The milke white Daffodill with the great cup.

There is yet another fort of thefe milke white Daffodils, whofe leaues are as broad as any of the former, and whofe cup in the middle of the flower, is fomewhat larger then in any of the leffer forts, and leffer then in the greater kinde : but the leaues of the flowers doe a little turne themfelues vpwards, which maketh a chiefe difference.

The Place.

Thefe Daffodils grow in Spaine, from whence I receiued many that flourifhed a while, but perifhed by fome fierce cold Winters : they likewife grow in France, from whence many alfo haue been brought vnto vs. They haue likewife been fent from Contantinople to vs, among other kindes of Daffodils.

\section{The Time.}

They that come from Conftantinople, for the moft part doe flower earlier then the other, euen after they are accuftomed to our ayre. Some of them flower notwithftanding in the end of March, the reft in Aprill.

\section{The Names.}

They are vfually called Narcifus totus albus polyanthos, adding thereunto the differences of maior, medius, and minor, that is, The milke white Daffodill, the greater, the middle, and the leffer; for fo fome doe diftinguifh them. The laft, for diftinction, hath his name in his title fufficient to expreffe him.

\section{Narcifus Narbonenfis, fiue medio luteus pracox.}

The early French Daffodill.

The leaues of this Daffodill, fpring vp out of the ground a moneth or two fometimes before the other of this kinde, that follow; being alfo thorter and narrower: the ftalke likewife is not very high, bearing diuers flowers at the top, breaking through a thinne skinne, as is vfuall with all the Daffodils, euery one whereof is fmall, confifting of fix white leaues, and a fmall yellow cup in the middle, which is of a prettie fmall fent, nothing fo ftrong as many others: the roote is great and round, and feldome parteth into of-fets, euen as all the other that follow, bearing many fingle flowers, doe.

\section{Narciffus Narbonenfis vulgaris. The ordinary French Daffodill.}

This Daffodill hath long and broad greene leaues, a little hollowifh in the middle, and edged on both fides; the ftalke is a foote and a halfe high, bearing at the toppe diuers flowers, fomewhat larger then the former, confifting of fix white leaues, fomewhat round; the cup is yellow in the middle, fmall and round, like vnto an Acorne cuppe, or a little fuller in the middle: this is the forme of that fort which was firft 


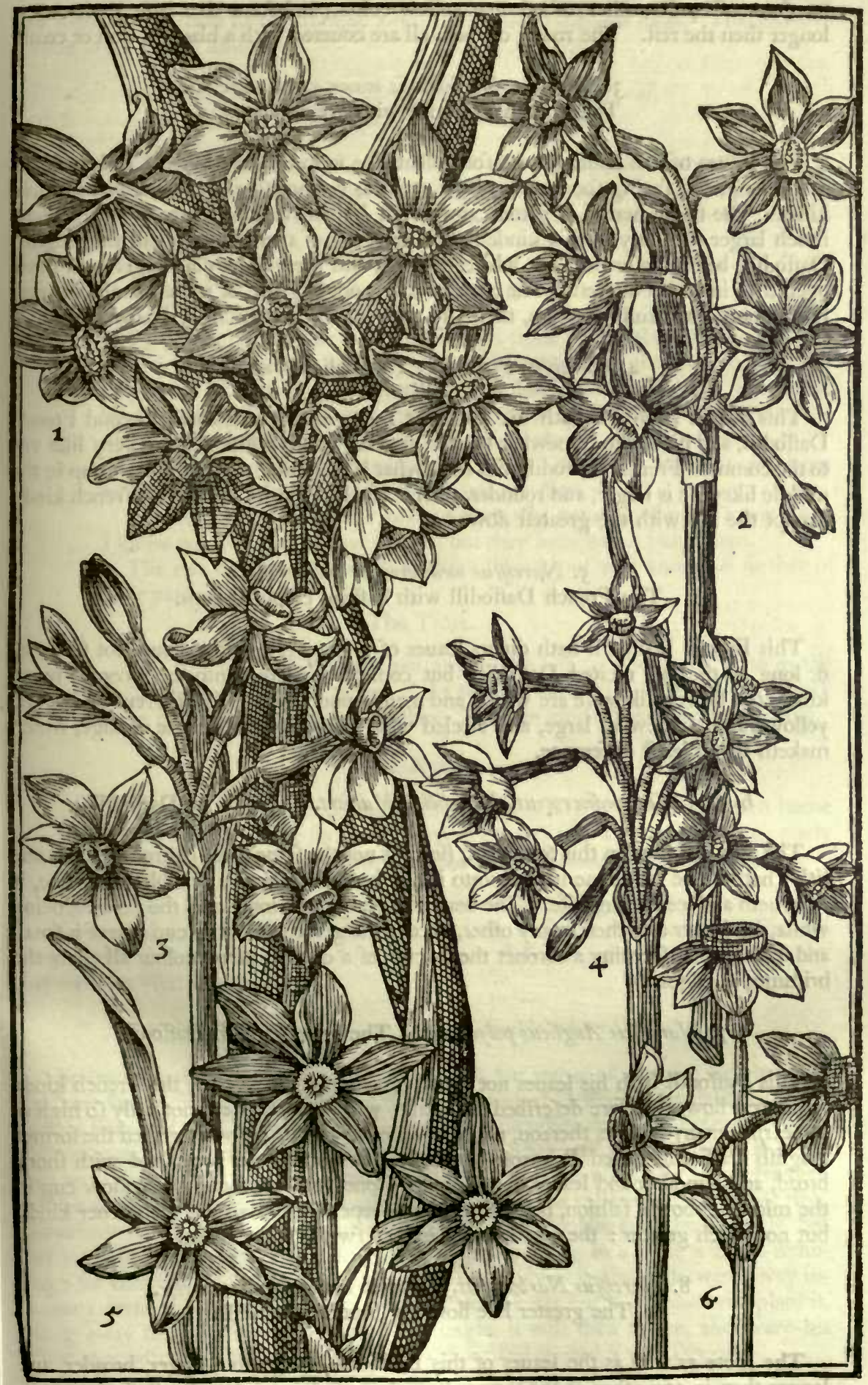

I Narciffus Africanus oureus maior. The great yellow Daffodill of Africa. 2 Narciffus Africanns luteus minor. The leffer yellow Daffodill of Africa. 3 Narciffus Narbonen/is medio lutcus. The Irench Daftodill. 4 Narciffus Pifanus, zel tolus albus. The Italian Daffodill, or the all white Daffodill. S Narciffus Mnffort. Muftart his Daffodill. 6, Niarciffus Anglicus folyanthos. The great Englifh Daffodill. 
brought vnto vs: But fince there is found out fome, whofe cup is fhorter, others flatter, fome of a paler, others of a deeper yellow colour, and fome that have their cuppe longer then the reft. The rootes of them all are couered with a blackifh skin or coate.

\section{Narcifus Narbonenfis maior amplo, flore.}

The French Daffodill with great flowers.

The leaues of this Daffodill are fomewhat like vnto the laft, but not fo broad, yet full as long, and fpring fooner out of the ground, yet not fo early as the firft of thefe kindes: the ftalke hereof is flatter, and rifeth higher, bearing foure or fiue flowers, much larger then any of this kinde; for euery one of them doth equall the Englifh Daffodill, before defcribed, but whiter then it, and the yellow cup larger, and more open then in any of the reft. The roote of this is not fo great, or round, as the former, but is more plentifull in of-fets, then any other of thefe French, or Italian kindes.

\section{Narcifus Pifamus. The Italian Daffodill.}

This Italian Daffodill hath his leaues as large, or larger then the fecond French Daffodill, and his ftalke fomewhat higher, bearing many white flowers, very like vnto the common French Daffodill, but fomewhat larger alfo; and the yellow cup in the middle likewife is larger, and rounder, then is vfually feen in any of the French kinds, except the laft with the greateft flowers.

\section{Narciffus mediocroceus polyantios.}

The French Daffodill with Saffron coloured cups.

This French Daffodill hath diuers leaues of a grayifh greene colour, not fo broad or long as the laft recited Daffodill, but comming neerer vnto the fecond French kinde, the flowers likewife are white, and many vpon a ftalke, like thereunto, but the yellow cup is fomewhat large, and circled with a Saffron like brimme or edge, which maketh the chiefeft difference.

\section{Narcifus mediocroceus alter, dictus Mufart. Muffart his Daffodill.}

The affinity between this \& the laft, (for it is not the fame to be expreffed vnder one title) hath made me ioyne it next vnto it, yet becaufe it hath a notable difference, it deferueth a place by himfelfe. The leaues are large and long, and the flowers, being white, are larger alfo then in any other, except the greateft, but the cup hereof is fmall and fhort, rather feeming a coronet then a cup, of a deepe Saffron colour all about the brimmes or edges.

\section{Narcifius Anglicus polyanthos. The great Englifh Daffodill.}

This Daffodill hath his leaues not much broader or longer, then the French kinde with great flowers, before defcribed, the ftalke with flowers rifeth not fully fo high as it, bearing many flowers thereon, not altogether fo white, yet whiter then the former Englifh Daffodill, called Primrofe Peerleffe, but nothing fo large, and with fhort, broad, and almoft round leaues, ftanding clofe one vnto another : the yellow cup in the middle is bowle fafhion, being fomewhat deeper then in any of the former kinds, but not much greater : the fmell hereof is very fweete and pleafant.

\section{Narciffus Narbonen/is, fiue medio lutens ferotimus maior.}

The greater late flowring French Daffodill.

The roote as well as the leaues of this Daffodill, are greater, larger, broader, and longer then in any other of the former French, or Italian kindes; the ftalke is as high as any of them, bearing at the toppe fiue or fixe white flowers, ftanding open fpread like a farre, and not clofe together, euery one whereof is large, and round pointed, 
the cup is yellow, fmall and fhort, yet not lying flat to the flower, but a little ftanding out with fome threads in the middle, as all the former Daffodils haue. This is not fo fweete as the earlier kindes.

\section{Narciffus medioluteus alter ferotinus calice breui. \\ The leffer late flowring French Daffodill.}

This Daffodill is of the fame kinde with the laft defcribed, the onely difference is, that it is leffer, and the yellow cuppe in the middle of the flower, is fomewhat fhorter then the former, although the former be fhorter then many others, otherwife it differeth not, no not in time; for it flowreth late as the former doth.

The Place.

Thefe Daffodils haue been brought vs from diuers places; The firft and fecond grow naturally in many places of Spaine, that are open to the Sea : they grow likewife about Mompelier, and thofe parts in France. They haue been likewife fent among many other forts of Daffodils from Conftantinople, fo that I may thinke, they grow in fome places neere thereunto.

The fourth groweth plentifully in Italy, about Pifa in Tufcane, from whence we haue had plants to furnifh our Gardens.

The feuenth is accounted beyond Sea to be naturall of our Country, but I know not any with vs that haue it, but they haue had it from them.

The reft haue been brought at diuers times, but wee know no further of their naturall places.

\section{The Time.}

The firft flowreth earlier then any of the reft by a moneth, euen in the beginning of March, or earlier, if the weather be milde. The other in Aprill, fome a little before or after another. The late kinds flower not vntill May.

\section{The Names.}

There can be no more faid of the names of any of them, then hath beene fet out in their titles; for they diftinguifh euery fort as fitly as we can : onely fome doe call the firft two forts, by the name of Donax Narbonenfis.

After all thefe Daffodils, that hauing broad leaues beare fingle flowers, either one or many vpon a ftalke, I fhall now goe on to fet forth thofe broad leafed Daffodils, that carry double flowers, either one or many vpon a ftalke together, in the fame order that we haue vfed before.

\section{Narciffus albus multiplex. The double white Daffodill.}

The leaues of this Daffodill are not very broad, but rather of a meane fize, being of the fame largeneffe with the leaues of the purple ringed Daffodill, the ftalke rifeth vp to be a foote and a halfe high, bearing out of a thinne white skinne or hofe, one flower and no more, confifting of many leaues, of a faire white colour, the flower is larger then any other double white Daffodill, hauing euery leafe, efpecially the outermoft, as large almoft as any leafe of the fingle Daffodill with the yellow cup, or purple ring. Sometimes it happeneth, that the flower is very little double, and almoft fingle, but that is either in a bad ground, or for that it hath ftood long in a place without remouing; for then it hath fuch a great encreafe of rootes about it, that it draweth away into many parts, the nourifhment that fhould be for a few : but if you doe tranfplant it, taking away the of-fets, and fet his rootes fingle, it will then thriue, and beare his flower as goodly and double, as I haue before defcribed it : and is very fweete.

2. Narcifus mediopurpureus multiplex. The double purple ringed Daffodill.

There is little difference in the leaues of this kinde, from the leaues of the fingle pur- 
ple ringed Daffodill ; for it is probable it is of the fame kinde, but by natures gift (and not by any humane art) made more plentifull, which abideth conftant, and hath not that dalliance, which oftentimes nature fheweth, to recreate the fenfes of men for the prefent, and appeareth not againe in the fame forme: the chiefeft difference is, that the flower (being but fometimes one on a ftalke, and fometimes two) confifteth of fix white outer leaues, as large as the leaues of the fingle kinde, hauing many fmall yellow peeces, edged with purple circles round about them, inftead of a cup; and in the middle of thefe peeces, ftand other fix white leaues, leffer then the former, and a yellow cup edged with a purple circle likewife, parted into peeces, and they comprehend a few other white leaues, rmaller then any of the other, hauing among them fome broken peeces of the cup, with a few chiues alfo in the middle of the flower. The flower is very fweete.

There is of this kinde another, whofe flower hath not fo plaine a diftinction, of a triple rowe of leaues in it : but the whole flower is confufedly fet together, the outer leaues being not fo large, and the inner leaues larger then the former; the broken yellow cuppe, which is tipt with purple, running diuerly among the leaues; fo that it fheweth a fairer, and more double flower then the former, as it is indeed.

\section{Narcifus medioluteus corona duplici.}

The Turkie Daffodill with a double crowne.

This Daffodill hath three or foure leaues, as large and long almoft, as the great double Daffodill of Conftantinople next following hath: the ftalke likewife is very neere as great, but as high altogether, bearing at the toppe foure or fiue flowers, the leaues whereof are as large, as of the firit or fecond kinde of French Daffodils, before defcribed, but not altogether of fo pure a white colour; and being fix in number, ftand like the former fingle French Daffodils, but that the yellow cup in the middle of this is thicke and double, or as it were crumpled together, not ftanding very high to be confpicuous, but abiding lowe and thort, fo that it is not prefently marked, vnleffe one looke vpon it precifely; yet is exceeding fweete. The roote is like vnto the roote of the purple ringed Daffodill, or fomewhat bigger.

\section{Narcifus Chalcedonicus flore pleno albo polyanthos.}

The double white Daffodill of Conftantinople.

This beautifull and goodly Daffodill (wherewith all Florifts greatly defire to bee acquainted, as well for the beauty of his double flowers, as allo for his fuperabounding fweete (mell, one ftalke with flowers being inftead of a nof egay) hath many very broad, and very long leaues, fomewhat greener then gray, among which rifeth vp a ftrong round ftalke, being fometimes almoft flat, and ribbed, bearing foure or fiue, or more white flowers at the toppe, euery one being very great, large, and double, the leaues being confufedly fet together, hauing little peeces of a yellow cup running among them, without any fhew of that purple ring that is in the former, and fall away without bearing feed, euen as all, or moft other double flowers doe: the fmell is fo exceeding fweet and ftrong, that it will foone offend the fenfes of any, that fhall fmell much vnto it: the roote is great and thicke, couered with a blackifh coate.

\section{Narciffus Chalcedonicus fimbriatus multiplex polyanthos.}

The great double purple ringed Daffodill of Conftantinople.

This Daffodill differeth very little or nothing in leafe from the former, the onely difference is in the flowers, which although they bee double, and beare many vpon a ftalke, like vnto them, yet this hath the peeces of the yellow cuppes tipt with purple, as if they were fhred or fcattered among the white leaues, whereas the other hath only the yellow, without any thew of purple tips vpon them: the fmell of this is as ftrong as of the other. 


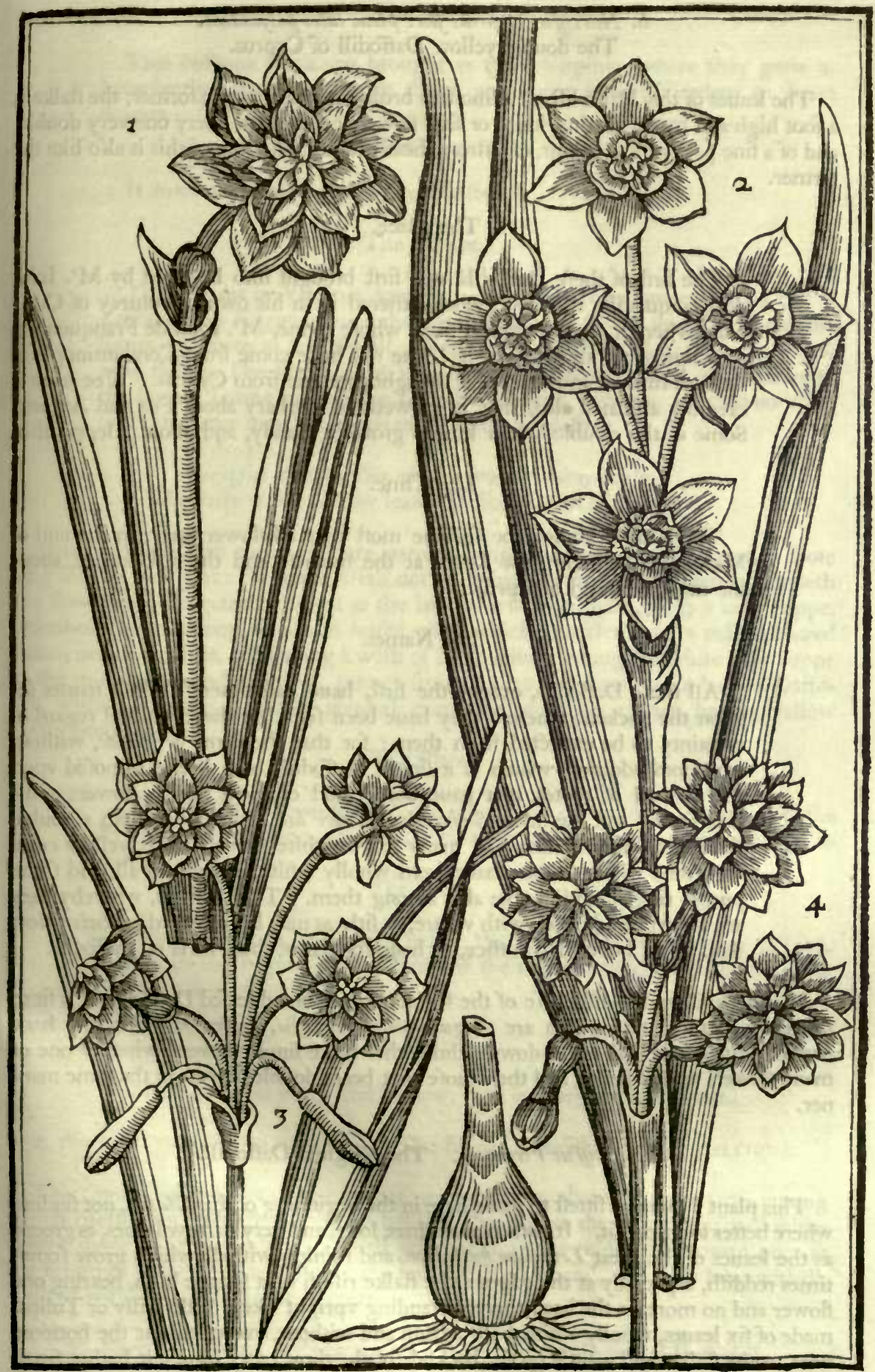

8. Narcifjus albus mulliplex. The double white Daffodill. 2 Narciffus medislwleus corona duplici. The Turkie Dafiodill with a double crowne. 3 Narciffus mediopurpureus multiplex. The double porple singed Daffodill, 4 Nareiffus Chalcelonicus flore pleno albo polyanthos. The double white Daffodill of Conftantinople. 


\section{Narcifius Cyprius fore pleno luteo polyanthos.}

The double yellow Daffodill of Cyprus.

The leaues of this Daffodill are almoft as broad and long as the former, the ftalke is a foot high and more, bearing foure or fiue flowers on the top, euery one very double, and of a fine pale yellow colour, of a ftrong heady fent. The root of this is alro like the former.

The Place.

The firft of thefe Daffodils, was firft brought into England by $\mathrm{M}^{\mathrm{r}}$. Iohn de Franqueuille the elder, who gathered it in his owne Countrey of Cambray, where it groweth wilde, from whofe fonne, $\mathrm{M}^{\mathrm{r}}$. Iohn de Franqueuille, now liuing, we all haue had it. The reft haue come from Conftantinople at feuerall times; and the laft is thought to come from Cyprus. Wee haue it credibly affirmed alfo, that it groweth in Barbary about $\mathrm{Fez}$ and Argiers. Some of the double white kindes grow in Candy, and about Aleppo alfo.

\section{The Time.}

The Turkie kindes doe for the molt part all flower early, in the end of March, or beginning of Aprill at the furtheft, and the firft double, about the middle or end of Aprill.

\section{The Names.}

All thefe Daffodils, except the firft, haue had diuers Turkifh names fet vpon the packets, wherein they, haue been fent, but there is fmall regard of certainty to be expected from them; for that the name Serincade, without any more addition, which is a fingle Daffodill, hath beene impofed vpon that parcell of rootes, that haue borne molt of them double flowers of diuers forts; and the name Serincade Catamer lale, which fignifieth a double flowred Daffodill, hath had many fingle white flowers, with yellow cups, and fome whofe flowers haue been wholly white, cuppe and all, and fome purple ringed, and double alfo among them. Their names, whereby they are knowne and called with vs, are, as fitly as may be, impofed in their titles: And this I hope fhall fuffice, to haue fpoken of thefe forts of Daffodils.

Hauing finifhed the difcourfe of the former fort of broad leafed Daffodils, it is fit to proceede to the next, which are Angustifolios Narcifos, thofe Daffodils that haue narrow leaues, and firft to fet downe thofe that beare fingle flowers, whether one or many flowers vpon a ftalke, and then thofe that beare double flowers in the fame manner.

\section{Narciffus Virgineus. The Virginia Daffodill.}

This plant I thought fitteft to place here in the beginning of this Cla $/ s i s$, not finding where better to fhroud it. It hath two or three long, and very narrow leaues, as greene as the leaues of the great Leucoium bulbofum, and fhining withall, which grow fometimes reddifh, efpecially at the edges : the ftalke rifeth vp a fpanne high, bearing one flower and no more on the head thereof, ftanding vpright like a little Lilly or Tulipa, made of fix leaues, wholly white, both within and without, except that at the bottome next to the ftalke, and a little on the backfide of the three outer leaues, it hath a fmall dafh or fhew of a reddifh purple colour: it hath in the middle a few chiues, ftanding about a fmall head pointed; which head groweth to bee finall and long, containing fmall blackifh flat feede: the roote is fmall, long, and round, a little blackifh on the outfide, and white on the infide. 
The Place.

This bulbous plant was brought vs from Virginia, where they grow aboundantly; but they hardly thriue and abide in our Gardens to beare flowers.

The Time.

It flowreth in May, and feldome before.

The Names.

The Indians in Virginia do call it Attamufco, fome among vs do call it Lilionarciffus Virginianus, of the likeneffe of the flower to a Lilly, and the leaues and roote to a Daffodill. Wee for breuity doe call it Narcifus Virgineus, that is, The Daffodill of Virginia, or elfe you may call it according to the former Latine name, The Lilly Daffodill of Virginia, which you will; for both names may ferue well to expreffe the plant.

\section{Narciffus anguftifolius albidus pracox oblongo calice.}

The early white narrow leafed Daffodill with a long cup.

This Daffodill hath three or foure narrow, long, and very greene leaues, a foote long for the moft part : the ftalke rifeth not $\mathrm{vp}$ fo high as the leaues, whereon ftandeth one flower, not altogether fo great as the late flowring Daffodill, with a long cuppe, defcribed before among the broad leafed ones, which confifteth of fix pale coloured leaues, not pure white, but hauing a wafh of light yellow among the white: the cuppe in the middle is round and long, yet not fo long as to bee accounted a baftard Daffodill, within which is a middle pointell, compaffed with fix chiues, hauing yellow mealy pendents.

The Place.

This Daffodill groweth with the other forts of broad leafed ones, on the Pyrenæan Mountaines, from whence they haue beene brought vnto vs, to furnifh our Gardens.

The Time.

It flowreth early, a moneth before the other forts of the fame fafhion, that is, in the beginning of March, if the time be milde, which the other before fpoken of doe not.

\section{The Names.}

It hath no other name that I know, then is expreffed in the title.

2. Narciffus mediocroceus temuifolius. The fmall Daffodill with a Saffron crown.

This fmall Daffodill hath foure or fiue narrow leaues, about a fpanne long, among which rifeth vp a ftalke fome nine inches high, bearing at the toppe one fmall white flower, made of fix leaues, with a fmall yellow cup in the middle, fhadowed ouer at the brimmes with a Saffron colour : the roote is fmall, round, and little long withall, couered with a blackifh skinne or coate.

\section{Narciffus minimus mediopurpureus. The leaft purple ringed Daffodill.}

This little Daffodill hath fmall narrow leaues, fhorter by much then any of the purple ringed Daffodils, before defcribed: the ftalke and flower keepe an equall proportion to the reft of the plant, being in forme and colour of the flower, like vnto the 
Starre Daffodill before recited, but vnlike in the greatneffe: this alfo is to bee obferued, that the purple colour that circleth the brimmes of the cuppe, is fo fmall, that fometimes it is not well perceiued.

\section{Narciffus minimus Iuncifolij flore. The leaft Daffodill of all.}

This leaft Daffodill hath two or three whitilh greene leaues, narrower then the two laft recited Daffodils, and fhorter by halfe, being not aboue two or three inches long, the ftalke likewife is not aboue three or foure inches high, bearing one fingle flower at the toppe, fomewhat bigger then the fmalneffe of the plant fhould feeme to beare, very like vnto the leaft Rufh Daffodill, and of the fame bigneffe, or rather fomewhat bigger, being of a faint yellow colour, both leaues, and cup, or crowne, (if you pleafe fo to call it); for the middle part is fpread very much, euen to the middle of the leaues almoft, and lyeth flat open vpon the flower : the roote is fmall, euen the fmalleft of any Daffodill, and couered with a blackifh skinne or coate.

The Place.

The firft of thefe Daffodils haue beene brought vs from the Pyrenæan Mountaines, among a number of other rare plants, and the laft by a French man, called Francis le Veau, the honefteft roote-gatherer that euer came ouer to vs. The fecond was fent to $\mathrm{M}^{\mathrm{r}}$. Iohn de Franqueuille, before remembred, who imparted it to mee, as hee hath done many other good things; but his naturall place wee know not.

\section{The Time.}

They all flower about the latter end of Aprill.

The Names.

Being brought without names, wee haue giuen them their names according to their face and fafhion, as they are fet downe in their titles.

\section{Narciffus Autumnalis minor albus. The little white Autumne Daffodill.}

This little Autumne Daffodill rifeth with his flowers firft out of the ground, without any leaues at all. It fpringeth vp with one or two ftalkes about a finger long, euery one bearing out of a fmall huske one fmall white flower, laid open abroad like vnto the Starre white Daffodill, before fpoken of: in the middle of the flower is a fmall yellow cup of a meane fize, and after the flower is paft, there commeth in the fame place a fmall head, containing fmall, round, blacke feede, like vnto the Autumne Hyacinth : the leaues come vp after the feede is ripe and gone, being fmall and narrow, not much bigger then the Autumne Hyacinth : the roote is fmall and blackifh on the outfide.

The Place.

This Daffodill groweth in Spaine, where Clufius faw it, and brought it into thefe parts.

\section{The Time.}

It flowreth in the beginning of Autumne, and his feede is ripe in the end of October in thofe hot Countries, but in ours it will fcarce abide to fhew a flower.

The Names.

The Spaniards, as Clufius reporteth, call it Toncida, and he vpon the fight thereof, 


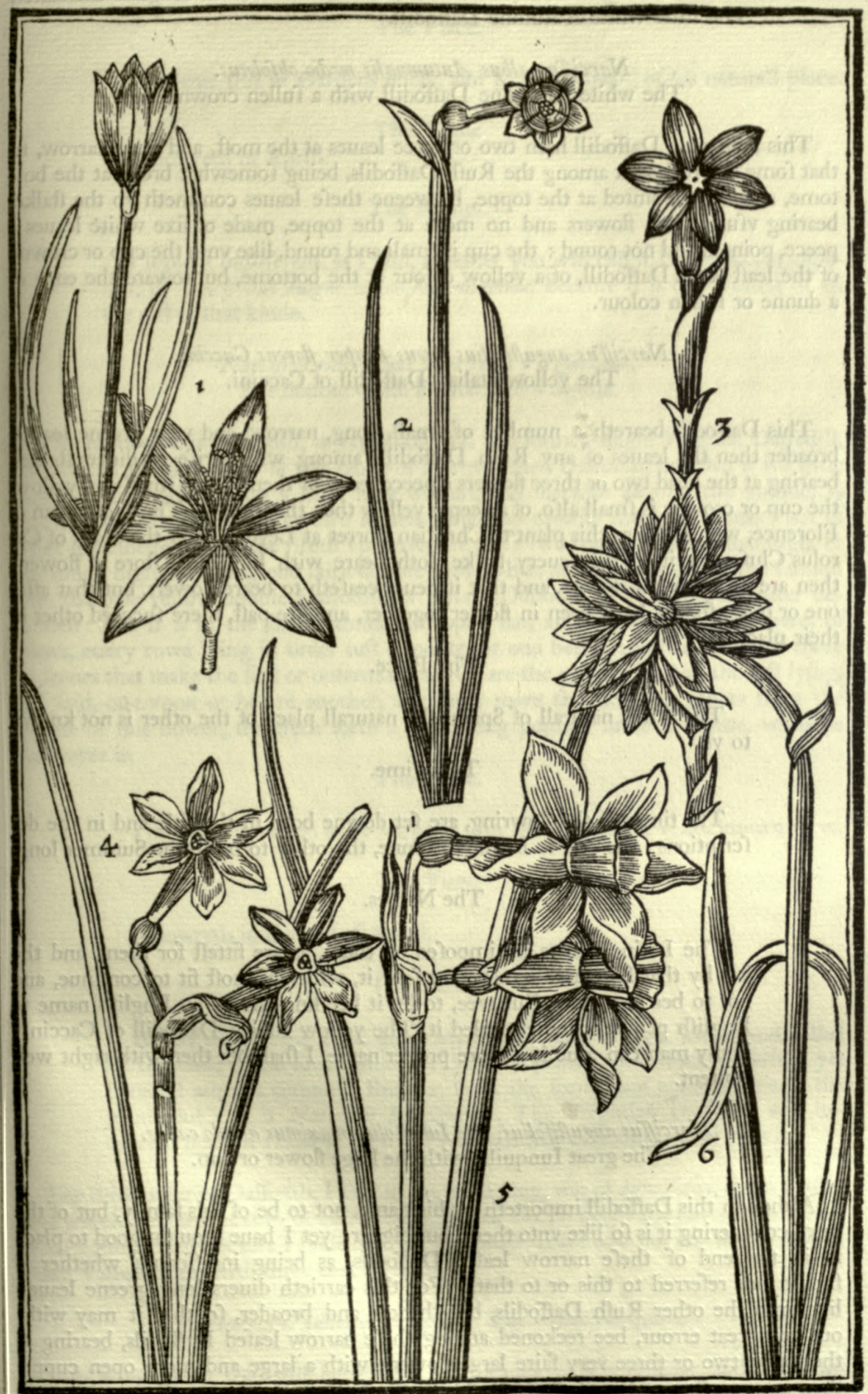

5. Narciffus Virgincus. The Virginian Daffodill. 2 Narciffus minimus Iuncifolij flore. The leaft Daffodill of all. 3 Narciffus Antumnalis'minor albus. The little white Autumne Daffodill. ${ }_{4}$ Narciffus albus Antumnalis medio obfoletus. The white Autumne Daffodill with a fullen crown. 5 Narciffusiluncifolins maximus amplo calice. The great Iunquilia with the largeft flower or cup. 6 Narciffus totus albus flore pleno Virginianus. The double white Daffodill of Virginia. 
thereof, Narciffus Autummalis minor albus, and wee in Englifh thereafter, The little white Autumne Daffodill.

Narcifus albus Autumnalis medio obfoletus.

The white Autumne Daffodill with a fullen crowne.

This Autumne Daffodill hath two or three leaues at the moit, and very narrow, fo that fome doe reckon it among the Rurh Daffodils, being fomewhat broad at the bottome, and more pointed at the toppe, betweene thefe leaues commeth vp the ftalke, bearing vfually two flowers and no more at the toppe, made of fixe white leaues a peece, pointed and not round : the cup is fmall and round, like vnto the cup or crowne of the leaft Rufh Daffodill, of a yellow colour at the bottome, but toward the edge of a dunne or fullen colour.

\section{Narciffus angufifolius luteus femper florens Caccini. \\ The yellow Italian Daffodill of Caccini.}

This Daffodill beareth a number of fmall, long, narrow, and very greene leaues, broader then the leaues of any Rufh Daffodill, among which rife vp diuers ftalkes, bearing at the head two or three flowers a peece, each of them being fmall and yellow, the cup or crowne is Imall alfo, of a deeper yellow then the flower. The Nobleman of Florence, who firft fent this plant to Chriftian Porret at Leyden, after the death of Carolus Clufius, writeth that euery ftalke doth beare with him more ftore of flowers, then are formerly fet downe, and that it neuer ceafeth to beare flowers, but that after one or more ftalkes haue been in flower together, and are paft, there fucceed other in their places.

The Place.

The firft is naturall of Spain, the naturall place of the other is not known to vs.

The Time.

The times of the flowring, are fet downe both in the title and in the defcriptions; the one to be in Autumne, the other to be all the Summer long.

\section{The Names.}

The Latine names are impofed on them, as are fitteft for them, and the laft by that honourable man that fent it, which is moft fit to continue, and not to bee changed. But wee, to let it bee knowne by an Englifh name to Englifh people, haue entituled it, The yellow Italian Daffodill of Caccini : if any man can giue it a more proper name, I fhall bee therewith right well content.

\section{Narciffus anguftifolius, fue Iuncifolius maximus amplo calice. The great Iunquilia with the large flower or cup.}

Although this Daffodill importeth by his name, not to be of this family, but of the next, confidering it is fo like vnto them, but bigger; yet I haue thought good to place it in the end of thefe narrow leafed Daffodils, as being indifferent, whether it fhould bee referred to this or to that. For this carrieth diuers long greene leaues, like vnto the other Rufh Daffodils, but thicker and broader, fo that it may without any great errour, bee reckoned among thefe narrow leafed Daffodils, bearing at the toppe two or three very faire large flowers, with a large and more open cuppe, then in any other of the Ruh Daffodils, both of them of a faire yellow colour, yet the cuppe a little deeper then the flower, and a little crumpled about the edges, and hath a pretty fharpe fent : the roote is greater and longer then the other Rufh Daffodill, and couered likewife with a blackifh coate. 
The Place.

We haue this in Gardens onely, and haue not heard of his naturall place.

It flowreth in Aprill.

The Time.

\section{The Names.}

I leaue it indifferent, as I faid, whether you will call it Narcifus anguftifolius, or Iuncifolius magno calice, or maximus, becaufe it is the greateft of all the reft of that kinde.

\section{Narciffus totus albus flore pleno Virginianus.}

The double while Daffodill of Virginia.

The roote of this Daffodill, is very like vnto the former fingle Virginia Daffodill, fet forth in the firft place of this ranke of narrow leafed Daffodils, but that it is a little bigger and rounder, being a little long withall, and blackifh alfo on the outfide, as that is: from whence rifeth vp two leaues, fomewhat broader then the former: but of a like greenneffe: the ftalke rifeth vp betweene thefe two leaues, about a fpan high, or not much higher, bearing one faire double fnow white flower, very like in the fafhion vnto the pale yellow double Daffodill, or baftard Daffodill of Robinus, hereafter defcribed: For it is in the like manner laid open flat, and compofed of fix rowes of leaues, euery rowe lying in order iuft oppofite, or one before another, whereof thofe fix leaues that make the firft or outermoft courfe, are the greateft, and all the reft lying, as I faid, one vpon or before another, are euery rowe fmaller then others from the middle of this flower, thrufteth forth a fmall long pointed forke or horne, white as the flower is.

The Place.

The place is named to be Virginia, but in what part it is not known to vs.

The Time.

It flowreth in the end of Aprill.

The Names.

It may be that this doth grow among the former fingle kinde, and called by the fame name Attamufco, for that the plant is not much differing, yet hereof I am not certaine: But we, from the forme and countenance of the plant, doe call it Narcifus Virginianus, The Virginian Daffodill, and becaufe it beareth a double flower, it hath the title of double added vnto it.

The third order of Daffodils, I faid in the beginning, was of Iuncifolios, Rufh Daffodils, which are now next to be entreated of, I fhall herein keepe the fame order I vfed in the former; but becaufe I finde none of this order, that beare but one flower vpon a ftalke, I muft begin with thofe that beare many.

\section{Narcifus Iuncifolius albus. The white Iunquilia.}

This white Rufh Daffodill hath fmall long leaues, a little broader, and of a whiter greene colour then the ordinary yellow Rufh Daffodils: the ftalke rifeth vp halfe a foote high or more, bearing two or three fmall white flowers vpon a ftalke, yet fomewhat bigger then the common yellow Rufh Daffodill, hauing a fmall round cuppe in the middle, white alfo as the leaues are. The feede is fmall, 
blacke, and round, as other feedes of Daffodils are : the roote is fmall and round, couered with a blackifh coate.

Narciffus Iuncifolius albus magno calice. The white Iunquilia with a great cup.

There is of this kinde another fort, that hath the cup in the middle of the flower, a little larger then the other, but in all other things alike.

\section{Narcifus Iuncifolius flore albo reflexo.}

The white turning Iunquilia, or Rufh Daffodill.

This turning white Daffodill hath foure or fiue long greene leaues, yet fhorter and broader then the ordinary yellow Iunquilia, and fully as greene alfo, from among which rifeth vp a flender greene ftalke, a foote high, bearing out of a thinne skinnie huske, three or foure, or more fnow white flowers, ftanding vpon long greene footftalkes, euery flower hanging downe his head, and turning vp his fix narrow and long leaues, euen to the very foot-ftalke againe: from the middle of the flower hangeth downe a long round cuppe, as white as the leaues, within which are contained three fmall white chiues, tipt with yellow, and a fmall long pointell, thrufting out beyond the brimmes of the cup : after the flowers are paft, there come vp in their places fmall three fquare heads, wherein is contained very fmall, round, and blacke fhining feede: the roote is fmall, round, and a little long withall, couered with a blackifh browne coate or skin. The flower is quite without any good fent, or indeed rather none at all.

3. Narcifus Iuncifolins flore luteo reflexo.

The yellow turning Iunquilia, or Ruh Daffodill.

The leaues of this Rufh Daffodill are greater and longer then the former, and of a paler greene colour : the ftalke rifeth fomewhat higher, bearing two or three flowers thereon wholly of a gold yellow colour, both the cuppe and the leaues that turne vp againe.

4. Narcifus Iuncifolius calice albo reflexis folijs luteis.

The yellow turning I unquilia with a white cup.

This Daffodill hath his long rufh-like leaues ftanding vpright as the former, betweene which rifeth vp a greene ftalke, about a foote high or more, bearing two or three flowers thereon, whofe turning leaues are of a faire pale yellow, and the cuppe pale white, and not fo pure a white as the former.

\section{Narciffus Iuncifolius calice luteo reflexis folijs albidis.}

The white turning Iunquilia with a yellow cup.

As the laft had the leaues of the flower that turne vp againe yellow, and the cuppe whitifh, fo this hath contrariwife the turning leaues of a whitifh yellow, and the long cup yellower, elfe in his long green leaues, or any other thing, there is fmall difference.

\section{Narciffus Iuncifolius luteus magno calice. \\ The Iunquilia, or Ruh Daffodill with a great cup.}

This Rufh Daffodill hath bigger leaues, and longer then the ordinary yellow Rufh Daffodill, being a little flat on the one fide, and round on the other, but of the fame greenneffe with all the reft: the ftalke rifeth vp two foote high, bearing two, and fometimes three flowers thereon, being of a faire yellow colour, with a large open cup in the middle, of a little deeper yellow colour, like vnto the great Iunquilia with the large flower, before fet downe, whereof this is a kinde, no doubt; but that is larger and greater then this, both in leafe, flower, cup, \&c. and this onely fomewhat leffe in all parts then that. 


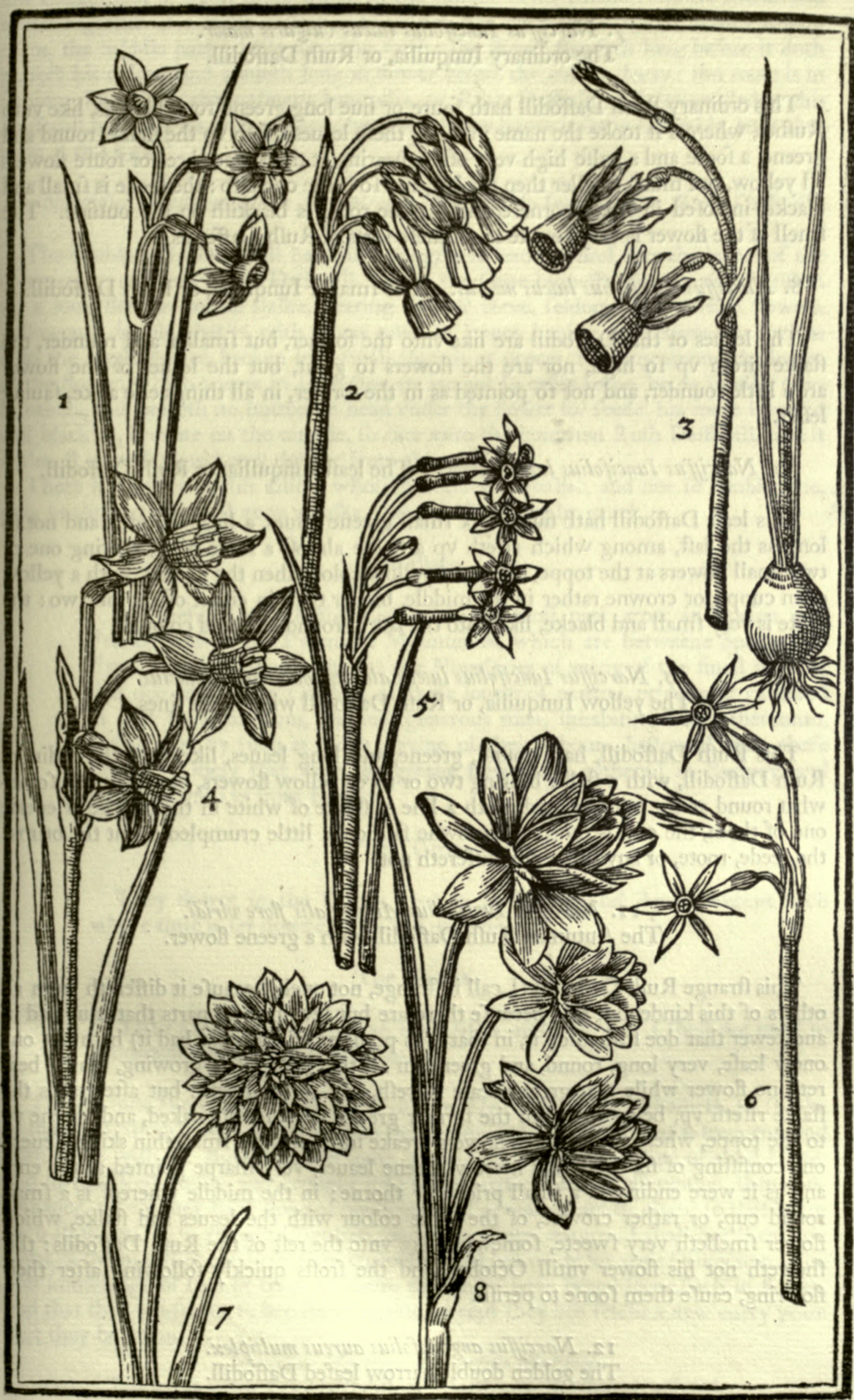

r Narciffus Inncifolius albus. The white Iunquilia. 2 Narciffus Inncifolius flore albo reflexo. The white turning Iunquilia. 3 Narciffus Iuncifolius calice luteo reflexis folijs albis. The yellow turning Iunquilia. 4 Narciffus Inncifolius lutens magno calice. The yellow Iunquilia with a great cuppe. 5 Narciffus Inncifolius luteus maior vulgaris. The ordinary yellow lunquilia 6 Narciffus Inncifolins Autumnalis flore viridi. The greene Autumne Iunquilia. 7 Narciffus anguftifolius aurens multiplex. The golden double narrow leafed Daffodill. 8 Narciffus Iuncifolins fore pleno. The double Iunquilia. 


\section{Narcifus Iuncifolius luteus vulgaris maior.}

The ordinary Iunquilia, or Rufh Daffodill.

This ordinary Rufh Daffodill hath foure or fiue long greene round leaues, like vnto Rufhes, whereof it tooke the name: among thefe leaues rifeth vp the ftalke, round and greene, a foote and a halfe high very often, bearing at the toppe three or foure flowers all yellow, but much fmaller then the laft, and fo is the cup alfo: the feede is fmall and blacke, inclofed in fmall cornered heads; the roote is blackifh on the outfide. The fmell of the flower is very fweete in all thefe forts of Rufh Daffodils.

\section{Narciffus Iuncifolius luteus medius. The fmaller Iunquilia, or Rufh Daffodill.}

The leaues of this Daffodill are like vnto the former, but fmaller and rounder, the ftalke rifeth vp fo high, nor are the flowers fo great, but the leaues of the flower are a little rounder, and not fo pointed as in the former, in all things elfe alike, fauing leffer.

\section{Narciffus Iuncifolius luteus minor. The leaft Iunquilia, or Rufh Daffodill.}

This leaft Daffodill hath fiue or fix fmall greene leaues, a little broader, and not fo long as the laft, among which rifeth vp a ftalke almolt a foote high, bearing one or two fmall flowers at the toppe, of a paler yellow colour then the former, with a yellow open cuppe, or crowne rather in the middle, bigger then in either of the laft two: the roote is very fmall and blacke, like vnto the laft in roundneffe and colour.

10. Narcifus Iuncifolius luteus albicantibus lineis difinctus.

The yellow Iunquilia, or Rufh Daffodill with white lines.

This Rufh Daffodill, hath round, greene, and long leaues, like vnto the ordinary Rufh Daffodill, with a falke bearing two or three yellow flowers, hauing leaues fomewhat round at the point or end, with a line or ftrake of white in the middle of euerie one of them, the cup is fhort, and crowne fafhion, a little crumpled about the brims: the feede, roote, or any thing elfe differeth not.

\section{Narciffus Iuncifolius Autumnalis flore viridi.}

The Autumne Rufh Daffodill with a greene flower.

This ftrange Rufh Daffodill (I call it ftrange, not onely becaufe it differeth from all others of this kinde, but alfo becaufe there are but few in thefe parts that have had it, and fewer that doe ftill enioy it, in that it is perifhed withall that had it) hath but one onely leafe, very long, round, and greene, in all that euer I faw growing, which beareth no flower while that greene leafe is frefh, and to bee feene: but afterwards the ftalke rifeth vp, being like vnto the former greene leafe, round, naked, and greene vp to the toppe, where two or three flowers breake forth out of a fmall thin skinne, euery one confifting of fix fmall and narrow greene leaues, very fharpe pointed at the end, and as it were ending in a fmall pricke or thorne: in the middle whereof is a fmall round cup, or rather crowne, of the fame colour with the leaues and falke, which flower fmelleth very fweete, fomewhat like vnto the reft of the Rufh Daffodils: this fheweth not his flower vntill October, and the frofts quickly following after their flowring, caufe them foone to perifh.

12. Narciffus anguftifolius aureus multiplex.

The golden double narrow leafed Daffodill.

The leaues of this Daffodill are very narrow, and of a whitifh greene colour, not aboue foure or fiue inches long, from among which rifeth vp a ftalke about a foote high, bearing at the top one flower, confifting of fome outer leaues, which are of a yel- 
low colour, and of many other leaues in the middle being fmaller, and fet thicke and round together of a more yellow gold colour, but with fome whiter leaues among them, the middle part a little pointing forth: the flower ftandeth long before it doth perfect his colour, and abideth long in flower before the colour decay: the roote is in fafhion almoft like the ordinary Iunquilia, or Rufh Daffodill. I acknowledge this Daffodill hath not his proper place; but becaufe the figure is fet in this table, let it thus paffe at this time.

\section{Narciffus Iuncifolius luteus flore pleno. The double Iunquilia, or Rufh Daffodill.}

The double Rufh Daffodill hath his long greene leaues round, like the leaues of the common or ordinary Rufh Daffodill, and of the fame bigneffe, among which rifeth vp a long flender greene ftalke, bearing two or three, feldome more fmall flowers, yellow and double, that is, with diuers rowes of leaues, hauing the yellow cup fuch as is in the fingle flower, broken into fmall fhreads or peeces, running among the leaues of the flower, which peeces in fome flowers are not fo eafily feene, being fmaller then in others, this beareth no button or head vnder the flower for feede, his roote is round and blackifh, browne on the outfide, fo like vnto the common Rufh Daffodill, that it is almoft impoffible to know the one from the other.

There is another of this kinde, whofe flowers are fmaller, and not fo double, one, Alter minori two, or three at the moft vpon a ftalke, and of leffe beauty by much.

\section{The Place.}

All thefe Rufh Daffodils, doe for the moft part grow in Spaine and France, and on the Pyrenæan Mountaines, which are betweene Spaine and France, which Mountains are the Nourferies of many of the fineft flowers, that doe adorne the Gardens of thefe louers of natures pride, and gathered in part by induftrious, learned, generous men, inhabiting neare thereunto, and in part by fuch as make a gaine of their labours, beftowed vpon thefe things. Onely that with the greene flower was gathered in Barbary, and imparted vnto vs from France.

\section{The Time.}

They flower in the Spring, that is, in March and Aprill, except fuch whofe time is fet downe to be in Autumne.

\section{The Names.}

Their names are fpecified in their titles, and therefore I fhall not need to fet downe any further repetitions.

To conclude therefore this difcourfe of true Daffodils, there remaineth to fpeake of the Sea Daffodils, which (as I faid in the beginning) is but one, that is frequent, and doth abide with vs. But there bee fome others found about the Cape of good Hope, and in the Weft Indies, and brought into thefe parts rather for oftentation, then continuance, where they haue flowred onely once (if peraduenture fo often) fo that being fuch ftrangers, of fo remote Countries, and of fo diuers natures, I fhall but thew you fome of them, rather curforily then curioufly; and but onely for your fatisfaction, giue you knowledge of two or three of them, that there haue beene feene fuch in flower, and that they are fcarce to bee feene againe, except they bee fetcht a new euery yeare that they be feene.

\section{Narciffus Marinus, fue tertius Matthioli.}

The great white Sea Daffodill, or Matthiolus his third Daffodill.

The roote of this Daffodill by long continuance, ftanding in one place without being remoued, groweth to be much greater and larger, then any other Daffodill what- 
foeuer, and as bigge as any meane Squilla or Sea Onion roote, hauing many long, thicke, and white fibres, or long rootes, diuerfly branched, and fpread vnder the vpper part of the earth, befide fome others that grow downward, and perifh not euery yeare, as the fibres of all, or moft of the other Daffodils doe; and therefore this plant will not thriue, and beare flowers, if it be often tranfplanted, but rather defire to abide in one place without remouing, as I faid, and that not to be ouerfhadowed, or couered with other herbes ftanding too neare it, which then will flourifh, and beare aboundantly: from this roote, which is couered with many blackifh coates, arifeth fix or feuen, or more leaues, twice fo broad almoft, as any of the former Daffodils, but not fo long by halfe as many of them, being but thort, in comparifon of the breadth, and of a white greene colour; from the middle of which leaues, as alfo from the fides fometimes, fpringeth vp one or two, or more ftalkes, roundifh and thicke, and fometimes a little flat and cornered, a foote high or fomewhat more, bearing at the toppe, out of a skinnie huske, eight, ten, twelue, or more very large flowers, confifting of fix white leaues a peece, fpread or laid open, with a white fhort cuppe or crowne in the middle, lying flat vpon the leaues, cut or diuided into fix corners (and not whole, as the cuppe or crowne of any other fingle Daffodill) from euery of which edges, or corners of this cup or crowne, ftandeth one white long thread, a little crooked or turning vp at the end, tipt with a yellow pendent, and fome other white threads tipt with yellow pendents, ftanding alfo in the middle: after the flower is paft, there come vp great three fquare heads, wherein the feede is contained, which is great, blacke, and round, like vnto the feede of other Daffodils, but greater: the flower hath a reafonable good fent, but not very ftrong.

The Place.

It was firt found by the Sea fide, in the Ine of Sardinia, and on the high Mountaines alfo of the fame Ine, where it hath borne by report, thirty fiue flowers vpon a ftalke: it groweth likewife about Illyricum, and in diuers other places.

\section{The Time.}

It Springeth later out of the ground then any other Daffodill, that is to fay, not vntill the later end of March, or beginning of Aprill, and flowreth in the end of May, or the beginning of Iune: the feede is ripe in the end of Iuly, or beginning of Auguit.

The Names.

The firt that hath made mention of this Daffodill, was Matthiolus, who placed it in the third place among his Daffodils, and is moft vfually now adayes called, Narciffus tertius Matthioli, Matthiolus his third Daffodill, the rather, becaufe Clufius vpon a more mature deliberation, firft referred it thereunto, but called it at the firft, Lilionarcifus Hemerocallidis facie, and, as hee faith, Iacobus Plateau (who firft fent him the figure hereof, with the defcription) called it Lilionarciffus Orientalis, but Clufius vpon certaine information, that it grew in the places aforefaid, milliked the name of Orientalis, and added Hemerocallis, which yet is not fit, for that his Hemerocallis Valentina, is a plaine Pancration or Sea baftard Daffodill, whofe middle cup is longer then the cup of any true Daffodill, which (as I faid in the beginning of this Chapter) is the chiefert note of difference, betweene a true and a baftard Daffodill. I receiued the feede of this Daffodill among many other feedes of rare plants, from the liberality of $\mathrm{Mr}^{\mathrm{r}}$. Doctor Flud, one of the Phyfitians of the Colledge in London, who gathered them in the Vniuerfity Garden at Pifa in Italy, and brought them with him, returning home from his trauailes into thofe parts, by the name of Martagon rarifsimum, (and hauing fowne them, expected fourteene yeares, before I faw them beare a flower, which the firft yeare that it did flower, bore foure ftalkes of 


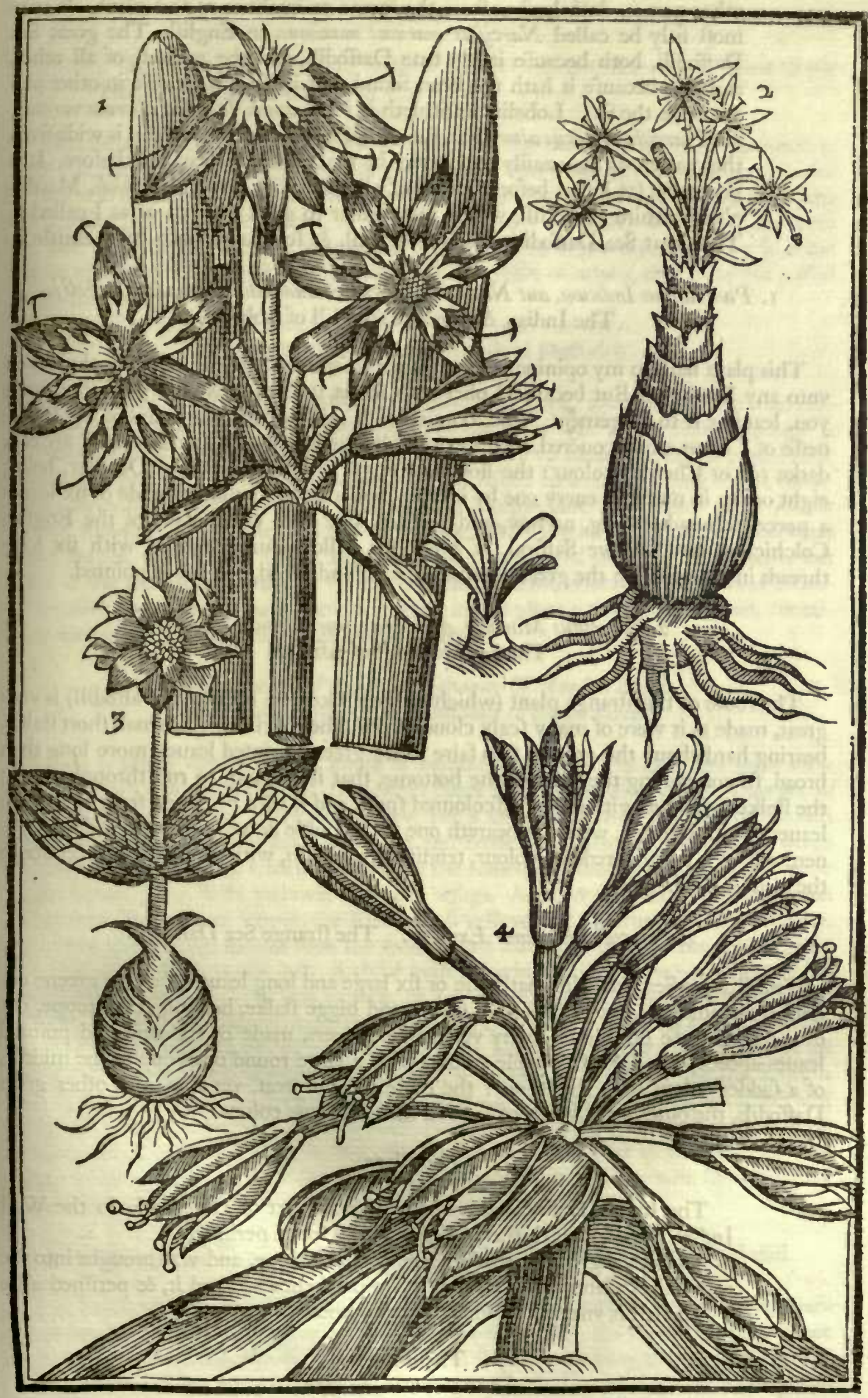

I Narciffus tertius Matthiols. The great white Sea Daffodill. 3 Narciffus marinus Africanus. The Sez Daffodill of Africa.

2 Narcifys Indicws Autumralis. The Indian Autumne Daffodill. 4 Narcs/fus marinus exolicus. The ftrange Sea Daffodill. 
flowers, with euery one of them eight or ten flowers on them) which of all other names, doth leaft anfwer the forme or qualities of this plant. It may moft fitly be called Narciffus marinus maximus, in Englifh, The great Sea Daffodill, both becaufe it is a true Daffodill, and the greateft of all other, and alfo becaufe it hath not been found, but in Iflands, or elfe in other places neare the Sea. Lobelius entituleth it Pancratium Indicum alterum vernum, fine Narciffus Indicus alter facie Pancratij Mon/peliaci, but all this is wide from the matter, as may eafily be known, by that that hath been faid before. It is generally (as I faid before) called of all Narciffus tertius Matthioli, Matthiolus his third Daffodill, which may either fo paffe with vs, or as I called it, The great Sea Daffodill, which you will, \& fo Clufius doth laftly entitle it.

1. Pancratium Indicum, aut Narcifus Indicus Autumnalis quorundan Lobelij. The Indian Autumne Daffodill of Lobel.

This plant hath in my opinion, a farre nearer refemblance vnto an Hyacinthus, then vnto any Daffodill : But becaure Lobel hath fo fet it forth, I will fo publifh it vnto you, leauing it to iudgement. The roote is, as he faith, a fpan long, and of the thickneffe of a mans arme, couered with many white fhells, whereof the outermoft are of a darke red or Chefnut colour: the flowers rife vp in September, and October, being eight or ten in number, euery one by it felfe vpon a fmall footftalke, made of fix leaues a peece, fomewhat long, narrow, and pointed, like vnto the flowers of the Englifh Colchicum, or Medowe Saffron, of a whitifh yellow dunne colour, with fix long threads in the middle: the greene leaues are long and broad, and broad pointed.

\section{Narcifus Marinus Africanus, fue Exoticus Lobelij. The Sea Daffodill of Africa.}

The roote of this Atrange plant (which of fome likeneffe is called a Daffodill) is very great, made as it were of many fcaly cloues, from whence rifeth vp a fmall fhort ftalke, bearing hard aboue the ground two faire broad greene pointed leaues, more long then broad, fo compaffing the ftalke at the bottome, that it feemeth to run through them: the ftalke is f potted with diuers difcoloured fpots, and is bare or naked from thefe two leaues vnto the toppe, where it beareth one faire double flower, like vnto a double Anemone, of a delayed reddifh colour, tending to a blufh, with many threads fet about the middle head.

\section{Narciffus Marinus Exoticus. The ftrange Sea Daffodill.}

This Atrange Sea Daffodill, hath fiue or fix large and long leaues of a pale greene colour, from among which rifeth vp a ftrong and bigge ftalke, bearing at the toppe, out of a thinne hofe or skinne, many very large flowers, made of fix long and pointed leaues apeece, of a blewith purple colour, with a large round open cup in the middle, of a fadder colour then the leaues: the roote is very great, yet like vnto other great Daffodils, the outer skins whereof are of a darke browne colour.

\section{The Place.}

The Indian Daffodils grew in the vpper part of Hifpaniola in the Weft Indies, and brought hither, where they all foone perifhed.

The other grew neare the Cape of good Hope, and was brought into the parts of Holland and thereabouts, from whence we had it, \& perifhed alfo.

The laft is vnknowne where it was gathered.

\section{The Time.}

The firft flowred in Autumne, as it is faid.

The other in the firft Summer of their bringing.

And fo did the laft, but the fame rootes will not flower with vs againe. 


\section{The Names.}

So inuch hath been faid of their names in their titles, as hath come to our knowledge; and therefore let that fuffice.

Thus hauing gone through the whole Family of the true Daffodils, (for fo much as hath come to our knowledge) and fet them downe euery one by his name, and in this order; it is fit that we fpeake of their baftard brethern, and fhew you them alfo, in the fame order held with the former, as neare as the plenty of variety herein, which is not the like with the former, will giue leaue, that when you know them both by face and naine, you may the better know to place or diftinguifh of others, that haue not paffed vnder this rod.

\section{Pfeudonarcifius aureus Hifpanicus maximus.}

The great yellow Spanifh baftard Daffodill.

The roote of this kinde of Daffodill is reafonable great, and blackifh on the outfide, defiring to be deepe in the ground; and therefore will runne downe, where it will then encreafe into many of-fets, from whence rife $\mathrm{vp}$ many thicke, long, and ftiffe leaues, of a grayifh greene colour, among which rifeth vp a round ftrong ftalke, fometimes three foote high or better, bearing at the toppe one onely faire great yellow flower, ftanding forth right, and not pendulous, confitting of fix fhort and fomewhat broad leaues, with a very great, large, and long trunke, of an equall largeneffe, but open at the mouth, and turning vp the brimmes a little, which are fomewhat crumpled : after the flower is paft, there commeth in the place a three fquare head, containing round, blacke feede, like vnto other Daffodils.

\section{Pfeudonarciffus Pyrenaus Hifpanico E Anglico fimilis.}

The Mountaine baftard Daffodill of diuers kindes.

There is much variety in this kinde of baftard Daffodill: For one fort hath verie broad and whition greene leaues, fomewhat Thort in comparifon of others, that are of that breadth: the flower is wholly yellow, but a little paler then the former Spanifh kinde, hauing the leaues of his flower long, and fomewhat narrow, ftanding like wings about the middle trunke, which is as long as the leaues, and fmaller then in many other of this kinde, but a little yellower then the wings. Another fort hath narrower green leaues then this laft, and longer, the flower is all yellow, but the trunke is larger, wider, and more open at the noouth then the former, and almoft as large as the former Spanifh, but not fo high as the laft. A third hath the wings of the flower of a Strawe colour, but the trunke is long and narrow, of a faire yellow. A fourth hath fuch like flowers, but that it is thorter, both the wings and the trunke: Some likewife haue the wings of the flower longer, then the long trunke, and fome fhorter. Some alfo are all yellow, and fome haue their wings onely a little more pale or white, like the Englifh kinde: Some againe haue their trunkes long and narrow, others have them larger and wider open, and crumpled at the brimmes; fo that it is needleffe, to fpend a great deale of time and labour vpon fuch fmally refpected flowers, but that in the beholding of them, we may therein admire the worke of the Creatour, who can frame fuch diuerfity in one thing: But this is befide the text, yet not impertinent.

\section{Pfindonarciffus pallidus pracox. The early Strawe coloured baftard Daffodill.}

The leaues of this Daffodill are of a meane fize, betweene the broadeft and the narrower kindes, of a grayifh greene colour, and not very long: the ftalke rifeth vp a foot high or more, whereon ftandeth one large great flower, equalling the greateft Spanifh baltard Daffodill, before defcribed, in the largeneffe of his trunke, and hauing the brinmes turned vp a little, which maketh it feeme the larger : the wings or outer leaues are in a maner as fhort, as they are in the greateft Spanifh kinde, (and not long flagging down, like vnto the Mountain kinds) and ftand ftraight outright : all the whole flower is 
of one euen colour, that is, of a fine pale yellow, fomewhat like vnto the colour of a Lemon peele or rinde, but fomewhat whiter, which vfually we call a Strawe colour : the greatneffe of the flower, the earlineffe of the flowring, and the difference of colour from all the reft of this kinde, hath made me entreate of it apart by it felfe, as being no leffe worthy.

\section{PSeudonarciffus Hispanicus flore albo maior.}

The great white Spanifh baftard Daffodill.

This baftard Daffodill hath diuers leaues rifing vp together, long and broad, fomewhat like vnto the firft Spanifh kinde, but a little broader, and of a whiter greene colour, yet not fo white, as in the leffer Spanifh white kindes, hereafter defcribed: among thefe leaues rifeth vp a round ftrong ftalke, about two foote high, bearing one white flower at the toppe, bending downe the head, as all there white kindes doe, but is not of fo pure a white, as the leffer kindes that follow, yet whiter then the greateft white Spanifh kinde, next of all to be defcribed: the whole flower, as well trunke as wings, is much larger then the leffer white kindes, and almoft equalling the firft Spanifh yellow, but a little longer and narrower, a little crumpled and turning vp at the brimmes: the head and feede are like the firft ; the roote is greater and thicker then the firf Spanifh, and doth not encreafe fo much, nor is couered with a blacke, but rather with a whitifh coate.

Pfeudonarcifus Hifpanicus maximus albidus.

The greateft Spanifh white baftard Daffodill.

This kinde of baftard Daffodill is very like the laft mentioned Daffodill, both in leaues and flowers, but larger in both : the flower of this is not full fo white, but hath fome fhew of paleneffe therein, and more vpon the firt opening of the flower then afterwards, and is as great altogether, as the great Spanifh yellow, at the leaft with a longer, and fomewhat narrower trunke : the feede is like vnto the former, and fo is the roote alfo, but greater, being white on the outfide, and not blacke.

\section{Pfeudonarcifus Hifpanicus flore albo medius \& minor.}

The two leffer white Spanifh baftard Daffodils.

There are two other of thefe kindes of white Spanifh Daffodils, one greater or leffer then the other, but neither of them fo great as the former. The leaues of both are of a whitifh greene colour, one a little broader then the other: the flowers of both are pure white, and bending downe the heads, that they almoft touch the ftalke againe, the greater flower hath the longer and narrower trunke; and the leffer flower, the fhorter and wider open, yet both a little crumpled at the edges or brimmes: the rootes of both are like one vnto another, but differ in the greatneffe. From the feede of thefe haue fprung much variety, few or none keeping either colour or height with the mother plants.

\section{PSeudonarcifus Anglicus vulgaris. Our common Englifh wilde baftard Daffodill.}

This baftard Daffodill is fo common in all England, both in Copfes, Woods, and Orchards, that I might well forbeare the defcription thereof, and efpecially, in that growing wilde, it is of little refpect in our Garden : but yet, left I bee challenged of ignorance in common plants, and in regard of fome variety therein worth the marking, I will fet downe his defcription and variety as briefly as I may: It hath three or foure grayifh greene leaues, long and fomewhat narrow, among which rifeth vp the ftalke, about a fpan high or little higher, bearing at the toppe, out of a skinnie huske, as all other Daffodils haue, one flower (although fometimes I haue feene two together) fomewhat large, hauing the fix leaues that ftand like wings, of a pale yellow colour, and the long trunke in the middle of a faire yellow, with the edges or brimmes a little crumpled or vneuen : after the flower is paft, it beareth a round head, feeming three fquare, containing round blacke feede; the roote is fomewhat blackifh on the outfide. 


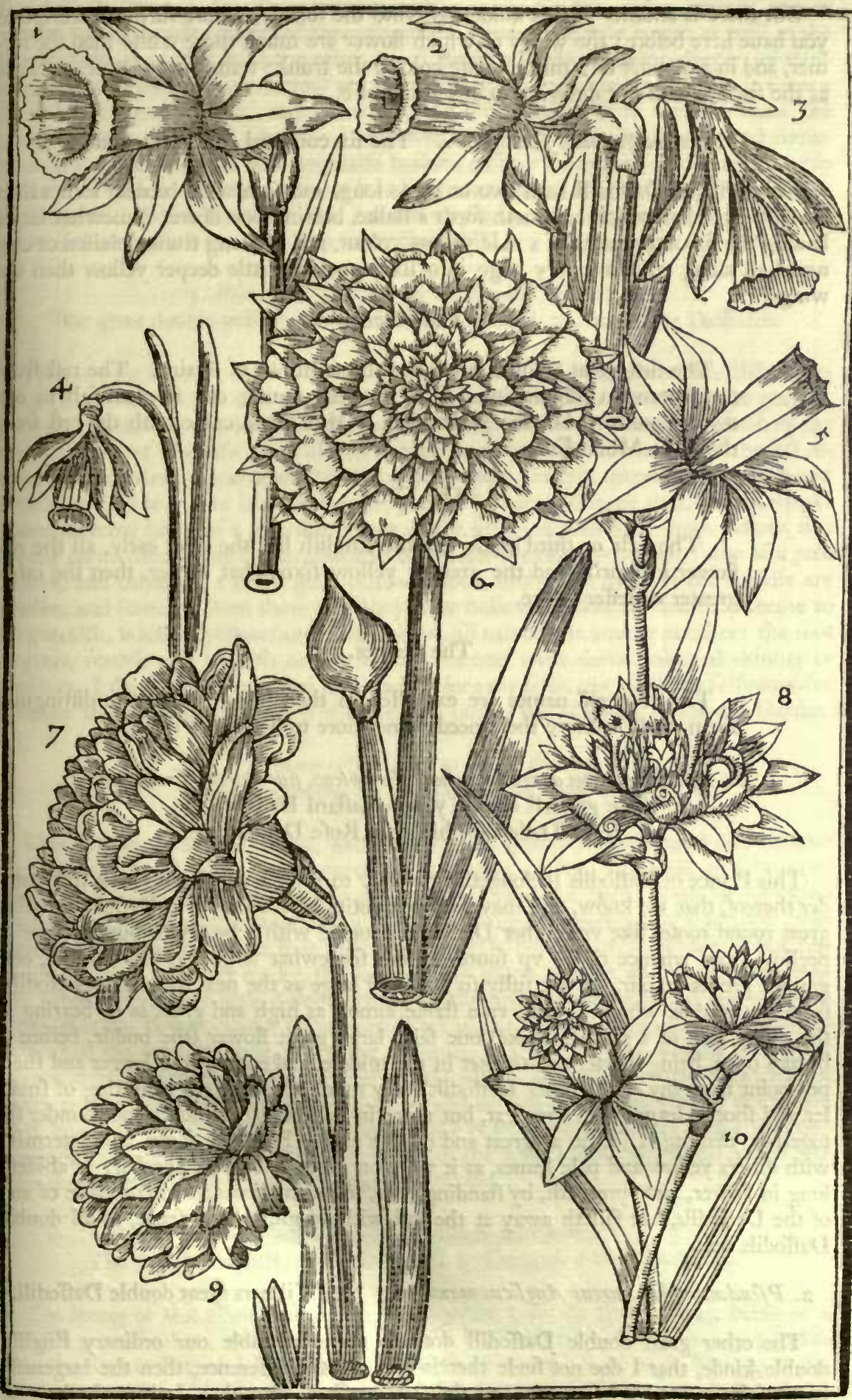

1. PfendonarcifJus Hifpanicus maximus aureus. The great yellow Spanith baftard Daffodill. 2 Pfeudonarciffus Pyrenaws vari. fomis. The Mountaine baftard Daffodill of diuers kindes. 3 Pfexdonarciffus Hifpanicus maior albus. The greater white Spanifn baftard Daffodill. 4 Pfeudonarciffus Hijpanicus minor albus. The leffer Spanin white baftard Daffodill. 5 P/endonarciffus fubo fexangulari. The fix cornered baftasd Daffodill. 6 Pfeudonarciffus maximus aureus, fue Rofeus Tradefcanti. Iohn Tradefcants great Rofe Daffodill. 7 Pfewionarciffus aureus Anglicus maximus. Mafter Wilmers great double Daffodill. 8 Pfendonarciffus Hifprnicus aurews fore pleno. The double Spanim Daffodill, or Parkinfons double Daffodill. o Pfeudanarciffus Gallicus maior Alore pleno. The greater double French Daffodill. To Pfendonarciffus Anglicus fore pleno. The douhle Englifh Daffodill, or
Gerrards double Daffodill. 
But there is another of this kinde like vnto the former, whofe further defcription you haue here before; the wings of which flower are much more white then the former, and in a manner of a milke white colour, the trunke remaining almoft as yellow as the former, and not differing in any thing elfe.

\section{Pfeudonarcifus tubo fexangulari. The fix cornered baftard Daffodill.}

This kinde of Daffodill hath two or three long, and fomewhat broader leaues then the laft, between which commeth forth a ftalke, bearing one flower fomewhat large, hauing the fix outer leaues of a pale yellow colour, and the long trunke plaited or cornered all along vnto the very edge into fix parts, of a little deeper yellow then the wings.

The Place.

The firft great Spanifh kinde was brought out of Spaine. The reft from the Pyrenæan Mountaines, onely the laft fauing one is plentifull in our owne Countrey, but the white fort of that kinde came with the reft from the fame Mountaines.

\section{The Time.}

The pale or third kinde, and the Englifh bee the moft early, all the reft flower in Aprill, and the greateft yellow fomewhat earlier, then the other greater or leffer white.

\section{The Names.}

Their feuerall names are expreffed in their titles fufficient to diftinguifh them, and therefore there needeth no more to be faid of them.

\section{Pfeudonarciffus aureus maximus flore pleno, fue Rofeus Tradefcanti.}

The greateft double yellow baftard Daffodill, or

Iohn Tradefcant his great Rofe Daffodill.

This Prince of Daffodils (belongeth primarily to Iohn Tradefcant, as the firft founder thereof, that we know, and may well bee entituled the Glory of Daffodils) hath a great round roote, like vnto other Daffodils, couered with a brownifh outer skinne or peeling, from whence rifeth vp foure or fiue fomewhat large and broad leaues, of a grayifh greene colour, yet not fully fo long and large as the next following Daffodill: from the middle whereof rifeth vp a ftalke almoft as high and great as it, bearing at the toppe (out of a skinnie huske) one faire large great flower (the budde, before it breake open, being fhorter and thicker in the middle, and ending in a longer and tharper point then any of the other Daffodils) very much fpread open, confifting of fmaller and fhorter leaues then the next, but more in number, and thicker and rounder fet together, making it feeme as great and double as any Prouince Rofe, and intermixt with divers yellow and pale leaues, as it were on rowes one vnder another. It abideth long in flower, and fpreadeth, by ftanding long, to be the broadeft in compaffe of any of the Daffodils, but falleth away at the laft without giuing any feede, as all double Daffodils doe.

\section{P.eudonarcifius aureus Anglicus maximus. $\mathrm{M}^{\mathrm{r}}$. Wilmers great double Daffodill.}

The other great double Daffodill doth fo neare refemble our ordinary Englifh double kinde, that I doe not finde therein any greater difference, then the largeneffe both of leaues and flowers, \&c. and the ftatelineffe of growth. It beareth three or foure large, long, and broad leaues, fomewhat longer and broader then the former, and of a whitifh greene colour: the ftalke rifeth to bee two foote high, growing (in a fruitfull and fat foyle) ftrong, and fomewhat round, bearing at the toppe, out of a thin skinne, one great and faire double flower, each leafe whereof is twice as large and 
broad as the former, diuerfly intermixt with a rowe of paler, and a rowe of deeper yellow leaues, wholly difperfed throughout the flower, the pale colour as well as the deeper yellow, in this as in the other fmall Englin kinde, growing deeper by ftanding: fometimes the leaues hereof are fcattered, and fpread wholly, making it fhew a faire, broad, open flower: and fometimes the outer leaues ftand feparate from the middle trunke, which is whole and vnbroken, and very thicke of leaues: and fometines the middle trunke, will bee halfe broken, neither exprefing a full open double flower, nor a clofe double trunke, as it is likewife feene in the fmall Englifh kinde, as thall bee declared in his place: this beareth no feede; the roote hereof is thicke and great, and encreafeth as well as any other Daffodill.

\section{Pesudonarcifius aureus Hifpanicus fore pleno.}

The great double yellow Spanifh baftard Daffodill, or Parkinfons Daffodill.

This double Spanifh Daffodill hath diuers leaues rifing from the roote, ftiffer, narrower, and not of fo whitih a greene colour as the former, but more fullen or grayifh, plainely refembling the leaues of the fingle great kinde, from whence this hath rifen: the ltalke hereof likewife rifeth almoft as high as it, and neare the height of the laft recited double, bearing one double flower at the toppe, alwayes fpread open, and neuer forming a double trunke like the former, yet not fo faire and large as it, the outermoft leaues whereof being of a greenifh colour at the firft, and afterward more yellow, doe a little turne themfelues backe againe to the ftalke, the other leaues are fome of a pale yellow, and others of a more gold yellow colour, thofe that ftand in the middle are finaller, and fome of them thew as if they were hollow trunked, fo that they feeme to be greenifh, whitifh, yellow, and gold yellow, all mixed one among another: the root is great, round, and whitith on the infide, couered with darke coloured skinnes or peelings. I thinke none euer had this kinde before my felfe, nor did I my felfe euer fee it before the yeare 1618 , for it is of mine own raifing and flowring firt in my Garden.

\section{PSeudonarcifius Gallicus maior flore pleno.}

The greater double French baftard Daffodill.

This greater double Daffodill, hath his whitifh greene leaues longer and broader then the finaller French kinde, hereafter following, to bee defcribed, and broader, longer, and more limber then the double Englifh kinde: the ftalke rifeth vp not much higher, then the fmaller French kinde, but a little bigger, bearing at the top one great double flower, which when it is fully and perfectly blowne open (which is but feldome; for that it is very tender, the leaues being much thinner, and thereby continually fubiect, vpon any little diftemperature of the time, to cleaue fo faft one vnto another, that the flower cannot blow open faire) is a faire and goodly flower, larger by halfe then the fmaller kinde, and fuller of leaues, of the fame pale whitifh yellow, or Lemon colour, with the leffer, or rather a little whiter, and not fet in the fame order of rowes as it is, but more confufedly together, and turning backe the ends of the outermoft leaues to the ftalke againe, and hauing the bottome of the flower on the backfide fomewhat greene, neither of which is found in the leffer kinde: the roote is very like vnto the leffer kinde, but a little bigger and longer.

\section{Pfiudonarcifius Anglicus flore pleno.}

The double Englifh baftard Daffodill, or Gerrards double Daffodill.

The leaues of this double Daffodill are very like vnto the fingle kinde, being of a whitifh greene colour, and fomewhat broad, a little horter and narrower, yet ftiffer then the former French kinde: the ftalke rifeth vp about a foote high, bearing at the toppe one very double flower, the outermoft leaues being of the fame pale colour, that is to bee feene in the wings of the fingle kinde; thofe that Itand next them, are fome as deepe a yellow as the trunke of the fingle, and others of the fame pale colour, with fome greene ftripes on the backe of diuers of the leaues: thus is the whole flower variably interınixt with pale and deepe yellow, and fome greene ftripes among them, 
when it is fully open, and the leaues difperfed and broken. For fometimes the flower fheweth a clofe and round yellow trunke in the middle, feparate from the pale outer wings, which trunke is very double, fhewing fome pale leaues within it, difperfed among the yellow: And fometimes the trunke is more open, or in part broken, Thewing forth the fame colours intermixt within it: the flower paffeth away without giuing any feede, as all other bulbous rootes doe that beare double flowers: the roote is fmall, very like vnto the French double kindes, efpecially the leffer, that it is verie hard to know the one from the other.

The Place.

The firft and greateft kinde, we had firf from Iohn Tradefcante (as I faid before) whether raifed from feed, or gained from beyond Sea, I know not.

The fecond we firft had from Vincent Sion, borne in Flanders, dwelling on the Bank fide, in his liues time, but now dead; an induftrious and worthy louer of faire flowers, who cherifhed it in his Garden for many yeares without bearing of any flowers vntill the yeare 1620 , that hauing flowrer with him, (and hee not knowing of whom hee receiued it, nor hauing eue feene the like flower before) he fheweth it to $\mathrm{M}^{\mathrm{r}}$. Iohn de Franqueuille, o whom he fuppofed he had receiued it, (for from beyond Sea he neuer recei ued any) who finding it to bee a kinde neuer feene or knowne to vs beforc caufed him to refpect it the more, as it is well worthy. And Mr. Georg Wilmer of Stratford Bowe Efquire, in his liues time hauing likewife recei ued it of him (as my felfe did alfo) would needes appropriate it to himfelf as if he were the firt founder thereof, and call it by his owne name Wi] mers double Daffodill, which fince hath fo continued.

The third is of mine owne foftering or raifing, as I faid before; for afft redly, it is rifen from the feede of the great Spanifh fingle kinde, which fowed in mine owne Garden, and cherifhed it, vntill it gaue fuch a flowe as is defcribed.

The fourth is not certainly knowne where his originall thould be: Sorr thinke it to be of France, and others of Germany.

The laft is affuredly firt naturall of our owne Countrey, for $\mathrm{M}^{\mathrm{r}}$. Gerra firft difcouered it to the world, finding it in a poore womans Garden in tl Wert parts of England, where it grew before the woman came to dwe there, and, as I haue heard fince, is naturall of the Inle of Wight.

The Time.

They doe all flower much about one time, that is, from the middle end of March, as the yeare is forward, vnto the middle of Aprill.

\section{The Names.}

$V$ pon the three firf I have impored the names in Latine, as they are $\epsilon$. preffed in their titles: and for the Englinh names, if you pleafe, you may t them paffe likewife as they are expreffed there alfo, that thereby euery $c$ : may be truely diftinguifhed, and not confounded. The fourth, befides $t$ ? name in the title, is called of fome Narciffus Germanicus, which whether t be of Germany, or no, I know not ; but that the name fhould import fo mur. The laft doth vfually carry $M^{\mathrm{r}}$. Gerrards name, and called Gerrards dou e Daffodill.

1. P.eudonarciffus anguflifolius fore flaue fente tubo quafi abfciffo. The narrow leafed baftard Daffodill with the clipt trunke.

This kinde of Daffodill hath long and narrow grayifh greene leaues, bearing c $e$ fingle flower at the toppe of his ftalke, like vnto the former fingle baftard kindes, :- 
fore fpecified, hauing his outer leaues of a pale yellow colour, and his trunke of a deeper yellow : the chiefe differences in this from the former, is in the leaues, being narrow, and then in the trunke of the flower, which is not crumpled or turned vp, as moft of the other are; and that the brimmes or edges of the flower is as if it had beene clipt off, or cut euen.

\section{Pfeudonarciffus Hispanicus medius $\&$ minor luteus.}

The two leffer Spanifh yellow baftard Daffodils.

Thefe two leffer kindes of Spanifh Daffodils, doe but differ in greatneffe the one from the other, and not in any thing elfe; fo that in declaring the one, you may vnderftand the other to bee a little greater. The leffer then hath three or foure narrow fhort whitifh greene leaues, from among which commeth forth a fhort ftalke, not aboue an hand breadth, or halfe a foote high, bearing one fingle flower, not fully ftanding outright, but a little bending downe, confifting of fix fmall leaues, ftanding as wings about a fmall, but long trunke, a little crumpled at the brimmes: the whole flower, as well leaues as trunke, are of one deepe yellow colour, like vnto the great Spanifh kinde: the roote is but fmall, and couered with a darkifh coate. The other is in all parts greater, and (as I faid) differeth not elfe.

\section{Pfeudonarcifus Hifpanicus luteus minimus.}

The leaft Spanifh yellow baftard Daffodill.

The leaues of this fmall kinde are fmaller and fhorter then the former, feldome exceeding the length of three inches, and very narrow withall, but of the fame grayifh greene colour with the former: euery flower ftandeth vpon a fmall and fhort footeitalke, fcarce rifing aboue the ground; fo that his nofe, for the moft part, doth lye or touch the ground, and is made after the fame fafhion, and of the fame colour with the former, but much fmaller, as his roote is fo likewife.

\section{Pfeudonarciffus Gallicus minor flore pleno.}

The leffer French double baftard Daffodill.

The rootes of this leffer French kinde (if I may lawfully call it, or the greater kinde before fpecified, a baftard Daffodill; for I fomewhat doubt thereof, in that the flower of either is not made after the fafhion of any of the other baftard Daffodils, but doth more nearely refemble the forme of the double white Daffodill, expreffed before among the true Daffodils) are like vnto the double Englifh kinde, as alfo to the former double great French kinde, and the leaues are of the fame whitifh greene colour alfo, but narrower and not longer : the ftalke rifeth a little higher then the Englifh, and not fully fo high as the greater French, bearing one faire double flower thereon, of a pale yellow or Lemon colour, confifting of fix rowes of leaues, euery rowe growing imaller then other vnto the middle, and fo fet and placed, that euery leafe of the flower doth ftand directly almoft in all, one vpon or before another vnto the middle, where the leaues are fmalleft, the outermoft being the greateft, which maketh the flower feeme the more beautifull: this and the greater kinde hath no trunke, or fhew of any other thing in the middle, as all or moft of the other former double baftard Daffodils haue, but are flowers wholly compofed of leaues, ftanding double euen to the middle.

\section{The Place.}

The firft is vndoubtedly a naturall of the Pyrenæan Mountaines.

The Spanifh kindes grew in Spaine, and

The French double kinde about Orleance in France, where it is faid to grow plentifully.

The Time.

The firlt flowreth at the end of March. 
The Spanifh kindes are the moft early, flowring betimes in March.

The French double doth flower prefently after.

\section{The Names.}

More cannot bee faid or added, concerning the names of any of thefe Daffodils, then hath been fet downe in their titles: onely the French kinde is moft vfually called Robinus his Daffodill.

Pfeudonarciffus Iuncifolius albus. The white baftard Rufh Daffodill, or Iunquilia.

This baftard Rufh Daffodill hath two or three long and very greene leaues, very like vnto the fmall yellow Rufh Daffodill, formerly defcribed, but not altogether fo round, among which rifeth $\mathrm{vp}$ a fhort ftalke, feldome halfe a foote high, bearing at the toppe, out of a fmall skinnie huske, one fmall white flower, fometime declining to a pale colour, hauing fix fmall and fhort leaues, ftanding about the middle of the trunke, which is long, and much wider open at the mouth, then at the bottome: the fmall outer leaues or wings are a little tending to greene, and the trunke (as I faid) is either white, or whitifh, hauing the brimmes a little vneuen : the feede is fmall, blacke, and round, like vnto other Rufh Daffodils, but fmaller.

\section{PSeudonarciffus Iuncifolius luteus maior.}

The greater yellow Iunquilia, or baftard Daffodill.

The leaues of this greater kinde are longer, greater, and a little broader then the former; the ftalke alfo is higher, and the flower larger, more open at the mouth and crumpled, then the white, but wholly of a yellow colour: the feede and the roots are bigger, according to the proportion of the plant.

\section{Pfeudonarcifus Iuncifolius luteus minor. The leffer yellow baftard Iunquilia.}

This is fo like vnto the laft in all things, that I thall not neede to trouble you with repetitions of the fame things formerly fpoken; the chiefeft difference is the rmallneffe of the plant in all parts.

\section{PSeudonarciffus Iuncifolius luteus ferotinus. The late yellow baftard Iunquilia.}

There is likewife a third kinde, as great as the greater yellow, and in all his parts ex. prefling and equalling it, but is accounted the fairer, and flowreth fomewhat later.

\section{The Place.}

The Pyrenæan Hils haue afforded vs all thefe varieties, and wee preferu them carefully; for they are all tender.

\section{The Time.}

All thefe flower in Aprill, except the laft, which is a moneth later.

\section{The Names.}

The French and Lowe-Countrey men call them. Trompettes, that is Trumpets, from the forme of the trunke; wee fometimes call them alfo b that name, but more vfually baftard Iunquilia's.

\section{PJeudonarciffus marinus albus, Pancratiuni vulgo.}

The white Sea baftard Daffodill.

The Sea baftard Daffodill (to conclude this Chapter, and the difcourfe of Daffo 


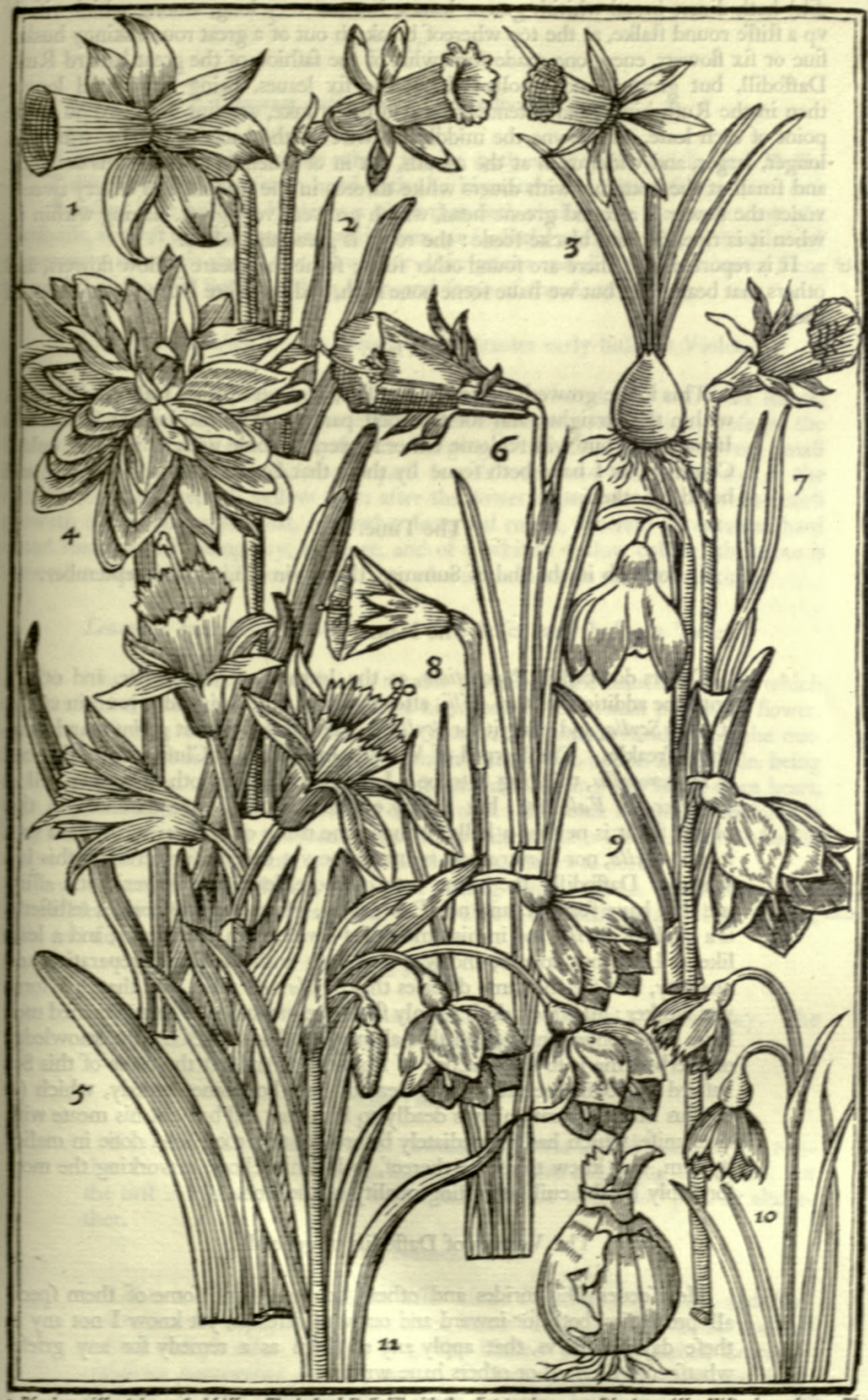

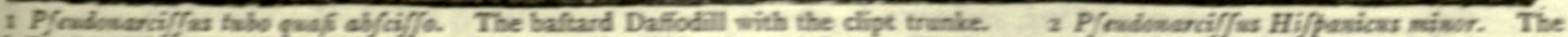

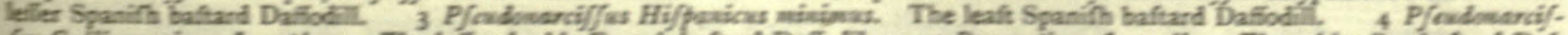

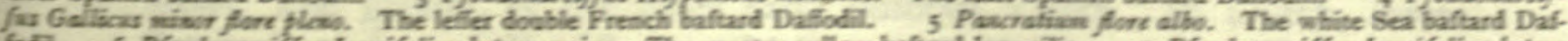

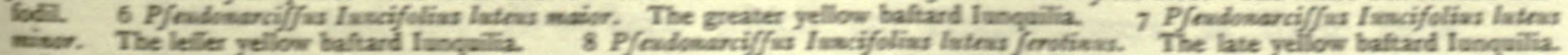

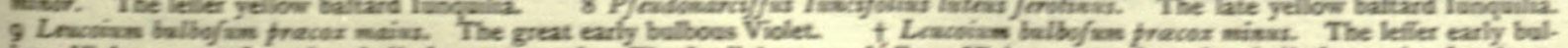

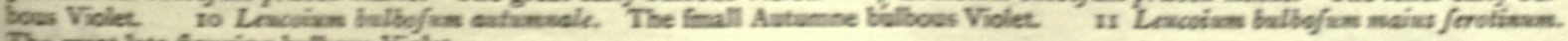
The great late flowring bulbous Violet. 
dils) hath diuers broad whitifh greene leaues, but not very long, among which rifeth $\mathrm{vp}$ a ftiffe round ftalke, at the top whereof breaketh out of a great round skinny huske, fiue or fix flowers, euery one made fomewhat of the fafhion of the great baftard Rufh Daffodill, but greater, and wholly white; the fix leaues, being larger and longer then in the Rufh kinde, and extending beyond the trunke, are tipt with greene at the point of each leafe, and downe the middle likewife on the backfide. The trunke is longer, larger, and wider open at the mouth, cut in or indented at the brims or edges, and fmall at the bottome, with diuers white threeds in the middle, and is very fweet: vnder the flower is a round greene head, which groweth very great, hauing within it, when it is ripe, flat and blacke feede: the roote is great and white.

Flore lute, $\xi^{\circ}$ It is reported, that there are found other forts; fome that beare yellow flowers, and fore rubro. others that beare red: but we haue feene none fuch, and therefore I can fay no more of them.

\section{The Place.}

This kinde groweth neare the Sea fide, both in Spaine, Italy, and France, within the Straights, and for the molt part, vpon all the Leuant fhoare and Iflands alfo, but will feldome either flower, or abide with vs in thefe colder Countries, as I have both feene by thofe that I receiued from a friend, and heard by others.

\section{The Time.}

It flowreth in the end of Summer, that is, in Auguft and September.

\section{The Name.}

Diuers doe call it Pancratium, as the learned of Mompeher, and others, with the addition of flore Lilij, after they had left their old errour, in taking it to be Scylla, and ving it for Scylla, in the Trochifces that go into Andromachus Treakle. The learned of Valentia in Spaine, as Clufius faith; doe call it Hemerocallis, thinking it to be a Lilly; and Clufius doth thereupon call it, Hemerocallis Valentina: but in my opinion, all thefe are deceiued in this plant ; for it is neither a Lilly, to haue the name of Hemerocallis given vnto it, nor Scylla, nor Pancratium, as many doe yet call it: for certainly this is a kinde of Daffodill; the forme both of roote, leafe, and flower, doth affure me that haue feene it, and not Pancratium, which (as Diofcorides teftifieth) is a kinde of Scylla, and in his time called Scylla, with a red roote, and a leafe like a Lilly, but longer, and was vfed both with the fame preparation and quantity, and for the fame difeafes that Scylla was vfed, but that his force was weaker : all which doth plainly fhew the errours that many learned men have been conuerfant in, and that all may fee how neceffary the knowledge of Herbarifme is to the practice of Phyficke; And left the roote of this Sea baftard Daffodill bee vfed in the ftead of an wholefome remedy, which (as Clufius maketh mention) was deadly to him that did but cut his meate with that knife, which had immediately before cut this roote, and done in malice by him, that knew the force thereof, to kill his fellow, it working the more forceably by the euill attracting quality of the iron.

The Vertues of Daffodils in generall.

Howfoeuer Diofcorides and others, doe giue vnto fome of them fpeciall properties, both for inward and outward difeafes, yet know I not any in thefe dayes with vs, that apply any of them as a remedy for any griefe, whatfoeuer Gerrard or others haue written. 
CHA . X.

Leucoium bulbofum. The bulbous Violet.

$\mathrm{H}$ Auing thus fet downe the whole family, both of the true and baftard Daffodils, I fhould next fet in hand with the Hyacinths; but becaufe Leucoium bulbofium, The bulbous Violet is a plant that doth challenge a place next vnto the Daffodils, as moft nearly partaking with them, and a little with the Hyacinthes, I muft of necessity interpofe them, and thew their defcriptions and differences, whereof fome are early, of the firft Spring, others later, and fome of the Autumne.

\section{Leucoium bulbofum pracox maius. The greater early bulbous Violet.}

This bulbous Violet hath three or foure very greene, broad, flat, and fhort leaues, among which rifeth vp a naked greene ftalke, bearing out of a fmall skinny hofe (as the former Daffodils doe) one white flower, hanging downe his head by a very fmall foot-ftalke, made of fix leaues, of an equall length, euery one whereof is tipt at the end with a fmall greenifh yellow fpot: after the flower is paft, the head or feed-veffell groweth to be reafonable great, fomewhat long and round, wherein is contained hard round feede, which being dry, is cleare, and of a whitifh yellow colour: the roote is fomewhat like a Daffodill roote, and couered with a blackifh outfide or skinne.

Leucoium bulbofum pracox minus. The leffer early bulbous Violet.

This leffer kinde rifeth vp with two narrow grayifh greene leaues, between which commeth forth the ftalke, fiue or fix inches high, bearing one fmall pendulous flower, confifting of three white leaues, which are fmall and pointed, ftanding on the outfide, and hauing three other fhorter leaues, which feeme like a cup in the middle, being each of them round at the ends, and cut in the middle, making the forme of an heart, with a greene tippe or fpot at the broad end or edge: the feede is whitifh, inclofed in long and round heads, like the former, but leffer : the roote is like a fmall Daffodill, with a blackifh gray coate, and quickly diuideth into many of-fets.

There is another of this kinde, that came among other bulbous rootes from Con-Minus Byzanftantinople, and differeth in nothing from it, but that it is a little greater, both in root, tinum.

leafe, and flower.

The Place.

The two firft are found in many places of Germany, and Hungary. The third, as I faid, was brought from Conftantinople.

\section{The Time.}

The two leffer forts doe moft commonly flower in February, if the weather be any thing milde, or at the furtheft in the beginning of March, but the firft is feldome in flower, before the other be well neare paft, or altogether.

\section{The Names.}

Lobel and Dodonæus call the leffer kinde Leucoium triphyllum, and Leuconarciffolirion triphyllum, of the three leaues in the flower. Some doe call it Viola bulbofa alba. The firft or greater kinde is called by Lobel, Leuconarciffolirion paucioribus floribus; and by Dodonæus, Leucoium bulbofum hexaphyllum. We doe moft vfually call them, Leucoium bulbof um pracox maius, छ minus, The greater, or the leffer early bulbous Violet. In Dutch, Somer Sottekens, and not Druifkens, which are Grape-flowers, as fome haue thought. 
1. Leucoium bulbof um Vernum minimum.

The fmall bulbous Violet of the Spring.

This fmall Leucoium fendeth forth his fmall and long greene leaues, like haires in Autumne, and before Winter, which abide greene vntill Aprill, and then wither away quite, and about May there arifeth vp a naked flender ftalke, at the toppe whereof breake forth two fmall white flowers, made of fix leaues a peece, hanging downe their heads, the three inner leaues being a little larger then the three outward, a little reddifh neare the ftalke, and very fweete: the root is fmall and round, and couered with a darke coate.

\section{Leucoium bulbof um Autumnale. The fmall Autumne bulbous Violet.}

As the former fmall Leucoium fprang vp with his leaues without flowers in Autumne, fo this contrariwife, rifeth vp with his flender brownifh ftalke of flowers in Autumne, before any greene leaues appeare, whereon ftand two or three very fmall fnow white pendulous flowers, confifting of fix leaues a peece, and a little reddith at the bottome of the flower next vnto the ftalke, fo like vnto the former, that one would take them to be both one: after which, there grow fmall browne heads, containing Imall, blacke, round feed; after the flower is paft, and the feede is ripening, and fometimes after the heads are ripe, the leaues begin to fpring vp, which when they are ful growne, are long, greene, and as fmall, or fmaller then the leaues of the Autumne $\mathrm{Hy}$. acinth, which abide all the Winter, and Spring following, and wither away in the be ginning of Summer: the roote is fmall, long, and white.

\section{Leucoium maius bulbofum ferotinum.}

The great late flowring bulbous Violet.

The late bulbous Violet hath three or foure broad flat greene leaues, very like vnt the firft, but longer, among which rifeth vp a flattifh ftalke, being thicker in the mid dle then at both edges, on the toppe whereof ftand three or foure flowers, hangin downe their heads, confifting of fix leaues a peece, all of an equall length and bigneffo wholly white, except that each leafe hath a greene tippe at the end of them: the feed hereof is blacke and round; the roote is reafonable great and white.

\section{The Place.}

The two former fmall ones were firf found in Spaine, and Portugall, ar fent to me by Guillaume Boel; but the firft was fo tender, that fcarce or of a fcore fprang with me, or would abide. The greateft have beene four wilde in Germany and Auftria.

The Time.

The fmall ones haue their times expreffed in their titles and defcrip ons, the laft flowreth not vntill May.

\section{The Names.}

Thefe names that are fet downe in their titles, doe paffe with all Herkrifts in thefe daies.

The Vertues.

Wee haue not knowne thefe plants vfed Phyfically, either inwardly $r$ outwardly, to any purpofes in thefe dayes. 


\section{C н A P. X I.}

Hyacinthus. The Hyacinth or Iacinth.

THe Iacinths are next to be entreated of, whereof there are many more kindes found out in thefe later times, then formerly were knowne, which for order and method fake, I will digeft vnder feuerall forts, as neare as I can, that auoiding confufion, by enterlacing one among another, I may the better put euery fort vnder his owne kinde.

\section{Hyacinthus Indicus maior tuberofa radice. \\ The greater Indian knobbed Iacinth.}

I haue thought fitteft to begin with this Iacinth, both becaufe it is the greateft and higheit, and alfo becaufe the flowers hereof are in fome likeneffe neare vnto a Daffodill, although his roote be tuberous, and not bulbous as all the reft are. This Indian Iacinth hath a thicke knobbed roote (yet formed into feuerall heads, fomewhat like vnto bulbous rootes) with many thicke fibres at the bottome of them; from the diuers heads of this roote arife diuers ftrong and very tall ftalkes, befet with diuers faire, long, and broad leaues, ioyned at the bottome clofe vnto the ftalke, where they are greateft, and grow fmaller to the very end, and thofe that grow higher to the toppe, being fmaller and fmaller, which being broken, there appeare many threeds like wooll in them: the toppes of the ftalkes are garnifhed with many faire large white flowers, each whereof is compofed of fix leaues, lying fpread open, as the flowers of the white Daffodill, with fome fhort threeds in the middle, and of a very fweete fent, or rather ftrong and headie.

\section{Hyacinthus Indicus minor tuberof a radice.}

\section{The fmaller Indian knobbed Iacinth.}

The roote of this Iacinth is knobbed, like the roote of Arum or Wake Robin, from whence doe fpring many leaues, lying vpon the ground, and compaffing one another at the bottome, being long and narrow, and hollow guttered to the end, which is fmall and pointed, no leffe woolly, or full of threeds then the former: from the middle of thefe leaues rifeth vp the ftalke, being very long and flender, three or foure foot long, fo that without it be propped vp, it will bend downe, and lye vpon the ground, whereon are fet at certaine diftances many fhort leaues, being broad at the bottome, where they doe almoft compaffe the ftalke, and are fmaller toward the end where it is fharpe pointed: at the top of the ftalke ftand many flowers, with a fmall peece of a green leafe at the bottome of euery foot-ftalke, which feeme to bee like fo many white Orientall Iacinths, being compofed of fix leaues, which are much thicker then the former, with fix chiues or threeds in the middle, tipt with pale yellow pendents.

The Place.

They both grow naturally in the Weft Indies, from whence being firft brought into Spaine, haue from thence been difperfed vnto diuers louers of plants.

The Time.

They flower not in thefe cold Countries vntill the middle of Auguit, or not at all, if they bee not carefully preferued from the iniury of our cold Winters; and then if the precedent Summer be hot, it may be flower a moneth fooner.

The Names.

Clufius calleth the leffer (for I thinke hee neuer faw the firft) Hyacinthus 
Indicus tuberof a radice, that is in Englifh, The Indian Iacinth with a tuberous roote: Some would call thefe Hyacinthus Eriophorus Indicus, that is, The Indian woolly Iacinth, becaufe they haue much wooll in them when they are broken; yet fome doe doubt that they are not two plants feuerall, as of greater and leffer, but that the greatneffe is caufed by the fertility of the foyle wherein it grew.

1. Hyacinthus Botroides maior Mofchatus, fine Mufcari fore flauo.

The great yellow Muske Grape-flower, or yellow Mufcari.

This Muske Iacinth or Grape-flower, hath fiue or fix leaues fpread vpon the ground in two or three heads, which at the firf budding or thooting forth out of the ground, are of a reddifh purple colour, and after become long, thicke, hollow, or guttered on the vpper fide, of a whitifh greene colour, and round and darke coloured vnderneath: in the middle of thefe heads of leaues, rife vp one or two hollow weake brownifh ftalkes, fometimes lying on the ground with the weight of the flowers, (but efpecially of the feede) yet for the moft part ftanding vpright, when they are laden towards the toppe, with many bottle-like flowers, which at their firft appearing, and vntill the flowers begin to blow open, are of a browne red colour, and when they are blowne, of a faire yellow colour, flowring firt below, and fo vpwards by degrees, euery one of thefe flowers is made like vnto a little pitcher or bottle, being bigge in the belly, and fmall at the mouth, which is round, and a little turned vp, very fweete in fmell, like vnto Muske, whereof it tooke the name Mufcari; after the flowers are paft, there come three fquare thicke heads, puffed vp as if it were bladders, made of a fpongie fubftance, wherein are here and there placed blacke round feed: the roote is long, round, and very thicke, and white on the outfide, with a little woollineffe on them, being broken, and full of a flimie iuice, whereunto are annexed thicke, fat, and long fibres, which perifh not as moft of the other Iacinths; and therefore defireth not to bee often remoued, as the other forts may.

\section{Hyacinthus Botroides maior Mofchatus, fell Mufcari flore cineritio.}

The Afhcoloured Muske Grape-flower, or Mufcari.

This Mufcari differeth not in rootes, or forme of leaues or flowers from the former, the chiefe differences are thefe: the leaues hereof do not appeare fo red at the firft budding out of the ground, nor are fo darke when they are fully growne; the ftalke alfo moft vfually hath more ftore of flowers thereon, the colour whereof at the firft budding is a little duskie, and when they are full blowne, are of a bleake, yet bright afhcolour, with a little thew of purple in them, and by long ftanding change a little more gray; being as fweete, or as fome thinke, more fweete then the former : the roote (as I faid) is like the former, yet yeeldeth more encreafe, and will better endure our cold clymate, although it doth more feldome give ripe feede.

3. Hyacinthus Botroides maior Mofchatus, fiue Mufcari flore rubro.

The red Muske Grape-flower.

This kinde (if there be any fuch, for I am in fome doubt thereof) doth chiefly differ in the colour of the flower from the firft, in that this hould beare flowers when they are blowne, of a red colour tending to yellowneffe.

\section{Hyacinthus Botroides maior Mofchatus, fue Mufcari flore albo.}

The white Muske Grape-flower.

This alfo is faid to have (if there bee fuch an one) his leaues like vnto the fecond kinde, but of a little whiter greene, and the flowers pale, tending to a white: the roots of thefe two laft are faid vfually not to grow to be fo great as of the former two.

The Place.

The rootes of the two firft forts, haue been often fent from Conftantino- 


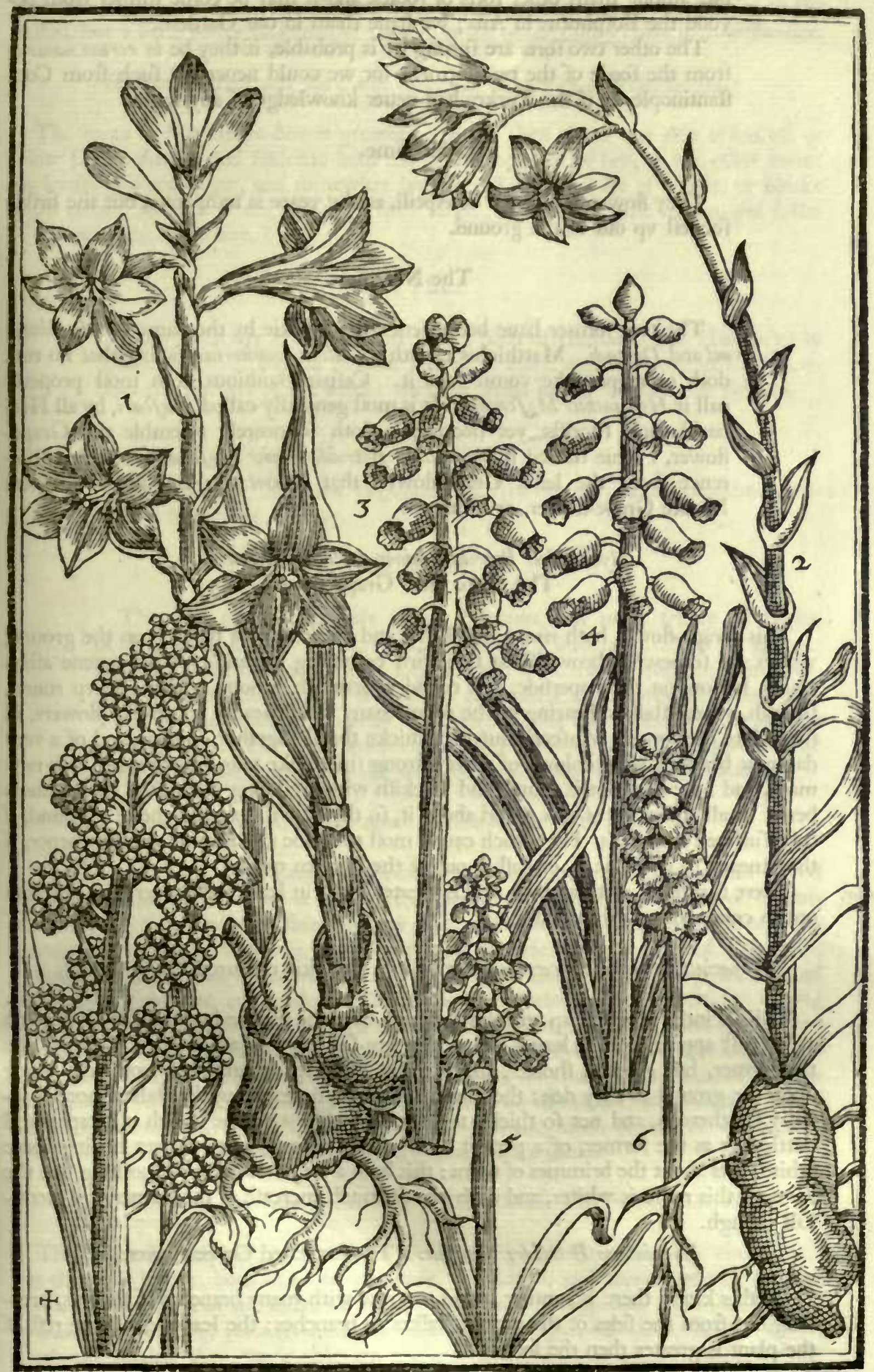

th Hycinthus Indicus maior tuberofa radice. The reater Indian knobbed Iacinth. 2 IIyacinthus Indicus minor tuberofa radice. The leffer Indian knobbed lacinth. 3 Mufcari fore Aawo. The yellow Mufeari. 4 Mufcari fore cineritio. The ahcoloured Mulcari. 5 Hyacinthus Botroides carulews amarus. The skie coloured Grape-tow cr.

white Grape-flower. + II yacinthus Botroides ramo/ws. The branched Grape-fiower. 
ple, among many other forts of rootes, and it may be come thither from beyond the Bofphorus in Afia; we haue them in our Gardens.

The other two forts are fprung (it is probable, if they be in rerum naturi) from the feede of the two former; for we could neuer get fuch from ConItantinople, as if the Turkes had neuer knowledge of any fuch.

\section{The Time.}

They flower in March or Aprill, as the yeare is temperate, but the firft is fooneft vp out of the ground.

\section{The Names.}

The two former haue beene fent from Turkie by the name of Mufchoromi and Dipcadi. Matthiolus calleth it Bulbus vomitorius, faying that no root doth more prouoke vomit then it. Cafpar Bauhinus doth moft properly call it Hyacinthus Mofchatus. It is molt generally called Mufcari, by all Herbarifts and Florifts, yet becaufe it doth fo neerely refemble the Grapeflower, I haue named it Hyacinthus Botroides maior Mofchatus, to put a difference from the leffer Grape-flowers that follow; in Englifh, The great Muske Grape-flower, or Mufcari.

\section{Hyacinthus Botroides minor caruleus obfcurus.}

The darke blew Grape-flower.

This Grape-flower hath many fmall, fat, and weake leaues lying vpon the ground, which are fomewhat brownifh at their firft comming vp, and of a fad greene afterwards, hollow on the vpperfide, and round vnderneath, among which rife vp round, fmooth, weake ftalkes, bearing at the toppe many fmall heauie bottle-like flowers, in thape like the former Mufcari, but very thicke thruft together, fmaller, and of a very darke or blackith blew colour, of a very ftrong finell, like vnto Starch when it is new made, and hot: the root is round, and blackifh without, being compaffed with a number of fmall rootes, or of-fets round about it, fo that it will quickly choke a ground, if it be fuffered long in it. For which caufe, moft men doe caft it into fome by-corner, if they meane to preferue it, or caft it out of the Garden quite.

Alter maior. There is another of this kinde that is greater, both in leafe and flower, and differeth not in colour or any thing elfe.

\section{Hyacinthus Botroides caruleus amanus. The skie coloured Grape-flower.}

This Iacinth fpringeth vp with fewer leaues then the firft, and not reddifh, but green at his firft appearing; the leaues, when they are full growne, are long and hollow, like the former, but greener, fhorter, and broader, ftanding vpright, and not lying along vpon the ground as they doe: the flowers grow at the toppe of the ftalke, more fparfedly fet thereon, and not fo thicke together, but like a thinne bunch of grapes, and bottle-like as the former, of a perfect blew or skie colour, euery flower hauing fome white fpots about the brimmes of them : this hath a very fweete fmell, nothing like the former: this roote is whiter, and doth not fo much encreafe as the former, yet plentifull enough.

\section{Hyacinthus Botroides ramofus. The branched Grape-flower.}

Of this kinde, there is another found to grow with many branches of flowers, breaking out from the fides of the greater ftalkes or branches: the leaues as all the reft of the plant is greater then the former.

\section{Hyacinthus Botroides flore albo. The white Grape-flower.}

The white Grape-flower hath his green leaues a little whiter, then the blew or 
skie coloured Grape-flower, his flowers are very pure white, alike fparfedly fet on the ltalkes, but a little lower and fmaller then it, in all other things there is no difference.

\section{Hyacinthus Botroides flori albo rubente. The bluth Grape-flower.}

The roote of this Grape-flower groweth greater, then either the skie coloured, or white Grape-flower, and feldome hath any fmall rootes or of-fets, as the other haue: his leaues alio are larger, and fomewhat broader; the flowers are of a pale, or bleake blufh colour out of a white, and are a little larger, and grow a little higher and fuller of flowers then the white.

\section{The Place.}

They naturally grow in many places both of Germany and Hungary; in Spaine likewife, and on Mount Baldus in Italy, and Narbone in France, about the borders of the fields: we haue them in our Gardens for delight.

\section{The Time.}

Thefe flower from the beginning of March, or fooner fometimes, vntill the beginning of May.

\section{The Names.}

They are moit commonly called Botroides, but more truely Botryodes, of Bórpus the Greeke word, which fignifieth a bunch or clufter of grapes: Lobelius calleth the white one, Dipcadi fore albo, transferring the name Dipcadi, whereby the Mufcari is called to this Iacinth, as if they were both one. Their feuerall names, whereby they are knowne and called, are fet downe in their titles. The Dutchmen call them Driuekens, as I faid before. Some Englifh Gentlewomen call the white Grape-flower Pearles of Spaine.

\section{Hyacinthus Comofus albus. The white haired Iacinth.}

This Iacinth doth more neerly refemble the Grape-flowers, then the faire haired Iacinths that follow, whereof it beareth the name, in that it hath no haire or threeds at the toppe of the ftalke or fides, as they: and therefore I haue placed it next vnto them, and the other to follow it, as being of another kinde. The root hereof is blackifh, a little long and round, from whence rife vp three or foure leaues, being fmooth and whitih, long, narrow, and hollow, like a trough or gutter on the vpperfide: among which the ftalke rifeth $\mathrm{vp}$ a foote high or more, bearing at the toppe diuers fmall flowers, fomewhat like the former, but not fo thicke fet together, being a little longer, and larger, and wider at the mouth, and as it were diuided into fix edges, of a darke whitifh colour, with fome blacker fpots about the brimmes on the infide: the heads or feedeveffels are three fquare, and fomewhat larger, then the heads of any of the former leffer Grape-flowers, wherein is contained round blacke feede.

\section{Hyocinthus Comofus Byzantimus. The Turkie faire haired Iacinth.}

This other Iacinth which came from Conftantinople, is fomewhat like the former, but that it is bigger, both in roote, and leafe, and flower, and bearing greater ftore of flowers on the head of the ftalke: the lower flowers, although they haue fhort ftalkes at their firft flowring, yet afterwards the ftalkes grow longer, and thofe that are lower, ftand out further then thofe that are higheft, whofe foot-ftalkes are fhort, and almoft clofe to the ftemme, and of a more perfect purple then any below, which are of a duskie greenilh purple colour: the whole ftalke of flowers feem like a Pyramis, broad belowe, and fmall aboue, or as other compare it, to a water fprinkle; yet neither of both thefe Iacinths haue any threeds at the tops of the ftalkes, as the other following haue. 


\section{Hyacinthus Comofus maior purpureus.}

The great purple faire haired Iacinth.

This faire haired Iacinth hath his leaues fofter, longer, broader, and leffe hollow then the former, lying for the moft part vpon the ground: the ftalke rifeth vp in the midft of the leaues, being ftronger, higher, and bearing a greater and longer head of flowers alfo then they: the flowers of this ftand not vpon fuch long foote-ftalkes, but are fhorter below, and clofe almoft to the ftalke aboue, hauing many bright purplifh blew threeds, growing higheft aboue the flowers, as it were in a bufh together, euery one of thefe threeds hauing a little head at the end of them, fomewhat like vnto one of the flowers, but much fmaller: the reft of the flowers below this burh, are of a fadder or deader purple, and not fo bright a colour, and the loweft wort of all, rather enclining to a greene, like vnto the laft Turkie kinde: the whole ftalke with the flowers vpon it, doth fomewhat refemble a long Purfe taffell, and thereupon diuers Gentlewomen haue fo named it: the heads and feede are like vnto the former, but greater: the roote is great and white, with fome redneffe on the outfide.

\section{Hyacinthus Comofus ramofus purpureus.}

The faire haired branched Iacinth.

The leaues of this Iacinth are broader, fhorter, and greener then of the laft, not lying fo weakly on the ground, but ftanding fomewhat more vpright: the ftalke rifeth vp as high as the former, but branched out on euery fide into many tufts of threeds, with knappes, as it were heads of flowers, at the ends of them, like vnto the head of threeds at the toppe of the former Iacinth, but of a little darker, and not fo faire a blewifh purple colour : this Iacinth doth fomewhat refemble the next Curld haire Iacinth, but that the branches are not fo fairely compofed altogether of curled threeds, nor of fo excellent a faire purple or Doue colour, but more duskie by much : the roote is greater and fhorter then of the next, and encreafeth fafter.

\section{Hyacinthus Pennatus, fue Comofus ramofus elegantior.}

The faire Curld-haire Iacinth.

This admirable Iacinth rifeth vp with three or foure leaues, fomewhat like vnto the leaues of the Muske Grape-flower, but leffer; betweene which rifeth vp the ftalke about a foote high, or fomewhat more, bearing at the toppe a bufh or tuft of flowers, which at the firt appearing, is like vnto a Cone or Piileapple, and afterwards opening it felfe, fpreadeth into many branches, yet ftill retaining the forme of a Pyramis, being broad fpread below, and narrow vp aboue : each of thefe branches is againe diuided into many tufts of threeds or ftrings, twifted or curled at the ends, and of an excellent purple or Doue colour, both ftalkes and haires. This abideth a great while in his beauty, but afterwards all thefe flowers (if you will fo call them) do fall away without any feede at all, fpending it felfe as it fhould feeme in the aboundance of the flowers: the roote is not fo great as the laft, but white on the outfide.

The Place.

The two firft haue been fent diuers times from Conftantinople, the third is found wilde in many places of Europe, and as well in Germany, as in Italy. The two laft are onely with vs in Gardens, and their naturall places are not knowne vnto vs.

\section{The Time.}

The three former kindes doe flower in Aprill, the two laft in May.

The Names.

The firft and fecond haue no other names then are expreffed in their titles. 


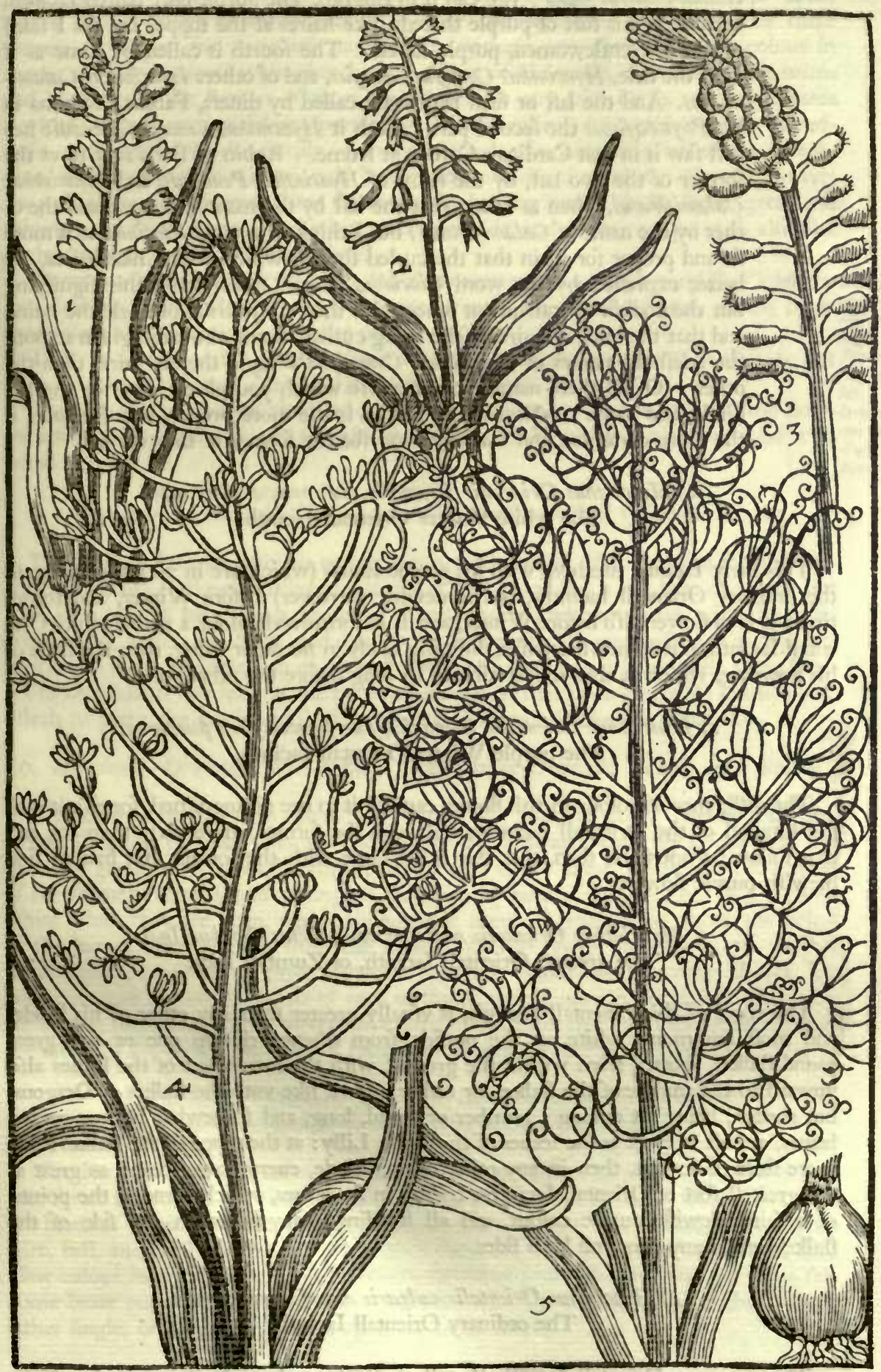

Hyacinthus Comofus albus. The white haired lacinth. 2 IIyacinshus Comofus Bjsantinus. The Turkie faire haired lacinth, 3 Hyacinthus Comofus maiar purpuress. The purple faire haired lacinth, or I'urfe taffels. 4 Hyacinthus Comofus ramofus, fune lacinth. 
tles. The third is called of fome onely Hyacinthus maior, and of others Hyacinthus comofus maior: We call it in Englifh, The purple faire haired Iacinth, becaufe of his tuft of purple threeds, like haires at the toppe, and (as I faid) of diuers Gentlewomen, purple taffels. The fourth is called by fome as it is in the title, Hyacinthus Comofius ramofius, and of others Hyacinthus Calamifratus. And the laft or fifth is diuerfly called by diuers, Fabius Columna in his Phytobafanos the fecond part, calleth it Hyacinthus Sannefius, becaufe hee firft faw it in that Cardinals Garden at Rome. Robin of Paris fent to vs the former of the two laft, by the name of Hyacinthus Pennatus, and Hyacinthus Calamiftratus, when as others fent the laft by the name Pennatus, and the other by the name of Calamiftratus; but I thinke the name Cincimnatus is more fit and proper for it, in that the curled threeds which feeme like haires, are better expreffed by the word Cincinmus, then Calamiftrum, this fignifying but the bodkin or inftrument wherewith they vfe to frifle or curle the haire, and that the bufh of haire it felfe being curled. Some alfo haue giuen to both the felaft the names of Hyacinthus Comofus Parnafsi, the one fairer then the other. Of all thefe names you may vre which you pleafe; but for the laft kinde, the name Cincinnatus, as I faid, is the more proper, but Pennatus is the more common, and Calamiftratus for the former of the two laft.

\section{Hyacinthus Orientalis Brumalis, fue pracox fore albo.}

The white Winter Orientall Iacinth.

This early Iacinth rifeth vp with his greene leaues (which are in all refpects like to the ordinary Orientall Iacinths, but fomewhat narrower) before Winter, and fometimes it is in flower alfo before Winter, and is in forme and colour a plaine white Orientall Iacinth, but fomewhat leffer, differing onely in no other thing, then the time of his flowring, which is alwayes certaine to be long before the other forts.

\section{Hyacinthus Orientalis Brumalis, fue pracox flore purpureo.} The purple Winter Orientall Iacinth.

The difference of colour in this flower caufeth it to bee diftinguifhed, for elfe it is of the kindred of the Orientall Iacinths, and is, as the former, more early then the reft that follow: Vnderftand then, that this is the fame with the former, but hauing fine blewifh purple flowers.

\section{Hyacinthus Orientalis maior pracox, dictus Zumbul Indi.}

The greateft Orientall Iacinth, or Zumbul Indi.

The roote of this Orientall Iacinth, is vfually greater then any other of his kinde, and moft commonly white on the outfide, from whence rife vp one or two great round ftalkes, fpotted from within the ground, with the lower part of the leaues alfo vpward to the middle of the ftalkes, or rather higher, like vuto the ftalkes of Dragons, but darker; being fet among a number of broad, long, and fomewhat hollow greene leaues, almont as large as the leaues of the white Lilly: at the toppe of the ftalkes ftand more ftore of flowers, then in any other of this kinde, euery flower being as great as the greateft fort of Orientall Iacinths, ending in fix leaues, which turne at the points, of a faire blewifh purple colour, and all ftanding many times on one fide of the ftalkes, and many times on both fides.

\section{Hyacinthus Orientalis vulgaris diuerforum colorum.} The ordinary Orientall Iacinth.

The common Orientall Iacinth (I call it common, becaufe it is now fo plentifull in all Gardens, that it is almoft not efteemed) hath many greene leaues, long, fomewhat broad and hollow, among which rifeth vp a long greene round falke, befet from the middle thereof almoft, with diuers flowers, ftanding on both fides 
of the ftalkes, one aboue another vnto the toppe, each whereof next vnto the footeftalke is long, hollow, round, and clofe, ending in fix fmall leaues laid open, and a little turning at the points, of a very fiveete finell: the colours of thefe flowers are diuers, for fome are pure white, without any fhew of other colour in them : another is almoft white, but hauing a fhew of blewneffe, efpecially at the brims and bottomes of the flowers. Others againe are of a very faint blufh, tending towards a white: Some are of as deepe a purple as a Violet; others of a purple tending to redneffe, and fome of a paler purple. Some againe are of a faire blew, others more watchet, and fome fo pale a blew, as if it were more white then blew: after the flowers are paft, there rife vp great three fquare heads, bearing round blacke feede, great and fhining: the roote is great, and white on the outfide, and oftentimes purplifh alfo, flat at the bottome, and finall at the head.

There is a kinde of thefe Iacinths, whofe flowers are of a deepe purplifh Violet co- Flore purpure lour, hauing whitilh lines downe the backe of euery leafe of the flower, which turne evilaceo lincis themfelues a little backwards at the points.

There is another, whofe flowers ftand all opening one way, and not on all fides, but Floribus antro. are herein like the great Zumbul Indi, before fet out.

fum refpicient bus.

There is againe another kinde which flowreth later then all the reft, and the flow-Serosinus ereers are fmaller, Ptanding more vpright, which are either white or blew, or mixt with scus foribus ers are finaller, Handing more vpright, which are either white or blew, or mixt with diuerforem ce white and purple. corum.

\section{Hyacinthus Orientalis foliofo caule. The buthy ftalked Orientall Iacinth.}

This Itrange Iacinth hath his rootes, leaues, and flowers, like vnto the former Orientall Iacinths: the onely difference in this is, that his ftalke is not bare or naked, but hath very narrow long leaues, growing difperfedly, and without order, with the flowers thercon, which are blew, and hauing for the moft part one leafe, and fometimes two at the foote, or fetting on of euery flower, yet fometimes it happeneth, fome flowers to be without any leafe at the bottome, as nature, that is very variable in this plant, lifteth to play: the heads and feede are blacke and round, like the other alfo.

\section{Hyacinthus Orientalis flore duplici. The bleake Orientall Iacinth once double.}

This double Iacinth hath diuers long leaues, like vnto the other Orientall Iacinths, almoft itanding vpright, among which rifeth vp a ftalke, brownifh at the firft, but growing greene afterwards, bearing many flowers at the toppe, made like the flowers of the former Iacinths, and ending in fix leaues, greene at the firft, and of a blewifh white when they are open, yet retaining forne thew of greeneffe in them, the brims of the leaues being white; from the middle of each flower ftandeth forth another imall flower, confifting of three leaues, of the fame colour with the other flower, but with a greene line on the backe of each of thefe inner leaues: in the middle of this little flower, there ftand fome threeds tipt with blacke: the fmell of this flower is not fo fweete as of the forme; the heads, feede, and rootes are like the former.

\section{Hyacinthus Orientalis flore plens carmleo, vel purpuro violacio.}

The faire double blew, or purple Orientall Iacinth.

The leaues of thefe Iacinths are limaller, then the leaues of molt of the other former forts; the ftalkes are fhorter, and fmaller, bearing but three or foure flowers on the heads of them for the molt part, which are not compofed like the laft, but are more faire, full, and double of leaues, where they thew out their full beauties, and of a faire blew colour in fome, and purple in others, fmelling pretty fweete; but thefe doe feldome beare out their flowers faire; and befides, liaue diuers other flowers that will be either fingle, or very little double vpon the fame ftalke.

\section{Hyacinthus Orientalis candidifsimus fore pleno.}

The pure white double Orientall Iacinth.

This double white Iacinth hath his leaues like vnto the fingle white Orientall Iacinth ; 
cinth; his ftalke is likewife long, flender, and greene, bearing at the toppe two or three flowers at the moft, very double and full of leaues, of a pure white colour, without any other mixture therein, hanging downe their heads a little, and are reafonable fweete. I haue this but by relation, not by fight, and therefore I can giue no further affurance as yet.

\section{The Place.}

All thefe Orientall Iacinths, except the laft, haue beene brought out of Turkie, and from Conftantinople: but where their true originall place is, is not as yet vnderftood.

\section{The Time.}

The two firft (as is faid) flower the earlieft, fometimes before Chriftmas, but more vfually after, and abide a great while in flower, in great beauty, efpecially if the weather be milde, when as few or no other flowers at that time are able to match them. The other greateft kinde flowreth alfo earlier then the reft that follow, for the moft part. The ordinary kindes flower fome in March, and fome in Aprill, and fome fooner alfo; and fo doe the double ones likewife. The bufhy ftalked Iacinth flowreth much about the fame time.

\section{The Names.}

The former two forts are called Hyacinthus Orientalis Brumalis, and Hyacinthus Orientalis precox flore albo, or caruleo. The third is called of many Zumbul Indicum, or Zumbul Indi, and corruptly Simboline; of others, and that more properly, Hyacinthus Orientalis maior pracox. The Turkes doe call all Iacinths Zumbul, and by adding the name of Indi, or Arabi, do thew from what place they are receiued. In Englifh, The greateft Orientall Iacinth; yet fome doe call it after the Turkifh name Zumbul Indi, or Simboline, as is faid before. The reft haue their names fet downe in their titles, which are molt fit for them.

\section{Hyacinthus Hifpanicus minor Orientalis facie.}

The little Summer Orientall Iacinth.

This little Iacinth hath foure or fiue long narrow greene leaues, lying vpon the ground, among which rifeth vp a flender fmooth ftalke, about a fpanne high or more, bearing at the toppe many flender bleake blew flowers, with fome white ftripes and edges to be feene in molt of them, fafhioned very like vnto the flowers of the Orientall Iacinth, but much fmaller : the flower hath no fent at all; the feede is like the feede of the Englifh Iacinth, or Haref-bels: the roote is fmall and white.

There is another of this kinde, differing in nothing but in the colour of the flower, which is pure white.

There is alfo another, whofe flowers are of a fine delayed red colour, with fome deeper coloured veines, running along the three outer leaues of the flower, differing in no other thing from the former.

\section{The Place.}

Thefe plants haue been gathered on the Pyrenæan Mountaines, which are next vnto Spaine, from whence, as is often faid, many rare plants haue likewife been gathered.

\section{The Time.}

They flower very late, euen after all or molt of the Iacinths, in May for the inoft part. 


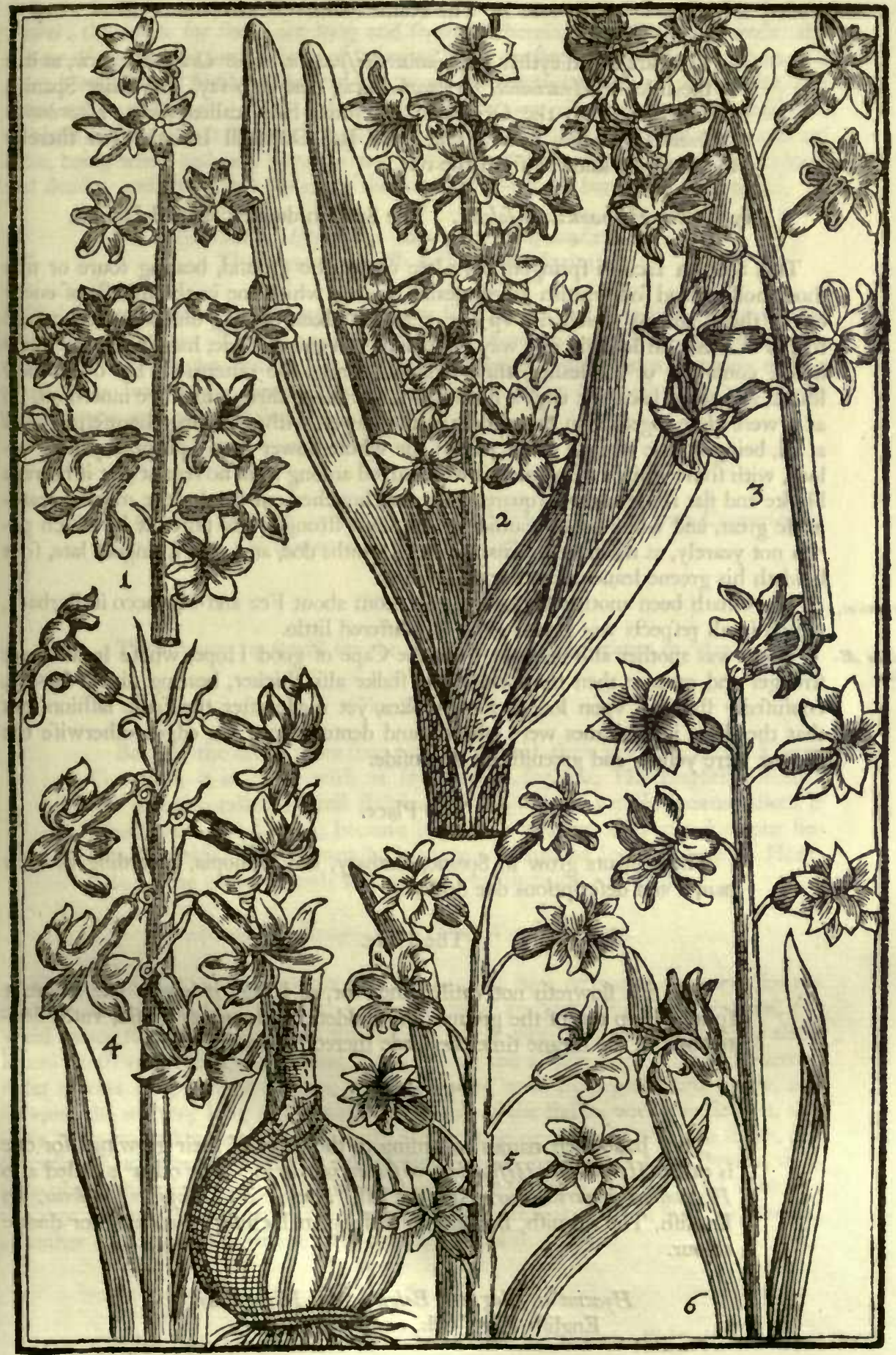

1 Hyasinthus Orientalis brumalis. The Winter Orientall Iacinth. 2 Zwmbul Indi. The greateft Orientall Iacinth. 3 IIya. cinthus Orientalis sulgaris. The ordinary Orientall Iacinth. Hyacinthus Orientalis foliofo caule. The buhy Ralked Orientall lacinth. 5 Ityacimthus Orientolis fore duptici 


\section{The Names.}

They are? called eyther Hyacinthus Hi/panicus minor Orientalis facie, as it is in the title, or Hyacinthus Orientalis facie, that is to fay, The leffer Spanifh Iacinth, like vnto the Orientall: yet fome haue called them, Hyacinthus Orientalis ferotinus minor, The leffer late Orientall Iacinth, that thereby they may be knowne from the reft.

\section{Hyacinthus Hifpanicus obfoletus. The Spanifh dunne coloured Iacinth.}

This Spanifh Iacinth fpringeth very late out of the ground, bearing foure or fiue fhort, hollow, and foft whitifh greene leaues, with a white line in the middle of euery one of them, among which rife vp one or more ftalkes, bearing diuers flowers at the toppes of them, all looking one way, or ftanding on the one fide, hanging downe their heads, confifting of fix leaues, three whereof being the outermoft, lay open their leaues, and turne back the ends a little again: the other three which are innermoft, do as it were clofe together in the middle of the flower, without laying themfelues open at all, being a little whitifh at the edges: the whole flower is of a purplifh yellow colour, with fome white and green as it were mixed among it, of no fent at all: it beareth blacke and flat feede in three fquare, great, and bunched out heads: the roote is reafonable great, and white on the outfide, with many ftrong white fibres at it, which perifh not yearely, as the fibres of many other Iacinths doe, and as it fpringeth late, fo it holdeth his greene leaues almoft vntill Winter.

Mauritanicus. There hath been another hereof brought from about Fez and Marocco in Barbary, which in all refpects was greater, but elfe differed little.

Maximus $\quad$ There was another alfo brought from the Cape of good Hope, whofe leaues were thiopicus. Atronger and greener then the former, the ftalke alfo thicker, bearing diuers flowers, confufedly ftanding vpon longer foote-ftalkes, yet made after the fame fafhion, but that the three inner leaues were whitifh, and dented about the edges, otherwife the flowers were yellow and greenifh on the infide.

\section{The Place.}

Thefe plants grow in Spaine, Barbary, and Ethiopia, according as their names and defcriptions doe declare.

\section{The Time.}

The firft flowreth not vntill Iune; for, as I faid, it is very late before it fpringeth vp out of the ground, and holdeth his leaues as is faid, vntill September, in the meane time the feede thereof ripeneth.

\section{The Names.}

They haue their names according to the place of their growing; for one is called Hyacinthus Hifpanicus obfoletioris coloris. The other is called alfo Hyacinthus Mauritanicus. And the laft, Hyacinihus Ethiopicus obfoletus. In Englifh, The Spanifh, Barbary, or Ethiopian Iacinth, of a dunne or duskie colour.

\section{Hyacinthus Anglicus Belgicus, vel Hifpanicus.}

Englifh Haref-bels, or Spanifh Iacinth.

Our Englifh Iacinth or Haref-bels is fo common euery where, that it fcarce needeth any defcription. It beareth diuers long and narrow greene leaues, not ftanding vpright, nor yet fully lying vpon the ground, among which fpringeth vp the ftalke, bearing at the toppe many long and hollow flowers, hanging downe their heads all 
forwards for the moft part, parted at the brimmes into fix parts, turning vp their points a little againe, of a fweetifh, but heady fent, fomewhat like vnto the Grapeflower: the heads for feede are long and fquare, wherein is much blacke feede: the colour of the flowers are in fome of a deeper blew, tending to a purple; in others of a paler blew, or of a bleake blew, tending to an afh colour: Some are pure white, and fome are party coloured, blew and white; and fome are of a fine delayed purplifh red or blufh colour, which fome call a peach colour. The rootes of all forts agree, and are alike, being white and very flimie; fome whereof will be great and round, others long and flender, and thofe that lye neare the toppe of the earth bare, will be greene.

\section{Hyacinthus Hi/panicus maior flore campanula inftar.}

The greater Spanifh bell-flowred Iacinth.

This Spanifh bell-flowred Iacinth, is very like the former Englifh or Spanifh Iacinth, but greater in all parts, as well of leaues as flowers, many growing together at the toppe of the ftalke, with many fhort greene leaues among them, hanging downe their heads, with larger, greater, and wider open mouths, like vnto bels, of a darke blew colour, and no good fent.

The Place.

The firft groweth in many places of England, the Lowe-Countries, as we call them, and Spaine, but the laft chiefly in Spaine.

\section{The Time.}

They flower in Aprill for the moft part, and fometimes in May.

\section{The Names.}

Becaufe the firft is more frequent in England, then in Spaine, or the LoweCountries, it is called with vs Hyacinthus Anglicus, The Englifh Iacinth; but it is alfo called as well Belgicus, as Hifpanicus: yet Dodonæus calleth it Hyacinthus non fcriptus, becaufe it was not written of by any Authour before himfelfe. It is generally knowne in England by the name of Harebels. The other Spanifh Iacinth beareth his name in his title.

\section{Hyacinthus Eriophorus. The Woolly Iacinth.}

This Woolly Iacinth hath many broad, long, and faire greene leaues, very like vnto fome of the Iacinths, but ftiffer, or ftanding more vpright, which being broken, doe yeeld many threeds, as if a little fine cotton wooll were drawne out: among thefe leaues rifeth vp a long greene round ftalke, a foote and a halfe high or more, whereon is fet a great long bufh of flowers, which blowing open by degrees, firft below, and fo vpwards, are very long in flowring: the toppe of the ftalke, with the flowers, and their little footitalkes, are all blew, euery flower ftanding outright with his ftalke, and fpreading like a ftarre, diuided into fix leaues, hauing many fmall blew threeds, ftanding about the middle head, which neuer gaue ripe feede, as farre as I can heare of: the root is white, fomewhat like the root of a Mufcari, but as full of wooll or threeds, or rather more, then the leaues, or any other part of it.

\section{The Place.}

This hath been fent diuers times out of Turkie into England, where it continued a long time as well in my Garden as in others, but fome hard frofty Winters caufed it to perifh with me, and diuers others, yet I haue had it againe from a friend, and doth abide frefh and greene euery yeare in my Garden. 
The Time.

This flowred in the Garden of $\mathrm{M}^{\mathrm{r}}$. Richard Barnefley at Lambeth, onely once in the moneth of May, in the yeare 1606 , after hee had there preferued it a long time: but neither he, nor any elfe in England that I know, but thofe that faw it at that time, euer faw it beare flower, either before or fince.

The Names.

It is called by diuers Bulbus Eriophorus, or Laniferus, that is, Woolly Bulbous; but becaufe it is a Iacinth, both in roote, leafe, and flower, and not a Narcifus, or Daffodill, it is called Hyacinthus Eriophorus, or Laniferus, The Woolly Iacinth. It is very likely, that Theophraftus in his feuenth Book \& thirteenth Chapter, did meane this plant, where hee declareth, that garments were made of the woolly fubftance of a bulbous roote, that was taken from between the core or heart of the roote (which, as he faith, was vfed to be eaten) and the outermoft thels or peelings; yet Clufius feemeth to faften this woolly bulbous of Theophraftus, vpon the next Iacinth of Spaine.

Hyacinthus Stellatus Baticus maior, vulgd Perïanus The great Spanifh Starry Iacinth, or of Peru.

This Iacinth (the greateft of thofe, whofe flowers are fpread like a ftarre, except the two firft Indians) hath fiue or fix, or more, very broad, and long greene leaues, fpread vpon the ground, round about the roote, which being broken are woolly, or full of threeds, like the former: in the middle of thefe leaues rifeth vp a round thort ftalke, in comparifon of the greatneffe of the plant (for the ftalke of the Orientall Iacinth is fometimes twice fo high, whofe roote is not fo great) bearing at the toppe a great head or bufh of flowers, fafhioned in the beginning, before they bee blowne or feparated, very like to a Cone or Pineapple, and begin to flower belowe, and fo vpwards by degrees, euery flower ftanding vpon a long blackifh blew foote-ftalke, which when they are blowne open, are of a perfect blew colour, tending to a Violet, and made of fix fmall leaues, laid open like a ftarre; the threeds likewife are blewifh, tipt with yellow pendents, ftanding about the middle head, which is of a deeper blew, not hauing any good fent to be perceiued in it, but commendable only for the beauty of the flowers : after the flowers are palt, there come three fquare heads, containing round blacke feede: the roote is great, and fomewhat yellowifh on the outfide, with a knobbe or bunch at the lower end of the roote, (which is called the feate of the roote) like vnto the Mufcari, Scylla, and many other bulbous rootes, at which hang diuers white, thicke, and long fibres, whereby it is faftened in the ground, which perifh not euery yeare, but abide continually, and therefore doth not defire much remouing.

Hyacinthus Stellatus Baticus, fue Perüanus flore albo. The great white Spanifh ftarry Iacinth.

This other Spanifh Iacinth is in moft parts like vnto the former, but that his leaues are not fo large, nor fo deep a greene: the ftalks of flowers likewife hath not fo thicke a head, or bufh on it, but fewer and thinner fet: the flowers themfelues alfo are whitifh, yet hauing a fmall dafh of blufh in them: the threeds are whitifh, tipt with yellow pendents: the feede and rootes are like vnto the former, and herein confifteth the difference betweene this and the other forts.

Hyacinthus Stellatus Baticus, fiue Perïamis flore carneo.

The great blufh coloured Spanilh Starry Iacinth.

This likewife differeth little from the two former, but onely in the colour of the flowers; 


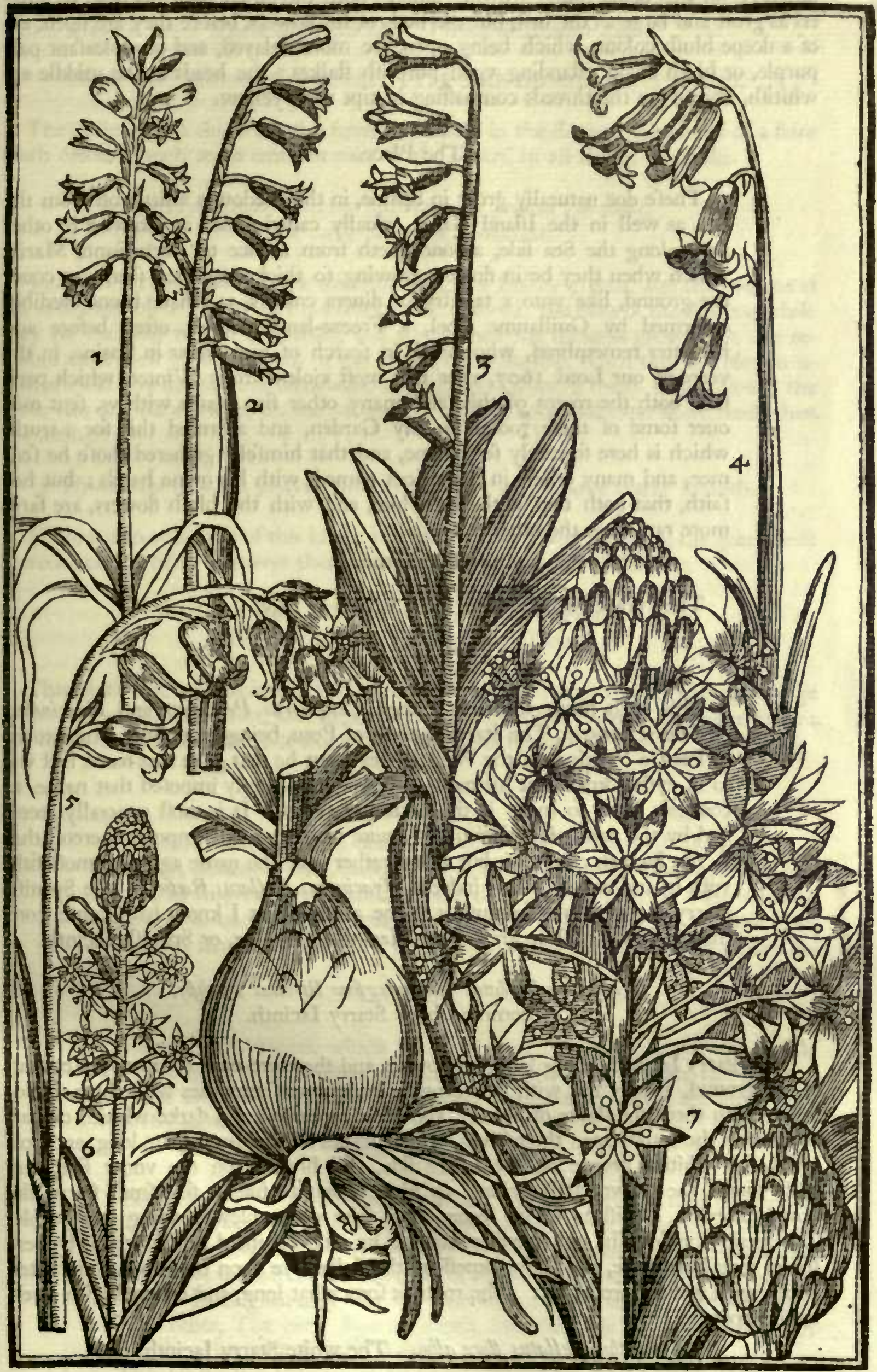

1 Hyacinthus Oricntalis facie. The little Summer Orientall Iacinth. 2 Hyasinthus Mauritanicns. The Barbary lacinth. 3 Hyacinthus obfoletus Hifpanieus. The Spanifh duskie lacinth. + Hyacinthus Ififparicus flore campanula. The greater Spanith bel-flowred Iacinth. SHyacinthus Anglicus. The Englin Iacinth or Harebels. 6 Hyacinthus Friophorus. The Woolly lacinth. 7 Hyacinthus Sicllaris Baticus major, fue Peruanus. The great Spanifh Starry lacinth, or of Pent 
flowers; for this being found growing among both the other, hath his head of flowers as great and large as the firft, but the buds of his flowers, before they are open, are of a deepe blufh colour, which being open, are more delayed, and of a pleafant pale purple, or blufh colour, ftanding vpon purplifh ftalkes: the heads in the middle are whitifh, and fo are the threeds compaffing it, tipt with yellow.

\section{The Place.}

Thefe doe naturally grow in Spaine, in the Medowes a little off from the Sea, as well in the Inland Gades, vfually called Cales, as likewife in other parts along the Sea fide, as one goeth from thence to Porto Santa Maria, which when they be in flower, growing fo thicke together, feeme to couer the ground, like vnto a tapiftry of diuers colours, as I haue beene credibly enformed by Guillaume Boel, a Freeze-lander borne, often before and hereafter remembred, who being in fearch of rare plants in Spaine, in the yeare of our Lord 1607 , after that moft violent frofty Winter, which perifhed both the rootes of this, and many other fine plants with vs, fent mee ouer fome of thefe rootes for my Garden, and affirmed this for a truth, which is here formerly fet downe, and that himfelfe gathered thofe he fent mee, and many others in the places named, with his owne hands; but hee faith, that both that with the white, and with the blufh flowers, are farre more rare then the other.

\section{The Time.}

They flower in May, the feede is ripe in Iuly.

The Names.

This hath beene formerly named Eriophorus Pernanus, and Hyacinthus Stellatus Peruamus, The Starry Iacinth of Peru, being thought to haue grown in Peru, a Prouince of the Weft Indies; but he that gaue that name firt vnto it, eyther knew not his naturall place, or willingly impofed that name, to conceale it, or to make it the better efteemed. It is moft generally receiued by the name Hyacinthus Peruanus, from the firft impofer thereof, that is, the Iacinth of Peru : but I had rather giue the name agreeing moft fitly vnto it, and call it as it is indeede Hyacinthus Stellatus Baticus, The Spanifh Starry Iacinth; and becaufe it is the greateft that I know hath come from thence, I call it, The great Starry Iacinth of Spaine, or Spanifh Iacinth.

\section{Hyacinthus Stellatus vulgaris, fiue Bifolius Fuch/fj.}

The common blew Starry Iacinth.

This Starry Iacinth (being longeft knowne, and therefore moft common) rifeth out of the ground, vfually but with two browne leaues, yet fometimes with three, inclofing within them the ftalke of flowers, the buds appearing of a darke whitifh colour, as foone as the leaues open themfelues, which leaues being growne, are long, and hollow, of a whitifh greene on the vpper fide, and browne on the vnder fide, and halfe round, the browne ftalke rifing vp higher, beareth fiue or fixe fmall ftarre-like flowers thereon, confifting of fix leaues, of a faire deepe blew, tending to a purple. The feede is yellowifh, and round, contained in round pointed heads, which by reafon of their heauineffe, and the weakneffe of the ftalke, lye vpon the ground, and often perifh with wet and frofts, \&cc. The roote is fomewhat long, and couered with a yellowilh coate.

\section{Hyacinthus fellatus flore albo. The white Starry Iacinth.}

The white Starry Iacinth hath his leaues like the former, but greene and frefh, not browne, and a little narrower alfo: the buddes for flowers at the firf appeare a little blufh, which when they are blowne, are white, but yet retaine in them a fmall thew of that bluih colour. 
We haue another, whofe flowers are pure white, and fmaller then the other, the Flore niueo. leaues whereof are of a pale frefh greene, and fomewhat narrower.

\section{Hyacinthus Stellatus fore rubente. The blufh coloured Starry Iacinth.}

The difference in this from the former, is onely in the flowers, which are of a faire blufh colour, much more eminent then in the others, in all things elfe alike.

\section{Hyacinthus Stellatus Martius, fiue pracox caruleus.}

The early blew Starry Iacinth.

This Iacinth hath his leaues a little broader, of a frefher greene, and not browne at all, as the firft blew Iacinth of Fuchfius laft remembred : the buds of the flowers, while they are enclofed within the leaues, and after, when the ftalke is growne vp, doe remaine more blew then the buds of the former: the flowers, when they are blowne open, are like the former, but fomewhat larger, and of a more liuely blew colour: the roote alfo is a little whiter on the outfide. This doth more feldome beare feede then the former.

\section{Hyacinthus Stellatus precox flore albo. The white early Starry Iacinth.}

There is alfo one other of this kinde, that beareth pure white flowers, the green leafe thereof being a little narrower then the former, and no other difference.

\section{Hyacinthus Stellatus pracox flore fuaue rubente. \\ The early blufh coloured Starry Iacinth.}

This blufh coloured Iacinth is very rare, but very pleafant, his flowers being as large as the firft of this laft kinde, and fomewhat larger then the blufh of the other kinde: the leaues and rootes differ not from the laft recited Iacinth.

\section{The Place.}

All thefe Iacinths have beene found in the Woods and Mountaines of Germany, Bohemia, and Auftria, as Fuchfius and Gefner doe report, and in Naples, as Imperatus and others doe teftifie. Wee cherifh them all with great care in our Gardens, but efpecially the white and the blufh of both kindes, for that they are more tender, and often perifh for want of due regard.

The Time.

The common kindes, which are firt expreffed, flower about the middle of February, if the weather bee milde, and the other kindes fometimes a fortnight after, that is, in March, but ordinarily much about the fame time with the former.

\section{The Names.}

The firft is called in Latine Hyacinthus Stellatus vulgaris, and Hyacinthus Stellatus bifolius, and Hyacinthus Stellaris Fuchfij, and of fome Hyacinthus Stellatus Germanicus; wee might very well call the other kinde, Hyacinthus Stellatus vulgaris alter, but diuers call it Pracox, and fome Martius, as it is in the title. In Englifh they may bee feuerally called: the firf, The common; and the other, The early Starry Iacinth (notwithstanding the firft flowreth before the other) for diftinction fake.

The Hyacinthus feemeth to be called Vacinium of Virgil in his Eclogues; for hee alwayes reckoneth it among the flowers that were vfed to decke Garlands, and neuer among fruits, as fome would haue it. But in that hee calleth it Vacinium nigrum, in feuerall places, that doth very fitly anfwer the 
common receiued cuftome of thofe times, that called all deepe blew colours, fuch as are purples, and the like, blacke; for the Violet it felfe is likewife called blacke in the fame place, where he calleth the Vacinium blacke; fo that it feemeth thereby, that he reckoned them to be both of one colour, and we know the colour of the Violet is not blacke, as we doe diftinguifh of blacke in thefe dayes. But the colour of this Starry Iacinth, being both of fo deepe a purple fometimes, fo neare vnto a Violet colour, and alfo more frequent, then any other Iacinth with them, in thofe places where Virgil liued, perfwadeth me to thinke, that Virgil vnderftood this Starry Iacinth by Vacinium: Let others iudge otherwife, if they can thew greater probabilitie.

\section{Hyacinthus Stellatus Byzantinus nigra radice.}

The Starry Iacinth of Turkie with the blacke roote.

This Starry Iacinth of Conftantinople hath three or foure frefh greene, thinne, and long leaues, of the bigneffe of the Englifh Iacinth, but not fo long, betweene which rifeth vp a flender lowe ftalke, bearing fiue or fix fmall flowers, difperfedly fet thereon, fpreading open like a ftarre, of a pale or bleake blew colour: the leaues of the flowers are fomewhat long, and ftand as it were fomewhat loofly, one off from another, and not fo compactly together, as the flowers of other kindes: it feldome beareth ripe feede with vs, becaufe the heads are fo heauie, that lying vpon the ground, they rotte with the wet, or are bitten with the frofts, or both, fo that they feldome come to good: the roote is fmall in fome, and reafonable bigge in others, round, and long, white within, but couered with deepe reddifh or purplifh peelings, next vnto it, and darker and blacker purple on the outfide, with fome long and thicke white fibres, like fingers hanging at the bottome of them, as is to be feene in many other Iacinths: the roote it felfe for the molt part doth runne downewards, fomewhat deep into the ground.

\section{Hyacinthus Stellatus Byzantinus maior.}

The greater Starry Iacinth of Conftantinople.

This Iacinth may rightly be referred to the former Iacinth of Conftantinople, and called the greater, it is fo like thereunto, that any one that knoweth that, will foone fay, that this is another of that fort, but greater as it is in all his parts, bearing larger leaues by much, and more ftore, lying vpon the ground round about the roote: it beareth many lowe ftalkes of flowers, as bleake, and ftanding as loofly as the former: onely the roote of this, is not black on the outfide, as the other, but three times bigger.

\section{Hyacinthus Stellatus Byzantinus alter, fute flore boraginis.}

The other Starry lacinth of Conftantinople.

This other Iacinth hath for the molt part onely foure leaves, broader and greener then the firlt, but not fo large or long as the fecond : the ftalke hath fiue or fix flowers vpon it, bigger and rounder fet, like other ftarry Iacinths, of a more perfect or deeper blew then either of the former, hauing a whitifh greene head or vmbone in the middle, befet with fix blew chiues or threeds, tipt with blacke, fo clofly compafing the vmbone, that the threeds feeme fo many prickes ftucke into a clubbe or head; fome therefore haue likened it to the flower of Borage, and fo haue called it: after the flowers are paft, come vp round white heads, wherein is contained round and white feede: the roote is of a darke whitifh colour on the outfide, and fometimes a little reddifh withall.

\section{The Place.}

The firft and the laft haue beene brought from Conftantinople; the firft among many other rootes, and the laft by the Lord Zouch, as Lobel witneffeth. The fecond hath been fent vs out of the Lowe-Countries, but from whence they had it, we do not certainly know. They growe with vs in our Gardens fufficiently. 
The Time.

Thefe flower in Aprill, but the firft is the earlieft of the reft, and is in flower prefently after the early Starry Iacinth, before defcribed.

\section{The Names.}

The former haue their names in their titles, and are not knowne vnto vs by any other names that I know; but as I faid before, the laft is called by fome, Hyacinthus Boraginis flore. The firft was fent out of Turkie, by the name of Sufamgiul, by which name likewife diuers other things haue beene fent, fo barren and barbarous is the Turkifh tongue.

\section{Hyacinthus Stellatus \&ffivus maior. The greater Summer Starry Iacinth.}

This late Iacinth hath diuers narrow greene leaues, lying vpon the ground, fomewhat like the leaues of the Englifh Iacinth, but ftiffer and ftronger; among which rifeth vp a round ftiffe ftalke, bearing many flowers at the toppe thereof, and at euery foote-ftalke of the flowers a fmall fhort leafe, of a purplifh colour: the flowers are ftarre-like, of a fine delayed purplifh colour, tending to a pale blew or afh colour, ftriped on the backe of euery leafe, and hauing a pointed vmbone in the middle, with fome whitifh purple threeds about it, tipt with blew : the feede is blacke, round, and fhining, like vnto the feede of the Englifh Iacinth, but not fo bigge: the roote is round and white, hauing fome long thicke rootes vnder it, befides the fibres, as is vfuall in many other Iacinths.

\section{Hyacinthus Stellatus Effivus minor. The leffer Summer Starry Iacinth.}

This leffer Iacinth hath diuers very long, narrow, and fhining greene leaues, fpread vpon the ground round about the roote, among which rifeth vp a very fhort round ftalke, not aboue two inches high, carrying fix or feuen fmall flowers thereon, on each fide of the ftalke, like both in forme and colour vnto the greater before defcribed, but leffer by farre: the feede is blacke, contained in three fquare heads: the roote is fmall and white, couered with a browne coate, and hauing fome fuch thicke rootes among the fibres, as are among the other.

\section{The Place.}

Both thefe Iacinths grow naturally in Portugall, and from thence haue been brought, by fuch as feeke out for rare plants, to make a gaine and profit by them.

The Time.

They both flower in May, and not before: and their feed is ripe in Iuly.

\section{The Names.}

Some doe call thefe Hyacinthus Lu fitanicus, The Portugall Iacinth. Clufius, who firft fet out the defcriptions of them, called them as is expreffed in their titles; and therefore we haue after the Latine name giuen their Englifh, according as is fet downe. Or if you pleafe, you may call them, The greater and the leffer Portugall Iacinth.

\section{Hyacinthus Stellaris flore cinereo. The afh coloured Starry Iacinth.}

This afh coloured Iacinth, hath his leaues very like vnto the leaues of the Englifh Iacinth, and fpreading vpon the ground in the fame manner, among which rife vp one or two ftalkes, fet at the toppe with a number of fmall ftarre-like flowers, bufhing big- 
ger below then aboue, of a very pale or white blew, tending to an afh colour, and very fweete in fmell: the feede is blacke and round, like vnto the feede of the Englin Iacinth, and fo is the roote, being great, round, and white; fo like, I fay, that it is hard to know the one from the other.

\section{The Place.}

The certaine originall place of growing thereof, is not knowne to vs.

\section{The Time.}

It flowreth in Aprill.

\section{The Names.}

Some doe call this Hyacinthus Someri, Somers Iacinth, becaufe as Lobel faith, he brought it firft into the Lowe-Countries, eyther from Conftantinople, or out of Italy.

\section{Hyacinthus Stellatus Lilifolio E radice caruleo.}

The blew Lilly leafed Starre Iacinth.

This Iacinth hath fix or feuen broad greene leaues, fomewhat like vnto Lilly leaues, but thorter (whereof it tooke his name as well as from the roote) Spread vpon the ground, and lying clofe and round: before the ftalke rifeth out from the middle of thefe leaues, there doth appeare a deepe hollow place, like a hole, to bee feene a good while, which at length is filled vp with the ftalke, rifing thence vnto a foote or more high, bearing many ftarre-like flowers at the toppe, of a perfect blew colour, neare vnto a Violet, and fometimes of paler or bleake blew colour, hauing as it were a fmall cuppe in the middle, diuided into fix peeces, without any threeds therein: the feede is blacke and round, but not thining: the roote is fomewhat long, bigge belowe, and fmall aboue, like vnto the fmall roote of a Lilly, and compofed of yellow fcales, as a Lilly, but the fcales are greater, and fewer in number.

\section{Hyacinthus Stellatus Lilifolius albus. The white Lilly leafed Starre Iacinth.}

The likeneffe of this Iacinth with the former, caufeth me to be briefe, and not to repeate the fame things againe, that haue already been expreffed: You may therefore vnderftand, that except in the colour of the flower, which in this is white, there is no difference betweene them.

Flore carmeo. I heare of one that fhould beare blufh coloured flowers, but I haue not yet feene any fuch.

\section{The Place.}

Thefe Iacinths haue been gathered on the Pyrenæan Hils, in that part of France that is called Aquitaine, and in fome other places.

\section{The Time.}

Thefe flower in Aprill, and fometimes later.

\section{The Names.}

Becaufe the roote is fo like vnto a Lilly, as the leafe is alfo, it hath moft properly beene called Hyacinthus Stellatus Lilifolio \& radice, or for breuity Lilifolius, that is, The Starry Lilly leafed Iacinth. It is called Sarahug by the Inhabitants where it groweth, as Clufius maketh the report from Venerius, who further faith, that by experience they haue found the cattell to fwell and dye, that haue eaten of the leaues thereof. 


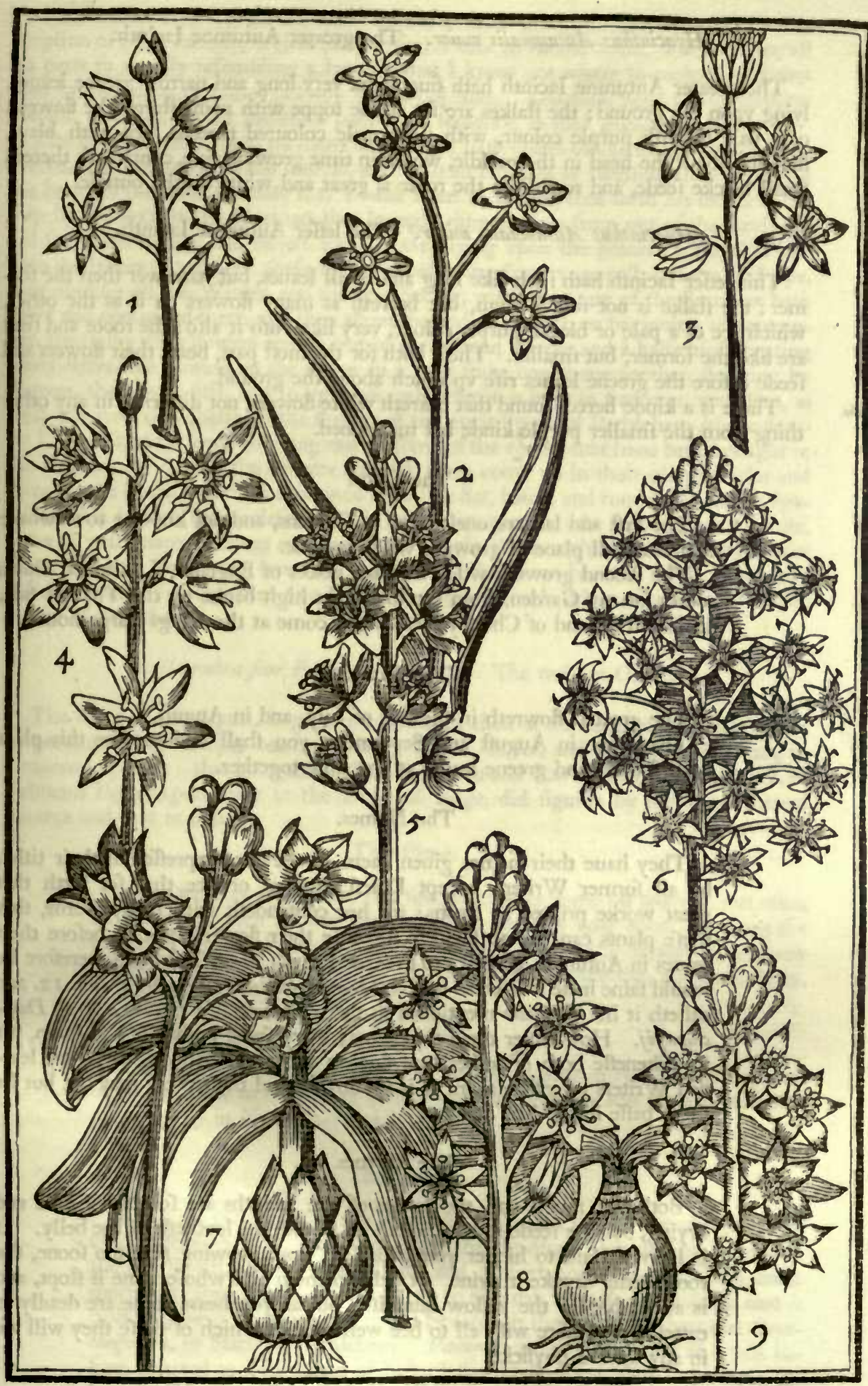

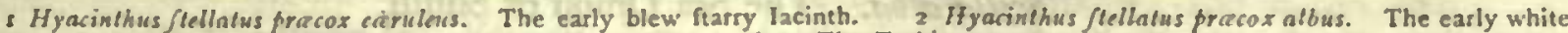

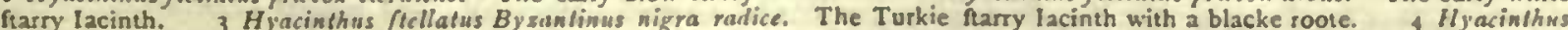
Byzartiuus aller fiue fore Boraginis. The other ftarry lacinth of Conftantinople. 5 Hyaciulhus aflious maior. The greater Summer ftarry Iacinth. 6 Hyacinthus flellalws fure cimerco. The an coloured Ram lacinth. 7 Hyaciuthus ficllatus Lilifolius. The Lilly leafed farre Iacinth. 8 Hyacinthus Aulumnalis. The Autumne Iacinth. 9 Scilla alba Jiue llyncinthus marinus.
The Sea Onion or Squill. 


\section{Hyacinthus Autumnalis maior. The greater Autumne Iacinth.}

The greater Autumne Iacinth hath fiue or fix very long and narrow greene leaues, lying vpon the ground; the ftalkes are fet at the toppe with many ftarre-like flowers, of a pale blewifh purple colour, with fome pale coloured threeds, tipt with blew, ftanding about the head in the middle, which in time growing ripe, containeth therein fmall blacke feede, and roundifh: the roote is great and white on the outfide.

\section{Hyacinthus Autumnalis minor. The leffer Autumne Iacinth.}

This leffer Iacinth hath fuch like long and fmall leaues, but narrower then the former : the ftalke is not full fo high, but beareth as many flowers on it as the other, which are of a pale or bleake purple colour, very like vnto it alfo: the roote and feed are like the former, but fmaller. Thefe both for the moft part, beare their flowers and feede before the greene leaues rife vp much aboue the ground.

There is a kinde hereof found that beareth white flowers, not differing in any other thing from the fmaller purple kinde laft mentioned.

\section{The Place.}

The firft and laft are onely kept in Gardens, and not knowne to vs where their naturall place of growing wilde may be.

The fecond groweth wilde in many places of England. I gathered diuers rootes for my Garden, from the foote of a high banke by the Thames fide, at the hither end of Chelfey, before you come at the Kings Barge-houfe.

\section{The Time.}

The greateft flowreth in the end of Iuly, and in Auguft.

The other in Auguft and September, you fhall feldome fee this plant with flowers and greene leaues at one time together.

The Names.

They haue their names giuen them; as they are expreffed in their titles, by all former Writers, except Dalefchampius, or hee that fet forth that great worke printed at Lyons; for hee contendeth with many words, that thefe plants can bee no Iacinths, becaufe their flowers appeare before their leaues in Autumne, contrary to the true Iacinth, as he faith : and therefore he would faine haue it referred to Theophrafun bulbus in libro primocap. I 2. and calleth it his Tiphyum mentioned in that place, as alfo Bulbus aftivus Dalechampij. Howfoeuer thefe things may carry fome probability in them, yet the likeneffe both of rootes, and flowers ef pecially, hath caufed very learned Writers to entitle them as is fet downe, and therefore I may not but let them paffe in the like manner.

\section{The Vertues.}

Both the rootes and the leaues of the Iacinths are fomewhat cold and drying, but the feede much more. It ftayeth the loof neffe of the belly. It is likewife faid to hinder young perfons from growing ripe too foone, the roote being drunke in wine. It helpeth them alfo whofe vrine is ftopt, and is auaileable for the yellow Iaundife; but as you heare fome are deadly to cattell, I therefore wifh all to bee well aduifed which of thefe they will vfe in any inward phyficke.

Scilla alba. The Sea Onion or Squill.

As I ended the difcourfe of both the true and the baftard Daffodils, with the Sea kindes 
kindes of both forts; fo I thinke it not amiffe, to finifh this of the Iacinths with the deicription of a Sea Iacinth, which (as you fee) I take to be the Scilla, or Sea Onion, all his parts fo nearely refembling a Iacinth, that I know not where to ranke him better then in this place, or rather not any where but here. You thall haue the defcription thereof, and then let the iudicious paffe their fentence, as they thinke meeteft.

The Squill or Sea Onion (as many doe call it) hath diuers thicke leaues, broad, long, greene, and hollowinh in the middle, and with an eminent or fwelling ribbe all along the backe of the leafe, (I relate it as I have feene it, hauing fhot forth his leaues in the thip by the way, as the Mariners that brought diuers rootes from out of the Straights, did fell them to mee and others for our vfe) lying vpon the ground, fomewhat like vnto the leaues of a Lilly: thefe fpring vp after the flowers are part, and the feed ripe, they abiding all the Winter, and the next Spring, vntill the heate of the Summer hath rpent and confumed them, and then about the end of Augurt, or beginning of Septemher, the ftalke with flowers arifeth out of the ground a foote and a halfe high, bearing many ftarre-like flowers on the toppe, in a long fpike one aboue another, flowring by degrees, the loweft firft, and fo vpwards, whereby it is long in flowring, very like, as well in forme as bigneffe, to the flowers of the great Starre of Bethlehem (thefe flowers I haue likewife feene fhooting out of fome of the rootes, that haue been brought in the like manner :) after the flowers are paft, there come vp in their places thicke and three fquare heads, wherin is contained fuch like flat, black, and round feed, as the Spanifh duskie Iacinth before defcribed did beare, but greater : the root is great $\&$ white, couered with many peelings or couerings, as is plainly enough feen to any that know them, and that fometimes wee haue had rootes, that haue beene as bigge as a pretty childes head, and fometimes two growing together, each whereof was no leffe then is faid of the other.

\section{Scilla rubra fuue Pancratium verum. The red Sea Onion.}

The roote of this Squill, is greater oftentimes then of the former, the outer coates or peelings being reddin, bearing greater, longer, ftiffer, and more hollow leaues, in a inanner vpright : this bringeth fuch a like ftalke and flowers, as the former doth, as Fabianus Ilges, Apothecary to the Duke of Briga, did fignifie by the figure thereof drawne and fent to Clufius.

The Place.

They grow alwayes neare the Sea, and neuer farre off from it, but often on the very baich of the Sea, where it watheth ouer them all along the coafts of Spaine, Portugal, and Italy, and within the Straights in many places : it will not abide in any Garden farre from the Sea, no not in Italy, as it is related.

\section{The Time.}

The time wherein they flower, is expreffed to be in Auguft and September : the feede to be ripe in October and Nouember, and the greene leaues to fpring vp in Nouember and December.

\section{The Names.}

Thefe are certainly the true kindes of Scilla that fhould bee vfed in medicines, although (as Clufius reporteth) the Spaniards forbade him to tafte of the red Squill, as of a moft ftrong and prefent poifon. Pliny hath made more forts then can be found out yet to this day with vs: that Scilla that is called Epimenidia, becaufe it might be eaten, is thought to be the great Ornithogalum, or Starre of Bethlehem. Pancratium is, I know, and as I faid before, referred to that kinde of baftard Sea Daffodill, which is fet forth before in the end of the hiftory of the baftard Daffodils; and diuers alfo would make the Narciffus tertius Matthioli, which I call the true Sea Daffodill, to be a Pancratiun; but feeing Diofcorides (and no other is againft him) 
maketh Pancratium to be a kinde of Squill with reddifh rootes, I dare not vphold their opinion againft fuch manifeft truth.

\section{The Vertues.}

The Squill or Sea Onion is wholly vfed phyfically with vs, becaufe wee can receiue no pleafure from the fight of the flowers. Pliny writeth, that Pithagoras wrote a volume or booke of the properties thereof, for the fingular effects it wrought; which booke is loft, yet the diuers vertues it hath is recorded by others, to be effectual for the fpleene, lungs, ftomach, liuer, head and heart ; and for dropfies, old coughs, Iaundife, and the wormes; that it cleareth the fight, helpeth the tooth-ache; cleanfeth the head of fcurfe, and running fores; and is an efpeciall Antidote againft poifon : and therefore is vfed as a principall ingredient into the Theriaca Andromachi, which we vfually call Venice Treakle. The Apothecaries prepare hereof, both Wine, Vinegar, and Oxymel or Syrupe, which is fingular to extenuate and expectorate tough flegme, which is the cause of much disquiet in the body, and an hinderer of concoction, or digeftion in the ftomach, befides diuers other wayes, wherein the fcales of the rootes, being dryed, are vfed. And Galen hath fufficiently explained the qualities and properties thereof, in his eight Booke of Simples.

\section{Cн A P. XII.}

\section{Ornithogalum. Starre of Bethlehem.}

A Fter the Family of the Iacinths, muft needes follow the kindes of Starre-flowers, or Starres of Bethlehem, as they are called, for that they doe fo nearely refemble them, that diuers haue named fome of them Iacinths, and referred them to that kindred : all of them, both in roote, leafe, and flower, come nearer vnto the Iacinths, then vnto any other plant. They thall therefore bee next defcribed, euery one in their order, the greateft firft, and the reft following.

\section{Ornithogalum Arabicum. The great Starre-flower of Arabia.}

'This Arabian Starre-flower hath many broad, and long greene leaues, very like vnto the leaues of the Orientall Iacinth, but lying for the moft part vpon the ground, among which rifeth vp a round greene ftalke, almoft two foote high, bearing at the toppe diuers large flowers, ftanding vpon long foote-ftalkes, and at the bottome of euery one of them a fmall thort pointed greene leafe : thefe flowers are made of fix pure white leaues a peece, laid open as large as an ordinary Daffodill, but of the forme of a Starre Iacinth, or Starre of Bethlehem, which clofe as they doe euery night, and open themfelues in the day time, efpecially in the Sunne, the fmell whereof is pretty fweete, but weake : in the middle of the flower is a blackifh head, compofed with fix white threeds, tipt with yellow pendents : the feede hath not beene obferued with vs: the roote is great and white, with a flat bottome, very impatient of our cold Winters, fo that it feldome profpereth or abideth with vs; for although fometimes it doe abide a Winter in the ground, yet it often lyeth without fpringing blade, or any thing elfe a whole yeare, and then perifheth : or if it doe fpring, yet many doe not beare, and moft after their firft bearing doe decay and perifh. But if any be defirous, to know how to preferue the roote of this plant, or of many other bulbous rootes that are tender, fuch as the great double white Daffodill of Conftantinople, and other fine Daffodils, that come from hot Countries; let them keepe this rule : Let either the roote be planted in a large pot, or tubbe of earth, and houfed all the Winter, that fo it may bee defended from the frofts; Or elfe (which is the eafier way) keepe the roote out of the ground euery yeare, from September, after the leaues and ftalkes are paft, vntill February, in 
fome dry, but not hot or windy place, and then plant it in the ground vnder a South wall, or fuch like defended place, which will fpring, and no doubt profper well there, in regard the greatelt and deepeft frofts are paft after February, fo that feldome any great frofts come after, to pierce fo deepe as the roote is to be fet, or thereby to doe any great harme to it in fuch a place.

\section{The Place.}

This hath been often fent out of Turkie, and likewife out of Italy; I had likewife two rootes fent mee out of Spaine by Guillaume Boel before remembred, which (as hee faid) hee gathered there, but they profpered not with me, for want of the knowledge of the former rule. It may be likely that Arabia is the place, from whence they of Conftantinople receiue it.

\section{The Time.}

It flowreth in May, if it be of the firft yeares bringing; or in Iune, if it haue been ordered after the manner before fet downe.

\section{The Names.}

It hath been fent out of Italy by the name of Lilium Alexandrinum, The Lilly of Alexandria, but it hath no affinity with any Lilly. Others call it Hyacinthus Arabicus; and the Italians, Iacintho del pater nofiro: but it is no Iacinth neither, although the flowers be like fome of them. Some alfo would referre it to a Narciffus or Daffodill, and it doth as little agree with it, as with a Lilly, although his flowers in largeneffe and whiteneffe refemble a Daffodill. Clufius hath moft fitly referred it to the ftocke or kindred of Ornithogala, or Starres of Bethlehem, as wee call them in Englifh, and from the Turkifh name, Zumbul Arabi, entituled it Ornithogalum Arabicum, although Zumbul, as I haue before declared, is with them, a Iacinth, wee may call it in Englifh, The Arabian Starre-flower, or Starre of Bethlehem, or the great Starre-flower of Arabia.

\section{Ornithogahum maximum album.}

The greateft white Starre-flower, or Starre of Bethlehem.

This great Starre-flower hath many faire, broad, long, and very frefh green leaues, rifing vp very early, and are greater, longer, and greener then the leaues of any Orientall Iacinth, which doe abide greene, from the beginning or middle of Ianuary, or before fometimes, vntill the end of May, at which time they begin to fade, and the ftalke with the head of flowers beginneth to rife, fo that it will haue either few or no leaues at all, when the flowers are blowne: the ftalke is ftrong, round, and firme, rifing two foote high or more, bearing at the toppe a great bufh of flowers, feeming at the firt to be a great greene eare of corne, for it is made fpike-fafhion, which when the flowers are blowne, doth rife to be very high, flender or fmall at the head aboue, and broad fpread and bufhing below, fo that it is long in flowring; for they flower below firft, and fo vpwards by degrees: thefe flowers are fnow white, without any line on the backfide, and is therein like vnto the former, as alfo in whiteneffe, but nothing fo large, with a white vmbone or head in the middle, befet with many white threeds, tipt with yellow: the feede is blacke and round, contained in three fquare heads: the roote is great, thicke, and fhort, and fomewhat yellowith on the outfide, with a flat bottome, both like the former, and next that followeth.

2. Ornithogalum maius Spicatum album.

The great white fpiked Starre-flower.

This fpiked Starre-flower in his growing, is fomewhat like vnto the laft defcribed, 
but fpringeth not vp fo early, nor hath his leaues fo greene, or large, but hath broad, long, whitifh greene hollow leaues, pointed at the end, among which rifeth vp the ftalke, which is ftrong and high, as the former, hauing a great burh of flowers at the toppe, ftanding fpike-falhion, fomewhat like the former, flowring in the fame maner by degrees, firft below, and fo vpwards; but it is not fo thicke fet with flowers, nor fo farre fpread at the bottome as it, the flowers alfo are not fo white, and each of the leaues of them haue a greene line downe the backe, leauing the edges on both fides white: after the flowers are paft, the heads for feede grow three fquare, like the other, bearing fuch like blacke feede therein : the roote hereof is vfually bigger then the laft, and whiter on the outfide.

\section{Ormithogalum Pamonicum. The Hungarian Starre-flower.}

This Hungarian Starre-flower thooteth out diuers narrow, long, whitifh greene leaues, fpread vpon the ground before Winter, which are very like vnto the leaues of Gilloflowers, and fo abide aboue the ground, hauing a ftalke rifing in the middle of them the next Spring, about halfe a foote high or thereabouts, bearing many white flowers at the toppe, with greene lines downe the backe of them, very like vnto the ordinary Starres of Bethlehem: the roote is greater, thicker, and longer then the ordinary Starres, and for the moft part, two ioyned together, fomewhat grayifh on the outfide.

\section{Ornithogalum vulgare. The Starre of Bethlehem.}

The ordinary Starre of Bethlehem is fo common, and well knowne in all countries and places, that it is almoft needleffe to defcribe it, hauing many greene leaues with white lines therein, and a few white flowers fet about the toppe of the ftalke, with greenifh lines downe the backe: the roote is whitifh, and encreafeth aboundantly.

\section{Afphodelus bulbofus Galeni, fiue Ornithogalum maius flore fubuirefcente.}

The bulbous Afphodill, or greene Starre-flower.

Diuers haue referred this plant vnto the Afphodils, becaure (as I thinke) the flowers hereof are ftraked on the backe, and the leaues long and narrow, like vnto the Afphodils; but the roote of this being bulbous, I rather (as fome others doe) ioyne it with the Ornithogala, for they alfo haue ftrakes on the backe of the flowers. It hath many whitifh greene leaues, long and narrow, fpread vpon the ground, which fpring vp in the beginning of the yeare, and abide vntill May, and then they withering, the ftalke fpringeth vp almoft as high as the firft, hauing many pale yellowifh greene flowers, but fmaller, and growing more fparfedly about the ftalke vpon fhort foot-ftalkes, but in a reafonable long head fpike-fafhion: the feede is like vnto the fecond kinde, but fmaller: the roote is fomewhat yellowifh, like the firft great white kinde.

\section{The Place.}

The firft is onely nurfed in Gardens, his originall being not well knowne, yet fome attribute it vnto Pannonia or Hungary. The fecond hath been found neare vnto Barcinone, and Toledo in Spaine. The third was found in Hungary by Clufius. Our ordinary euery where in the fields of Italy and France, and (as it is faid) in England alfo. And the laft groweth likewife by the corne fields in the vpper Hungary.

\section{The Time.}

They flower in Aprill and May, and fometimes in Iune.

\section{The Names.}

The firft is called by Clufius Ornithogalum maximum album, becaufe it is 


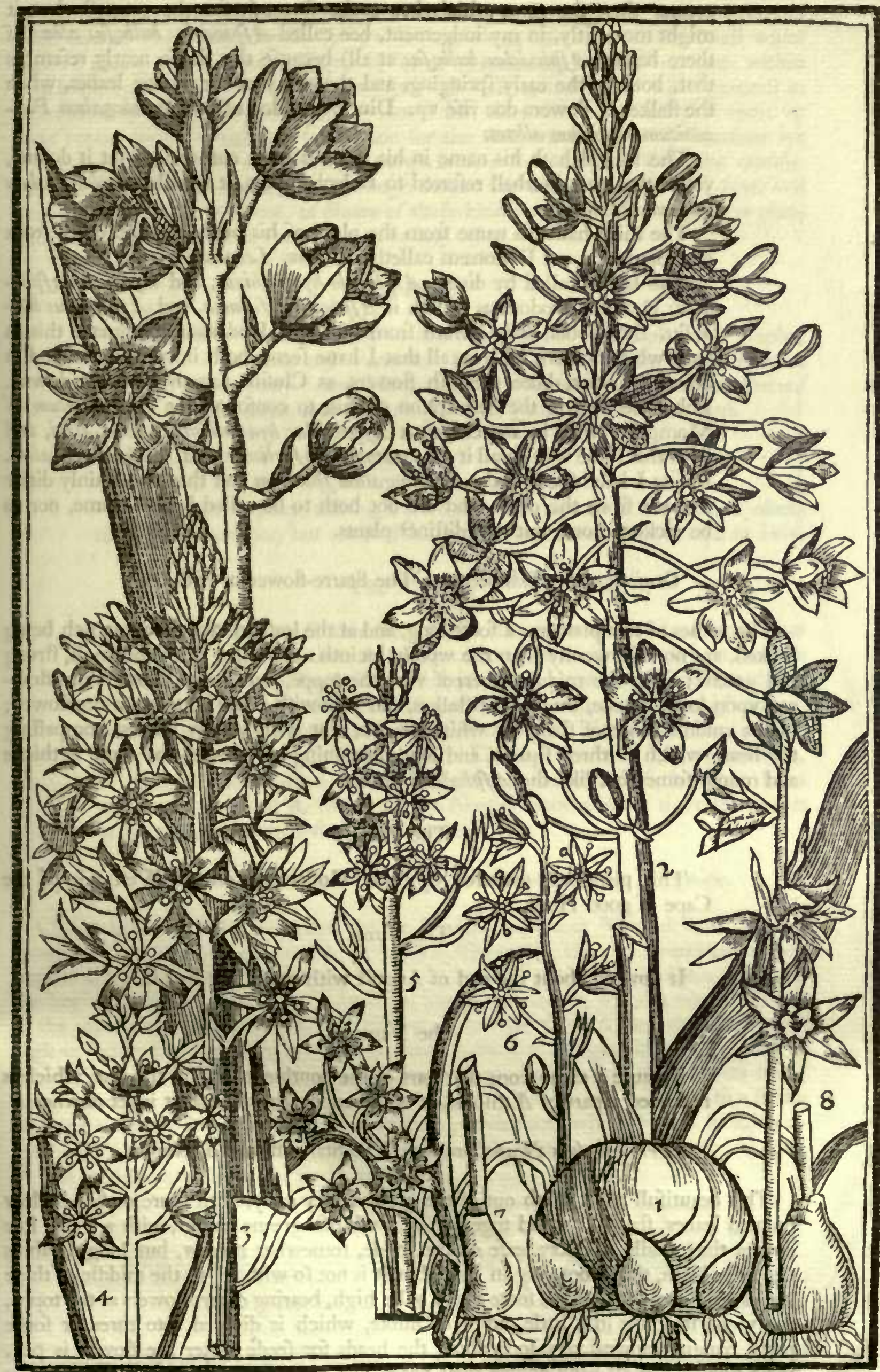

1. Ornithogalum Arabicum. The great fearre-flower of Arabia. 2 Ornithogalum maximum album. The greateft white starre-lower. 3 Orwithogalum maius fpicatum albwm. The great white fpiked ftarre-flower. 4 Orrithogalum Pannonicum album. The Hungarian ftarre-flower. 5 Afphoddus bulbofus Galevi, fwe Ornithogalum maims fubuirefcente fore. The bulbed Afphodill, or greene ftarre-fower. 6 Ormithogalum Hifpanicum minus. The little Sarre-flower of Spaine. 7 Ornilhogalum Iutcum. The yellow ftarre-flower of Bethlehem. \& Omithogalum Nickplifanum. The ftarre-flower of Naples. 
greater then the next, which hee tooke formerly for the greateft: but it might more fitly, in my iudgement, bee called ASphodelus bulbofus albus (if there be any $A$ Sphodelus bulbofus at all) becaufe this do fo nearly refemble that, both in the early fpringing, and the decay of the greene leaues, when the ftalkes of flowers doe rife vp. Diuers alfo doe call it Ornithogalum Pannonicum maximum album.

The fecond hath his name in his title, as moft authors doe fet it downe, yet in the great Herball referred to Dalechampius, it is called Ornithogalum magnum Myconi.

The third hath his name from the place of his birth, and the other from his popularity, yet Dodonæus calleth it Bulbus Leucanthemos.

The laft is called by diuers A.Sphodelo-hyacinthinus, and Hyacintho-asphodelus Galeni. Dodonæus calleth it ASphodelus famina, and ASphodelus bulbofus. But Lobel, and Gerrard from him, and Dodonæus, doe make this to haue white flowers, whereas all that I haue feene, both in mine owne, and in others Gardens, bore greenifh flowers, as Clufius fetteth it truely downe. Lobel feemeth in the defcription of this, to confound the Ornithogalum of Mompelier with it, and calleth it ASphodelus hyacinthinus forte Galeni, and faith that fome would call it Pancratium Monspelien fe, and AJphodelus Galeni. But as I haue (hewed, the Ornithogalum Spicatum and this, doe plainly differ the one from the other, and are not both to be called by one name, nor to be reckoned one, but two diftinct plants.

\section{Ornithogalum Ethiopicum. The Starre-flower of Æthiopia.}

The leaues of this plant are a foote long, and at the leaft an inch broad, which being broken, are no leffe woolly then the woolly Iacinth: the ftalke is a cubit high, ftrong and greene; from the middle whereof vnto the toppe, ftand large fnow white flowers, vpon long, greene, thicke foot-ftalkes, and yellowilh at the bottome of the flower; in the middle whereof ftand fix white threeds, tipt with yellow chiues, compaffing the head, which is three fquare, and long containing the feede: the roote is thicke and round, fomewhat like the $A \int p$ hodelus Galeni.

The Place.

This plant was gathered by fome Hollanders, on the Weft fide of the Cape of good Hope.

The Time.

It flowred about the end of Augult with thofe that had it.

The Names.

Becaufe it came from that part of the continent beyond the line, which is reckoned a part of Æthiopia, it is thereupon fo called as it is fet downe.

\section{Ornithogalum Neapolitanum. The Starre-flower of Naples.}

This beautifull plant rifeth out of the ground very early, with foure or fiue hollow pointed leaues, ftanding round together, of a whitifh greene colour, with a white line downe the middle of euery leafe on the infide, fomewhat narrow, but long, (Fabius Columna faith, three foot long in Italy, but it is not (o with vs) in the middle of thefe leaues rifeth vp the ftalke, a foote and a halfe high, bearing diuers flowers at the toppe, euery one ftanding in a little cuppe or huske, which is diuided into three or foure parts, hanging downe very long about the heads for feede: after the flower is paft, thefe flowers doe all hang downe their heads, and open one way, although their little foot-ftalkes come forth on all fides of the greater ftalke, being large, and compofed of fix long leaues, of a pure white on the infide, and of a blewifh or whitifh greene colour 
on the outfide, leauing the edges of euery leafe white on both fides: in the middle of thefe flowers ftand other fmall flowers, each of them alfo made of fix fmall white leaues a peece, which meeting together, feeme to make the fhew of a cuppe, within which are contained fix white threeds, tipt with yellow, and a long white pointell in the middle of them, being without any fent at all: after the flowers are paft, come vp great round heads, which are too heauie for the ftalke to beare; and therefore lye downe vpon the leaues or ground, hauing certaine lines or ftripes on the outfide, wherein is contained round, blacke, rough feede: the roote is great and white, and fomewhat flat at the bottome, as diuers of thefe kindes are, and doe multiply as plentifully into fmall bulbes as the common or any other.

The Place.

This Starre-flower groweth in the Medowes in diuers places of Naples, as Fabius Columna, and Ferrantes Imperatus doe teftifie, from whence they haue been fent. And Matthiolus, who fetteth out the figure thereof among his Daffodills, had (it fhould feeme) feene it grow with him.

The Time.

It flowreth in May, although it begin to fpring out of the ground oftentimes in Nouember, but moft vfually in Ianuary: the feede is ripe in Iuly.

The Names.

Matthiolus reckoneth this (as is faid) among the Daffodils, for no other refpect, as I conceiue, then that he accounted the middle flower to bee the cuppe or trunke of a Daffodill, which it doth fomewhat refemble, and fetteth it forth in the fourth place, whereupon many doe call it Narcifus quartus Matthioli, The fourth Daffodill of Matthiolus. Fabius Columna calleth it Hyacinthus aruorum Ornithogali flore. Clufius (to whom Imperatus fent it, in ftead of the Arabian which hee defired) calleth it of the place from whence he receiued it, Ornithogalum Neapolitanum, and we thereafter call it in Englifh, The Starre-flower of Naples.

Ornithogalum Hifpanicum minus. The little Starre-flower of Spaine.

Clufius hath fet forth this plant among his Ornithogala or Starre-flowers, and although it doth in my minde come nearer to a Hyacinthus, then to Ornithogalum, yet pardon it, and let it paffe as he doth. From a little round whitifh roote, fpringeth vp in the beginning of the yeare, fiue or fix fmall long green leaues, without any white line in the middle of them, among which rife vp one or two fmall ftalkes, an hand length high or better, bearing feuen or eight, or more flowers, growing as it were in a tuft or vmbell, with fmall long leaues at the foote of euery ftalke, the lower flowers being equall in length with the vppermoft, of a pale whitifh blew or afh colour, with a ftrake or line downe the backe of euery leafe of them, with fome white threeds ftanding about a blewifh head in the middle: thefe flowers paffe away quickly, and giue no feed, fo that it is not knowne what feede it beareth.

The Place.

This groweth in Spaine, and from thence hath been brought to vs.

The Time.

It flowreth in May.

The Names.

It hath no other name then is fet down in the title, being but lately found out.

I. Orni- 
I. Ornithogalum album vnifolium. The white ftarre-flower with one blade.

This little ftarre-flower I bring into this place, as the fitteft in my opinion where to place it, vntill my minde change to alter it. It hath a very fmall round white roote, from whence fpringeth vp one very long and round greene leafe, like vnto a rufh, but that for about two or three inches aboue the ground, it is a little flat, and from thence fpringeth forth a fmall ftalke not aboue three or foure inches high, bearing at the top thereof three or foure fmall white flowers, confifting of fix leaues a peece, within which are fix white chiues, tipt with yellow pendents, ftanding about a fmall three fquare head, that hath a white pointell fticking as it were in the middle thereof: the flower is pretty and fweete, but not heady.

\section{Ornithogalum luteum. The yellow Starre of Bethlehem.}

This yellow Starre-flower rifeth vp at the firft, with one long, round, greenifh leafe, which openeth it felfe fomewhat aboue the ground, and giueth out another fmall leafe, leffer and thorter then the firt, and afterward the ftalke rifeth from thence alfo, being foure or fiue inches high, bearing at the toppe three or foure fmall green leaues, and among them foure or fiue fmall yellow ftarre-like flowers, with a greenifh line or ftreake downe the backe of euery leafe, and fome fmall reddifh yellow threeds in the middle: it feldome giueth feede: the roote is round, whitifh, and fomewhat cleare, very apt to perifh, if it bee any little while kept dry out of the ground, as I haue twice tryed to my loffe.

\section{The Place.}

The firt grew in Portugall, and Clufius firt of all others defciphers it.

The other is found in many places both of Germany and Hungary, in the moifter grounds.

\section{The Time.}

The firt flowreth in May: the other in Aprill, and fometimes in March.

\section{The Names.}

Carolus Clufius calleth the firt Bulbus vnifolins, or Bolbine, but referreth it not to the ftocke or kindred of any plant; but (as you fee) I haue ranked it with the fmall forts of Ornithogalum, and give it the name accordingly.

The other is referred for likeneffe of forme, and not for colour, vnto the Ornithogala, or Starres of Bethlehem. It is called by Tragus and Fuchfius Bulbus filueftris, becaufe of the obuioufneffe. Cordus taketh it to be Si/yrinchium. Lacuna calleth it Bulbus efculentus. Lobel and others in thefe dayes generally, Ornithogalum luteum, and wee thereafter in Englifh, The yellow Starre-flower, or Starre of Bethlehem.

\section{The Vertues.}

The firt kinde being but lately found out, is not knowne to be vfed. The rootes of the common or vulgar, are (as Matthiolus faith) much eaten by poore people in Italy, either rawe or roafted, being fweeter in tafte then any Cheftnut, and feruing as well for a neceffary food as for delight. It is doubtfull whether any of the reft may be fo vfed; for I know not any in our Land hath made any experience.

There are many other forts of Starre-flowers, which are fitter for a generall then this Hiftory; and therefore I referre them thereunto. 


\section{CH А P. XIII.}

\section{Moly. Wilde Garlicke.}

$\mathrm{V}$

Nto the former Starre-flowers, muft needes bee ioyned another tribe or kindred, which carry their ftraked flowers Starre-fafhion, not fpikewife, but in a tuft or vmbell thicke thruft or fet together. And although diuers of them finell not as the former, but moft of their firft Grandfathers houfe, yet all doe not fo ; for fome of them are of an excellent fent. Of the whole Family, there are a great many which I muft leaue, I will onely felect out a few for this our Garden, whole flowers for their beauty of ftatelineffe, forme, or colour, are fit to bee entertained, and take place therein, euery one according to his worth, and are accepted of with the louers of thefe delights.

\section{Moly Homericum, vel potius Theophrafit.}

The greateft Moly of Homer.

Homers Moly (for fo it is moft vfually called with vs) rifeth vp moft commonly with two, and fometimes with three great, thicke, long, and hollow guttered leaues, of a whitifh greene colour, very neare the colour of the Tulipa leafe, hauing fometimes at the end of fome of the leaues, and fometimes apart by it felfe, a whitin round finall button, like vnto a fmall bulbe, the like whereof alfo, but greater, doth grow betweene the bottome of the leaues and the ftalke neare the ground, which being planted when it is ripe, will grow into a roote of the fame kinde: among thefe leaues rifeth vp a round, ftrong, and tall ftalke, a yard high or better, bare or naked vnto the toppe, where it beareth a great tuft or vmbell of pale purplifh flowers, all of them almoft ftanding vpon equall foot-ftalkes, or not one much higher then another, confifting of fiue leaues a peece, ftriped downe the backe with a fmall pale line, hauing a round head or vmbone with fome threeds about it in the midft: Thefe flowers doe abide a great while blowne before they vade, which fmell not very ftrong, like any Onion or Garlicke, but of a faint fmell : and after they are paft come the feede, which is blacke, wrapped in white clore huskes: the roote groweth very great, fometimes bigger then any mans clofed fift, fmelling ftrong like Garlicke, whitifh on the outfide, and greene at the toppe, if it be but a while bare from the earth about it.

\section{Moly Indicum fiue Caucafon. The Indian Moly.}

The Indian Moly hath fuch like thicke large leaues, as the Homers Moly hath, but fhorter and broader, in the middle whereof rifeth vp a fhort weake ftalke, almoft flat, not hauing any flowers vpon it, but a head or clufter of greenifh fcaly bulbes, inclofed at the firft in a large thinne skinne, which being open, euery bulbe flieweth it felfe, ftanding clofe one vnto another vpon his foot-ftalke, of the bigneffe of an Acorne, which being planted, will grow to bee a plant of his owne kinde: the roote is white and great, couered with a darke coate or skinne, which encreafeth but little vnder ground; but befides that head, it beareth fmall bulbes aboue the ground, at the bottome of the leaues next vnto the ftalke, like vnto the former.

\section{The Place.}

Both thefe doe grow in diuers places of Spaine, Italy, and Greece; for the laft hath been fent out of Turkie among other rootes. Ferrantes Inperatus a learned Apothecary of Naples, fent it to diuers of his friends in thefe parts, and hath defcribed it in his naturall hiftory among other plants, printed in the Italian tongue. It grew alfo with Iohn Tradefcante at Canterbury, who fent me the head of bulbes to fee, and afterwards a roote, to plant it in my Garden. 


\section{The Time.}

The firft flowreth in the end of May, and abideth vnto the midft of Iuly, and fometimes longer. The other beareth his head of bulbes in Iune and Iuly.

\section{The Names.}

We haue receiued them by their names expreffed in their titles, yet the laft hath alfo been fent by the name of Ormithogalum Italicum, but as all may eafily fee, it is not of that kindred.

\section{Moly montamum Pannonicum bulbiferum primum.}

The firt bulbed Moly of Hungary.

This firft Hungarian Moly hath three or foure broad and long greene leaues, folded together at the firft, which after open themfelues, and are carried vp with the ftalke, ftanding thereon one aboue another, which is a foote high; at the toppe whereof doe grow a few fad reddifh bulbes, and betweene them long footitalkes, bearing flowers of a pale purplifh colour; after which followeth blacke feede, inclofed in roundifh heads: the roote is not great, but white on the outfide, very like vnto the roote of Serpents Moly, hereafter defcribed, encreafing much vnder ground, \& fmelling ftrong.

\section{Moly montanum Pannonicum bulbiferum fecundum.}

The fecond bulbed Moly of Hungary.

The fecond Moly hath narrower greene leaues then the former: the ftalke is about the fame height, and beareth at the toppe a great clufter of fmall greene bulbes, which after turne of a darker colour; from among which come forth long foot-ftalks, whereon ftand purplifh flowers: the roote is couered with a blackifh purple coate or skinne.

\section{Moly Serpentinum. Serpents Moly.}

This Moly muft alfo be ioyned vnto the bulbous Molyes, as of kindred with them, yet of greater beauty and delight, becaufe the bulbes on the heads of the fmall ftalkes are redder, and more pleafant to behold: the ftalke is lower, and his graflie winding leaues, which turne themfelues (whereof it tooke the name) are fmaller, and of a whiter greene colour: it beareth among the bulbes purplifh flowers alfo, but more beautifull, the fent whereof is nothing fo ftrong: the roote is fmall, round, and whitifh, encreafing into a number of fmall rootes, no bigger then peafe round about the greater roote.

\section{Moly caule \& folijs triangularibus. The three cornered Moly.}

This three fquare Moly hath foure or fiue long, and fomewhat broad pale greene leaues, flat on the vpper fide, and with a ridge downe the backe of the leafe, which maketh it feeme three fquare: the ftalke which rifeth vp a foote and a halfe high or better, is three fquare or three cornered alfo, bearing at the toppe out of a skinnie huske diuers white flowers, fomewhat large and long, almoft bell-fafhion, with ftripes of greene downe the middle of euery leafe, and a few chiues tipt with yellow in the middle about the head, wherein when it is ripe, is inclofed fmall blacke feede: the roote is white on the outfide, and very like the yellow Moly; both roote, leafe, and flower hath a fmacke, but not very ftrong of Garlicke.

\section{Moly Narcifsinis folijs. Daffodill leafed Moly.}

This Moly hath many long, narrow, and flat greené leaues, very like vnto the leaues of a Daffodill, from whence it tooke his name (or rather of the early greater Leucoium 


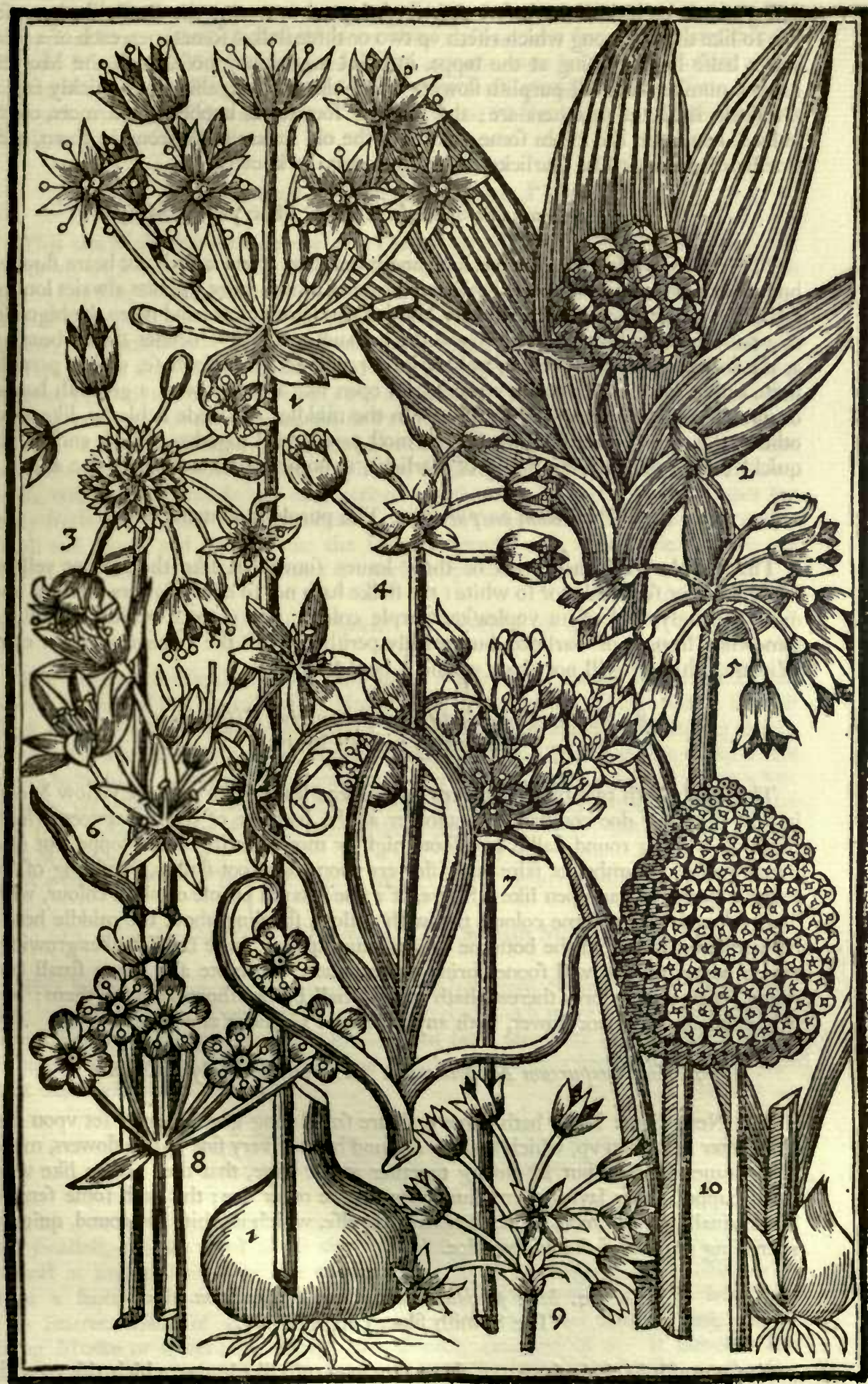

1. Moly Homericum ad polius Throphrafti. The greater Moly of Homer. 2 Moly Indicum fur Caucafon. The Indian Moly. 3 Moly Pannonicum bubiforum. The bulbed Moly of Hungary. 4 Moly Serpentimum. Serpents Moly. 5 Moly furpureum folium fore lutro. The yellow Moly. 8 Moly Diofcorideum Hifpanicum. The Spanifh Moly of Diofcorides. 9 Moly Zibeltinum vel Mofchatinum. The fweete fmelling Moly of Mompelier. to Moly ferolinum Coniforum. The late Pine apple Moly. 
bulbo fum, or bulbed Violet before defcribed, ioyned next vnto the Daffodils, becaufe it is fo like them) among which rifeth vp two or three ftalkes fometimes, each of a foot and a halfe high, bearing at the toppe, inclofed in a skinny hofe, as all the Molyes haue, a number of fmall purplifh flowers, which doe not long abide, but quickly fade: the feede is blacke as others are; the roote is fometimes knobbed, and more often bulbed, hauing in the knobs fome markes of the old ftalkes to be feene in them, and fmelleth fomewhat like Garlicke, whereby it may be knowne.

\section{Moly montanum latifolium luteo flore. The yellow Moly.}

The yellow Moly hath but one long and broad leafe when it doth not beare flower, but when it will beare flower, it hath two long and broad leaues, yet one alwaies longer and broader then the other, which are both of the fame colour, and neare the bigneffe of a reafonable Tulipa leafe: betweene thefe leaues groweth a flender ftalke, bearing at the toppe a tuft or vmbell of yellow flowers out of a skinnie hofe, which parteth three wayes, made of fix leaues a peece, laid open like a Starre, with a greenifh backe or outfide, and with fome yellow threeds in the middle: the feede is blacke, like vnto others: the roote is whitifh, two for the moft part ioyned together, which encreafeth quickly, and fmelleth very ftrong of Garlicke, as both flowers and leaues doe alfo.

\section{Moly Pyrenaum purpureum. The purple mountaine Moly.}

This purple Moly hath two or three leaues, fomewhat like the former yellow Moly, but not fo broad, nor fo white: the ftalke hath not fo many flowers thereon, but more fparingly, and of an vnpleafant purple colour: the roote is whitifh, fmelling fomewhat ftrongly of Garlicke, but quickly perifheth with the extremity of our cold Winters, which it will not abide vnleffe it be defended.

\section{Moly montamum latifolium purpureum Hifpanicum.}

The purple Spanifh Moly.

This Moly hath two broad and very long greene leaues, like vnto the yellow Moly, in this, that they doe compaffe one another at the bottome of them, between which rifeth vp a ftrong round ftalke, two foote high or more, bearing at the toppe, out of a thinne huske, a number of faire large flowers vpon long foot-ftalkes, confifting of fix leaues a peece, fpread open like a Starre, of a fine delayed purple or blufh colour, with diuers threeds of the fame colour, tipt with yellow, ftanding about the middle head: betweene the ftalke and the bottome of the leaues it hath fome fmall bulbes growing, which being planted, will foone fpring and encreafe: the roote alfo being fmall and round, with many fibres thereat, hath many fmall bulbes fhooting from them; but neither roote, leafe, nor flower, hath any ill fent of Garlicke at all.

\section{Moly purpureum Neapolitanum. The purple Moly of Naples.}

The Neapolitane Moly hath three or foure fmall long greene leaues fet vpon the ftalke after it is rifen vp, which beareth a round head of very fine purple flowers, made of fix leaues a peece, but fo clofing together at the edge, that they feeme like vnto fmall cuppes, neuer laying themfelues open, as the other doe; this hath fome fent of his originall, but the roote more then any part elfe, which is white and round, quickly encreafing as moft of the Molyes doe.

\section{I0. Moly pyxidatum argenteum Hi/panicum.}

The Spanifh filuer cupped Moly.

This Spanifh Moly hath two or three very long rufh like leaues, which rife vp with the ftalke, or rather vanifh away when the ftalke is rifen vp to bee three foote high or more, bearing a great head of flowers, ftanding clofe at the firft, but afterwards fpreading much one from another, euery flower vpon a long foote-ftalke, being of a white 
filuer colour, with ftripes or lines on euery fide, and fafhioned fmall and hollow, like a cuppe or boxe: the feede I could neuer obferue, becaufe it flowreth fo late, that the Winter hindereth it from bearing feede with vs: the roote is fmall and round, white, and in a manner tranfparent, at lealt fo fhining, as if it were fo, and encreafeth nothing fo much, as many of the other forts: this hath no ill fent at all, but rather a pretty fmell, not to bee milliked.

\section{Moly Serotinum Coniferum. The late Pineapple Moly.}

This late Moly that was fent me with the laft defcribed, and others alfo from Spain, rifeth vp with one long greene leafe, hollow and round vnto the end, towards this end on the one fide, breaketh out a head of flowers, enclofed in a thinne skinne, which after it hatls fo ftood a good while, (the leafe in the meane time rifing higher, and growing harder, becommeth the ftalke) breaketh, and fheweth a great burh or head of buds for flowers, thicke thruft together, fanhioned very like vnto the forme of a Pineapple (from whence I gaue it the name) of the bignefs of a $\mathrm{W}$ alnut : after this head hath ftood in this manner a moneth or thereabouts, the flowers fhew themfelues to bee of a fine delayed or whitini purple colour, with diuers ftripes in euery of them, of the fame cup-farhion with the former, but not opening fo plainly, fo that they cannot bee difcerned to bee open, without good heede and obferuation. It flowreth fo late in Autume, that the early frofts doe quickly fpoile the beauty of it, and foone caufe it to rotte: the roote is fmall and round, and hining like the laft, very tender alfo, as not able to abide our fharpe Winters, which hath caufed it vtterly to perifh with me.

\section{Moly Diofcorideum. Diofcorides his Moly.}

The roote of this fmall Moly is tranfparent within, but couered with a thicke yellowin skinne, of the bigneffe of an Hafell Nut, or fomewhat bigger, which fendeth forth three or foure narrow graffie leaues, long and hollow, and a little bending downwards, of a whitifh greene colour, among which rifeth vp a flender weake ftalke, a foot and a halfe high, bearing at the toppe, out of a thinne skinne, a tuft of milke white flowers, very like vnto thofe of Ramfons, which ftand a pretty while in their beauty, and then paffe away for the moft part without giuing any feede: this hath little or no fent of Garlicke.

We haue anothor of this fort that is leffer, and the flowers rounder pointed.

\section{Moly Diofcorideum Hifpanicum. The Spanifh Moly of Diofcorides.}

This Moly came vnto me among other Molyes from Spaine, and is in all things like vnto the laft defcribed, but fairer, larger, and of much more beauty, as hauing his white flowers twice as great as the former; but (as it feemeth) very impatient of our Winters, which it could not at any hand endure, but quickly perifhed, as fome others that came with it alfo.

\section{Moly Mofchatimum vel Zibetrimum Monspetienfe.}

The fweete fmelling Moly of Mompelier.

This fweete Moly, which I have kept for the laft, to clofe vp your fenfes, is the fmalleft, and the fineft of all the reft, hauing foure or fiue fmall greene leaues, almoft as fine as haires, or like the leaues of the Feather-graffe: the ftalke is about a foote high, bearing fiue or fix or more fmall white flowers, laid open like Starres, made of fix leaues a peece, of an excellent fweete fent, refembling Muske or Ciuet; for diuers haue diuerly cenfured of it. It flowreth late in the yeare, fo that if the precedent Summer bee either ouer moift, or the Autumne ouer early cold, this will not haue that fweete fent, that it will haue in a hot drie time, and befides muft be carefully refpected : for it will hardly abide the extremity of our fharpe Winters. 
The Place.

The places of thefe Molyes, are for the moft part expreffed in their titles, or in their defcriptions.

\section{The Time.}

The time is fet downe, for the moft part to bee in Iune and Iuly, the reft later.

\section{The Names.}

To make further relation of names then are expreffed in their titles, were needleffe ; let thefe therefore fuffice.

The Vertues.

All thefe forts of Molyes are fmall kindes of wilde Garlicke, and are to be vfed for the fame purpofes that the great Garden Garlicke is, although much weaker in their effects. For any other ef peciall property is in any of thefe, more than to furnifh a Garden of variety, I haue not heard at all.

And thus much may fuffice of thefe kindes for our Garden, referuing manie others that might be fpoken of, to a generall worke, or to my Garden of Simples, which as God Thall enable me, and time giue leaue, may fhew it felfe to the world, to abide the iudicious and criticke cenfures of all.

\section{H A P. X I I I I.}

Afphodelus. The Afphodill.

T Here remaine fome other flowers, like vnto the laft defcribed, to be fpecified, which although they haue no bulbous rootes, yet I thinke them fitteft to bee here mentioned, that fo I may ioyne thofe of neereft fimilitude together, vntill I have finifhed the reft that are to follow.

I. Afphodelus maior albus ramo/us. The great white branched Afphodill:

The great white Afphodill bath many long, and narrow, hollow three fquare leaues, tharpe pointed, lying vpon the ground round about the roote : the ftalke is fmooth, round, and naked without leaues, which rifeth from the midft of them, diuided at the toppe into diuers branches, if the plant bee of any long continuance, or elfe but into two or three fmall branches, from the fides of the maine great one, whereon doe ftand many large flowers Starre-fafhion, made of fix leaues a peece, whitifh on the infide, and ftraked with a purplifh line downe the backfide of euery leafe, hauing in the middle of the flowers fome fmall yellow threeds: the feede is blacke, and three fquare, greater then the feede of Bucke wheate, contained in roundifh heads, which open into three parts : the roote is compofed of many tuberous long clogges, thickeft in the middle, and fmaller at both ends, faftened together at the head, of a darke grayifh colour on the outfide, and yellow within.

\section{Afphodelus albus non ramofus. The white vnbranched Afphodill.}

The vnbranched Afphodill is like vnto the former, both in leaues and flowers, but that the flowers of this are whiter, and without any line or ftrake on the backe fide, 
and the ftalkes are without branches: the rootes likewife are fmaller, and fewer, but made after the fame fafhion.

3. Afphodelus maior flore carneo. The blufh coloured Afphodill.

This Afphodill is like to the laft in forme of leaues and branches, and differeth in this, that his leaues are marked with fome fpots, and the flowers are of a blufh or flefh colour, in all other things alike.

\section{Afphodelus minimus albus. The leaft white Afphodill.}

This leaft Afphodill hath foure or fiue very narrow long leaues, yet feeming three fquare like the greateft, bearing a fmall ftalke, of about a foote high among them, without any branches, and at the toppe a few white flowers, ftraked both within and without, with a purplifh line in the middle of euery leafe. The rootes are fuch like tuberous clogges as are in the former, but much leffer.

\section{Afphodelus albus minor fue Fiftulofus. The little hollow white Afphodill.}

This little white Afphodill hath a number of leaues growing thicke together, thicker and greener then thofe of the fmall yellow Afphodill, or Kings Speare next following, among which rifeth vp diuers round ftalkes, bearing flowers from the middle to the toppe, Starre-fafhion, with fmall greene leaues among them, which are white on the infide, and ftriped on the backe with purple lines, like vnto the firft defcribed : the feede, and heads containing them, are three fquare, like the feede of the little yellow Afphodill: the rootes of this kinde are not glandulous, as the former, but ftringie, long and white : the whole plant is very impatient of our cold Winters, and quickly perifheth, if it be not carefully preferued, both from the cold, and much wet in the Winter, by houfing it; and then it will abide many yeares: for it is not an annuall plant, as many haue thought.

\section{Afphodelus luteus minor, fue Haftula regia.}

The fmall yellow Afphodill, or Kings fpeare.

This fmall yellow Afphodill, which is vfually called the Kings fpeare, hath many long narrow edged leaues, which make them feeme three fquare, of a bluifh or whitifh greene colour : the ftalke rifeth vp three foote high oftentimes, befet with fmall long leaues vp vnto the very flowers, which grow thicke together fpike-fafhion one aboue another, for a great length, and wholly yellow, laid open like a Starre, fomewhat greater then the laft white Afphodill, and fmaller then the firft, which when they are paft yeeld round heads, containing blacke cornered feede, almoft three fquare : the rootes are many long yellow ftrings, which fpreading in the ground, doe much encreafe.

The Place.

All thefe Afphodils doe grow naturally in Spaine and France, and from thence were firft brought vnto vs, to furnifh our Gardens.

\section{The Time.}

All the glandulous rooted Afphodils doe flower fome in May, and fome in Iune; but the two laft doe flower, the yellow or laft of them in Iuly, and the former white one in Auguft and September, and vntill the cold and winter hinder it.

\section{The Names.}

Their feuerall names are giuen them in their titles, as much as is fit for 
this difcourfe. For to thew you that the Greekes doe call the ftalke of the great Afphodill $A \nu \theta \epsilon \rho i k \eta$, and the Latines Albucum, or what elfe belongeth to them, is fitter for another worke, vnto which I leaue them.

The baftard Afphodils fhould follow next in place, if this worke were fit for them; but becaufe I have tyed my felfe to expreffe onely thofe flowers and plants, that for their beauty, or fent, or both, doe furnifh a Garden of Pleafure, and they haue none, I leaue them to a generall Hiftory of plants, or that Garden of Simples before fpoken of, and will defcribe the Lilly Afphodils, and the Phalangia or Spider-worts, which are remaining of thofe, that ioyne in name or fafhion, and are to be here inferted, before I paffe to the reft of the bulbous rootes.

\section{Liliajphodelus phaniceus. The gold red Day Lilly.}

Becaufe the rootes of this and the next, doe fo nearely agree with the two laft recited Arphodils, I haue fet them in this place, although fome doe place them next after the Lillies, becaufe their flowers doe come neareft in forme vnto Lillies; but whether you will call them Afphodils with Lilly flowers, as I thinke it fitteft, or Lillies with Afphodill rootes, or Lillies without bulbous rootes, as others doe, I will not contend.

The red Day Lilly hath diuers broad and long frefh greene leaues, folded at the firft as it were double, which after open, and remaine a little hollow in the middle; among which rifeth vp a naked ftalke three foot high, bearing at the toppe many flowers, one not much diftant from another, and flowring one after another, not hauing lightly aboue one flower blown open in a day, \& that but for a day, not lafting longer, but clofing at night, and not opening againe; whereupon it had his Englifh name, The Lilly for a day: thefe flowers are almoft as large as the flowers of the white Lilly, and made after the fame farhion, but of a faire gold red, or Orange tawny colour. I could neuer obferue any feede to follow thefe flowers; for they feeme the next day after they haue flowred, (except the time be faire and dry) to bee fo rotten, as if they had lyen in wet to rotte them, whereby I thinke no feede can follow: the rootes are many thicke and long yellow knobbed ftrings, like vnto the fmall yellow Afphodill rootes, but fomewhat greater, running vnder ground in like fort, and thooting young heads round about.

\section{Lilia/phodelus luteus. The yellow Day Lilly.}

I thall not neede to make a repetition of the defcription of this Day Lilly, hauing giuen you one fo amply before, becaufe this doth agree thereunto fo nearely, as that it might feeme the fame; thefe differences onely it hath, the leaues are not fully fo large, nor the flower fo great or fpread open, and the colour thereof is of a faire yellow wholly, and very fweet, which abideth blowne many daies before it fade, and hath giuen blacke round feede, growing in round heads, like the heads of the fmall yellow Afphodill, but not fo great.

Clufius hath fet downe, that it was reported, that there fhould be another Liliaf phodill with a white flower, but we can heare of none fuch as yet; but I rather thinke, that they that gaue that report might be miftaken, in thinking the Sauoye Spider-wort to be a white Liliaf phodill, which indeede is fo like, that one not well experienced, or not well regarding it, may foone take one for another.

The Place.

Their originall is many moift places in Germany.

The Time.

They flower in May and Iune.

The Names.

They are called by fome Liliago, and Lilium non bulbofum, and Liliafphodelus, 


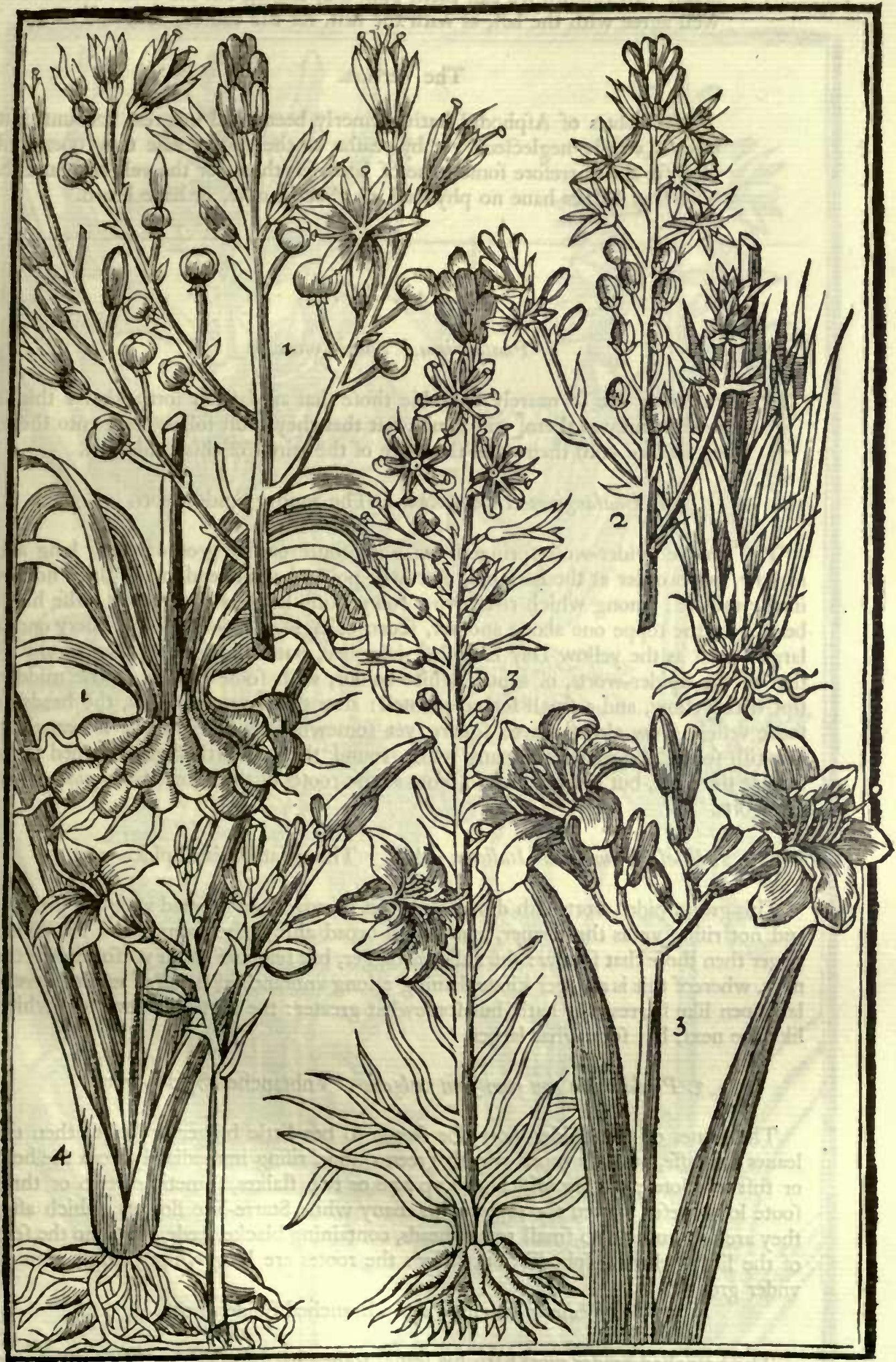

1 Afphodelus maior albus ramofus. The great white branched Afphodill. 2 Afphodelus minor albus feu fffulofus. The little hollow white Afphodill. 3 Afphodelus minor luteus, fiue Ilaftula "gia. The fmall yellow Alphodill, or Kings ipease. 4 Liliafphodelus luleus. The yellow Day Lilly. 5 Liliafphodelus phanicens. The gold red Day Lilly. 
delus. In Englifh we call them both Day Lillies, but the name doth not fo well agree with the laft, as with the firft, for the caufes aboue fpecified.

\section{The Vertues.}

The rootes of Afphodill hath formerly beene had in great account, but now is vtterly neglected; yet by reafon of their fharpneffe they open and cleanfe, and therefore fome haue of late vfed them for the yellow Iaundife. The Day Lillies haue no phyficall vfe that I know, or haue heard.

\section{C н А P. X V.}

\section{Phalangium. Spider-wort.}

Hefe plants doe fo nearely refemble thofe that are laft fet forth, that I thinke none that knowes them, will doubt, but that they muft follow next vnto them, being fo like vnto them, and therefore of the faireft of this kinde firft.

\section{Phalangium Allobrogicum. The Sauoye Spider-wort.}

The Sauoye Spider-wort fpringeth vp with foure or fiue greene leaues, long and narrow, yet broader at the bottome, narrower pointed at the end, and a little hollow in the middle; among which rifeth vp a round ftiffe ftalke, a foote and a halfe high, bearing at the toppe one aboue another, feuen or eight, or more flowers, euery one as large almoft as the yellow Day Lilly laft defcribed, but much greater then in any other of the Spider-worts, of a pure white colour, with fome threeds in the middle, tipt with yellow, and a fmall forked pointell: after the flowers are paft, the heads or feede veffels grow almoft three fquare, yet fomewhat round, wherein is contained blackifh feede: the rootes are many white, round, thicke, brittle ftrings, ioyned together at the head, but are nothing fo long, as the rootes of the other Phalangia or Spider-worts.

\section{Phalangium maius Italicum album. The great Italian Spider-wort.}

This great Spider-wort hath diuers long and narrow leaues fpread vpon the ground, and not rifing vp as the former, and not fo broad alfo as the former, but fomewhat larger then thofe that follow: the ftalke is bigger, but feldome rifeth vp fo high as the next, whereof this is a larger kinde, hauing a long vnbranched ftalke of white flowers, laid open like ftarres as it hath, but fomewhat greater: the rootes are long and white, like the next, but fomewhat larger.

\section{Phalangium non ramofum vulgare. Vnbranched Spider-wort.}

The leaues of this Spider-wort doe feeme to bee little bigger or longer then the leaues of graffe, but of a more grayilh green colour, rifing immediately from the head or tuft of rootes; among which rife vp one or two ftalkes, fometimes two or three foote long, befet toward the toppe with many white Starre-like flowers, which after they are paft turne into fmall round heads, containing blacke feede, like vnto the feed of the little yellow Afphodill, but leffer: the rootes are long white ftrings, running vnder ground.

\section{Phalangium ramofum. Branched Spider-wort.}

The branched Spider-wort hath his leaues fomewhat broader then the former, and of a more yellowifh greene colour : the ftalke hereof is diuerfly branched at the top, bearing many white flowers, like vnto the former, but fmaller: the feedes and rootes are like the former in all things. 


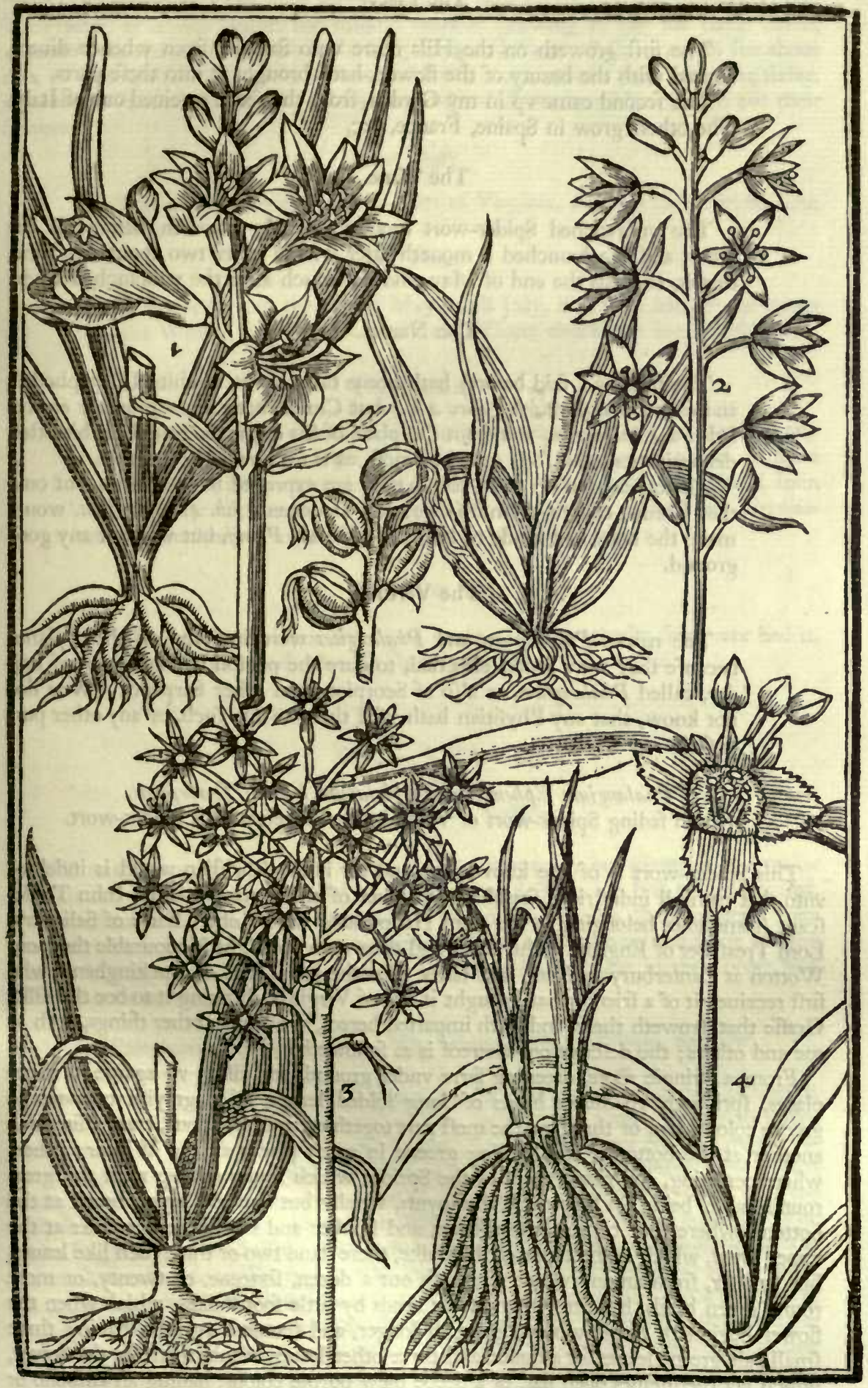

I Phalangium Allobrogicum. The Sauoye Spider-wort, 2 Phalangium non rnmofum. Vnbranched Spider-wort. gixm ramofum. Branched Spider-wort. 4 Phnlangium Ephemerwm Virginianum. Iohn Tradefcante's Spider-wort. 
The Place.

The firft groweth on the Hils neare vnto Sauoye, from whence diuers, allured with the beauty of the flower, haue brought it into thefe parts.

The fecond came vp in my Garden, from the feede receiued out of Italy. The others grow in Spaine, France, \&c.

The Time.

The vnbranched Spider-wort moft commonly flowreth before all the other, and the branched a moneth after it: the other two about one time, that is, towards the end of May, and not much after the vnbranched kinde.

The Names.

The firft (as I faid before) hath beene taken to be a white Lilliafphodill, and called Liliafphodelus flore albo; but Clufius hath more properly entituled it a Phalangium, and from the place of his originall, gaue him his other denomination, and fo is called of moft, as is fet downe in the title.

The other haue no other names then are expreffed in their titles, but only that Cordus calleth them Liliago; and Dodonæus, lib. 4. hift. plant. would make the branched kinde to bee Moly alterum Plinij, but without any good ground.

\section{The Vertues.}

The names Phalangium and Phalangites were impofed on thefe plants, becaufe they were found effectual, to cure the poyfon of that kinde of Spider, called Phalangium, as alfo of Scorpions and other Serpents. Wee doe not know, that any Phyfitian hath vfed them to any fuch, or any other purpofe in our dayes.

\section{Phalangium Ephemerum Virginianum Ioamis Trade fant.}

The foon fading Spider-wort of Virginia, or Tradefcant his Spider-wort.

This Spider-wort is of late knowledge, and for it the Chriftian world is indebted vnto that painfull induftrious fearcher, and louer of all natures varieties, Iohn Tradefcant (fometimes belonging to the right Honourable Lord Robert Earle of Salisbury, Lord Treafurer of England in his time, and then vnto the right Honourable the Lord Wotton at Canterbury in Kent, and laftly vnto the late Duke of Buckingham) who firft receiued it of a friend, that brought it out of Virginia, thinking it to bee the Silke Graffe that groweth there, and hath imparted hereof, as of many other things, both to me and others; the defcription whereof is as followeth:

From a Atringie roote, creeping farre vnder ground, and rifing vp againe in many places, fpringeth vp diuers heads of long folded leaues, of a grayifh ouer-worne greene colour, two or three for the moft part together, and not aboue, compaffing one another at the bottome, and abiding greene in many places all the Winter; otherwhere perifhing, and rifing anew in the Spring, which leaues rife vp with the great round ftalke, being fet thereon at the ioynts, vfually but one at a ioynt, broad at the bottome where they compaffe the ftalke, and fmaller and fmaller to the end: at the vpper ioynt, which is the toppe of the ftalke, there ftand two or three fuch like leaues, but fmaller, from among which breaketh out a dozen, fixteene, or twenty, or more round green heads, hanging downe their heads by little foot-ftalkes, which when the flower beginneth to blow open, groweth longer, and ftandeth vpright, hauing three fmall pale greene leaues for a huske, and three other leaues within them for the flower, which lay themfelues open flat, of a deepe blew purple colour, hauing an vmbone or fmall head in the middle, clofely fet about with fix reddifh, hairy, or feathered threeds, tipt with yellow pendents : this flower openeth it felfe in the day, \& fhutteth vfually at 
night, and neuer openeth againe, but perifheth, and then hangeth downe his head againe; the greene huske of three leaues, clofing it felfe againe into the forme of a head, but greater, as it was before, the middle vmbone growing to bee the feede veffell, wherein is contained fmall, blackifh, long feede : Seldome fhall any man fee aboue one, or two at the moft of thefe flowers blowne open at one time vpon the ftalke, whereby it ftandeth in flowring a long time, before all the heads haue giuen out their flowers.

The Place.

This plant groweth in fome parts of Virginia, and was deliuered to Iohn Tradef cant.

The Time.

It flowreth from the end of May vntill Iuly, if it haue had greene leaues all the Winter, or otherwife, vntill the Winter checke his luxurioufneffe.

\section{The Names.}

Vnto this plant I confeffe I firt impofed the name, by confidering duely all the parts thereof, which vntill fome can finde a more proper, I defire may ftill continue, and to call it Ephemerum Virginianum Tradefcanti, Iohn Tradefcante's Spider-wort of Virginia, or Phalangium Ephemerum Virginianum, The foone fading or Day Spider-wort of Virginia.

\section{The Vertues.}

There hath not beene any tryall made of the properties fince wee had it, nor doe we know whether the Indians haue any vfe thereof.

\section{Cн А P. X VI.}

\section{Colchicum. Medowe Saffron.}

T

O returne to the reft of the bulbous and tuberous rooted plants, that remaine to bee entreated of, the Colchica or Medowe Saffrons are firft to bee handled, whereof thefe later dayes haue found out more varieties, then formerly were knowne; fome flowring in the Spring, but the moft in Autumne, and fome bearing double, but the greateft part fingle flowers: whereof euery one in their order, and firft of our owne Country kindes.

\section{Colchicum Anglicum album. The white Englifh Medowe Saffron.}

It is common to all the Medowe Saffrons, except that of the Spring, and one other, to beare their flowers alone in Autumne or later, without any green leaues with them, and afterwards in February, their greene leaues: So that I thall not neede to make manie defcriptions, but to fhew you the differences that confift in the leaues, and colours of the flowers; and briefly to paffe (after I haue giuen you a full defcription of the firft) from one vnto another, touching onely thofe things that are note worthy. The white Englifh Medowe Saffron then doth beare in Autumne three or foure flowers at the moft, ftanding feuerally vpon weake foote-ftalkes, a fingers length or more aboue the ground, made of fix white leaues, fomewhat long and narrow, and not fo large as moft of the other kindes, with fome threeds or chives in the middle, like vinto the Saffron flowers of the Spring, wherein there is no colour of Saffron, or vertue to that effect : after the flowers are paft and gone, the leaues doe not prefently follow, but the roote remaineth in the ground without fhew of leafe aboue ground, moft part of the Winter, and then in February there fpring vp three or foure large and long greene 
leaues, when they are fully growne vp, ttanding on the toppe of a round, weake, green, and fhort foote-ftalke, fomewhat like the leaues of white Lillies, but not fo large, and in the middeft of thefe leaues, after they haue been vp fome time, appeare two or three loofe skinny heads, ftanding in the middle of the leaues vpon fhort, thicke, greene ftalkes, and being ripe, conteine in them round fmall brownifh feede, that lye as it were loofe therein, and when the head is dry, may bee heard to rattle being fhaken : the roote is white within, but couered with a thicke blackifh skinne or coate, hauing one fide thereof at the bottome longer then the other, with an hollowneffe alfo on the one fide of that long eminence, where the flowers rife from the bottome, and thooting downe from thence a number of white fibres, whereby it is faftened in the ground: the greene leaues afterwards rifing from the top or head of the roote.

\section{Colchicum Anglicum purpureum. The purple Englifh Medowe Saffron.}

There is no difference at all in this Medowe Saffron from the former, but only in the colour of the flowers, which as they were wholly white in the former, fo in this they are of a delayed purple colour, with a fmall thew of veines therein.

\section{Colchicum Pannonicum album. The white Hungary Medowe Saffron.}

The greateft difference in this Colchicum from the former Englifh white one, is, that it is larger both in roote, leafe, and flower, and befides, hath more ftore of flowers together, and continuing longer in beauty, without fading fo foone as the former, and are alfo fomewhat of a fairer white colour.

\section{Colchicum Pannonicum purpureum. The purple Hungary Medowe Saffron.}

This purple Medowe Saffron is fomewhat like vnto the white of this kinde, but that it beareth not fo plentifully as the white, nor doth the roote grow fo great; but the flowers are in a manner as large as they, and of the like pale delayed purple colour, or fomewhat deeper, as is in the purple Englifh, with fome veines or markes vpon the flowers, making fome thew of a checker on the out fide, but not fo confpicuous, as in the true checkerd kindes. Wee haue a kinde hereof is party coloured with white ftreakes and edges, which abide conftant, and hath been raifed from the feede of the former.

\section{Colchicum Byzantinum. Medowe Saffron of Conftantinople.}

This Medowe Saffron of Conftantinople hath his leaues fo broad and large, that hardly could any that neuer faw it before, iudge it to be a Colchicum; for they are much larger then any Lilly leaues, and of a darke greene colour: the flowers are correfpondent to the leaues, larger and more in number then in any of the former purple kindes, of the fame colour with the laft purple kinde, but of a little deeper purple on the infide, with diuers markes running through the flowers, like vnto it, or vnto checkers, but yet fomewhat more apparently: the roote is in the middle greater and rounder then the others, with a longer eminence, whereby it may eafily bee knowne from all other forts.

\section{Colchicum Lufitanicum Fritillaricum.}

The checkerd Medowe Saffron of Portugall.

The flowers of this Medowe Saffron are larger and longer then the flowers of either the Englifh or Hungarian, and almoft as large as the laft before mentioned, and of the fame colour, but a little deeper, the fpots and markes whereof are fomewhat more eafie to be feene euen a farre off, like vnto the flower of a Fritillaria, from whence it tooke his fignificatiue name: the leaues of this Medowe Saffron doe rife vp fooner then in any other of the Autumne kindes; for they are alwayes vp before Winter, and are foure or fiue in number, fhort rather then long, broad belowe, and pointed at the end, canaled or hollow, and ftanding round aboue the ground, one encompaffing another at the bottome, like the great Spanifh Starre Iacinth, called the Iacinth of Peru, 


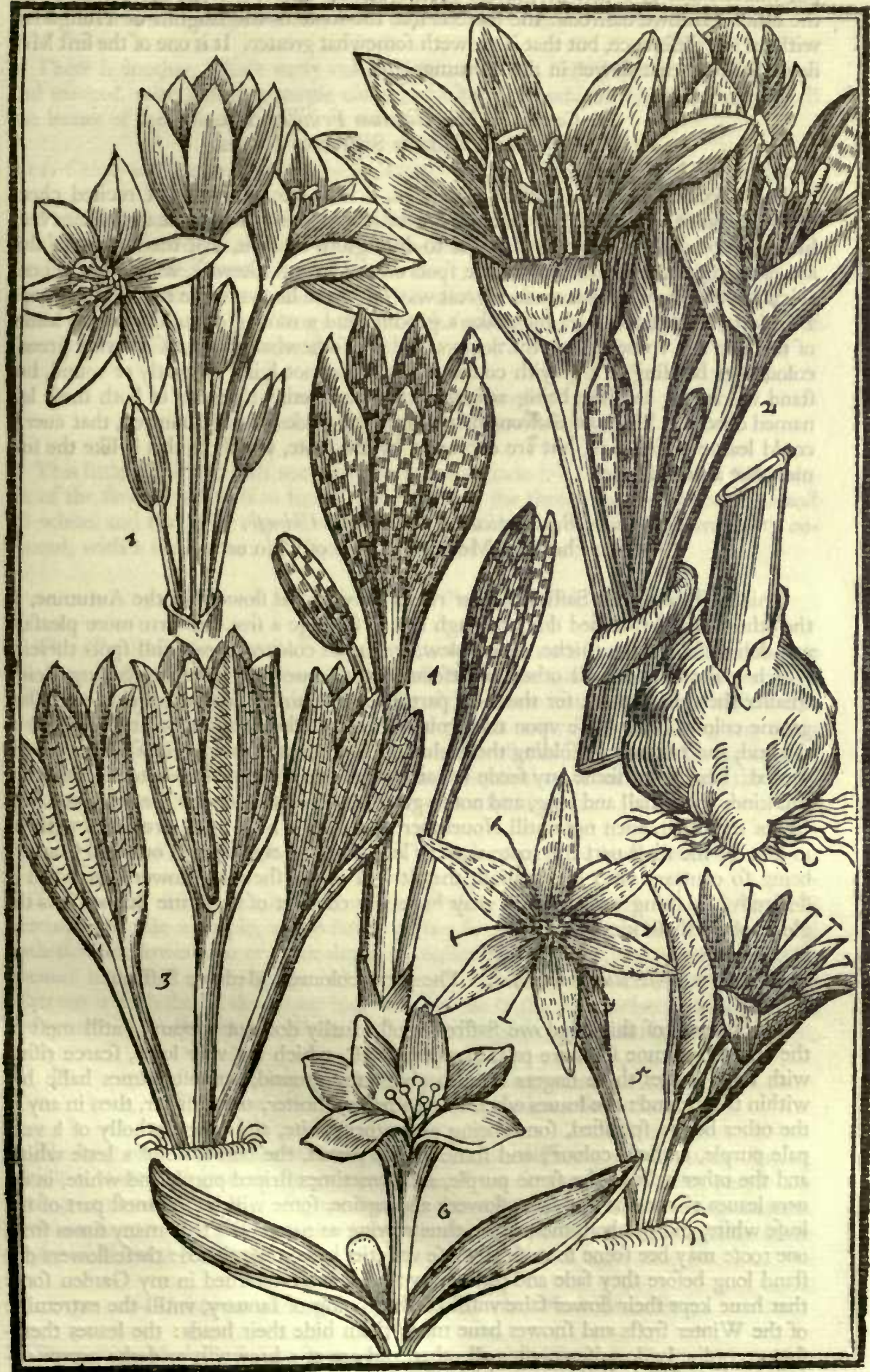

I Colchicum Pannonicum. The II angarian Medow Saffron. I Colihicum Bysantimum. Medowe Saffron of Conftantinople 3 Colchicum Lufitanicum Fritillaricum. The checkerd Medowe Saffron of Portugall. 4 Colehicum. Neapolitamum Frivillaricum, 6 Colchicum Hermodactylum. Phyficall Medowe Saffron. 
but fhorter, and of a pale or grayifh greene colour, differing from the colour of all the other Medowe Saffrons: the roote is like the roote of the Englifh or Hungarian without any difference, but that it groweth fomewhat greater. It is one of the firft $\mathrm{Me}$ dowe Saffrons that flower in the Autumne.

\section{Colchicum Neapolitanum Fritillaricum.}

The checkerd Medowe Saffron of Naples.

This checkerd Medowe Saffron of Naples, is very like vnto the laft recited checkerd Saffron of Portugall, but that the flower is fomewhat larger, yet fometimes very little, or not at all : the greateft marke to diftinguifh them is, that the flowers of this are of a deeper colour, and fo are the fpots on the flowers likewife, which are fo confpicuous, that they are difcerned a great way off, more like vnto the flowers of a deepe Fritillaria, then the former, and make a goodlier and a more glorious thew: the leaues of this doe rife vp early after the flowers, and are fomewhat longer, of a darker greene colour, yet bending to a grayifh colour as the other, not lying fo neatly or round, but ftand vp one by another, being as it were folded together: neither of both thefe laft named checkerd Medowe Saffrons haue giuen any feede in this Countrey, that euer I could learne or heare of, but are encreafed by the roote, which in this is like the former, but a little bigger.

\section{Colchicum Fritillaricum Chien/e.}

The checkerd Medowe Saffron of Chio or Sio.

This moft beautifull Saffron flower rifeth vp with his flowers in the Autumne, as the others before fpecified doe, although not of fo large a fize, yet farre more pleafant and delightfull in the thicke, deepe blew, or purple coloured beautifull fpots therein, which make it excell all others whatfoeuer: the leaues rife vp in the Spring, being fmaller then the former, for the moft part three in number, and of a paler or frefher greene colour, lying clofe vpon the ground, broad at the bottome, a little pointed at the end, and twining or folding themfelues in and out at the edges, as if they were indented. I haue not feene any feede it hath borne: the roote is like vnto the others of this kinde, but fmall and long, and not fo great : it flowreth later for the moft part then any of the other, euen not vntill Nouember, and is very hard to be preferued with vs, in that for the moft part the roote waxeth leffe and leffe euery yeare, our cold Country being fo contrary vnto his naturall, that it will fcarce thew his flower; yet when it flowreth any thing early, that it may haue any comfort of a warme Sunne, it is the glorie of all thefe kindes.

\section{Colchicum verficolor. The party coloured Medowe Saffron.}

The flowers of this Medowe Saffron molt vfually doe not appeare, vntill moft of the other Autumne forts are paft, except the laft, which are very lowe, fcarce rifing with their ftalkes three fingers breadth aboue the ground, but oftentimes halfe hid within the ground: the leaues whereof are fmaller, fhorter, and rounder, then in any of the other before fpecified, fome being altogether white, and others wholly of a very pale purple, or flefh colour; and fome againe parted, the one halfe of a leafe white, and the other halfe of the fame purple, and fometimes ftriped purple and white, in diuers leaues of one and the fame flower: and againe, fome will be the moft part of the leafe white, and the bottome purple, thus varying as nature lift, that many times from one roote may bee feene to arife all thefe varieties before mentioned: thefe flowers doe ftand long before they fade and paffe away; for I haue obferued in my Garden fome that haue kept their flower faire vntill the beginning of Ianuary, vntill the extremitie of the Winter frofts and fnowes haue made them hide their heads: the leaues therefore accordingly doe rife vp after all other, and are of a brownifh or darke greene colour at their firf fpringing vp, which after grow to be of a deepe greene colour: the roote is like the former Englifh or Hungarian kindes, but thicker and greater for the moft part, and fhorter alfo. 
10. Colchicum variegatum alterum. Another party coloured Medowe Saffron.

There is another, whofe party coloured flowers rife a little higher, diuerfly ftriped and marked, with a deeper purple colour, and a pale or whitifh blufh throughout all the leaues of the flower.

\section{I1. Golchicum montanum Hifpanicum minus. The little Spanifh Medowe Saffron.}

The flowers of this little Medowe Saffron are narrower and fmaller then any of the former, and of a deeper reddifh purple colour then either the Englifh or Hungarian kindes: the greene leaues alfo are fmaller then any other, lying on the ground, of a deepe or fad greene colour, rifing vp within a while after the flowers are paft, and doe abide greene all the Winter long: the roote is fmall and long, according to the reft of the plant, and like in forme to the others.

\section{Colchicum montanum minus verficolore flore.}

The fmall party coloured Medowe Saffron.

This little kinde differeth not from the Spanifh kinde laft fet forth, but in the varietie of the flower, which is as fmall as the former; the three inner leaues being almoft all white, and the three outer leaues fome of them pale or blufh, and fome party coloured, with a little greene on the backe of fome of them.

\section{Colchicum Hermodactilum. Phyficall Medowe Saffron.}

This Phyficall Medowe Saffron fpringeth vp with his leaues in Autumne, before his flowers appeare beyond the nature of all the former kindes, yet the flower doth, after they are vp, fhew it felfe in the middle of the greene leaues, confifting of fix white leaues, with diuers chiues in the middle, and paffeth away without giuing any feede that euer I could obferue: the greene leaues abide all the Winter and Spring following, decaying about May, and appeare not vntill September, when (as I faid) the flowers fhew themfelues prefently after the leaues are fprung vp.

\section{I4. Colchicum atropurpureum. The darke purple Medowe Saffron.}

The greateft difference in this kinde confifteth in the flower, which at the firft appearing is as pale a purple, as the flower of the former Hungarian kinde: but after it hath ftood in flower two or three dayes, it beginneth to change, and will after a while become to bee of a very deepe reddifh purple colour, as alfo the little foote-ftalke whereon it doth ftand: the flower is of the bigneffe of the Hungarian purple, and fo is the greene leafe: the feede and roote is like the Englifh purple kinde.

\section{5. Colchicum atropurpureum variegatum.}

The party coloured darke purple Medowe Saffron.

We haue of late gained another fort of this kinde, differing chiefly in the flower, which is diuerfly ftriped thorough euery leafe of the flower, with a paler purple colour, whereby the flower is of great beauty: this might feeme to bee a degeneration from the former, yet it hath abiden conftant with me diuers yeares, and giueth feede as plentifully as the former.

\section{I6. Colchicum flore pleno. Double flowred Medowe Saffron.}

The double Medowe Saffron is in roote and leafe very like unto the Englifh kinde: the flowers are of a fine pale or delayed purple colour, confifting of many leaues fet thicke together, which are fomewhat fmaller, as in the Englifh flower, being narrow and long, and as it were round at the points, which make a very double flower, hauing 
fome chiues with their yellow tips, difperfed as it were among the leaues in the middle : it flowreth in September, a little after the firft thew of the earlier Medowe Saffrons are paft.

17. Colchicum variegatum pleno fore.

The party coloured double Medowe Saffron.

We haue another of thefe double kinds (if it be not the very fame with the former, varying in the flower as nature pleafeth oftentimes; for I haue this flower in iny garden, as I here fet it forth, euery yeare) whofe flowers are diuerfified in the partition of the colours, as is to be feene in the fingle party coloured Medowe Saffron before defcribed, hauing fome leaues white, and others pale purple, and fome leaues halfe white and halfe purple, diuerlly fet or placed in the double flower, which doth confift of as many leaues as the former, yet fometime this party coloured flower doth not fhew it felfe double like the former, but hath two flowers, one rifing out of another, making each of them to be almoft but fingle flowers, confifting of eight or ten leaues a peece: but this diuerfity is not conftant; for the fame roote that this yeare appeareth in that manner, the next yeare will returne to his former kinde of double flowers againe.

\section{8. Colchicum Vernum. Medowe Saffron of the Spring.}

This Medowe Saffron rifeth vp very early in the yeare, that is, in the end of Ianuarie fometimes, or beginning, or at the furtheft the middle of February, prefently after the deepe Frofts and Snowes are paft, with his flowers inclofed within three greene leaues, which opening themfelues as foone almoft as they are out of the ground, fhew their buds for flowers within them very white oftentimes, before they open farre, and fometimes alfo purplifh at their firft appearing, which neuer fhew aboue two at the moft vpon one roote, and neuer rife aboue the leaues, nor the leaues much higher then they, while they laft : the flower confifteth of fix leaues, long and narrow, euery leafe being diuided, both at the bottome and toppe, each from other, and ioyned together onely in the middle, hauing alfo fix chiues, tipt with yellow in the middle, euery chiue being ioyned to a leafe, of a pale red or deepe blufh colour, when it hath ftood a while blowne, and is a fmaller flower then any Medowe Saffron, except the fmall Spanifh kindes onely, but continueth in his beauty a good while, if the extremity of tharpe Frofts and Windes doe not fpoile it : the leaues wherein thefe flowers are enclofed, at their firt comming vp, are of a brownifh greene colour, which fo abide for a while, efpecially on the outfide, but on the infide they are hollow, and of a whitifh or grayifh greene colour, which after the flowers are paft, grow to bee of the length of a mans longeft finger, and narrow withall: there rifeth vp likewife in the middle of them the head or feede veffell, which is fmaller and thorter, and harder then any of the former, wherein is contained fmall round browne feede: the roote is fmall, fomewhat like vnto the rootes of the former, but fhorter, and not hauing fo long an eminence on the one fide of the bottome.

\section{Colchicum vernum atropurpureum. Purple Medowe Saffron of the Spring.}

The flower of this Medowe Saffron, is in the rifing vp of his leaues and flowers together, and in all things elfe, like vnto the former, onely the flowers of this fort are at their firt appearing of a deeper purple colour, and when they are blowne alfo are much deeper then the former, diuided in like manner, both at the bottome and toppe as the other, fo that they feeme, like as if fix loofe leaues were ioyned in the middle part, to make one flower, and hath his fmall chiues tipt with yellow, cleauing in like manner to euery leafe.

\section{The Place.}

All thefe Medowe Saffrons, or the moft part of them, haue their places expreffed in their titles; for fome grow in the fields and medowes of the champion grounds, others on the mountaines and hilly grounds. The Englifh kindes grow in the Weft parts, as about Bathe, Briftow, Warmi- 


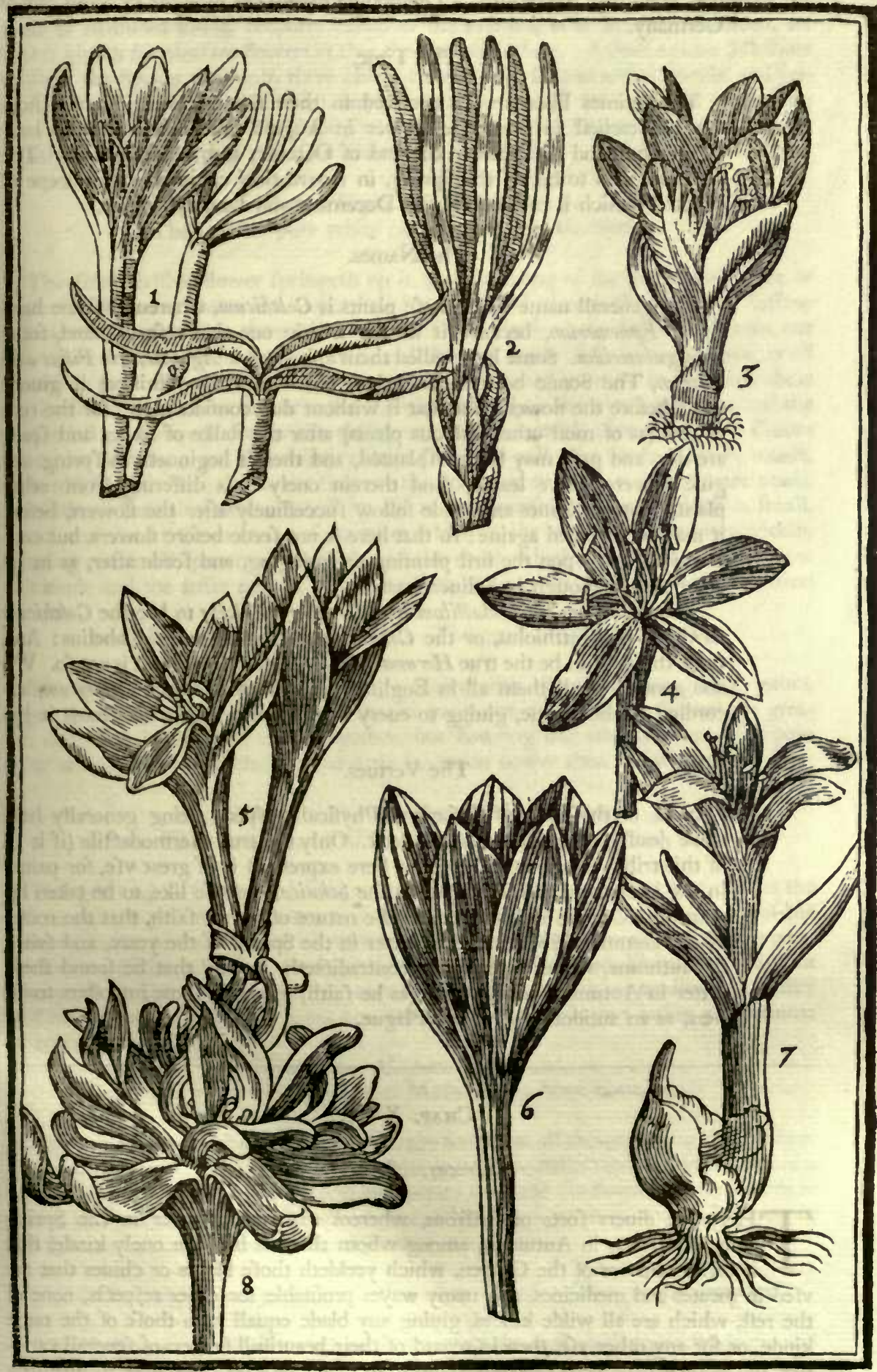

1 Colshicum monlanum Hifparicum. The little Spanith Medowe Saffron. a Colchicum monlanum minus verficoloreflore. The Imall party coloured Medowe Safiron. 3 Colchicum verficolor. The party coloured Medowe Saftron. 4 Colchicum sariegatum altrum. Another party coloured Medowe Saffron. 5 Colchirum atropurpurcum. The darke purple Medowe Saffron. 6 Col. fpring. 8 Calchicum fore pleno. Double Medowe Safiron. 
fter, and other places alfo. The double kindes are thought to come out of Germany.

\section{The Time.}

Their times likewife are declared in their feuerall defcriptions: thofe that are earlieft in Autumne, flower in Augutt and September, the later in October, and the lateft in the end of October, and in November. The other are faid to bee of the Spring, in regard they come after the deepe of Winter (which is moft vfually in December and Ianuary) is paft.

The Names.

The generall name to all thefe plants is Colchicum, whereunto fome haue added Ephemerum, becaufe it killeth within one dayes fpace; and fome Strangulatorium. Some haue called them alfo Bulbus Agrefits, and Filius ante Patrem, The Sonne before the Father, becaufe (as they thinke) it giueth feede before the flower: but that is without due confideration; for the root of this (as of molt other bulbous plants) after the ftalke of leaues and feede are dry, and paft, may be tranfplanted, and then it beginneth to fpring and giue flowers before leaues, (and therein onely it is differing from other plants) but the leaues and feede follow fucceffiuely after the flowers, before it may be remoued againe; fo that here is not feede before flowers, but contrarily flowers vpon the firft planting or fpringing, and feede after, as in all other plants, though in a diuers manner.

The Colchicum Hermodactilum may feeme very likely to bee the Colchicum Orientale of Matthiolus, or the Colchicum Alexandrinum of Lobelius: And fome thinke it to be the true Hermodactilus, and fo call it, but it is not fo. We doe generally call them all in Englifh Medowe Saffrons, or Colchicum, according to the Latine, giuing to euery one his other adiunct to know it by.

\section{The Vertues.}

None of thefe are vfed for any Phyficall refpect, being generally held to be deadly, or dangerous at the leaft. Only the true Hermodactile (if it be of this tribe, and not this which is here expreffed) is of great vfe, for paines in the ioynts, and of the hippes, as the Sciatica, and the like, to be taken inwardly. Coftæus in his Booke of the nature of plants, faith, that the rootes of our common kindes are very bitter in the Spring of the yeare, and fweet in Autumne, which Camerarius contradicteth, faying, that he found them bitter in Autumne, which were (as he faith) giuen by fome impofters to diuers, as an antidote againt the Plague.

\section{CHAP. XVII. \\ Crocus. Saffron.}

$\mathrm{T}$

Here are diuers forts of Saffrons, whereof many doe flower in the Spring time, and fome in Autumne, among whom there is but one onely kinde, that is called tame or of the Garden, which yeeldeth thofe blades or chiues that are vfed in meates and medicines, and many wayes profitable for other refpects, none of the reft, which are all wilde kindes, giuing any blade equall vnto thofe of the tame kinde, or for any other vfe, then in regard of their beautifull flowers of feuerall varieties, and as they haue been carefully fought out, and preferued by diuers, to furnifh a Garden of dainty curiofity. To entreate therefore of thefe, I muft, to obferue an orderly declaration, diuide them into two primary families: the former thall be of thofe that yeeld their pleafant flowers in the Spring of the yeare, and the other that fend out 
their colours in the Autumne, among whom that Rexpomarij (as I may fo call it) the tame or manured kinde, properly called of the Garden, is to be comprehended, for that it giueth his pleafant flowers at that time among others. I thall againe diftribute thofe of the Spring time into three chiefe colours, that is, into white, purple, and yellow, and vnder euery one of them, comprehend the feuerall varieties that doe belong vinto them; which courfe I will alfo hold with thofe of the Autumne, that thus being rightly ranked, they may the more orderly be defcribed.

\section{Crocus Vermus albus purus minor.}

The fmaller pure white Saffron flower of the Spring.

This fmall Saffron flower fpringeth vp in the beginning of the yeare, with three or foure fmall greene leaues, fomewhat broader, but much fhorter then the true Saffron leaues, with a white line downe the middle of euery leafe: betweene thefe leaues, out of a white skinne, rifeth vp one or two fmall flowers, made of fix leaues a peece, as all the reft in generall are, of a pure white colour, without any mixture in it, which abide not in flower aboue a weeke, or rather leffe, fo fodainly is the pleafure of this, and the purple loft: it flowreth not for the moft part, vntill a moneth after the yellow Crocus appeareth in flower, and the ordinary ftript Crocus is paft : the feede is fmall, round, and reddifh, yet not fo red as the feede of the yellow, contained in three fquare heads, yet feldome beareth, but encreafeth by the roote plentifully enough, which is fmall, round, and flat at the bottome, fomewhat white on the outfide, but whiter within, thooting out fmall fprouts on euery fide of the roote, which is the beft note to know this kinde and the leffer purple, which are both alike, from all other rootes of Saffron flowers.

\section{Crocus albus maior multiflorus. The great fnow white Crocus.}

This greater Saffron flower rifeth vp vfually with three or foure greene leaues, larger then the former, with a white line in euery one of them: the flowers are greater, and more in number, rifing together, but flowring one after another, of a pure fnow white colour, and abiding but little longer in flower then the former.

\section{Crocus albus maior alter dictus Mafiacus.}

The great white Saffron flower or Crocus of Mefia.

This great white Crocus of Mefia, rifeth vp out of the ground, almoft as early as the firt fort of the yellow, with foure or fiue leaues, being very like vnto the leaues of the yellow Crocus, and as large, with white lines in them: the flowers alfo are as large as the flowers of the yellow, and many alfo rifing one after another like vnto it, but not of fo pure a white colour, as the former or laft def cribed, but rather tending to a Milky or Creane colour: the roote is not couered with any reddifh, but rather pale skinnes or coates.

\section{Crocus albus Mafiacus fundo violaceo.}

The great white Crocus of Mefia with a blew bottonse.

There is another of this kinde, like vnto the former in all things, fauing that the bottomes of the flowers of this kinde, with fome part of the ftalke next the flower, are of a pale fhining purple colour, and rifing vp a pretty way into the flower; whereas another alfo of this kind, hath a little thew or marke of blew, and not purple, at the bottome of the flower onely, which maketh a difference.

\section{Crocus albus fundo purpurea. The white Crocus with a purple bottome.}

This Saffron flower is of the fame kinde with the firt, both in roote, leafe, and flower, in none of them differing from it, but in that the bottome of this flower, with that part of the fhort foote-ftalke next vnto it, is of a violet or purple colour, and fometimes hauing here and there fome purple fmall lines, or fpots on the white leaues: it flowreth alfo with the firft white, or fomewhat later. 


\section{Crocus vernus albus friatus. The white ftript Crocus.}

This ftript Saffron flower is likewife neare the fame firft kind, or firf white Crocus, hauing the like leaues and flowers, fomewhat larger, but as foone fading almoft as it: but herein this flower differeth, that it hath pale blewifh lines and fpots in all the leaues thereof, and more principally in the three outer leaues: the root is alfo white on the outfide, like the firft white, but greater, with young ones growing round about it.

\section{Crocus vernus albus polyanthos verficolor.}

The greater party coloured white Crocus.

The greater party coloured Saffron flower, hath his greene leaues like vnto the fecond great white Crocus before mentioned, hauing more flowers then any of the former, except the firft great white, the leaues whereof haue greater ftripes then the laft recited Crocus, but of a purple Violet colour, making each leafe feeme oftentimes to haue as much purple as white in them: the roote hereof is fomewhat like the fecond white, but of a little more duskie colour on the outfide, and not budding out on the fides at all, or very little.

\section{Grocus vernus albus verficolor. The leffer party coloured white Crocus.}

The leaues and flowers of this other party coloured Crocus, are for bigneffe in a manner equall with the laft, but hath not fo many flowers rifing together from the roote: the flower is finely marked with blew ftrakes on the white flower, but nothing fo much as in the former: the roote alfo is like the laft.

\section{Crocus Epifcopalis. The Bifhops Crocus.}

This party coloured or Bifhops Saffron flower, is very like both in leaues and rootes vnto the Neapolitane blew Crocus, but fomewhat greater: the flowers doe abide not fo long time blowne, and hath all the leaues either wholly white, with blew ftripes on both fides of them, or wholly of a fine delayed blew Violet colour, and the three innermoft more blew and finely ftriped, both on the infide and outfide of them, and fometimes it hath been feen to haue three leaues white, and three leaues of a pale blew.

\section{Grocus vernus Ariatus vulgaris. The ordinary ftript Crocus.}

There is another fort of Atript Saffron flower, which is moft common and plentifull in moft Gardens, which I muft needes bring vnder the ranke of thefe white kinds, although it differre very notably, both in roote, leafe, and flower, from all of them: the leaues of this rife vp fooner then the yellow or white Crocus, lying fpread vpon the ground for the molt part, but narrower then any of the former: among thefe leaues fpring vp diuers flowers, almoft as large as the former great white Crocus, of a very bleake or pale purple colour, tending to white on the infide, and in many almoft white, with fome fmall whitifh chives tipt with yellow in the middle: the three outer leaues are of a yellowifh white colour on the backe fide of them, ftript euery one of them with three broad ftripes, of a darke murrey or purple colour, and a little fprinkled with fome fmall purple lines, on both fides of thofe ftripes; but on the infide, of the fame pale purple or white colour with the reft: the feede hereof is fomewhat darker coloured then of the white, and is more liberall in bearing: the roote is differing from all the former, being rounder and bigger then any of them, except the kindes of Mifia, yet fomewhat flat withall, not hauing any thootes from the fides, but fetting off into rootes plentifully, hauing a round circle compaffing the bottome of the roote, which eafily falleth away, when it is taken vp out of the ground, and couered with a browne coate, fomewhat neare the colour of the yellow Crocus, but not altogether fo bright: it flowreth vfually the firt of all thefe forts, or with the firft of the early yellowes. 


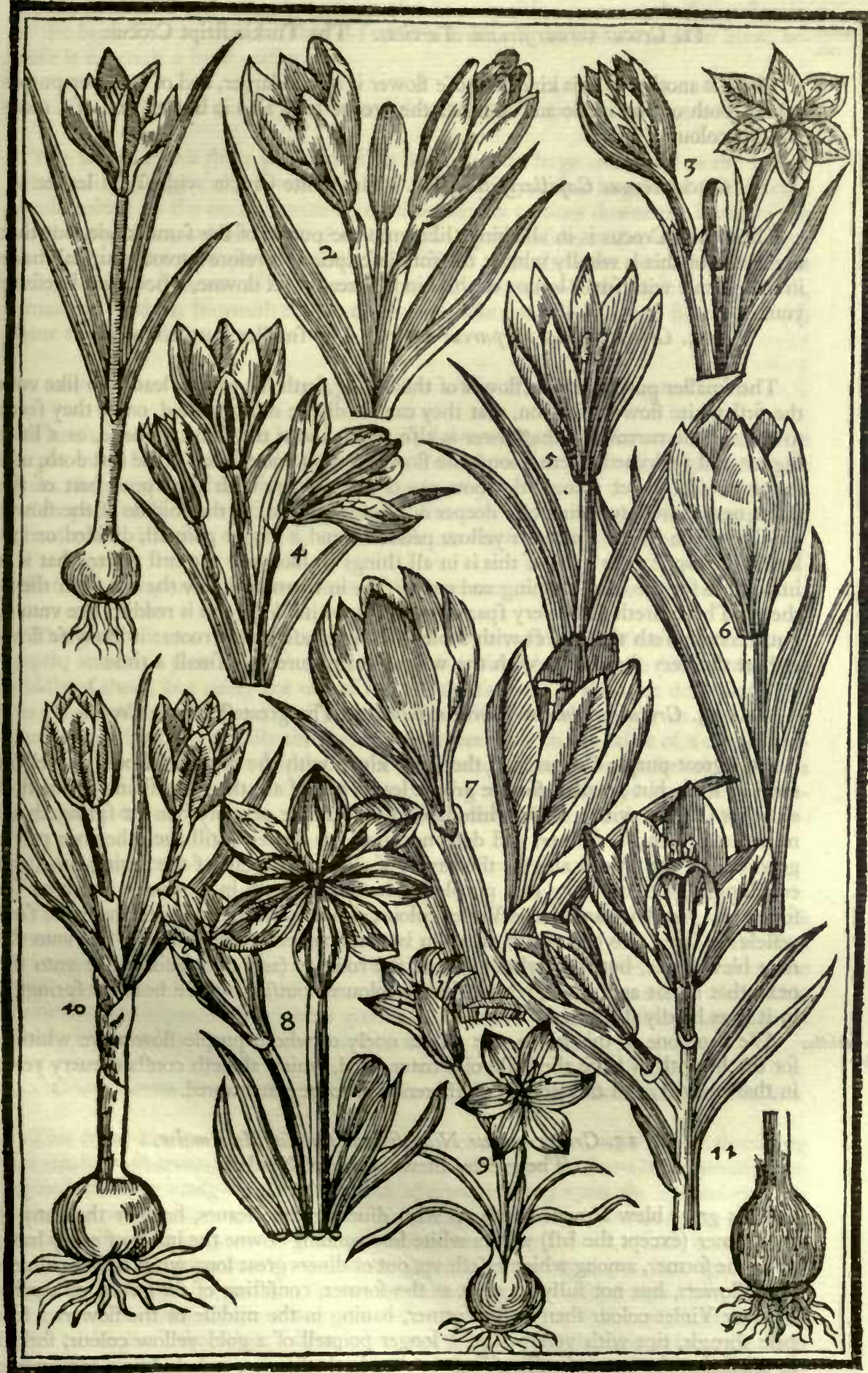

I Crocus vernus albus minor. The fmall white Saffron flower of the fpring. 2 Crocus zernus Mofiocus albus. The great white

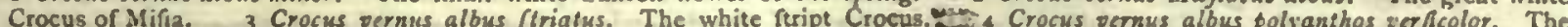
parey coloured white Crocus. 5 Crocus albus fundo purpureo. The white Crocus with a purple bottome. 6 Crocus vernus Nea. polisanus. The great blew Crocus of Naples. 7 Crocusgermus phingurns maximus. The great purple Crocus. 8 Crosus vermus purpurcus firiatus. The purple ftript Crocus. 9 Crosus vernus purpureus Capillarifolio. The purple Crocus with fmall leaues. to Crocus vernus fagus frialus. The yellow ftript Crocus. Is Crosws vernus luieus verffcalor. The cloth of gold Crocus. 


\section{I1. Crocus vernus frialus Turcitus. The Turkie ftript Crocus.}

There is another of this kinde, whofe flower is a little larger, and of a deeper purple colour, both on the infide and outfide; the greene leafe alfo is bigger, and of a more whitifh colour.

\section{Crocus vernus Capillarifolio albus. The white Crocus with Imall leaues.}

This white Crocus is in all things like vnto the purple of the fame kinde, but that the flower of this is wholly white: the full defcription therefore hereof, you thall haue in that purple with fmall leaues, of this kinde hereafter fet downe, whereunto I referre you.

\section{Crocus vernus purpureus minor. The fmaller purple Crocus.}

The fmaller purple Saffron flower of the Spring, hath his greene leaues fo like vnto the firft white flowred Saffron, that they can hardly be diftinguifhed, onely they reem to bee a little narrower: the flower is alfo much about the fame bigneffe, or a little bigger, and feldome beareth aboue one flower from a roote, euen as the firft doth, of a deepe purple Violet colour, the bottome of the flower, with the vpper part of the ftalke next thereunto, being of a deeper or blacker purple; in the middle of the flower are fome pale chiues tipt with yellow pendents, and a longer pointell, diuided or forked at the toppe: the roote of this is in all things fo like vnto the firft white, that it is impoffible for the moft cunning and conuerfant in them, to know the one from the other. This beareth feede very fparingly, as the white doth, and is reddifh like vnto it, but recompenfeth that defect with a plentifull encreare by the roote: it likewife flowreth at the very fame time with the white, and endureth as fmall a time.

\section{Crocus vernus purpureus maximus. The greateft purple Crocus.}

This great purple Crocus is of the fame kinde with the next defcribed, as well in roote as leafe, but greater; for the greene leaues hereof are the greateft and broadeft of all other Crocus, with a large white line in the middle of euery one: it fpringeth vp much later then the former, and doth not thew his flower vntill the other bee paft a good while: the flowers alfo are the largeft of all thefe Crocus of the Spring time, and equalling, if not furpaffing that purple kinde that flowreth in Autumne, hereafter fet forth, of a very faire and deepe Violet colour, almoft as deepe as the former: the feed veffels are large alfo and white, wherein is contained pale reddifh feede, like vnto the next blew kinde, but fomewhat greater: the roote is (as I faid before) like vnto the next, that is, flat and round, with a duskie coloured outfide, whofe head for fpringing in it is as hardly difcerned.

Alter Apicibus We haue one of this kinde, the toppes onely of whofe purple flower are whitifh, albidis. for the breadth of halfe the naile of a mans hand, which abideth conftant euery yeare in that manner, and therefore is a difference fit to be remembred.

\section{Grocus vernus Neapolitanus fue caruleus maior. \\ The greater blew Crocus of Naples.}

This great blew Crocus rifeth vp with diuers greene leaues, broader then any of the former (except the laft) with a white line running downe the infide of euery leafe, as in the former, among which rifeth vp, out of diuers great long white skinnes, diuers large flowers, but not fully fo great as the former, confifting of fix leaues, of a paler blew or Violet colour then in the former, hauing in the middle of the flowers a few pale threeds, tipt with yellow, and a longer pointell of a gold yellow colour, forked or diuided at the toppe, fmelling fweeter then in the former, and abiding a great while longer, being in flower vfually euen with the ftript yellow Crocus, or before the former purple, and yeelding more plenty of feede : the roote hereof is not very great, but a little darke on the outfide, being round and flat withall, that one can hardly know which is the vpperfide thereof. 
This kinde differeth very little from the former, either in roote, leafe, or florver, Crosus Neap for the bignefle or colour, but that it feemeth to be a little bleaker or paler blew, be- liramus pres caufe it flowreth a little earlier.

\section{Crocus vernus purpureus friatus. The Atript purple Crocus.}

The leaues of this ftript purple Saffron flower, are as large and broad as the laft, or rather a little longer: the flowers alfo are as plentifull, and as large, of a fine delayed purple colour on the outfide, with three broad ftrakes or lines downe the backe of the three outer leaues, and of a little deeper purple on the infide, as the other three leaues are alfo of a deeper purple colour, and are ftriped with the fame deepe purple about the ground, or bottome of the leaues: this fometimes yeeldeth three fquare heads, containing in them brownifh feede: the roote is like vnto the laft, and flowreth much about the time of the former.

\section{Crocus vermus purpureus verficolor. The filuer ftript purple Crocus.}

This ftript Saffron flower, is in leaues and flowers fomewhat like vnto the laft ftript purple, but a little fmaller : the flowers are of a little deeper purple through the whole leaues, ftriped with white lines, both on the leaues, and towards the edges, which maketh a peculiar difference from all the reft: the roote of this is not fo flat, though like it, and couered with a darke afh coloured skinne: it flowreth about the fame time.

\section{Crocus purpureus flammeus maior. The greater purple flame coloured Crocus.}

The greene leaues of this Crocus or Saffron flower, are of a reafonable breadth and length, and of a pleafant frefh greeneffe, with a faire broad white line downe the middle of them, but rifing not out of the ground fo early as the next defcribed Crocus: the flowers are likewife of a meane bigneffe, of a pale purple on the outfide, fomewhat whitifh, efpecially the three outer leaues; but on the infide of a deeper purple, and friped with great ftripes like flames, hauing fome chiues in the middle, and a longer one alfo feathered a little at the toppe: the roote is white on the outfrde, fomewhat flat and round, but not fo flat as the Neapolitane Crocus before defcribed.

19. Crocus purpureus flammeus minor. The leffer purple flame coloured Crocus.

This Crocus hath almoft as broad and long greene leaues as the former, and of the fame verdure, which rife vp earlier then it, and is in flower likewife fomewhat before it, being fmaller for fize by a little, but of as deepe a purple on the outfide, as on the infide, flamed with faire broad ftripes from the middle of the leaues, or fomewhat lower vnto the edges: each of thefe giue feed that is of a pale reddifh colour: the root is very like vnto the former, but a little leffer.

\section{Crocus vernus purpureus Capillarifolio. The purple Crocus with fmall leaues.}

This fmall kinde of Saffron flower rifeth out of the ground, with two or three long and fmall green leaues, very like vnto the leaues of the fine Fether-Graffe hereafter defcribed, ftanding vpright at the firft, but afterwards lying vpon the ground; among which come the flowers, fometimes three, but moft vfually two vpon one ftalke, if the roote be not young, which then will beare but one on a ftalke, which is very fhort, fo that the flowers (carce arife aboue the ground, yet laying themfelues open in the day time, if it be faire, and the Sunne doe hine, otherwife they keepe clofe, and doe not open at all: and after one flower is paft, which doth not laft aboue three or foure dayes at the moft, the others follow, which are of a bleake blewifh purple in the middle of the flower, and of a deeper purple towards the ends or points of the leaues, but of a more fullen or darke purple on the outfide of them, and yellowifh at the bottome, with fome yellow chiues in the middle: the feede is fmall and darker coloured then any of the former Crocus, contained alfo in fmaller heads, ftanding one by another 
vpon the fame fhort foote-ftalke, which then rifeth vp a little higher, fhewing the maner of the ftanding of the flowers, which in their flowring time could not fo eafily bee difcerned: the roote is very fmall and round, hauing one fide at the bottome lower then the other, very like the roote of a Colchicum or Medowe Saffron, and fomewhat neare refembling alfo the hoofe of an horfe foote, couered with a very thicke skinne, of a darke or blackifh browne colour: this flowreth the laft of all the former forts of Saffron flowers, euen when they are all patt.

\section{I. Crocus vernus purpureus ftriatus Capillarifolio.}

The ftript purple Crocus with fmall leaues.

This fmall ftript purple Saffron flower hath fuch like leaues, as the laft defcribed hath, betweene which rifeth the flower vpon as fhort a foote-ftalke, confifting of fix leaues like the former, of a faire purple colour on the outfide of the three outer leaues, with three lines or ftrakes downe euery leafe, of a deeper purple colour, and on the infide of a paler purple, as the other three leaues are alfo, with fome chiues tipt with yellow pendents, and a forked pointell in the middle: the roote of this is fomewhat bigger then the former, and rounder, but couered with as thicke and as browne a skinne: it flowreth about the fame time with the former.

\section{Crocus vernus luteus fiue Mafiacus. The yellow Crocus.}

The yellow Crocus or Saffron flower, rifeth vp with three or foure leaues out of the ground, being fomewhat neare the breadth of the great purple kindes, with a white line in them, as in moft of the reft: the flowers ftand in the middle of thefe leaues, and are very large, of a gold yellow colour, with fome chiues, and a forked point in the middle: the feede hereof is of a brighter colour then in any of the other: the roote is great and round, as great or greater then a Wall Nut fometimes, and couered with reddifh skinnes or coates, yeelding more ftore of flowers then moft of the former, and beginning to blowe with the firft forts, or prefently after, but outlaft many of them, and are of a pleafant good fent.

Flore aure. Of this kinde we have fome, whofe flowers are of a deeper gold yellow colour then others, fo that they appeare reddifh withall.

Flore pallido. And we haue alfo another fort, whofe flowers are very pale, betweene a white and a yellow, not differing in any thing elfe.

Flore viridante And another fmaller, whofe flower hath a fhew of greenneffe in the yellow, and Inteo. more greene at the bottome.

\section{Crocus vernus flavus friatus. The yellow ftript Crocus.}

This kinde of yellow ftript Crocus or Saffron flower, rifeth vp with more ftore of narrower and greener leaues then the former, and after the leaues are fpread, there rife vp many yellow flowers from among them, which are not of fo faire and bright a yellow colour, but more dead and fullen, hauing on the backfide of each of the three outtermoft leaues, three fmall ftripes, of an ouer-worne or dull purple colour, with fome chiues and a pointell in the middle: the roote of this kinde, is very like the roote of the former yellow, but fomewhat fmaller and fhorter, and couered with the like reddifh skinnes, but a little fadder : it flowreth not fo early as the former yellow, but abideth almolt as long as it.

\section{Crocus vermus luteus verficolor primus. The beft cloth of gold Crocus.}

The faireft cloth of gold Crocus or Saffron flower, rifeth vp very early, euen with the firft, or the firft of all other Crocus, with three or foure very narrow and fhort leaues, of a whiter colour then any of the former, which by and by after doe thew forth the flowers, rifing from among them out of the fame white skinne, which includeth the leaues, but are not fo plentifull as the former yellow, being but two or three at the moft, of a faire gold yellow colour, yet fomewhat paler then the firft, ha- 
uing on the backe of euery of the three outer lenues, three faire and great ftripes, of a faire deepe purple colour, with fome fmall lines at the fides or edges of thofe purple ftripes; on the infide of thefe flowers, there is no figne or Mew of any line or fpot, but wholly of a faire gold yellow, with chiues and a fethertopt pointell in the middle : the feede hereof is like the former, but not fo red : the roote of this kinde is eafily knowne from the roote of any other Saffron flower, becaufe the outer peelings or thels being hard, are as it were netted on the outfide, hauing certaine ribbes, rifing $v p$ higher then the reft of the skinnes, diuided in the forme of a net-worke, of a darke browne colour, and is fmaller and rounder then the former yellow, and not encreafing fo plentifully by the roote.

25. Crocus vermus luteus verficolor alter.

The fecond cloth of gold, or Duke Crocus.

There is no difference either in roote, leafe, or colour of flower, or time of flowring in this fort from the laft before mentioned; for the flower of this is of the fame bigneffe and colour, the only note of difference is in the marking of the three outer leaues, which haue not three Atripes like the former, but are wholly of the fame deepe purple colour on the backe of them, fauing that the edges of them are yellow, which is the forme of a Duke Tulipa, and from thence it tooke the name of a Duke Crocus.

\section{Crocus vernus verficolor pallideluteus. The pale cloth of gold Crocus.}

We haue a third fort of this kinde of cloth of gold Crocus, which hath leanes and flowers like the former, but differeth in this, that the colour of the flower is of a paler yellow by much, but ftript in the fame manner as the firft, but with a fainter purple colour: the roote alfo is netted like them, to thew that this is but a variation of the fame kinde.

\section{Crocus vernus verficolor albidoluteus. The cloth of filuer Crocus.}

The chiefert note of difference in this Saffron flower is, that being as large a flower as any of the former of this kinde, it is of fo pale a yellowifh white, that it is more white then yellow, which fome doe call a butter colour: the three outer leaues are Itriped on the backe of them, with a paler purple blew fhining colour, the bottome of the flower, and the vpper part of the ftalke, being of the fame purple blew colour: the roote of this is alfo netted as the other, to thew it is a variety of the fame kinde.

And thus much for thofe Saffron flowers that come in the Spring time; now to thofe that flower in Autumne onely: and firt of the true Saffron.

\section{Crocus verus fativus Autumnalis. The true Saffron.}

The true Saffron that is vfed in meates and medicines, fhooteth out his narrow long greene leaues firt, and after a while the flowers in the middle of them appeare about the end of Auguft, in September and Oetober, according to the foile, and climate where they growe; thefe flowers are as large as any of the other former or later forts, coinpofed of fix leaues a peece, of a murrey or reddifh purple colour, hauing a thew of blew in them: in the middle of thefe flowers there are fome fmall yellow chiues ftanding vpright, which are as vnprofitable, as the chiues in any other of the wilde Saffrons, before or hereafter fpecified; but befides thefe, each flower hath two, three, or foure greater and longer chiues, hanging downe vpon or betweene the leaues, which are of a fierie red colour, and are the true blades of Saffron, which are vied phyfically or otherwife, and no other: All thefe blades being pickt from the feuerall flowers, are laid and preffed together into cakes, and afterwards dryed very warily on a Kill to preferue them; as they are to be feene in the fhops where they are fold. I neuer heard that euer it gaue feede with any: the roote groweth often to be as great, or greater then a green Wall Nut, with the outer fhell on it, couered with a grayifh or afh-coloured skin, which breaketh into long haire threeds, otherwife then in any other roote of Crocus. 


\section{Crocus Byzantinus argenteus. The filuer coloured Autumne Crocus.}

This Saffron flower fpringeth vp in October, and feldome before, with three or foure thort greene leaues at the firft, but growing longer afterwards, and in the midnt of them, prefently after they haue appeared, one flower for the moft part, and feldome two, confifting of fix leaues, the three outermoft whereof are fomewhat larger then the other three within, and are of a pale bleake blew colour, almoft white, which many call a filuer colour, the three innermoft being of a purer white, with fome yellow chives in the middle, and a longer pointell ragged or fethered at the toppe: this very feldome beareth feede, but when the yeare falleth out to bee very milde; it is fmall, round, and of a darke colour: the roote is pretty bigge, and rounder then any other Crocus, without any flat bottome, and couered with a darke ruffet skinne.

\section{Crocus Pyrenceus purpureus. The purple mountaine Crocus.}

This purple Saffron flower of the Autumne, rifeth vp but with one flower vfually, yet fometimes with two one after another, without any leaues at all, in September, or fometimes in Auguft, ftanding vpon a longer foote-ftalke then any kinde of Saffron flower, either of the Spring or Autumne, and is as large as the flower of the greateft purple Saffron flower of the Spring, of a very deepe Violet purple colour, which decayeth after it hath ftood blowne three or foure dayes, and becommeth more pale, hauing in the middle fome yellow chiues, and a long fether topt pointell, branched, and rifing fometimes aboue the edges of the flowers: about a moneth after the flowers are paft, and fometimes not vntill the firf of the Spring, there rifeth vp three or foure long and broad greene leaues, with a white line in euery one of them, like vnto the firft purple Vernall kindes, which abide vntill the end of May or Iune: the roote is fmall and white on the outfide, fo like vnto the roote of the leffer Vernall purple or white Crocus, that it cannot be diftinguifhed, vntill about the end of Auguft, when it doth begin to thoot, and then by the early thooting $\mathrm{vp}$ a long white fprout for flower, it may be knowne. I neuer could obferue it to giue any feede, the Winter (as I thinke) comming on it fo quickly after the flowring, being the caufe to hinder it.

\section{Crocus montanus Autumnalis. The Autumne mountaine Crocus.}

The mountaine Saffron flower fpringeth $\mathrm{vp}$ later then any of the former, and doth not appeare vntill the middle or end of October, when all the flowers of the former are paft, appearing firft with three or foure fhort greene leaues, like vnto the Byzantine Crocus, and afterwards the flowers betweene them, which are of a pale or bleake blew tending to a purple, the foote-ftalkes of them being fo fhort, that they fcarce appeare aboue ground at the firft, but after two or three dayes they grow a little higher: the roote is very great and flat bottomed, couered with a grayifh duskie coate or skinne, and encreafeth very little or feldome.

\section{The Place.}

The feuerall places of thefe Saffron flowers, are in part fet downe in their titles; the others haue beene found out, fome in one Countrey, and fome in another, as the fmall purple and white, and ftript white in Spaine: the yellow in Mefia about Belgrade, the great purple in Italy; and now by fuch friends helpes as haue fent them, they profper as well in our Gardens, as in their naturall places. Yet I muft giue you this to vnderftand, that fome of thefe formerly expreffed, haue been raifed vp vnto vs by the fowing of their feede.

\section{The Time.}

Their feuerall times are likewife expreffed in their defcriptions; for fome fhew forth their pleafant flowers in the Spring, wherein for the three firft moneths, 


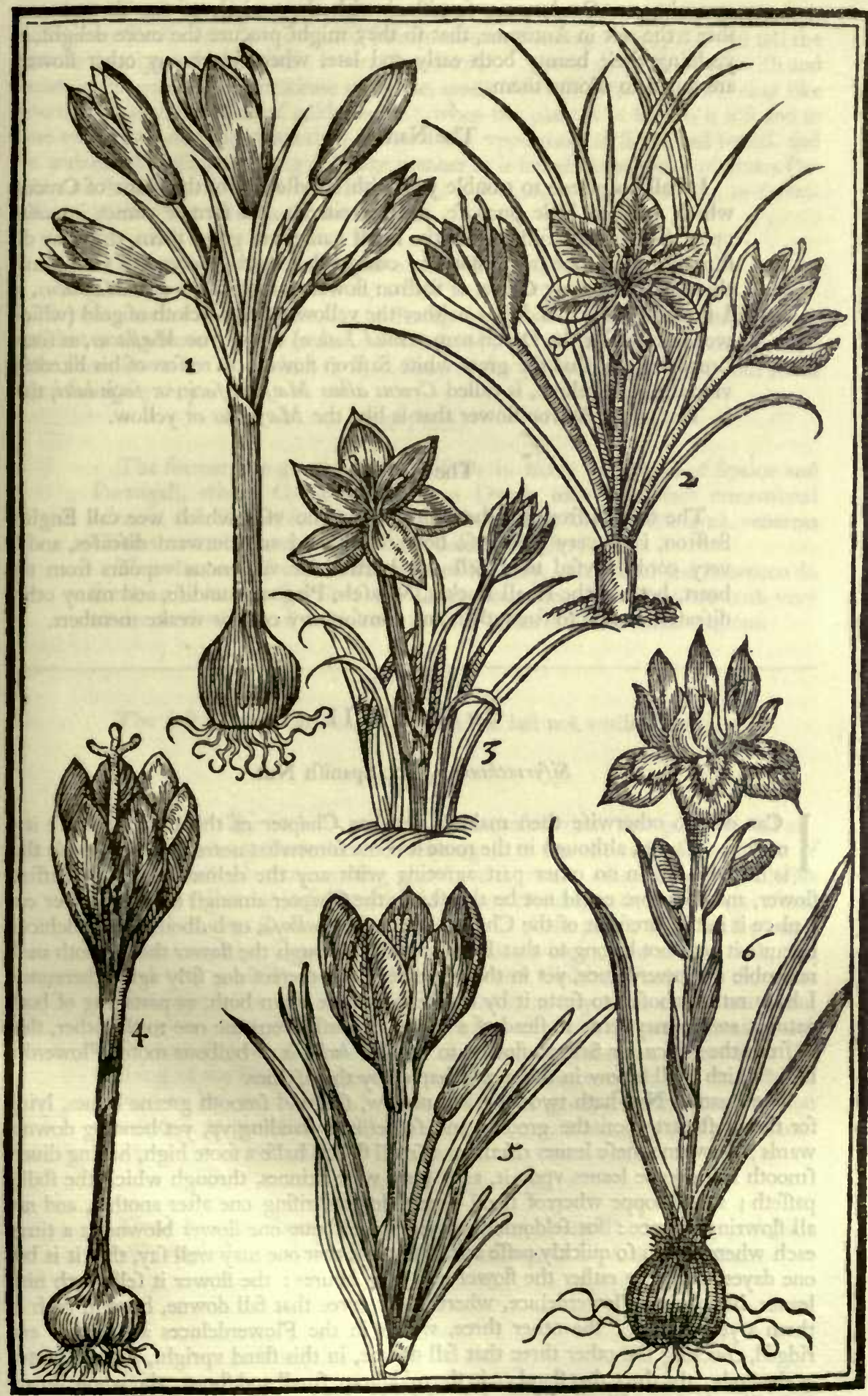

I Crocus reenws lulews rulgaris. The common yellow fpring Crocus. 2 Crocus verus fativns Aulumnalis. The true Saffron. 3 Cracus Bysantiuns argenters. The fluer coloured Autumne Crocus.

Crocus. 5 Crocus montanns Antumnalis. The Autumne mountaine Crocus. 
moneths, our Gardens are furnifhed with the varietie of one fort or another : the relt in Autumne, that fo they might procure the more delight, in yeelding their beauty both early and late, when fcarce any other flowers are found to adorne them.

\section{The Names.}

I fhall not neede to trouble you with an idle tale of the name of Crocus, which were to little purpofe, nor to reiterate the former names impofed vpon them ; let it fuffice that the fitteft names are giuen them, that may diftinguifh them one from another; onely this I mult giue you to vnderftand, that the gold yellow Crocus or Saffron flower, is the true Crocus Mafiacus, as I thewed before; and that neither the yellow ftript, or cloth of gold (which wee fo call after the Dutch name Gaud Laken) is the true Mafiacus, as fome fuppore ; and that the great white Saffron flower, by reafon of his likeneffe vito the gold yellow, is called Crocus albus Mafiaci facie, or facie lutei, that is, The white Saffron flower that is like the Mafiacus or yellow.

\section{The Vertues.}

The true Saffron (for the others are of no vfe) which wee call Englifh Saffron, is of very great vfe both for inward and outward difeafes, and is very cordiall, vfed to expell any hurtfull or venomous vapours from the heart, both in the fmall Pockes, Meafels, Plague, Iaundife, and many other difeafes, as alfo to ftrengthen and comfort any cold or weake members.

\section{Cн а P. X V I I I.}

\section{Sifyrinchium. The Spanifh Nut.}

Can doe no otherwife then make a peculiar Chapter of this plant, becaufe it is neither a Crocus, although in the roote it come fomewhat neare vnto that kinde that is netted; but in no other part agreeing with any the delineaments of a Saffron flower, and therefore could not be thruft into the Chapter amongft them : neither can I place it in the forefront of the Chapter of the Iris bulbofa, or bulbous Flowerdeluces, becaufe it doth not belong to that Family : and although the flower thereof doth moft refemble a Flowerdeluce, yet in that no other parts thereof doe fitly agree thereunto, I haue rather chofen to feate it by it felfe betweene them both, as partaking of both natures, and fo may ferue in ftead of a bridge, to paffe from the one to the other, that is, from the Crocus or Saffron flower, to the Iris bulbofa or bulbous rooted Flowerdeluce, which thall follow in the next Chapter by themfelues.

The Spanifh Nut hath two long and narrow, foft and fmooth greene leaues, lying for the molt part vpon the ground, and fometimes ftanding vp, yet bending downewards; betweene thefe leaues rifeth vp a fmall ftalke, halfe a foote high, hauing diuers fmooth foft greene leaues vpon it, as if they were skinnes, through which the ftalke paffeth ; at the toppe whereof ftand diuers flowers, rifing one after another, and not all flowring at once : for feldome fhall you haue aboue one flower blowne at a time, each whereof doth fo quickly paffe and fade away, that one may well fay, that it is but one dayes flower, or rather the flower of a few houres: the flower it felfe hath nine leaues, like vnto a Flowerdeluce, whereof the three that fall downe, haue in each of them a yellow fpot: the other three, which in the Flowerdeluces are hollow and ridged, couering the other three that fall downe, in this ftand vpright, and are parted at the ends : the three that ftand vp in the middle are fmall and fhort : the whole flower is fmaller then any Flowerdeluce, but of fundry colours; for fome are of an excellent skie colour blew, others of a Violet purple, others of a darker purple colour, and fome white, and many others mixed, either pale blew and deepe purple, or white and blew 
mixed or ftriped together very variably, quickly fading as I faid before : the feede is enclofed in fmall cods, fo thinne and tranfparent, that one may eafily fee, and tell the feeds as they lye, which are of a brownifh red colour : the roote is fmall, blackifh and round, wrapped in a thicke skinne or huske, made like vnto a net, or fomewhat like vnto the roote of the cloth of gold Crocus : when the plant is in flower, it is found to haue two rootes one aboue another, whereof the vppermoft is firme and found, and the vndermoft loofe and fpongie, in like manner as is found in the rootes of diuers Orchides or Satyrions, Bee-flowers and the like, and without any good tafte, or fweetneffe at all, although Clufius faith otherwife.

\section{Sifyrinchium Mauritanicum. The Barbary Nut.}

There is another of this kinde, not differing from the former in any other notable part, but in the flower, which in this is of a delayed purplifh red colour, hauing in each of the three lower leaues a white fpot, in ftead of the yellow in the former, but are as foone fading as they.

\section{The Place.}

The former doe grow very plentifully in many parts both of Spaine and Portugall, where Guillaume Boel, a Dutch man heretofore remembred often in this Booke, found them; of the fundry colours fpecified, whereas Clufius maketh mention but of one colour that he found.

The other was found in that part of Barbary, where Fez and Morocco do ftand, and brought firft into the Lowe-Countries : but they are both very tender, and will hardly abide the hard Winters of thefe colder regions.

\section{The Time.}

The firft flowreth in May and Iune, the laft not vntill Auguft.

The Names.

The name Sifyrinchium is generally impofed vpon this plant, by all authors that haue written thereof, thinking it to bee the right Sifyrinchium of Theophraftus: but concerning the Spanifh name Norelha, which Clufius faith it is called by in Spaine, I haue beene credibly enformed by the aforenamed Boel, that this roote is not fo called in thofe parts; but that the fmall or common ftript Crocus is called Nozelha, which is fweete in tafte, and defired very greedily by the Shepheards and Children, and that the roote of this Sijyrinchium or Spanifh Nut, is without any tafte, and is not eaten. And againe, that there is not two kindes, although it grow greater, and with more flowers, in thofe places that are neare the Sea, where both the wafhing of the Sea water, and the moifture and ayre of the Sea, caufeth the ground to bee more fertile. This I thought good, from the true relation of a friend, to giue the world to vnderftand, that truth might expell errour.

\section{The Vertues.}

Thefe haue not beene knowne to bee vfed to any Phyficall purpofe, but wholly neglected, vnleffe fome may eate them, as Clufius reporteth. 


\section{Сна Р. XIX.}

Iris bulbofa. The bulbous Flowerdeluce.

T He Flowerdeluces that haue bulbous rootes are of two forts, the one ${ }^{7}$ greater then the other : the greater bearing larger and broader leaues and flowers, and the leffer narrower. But before I giue you the defcriptions of the vfuall greater kindes, I muft needes place one or two in the fore-front that haue no fellowes; the one is called of Clufius, his broad leafed Flowerdeluce, and the other a Perfian, fomewhat like vnto it, which although they differ notably from the reft, yet they haue the neareft refemblance vnto thofe greater kindes, that come next after them.

\section{Iris bulbofa prima latifolia Clufij.}

Clufius his firft great bulbous Flowerdeluce.

This Flowerdeluce hath diuers long and broad leaues, not ftiffe, like all the other, but foft and greenifh on the vpperfide, and whitifh vnderneath ; among which rife vp fometimes feuerall fmall, hhort, flender ftalkes, and fometimes but one, not aboue halfe a foote high, bearing at the top one flower a peece, fomewhat like vnto a Flowerdeluce, confifting of nine leaues, whereof thofe three that ftand vpright, are thorter and more clofed together, then in other forts of Flowerdeluces; the other three that fall downe, turne vp their ends a little, and thofe three, that in other Flowerdeluces doe couer them at the bottome, ftand like the vpright leaues of other Flowerdeluces, but are parted into two ends, like vnto two fmall eares : the whole flower is of a faire blew, or pale skie colour in moft, with a long ftripe in the middle of each of the three falling leaues, and in fome white, but more feldome : the roote is reafonable great, round and white, vnder the blackifh coates wherewith it is couered, hauing many long thicke white rootes in ftead of fibres, which make them feeme to be Afphodill rootes. The flower is very fweete.

\section{Iris bulbofa Perfica. The Perfian bulbous Flowerdeluce.}

This Perfian Flowerdeluce is fomewhat like vnto the former, both in roote and in leafe, but that the leaues are fhorter and narrower, and the flower being much about the fame fafhion, is of a pale blew ruffetifh colour, each of the three lower falling leaues are almoft wholly of a browne purple colour, with a yellow fpot in the middle of them : this as it is very rare, fo it feldome beareth flowers with vs.

\section{The Place.}

The firt groweth in many places of Spaine and Portugall, from whence I and others haue often had it for our Gardens, but by reafon of the tenderneffe thereof, it doth hardly endure the Tharpneffe of our cold Winters, vnleffe it be carefully preferued.

The other is faid to come from Perfia, and therefore it is fo entituled, and is as tender to be kept as the other.

The Time.

The firft flowreth moft vfually not vntill May with vs, yet many times fooner: but in Ianuary and February, as Clufius faith, in the naturall places thereof.

The other is as early oftentimes when it doth flower with vs.

The Names.

Becaufe Clufius by good iudgement referreth the firft to the greater kindes 
kindes of Flowerdeluces, and placeth it in the fore ranke, calling it Iris bulbofa latifolia prima, that is, The firft broad leafed Flowerdeluce, and all others doe the like, I haue (as you fee) in the like manner put it before all the other, and keepe the fame name. The Spaniards, as he faith, called it Lirio c/padanal, and they of Corduba, Lirios azules.

The other hath no other name then as it is in the title.

\section{Iris bulbofa maior füe Anglica crerulea.}

The blew Englith bulbous Flowerdeluce.

This bulbous Flowerdeluce rifeth vp early, euen in Ianuary oftentimes, with fiue or fix long and (narrow, in comparifon of any great breadth, but in regard of the other kinde) broad whitifh green leaues, crefted or ftraked on the backfide, and halfe round, the infide being hollow like a trough or gutter, white all along the infide of the leafe, and blunt at the end; among which rifeth vp a ftiffe round ftalke, a cubit or two foot high, at the toppe whereof, out of a skinnie huske, commeth forth one or two flowers, confifting of nine leaues a peece, three whereof that are turned downewards, are larger and broader then the other, hauing in each of them a yellow fpot, about the middle of the leafe, other three are finall, hollow, ridged or arched, couering the lower part next the ftalke of thofe falling leaues, turning vp their ends, which are diuided into two parts, other three ftand vpright, and are very fmall at the bottome of them, and broader toward the toppe: the whole flower is of a faire blew colour; after the flowers are paft, come vp three fquare heads, fonsewhat long, and lanke, or loofe, containing in them round yellowifh feede, which when it is ripe, will rattle by the thaking of the winde in the dry huskes: the roote of this kinde is greater and longer then any of the fmaller kindes with narrow leaues, couered with diuers browne skinnes, which feeme to be fraught with long threeds like haires, ef pecially at the finall or vpper end of the roote, which thing you thall not finde in any of the fmaller kindes.

\section{Iris bulbofa maior purpurea E purpuro violacea.}

The paler or deeper purple great bulbous Flowerdeluce.

There purple Flowerdeluces differ not from the laft defcribed, either in roote or leafe: the chiefeft difference confifteth in the flowers, which in thefe are fomewhat larger then in the former, and in the one of a deepe blew or Violet purple colour, and in the other of a deepe purple colour, in all other things alike.

There is allo another, in all other things like vnto the former, but only in the flower, Flore cinereo. which is of a pale or bleake blew, which we call an afh-colour.

\section{Iris bulbofa maior purpurea variegata fuu friata. \\ The great purple ftript bulbous Flowerdeluce.}

There is another of the purple kinde, whofe flower is purple, but with fome veines or ftripes of a deeper Violet colour, diuerly running through the whole leaues of the flower.

And another of that bleake blew or afh-colour, with lines and veines of purple in Flore cinereo the leaues of the flowers, fome more or leffe then other.

And againe another, whofe flower is of a purple colour like vnto the fecond, but ${ }^{\text {reo. }}$. that round about that yellow fpot, in the middle of each of the three falling leaues (as orbe cinereo. is vfuall in all the bulbous Flowerdeluces) there is a circle of a pale blew or alh-colour, the reft of the leafe remaining purple, as the other parts of the flower is.

\section{Iris bulbofa maior flore rubente.}

The great peach coloured bulbous Flowerdeluce.

There is another of thefe greater kindes, more rare then any of the former, not differing in roote, leafe, or flower, from the former, but onely that the flower in this is of a pale reddifh purple colour, comming fomewhat neare vnto the colour of a peach bloffome. 


\section{Iris bulbofa maior fiue latifolia alba.}

The great white bulbous Flowerdeluce.

The great white bulbous Flowerdeluce, rifeth not vp fo early out of the ground as the blew or purple doth, but about a moneth or more after, whofe leaues are fomewhat larger, and broader then of the others: the ftalke is thicker and fhorter, bearing vfually two very large and great flowers, one flowring a little before the other, yet oftentimes both in flower together in the end, of a bleake blewirh white colour, which wee call a filuer colour, while they are in the budde, and before they be blowne open, but then of a purer white, yet with an eye or thew of that filuer colour remaining in them, the three falling leaues being very large, and hauing that yellow fpot in the middle of each of them: the feedes are likewife inclofed in heads, like vnto the blew or purple kindes, but larger, and are of a reddifh yellow colour like them: the roote likewife is not differing, but greater.

\section{Iris bulbofa maior alba variegata.}

The great white ftript bulbous Flowerdeluce.

This white ftript Flowerdeluce, is in roote, leafe, and flower, and in manner of growing, like vnto the former white Flowerdeluce; the onely difference is in the marking of the flower, being diuers from it: for this hath in the white flower great veines, ftripes, or markes, of a Violet blew colour, difperfed through the leaues of the flower very variably, which addeth a fuperexcellent beauty to the flower.

\section{Iris bulbofa maior fiue latifolia verficolor.}

The great party coloured bulbous Flowerdeluce.

There is no difference in this from the former, but in the flower, which is of a whitifh colour in the three falling leaues, hauing a circle of afh-colour about the yellow fpot, the three rigged leaues being likewife whitifh, but ridged and edged with that anh-colour, and the three vpright leaues of a pale blewifh white colour, with fome veines therein of a blewifh purple.

There hath beene brought vnto vs diuers rootes of thefe kindes, with the dryed flowers remaining on them, wherein there hath beene feene more varieties, then I can well remember to expreffe, which variety it is very probable, hath rifen by the fowing of the feeds, as is truely obferued in the narrower leafed kinde of Flowerdeluce, in the Tulipa, and in fome other plants.

Wee haue heard of one of this kinde of broad leafed Flowerdeluces, that fhould Flore luteo. beare a yellow flower, in the like manner as is to be feene in the narrow leafed ones: but I haue not feene any fuch, and therefore I dare report no further of it, vntill time hath difcouered the truth or falfhood of the report.

The Place.

Lobelius is the firft reporter, that the blew Flowerdeluce or firf kinde of thefe broad leafed Flowerdeluces, groweth naturally in the Weft parts of England; but I am in fome doubt of the truth of that report: for I rather thinke, that fome in their trauels through Spaine, or other parts where it groweth, being delighted with the beauty of the flower, did gather the rootes, and bring them ouer with them, and dwelling in fome of the Weft parts of England, planted them, and there encreafing fo plentifully as they doe, they were imparted to many, thereby in time growing common in all Countrey folkes Gardens thereabouts. They grow alfo, and all the other, and many more varieties, about Tholoufe, from whence Plantinianus Gaffanus both fent and brought vs them, with many other bulbous rootes' and rare plants gathered thereabouts. 


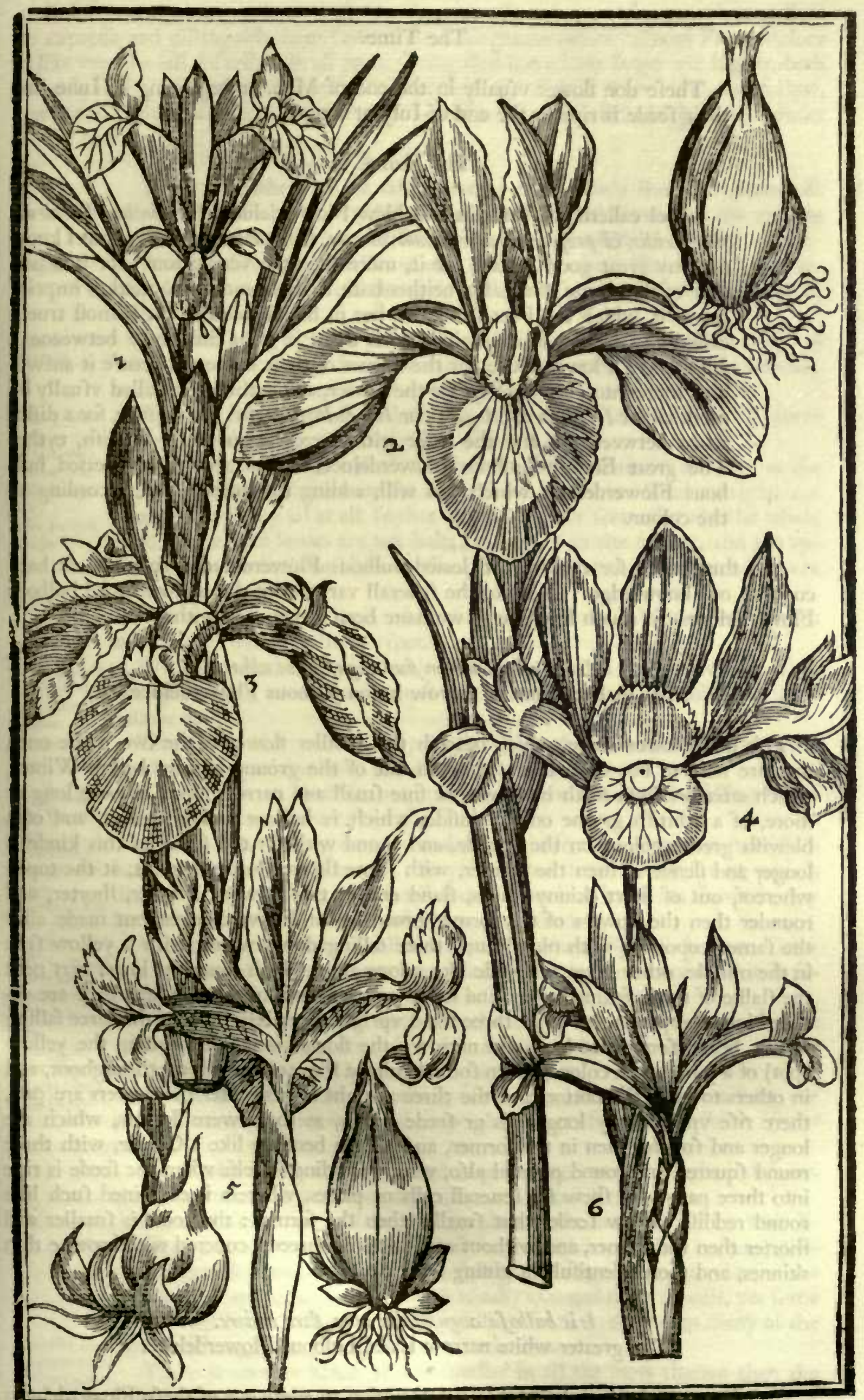

I Iris bulbofa batifolia prima Clmai. Clufius his firftgreat bulbous Flowerdeluce. 2 Iris bulbofa maior carnlea fiue Anglica. The great blew or Englith bulbous Flowerdeluce. 3 Iris bulbefa maior purpurca varisgafa. The great purple ftript bulbous Flowerdeluce. 4 Iris bulbofa anguftifolia maior alba. The greater white narrow leafed bulbous Flowerdeluce. 5. Iris bwlbafa angufli folia verficolor. The party coloured narrow leafed bulbous. Flowerdeluce. G. Iris bulbafa anguftifolia Africana. The purple African bulbous narrow leafed Flowerdeluce. 
The Time.

Thefe doe flower vfually in the end of May, or beginning of Iune, and their" feede is ripe in the end of Iuly or Auguit.

\section{The Names.}

Lobel calleth the firf Englinh blew Flowerdeluce, Hyacinthus Poctarum flore Iridis, Eे propter Hyacinthinum colorem, id eft riolaceum diclus: but I know not any great good ground for it, more then the very colour; for it is neither of the forme of a Lilly, neither hath it thofe mourning markes imprinted in it, which the Poet faineth to bee in his Hyacinth. It is moft truely called an Iris, or Flowerdeluce (and there is great difference betweene a Lilly and a Flowerdeluce, for the formes of their flowers) becaufe it anfwereth thereunto very exactly, for the flower, and is therefore called vfually by moft, either Iris bulbofa Anglica, or Iris bulbofa maior fue latifolic, for a difference betweene it, and the leffer with narrow leaues: In Englin, eyther The great Englifh bulbous Flowerdeluce, or the great broad leafed bulbous Flowerdeluce, which you will, adding the other name, according to the colour.

And thus much for thefe broad leafed bulbous Flowerdeluces, fo much as hath come to our knowledge. Now to the feuerall varieties of the narrow leafed bulbous Flowerdeluces, fo much likewife as we haue been acquainted with.

\section{Iris bulbofa minor fiue angufifolia alba.}

The fmaller white or narrow leafed bulbous Flowerdeluce.

This firf Flowerdeluce, which beareth the fmaller flower of the two white ones, that are here to bee defcribed, fpringeth out of the ground alwaies before Winter, which after breaketh forth into foure or fiue fmall and narrow leaues, a foote long or more, of a whitifh greene on the infide, which is hollow and chanalled, and of a blewifh greene colour on the outfide, and round withall: the ftalke of this kinde is longer and flenderer then the former, with fome fhorter leaues vpon it, at the toppe whereof, out of fhort skinny leaues, ftand one or two flowers, fmaller, fhorter, and rounder then the flowers of the former broad leafed Flowerdeluces, but made after the fame proportion with nine leaues, three falling downewards, with a yellow fpot in the middle, other three are made like a long arch, which couer the lower part next the ftalke of thore falling leaues, and turne vp at the ends of them, where they are diuided into two parts: the other three ftand vpright, betweene each of the three falling leaues, being fomewhat long and narrow: the flower is wholly (fauing the yellow fpot) of a pure white colour, yet in fome hauing a thew of fome blew throughout, and in others towards the bottome of the three vpright leaues: after the flowers are paft, there rife vp fo many long cods or feede veffels, as there were flowers, which are longer and fmaller then in the former, and a little bending like a Corner, with three round fquares, and round pointed alfo, which diuiding it felfe when the feede is ripe into three parts, doe thew fix feuerall cells or places, wherein is contained fuch like round reddifh yellow feedes, but fmaller then the former: the roote is fmaller and fhorter then the former, and without any haires or threeds, couered with browne thin skinnes, and more plentifull in giuing encreafe.

\section{Iris bulbofa angufifolia alba flore maiore.}

The greater white narrow leafed bulbous Flowerdeluce.

I thall not neede to make a feuerall defcription to euery one of thefe Flowerdeluces that follow, for that were but to make often repetition of one thing, which being once done, as it is, may well ferue to expreffe all the reft, and but onely to adde the efpe- 
ciall differences, either in leafe or flower, for bigneffe, colour, or forme, as is expedient to expreffe and diftinguifh them feuerally. This greater white bulbous Flowerdeluce is like vnto the laft defcribed in all parts, fauing that it is a little larger and higher, both in leafe, Italke, and flower, and much whiter then any of thefe mixed forts that follow, yet not fo white as the former : the roote hereof is likewife a little bigger and rounder in the middle.

Abeficens. There is another, whofe falling leaues haue a little thew of yellowneffe Milke white. in them, and fo are the middle ridges of the arched leaues, but the vpright leaues are more white, not differing in roote or leafe from the firf white.

Argented. And another, whore falls are of a yellowifh white, like the laft, the arSiluer colour. ched leaues are whiter, and the vpright leaues of a blewifh white, which we call a filuer colour.

Albida. Another hath the fals yellowilh, and fometimes with a little edge of Whition. white about them, and fometimes without; the vpright leaues are whitifh, as the arched leaues are, yet the ridge yellower.

Albida labris Another hath his fals yellow, and the vpright leaues white, all thefe Ineris flowers are about the fame bigneffe with the firft.

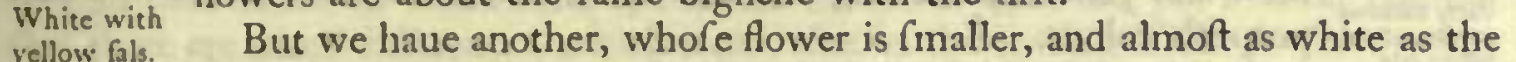
Albida angu- fecond, the lower leaues are fmall, and doe as it were ftand outright, not fior. hauing almoft any fal at all, fo that the yellow fpot feemeth to be the whole The narrow leafe, the arched leaues are not halfe fo large as in the former, and the vp-
white. right leaues bowe themfelues in the middle, fo that the tops doe as it were meete together.

And another of the fame, whofe falling leaues are a little more eminent and yellow, with a yellower fpot.

Aurea fine in- We haue another kinde that is called the Spanifh yellow, which rifeth tes Hifpanica. not vp fo high, as ordinarily molt of the reft doe, and is wholly of a gold The Spanifh yellow colour.
yellow.

yellow.

There is another, that vfually rifeth higher then the former yellow, and Straw colour. is wholly of a pale yellow, but deeper at the fpot.

Abida lusec. There is alfo another like vnto the pale yellow, but that the falling leaues Pale Straw co-are whiter then all the reft of the flower.

lour. There is a fmaller or dwarfe kinde, brought from the backe parts of Barfaus ferotine bary, neare the Sea, like vnto the yellow, but fmaller and lower, and in minor. 1 ftead of vpright leaues, hath fmall fhort leaues like haires: it flowreth very Thefmall Bar- late, after all others haue almoft given their feede.

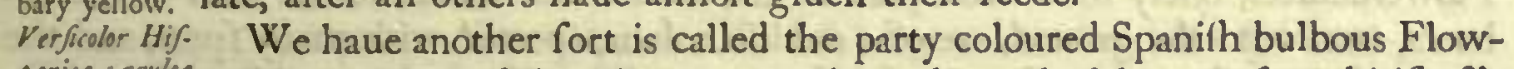
panica cerules erdeluce, whofe falling leaues are white, the arched leaues of a whitith fil-
labris albis. The party co-uer colour, and the vpright leaues of a fine blewilh purple.

loured Span- Yet fometimes this doth vary; for the falling leaues will haue either an Dinerfias. edge of blew, circling the white leaues, the arched leaues being a little The diuerfity blewer, and the vpright leaues more purple.

or variation of Or the fals will be almoft wholly blew, edged with a blewer colour, the
this fowcr. this \&owcr. arched leaues pale blew, and the vpright leaues of a purplifh blew Violet colour.

Or the fals white, the arched leaues pale white, as the vpright leaues are.

Or not of fo faire a blewilh purple, as the firft fort is.

Some of them alfo will haue larger flowers then others, and be more liberall in bearing flowers: for the firt fort, which is the molt ordinary, feldome beareth aboue one flower on a ftalke, yet fometimes two. And of the others there are fome that will beare vfually two and three flowers, yet fome againe will beare but one. All thefe kindes fmell fweeter then many of the Carulea fiue other, although the moft part be without fent.

purpureaminor There is another kinde, that is fmaller in all the parts thereof then the Lufitanicapre-
rox. The fmall two fmall flowers, all wholly of a faire blewifh purple, with a yellow fpot early purple Portugall. 
in euery one of the three falling leaues, this vfually flowreth early, euen with the firft bulbous Flowerdeluces.

Purpurea ma- We haue another purple, whofe flower is larger, and ftalke higher, and ior. is of a very reddifh purple colour, a little aboue the ground, at the foote or The greater bottome of the leaues and ftalke: this flowreth with the later fort of Flow-
purple. erdeluces.

Purpureafero. There is another, whofe flower is wholly purple, except the yellow the late purple. f pot, and flowreth later then any of the other purples.

Purpurea rubef. There is yet another purple, whofe vpright leaues are of a reddifh purcenstabriscaric ple, and the falling leaues of a blew colour.

A reddith purple
with blew fals.

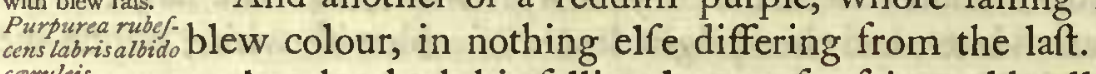

cerreleis. Another hath his falling leaues of a faire gold yellow, without any ftripe, with whititi yet in fome there are veines running through the yellow leaues, and fome Purppurea labris haue an edge of a fullen darke colour about them : the vpright leaues in eParty coloured uery of thefe, are of a Violet purple.
purple \& yellow,

purple \& y yelow, exalbidocerulco Another is altogether like this laft, but that the falling leaues are of a pale

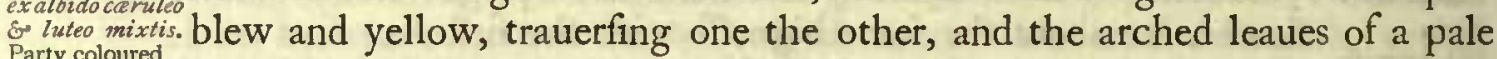
Party coloured
purple with fuript purplifh colour.

Sellow fals.
Subpurvurea Another hath his vpright leaues of a paler purple, and the falling leaues Labris luteis.

yellow fals. And another little differing from it, but that the arched leaues are whitifh.

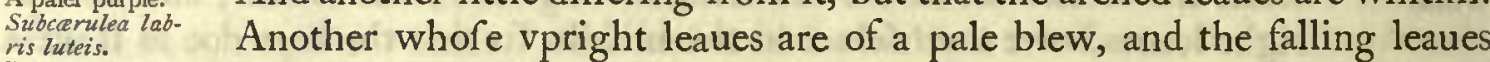
party coloured yellow.

Crinis coloris
eleagnitions. And another of the fame fort, but of a little paler blew.

Aleaire haire co- We haue another fort, whofe vpright leaues are of a faire brownifh yel-
lour. litiera obfle
tior. A dull haire co. falling leaues yellow.

lour.

And another of the fame colour, but fomewhat deader.

\section{Iris bulbofa Africana ferpentria caule.}

The purple or murrey bulbous Barbary Flowerdeluce.

This Flowerdeluce as it is more ftrange (that is, but lately knowne and poffeffed by a few) fo it is both more defired, and of more beauty then others. It is in all refpects, of roote, leafe, and flower, for the forme like vnto the middle fort of thefe Flowerdeluces, onely the loweft part of the leaues and ftalke, for an inch or thereabouts, next vnto the ground, are of a reddifh colour, f potted with many fpots, and the flower, being of a meane fize, is of a deepe purplinh red or murrey colour the whole flower throughout, except the yellow fpot in the middle of the three lower or falling leaues, as is in all others.

Purpureacceru- And laftly, there is another fort, which is the greateft of all thefe narkea obfoletala- row leafed Flowerdeluces, in all the parts of it; for the roote is greater bris fufis. the duskie any of the other, being thicke and fhort: the leaues are broader and party colour- longer, but of the fame colour : the ftalke is ftronger and higher then any of ed purple. them, bearing two or three flowers, larger alfo then any of the reft, whofe falling leaues are of a duskie yellow, and fometimes with veines and borders about the brimmes, of another dunne colour, yet hauing that yellow fpot that is in all : the arched leaues are of a fullen pale purplifh yellow, and the vpright leaues of a dull or duskie blewirh purple colour : the heads or hornes for feede are likewife greater, and fo is the feede alfo a little.

\section{The Place.}

Thefe Flowerdeluces haue had their originall out of Spaine and Portugall, as it is thought, except thofe that haue rifen by the fowing, and thofe which are named of Africa. 
The Time.

Thefe flower in Iune, and fometimes abide vnto Iuly, but vfually not fo early as the former broad leafed kindes, and are foone fpoiled with wet in their flowring.

\section{The Names.}

The feuerall names, both in Latine and Englifh, are fufficient for them as they are fet downe; for we know no better.

The Vertues.

There is not any thing extant or to be heard, that any of thefe kindes of Flowerdeluces hath been vfed to any Phyficall purpofes, and ferue onely to decke vp the Gardens of the curious.

And thus much for thefe forts of bulbous Flowerdeluces, and yet I doubt not, but that there are many differences, which haue rifen by the fowing of the feede, as many may obferue from their owne labours, for that euery yeare doth fhew forth fome variety that is not feene before. And now I will conuert my difcourfe a while likewife, to paffe through the feuerall rankes of the other kindes of tuberous rooted Flowerdeluces, called Flagges.

\section{C н A P. X X.}

\section{Iris latifolia tuberofa. The Flagge or Flowerdeluce.}

T Here are two principall kindes of tuberous or knobby rooted Flowerdeluces, that is, the tall and the dwarfe, or the greater and the leffer; the former called Iris maior or latifolia, and the other Iris minor, or rather Chamairis; and each of thefe haue their leffer or narrow leafed kindes to bee comprehended vnder them: Of all which in their order. And firft of that Flowerdeluce, which for his excellent beautie and raritie, deferueth the firft place.

\section{Iris Chalcedonica fue Sufiana maior. The great Turkie Flowerdeluce.}

The great Turkie Flowerdeluce, hath diuers heads of long and broad frefh greene leaues, yet not fo broad as many other of thofe that follow, one folded within another at the bottome, as all other of thefe Flowerdeluces are : from the middle of fome one of thofe heads (for euery head of leaues beareth not a flower) rifeth vp a round ftiffe ftalke, two foote high, at the toppe whereof ftandeth one flower (for I neuer obferued it to beare two) the largeft almoft, but rareft of all the reft, confifting of nine leaues, like the others that follow, but of the colour almoft of a Snakes skinne, it is fo diuerly fpotted; for the three lower falling leaues are very large, of a deepe or darke purple colour, almoft blacke, full of grayifh fpots, ftrakes, and lines through the whole leaues, with a blacke thrume or freeze in the middle of each of them: the three arched leaues that couer them, are of the fame darke purple colour, yet a little paler at the fides, the three vpper leaues are very large alfo, and of the fame colour with the lower leaues, but a little more liuely and frefh, being fpeckled and ftraked with whiter fpots and lines; which leaues being laid in water, will colour the water into a Violet colour, but if a little Allome be put therein, and then wrung or preffed, and the iuice of thefe leaues dryed in the fhadow, will giue a colour almoft as deepe as Indico, and may ferue for fhawdowes in limming excellent well: the flower hath no fent that can be perceiued, but is onely commendable for the beauty and rarity thereof: it feldome beareth feedes in thefe cold Countries, but when it doth, it is contained in great heads, 
being brownifh and round, but not fo flat as in other forts, the roots are more browne on the outfide, and growing tuberous thicke, as all other that are kept in Gardens.

\section{Iris Chalcedonica fiue Sufiana minor. The leffer Turkie Flowerdeluce.}

There is another hereof little differing, but that the leafe is of a more yellowith greene colour, and the flower neither fo large or faire, nor of fo perfpicuous markes and fpots, nor the colour of that liuely (though darke) luftre.

\section{The Place.}

Thefe haue been fent out of Turkie diuers times among other things, and it Thould feeme, that they haue had their originall from about Sufis, a chiefe Citie of Perfia.

\section{The Time.}

They flower in May moft vfually, before any of the other kindes.

The Names.

They haue been fent vnto vs, and vnto diuers other in other parts, from Conftantinople vnder the name of Alaia Sufiana, and thereupon it hath been called, both of them and vs, either Iris Chalcedonica, or Sufiana, and for diftinction maior or minor: In Englifh, The Turkie Flowerdeluce, or the Ginnie Hen Flowerdeluce, the greater or the leffer.

\section{Iris alba Florentina. The white Flowerdeluce.}

The great white Flowerdeluce, hath many heads of very broad and flat long leaues, enclofing or folding one within another at the bottome, and after a little diuided one from another toward the top, thin edged, like a fword on both fides, and thicker in the middle : from the middle of fome of thefe heads of leaues, rifeth vp a round ftiffe ftalk, two or three foot high, bearing at the top one, two, or three large flowers, out of feuerall huskes or skins, confilting of nine leaues, as all the other do, of a faire white colour, hauing in the middle of each of the three falling leaues, a fmall long yellow frize or thrume, as is moft vfuall in all the forts of the following Flowerdeluces, both of the greater and fmaller kindes: after the flowers are paft, come the feed, inclofed in thicke thort pods, full fraught or ftored with red roundifh and flat feede, lying clofe one vpon another: the roote is tuberous or knobby, fhooting out from euery fide fuch like tuberous heads, lying for the moft part vpon or aboue the ground, and faftened within the ground with long white ftrings or fibres, which hold them ftrongly, and encreafeth

Flore pallido. faft. There is another like vnto this laft in all things, fauing that the colour of the flower is of a more yellowifh white, which we vfually call a Straw colour.

Iris alba maior verficolor. The white party coloured Flowerdeluce.

This variable Flowerdeluce is like vnto the former, but that the leaues are not fo large and broad, the flower hereof is as large almoft, and as white as the former, but it hath a faire lift or line of a blewith purple downe the backe of euery one of the three vpright leaues, and likewife round about the edges, both of the vpper and lower leaues, and alfo a little more purplifh vpon the ridge of the arched leaues, that couer the falling leaues: the roote hereof is not fo great as of the former white, but a little flenderer and browner.

Iris Dalmatica maior. The great Dalmatian Flowerdeluce.

This greater Flowerdeluce of Dalmatia, hath his leaues as large and broad as any of the Flowerdeluces whatfoeuer, his ftalke and flower doe equall his other propor- 
tion, onely the colour of the flower is differing, being of a faire watchet or bleake blew colour wholly, with the yellow frize or thrum downe the middle of the lower or falling leaues, as before is faid to be common to all thefe forts of Flowerdeluces; in all other parts it little differeth, fauing onely this is obferued to haue a fmall fhew of a purplifh red about the bottome of the greene leaues.

\section{Iris purpurea fute vulgaris. The common purple Flowerdeluce.}

This Flowerdeluce, which is moft common in Gardens, differeth nothing at all from thofe that are formerly defcribed, either in roote, leafe, or flower for the forme of them, but onely that the leaues of this are not fo large as the laft, and the flower it felfe is of a deep purple or Violet colour, and fometimes a little declining to redneffe, efpecially in fome places.

Sometimes this kinde of Flowerdeluce will haue flowers of a paler purple colour, Purpurea pat comming neare vnto a blew, and fometimes it will have veines or ftripes of a deeper lidior verficoblew, or purple, or afh-colour, running through all the vpper and lower leaues.

There is another like vnto this, but more purple in the fals, and more pale in the Carulea labr vpright leaues.

\section{Iris Afiatica carulea. The blew Flowerdeluce of Afia.}

This Flowerdeluce of Afia, is in largeneffe of leaues like vnto the Dalmatian, but beareth more ftore of flowers on feuerall branches, which are of a deeper blew colour, and the arched leaues whitifh on the fide, and purplifh on the ridges, but in other things like vnto it.

There is another neare vnto this, but that his leaues are a little narrower, and his Purpurea. flowers a little more purple, ef pecially the vpper leaues.

\section{Iris Damafcena. The Flowerdeluce of Damafco.}

This is likewife altogether like the Flowerdeluce of Afia, but that it hath fome white veines in the vpright leaues.

\section{Iris Lufitanica biffora. The Portugall Flowerdeluce.}

This Portugall Flowerdeluce is very like the common purple Flowerdeluce, but that this is not fo large in leaues, or flowers, and that it doth often flower twice in a yeare, that is, both in the Spring, and in the Autumne againe, and befides, the flowers haue a better or fweeter fent, but of the like purple or Violet colour as it is, and comming forth out of purplifh skins or huskes.

\section{Iris Camerarij fiue purpurea verficolor maior.}

The greater variable coloured purple Flowerdeluce.

The greater of the variable purple Flowerdeluces, hath very broad leaues, like vnto the leaues of the common purple Flowerdeluce, and fo is the flower alfo, but differing in colour, for the three lower leaues are of a deepe purple colour tending to redneffe, the three arched leaues are of the colour with the vpper leaues, which are of a pale or bleake colour tending to yellowneffe, fhadowed ouer with a fmoakie purplifh colour, except the ridges of the arched leaues, which are of a more liuely purple colour.

\section{Iris purpurea verficolor minor. The leffer variable purple Flowerdeluce.}

This Flowerdeluce differeth not in any thing from the laft, but onely that it hath narrower greene leaues, and fmaller and narrower flowers, elfe if they be both conferred together, the colours will not feeme to varie the one from the other any whit at all.

There is another fomewhat neare vnto thefe two laft kindes, whofe huskes from Altera minus whence fuliginea. 
whence the flowers doe fhoote forth, haue purple veines in them, and fo have the falling purplifh leaues, and the three vpright leaues are not fo fmoakie, yet of a dun purple colour.

\section{Iris cerulea verficolor. The blew party coloured Flowerdeluce.}

This party coloured Flowerdeluce hath his leaues of the fame largeneffe, with the leffer variable purple Flowerdeluce laft defcribed, and his flowers diuerny marked: for fome have the fals blew at the edges, and whitifh at the bottome, the arched leaues of a yellowin white, and the vpright leaues of a whitifh blew, with yellowifh edges. Some againe are of a darker blew, with brownifh fpots in them. And fome are fo pale a blew, that we may well call it an afh-colour: And laftly, there is another of this fort, whofe vpright leaues are of a faire pale blew, with yellowifh edges, and the falling leaues parted into two colours, fometimes equally in the halfe, each fide futable to the other in colour: And fometimes hauing the one leafe in that manner: And fometimes but with a diuers coloured lift in them; in the other parts both of flower and leafe, like vnto the other.

\section{Iris lutea variegata. The yellow variable Flowerdeluce.}

This yellow variable Flowerdeluce lofeth his leaues in Winter, contrary to all the former Flowerdeluces, fo that his roote remaineth vnder ground without any fhew of leafe vpon it: but in the beginning of the Spring it thooteth out faire broad leaues, falling downwards at the points or ends, but fhorter many times then any of the former, and fo is the ftalke likewife, not rifing much aboue a foote high, whereon are fet two or three large flowers, whofe falling leaues are of a reddifh purple colour, the three that ftand vpright of a fmoakie yellow, the arched leaues hauing their ridges of a bleake colour tending to purple, the fides being of the former fmoakie yellow colour, with fome purplifh veines at the foote or bottome of all the leaues: the roote groweth fomewhat more flender and long vnder ground, and of a darker colour then manie of the other.

Another fort hath the vpright leaues of a reafonable faire yellow, and ftand more vpright, not bowing downe as moft of the other, and the purple fals haue pale edges. Some haue their greene leaues party coloured, white and greene, more or leffe, and fo are the huskes of the flowers, the arched leaues yellow, as the vpright leaues are, with purplifh veines at the bottome. And fome haue both the arched and vpright leaues of fo pale a yellow, that we may almoft call it a ftraw colour, but yellower at the bottome, with purple veines, and the falling leaues purple, with two purple fpots in them.

And thefe are the forts of the greater tuberous or Flagge Flowerdeluces that haue come to our knowledge: the next hereunto are the leffer or narrow leafed kindes to be defcribed; and firft of the greateft of them.

\section{Iris angufifolia Tripolitana aurea. The yellow Flowerdeluce of Tripoly.}

This Flowerdeluce I place in the forefront of the narrow leafed Flowerdeluces, for the length of the leaues, compared with the breadth of them; it may fitly bee called a narrow leafed Flowerdeluce, although they be an inch broad, which is broader then any of them that follow, or fome of thofe are fet downe before, but as I faid, the length make them feem narrow, and therefore let it take vp his roome in this place, with the defcription that followeth. It beareth leaues a yard long, or not much leffe, and an inch broad, as is faid before, or more, of a fad greene colour, but not fhining: the ftalke rifeth vp to be foure or fiue foote high, being ftrong and round, but not very great, bearing at the toppe two or three long and narrow gold yellow flowers, of the fafhion of the bulbous Flowerdeluces, as the next to bee defcribed is, without any mixture or variation therein: the heads for feede are three fquare, containing within them many flat cornered feedes: the roote is long and blackifh, like vnto the reft that follow, but greater and fuller. 


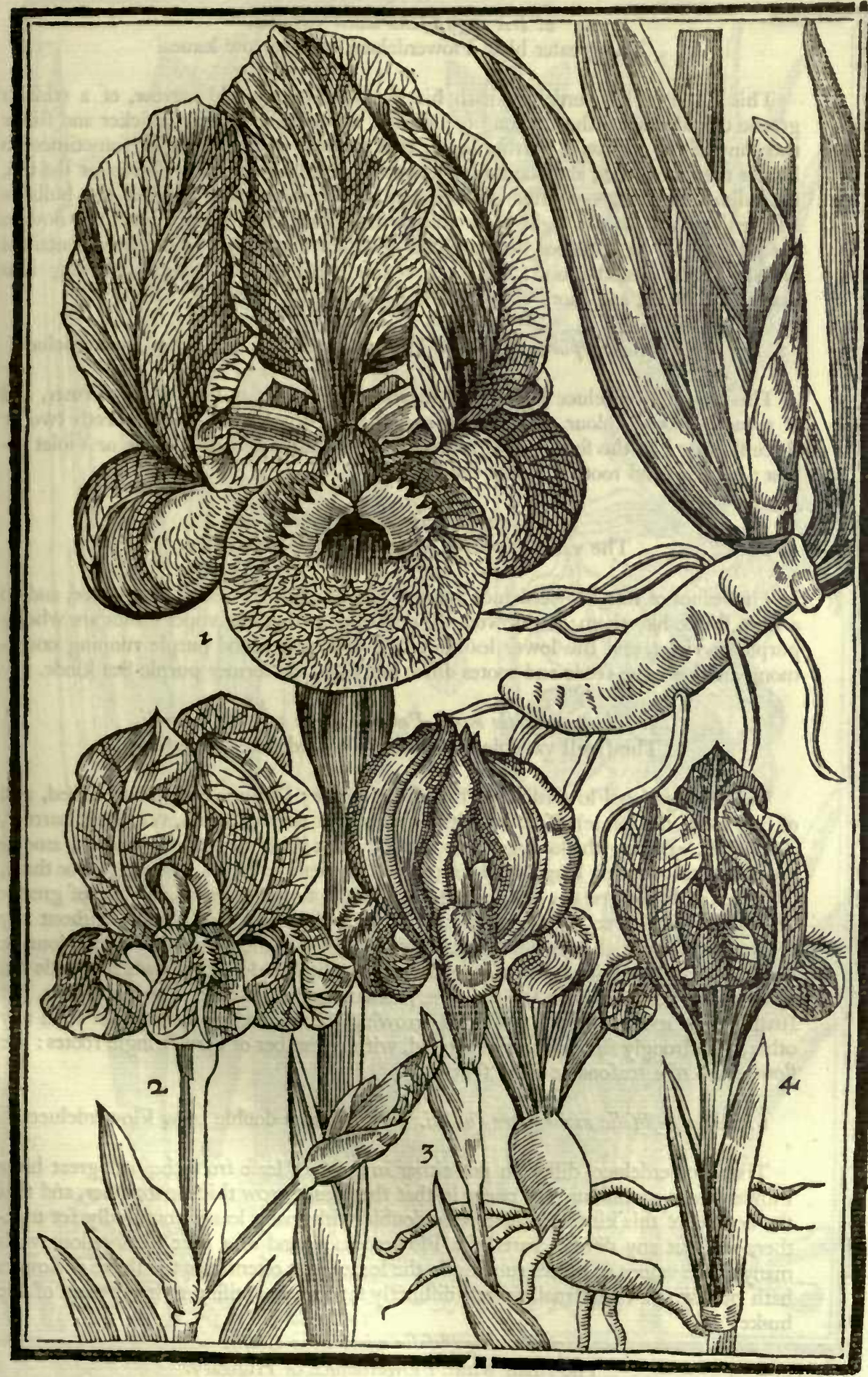

I Iris Chalcedonica fiue Sufiana maior. The great Turkie Flowerdeluce. latifolia zariegata. The variable Flowerdeluce. 


\section{Iris anguffifolia maior carulea.}

The greater blew Flowerdeluce with narrow leaues.

This kinde of Flowerdeluce hath his leaues very long and narrow, of a whitin greene colour, but neither fo long or broad as the lant, yet broader, thicker and ftiffer then any of the reft with narrow leaues that follow: the ftalke rifeth fometimes no higher then the leaues, and fometimes a little higher, bearing diuers flowers at the top, fucceffiuely flowring one after another, and are like vnto the flowers of the bulbous Flowerdeluces, but of a light blew colour, and fometimes deeper: after the flowers are paft, rife vp fix cornered heads, which open into three parts, wherein is contained browne feede, almoft round: the roote is fmall, blackin and hard, fpreading into many long heads, and more clofely growing or matting together.

\section{Iris anguftifolia purpurea marina. The purple narrow leafed Sea Flowerdeluce.}

This Sea Flowerdeluce hath many narrow hard leaues as long as the former, and of a darke greene colour, which doe fmell a little ftrong: the ftalke beareth two or three flowers like the former, but fomewhat leffe, and of a darke purple or Violet colour : in feede and roote it is like the former.

\section{Iris anguffifolia purpurea verficolor.}

The variable purple narrow leafed Flowerdeluce.

The leaues of this Flowerdeluce are very like the former Sea Flowerdeluce, and do a little ftinke like them; the flowers are differing, in that the vpper leaues are wholly purple or violet, and the lower leaues haue white veines, and purple running one among another: the feede and rootes differ not from the former purple Sea kinde.

\section{Iris anguffifolia minor Pannonica fiue verficolor Clufij.}

The fmall variable Hungarian Flowerdeluce of Clufius.

This Hungarian Flowerdeluce (firft found out by Clufius, by him defcribed, and of him tooke the name) rifeth vp with diuers (mall tufts of leaues, very long, narrow, and greene, growing thicke together, ef pecially if it abide any time in a place; among which rifeth vp many long round ftalkes, higher then the leaues, bearing two or three, or foure fmall flowers, one aboue another, like the former, but fmaller and of greater beauty: for the lower leaues are variably ftriped with white and purple, without any thrume or fringe at all; the vpper leaues are of a blewinh fine purple or Violet colour, \& fo are the arched leaues, yet hauing the edges a little paler: the heads for feede are fmaller, and not fo cornered as the other, containing feedes much like the former, but fmaller: the roote is blacke and fmall, growing thicker and clofer together then any other, and ftrongly faftened in the ground, with a number of hard ftringie rootes: the flowers are of a reafonable good fent.

\section{Iris anguffifolia maior flore duplici. The greater double blew Flowerdeluce.}

This Flowerdeluce, differeth not either in roote or leafe from the firft great blew Flowerdeluce of Clufius, but onely in that the leaues grow thicker together, and that the flowers of this kinde are as it were double with many leaues confuredly fet together, without any diftinct parts of a Flowerdeluce, and of a faire blew colour with many white veines and lines running in the leaues; yet oftentimes the ftalke of flowers hath but two or three fmall flowers diftinctly fet together, rifing as it were out of one huske.

7. Iris angufifolia minor alba Clufij.

The fmall white Flowerdeluce of Hungary.

This likewife differeth little from the former Hungarian Flowerdeluce of Clufius, 


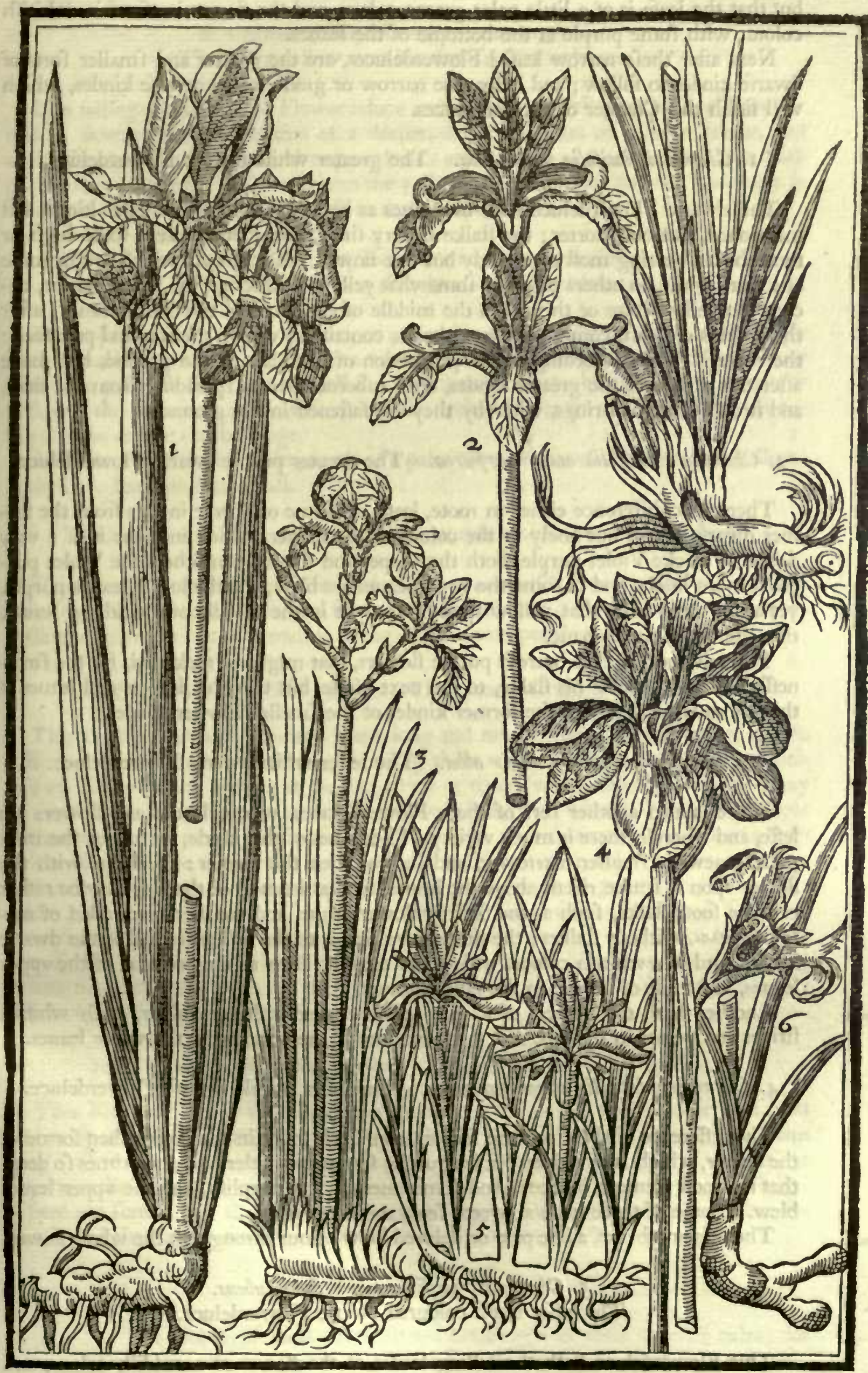

Iris angm flifolia Tripolitana. The yellow Flowerdeluce of Tripoli. 2 Iris anguftifolia maior carvlen. The greater blew Flow. eideluce with narrow luce of Clufius. \& Iris angwfifolia maior pore duplici. The greater double blew Fowerdeluce. 5 Chamairis angwfifolia minnr. The leffer Grafte Filowerdeluce. I I ris tuberofa. The veluet Flowerdeluce. 
but that the leafe is of a little paler greene colour, and the flower is of a faire whitifh colour, with fome purple at the bottome of the leaues.

Next after thefe narrow leafed Flowerdeluces, are the greater and fmaller forts of dwarfe kindes to follow; and laftly, the narrow or graffe leafed dwarfe kindes, which will finifh this Chapter of Flowerdeluces.

\section{Chamairis latifolia maior alba. The greater white dwarfe Flowerdeluce.}

This dwarfe Flowerdeluce hath his leaues as broad as fome of the leffer kindes laft mentioned, but not Thorter; the ftalke is very fhort, not aboue halfe a foote high or thereabouts, bearing moft commonly but one flower, feldome two, which are in fome of a pure white, in others paler, or fomewhat yellowifh through the whole flower, except the yellow frize or thrume in the middle of euery one of the falling leaues: after the flowers are paft, come forth great heads, containing within them round pale feed: the roote is fmall, according to the proportion of the plant aboue ground, but made after the fafhion of the greater kindes, with tuberous peeces fpreading from the fides, and ftrong fibres or ftrings, whereby they are faftened in the ground.

\section{Chamairis latifolia maior purpurea. The greater purple dwarfe Flowerdeluce.}

There is no difference either in roote, leafe, o: forme of flower in this from the former dwarfe kinde, but onely in the colour of the flower, which in fome is of a very deepe or blacke Violet purple, both the toppes and the fals: in others the Violet purple is more liuely, and in fome the vpper leaues are blew, and the lower leaues purple, yet all of them haue that yellow frize or thrume in the middle of the falling leaues, that the other kindes haue.

There is another that beareth purple flowers, that might be reckoned, for the fmalneffe and fhortneffe of his ftalke, to the next kinde, but that the flowers and leaues of this are as large as any of the former kindes of the fmaller Flowerdeluces.

\section{Chamairis latifolia minor alba. The leffer white dwarfe Flowerdeluce.}

There is alfo another fort of thefe Flowerdeluces, whofe leaues and flowers are leffe, and wherein there is much variety. The leaues of this kinde, are all for the moft part fomewhat fmaller, narrower, and fhorter then the former: the ftalke with the flower vpon it farce rifeth above the leaues, fo that in moft of them it may be rather called a foote-ftalke, fuch as the Saffron flowers haue, and are therefore called of manie äkaviou, without ftalkes; the flowers are like vnto the firft defcribed of the dwarfe kindes, and of a whitifh colour, with a few purplifh lines at the bottome of the vpper leaues, and a lift of greene in the falling leaues.

Another hath the flowers of a pale yellow, called a Straw colour, with whitifh ftripes and veines in the fals, and purplifh lines at the bottome of the vpper leaues.

\section{Chamairis latifolia minor purpurea. The leffer purple dwarfe Flowerdeluce.}

The difference of this from the former, confifteth more in the colour then forme of the flower, which is of a deep Violet purple, fometimes paler, and fometimes fo deep, that it almoft feemeth blacke: And fometimes the fals purplifh, and the vpper leaues blew. Some of thefe haue a fweete fent, and fome none.

Garulea. There is another of a fine pale or delayed blew colour throughout the whole flower.

\section{Chamairis latifolia minor. fuauerubens.}

The leffer blun coloured dwarfe Flowerdeluce.

This Flowerdeluce hath the falling leaues of the flower of a reddifh colour, and the thrumes blew: the vpper and arched leaues of a fine pale red or fleth colour, called a blufh colour; in all other things it differeth not, and fmelleth little or nothing at all. 


\section{Chameiris latifolia minor lutea verficolor.}

The leffer yellow variable dwarfe Flowerdeluce.

The falling leaues of this Flowerdeluce are yellowifh, with purple lines from the middle downewards, fometimes of a deeper, and fometimes of a paler colour, and white thrumes in the middle, the vpper leaues are likewife of a yellowifh colour, with purple lines in them: And fometimes the yellow colour is paler, and the lines both in the vpper and lower leaues of a dull or dead purple colour.

\section{Chamairis latifolia minor carulea verficolor.}

The leffer blew variable dwarfe Flowerdeluce.

The vpper leaues of this flower are of a blewifh yellow colour, fpotted with purple in the broad part, and at the bottome very narrow: the falling leaues are fpread ouer with pale purplifh lines, and a fmall fhew of blew about the brimmes: the thrume is yellow at the bottome, and blewifh aboue : the arched leaues are of a blewifh white, being a little deeper on the ridge.

And fometimes the vpper leaues are of a paler blew rather whitifh, with the yellow: both thefe haue no fent at all.

\section{Chameiris marina purpurea. The purple dwarfe Sea Flowerdeluce.}

This fmall Flowerdeluce is like vnto the narrow leafed Sea Flowerdeluce before defcribed, both in roote, leafe, and flower, hauing no other difference, but in the fmalneffe and lowneffe of the growing, being of the fame purple colour with it.

\section{Chameiris anguftifolia maior. The greater Graffe Flowerdeluce.}

This Graffe Flowerdeluce hath many long and narrow darke greene leaues, not fo ftiffe as the former, but lither, and bending their ends downe againe, among which rife vp diuers ftalkes, bearing at the toppe two or three fweete flowers, as fmall as any of them fet downe before, of a reddifh purple colour, with whitifh yellow and purple ftrakes downe the middle of the falling leaues: the arched leaues are of a horfe flefh colour all along the edges, and purple vpon the ridges and tips that turne vp againe: vnder thefe appeare three browne aglets, like vnto birds tongues: the three vpper leaues are fmall and narrow, of a perfect purple or Violet colour : the heads for feede have fharper and harder cornered edges then the former: the feedes are fomewhat grayifh like the former, and fo are the rootes, being fmall, blacke, and hard, growing thicke together, faftened in the ground with fmall blackifh hard ftrings, which hardly fhoote againe if the roote be remoued.

\section{Iо. Chamairis anguftifolia minor. The leffer Graffe Flowerdeluce.}

This Flowerdeluce is in leaues, flowers, and rootes fo like the laft defcribed, that but onely it is fmaller and lower, it is not to be diftinguifhed from the other. And this may fuffice for thefe forts of Flowerdeluces, that furnifh the Gardens of the curious louers of thefe varieties of nature, fo farre forth as hath paffed vnder our knowledge. There are fome other that may be referred hereunto, but they belong to another hiftory; and therefore I make no mention of them in this place.

\section{The Place.}

The places of moft of thefe are fet downe in their feuerall titles; for fome are out of Turkie, others out of Hungaria, Dalmatia, Illyria, \&c. as their names doe import. Thofe that grow by the Sea, are found in Spaine and France. 
The Time.

Some of thefe do flower in Aprill, fome in May, and fome not vntill Iune.

The Names.

The names expreffed are the fitteft agreeing vnto them, and therefore it is needleffe againe to repeate them. Many of the rootes of the former or greater kindes, being dryed are fweete, yet fome more then other, and fome haue no fent at all: but aboue all the reft, that with the white flower, called of Florence, is accounted of all to be the fweeteft root, fit to be vfed to make fweete powders, \&c. calling it by the name of Orris rootes.

\section{Iris tuberofa. The Veluet Flowerdeluce.}

Vnto the Family of Flowerdeluces, I muft needes ioyne this peculiar kinde, becaufe of the neare refemblance of the flower, although it differ both in roote and leafe; left therefore it fhould haue no place, let it take vp a roome here in the end of the Flowerdeluces, with this defcription following. It hath many fmall and foure fquare leaues, two foote long and aboue fometimes, of a grayilh greene colour, ftiffe at the firft, but afterwards growing to their full length, they are weak and bend downe to the ground: out of the middle, as it were of one of thefe leaues, breaketh out the ftalke, a foot high and better, with fome leaues thereon, at the toppe whereof, out of a huske rifeth one flower, (I neuer faw more on a ftalke) confifting of nine leaues, whereof the three that fall downe are of a yellowifh greene colour round about the edges, and in the middle of fo deepe a purple, that it feemeth to be blacke, refembling blacke Veluet : the three arched leaues, that couer the lower leaues to the halfe, are of the fame greenifh colour that the edges and backfide of the lower leaues are: the three vppermoft leaues, if they may be called leaues, or rather fhort peeces like eares, are green alfo, but wherein a glimpfe of purple may be feene in them: after the flower is paft, there followeth a round knob or whitifh feede veffell, hanging downe by a fmall foote-ftalke, from betweene the huske, which is diuided as it were into two leaues, wherein is contained round white feede. The roote is bunched or knobbed out into long round rootes, like vnto fingers, two or three from one peece, one diftant from another, and one longer then another, for the moft part of a darkifh gray colour, and reddifh withall on the outfide, and fomewhat yellowifh within.

\section{The Place.}

It hath beene fent out of Turkie oftentimes (as growing naturally thereabouts) and not knowne to grow naturally any where elfe.

\section{The Time.}

It flowreth in Aprill or May, fometimes earlier or later, as the Spring falleth out to be milde or fharpe.

\section{The Names.}

Matthiolus contendeth to make it the true Hermodactylus, rather from the fhew of the rootes, which (as is faid) are like vnto fingers, then from any other good reafon: for the rootes hereof eyther dry or greene, do nothing refemble the true Hermodactyli that are vfed in Phyficke, as any that knoweth them may eafily perceiue, either in forme or vertue. It is more truely referred to the Flowerdeluces, and becaufe of the tuberous rootes, called Iris tuberofa, although all the Flowerdeluces in this Chapter haue tuberous

rootes, 
rootes, yet this much differing from them all. In Englifh it is vfually called, The Veluet Flowerdeluce, becaufe the three falling leaues feeme to be like finooth blacke Veluet.

\section{The Vertues.}

Both the rootes and the flowers of the great Flowerdeluces, are of great vfe for the purging and cleanfing of many inward, as well as outward difeafes, as all Authors in Phyficke doe record. Some haue vfed alfo the greene rootes to cleanfe the skinne, but they had neede to be carefull that vfe them, left they take more harme then good by the vfe of them. The dryed rootes called Orris (as is faid) is of much vfe to make fweete powders, or other things to perfume apparrell or linnen. The iuice or decoction of the green roots doth procure both neezing to be fnuft vp into the noftrils, and vomiting very ftrongly being taken inwardly.

С н A P. X X I.

\section{Gladiolus. Corne Flagge.}

$\mathrm{N}$ Ext vnto the Flagges or Flowerdeluces, come the Gladioli or Corne Flagges to bee entreated of, for fome refemblance of the leaues with them. There are hereof diuers forts, fome bigger and fome leffer, but the chiefeft difference is in the colour of the flowers, and one in the order of the flowers. Of them all in their feuerall orders.

\section{Gladiolus narbonen/is. The French Corne Flagge.}

The French Corne Flagge rifeth vp with three or foure broad, long, and ftiffe greene leaues, one as it were out of the fide of another, being ioyned together at the bottome, fomewhat like, vnto the leaues of Flowerdeluces, but ftiffer, more full of ribbes, and longer then many of them, and tharper pointed: the ftalke rifeth vp from among the leaues, bearing them on it as it rifeth, hauing at the toppe diuers huskes, out of which come the flowers one aboue another, all of them turning and opening themfelues one way, which are long and gaping, like vnto the flowers of Foxegloue, a little arched or bunching vp in the middle, of a faire reddifh purple colour, with two white fpots within the mouth thereof, one on each fide, made like vnto a Lozenge that is fquare and long pointed: after the flowers are paft, come vp round heads or feede veffels, wherein is contained reddifh flat feede, like vnto the feece of the Fritillaria, but thicker and fuller : the roote is fomewhat great, round, flat, and hard, with a fhew as if it were netted, hauing another thort fpongie one vnder it, which when it hath done bearing, and the ftalke dry, that the roote may be taken vp, fticketh clofe to the bottome, but may be eafily taken away, hauing vfually a number of fmall rootes encreafed about it, the leaft whereof will quickly grow, fo that if it be fuffered any long time in a Garden, it will rather choake and pefter it, then be an ornament vnto it.

\section{Gladiolus Italicus binis foribus ordinibus. The Italian Corne Flagge.}

The Italian Corne Flagge is like vnto the French in roote, leafe, and flower, without any other difference, then that the roote is fmaller and browner, the leafe and ftalke of a darker colour, and the flowers (being of a little darker colour like the former, and fomewhat fmaller) ftand out on both fides of the ftalke.

\section{Gladiolus Byzantinus. Corne Flagge of Conftantinople.}

This Corne Flagge that came firft from Conftantinople, is in all things like vnto the French Corne Flagge laft defcribed, but that it is larger, both in rootes, leaues, and 
flowers, and likewife that the Flowers of this, which ftand not on both fides, are of a deeper red colour, and flower later, after all the reft are paft: the roote hereof being netted as plainly as any of the former, is as plentifull alfo to giue encreafe, but is more tender and leffe able to abide our fharpe cold Winters.

\section{Gladiolus flore rubente. Blufh Corne Flagge.}

This blufh kinde is like vnto the French Corne Flagge in all refpects, fauing onely that the flowers are of a pale red colour, tending to whiteneffe, which wee vfually call a blufh colour.

\section{Gladiolus flore albo. White Corne Flagge.}

This white Corne Flagge alfo differeth not from the laft, but onely that the rootes are whiter on the outfide, the leaues are greener, without any browneffe or darkneffe as in the former, and the flowers are fnow white.

\section{Gladiolus purpureus minor. The fmall purple Corne Flagge.}

This alfo differeth not from any of the former, but onely in the fmallneffe both of leafe, ftalke, and flowers, which ftand all on the one fide, like vnto the French kinde, and of the fame colour: the roote of this kinde is netted more then any other.

The Place.

They grow in France and Italy, the leaft in Spaine, and the Byzantine, as it is thought, about Conftantinople, being (as is faid) firft fent from thence. Iohn Tradefcante affured mee, that hee faw many acres of ground in Barbary fpread ouer with them.

The Time. fore.

They all flower in Iune and Iuly, and the Byzantine lateft, as is faid be-

The Names.

It hath diuers names; for the Latines call it Gladiolus, of the forme of a fword, which the leafe doth refemble. The Romanes Segetalis, becaufe it groweth in the Corne fields. Some call it Victorialis rotunda, to put a difference between it, and the longa, which is a kinde of Garlicke. Plinie faith, that Gladiolus is Cypirus, but to decide that controuerfie, and many others, belongeth to another difcourfe, this being intended only for pleafure. Gerrard miftaketh the French kinde for the Italian.

\section{The Vertues.}

The roote being bruifed, and applyed with Frankinfenfe (and often of it (elfe without it) in the manner of a pultis or plaifter, is held of diuers to be fingular good to draw out fplinters, thornes, and broken bones out of the flefh. Some take it be effectuall to Ptirre vp Venerie, but I fomewhat doubt thereof: For Galen in his eighth Booke of Simples, giueth vnto it a drawing, digefting and drawing faculty. 


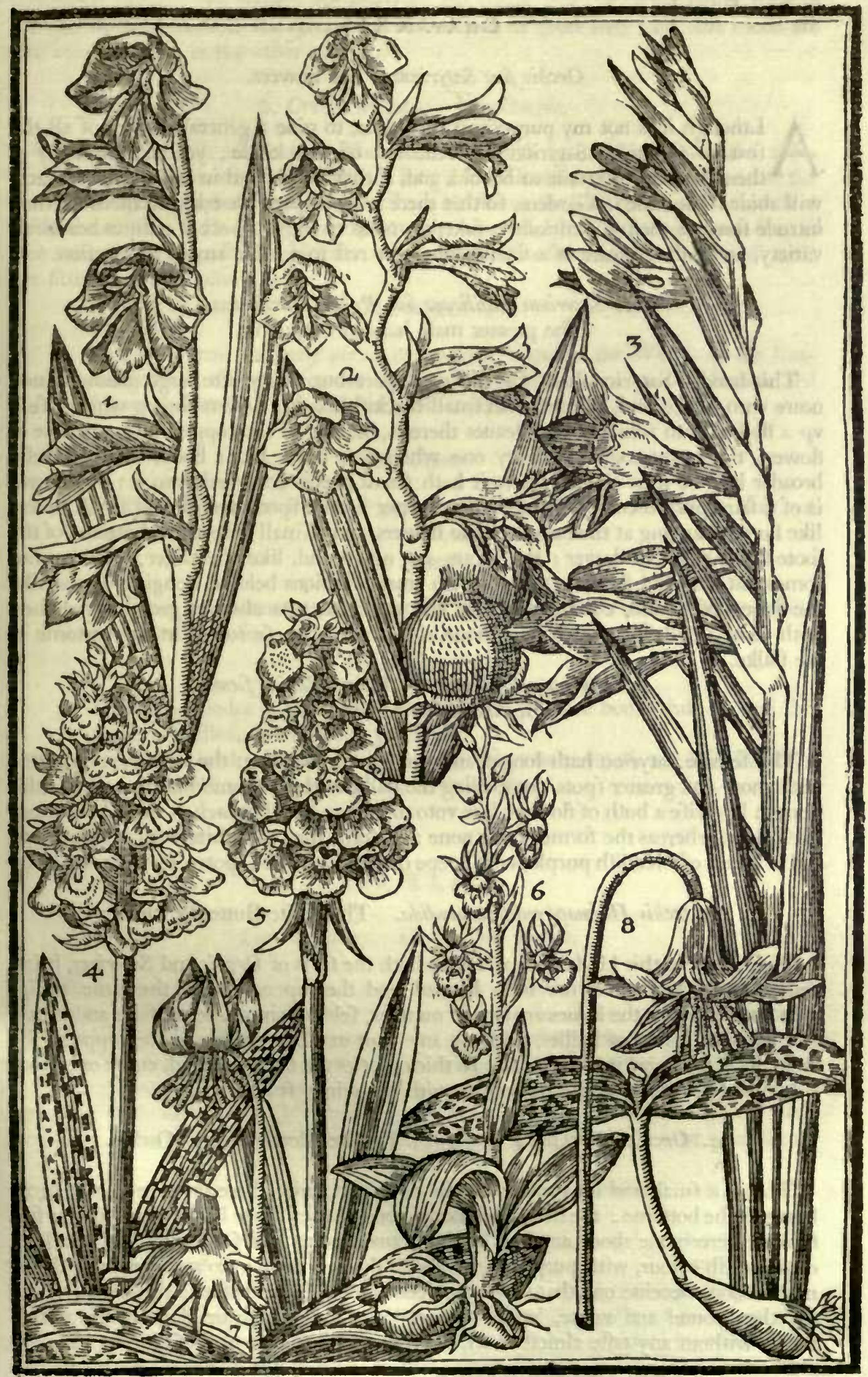

Gladiolus Norbonenfis. The French Corne Flagge. 2 Gladiolus Italicuss. The Italian Corne Flagge. 3 Gladiolus Brzan. linus. Corne Flagge of Conftantinople. ${ }_{4}$ Palma Chrifti mas. The great male handed Satyrion. 5 Orchis Hermaphroditicn candida. The white Butterflie Orchis. 6 Orchis Melitias fiue apifera. The Bee flower or Bee Orehis. 7 Dens Caninus fore purpurante. Dogges tooth Violet with a pale purplith fower. 8 Dens Caninus flore albo. Dogges tooth Violet with a white flower, 


\section{Cн A P. X X I I.}

\section{Orchis fiue Satyrium. Bee flowers.}

A Lthough it is not my purpofe in this place, to giue a generall hiftory of all the forts of Orchides, Satyrions, and the reft of that kinde; yet becaure many of them are very pleafant to behold, and, if they be planted in a conuenient place, will abide fome time in Gardens, fo that there is much pleafure taken in them : I thall intrude fome of them for curiofities fake, to make vp the profpect of natures beautifull variety, and only entreate of a few, leauing the reft to a more ample declaration.

\section{Satyrium Bafilicum fiue Palma Chrifi mas.}

The greater male handed Satyrion.

This handed Satyrion hath for the molt part but three faire large greene leaues, neare vnto the ground, fpotted with fmall blackifh markes : from among which rifeth vp a ftalke, with fome fmaller leaues thereon, bearing at the toppe a bufh or fpike of flowers, thicke fet together, euery one whereof is made like a body, with the belly broader belowe then aboue, where it hath fmall peeces adioyned vnto it : the flower is of a faire purple colour, fpotted with deeper purple fpots, and hauing fmall peeces like hornes hanging at the backes of the flowers, and a fmall leafe at the bottome of the foote-ftalke of euery flower: the rootes are not round, like the other Orchides, but fomewhat long and flat, like a hand, with fmall diuifions belowe, hanging downe like the fingers of a hand, cut fhort off by the knockles, two alwayes growing together, with fome fmall fibres or ftrings aboue the heads of thefe rootes, at the bottome of the ftalke.

\section{Satyrium Bafilicum fue Palma Chrift fremina.}

The female handed Satyrion.

This female Satyrion hath longer and narrower leaues then the former, and fpotted with more and greater fpots, compafing the ftalke at the bottome like the other : this beareth likewife a burh of flowers, like vnto the other, but that each of thefe haue heads like hoods, whereas the former haue none : in fome they are white with purple fpots, and in others of a reddifh purple, with deepe or darke coloured fpots : the roots are alike.

\section{Orchis Hermaphroditica candida. The white Butterflie Orchis.}

The rootes of this kinde take part with both the forts of Orchis and Satyrium, being neither altogether round, nor fully handed, and thereupon it tooke the name, to fignifie both kindes: the leaues are two in number, feldome more, being faire and broad, like vnto the leaues of Lillies, without any fpot at all in them : at the toppe of the ftalke ftand many white flowers, not fo thicke fet as the firft or fecond, euery one being fahioned like vnto a white Butterflie, with the wings fpread abroad.

\section{Orchis Melitias fiue apifera. The Bee flower or Bee Orchis.}

This is a fmall and lowe plant for the moft part, with three or foure fmall narrow leaues at the bottome : the ftalke is feldome aboue halfe a foote high, with foure or fiue flowers thereon one aboue another, hauing round bodies, and fomewhat flat, of a kind of yellowifh colour, with purple wings aboue them, fo like vnto an honey Bee, that it might foone deceiue one that neuer had feene fuch a flower before : the roots are two together, round and white, hauing a certaine muccilagine fe or clammineffe within them, without any tafte almoft at all, as all or the moft part of thefe kindes haue.

\section{Orchis Sphegodes. Gnats Satyrion.}

The leaues of this Orchis are fomewhat larger then of the Bee flower, the ftalke alfo fomewhat 
fomewhat higher: the flowers are fewer on the toppe, but fomewhat larger then of the Bee flowers, made to the refemblance of a Gnat or great long Flie : the rootes are two round bulbes, as the other are.

\section{Orchis Myodes. Flie Orchis.}

The Flie Orchis is like vnto the laft defcribed, both in leafe and roote, the difference is in the flower, which is neither fo long as the Gnat Satyrion, nor fo great as the Bee Orchis, but the neather part of the Flie is blacke, with a lift of afh-colour croffing the backe, with a fhew of legges hanging at it: the naturall Flie feemeth fo to bee in loue with it, that you fhall feldome come in the heate of the day, but you fhall finde one fitting clofe thereon.

\section{The Place.}

Thefe grow in many places of England, fome in the Woods, as the Butterflie, and the two former handed Satyrions: others on dry bankes and barren balkes in Kent, and many other places.

\section{The Time.}

They flower for the moft part in the beginning or middle of May, or thereabouts.

The Names.

Their feuerall names are expreffed in their titles, fo much as may fuffice for this difcourfe.

\section{The Vertues.}

All the kindes of Orchis are accounted to procure bodily luft, as well the flowers diftilled, as the rootes prepared.

The rootes boyled in red Wine, and afterwards dryed, are held to bee a fingular good remedie againft the bloody Flixe.

\section{Ch A P. X X I I I.}

\section{Dens Caninus. Dogs tooth Violet.}

$\mathrm{V}$ Nto the kindes of Orchides, may fitly be ioyned another plant, which by many is reckoned to be a Satyrium, both from the forme of roote and leafe, and from the efficacy or vertue correfpondent thereunto. And although it cannot be the Satyrium Erythronium of Diofcorides, as fome would entitle it, for that as I haue fhewed before, his Satyrium tryphillum is the Tulipa without all doubt; yet becaufe it differeth very notably, and carrieth more beauty and refpect in his flower then they, I thall entreate thereof in a Chapter by it felfe, and fet it next vnto them.

\section{Dens Caninus flore albo. Dogs tooth Violet with a white flower.}

The white Dogs tooth hath for his roote a white bulbe, long and fmall, yet vfually greater then either of the other that follow, bigger belowe then aboue, with a fmall peece adioyning to the bottome of it, from whence rife vp in the beginning of the Spring, after the Winter frofts are paft, two leaues for the moft part (when it will flower, or elfe but one, and neuer three together that euer I faw) clofed together when they firft come vp out of the ground, which inclofe the flower betweene them: the leaues when they are opened do lay themfelues flat on the ground, or not much aboue it, one oppofite vnto the other, with the ftalke and the flower on it ftanding betweene them, which leaues are of a whitifh greene colour, long and narrow, yet broader in the 
middle then at both ends, growing leffe by degrees each way, fpotted and ftriped all ouer the leaues with white lines and fpots: the ftalke rifeth vp halfe a foote high or more, bearing at the toppe one flower and no more, hanging downe the head, larger then any of the other of this kinde that follow, made or confifting of fix white long and narrow leaues, turning themfelues vp againe, after it hath felt the comfort of the Sunne, that they doe almoft touch the ftalke againe, very like vnto the flowers of $C y$ clamen or Sowebread: it hath in the middle of the flower fix white chiues, tipt with darke purple pendents, and a white three forked ftile in the middle of them: the flower hath no fent at all, but commendable onely for the beauty and forme thereof: after the flower is paft, commeth in the place a round head feeming three fquare, containing therein fmall and yellowifh feede.

\section{Dens Caninus flore purpurafcente. Dogs tooth with a pale purple flower.}

This other Dogs tooth is like vnto the former, but leffer in all parts, the leafe whereof is not fo long, but broad and fhort, fpotted with darker lines and fpots: the flower is like the other, but fmaller, and of a delayed purple colour, very pale fometimes, and fometimes a little deeper, turning it felfe as the other, with a circle round about the vmbone or middle, the chiues hereof are not white, but declining to purple: the roote is white, and like vnto the former, but leffer, as is faid before.

\section{Dens Caninus flore rubro. Dogs tooth with a red flower.}

This is in all things like vnto the laft, both for forme and bigneffe of flower and leafe: the chiefe difference confifteth in this, that the leaues hereof are of a yellowifh mealy greene colour, fpotted and ftreaked with redder fpots and ftripes, and the flower of a deeper reddifh purple colour, and the chiues alfo more purplifh then the laft, in all other things it is alike.

\section{The Place.}

The forts Dens Caninus doe growe in diuers places; fome in Italy on the Euganean Hils, others on the Apenine, and fome about Gratz, the chiefe Citie of Stiria, and alfo about Bayonne, and in other places.

\section{The Time.}

They flower in March moft vfually, and many times in Aprill, according to the feafonableneffe of the yeare.

\section{The Names.}

Clufius did call it firft Dentali, and Lobel, and from him fome others $S a$ tyrium, and Erythronium, but I haue faid enough hereof in the beginning of the Chapter. It is moft commonly called Dens Caninus, and we in Englinh, either Dogs tooth, or Dogs tooth Violet. Gefner called it Hermodactylus, and Matthiolus P feudohermodactylus.

\section{The Vertues.}

The roote hereof is held to bee of more efficacy for venerous effects, then any of the Orchides and Satyrions.

They of Stiria vfe the rootes for the falling fickneffe.

Wee haue had from Virginia a roote fent vnto vs, that wee might well iudge, by the forme and colour thereof being dry, to be either the roote of this, or of an Orchis, which the naturall people hold not onely to be fingular to procure luft, but hold it as a fecret, loth to reueale it. 


\section{II A P. X X IIII.}

\section{Cyclamen. Sowebread.}

T

He likenefie of the flowers, and the fpotting of the leaues of the Dens Conimus, with thefe of the Cyclamen or Sowebread, maketh mee ioyne it next thereunto: as alfo that after the bulbous rooted plants I might begin with the tuberous that remaine, and make this plant the beginning of then. Of this kinde there are diuers forts, differing both in forme of leaues and time of flowring: for fome doe flower in the Spring of the yeare, others afterwards in the beginning of Summer : but the moft number in the end of Summer, or beginning of Autumne or Harueft, whereof fome haue round leaues, others cornered like vnto Iuie, longer or Phorter, greater or fmaller. Of them all in order, and firft of thofe that come in the Spring.

\section{Cyclumen Vernum flore purpureo. Purple flowred Sowebread of the Spring.}

This Sowebread hath a fmaller roote then moft of the others, yet round and blackifh on the outfide, as all or moft of the reft are (I fpeake of them that I haue feene; for Clufius and others doe report to haue had very great ones) from whence rife vp diuers round, yet pointed leaties, and fomewhat cornered withall, greene aboue, and fpotted with white fpots circlewife about the leafe, and reddifh vnderneath, which at their firft comming vp are folded together; among which come the flowers, of a reddifh purple colour and very fweete, euery one vpon a fmall, long, and fender reddifh foote-ftalke, which hanging downe their heads, turne vp their leaues againe: after the flowers are paft, the hend or feede veffel Anrinketh downe, winding his footeftalke, and coyling it felfe like a cable, which when it toucheth the ground, there abideth hid among the leaues, till it be growne great and ripe, wherein are contained a few fmall round feedes, which being prefently fowne, will growe firft into round rootes, and afterwards from them thoote forth leaues.

\section{Cyclamen Vernum flore albo. White flowred Sowebread of the Spring.}

The white flowring Sowebread hath his leaues like the former, but not fully fo much cornered, bearing fmall fnow white flowers, as fweete as the other: and herein confifteth the chiefeft difference, in all other things it is alike.

\section{Cyclamen Vermum Creticum flore albo. White Candy Sowebread of the Spring.}

This Sowebread is fomewhat like the former white kinde, but that the leaues grow much larger and longer, with more corners at the edges, and more eminent fpots on them: the flowers alfo fornewhat longer and larger, and herein confifteth the whole difference.

\section{Cyclamen Affrivum. Summer Sowebread.}

Summer Sowebread hath round leaues like vnto the Romane Sowebread, but foinewhat cornered, yet with Thorter corners then the Iuie leafed Sowebread, full of white fpots on the vpperfide of the leaues, and very purple vnderneath, fometimes they baue fewer fpots, and little or no purple vnderneath: the flowers hereof are as fmall, as purple, and as fweete, as the purple Sowebread of the Spring time: the roote hereof is likewife fmall, blacke, and round.

\section{Cyclamen Romanum rotundifolium. Romane Sowebread with round leaues.}

The Romane Sowebread hath round leaues, fomewhat like vnto the common Sowebread, but not fully fo round pointed at the ends, a little cornered fometimes alfo, or as it were indented, with white fpots round about the middle of the leaues, 
and very confpicuous, which make it feeme the more beautifull: the flowers appeare in Autumne, and are fhorter, and of a deeper purplifh red colour then the Iuie Sowebread, rifing vp before the leaues for the moft part, or at leaft with them, and little or nothing fweete: the roote is round and blacke, vfually not fo flat as it, but growing fometimes to bee greater then any other kinde of Sowebread. There is fometimes fome variety to be feene, both in the leaues and flowers of this kinde; for that fometime the leaues haue more corners, and either more or leffe fpotted with white; the flowers likewife of fome are larger or leffer, longer or rounder, paler or deeper coloured one then another. This happeneth moft likely from the fowing of the feede, caufing the like variety as is feene in the Iuie leafed Sowebread. It doth alfo many times happen from the diuerfity of foyles and countries where they grow: the feed of this, as of all the reft, is fmall and round, contained in fuch like heads as the former, ftanding almoft like the head of a Snake that is twined or folded within the body thereof. This and the other Autumnall kindes, prefently after their fowing in Autumne, fhoote forth leaues, and fo abide all the Winter, according to their kinde.

\section{Cyclamen folio hedera autumnale. Iuie leafed Sowebread.}

The Iuie leafed Sowebread groweth in the fame manner that the former doth, that is, bringeth forth flowers with the leaues fometimes, or moft commonly before them, whofe flowers are greater then the common round leafed Sowebread, fomewhat longer then the former Romane or Italian Sowebreads, and of a paler purple colour, almort bluifh, without that fweete fent as is in the firft kinde of the Spring: the greene leaues hereof are more long then round, pointed at the ends, and hauing alfo one or two corners on each fide, fometimes much fpotted on the vpperfide with white fpots and marks, and fometimes but a little or not at all; and fo likewife fometimes more or leffe purple vnderneath: all the leaues and flowers doe ftand vfually euery one feuerally by themfelues, vpon their owne flender foote-ftalkes, as moft of all the other kindes doe: but fometimes it happeneth, that both leaues and flowers are found growing from one and the fame ftalke, which I rather take to be accidentall, then naturall fo to continue: the feede hereof is like the former kindes, which being fowne produceth variety, both in the forme of the leaues, and colour and fmell of the flowers: fome being paler or deeper, and fome more or leffe fweete then others: the leaues alfo, fome more or leffe cornered then others: the root groweth to be great, being round and flat, and of a blackifh browne colour on the outfide.

\section{Cyclamen autumnale hedera folio flore albo.}

Iuie leafed Sowebread with white flowers.

There is one of this kinde, whore leaues are rounder, and not fo much cornered as the former, flowring in Autumne as the laft doth, and whofe flowers are wholly white, not hauing any other notable difference therein.

\section{Cyclamen autumnale anguftifolium. Long leafed Sowebread.}

This kinde of Sowebread may eafily be knowne from all the other kindes, becaufe his leafe is longer and narrower then others, fafhioned at the bottome thereof with points, fomewhat like vnto Arum or Wake Robin leaues: the flowers are like the former forts for forme, but of a purple colour. There is alfo another of this kinde in all things like the former, but that the flowers are white.

\section{Cyclamen Antiochenum Autumnale flore purpureo duplici.}

Double flowred Sowebread of Antioch.

This Sowebread of Antioch with double flowers, hath his leaues fomewhat round, like vnto the leaues of the Summer Sowebread, but with leffe notches or corners, \& full of white fpots on them: it beareth flowers on ftalks, like vnto others, \& likewife fome ftalks that haue two or three flowers on them, which are very large, with ten or twelue 


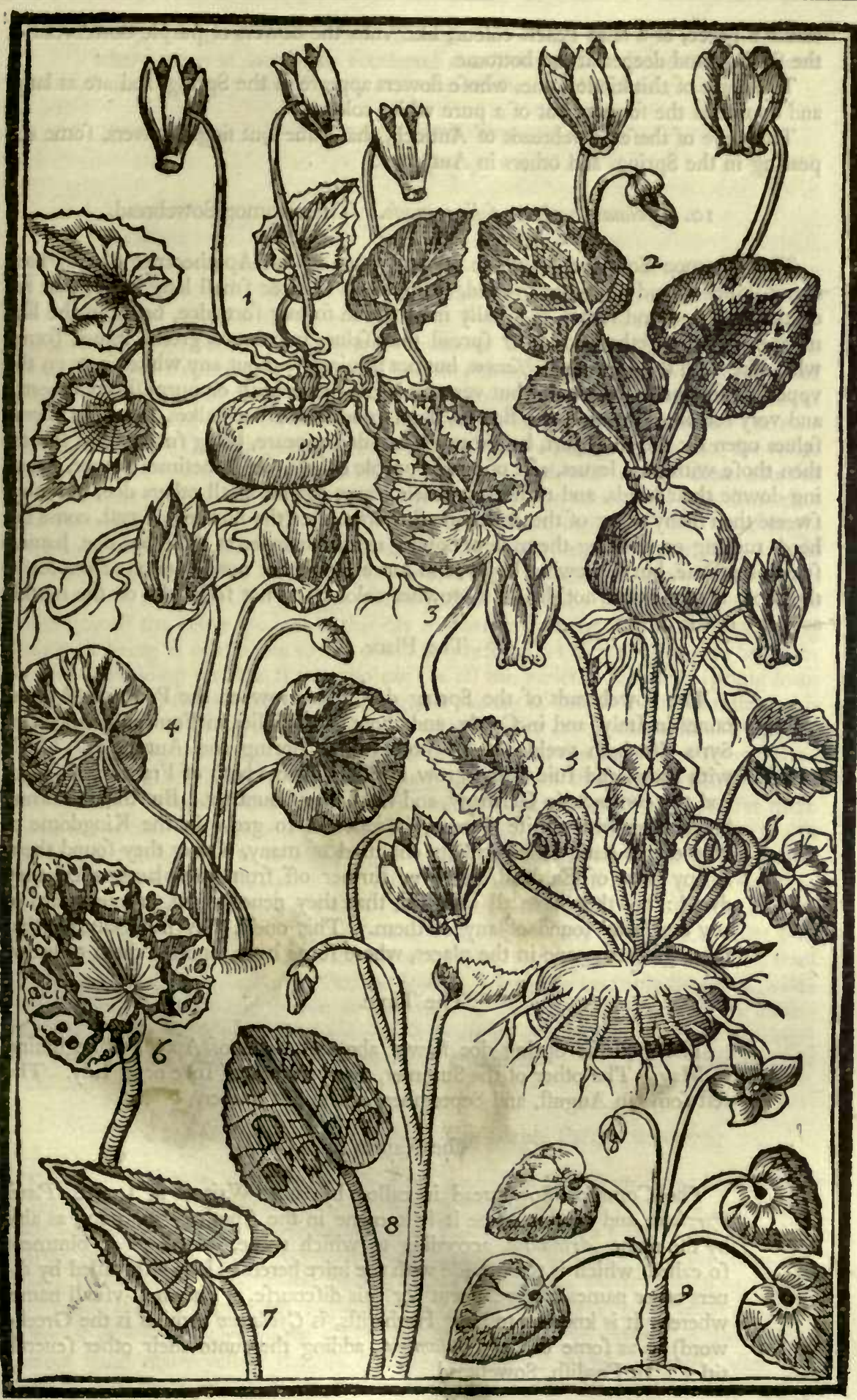

I Cyclamen Vermum Alore purpureo. Purple flowred Sowebread of the Spring. 2 Cyclamen aftivum. Summer Sowebread. 3 Folium Cyclaminis Cretici sernalis Aore candido. A leafe of Candie Sowebread. + Cyelamen Romanum Autumnale. Romane Sowebread of the Autumne. 5 Cyclamen hederafolio Autwmmale. Iuie leafed Autumne Sowebread. 6 Folium Cyclaminis Autumenalis fore albo. A leafe of the Autumne Sowebread with a white flower. 7 Folimm Cyelaminis anguftifolij Autumnalis. A leafe of the long leafed Sowebread. 8 Cyelamen Antiochenum Autumnale pore amplo purpureo duflici. The double flowred Sowebread of Antioch. 
leaues a peece, of a faire Peach colour, like vnto the flowers of purple Sowebread of the Spring, and deeper at the bottome.

There are of this kinde fome, whofe flowers appeare in the Spring, and are as large and double as the former, but of a pure white colour.

There are of thefe Sowebreads of Antioch, that haue but fingle flowers, fome appearing in the Spring, and others in Autumne.

\section{Cyclamen vulgare folio rotundo. The common Sowebread.}

The common Sowebread (which is molt vfed in the Apothecaries Shops) hath many leaues fpread vpon the ground, rifing from certaine fmall long heads, that are on the greater round rootes, as vfually moft of the former forts doe, being in the like manner folded together, and after fpread themfelues into round greene leaues, fomewhat like vnto the leaues of Afarum, but not fhining, without any white fpots on the vpperfide for the moft part, or but very feldome, and reddifh or purplifh vnderneath, and very feldome greener : the flowers ftand vpon fmall foot-ftalkes, and fhew themfelues open for the moft part, before any leaues doe appeare, being fmaller and thorter then thofe with Iuie leaues, and of a pale purple colour, yet fometimes deeper, hanging downe their heads, and turning vp their leaues againe, as all others doe, but more fweete then many other of the Autumne flowers : after the flowers are paft, come the heads turning or winding themfelues downe in like manner as the other doe, hauing fuch like feede, but fomewhat larger, and more vneuen, or not fo round at the leaft : the roote is round, and not flat, of a browner colour, and not fo blacke on the outfide as many of the others.

\section{The Place.}

The Sowebreads of the Spring doe both grow on the Pyrenæan Mountaines in Italy, and in Candy, and about Mompelier in France; Antioch in Syria alfo bath yeelded fome both of the Spring and Autumne. Thofe with round and Iuie leaues grow in diuers places both of France and Italy : and the common in Germany, and the Lowe-Countries. But that Autumne Sowebread with white flowers, is reported to grow in the Kingdome of Naples. I haue very curioully enquired of many, if euer they found them in any parts of England, neare or further off from the places where they dwell : but they haue all affirmed, that they neuer found, or euer heard of any that have found of any of them. This onely they haue affured, that there groweth none in the places, where fome haue reported them to grow.

\section{The Time.}

Thofe of the Spring doe flower about the end of Aprill, or beginning of May. The other of the Summer, about the end of I une or in Iuly. The reft fome in Auguft, and September, others in October.

\section{The Names.}

The Common Sowebread is called by moft Writers in Latine, Panis Porcimus, and by that name it is knowne in the Apothecaries Thops, as alro by the name Arthanita, according to which name, they haue an ointment fo called, which is to be made with the iuice hereof. It is alfo called by diuers other names, not pertinent for this difcourfe. The moft vfuall name, whereby it is knowne to moft Herbarifts, is Cyclamen (which is the Greeke word) or as fome call it Cyclamimus, adding thereunto their other feuerall titles. In Englifh, Sowehread.

\section{The Vertues.}

The leaues and rootes are very effectuall for the fpleene, as the Ointment before remembred plainly proueth, being vfed for the fame purpofe, 
and that to good effect. It is vfed alfo for women in long and hard trauels, where there is danger, to accelerate the birth, either the roote or the leafe being applyed. But for any amorous effects, I hold it meere fabulous.

\section{С н А. X X V.}

Ancmome. Windeflower and his kindes.

T He next tuberous rooted plants that are to follow (of right in my opinion) are the Anemones or Windeflowers, and although fome tuberous rooted plants, that is, the Afphodils, Spiderworts, and Flowerdeluces haue beene before inferted, it was, both becaufe they were in name or forme of flowers futable to them whom they were ioyned vnto, and alfo that they fhould not be feuered and entreated of in two feuerall places: the reft are now to follow, at the leaft fo many of them as be beautifull flowers, fit to furnifh a Florifts Garden, for natures delightfome varieties and excellencies. To diftinguifh the Family of Anemones I may, that is, into the wilde kindes, and into the tame or mannured, as they are called, and both of them nourfed $v p$ in Gardens; and of them into thofe that haue broader leaues, and into thofe that haue thinner or more iagged leaues: and of each of them, into thofe that beare fingle flowers, and thofe that beare double flowers. But to def cribe the infinite (as I may ro fay) variety of the colours of the flowers, and to give to each his true diftinction and denomination, Hic labor, hoc opus eft, it farre paffeth my ability I confeffe, and I thinke would grauell the beft experienced this day in Europe (and the like I faid concerning Tulipas, it being as contingent to this plant, as is before faid of the Tulipa, to be without end in yeelding varieties:) for who can fee all the varieties that haue fprung from the fowing of the feede in all places, feeing the variety of colours rifen from thence, is according to the variety of ayres $\&$ grounds wherein they are fowne, skill alfo helping nature in ordering them aright. For the feede of one and the fame plant fowne in diuers ayres and grounds, doe produce that variety of colours that is much differing one from another; who then can difplay all the mixtures of colours in them, to fet them downe in fo finall a roome as this Book? Yet as I haue done (in the former part of this Treatife) my good will, to expreffe as many of each kinde haue come to my knowledge, fo if I endeauour the like in this, I hope the courteous wil accept it, and hold me excufed for the reft : otherwife, if I were or could be abfolute, I thould take from my felf and others the hope of future augmentation, or addition of any new, which neuer will be wanting. To begin therefore with the wilde kinds (as they are fo accounted) I thall firt entreate of the Pulfatillas or Pafque flowers, which are certainly kindes of wilde Ancmones, both in leafe and flower, as may well be difcerned by them that are iudicious (although fome learned men have not fo thought, as appeareth by their writings) the rootes of them making one fpeciall note of difference, from the other forts of wilde Anemones.

\section{Pulfatilla Anglica purpurea. The purple Pafque flower.}

The Pafque or Paffe flower which is of our owne Country, hath many leaues lying on the ground, fomewhat rough or hairie, hard in feeling, and finely cut into many fmall leaues, of a darke greene colour, almoft like the leaues of Carrets, but finer and Imaller, from among which rife vp naked ftalkes, rough or hairie alfo, fet about the middle thereof with fome fmall diuided leaues compaffing them, and rifing aboue thefe leaues about a fpanne, bearing euery one of them one pendulous flower, made of fix leaues, of a fine Violet purple colour, but fomewhat deepe withall, in the middle whereof ftand many yellow threeds, ret about a middle purple pointell : after the flower is paft, there commeth vp in the ftead thereof a burhic head of long feedes, which are fmall and hoarie, hauing at the end of euery one a finall haire, which is gray likewife: the roote is fmall and long, growing downewards into the ground, with a tuft of haire at the head thereof, and not lying or running vnder the vpper cruft thereof, as the other wilde Anemones doe. 


\section{Pulfatilla Danica. The Paffe flower of Denmarke.}

There is another that was brought out of Denmarke, very like vnto the former, but that it is larger both in roote and leafe, and flower alfo, which is of a fairer purple colour, not fo deepe, and befides, will better abide to bee mannured then our Englifh kinde will, as my felfe haue often proued.

Of both thefe forts it is faid, that fome plants haue bin found, that have borne white flowers. And likewife one that bore double flowers, that is, with two rowes of leaues.

\section{Pulfatilla flore rubro. The red Paffe flower.}

Lobel, as I take it, did firf fet forth this kinde, being brought him from Syria, the leaues whereof are finer cut, the flower fmaller, and with longer leaues, and of a red colour.

\section{Pulfatilla flore luteo. The yellow Paffe flower.}

The yellow Paffe flower hath his leaues cut and diuided, very like vnto the leaues of the firft kinde, but fomewhat more hairie, greene on the vpperfide, and hairie vnderneath: the ftalke is round and hoary, the middle whereof is befet with fome fmall leaues, as in the other, from among which rifeth vp the ftalke of the flower, confifting of fix leaues of a very faire yellow colour on the infide, and of a hoary pale yellow on the outfide; after which followeth fuch an head of hairie thrummes as in the former: the roote is of the bigneffe of a mans finger.

\section{Pulfatilla flore albo. The white Paffe flower.}

The white Paffe flower (which Clufius maketh a kinde of Anemone, and yet as hee faith himfelfe, doth more nearely refemble the Pulfatilla) hath, from amongft a tuft or head of haires, which grow at the toppe of a long blacke roote, many leaues ftanding vpon long ftalkes, which are diuided as it were into three wings or parts, and each part finely cut and divided, like vnto the Paffe flower of Denmarke, but fomewhat harder in handling, greenifh on the vpperfide, and fomewhat gray vnderneath, and very hairie all ouer: among thefe leaues rife vp the ftalkes, befet at the middle of them with three leaues, as finely cut and diuided as thofe belowe, from aboue which ftandeth the flower, being fmaller, and not fo pendulous as the former, but in the like manner confifting of fix leaues, of a fnow white colour on the infide, and a little browner on the outfide, with many yellow thrums in the middle: after the flower is paft, rifeth vp fuch a like hoary head, compofed as it were of many haires, each whereof hath a fmall feede faftened vnto it, like as the former Paffe flowers haue.

The Place.

The firft is found in many places of England, vpon dry bankes that lye open to the Sunne.

The fecond was firft brought, as I take it, by Doctor Lobel from Denmarke, \& is one of the two kinds, that Clufius faith are common in Germanie, this bearing a paler purple flower, and more early then the other, which is the fame with our Englifh, whofe flower is fo darke, that it almoft feemeth blacke.

The red kinde, as Lobel faith, came from Syria.

The yellow Paffe flower, which Clufius maketh his third wilde Anemone, was found very plentifully growing at the foote of St. Bernards Hill, neare vnto the Cantons of the Switzers.

The white one groweth on the Alpes neare Auftria, in France likewife, and other places. 


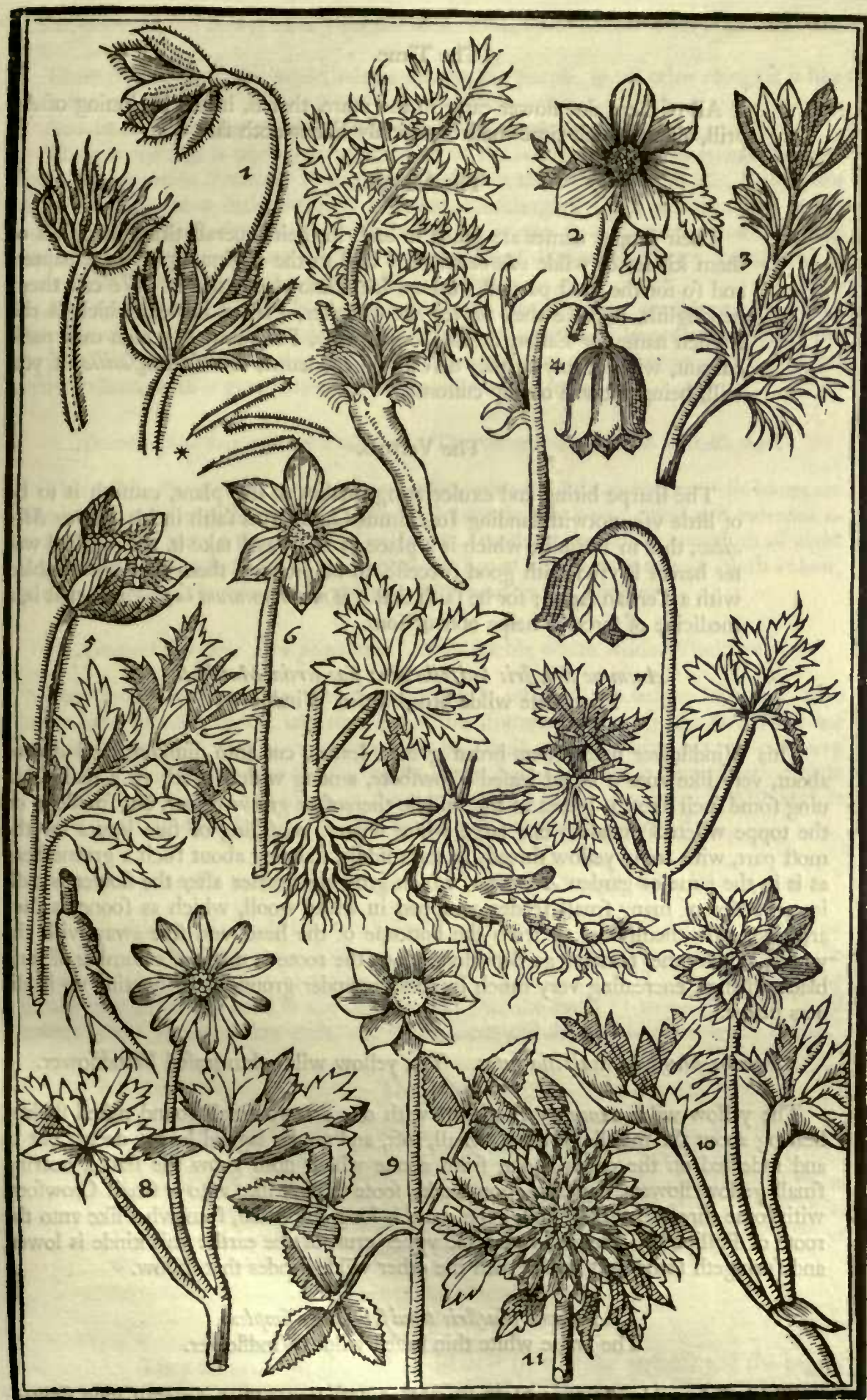

1. Pulfatilla furpurea cum folio, Semine, \& radice. The purple Pafque flower with leafe, feed, and root. 2. Pulfatilla lubo flore. The yellow Pafque flower. 3 Pulfalilla rubra Syriaca Lobelij. Red Pafque flower of Lobei. 4 Pulfalilla rubra Sucrtij.

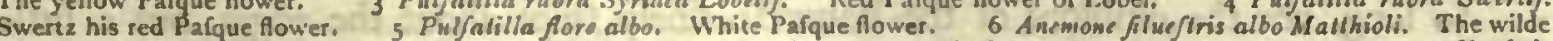
white broad leafed Windflower. 7 Anemone filwefiris tenwifolia alba. The wilde fingle white Windflower. 8 Anemone filueflris icnuifolia luteo. The yellow wilde thin leafed Windnower. 9 Ansmone filweftris irifolia Dodonat. The three-leafed wilde Wind. flower. 10 Anemane filuefris fore pleno albo. The double white wilde Windflower. "1. A remone filueflris flare pleno pur. pureo. The double purple wilde Windeflower. "Semen leperatim divul/um. The feed feparated. † Radice eum folio inferiore. The roote with a lower leafe. 
The Time.

All of them doe flower early in the yeare, that is, in the beginning of Aprill, about which time moft commonly Eafter doth fall.

\section{The Names.}

Their proper names are giuen to each in their feuerall titles, being all of them kindes of wilde Anemones, as I faid in the beginning of the Chapter, and fo for the molt part all Authors doe acknowledge them. We call them in Englifh, becaufe they flower about Eafter, Pafque flower, which is the French name for Eafter, or Euphonice gratia, Paffe flower, which may paffe currant, without any further defcant on the name, or elfe Pulfatilla, if you will, being growne old by cuftome.

\section{The Vertues.}

The fharpe biting and exulcerating quality of this plant, caufeth it to be of little vfe, notwithftanding Ioachimus Camerarius faith in his Hortus Medicus, that in Boruffia, which is a place in Italy, as I take it, the diftilled water hereof is vfed with good fucceffe, to be giuen to them that are troubled with a Tertian Ague; for he faith that it is medicamentum oкфрактєкоे, that is, a medicine of force to helpe obftructions.

\section{Anemone filueftris latifolia alba fiue tertia Matthioli.}

The white wilde broad leafed Windflower.

This Windflower hath diuers broad greene leaues, cut into diuifions, and dented about, very like vnto a broad leafed Crowfoote, among which rifeth vp a ftalke, hauing fome fuch like cut leaues in the middle thereof, as growe below, but fmaller; on the toppe whereof ftandeth one large white flower, confinting of fiue leaues for the moft part, with fome yellow threads in the middle, ftanding about fuch a greene head as is in the tame or garden Anemones, which growing greater after the flower is paft, is compofed of many fmall feedes, wrapped in white wooll, which as foone as they are ripe, raife themfelues vp from the bottome of the head, and flye away with the winde, as the other tame or garden kindes doe: the roote is made of a number of long blacke ftrings, encreafing very much by running vnder ground, and thooting vp in diuers places.

\section{Anemone filueftris tenuifolia lutea. The yellow wilde thin leafed Windflower.}

The yellow wilde Anemone rifeth vp with one or two fmall round naked ftalkes, bearing about the middle of them, fmall, foft, and tender iagged leaues, deeply cut in and indented on the edges about, from aboue which doth grow the ftalke, bearing fmall yellow flowers, ftanding vpon weake foote-ftalkes, like vnto a fmall Crowfoot, with forme threads in the middle: the roote is long and fmall, fomewhat like vnto the roote of Pollipodie, creeping vnder the vpper cruft of the earth: this kinde is lower, and fpringeth fomewhat earlier then the other wilde kindes that follow.

\section{Anemone filueftris tenuifolia alba fimplex.}

The fingle white thin leafed wilde Windflower.

This white wilde Anemone rifeth vp with diuers leaues vpon feuerall long ftalkes; which are fomewhat like vnto the former, but that they are fomewhat harder, and not fo long, nor the diuifions of the leaues fo finely fnipt about the edges, but a little broader, and deeper cut in on euery fide: the flowers hereof are larger and broader then the former, white on the infide, and a little purplifh on the outfide, efpecially at 
the bottome of the flower next vnto the ftalke: the roote of this is very like vnto the laft.

There is another of this kinde, whofe flowers are purple, in all other things it is like Purpurca. vito the white.

And likewife another, with a blufh or carnation coloured flower.

There is one that is onely nurfed vp with vs in Gardens, that is fomcwhat like vnto/wawe rubens. thefe former wilde Anemones in roote and leafe, but that the flower of this, being pure white within, and a little purplifh without, confifting of eight or nine fmall round Peregrina alb pointed leaues, hath fometimes fome leaues vnder the flower, party coloured white and greene : the flower hath likewife a greene head, like a Strawberry, compaffed about with white threads, tipt with yellow pendents.

And another of the fame kinde with the laft, whofe flower confifting of eight or Peregrina viri nine lenues, is of a greenifh colour, except the foure outermont leaues, which are a lit-dis. tle purplifh, and diuided at the points into three parts; the middle part is of a greenith white colour, with a greene head in the middle as the other.

\section{Anemone filueftris trifolia Dodoncei. The three leafed wilde Windflower.}

This wilde Anemone hath his rootes very like vnto the former kindes; the leaues are alwaies three fet together at the toppe of nender ftalkes, being fmall and indented about, very like vnto a three leafed Graffe, but fmaller : the flower confifteth of eight fmall leaues, fomewhat like vnto a Crowfoote, but of a whitifh purple or blufh colour, with fome white threads, and a greene rough head in the middle.

\section{Anemone filuefris fore pleno albo. The double white wilde Windflower.}

This double kinde is very like vnto the fingle white kinde before defcribed, both in his long running rootes, and thin leaues, but fomewhat larger: the flowers hereof are very thicke and double, although they be fmall, and of a faint fweete fent, very white after it is full blowne for fiue or fix dayes, but afterwards it becommeth a little purplifh on the infide, but more on the outfide: this neuer giveth feede (although it haue a fmall head in the middle) like as many other double flowers doe.

\section{Anemone filueftris flore pleno purpureo. The double purple wilde Windflower.}

This double purple kinde hath fuch like iagged leaues as the laft def cribed hath, but more hoarie vnderneath : the flower is of a fine light purple toward the points of the leaues, the bottomes being of a deeper purple, but as thicke, and full of leaues as the former, with a greene head in the middle, like vnto the former : this kinde hath fmall greene leaues on the ftalkes vnder the flowers, cut and diuided like the lower leaues.

\section{The Place.}

The firt broad leafed Anemone groweth in diuers places of Auftria and Hungary. The yellow in diuers woods in Germany, but not in this Countrey that euer I could learne. The other fingle wilde kindes, fome of them are very frequent throughout the moft places of England, in Woods, Groues, and Orchards. The double kindes were found, as Clufius faith, in the Lowe-Countries, in a Wood neare Louaine.

\section{The Time.}

They flower from the end of March (that is the earlieft) and the beginning of Aprill, vntill May, and the double kindes begin within a while after the fingle kinds are part.

The Names.

They are called Ranunculi fluarum, and Ranunculi nemorum, and as Clu- 
fius would haue them, Leimonia of Theophraftus; they are generally called of mott Herbarifts Anemones filueftres, Wilde Anemones or Windflowers. The Italians call them Gengeuo faluatico, that is, Wilde Ginger, becaufe the rootes are, befides the forme, being fomewhat like finall Ginger, of a biting hot and tharpe tafte.

\section{Anemone Lufitanica fuue hortenfis latifolia flore fimplici luteo.}

The fingle Garden yellow Windflower or Anemone.

This fingle yellow Anemone or Windflower hath diuers broad round leaues, fomewhat diuided and endented withall on the edges, brownifh at the firft rifing vp out of the ground, and almolt folded together, and after of a fad greene on the vpperfide, and reddifh vnderneath; among which rife vp fmall flender ftalkes, befet at the middle of them with two or three leaues, more cut and diuided then thofe belowe, with fmall yellow flowers at the toppe of them, confifting of ten or twelue leaues a peece, hauing a few yellow threads in the middle of them, ftanding about a fmall greene head, which in time growing ripe hath fmall flat feede, inclofed within a foft wooll or downe, which is eafily blowne away with the winde: the roote groweth downeward into the ground, diuerlly fpread with branches here and there, of a brownifh yellow on the outfide, and whitifh within, fo brittle, that it can hardly bee touched without breaking.

\section{Anemone latifolia flore luteo duplici. The double yellow Anemone or Windflower.}

This double yellow Anemone hath fuch broad round leaues as the fingle kinde hath, but fomewhat larger or ranker : the ftalkes are befet with larger leaues, more deeply cut in on the edges : the flowers are of a more pale yellow, with fome purplifh veines on the outfide, and a little round pointed; but they are all on the infide of a faire yellow colour, confifting of two rowes of leaues, whereof the innermort is the narrower, with a fmall greene head in the middle, compaffed with yellow threads as in the former : the roote is like the roote of the fingle; neither of thefe haue any good fent, and this fpringeth vp and flowreth later then the fingle kinde.

\section{Anemone latifolia purpurea fellata fiue papaveracea.}

The purple Starre Anemone or Windflower.

The firt leaues of this purple Anemone, which alwayes fpring vp before Winter, (if the roote be not kept too long out of the ground,) are fomewhat like the leaues of Sanicle or Selfe-heale, but the reft that follow are more deeply cut in and iagged; among which rife vp diuers round ftalkes, befet with iagged leaues as all other Anemones are, aboue which leaues, the ftalkes rifing two or three inches high, beare one flower a peece, compofed of twelue leaues or more, narrow and pointed, of a bleake purple or whitifh afh-colour, fomewhat fhining on the outfide, and of a fine purple colour tending to a murrey on the infide, with many blackifh blew threads or thrummes in the middle of the flower, fet about a head, whereon groweth the feede, which is fmall and blacke, inclofed in foft wooll or downe, which flieth away with the winde, carrying the feede with it, if it be not carefully gathered : the roote is blackifh on the outfide, and white within, tuberous or knobby, with many fibres growing at it.

\section{Anemone purpurea Stellata altera. Another purple Starre Anemone.}

There is fo great diuerfity in the colours of the flowers of thefe broad leafed kinds of Anemones or Windflowers, that they can very hardly be expreffed, although in their leaues there is but little or no difference. I hall not neede therefore to make feuerall defcriptions of euery one that thall be fet downe; but it will be fufficient, I thinke, to giue you the diftinctions of the flowers: for as I faid, therein is the greateft and chiefeft difference. This other Starre Anemone differeth not from the former in leafe or flower, but onely that this is of a more pale fullen colour on the outfide, and of a paler purple colour on the infide.

There 


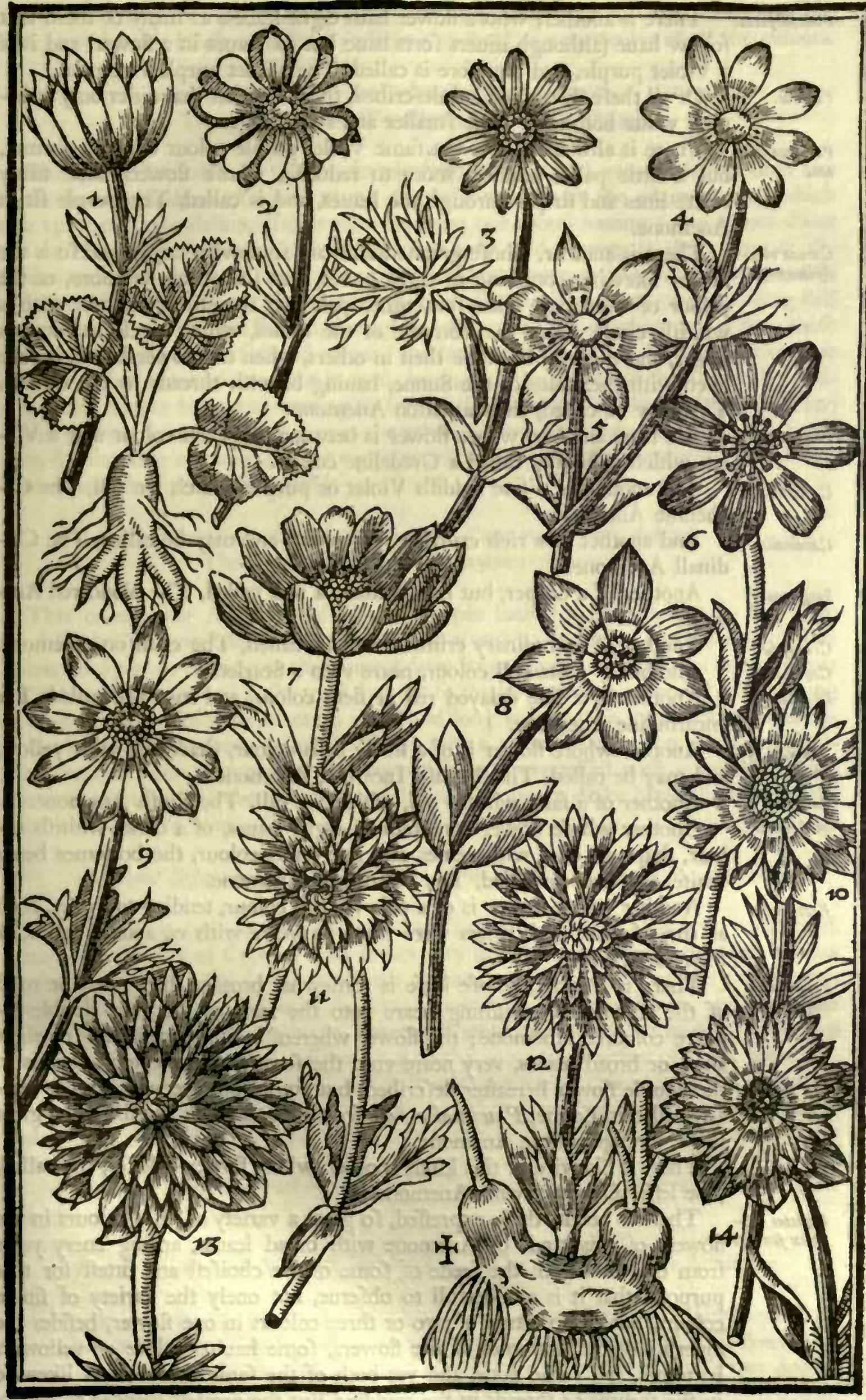

1 Aremone latifolia fore lufeo fimplict. The fingle yellow Anemone. 2 Anmone latifolia flore luseo duplici. The double yellow Anemone. 3 Anewore latifolia fiore purpureo Stellato. The purple Starre Anemone. 4 Aremone latifolia purpurea dilution. The pale purple Starre Anemone. 5 Anemone lafifolia fore miniato diluto. The pale sed Anemone. 6 Anemone lafifolia coc8 Aremone latifolia Paro fimflex dicla. The leffer Orenge tawney Anemone. 9 Anemone lalifolia flore carnco. The carnation Anemone. 10 Anomone lafifolia Arantiesa fiue Pawo maior. The double Orenge tawney Anemone. It Anemone Superitica fiwe Cyparifsia. The double Anemone of Cyprus. 12 Anemone latifolia fore pleno albicante. The double pale bluth Anemone. Perfian Anemone. themonis lafifolia radice. The roote of a steat Anemone. 
Viola purpurea. There is another, whofe flower hath eight leaues, as many of them that follow haue (although diuers forts haue but fix leaues in a flower) and is of a Violet purple, and therefore is called, The Violet purple Anemone.

Varietas. $\quad$ Of all thefe three forts laft defcribed, there be other that differ only in hauing white bottomes, fome fmaller and fome larger.

Purpurea fori- There is alfo another of the fame Violet purple colour with the former, ata. but a little paler, tending more to redneffe, whofe flowers haue many white lines and ftripes through the leaues, and is called, The purple ftript Anemone.

Carnea viva- There is another, whofe greene leaues are fomewhat larger, and fo is the ifsimasimplex. flower likewife, confifting of eight leaues, and fometimes of more, of the colour of Carnation filke, fometimes pale and fometimes deeper, with a whitifh circle about the bottome of the leaues, which circle in fome is larger, and more to be feene then in others, when the flower layeth it felfe open with the heate of the Sunne, hauing blewifh threads in the middle. This may be called, the Carnation Anemone.

Perficiviolacea. We haue another, whofe flower is betweene a Peach colour and a Violet, which is vfually called a Gredeline colour.

Gochenille. And another of a fine reddifh Violet or purple, which we call, The Cochenille Anemone.

Cardinalis. And another of a rich crimfon red colour, and may be called, The Cardinall Anemone.

Sanguinea. Another of a deeper, but not fo liuely a red, called, The bloud red Anemone.

Cramejina. Another of an ordinary crimfon colour, called, The crimfon Anemone. Cocinea. Another of a Stamell colour, neare vnto a Scarlet.

Incarnata. Another of a fine delayed red or fleth colour, and may bee called, The Incarnidine Anemone.

Incarnata Hif- Another whofe flower is of a liuely fleth colour, thadowed with yellow, panica. and may be called, The Spanifh Incarnate Anemone.

Rubescens. Another of a faire whitifh red, which we call, The Blurh Anemone.

Mofchutella. Another whofe flower confifteth of eight leaues, of a darke whitifh colour, ftript all ouer with veines of a fine blufh colour, the bottomes being white, this may be called, The Nutmegge Anemone.

Enfumats. Another whore flower is of a pale whitifh colour, tending to a gray, fuch as the Monkes and Friers were wont to weare with vs, and is called, A Monkes gray.

Pauo maior. There is another, whofe leafe is fomewhat broader then many or moft fimplici fore of the Anemones, comming neare vnto the leafe of the great double Orenge coloured Anemone; the flower whereof is fingle, confifting of eight large or broad leaues, very neare vnto the fame Orenge colour, that is in the double flower hereafter defcribed, but fomewhat deeper. This is vfually called in Latine, Pawo maior fimplici flore, and we in Englifh, The great fingle Orenge tawnie Anemone.

Pauo mino: $\quad$ There is likewife of this kinde another, whofe flower is leffer, and called, The leffer Orenge tawnie Anemone.

Varietas mag- There is befides thefe expreffed, fo great a variety of mixt colours in the na ex seminio. flowers of this kinde of Anemone with broad leaues, arifing euery yeare from the fowing of the feede of fome of the choifelt and fitteft for that purpore, that it is wonderfull to obferue, not oncly the variety of fingle colours, but the mixture of two or three colours in one flower, befides the diuerfity of the bottomes of the flowers, fome hauing white or yellowifh bottomes, and fome none, and yet both of the fame colour; and likewife in the thrums or threads in the middle: But the greateft wonder of beauty is in variety of double flowers, that arife from among the other fingle ones, fome hauing two or three rowes of leaues in the flowers, and fome fo thicke of leaues as a double Marigold, or double Crowfoote, and of the fame feuerall colours that are in the fingle flowers, that it is almoft impoffible to expreffe them feuerally, and (as is faid before) fome falling out to bee double in one yeare, which will proue fingle or leffe double in an- 
other, yet very many abiding conftant double as at the firft; and therefore let this briefe recitall be fufficient in ftead of a particular of all the colours.

\section{Anemone Chalcedonica maximu verficolor.}

The great double IWindflower of Conftantinople.

This great Anemone of Conftantinople hath broader and greener leaues then any of the former kindes, and not fo much diuided or cut in at the edges, among which rife vp one or two ftalkes, (feldome more from one roote) hauing fome leaues about the middle of the ftalke, as other Anemones haue, and bearing at the toppes of the ftalkes one large flower a peece, very double, whofe outermoft leaues being broadeft, are greenifh at the firft, but afterwards red, hauing fometimes fome greene abiding ftill in the leaues, and the red ftriped through it: the other leaues which are within thefe are fmaller, and of a perfect red colour; the innermoft being fmalleft, are of the fame red colour but turned fomewhat inward, hauing no thrummes or threads in the middle, as the former haue, and bearing no feede: the roote is blackifh on the outfide, and white within, thicke and tuberous as the other kindes, but thicker fet and clofe together, not Thooting any long flender rootes as others doe. Some Gentlewomen call this Anemone, The Spanifh Marigold.

\section{Anemone Chalcedonica altera fue Pawo maior flore duplici.}

The great double Orenge tawney Anemone.

This other great Anemone of Conftantinople hath his large leaues fo like vnto the laft, that one can hardly diftinguifh them af under; the ftalke hath alfo fuch like leaues fet vpon it, bearing at the toppe a faire large flower, confifting of many leaues fet in two or three rowes at the moft, but not fo thicke or double as the laft, yet feeming to be but one thicke rowe of many fmall and long leaues, of an excellent red or crimfon colour, wherein fome yellow is mixed, which maketh that colour is called an Orenge tawney; the bottomes of the leaues are red, compaffed with a whitifh circle, the thrumınie head in the middle being befet with many darke blackin threads: the roote is like the former.

\section{Anemome Superitica fiue Cyparifsia. The double Anemone of Cyprus.}

This Anemone (which the Dutchmen call Superitz, and as I haue beene enformed, came from the Inle of Cyprus) hath leaues very like the laft double Anemone, but not altogether fo large: the flower confifteth of rmaller leaues, of colour very neare vnto the laft double Orenge coloured Anemone, but more thicke of leaues, and as double as the firf, although not fo great a flower, without any head in the middle, or thrums about it as is in the laft, and differeth not in the roote from either of them both.

Somewhat like vnto this kinde, or as it were betweene this and the firft kinde of thefe great double Anemones, we haue diuers other forts, bearing flowers very thicke and double; fome of them being white, or whitifh, or purple, deeper or paler, and fome of a reddifh colour tending to Scarlet or a Carnation colour, and fome alfo of a blufh or flefh colour, and diuers other colours, and all of them continue conftant in their colours.

\section{Anemone Cacumeni Maringi fue Perfica. The double Perfian Anemone.}

This rare Anemone, which is faid to come out of Perfia to Conftantinople, and from thence to vs, is in leafe and roote very like vinto the former double Anemones before defcribed; onely the flower hereof is rather like vnto the fecond great double Orenge coloured Anemone, vfually called Pauo maior fore pleno, being compofed of three rowes of leaues, the outermoft rowe confifting of ten or twelue larger leaues, and thofe more inward leffer and more in number, but all of them variably mixed with white, red, and yellow, hauing the bottomes of the leaues white: but inftead of a middle head with thrums about it, as the other hath, this hath a few narrow leaues, of a deepe yellow colour in the middle of the flower, ftanding vpright. 
Hauing thus farre proceeded in the two parts of the kindes of Anemones or Windflowers, it remaineth to entreate of the reft, which is thofe Anemones which have thin cut leaues, whereof fome haue reckoned vp thirty forts with fingle flowers, which I confeffe I haue not feene; but fo many as haue come to my knowledge, I fhall here fet downe.

\section{Anemone tenuifolin fiue Geranifolia carulea.}

The Watchet Anemone or Storkes bill leafed Windflower.

This firf Windflower with thin cut leaues, rifeth not out of the ground vntil the great Winter frofts be paft, that is, about the middle or end of February, and are fomewhat brownifh at their firft appearing, but afterwards fpread into wings of greene leaues, fomewhat broader then the reft that follow, diuided into three parts, \& each part into three leaues, euery one cut in about the edges, one ftanding againft another vpon a long flender foote-ftalke, and the end leafe by it felfe: among thefe rifeth vp two or three greene ftalkes, garnifhed with fuch like thin leaues as are at the bottome, from aboue which rife the flowers, but one vpon a ftalke, confifting of fourteene or fifteene fmall pale blew or watchet leaues, leffer then any of the fingle kindes that follow, compaffing many whitifh threads, and a fmall greene head in the middle, fomewhat like the head of the wilde Crowfoote, wherein is contained fuch like feede: the roote is blackifh without, thrufting out into long tuberous peeces, fomewhat like vnto fome of the broad leafed Anemones.

Of this kinde there is another, whofe leaues are not browne at their firft rifing, but greene, and the flowers are white, in other things not differing.

Anemone tenuifolia purpurea vulgaris.

The ordinary purple Anemone with thin leaues.

This purple Anemone which is molt common, and therefore the leffe regarded, hath many winged leaues ftanding vpon feuerall ftalkes, cut and diuided into diuers leaues, much like vnto the leaues of a Carrot; among which rife vp ftalkes with fome leaues thereon (as is vfuall to the whole Family of Anemones, both wilde and tame, as is before faid;) at the toppes whereof ftand the flowers, made of fix leaues moft vfually, but fometimes they will haue feuen or eight, being very large, and of a perfect purple Violet colour, very faire and liuely: the middle head hath many blackifh thrums or threads about it, which I could neuer obferue in my Gardens to beare feed: the roote is fmaller, and more fpreading euery way into fmall long flat tuberous parts, then any other kindes of fingle or double Anemones.

Carneapallida. There is another very like in leafe and roote vnto the former, but the flower is nothing fo large, and is whitifh, tending to a blufh colour, and of a deeper blufh colour toward the bottome of the flower, with blackifh blew thrums in the middle, and giueth no feede that I could euer obferue.

Carnea viuida There is likewife another like vnto the laft in leafe and flower, but anguibus albis. that the flower is larger then it, and is a of a liuely blufh colour, the leaues hauing white bottomes.

Albavenispur- And another, whofe flower is white, with purple coloured veines and purcis. $\quad$ ftripes through euery leafe, and is a leffer flower then the other.

Anemone tenuifolia coccinea fimplex. The fingle Scarlet Anemone with thin leaues.

The leaues of this Scarlet Windflower are fomewhat like vnto the former, but a little broader, and not fo finely cut and diuided: the flower confifteth of fix reafonable large leaues, of an excellent red colour, which we call a Scarlet; the bottomes of the leaues are large and white, and the thrums or threads in the middle of a blackinh purple colour: the roote is tuberous, but confifting of thicker peeces, fomewhat like vnto the rootes of the broad leafed Anemones, but fomewhat browne, and not fo blacke, and moft like vnto the roote of the double Scarlet Anemone.

Coccinea abfy; There is another of this kinde, whofe flower is neare vnto the fame covnguibus. lour, but this hath no white bottomes at all in his leaues. 
Flore holofe- We haue another which hath as large a flower as any fingle, and is of an riceo. Orient deepe red crimfon Veluet colour.

Sanguinea. There is another of a deeper red colour, and is called, The bloud red fingle Anemone.

Rubra furdo And another, whofe flower is red with the bottome yellow.

luseo. Another of a perfect crimfon colour, whereof fome haue round pointed Caccines dilu- leaues, and others fharpe pointed, and fome a little lighter or deeper then
tior. others.

Alba famini- There is alfo one, whofe flower is pure white with blewilh purple bus purpureis. thrums in the middle.

Comea Hiffa- And another, whofe flower is very great, of a kinde of fullen blufh conica. lour, but yet pleafant, with blewifh threads in the middle.

erenis.

Alba purpurcis And another, the flower whereof is white, the bottomes of the leaues snguibus. being purple.

Purpurafens. Another whofe flower confifteth of many fmall narrow leaues, of a pale purple or blufh colour on the outfide, and fomewhat deeper within.

foric forum There is another like in leafe and roote vnto the firt Scarlet Anemone, pomi simplex. but the flower hereof confifteth of feuen large leaues without any bottomes, of a white colour, hauing edges, and fome large ftripes alfo of a carnation or flefh colour to bee feene in them, marked fomewhat like an Apple bloffome, and thereupon it is called in Latine, Anemone temuifolia fimplex alba instar florum pomi, or facie forum pomi, that is to fay in Englifh, The fingle thin leafed Anemone with Apple bloffome flowers.

Muliplex. I haue heard that there is one of this kinde with double flowers.

\section{Anemone tenuifolia flore coccineo pleno vulgaris.}

The common double red or Scarlet Anemone.

The leaues of this double Anemone are very like vnto the leaues of the fingle Scarlet Anemone, but not fo thin cut and diuided as that with the purple flower : the flower hereof when it firft openeth it felfe, confifteth of fix and fometimes of feuen or eight broad leaues, of a deepe red, or excellent Scarlet colour, the middle head being thick clored, and of a greenifh colour, which after the flower hath ftood blowne fome time, doth gather colour, and openeth it felfe into many fmall leaues, very thicke, of a more pale red colour, and more Stamell like then the outer leaues: the root of this is thicke and tuberous, very like vnto the root of the fingle Scarlet Anemone.

\section{Anemone tenuifolia flore coccineo pleno variegata.}

The party coloured double Crimfon Anemone.

We haue a kinde hereof, varying neither in roote, leafe, or forme of flower from the former, but in the colour, in that this will haue fometimes the outer broad leaues party coloured, with whitifh or blufh coloured great ftreakes in the red leaues both infide and outfide; as alfo diuers of the iniddle or inner leaues ftriped in the fame manner: the roote hereof giueth fairer flowers in fome yeares then in others, and foinetimes giue flowers all red againe.

\section{Anemone tenuifolia fore coccineo faturo pleno.}

The double crimfon Veluet Anemone.

Wee have another alfo, whole flower is of a deepe Orenge tawny crimfon colour, neare vnto the colour of the outer leaues, of the leffer French Marigold, and not differing from the former in any thing elfe.

4. Anemone tenuifolia fore plens fuauerubente. The greater double blufh Anemone.

There is fmall difference to be difcerned, either in the roote or leaues of this from 
the former double Scarlet Anemone, fauing that the leaues hereof are a little broader, and feeme to bee of a little frether greene colour: the flower of this is as large almoft, and as double as the former, and the inner leaues likewife almoft as large as they, being of a whitifh or flefh colour at the firft opening of them, but afterwards become of a moft liuely blufh colour; the bottomes of the leaues abiding of a deeper blufh, and with long ftanding, the tops of the leaues will turne almoft wholly white againe.

\section{Anemone tenuifolia flore albo pleno. The double white Anemone.}

This double white Anemone differeth little from the former blufh Anemone, but in that it is fmaller in all the parts thereof, and alfo that the flower hereof being wholly of a pure white colour, without any fhew of blufh therein, hath the middle thrummes much fmaller and thorter then it, and not rifing vp fo high, but feeme as if they were chipped off euen at the toppes.

\section{Anemone tenuifolia fore pleno albicante. The leffer double blufh Anemone.}

This fmall double blufh Anemone differeth very little from the double white laft recited, but onely in the colour of the flower: for they are both much about the bigneffe one of another, the middle thrums likewife being as fmall and fhort, and as euen aboue, onely the flower at the firft opening is almoft white, but afterwards the outer leaues haue a more fhew of blufh in them, and the middle part a little deeper then they.

\section{Anemone tenuifolia fore pleno purpureo violaceo. The double purple Anemone.}

This double purple Anemone is alfo of the fame kindred with the firft double red or Scarlet Anemone for the form or doubleneffe of the flower, confinting but of fix or feuen leaues at the moft in this our Country, although in the hotter it hath ten or twelue, or more as large leaues for the outer border, and as large fmall leaues for the inner middle alro, and almoft as double, but of a deepe purple tending toward a Violet colour, the outer leaues being not fo deepe as the inner: the roote and leafe commeth neare vnto the fingle purple Anemone before defcribed, but that the roote fpreadeth not fo fmall and fo much.

\section{Anemone temuifolia flore pleno purpureo caruleo.}

The double blew Anemone.

This Anemone differeth not in any thing from the former double purple, but onely that the flower is paler, and more tending to a blew colour.

\section{Anemone temuifolia fore pleno rofeo. The double Rofe coloured Anemone.}

The double Rofe coloured Anemone differeth alfo in nothing from the former double purple, but onely in the flower, which is fomewhat fmaller, and not fo thicke and double, and that it is of a reddifh colour, neare vnto the colour of a pale red Rofe, or of a deepe coloured Damaske.

\section{Anemone tenuifolia flore pleno carneo viuacifsimo.}

The double Carnation Anemone.

This Anemone, both in roote, leafe, and flower, commeth neareft vnto the former double white Anemone, for the largeneffe and doubleneffe of the flower, and in the fmalneffe of the middle thrums, and euenneffe at the toppes of them, being not fo large and great a flower as the double purple, either in the inner or outer leaues, but yet is very faire, thicke and double, and of a moft liuely Carnation filke colour, very deepe, both the outer leaues and middle thrums alfo fo bright, that it doth as it were amaze, and yet delight the minde of the beholder, but by long ftanding in the Sun, waxe a little paler, and fo paffe away as all the moft beautifull flowers doe. 


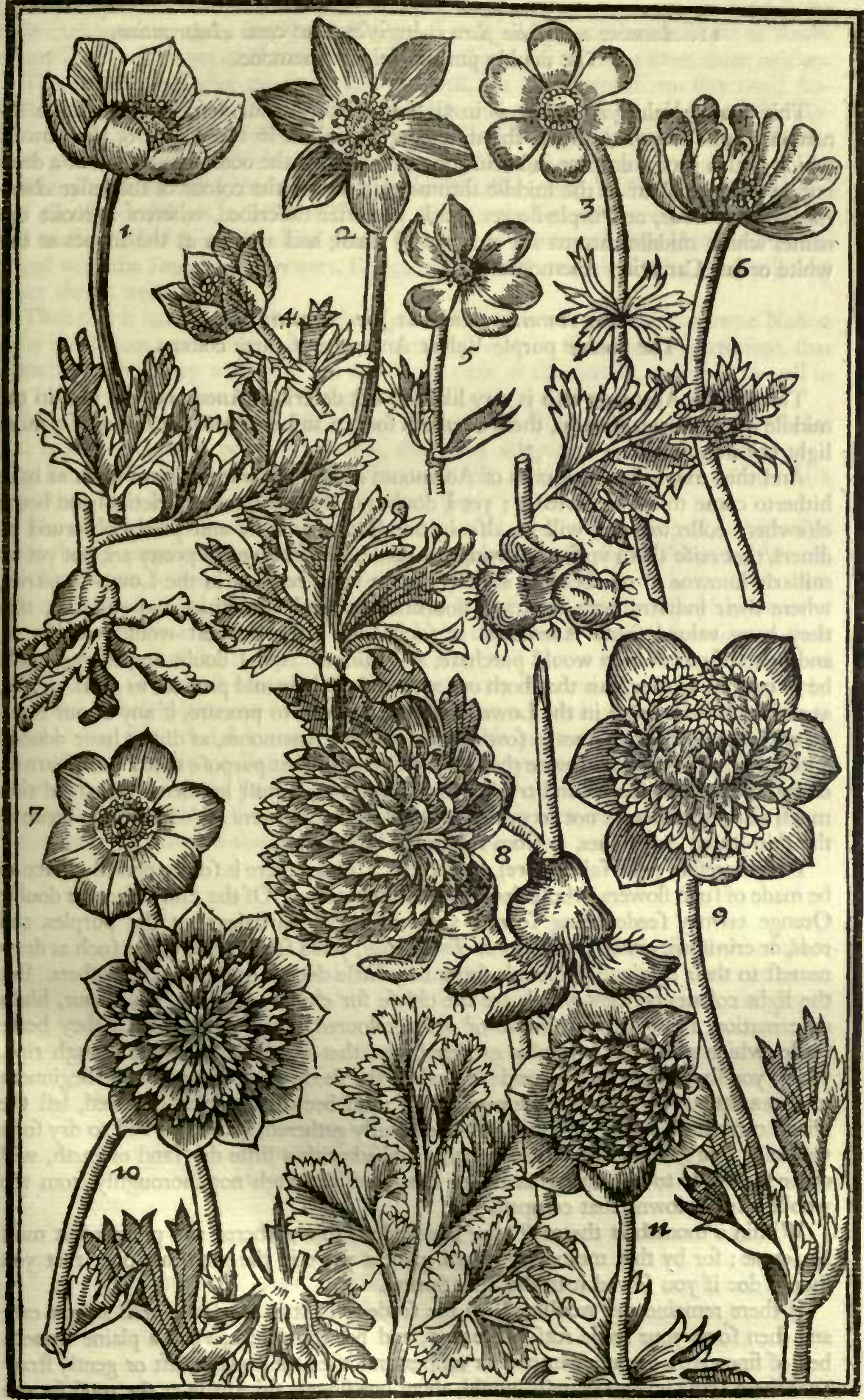

Insmone tenvifolia fimplex purpurea. The fingle purple Anemone with thin cut leaves. 2 Anemone tennifolia fimplex alba pura. The fingle pure white Anemone. 3 Anemone ienuifolia fimplex ehermefina. The fingle bright Crimfon Anemone. 4 Anemare lenuifolia fimplex fanguinea. Tbe fingle bloud red Anemone. 5 Anemone lenuifolia fimflex facie florwm pomi. The fingle Apple bloome Anemone. 6 Anemons benwifolia fimplex purpurofcens. The fingle purplith blum Anemone. 7 A wemons terwifolia fimplex pleno coccineo. The double red or ordinary Scarlet Anemone. I Anmone tew wifolia flore pleno rubrofufca coma Amarantina. The double purple Veluet Anemone. 10 Anemone tenuifolia fore pleno purpwro violacio. The double blewilh purple Anemone. II Anemone lemsifolia fare pleno incarmedini coloris fericei rivasissimi. The double Carnation Anemone, or of a liuely Carna-
tion filke colour. 
11. Anemone tenuifolia flore rubrofufco pleno coma Amarantina.

The double purple Veluet Anemone.

This double Veluet Anemone is in all things like the laft defcribed Carnation Anemone, but fomewhat larger, the difference confifteth in the colour of the flower, which in this is of a deep or fad crimfon red colour for the outer leaues, and of a deep purple Veluet colour in the middle thrums, refembling the colour of the leffer $\mathrm{Ama}$ ranthus purpureus, or Purple flower gentle hereafter defcribed, whereof it tooke the name, which middle thrums are as fine and fmall, and as euen at the toppes as the white or laft Carnation Anemones.

12. Anemone tenuifolia fore pleno tricolor.

The double purple Veluet Anemone of three colours.

This double Anemone alfo is very like the laft defcribed Anemone, but that in the middle of the purple thrums, there thrufteth forth a tuft of threads or leaues of a more light crimfon colour.

And thus much for the kindes of Anemones or Windflowers, fo farre forth as have hitherto come to our knowledge; yet I doubt not, but that more varieties haue beene elfewhere collected, and will be alfo in our Countrey daily and yearly obferued by diuers, that raife them $\mathrm{vp}$ from fowing the feede, wherein lyeth a pretty art, not yet familiarly knowne to our Nation, although it be very frequent in the Lowe-Countries, where their induftry hath bred and nourifhed vp fuch diuerfities and varieties, that they haue valued fome Anemones at fuch high rates, as moft would wonder at, and none of our Nation would purchafe, as I thinke. And I doubt not, if wee would be as curious as they, but that both our ayre and foyle would produce as great variety, as euer hath been feene in the Lowe-Countries; which to procure, if any of our Nation will take fo much paines in fowing the feedes of Anemones, as diuers have done of Tulipas: I will fet them downe the beft directions for that purpofe that I haue learned, or could by much fearch and tryall attaine vnto; yet I muft let them vnderftand thus much alfo, that there is not fo great variety of double flowers raifed from the feede of the thin leafed Anemones, as from the broad leafed ones.

Firft therefore (as I faid before) concerning Tulipas, there is fome fpeciall choice to be made of fuch flowers, whofe feed is fitteft to be taken. Of the Latifolias, the double Orenge tawney feede being fowne, yeeldeth pretty varieties, but the purples, and reds, or crimfons, either Latifolias or Tenuifolias, yeeld fmall variety, but fuch as draw neareft to their originall, although fome be a little deeper or lighter then others. But the light colours be they which are the chiefe for choice, as white, afh-colour, blufh or carnation, light orenge, fimple or party coloured, fingle or double, if they beare feede, which muft bee carefully gathered, and that not before it bee thorough ripe, which you thall know by the head; for when the feede with the wollineffe beginneth to rife a little of it felfe at the lower end, it muft bee then quickly gathered, left the winde carry it all away. After it is thus carefully gathered, it muft be laid to dry for a weeke or more, which then being gently rubbed with a little dry fand or earth, will caufe the feede to be fomewhat better feparated, although not thoroughly from the woollineffe or downe that compaffeth it.

Within a moneth at the moft after the feede is thus gathered and prepared, it muft be fowne; for by that meanes you thall gaine a yeare in the growing, ouer that you fhould doe if you fowed it in the next Spring.

If there remaine any woollineffe in the feede, pull it in funder as well as you can, and then fowe your feede reafonable thin, and not too thicke, vpon a plaine fmooth bed of fine earth, or rather in pots or tubbes, and after the fowing, fift or gently ftraw ouer them fome fine good frefh mould, about one fingers thickneffe at the moft for the firft time: And about a moneth after their firft rpringing vp, fift or ftraw ouer them in like manner another fingers thickneffe of fine earth, and in the meane time if the weather proue dry, you muft water them gently and often, but not to ouerglut them with moifture; and thus doing, you thall haue them fpring vp before Winter, and 
grow pretty ftrong, able to abide the fharpe Winter in their nonage, in vfing fome little care to couer them loof ely with fome fearne, or furfe, or beane hame, or ftraw, or any fuch, which yet muft not lye clofe vpon them, nor too farre from them neither.

The next Spring after the fowing, if you will, but it is better if you ftay vntill Auguft, you may then remoue them, and fet them in order by rowes, with fufficient diitance one from another, where they may abide, vntill you fee what manner of flower each plant will beare, which you may difpole of according to your minde.

Many of them being thus ordered (if your mould be fine, loofe, and frefh, not ftonie, clayifh, or from a middin) will beare flowers the fecond yeare after the fowing, and moft or all of them the third yeare, if the place where you fowe then, be not annoyed with the fmonke of Brewers, Dyers, or Maultkils, which if it be, then will they neuer thriue well.

Thus much have I thought good to fet downe, to incite fome of our owne Nation to be induftrious; and to helpe them forward, haue giuen fuch rules of directions, that I doubt not, but they will vpon the tryall and view of the variety, proceede as well in the fowing of Anemones as of Tulipas.

I cannot (Gentlewomen) withold one other fecret from you, which is to informe you how you may fo order Anemones, that after all others ordinarily are paft, you may laue them in flower for two or three moneths longer then are to be feene with any other, that vfeth not this courfe I direct you.

The ordinary time to plant Anemones, is moft commonly in Auguft, which will beare flower fome peraduenture before Winter, but moft vfually in February, March, and Aprill, few or none of them abiding vntill May ; but if you will keepe fome roots out of the ground vnplanted, vntill February, March, and Aprill, and plant fome at one time, and fome at another, you Thall haue them beare flower according to their planting, thofe that thall be planted in February, will flower about the middle or end of May, and fo the reft accordingly after that manner: And thus may you haue the pleafure of thefe plants out of their naturall feafons, which is not permitted to be enioyed in any other that I know, Nature being not fo prone to bee furthered by art in other things as in this. Yet regard, that in keeping your Anemone rootes out of the ground for this purpofe, you neither keep them too dry, nor yet too moift, for fprouting or rotting; and in planting them, that you fet them not in too open a funny place, but where they may be fomewhat hadowed.

\section{The Place.}

I thall not need to fpend much time in relating the feuerall places of thefe Anemones, but onely to declare that the moft of them that have not beene raifed from feed, haue come from Conftantinople to vs; yet the firft broad leafed or yellow Anemone, was firt found in Portugall, and from thence brought into thefe parts. And the firft purple Starre Anemone in Germanie, yet was the fame fent among others from Conftantinople alfo. And the firft thin cut leafed Anemone came firt out of Italy, although many of that fort haue come likewife from Conftantinople. And fo haue the double red or Scarlet Anemones, and the great double blufh, which I firft had by the gift of $\mathrm{M}^{\mathrm{r}}$. Humfrey Packington of Worcefterhire Efquire, at Haruington.

The Time.

The times of their flowring are fufficiently expreffed in the defcriptions, or in the rules for planting.

\section{The Names.}

The Turkifh names whereby the great double broad leafed kindes haue beene fent vnto vs, were Giul Catamer, and Giul Catamer lale; And Bimizade, Binizante, and Galipoli lale for the thinne cut leafed Anemones. All Authors haue called them Anemones, and are the true Herba venti. 
Wee call them in Englifh eyther Anemones, after the Greeke name, or Windflowers, after the Latine.

The Vertues.

There is little vfe of thefe in Phyficke in our dayes, eyther for inward or outward difeafes; onely the leaues are vfed in the Ointment called Marciatum, which is compofed of many other hot herbes, and is vfed in cold griefes, to warme and comfort the parts. The roote, by reafon of the harpeneffe, is apt to drawe downe rheume, if it be tafted or chewed in the mouth.

\section{С н а Р. XXVI.}

Aconitum. Wolfebane.

T Here be diuers forts of Wolfebanes which are not fit for this booke, but are referued for a generall Hiftory or Garden of Simples, yet among them there are fome, that notwithftanding their euill quality, may for the beauty of their flowers take vp a roome in this Garden, of whom I meane to entreate in this place: And firft of the Winter Wolfesbane, which for the beauty, as well as the earlineffe of his flowers, being the firt of all other, that thew themfelues after Chriftmas, deferueth a prime place; and therefore for the likeneffe of the rootes vnto the Anemones, I ioyne it next vito them.

\section{Aconitum Hyemale. The Winters Wolfesbane.}

This little plant thrufteth vp diuers leaues out of the ground, in the deepe of Winter oftentimes, if there be any milde weather in Ianuary, but moft commonly after the deepe frofts, bearing vp many times the fnow vpon the heads of the leaues, which like vnto the Anemone, doe euery leafe rife from the roote vpon feuerall fhort footeftalkes, not aboue foure fingers high, fome hauing flowers in the middle of them, (which come vp firt moft vfually) and fome none, which leaues ftand as it were round, the ftalke rifing vp vnder the middle of the leafe, deeply cut in and garhed to the middle ftalke almoft, of a very faire deepe greene colour, in the middle whereof, clofe vnto the leafe, ftandeth a fmall yellow flower, made of fix leaues, very like a Crowfoote, with yellow threads in the middle : after the flower is fallen, there rife vp diuers fmall hornes or cods fet together, wherein are contained whitifh yellow round feede. The roote is tuberous, fo like both for thape and colour vnto the rootes of Anemones, that they will eafily deceiue one not well experienced, but that it is browner and fmooth without, and yellow within, if it be broken.

\section{Aconitum flore albido, fue Aconitum luteun Ponticum.} The whitifh yellow Wolfesbane.

This Wolfesbane thooteth not out of the ground vntill the Spring be well begun, and then it fendeth forth great broad greene leaues, deeply cut in about the edges, not much vnlike the leaues of the great wilde Crowfoote, but much greater; from among which leaues rifeth vp a ftrong ftiffe ftalke, three foote high, hauing here and there leaues fet vpon it, like vnto the loweft, but fmaller; the toppe of the ftalke is diuided into three or foure branches, whereon are fet diuers pale yellow flowers, which turne at the laft to be almoft white, in fafhion like almoft vnto the flowers of the Helmet flower, but much fmaller, and not gaping fo wide open: after the flowers are paft come vp diuers thort poddes, wherein is contained blacke feede: the roote is made of a number of darke browne ftrings, which fpread and faften themfelues ftrongly in the ground. 


\section{Napellus verus fore caruleo. Blew Helmet flower or Monkes hood.}

The Helmet flower hath diuers leaues of a frefh greene colour on the vpperfide, and grayifh vnderneath, much fpread abroad and cut into many flits and notches, more then any of the Wolfebanes; the Italke rifeth vp two or three foot high, befet to the top with the like leaues, but fmaller: the toppe is fometimes diuided into two or three branches, but more vfually without, whereon ftand many large flowers one aboue another, in forme very like vito a Hood or open Helmet, being compofed of fiue leaues, the vppermoft of which and the greateft, is hollow, like vnto an Helmet or Headpeece, two other fmall leaues are at the fides of the Helinet, clofing it like cheekes, and come fomewhat vnder, and two other which are the fmalleft hang down like labels, or as if a clofe Helmet were opened, and fome peeces hung by, of a perfect or faire blew colour, (but grow darker, hauing ftood long) which caufeth it be fo nourifhed vp in Gardens, that their flowers, as was vfuall in former times, and yet is in many Countrey places, may be laid among grcene herbes in windowes and roomes for the Summer time : but although their beauty may be entertained for the vfes aforefaid, yet beware they come not neare your tongue or lippes, left they tell you to your colt, they are not fo good as they feeme to be: in the middeft of the flower, when it is open and gapeth wide, are feene certaine fmall threads like beards, ftanding about a middle head, which when the flower is paft, groweth into three or foure, or more fmall blackith pods, containing in them blacke feede: the rootes are brownith on the outfide, and white within, fomewhat bigge and round aboue, and fmall downewards, fomewhat like vnto a fmall thort Carrot roote, fornetimes two being ioyned at the head together. But the name Napellus anciently giuen vnto it, doth thew they referred the forme of the roote vnto a fmall Turnep.

\section{Anthora. The wholfome Helmet flower, or counterpoifon Monkes hood.}

This wholfome plant I thought good to infert, not onely for the forme of the flower, but alfo for the excellent properties thereof, as you fhall haue them related hereafter. The rootes hereof are fmall and tuberous, round and fomewhat long, ending for the moft part in a long fibre, and with fome other fmall threads from the head downeward: from the head whereof rifeth vp diuers greene leaues, euery one feuerally vpon a ftalke, very much diuided, as finely almoft as the leaues of Larkes heeles or fpurres: among which rifeth vp a hard round ftalke, a foote high and better, with fome fuch leaues thereon as grow belowe, at the toppe whereof ftand many fmall yellowilh flowers, formed very like vnto the former whitifl Wolfesbane, bearing many blacke feedes in pods afterwards in the like manner.

Many more forts of varieties of thefe kindes there are, but thefe oncly, as the inoft fpecious, are nourfed vp in Florifts Gardens for pleafure; the other are kept by fuch as are Catholicke obferuers of all natures ftore.

\section{The Place.}

All thefe grow naturally on Mountaines, in many thadowie places of the Alpes, in Germany, and elfewhere.

The Time.

The firlt flowreth (as is faid) in Ianuary, and February, and fometimes vntill March be well fpent, and the feede is foone ripe after.

The other three flower not vntill Iune and Iuly.

The Names.

- The firf is vfually called Aconitum hyemale Belgarum. Lobelius calleth it 
Bulbofus vnifolius Batrachoides, Aconitum Elleboraceum, and Ranunculus Monophyllos, and fome by other names. Moft Herbarifts call it Aconitum hyemale, and we in Englifh thereafter, Winters Wolfesbane; and of fome, Yellow Aconite.

The fecond is called by moft Writers, Aconitum luteum Ponticum: Some alfo Lupicida, Luparia, and Canicida, of the effect in killing Wolues and Dogs: And fome, becaufe the flower is more white then yellow, doe call it Aconitum flore albido, we call it in Englifh, The whitifh yellow Aconite, or Wolfesbane, but fome after the Latine name, The yellow Wolfesbane.

The third is called generally Napellus, and Verus, becaufe it is the true Napellus of the ancient Writers, which they fo termed from the forme of a Turnep, called Napus in Latine.

The fourth is called Aconitum Salutiferum, Napellus Moyfis, Antora and Anthora, quafi Antithora, that is, the remedy againft the poifonfull herbe Thora, in Englifh according to the title, eyther wholfome Helmet flower, or counterpoifon Monkes hood.

\section{The Vertues.}

Although the firft three forts of plants be very poifonfull and deadly, yet there may bee very good vfe made of them for fore eyes (being carefully applyed, yet not to all forts of fore eyes neither without difcretion) if the diftilled water be dropped therein.

The rootes of the counterpoifon Monkes hood are effectuall not onely againt the poif on of the poifonfull Helmet flower, and all others of that kinde, but alfo againt the poif on of all venemous beafts, the plague or peftilence, and other infectious difeafes, which raife fpots, pockes, or markes in the outward skinne, by expelling the poif on from within, and defending the heart as a moft foueraigne Cordiall. It it vfed alfo with good fucceffe againt the wormes of the belly, and againft the paines of the Wind collick.

\section{Ch Á P. X X V I I.}

\section{Ranunculus. The Crowfoote.}

$\mathrm{N}^{\mathrm{s}}$ Ext vnto the Aconites, of right are to follow the Ranunculi, or Crowfeete, for the neareneffe both of forme, of leaues, and nature of the plants, although leffe hurtfull, yet all of them for the molt part being tharpe and exulcerating, and not without fome danger, if any would be too bold with them. The whole Family of the Ranunculi is of a very large extent, and I am conftrained within the limits of a Garden of Pleafure; I muft therefore felect out onely fuch as are fit for this purpofe, and fet them here downe for your knowledge, leauing the reft for that other generall worke, which time may perfect and bring to light, if the couetous mindes of fome that fhould be moft affected towards it, doe not hinder it : or if the helpe of generous fpirits would forward it.

\section{Ranunculus montanus albus humilior. The lowe white mountaine Crowfoot.}

This lowe Crowfoote hath three or foure broad and thicke leaues, almoft round, yet a little cut in and notched about the edges, of a fine greene and Thining colour on the vpperfide, and not fo green vnderneath, among which rifeth a fmall fhort ftalke, bearing one fnow white flower on the toppe, made of fiue round pointed leaues, with diuers yellow threads in the middle, ftanding about a greene head, which in time groweth to be full of feede, in forme like vnto a fmall greene Strawberry: the roote is compofed of many white ftrings.

Duplici flore. There is another of this lowe kinde, whofe leaues are fomewhat more ideeply cut in on the edges, and the flower larger, and fometimes a little double, as it were with two rowes of leaues, in other things not differing from the former. 


\section{Ranunculus montanus albus maior vel elatior.}

The great fingle white mountaine Crowfoote.

The leaues of this Crowfoote are large and greene, cut into three, and fometimes into fue fpeciall diuifions, and each of them befides cut or notched about the edges, fomewhat refembling the leaues of the Globe Crowfoote, but larger: the ftalke is two foote and a halfe high, hauing three fmall leaues fet at the ioynt of the ftalke, where it brancheth out into flowers, which ftand foure or fiue together vpon long foote-ftalkes, made of fiue white leaues a peece, very fweete, and fomewhat larger then the next white Crowfoote, with fome yellow threads in the middle compaffing a greene head, which bringeth feede like vnto other wilde Crowfeete: the roote hath many long thicke whitifh ftrings, comming from a thicke head.

\section{Ramunculus montanus albus minor. The leffer fingle white Crowfoote.}

This Crowefoote hath faire large fpread leaues, cut into fiue diuifions, and fomewhat notched about the edges, greene on the vpperfide, and paler vnderneath, hauing many veines running through the leaues: the ftalke of this rifeth not fo high as the former, although this be reafonable tall, as being neare two foote high, fpread into inany branches, bearing fuch like white flowers, as in the former, but fmaller: the feede of this is like the former, and fo are the rootes likewife.

\section{Ranunculus albus fore plens. The double white Crowfoot.}

The double white Crowfoote is of the fame kinde with the laft fingle white Crowfoote, hauing fuch like leaues in all refpects: the onely difference is in the flowers, which in this are very thicke and double. Some doe make mention of two forts of double white Crowfeete, one fomewhat lower then another, and the lower likewife bearing more ftore of flowers, and more double then the higher: but I confeffe, I haue neuer feene but one fort of double, which is the fame here expreffed, not growing very high, and reafonably well ftored with flowers.

\section{Ranunculus precox Rutafolio frue Coriandrifolio.}

The early Coriander leafed Crowfoote.

This Crowfoote hath three or foure very greene leaues, cut and diuided into many finall peeces, like vnto the wing of leaues of Rue, or rather like the lower leaues of the Coriander (for they well refemble either of them) euery of them ftanding vpon a long purplifh ftalke, at the toppe whereof groweth the flower alone, being compofed or made of twelue fmall white leaues, broad pointed, and a little endented at the ends, fomewhat purplifh on the outfide, and white on the infide, fuftained by diuers fmall greene leaues, which are in ftead of a cup or huske: in the middle of the flower are many imall white threads, tipt with yellow pendents, ftanding about a fmall greene head, which after groweth to bee full of feedes like a Strawberry, which knobs giue fmall blackifh feede: the roote is white and fibrous.

\section{Ramunculus Thalictrifolio maior. The great colombine leafed Crowfoot.}

The lower leaues of this Crowfoote haue long ftalkes, and are very like vnto the fmaller leaues of Colombines, or the great Spanifh Thalictrum, which hath his leaues very like unto a Colombine, foure or flue rifing from the roote: the ftalke rifeth about a foote and a halfe high, fomewhat reddifh, befet here and there with the like leaues, at the toppe whereof ftand diuers fmall white flowers, made of fiue leaues a peece, with fome pale white threads in the middle: the reede is round and reddifh, contained in fmall huskes or hornes: the roote is made of a bufh or tuft of white ftrings. 


\section{Ramunculus Thaliztrifolio minor ASphodeli radice.}

The (mall white Colombine leafed Crowfoote.

This fmall Crowfoote hath three or foure winged leaues fpread vpon the ground, ftanding vpon long ftalkes, and confifting of many fmall leaues fet together, fpreading from the middle ribbe, euery leafe fomewhat refembling both in fhape and colour the fmalleft and youngeft leaues of Colombines: the flowers are white, ftanding at the toppe of the ftalkes, made of fiue round leaues: the root hath three or foure thick, Thort, and round yellowifh clogs hanging at the head, liko vnto the Arphodill roote. The great Herball of Lyons, that goeth vnder the name of Dale fchampius, faith, that $\mathrm{Dr}$. Myconus found it in Spaine, and fent it vnder the name of Oenanthe; and therefore Ioannes Molineus who is thought to haue compofed that booke, fet it among the vmbelliferous plants, becaufe the Oenanthes beare vmbels of flowers and feede, and haue tuberous or cloggy rootes; but with what iudgement, let others fay, when they haue compared the vmbels of flowers and feede of the Oenanthes, with the flowers and feede of this plant, and whether I haue not more properly placed it among the Ranunculi or Crowfeete, and giuen it a denomination agreeable to his forme.

\section{Ranunculus Globofus. The Globe Crowfoot.}

This Crowfoote (which in the Northerne countries of England where it groweth plentifully, is called Locker goulous) hath many faire, broad, darke greene leaues next the ground, cut into fiue, fixe, or feuen diuifions, and iagged befides at the edges; among which rifeth vp a ftalke, whereon are fet fuch like leaues as are belowe, but fmaller, diuided toward the toppe into fome branches, on the which ftand feuerall large yellow flowers, alwayes folded inward, or as a clofe flower neuer blowing open, as other flowers doe, confifting of eleuen leaues for the moft part, fet or placed in three rowes, with many yellow threads in the middle, ftanding about a greene rough head, which in time groweth to be fmall knops, wherein are contained blacke feede: the roote is compofed of many blackifh ftrings.

\section{Ranunculus pratenfis fore multiplici. The double yellow field Crowfoot.}

There is little or no difference in the leaues of this double Crowfoot, from thofe of the fingle kindes that growe in euery medowe, being large and diuided into foure or fiue parts, and indented about the edges, but they are fomewhat fmaller, and of a frefher greene: the flowers ftand on many branches, much diuided or feparated, being not very great, but very thicke and double: the roote runneth and creepeth vnder ground like as the fingle doth.

\section{Ranunculus Anglicus maximus multiplex.}

The Garden double yellow Crowfoot or Batchelours buttons.

This great double Crowfoote, which is common in euery Garden through England, hath many great blackifh greene leaues, iagged and cut into three diuifions, each to the middle ribbe : the ftalkes haue fome fmaller leaues on them, and thofe next vnder the branches long and narrow: the flowers are of a greenifh yellow colour, very thicke and double of leaues, in the middle whereof rifeth vp a fmall ftalke, bearing another double flower, like to the other, but fmaller: the roote is round, like vnto a fmall white Turnep, with diuers other fibres annexed vnto it.

\section{1: Ranunculus Gramineus. Graffe leafed Crowfoot.}

The leaues of this Crowfoote are long and narrow, fomewhat like vnto Graffe, or rather like the leaues of fingle Gilloflowers or Pinckes, being fmall and tharpe pointed, a little hollow, and of a whitifh greene colour: among thefe leaues rife vp diuers flender ftalkes, bearing one fmall flower at the toppe of each, confifting of fiue yellow 


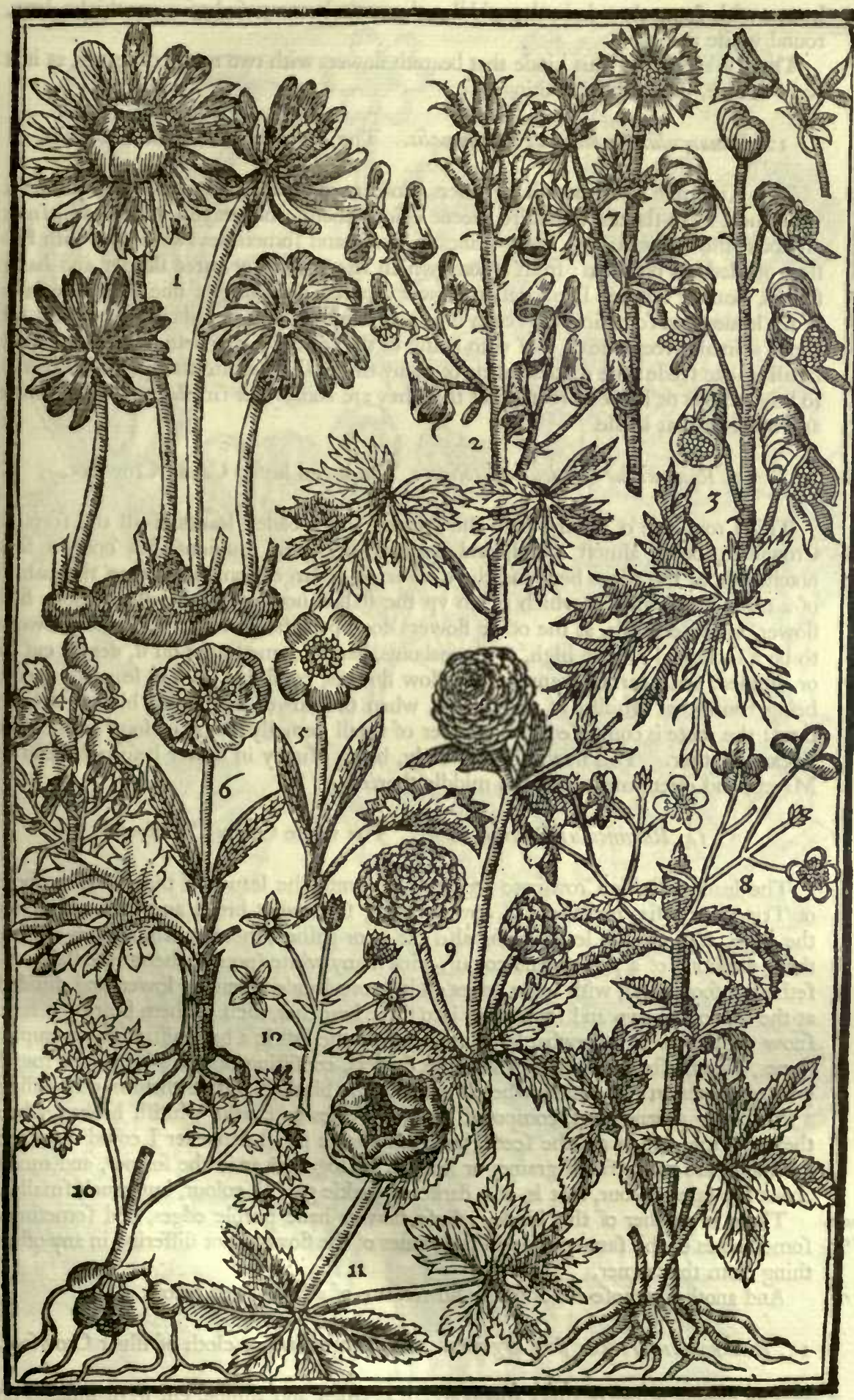

1 Aconifum Hyowale. Winter Wolfesbane. 2 Aconilum fore albido fouc luteum Ponticum. Tbe whitifh sellow Wolfesbane. 3 Napellus scrus. Blew Helmets or Monkes hood. \& Anthora. The counterpoifon Monkes hood. 5 Ranxmeulus humilis albus fimplex. The fingle white low Crowfoot. 6 Ranumculns humilis albus duplici fore. The double lowe uhite Crowfoot. 7 Ranumculus Coriandrifolio. The early Coriander leafed Crowfoot. 8 Ranurculus montanus clatior albus. The great fingle white mountain Crowfoot. 9 Ranunculus montanus albus flore pleno. The double white mountain Crowfoot. so Rarunculus 
leaues, with fome threads in the middle: the roote is compofed of many thicke, long, round white ftrings.

There is another of this kinde that beareth flowers with two rowes of leaues, as if it were double, differing in nothing elfe.

\section{Ranunculus Lufitanicus Autumnalis. The Portugall Autumne Crowfoot.}

This Autumne Crowfoote hath diuers broad round leaues lying on the ground, fet vpon fhort foote-ftalkes, of a faire greene colour aboue, and grayilh vnderneath, fnipt all about the edges, hauing many veines in them, and fometimes fwelling as with blifters or bladders on them; from among which rife vp two or three flender and hairy ftalkes, bearing but one fmall yellow flower a peece, confifting of fiue and fometimes of fix leaues, and fometimes of feuen or eight, hauing a few threads in the middle, fet ábout a fmall greene head, like vnto many of the former Crowfeete, which bringeth fmall blacke feede: the roote is made of many thicke fhort white ftrings, which feeme to be grumous or kernelly rootes, but that they are fomewhat fmaller, and longer then any other of that kinde.

\section{I3. Ranunculus Creticus latifolius. The broad leafed Candy Crowfoot.}

This Crowfoote of Candy, hath the greateft and broadeft leaues of all the forts of Crowfeete, being almoft round, and without any great diuifions, but onely a few notches about the edges here and there, as large or larger fometimes then the palme of a mans hand; among which rifeth vp the ftalke, not very high when it doth firft flower, but afterwards, as the other flowers doe open themfelues, the ftalke groweth to be a foote and a halfe high, or thereabouts, hauing fome leaues on it, deeply cut in or diuided, and bearing many faire yellow flowers, confifting of fiue leaues a peece, being fomewhat whitifh in the middle, when the flower hath ftood blowne a little time: the roote is compofed of a number of fmall kernelly knobs, or long graines, fet thicke together. This flowreth very early, being vfually in flower before the end of March, and oftentimes about the middle thereof.

\section{Ranunculus Creticus albus. The white Candy Crowfoote.}

The leaues of this Crowfoote are very like vnto the leaues of the red Crowfoote of Tripoli or Afia, hereafter fet downe, being fomewhat broad and indented about the edges, fome of the leaues being alfo cut in or gafhed, thereby making it as it were three diuifions, of a pale greene colour, with many white fpots in them: the ftalke rifeth vp a foote high, with fome leaues on it, more diuided then the lower, and diuided at the toppe into two and fometimes into three branches, each of them bearing a faire fnow white flower, fomewhat large, included at the firt in a brownith huske or cup of leaues, which afterwards ftand vnder the flowers, confifting of fiue white large round pointed leaues, in the middle whereof is fet many blackifh purple thrums, compaffing a fmall long greene head, compofed of many fcales or chaffie whitifh huskes, when they are ripe, which are the feede, but vnprofitable in all that euer I could obferue: the rootes are many fmall graines or kernels, fet together as in the former, and much about the fame colour, that is, of a darke or duskie grayifh colour, but much fmaller. Alba purpureis There is another of this kinde, whofe flowers haue purple edges, and fometimes oris $\varepsilon$ venis. fome veines of the fame purple in the leaues of the flowers, not differing in any other thing from the former.

Alba oris ru- And another, whofe edges of the flowers are of a bright red colour.
bris.

\section{Ranunculus Creticus flore argenteo. The Argentine, or cloth of filuer Crowfoot.}

The greene leaues of this Crowfoote are as fmall and thinne, cut in or diuided on the edges, as the laft two forts; the ftalke rifeth vp fomewhat higher, and diuided into fome branches, bearing at the toppe of euery of them one flower, fomewhat fmaller then the former, compofed of fix, feuen, and fometimes of eight fmall round pointed 


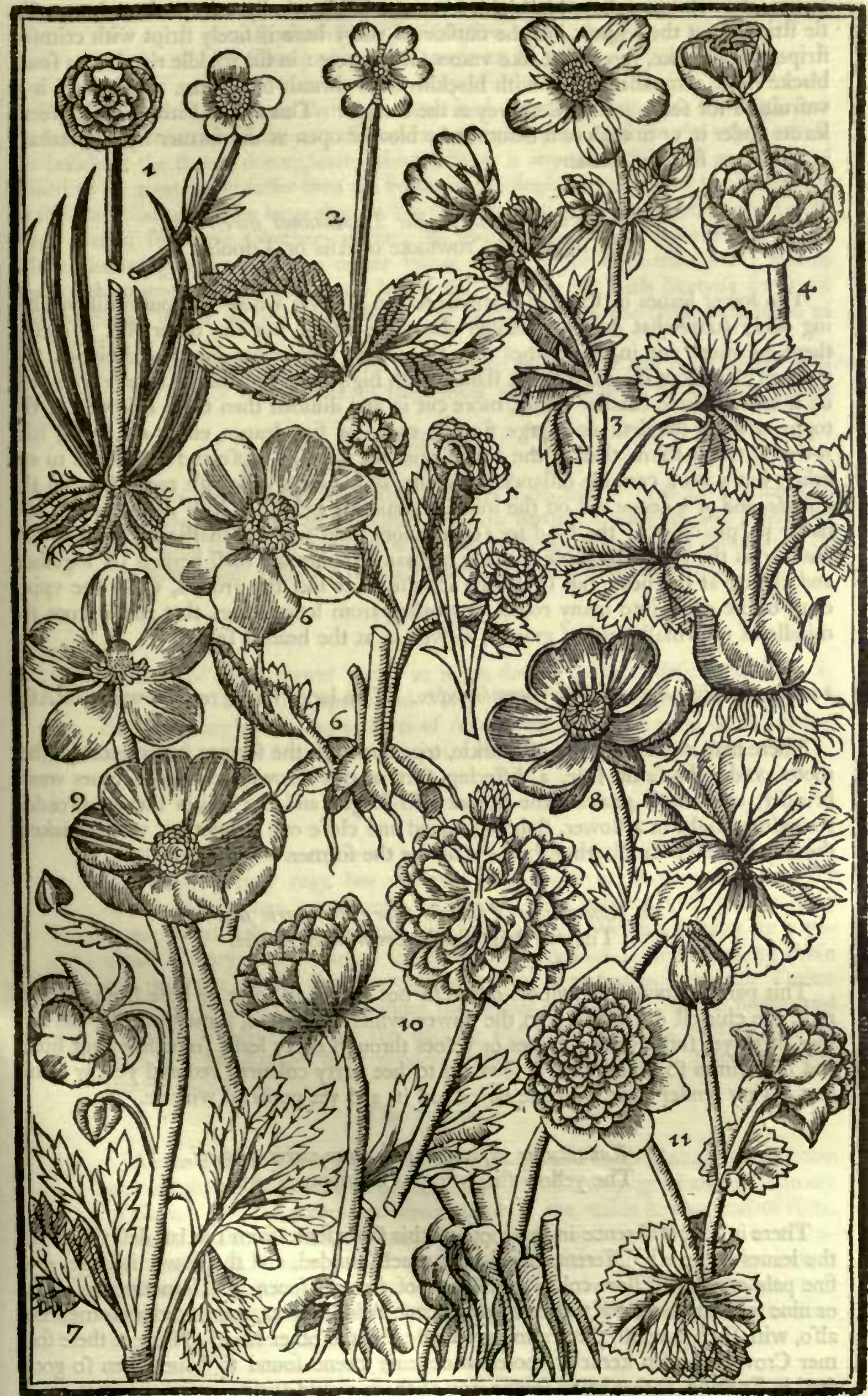

I Ranunculus gramineus fore fimplici o duplici. The fingle and the dooble graffe Crowfoot. 2 Ranusculus Lufslanicus Autum malis. The Portugall Autumne Crowfoot. 3 Ranunculus Creticus latifolius. The broad leafed Candy Crowfoot. 4 Ranunculus Anglicus maximus multiplex. The double Englith Crowfoot. 5 Ranunculus pratenfis flore multiplici. The double yellow field Crowfoot. 6 Ranunulus Creticus albus. The white Candy Crowfoot. 7 Ranunculus Afraticus fore albo vol pallido vario. The white or the furaw coloured Crowfoot with red tops or edges. 8 Ranunculus Tripolitanus fore rubro fimplici. The fingle red Crowfoot of Tripoli. 9 Ranunculus Afiaticus fore rubro amplo. The large fingle red Crowfoot of Afia. To Ranunculus Afaticus flore rubro pleno. The double red Crowfoot of Afia. II Caltha palmfiris Aore plono. Double Marfh Marigold or Batchelours buttons. 
leaues, of a whitifh yellow blurh colour on the infide wholly, except fometimes a little ftript about the edges : but the outfide of euery leafe is finely ftript with crimfon ftripes, very thicke, fomewhat like vnto a Gilloflower : in the middle rifeth vp a fmall blacke head, compaffed about with blackifh blew threads or thrums, which head is as vnfruitfull for feede in our Countrey as the former. This flower hath no fuch greene leaues vnder it, or to enclofe it before it be blowne open as the former : the rootes are in all things like the former.

\section{Ranunculus A faticus fue Tripolitanus flore rubro.} The fingle red Crowfoote of Afia or Tripoli.

The lower leaues of this red Crowfoote are alwayes whole without diuifions, being onely fomewhat deeply indented about the edges, but the other that rife after them are more cut in, fometimes into three, and fometimes into fiue diuifions, and notched alfo about the edges : the ftalke rifeth higher then any of the former, and hath on it two or three fmaller leaues, more cut in and diuided then thofe belowe : at the toppe whereof ftandeth one large flower, made of fiue leaues, euery one being narrower at the bottome then at the toppe, and not ftanding clofe and round one to another, but with a certaine diftance betweene, of a duskie yellowifh red colour on the outfide, and of a deepe red on the infide, the middle being fet with many thrums of a darke purple colour : the head for feede is long, and fcaly or chaffie, and idle in like manner as the reft : the roote is made of many graines or fmall kernels fet together, and clofing at the head, but fpreading it felfe, if it like the ground, vnder the vpper cruft of the earth into many rootes, encreafing from long ftrings, that runne from the middle of the fmall head of graines, as well as at the head it felfe.

\section{Ranunculus Afiaticus flore amplo rubro. The large fingle red Crowfoot of Afia.}

There hath come to vs out of Turkie, together with the former, among many other rootes, vnder the fame title, a differing fort of this Crowfoote, whofe leaues weare broader, and much goaler; the flower alfo larger, and the leaues thereof broader, fometimes eight in a flower, ftanding round and clofe one to another, which maketh the fairer fhew : in all other things it is like the former.

\section{Ranunculus Afiaticus flore rubro vario fimplici.}

The red Atript fingle Crowfoote of Afia.

This party coloured Crowfoote differeth not eyther in roote or leafe from the former, the chiefeft difference is in the flower, which being red, fomewhat like the former, hath yet fome yellow ftripes or veines through euery leafe, fometimes but little, and fometimes fo much, that it feemeth to bee party coloured red and yellow: this fort is very tender; for we haue twice had it, and yet perifhed with vs.

\section{Ranunculus Afiaticus flore luteo vario fimplici.} The yellow ftript fingle Crowfoote of Afia.

There is little difference in the roote of this Crowfoote from the laft defcribed, but the leaues are much different, being very much diuided, and the flower is large, of a fine pale greenifh yellow colour, confifting of fix and feuen, and fometimes of eight or nine round leaues; the toppes whereof haue reddifh (pots, and the edges fometimes alfo, with fuch purplifh thrums in the middle that the other haue. None of these former Crowfeete with kernelly rootes, haue euer beene found to haue giuen fo good feed in England, as that being fowne, any of them would fpring vp; for hereof tryall hath been often made, but all they haue lost their labour, that haue bestowed their paines therein, as farre as I know. 


\section{Ranunculus Afiaticus flore rubro pleno.}

The double red Crowfoote of Afia.

The double red Crowfoote hath his rootes and leaues fo like vnto the fingle red kinde, that none can perceiue any difference, or know the one from the other, vntill the budde of the flower doe appeare, which after it is any thing forward, may be perceiued to be greater and fuller then the budde of the fingle kinde. This kinde beareth moft vfually but one faire large double flower on the toppe of the ftalke, compofed of many leaues, fet clofe together in three or foure rowes, of an excellent crimfon colour, declining to Scarlet, the outter leaues being larger then the inner; and in ftead of thrummes, hath many fmall leaues fet together: it hath likewife fix fmall narrow greene leaues on the backfide of the flower, where the ftalke is faftened to the flower.

There is of this double kinde another fort, whofe flower is of the fame colour with Prolifere forc the former, but out of the middle of the flower arifeth another double flower, but fmaller.

The Place.

Thefe plants grow naturally in diuers Countries; fome in France, and Germany, and fome in England, fome in Spaine, Portugall, and Italy, and fome haue been fent out of Turkie from Conftantinople, and fome from other parts, their titles for the moft part defcrying their Countries.

\section{The Time.}

Some of them flower early, as is fet downe in their defcriptions, or titles. The others in Aprill and May. The white Candy Crowfoote, and the other fingle and double forts of Afia, about the fame time, or fomewhat later, and one in Autumne, as it is fet downe.

\section{The Names.}

The names that are giuen feuerally to them may well ferue this worke, that thereby they may bee diftinguifhed one from another: For to fet downe any further controuerfie of names, how fitly or vnfitly they haue beene called, and how variably by diuers former Writers, is fitter for a generall Hiftory, vnto which I leaue what may be faid, both concerning thefe and the reft: Onely this I would giue you to vnderftand, that the Turkie kindes haue been fent to vs vnder the names of Terobolos for the fingle, and Terobolos Catamer lale for the double, and yet oftentimes, thofe that haue been fent for double, haue proued fingle, fo little fidelity is to bee found among them.

\section{The Vertues.}

All or moft of thefe plants are very fharpe and exulcerating, yet the care and induftry of diuers learned men haue found many good effects in many of them. For the rootes and leaues both of the wilde kindes, and of fome of thefe of the Garden, ftamped and applyed to the wrifts, haue driuen away the fits in Feuers. The roote likewife of the double Englifh kinde is applyed for peftilent fores, to helpe to breake them, by drawing the venome to the place. They helpe likewife to take away fcarres and markes in diuers places of the body. 


\section{С н А Р. X X V III.}

\section{Galtha paluftris flore pleno. Double Marh Marigold.}

A $\mathrm{S}$ an appendix to the Crowfeete, I muft needes adde this plant, yet feuerally by it felfe, becaufe both it and his fingle kinde are by mont adioyned thereunto, for the neare refemblance both in thape and tharpneffe of quality. The fingle kinde I leaue to the Ditch fides, and moift grounds about them, as the fitteft places for it, and onely bring the double kinde into my Garden, as fitteft for his goodly proportion and beauty to be entertained, and haue place therein.

The double Marfh Marigold hath many broad and round greene leaues, a little endented about the edges, like vnto the fingle kinde, but not altogether fo large, efpecially in a Garden where it ftandeth not very moift : the ftalkes are weake, round, hollow, and greene, diuided into three or foure branches at the toppe, with leaues at the feuerall ioynts, whereon ftand very double flowers, of a gold yellow colour : the fiue outer leaues being larger then any of the reft that are encompaffed by them, which fall away after they haue ftood blowne a great while (for it endureth in flower a moneth or more, ef pecially if it ftand in a thadowie place) without bearing any feed : the rootes are compofed of many thicke, long, and round whitifh ftrings, which runne downe deep into the ground, and there are faftened very ftrongly.

The Place.

This plant groweth naturally in diuers Marfhes, and moift grounds in Germany, yet in fome more double then in others; it hath long agoe beene cherifhed in our Gardens.

\section{The Time.}

It flowreth in Aprill or May, as the yeare proueth earlier or later: all his leaues doe in a manner quite perifh in Winter, and fpring anew in the end of February, or thereabouts.

\section{The Names.}

There is great controuerfie among the learned about the fingle kinde, but thereof I thall not neede to fpeake in this place; if God permit I may in a fitter. This is called generally in Latine, Galtha paluftris multiplex, or flore pleno. And wee in Englifh (after the Latine, which take Caltha to be that which wee vfually call Calendula, a Marigold) The double Marh Marigold.

The Vertues.

The roote hereof is tharpe, comming neare vnto the quality of the Crowfeete, but for any f peciall property, I have not heard or found any. 


\section{CH A P. X XIX.}

\section{Hepatica nobilis fue trifolia. Noble Liuerwort.}

$\mathrm{N}$ Ext vnto the Crowfeete are to follow the Hepaticas, becaufe of the likeneffe with them, feeming to be fmall Crowfeete in all their parts, but of another and more wholfome kinde. Their diuerfity among themfelues confifteth chiefly in the colour of the flowers, all of them being fingle, except one which is very thicke and double.

\section{Hepatica flore caruleo fimplici maior.}

The great fingle blew Hepatica or noble Liuerwort.

The flowers of this Hepatica doe fpring vp, blow open, and fometimes thed and fall away, before any leaues appeare or fpread open. The rootes are compofed of a bufh of blackifh ftrings, from the feuerall heads or buttons whereof, after the flowers are rifen and blowne, arife many frefh greene leaues, each feuerally ftanding vpon his foot-ftalke, folded together, and fomewhat browne and hairy at their firft comming, which after are broad, and diuided at the edges into three parts: the flowers likewife ftand euery one vpon his owne feuerall foote-ftalke, of the fame height with the leaues for the moft part, which is about foure or fiue fingers breadth high, made of fix leaues moft vfually, but fometimes it will haue feuen or eight, of a faire blew colour, with many white chiues or threads in the middle, ftanding about a middle green head or vmbone, which after the flower is fallen groweth greater, and fheweth many fmall graines or feede fet clofe together (with three fmall greene leaues compaffing them vnderneath, as they did the flower at the bottome) very like the head of feed of manie Crowfeete.

\section{Hepatica minor flore pallido caruleo. The fmall blew Hepatica.}

The leaues of this. Hepatica are fmaller by the halfe then the former, and grow more aboundantly, or bufhing thicke together: the flowers (when it fheweth them, for I haue had the plant halfe a fcore yeares, and yet neuer faw it beare flower aboue once or twice) are of a pale or bleake blew colour, not fo large as the flowers of the former.

\section{Hepatica flore purpureo. Purple Hepatica or noble Liuerwort.}

This Hepatica is in all things like vnto the firft, but onely the flowers are of a deeper blew tending to a Violet purple: and therefore I fhall not neede to reiterate the former defcription.

\section{Hepatica flore albo minor. The leffer white Hepatica.}

The flowers of this Hepatica are wholly white, of the bigneffe of the red or purple, and the leaues fomewhat fmaller, and of a little whiter or paler greene colour, elfe in all other things agreeing with the former.

\section{Hepatica alba magno flore. The great white Hepatica.}

There is no other difference herein from the laft, but that the flower being as white, is as large as the next.

\section{Hepatica albida fue argentea. Afh-coloured or Argentine Hepatica.}

Both the leaues and the flowers of this Hepatica are larger then any of the former, except the laft: the flowers hereof at the firft opening feeme to bee of a blufh afh-colour, which doe fo abide three or foure dayes, decaying ftill vntill it turne almoft 
white, hauing yet ftill a fhew of that blufh afh-colour in them, till the very laft.

7. Hepatica alba Araminibus rubris. White Hepatica with red threads.

There is no difference between this Hepatica and the firt white one, fauing that the threads in the middle of the flower, being white, as in the former, are tipt at the ends with a pale reddifh colour, which adde a great beauty to the flowers.

\section{Hepatica flore rubro. Red Hepatica or noble Liuerwort.}

The leaues of this Hepatica are of a little browner red colour, both at their firft comming vp, and afterwards, efpecially in the middle of the leafe more then any of the former : the flowers are in forme like vnto the reft, but of a bright blufh, or pale red colour, very pleafant to behold, with white threads or chiues in the middle of them.

\section{Hepatica flore purpureo multiplici fue pleno.}

The double purple Hepatica.

The double Hepatica is in all things like vnto the fingle purple kinde, fauing onely that the leaues are larger, and ftand vpon longer foote-ftalkes, and that the flowers are fmall buttons, but very thicke of leaues, and as double as a flower can be, like vnto the double white Crowfoote before defcribed, but not fo bigge, of a deepe blew or purple colour, without any threads or head in the middle, which fall away without giuing any feede.

\section{Hepatica flore caruleo pleno. The double blew Hepatica.}

In the colour of this flower, confifteth the chiefeft difference from the laft, except one may fay it is a little leffe in the bigneffe of the flower, but not in doubleneffe of leaues.

\section{The Place.}

All thefe plants with fingle flowers grow naturally in the Woods, and fhadowie Mountaines of Germany in many places, and fome of them in Italy alfo. The double kinde likewife hath been fent from Alphonfus Pantius out of Italy, as Clufius reporteth, and was alfo found in the Woods, neare the Caftle of Starnbeg in Auftria, the Lady Heufenftains poffeffion, as the fame Clufius reporteth alfo.

\section{The Time.}

Thefe plants doe flower very early, and are of the firft flowers that fhew themfelues prefently after the deepe frofts in Ianuary, fo that next vnto the Winter. Wolfesbane, thefe making their pride appeare in Winter, are the more welcome early guefts. The double kinde flowreth not altogether fo early, but fheweth his flower, and abideth when the others are paft.

\section{The Names.}

They haue obtained diuers names; fome calling them Hepatica, Hepatica nobilis, Hepaticum trifolium, Trifolium nobile, T'rifolium aureum, and fome T'rinitas, and Herba Trinitatis. In Englifh you may call them either Hepatica, after the Latine name, as moft doe, or Noble Liuerwort, which you pleafe.

\section{The Vertues.}

Thefe are thought to coole and ftrengthen the liuer, the name importing as much; but I neuer faw any great vfe of them by any the Phyfitians of our London Colledge, or effect by them that haue vfed them in Phyficke in our Country. 


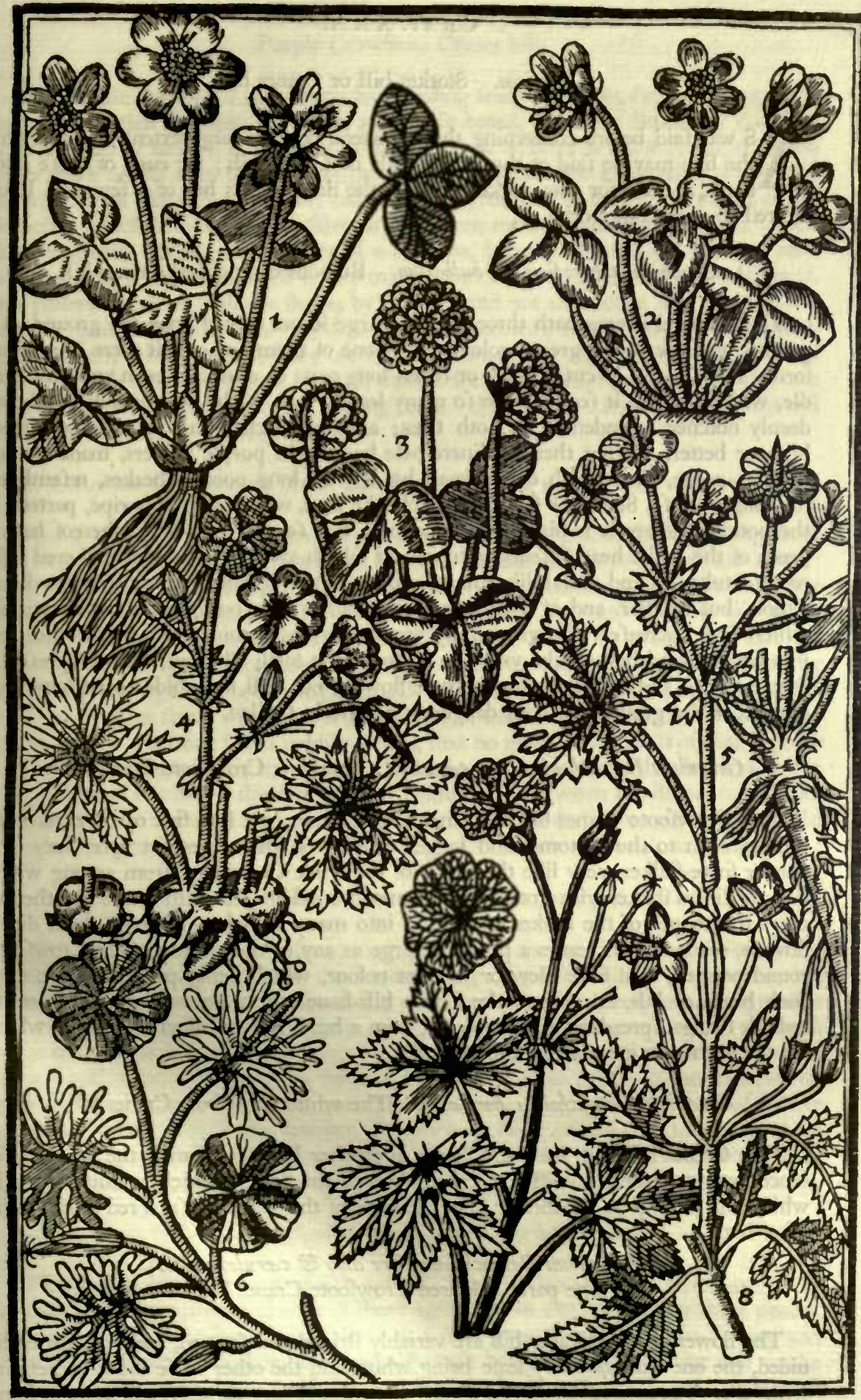

I Hepatia fore albo amplo fomplici. The large white Hepatica. a Hepatisa fore rubra fimplici. The red Hepatica. 3 He patica fore purpurca pleno. The double purple Hepatica. 4 Geraniusm twberofum. Knobbed Cranes bill. 5 Geraniusm Iatra. chosdes fiare alba oel carileo. The The variable flript Cranes bill. 8 Geranium Craticun. Candy Cranes bill. 7 Goranium Romanum ftrictum. The variable ftript Cranes bill. 8 Geranium Crcticum. Candy Cranes bill. 
CH A P. XXX.

Geranium. Storkes bill or Cranes bill.

A $\mathrm{S}$ was faid before concerning the Crowfeet, of their large extent and reftraint, the like may be faid of the Storkes bils or Cranes bils; for euen of thefe as of them, I muft for this worke fet forth the defcriptions but of a few, and leaue the reft to a generall worke.

\section{Geranium tuberofium vel bulbofum. Bulbous or knobbed Cranes bill.}

The knobbed Cranes hath three or foure large leaues fpread vpon the ground, of a grayinh or rather dufty greene colour, euery one of them being as it were of a round forme, but diuided or cut into fix or feuen long parts or diuifions, euen vnto the middle, which maketh it feeme to be fo many leaues, each of the cuts or diuifions being deeply notched or indented on both fides; among which rifeth vp a ftalke a foote high or better, bearing thereon diuers pale but bright purple flowers, made of fiue leaues a peece, after which come fmall heads with long pointed beakes, refembling the long bill of a Storke or Crane, or fuch like bird, which after it is ripe, parteth at the bottome where it is biggent, into foure or fiue feedes, euery one whereof hath a peece of the beake head faftened vnto it, and falleth away if it bee not gathered: the roote is tuberous and round, like vnto the roote of the Cyclamen or ordinary Sowbread almoft, but fmaller, and of a darke ruffet colour on the outfide, and white within, which doth encreafe vnder ground, by certaine ftrings running from the mother root into fmall round bulbes, like vnto the rootes of the earth Chefnut, and will prefently (hoote leaues, and quickly grow to beare flowers, but will not abide to be kept long dry out of the ground, without danger to be vtterly fpoiled.

Geranium Batrachoides flore caruleo. The blew Crowfoote Cranes bill.

This Crowfoote Cranes bill hath many large leaues, cut into fiue or fix parts or diuifions, euen to the bottome, and iagged befides on the edges, fet vpon very long nlender foote-ftalkes, very like the leaues of the wilde Crowfoot; from among which rife vp diuers ftalkes with great ioynts, fomewhat reddifh, fet with leaues like the former: the toppes of the ftalkes are fpread into many branches, whereon ftand diuers flowers, made of fiue leaues a peece, as large as any of the wilde or field Crowfeete, round pointed, of a faire blew or watchet colour, which being paft, there doe arife fuch heads or bils, as other of the Cranes bils haue: the roote is compofed of many reddifh ftrings, fpreading in the ground, from a head made of diuers red heads, which lye oftentimes eminent aboue the ground.

\section{Geranium Batrachoides flore albo. The white Crowfoote Cranes bill.}

This Cranes bill is in leafe and flower altogether like the former, the onely difference betweene them confifteth in the colour of the flower, which in this is wholly white, and as large as the former: but the roote of this hath not fuch red heads as the other hath.

\section{Geranium Batrachoides flore albo Es caruleo vario.}

The party coloured Crowfoote Cranes bill.

The flowers of this Cranes bill are variably ftriped and f potted, and fometimes diuided, the one halfe of euery leafe being white, and the other halfe blew, fometimes with leffer or greater fpots of blew in the white leafe, very variably, and more in fome years then in others, that it is very hard to expreffe all the varieties that may be obferued in the flowers, that blow at one time. In all other parts of the plant, it is fo like vnto the former, that vntill it be in flower, the one cannot be knowne from the other. 


\section{Geranium Batrachides alterum flore purpureo.}

Purple Crowfoote Cranes bill.

This purple Cranes bill hath many leaues rifing from the roote, fet vpon long footftalkes, fomewhat like vnto the other, yet not fo broad, but more diuided or cut, that is, into feuen or more nits, euen to the middle, ench whereof is likewife cut in on the edges more deeply then the former; the ftalkes are fomewhat knobbed at the ioynts, fet with leaues like vnto the lower, and bearing a great tuft of buds at the toppes of the branches, which breake out into faire large flowers, made of fiue purple leaues, which doe fomewhat refemble the flower of a Mallow, before it be too full blowne, each whereof hath a reddifh pointell in the iniddle, and many fmall threads compaffing it, this vimbell or tuft of buds doe flower by degrees, and not all at once, and euery flower abideth open little more then one day, and then theddeth, fo that euery day yeeldeth frefh flowers, which becaufe they are fo many, are a long while before they are all paft or fpent : after the flowers are paft, there arife fmall beake heads or bils, like vnto the other Cranes bils, with fmall turning feede : the roote is compofed of a great tuft of ftrings, faftened to a knobby head.

\section{Geranium Romanum ver ficolor fuue friatum. The variable ftript Cranes bill.}

This beautifull Cranes bill hath many broad yellowith greene leaues arifing from the roote, diuided into fiue or fix parts, but not vnto the middle as the firt kindes are : each of thefe leaues hath a blackifh fpot at the bottome corners of the diuifions, the whole leafe as well in forme as colour and fpots, is very like vnto the leafe of the Geranium fufcum, or fpotted Cranes bill, next following to be defcribed, but that the leaues of this are not fo large as the other : from among thefe leaues fpring vp fundry ftalkes a foote high and better, ioynted and knobbed here and there, bearing at the tops two or three fnall white flowers, confifting of fiue leaues a peece, fo thickly \& variably ftriped with fine fmall reddinh veines, that no green leafe that is of that bigneffe can fhew fo many veines in it, nor fo thick running as euery leafe of this flower doth : in the middle of the flower ftandeth a fmall pointell, which when the flower is paft doth grow to be the feed veffell, whereon is fet diuers fmall feeds, like vnto the fmall feedes of other Cranes bils: the root is made of many fmall yellow threads or ftrings.

\section{Geranium fufcum fiue maculatum. Swart tawny or fpotted Cranes bill.}

The leaues of this Cranes bill are in all points like the laft defcribed, as well in the forme and diuifions as colour of the leaues, being of a yellowifh greene colour, but larger and ftronger by much : the ftalkes of this rife much higher, and are ioynted or knobbed with reddifh knees or ioynts, on the tops whereof ftand not many although large flowers, confilting of fiue leaues a peece, each whereof is round at the end, and a little fnipt round about, and doe bend or turne themfelues backe to the ftalkewards, making the middle to be higheft or moft eminent ; the colour of the flower is of a darke or deepe blackifh purple, the bottome of euery leafe being whiter than the reft; it hath alfo a middle pointell ftanding out, which afterwards bring forth feede like vnto others of his kinde : the roote confifteth of diuers great ftrings, ioyned to a knobby head.

\section{Geranium Hematodes. The red Rofe Cranes bill.}

This Cranes bill hath diuers leaues fpread vpon the ground, very much cut in or diuided into many parts, and each of them againe fit or cut into two or three peeces, ftanding vpon flender long foote-ltalkes, of a faire greene colour all the Spring and Summer, but reddifh in Autumne : among thefe leaues (pring vp nender and weake ftalkes, befet at euery ioynt (which is fomewhat reddifh) with two leaues for the moft part, like vnto the lower : the flowers grow feuerally on the toppe of the ftalkes, and not many together in bunches or branches, as in all other of the Cranes bils, euery flower being as large as a fingle Rofe Campion flower, confifting of fiue large leaues, 
of a deeper red colour then in any other Cranes bill at the firft opening, and will change more blewifh afterwards : when the flower is paft, there doth arife fuch like beakes as are in others of the fame kinde, but fmall : the roote is hard, long, and thicke, with diuers branches fpreading from it, of a reddifh yellow colour on the outfide, and whitifh within, which abideth and perifheth not, but thooteth forth fome new greene leaues, which abide all the Winter, although thofe that turne red doe fall away.

\section{Geranium Creticum. Candy Cranes bill.}

Candy Cranes bill beareth long and tender ftalkes, whereon growe diuers broad and long leaues, cut in or iagged on the edges : the toppes of the ftalkes are branched into many flowers, made of fiue leaues of a reafonable bigneffe, and of a faire blew or watchet colour, with a purplifh pointell in the middle, which being paft, there follow beake heads like other Cranes bils, but greater, containing larger, greater, and fharper pointed feede, able to pierce the skinne, if one be not warie of it : the roote is white and long, with fome fibres at it, and perifheth when it hath perfected his feede, and will fpring of it owne fowing many times, if the Winter be not too fharpe, otherwife (being annuall) it muft be fowne in the Spring of the yeare.

\section{The Place.}

Moft of thefe Cranes bils are ftrangers vnto vs by nature, but endenizond in our Englifh Gardens. It hath beene reported vnto mee by fome of good credit, that the fecond or Crowfoot Cranes bill hath been found naturally growing in England, but yet I neuer faw it, although I haue feen many forts of wilde kindes in many places. Matthiolus faith that the firft groweth in Dalmatia and Illyria very plentifully. Camerarius, Clufius, and others, that moft of the reft grow in Germany, Bohemia, Auftria, \&c. The laft hath his place recorded in his title.

The Time.

All thefe Cranes bils doe for the molt part flower in Aprill, and May, and vntill the middle of Iune. The variable or ftript Cranes bill is vfually the lateft of all the reft.

\section{The Names.}

The firt is vfually called Geranium tuberofum, of fome Geranium bulbofum, of the likeneffe of the roote vnto a bulbe : It is without controuerfie Geranium primum of Diofcorides. The fecond is called Geranium Gratia Dei, of others, Geranium caruleum. The blew Cranes bill Lobel calleth it Batrachoides, becaufe both leafe and flower are like vnto a Crowfoote ; and the affinity with the Cranes bils in the feede caureth it rather to be referred to them then to the Crowfeete. The ftript Cranes bill is called by fome Geranium Romanum. The laft fauing one is called Geranium Hamatodes, or Sanguineum, of Lobel Geranium Gruinale Hamatodes fupinum radice repente. In Englinh it may be called after the Greek and Latine, The bloudy Cranes bill, but I rather call it, The Rofe Cranes bill, becaufe the flowers are as large as fingle Rofes, or as the Rofe Campion. Some of them are called in many places of England Baffinets.

\section{The Vertues.}

All the kindes of Cranes bils are accounted great wound herbes, and effectuall to ftay bleedings, yet fome more then others. The Emperickes of Germanie, as Camerarius faith, extoll it wonderfully, for a fingular remedie againft the Stone, both in the reines and bladder. 
$\mathrm{C}_{\text {н }}$ P. X X XI.

Sanicula guttata maior. Spotted Sanicle.

$\mathrm{H}$ Auing long debated with my felfe, where to place this \& the other plants that follow in the two next Chapters, I haue thought it not amiffe for this worke to fet them downe here, both before the Beares eares, which are kindes of Sanicle, as the beft Authors doe hold, and after the Cranes bils, both for fome qualities fomewhat refembling them, and for fome affinity of the flowers with the former.

The fpotted Sanicle hath many fmall round leaues, bluntly endented about the edges, fomewhat like vnto the leaues of our white Saxifrage, of a full greene colour aboue, and whitifh hairy, and fomewhat reddifh withall vnderneath: the ftalkes are fet here and there with the like leaues, rifing a foote and a halfe high or more, very much diuided at the toppe into fundry fmall branches, bearing many very fmall white flowers, confifting of fiue fmall leaues, wherein are many fmall red fpots to be feene, as fmall as pins points, of a pretty fweete fent, almoft like Hawthorne flowers, in the middle whereof are many fmall threads compaffing a head, which when it is ripe containeth fmall blacke feede : the roote is fcaly, or couered with a chaffie matter, hauing many fmall white fibres vnderneath, whereby it is faftened in the ground.

There is another of this kinde, like both in roote, leafe, and flower to the former, Minor non gutthe onely difference is, that this is leffer then the former, and hath no fpots in the ${ }^{\text {tata. }}$ flower, as the other hath.

We haue alfo another fmaller kinde then the laft, both in leafe and flower, the leaues Minus guttata. whereof are fmaller, but rounder, and more finely fnipt or indented about the edges, like the teeth of a fine fawe: the ftalke is little aboue a fpan high, hauing many fmall white flowers fpotted as the firft, but with fewer fpots.

The Place.

Thefe growe in the fhadowie Woods of the Alpes, in diuers places, and with vs they more delight in the fhade then the funne.

\section{The Time.}

All thefe Sanicles doe flower in May, and continue flowring vntill Iune, and the feede foone ripeneth after : the rootes abide all the Winter, with fome leaues on them, fpringing a frefh in the beginning of the yeare.

\section{The Names.}

The former two are called by Clufius Sanicula montana, and by others Sanicula guttata : by Lobel Geum Alpinum. The third or laft hath been fent vs vnder the name of Sanicula montana altera minor.

\section{The Vertues.}

The name impofed on thefe plants doe certainly affure vs of their vertues, from the firft founders, that they are great healers, and from their tafte, that they are great binders, 


\section{CH A P. XXXII.}

\section{Cotyledon altera Matthioli. Spotted Nauelwort.}

$\mathrm{T}$ His fpotted Nauelwort, as many doe call it, hath. many thicke (mall leaues, not fo broad as long, of a whitifh greene colour, lying on the ground in circles, after the manner of the heads of Houfeleeke, and dented about the edges; from the middle whereof fometimes (for it doth not flower euery yeare in many places) arifeth vp a ftalke, fcarce a foote high, befet with fuch like leaues as are belowe, but fomewhat longer: from the middle of the ftalke vp to the top it brancheth forth diuerny, with a leafe at euery ioynt, bearing three or foure flowers on euery branch, confifting of fiue white leaues, fpotted with fmall red fpots, like vnto the fpotted Sanicle, but with fewer and greater f pots, hauing a yellowifh circle or eye in the bottome of euery flower, and many whitifh threads with yellowifh tips in it: the feede is fmall and blacke, contained in fmall round heads: the roote is fmall, long, and threadie, fhooting out fuch heads of leaues, which abide all the Winter, thofe that beare flower perifhing.

\section{Cotyledon altera minor. Small dented Nauelwort.}

There is another like vnto that before defcribed in moft things, the differences be thefe: It hath thorter leaues then the former, and dented about the edges in the like manner: the flowers hereof are white, but greater, made of fix leaues, and most vfually without any fpots at all in them, fome are feene to haue fpots alfo: the heads or feede veffels are more cornered then the former.

\section{Cotyledon altera flore rubro fellato. Small red flowred Nauelwort.}

This hath alfo many heads of leaues, but more open, which are longer, greener, and Tharper pointed then eyther of the former, fomewhat reddifh alfo, and not dented about the edges, but yet a little rough in handling: the ftalke. arifeth from among the leaues, being fomewhat reddifh, and the leaues thereon are reddifh pointed, diuided at the toppe into many branches, with diuers flowers thereon, made of twelue fmall long leaues, ftanding like a ftarre, of a reddith purple colour, with many threads therein, fet about the middle head, which is divided at the toppe into many fmall ends, like pods or hornes, containing therein very fmall feede: the roote is fmall like the former.

\section{Sedum ferratum fore rubente maculato. The Princes Feather.}

This kinde of Sengreene is compofed of heads of larger, broader, and thinner leaues then any of the former, of a fadder greene colour, fomewhat vneuenly endented about the edges, and not fo clofe fet together, but fpreading forth into feuerall heads like as the former forts doe, although not fo plentifully; from the middle of diuers of which heads rife vp brownifh or reddin ftalkes, fet with fmaller leaues thereon to the middle thereof, and then brancheth forth into feuerall fprigs, fet with diuers fmall reddifh flowers confifting of fiue leaues a peece, the innerfide of which are of a pale red, fomewhat whitifh, fpotted with many fmall bloud red fpots, as fmall almoft as pins points, with fome fmall threads in the middle, ftanding about a fmall greene head, which turneth into the feede veffell, parted foure wayes at the head, wherein is contained fmall blackifh feede: the rootes are fmall threads, which fpread vnder the ground, and thoote vp feuerall heads round about it.

\section{The Place.}

All thefe growe in Germany, Hungarie, Auftria, the Alpes, and other fuch like places, where they cleaue to the rocke it felfe, that hath but a cruft of earth on it to nourifh them. They will abide in Gardens reafonable well, if they be planted in hadowie places, and not in the fun. 


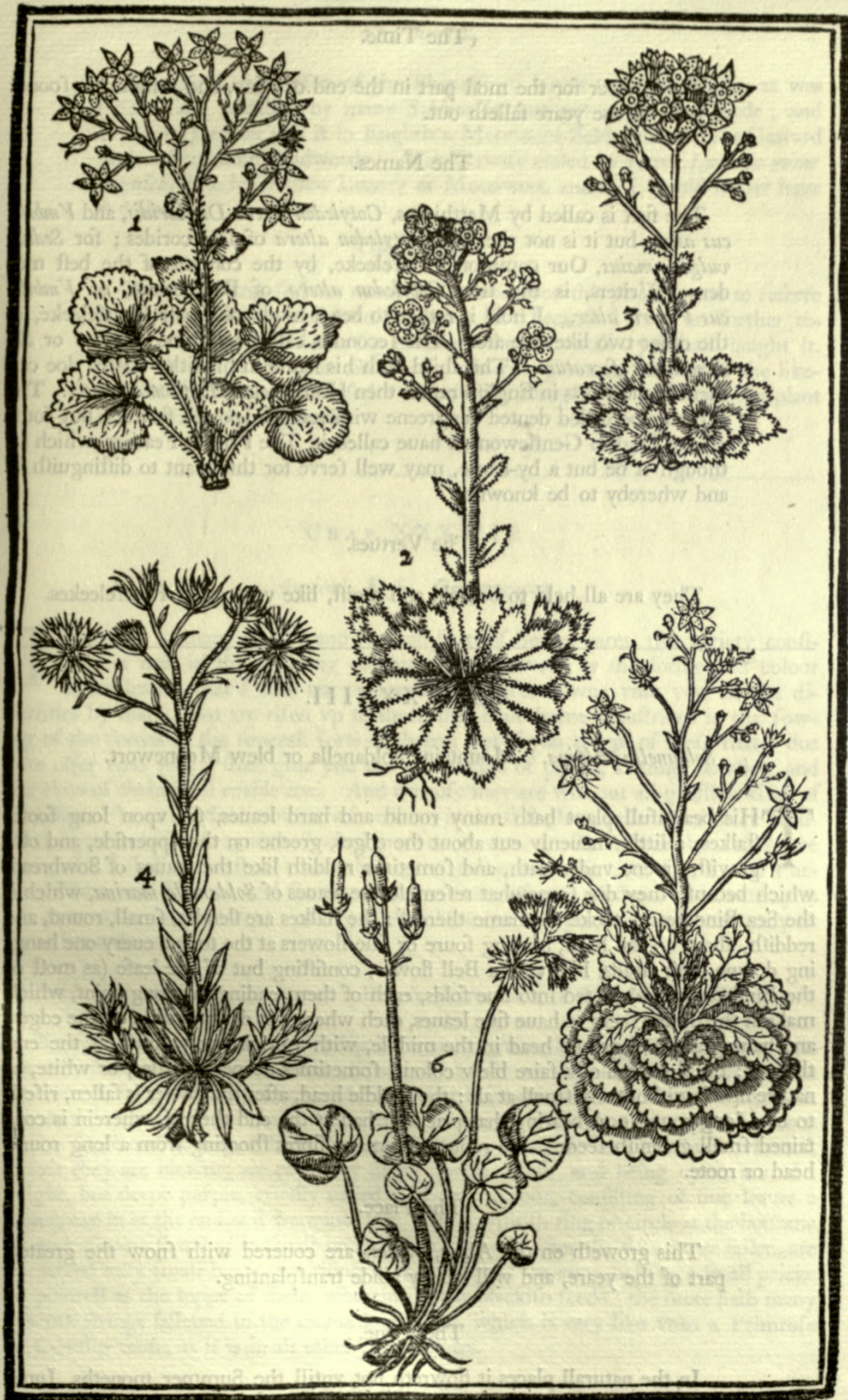

I Sanicula guttata. Spotted Sanicle. ${ }_{2}$ Cotyledon altera Matthioli. Spotted Nauelwort. ${ }_{1}$ i Cotyledon altera minor. Small dented Nauelwort. 4 Cotyledon altera flore rubro ftellato. Small red:flowred Nauelwort, 5 Sedum ferratum flore rubente ma. culato. The Princes Feather, 6 Soldanella Alpina, Blew Moonwort. 


\section{The Time.}

They flower for the moft part in the end of May, and fometimes fooner or later, as the yeare falleth out.

The Names.

The firft is called by Matthiolus, Cotyledon altera Diofcoridis, and Vmbilicus alter, but it is not the true Cotyledon altera of Diofcorides; for Sedum vulgare maius, Our common Houfeleeke, by the confent of the beft moderne Writers, is the true Cotyledon altera of Diofcorides, or Vmbilicus Veneris alter. I hold it rather to bee a kinde of fmall Houfeleeke, as the other two likewife are. The fecond is called by fome Aizoum or Sedum minus ferratum. The third hath his name in his title. Wee doe call them Nauelworts in Englifh rather then Houfeleekes, Euphonia gratia. The laft may be called dented Sengreene with reddifh fpotted flowers, but fome of our Englifh Gentlewomen haue called it, The Princes Feather, which although it be but a by-name, may well ferve for this plant to diftinguifh it, and whereby to be knowne.

The Vertues.

They are all held to be cold and moift, like vnto other Houfeleekes.

\section{C н A P. X X X I I I.}

\section{Soldanella Alpina. Mountaine Soldanella or blew Moonewort.}

T

His beautifull plant hath many round and hard leaues, fet vpon long footeftalkes, a little vneueniy cut about the edges, greene on the vpperfide, and of a grayifh greene vnderneath, and fometime reddilh like the leaues of Sowbread, which becaufe they doe fomewhat refemble the leaues of Soldanella marina, which is the Sea Bindweede, tooke the name thereof : the ftalkes are flender, fmall, round, and reddilh, about a fpan high, bearing foure or fiue flowers at the toppe, euery one hanging downe their heads, like vnto a Bell flower, confifting but of one leafe (as moft of the Bindweeds doe) plated into fiue folds, each of them ending in a long point, which maketh the flower feem to haue fiue leaues, each whereof is deeply cut in on the edges, and hauing a round greene head in the middle, with a pricke or pointell at the end thereof : the flower is of a faire blew colour, fometimes deeper or paler, or white, as nature lifteth without any fmell at all : the middle head, after the flower is fallen, rifeth to be a long round pod, bearing that pricke it had at the end thereof, wherein is contained fmall greenifh feede : the roote hath many fibres fhooting from a long round head or roote.

\section{The Place.}

This groweth on the Alpes, which are couered with fnow the greateft part of the yeare, and will hardly abide tranf planting.

\section{The Time.}

In the naturall places it flowreth not vntill the Summer moneths, Iune, Iuly, and Auguft, after the fnow is melted from the Hils, but being brought into Gardens, it flowreth in the beginning of Aprill, or thereabouts. 


\section{The Names.}

This plant, by reafon of the likeneffe of leaues with Soldanella, as was before faid, is called by many Soldanella, but yet is no Bindweede; and therefore I rather call it in Englifh a Mountaine Soldanella, then as Gerrard doth, Mountaine Bindweede. It is likewife called by fome, Lunaria minor carulea, The leffer blew Lunary or Moonwort, and fo I would rather have it called.

The Vertues.

They that impofed the name of Lunaria vpon this plant, feeme to referre it to the wound or confolidating herbes, but becaufe I haue no further relation or experience, I can fay no more thereof vntill tryall hath taught it. Some alfo from the name Soldanella, which is giuen it, becaufe of the likeneffe of the leaues, haue vfed it to help the Dropfie, for which the Sea plant is thought to be effectuall.

\section{CHA P. X X XIIII.}

\section{Auricula Vrfi. Beares eares.}

T

Here are fo many fundry and feuerall forts of Beares eares, the variety confifting as well in the differing colours of the flowers, as the forme and colour of the leaues, that I fhall not comprehend and fet downe vnto you all the diuerfities by many, that are rifen vp to thofe that haue beene induftrious in the fowing of the feedes of the feuerall forts of them; yet if you accept of thefe that I doe here offer vnto you, I fhall giue you the knowledge of others, as time, occafion, and the view of them fhall enable me. And becaufe they are without all queftion kinds of Cowllips, I haue fet them downe before them in the firft place, as being of more beautie and greater refpect, or at the leaft of more rarity vnto vs. To difpofe them therefore into order, I thall ranke them vnder three principall colours, that is to fay, Red or Purple, White, and Yellow, and thew you the varieties of each of them (for fo many as are come to my knowledge) apart by themfelues, and not promifcuoufly as many others haue done.

\section{Auricula $V r f i$ flore purpureo. Purple Beares eare, or The Murrey Cowflip.}

This purple Beares eare or Cowflip hath many greene leaues, fomewhat long and fmooth, narrow from the bottome of the leafe to the middle, and broad from thence to the end, being round pointed, and fomewhat fnipt or endented about the edges; in the middle of thefe leaues, and fometimes at the fides alfo, doe fpring round greene ftalkes foure or fiue fingers high, bearing at the top many flowers, the buds whereof, before they are blowne, are of a very deepe purple colour, and being open, are of a bright, but deepe purple, vfually called a Murrey colour, confifting of fiue leaues a peece, cut in at the end as it were into two, with a whitifh ring or circle at the bottome of each flower, ftanding in fmall greene cups, wherein after the flowers are fallen, are contained very fmall heads, not rifing to the height of the cups, bearing a fmall pricke or pointell at the toppe of them, wherein is little blackifh feede : the roote hath many whitifh ftrings faftened to the maine long roote, which is very like vnto a Primrofe or Cowflip roote, as it is, in all other parts befides.

2. Auricula, $V r f$ purpurea absque orbe. The murrey Cowlip without eyes.

There is another of this kinde, whofe leafe is fomewhat leffe, as the flower is alfo, 
but of the fame colour, and fometimes fomewhat redder, tending to a Scarlet, without any circle at the bottome of the flower, in no other things differing from it.

\section{Auricula $V r f i$ minor flore tannetto. Tawney Beares eares.}

The leaues of this kinde haue a greater thew of mealineffe to be feene in them, and not much fmaller then the former, yet fnipt or endented about the ends like vnto them : the flowers are many, of the fame fafhion with the former, but fmaller, each whereof is of as deepe a murrey or tawnie colour when it is blowne; as the buds of the former are before they are blowne, hauing a white circle at the bottome of the flower, and yellowifh in the middle belowe the circle.

\section{Auricula Vrfi flore rubro faturo orbe luteo.}

Deepe or bloud red Beares eares with eyes.

This kinde hath fmall and long greene leaues, nothing mealy, but fnipt about the edges, from the middle of the leaues forwards to the ends : the flowers hereof are of a deepe red colour, tending to a bloud red, with a deepe yellow circle, or rather bottome in the middle.

There is another of this kinde, whofe leaues are fomewhat mealy, and fmaller then fore rubro fa- any (that I haue feene) that haue mealy leaues : the flowers are of the fame deepe red orbe. colour with the laft defcribed, yet hath no circle or bottome of any other colour at all.

\section{Auricula Vr/i fore purpuro caruleo. The Violet coloured Beares eare.}

We haue another, whofe leaues are fomewhat mealy and large; the flowers whereof are of a paler purple then the firft, fomewhat tending to a blew.

\section{Auricula Vrfi flore obfoleto magno. The Spaniards blufh Beares eare.}

This great Beares eare hath as large leaues as any other of this kindred whatfoeuer, and whitifh or mealy withall, fomewhat fnipt about the edges, as many other of them are : the flowers ftand at the toppe of a Atrong and tall ftalke, larger then any of the other that I haue feene, being of a duskie blurh colour, refembling the blufh of a Spaniard, whofe tawney skinne cannot declare fo pure a blufh as the Englifh can ; and therefore I haue called it the Spaniards blufh.

\section{Auricula Vrfi flore rubello. Scarlet or light red Beares eares.}

The leaues of this kinde are very like the leaues of the firft purple kinde, but that they are not so thicke; of a little paler greene colour, and little or nothing fnipt about the edges: the flowers are of a bright, but pale reddifh colour, not halfe fo deepe as the two laft with white circles in the bottomes of them, in other things this differeth not from others.

\section{Auricula Vrfi rofeo colore. The Rofe coloured Beares eare.}

We have another, whofe leafe is a little mealy, almoft as large as any of the former, whofe flowers are of a light red colour, very neare the colour of an ordinary Damaske Rofe, with a white eye at the bottome.

\section{Auricula Vrfi flore caruleo folio Boraginis.}

Blew Beares eares with Borage leaues.

This plant is referred to the kindred or family of the Beares eares, onely for the forme of the flower fake, which euen therein it doth not affimilate to the halfe; but becaufe it hath paffed others with that title, I am content to infert it here, to giue you 


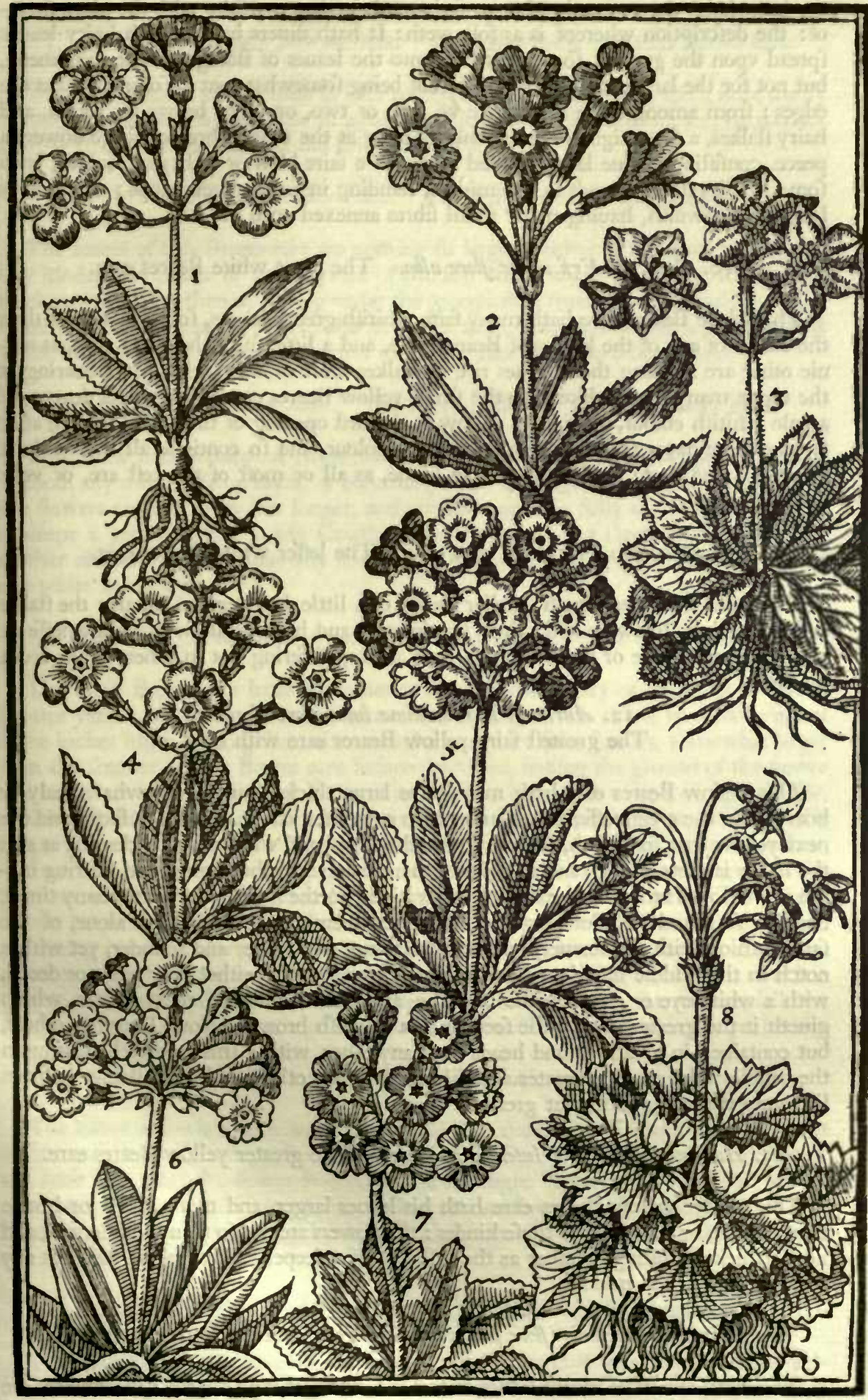

3 Anricula Vrfi flore purfureo. Purple Coswlips or Beares eares. 2 Auricula Vrfo flore tannelto. Tawney Beares care. 3 Au. ricula Vrfi fore \& folio Boraginis. Blew Beares eares with Borage leaues. 4Awricula Vrfi fore carneo. Blurh Beares eare. 5 A uricula Vrfi maxima lutea fore cleganti. The greateft faire yellow Beares eares with eyes. 6 Auricula V $r f$ allera fore inteo. The yellow Beares eare. 7 Auricula Vrfic crinis coloris fiuc florc fusco. The haire coloured Beares eare. 8 Cortufa
Mathioli. Beares eare Sanicle. 
the knowledge thereof, and rather to fatisfie others then my felfe with the place thereof: the defcription whereof is as followeth: It hath diuers broad rough hairy leaues fpread vpon the ground, fomewhat like vnto the leaues of Borage for the roughneffe, but not for the largeneffe; the leaues hereof being fomewhat rent in fome places at the edges : from among thefe leaues rife vp one, or two, or more brownifh, round, and hairy ftalkes, a fpan high or thereabouts, bearing at the toppes three or foure flowers a peece, confifting of fiue large pointed leaues, of a faire blew or light azur colour, with fome fmall yellow threads in the middle, ftanding in fmall greene cups: the roote is long and brownifh, hauing many fmall fibres annexed vnto it.

\section{Auricula. $\operatorname{Vrfi}$ maior flore albo. The great white Beares eare.}

This white Beares eare hath many faire whitifh greene leaues, fomewhat paler then the leaues of any of the kindes of Beares eares, and a little fnipt about the ends, as manie other are : among thefe leaues rife vp ftalkes foure or fiue inches high, bearing at the toppe many flowers like vnto the fmall yellow Beares eare hereafter fet downe, of a pale whitifh colour, tending to yellow at the firft opening of the flower, which after two or three dayes change into a faire white colour, and fo continue all the while it flowreth : the roote is like the purple kinde, as all or moft of the reft are, or very little differing.

\section{Auricula $V r f i$ minor flore albo. The leffer white Beares eare.}

The leffer Beares eare hath fmaller leaues, of a little darker green colour : the ftalke and flowers are likewife leffer then the former, and have no thew of yellowneffe at all, eyther in budde or flower, but is pure white, differing not in other things from the reft.

\section{2. Auricula Vrfi maxima lutea flore eleganti.}

The greateft faire yellow Beares eare with eyes.

This yellow Beares eare hath many faire large thicke leaues, fomewhat mealy or hoary vpon the greenneffe, being larger then any other kinde, except the fixth, and the next yellow that followeth, fmooth about the edges, and without any endenting at all : the ftalke is great, round, and not higher then in other of the former, but bearing manie more flowers thereon then in any other kinde, to the number of thirty many times, ftanding fo round and clofe together, that they feeme to be a Nofegay alone, of the fame falhion with the former, but that the leaues are fhorter and rounder, yet with a notch in the middle like the reft, of a faire yellow colour, neither very pale nor deepe, with a white eye or circle in the bottome, about the middle of euery flower, which giueth it the greater grace : the feede is of a blackilh browne colour, like vnto others, but contained in greater round heads then any other, with a fmall pointell fticking in the middle : the roote is greater and thicker then any other, with long ftrings or fibres like vnto the other forts, but greater.

\section{I3. Auricula Vrfi maior lutea folio incano. The greater yellow Beares eare.}

This greater yellow Beares eare hath his leaues larger, and more mealy or hoarie then the laft, or any other of thefe kindes : the flowers are not fo many, but longer, and not fo thicke thrufting together as the firt, but of a deeper yellow colour, without any eye or circle in the middle.

\section{Auricula Vrfi maior flore pallido. The great Straw coloured Beares eare.}

This hath almoft as mealy leaues as the laft, but nothing fo large; the flowers are of a faire ftrawe colour, with a white circle at the bottome of them, thefe three laft have no thew or thadow of any other colour in any part of the edge, as fome others that follow haue. 
15. Auricula Vrfi minor flore pallente. The leffer ftraw coloured Beares eare.

We haue another, whore leafe is leffe mealy, or rather pale green, and a little inealy withall ; the flowers whereof are of a paler yellow colour then the laft, and beareth almont as many vpon a ftalke as the firft great yellow.

\section{Auricula Vrfi minor luten. The leffer yellow Beares eares.}

The leaues of this Beares care are nothing fo large as either of the three former yellow kindes, but rather of the bigneffe of the firt white kinde, but yet a little larger, thicker, and longer then it, hauing vnder the greenneffe a fmall fhew of mealineffe, and fomewhat fnipt about the edges : the flowers are of a pale yellow colour, with a little white bottome in them : the feed and rootes are like vnto the other kindes.

\section{Auricula Vrfi flore faus. The deepe yellow or Cowflip Beares eare.}

This kinde hath fomewhat larger leaues then the laft, of a yellowith greene colour, without any mealineffe on them, or endenting about the edges, but fmooth and whole: the flowers are not larger but longer, and not laide open fo fully as the former, but of as deepe a yellow colour as any Cownlip almoft, without any circle in the bottome: neither of thefe two laft have any fhew of other colour then yellow in them, fauing the white in the eye.

\section{Auricula Vrfi verficolor prima fue fore rubefcente. The blufh Beares eare.}

The blufh Beares eare hath his leaues as large, and as hoary or mealy as the third greater yellow, or ftraw coloured Beares eare; among which rifeth vp a ftalke about foure inches high, bearing from fix to twelue, or more faire flowers, fomewhat larger then the fmaller yellow Beares eare before defcribed, hauing the ground of the flower of a darke or dunne yellow colour, fhadowed ouer a little with a fhew of light purple, which therefore we call a blufh colour, the edges of the flower being tipt with a little deeper thew of that purple colour, the bottome of the flower abiding wholly yellow, without any circle, and is of very great beauty, which hath caured me to place it in the forefront of the variable coloured Beares eares. And although fome might thinke it Thould be placed among the firft ranke of Beares eares, becaufe it is of a blufh colour, yet fecing it is affuredly gained from fome of the yellow kindes by fowing the feede, as many other forts are, as may be feene plainly in the ground of the flower, which is yellow, and but fhadowed ouer with purple, yet more then any of the reft that follow ; I thinke I haue giuen it his right place : let others of skill \& experience be iudges herein.

\section{Auricula Vrfi crinis coloris. Haire coloured Beares eares.}

The leaues of this kinde are more mealy like then the laft blufh kinde, but fomewhat longer and larger, and fnipt about the edges in the fame manner, from the middle of the leafe forwards : the flower is vfually of a fine light browne yellow colour, which wee doe vfually call an Haire colour, and fometimes browner, the edges of the flower haue a fhew or fhadow of a light purple or blufh about them, but more on the outfide then on the infide.

\section{Auricula $V r / s$ verficolor luten. The yellow variable Beares eare.}

This variable Beares eare hath his greene leaues fomewhat like vnto the deepe yellow, or Cownlip Beares eare before defcribed, but fomewhat of a frefher greene, more Phining and fmaller, and fnipt about the edges towards the ends, as many of thofe before are : the flowers are of a faire yellow colour, much laid open when it is full blowne, that it feemeth almoft flat, dafht about the edges onely with purple, being more yellow in the bottome of the flower, then in any other part. 
21. Auricula $V r f$ verficolor lutefcente viridi flore. The variable greene Beares eare.

This kinde of Beares eare hath greene leaues, very like vnto the laft defcribed, and fnipt in the like manner about the edges, but in this it differeth, that his leaues do turne or fold themfelues a little backwards: the flowers are of a yellowifh greene colour, more clofed then the former, hauing purplifh edges, ef pecially after they haue ftood blowne fome time, and haue little or none at the firft opening : thefe haue no circles at all in them.

Many other varieties are to be found, with thofe that are curious conferuers of thefe delights of nature, either naturally growing on the mountaines in feuerall places, from whence they (being fearched out by diuers) haue been taken and brought, or elfe raifed from the feede of fome of them, as it is more probable : for feuerall varieties haue beene obferued (and no doubt many of thefe before fpecified) to bee gotten by fowing of the feedes, euery yeare lightly thewing a diuerfity, not obferued before, either in the leafe, diuers from that from whence it was taken, or in the flowers. I haue onely fet downe thofe that haue come vnder mine owne view, and not any by relation, euen as I doe with all or moft of the things contained in this worke.

The Place.

Many of thefe goodly plants growe naturally on mountaines, efpecially the Alpes, in diuers places; for fome kindes that growe in fome places, doe not in others, but farre diftant one from the other. There hath likewife fome beene found on the Pyrenæan mountaines, but that kinde with the blew flower and Borage leafe, hath beene gathered on the mountaines in Spaine, and on the Pyrenæans next vnto Spaine.

\section{The Time.}

They all flower in Aprill and May, and the feede is ripe in the end of Iune, or beginning of Iuly, and fometimes they will flower againe in the end of Summer, or in Autumne, if the yeare proue temperate, moift, and rainie.

The Names.

It is very probable, that none of thefe plants were euer knowne vnto the ancient Writers, becaufe we cannot be affured, that they may be truely referred vnto any plant that they name, vnleffe we beleeue Fabius Columna, that it fhould be Alifma of Diofcorides, for thereunto hee doth referre it. Diuers of the later W riters haue giuen vnto them diuers names, euery one according to his owne conceit. For Gefner calleth it Lunaria arthritica, and Paralytica Alpina. Matthiolus accounteth it to bee of the kindred of the Sanicles, and faith, that in his time it was called by diuers Herbarifts, Auricula $V r f$, which name hath fince bin receiued as moft vfuall. We in Englifh call them Beares eares, according to the Latine, or as they are called by diuers women, French Cowllips; they may be called Mountaine Cowllips, if you will, for to diftinguifh betweene them and other Cowlips, whereof thefe are feuerall kindes.

\section{Sanicula Alpina fiue Cortufa Matthioli. Beares eare Sanicle.}

I cannot chufe but infert this delicate plant in the end of the Beares eares, for that it is of fo neare affinity, although it differ much in the forme of the leaues, the defcription whereof is in this manner: The leaues that fpring vp firft are much crumpled, and as it were folded together, which afterwards open themfelues into faire, broad, and roundifh leaues, fomewhat rough or hairy, not onely cut into fine diuifions, but fomewhat notched alfo about the edges, of a darke greene colour on the vpperfide, and 
more whitifh greene vnderneath; amongft thefe leaues rifeth vp one or two naked round ftalkes, fiue or fix inches high, bearing at the toppes diuers fmall flowers, fomewhat fweete, like vnto the firft purple Beares eare, hanging downe their heads, confifting of fiue fmall pointed leaues a peece, of a darke reddifh purple colour, with a white circle or bottome in the middle, and fome fmall threads therein : after the flowers are paft, there come fmall round heads, fomewhat longer then any of the Beares eares, ftanding vpright vpon their fmall foot-ftalkes, wherein is contained fmall round and blackifh feede : the roote confifteth of a thicke tuft of fmall whitifh threads, rather then rootes, much enterlaced one among another : the leaues of this plant dye downe euery yeare, and fpring vp a new in the beginning of the yeare, whereas all the Beares eares doe hold their leaues greene all the Winter, ef pecially the middlemoft, which ftand like a clofe head, the outermoft for the moft part perifhing after feed time.

\section{The Place.}

This groweth in many fhadowie Woods both of Italy and Germany; for both Clufius hath defcribed it, finding it in the Woods of Auftria and Stiria ; and Matthiolus fetteth it downe, hauing receiued it from Anthonius Cortufus, who was Prefident of the Garden at Padua, and found it in the woody mountaines of Vicenza, neare vnto Villeftagna, whereon (as Matthiolus faith) there is found both with white flowers as well as with blew, but fuch with white flowers or blew we neuer could fee or heare further of.

\section{The Time.}

It flowreth much about the time of the Beares eares, or rather a little later, and the feede is ripe with them.

\section{The Names.}

Clufius calleth it Sanicula montana, and Sanicula Alpina, and referreth it to the Auricula $V r / i$, or Beares eare, which it doth moft nearly refemble : but Matthiolus referreth it to the Cariophyllata or Auens, making it to be of that tribe or family, and calleth it Cortufa of him that firft fent it him. Wee may call it eyther Cortufa, as for the moft part all Herbarifts doe, or Beares eare Sanicle as Gerrard doth.

\section{The Vertues.}

All the forts of Beares eares are Cephalicall, that is, conducing helpe for the paines in the head, and for the giddineffe thereof, which may happen, eyther by the fight of fteepe places fubiect to danger, or otherwife. They are accounted alfo to be helping for the Palfey, and fhaking of the ioynts; and alfo as a Sanicle or wound-herbe. The leaues of the Cortufa tafte a little hot, and if one of them bee laide whole, without bruifing, on the cheeke of any tender skind woman, it will raife an orient red colour, as if fome fucus had beene laide thereon, which will paffe away without any manner of harme, or marke where it lay: This is Cortufus his obferuation. Camerarius in his Hortus Medicus faith, that an oyle is made thereof, that is admirable for to cure wounds. 


\section{Ch A P. X X X V.}

\section{Primula veris $\&$ Paraly/is. Primrofes and Cownlips.}

W E have fo great variety of Primrofes and Cownlips of our owne Country breeding, that ftrangers being much delighted with them, haue beene often furnifhed into diuers Countries, to their good content: And that I may fet them downe in fome methodicall manner, as I haue done other things, I will firft fet downe all the forts of thofe we call Primrofes, both fingle and double, and afterwards the Cowflips with their diuerfities, in as ample manner as my knowledge can direct me. And yet I know, that the name of Primula veris or Primrofe, is indifferently conferred vpon thofe that I diftinguifh for Paraly/es or Cowflips. I doe therefore for your better vnderftanding of my diftinction betweene Primrofes and Cowflips, call thofe onely Primrofes that carry but one flower vpon a ftalke, be they fingle or double, except that of Matter Hesket, and that with double flowers many vpon a ftalke, fet out in Gerards Herball, which is his onely, not found (as I thinke) in rerum natura, I am fure, fuch a one I could neuer heare of: And thofe Cowllips, that beare many flowers vpon a ftalke together conftantly, be they fingle or double alfo. I might otherwife diftinguifh them alfo by the leafe; that all the Primrofes beare their long and large broad yellowinh greene leaues, without ftalkes moft vfually; and all the Cowllips haue fmall ftalkes vnder the leaues, which are fmaller, and of a darker greene, as vfually, but that this diftinction is neither fo certaine and generall, nor fo well knowne.

1. Primula veris flore albo. The fingle white Primrofe.

The Primrofe that groweth vnder euery bufh or hedge, in all or moft of the Woods, Groues, and Orchards of this Kingdome, I may well leaue to his wilde habitation, being not fo fit for a Garden, and fo well knowne, that I meane not to giue you any further relation thereof: But we haue a kinde hereof which is fomewhat fmaller, and beareth milke white flowers, without any thew of yellowneffe in them, and is more vfually brought into Gardens for the rarity, and differeth not from the wilde or ordinary kinde, either in roote or leafe, or any thing elfe, yet hauing thofe yellow fpots, but fmaller, and not fo deepe, as are in the other wilde kinde.

\section{Primula veris flore viridi fimplici. The fingle greene Primrofe.}

The fingle greene Primrofe hath his leaues very like vnto the greater double Primrofe, but fmaller, and of a fadder greene colour : the flowers ftand feuerally vpon long foot-ftalkes, as the firtt fingle kinde doth, but larger then they, and more laide open, of the fame, or very neare the fame yellowilh greene colour that the huske is of, fo that at the firft opening, the huske and the flower feeme to make one double greene flower, which afterwards feparating themfelues, the fingle flower groweth aboue the huske, and fpreadeth it felfe open much more then any other fingle Primrofe doth, growing in the end to be of a paler greene colour.

\section{Primula veris flore viridante $E^{2}$ albo fimplici.}

The fingle greene and white Primrofe.

The leaues of this differ in a manner nothing from the former, neither doth the flower but only in this, that out of the large yellowifh green huskes, which contain the flowers of the former, there commeth forth out of the middle of each of them either a fmall peece of a whitifh flower, or elfe a larger, fometimes making vp a whole flower, like an ordinary Primrofe.

4. Primula veris flore viridi duplici. The double greene Primrofe.

This double Primrofe is in his leaues fo like the former fingle greene kindes, that 


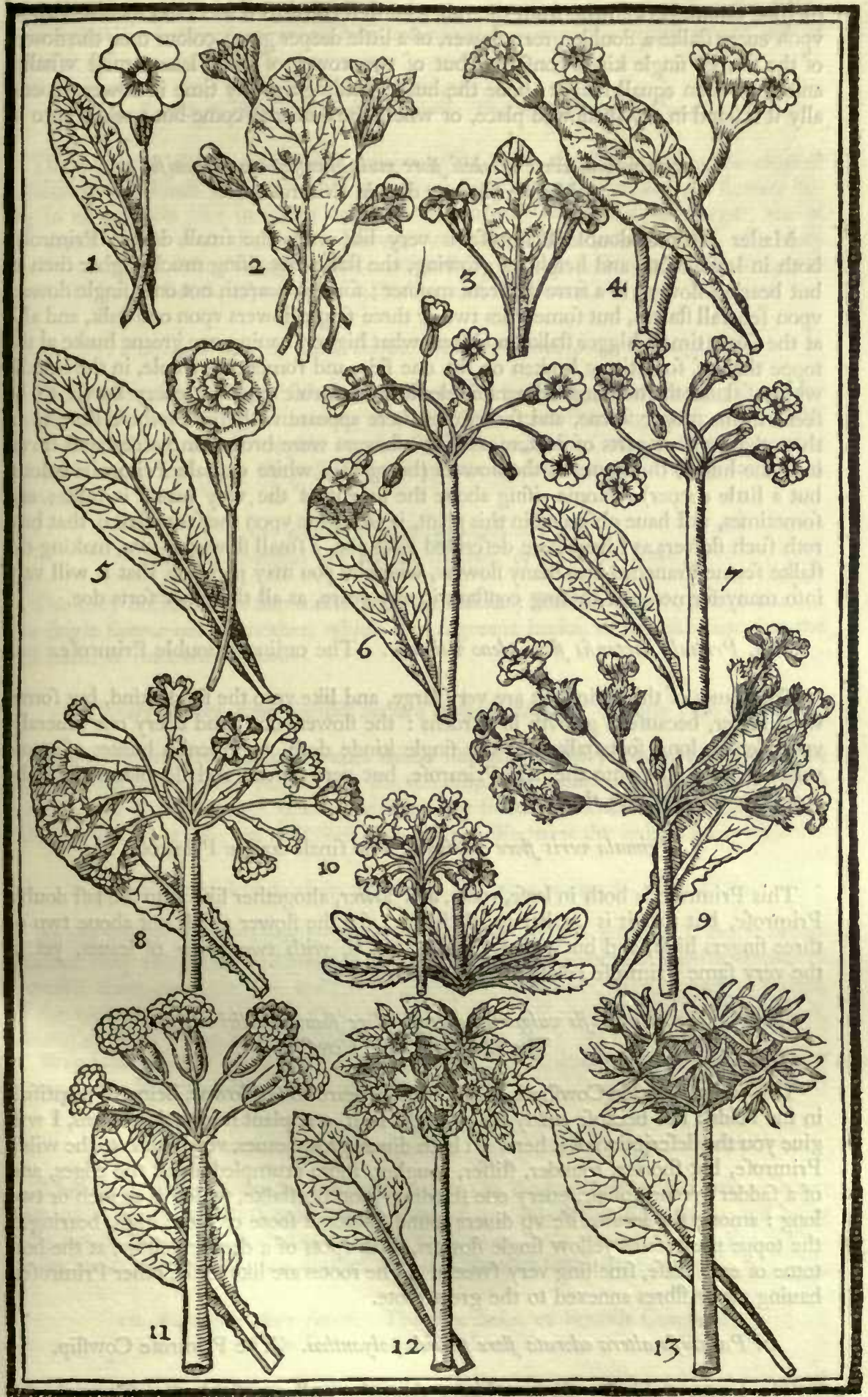

I Primula ceris forc albo. The white Primsofe. 2 Primula geris Pore viridi \& albo fimplici. The green and white Primrofe. 3 Primula veris flore viridi duplici. The double green Primrofe. 4 Primula veris Heskeli. Mafter Heskets double Primrofe. 5 Primula erris pore pleno vulgaris. The ordinary double Primrofe. 6 Paraly is seris fore viridanle fimplici. The fingle green Cowflip. 7 Paralyfis fore geminato odorato. Double Cownlips or hofe in hole. 8 Paralyfis inodora fore geminalo. Double Cowntip. 7 Paralyfis Alore geminate odorato. Double Cowhlips or hore in hore. 8 Paralysis inodora fore geminato. Double

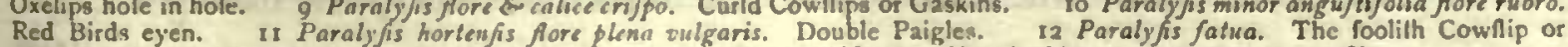
lacke 2n Apes on horfe backe. 13 Paralyfis fiore viridi rofeo calamiflroto. The double greene feathered Cowllip. 
the one cannot be knowne from the other vntill it come to flower, and then it beareth vpon euery ftalke a double green flower, of a little deeper green colour then the flower of the former fingle kinde confifting but of two rowes of fhort leaues moft vfually, and both of an equall height aboue the huske, abiding a pretty time in flower, ef pecially if it ftand in any fhadowed place, or where the Sun may come but a while vnto it.

\section{Primula veris Hesketi flore multiplici feparatim dinifo.} Mafter Heskets double Primrofe.

Mafter Heskets double Primrofe is very like vnto the fmall double Primrofe, both in leafe, roote, and height of growing, the ftalke not rifing much higher then it, but bearing flowers in a farre different manner; for this beareth not only fingle flowers vpon feuerall ftalkes, but fometimes two or three fingle flowers vpon one ftalk, and alfo at the fame time a bigger ftalke, and fomewhat higher, hauing one greene huske at the toppe thereof, fometimes broken on the one fide, and fometimes whole, in the middle whereof ftandeth fometimes diuers fingle flowers, thruft together, euery flower to be feene in his proper forme, and fometimes there appeare with fome whole flowers others that are but parts of flowers, as if the flowers were broken in peeces, and thruft into one huske, the leaues of the flowers (being of a white or pale Primrofe colour, but a little deeper) (eldome rifing aboue the height of the very huske it felfe ; and fometimes, as I haue obferued in this plant, it will have vpon the fame ftalke, that beareth fuch flowers as I haue here defcribed vnto you, a fmall flower or two, making the ftalke feeme branched into many flowers, whereby you may perceiue, that it will vary into many formes, not abiding conftant in any yeare, as all the other forts doe.

\section{Primula hortenfis flore pleno vulgaris. The ordinary double Primrofe.}

The leaues of this Primrofe are very large, and like vnto the fingle kind, but fomewhat larger, becaufe it growth in gardens : the flowers doe ftand euery one feuerally vpon Alender long footeftalkes, as the fingle kinde doth, in greenifh huskes of a pale yellow colour, like vnto the field Primrore, but very thicke and double, and of the fame fweete fent with them.

\section{Primula veris flore duplici. The fmall double Primrofe.}

This Primrofe is both in leafe, roote, and flower, altogether like vnto the laft double Primrofe, but that it is fmaller in all things; for the flower rifeth not aboue two or three fingers high, and but twice double, that is, with two rowes of leaues, yet of the very fame Primrofe colour that the former is of.

\section{Paralyfis vulgaris praten fis flore flaus fimplici odorato. The Common field Cowlip.}

The common fielde Cowflip I might well forbeare to fet downe, being fo plentifull in the fields : but becaure many take delight in it, and plant it in their gardens, I will giue you the defcription of it here. It hath diuers green leaues, very like vnto the wilde Primrofe, but fhorter, rounder, ftiffer, rougher, more crumpled about the edges, and of a fadder greene colour, euery one ftanding vpon his ftalke, which is an inch or two long : among the leaues rife vp diuers round ftalkes, a foote or more high, bearing at the toppe many faire yellow fingle flowers, with fpots of a deeper yellow, at the bottome of each leafe, fmelling very fweete. The rootes are like to the other Primrofes, hauing many fibres annexed to the great roote.

\section{Paralyfis altera odorata flore pallido polyanthos. The Primrofe Cowflip.}

The leaues of this Cowflip are larger then the ordinary fielde Cowflip, and of a darke yellowinh greene colour: the flowers are many ftanding together, vpon the toppes of the ftalkes, to the number of thirty fometimes vpon one ftalke, as I haue counted them in mine owne Garden, and fometimes more, euery one hauing a longer 
foote ftalke then the former, and of as pale a yellowifh colour almoft as the fielde Primrofe, with yellow fpots at the bottome of the leaues, as the ordinary hath, and of as fweet a fent.

\section{Paralyfis flore viridante fimplici. The fingle greene Cowflip.}

There is little difference in leafe or roote of this from the firft Cowllip, the chiefeft varietie in this kinde is this, that the leaues are fomewhat greener, and the flowers being in all refpects like in forme vnto the firft kinde, but fomewhat larger, are of the fame colour with the greene huskes, or rather a little yellower, and of a very fmall fent; in all other things I finde no diuerfitie, but that it ftandeth much longer in flower before it fadeth, efpecially if it ftand out of the Sunne.

\section{Paraly fis flore $\Theta^{\circ}$ calice crifpo. Curl'd Cowflips or Gallegaskins.}

There is another kinde, whofe flowers are folded or crumpled at the edges, and the huskes of the flowers bigger than any of the former, more fwelling out in the middle, as it were ribbes, and crumpled on the fides of the huskes, which doe fomewhat refemble mens hofe that they did weare, and tooke the name of Gallegaskins from thence.

\section{Paraly fis flore geminato odorato.}

Double Cowflips one within another, or Hofe in Hofe.

The only difference of this kinde from the ordinary field Cowllip is, that it beareth one fingle flower out of another, which is as a greene huske, of the like fent that the firft hath, or fomewhat weaker.

\section{3. Paraly fis flore flauo fimplici inodoro abfque calicibus. Single Oxe lippes.}

This kinde of Cowllip hath leaues much like the ordinary kinde, but fomewhat fmaller : the flowers are yellow like the Cowlip, but fmaller, ftanding many vpon a ftalke, but bare or naked, that is, without any huske to containe them, hauing but little or no fent 'at all; not differing in any thing elfe from the ordinary Cowflip.

\section{Paralyfis flore geminato inodora. Double Oxelips Hofe in Hofe.}

As the former double Cowflip had his flowers one within another, in the very like manner hath this kinde of Cowlip or Oxelippe, fauing that this hath no huske to containe them, no more then the former fingle Oxelippe hath, ftanding bare or naked, of the very fame bigneffe each of them, and of the fame deepe yellow colour with it, hauing as fmall a fent as the former likewife.

Wee haue another of this kinde, whofe leaues are fomewhat larger, and fo are the Florepallidior flowers alfo, but of a paler yellow colour.

\section{Paraly fis inodora calicibus diffectis. Oxelips with iagged huskes.}

This kinde differeth not from the firf Oxelip in the fmalnefle of the greene leaues, but in the flower, which ftanding many together on a reaf onable high ftalke, and being very fmall and yellow, fcarce opening themfelues or layde abroade as it, hath a greene huske vnder each flower, but diuided into fixe feuerall fmall long peeces.

\section{I6. Paraly fis flore fatuo. The Franticke, or Foolifh Cowflip :}

Or Iacke an apes on horfe backe.

Wee haue in our gardens another kinde, not much differing in leaues from the former Cowflip, and is called Fantafticke or Foolifh, becaufe it beareth at the toppe of the ftalke a bufh or tuft of fmall long greene leaues, with fome yellow leaues, as it were peeces of flowers broken, and ftanding among the greene leaues. And fometimes 
fome ftalkes among thofe greene leaues at the toppe (which are a little larger then when it hath but broken peeces of flowers) doe carry whole flowers in huskes like the fingle kinde.

\section{Paraly/is minor. fore rubro. Red Birds eyes.}

This little Cowflippe (which will hardly endure in our gardens, for all the care and induftrie we can vfe to keepe it) hath all the Winter long, and vntill the Spring begin to come on, his leaues fo clofed together, that it feemeth a fmall white head of leaues, which afterwards opening it felfe, fpreadeth round vpon the ground, and hath fmall long and narrow leaues, fnipt about the edges, of a pale greene colour on the vpperfide, \& very white or mealy vnderneath, among thefe leaues rife vp one or two ftalks, fmall \& hoary, halfe a foot high, bearing at the top a bufh or tuft of much fmaller flowers, ftanding vpon fhort foot ftalkes, fomewhat like vnto Cowflips, but more like vnto the Beares eares, of a fine reddifh purple colour, in fome deeper, in others paler, with a yellowifh circle in the bottomes of the flowers, like vnto many of the Beares eares, of a faint or fmall fent : the feede is fmaller than in any of the former kindes, and fo are the rootes likewife, being fmall, white and threddy.

\section{Paralyfis minor flore albo. White Birds eyes.}

This kinde differeth very little or nothing from the former, fauing that it feemeth a little larger both in leafe and flower, and that the flowers hereof are wholly white, without any great appearance of any circle in the bottome of them, vnleffe it be well obferued, or at leaft being nothing fo confpicuous, as in the former.

Flore geminato. Thefe two kindes haue fometimes, but very feldome, from among the middle of the flowers on the ftalke, fent out another fmall ftalke, bearing flowers thereon likewife.

\section{Paraly fis hortenfis flore pleno. Double Paigles or Cowflips.}

The double Paigle or Cowlip hath fmaller and darker greene leaues then the fingle kinde hath, and longer ftalkes alfo whereon the leaues doe ftand : it beareth diuers flowers vpon a ftalke, but not fo many as the fingle kinde, euery one whereof is of a deeper and fairer yellow colour then any of the former, ftanding not much aboue the brimmes of the huskes that hold them, confifting of two or three rowes of leaues fet round together, which maketh it fhew very thicke and double, of a prettie fmall fent, but not heady.

\section{Paralyfis fore viridante pleno. Double greene Cowllips.}

This double greene Cowllip is fo like vnto the fingle greene kinde formerly expreffed, that vntill they be neare flowring, they can hardly be diftinguirhed : but when it is in flower, it hath large double flowers, of the fame yellowith greene colour with the fingle, and more laid open then the former double Paigle.

\section{Paraly fis flore viridante fue calamiftrato.}

The greene Rofe Cownlip, or double greene feathered Cowflip.

There is fmall difference in the leaues of this double kinde from the laft, but that they are not of fo darke a greene : the chiefert difference confifteth in the flowers, which are many, ftanding together at the toppes of the ftalkes, but farre differing from all other of thefe kindes : for euery flower ftanding vpon his owne ftalke, is compored of many very fmall and narrow leaues, without any huske to containe them, but fpreading open like a little Rofe, of a pale yellowifh greene colour, and without any fent at all, abiding in flower, efpecially if it ftand in a fhadowie place out of the funne, aboue two moneths, almoft in as perfect beauty, as in the firft weeke.

The Place.

All thefe kindes as they haue been found wilde, growing in diuers places 
in England, fo they haue been tranfplanted into Gardens, to be there nourithed for the delight of their louers, where they all abide, and grow fairer then in their naturall places, except the fmall Birds eyes, which will (as I faid) hardly abide any culture, but groweth plentifully in all the North Countries, in their fqually or wet grounds.

The Time.

Thefe doe all flower in the Spring of the yeare, fome earlier and fome later, and fome in the midft of Winter, as they are defended from the colds and frofts, and the mildneffe of the time will permit : yet the Cowflips doe alwayes flower later then the Primrofes, and both the fingle and double greene Cownlips latelt, as I faid in their defcriptions, and abide much after all the reft.

\section{The Names.}

All thefe plants are called moft vfually in Latine, Primula veris, Primulce pratenfes, and Primula filuarum, becaufe they fhew by their flowring the new Spring to bee comming on, they being as it were the firft Embaffadours thereof. They haue alfo diuers other names, as Herba Paraly fis, Arthritica, Herba Sanczi Petri, Claues Sancti Petri, Verbafculum odoratum, Lunaria arthritica, Phlomis, Alifma filuarum, and Alifmatis alterum genus, as Fabius Columna calleth them. The Birds eyes are called of Lobel in Latine, Paralytica Alpina, Sanicula angufifolia, making a greater and a leffer. Others call them Sanicula angufifolia, but generally they are called Primula veris minor. I haue (as you fee) placed them with the Cownlips, putting a difference betweene Primrofes and Cowlips. And fome have diftinguifhed them, by calling the Cowlips, Primula veris Elatior, that is, the Taller Primrofe, and the other Humilis, Lowe or Dwarfe Primrofes. In Englifh they haue in like manner diuers names, according to feuerall Countries, as Primrofes, Cowflips, Oxelips, Palfieworts, and Petty Mulleins. The firt kindes, which are lower then the reft, are generally called by the name of Primrofes (as I thinke) throughout England. The others are diuerly named; for in fome Countries they call them Paigles, or Palfieworts, or Petty Mulleins, which are called Cownlips in others. Thofe are vfually called Oxelips, whofe flowers are naked, or bare without huskes to containe them, being not fo fweete as the Cownlip, yet haue they fome little fent, although the Latine name doth make them to haue none. The Franticke, Fantafticke, or Foolifh Cowlip, in fome places is called by Country people, Iacke an Apes on horfe-backe, which is an vfuall name with them, given to many other plants, as Daifies, Marigolds, \&c. if they be Atrange or fantafticall, differing in the forme from the ordinary kinde of the fingle ones. The fmalleft are viually called through all the North Country, Birds eyen, becaufe of the fmall yellow circle in the bottomes of the flowers, refembling the eye of a bird.

\section{The Vertues.}

Primrofes and Cownlips are in a manner wholly vfed in Cephalicall difeafes, either among other herbes or flowers, or of themfelues alone, to cafe paines in the head, and is accounted next vnto Betony, the beft for that purpole. Experience likewife hath thewed, that they are profitable both for the Palfie, and paines of the ioynts, euen as the Beares eares are, which hath caufed the names of Arthitica, Paralyfis, and Paralytica, to bee giuen them. The iuice of the flowers is commended to cleanfe the fpots or marks of the face, whereof fome Gentlewomen have found good experience. 


\section{C н A P. XXX V I.}

\section{Pulmonaria. Lungwort, or Cowflips of Ierufalem.}

Lthough thefe plants are generally more vfed as Pot-herbes for the Kitchen, then as flowers for delight, yet becaufe they are both called Cowllips, and are of like forme, but of much leffe beauty, I haue ioyned them next vnto them, in a diftinct Chapter by themfelues, and fo may paffe at this time.

\section{Pulmonaria maculofa. Common fpotted Cowhlips of Ierufalem.}

The Cowllip of Ierufalem hath many rough, large, and round leaues, but pointed at the ends, ftanding vpon long foot-ftalkes, fpotted with many round white fpots on the vpperfides of the fad greene or browne leaues, and of a grayer greene vnderneath: among the leaues fpring vp diuers browne ftalkes, a foote high, bearing many flowers at the toppe, very neare refembling the flowers of Cowllips, being of a purple or reddifh colour while they are buds, and of a darke blewifh colour when they are blowne, ftanding in brownin greene huskes, and fometimes it hath beene found with white flowers: when the flowers are paft, there come vp fmall round heads, containing blacke feed : the roote is compofed of many long and thicke blacke ftrings.

\section{Pulmonaria altera non maculofa. Vnfpotted Cowllips of Ierufalem.}

The leaues of this other kinde are not much vnlike the former, being rough as they are, but fmaller, of a fairer greene colour aboue, and of a whiter greene vnderneath, without any fpots at all vpon the leaues: the flowers alfo are like the former, and of the fame colour, but a little more branched vpon the ftalkes then the former: the rootes alfo are blacke like vnto them.

\section{Pulmonaria angufifolia. Narrow leafed Cownlips of Ierufalem.}

The leaues hereof are fomewhat longer, but not fo broad, and fpotted with whitih fpots alfo as the former : the ftalke hereof is fet with the like long hairy leaues, but fmaller, being a foote high or better, bearing at the toppe many flowers, ftanding in huskes like the firt, being fomewhat reddifh in the bud, and of a darke purplinh blew colour when they are blowne open : the feede is like the former, all of them doe well refemble Bugloffe and Comfrey in moft parts, except the roote, which is not like them, but ftringie, like vnto Cownlips, yet blacke.

The Place.

The Cowflips of Ierufalem grow naturally in the Woods of Germany, in diuers places, and the firft kinde in England alfo, found out by Iohn Goodier, a great fearcher and louer of plants, dwelling at Maple-durham in Hamphire.

The Time.

They flower for the moft part very early, that is, in the beginning of Aprill.

\section{The Names.}

They are generally called in Latine, Pulmonaria, and maculofa, or non maculofa, is added for diftinctions fake. Of fome it is called Symphitum maculofum, that is, fpotted Comfrey. In Englinh it is diuerfly called; as fpotted Cowlips of Ierufalem, Sage of Ierufalem, Sage of Bethlehem, Lungwort, 
and fpotted Comfrey, and it might bee as fitly called fpotted Buglofe, whereunto it is as like as vinto Comfrey, as I faid before.

\section{The Vertues.}

It is much commended of fome, to bee fingular good for vlcered lungs, that are full of rotten matter. As alfo for them that (pit bloud, being boyled and drunke. It is of greateft vfe for the pot, being generally held to be good, both for the lungs and the heart.

\section{CH A P. X X X V I I.}

\section{Buglofium \& Borrago. Bugloffe and Borage.}

A Lthough Borage and Bugloffe might as fitly haue been placed, I confeffe, in the Kitchen Garden, in regard they are wholly in a manner Spent for Phyficall properties, or for the Pot, yet becaufe anciently they haue been entertained into Gardens of pleafure, their flowers hauing been in fome refpect ; in that they haue alwaies been enterpofed ainong the flowers of womens needle-worke, I am more willing to giue them place here, then thruft them into obfcurity, and take fuch of their tribe with them alfo as may fit for this place, either for beauty or rarity.

The Garden Bugloffe and Borage are fo well knowne vnto all, that I thall (I doubt) but fpend time in wafte to defcribe them; yet not vfing to paffe ouer any thing I name and appropriate to this Garden fo fleightly, they are thus to bee knowne: Bugloffe hath inany long, narrow, hairy, or rough fad greene leaues, among which rife vp two or three very high ftalks, branched at the top, whereon ftand many blew flowers, confifting of fue finall round pointed leaues, with a fmall pointell in the middle, which are very fmooth, fhining, and of a reddifh purple while they are buds, and not blowne open, which being fallen, there groweth in the greene huske, wherein the flower ftood, three or foure roundin blacke feedes, hauing that thread or pointell ftanding ftill in the iniddle of them : the roote is blacke without, and whitifh within, long, thicke, and full of flimie iuice (as the leaues are alfo) and periheth not euery yeare, as the roote of Borage doth.

\section{Borrago. Borage.}

Borage hath broader, fhorter, greener, and rougher leaues then Bugloffe, the ftalkes hereof are not so high, but branched into many parts, whereon ftand larger flowers, and more pointed at the end then Bugloffe, and of a paler blew colour for the moft part (yet fometimes the flowers are reddin, and fometimes pure white) each of the flowers confifting of flue leaues, ftanding in a round hairy whitifh huske, diuided into fiue parts, and haue a fmall vmbone of fiue blackinh threads in the middle, ftanding out pointed at the end, and broad at the bottome : the feed is like the other : the root is thicker and horter then the roote of Bugloffe, fomewhat blackifh without alfo, and whitifh within, and perifheth after feede time, but rifeth of it owne feede fallen, and pringeth in the beginning of the yeare.

\section{Borrago femper virens. Euerliuing Borage.}

Euerliuing Borage hath many broad greene leaues, and fomewhat rough, more refembling Comfrey then Borage, yet not fo large as either; the ftalkes are not fo high as Borage, and haue many rmall blew flowers on them, very like to the flowers of Bugloffe for the forme, and Borage for the colour : the rootes are blacke, thicker then either of them, fomewhat more fpreading, and not perifhing, hauing greene leaues all the Winter long, and thereupon tooke his name. 


\section{Anchufa. Sea Bugloffe or Alkanet.}

The Sea Bugloffe or Alkanet hath many long, rough, narrow, and darke greene leaues, fpread vpon the ground (yet fome that growe by the Sea fide are rather hoarie and whitifh) among thefe leaues rifeth vp a ftalke, fpread at the toppe into many branches, whereon ftand the flowers in tufts, like vnto the Garden Bugloffe, or rather Comfrey, but leffer ; in fome plants of a reddifh blew colour, and in others more red or purplifh, and in others of a yellowilh colour : after which come the feedes, very like vnto Bugloffe, but fomewhat longer and paler : the roote of moft of them being tranfplanted, are fomewhat blackifh on the outfide, vntill the later end of Summer, and then become more red : for those that grow wilde, will be then fo red, that they will give a very deepe red colour to thofe that hahdle them, which being dryed keepe that red colour, which is vfed to many purpofes; the roote within being white, and hauing no red colour at all.

\section{Limonium Rauwolfij. Marfh Bugloffe.}

This Limonium (which I referre here to the kindes of Bugloffe, as prefuming it is the fitteft place where to infert it) hath many long narrow, and fomewhat rough leaues lying vpon the ground, waued or cut in on both fides, like an Indenture, fomewhat like the leaues of Ceterach or Miltwaft; among which rife vp two or three ftalkes, fomewhat rough alfo, and with thin skinnes like wings, indented on both fides thereof alfo, like the leaues, hauing three fmall, long, rough, and three fquare leaues at euery ioynt, where it brancheth forth; at the toppe whereof ftand many flowers vpon their foote ftalkes, in fuch a manner, as is not feene in any other plant, that I know : for although that fome of the fmall winged foot ftalkes are fhorter, and fome longer, ftanding as it were flatwife, or all on one fide, and not round like an vmbell, yet are they euen at the toppe, and not one higher than another; each of which fmall foote ftalkes doe beare foure or fiue greenifh heads or huskes, ioyned together, out of each of which doe arife other pale or bleake blew ftiffe huskes, as if they were flowers, made as it were of parchment, which hold their colour after they are dry a long time ; and out of thefe huskes likewife, doe come (at feuerall times one after another, and not all at one time or together) white flowers, confifting of fiue fmall round leaues, with fome white threds in the middle : after thefe flowers are paft, there come in their places fmall long feede, inclofed in many huskes, many of thofe heads being idle, not yeelding any goode feede, but chaffe, efpecially in our Countrey, for the want of fufficient heate of the Sunne, as I take it : the roote is fmall, long, and blackin on the outfide, and perifheth at the firft approach of Winter.

\section{The Place.}

Borage and Bugloffe grow onely in Gardens with vs, and fo doth the Semper virens, his originall being vnknowne vnto vs. Alkanet or Sea Bugloffe groweth neare the Sea, in many places of France, and Spaine, and fome of the kindes alfo in England. But the Limonium or Marfhe Bugloffe groweth in Cales, and Malacca in Spaine, and is found alfo in Syria, as Rauwolfius relateth : and in other places alfo no doubt; for it hath beene fent vs out of Italie, many yeares before eyther Guillaume Boel found it in Cales, or Clufius in Malacca.

\section{The Time.}

Borage and Bugloffe doe flower in Iune, and Iuly, and fometimes fooner, and fo doth the euer-liuing or neuer-dying Borage, but not as Gerrard faith, flowring Winter and Summer, whereupon it fhould take his name, but leaueth flowring in Autumne, and abideth greene with his leaues all the Win- 


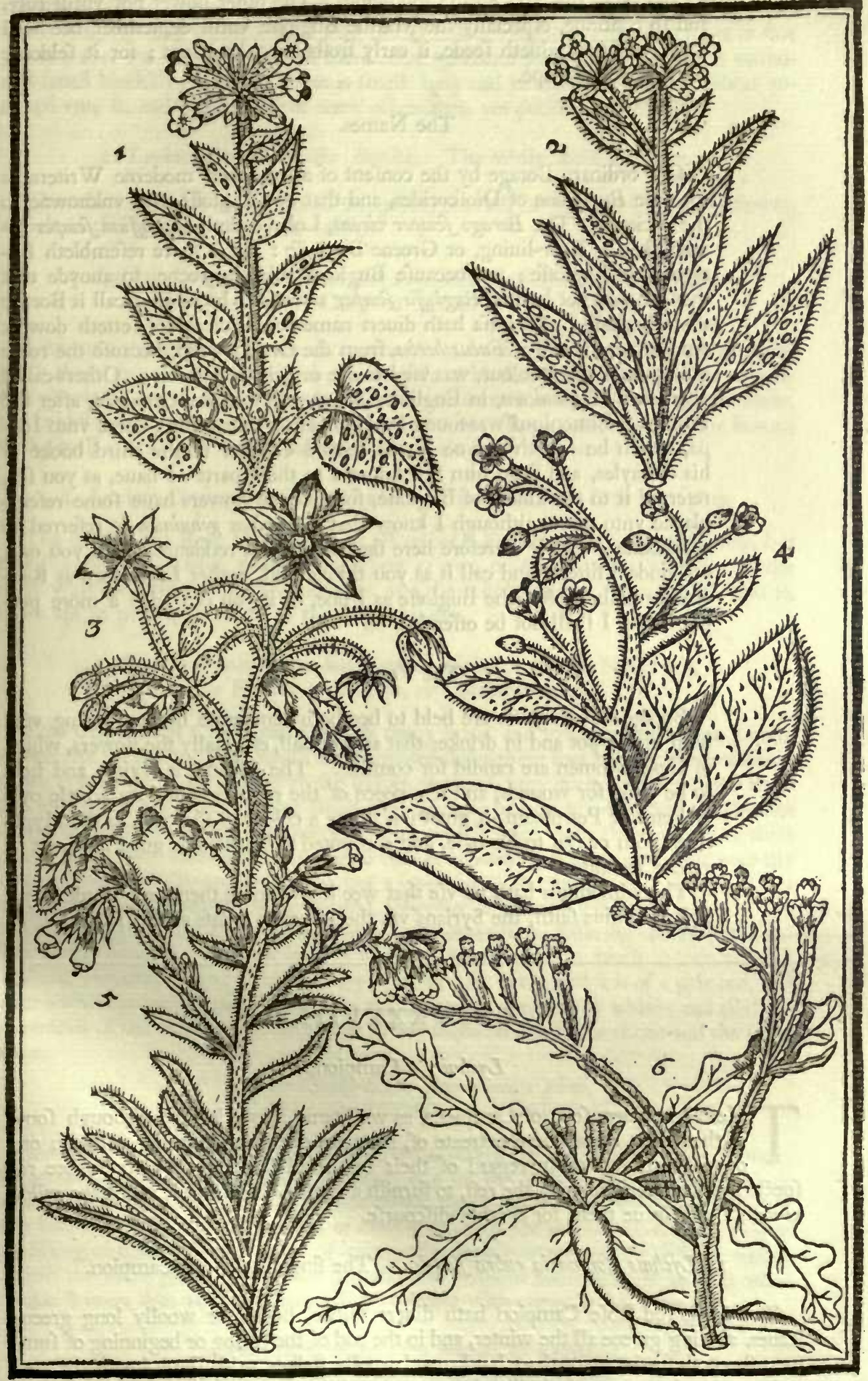

1. Pulmonaria latifolia maculofa. Cowflips of lerufalem. 2 Pulmonaria anguflifolia. Narrow leafed Cownips of lerufalem. 3 Borrago. Borage. 4 Borrago fompar virens. Euerliuing Borage. 5 Anchufa. Sea Bugloffe or Alkanet. 6 Limonium Rausalfij. Marm Bugloffe. 
ter, flowring the next Spring following. The other flower not vntill Iuly, and fo continue, efpecially the Marfhe Bugloffe vntill September bee well fpent, and then giueth feede, if early frofts ouertake it not ; for it feldome commeth to be ripe.

\section{The Names.}

Our ordinary Borage by the confent of all the beft moderne Writers, is the true Buglo/fum of Diofcorides, and that our Bugloffe was vnknowne to the ancients. The Borago Jemper virens, Lobel calleth Buglo:Jum femper virens, that is, Euer-liuing, or Greene Buglofle : but it more refembleth Borage then Bugloffe; yet becaufe Bugloffe abideth greene, to auoyde that there fhould not be two Buglofa Jemper virentia, I had rather call it Borage then Bugloffe. Anchufa hath diuers names, as Diofcorides fetteth downe. And fome doe call it Fucus herba, from the Greeke word, becaufe the roote giuing fo deepe a colour, was vfed to dye or paint the skinne. Others call it Bugloflum Hispanicum, in Englifh Alkanet, and of fome Orchanet, after the French. Limonium was found by Leonhartus Rauwolfius, neere vnto Ioppa, which he fetteth downe in the fecond Chapter of the third booke of his trauayles, and from him firf knowne to thefe parts: I haue, as you fee, referred it to the kindes of Bugloffe, for that the flowers haue fome refemblance vnto them, although I know that Limonium genuinum is referred to the Beetes. Let it therefore here finde a place of refidence, vntill you or I can finde a fitter ; and call it as you thinke beft, eyther Limonium as Rauwolfius doth, or Marnhe Bugloffe as I doe, or if you can adde a more proper name, I thall not be offended.

\section{The Vertues.}

Borage and Bugloffe are held to bee both temperate herbes, beeing vfed both in the pot and in drinkes that are cordiall, efpecially the flowers, which of Gentlewomen are candid for comfitts. The Alkanet is drying, and held to be good for wounds, and if a peece of the roote be put into a little oyle of Peter or Petroleum, it giveth as deepe a colour to the oyle, as the Hypericon doth or can to his oyle, and accounted to be fingular good for a cut or greene wound.

The Limonium hath no vfe that wee know, more then for a Garden; yet as Rauwolfius faith, the Syrians vfe the leaues as fallats at the Table.

\section{CH A P. XXX VIII.}

\section{Lychnis. Campions.}

T

Here bee diuers forts of Campions, as well tame as wilde, and although fome of them that I fhall here entreate of, may peraduenture be found wilde in our owne Countrey, yet in regard of their beautifull flowers, they are to bee refpected, and nourfed vp with the reft, to furnith a garden of pleafure ; as for the wilde kindes, I will leaue them for another difcourfe.

\section{Lychnis Coronaria rubra fimplex. The fingle red Rofe Campion.}

The fingle red Rofe Campion hath diuers thicke, hoary, or woolly long greene leaues, abiding greene all the winter, and in the end of the fpring or beginning of fummer, fhooteth forth two or three hard round woolly ftalkes, with fome ioynts thereon, and at euery ioynt two fuch like hoary greene leaues as thofe below, but fmaller, diuerfly branched at the toppe, hauing one flower vpon each feuerall long foot ftalke, 
confilting of fiue leaues, fomewhat broade and round pointed, of a perfect red crimfon colour, ftanding out of a hard long round huske, ridged or crefted in foure or fiue places ; after the flowers are fallen there come $\mathrm{vp}$ round hard heads, wherein is contained fmall blackilh feed : the roote is finall, long and wooddy, with nany fibres annexed vnto it, and fhooteth forth anew oftentimes, yet perilheth often alfo.

\section{Lychnis Coronaria alba fimplex. The white Rofe Campion.}

The white Rofe Campion is in all things like the red, but in the colour of the flower, which in this is of a pure white colour.

\section{Lychinis Coronaria albefcens fiue incarnata maculata $E^{\circ}$ non maculata. The blufh Rofe Campion fpotted and not fpotted.}

Like vito the former alfo are thefe other forts, hauing no other difference to diftinguifh them, but the flowers, which are of a pale or bleake whitith blufh colour, efpecially about the brims, as if a very little red were mixed with a great deale of white, the middle of the flower being more white; the one being fpotted all ouer the flower, with fmall fpots and ftreakes, the other not hauing any fpot at all.

\section{Lychinis Coronario rubra multiplex. The double red Rofe Campion.}

The double red Rofe Campion is in all refpects like vnto the fingle red kinde, but that this beareth double flowers, confifting of two or three rowes of leaues at the moft, which are not fo large as the fingle, and the whole plant is more tender, that is, more apt to perilh, then any of the fingle kindes.

\section{Lychinis Chalcedonica flore fimplici miniato. Single Nonefuch, or Flower of Briftow, or Conftantinople.}

This Campion of Conftantinople hath many broad and long greene leaues, among which rife vp fundry ftiffe round hairy ioynted ftalks three foot high, with two leaues euery ioynt : the flowers ftand at the toppes of them, very many together, in a large tuft or vimbell, confifting of fiue fmall long leaues, broade pointed, and notched-in in the middle, of a bright red orenge colour, which being paft, there come in their places fmall hard whitifh heads or feede veffels, containing blacke feede, like vnto the feede of fweet Williams, and hauing but a fmall fent ; the roote is very ftringie, faftening it felfe very ftrongly in the ground, whereby it is much encreafed.

Of the fingle kinde there is alfo two or three other forts, differing chiefly in the co-Es carmeo. lour of the flowers. The one is pure white. Another is of a bluilh colour wholly, verficolor. without variation. And a third is very variable ; for at the firft it is of a pale red, and after a while groweth paler, vntill in the end it become almoft fully white ; and all thefe diuerfities of the flowers are fornetimes to bee feene on one ftalke at one and the fame time.

\section{Lychnis Chalcedonica fore miniato plens.}

Double Flower of Briftow, or Nonefuch.

This glorious flower being as rare as it is beautifull, is for rootes beeing ftringie, for leaues and ftalkes being hairy and high, and for the flowers growing in tufts, altogether like the firft fingle kinde : but herein confifteth the chiefeft difference, that this beareth a larger vmbell or tuft of flowers at the toppe of the ftalke, euery flower confilting of three or foure rowes of leaues, of a deeper orenge colour then it, which addeth the more grace vnto it, but paffeth away without bearing feede, as moft other double flowers doe, yet recompenceth that defect with encreafe from the roote.

\section{Lychnis plumaria folueftris fimplex E multiplex.}

The featherd wilde Campion fingle and double.

The leaues of this wilde Campion are fomewhat like the ordinary white wilde 
Campion, but not fo large, or rather refembling the leaues of fweete Williams, but that they grow not fo clofe, nor fo many together : the ftalkes haue fmaller leaues at the ioynts then thofe belowe, and branched at the toppe, with many pale, but bright red flowers, iagged or cut in on the edges, like the feathered Pinke, whereof fome haue taken it to be a kinde, and fome for a kinde of wilde William, but yet is but a wilde Campion, as may be obferued, both by his huske that beareth the flowers, and by the greyifh roundifh feede, being not of the Family of Pinkes and Gillowers, but (as I faid) of the Campions : the roote is full of ftrings or fibres.

Flore pleno. The double kinde is very like vnto the fingle kinde, but that it is lower and fmaller, and the flowers very double.

\section{Lychnis fluefris flore pleno rubro. Red Batchelours buttons.}

The double wilde Campion (which of our Countrey Gentlewomen is called Batchelours buttons) is very like both in rootes, leaues, ftalkes, and flowers vnto the ordinary wilde red Campion, but fomewhat leffer, his flowers are not iagged, but fmooth, and very thicke and double, fo that moft commonly it breaketh his fhort huske, wherein the flower ftandeth on the one fide, feldome hauing a whole huske, and are of a reddifh colour.

\section{Lychnis filueftris flore albo pleno. White Batchelours buttons.}

As the leaues of the former double Campion was like vnto the fingle kinde that had red flowers, fo this hath his leaues like vnto the fingle white kinde, differing in no other thing from it, but in the doubleneffe of the flowers, which by reafon of the multiplicity of leaues in them thrufting forth together, breaketh his huskes wherein the flowers doe ftand, as the other doth, and hath fcarce one flower in many that is whole.

10. Ocymoides arborea femper virens. Strange Baffil Campion.

This Strange Campion (for thereunto it muft bee referred) fhooteth forth many round, whitifh, wooddy, but brittle ftalkes, whereon ftand diuers long, and fomewhat thicke leaues, fet by couples, narrow at the bottome, and broader toward the point, of a very faire greene and fhining colour, fo that there is more beauty in the greene leaues, which doe fo alwaies abide, then in the flowers, which are of a pale red or blufh colour, confifting of fiue fmall long broad pointed leaues, notched in the middle, which doe not lye clofe, but loofly as it were hanging ouer the huskes : after the flowers are paft, there come heads that containe blackifh feede : the roote is fmall, hard, white, and threadie.

\section{I. Mufcipula Lobelij fiue Ben rubrum Monfpelienfium. Lobels Catch Flie.}

I muft needes infert this fmall plant, to finifh this part of the Campions, whereunto it belongeth, being a pretty toye to furnifh and decke out a Garden. It fpringeth vp (if it haue beene once fowne and fuffered to thed) in the later end of the yeare moft commonly, or elfe in the Spring with fiue or fix fmall leaues, very like vnto the leaues of Pinkes, and of the fame grayifh colour, but a little broader and Thorter, and when it beginneth to thoote vp for flower, it beareth fmaller leaues on the clammy or vifcous ftalkes (fit to hold any fmall thing that lighteth on it) being broad at the bottome compafling them, and ftanding two at a ioynt one againt another : the toppes of the ftalkes are diuerly branched into feuerall parts, euery branch hauing diuers fmall red flowers, not notched, but fmooth, ftanding out of fmall, long, round, ftript huskes, which after the flowers are paft, containe fmall grayifh feede : the roote is fmall, and perifheth after it hath giuen feede; but rifeth (as is before faid) of its owne feede, if it be suffered to thed.

\section{The Place.}

The Rofe Campions, Flowers of Briftow, or Nonefuch, the Baflil Campion, 


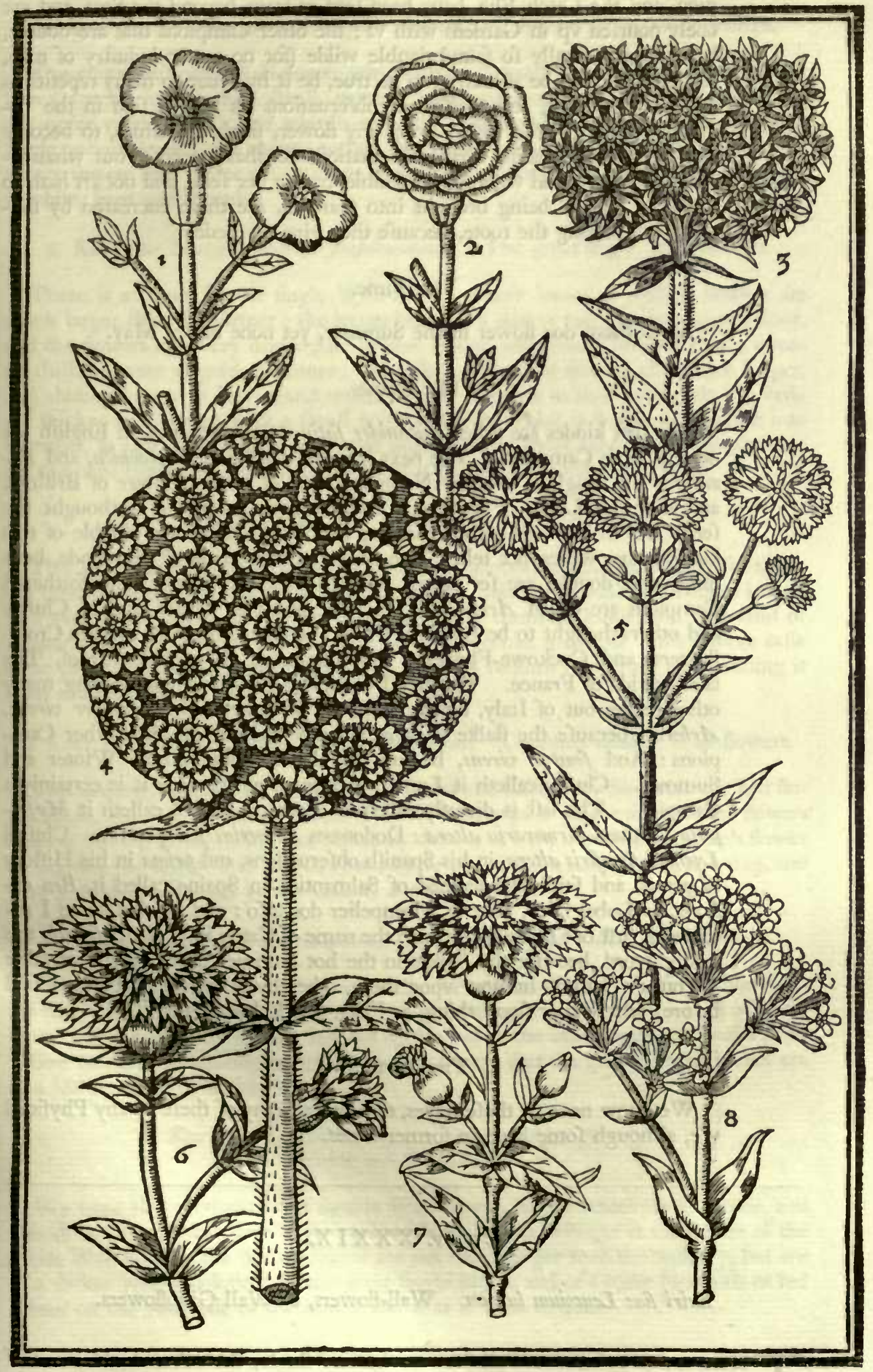

1 Lychnis Coranaria fimplex. Single Rofe Campion. 2 Lyehnis Coronaria rubra mulliplex. The double red Rofe Campion. 3 Lychnis Chalcedonica fimplex. Single None fuch, or flower of Briftow. 4 Lychnis Chalcedonica fore pleno. Double None fuch, or flower of Briftow. 5 Lychnis plumaria multiplex. Plezlant in fight. 6 Lychnis filueftris flore pleno rubro. Red Batchelours Butrons. 7 Lychnis filuefiris fore pleno albo. White Batchelours Butrons, 8 Mufcipuln Lobelij. Lobels Catch Flie. 
pion, and the Catch Flie, haue been fent vs from beyond the Seas, and are onely nourfed vp in Gardens with vs; the other Campions that are double, haue been naturally fo found double wilde (for no art or induftry of man, that euer I could be affured of to be true, be it by neuer fo many repetitions of tranfplantations, and planeticall obferuations (as I haue faid in the beginning of this worke) could bring any flower, fingle by nature, to become double, notwithftanding many affirmations to that purpofe, but whatfoeuer hath been found wilde to be double, nature her felfe, and not art hath fo produced it) and being brought into Gardens, are there encreafed by nipping, and parting the roote, becaufe they giue no feede.

\section{The Time.}

All of them doe flower in the Summer, yet none before May.

The Names.

The firft kindes are called Lychnides fatiue, and coronarice, in Englifh generally Rofe Campions. The next is called Lychnis Chalcedonica, and Byzantina; in Englifh, of fome Nonefuch, and of others Flower of Briftow, and after the Latine, Flower of Conftantinople, becaure it is thought the feede was firft brought from thence; but from whence the double of this kinde came, we cannot tell. The names of the others of this kinde, both fingle and double, are fet downe with their defcriptions. The feathered Campions are called Armoraria pratenfis, and Flos Cuculi, and of Clufius and others thought to be Odontitis Plinij. Some call them in Englifh Crowflowers, and Cuckowe-Flowers; and fome call the double hereof, The faire Maide of France. The Baffil Campions were fent ouer among many other feedes out of Italy, by the name of Ocinvoides arborea femper virens. Arborea, becaufe the ftalke is more wooddy and durable then other Campions: And femper virens, becaufe the leaues abide greene Winter and Summer. Clufius calleth it Lychnis Jemper virens, becaufe it is certainly a Campion. The laft is diuerny called of Authors; Lobel calleth it Mufcipula: Others Armoraria altera: Dodonæus Armerius flos quartus. Clufius Lychnis filueftris altera, in his Spanifh obferuations, and prima in his Hiftory of plants, and faith, the learned of Salmantica in Spaine called it, Ben rubrum, as Lobel faith, they of Mompelier doe alfo : and by that name I receiued it firft out of Italy. It hath the name of Catch Flie, of Mufcipula the Latine word, becaufe the ftalkes in the hot Summer dayes haue a certaine vifcous or clammy humour vpon them, whereby it eafily holdeth (as I faid before) whatfoeuer fmall thing, as Flies, \&rc. lighteth vpon it.

\section{The Vertues.}

We know none in thefe dayes, that putteth any of thefe to any Phyficall vfe, although fome haue in former times.

\section{Cн A P. X X XI X.}

Keiri fue Leucoium luteum. Wall-flowers, or Wall Gilloflowers. each of them there is likewife fome differences, as fhall be thewed in their defcriptions. 
1. Keiri fune Leucoum luteum fimplex vulgare. Common fingle Wall-flowers.

The common fingle Wall-flower which groweth wilde abroad, and yet is brought into Gardens, hath fundry fmall, narrow, long, and darke greene leaues, fet without order vpon finall round whitifh wooddy ftalkes, which beare at the tops diuers fingle yellow flowers one aboue another, euery one hauing foure leanes a peece, and of a very fweete fent : after which come long pods, containing reddifh feede : the roote is white, hard and thready.

\section{Keiri fun Leucoium luteum fimplex maius. The great fingle Wall-flower.}

There is another fort of fingle Wall-flower, whole leaues as well as flowers are much larger then the former : the leaues being of a darker and nining greene colour, and the flowers of a very deepe gold yellow colour, and vfually broader then a twentie Thilling peece of gold can couer : the fpike or toppe of flowers alfo much longer, and abiding longer in flower, and much fweeter likewife in fent : the pods for feede are thicker and fhorter, with a fmall point at the end : this is fower to encreafe into branches, as alfo to be encreafed by the branches, and more tender to be preferued; for the hard frofts doe caufe it to perifh, if it be not defended from them.

\section{Keiri fumplex fore albo. White Wall-flower.}

This Wall-flower hath his leaues as greene as the great kinde, but nothing fo large : the flowers ftand at the toppe, but not in fo long a fpike, and confifteth of foure leaues, of a very white colour, not much larger then the common kinde, and of a faint or weaker fent: the pods are nothing fo great as the former great one : this is more eafie to be propagated and encreafed alfo, but yet will require fome care in defending it from the colds of the Winter.

\section{Keiri fuu Leucoium luteum vulgare fore pleno. Common double Wall-flowers.}

This ordinary double Wall-flower is in leaues and ftalke very like vnto the firft fingle kinde, but that the leaues hereof are not of fo deepe a greene colour : the flowers itand at the top of the ftalkes one aboue another, as it were a long fpike, which flower by degrees, the loweft firft, and fo vpwards, by which it is a long time in flowring, and is very double, of a gold yellow colour, and very fweete.

\section{Keiri fue Leucoium luteum alterum fore pleno. Pale double Wall-flowers.}

Wee haue another fort of this kinde of double Wall-flower, whofe double flowers ftand not Spike-fafhion as the former, but more open Spread, and doe all of them blowe open at one time almoft, and not by degrees as the other doth, and is of a paler yellow colour, not differing in any thing elfe, except that the greene leaues hereof are of a little paler greene then it.

\section{Ke iri fune Leucoium luteum maius fore pleno ferrugineo. \\ Double red Wall-flowers.}

We have alfo another fort of double Wall-flower, whofe leaues are as greene, and almoft as large as the great fingle yellow kinde, or full as bigge as the leaues of the white Wall-flower : the flowers hereof are not much larger then the ordinary, but are of a darker yellow colour then the great fingle kinde, and of a more brownifh or red colour on the vnderfide of the leaues, and is as it were ftriped.

\section{Keiri fun Leucoium maximum luteum fore pleno.}

The greateft double yellow Wall-flower.

This great double Wall-flower is as yet a ftranger in England, and therefore what I 
here write is more vpon relation (which yet I beleeue to be moft true) then vpon fight and fpeculation. The leaues of this Wall-flower are as greene and as large, if not larger then the great fingle kinde : the flowers alfo are of the fame deepe gold yellow colour with it, but much larger then any of the former double kindes, and of as fweet a fent as any, which addeth delight vnto beauty.

\section{The Place.}

The firft fingle kind is often found growing vpon old wals of Churches, and other houfes in many places of England, and alfo among rubbirh and ftones. The fingle white and great yellow, as well as all the other double kindes, are nourfed vp in Gardens onely with vs.

\section{The Time.}

All the fingle kindes doe flower many times in the end of Autumne, and if the Winter be milde all the Winter long, but efpecially in the moneths of February, March, and Aprill, and vntill the heate of the Spring doe fpend them : but the other double kindes doe not continue flowring in that manner the yeare throughout, although very early fometimes, and very late alfo in fome places.

\section{The Names.}

They are called by diuers names, as Viola lutea, Leucoium luteum, and Keiri, or Cheiri, by which name it is chiefly knowne in our Apothecaries hops, becaufe there is an oyle made thereof called Cheirinum: In Englifh they are vfually called in thefe parts, Wall-flowers: Others doe call them Bee-flowers; others Wall-Gilloflowers, Winter-Gilloflowers, and yellow Stocke-Gilloflowers; but we haue a kinde of Stocke-Gilloflower that more fitly deferueth that name, as thall be thewed in the Chapter following.

\section{The Vertues.}

The fweetneffe of the flowers caufeth them to be generally vfed in Nofegayes, and to decke vp houfes; but phyfically they are vfed in diuers manners: As a Conferue made of the flowers, is vfed for a remedy both for the Appoplexie and Palfie. The diftilled water helpeth well in the like manner. The oyle made of the flowers is heating and refoluing, good to eafe paines of ftrained and pained finewes.

\section{CHA P. XL.}

\section{Leucoium. Stocke-Gilloflower.}

$T$

Here are very many forts of Stocke-Gilloflowers, both fingle and double, fome of the fields and mountaines, others of the Sea marhes and medowes; and fome nourfed vp in Gardens, and there preferued by feede or flippe, as each kinde is apteft to bee ordered. But becaufe fome of thefe are fitter for a generall Hiftory then for this our Garden of Pleafure, both for that diuers haue no good fent, others little or no beauty, and to be entreated of onely for the variety, I fhall fpare fo many of them as are not fit for this worke, and onely fet downe the reft.

\section{Leucoium fimplex fativum diuer forum colorum.}

Garden Stocke-Gilloflowers fingle of diuers colours

Thefe fingle Stocke-Gilloflowers, although they differ in the colour of their flow- 


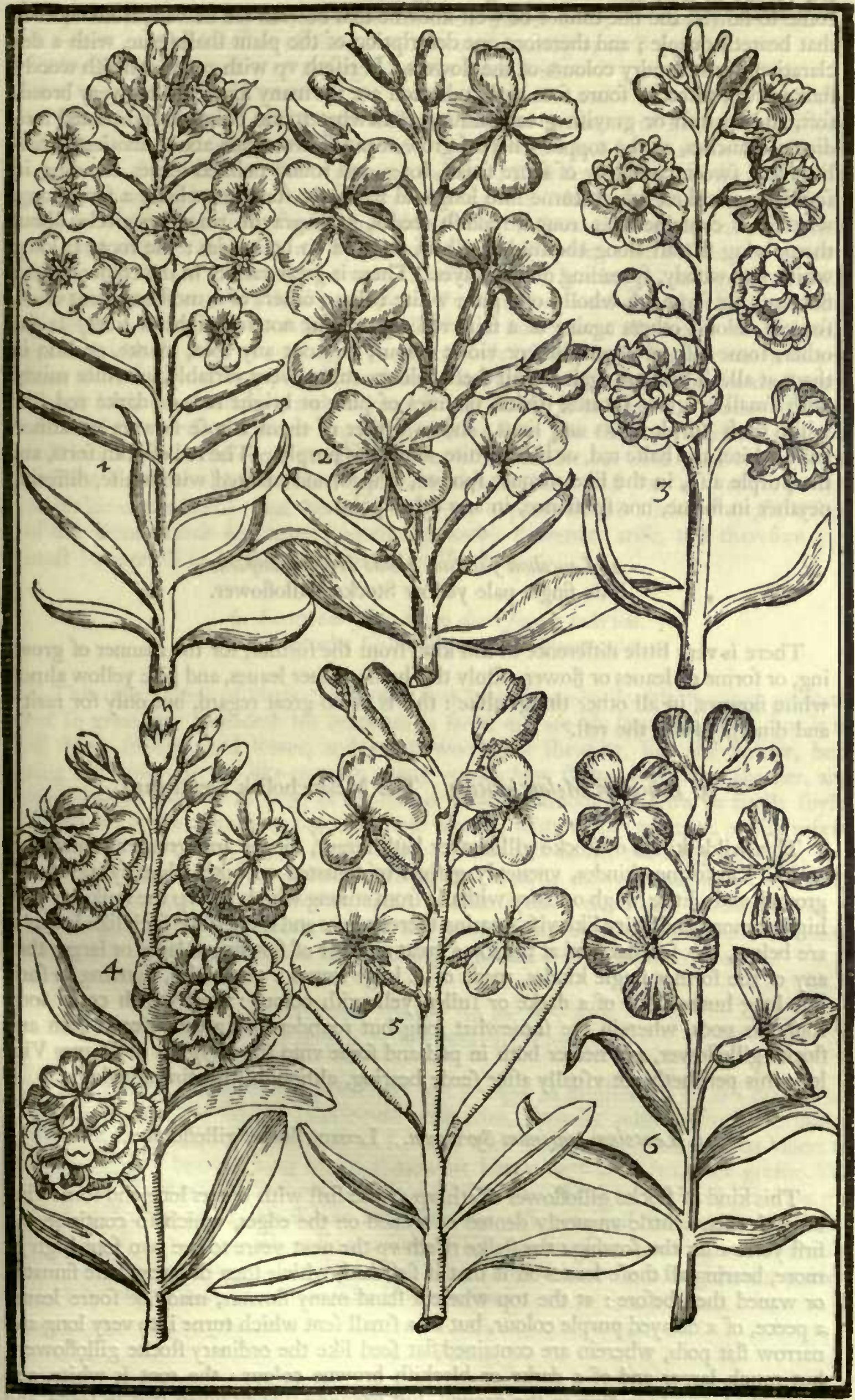

I Keiri fime Leucoium luteum vulgare. Common Wall-flowers. 2 Keiri fue Lewcoium lubeum maius fimplex. The great fingle

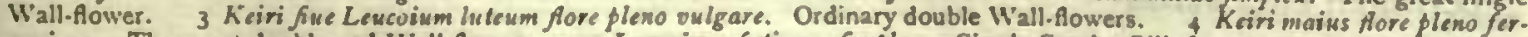
rugineo. The great double red Wall-flower. 5 Lencoium fativum fimplex. Single Stocke-Gillohowers. 6 Leucoinm fat rum fimplex flore firiato. Single ftript Stocke-Gilloßhowers. 
ers, yet are in leafe and manner of growing, one fo like vnto another, that vntill they come to flower, the one cannot be well knowne that beareth red flowers, from another that beareth purple ; and therefore one defcription of the plant thall ferue, with a declaration of the fundry colours of the flowers. It rifeth vp with round whitifh woody ftalkes, two, three, or foure foot high, whereon are fet many long, and not very broad, foft, and whitifh or grayifh greene leaues, fomewhat round pointed, and parted into diuers branches, at the toppes whereof grow many flowers, one aboue another, fmelling very fweet, confifting of foure fmall, long, and round pointed leaues, ftanding in fmall long huskes, which turne into long and flat pods, fometimes halfe a foote long, wherein is contained flat, round, reddin feedes, with grayifh ringes or circles about them, lying flat all along the middle rib of the pod on both fides: the roote is long, white, and woody, fpreading diuers wayes. There is great variety in the colours of the flowers : for fome are wholly of a pure white colour, others of a moft excellent crimfon red colour, others againe of a faire red colour, but not fo bright or liuely as the other, fome alfo of a purplifh or violet colour, without any fpot, marke, or line in them at all. There are againe of all thefe colours, mixed very variably, as white mixed with Imall or great fpottes, ftrakes or lines of pure or bright red, or darke red, and white with purple fpots and lines; and of eyther of them whofe flowers are almoft halfe white, and halfe red, or halfe white, and halfe purple. The red of both forts, and the purple alfo, in the like manner fpotted, ftriped, and marked with white, differing neyther in forme, nor fubftance, in any other point.

\section{Leucoium fatiuum albido luteum fimplex.}

The fingle pale yellow Stocke-Gilloflower.

There is very little difference in this kind from the former, for the manner of growing, or forme of leaues or flower. Only this hath greener leaues, and pale yellow almoft white flowers, in all other things alike : this is of no great regard, but only for rarity, and diuerfity from the reft.

\section{Leucoium Melancholicum. The Melancholick Gentleman.}

This wilde kinde of ftocke gilloflower hath larger, longer and greener leaues then any of the former kindes, vneuenly gafhed or finuated on both edges lying on the ground, and a little rough or hairy withall : from among which rife vp the ftalkes, a yard high or more, and hairy likewife, bearing thereon here and there fome fuch like leaues as are below, but fmaller, and at the top a great number of flowers, as large or larger then any of the former fingle kindes, made of 4 . large leaues a peece alfo, ftanding in fuch like long huskes, but of a darke or fullen yellowifh colour : after which come long roundifh pods, wherein lye fomewhat long but rounder and greater feede then any ftocke gilloflower, and nearer both in pod and feede vnto the He/peris or Dames Violet : this perifheth not vfually after feede bearing, although fometimes it doth.

\section{Leucoium marinum Syriacum. Leuant ftocke gilloflowers.}

This kind of ftocke gilloflower rifeth vp at the firft with diuers long and fomewhat broad leaues, a little vneuenly dented or waued on the edges, which fo continue the firft yeare after the fowing: the ftalke rifeth vp the next yeare to bee two foot high or more, bearing all thofe leaues on it that it firf had, which then do grow leffe finuated or waued then before: at the top whereof ftand many flowers, made of foure leaues a peece, of a delayed purple colour, but of a fmall fent which turne into very long and narrow flat pods, wherein are contained flat feed like the ordinary ftocke gilloflowers, but much larger and of a darke or blackifh browne colour: the root is white, and groweth deepe, fpreading in the ground, but growing woody when it is in feede, and perinheth afterwards. 


\section{Leucoij alterum genus, fore tum multiplici qunm fimplici ex. feminio oriundum.}

Another fort of Stocke gilloflowers bearing as well double as fingle flowers froin feede.

This kinde of Stocke gilloflower differeth neyther in forme of leaues, ftalkes, nor flowers from the former, but that it oftentimes groweth much larger and taller ; fo that whofoeuer thall fee both thefe growing together, fhall fcarce difcerne the difference, onely it beareth flowers, eyther white, red or purple, wholly or entire, that is, of one colour, without mixture of other colour in them (for fo much as euer I haue obferued, or could vnderftand by others) which are eyther fingle, like vnto the former, or very thicke and double, like vnto the next that followeth ; but larger, and growing with more ftore of flowers on the long ftalke. But this you must vnderftand withall, that thofe plants that beare double flowers, doe beare no feede at all, and is very feldome encreafed by lipping or cutting, as the next kinde of double is : but the onely way to haue double flowers any yeare, (for this kinde dyeth euery winter, for the moft part, after it hath borne flowers, and feldome is preferued) is to faue the feedes of thofe plants of this kinde that beare fingle flowers, for from that feede will rife, fome that will beare fingle, and fome double flowers, which cannot bee diftinguifhed one from another, I meane which will be fingle and which double, vntill you fee them in flower, or budde at the leaft. And this is the only way to preferue this kinde : but of the feed of the former kinde was neuer known any double flowers to arife, and therefore you muft be carefull to marke this kinde from the former.

\section{Leucoium flore pleno diuer forum colorum.}

Double Stocke Gillowflowers of diuers colours.

This other kinde of Stock gilloflower that beareth onely double flowers, groweth not fo great, nor fpreadeth his branches fo farre, nor are his leaues fo large, but is in all things fmaller, and lower, and yet is woody, or fhrubby, like the former, bearing his flowers in the like manner, many vpon a long ftalke, one aboue another, and very double, but not fo large as the former double, although it grow in fertile foyle, which are eyther white, or red, or purple wholly, without any mixture, or elfe mixed with fpots and ftripes, as the fingle flowers of the firt kinde, but more variably, and not in all places alike, neuer bearing feede, but muft be encreafed, only by the cutting of the young fproutes or branches, taken in a fit feafon : this kinde perifheth not, as the former double kinde doth, fo as it bee defended in the winter from the extreame frofts, but efpecially from the fnow falling, or at the leaft remaining vpon it.

\section{Leucoium fatiuum luteum flore plens.}

The double yellow Stocke Gilloflower.

This double yellow Stock gilloflower is a ftranger in England, as far as I can learne, neyther haue I any further familiaritie with him, then by relation from Germany, where it is affirmed to grow only in fome of their gardens, that are curious louers of thefe delights, bearing long leaues fornewhat hoary or white, (and not greene like vnto the Wallfower, whereunto elfe it might be thought to be referred) like vnto the Stock gilloflowers, as the ftalkes and branches alfo are, and bearing faire double flowers, of a faire, but pale yellow colour. The wholc plant is tender, as the double Stock gilloflowers are, and muft be carefully preferued in the winter from the coldes, or rather more then the laft double, left it perifh.

The Place.

The fingle kindes, efpecially fome of them, grow in Italie, and fome in Greece, Candy, and the Inles adiacent, as may be gathered out of the verfes in Plutarches Booke De Amore fraterno: 


\section{Inter Echinopodas velut afperam, छ inter Ononim, Interdum crefcunt mollia Leucoia.}

Which fheweth, that the foft or gentle ftocke gilloflowers doe fometimes grow among rough or prickely Furfe and Cammocke. The other forts are only to be found in gardens.

\section{The Time.}

They flower in a manner all the yeare throughout in fome places, efpecially fome of the fingle kindes, if they ftand warme, and defended from the windes and cold : the double kindes flower fometimes in Aprill, and more plentifully in May, and Iune ; but the double of feed, flowreth vfually late, and keepeth flowring vnto the winter, that the froftes and colde miftes doe pull it downe.

The Names.

It is called Leucoium, E Viola alba : but the name Leucoium (which is in Englifh the white Violet) is referred to diuers plants; we call it in Englifh generally, Stocke gilloflower, (or as others doe, Stocke gillouer) to put a difference betweene them, and the Gilloflowers and Carnations, which are quite of another kindred, as thall be fhewne in place conuenient.

\section{The Vertues.}

Thefe have no great vfe in Phyfick that I know : only fome haue vfed the leaues of the fingle white flowred kinde with falt, to be laid to the wrefts of them that haue agues, but with what good fucceffe I cannot fay, if it happen well I thinke in one (as many fuch things elfe will) it will fayle in a number.

\section{CH A P. XLI.}

1. Hesperis, fune Viola Matronalis. Dames Violets, or Queenes Gilloflowers.

$\mathrm{T}$ He ordinary Dames Violets, or Queene Gilloflowers, hath his leaues broader, greener, and Tharper pointed, then the Stock gilloflowers, and a little endented about the edges : the ftalkes grow two foot high, bearing many greene leaues vpon them, fmaller then thofe at the bottome, and branched at the toppe, bearing many flowers, in fafhion much like the flowers of ftocke gilloflowers, confifting of foure leaues in like manner, but not fo large, of a faint purplifh colour in fome, and in others white, and of a pretty fweet fent, efpecially towards night, but in the day time little or none at all : after the flowers are paft, there doe come fmall long and round pods, wherein is contained, in two rowes, fmall and long blacke feede : the roote is wholly compofed of ftringes or fibres, which abide many yeares, and fpringeth frefh ftalks euery yeare, the leaues abiding all the Winter.

\section{Hesperis Pannonica. Dames Violets of Hungary.}

The leaues of this Violet are very like the former, but fmoother and thicker, and not at all indented, or cut in on the edges: the flowers are like the former, but of a fullen pale colour, turning themfelues, and feldome lying plaine open, hauing many purple veines, and ftreakes running through the leaues of the flowers, of little or no fent in the day time, but of a very fweete fent in the euening and morning; the feedes are alike alfo, but a little browner. 


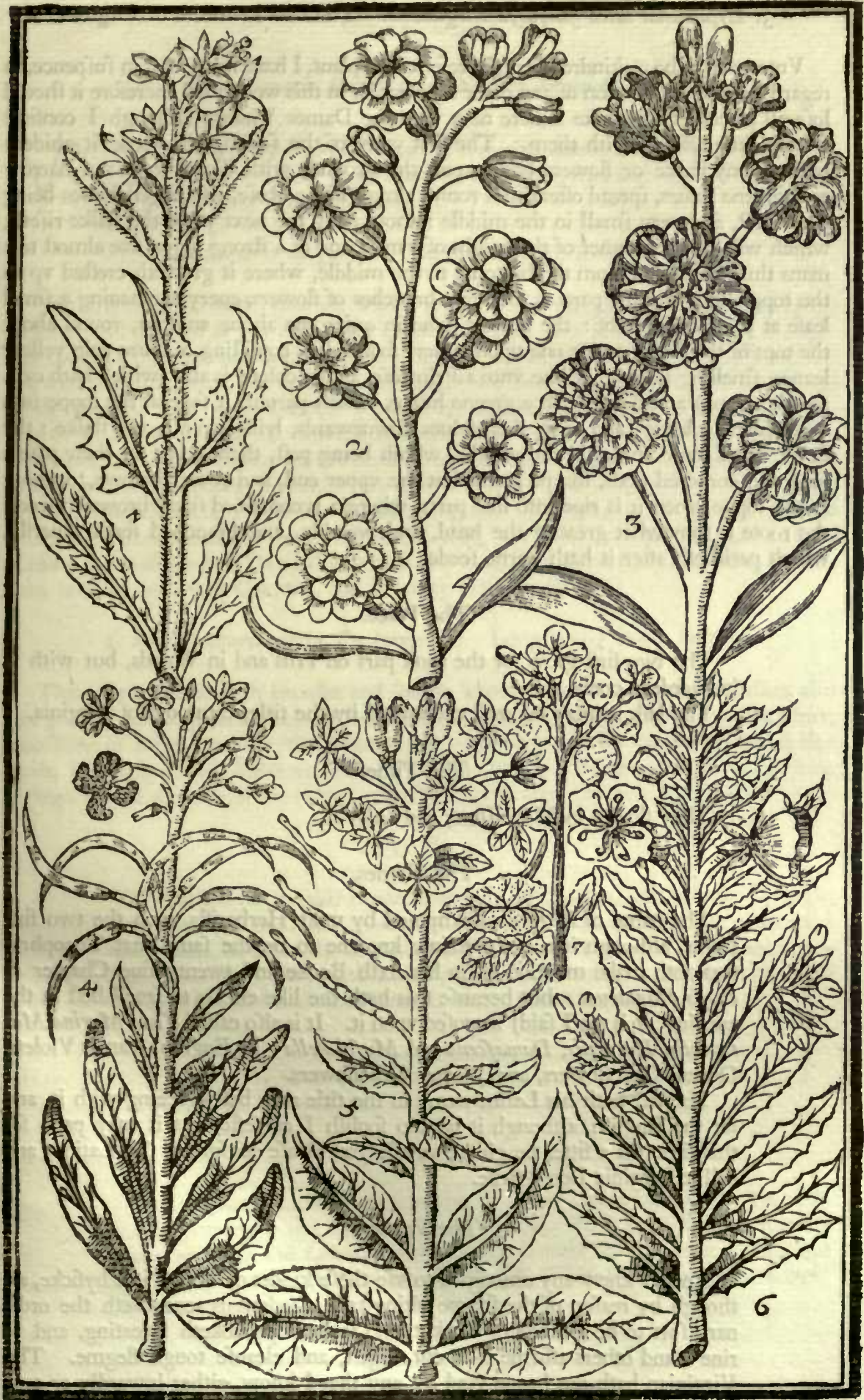

t Loxcoium Melnucholicum. Sullen Stocke-Gilloflowers. 2 Loncoiwm fativum fore pleno. Double Stocke.Gilloflowers. 3 locucoinm'fatisum fore pleno vario. Party coloured Stocke-Gilloflowers. 4 Lencoium marinum Syriacum. Leuant Stocke. Gillo-
dowers. 5 Hefperis vulgaris. Dames Violets or Winter Gillofouers. 6 Lyfimachia lutea fliquofa Virgiviana. The tree Primrole of Virginia. 7 Viola hnnaris fiwe Bolbonach. The white Sattin flower. 


\section{Lyfimachia lutea filiquofa Virginiana. The tree Primrofe of Virginia.}

Vnto what tribe or kindred I might referre this plant, I haue ftood long in fufpence, in regard I make no mention of any other Ly/machia in this work : left therefore it fhould lofe all place, let me ranke it here next vnto the Dames Violets, although I confeffe it hath little affinity with them. The firt yeare of the fowing the feede it abideth without any ftalke or flowers lying vpon the ground, with diuers long and narrow pale greene leaues, fpread oftentimes round almoft like a Rofe, the largeft leaues being outermoft, and very fmall in the middle : about May the next yeare the ftalke rifeth, which will be in Summer of the height of a man, and of a ftrong bigge fize almoft to a mans thumbe, round from the bottome to the middle, where it groweth crefted vp to the toppe, into as many parts as there are branches of flowers, euery one hauing a fmall leafe at the foote thereof : the flowers ftand in order one aboue another, round about the tops of the ftalks, euery one vpon a thort foot-ftalke, confifting of foure pale yellow leaues, fmelling fomewhat like vnto a Primrofe, as the colour is alfo (which hath caufed the name) and ftanding in a greene huske, which parteth it felfe at the toppe into foure parts or leaues, and turne themfelues downewards, lying clofe to the ftalke : the flower hath fome chiues in the middle, which being paft, there come in their places long and cornered pods, tharpe pointed at the vpper end, and round belowe, opening at the toppe when it is ripe into fiue parts, wherein is contained fmall brownifh feed : the roote is fomewhat great at the head, and wooddy, and branched forth diuerfly, which perifheth after it hath borne feede.

\section{The Place.}

The two firft grow for the moft part on Hils and in Woods, but with vs in Gardens onely.

The laft, as may be well vnderftood by the title, came out of Virginia.

\section{The Time.}

They flower in May, Iune, and Iuly.

\section{The Names.}

The name of Hesperis is impofed by moft Herbarifts vpon the two firft plants, although it is not certainly knowne to be the fame that Theophraftus doth make mention of, in his fixth Booke and twenty fiue Chapter de caufis plantarum : but becaufe this hath the like effects to fmell beft in the euening, it is (as I faid) impofed vpon it. It is alfo called Viola Marina $M a$ tronalis, Hyemalis, Damafcena and Mufchatella: In Englifh, Dames Violets, Queens Gilloflowers, and Winter Gilloflowers.

The laft hath his Latine name in the title as is beft agreeing with it, and for the Englifh, although it be too foolifh I confeffe, yet it may paffe for this time till a fitter be giuen, vnleffe you pleafe to follow the Latine, and call it Virginia Loofe-ftrife.

\section{The Vertues.}

I neuer knew any among vs to vfe thefe kindes of Violets in Phyficke, although by reafon of the fharpe biting tafte, Dodonæus accounteth the ordinary fort to be a kinde of Rocket, and faith it prouoketh fweating, and vrine : and others affirme it to cut, digeft, and cleanfe tough flegme. The Virginian hath not beene vfed by any that I know, either inwardly or outwardly. 


\section{Cн A P. X L I I.}

\section{Viola Lunaris fue Bolbonach. The Sattin flower.}

$\mathrm{V}$

Nto the kindes of Stocke-Gilloflowers I thinke fitteft to adioyne thefe kindes of Sattin-flowers, whereof there are two forts, one frequent enough in all our Countrie, the other is not fo common.

\section{Viola Lunaris vulgaris. The common white Sattin flower.}

The firt of thefe Sattin flowers, which is the moft common, hath his leaues broad belowe, and pointed at the end, fnipt about the edges, and of a darke greene colour : the ftalkes are round and hard, two foot high, or higher, diuided into many branches, fet with the like leaues, but fmaller : the tops of the branches are befet with many purplifh flowers, like vnto Dames Violets, or Stocke-Gilloflowers, but larger, being of little fent : after the flowers are paft, there come in their places round flat thin cods, of a darke colour on the outfide, but hauing a thinne middle skinne, that is white and cleare fhining, like vnto very pure white Sattin it felfe, whereon lye flat and round brownifh feede, fomewhat thicke and great : the rootes perifh when they haue giuen their feede, and are fomewhat round, long, and thicke, refembling the rootes of Lilium non bulbofum, or Day Lilly, which are eaten (as diuers other rootes are) for Sallets, both in our owne Country, and in many places befide.

\section{Viola Lunaris altera feu peregrina. Long liuing Sattin flower.}

This fecond kinde hath broader and longer leaues then the former, the ftalkes alfo are greener and higher, branching into flowers, of a paler purple colour, almoft white, confifting of foure leaues in like manner, and fmelling pretty fweete, bearing fuch like pods, but longer and flenderer then they : the rootes are compofed of many long ftrings, which dye not as the former, but abide, and fhoot out new ftalkes euery yeare.

\section{The Place.}

The firft is (as is faid) frequent enough in Gardens, and is found wilde in fome places of our owne Country, as Mafter Gerard reporteth, whereof I neuer could be certainly affured, but I haue had it often fent mee among other feedes from Italy, and other places. The other is not fo common in Gardens, but found ábout Watford, as he faith alfo.

\section{The Time.}

They flower in Aprill or May, and fometimes more early.

\section{The Names.}

It hath diuers names, as well in Englifh as in Latine; for it is called moft vfually Bolbonach, and Viola Lunaris: Of fome Viola latifolia, and of others Viola Peregrina, and Lunaria Graca, Lunaria maior, and Lunaria odorata, and is thought to be Thlaspi Grateuce: In Englifh, White Satten, or Satten flower: Of fome it is called Honefty, and Penny-flower.

\section{The Vertues.}

Some doe vfe to eate the young rootes hereof, before they runne vp to flower, as Rampions are eaten with Vinegar and Oyle; but wee know no Phyficall vfe they haue. 
Сн A.P. XLIII.

\section{Linum flueftre $\mathcal{E}$ Linaria... Wilde Flaxe and Tode Flaxe.}

A Lthough neither the manured Line or Flaxe is a plant fit for our Garden, nor many of the wilde forts, yet there are fome, whofe pleafant and delightfull afpect doth entertaine the beholders eyes with good content, and thore I will fet downe here for varietie, and adioyne vnto them fome of the Linarias, or Tode Flaxe, for the neare affinity with them.

\section{Linum flueftre flore albo. Wilde Flaxe with a white flower.}

This kinde of wilde Flaxe rifeth vp with diuers flender branches, a foote high or better, full of leaues, ftanding without order, being broader and longer then the manured Flaxe : the tops of the branches haue diuers faire white flowers on them, compofed of fiue large leaues a peece, with many purple lines or ftrikes in them: the feede veffell as well as the feede, is like vnto the heads and feede of the manured Flaxe : the rootes are white ftrings, and abide diuers yeares, fpringing frefh branches and leaues euery yeare, but not vntill the Spring of the yeare.

\section{Linum flueftre luteum. Wilde Flaxe with a yellow flower.}

This wilde Flaxe doth fo well refemble a kinde of St. Iohns wort, that it will foone deceiue one that doth not aduifedly regard it : For it hath many reddifh ftalkes, and fmall leaues on them, broader then the former wilde Flaxe, but not fo long, which are well ftored with yellow flowers, as large as the former, made of fiue leaues a peece, which being paft, there come fmall flattifh heads, containing blackifh feede, but not fhining like the former : the rootes hereof dye not euery yeare, as many other of the wilde kindes doe, but abide and fhoote out euery yeare.

\section{Linaria purpurea. Purple Tode Flaxe.}

This purple Tode Flaxe hath diuers thicke, fmall, long, and fomewhat narrowin leaues, fnipt about the edges, of a whitifh greene colour, from among which rife vp diuers ftalkes, replenifhed at the tops with many fmall flowers, ftanding together one aboue another fpike-fafhion, which are fmall and fomewhat fweete, while they are frefh, fafhioned fomewhat like the common Tode flaxe that groweth wilde abroad almoft euery where, but much fmaller, with a gaping mouth, but without any crooked fpurre behinde, like vnto them, fometimes of a fad purple neare vnto a Violet, and fometimes of a paler blew colour, hauing a yellow fpot in the middle or gaping place : after the flowers are paft, there come fmall, hard, round heads, wherein are contained fmall, flat, and grayinh feede : the roote is fmall and perifheth for the moft part euery yeare, and will fpring againe of it owne fowing, if it be fuffered to thed it felfe, yet fome hard Winters haue killed the feede it fhould feeme, in that fometimes it faileth to fpring againe, and therefore had neede to be fowne anew in the Spring.

\section{Linaria purpurea odorata. Sweete purple Tode Flaxe.}

The lower leaues of this purple Tode Flaxe are notbing like any of the reft, but are long and broad, endented about the edges, fomewhat refembling the leaues of the greater wilde white Daifie : the ftalke is fet at the bottome with fuch like leaues, but a little more diuided and cut in, and ftill fmaller and fmaller vpward, fo that the vppermoft leaues are very like the common Tode Flaxe, the toppe whereof is branched, hauing diuers fmall flowers growing along vpon them; in fafhion and colour almoft like the laft defcribed!Tode Flaxe, but not altogether: fo deepe a purple: the heads and feedes are very like the former, but that the feede of this is reddifh : the flowers 


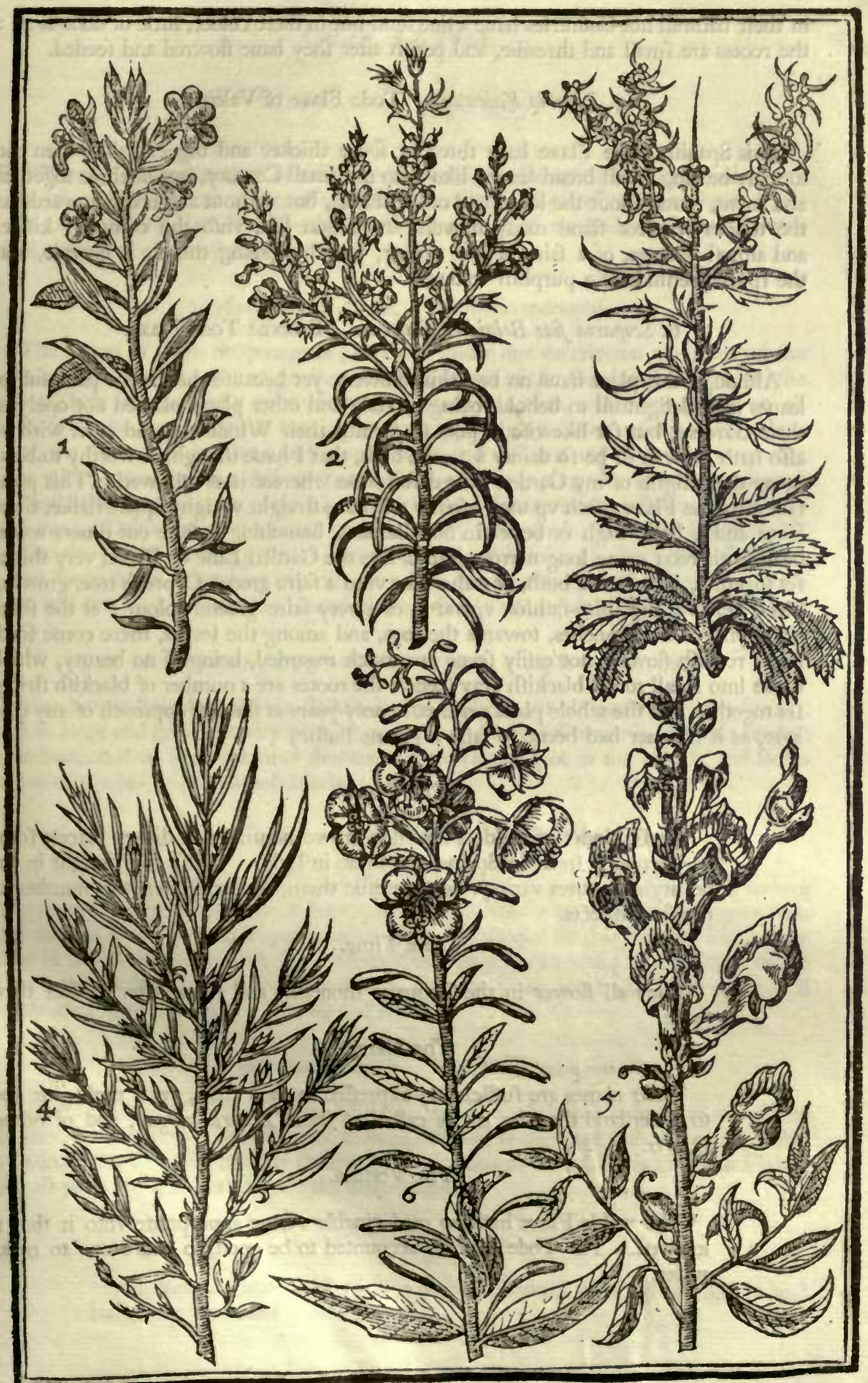

1 Limum flueftre fore albo. Wilde Flaxe with a white flower. 2 Liwaria purfwren fiwe curvilca. Purple Tode Flaxe. 3 hinum 6 Chamanerium flore delphixij. The willowe flower. 
in their naturall hot Countries have a fine fent, but in thefe colder, little or none at all : the rootes are fmall and threadie, and perifh after they haue flowred and feeded.

\section{Linaria Valentina. Tode Flaxe of Valentia.}

This Spanifh Tode Flaxe hath three or foure thicker and bigger ftalkes then the former, bearing fmall broad leaues, like vnto the fmall Centory, two or three together at a ioynt, round about the lower end of the ftalkes, but without any order vpwards, at the toppes whereof ftand many flowers, in fafhion like vnto the common kinde, and almoft as large, of a faire yellow colour, but the gaping mouth is downie, and the fpurre behinde of a purplifh colour.

\section{Scoparia fue Beluidere Italorim. Broome Tode Flaxe.}

Although this plant haue no beautifull flowers, yet becaufe the greene plant full of leaues is fo delightfull to behold, being in Italy and other places planted not onely in their Gardens, but fet likewife in pots to furnifh their Windowes, and euen with vs alfo hath growne to be fo dainty a greene bufh, that I haue thought it worthy to be among the delights of my Garden ; the defcription whereof is as followeth : This pleafant Broome Flaxe rifeth vp moft vfually with one ftraight vpright fquare ftalke, three foote and a halfe high or better in our Gardens, branching it felfe out diuers waies, bearing thereon many long narrow leaues, like the Garden Line or Flaxe, very thicke fet together, like vnto a bufh, or rather like vinto a faire greene Cypreffe tree, growing broad belowe, and fpire-fafhion vpwards, of a very faire greene colour: at the feuerall ioynts of the branches, towards the tops, and among the leaues, there come forth fmall reddifh flowers, not eafily feene nor much regarded, being of no beauty, which turne into fmall round blackifh gray feede : the rootes are a number of blackifh ftrings fet together, and the whole plant perifheth euery yeare at the firft approach of any cold ayre, as if it neuer had beene fo faire a greene bufh.

\section{The Place.}

Thefe kindes of wilde Flaxe doe growe naturally in diuers places, fome in Germany, forne in Spaine, and fome in Italy. Thofe that delight in the beauty of natures variety, doe preferue them, to furnifh $\mathrm{vp}$ the number of pleafant af pects.

\section{The Time.}

They all flower in the Summer moneths, and foone after perfect their feede.

\section{The Names.}

Their names are fufficiently expreffed in their titles, yet I muft giue you to vnderftand that the laft is called of fome Linaria magna, and of others Ofyris.

\section{The Vertues.}

The wilde Flaxe hath no medecinable vertue appropriate vnto it that is knowne. The Tode Flaxe is accounted to be good, to caufe one to make water. 
Ch A P. X L I I I I.

Antirrhinum. Snapdragon.

THere is fome diuerfity in the Snapdragons, fome being of a larger, and others of a leffer ftature and bigneffe ; and of the larger, fome of one, and fome of another colour, but becaufe the fmall kindes are of no beautie, I fhall at this time onely entreate of the greater forts.

\section{Antirrhinum album. White Snapdragon.}

The leaues of thefe Snapdragons (for I doe vnder one defcription comprehend the reft) are broader, longer, and greener then the leaues of the Garden Flaxe, or of the wilde Flaxe fet confufedly vpon the tender greene branches, which are fpread on all fides, from the very bottome, bearing at the toppes many flowers, fomewhat refembling the former Tode Flaxe, but much larger, and without any heele or fpurre, of a faire white colour, with a yellow fpot in the mouth or gaping place : after the flowers are paft, there come vp in their places hard round feede veffels, farhioned fomewhat like vnto a Calues head, the fnout being cut off, wherein is contained fmall blacke feede : the rootes are many white ftrings, which perifh in moft places after they haue giuen feede, notwithftanding any care or paines taken with them to preferue them aliue, and yet they will abide in fome places where they are defended in the Winter.

\section{Antirrhinum purpureum fue rofeum. Purple Snapdragon.}

The purple Snapdragon is in ftalkes, leaues, and flowers altogether like the former, and as large and great in euery part, or greater ; the only difference is, that this beareth pale Stammell or Rofe coloured flowers, with a yellow fpot in the mouth, and fometimes of a paler colour, almoft blufh.

\section{Antirrhinum variegatum. Variable Snapdragon.}

This variable kinde is fomewhat leffe, and tenderer then the laft defcribed, hauing alfo a reddifh or blufh coloured flower, leffer then the former, but much bigger then the middle kinde of Snapdragon (which is not fet downe in this worke) the yellow fpot in the mouth of it hath fome white about it, and extending to both fides of the fpot : the heads and feede are like the former : the rootes are fmaller, but neuer will abide after they haue giuen flowers and feede.

\section{Antirrhinum luteum. Yellow Snapdragon.}

There is likewife another of thefe kindes, that beareth leaues as large as any of the former, \& very faire yellow flowers, as large likewife as they, not differing in any thing elfe from the firft ; let not any therefore imagine this to be a Linaria or Tode Flaxe : for all parts are anfwerable vnto the Snapdragons.

\section{The Place.}

All thefe are nourifhed with vs in our Gardens, although in Spaine and Italy they are found growing wilde.

The Time.

They flower for the moft part the fecond yeare after the fowing, from Aprill vntill Iuly, and the feede is quickly ripe after. 
The Names.

The name Antirrhinum is vfually giuen to this plant, although it fully agreeth not eyther with the defcription of Diofcorides, or Theophraftus : It hath alfo diuers other names in Latine, as Orontium, Canis cerebrum Os Leonis, Leo herba, $\Xi^{2} c$. In Englifh Calues fnout, from the forme of the feede veffels, and Snapdragon, or Lyons mouth, from the forme of the flowers.

\section{The Vertues.}

They are feldome or neuer vfed in Phyficke by any in our dayes.

\section{CH A P. X L V.}

Chamanerium flore delphinij. The Willowe flower.

$\mathrm{T}$

His plant rifeth vp with many ftrong, woddy, round, brownifh great ftalkes, three or foure foote high, befet here and there without order, with one broad and long whitifh greene leafe at a ioynt, fomewhat like vnto a Lyfimachia, or Willowe herbe, as alfo vnto a Peach leafe, but larger and longer : at the toppe of the branches ftand many flowers one aboue another, of a pale, reddifh purple colour, confifting of fiue leaues, fpread open with an heele or fpurre behinde them, with many yellow threads in the middle, much larger then any flower of the Larkes fpurres, and fmelling fomewhat fweete withall ; it beareth a thew of long pods with feede, but I could neuer obferue the feede : the rootes are like the rootes of Ly fimachia, or the ordinary yellow Loofe-ftrife, or Willowe herbe, but greater : running and fpreading vnder ground, and thooting vp in many places, whereby, it filleth a ground that it likes quickly : the ftalkes dye downe euery yeare, and fpring againe in many places farre afunder.

\section{The Place.}

Wee haue not knowne where this Willowe flower groweth naturally, but we haue it ftanding in an out corner of our Gardens, to fill vp the number of delightfull flowers.

\section{The Time.}

It flowreth not vntill May, and abideth a long while flowring.

The Names.

It nay feeme to diuers, that this is that plant that Dodonxus called $P$ feudolyfimachium purpureum minus, and Lobel feemeth by the name of Delphinium buccinum to aime at this plant, but withall calleth it Chamenerium Gefneri, and giueth the fame figure that Dodonæus hath for his Pfeudolyfmachium: But that is one kinde of plant (which hath fmaller and fhorter ftalkes, and very narrow long leaues, whofe flowers ftand vpon long flender cods, full of downe, with reddifh feede, like vnto the Lyfmachia faliquofa flueftris, and rootes that abide many yeares, but creepe not) and this is another, much greater, whofe true figure is not extant in any Author that I know. It is vfually called Chamanerium flore delphinij; but the name of Delphinium buccinum in my minde may not fo conueniently be applyed vnto it. It is called in Englifh, The Willowe flower, for the likeneffe of the leaues, and the beauty and refpect of the flowers. 


\section{The Vertues.}

There is no vfe hereof in Phyficke that euer I could learne, but is onely cherifhed among other forts of flowers, that ferue to decke and fet forth a Garden of varieties.

\section{CH А P. X L VI. \\ Aquilegia. Colombines.}

$\mathrm{T}$

Here are many forts of Colombines, as well differing in forme as colour of the flowers, and of them both fingle and double carefully nourfed vp in our Gardens, for the delight both of their forme and colours.

\section{Aquilegia vulgaris fore fimplici. Single Colombines.}

Becaufe the whole difference of thefe Colombines ftandeth in the varieties of the forme, and colour of the flowers, and little in the leaues, I thall not neede to make anie repetitions of the defcription of them, feeing one onely fhall fuffice for each peculiar kinde. The Colombine hath diuers large fpread leaues, ftanding on long ftalkes: euery one diuided in feuerall partitions, and roundly endented about the edges, in colour fomewhat like the leaues of Celondine, that is, of a darke blewifh greene colour : the ftalkes rife vp fometimes two or three foote high, diuided vfually into many branches, bearing one long diuided leafe at the lower ioynt, aboue which the flowers growe, euery one ftanding on a long ftalke, confifting of fiue hollow leaues, crooked or horned at the ends, turning backward, the open flower fhewing almoft like vnto a Cinquefoile, but more hollow : after the flowers are paft, there arife fmall long cods, foure or fiue together, wherein are contained blacke fhining feede : the rootes are thicke and round, for a little fpace within the ground, and then diuided into branches, ending in many fmall fibres, abiding many yeares, and fhooting a frefh euery Spring from the round heads, that abide all the Winter. The variety of the colours of thefe flowers are very much, for fome are wholly white, fome of a blew or violet colour, others of a blufh or flefh colour, or deepe or pale red, or of a dead purple, or dead murrey colour, as nature lifteth to fhew it felfe.

\section{Aquilegia vulgaris flore pleno. Double Colombines.}

The double Colombines differ not in leafe or manner of growing from the fingle, fo thiat vntill they come to flower, they cannot bee difcerned one from another; the onely difference is, it beareth very thicke and double flowers, that is, many horned or crooked hollow leaues fet together, and are not fo large as the leaues of the fingle flowers. The variety of colours in this double kinde is as plentifull, or rather more then in the fingle; for of thefe there is party coloured, blew and white, and fpotted very variably, which are not in the fingle kinde, and alfo a very deepe red, very thicke and double, but a fmaller flower, and leffe plentifull in bearing then many of the other double forts. Thefe double kindes doe giue as good feede as the fingle kindes doe, which is not obferued in many other plants.

\section{Aquilegia inuer fis corniculis. Double inuerted Colombines.}

Thefe Colombines are not to be diftinguifhed eyther in roote, leaues, or feed from the former, the flowers onely make the difference, which are as double as the former, but that the heeles or hornes of thefe are turned inward, and ftand out in the middle of the flowers together : there is not that plentifull variety of colours in this kinde, as there is in the former : for I neuer faw aboue three or foure feuerall colours in this 
kinde, that is, white, purplifh, reddifh, and a dun or darke ouerworne purplifh colour. Thefe double flowers doe likewife turne into pods, bearing feede, continuing his kind, and not varying into the former.

\section{Aquilegia Rofea. Rofe Colombines.}

The leaues and other parts of this kinde of Colombine, differ little or nothing from the former, the diuerfitie confifteth likewife in the flowers, which although they ftand in the fame manner feuerally vpon their fmall ftalkes, fomewhat more fparingly then the former doe, yet they haue no heeles or hornes, eyther inward or outward, or very feldome, but ftand fometimes but with eight or tenne fmooth fmall plaine leaues, fet in order one by one in a compaffe, in a double rowe, and fometimes with foure or fiue rowes of them, euery one directly before the other, like vnto a fmall thick double Rofe layd open, or a fpread Marigold : yet fometimes it happeneth, that fome of thefe flowers will haue two or three of the firft rowes of leaues without any heele, and the reft that are inward with each of them a peece of a fmall horne at them, as the former haue : the colours of thefe flowers are almoft as variable, and as variably mixed as the former double kindes. This likewife giueth feede, preferuing his owne kinde for the moft part.

\section{Aquilegia degener. Degenerate Colombines.}

This kinde of Colombine might feeme to fome, to bee but a cafuall degeneration, and no true naturall kinde, happening by fome caufe of tranfplanting, or otherwife by the art of man : but I have not fo found it, in that it keepeth, and holdeth his own proper forme, which is like vnto the double Rofe Colombine, but that the outermoft row of leaues are larger then any of the reft inwardes, and is of a greenifh, or elfe of a purplifh greene colour, and is not altogether fo apt to giue good feed like the former.

The Place.

The fingle kindes haue beene often found in fome of the wooddy mountaines of Germany, as Clufius faith, but the double kindes are chiefly cherifhed in gardens.

\section{The Time.}

They flower not vntill May, and abide not for the moft part when Iune is paft, and in the meane time perfecteth their feede.

\section{The Names.}

Coftæus doth call this plant Pothos of Theophraftus, which Gaza tranflateth Defiderium. Dalechampius vpon Athenæus, calleth it Diofanthos, or Iouis flos of Theophraftus, who in his fixth Booke and feuenth Chapter reckoneth them both, that is, Diofanthos and Pothos, to be Summer flowers, but feuerally. Dodonæus Leoherba, and Gefner Leontofomium. Fabius Columna in his Phytobafanos, vnto whom Clufius giueth the greateft approbation, referreth it to the Ifopyrum of Diofcorides. All later Writers doe generally call it, eyther Aquileia, Aquilina, or Aquilegia ; and we in Englifh, generally (I thinke) through the whole Countrey, Colombines. Some doe call the Aquilegia rofea, Aquilegia ßellata, The ftarre Colombine; becaufe the leaues of the flowers doe ftand fo directly one by another; befides the doubleneffe, that they fomewhat reprefent eyther a Rofe or a Starre, and thereupon they giue it the name eyther of a Starre or Rofe.

The Vertues.

Some in Spaine, as Camerarius faith, vfe to eate a peece of the roote here- 


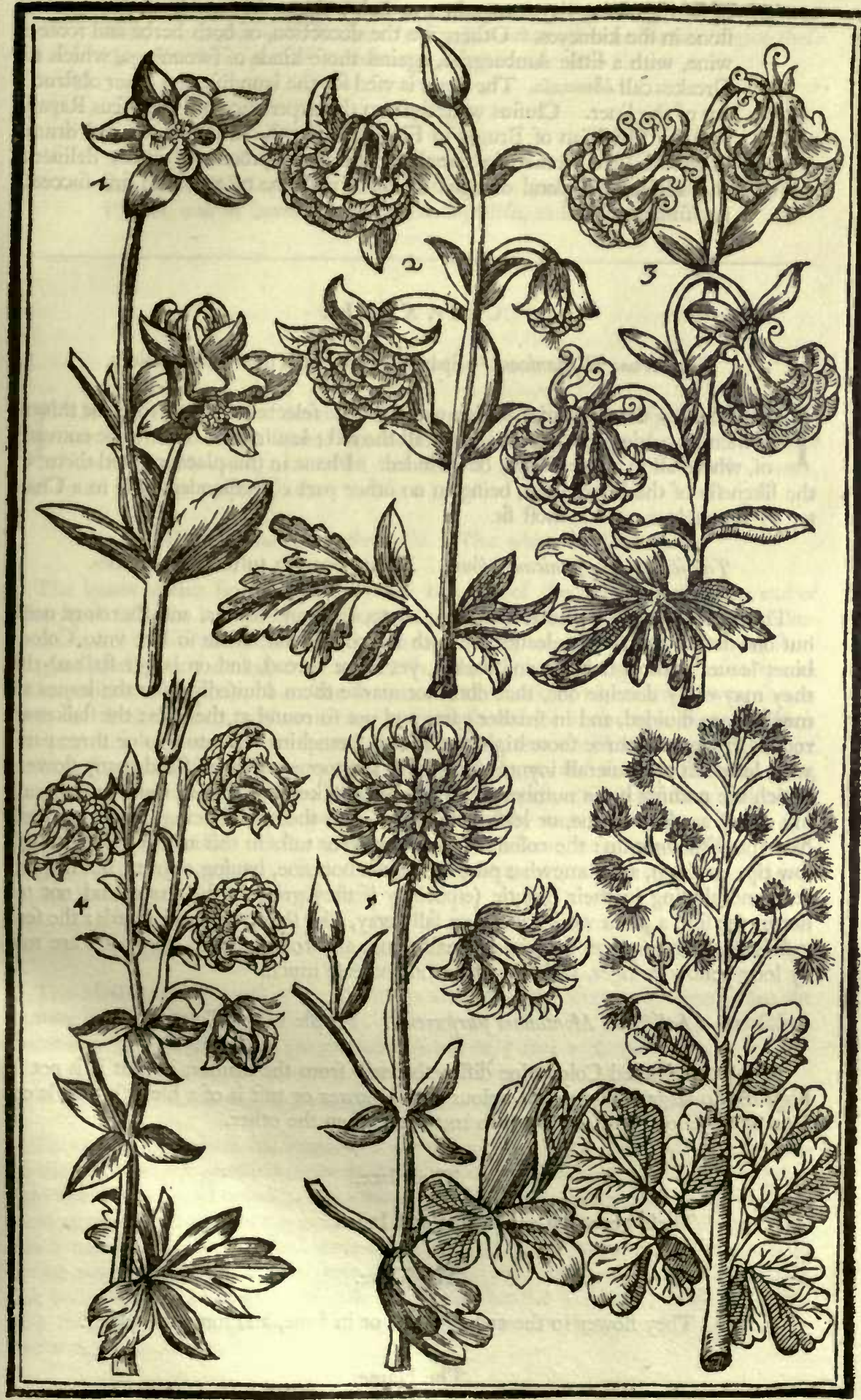

1 Aquilgria fimplex. The fingle Colombine. 2 Aquilegia fore multiplici. The double Colombine. The party coloured Colombine. Aquilegia inuerfis comicwlis. The double inuerted Colombine. Sicllata. The Rofe or the Starre Colombine. 6 Thalicinum Hifpanicum album. White Spanifh tufts. 
of fafting, many dayes together, to helpe them that are troubled with the ftone in the kidneyes. Others vfe the decoction, of both herbe and roote in wine, with a little Ambargrife, againft thofe kinds of fwounings, which the

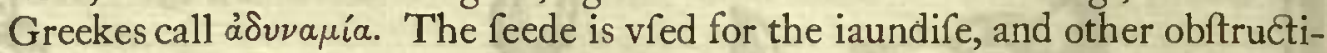
ons of the liuer. Clufius writeth from the experience of Francifcus Rapard, a chiefe Phyfician of Bruges in Flanders, that the feede beaten and drunke is effectuall to women in trauell of childe, to procure a fpeedy deliuerie, and aduifeth a fecond draught thereof fhould be taken if the firf fucceede not fufficiently.

\section{C н A P. X L V I I.}

Thalictrum Hifpanicum. Spanifh Tufts, or Tufted Colombines.

CRom among the diuerfities of this plant, I have felected out two forts for this my garden, as hauing more beautie then all the reft; leauing the other to be entreated of, where all in generall may be included. I haue in this place inferted them, for the likeneffe of the leaues only, being in no other part correfpondent, and in a Chapter by themfelues, as it is moft fit.

\section{Thalictrum Hifpanicum album. White Spanifh tufted Colombines.}

Thefe plants haue both one forme, in roote, leafe and flower, and therefore neede but one defcription. The leaues are both for colour and forme fo like vnto Colombines leaues (although leffer and darker, yet more fpread, and on larger ftalkes) that they may eafily deceiue one, that doth not marke them aduifedly; for the leaues are much more diuided, and in fmaller parts, and not fo round at the ends: the ftalkes are round, ftrong, and three foote high at the leaft, branching out into two or three parts, with leaues at the feuerall ioynts of them, at the toppes whereof ftand many flowers, which are nothing but a number of threads, made like vnto a fmall round tuft, breaking out of a white skinne, or leafe, which inclofeth them, and being vnblowne, thew like vnto little buttons: the colour of thefe threds or tufts in this are whitifh with yellow tips on them, and fomewhat purplifh at the bottome, hauing a ftrong but no good fent, and abiding in their beautie (efpecially if they grow in the fhade, and not too hot in the fun) a great while, and then fall away, like fhort downe or threds: the feed veffels are three fquare, containing fmall, long, and round feede; the rootes are many long yellow ftringes, which endure and encreafe much.

\section{Thalictrum Montanum purpureum. Purple tufted Colombines.}

This purple tufted Colombine differeth onely from the former, in that it is not to high nor fo large, and that the colour of the flower or tuft is of a blewifh purple colour with yellow tips, and is much more rare then the other.

The Place.

Thefe grow both in Spaine and Italie.

The Time.

They flower in the end of May, or in Iune, and fometimes later.

The Names.

Some doe call them Thaliotrum, and fome Thalictrum. Others Ruta palufris, and Ruta pratenfis, and fome Rhabarbarum Monachorum, or Pfeudo- 
rhabarbarum, by reafon that the rootes being yellow, haue an opening qualitie, and drying as Rubarbe. In Englifh what other fit Names to giue thefe then I haue expreffed in the titles, I know not.

\section{The Vertues.}

They are a little hot and drying withall, good for old Vlcers, as Diof corides faith, to bring them to cicatrifing : in Italy they are vfed againft the Plague, and in Saxonye againft the Iaundife, as Camerarius faith.

\section{Сна P. X L VIII.}

\section{Radix caua. Hollow roote.}

THe likenefle of the leaues likewife of this plant with Colombines, hath caufed mee to infert it next the other, and although fome of this kinde bee of fmall refpect, being accounted but foolifh, yet let it fill vp a wafte corner, that fo no place be vnfurnifhed.

\section{Radix Caua maior flore albo. The white Hollow roote.}

The leaues of this hollow roote breake not out of the ground, vntill the end of March, or feldome before, and are both for proportion and colour fomewhat like vnto the leaues of Colombines, diuided into fiue parts, indented about the edges, ftanding on fmall long footeftalkes of a whitifh greene colour, among which rife vp the ftalkes, without any leaues from the bottome to the middle, where the flowers fhoote forth one aboue another, with euery one a fmall fhort leafe at the foote thereof, which are long and hollow, with a fpurre behinde it, fomewhat like vnto the flowers of Larckes fpurres, but hauing their bellies fomwhat bigger, and the mouth not fo open, being all of a pure white colour : after the flowers are paft, arife fmall long and round cods, wherein are contained round blackifh feede : the roote is round and great, of a yellowifh browne colour on the outfide, and more yellow within, and hollow vnderneath, fo that it feemeth but a fhell : yet being broken, euery part will grow: it abideth greene aboue ground but a fmall time.

\section{Radix Caua maior flore carneo. Blufh colourd Hollow roote.}

The blufh Hollow roote is in all things like vnto the former, but onely that the flowers hereof are of a delayed red or purple colour, which we call blufh : and fometimes of a very deepe red or purple colour; but very rare to meete with.

\section{Radix Caua minor, feu Capnos fabacea radice. Small hollow roote.}

This fmall kinde hath his leaues of a blewifh greene colour, yet greener and fmaller then the former, growing more thicke together : the flowers are like in proportion vnto the former in all refpects, but leffer, hauing purplifh backes, and white bellyes: ftanding clofer and thicker together vpon the fhort ftalkes: the roote is folid or firme, round and a little long withall, two being vfually ioyned together, yellowifh both within and without: but I have feene the dry roots that came from beyond Sea hither, that haue beene as fmall as hafell nuts, and fomewhat flat with the roundneffe, differing from thofe that growe with vs, whether the nature thereof is to alter by manuring, I know not.

The Place.

The greater kindes Clufius reporteth he found in many places of Hunga- 
rie, and the other parts neare thereunto : the leffer in the lower Germany, or Low Countries, as we call them.

\section{The Time.}

Thefe are moft truely to bee reckoned Vernall plants, for that they rife not out of the ground vntill the Spring bee come in, and are gone likewife before it be paft, remaining vnder ground all the reft of the yeare, yet the leffer abideth longer aboue ground then the greater.

\section{The Names.}

Concerning the former of thefe, there is a controuerfie among diuers, whether it hould be The frum of Theophraftus, or Eriphium of Galen, but here is no fit place to trauerfe thofe opinions. Some would have it to bee Corydalis, and fome referre it to Plinie his Capnos Cheledonia, for the likeneffe it hath both with Fumeterie and Celandine. It is generally called of all moderne Writers, Radix Caua, and we in Englifh thereafter, Hollow roote. The leffer for the firmneffe of his round roote, is vfually called, Capnos fabacea radice, and the Dutch men thereafter, Boonkens bollwostell: we of the likeneffe with the former, doe call it the leffe Hollow roote.

The Vertues.

Some by the bitterneffe doe coniecture (for little proofe hath beene had thereof, but in outward cafes) that it clenfeth, purgeth, and dryeth withall.

Сна P. XLIX.

\section{Delphinium. Larkes heeles.}

$\mathrm{O}^{\mathrm{r}}$ F Larkes heeles there are two principall kindes, the wilde kinde, and the tame or garden; the wilde kinde is of two forts, one which is with vs nourfed vp chiefly in gardens, and is the greatelt ; the other which is fmaller and lower, often found in our plowed landes, and elfewhere : of the former of thefe wilde forts, there are double as well as fingle : and of the tame or more vpright, double alfo and fingle : and of each of diuers colours, as thall be fet downe.

\section{Delphinium maius fue vulgare. The ordinary Larkes heeles.}

The common Larkes heele fpreadeth with many branches much more ground then the other, rather leaning or bending downe to the ground, then ftanding vpright, whereon are fet many fmall long greene leaues, finely cut, almoft like Fennell leaues: the branches end in a long fpike of hollow flowers, with a long fpurre behinde them, very like vnto the flowers of the Hollow roote laft defcribed, and are of Varietas. diuers feuerall colours, as of a blewifh purple colour, or white, or afh colour or red, paler or deeper, as alfo party coloured of two colours in a flower : after the flowers are paft, (which in this kinde abide longer then in the other) there come long round cods, containing very blacke feede : the root is hard after it groweth vp to feede, fpreading both abroad and deepe, and perifheth euery yeare, vfually raifing it felfe from it own fowing, as well as from the feede fowen in the fpring time.

\section{Delphinium vulgare flore pleno. Double common Larkes heeles.}

Of this vulgar kinde there is fome difference in the flower, although in nothing elfe: the flowers ftand many vpon a ftalke like the former, but euery one of them are as if 
three or foure finall flowers were ioyned together, with euery one his fpurre behinde, the greateft flower being outermoft, and as it were containing the reft, which are of a pale red, or deepe blufh colour: Another of this kinde will beare his flowers with three or foure rowes of leaues in the middle, making a double flower with one fpurre behinde onely: and of this kinde there is both with purple, blew, blufh, and white flowers, and party coloured alfo; thefe doe all beare feed like the fingle, wherby it is increafed euery yeare.

\section{Delphinium aruenfe. Wilde Larkes fpurres.}

This wilde Larkes fpurre hath fmaller and thorter leaues, fmaller and lower branches, and more thinly or fparfedly growing vpon them, then any of the former : the flowers likewife are neyther fo large as any of the former, nor fo many growing together, the cods likewife have fmaller feede, and is harder to grow in gardens then any of the former, the moft vfuall colour hereof is a pale reddifh or blufh colour, yet fometimes they are found both white and blew, and fometimes mixt of blew and blufh, variably difpofed, as nature can when the lifteth; but are much more rare.

\section{Delphinium elatius fore finplici diuer forum colorum.}

Single vpright bearing Larkes heeles of many colours.

The difference betweene this and the laft is, that the leaues of this are not fully fo greene, nor fo large; the ftalkes grow vpright, to the height of a man, and fometimes higher, hauing fome branches thereon, but fewer then the former, and ftanding likewife vpright, and not leaning downe as the former : the toppes of the ftalkes are better ftored with flowers then the other, being fometimes two foote long and aboue, of the fame fafhion, but not altogether fo large, but of more diuers and feueral colours, as white, pale, blufh, redde deeper or paler, afhcoloured, purple or violet, and of an ouerworne blewilh purple, or iron colour : for of all thefe we have fimple, without any mixture or fpot: but we haue other forts, among the fimple colours, that rife from the fame feede, and will haue flowers that wil be halfe white, and halfe blurh or purple, or one leafe white, and another blufh or purple, or elfe variably mixed and fpotted: the feede and feede veffels are like the former but larger and harder.

\section{Delphinium elatius flore pleno diuer forum colorum. Double vpright Larkes heeles of many colours.}

Thefe double Larkes heeles cannot bee knowne from the fingle of the fame kinde, vntill they come towards flowring; for there appeare many flowers vpon the falkes, in the fame manner, and of as nany colours almoft as of the fingle, except the party coloured, which ftand like little double Rofes, layd or fpread broade open, as the Rofe Colombine without any heeles behinde them, very delightfull to behold, confifting of many fmall leaues growing together, and after they are fallen there come vp in their places three or foure fmall cods fet together, wherein is contained here and there (for all are not full of feede, as the fingle kindes) blacke feede, like unto all the reft, but fmaller, which being fowen will bring plants that will beare both fingle and double flowers againe, and it often happeneth, that it variably altereth in colours from it owne fowing: for none of them hold conttantly his owne colour, (fo farre as euer I could obferue) but fall into others as nature pleafeth.

\section{Delphinium Hifpanicum paruum. Spanifh wilde Larkes fpurres.}

This fmall Larkes Spurre of Spaine, hath diuers long and broad leaues next the ground, cut-in on both fides, fomewhat like vnto the leafe of a Scabious, or rather that kinde of Stæbe, which Lobel calleth Crupina, for it doth fomewhat neerly refemble the fame, but that this is fmooth on the edges, and not indented befides the cuts, as the Crupina is, being of a whitifh greene colour, and fomewhat fmooth and foft in handling: among the leaues rifeth vp a whitifh greene ftalke, hauing many fmaller 
leaues vpon it that grow belowe, but not diuided, branching out into many fmall ftalkes, bearing flowers like vnto the wilde Larkes heeles, but fmaller, and of a bleake blewifh colour, which being paft, there come vp two or three fmall cods ioyned together, wherein is blacke feede, fmaller and rounder then any of the former: the roote is fmall and thready, quickly perifhing with the firft cold that ouertaketh the plant.

The Place.

The greateft or firt wilde kindes growe among corne in many countries beyond the Seas, and where corne hath beene fowne, and for his beauty brought and nourifhed in our Gardens: the leffer wilde kinde in fome fields of our owne Country. The Spanifh kinde likewife in the like places, which I had among many feedes that Guillaume Boel brought mee out of Spaine. The firft double and fingle haue been common for many yeares in all countries of this Land, but the tall or vpright fingle kindes haue been entertained but of late yeares. The double kindes are more rare.

\section{The Time.}

Thefe flower in the Summer onely, but the Spanifh wilde kinde flowreth very late, fo that oftentimes in our Country, the Winter taketh it before it can giue ripe feede : the double kindes, as well the vpright as the ordinary or wilde, are very choife and dainty many times, not yeelding good feede.

The Names.

They are called diuerlly by diuers Writers, as Confolida regulis, Galcaris flos; Flos regius, Buccinum Romanorum, and of Matthiolus, Cuminum flueftre alterum Diofcoridis : but the molt vfuall name with vs is Delphinium : but whether it be the true Delphinium of Diofcorides, or the Poets Hyacinth, or the flower of Aiax, another place is fitter to difcuffe then this. Wee call them in Englifh Larkes heeles, Larkes fpurres, Larkes toes or clawes, and Monkes hoods. The laft or Spanifh kinde came to mee vnder the name of Delphinium latifolium trigonum, fo Atiled eyther from the diuifion of the leaues, or from the pods, which come vfually three together. Bauhinus vpon Matthiolus calleth it, Confolida regalis peregrina paruo flore.

The Vertues.

There is no vfe of any of thefe in Phyficke in thefe dayes that I know, but are wholly fpent for their flowers fake.

\section{C н A P. L.}

\section{Balfamina famina. The Female Balfam Apple.}

Haue fet this plant in this place, for fome likeneffe of the flower, rather then for any other comparifon, euen as I muft alfo with the next that followeth. This plant rifeth $\mathrm{vp}$ with a thicke round reddifh ftalke, with great and bunched ioynts, being tender and full of iuice, much like to the ftalke of Purflane, but much greater, which brancheth it felfe forth from the very ground, into many ftalkes, bearing thereon manie long greene leaues, fnipt about the edges, very like vnto the Almond or Peach tree leaues; among which from the middle of the ftalkes vpwards round about them, come forth vpon feuerall fmall thort foot-ftalkes many faire purplifh flowers, of two or three colours in them, fafhioned fomewhat like the former Larkes heeles, or Monks hoods, but that they are larger open at the mouth, and the fpurres behinde crooke or bend downewards : after the flowers are paft, there come in their places round rough 


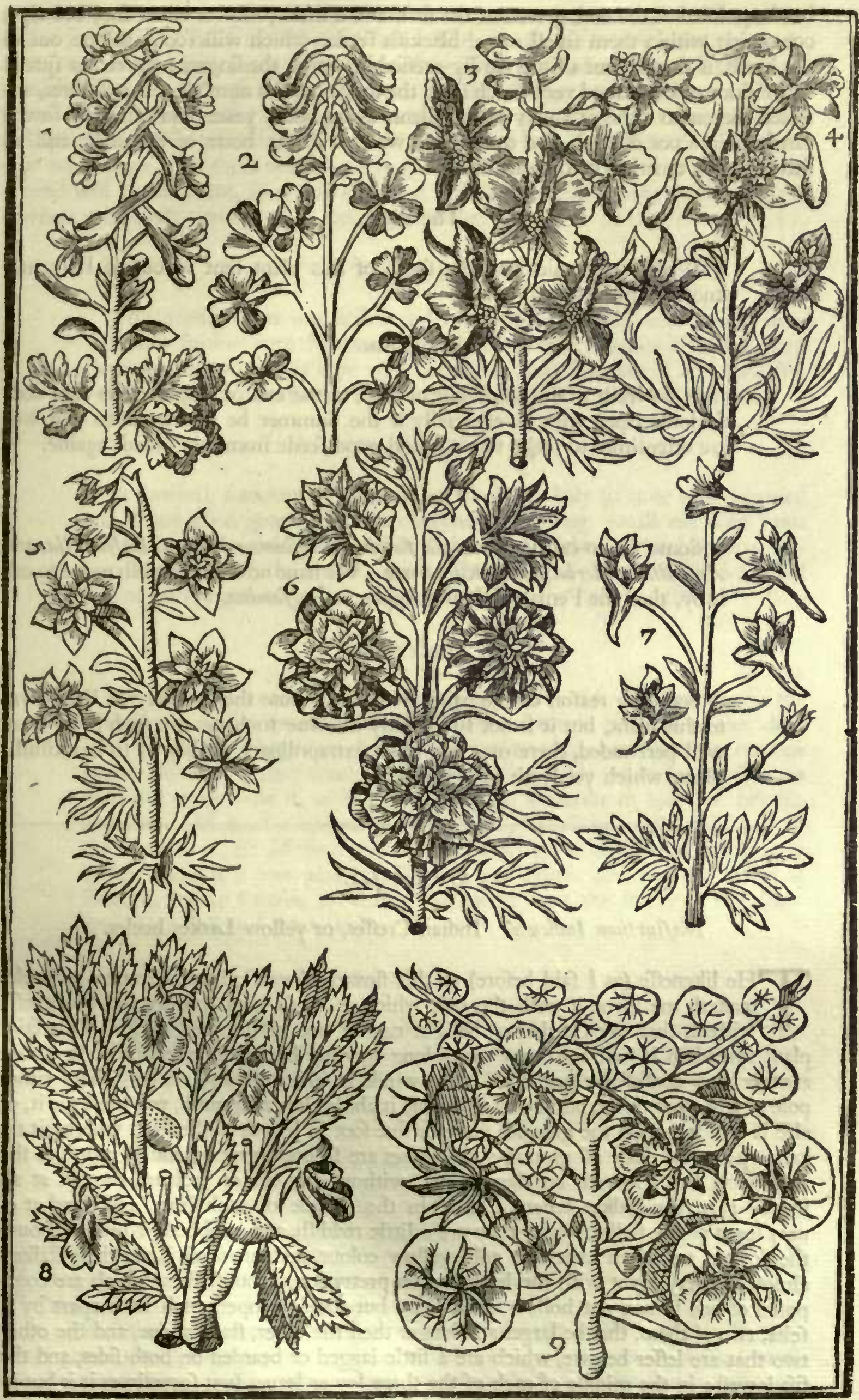

1 Radix Cawa maior flare alba. The white flowred Hollow roote. 2 Capmos fabacea radice. The fmall Hollow roote. Dilphinium Rare fimplici. Single Larkes fpurs. 4 Delphinium sulgare forc media duplici. Larkes fpurs double in the middle. fpurs. 7 Delphinium Hifpanicum parowm. Small Spanifh Larkes fpurs, 8 Balfamina funina. The Female Balfam apple. 9 Nafturtium Indicum. Indian Creffes, or yellow Larkes fpurs. 
heads, pointed at the end, greene at the firt, and a little yellower when they bee ripe, containing within them fmall round blackifh feede, which will foone skippe out of the heads, if they be but a little hardly preffed betweene the fingers : the rootes fpread themfelues vnder ground very much from the toppe, with a number of finall fibres, annexed thereunto : this is a very tender plant, dying euery yeare, and muft bee fowne carefully in a pot of earth, and tended and watered in the heate of Summer, and all little enough to bring it to perfection.

The Place.

Wee haue alwaies had the feede of this plant fent vs out of Italy, not knowing his originall place.

The Time.

It flowreth from the middle of Iuly, to the end of Augurt: the feed doth feldome ripen with vs, efpecially if the Summer be backward, fo that wee are oftentimes to feeke for new and good feede from our friends againe.

The Names.

Some vfe to call it Charantia fomina, Balfamina fremina, Balfamella, and Anguillara, Herba Sancta Katharina We haue no other Englifh name to call it by, then the Female Balfame Apple, or Balfamina.

\section{The Vertues.}

Some by reafon of the name, would attribute the property of Balme vnto this plant, but it is not fufficiently knowne to haue any fuch; yet I am well perfwaded, there may bee fome extraordinary quality in fo beautifull a plant, which yet lyeth hid from vs.

\section{CHA P. L I.}

Nafturtium Indicum. Indian Creffes, or yellow Larkes heeles.

T He likeneffe (as I faid before) of this flower likewife, hauing fpurres or heeles maketh me ioyne it with the reft, which is of fo great beauty and fweetneffe withall, that my Garden of delight cannot bee vnfurnifhed of it. This faire plant fpreadeth it felfe into very many long trayling branches, enterlaced one within another very confufedly (yet doth it not winde it felfe with any clafpers about either pole or any other thing, but if you will haue it abide clofe thereunto, you muft tye it, or elfe it will lye vpon the ground) foure or fiue foot in length at the leaft, wherby it taketh vp a great deale of ground : the leaues are fmooth, greene, and as round as the Penniwort that groweth on the ground, without any cut or incifure therein at all in any part, the ftalkes whereof ftand in the middle of each leafe, and ftand at euery ioynt of the ftalke, where they are a little reddifh, and knobbed or bunched out: the flowers are of an excellent gold yellow colour, and grow all along thefe ftalkes, almoft at euery ioynt with the leaues, vpon pretty long foote-ftalkes, which are compofed of fiue leaues, not hollow or gaping, but ftanding open each leafe apart by it felfe, two of them, that be larger and longer then the other, ftand aboue, and the other two that are leffer belowe, which are a little iagged or bearded on both fides, and the fift loweft: in the middle of each of the three lower leaues (yet fometimes it is but in two of them) there is a little long fpot or ftreake, of an excellent crimfon colour, with a long heele or fpurre behinde hanging downe: the whole flower hath a fine fmall fent, very pleafing, which being placed in the middle of fome Carnations or Gillo- 
flowers (for they are in flower at the fame time) make a delicate Tuffimuffie, as they call it, or Nof egay, both for fight and fent: After the flower is paft, come the feede, which are rough or vneuen, round, greenifh yellow heads, fometimes but one, and fometimes two or three ftanding together vpon one ftalke, bare or naked of themfelues, without any huske, containing a white pulpy kernell; the rootes are fmall, and fpreading vnder ground, which perifh with the firft frofts, and muft be fowne a new euery yeare ; yet there needeth no bed of horfe-dung for the matter : the naturall ground will be fufficient, fo as you defend it a little from thofe frofts, that may fpoile it when it is newly fprung vp, or being yet tender.

The Place.

This goodly plant was firft found in the Weft Indies, and from thence fent into Spaine vnto Monardus and others, from whence all other parts haue receiued it. It is now very familar in moft Gardens of any curiofity, where it yearly giueth ripe feed, except the yeare be very vnkindly.

\section{The Time.}

It flowreth fometimes in Iune, but vfually in Iuly (if it be well defended and in any good ground) and fo continueth flowring, vntill the cold frofts and miftes in the middle or end of October, doe checke the luxurious nature thereof, and in the meane time the feede is ripe, which will quickly fall downe on the ground, where for the moft part the beft is gathered.

The Names.

Some doe reckon this plant among the Clematides or Convolvuli, the Clamberers or Bindweedes; but (as I faid) it hath no clafpers, neither doth it winde it felfe : but by reafon of the number of his branches, that run one within another, it may feeme to climbe vp by a pole or fticke, which yet doth but onely clofe it, as hauing fomething whereon to leane or reft his branches. Monardus and others call it Flos fanguineus, of the red fpots in the flowers, as alfo Maftnerzo de las Indias, which is Nafturtium Indicum, by which name it is now generally knowne and called, and wee thereafter in Englifh, Indian Creffes, yet it may bee called from the forme of the flowers onely, Yellow Larkes heeles.

\section{The Vertues.}

The Spaniards and others vfe the leaues hereot in ftead of ordinary Creffes, becaufe the tafte is fomewhat fharpe agreeing thereunto, but other Phyficall properties I haue heard of none attributed to it.

\section{C н A P. L I I.}

Viola. Violets.

T

He Garden Violets (for the Wilde I leaue to their owne place) are fo well knowne vnto all, that either keepe a Garden, or hath but once come into it, that I fhall (I thinke) but lofe labour and time to defcribe that which is fo common. Yet becaufe it is not onely a choife flower of delight, notwithftanding the popularity, and that I let not paffe anything without his particular defcription, I muft alfo doe fo by this. And hereunto I muft adde that kinde of Violet, which, although it want that fmell of the other, goeth beyond it in variety of dainty colours, called Viola tricolor \& flammea, or Harts eafes. 


\section{Viola fimplex Martia. Single March Violets.}

The fingle Garden Violet hath many round greene leaues, finely fnipt or dented about the edges, ftanding vpon feuerall fmall ftalkes, fet at diuers places of the many creeping branches, which as they runne, doe here and there take roote in the ground, bearing thereon many flowers feuerally at the ioynts of the leaues, which confift of fiue fmall leaues, with a fhort round tayle or fpurre behinde, of a perfect blew purple colour, and of a very fweete fent, it bringeth forth round feede veffels, ftanding likewife vpon their feuerall fmall ftalkes, wherein is contained round white feede : but thefe heads rife not from where the flowers grew, as in all other plants that I know, but apart by themfelues, and being fowne, will produce others like vnto it felfe, whereby there may be made a more fpeedy encreafe to plant a Garden (as I haue done) or any other place, then by flipping, as is the vfuall manner : the rootes fpread both deepe and wide, taking ftrong hold in the ground.

Of this kinde there is another that beareth white flowers, not differing in fmell or any thing elfe from the former.

And alfo another, that beareth flowers of a dead or fad reddifh colour, in all other things alike, fauing that this hath not altogether fo good a fent as the other.

\section{Viola Martia flore multiplici. Double March Violets.}

There is no difference betweene this Violet and the former, in any other thing then in the doubleneffe of the flowers, which haue fo many leaues fet and thruft together, that they are like vnto hard buttons. There is of this double kinde both white and purple, as in the fingle ; but the white fort is feldome fo thicke and double as the purple : but of the red colour to be double I neuer heard.

\section{Viola flammea fue tricolor. Harts eafes or Panfies.}

The Harts eafe hath his leaues longer, and more endented or cut in on the edges then the Violet hath, and fomewhat round withall : the ftalkes are vpright, yet weake, and ready to fall downe, and lye vpon the ground, fet here and there with the like leaues, from whence come forth the flowers, of little or no fent at all, made like vnto a Violet, yet more open, and with larger leaues; but fo variably mixed with blew or purple, white and yellow, that it is hard to fet downe all the varieties : For fome flowers will be more white, and but fome fpots of purple or blew in the two vpper leaues, and the lower leaues with fome ftripes of yellow in the middle: others will haue more purple in them then any other colour, both in the vpper and lower leaues, the fide leaues blew, and the middle yellow, and others white and blew with yellow ftripes, as nature lifteth to diftribute their colours : the feede is fmall, whitifh, and round, contained in fmall round heads : the roote perifheth euery yeare, and raifeth it felfe vp plentifully by it owne fowing, if it be fuffered.

\section{Viola tricolor fore duplici. Double Harts eafe.}

We haue in our Gardens another fort, that beareth flowers with more leaues then the former, making it feeme to be twice double, and that onely in Autumne ; for the firft flowers are fingle that come in Summer : This is of that fort that beareth purple flowers : And it is to be obferued, that the feed of this kinde will not all bring double flowers, but only fome, if the ground be fit and liking, fo that if you haue once had of this double kinde, you fhall feldome miffe to have double flowers againe euery yeare of it owne growing or fowing.

\section{Viola flammea lutea maxima. The great yellow Panfie.}

There is one other kinde of Harts eafe, that decketh vp our Gardens not to be forgotten, whofe leaues and flowers are like the former, but more plentifull in ftalkes and branches, and better abideth our Winters; the flowers are larger then any of the 
former, of a faire pale yellow colour, with fome yellower ftripes now and then about the middle ; for it is fometimes without any ftripes; and alfo of a little deeper yellow colour : this is to bee encreafed by flips, which will foone comprehend in a moift or moiftened ground, for that I neuer could obferue that it bore feede.

The Place.

Thefe plants were firft wilde, and by manuring brought to be both fairer in colour, and peraduenture of a better fent then when they grew wilde.

\section{The Time.}

The Violets flower in March, and fometimes earlier, and if the yeare be temperate and milde, in Autumne againe. The double Violets, as they are later before they flower then the fingle, fo they hold their flowers longer. The Harts eafe flowreth feldome vntill May ; but then fome will abide to flower vntill the end of Autumne almoft, efpecially if the frofts be not early.

The Names.

The Violet is called Viola nigra, purpurea, and Martia : In Englifh, Violets, March Violets, and purple Violets. The Harts eafe is called Viola flammea, Viola tricolor, Viola multicolor, and of fome, Iacea, Flos trinitatis, and Herba clauellata : In Englifh, Harts eafe, and Panfies, of the French name Penfees. Some giue it foolifh names, as Loue in idleneffe, Cull mee to you, and Three faces in a hood. The great yellow Harts eafe is fo called, becaufe it is like in forme, and is the greateft of all other, although it haue not that diuerfity of colours in it that the other haue.

\section{The Vertues.}

The properties of Violets are fufficiently knowne to all, to coole and moiften : I fhall forbeare to recite the many vertues that may be fet downe, and onely let you knowe, that they haue in them an opening or purging quality, being taken either frefh and greene, or dryed, and made into powder, efpecially the flowers; the dryed leaues will doe the like, but in greater quantity. Coftrus in his booke of the nature of all plants faith, that the diftilled water of Harts eafe, is commended in the French difeafe, to be profitable, being taken for nine dayes or more, and fweating vpon it, which how true it is, I know not, and wifh fome better experience were made of it, before we put any great confidence in that affertion.

\section{H A P. L I I I.}

\section{Epimedium. Barrenwort.}

$\mathrm{T}$

His pretty plant rifeth vp out of the ground with vpright, hard, round, fmall ftalkes, a foote and a halfe high, or not two foote high at the higheft, diuided into three branches for the moft part, each branch whereof is againe diuided for the moft part into three other branches, and each of them beare three leaues (feldome either more or leffe) fet together, yet each vpon his owne foote-ftalke, each leafe being broad, round, and pointed at the end, fomewhat hard or dry in feeling, hayrie, or as it were prickly about the edges, but very tenderly, without harme, of a light greene colour on the vpperfide, and a little whiter vnderneath : from the middle of the ftemme or ftalke of leaues doth likewife come forth another long ftalke, not much higher then thofe with the leaues on them, diuided into other branches, each 
whereof hath likewife three flowers, each vpon his owne footeftalke, confifting of eight fmall leaues a peece, yet feeming to be but of foure leaues fpread or layd open flat, for that the foure vppermoft, which are the fmaller and being yellow, doe lye fo clofe on the foure vndermoft, $\mathrm{w}^{\mathrm{ch}}$ are a little broader and red, that they fhew as if they were yellow flowers with red edges, hauing yellow threds tipt with greene, ftanding in the middle of the flowers : the vnderfide of the lower leaues are of a pale yellowifh red, ftriped with white lines : after the flowers are paft, there come fmall long pods, wherin are contained flat reddifh feede : the rootes are fmall, reddifh and hard, fpreading, branching and enterlacing themfelues very much, and is fit to be placed on fome thady fide of a garden : the whole plant is rather of a ftrong then any good fent, yet is cherifhed for the pleafant varietie of the flowers.

\section{The Place.}

Cefalpinus faith it groweth on the mountaines of Liguria, that is nigh vnto Ligorne, in the Florentine Dominion. Camerarius faith, nigh vnto Vicenzo in Italie. Bauhinus on the Euganian hils, nigh vnto Padoa, and in Romania in Madowie wet grounds.

\section{The Time.}

It flowreth from Iune vntill the end of Iuly, and to the middle of Auguft, if it ftand, as I faid it is fitteft, in a fhadowie place.

\section{The Names.}

It is of moft Writers accepted for the true Epimedium of Diofcorides, though he faith it is without flower or feede, being therein eyther miftaken, or mif-informed, as he was alfo in Diczamnus of Candy, and diuers other plants. From the triple triplicitie of the ftanding of the ftalkes and leaues, and quadriplicitie of the flowers, it might receiue another name in Englifh then is already impofed vpon it : but left I might be thought to be fingular or full of noueltie, let it paffe with the name Barrenwort, as it is in the title.

\section{The Vertues.}

It is thought of diuers to agree in the propertie of caufing barrenneffe, as the ancients doe record of Epimedium.

\section{C н A P. L I I I I.}

\section{Papauer fatiuum. Garden Poppies.}

F Poppies there are a great many forts, both wilde and tame, but becaufe our Garden doth entertaine none, but thofe of beautie and refpect, I wil onely giue you here a few double ones, and leaue the reft to a general furuey.

\section{Papauer multiplex album. Double white Poppies.}

The double white Poppy hath diuers broade, and long whitifh greene leaues, giuing milke (as all the reft of the plant aboue ground doth, wherefoeuer it is broken) very much rent or torne in on the fides, and notched or indented befides, compaffing at the bottome of them a hard round brittle whitifh greene ftalke, branched towards the toppe, bearing one faire large great flower on the head of euery branch, which before it breaketh out, is contained within a thin skinne, and being blowne open is very thick of leaues, and double, fomewhat iagged at the ends, and of a white colour ; in the 


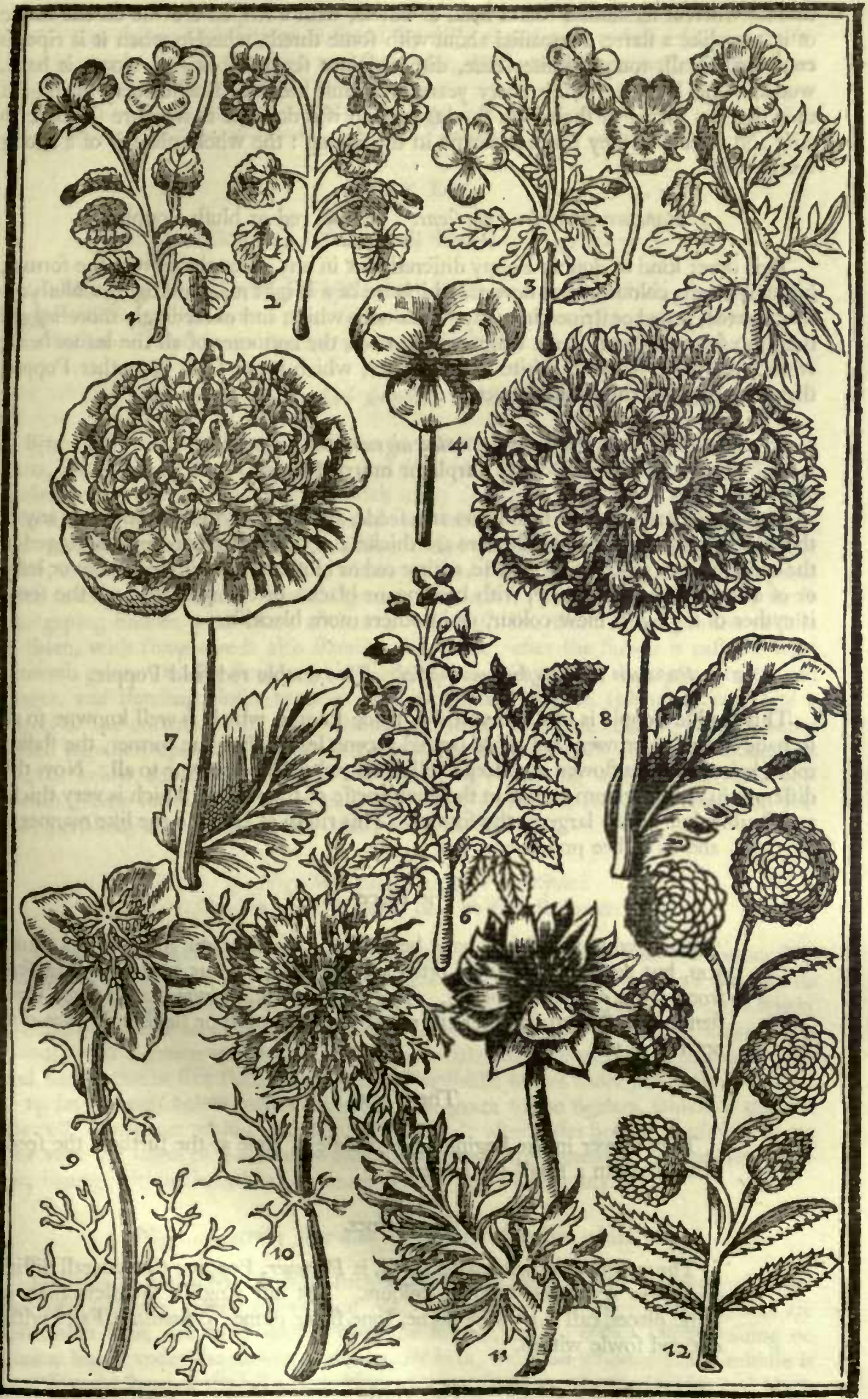

I Viola Marlia fimplex. Single March Violets, 2 Viola Marliu muliplox. Double March Violets. 3 Viola fammea fiue tricolor. Ordinary garden Panfies or llarts ease. \& Viola fammea lulea magna. Great yellow Panfies. 5 Viola tricolor du. plex. Double Panfies or Harts eafes. 6 Epimedium. Barrenwor. 7 Pafaucr falivum florc pleno. Double garden Poppies. Hower. to Nigella mulliplex curulea. Double blew Nigella or Fenell fower. II Nigella duplix fore albo. Double white Nigella. $\$ 2$ Piarmica Rore pleno. Double wilde Pelletory. 
middle whereof ftandeth a round head or bowle, with a ftriped crowne on the heade of it, very like a ftarre, compaffed about with fome threds, wherein when it is ripe, is contained fmall, round, white feede, difpofed into feuerall cels : the roote is hard, wooddy, and long, perifhing euery yeare, and muft bee new fowne euery Spring, if they doe not fpring of their own fowing, which if it doe, the flowers are feldome fo faire and double as they that are fowne in the Spring : the whole plant is of a ftrong heady fmell.

\section{Papaner multiplex rubefcens. Double red or blufh Poppies.}

This other kind of double Poppy differeth not in any other thing from the former, but only in the colour of the flowers, which are of a bright red, tending to a blufh colour, parted, paned or ftriped in many places with white, and exceedingly more iagged then the former, almoft like a feather at the ends, the bottomes of all the leaues being white : the feede hereof is white as the former, which is not fo in any other Poppie, that beareth not a full white flower.

\section{Papaner multiplex nigrum fune purpureum. \\ Double purple or murry Poppies.}

This kinde varyeth both in flowers and feede, although neyther in leaues or any other thing from the firft : the flowers are thicke and double, and fomewhat iagged at the ends, in fome more, in fome leffe, eyther red or blufh, or purplifh red, more or leffe, or of a fad murrey or tawney, with browne, or blacke, or tawny bottomes : the feede is eyther of a grayifh blew colour, or in others more blackifh.

\section{Papauer Rhcas flore multiplici. The double red field Poppie.}

This double Poppie is like the wilde or fielde Poppie, which is well knowne to all to haue longer, narrower, and more iagged greene leaues then the former, the ftalkes more hairy, and the flower of a deepe yellowifh red colour, knowne to all. Now this differeth in nothing from it, but in the doubleneffe of the flower, which is very thicke and double, but not fo large as the former. This rifeth of feede in the like manner as they doe, and fo to bee preferued.

\section{The Place.}

From what place they haue beene firf gathered naturally I cannot affure you, but we have had them often and long time in our gardens, being fent from Italie and other places. The double wilde kindes came from Conftantinople, which whether it groweth neere vnto it or further off, we cannot tell as yet.

The Time.

They flower in the beginning or middle of Iune at the furtheft, the feede is ripe within a fmall while after.

\section{The Names.}

The generall knowne name to all, is Papauer, Poppie: the feuerall diftinctions are according to their colours. Yet our Englifh Gentlewomen in fome places, call it by a by-name, Ione filuer pinne: fubauditur, Faire without and fowle within.

\section{The Vertues.}

It is not vnknowne, I fuppore to any, that Poppie procureth fleepe, for which caure it is wholly and onely vfed, as I thinke: but the water of the wilde 
wilde Poppies, befides that it is of great vfe in Pleurifies, and Rheumatick, or thinne Diftillations, is found by daily experience, to bee a foueraigne remedy againt furfeits; yet fome doe attribute this propertie to the water of the wilde Poppies.

\section{C и A P. L V.}

Nigella. The Fenell flower, or Nigella.

A Mong the many forts of Nigella, both wilde and tame, both fingle and double, I will onely fet downe three forts, to be nourfed vp in this garden, referring the relt to a Phyficke garden, or a generall Hiftorie, which may comprehend all.

\section{Nigella HiSpanica fore fimplici. The great Spanih Nigella.}

Spanifh Nigella rifeth vp with diuers greene leaues, fo finely cut, and into fo many parts, that they are finer then Fenell, and diuided fomewhat like the leaues of Larkes heeles, among which rife vp ftalkes, with many fuch like leaues vpon them, branched into three or foure parts, at the toppe of each whereof ftandeth one faire large flower, like vnto other fingle Nigella's, confifting of fiue or fix leaues fometimes, of a bleake blew, or of a purplifh blew colour, with a greene head in the middle, compaffed about with feuen or eight fmall blewifh greene flowers, or peeces of flowers rather, made like gaping hoodes, with euery of them a yellowifh line thwart or croffe the middle of them, with fome threds alfo ftanding by them: after the flower is paft the head groweth greater, hauing fixe, feuen or eight hornes as it were at the toppe, greater and longer, and ftanding clofer together then any other Nigella, fpreading very like a ftarre, or the crowne of the Poppy head, but larger and longer, each whereof being folded together, openeth a little when the head is ripe, which is greater aboue, and fmaller below, and not fo round as the others are, containing within them fmall yellowifh greene feede, or not fo blacke as the other forts: the rootes are fmall and yellow, perifhing euery yeare as the others likewife doe.

\section{Nigella Damafcena fore multiplici.}

Double blew Nigella, or The Fenell flower.

The double Nigella is in leaues, ftalkes and rootes, very like vnto the former Nigella, fo that the one can very hardly bee difcerned from the other before this rife vp to flower, except it be that the leaues hereof are not fully fo large as they : the flower confifteth of three or foure rowes of leaues, layde one vpon another, of a pale blew colour, with a greene round head compaffed with diuers fhort threads in the middle, and hauing fiue or fixe fuch fmall greene Fenell-like leaues vnder the flower, to beare it vp (as it were) below, which adde a greater grace to the flowers, which at the firft fheweth fometimes white, but changeth quickely after : the horned heads hereof are like vnto the heads of the other wilde kinde, which are fomewhat rounder and greater, hauing within them blacke vneuen feedes, but without any fent.

\section{Nigella Catrina fore albo multiplici. Double white Nigella.}

This double white Nigella hath fuch like leaues as the laft hath, but fomewhat larger, of a yellower greene colour, and not fo finely cut and iagged: the flowers are fomewhat leffe, and leffer double then the former, and in colour white, hauing no greene leaues vnder the flower, as the former hath, the head whereof in the middle is very like the head of the laft double kinde, but not fo great, wherein is contained black feede for the moft part, and fweete like the Romane Nigella, which only is fweet befides this : yet fometimes it is not fo blacke, but rather a little more white or yellowifh : the roote is yellow, and perifheth as the others euery yeare. 


\section{The Place.}

All thefe, and the reft be found wilde in diuers Countreyes, as France, Spaine, Italie, \&cc. but wee onely cherifh them in our Gardens for our delight.

The Time.

They flower in the end of Iune, and in Iuly, or thereabouts.

The Names.

They are called Melanthium, Gith, and Nigella, and of fome Flos Diuce Catherina. We may either call them Nigella according to the Latine name, or the Fenell flower, as fome doe, becaufe the double blew Nigella hath fmall Fenell-like leaues bearing vp the flower, as I thewed before in the defcription.

\section{The Vertues.}

Thefe Nigella's are nothing fo hot in qualitie as the fingle Romane kind is, as may well be knowne by the fmell of the feede thereof, and therefore are not fit to be vfed in the fteed of it, as many ignorant perfons vfe to doe: for the fingle Romane feede is vfed to helpe paines, and cold diftillations in the head, and to dry vp the rheume. Pena faith, that the preffed oyle of the feede as well taken inwardly as vfed outwardly is an excellent remedy for the hardneffe and fwelling of the fpleene.

\section{Cна P. LVI.}

\section{Ptarmica flueftris fore pleno. Double wilde Pelletory.}

T He double wilde Pelletorie hath ftraight and flender ftalkes, befet with long and narrow leaues, fnipt round about the edges, in all points like vnto the fingle wilde kinde, that groweth common with vs almoft euery where: on the toppes of the ftalkes ftand foure or fiue, or more white flowers, one aboue another, with a greene leafe at the bottome of the footeftalke of euery one of them, beeing fmall, thicke, and very double, with a little yellowifhneffe in the middle of euery flower, like both for forme and colour vnto the flower of the double Featherfew, but fmaller: the rootes are many long ftrings, running here and there in the ground: this hath no fmell at all, but is delightfome only for the double white flowers.

\section{The Place.}

It is only cherifhed in fome few Gardens, for it is very rare.

The Time.

It flowreth in the end of Iune or thereabouts.

\section{The Names.}

It is called of mort Ptarmica, or Sternutamentoria, of his qualitie to prouoke neefing; and of fome Pyrethrum, of the hot biting tafte. We vfually call it double wilde Pelletorie, and fome Sneefewort, but Elleborus albus is vfually fo called, and I would not two things fhould be called by one name, for the miftaking and mif-ufing of them. 
The Vertues.

The properties hereof, no doubt, may well bee referred to the fingle kinde, beeing of the fame qualitie, yet as I take it, a little more milde and temperate.

\section{CHA P. L V I I.}

Parthenium fore pleno. Double Featherfew.

$F^{\mathrm{s}}$ Eatherfew that beareth double flowers is fo like vnto the fingle kinde, that the one cannot be difcerned from the other, vntill it come to flower, bearing broad, pale or frefh greene leaues, much cut in on the fides : the ftalkes haue fuch like leaues on them as grow below, from the toppes whereof come forth many double white flowers, like vnto the flowers of the former wilde Pelletory, but larger, and like alfo vnto the flowers of the double Camomill : the fent whereof is as ftrong as of the fingle.

The Place.

We haue this kinde only in Gardens, and as it is thought by others, is peculiar only to our owne Countrey.

\section{The Time.}

It flowreth in the end of May, and in Iune and Iuly.

\section{The Names.}

It is called diuerfly by diuers: Some thinke it to be Parthenium of Diofcorides, but not of Galen; for his Parthenium is a fweet herbe, and is thought to bee Amaracus, that is Marierome: others call it Matricaria; and fome Amarella. Gaza tranflateth it Muraleum, Theoph. lib.7.cap. 7. It is generally in thefe parts of our Country called Double Feaverfew, or Featherfew.

\section{The Vertues.}

It is anfwerable to all the properties of the fingle kinde which is vfed for womens difeafes, to procure their monthly courfes chiefly. It is held to bee a fpeciall remedy to helpe thofe that haue taken Opium too liberally. In Italy fome vfe to eate the fingle kinde among other greene herbes, as Camerarius faith, but efpecially fryed with egges, and fo it wholly lofeth his ftrong and bitter tafte.

\section{CHAP. L VIII.}

\section{Chamamalum. Camomill.}

$\mathrm{Vr}$ ordinary Camomill is well knowne to all, to haue many fmal trayling branches, fet with very fine fmal leaues, bufhing and fpreading thicke ouer the ground, taking roote ftill as it fpreadeth: the toppes of the branches haue white flowers, with yellow thrummes in the middle, very like vnto the Featherfew, before defcribed, but fomewhat greater, not fo hard, but more foft and gentle in handling, and the whole herbe to be of a very fweet fent. 


\section{Chamanalum nudum. Naked Camomill.}

We haue another fort of Camomill in fome Gardens, but very rare, like vnto the former, but that it is whiter, finer, and fmaller, and raifeth it felfe vp a little higher, and beareth naked flowers; that is, without that border of white leaues that is in the former, and confifteth onely of a yellow round thrummie head, fmelling almoft as fweete as the former.

\section{Chamamalum flore pleno. Double flowred Camomill.}

The double Camomill groweth with his leaues vpon the ground, as the other fingle kinde doth, but of a little frefher greene colour, and larger withall: the ftalkes with the flowers on them, doe raife themfelues vp a little higher then the ordinary, and bearing one or two flowers vpon a ftalk, which are compofed of many white leaues fet together in diuers rowes, which make a fine double flower, with a little yellow fpot in the middle for the moft part of euery one, and are much larger then any fingle kinde, fmelling better, and more pleafing then the ordinary: this doth creepe vpon the ground as the other, but is more tender to be kept in the Winter. Yet if you faue the flowers hereof (and fo will the double Featherfew alfo) when they haue ftood long, and ready to fade, and keepe them dry vntill the Spring, and then breaking them or pulling them to peeces, fowe them, there will fpring vp from them Camomill, and alfo Featherfew, that will againe beare double flowers.

\section{The Place.}

Our ordinary Camomill groweth wilde in many places of our Country, and as well neare London as in other places. The others are onely found in our Gardens, where they are cherifhed. Bauhinus faith, that the double flowred Camomill is found wilde about Orleance in France.

\section{The Time.}

The double kinde is vfually in flower in Iune, before the ordinary kinde, and moft commonly paft before it flowreth, which is not vntill Iuly or Auguft. The naked Camomill flowreth betweene them both, or later.

\section{The Names.}

Camomill is called Anthemis, Leucanthemis, and Leucanthemum, of the whiteneffe of the flowers; and Chamamalum of the corrupted Italian name Camomilla. Some call the naked Camomill, Chry fanthemim odoratum. The double Camomill is called by fome Chamamalum Romanum fore multiplici.

\section{The Vertues.}

Camomill is put to diuers and fundry vfes, both for pleafure and profit, both for inward and outward difeafes, both for the ficke and the found, in bathings to comfort and ftrengthen the found, and to eafe paines in the difeafed, as alfo in many other formes applyed outwardly. The flowers boyled in Poffet drinke prouoketh fweat, and helpeth to expell colds, aches, and other griefes. A Syrupe made of the iuice of the double Camomill, with the flowers and white wine, as Bauhinus faith, is vfed by fome againft the Iaundife and Dropfie, caufed by the euill difpofition of the fplene. 


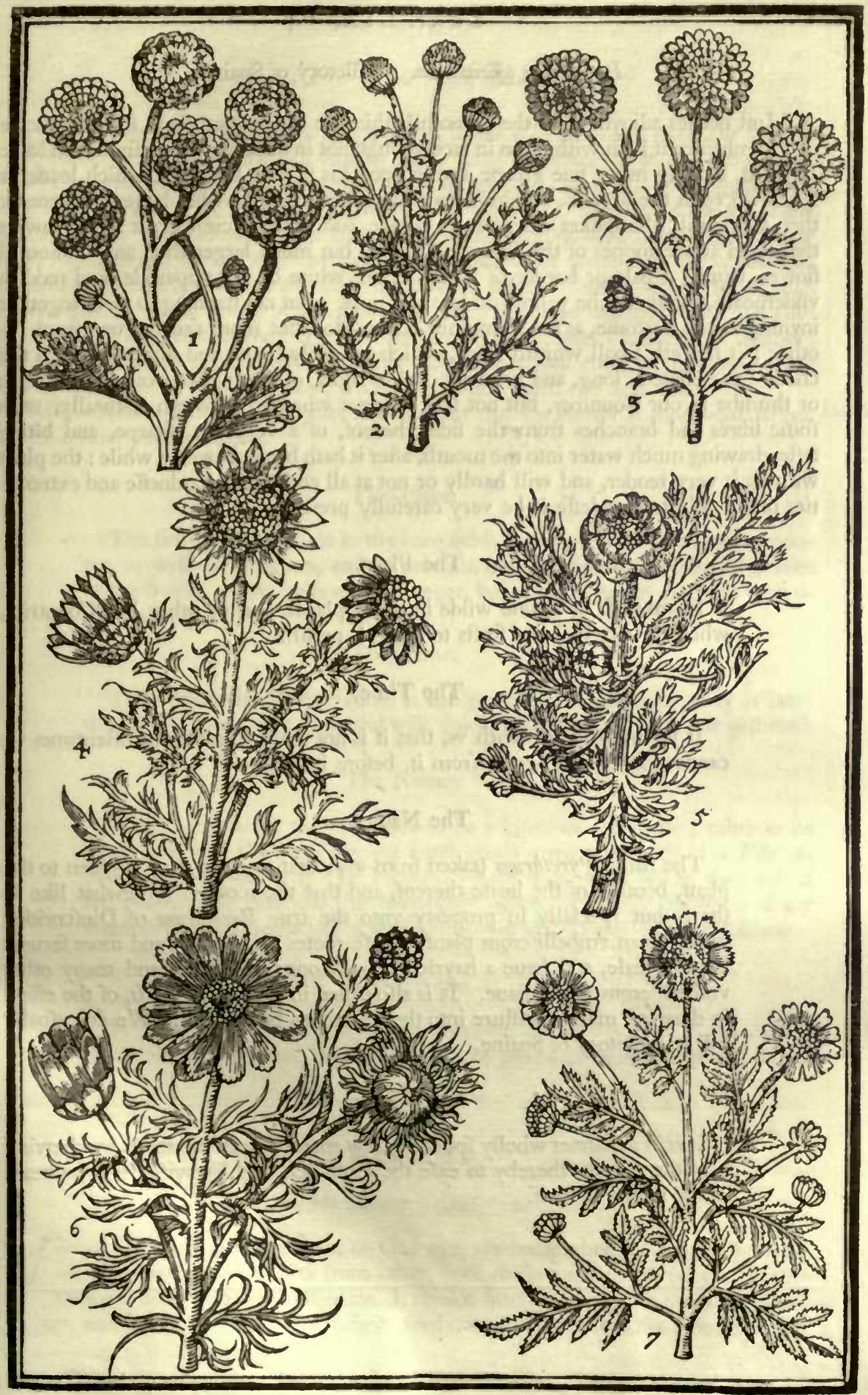

I Parthenism fore ticno. Double Featherfew. 2 Chamamalum nudum. Naked Camornill. 3 Chamamalum fare pleno. Double Camomill. Pyrefhrum officinarum. Pelletory of Spaine. 5 Flos Adonis flore rubro \& fore lutca. Adonis tower both red \& yellow. 6 Helleborus niger ferulncens fiue Buphtholmum. The great Oxe eye or the great yellow Anemone. 7 Buphthalmum vulgare. The common yellow Oxe eye. 


\section{CH A P. L I X.}

\section{Pyrethrum officinarum. Pelletory of Spaine.}

Muft needes adioyne vnto the Camomils this fine and tender plant, for fome neare refemblance it hath with them in face, though not in quality. It is a fmall and lowe plant, bearing many fine greene leaues vpon his flender branches, which leane or lye down vpon the ground, diuided into many parts, yet fomewhat larger and broader then Camomill, the ftalkes whereof are bigger, and more iuicie then it : the flowers that ftand at the toppes of the ftalkes are fingle, but much larger then any Camomill flower, hauing a pale or border of many leaues, white on the vpperfide, and reddifh vnderneath, fet about the yellow middle thrumme ; but not ftanding fo clofe together ioyning at the bottome, as the Camomill flowers doe, but more feuered one from another : it beareth fmall whitifh feede, which is hardly found and difcerned from the chaffe : the roote is long, and growing downe right, of the bigneffe of a mans finger or thumbe in our Countrey, but not half fo great where it groweth naturally, with fome fibres and branches from the fides thereof, of a very hot, tharpe, and biting tafte, drawing much water into the mouth, after it hath been chewed a while : the plant with vs is very tender, and will hardly or not at all endure the hardneffe and extremities of our Winters, vnleffe it be very carefully preferued.

The Place.

It groweth in Spaine wilde in many places, and in other hot Countries, where it may feele no frolts to caufe it perifh.

The Time.

It flowreth fo late with vs, that it is not vntill Auguft, that oftentimes we cannot gather ripe feedes from it, before it perifh.

\section{The Names.}

The name Pyrethrum (taken from $\pi \dot{v} \rho$, that is, ignis, fire) is giuen to this plant, becaufe of the heate thereof, and that the roote is fomewhat like in thew, but fpecially in property vnto the true Pyrethrum of Diofcorides, which is an vmbelliferous plant, whofe rootes are greater, and more feruent a great deale, and haue a hayrie bufh or toppe as Meum, and many other vmbelliferous plants haue. It is alfo called in Latine, Salinaris, of the effect in drawing much moifture into the mouth, to be fpit out. We doe vfually call it Pelletory of Spaine.

\section{The Vertues.}

It is in a manner wholly fpent to draw rheume from the teeth, by chewing it in the mouth, thereby to eafe the tooth-ach, and likewife from the head, in the paines thereof. 
C H A P. L X.

Flos Adonis flore rubro. Red Adonis flower.

A Donis flower may well be accounted a kinde of Camomill, although it hath fome efpeciall differences, hauing many long branches of leaues lying vpon the ground, and fome rifing vp with the ftalke, fo finely cut and iagged, that they much refemble the leaues of Mayweed, or of the former Nigella : at the top of the ftalkes, which rife a foote high or better, ftand fmall red flowers, confifting of fix or eight round leaues, hauing a greene head in the middle, fet about with many blackifh threads, without any fmell at all : after the flowers are paft, there grow vp heads with many roundifh white feedes at the toppes of them, fet clofe together, very like vnto the heads of feede of the great Oxe eye, fet downe in the next Chapter, but fmaller: the rootes are fmall and thready, perifhing euery yeare, but rifing of his owne feede againe, many times before Winter, which will abide vntill the next yeare.

Yellow Adonis flower is like vnto the red, but that the flower is fomewhat larger, Flore luteo. and of a faire yellow colour.

\section{The Place.}

The firf groweth wilde in the corn fields in many places of our own country, as well as in others, and is brought into Gardens for the beauties fake of the flower. The yellow is a ftranger, but nourfed in our Gardens with other rarities.

\section{The Time.}

They flower in May or Iune, as the yeare falleth out to be early or late: the feed is foone ripe after, and will quickly fall away, if it be not gathered.

\section{The Names.}

Some haue taken the red kinde to be a kinde of Anemone; other to be Eranthemum of Diofcorides : the moft vfuall name now with vs is Flos $A$ donis, and Flos Adonidis: In Englifh, where it groweth wilde, they call it red Maythes, as they call the Mayweede, white Maythes; and fome of our Englifh Gentlewomen call it Rofarubie: we vfually call it Adonis flower.

\section{The Vertues.}

It hath been certainly tryed by experience, that the feed of red Adonis flower drunke in wine, is good to eafe the paines of the Collicke and Stone.

\section{Cн A P. L X I.}

\section{Buphthalmum. Oxe eye.}

$\mathrm{V}$ Nder the name Buphthalmum, or Oxe eye, are comprehended two or three feuerall plants, each differing from other, both in face and property, yet becaufe they all beare one generall name, I thinke fitteft to comprife them all in one Chapter, and firt of that which in leafe \& feed commeth neareft to the Adonis flower.

\section{Buphthalmum maius fue Helleborus niger ferulaceus.}

Great Oxe eye, or the yellow Anemone.

This great Oxe eye is a beautifull plant, hauing many branches of greene leaues 
leaning or lying vpon the ground for the molt part, yet fome ftanding vpright, which are as fine, but fhorter then Fenell ; fome of them ending in a fmall tuft of green leaues, and fome hauing at the toppes of them one large flower a peece, fomewhat reddifh or brownifh on the outfide, while they are in bud, and a while after, and being open, thew themfelues to confift of twelue or fourteene long leaues, of a faire fhining yellow colour, fet in order round about a greene head, with yellow thrums in the middle, laying themfelues open in the funne, or a faire day, but elfe remaining clofe: after the flower is paft, the head growing greater, theweth it felfe compact of many round whitifh feede, very like vnto the head of feede of the Adonis flower laft defcribed, but much greater: the rootes are many long blackifh fibres or ftrings, fet together at the head, very like vnto the rootes of the leffer blacke Hellebor or Bearefoote, but fomewhat harder, ftiffer, or more brittle, and feeming without moifture in them, which abide and encreafe euery yeare.

\section{Buphthalmum minus, feu Anthemis flore luteo. Small Oxe eye.}

This plant might feeme to be referred to the Camomils, but that it is not fweete, or to the Corne-Marigolds, but that the ftalkes and leaues are not edible: it is therefore put vnder the Oxe eyes, and fo we will defcribe it ; hauing many weake branches lying vpon the ground, befet with winged leaues, very finely cut and iagged, fomewhat like vnto Mayweede, but a little larger: the flowers are like vnto the Corne Marigold, and larger then any Camomill, being wholly yellow, as well the pale or border of leaues, as the middle thrummes: the rootes are fomewhat tough and long.

\section{Buphthalmum vulgare. Common Oxe eye.}

This Oxe eye rifeth vp with hard round ftalkes, a foote and a halfe high, hauing many winged leaues vpon them, made of diuers long and fomething broad leaues, fnipt about the edges, fet together fomewhat like vnto Tanfie, but fmaller, and not fo much winged: the flowers ftand at the toppes of the ftalkes, of a full yellow colour, both the outer leaues and the middle thrum, and not altogether fo large as the laft : the rootes of this kinde perifh euery yeare, and require a new fowing againe.

\section{The Place.}

The firft groweth in diuers places of Auftria, Bohemia, and thofe parts, it hath beene likewife brought out of Spaine. The fecond in Prouence, a country in France. The laft in diuers places, as well of Auftria as Morauia, and about Mentz and Norimberg, as Clufius fetteth downe. We haue them in our Gardens, but the firft is of the greateft refpect and beauty.

\section{The Time.}

The firft flowreth betimes, oftentimes in March, or at the furtheft in Aprill; the feede is ripe in May, and muft be quickly gathered, left it bee loft. The other two flower not vntill Iune.

\section{The Names.}

The firft is called Buphthalmum of Dodoneus, Pfeudohelleborus of Matthiolus, Helleborus niger ferulaceus Theophrafi by Lobel, of fome others Elleborus niger verus, vfing it for the true blacke Ellebor, but it is much differing, as well in face as properties. Of others Sefamoides minus. Some haue thought it to be a yellow Anemone, that haue looked on it without further iudgement, and by that name is moft vfually knowne to moft of our Englifh Gentlewomen that know it. But it may moft fitly be called a Buphthalmum, as Dodonæus doth, and Hifpanicum or Auftriacum, for diftinctions fake. We doe moft vfually call it Helleborus niger ferulaceus, as Lobel doth: Bauhinus 
calleth it Helleborus niger tenuifolius Buphthatmi flore. The fecond is called Buphthalmum Narbonenfe: In Englifh, The French, or leffer Oxe eyc, as the firtt is called, The great Oxe eye. The laft, The common Oxe eye.

\section{The Vertues.}

The firt hath been vfed in diuers places for the true blacke Ellebor, but now is fufficiently knowne to haue been an errour; but what Phyficall property it hath, other then Matthiolus hath expreffed, to be vfed as Setterwort for cattell, when they rowell them, to put or draw the rootes hereof through the hole they make in the dewe lappe, or other places, for their coughes or other difeafes, I know not, or haue heard or rend of any. The others likewife haue little or no vfe in Phyficke now a dayes that I know.

\section{C н А P. L X I I.}

\section{Chryfanthemum. Corne Marigold.}

A

Lthough the forts of Corne Marigolds, which are many, are fitter for another then this worke, and for a Catholicke Garden of Simples, then this of Pleafure and Delight for faire Flowers; yet giue me leaue to bring in a couple: the one for a corner or by-place, the other for your choifeft, or vnder a defenced wall, in regard of his ftatelineffe.

\section{Chry fanthemum Creticum. Corne Marigold of Candy.}

This faire Corne Marigold hath for the moft part one vpright ftalke, two foote high, whereon are fet many winged leaues, at euery ioynt one, diuided and cut into diuers parts, and they againe parted into feuerall peeces or leaues: the flowers growe at the toppes of the ftalkes, rifing out of a fcaly head, compofed of ten or twelue large leaues, of a faire, but pale yellow colour, and more pale almoft white at the bottome of the leaues, round about the yellow thrumme in the middle, being both larger and fweeter then any of the other Corne Marigolds: the feede is whitifh and chaffie: the roote perifheth euery yeare.

\section{Chry fanthemum Periuuianum, fiue Flos Solis.}

The golden flower of Peru, or the Flower of the Sunne.

This goodly and ftately plant, wherewith euery one is now a dayes familiar, being of many forts, both higher and lower (with one ftalke, without branches, or with many branches, with a blacke, or with a white feede, yet differing not in forme of leaues or flowers one from another, but in the greatneffe or fmalneffe) rifeth $v p$ at the firft like vnto a Pompion with two leaues, and after two, or foure more leaues are come forth, it rifeth vp into a great ftalke, bearing the leaues on it at feuerall diftances on all fides thereof, one aboue another vnto the very toppe, being fornetimes, and in fome places, feuen, eight, or ten foote high, which leaues ftanding out from the ftemme or ftalke vpon their feuerall great ribbed foote-ftalkes, are very large, broad belowe, and pointed at the end, round, hard, rough, of a fad greene colour, and bending downewards: at the toppe of the ftalke ftandeth one great, large, and broad flower, bowing downe the head vnto the Sunne, and breaking forth from a great head, made of fcaly greene leaues, like vnto a great fingle Marigold, hauing a border of manie long yellow leaues, fet about a great round yellow thrumme, as it were in the middle, which are very like vnto fhort heads of flowers, vnder euery one whereof there is a feede, larger then any feede of the Thiftles, yet fomewhat like, and leffer, and rounder then any Gourd feede, fet in fo clofe and curious a manner, that when the feede is taken out, the head with the hollow places or cels thereof, feemeth very like vnto an hony combe; which feede is in fome plants very blacke, in the hotter countries, or very 
white, and great, or large, but with vs is neither fo large, blacke, or white; but fometimes blackifh or grayifh. Some fort rifeth not vp halfe the height that others doe, and fome againe beare but one ftemme or ftalke, with a flower at the toppe thereof; and others two or three, or more fmall branches, with euery one his flower at the end; and fome fo full of branches from the very ground almoft, that I haue accounted threefcore branches round about the middle ftalke of one plant, the loweft neare two yards long, others aboue them a yard and a halfe, or a yard long, with euery one his flower thereon; but all fmaller then thofe that beare but one or two flowers, and leffer alfo for the moft part then the flower on the middle ftalke it felfe. The whole plant, and euery part thereof aboue ground hath a ftrong refinous fent of Turpentine, and the heads and middle parts of the flowers doe oftentimes (and fometimes the ioynts of the ftalke where the leaues ftand) fweat out a moft fine thin \& cleare Roflin or Turpentine, but in fmall quantity, and as it were in drops, in the heate and dry time of the year, fo like both in colour, fmell, and tafte vnto cleare Venice Turpentine, that it cannot be knowne from it: the roote is ftrongly faftened in the ground by fome greater roots branching out, and a number of fmall ftrings, which growe not deepe, but keepe vnder the vpper cruft of the earth, and defireth much moifture, yet dyeth euery yeare with the firft frofts, and muft be new fowne in the beginning of the Spring.

\section{The Place.}

Their places are fet downe in their titles, the one to come out of Candy, the other out of Peru, a Prouince in the Weft Indies.

\section{The Time.}

The firf flowreth in Iune, the other later, as not vntill Auguft, and fometimes fo late, that the early frofts taking it, neuer fuffer it to come to ripenefs.

\section{The Names.}

The firt hath his name in his title. The fecond, befides the names fet downe, is called of fome Planta maxima, Flos maximus, Sol Indianus, but the moft vfuall with vs is, Flos Solis: In Englin, The Sunne Flower, or Flower of the Sunne.

\section{The Vertues.}

There is no vfe of either in Phyficke with vs, but that fometimes the heads of the Sunne Flower are dreffed, and eaten as Hartichokes are, and are accounted of fome to be good meate, but they are too ftrong for my tafte.

\section{H A P. L XIII.}

\section{Calendula. Marigolds.}

S

Ome haue reckoned vp many forts of Marigolds, I had rather make but two, the fingle and the double; for doubtleffe, thofe that be moft double, rife from the beft feede, which are the middlemoft of the great double, and fome would be leffe double, whofe feede is greater then the reft, according to the ground where it groweth; as alfo thofe that be of a paler colour, doe come of the feed of the yellower fort.

\section{Calendula maxima. The great Garden Marigold.}

The Garden Marigold hath round greene ftalkes, branching out from the ground into many parts, whereon are fet long flat greene leaues, broader and rounder at the 


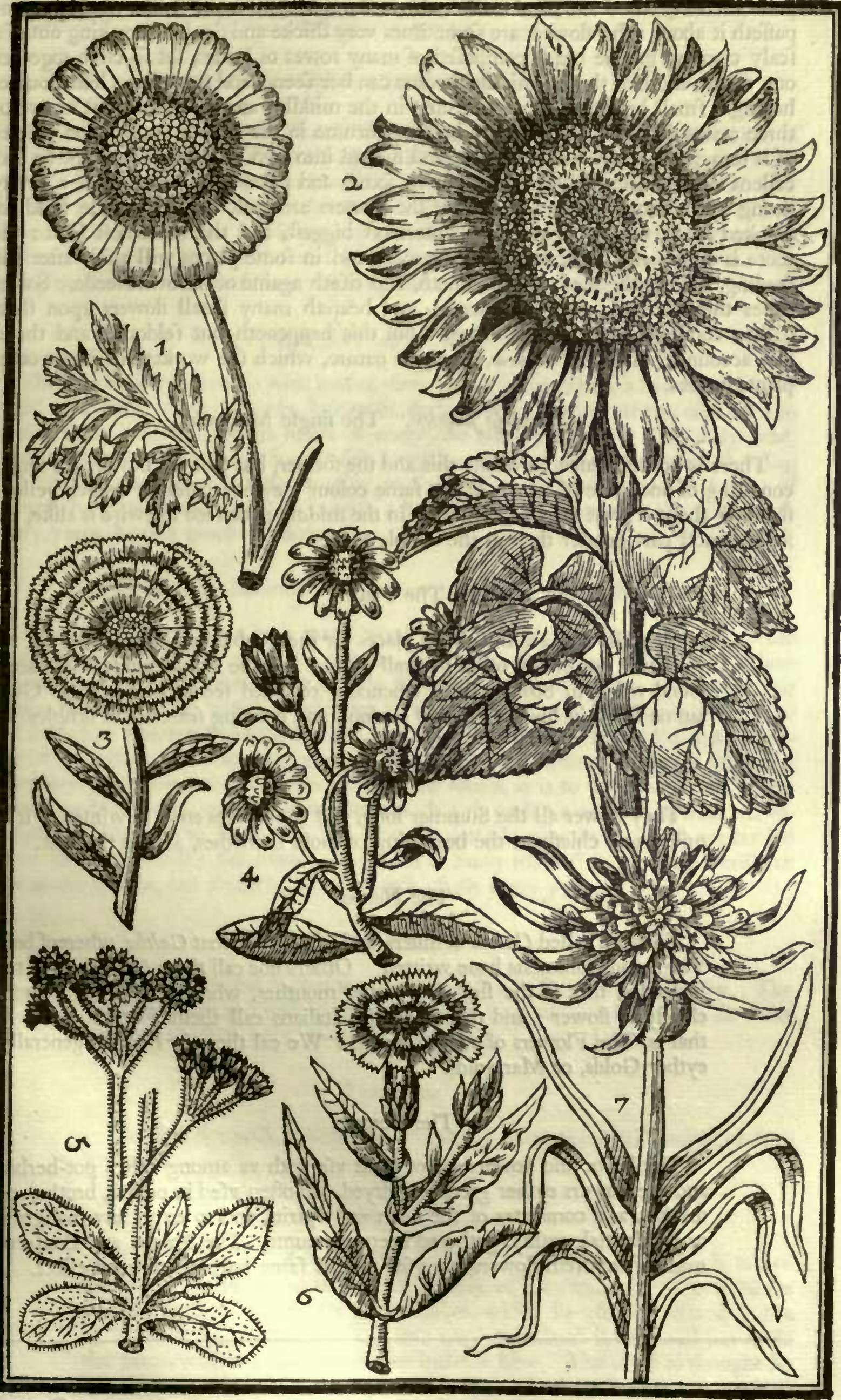

8 Chryanthemum Cresicum. Corne Marigolds of Cands. 4 Afier Asticus fiue Italorum. The Purple Marigold. 5 Pilofella maior. Golden Moufe-eare. 6 Scorfonera Hifpanica. Spanifh Vipers graffe. 7 Tragopogon. Goates beard, or goe to bed at noone. 
point then any where elfe, and fmaller alfo at the fetting to of the falke, where it compaffeth it about : the flowers are fometimes very thicke and double (breaking out of a fcaly clammy greene head) compofed of many rowes of leaues, fet fo clofe together one within another, that no middle thrume can bee feene, and fometimes leffe double, hauing a fmall browne fpot of a thrume in the middle: and fometimes but of two or three rowes of leaues, with a large browne thrume in the middle; euery one whereof is fomewhat broader at the point, and nicked into two or three corners, of an excellent faire deepe gold yellow colour in fome, and paler in others, and of a pretty ftrong and refinous fweete fent : after the flowers are paft, there fucceede heads of crooked feede, turning inward, the outermoft biggeft, and the innermoft leaft : the roote is white, and fpreadeth in the ground, and in fome places will abide after the feeding, but for the moft part perifheth, and rifeth againe of his owne feede. Sometimes this Marigold doth degenerate, and beareth many fmall flowers vpon fhort ftalkes, compaffing the middle flower : but this happeneth but feldome, and therefore accounted but lufus natura, a play of nature, which the worketh in diuers other plants befides.

\section{Calendula fimplex. The fingle Marigold.}

There is no difference betweene this and the former, but that the flowers are fingle, confifting of one rowe of leaues, of the fame colour ; eyther paler or deeper yellow, ftanding about a great browne thrumme in the middle : the feed likewife is alike, but for the moft part greater then in the double kindes.

\section{The Place.}

Our Gardens are the chiefe places for the double flowers to grow in; for we know not of any other naturall place : but the fingle kinde hath beene found wilde in Spaine, from whence I receiued feede, gathered by Guillaume Boel, in his time a very curious, and cunning fearcher of fimples.

\section{The Time.}

They flower all the Summer long, and fometimes euen in winter, if it be milde, and chiefly at the beginning of thore monethes, as it is thought.

\section{The Names.}

They are called Caltha of diuers, and taken to be that Caltha, whereof both Virgil and Columella haue written. Others doe call them Calendula, of the Kalendes, that is the firft day of the monthes, wherein they are thought chiefly to flower; and thereupon the Italians call them Fiori di ogmi me $\int$, that is, The Flowers of euery moneth :- We cal them in Englifh generally, eyther Golds, or Marigolds.

\section{The Vertues.}

The herbe and flowers are of great vfe with vs among other pot-herbes, and the flowers eyther greene or dryed, are often vfed in poffets, broths, and drinkes, as a comforter of the heart and fpirits, and to expel any malignant or peftilential quality, gathered neere thereunto. The Syrupe and Conferue made of the frefh flowers, are vfed for the fame purpofes to good effect. 


\section{CH A P. L X I I I I.}

Afler. Starre-wort.

$\mathrm{D}$

Iofcorides and other of the ancient Writers, haue fet forth but one kinde of Starre-wort, which they call After Atticus, of the place no doubt, where the greateft plentie was found, which was the Countrey of Athens: the later Writers haue found out many other plants which they referre to this kinde, calling them by the fame name. It is not my purpofe to entreate of them all, neyther doth this garden fitly agree with them: I fhall therefore felect out one or two from the reft, and giue the knowledge of them, leauing the reft to their proper place.

\section{After Atticus flore luteo. Yellow Starre-wort.}

This Starre-wort rifeth vp with two or three rough hairy ftalkes, a foote and a halfe high, with long, rough or hairie, brownifh, darke greene leaues on them, diuided into two or three branches: at the toppe of euery one whereof ftandeth a flat fcaly head, compaffed vnderneath with fiue or fixe long, browne, rough greene leaues, ftanding like a Starre, the flower it felfe ftanding in the middle thereof, made as a border of narrow, long, pale yellow leaues, fet with a brownifh yellow thrume: the roote dyeth euery yeare, hauing giuen his flower.

\section{After Atticus Italorum flore purpureo. Purple Italian Starre-wort.}

This Italian Starre-wort hath many wooddy, round brittle ftalkes, rifing from the roote, fomewhat higher then the former, fometimes ftanding vpright, and otherwhiles leaning downewards, whereon are fet many fomewhat hard, and rough long leaues, round pointed, without order vp to the toppe, where it is diuided into feuerall branches, whereon ftand the flowers, made like vnto a fingle Marigold, with a border of blewifh purple leaues, fet about a browne middle thrume, the heads fuftaining the flowers, are compofed of diuers fcaly greene leaues, as is to be feene in the Knapweedes or Matfelons, which after the flowers are paft yeelde a certaine downe, wherein lye fmall blacke and flat feedes, fomewhat like vnto Lettice feede, which are carried away with the winde : the roote is compofed of many white ftrings, which perifheth not as the former, but abideth, and fpringeth afrefh euery yeare.

\section{The Place.}

The firft is found in Spaine, as Clufius, and in France, as Lobel fay. The other hath beene found in many places in Germany, and Auftria : in Italie alfo, and other places; we haue it plentifully in our Gardens.

The Time.

The firft flowreth in Summer. And the other not vntill Auguft or September.

The Names.

The firt is called After Atticus flore luteo, Bubonium, \& Inguinalis, and of many is taken to be the true After Atticus of Diofcorides: yet Matthiolus thinketh not fo, for diuers good reafons, which hee fetteth downe in the Chapter of After Atticus, as any man may vnderitand, if they will but reade the place, which is too long to bee inferted here. The other is thought by Matthiolus, to bee the truer After Atticus, (vnto whom I muft alfo confent) and conftantly alfo affirmed to be the Amellus Virgilij, as may be feene in the fame place: but it is ufually called at this day, After Italorum fore caruleo or 
purpureo. Their Englifh names are fufficiently expreffed in their titles, yet fome call the laft, The purple Marigold, becaufe it is fo like vnto one in form.

\section{The Vertues.}

They are held, if they bee the right, to bee good for the biting of a mad dogge, the greene herbe being beaten with old hogs greafe, and applyed; as alfo for fwolne throats: It is likewife vfed for botches that happen in the groine, as the name doth import.

\section{C н А. L X V.}

\section{Pilofella maior. Golden Moufe-eare.}

Ome refemblance that the flowers of this plant hath with the former Golds, maketh me to infert it in this place, although I know it agreeth not in any other part, yet for the pleafant afpect thereof, it muft bee in this my garden, whofe defcription is as followeth: It hath many broade greene leaues fpread vpon the ground, fpotted with pale fpots, yet more confpicuous at fometimes then at other; fomewhat hairy both on the vpper and vnderfide, in the middle of thefe leaues rife vp one, two or more blackifh hairy ftalkes, two foote high at the leaft, bare or naked vp to the top, where it beareth an vmbell, or fhort tuft of flowers, fet clofe together vpon fhort ftalkes, of the forme or fafhion of the Haukeweedes, or common Moufe-eare, but fomewhat fmaller, of a deep gold yellow, or orenge tawney colour, with fome yellow threds in the middle, of little or no fent at all : after the flowers are paft, the heads carry fmall, fhort, blacke feede, with a light downie matter on them, ready to bee carried away with the winde, as many other plants are, when they be ripe: the rootes fpread vnder ground, and fhoote vp in diuers other places, whereby it much encreafeth, efpecially if it be fet in any moift or fhadowie place.

The Place.

It groweth in the hadowie woods of France, by Lions, and Mompelier, as Lobell teftifieth: we keepe it in our gardens, and rather in a hadowie then funnie place.

\section{The Time.}

It flowreth in Somer, and fometimes againe in September.

The Names.

It is called by Lobell, Pulmonaria Gallorum Hieratij facie : and the Herbarifts of France take it to be the true Pulmonaria of Tragus. Others call it Hieratium flore aureo. Pelleterius Hieratium Indicum. Some Pilofella, or Auricula muris maior flore aureo. And fome Chondrilla flore aureo. Dalechamptus would haue it to bee Corchorus, but farre vnfitly. The fitteft Englifh name we can give it, is Golden Moufe-eare, which may endure vntill a fitter bee impofed on it: for the name of Grim the Collier, whereby it is called of many, is both idle and foolifh.

\section{The Vertues.}

The French according to the name vfe it for the defects of the lunges, but with what good fucceffe I know not. 


\section{CHAP. LX VI.}

Scorfonera. Vipers graffe.

A

Lthough there be foure or fiue forts of Scor fonera, yet I fhall here defire you to be content with the knowledge only of a couple.

\section{Scorfonera Hifpanica maior. The greater Spanifh Vipers graffe.}

This Spanifh Vipers graffe hath diuers long, and fomewhat broad leaues, hard and crumpled on the edges, and fometimes vneuenly cut in or indented alfo, of a blewifh greene colour : among which rifeth vp one ftalke, and no more for the moft part, two foote high or thereabouts, hauing here and there fome narrower long leaues thereon then thofe below : the toppe of the ftalke brancheth it felfe forth into other parts, euery one bearing a long fcaly head, from out of the toppe whereof rifeth a faire large double flower, of a pale yellow colour, much like vnto the flower of yellow Goates beard, but a little leffer, which being paft, the feede fucceedeth, being long, whitifh and rough, inclofed with much downe, and among them many other long fmooth feedes, which are limber and idle, and are carryed away at the will of the winde : the roote is long, thicke and round, brittle and blacke, with a certaine roughneffe on the outfide: but very white within, yeelding a milkie liquor being broken, as euery other part of the plant doth befides, yet the roote more then any other part, and abideth many yeares without perifhing.

\section{Scorfonera Pannonica purpurea. Purple flowred Vipers grafle.}

This purple flowred Vipers graffe hath long and narrow leaues, of the fame blewifh greene colour with the former : the ftalke rifeth vp a foote and a halfe high, with a few fuch like leaues, but fhorter thereon, breaking at the toppe into two or three parts, bearing on each of them one flower, fafhioned like the former, and ftanding in the like fcaly knoppe or head, but of a blewifh purple colour, not fully fo large, of the fweeteft fent of any of this kinde, comming neereft vnto the fmell of a delicate perfume.

The Place.

The firft is of Spaine. The other of Hungarie and Auftrich : which now furnifh our gardens.

The Time.

They flower in the beginning of May : the feede is foone ripe after, and then perifhing downe to the roote for that yeare, fpringeth afrefh before Winter againe.

The Names.

They are called after the Spanifh name Scorfonera, which is in Latine Viperaria, of fome Viperina, and Serpentina : Wee call them in Englifh Vipers grafle, or Scorfonera.

The Vertues.

Manardus as I thinke firft wrote hereof, and faith that it hath been found to cure them that are bitten of a Viper, or other fuch like venemous Creature. The rootes hereof being preferued with fugar, as I haue done often, doe eate almoft as delicate as the Eringus roote, and no doubt is good to comfort and ftrengthen the heart, and vitall fpirits. Some that haue vfed the preferued roote haue found it effectuall to expelling winde out of the ftomacke, and to helpe fwounings and faintneffe of the heart.

C н A P. 
C н А P. L X V I I.

Tragopogon. Goates beard.

Muft in this place fet downe but two forts of Goates beards; the one blew or afhcolour, the other red or purple, and leaue the other kindes: fome to bee fpoken of in the Kitchin Garden, and others in a Phyficall Garden.

\section{Tragopogon flore caruleo. Blew Goates beard.}

All the Goates beards haue long, narrow, and fomewhat hollow whitifh greene leaues, with a white line downe the middle of euery one on the vpperfide : the ftalke rifeth vp greater and ftronger then the Vipers graffe, bearing at the toppe a great long head or huske, compofed of nine or ten long narrow leaues, the fharpe points or ends whereof rife vp aboue the flower in the middle, which is thicke and double, fomewhat broad and large fpread, of a blewifh afh-colour, with fome whitifh threads among them, fhutting or clofing it felfe within the greene huske euery day, that it abideth blowing, vntill about noone, and opening not it felfe againe vntill the next morning : the head or huske, after the flower is paft, and the feede neare ripe, openeth it felfe ; the long leaues thereof, which clofed not before now, falling downe round about the ftalke, and thewing the feede, ftanding at the firft clofe together, and the doune at the toppe of them : but after they haue ftood a while, it fpreadeth it felfe round, and is ready to be carried away with the winde, if it be not gathered : the feede it felfe is long, round, and rough, like the feede of the Vipers graffe, but greater and blacker : the roote is long, and not very great, but perifheth as foone as it hath borne feede, and fpringeth of the fallen feede, that yeare remaining greene all Winter, and flowring the next yeare following: the whole yeeldeth milke as the former, but fomewhat more bitter and binding.

\section{Tragopogon purpureum. Purple Goates beard.}

There is little difference in this kind from the former, but that it is a little larger, both in the leafe, and head that beareth the feed : the flowers alfo are a little larger, and fpread more, of a darke reddifh purple colour, with fome yellow duft as it were caft vpon it, efpecially about the ends: the roote perifheth in the like manner as the other.

The Place.

Both thefe haue been fent vs from the parts beyond the Seas, I have had them from Italy, where no doubt they grow naturally wilde, as the yellow doth with vs: they are kept in our Gardens for their pleafant flowers.

The Time.

They flower in May and Iune: the feede is ripe in Iuly.

The Names.

Their generall name is after the Greeke word Tragopogon, which is in Latine, Barbahirci: In Englifh, Goates beard; the head of feede when it is readie to bee carried away with the winde, caufing that name for the refemblance: and becaufe the flower doth euery day clofe it felfe at noone (as I faid before) and openeth not againe vntill the next Sunne, fome have fitly called it, Goe to bed at noone.

\section{The Vertues.}

The rootes of thefe kindes are a little more bitter and more binding alfo then 
then the yellow kinde expreffed in the Kitchin Garden; and therefore fitter for medicine then for meate, but yet is vfed as the yellow kinde is, which is more fit for meate then medicine. The diftilled water is good to wafh old fores and wounds.

\section{С и А P. LXVIII.}

\section{Flos Africanus. The French Marigold.}

$\mathrm{O}$ F the French or African Marigolds there are three kindes as principall, and of each of them both with fingle and double flowers: of thefe, fome dinerfity is obferued in the colour of the flowers, as well as in the forme or largeneffe, fo that as you may here fee, I haue expreffed eight differences, and Fabius Columna nine or ten, in regard hee maketh a diuerfity of the paler and deeper yellow colour: and although the leffer kinde, becaufe of its euill fent, is held dangerous, yet for the benuty of the flower it findeth roome in Gardens.

\section{Flos Africanus maior fune maximus multiplex.}

The great double French Marigold.

This goodly double flower, which is the grace and glory of a Garden in the time of his benuty, rifeth vp with a ftraight and hard round greene ftalke, hauing fome crefts or edges all along the ftalke, befet with long winged leaues, euery one whereof is like vnto the leafe of an Afh, being compofed of many long and narrow leaues, fnipt about the edges, ftanding by couples one againit another, with an odde one at the end, of a darke or full greene colour: the ftalke rifeth to be three or foure foote high, and divideth it felfe from the middle thereof into many branches, fet with fuch like leaues to the toppes of them, euery one bearing one great double flower, of a gold yellow colour aboue, and paler vnderneath, yet fome are of a pale yellow, and fome betweene both, and all thefe rifing from one and the fame feede: the flower, before it be blowne open, hath all the leaues hollow; but when it is full blowne open, it fpreadeth it felfe larger then any Prouince Rofe, or equall vnto it at the leaft, if it be in good earth, and rifeth out of a long greene huske, ftriped or furrowed, wherein after the flower is paft, (which ftandeth in his full beauty a moneth, and oftentimes more, and being gathered, may be preferued in his full beauty for two moneths after, if it be fet in water) ftandeth the feede, fet thicke and clofe together vpright, which is blacke, fomewhat flat and long: the roote is full of fmall ftrings, whereby it ftrongly comprehendeth in the ground: the flower of this, as well as the fingle, is of the very fmell of new waxe, or of an honie combe, and not of that poifonfull fent of the fmaller kindes.

\section{Flos Africanus maior fimplex. The great fingle French Marigold.}

This fingle Marigold is in all things fo like vnto the former, that it is hard to difcerne it from the double, but by the flowers, onely the ftalke will be browner then the double; and to my beft obferuation, hath and doth euery yeare rife from the feede of the double flower: fo that when they are in flower, you may fee the difference (or not much before, when they are in bud) this fingle flower euer appearing with thrums in the middle, and the leaues, which are the border or pale ftanding about them, Thewing hollow or fiftulous, which after lay themfelues flat and open (and the double flower appearing with all his leaues folded clofe together, without any thrum at all) and are of a deeper or paler colour, as in the double.

3. Flos Africanus fifulofo fore fimplex \& multiplex.

Single and double French Marigolds with hollow leafed flowers.

As the former two greateft forts haue rifen from the feede of one and the fame (I 
meane the pod of double flowers) fo doe thefe alfo, not differing from it in anything, but that they are lower, and have fmaller greene leaues, and that the flower alfo being fmaller, hath euery leafe abiding hollow, like vnto an hollow pipe, broad open at the mouth, and is of as deepe a yellow colour for the moft part as the deepeft of the former, yet fometimes pale alfo.

\section{Flos Africanus minor multiplex. The leffer double French Marigold.}

The leffer double French Marigold hath his leaues in all things like vnto the former, but fomewhat leffer, which are fet vpon round browne ftalkes, not fo ftiffe or vpright, but bowing and bending diuers wayes, and fometimes leaning or lying vpon the ground: the italkes are branched out diuerly, whereon are fet very faire double flowers like the former, and in the like greene huskes, but fmaller, and in fome the outermoft leaues will be larger then any of the reft, and of a deeper Orenge colour, almoft crimfon, the innermoft being of a deepe gold yellow colour, tending to crimfon : the whole flower is fmaller, and of a ftronger and more vnpleafant fauour, fo that but for the beautifull colour, and doublenefie of the flower, pleafant to the eye, and not to any other fenfe, this kinde would finde roome in few Gardens: the rootes and feedes are like the former, but leffer.

\section{Flos Africanus minor fimplex. The fmall fingle French Marigold.}

This fingle kinde doth follow after the laft in all manner of proportion, both of ftalkes, leaues, feedes, and rootes: the flowers onely of this are fingle, hauing fiue or fix broad leaues, of a deepe yellow crimfon colour, with deepe yellow thrummes in the middle, and of as ftrong a ftinking fent, or more then the laft.

The Place.

They growe naturally in Africa, and efpecially in the parts about Tunis, and where old Carthage ftood, from whence long agoe they were brought into Europe, where they are onely kept in Gardens, being fowne for the moft part euery yeare, vnleffe in fome milde Winters. The laft fingle and double kindes (as being more hardy) haue fometimes endured: but that kinde with hollow leafed flowers, as Fabius Columna fetteth it downe, is accounted to come from Mexico in America.

The Time.

They flower not vntill the end of Summer, efpecially the greater kindes: but the leffer, if they abide all the Winter, doe flower more early.

\section{The Names.}

They haue been diuerfly named by divers men: Some calling them $\mathrm{Ca}$ ryophyllus Indicus, that is, Indian Gilloflowers, and Tanacetum Perïvianum, Tanfie of Peru, as if it grew in Peru, a Prouince of America; and Flos Indicus, as a flower of the Indies; but it hath not beene knowne to have beene brought from thence. Others would haue it to be Othonna of Plinie, and others; fome to be Lycoperficum of Galen. It is called, and that more truely, Flos Tuneten fis, Flos Africanus, and Caltha Africana, that is, the flower of Tunis, the flower of Africa, the Marigold of Africa, and peraduenture Pedna Penorum. We in Englifh moft vfually call them, French Marigolds, with their feuerall diftinctions of greater or fmaller, double or fingle. To that with hollow leafed flowers, Fabius Columna giueth the name of $F$ ifilufo flore, and I fo continue it 


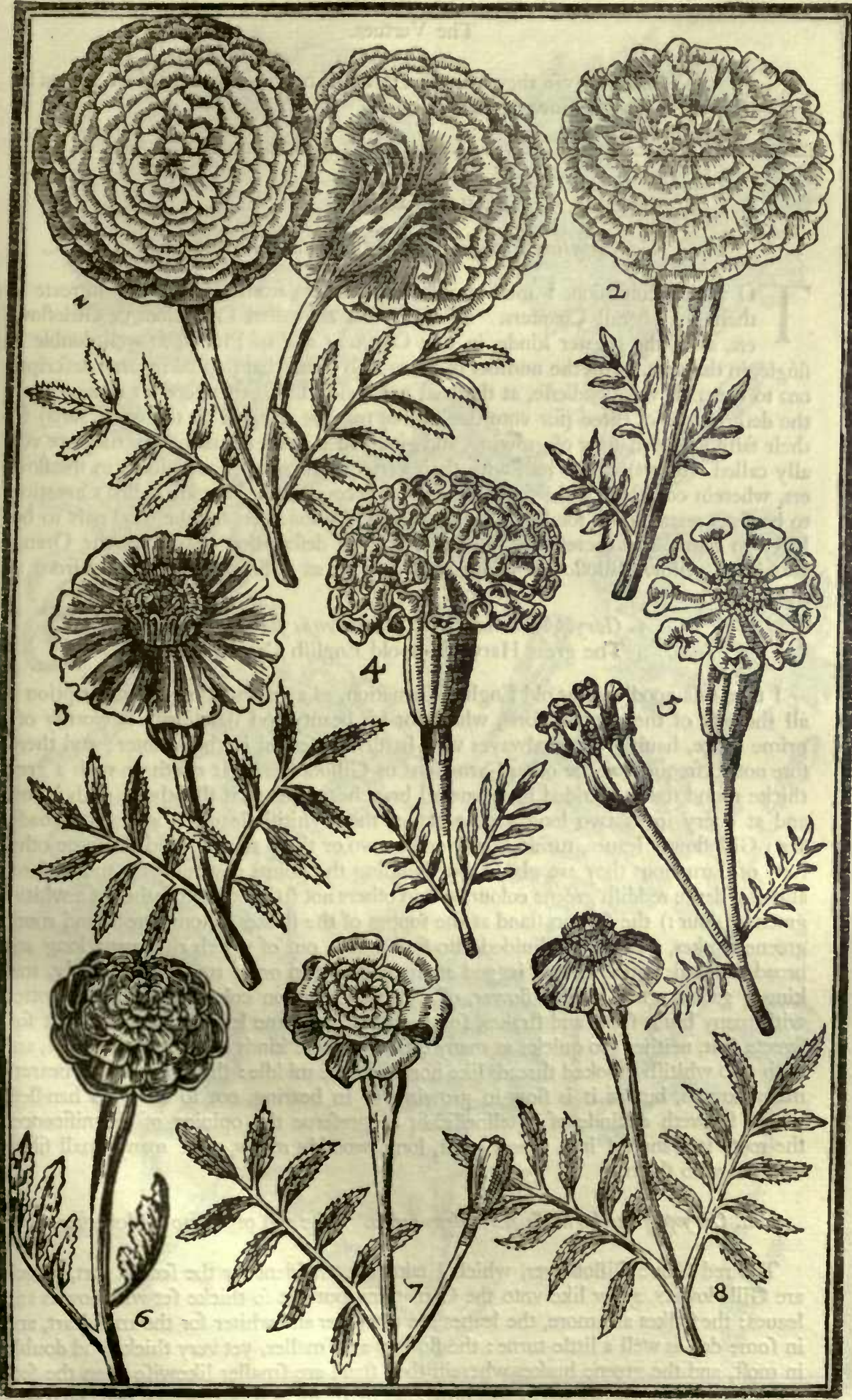

1Flos Africanus maximus mulliplex. The greateft double French Marigold. 2 Flos Africanus maior multiplex. The greater double Prench Marigold. 3 Flos Africanus maximus fimplex. The greateft fingle French Marigold. 4 Flas Africanus multiplex Africanss minor multiplex. The fmaller double French Marigold. 7 Flos Africanns minor multiples aller. Another fort of the lefter double French Marigold. 8 Flos Africanus minor fimplex. The leffer fingle French Marigold. 
The Vertues.

We know no vfe they haue in Phyficke, but are cherifhed in Gardens for their beautifull flowers fake.

\section{С н А P. L XIX.}

Caryophyllus hortenfis. Carnations and Gilloflowers.

$\prod$ $O$ auoide confufion, I muft diuide Gilloflowers from Pinkes, and intreate of them in feuerall Chapters. Of thofe that are called Carnations or Gilloflowers, as of the greater kinde, in this Chapter; and of Pinkes, as well double as fingle, in the next. But the number of them is fo great, that to giue feuerall defcriptions to them all were endleffe, at the leaft needleffe: I will therefore fet downe onely the defcriptions of three (for vnto thefe three may be referred all the other forts) for their farhion and manner of growing, and giue you the feuerall names (as they are vfually called with vs) of the reft, with their variety and mixture of colours in the flowers, wherein confifteth a chiefe difference. I account thofe that are called Carnations to be the greateft, both for leafe and flower, and Gilloflowers for the moft part to bee leffer in both; and therefore will giue you each defcription apart, and the Orenge tawnie or yellow Gilloflower likewife by it felfe, as differing very notably from all the reft.

\section{Caryophyllus maximus Harwicenfis fiue Anglicus.}

The great Harwich or old Englifh Carnation.

I take this goodly great old Englifh Carnation, as a prefident for the defcription of all the reft of the greateft forts, which for his beauty and ftatelineffe is worthy of a prime place, hauing beene alwayes very hardly preferued in the Winter; and therefore not fo frequent as the other Carnations or Gilloflowers. It rifeth vp with a great thicke round ftalke, diuided into feuerall branches, fomewhat thickly fet with ioynts, and at euery ioynt two long greene rather then whitifh leaues, fomewhat broader then Gilloflower leaues, turning or winding two or three times round (in fome other forts of Carnations they are plaine, but bending the points downewards, and in fome alfo of a darke reddifh greene colour, and in others not fo darke, but rather of a whitifh greene colour:) the flowers ftand at the toppes of the ftalkes in long, great, and round greene huskes, which are diuided into fiue points, out of which rife many long and broad pointed leaues, deeply iagged at the ends, fet in order round and comely, making a gallant great double flower, of a deepe Carnation colour, almoft red, fpotted with many blufh fpots and ftrakes, fome greater and fome leffer, of an excellent foft fweete fent, neither too quicke as many others of thefe kinds are, nor yet too dull, and with two whitifh crooked threads like hornes in the middle: this kinde neuer beareth many flowers, but as it is flow in growing, fo in bearing, not to be often handled, which theweth a kinde of ftatelineffe, fit to preferue the opinion of magnificence: the roote is branched into diuers great, long, wooddy rootes, with many fmall fibres annexed vnto them.

\section{Caryophyllus horten fis flore pleno rubro. The red or Cloue Gilloflower.}

The red Cloue Gilloflower, which I take as a prefident for the fecond fort, which are Gilloflowers, grow like vnto the Carnations, but not fo thicke fet with ioynts and leaues: the ftalkes are more, the leaues are narrower and whiter for the moft part, and in fome doe as well a little turne: the flowers are fmaller, yet very thicke and double in moft, and the greene huskes wherein they ftand are fmaller likewife then the former: the ends of the leaues in this flower, as in all the reft, are dented or iagged, yet in fome more then in others; fome alfo hauing two fmall white threads, crooked at the ends-like hornes, in the middle of the flower, when as diuers other haue none. Thefe 


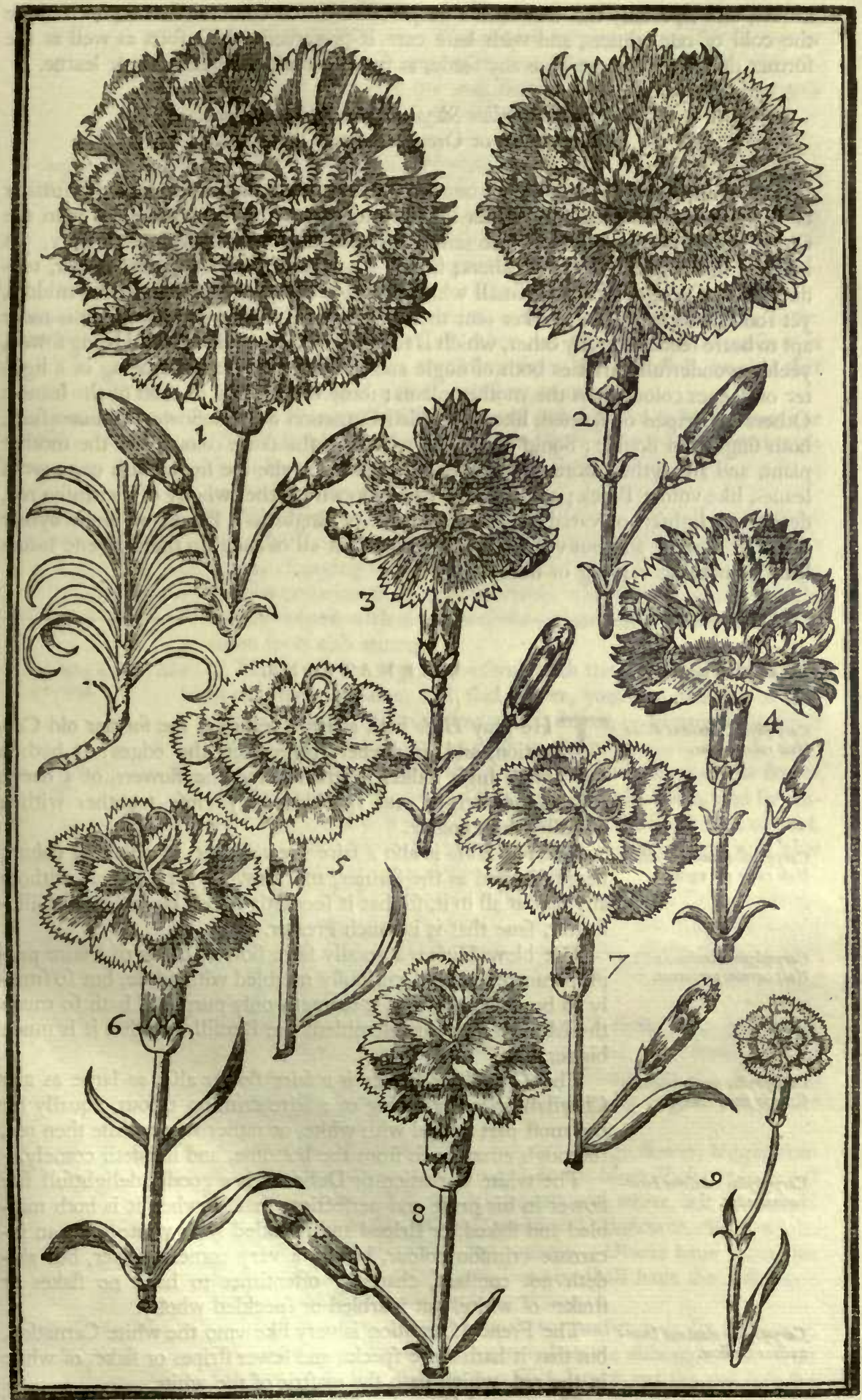

Curvophy llus maximus rubro varius. The great old Carnation or gray lifulo. 2 Caryophyllus maior rubro En albo sarius. The white Carnation. 3 Caryophyllus albo rubens. The Camberfine or the Poole flower. 4 Carjophy llus Canlij ftriatus. The faire made of kent. 5 Caryophyllus Sabandicus carneus. The blush Sauadge. 6 Caryophyllus xerampelinus. The Gredeline Carnation. I Caryophyilus dinus Grimelo. The Grimelo of Prince. 8 Carjophyllus albus major. The great white Gilloflower. 9 Elegans Heroina Bradfharij. Mafter Bradihawes dainty Lady. 
kindes, and efpecially this that hath a deepe red crimfon coloured flower, doe endure the cold of our winters, and with leffe care is preferued: thefe forts as well as the former doe very feldome giue any feede, as far as I could euer obferue or learne.

\section{Caryophyllus Silefacus flore pleno miniato.}

The yellow or Orenge tawny Gilloflower.

This Gilloflower hath his ftalkes next vnto the ground, thicker fet, and with fmaller or narrower leaues then the former for the moft part: the flowers are like vnto the Cloue Gilloflowers, and about the fame bigneffe and doubleneffe moft vfually, yet in fome much greater then in others; but of a pale yellowilh Carnation colour, tending to an Orenge, with two fmall white threds, crooked at the ends in the middle, yet fome haue none, of a weaker fent then the Cloue Gilloflower: this kinde is more apt to beare feede then any other, which is fmall, black, flat, and long, and being fowen, yeelde wonderfull varieties both of fingle and double flowers: fome being of a lighter or deeper colour then the mother plants: fome with ftripes in moft of the leaues: Others are ftriped or fpotted, like a fpeckled Carnation or Gilloflower, in diuers forts, both fingle and double: Some againe are wholly of the fame colour, like the mother plant, and are eyther more or leffe double then it, or elfe are fingle with one row of leaues, like vnto a Pinck; and fome of thefe likewife eyther wholly of a crimfon red, deeper or lighter, or variably fpotted, double or fingle as a Pinck, or blufh eyther fingle or double, and but very feldome white: yet all of them in their greene leaues little or nothing varying or differing.

Caryophylli maximi.

CAR N A TIONS.

Caryophyllus maximus dilus Hulo mibro-varius.

Caryopliyllus maximus dicus Hulo inber non varialus.

Caryophyllus maximus diftus Hulo carruleo purpureus.

Caryophyllus maximus dillus Grimelo fine Princeps.

Coryophyllus maximus Incar:nadinus albus.

Caryophylius maximus Incarnadinus Gallicus.

Caryophyllus maximus Incarnadinus grandis.
7 He gray Hulo hath as large leaues as the former old Carnation, and as deepely iagged on the edges: it hath a great high ftalke, whereon ftand the flowers, of a deepe red colour, ftriped and fpeckled very clofe together with a darkifh white colour.

The red Hulo is alfo a faire great flower, of a famell colour, deeply iagged as the former, and groweth very comely without any fpot at all in it, fo that it feemeth to bee but a ftamell Gilloflower, faue that it is much greater.

The blew Hulo is a goodly faire flower, being of a faire purplifh murrey colour, curiounly marbled with white, but fo fmally to be difcerned, that it feemeth only purple, it hath fo much the Maftrie in it; it refembleth the Brafill, but that it is much bigger.

The Grimelo or Prince is a faire flower alfo, as large as any Chryftall or larger, being of a faire crimfon colour, equally for the moft part ftriped with white, or rather more white then red, thorough euery leafe from the bottome, and ftandeth comely.

The white Carnation or Delicate, is a goodly delightfull fair flower in his pride and perfection, that is, when it is both marbled and flaked, or ftriped and fpeckled with white vpon an incarnate crimfon colour, beeing a very comely flower, but abideth not conftant, changing oftentimes to haue no flakes or ftrakes of white, but marbled or fpeckled wholly.

The French Carnation is very like vnto the white Carnation, but that it hath more fpecks, and fewer ftripes or flakes of white in the red, which hath the maftrie of the white.

The ground Carnation (if it be not the fame with the graund or great old Carnation firft fet downe, as the alteration but of one letter giueth the coniecture) is a thicke flower, but fpreadeth 
not his lenues abroade as others doe, hauing the middle ftanding higher then the outer leaues, and turning vp their brimmes or edges; it is a fad flower, with few ftripes or fpots in it: it is very fubiect to breake the pod, that the flower feldome commeth faire and right; the greene leaues are as great as the Hulo or Lombard red.

Ciaryophyllas maximus Chry. The Chryftall or Chryitalline (for they are both one, howfofrallinus. euer fome would make them differ) is a very delicate flower when it is well marked, but it is inconftant in the markes, being fometimes more ftriped with white and crimfon red, and fometimes leffe or little or nothing at all, and changing alfo fometimes to be wholly red, or wholly blufh.

Caryoghyllus maximus fore The red Chryftall, which is the red hereof changed, is the rabro. moft orient flower of all other red Gilloflowers, becaufe it is both the greateft, as comming from the Chryftall, as also that the red hereof is a moft excellent crimfon.

Caryophyllus maximus dions The Fragrant is a faire flower, and thought to come from the Fragrans. Chryftall, being as large, but of a blufh red colour, fpotted with fmall fpeckes, no bigger then pinnes points, but not fo thicke as in the Pageant.

Caryophyllus maximus Saban-

The ftript Sauadge is for forme and bigneffe equall with the dicus rariws. Chryftall or White Carnation, but as inconftant as eyther of them, changing into red or blufh; fo that few branches with flowers containe their true mixtures, which are a whitifh blufh, fairely friped with a crimfon red colour, thicke and fhort, with fome fpots alfo among.

Caryophyllus maximus Sabau- The blufh Sauadge is the fame with the former, the fame root dicus caineus. of the ftript Sauadge, as I faid before, yeelding one fide or part whofe flowers will be eyther wholly blufh, or hauing fome fmall fpots, or fometimes few or none in them.

Ciayophyllus maximus Sabau- The red Sauadge is as the blum, when the colour of the flower dicus ruber. is wholly red without any ftripes or fpots in them, and fo abideth long; yet it is fometimes feene, that the fame fide, or part, or roote being feparate from the firt or mother plant, will giue Itriped and well marked flowers againe.

Caryophyslus maximus Oxoni- The Oxeford Carnation is very like vnto the French Carnainfis. tion, both for forme, largeneffe and colour; but that this is of a fadder red colour, fo finely marbled with white thereon, that the red hauing the maiftry, heweth a very fad flower, not hauing any flakes or itripes at all in it.

Ciryophyllus maximus Regius, The Kings Camation or ordinary Briftow, is a reafonable fime Brifolicusfis maior. great flower, deepely iagged, of a fad red, very fmally itriped and fpeckled with white: fome of the leaues of the flower on the one fide will turne vp their brimmes or edges: the greene leafe is very large.

Caryophyllus maximus Granc- The greateft Granado is a very faire large flower, bigger then $\sin / \mathrm{sis}$. the Chryftall, and almoft as bigge as the blew Hulo: it is almoft equally diuided and itript with purple and white, but the purple is fadder then in the ordinary Granado Gilloflower, elfe it might bee faid it were the fame, but greater. Diuers haue taken this flower to bee the Gran Pere, but you thall haue the difference thewed you in the next enfuing flower.

Caryophyllus maximus Gran The Gran Pere is a fair great flower, and comely for the forme, Pire dicous. but of no great beautic for colour, becaufe although it be ftript red and white like the Queenes Gilloflower, yet the red is fo fad that it taketh away all the delight to the flower. Caryophylusmaximusciamber. The Camberfine is a great flower and a faire, beeing a redde
line disous. flower, well marked or ftriped with white, fomewhat like vnto a 
Gasyophyllus maximus Longobardicus rwber.

Sauadge, fay fome, but that the red is not crimfon as the Sauadge; others fay the Daintie, but not fo comely: the leaues of the flowers are many, and thruft together, without any due forme of fpreading.

The great Lombard red is a great fad red flower, fo double and thick of leaues, that it moft vfually breaketh the pod, and feldome fhoweth one flower among twenty perfect : the blades or greene leaues are as large as the $\mathrm{Hulo}$.

Canyophylli majores.

G I L L O F L OWERS.

Caryophyllus maior. WeftminSterienfis.

T He luftie Gallant or Weftminfter (fome make them to be one flower, and others to bee two, one bigger then the other) at the firft blowing open of the flower fheweth to be of a reafonable fize and comelineffe, but after it hath ftood blowen fome time it theweth fmaller and thinner : it is of a bright red colour, much ftriped and fpeckled with white.

Caryophyllus maior Briffolien- The Briftow blew hath greene leaues, fo large, that it would fis purpureus. feeme to bring a greater flower then it doth, yet the flower is of a reafonable fize, and very like vnto the ordinary Granado Gilloflower, ftriped and flaked in the fame manner, but that the white of this is purer then that, and the purple is more light, and tending to a blew : this doth not abide conftant, but changeth into purple or blurh.

Caryophylus maio Brifolien- The Briftow blufh is very like the laft both in leafe and flower, fis carmeus.

the colour only theweth the difference, which feldome varyeth to be fpotted, or change colour.

Caryophyllus maior Doroborni- The red Douer is a reafonable great Gilloflower and conftant, enfis ruber. being of a faire red thicke poudered with white fpots, and feemeth fomewhat like vnto the ground Carnation.

Caryophyllus maior Doroborni- The light or white Douer is for forme and all other things enfis dilutus fine albus. more comely then the former, the colour of the flower is blufh, thicke fpotted with very fmall fpots, that it feemeth all gray, and is very delightfull.

Caryophyllus maior Cantii. The faire maide of Kent, or Ruffling Robin is a very beautiful flower, and as large as the white Carnation almolt: the flower is white, thicke poudered with purple, wherein the white hath the maftrie by much, which maketh it the more pleafant.

Caryophyllus maior Regineus. The Queenes Gilloflower is a reafonable faire Gilloflower although very common, ftriped red and white, fome great and fome fmall with long ftripes.

Caryophyllus maior elegans. The Daintie is a comely fine flower, although it be not great, and for the fmallneffe and thinneffe of the flower being red fo finely marked, ftriped and fpeckled, that for the liuelineffe of the colours it is much defired, beeing inferiour to very few Gilloflowers.

Caryophylus maior Brafilienfis. The Braffill Gilloflower is but of a meane fize, being of a fad purple colour, thicke poudered and fpeckled with white, the purple herein hath the maftrie, which maketh it fhew the fadder, it is vnconftant, varying much and often to bee all purple: the greene leaues lye matting on the ground.

Caryophyllus maior Grana- The Granado Gilloflower is purple and white, flaked and ftritenjis. ped very much : this is alfo much fubiect to change purple. There is a greater and a leffer of this kinde, befides the greateft that is formerly defcribed. 
Caryophyllus Turcicus. The Turkie Gilloflower is but a fnall flower, but of great delight, by rearon of the well marking of the flower, being moft vfually equally ftriped with red and white.

Caryophyllas Cambrenfis Poole. The Poole flower, growing naturally vpon the rockes neare Cogthot Caftle in the Ine of Wight, is a fmall flower, but very pleafant to the eye, by realon of the comely proportion thereof; it is of a bright pale red, thicke fpeckled, and very fmall with white, that it fecincth to bee but onc colour, the leaues of the flower are but fmally iagged about : it is conftant.

Caryophyllus Pegma dilutior. The light or pale Pageant is a flower of a middle fize, very pleafant to behold, and is both conftant and comely, and but that it is fo common, would be of much more refpect then it is: the flower is of a pale bright purple, thicke poudered, and very euenly with white, which hath the maftery, and maketh it the more gracefull.

Caryophyllas Pcgma faturatior. The fad Pageant is the fame with the former in forme and bigneffe, the difference in colour is, that the purple hath the maftery, which maketh it fo fad, that it doth refemble the Braffill for colour, but is not fo bigge by halfe.

Caryophyllus Hervina dinus Mafter Bradfhawe his dainty Lady may bee well reckoned adegans Magifri Bradhnoxij. mong thefe forts of Gilloflowers, and compare for neateneffe with moft of them : the flower is very neate, though Imall, with a fine fmall iagge, and of a fine white colour on the vnderfide of all the leaues, as alfo all the whole iagge for a pretty compaffe, and the bottome or middle part of the flower on the vpperfide alfo: but each leafe is of a fine bright pale red colour on the vpperfide, from the edge to the middle, which mixture is of wonderfull great delight.

The beft white Gilloflower groweth vpright, and very dou-

Caryophyllus albus optimus maior Londinenfis E" alius. Caryophyllus ble, the blades growe vpright alfo, and crawle not on the ground.

The London white is greater and whiter then the other ordinary white, being wholly of one colour.

The ftamell Gilloflower is well knowne to all, not to differ from the ordinary red or cloue Gilloflower, but only in being of a brighter or light red colour: there is both a greater and a leffer of this kinde.

Cargophylius purpureas maior. The purple Gilloflower a greater and a leffe: the ftalke is fo E̊ minor. flender, and the leaues vpon them fo many and thicke, that they lye and traile on the ground: the greatert is almoft as bigge as a Chryftall, but not fo double: the leffe hath a fmaller flower.

Caryophyllus Perfice sialaceus. The Gredeline Gilloflower is a very neate and handfome flower, of the bigneffe of the Cloue red Gilloflower, of a fine pale reddifh purple or peach colour, enclining to a blew or violet, which is that colour is vfually called a gredeline colour: it hath no affinity with eyther Purple, Granado, or Pageant.

Caryophylus purparo carvens. The blew Gilloflower is neither very double nor great, yet round and handfome, with a deepe iagge at the edge, and is of an exeeding deepe purple colour, tending to a tawnie: this differeth from all other forts, in that the leafe is as greene as graffe, and the ftalkes many times red or purple: by the greene leaues it may be knowne in the Winter, as well as in the Summer.

Caryophyllus carneus.

Caryophy'llus Sileficcus maximus Wittin.
The blufh Gilloflower differeth not from the red or ftamell, but only in the colour of the flower, which is blufh.

Iohn Wittie his great tawny Gilloflower is for forme of growing, in leafe and flower altogether like vnto the ordinary tawny, the flower onely, becaufe it is the faireft and greateft that any o- 
ther hath nourfed vp, maketh the difference, as alfo that it is of a faire deepe fcarlet colour.

There are alfo diuers other Tawnies, either lighter or fadder, either leffe or more double, that they cannot be numbered, and all rifing (as I faid before) from fowing the feede of fome of them: befides the diuerfities of other colours both fimple and mixed, euery yeare and place yeelding fome variety was not feen with them before: I thall neede but onely to give you the names of fome of them we haue abiding with vs, I meane fuch as haue receiued names, and leaue the reft to euery ones particular denomination.

Of Blufhes there are many forts, as the deepe blufh, the pale blufh, the Infanta blufh, a blufh enclining to a red, a great blufh, the faireft and moft double of all the other blufhes, and many others both fingle and double.

Of Reds likewife there are fome varieties, but not fo many as of the other colours; for they are moft dead or deepe reds, and few of a bright red or ftamell colour; and they are fingle like Pinkes, either ftriped or fpeckled, or more double ftriped and fpeckled variably, or elfe

There are neither purple nor white that rife from this feede that I haue obferued, except one white in one place.

Caryophyllus Silefacus jtriatus. The ftriped Tawny are either greater or leffer, deeper or lighter flowers twenty forts and aboue, and all ftriped with fmaller or larger ftripes, or equally diuided, of a deeper or lighter colour : and fome alfo for the very thape or forme will bee more neate, clofe, and round; others more loofe, vnequall, and fparfed.

Caryophyllus Silefiacus marmor-amulus.

Heroins Rodolphi forum Imperatonis.

The marbled Tawny hath not fo many varieties as the ftriped, but is of as great beauty and delight as it, or more : the flowers are greater or fmaller, deeper or lighter coloured one then another, and the veines or markes more confpicuous, or more frequent in fome then in others: but the moft beautifull that euer I did fee was with Mafter Ralph Truggie, which I muft needes therefore call

Mafter Tuggies Princeffe, which is the greateft and faireft of all thefe forts of variable tawnies, or feed flowers, being as large fully as the Prince or Chryftall, or fomething greater, ftanding comely and round, not loofe or thaken, or breaking the pod as fome other forts will; the marking of the flower is in this manner: It is of a famell colour, ftriped and marbled with white ftripes and veines quite through euery leafe, which are as deeply iagged as the Hulo: fometimes it hath more red then white, and fometimes more white then red, and fometimes fo equally marked, that you cannot difcerne which hath the maftery; yet which of thefe hath the predominance, ftill the flower is very beautifull, and exceeding delightfome.

Caryophyllus Silefincus afulofiss. The Flaked Tawny is another diuerfity of thefe variable or mixt coloured flowers, being of a pale reddifh colour, flaked with white, not alwaies downeright, but often thwart the leaues, fome more or leffe then others; the marking of them is much like vnto the Chryftall: thefe alfo as well as others will be greater or fmaller, and of greater or leffe beauty then others.

Conyophyllus Sileforns plumintus.

The Feathered Tawny is more rare to meete with then many of the other; for moft vfually it is a faire large flower and double, equalling the Lumbard red in his perfection: the colour hereof is vfually a fcarlet, little deeper or paler, moft curioufly feathered and ftreamed with white through the whole leafe.

Caryophyllhs Silefiacus $\quad$ The Speckled Tawny is of diuers forts, fome bigger, fome puncatus. leffe, 


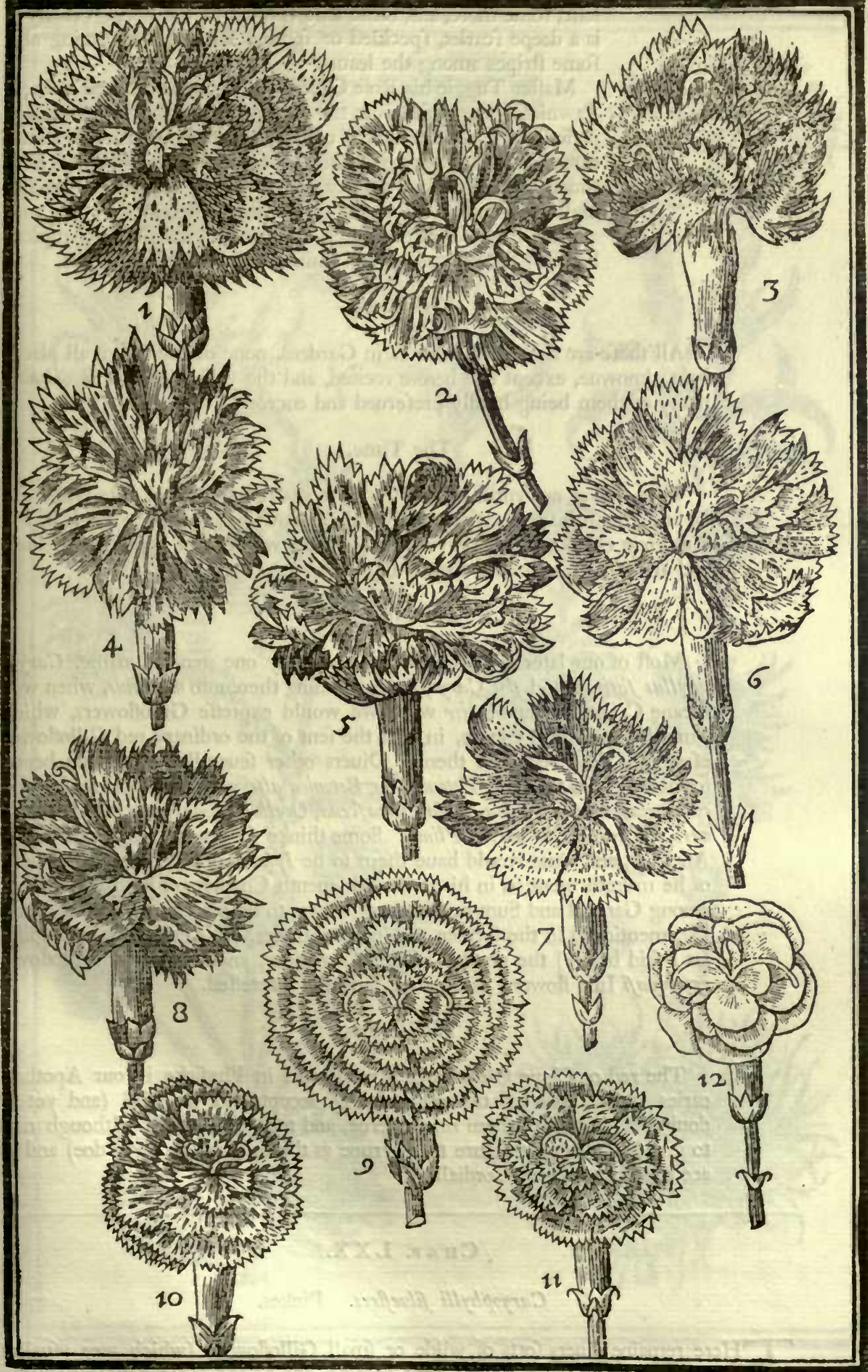

1. Heroina Rodolphi forum Imperatoris Princeffa dietus. Mafter Tuggie his Princefie. 2 Caryophyllus Oxonienfis. The French os Oxford Carnation. 3 Caryophyllus Weftuonafterienfis. The Gallant of Weftminfier Gilloflower. 4 Caryophyllus Briflolienfis. The Briftow: 5 Cayophyllus Chryftallinus. The Chryftall or Chryflalline. 6 Caryophyllws Sabaudicus firialus. The Stript Sauadge. 7 Carjophyllus Granatonfis maximus. The Granpere or greateft Granado. 8 Carjophyllus peramanus. The Dainty. The ftripe Tawny. 11 Caryophyllus marmor-anulus. The marbled Tawny. 12 Caryopkyllus rofeus rolundus magiflri Tuggie. Mafter Tuggie his Rore Gilloflower. 
leffe, fome more, and fome leffe fpotted then others: Vfually it is a deepe fcarlet, f peckled or fpotted with white, hauing alfo fome ftripes among the leaues.

Caryophyllus rofeus rotundus Magiftri Tuggie

Mafter Tuggie his Rofe Gilloflower is of the kindred of thefe Tawnies, being raifed from the feede of fome of them, and onely poffeffed by him that is the moft induftrious preferuer of all natures beauties, being a different fort from all other, in that it hath round leaues, without any iagge at all on the edges, of a fine ftamell full colour, without any fpot or ftrake therein, very like vnto a fmall Rofe, or rather much like vnto the red Rofe Campion, both for forme, colour, and roundneffe, but larger for fize.

The Place.

All thefe are nourifhed with vs in Gardens, none of their naturall places being knowne, except one before recited, and the yellow which is Silefia ; many of them being hardly preferued and encreafed.

\section{The Time.}

They flower not vntill the heate of the yeare, which is in Iuly (vnleffe it be an extraordinary occafion) and continue flowring, vntill the colds of the Autumne checke them, or vntill they have wholly out fpent themfelues, and are vfually encreafed by the flips.

\section{The Names.}

Molt of our later Writers doe call them by one generall name, Caryophyllus fativus, and fos Caryophylleus, adding thereunto maximus, when wee meane Carnations, and maior when we would expreffe Gilloflowers, which name is taken from Cloues, in that the fent of the ordinary red Gilloflower efpecially doth refemble them. Diuers other feuerall names haue beene formerly giuen them, as Vetonica, or Betonica altera, or Vetonica altilis, and coronaria. Herba Tunica, Viola Damafcena, Ocellus Damafcenus, and Barbaricus. Of fome Cantabrica Plinij. Some thinke they were vnknowne to the Ancients, and fome would haue them to be Iphium of Theophraftus, wherof he maketh mention in his fixth and feuenth Chapters of his fixth booke, among Garland and Summer flowers; others to be his Dios anthos, or Iouis flos, mentioned in the former, and in other places. We call them in Englifh (as I faid before) the greateft kindes, Carnations, and the others Gilloflowers (quafi Iuly flowers) as they are feuerally expreffed.

\section{The Vertues.}

The red or Cloue Gilloflower is molt vfed in Phyficke in our Apothecaries thops, none of the other being accepted of or vfed (and yet I doubt not, but all of them might ferue, and to good purpofe, although not to giue fo gallant a tincture to a Syrupe as the ordinary red will doe) and is accounted to be very Cordiall.

CH A P. L XX.

\section{Caryophylli filueftres. Pinkes.}

$\mathrm{T}$ Here remaine diuers forts of wilde or fmall Gilloflowers (which wee vfually call Pinkes) to be entreated of, fome bearing fingle, and fome double flowers, fome fmooth, almoft without any deepe dents on the edges, and fome iagged, or as it were feathered. Some growing vpright like vnto Gilloflowers, others cree- 


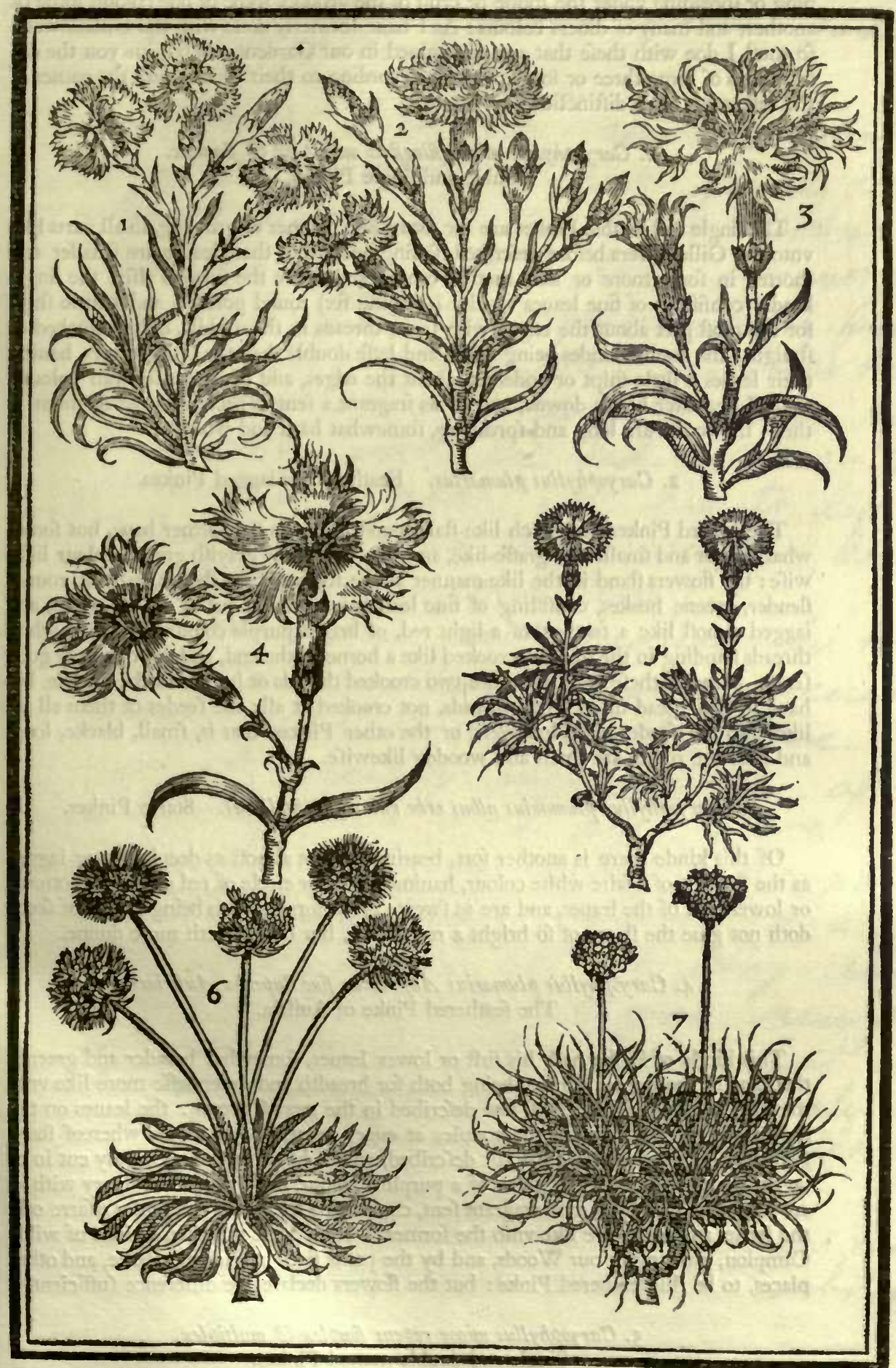

I Caryophyllus flueflris fimplex. The vfuall fingle Pinke. 2 Caryoshyllus mulliplex filweftris. Double Pinkes. 3 Caryophyllus filuefiris flumariws. Feathered or iagged Pinkes. 4 Caryophyllws Stellatws. Starre Pinkes. 5 Cargophyilus repens. Matted Pinkes. 6 Carjophyllus mediserraseus. The great Thifte or Sea Gilloflower. 7 Caryophyllus marinus. The ordinary Thifte or
Sea Cumion. 
ping or fpreading vnder the toppe or cruft of the ground, fome of one colour, fome of another, and many of diuers colours: As I haue formerly done with the Gilloflowers, fo muft I doe with thefe that are entertained in our Gardens, onely giue you the defcriptions of fome three or foure of them, according to their variety, and the names of the reft, with their diftinctions.

\section{Caryophyllus minor filueftris multiplex E fimplex. Double and fingle Pinkes.}

The fingle and double Pinkes are for forme and manner of growing, in all parts like vnto the Gilloflowers before defcribed, fauing onely that their leaues are fmaller and fhorter, in fome more or leffe then in others, and fo are the flowers alfo: the fingle kindes confifting of fiue leaues vfually (feldome fix) round pointed, and a little fnipt for the moft part about the edges, with fome threads in the middle, either crooked or ftraight: the double kindes being leffer, and leffe double then the Gilloflowers, hauing their leaues a little fnipt or endented about the edges, and of diuers feuerall colours, as thall hereafter be fet downe, and of as fragrant a fent, efpecially fome of them as they: the rootes are long and fpreading, fomewhat hard and wooddy.

\section{Caryophyllus plumarius. Feathered or iagged Pinkes.}

The iagged Pinkes haue fuch like ftalkes and leaues as the former haue, but fomewhat horter and fmaller, or graffe-like, and of a whitifh or grayifh greene colour likewife: the flowers ftand in the like manner at the toppes of the ftalkes, in long, round, flender, greene huskes, confirting of fiue leaues, very much cut in on the edges, and iagged almoft like a feather, of a light red, or bright purple colour, with two white threads ftanding in the middle, crooked like a horne at the end, and are of a very good fent. Some of thefe haue not thofe two crooked threads or hornes in the middle, but haue in their ftead many fmall threads, not crooked at all: the feedes of them all are like vnto the feedes of Gilloflowers, or the other Pinkes, that is, fmall, blacke, long, and flat: the rootes are fmall and wooddy likewife.

\section{Caryophyllius plumarius albus orbe rubro fue Stellatus. Starre Pinkes.}

Of this kinde there is another fort, bearing flowers almoft as deeply cut or iagged as the former, of a faire white colour, hauing a ring or circle of red about the bottome or lower part of the leaues, and are as fweete as the former: this being fowne of feede doth not giue the ftarre of fo bright a red colour, but becommeth more dunne.

\section{Garyophyllus plumarius Auftriacus fiue Superba Aufriaca.}

The feathered Pinke of Auftria.

This kinde of Pinke hath his firt or lower leaues, fomewhat broader and greener then any of the former Pinkes, being both for breadth and greenneffe more like vnto the Sweete Iohns, which thall bee defcribed in the next Chapter: the leaues on the ftalkes are fmaller, ftanding by couples at euery ioynt, at the toppes whereof ftand fuch like iagged flowers as the laft defcribed, and as large, but more deeply cut in or iagged round about, fome of them of a purplifh colour, but the moft ordinary with vs are pure white, and of a moft fragrant fent, comforting the fpirits and fenfes a farre off: the feedes and rootes are like vnto the former. Some haue miftaken a kinde of wilde Campion, growing in our Woods, and by the paths fides in Hornfie Parke, and other places, to be this feathered Pinke: but the flowers declare the difference fufficiently.

\section{Caryophyllus minor repens fimplex $\mathcal{E}^{2}$ multiplex.}

\section{Single and double matted Pinkes.}

The matted Pinke is the fmalleft, both for leafe and flower of all other Pinkes that are nourifhed in Gardens, hauing many thort and fmall graffie greene leaues vpon the 
ftalkes, which as they grow and lye vpon the ground (and not ftanding fo vpright as the former) doe take roote againe, whereby it quickly fpreadeth, and couereth a great deale of ground in a little fpace: the flowers are finall and round, a little fnipt about the edges, whereof fome are white, and fome red, and fome are white fpotted with red, and fome red fpotted with white, all of them being fingle flowers. But there is another of this kinde, not differing in leafe, but in flower : for that the first flowers are but once double, or of two rowes of leaues, of a fine reddilh colour, fpotted with filuer fpots : but thofe that follow, are fo thicke and double, that they oftentimes doe breake the pod or huske; being not altogether of fo deepe a red colour, but more pale.

\section{Caryophyllus Mediterraneus fue Marinus maior. Great Sea Gilloflower or Great Thrift.}

Vnto thefe kindes of Pinkes I muft needs adde, not only our ordinary Thrift (which is more frequent in gardens, to empale or border a knot, becaufe it abideth greene Winter and Summer, and that by cutting, it may grow thick, and be kept in what form one lift, rather then for any beautie of the flowers) but another greater kinde, which is of as great beautie and delight almoft as any of the former Pinkes, as well for that the leaues are like vnto Gilloflowers, being longer and larger then any Pinkes, and of a whitifh greene colour like vnto them, not growing long or by couples vpon the ftalkes as Pinkes and Gilloflowers doe, but tufting clofe vpon the ground, like vnto the common Thrift: as alfo that the ftalkes, rifing from among the leaues (being fometimes two foote high (as I haue obferued in my garden) are yet fo flender and weake, that they are fcarce able to beare the heads of flowers, naked or bare, both of leaues and ioynts, fauing only in one place, where at the ioynt each ftalke hath two fmall and very thort leaues, not rifing vpwards as in all other Gilloflowers, Pinkes, and other herbes, but growing downewards) and doe beare each of them a tuft or vmbell of finall purplifh, or blufh coloured flowers, at the toppes of them ftanding fomewhat like vnto fweete Williams, but more roundly together, each flower confifting of fiue finall, round, ftiffe or hardifh leaues, as if they were made of paper, the bottome or middle being hollow, not blowing all at once as the ordinary Thrift, but for the moft part one after another, not fhewing vfually aboue foure or fiue flowers open at one time (fo farre as I could obferue in the plants that I kept) fo that it was long before the whole tuft of flowers were paft ; but yet the hoter and dryer the time was, the fooner it would be gone : the feede I haue not perfectly obferued, but as I remember, it was fomewhat like vnto the feede of Scabious; I am fure nothing like vnto Gilloflowers or Pinkes : the roote is fomewhat great, long and hard, and not fo much fpreading in the ground as Gilloflowers or Pinkes.

\section{Caryophyllus Marinus. Thrift, or Sea Cufhion.}

Our common Thrift is well knowne vnto all, to haue many fhort and hard greene leaues, fmaller then many of the graffes, growing thicke together, and fpreading vpon the ground : the ftalkes are naked of leaues a fpanne high, bearing a fmall tuft of light purple, or blufh coloured flowers, ftanding round and clofe thrufting together.

Double Pinkes.

$7 \mathrm{He}$ double white Pinke is onely with more leaues in it then the fingle, which maketh the difference.

The double red Pinke is in the fame edges.

manner double, differing from the fingle The fingle red Pink is like the white, but of the fame colour.

The double purple Pinke differeth not the flower is of a pale purpliflaged, and
Single Pinkes.

THe fingle white ordinary Pinke hath a fingle white flower of fiue leaues, finely iagged about the

hat the leaues are not fo much iagged, and from 
from the fingle purple for colour, but on- The fingle purple Pinke is of a faire ly in the doubleneffe of the flower.

The Granado Pinke differeth not from Gilloflower.

the Gilloflower of the fame name, but in The great blurh Pinke hath broader and the fmalneffe both of leaues and flower. larger leaues in the flower then any other

The double Matted Pinke is before de- Pinke, and of a faire blufh colour. fribed.

The white Featherd Pinke hath the

The double blurh Pinke is almoft as edges of the flower more finely and deepgreat as the ordinary blufh Gilloflower, ly cut in then the former.

and fome haue taken it for one, but the The red or light purple featherd Pinke greene leaues are almoft as fmall as Pinks, is like the former featherd Pinke, but only and therefore I referre it to them. differeth in colour.

The Starre Pinke is a faire flower, finely iagged on the edges, with a faire red circle at the lower end of the leanes on the infide.

The white featherd Pinke of Auftria is defcribed before. The purple featherd Pinke of Auftria is fo likewifc. The fingle matted Pinke is before defcribed. The fpeckled Pinke is a fmall flower hauing finall fpots of red here and there difperfed ouer the white flower.

Thofe fingle flowers being like vnto Pinkes that rife from the fowing of the orenge tawney, I bring not into this cla/sis, hauing already fpoken of them in the precedent Chapter.

The Place.

Thefe are all like as the former, nourifhed in Gardens with vs, although many of them are found wilde in many places of Auftria, Hungarie, and Germany, on the mountaines, and in many other places, as Clufius recordeth. The ordinary Thrift groweth in the falt Marfhes at Chattam by Rochefter, and in many other places in England: but the great kinde was gathered in Spaine, by Guillaume Boel that painefull fearcher of fimples, and the feede thereof imparted to me, from whence I had diuers plants, but one yeare after another they all perifhed.

\section{The Time.}

Many of thefe Pinkes both fingle and double, doe flower before any Gilloflower, and fo continue vntill Auguft, and fome, moft of the Summer and Autumne.

\section{The Names.}

The feuerall titles that are giuen to thefe Pinkes, may fuffice for their particular names: and for their generall they haue beene expreffed in the former Chapter, beeing of the fame kindred, but that they are fmaller, and more frequently found wilde. The two forts of Thrift are called Caryophyllus Marinus. The greater, Maior \& Mediterraneus; In Englifh, The greater or Leuant Thrift, or Sen Gilloflower. The leffer Minimus, and is accounted of fome to be a graffe, and therefore called Gramen Marinum है Polyanthemum; In Englifh, Thrift, Sea grafe, and our Ladies Cufhion, or Sea Cuhion.

\section{The Vertues.}

It is thought by diuers, that their vertues are anfwerable to the Gilloflowers, yet as they are of little vfe with vs, fo I thinke of as fmall effect. 


\section{CHAP. L X XI.}

\section{Armerius. Sweet Iohns, and fweet Williams.}

$\mathrm{T}$

Hefe kindes of flowers as they come neereft vnto Pinkes and Gilloflowers, though manifeftly differing, fo it is fitteft to place them next vnto them in a peculiar Chapter.

\section{Armerius anguftifolius rubens fimplex. Single red fweete Iohns.}

The fweete Iohn hath his leaues broader, fhorter and greener then any of the former Gilloflowers, but narrower then fweete Williams, fet by couples, at the ioynts of the ftalkes, which are fhorter then moft of the former, and not aboue a foote and a halfe high, at the tops whereof ftand many fmall flowers, like vnto fmall Pinkes, but ftanding clofer together, and in fhorter huskes, made of fiue leaues, fmaller then moft of them, and more deeply iagged then the Williams, of a red colour in the middle, and white at the edges, but of a fmall or foft fent, and not all flowring at once, but by degrees: the feede is blacke, fomewhat like vnto the feede of Pinkes, the roote is difperfed diuerfly, with many fmall fibres annexed vnto it.

\section{Armerius anguftifolius albus fimplex. Single white fweet Iohns.}

This white Iohn differeth not in any thing from the former, but onely that the leafe doth neuer change brownifh, and that the flower is of a faire white colour, without any mixture.

\section{Armerius anguftifolius duplex. Double fweet Iohns.}

There is of both thofe former kindes, fome whofe flowers are once double, that is, confifting of two or three rowes of leaues, and the edges not fo deeply iagged; not differing in any thing elfe.

\section{Armerius latifolius fimplex flore rubro. Single red fweet Williams.}

The fweet Williams doe all of them fpread into many very long trayling branches, with leaues lying on the ground, in the very like manner that the fweete Iohns doe: the chiefe differences betweene them are, that thefe haue broader, and darker greene leaues, fomewhat brownifh, efpecially towards the points, and that the flowers ftand thicker and clofer, and more in number together, in the head or tuft, hauing many fmall pointed leaues among them, but harmleffe, as all men know; the colour of the flower is of a deep red, without any mixture or fpot at all.

\section{Armerius latifolius flore rubro multiplici.}

Double red fweete Williams.

The double kinde differeth not from the fingle kinde of the fame colour, but only in the doubleneffe of the flowers, which are with two rowes of leaues in euery flower.

\section{Armerius latifolitus variegatus fue verficolor.}

Speckled fweete Williams, or London pride.

Thefe fpotted Williams are very like the firf red Williams, in the forme or maner of growing, hauing leaues as broade, and browne fometimes as they, the flowers ftand as thicke or thicker, cluftring together, but of very variable colours: for fome flowers will be of a fine delayed red, with few markes or fpots vpon them, and others 
will bee full fpeckled or fprinkled with white or filuer fpots, circlewife about the middle of the flowers, and fome will haue many. fpecks or fpots vpon them difperfed: all thefe flowers are not blowne at one time, but fome are flowring, when others are decaying, fo that abiding long in their pride, they become of the more respect : The feede is blacke, as all the reft, and not to be diftinguifhed one from another : the roots are fome long, and fome fmall and threddy, running vnder the vpper cruft of the earth.

\section{Armerius latifolius flore rubro faturo holofericeo.}

Sweet Williams of a deepe red or murrey colour.

The leaues of this kinde feeme to be a little larger, and the ioints a little redder then the former, but in the flower confifteth the chiefeft difference, which is of a deepe red, or murrey purple colour, like vnto veluet of that colour, without any fpots, but fmooth, and as it were fort in handling, hauing an eye or circle in the middle, at the bottome of the leaues.

\section{Armerius latifolius fimplex flore albo. Single white fweete Williams.}

The white kinde differeth not in forme, but in colour from the former, the leaues are not browne at all, but of a frefh greene colour, and the flowers are wholly white, or elfe they are all one.

The Place.

Thefe for the moft part grow wilde in Italie, and other places: we haue them in our Gardens, where they are cherifhed for their beautifull varietie.

The Time.

They all generally doe flower before the Gilloflowers or Pinkes, or with the firft of them: their feede is ripe in Iune and Iuly, and doe all well abide the extremitie of our coldeft winters.

\section{The Names.}

They all generally are called Armerius, or Armeria, as fome doe write, and diftinguinhed as they are in their titles: Yet fome haue called them $V e$ tonica agrefiis, and others Herba Tunica, Scarlatea, \& Caryophyllus fluefiris: Wee doe in Englifh in moft places, call the firt or narrower leafed kindes, Sweet Iohns, and all the reft Sweete Williams; yet in fome places they call the broader leafed kindes that are not fpotted, Tolmeiners, and London tufts: but the fpeckled kinde is termed by our Englifh Gentlewomen, for the moft part, London pride.

\section{The Vertues.}

We haue not knowne any of thefe vfed in Phyficke.

Ch A P. LX XII.

\section{Bellis. Daifie.}

T

Here be diuers forts of Daifies, both great and fmall, both fingle and double, both wilde growing abroade in the fieldes, and elfewhere, and manured growing only in Gardens: of all which I intend not to entreate, but of thofe that are of mont beautie and refpect, and leaue the reft to their proper place. 


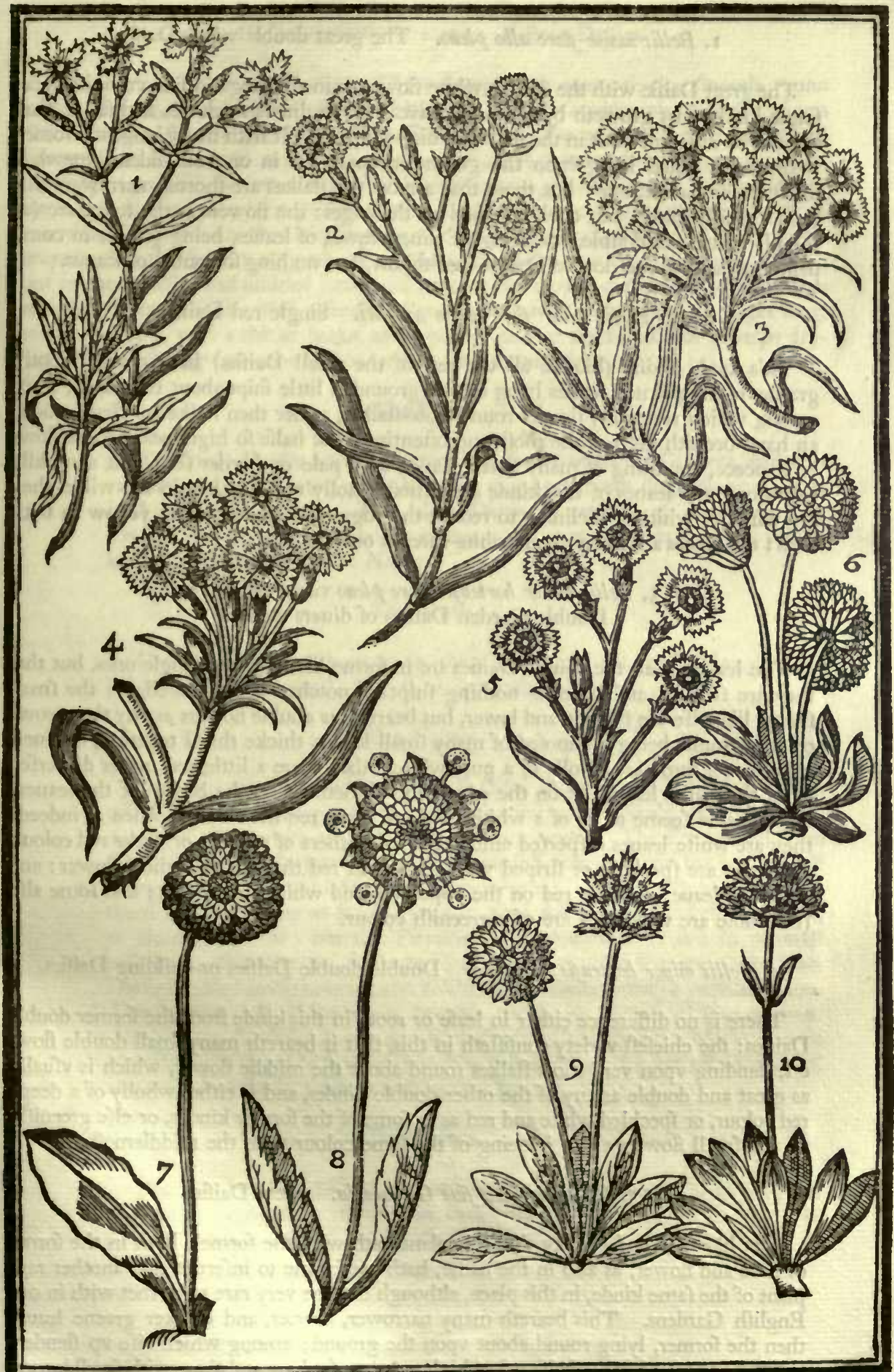

3 Armerius anguftifalius fimblex. Single fweete Iohna 2 Armorius anguftifolius multiplex. Double flveet Iohns. 3 Amerius latifoliws fimplex. Single fweete Williams. Armerius latifolius serficolor. Spotted fweet Williams or pride of London. 5 Armerius latifolims nattiplex. Double fiveet Williams. 6 Bellis hortenfis minor multiplex. Double Garden Daifies. 7 Bellis minor hortewfis fare vario Double red Daifies ftript. 8 Bellis minor horternfis prolifers. Double fruiffull Daifies or Iacke an Apes on horfebacke. 9. Bellis carulea fine Globularia. Double blew Daifies or blew Globeflower so Bellis lusea montana five Globularia lulea moniana. Double yeliow Daifies or yellow Globeflower. 


\section{Bellis maior flore albo pleno. The great double white Daifie.}

The great Daifie with the double white flower, is in all things fo like vnto the great fingle kinde, that groweth by the high wayes, and in diuers medowes and fields, that there is no difference but in the flower, which is double. It hath many long, and fomewhat broad leaues lying vpon the ground, deepely cut in on both fides, fomewhat like vnto an 'oaken leafe; but thofe that are on the ftalkes are fhorter, narrower, and not fo deeply cut in, but onely notched on the edges: the flowers at the toppe are (as I faid) white and double, confinting of diuers rowes of leaues, being greater in compaffe then any of the double Daifies that follow, but nothing fo double of leaues.

\section{Bellis minor flore rubro fimplici. Single red Daifies.}

This fingle Daifie (like as all the reft of the fmall Daifies) hath many fmooth, greene, round pointed leaues lying on the ground, a little fnipt about the edges; from among which rife many flender round foote-ftalkes, rather then ftalkes or ftems, about an hand breadth high at the moft, and oftentimes not halfe fo high, bearing one flower a peece, confifting of many fmall leaues, as a pale or border fet about a middle thrumme: the leaues of this kinde are almoft wholly red, whereas in the wilde they are white or whitifh, enclining to red on the edges, the middle being yellow in both forts: the rootes are many fmall white threads or ftrings.

\section{3, Bellis minor horten fis fore pleno variorum colorum.}

Double Garden Daifies of diuers colours.

The leaues of all the double Daifies are in forme like vnto the fingle ones, but that they are fmaller, and little or nothing fnipt or notched about the edges: the fmall ftalkes likewife are fmaller and lower, but bearing as double flowers as any that growe on the ground, being compofed of many fmall leaues, thicke thruft together, of diuers colours; for fome are wholly of a pure white, others haue a little red, either difperfed vpon the white leaues, or on the edges, and fometimes on the backes of the leaues: fome againe feeme to be of a whitifh red, or more red then white, when as indeede they are white leaues difperfed among the red; others of a deepe or darke red colour, and fome are fpeckled or ftriped with white and red through the whole flower: and fome the leaues will bee red on the vpperfide, and white vnderneath; and fome alfo (but thofe are very rare) are of a greenifh colour.

\section{Bellis minor hortenfis prolifera. Double double Daifies or childing Daifies.}

There is no difference either in leafe or roote in this kinde from the former double Daifies: the chiefeft variety confifteth in this, that it beareth many fmall double flowers, ftanding vpon very fhort ftalkes round about the middle flower, which is vfually as great and double as any of the other double kindes, and is either wholly of a deepe red colour, or fpeckled white and red as in fome of the former kindes, or elfe greenifh, all the fmall flowers about it being of the fame colour with the middlemoft.

\section{Bellis carulea fue Globularia. Blew Daifies.}

The likeneffe and affinity that this plant hath with the former, both in the forme of leafe and flower, as alfo in the name, hath caufed me to infert it, and another rare plant of the fame kinde, in this place, although they be very rare to be met with in our Englifh Gardens. This beareth many narrower, horter, and blacker greene leaues then the former, lying round about vpon the ground; among which rife vp flender, but fiffe and hard Italks, halfe a foot high or more, fet here and there with fmall leaues, and at the top a fmall round head, compofed of many fmall blew leaues, fomewhat like vnto the head of a Scabious: It hath bin found likewife with a white head of flowers: the roote is hard and ftringie: the whole plant is of a bitter tafte. 


\section{Globularia lutea montana. Yellow Daifies.}

This mountaine yellow Daifie or Globe-flower hath many thicke, fmooth, round pointed leaues, fpread vpon the ground like the former; among which fpring diuers fmall round rufhie ftalkes, a foote high, bearing about the middle of them two fmall leaues at the ioynts, and at the toppes round heads of flowers thruft thicke together, ftanding in purplifh huskes, euery of which flowers do blow or fpread into fiue leaues, ftarre-fafhion, and of a faire yellow colour, fmelling like vnto broome flowers, with many fmall threads in the middle compaffing a flat pointell, horned or bended two wayes: after the flowers are paft rife vp the feede veffels, which are round, fwelling out in the middle, and diuided into foure parts at the toppes, containing within them round, flat, blacke feede, with a fmall cut or notch in them: the roote is a finger long, round and hard, with a thicke barke, and a woddy pith in the middle, of a fharpe drying tafte and ftrong fent: the leaues are alfo fharpe, but bitter.

The Place.

The fmall Daifies are all planted, and found onely in Gardens, and will require to be replanted often, left they degenerate into fingle flowers, or at leaft into leffe double. The blew Daifie is naturall of Mompelier in France, and on the mountaines in many places of Italy, as alfo the yellow kinde in the Kingdome of Naples.

The Time.

The Daifies flower betimes in the Spring, and laft vntill May, but the laft two flower not vntill Auguft or September.

\section{The Names.}

They are vfually called in Latine Bellides, and in Englifh Daifies. Some call them Herba Margarita, and Primula veris, as it is likely after the Italian names, of Marguerite, and Flor di prima vera gentile. The French call them Pafquettes, and Marguerites, and the Fruitfull fort, or thofe that beare fmall flowers about the middle one, Margueritons: our Englifh women call them Iacke an Apes on horfe-backe, as they doe Marigolds before recited, or childing Daifies: but the Phyfitians and Apothecaries doe in generall call them, efpecially the fingle or Field kindes, Confolida minor. The blew Daifie is called Bellis carulea, and Globularia, of fome Scabiofa pumilum genus. The Italians call it Botanaria, becaufe the heads are found like buttons. The yellow, Globularia montana, is onely defcribed by Fabius Columna, in his laft part of Phytoba fanos, and by him referred vnto the former Globularia, although it differ in fome notable points from it.

\section{The Vertues.}

The properties of Daifies are certainly to binde, and the roote efpecially being dryed, they are vfed in medicines to that purpofe. They are alfo of fpeciall account among thofe herbes, that are vfed for wounds in the head. 


\section{C н A P. L X X I I I.}

\section{Scabiofa. Scabious.}

T He forts of Scabious being many, yeeld not flowers of beauty or refpect, fit to bee cherifhed in this our Garden of delight; and therefore I leaue them to the Fields and Woods, there to abide. I haue onely two or three ftrangers to bring to your acquaintance, which are worthy this place.

\section{Scabiofa flore albo. White flowred Scabious.}

This white Scabious hath many long leaues, very much iagged or gafht in on both fides, of a meane bigneffe, being neither fo large as many of the field, nor fo fmall as any of the fmall kindes: the ftalkes rife about a foote and a halfe high, or fomewhat higher, at the tops whereof grow round heads, thicke fet with flowers, like in all points vnto the field Scabious, but of a milke white colour.

\section{Scabiofa rubra Aufriaca. Red Scabious of Auftria.}

This red Scabious hath many leaues lying vpon the ground, very like vnto Deuils bit, but not fo large, being fhorter and fnipt, not gafhed about the edges, of a light greene colour; yet (there is another of a darker greene colour, whofe flower is of a deeper red) the ftalkes haue diuers fuch leaues on them, fet by couples at the ioynts as grow belowe, and at the tops fmall heads of flowers, each confifting of fiue leaues, the biggeft flowers ftanding round about in the outer compaffe, as is vfuall almoft in all the kinds of Scabious, of a fine light purple or red colour : after the flowers are paft, come the feede, which is fomewhat long and round, fet with certaine haires at the head thereof, like vnto a Starre: the roote is compofed of a number of flender ftrings, faftened at the head.

\section{Scabiofa rubra Indica. Red flowred Indian Scabious.}

This (reputed Indian) Scabious hath many large faire greene leaues lying on the ground, iagged or cut in on both fides to the middle ribbe, euery peece whereof is narrower then that at the end, which is the broadeft : among thefe leaues rife vp fundry flender and weake ftalkes, yet ftanding vpright for the moft part, fet with fmaller and more iagged leaues at certaine diftances, two or three at euery ioynt, branching forth at the toppe into other fmaller branches, bearing euery one head of flowers, like in forme vnto other Scabioufes, but of an excellent deepe red crimfon colour (and fometimes more pale or delayed) of no fent at all : after which doe come fmall roundifh feede, like vnto the field Scabious: the roote is long and round, compaffed with a great many fmall ftrings, and perifheth vfually as foone as it hath borne out his flowers and feede: otherwife if it doe not flower the firft yeare of the fowing, if it be carefully defended from the extremity of Winter, it will flower the fooner the next yeare, as I my felfe haue often found by experience.

\section{The Place.}

The firf is fometimes found wilde in our owne Countrey, but it is very geafon, and hath been fent among other rare feedes from Italy.

The fecond was firft found and written of by Clufius, in Pannonia and Auftria, where it is very plentifull.

The third hath been fent both from Spaine \& Italy, and is verily thought to grow naturally in both thofe parts. 


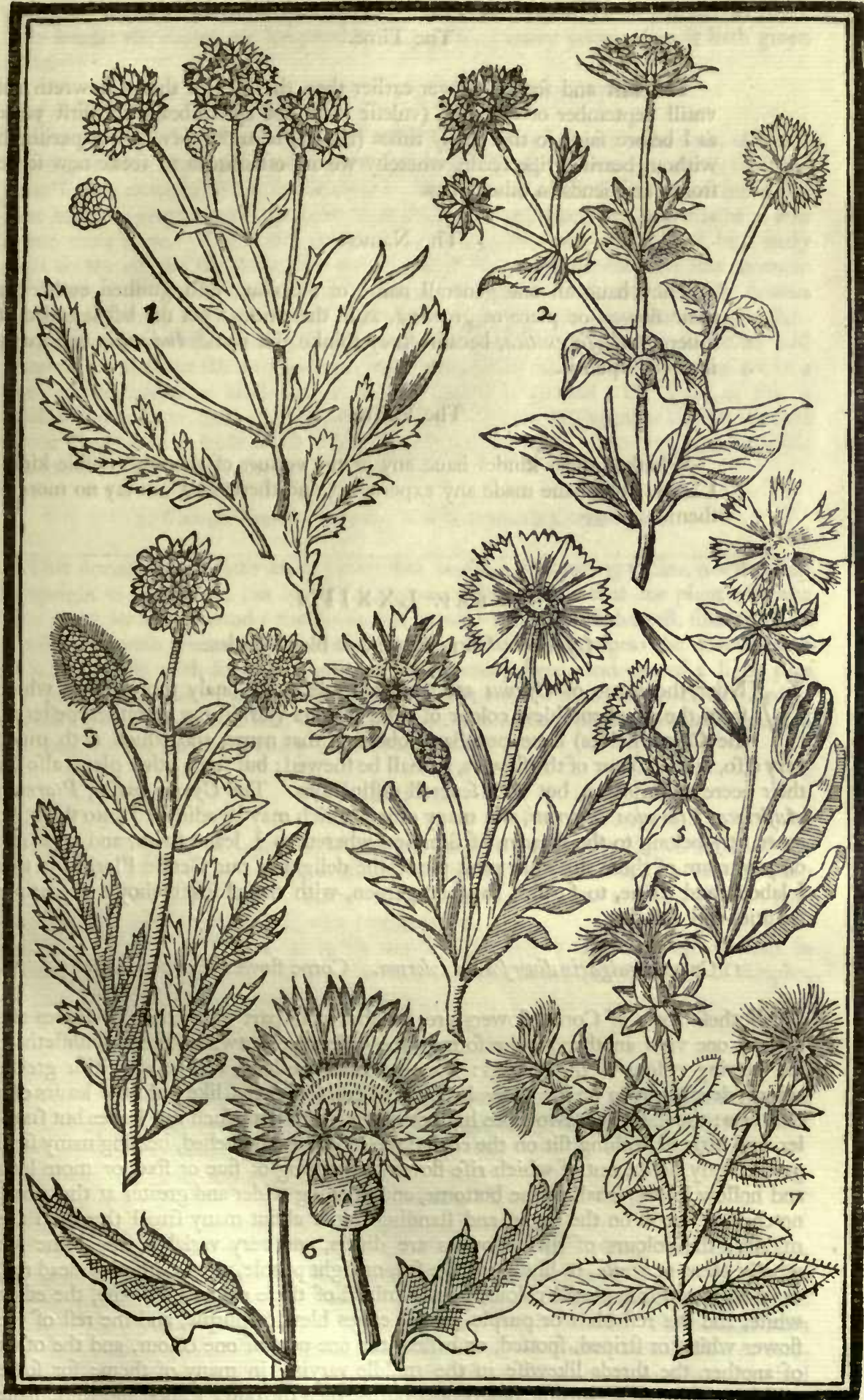

8cabiofa forc albu. White fowred Scabious. 2 Scabiofa rubra Anffriaca. Red Scabious of Auftria. 3 Scabiufa rubra In. dica. Red fowred Indian Scabious. 4 Cyanus vulgaris minor. Corn-flower of diuers colours. 5 Cyauns Baticus. Spanißh Corn-fiower. 6 Cyanus foridus Turcicus. The braue Sultans flower. 7 Carlkamus falious. Spanifh Saffron. 


\section{The Time.}

The firft and fecond flower earlier then the laft, for that it flowreth not vntill September or October, (vnleffe it be not apt to beare the firft yeare as I before faid) fo that many times (if none be more forward) it perifheth without bearing ripe feede, whereby we are oftentimes to feeke new feede from our friends in other parts.

The Names.

They haue all one generall name of Scabious, diftinguifhed eyther by their flower, or place of growing, as in their titles: yet the laft is called of diuers Scabiofa exotica, becaufe they thinke the name Indica, is not truely impofed vpon it.

\section{The Vertues.}

Whether thefe kindes haue any of the vertues of the other wilde kinds, I know none haue made any experience, and therefore I can fay no more of them.

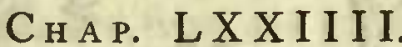

Cyanus. Corne flower, or blew Bottles.

V Nder the name of Cyanus are comprehended, not onely thofe plants which from the excellent blew colour of their flowers (furnifhing or rather peftering the Corne fieldes) haue peculiarly obtained that name, and which doth much vary alfo, in the colour of the flowers, as fhall be fhewed; but fome other plants alfo for their neere refemblance, but with feuerall diftinctions. The Cyanus maior, Ptarmica Auftiaca, Ptarmica Imperati, and many others which may be adioyned vnto them, do more fitly belong to the Garden of Simples, whereunto I leaue them, and will here only entreate of thofe that may moft pleafe the delight of our Gentle Florifts, in that I labour and ftriue, to furnifh this our garden, with the chiefert choyfe of natures beauties and delights.

\section{Cyanus vulgaris diuer forum colorum. Corne flower of diuers colours.}

All thefe forts of Corne flowers are for the moft part alike, both in leaues and flowers one vnto another for the forme: the difference betweene them confifteth in the varying colour of the flowers: For the leaues are long, and of a whitifh greene colour, deeply cut in on the edges in fome places, fomewhat like vnto the leaues of a Scabious: the ftalkes are two foote high or better, befet with fuch like leaues but fmaller, and little or nothing flit on the edges: the toppes are branched, bearing many fmal greene fcaly heads, out of which rife flowers, confifting of fiue or fixe, or more long and hollow leaues, fmall at the bottome, and opening wider and greater at the brims, notched or cut in on the edges, and ftanding round about many fmall threds in the middle: the colours of thefe flowers are diuers, and very variable; for fome are wholly blew, or white, or blufh, or of a fad, or light purple, or of a light or dead red, or of an ouerworne purple colour, or elfe mixed of thefe colours, as fome, the edges white, and the reft blew or purple, or the edges blew or purple, and the reft of the flower white, or ftriped, fpotted, or halfed, the one part of one colour, and the other of another, the threds likewife in the middle varying in many of them; for fome will haue the middle thrume of a deeper purple then the outer leaues, and fome haue white or blufh leaues, the middle thrume being reddifh, deeper or paler: After the flowers are paft, there come fmall, hard, white and thining feede in thofe heads, wrap- 
ped or fet among a deale of flockie matter, as is moft vfuall, in all plants that beare fcaly heads: the rootes are long and hard, perifhing euery yeare when it hath giuen feede.

\section{Cyanus floridus Turcicus. The Sultans flower.}

As a kinde of thefe Corne flowers, I mutt needes adioyne another ftranger, of much beautie, and but lately obtained from Conftantinople, where, becaufe (as it is faid) the great Turke, as we call him, faw it abroade, liked it, and wore it himfelfe; all his vaffals haue had it in great regard, and hath been obtained from them, by fome that haue fent it into thefe parts. The leaues whereof are greener, and not only gafhed, but finely fnipt on the edges : the ftalkes are three foote high, garnithed with the like leaues as are below, and branched as the former, bearing large faly heads, and fuch like flowers but larger, hauing eight or nine of thofe hollow gaping leaues in euery flower, ftanding about the middle threds (if it be planted in good and fertile ground and be well watered, for it foone ftarueth and perifheth with drought) the circling leaues are of a fine delayed purple or bluth colour, very beautifull to behold; the feede of this is fmaller and blacker, and not enclofed in fo much dounie fubftance, as the former (yet in our Countrey the feede is not fo blacke, as it came vnto vs, but more gray) the roote perifheth likewife euery yeere.

\section{Cyanus Baticus Jupinus. The Spanith Corne-flower.}

This Spanifh kinde hath many fquare low bending or creeping ftalkes, not ftanding fo vpright as the former, but branching out more diuernly; fo that one plant will take vp a great deale of ground: the leaues are broader then any of the reft, fofter alfo, of a pale or whitifh greene colour, and not much gafhed on the edges: the flowers ftand in bigger heads, with foure or fiue leaues vnder euery head, and are of a light pale. purple or blufh colour; after which come feede, but not fo plentifully, yet wrapped in a great deale of flockie matter, more then any: the roote groweth downe deepe into the ground, but perifheth euery yeare as they doe.

\section{The Place.}

The firt or former kindes, grow many times in the Corne fields of our own Countrey, as well as of others, efpecially that fort with a blew flower: but the other forts or colours are not fo frequent, but are nourifhed in gardens, where they will vary wonderfully.

The fecond as is before fet downe, groweth in Turkie : and the laft in Spaine, found out and firft fent to vs by that induftrious fearcher of fimples, Guillaume Boel before remembred.

\section{The Time.}

The firt doe flower in the end of Iune, and in Iuly, and fometimes fooner. The other two later, and not vntill Auguft moft commonly, and the feede is foone ripe after.

\section{The Names.}

The firft is generally called Cyanus, and fome following the Ditch name, call it Flos frumenti. The olde Writers gaue it the name of Bapti facuba, which is almoft worne out. We doe call them in Englifh, Blew Bottles, and in forme places, Corne flowers, after the Ditch names. The fecond hath beene fent by the name of Ambreboi, which whether it be a Turkie or Arabian name, I know not. I have called it from the place, from whence we had it, Turcicus, and for his beauty, Floridus. The Turkes themfelucs as I vnderftand, doe call it The Sultans flower, and I haue done fo likewife, that it may bee diftinguifhed from all the other kindes, or elfe you may call it, 
The Turkey blufh Corne flower, which you pleafe. The laft was fent by the name of Iacea Batica, but I had rather to referre it to the Cyanus, or Corne flowers, becaufe the flowers are like vnto the Corne flowers, and not vnto the Iaceas or Knapweedes.

The Vertues.

Thefe had no vfe in Phyficke in Galen and Diofcorides time, in that (as it is thought) they haue made no mention of them: We in thefe dayes doe chiefly vfe the firft kindes (as alfo the greater fort) as a cooling Cordiall, and commended by fome to be a remedy, not onely againft the plague and peftilentiall difeafes, but againt the poifon of Scorpions and Spiders.

\section{CHAP. LXXV.}

Iacea Marina Batica. Spanifh Sea Knapweede.

T

Here are a great many forts of Knapweedes, yet none of them all fit for this our Garden, but this only ftranger, which I haue beene bold to thruft in here, for that it hath fuch like gaping or open flowers, as the former Corne flowers haue, but notably differing, and therefore deferueth a peculiar Chapter, as partaking both with Cyanus and Iacea. It hath many long and narrow leaues vneuenly dented or waued on both edges (and not notched, ganhed or indented, as many other herbes are) being thicke, flefhie and brittle, a little hairy, and of an ouerworne darke greene colour, among which rife lowe weake ftalkes, with fuch like leaues as grow at the bottome, but fmaller, bearing but here and there a flower, of a bright reddifh purple colour, like in forme vnto the Corne flowers, but much larger, with many threds or thrumes in the middle of the fame colour, ftanding vp higher then any of the former: this flower rifeth out of a large fcaly head, all fet ouer with fmall tharpe (but harmeleffe) white prickles : the feedes are blackifh, like vnto the Knapweedes, and larger then any of the former Corne flowers: the roote is great and thicke, growing deepe into the ground, flefhie and full of a flimie or clammy iuice, and eafie to bee broken, blackifh on the outfide, and whitifh within, enduring many yeares, like as the other Knapweedes, or Matfelons doe, growing in time to be very thicke and great.

The Place.

It groweth naturally by the Sea fide in Spaine, from whence I receiued the feedes of Guillaume Boel, and did abide well in my garden a long time, but is now perifhed.

The Time.

It flowreth in the beginning of Iuly, or thereabouts, and continueth not long in flower : but the head abideth a great while, and is of fome beauty after the flower is paft; yet feldome giueth good feed with vs.

The Names.

It hath no other name then is fet down in the title, being altogether a Nouelift, and not now to be feene with any fauing my felfe.

The Vertues.

We haue not yet known any vfe hereof in Phyfick. 


\section{CH A P. L X X VI.}

\section{Cnicus fue Garthamus fativus. Baftard or Spanifh Saffron.}

T

Here are two or three forts of Cnicus or baftard Saffrons which I paffe ouer, as not fit for this Garden, and onely fet downe this kinde, whofe flowers are of a fairer and more liuely colour in our Country, then any hath come ouer from Spaine, where they manure it for the profit they make thereof, feruing for the dying of Silke efpecially, and tranfporting great quantities to diuers Countries. It hath large broad leaues, without any prickes at all vpon them in our Country, growing vpon the ftalke, which is ftrong, hard, and round, with fhorter leaues thereon vp to the toppe, where they are a little fharpe pointed, and prickly about the edges fometimes, which ftalke rifeth three or foure foote high, and brancheth it felfe toward the toppe, bearing at the end of euery branch one great open fcaly head, out of which thrufteth out many gold yellow threads, of a moft orient fhining colour, which being gathered in a dry time, and kept dry, will abide in the fame delicate colour that it bare when it was frefh, for a very long time after: when the flowers are paft, the feede when it is come to maturity, which is very feldome with vs, is white and hard, fomewhat long, round, and a little cornered: the roote is long, great, and wooddy, and perifheth quickly with the firft frofts.

The Place.

It groweth in Spaine, and other hot Countries, but not wilde, for that it is accounted of the old Writers, Theophraftus and Diofcorides, to be a manured plant.

The Time.

It flowreth with vs not vntill Auguft, or September fometimes, fo that it hardly giueth ripe feede (as I faid) neither is it of that force to purge, which groweth in thefe colder Countries, as that which commeth from Spaine, and other places.

\section{The Names.}

The name Cricus is deriued from the Greekes, and Carthamus from the Arabians, yet ftill fativus is added vnto it, to fhew it is no wilde, but a manured plant, and fowne euery where that wee know. Of fome it is called Grocus hortenfis, and Sarafenicus, from the Italians which fo call it. We call it in Englifh Baftard Saffron, Spanifh Saffron, and Catalonia Saffron.

\section{The Vertues.}

The flowers are vfed in colouring meates, where it groweth beyond Sea, and alfo for the dying of Silkes: the kernels of the feede are onely vfed in Phyficke with vs, and ferueth well to purge melancholicke humours,

\section{Cha P. L X X VII.}

Carduus. Thiftles.

Yu may fomewhat maruaile, to fee mee curious to plant Thiftles in my Garden, when as you might well fay, they are rather plagues then pleafures, and more trouble to weede them out, then to cherifh them vp, if I made therein no diftinction or choife; but when you haue viewed them well which I bring in, I will 
then abide your cenfure, if they be not worthy of fome place, although it be but a corner of the Garden, where fomething muft needes be to fill vp roome. Some of them are fmooth, and without prickes at all, fome at the heads onely, and fome all ouer; but yet not without fome efpeciall note or marke worthy of refpect: Out of this difcourfe I leaue the Artichoke, with all his kindes, and referue them for our Kitchin Garden, becaufe (as all know) they are for the pleafure of the tafte, and not of the fmell or fight.

\section{Acanthus fativus. Garden Beares breech.}

The leaues of this kinde of fmooth thifte (as it is accounted) are almoft as large as the leaues of the Artichoke, but not fo harp pointed, very deeply cut in and gafhed on both edges, of a fad green \& fhining colour on the vpperfide, and of a yellowifh green vnderneath, with a great thicke rib in the middle, which fpread themfelues about the root, taking vp a great deale of ground. After this plant hath ftood long in one place, and well defended from the iniury of the cold, it fendeth forth from among the leaues one or more great and ftrong ftalkes, three or foure foote high, without any branch at all, bearing from the middle to the top many flowers one aboue another, $\mathrm{f}$ pike-fafhion round about the ftalke, with fmaller but not diuided greene leaues at euery flower, which is white, and fafhioned fomewhat like vnto a gaping mouth; after which come broad, flat, thicke, round, brownifh yellow feede (as I haue well obferued by them haue beene fent me out of Spaine, and which haue fprung vp, and doe grow with me; for in our Countrey I could neuer obferue any feede to haue growne ripe) the rootes are compofed of many great and thicke long ftrings, which fpread farre in and vnder the ground, fomewhat darkifh on the outfide, and whitifh within, full of a clammy moifture (whereby it heweth to have much life) and doe endure our Winters, if they be not too much expofed to the fharpe violence thereof, which then it will not endure, as I haue often found by experience.

\section{Acanthus filuefris. Wilde or prickly Beares breech.}

This prickly Thiftle hath diuers long greenifh leaues lying on the ground, much narrower then the former, but cut in on both fides, thicke fet with many white prickes and thornes on the edges: the ftalke rifeth not vp fo high, bearing diuers fuch like thornie leaues on them, with fuch a like head of flowers on it as the former hath : but the feede hereof (as it hath come to vs from Italy and other places, for I neuer faw it beare feed here in this Country) is blacke and round, of the bigneffe of a fmall peafe: the roote abideth reafonable well, if it be defended fomewhat from the extremity of our Winters, or elfe it will perifh.

\section{Eringium Pannonicum fue Montanum. Hungary Sea Holly.}

The lower leaues of this Thiftle that lye on the ground, are fomewhat large, round, and broad, hard in handling, and a little fnipt about the edges, euery one ftanding vpon a long foote-ftalke: but thofe that growe vpon the ftalke, which is ftiffe, two or three foote high, haue no foote-ftalke, but encompaffe it, two being fet at euery ioynt, the toppe whereof is diuided into diuers branches, bearing fmall round rough heads, with fmaller and more prickly leaues vnder them, and more cut in on the fides then thofe belowe: out of thefe heads rife many blew flowers, the foote-ftalkes of the flowers, together with the toppes of the branches, are likewife blew and tranfparent, or fhining.

We haue another of this kinde, the whole toppes of the ftalkes, with the heads and branches, are more white then blew: the feede contained in thefe heads are white, flat, and as it were chaffie : the roote is great and whitih, fpreading farre into many branches, and fomewhat fweete in tafte, like the ordinary Sea Holly rootes.

4. Carduus mollis. The gentle Thiftle.

The leaues of this foft and gentle Thiftle that are next vnito the ground, are greene 


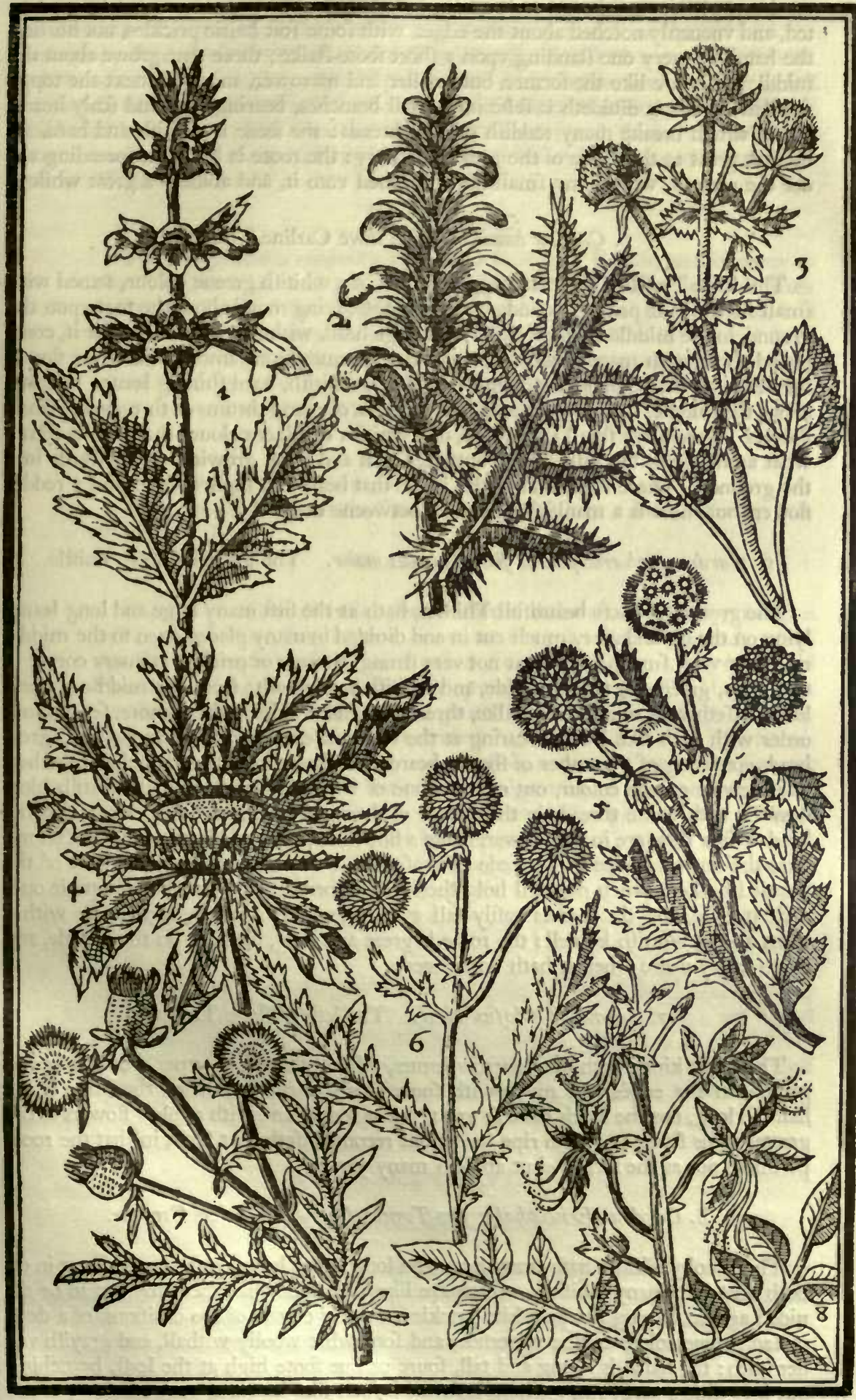

I Acanthus fativus. Garden Beares breech. 2 Acanthus flusftris. Wilde Beases breech. 3 Eringium Pannonicum. Moun. raine Sea Holly. +Carlike humilis. The lowe Carline Thiftle, 5 Carduus Sphacrocapholus maior. The greater Globe-Thifte. 6 Carduss fpharoccphalus minor. The leffer Globe-Thistle. 7 Carduus Eriocophalus. The Friers crowne. \& Fraxinulla. Baltard Dittanic. 
on the vpperfide, and hoary vnderneath, broad at the bottome, fomewhat long pointed, and vneuenly notched about the edges, with fome foft hairie prickles, not hurting the handler, euery one ftanding vpon a fhort foote-ftalke; thofe that growe about the middle ftalke are like the former, but fmaller and narrower, and thore next the toppe fmalleft, where it diuideth it felfe into fmall branches, bearing long and fcaly heads, out of which breake many reddifh purple threads: the feede is whitifh and hard, almoft as great as the feede of the greater Centory: the roote is blackifh, fpreading vnder the ground, with many fmall fibres faftened vnto it, and abideth a great while.

\section{Carlina humilis. The lowe Carline Thiftle.}

This lowe Thiftle hath many iagged leaues, of a whitifh greene colour, armed with fmall tharp white prickles round about the edges, lying round about the toot vpon the ground, in the middle whereof rifeth vp a large head, without any ftalke vnder it, compaffed about with many fmall and long prickly leaues, from among which the flower fheweth it felfe, compofed of many thin, long, whitifh, hard thining leaues, ftanding about the middle, which is flat and yellow, made of many thrums or threads like fmall flowers, wherein lye fmall long feede, of a whitifh or filuer colour: the roote is fomewhat aromaticall, blackifh on the outfide, fmall and long, growing downewards into the ground. There is another of this kinde that beareth a higher ftalke, and a redder flower, but there is a manifeft difference betweene them.

\section{Carduus Spharocephalus fune Globofus maior. The greater Globe Thiftle.}

The greateft of thefe beautifull Thiftles, hath at the firft many large and long leaues lying on the ground, very much cut in and diuided in many places, euen to the middle ribbe, fet with fmall tharpe (but not very ftrong) thornes or prickles at euery corner of the edges, greene on the vpperfide, and whitifh vnderneath: from the middle of thefe leaues rifeth vp a round ftiffe ftalke, three foote and a halfe high, or more, fet without order with fuch like leaues, bearing at the toppe of euery branch a round hard great head, confifting of a number of harpe bearded huskes, compact or fet clofe together, of a blewifh greene colour, out of euery one of which huskes ftart fmall whitifh blew flowers, with white threads in the middle of them, and rifing aboue them, fo that the heads when they are in full flower, make a fine fhew, much delighting the fpectators: after the flowers are paft, the feede encreafeth in euery one, or the moft part of the bearded huskes, which doe ftill hold their round forme, vntill that being ripe it openeth it felfe, and the huskes eafily fall away one from another, containing within them a long whitifh kernell : the roote is great and long, blackifh on the outfide, and dyeth euery yeare when it hath borne feede.

\section{Carduus Globofus minor. The leffer Globe Thifte.}

The leffer kinde hath long narrow leaues, whiter then the former, but cut in and gafhed on the edges very much with fome fmall prickes on them; the ftalke is not halfe fo long, nor the heads halfe fo great, but as round, and with as blew flowers as the greater: this feldome giueth ripe feede, but recompenfeth that fault, in that the roote perifheth not as the former, but abideth many yeares.

\section{Carduus Eriocephalus fiue Tomento/us. The Friers Crowne.}

This woolly Thiftle hath many large and long leaues lying on the ground, cut in on both fides into many diuifions, which are likewife fomewhat vnequally cut in or diuided againe, hauing tharpe white prickles at euery corner of the diuifions, of a dead or fad greene colour on the vpperfide, and fomewhat woolly withall, and grayifh vnderneath: the ftalke is ftrong and tall, foure or fiue foote high at the leaft, branching out into diuers parts, euery where befet with fuch like leaues as growe below; at the toppe of euery branch there breaketh out a great whitifh round prickly head, flattifh at the toppe, fo thicke fet with wooll, that the prickles feeme but fmall fpots or haires, 
and doth fo well refemble the bald crowne of a Frier, not onely before it be in flower, but efpecially after it hath done flowring, that thereupon it deferuedly receiued the name of the Friers Crowne Thiftle: out of thefe heads rifeth forth a purple thrumme, fuch as is to be feene in many other wilde Thiftles, which when they are ripe, are full of a flockie or woolly fubftance, which breake at the toppe fhedding it, and the feede which is blackifh, flat, and fmooth: the roote is great and thicke, enduring for fome yeares, yet fometimes perifhing, if it be too much expofed to the violence of the frofts in Winter.

The Place.

The firft groweth naturally in Spaine, Italy, and France, and in many other hot Countries, and growe onely in Gardens in thefe colder climates, and there cherifhed for the beautifull af pect both of the greene plants, and of the ftalkes when they are in flower. The Carline Thiftle is found both in Germany and Italy in many places, and as it is reported, in fome places of the Weft parts in England. The others are found fome in France, fome in Hungary, and on the Alpes, and the laft in Spaine.

\section{The Time.}

They doe all flower in the Summer moneths, fome a little earlier or later then others.

\section{The Names.}

The firft is called Acanthus fativus (becaufe the other that is prickly, is called filueftris or Jpinofus) and Branea vrfina; In Englifh, Branck vrfine, and Beares breech. The third is called Eringium montanum, Alpinum, and Pannonicum latifolium: In Englifh, Mountaine or Hungary Sea Holly. The fourth is called Carduus mollis, The gentle Thiftle, becaufe it hath no harmfull prickles, although it feeme at the firft fhew to be a Thiftle. The fifth is called of diuers Chamaleo albus, and Carlina, as if they were both but one plant; but Fabius Columna hath in my iudgement very learnedly defcided that controuerfie, making Carlina to be Ixine of Theophraftus, and Chamaleo another differing Thiftle, which Gaza tranflateth Vernilago. We call it in Englifh, The Carline Thiftle. The other haue their names in their titles, as much as is conuenient for this difcourfe.

\section{The Vertues.}

The firft hath alwaies been vfed Phyfically, as a mollifying herbe among others of the like flimie matter in Glifters, to open the body ; yet Lobel feemeth to make no difference in the vfe of them both (that is, the prickly as well as the fmooth.) The Carline Thiftle is thought to bee good againft poyfons and infection. The reft are not vfed by any that I know.

\section{Ch A P. L XXVIII.}

\section{Fraxinella. Baftard Dittany.}

W Auing finifhed thofe pleafing Thiftes, I come to other plants of more gentle handling, and firft bring to your confideration this baftard Dittany, whereof there are found out two efpeciall kindes, the one with a reddifh, the other with a whitifh flower, and each of thefe hath his diuerfity, as fhall be prefently declared.

1. Fraxinella flore rubente. Baftard Dittany with a reddifh flower.

This goodly plant rifeth vp with diuers round, hard, brownifh ftalkes, neare two.

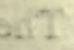


foote high, the lower parts whereof are furnifhed with many winged leaues, fomewhat like vnto Liquerice, or a fmall young Afhe tree, confifting of feuen, nine, or eleuen leaues fet together, which are fomewhat large and long, hard and rough in handling, of a darkifh greene colour, and of an vnpleafant trong refinous fent: the vpper parts of the ftalkes are furnifhed with many flowers, growing fpike fafhion, at certaine diftances one aboue another, confifting of fiue long leaues a peece, whereof foure that ftand on the two fides, are fomewhat bending vpwards, and the fift hanging downe, but turning vp the end of the leafe a little againe, of a faint or pale red colour, ftriped through euery leafe with a deeper red colour, and hauing in the middle a taffell of fiue or fix long purplifh threds, that bowe downe with the lower leafe, and turne vp alfo the ends againe, with a little freefe or thrume at the ends of euery one : after the flowers are paft, arife hard, ftiffe, rough, clammy huskes, horned or pointed at the end, foure or fiue ftanding together, fomewhat like the feede veffels of the Wolfes-banes, or Colombines, but greater, thicker and harder, wherein is contained round fhining blacke feede, greater then any Colombine feede by much, and fmaller then Peony feede: the roote is white, large, and fpreading many wayes vnder ground, if it ftand long: the whole plant, as well roots as leaues and flowers, are of a ftrong fent, not fo pleafing for the fmell, as the flowers are beautifull to the fight.

\section{Fraxinella flore rubro. Baftard Dittaine with a red flower.}

This differeth not from the former eyther in roote, leafe or flower for the forme, but that the ftalkes and leaues are of a darker greene colour, and that the flowers are of a deeper red colour, (and growing in a little longer (pike), wherein the difference chiefly confifteth, which is fufficient to diftinguifh them.

\section{Fraxinella flore albo. Baftard Dittanie with a white flower.}

The white flowred Fraxinella hath his leaues and Italkes of a frefher greene colour then any of the former; and the flowers are of a pure white colour, in forme differing nothing at all from the other.

\section{Fraxinella flore albo caruleo.}

\section{Baftard Dittanie with an afh coloured flower.}

The colour of the flower of this Fraxinella onely putteth the difference betweene this, and the laft recited with a white flower : for this beareth a very pale, or whitifh blew flower, tending to an afh colour.

\section{The Place.}

All thefe kindes are found growing naturally, in many places both of Germany, and Italie : and that with the white flower, about Franckford, which being fent me, perifhed by the way by long and euill carriage.

\section{The Time.}

They flower in Iune and Iuly, and the feede is ripe in Auguft.

The Names.

The name Fraxinella is moft generally impofed on thofe plants, becaufe of the refemblance of them vnto young Afhes, in their winged leaues. Yet fome doe call them Dictamus albus, or Dictamnus albus, and Diptamus albus, as a difference from the Dictamnus Creticus, which is a farre differing plant. Some would haue it to be Tragium of Diofcorides, but befide other things wherein this differeth from $\mathcal{T}$ ragium, this yeeldeth no milkie iuice, as Diofcorides faith Tragium doth: We in Englifh doe eyther call it Fraxinella, or after the other corrupted name of Dictamus, Baftard Dittanie. 
The Vertues.

It is held to be profitable againft the ftingings of Serpents, againft contagious and peftilent difeafes, to bring downe the feminine courfes, for the paines of the belly and the ftone, and in Epilepticall difeafes, and other cold paines of the braines: the roote is the moft effectual for all thefe, yet the feede is fometimes vfed.

\section{Ch а P. LXXIX.}

\section{Legumina. Pulce.}

T I thould defcribe vnto you all the kindes of Pulfe, I thould vnfold a little world of varieties therein, more knowne and found out in thefe dayes, then at any time before, but that muft bee a part of a greater worke, which will abide a longer time before it fee the light. I thall only felect thofe that are fit for this garden, and fet them downe for your confideration. All forts of Pulfe may be reduced under two generall heads, that is, of Beanes and Peafe, of each whereof there is both tame and wilde: Of Beanes, befides the tame or vfuall garden Beane, and the French or Kidney Beane, (whereof I meane to entreate in my Kitchen garden, as pertinent thereto) there is the Lupine or flat Beane, whereof I meane to entreate here, and the blacke Beane and others which muft bee referued for the Phyficke Garden. And of the kindes of Peafe fome are fit for this Garden; (whereunto I will adioyne two or three other plants as neereft of affinitie, the flowers of fome, and the fruit of others being delightfull to inany, and therefore fit for this garden) fome for the Kitchen, the reft for the Phyficke garden. And firt of Lupines or flat Beanes, accepted as delightfull to many, and therefore fit for this garden.

\section{Lupinus fativus albus. The white garden Lupine.}

The garden Lupine rifeth vp with a great round ftalke, hollow and fomewhat woolly, with diuers branches, whereon grow vpon long footeftalkes many broade leaues, diuided into feuen or nine parts, or [maller leaues, equally ftanding round about, as it were in a circle, of a whitifh greene colour on the vpperfide, and more woolly vnderneath : the flowers ftand many together at feuerall ioynts, both of the greater ftalke, and the branches, like vnto beanes, and of a white colour in fome places, and in others of a very bleake blew tending to white: after the flowers are paft, there come in their places, long, broade, and flat rough cods, wherein are contained round and flat feede, yellowifh on the infide, and couered with a tough white skin, and very bitter in tafte: the rootes are not very great, but full of (mall fibres, whereby it fafteneth it felfe ftrongly in the ground, yet perifheth euery yeare, as all the reft of thefe kindes doe.

\section{Lupinus caruleus maximus. The greater blew Lupine.}

The Stemme or ftalke of this Lupine is greater then the laft before recited, as alfo the leaues more foft and woolly, and the flowers are of a moft perfect blew colour, with fome white [pots in the middle: the long rough greenifh cods are very great and large, wherein are contained hard, flat and round feede, not fo white on the outfide as the former, but fomewhat yellower, greater alfo, and more rough or hard in handling.

\section{Lupinus caruleus minor. The leffer blew Lupine.}

This kinde of wilde Lupine differeth not in the forme of leafe or flower from the former, but only that it is much fmaller, the leaues are greener, and haue fewer diuifions in them : the flower is of as deepe a blew colour as the laft; the cods likewife are fmall and long, containing fmall round feede, not fo flat as the former, but more 
Minimus. difcoloured or fpotted on the outfide, then the greater kinde is. There is a leffer kind then this, not differing in any thing from this, but that it is leffer.

\section{Lupinus flore luteo. The yellow Lupine.}

The yellow Lupine groweth not vfually fo high, but with larger leaues then the fmall blew Lupine; the flowers grow in two or three rundles or tufts, round about the ftalke and the branches at the ioynts, of a delicate fine yellow colour, like in fafhion vnto the other kindes, being larger then the laft, but nothing fo large as the greater kindes, and of a fine fmall fent : the feede is round, and not flat, but much about the forme and bigneffe of the fmall blew, or fomewhat bigger, of a whitifh colour on the outfide, fpotted with many fpots.

\section{The Place.}

The firft groweth in many places of Greece, and the Eafterne Countries beyond it, where it hath beene anciently cherifhed for their foode, being often watered to take away the bitterneffe. It groweth alfo in thefe Weitern parts, but ftill where it is planted. The great blew Lupine is thought to come from beyond the parts of Perfia, in Caramania. The leffer blew is found very plentifully wilde, in many places both of Spaine and Italy. The laft hath beene brought vs likewife out of Spaine, whereas it is thought it groweth naturally. They all grow now in the gardens of thofe, that are curious louers of thefe delights.

\section{The Time.}

They flower in Summer, and their feede is ripe quickly after.

\section{The Names.}

They are generally called Lupini. Plautus in his time faith, they were vfed in Comedies in ftead of money, when in any Scene thereof there was any thew of payment, and therefore he calleth them Aurum Comicum. And Horace hath this Verfe,

\section{Nec tamen ignorant, quid diftent ara Lupinis,}

to thew that counterfeit money (fuch as counters are with vs, or as thefe Lupines were vfed in thofe times) was eafily knowne from true and currant coine. In Englifh wee vfually call them after the Latine name, Lupines; and fome after the Dutch name, Figge-beanes, becaufe they are flat and round as a Figge that is preffed; and fome Flat-beanes for the fame reafon. Some haue called the yellow Lupine, Spanifh Violets: but other foolifh names haue beene giuen it, as Virginia Rores, and the like, by knauifh Gardiners and others, to deceiue men, and make them beleeue they were the finders out, or great preferuers of rarities, of no other purpofe, but to cheate men of their money: as you would therefore auoyde knaues and deceiuers, beware of thefe manner of people, whereof the skirts of our towne are too pitifully peftered.

\section{The Vertues.}

The firt or ordinary Lupine doth fcoure and cleanfe the skin from fpots, morphew, blew markes, and other difcolourings thereof, beeing vfed eyther in a decoction or pouther. Wee feldome vfe it in inward medicines, not that it is dangerous, but of neglect, for formerly it hath beene much vfed for the wormes, \&c. 


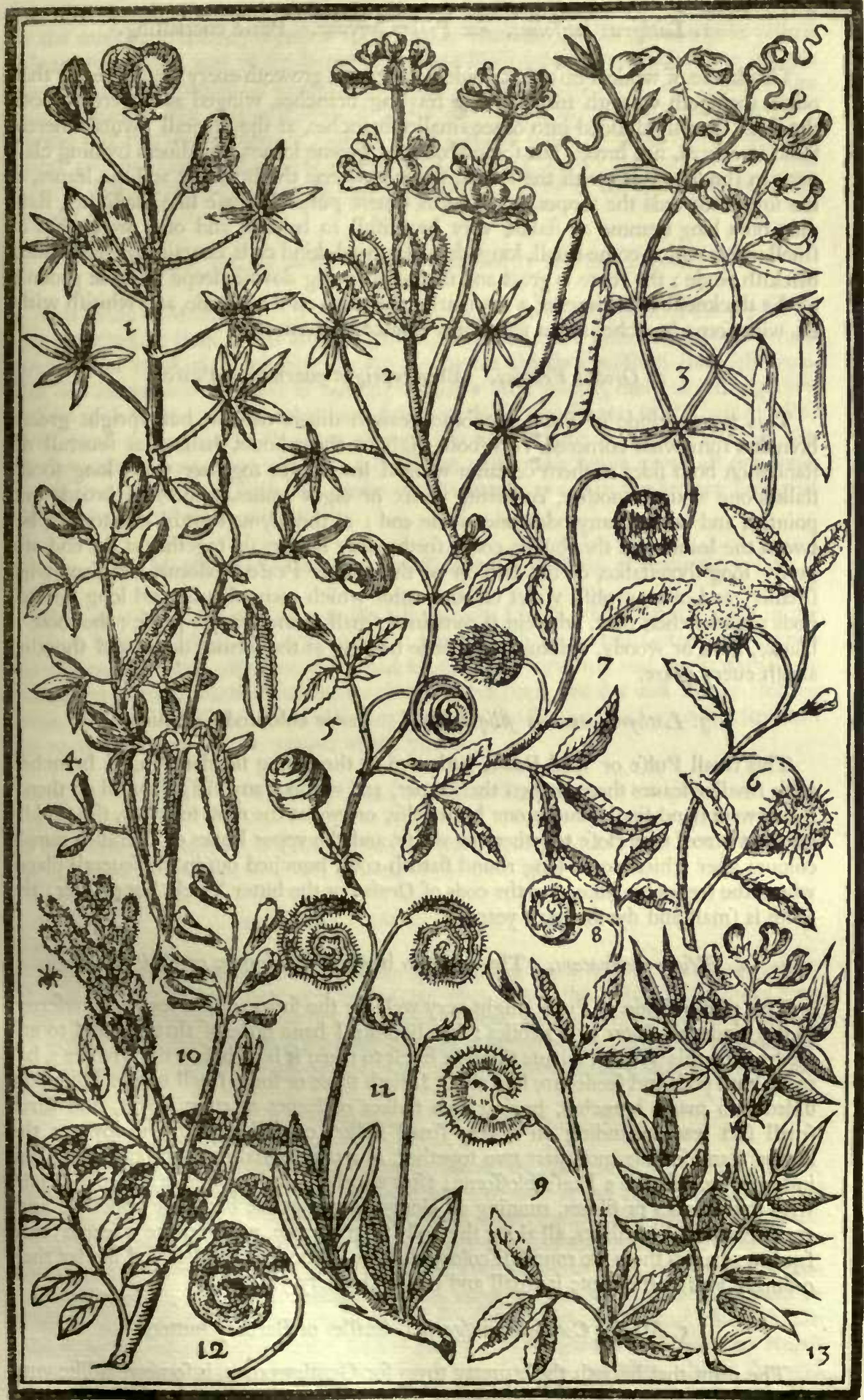

I Lupinus maior. The great Lupine. 2 Lupinus luteus. The yellow Lupine. 3 Lashyrus Latifolius feu Pifwm perenne. Peafe euerlafting. 4 Pifum quadratum. The crimfon blofiond or fquare Peafe. 5 Medica cochleata vinlgaris. Snailes or
Barbary buttons. 6 Medica fpinofa. Prickly Snailes. 7 Medica Spinefa altera. Another fort of prickly Snailes. 8 Medica folliculo Lala. Broad buttons or Snailes. 9 Medica lunala. Halfe Moons. Jo Hedyfarum clypeatum. The red Sattin flower or French Honerfuckle. 11 Scoppioides minus. The leffer Caterpillar. 32 Scorpioides maius. The greater Caterpillar, 13 Orobus Venetus. Blew vpright Peafe euerlafting. 


\section{Lathyrus latifolius, fuue Pifum perenne. Peafe euerlafting.}

This kinde of wilde Peafe that abideth long, and groweth euery yeare greater then other, fpringeth vp with many broade trayling branches, winged as it were on both the fides, diuerly diuided into other fmaller branches, at the feuerall ioynts whereof ftand two hard, not broad, but fomewhat long greene leaues, and diuers twining clafpers, in fundry places with the leaues, from betweene the branches and the leaues, at the ioynts towards the toppes, come forth diuers purplifh peafe like bloffomes, ftanding on a long ftemme or ftalke, very beautifull to behold, and of a pretty fent or fmell : after which come fmall, long, thin, flat, hard skind cods, containing $\mathrm{fmall}$ round blackifh feede : the roote is great and thicke, growing downe deepe into the ground, of the thickneffe fometimes of a mans arme, blackifh on the outfide, and whitifh within, with fome branches and a few fibres annexed thereunto.

\section{Orobus Venetus. Blew vpright euerlafting Peafe.}

This pretty kinde of Peafe bloffome beareth diuers flender, but vpright greene branches fomewhat cornered, two foote high or thereabouts, hauing at feuerall diftances on both fides of them certaine winged leaues, fet together vpon long footeftalkes one againft another, confifting of fix or eight leaues, fomewhat broade and pointed; and without any odde one at the end : at the ioynts toward the toppes, between the leaues and the ftalkes, come forth many flowers fet together at the end of a pretty long footeftalke, of the fafhion of the former Peafe bloffome, but fomewhat imaller, and of a purplifh violet colour : after which come flender and long pointed pods rounder then they, wherein is contained fmall round grayin peafe : the roote is blacke, hard or woody, abiding after feede bearing as the former doth, and fhooting afrefh euery yeare.

\section{Lathyrus annuus filiquis orobi. Partie coloured Cichelings.}

This fmall Pulfe or wild Peafe, hath two or three long flender winged branches, with fmaller leaues thereon then the former, and without any clafpers at all on them: the flowers ftand fingle, euery one by it felfe, or two at the moft together, the middle leaues whereof that clofe together are white, and the vpper leaues of a reddifh purple colour: after which come long round flattifh cods, bunched out in the feuerall places where the feedes lye, like vnto the cods of Orobus or the bitter Vetch, but greater: the roote is fmall and dyeth euery yeare.

\section{Pifum quadratum. The crimfon bloffomd or fquare codded Peafe.}

This pretty kinde of Pulfe might very well for the forme of the leaues, be referred to the kindes of Lotus or Trefoiles : but becaufe I haue none of that kindred to entreate of in this Worke, I haue thought fitteft to place it here before the Medica's, becaufe both pods and feedes are like alfo. It hath three or foure fmall weake ftalkes, diuided into many branches, hauing two ftalkes of leaues at euery ioynt, and three fmall foft leaues ftanding on a very fmall ftalke, comming from the ioynts: the flowers ftand for the mort part two together, of a perfect red or crimfon colour, like in forme almoft vnto a Peafe bloffome; after which come long thicke and round cods, with two skinnes or filmes, running all along the cod at the backe or vpperfide and, two other fuch like filmes, all along the belly or vnder fide, which make it feeme foure fquare, wherein there lye round difcoloured Peafe, fomewhat fmaller and harder then ordinary Peafe : the roote is fmall and perifheth euery yeare.

\section{Medica Cochleata vulgaris. Snailes or Barbary buttons.}

The plant that beareth thefe pretty toyes for Gentlewomen, is fomewhat like vnto a Three leafed graffe or Trefoile, hauing many long trayling branches lying vpon the ground, whereon at diuers places are three fmall greene leaues, fet together at the end of a little footeftalke, each of them a little fnipt about the edges: at feuerall diftances, 
from the middle of thefe branches to the ends of them, come forth the flowers, two for the moft part ftanding together vpon a little footftalke, which are of a pale yellow colour, very fmall, and of the forme of a Peafe bloffome: after which come finooth heads, which are turned or writhen round, almoft like a Snaile, hard and greene at the firft, fomewhat like a greene button (from the formes of both which came their names) but afterwards growing whiter, more foft and open, wherein lyeth yellowifh round and flat feede, fornewhat like vnto the Kidney beane: the roote is finall and ftringie, dying downe euery yeare, and muft be new fowne in the fpring, if you defire to have it.

\section{Medica Spinofa maior. Prickly or thorny Snailes, or Buttons.}

This kinde of Medica is in all things very like vnto the former, both in the long trayling branches, \& three leaues alwaies growing together, but a little greater pale yellow flowers, and crooked or winding heads: but herein chiefly confifteth the difference, that this kinde hath his heads or buttons harder, a little greater, more clofed together, and fet with fhort and fomewhat hard prickles, all the head ouer, which being pulled open, haue thofe prickles ftanding on each fide of the filme or skinne, whereof the head confifteth, fomewhat like vnto a fifh bone, and in this kinde goeth all one way; in which are contained fuch like feedes for the forme, as are in the former, but great and blacke, and thining withall.

\section{Medica Spinofa altera. Sinall thorney Buttons, or Snailes.}

This other kinde is alfo like vnto the laft defcribed in all other things, except in the heads or buttons, which are a little fmaller, but fet with longer and fofter prickes vpon the filmes, and may eafily bee difcerned to goe both forwards and backewards, one enterlacing within another, wherein are contained fuch like flat and blacke fhining feede, made after the fafhion of a kidney, as are in the former, but fomewhat Imaller: the roote perifheth in like manner euery yeare.

\section{Medica lata. Broade Buttons.}

This kinde differeth not from the firt in leafe or flower, the fruite onely hereof is broade and flat, and not fo much twined as it.

\section{Medica Lunata. Halfe Moones.}

This is alfo a kinde of thefe Medicke fodders, hauing a trefoyle leafe and yellow flowers like the former forts, but both fomewhat larger, the chiefeft difference confilteth in the head or fruite, which is broade and flat, and not twined like the reft, but abideth halfe clofed, refembling a halfe Moone (and thereupon hath affumed both the Latine and Englifh name) wherein is contained flat feede, kidney fafhion like the former.

\section{Hedy farum clypeatum. The red Sattin flower.}

This red flowred Fitchling, hath many ftalkes of winged faire greene leaues, that is, of many fet on both fides a iniddle ribbe, whereof that at the end is the greateft of the reft: from the ioynts where the leaues itand, come forth pretty long fmall ftalkes, bearing on them very many flowers, vp to the toppe one aboue another, of an excellent fhining red or crimfon colour, very like vnto Sattin of that colour, and fometimes of a white colour, (as Mafter William Coys, a Gentleman of good refpect in Effex, a great and ancient louer and cherifher of thefe delights, and of all other rare plants, in his life time affured me, he had growing in his garden at Stubbers by North Okenden) which are fomewhat large, and more clofed together, almoft flat and not open, as in moft of the other forts: after the flowers are paft, there come rough, flat, round huskes, fomewhat like vnto the old fafhioned round bucklers without pikes, three or foure ftanding one vpon or aboue another, wherein are contained 
fmall brownifh feede: the roote perifheth the fame yeare it beareth feede, for oftentimes it flowreth not the firft yeare it is fowne.

\section{Scorpioides maius $\&$ mintes.}

Great and fmall Caterpillers.

Vnder one defcription I comprehend both thefe forts of Scorpions graffe, or Caterpillers, or Wormes, as they are called by many, whereof the greater hath been known but of late yeares; and ioyne them to thefe pulfes, not hauing a fitter place where to infert them. It is but a fmall low plant, with branches lying vpon the ground, and fomewhat long, broad, and hard leaues thereon, among which come forth fmall ftalkes, bearing at the end for the moft part, two fmall pale yellowifh flowers, like vnto Tares or Vetches, but fmaller, which turne into writhed or crooked tough cods; in the greater fort they are much thicker, rounder and whiter, and leffer wound or turned together then in the fmaller, which are flenderer, more winding, yet not clofing like vnto the Snailes, and blacker more like vnto a Caterpiller then the other, wherein are contained brownith yellow feede, much like vnto a Medica: the rootes of both are fmall and fibrous, perifhing euery yeare.

\section{The Place.}

Thefe are found feuerally in diuers and feuerall places, but wee fow and plant them vfually to furnifh our Gardens.

\section{The Time.}

They doe all flower about the moneths of Iune and Iuly, and their feede is ripe foone after: but the fecond is earlier then the reft.

\section{The Names.}

The firft is called Clymenum of Matthiolus, and Lathyris of Lobel and others: but Lathyris in Greeke is Cataputia in Latine, which is our Spurge, farre differing from this Pulfe; and therefore Lathyrus is more proper to diftinguifh them afunder, that two plants fo farre vnlike fhould not bee called by one name: this is alfo called Lathyrus latifolius, becaufe there is another called angufifolius, that differeth from it alfo: It is moft vfually called with vs, Pifum perenne, and in Englifh Peafe bloffome, or Peafe euerlafting. The fecond is called by Clufius, Orabus venetus, becaufe it was fent him from Venice, with another of the fame kinde that bore white flowers; yet differeth but little or nothing from that kinde he found in Hungary, that I thinke the feuerall places of their growing only caufe them to beare feuerall names, and to be the fame in deede. Although I yeeld vnto Clufius the Latine name which doth not fufficiently content mee; yet I haue thought good to giue it a differing Englifh name, according as it is in the title. The third, becaufe I firft receiued it among other feeds from Spaine, I haue giuen it the name, as it is entituled. The fourth is called of fome Sandalida Cretica, E Lotus filiquofus fore rubello, Lotus tetragonolobus, Pifium rubrum, \& Pifum quadratum: We vfually call it in Englifh, Crimfon Peafe, or fquare Peafe. The Medica Cochleata is called of Dodonæus T'rifolium Cochleatum, but not iudged to be the true Medica. Wee call it in Englifh, Medick fodder, Snailes Clouer, or as it is in the title, and fo the reft of the Medica's accordingly. The Hedyfarum clypeatum or Securidaca is called of Dodonæus Onobrichis altera, and we in Englith for the likeneffe, The red Sattin flower, although fome foolifhly call it, the red or French Honyfuckle. The laft is called by Lobel, Scorpioides bupleurifolio, I haue called it minus, becaufe the greatent fort which came to me out of Spaine was not knowne vnto him : in Englifh they are generally called Caterpillers. 


\section{The Vertues.}

The Medica's are generally thought to feede cattell fat much more then the Medow Trefoile, or Clouer grafle, and therefore I haue known diuers Gentlemen that haue plowed vp fome of their pafture grounds, and fowen them with the feedes of fome Medica's to make the experience. All the other forts are pleafures to delight the curious, and not any way profitable in Phyficke that I know.

\section{Ch A P. L X X X.}

\section{Pronia. Peonie.}

$\mathrm{T}$

Here are two principall kindes of Peonie, that is to fay, the Male and the Female. Of the male kinde, I haue onely known one fort, but of the Female a great many; which are thus to be diftinguifhed. The Male his leafe is whole, without any particular diuifion, notch or dent on the edge, \& his rootes long \& round, diuided into many branches, fomewhat like to the rootes of Gentian or Elecampane, and not tuberous at all. The Female of all forts hath the leaues diuided or cut in on the edges, more or leffe, and hath alwaies tuberous rootes, that is, like clogs or Afphodill rootes, with many great thick round peeces hanging, or growing at the end of fmaller ftrings, and all ioyned to the toppe of the maine roote.

\section{Pconia mas. The Male Peonie.}

The Male Peonie rifeth vp with many brownifh ftalkes, whereon doe grow winged leaues, that is, many faire greene, and fometimes reddifh leaues, one fet againft another vpon a ftalke, without any particular diuifion in the leafe at all : the flowers ftand at the toppes of the ftalkes, confifting of fiue or fix broade leaues, of a faire purplifh red colour, with many yellow threds in the middle, ftanding about the head, which after rifeth to be the feede veffels, diuided into two, three or foure rough crooked pods like hornes, which when they are ful ripe, open and turn themfelues down one edge to another backeward, fhewing within them diuers round black fhining feede, which are the true feede, being full and good, and hauing alfo many red or crimfon graines, which are lancke and idle, intermixed among the blacke, as if they were good feede, whereby it maketh a very pretty thew : the roots are great, thick and long, f preading in the ground, and running downe reafonable deepe.

\section{Paonia famina vulgaris flore fimplici.}

The ordinary fingle Female Peonie.

This ordinary Female Peonie hath many ftalkes, with more ftore of leaues on them then the Male kinde hath, the leaues alfo are not fo large, but diuided or nicked diuerfly on the edges, fome with great and deepe, and others with fmaller cuts or diuifions, and of a darke or dead greene colour : the flowers are of a ftrong heady fent, moft vfually fmaller then the male, and of a more purple tending to a murrey colour, with yellow thrumes about the head in the middle, as the male kinde hath: the heads or hornes with feed are like alfo but fmaller, the feede alfo is blacke, but leffe fhining: the rootes confift, as I faid, of many thicke and fhort tuberous clogs, faftened at the ends of long ftrings, and all from the head of the roote, which is thicke and fhort, and tuberous alfo, of the fame or the like fent with the male.

\section{Paonia famina vulgaris flore pleno rubro.}

The double red Peonie.

This double Peonie as well as the former fingle, is fo frequent in euerie Garden of note, through euery Countrey, that it is almoft labour in vaine 
to defcribe it: but yet becaufe I vfe not to paffe ouer any plant fo flightly, I will fet down the defcription briefly, in regard it is fo common. It is very like unto the former fingle female Peony, both in ftalkes and leaues, but that it groweth fomewhat higher, and the leaues are of a frefher greene colour: the flowers at the tops of the ftalkes are very large, thicke and double (no flower that I know fo faire, great, and double; but not abiding blowne aboue eight or ten daies) of a more reddifh purple colour then the former female kinde, and of a fweeter fent : after thefe flowers are paft, fometimes come good feed, which being fowne, bring forth fome fingle flowers, and fome double: the rootes are tuberous, like vnto the former female.

\section{Paonia famina fore carneo fimplici. The fingle blufh Peony.}

The fingle blufh Peony hath his ftalkes higher, and his leaues of a paler or whiter greene colour then the double blufh, and more white vnderneath (fo that it is very probable it is of another kinde, and not rifen from the feede of the double blufh, as fome might thinke) with many veines, that are fomewhat difcoloured from the colour of the leafe running through them : the flowers are very large and fingle, confifting of fiue leaues for the moft part, of a pale fleth or blufh colour, with an eye of yellow difperfed or mixed therewith, hauing many whitifh threads, tipt with yellow pendents ftanding about the middle head: the rootes are like the other female Peonies.

\section{Paronia famina fore pleno albicante. The double bluh Peony.}

The double blufh Peony hath not his ftalkes fo high as the double red, but fomewhat lower and ftiffer, bearing fuch like winged leaues, cut in or diuided here and there in the edges, as all thefe female kindes are, but not fo large as the laft : the flowers are fmaller, and leffe double by a good deale then the former double red, of a faint thining crimfon colour at the firft opening, but decaying or waxing paler euery day: fo that after it hath ftood long (for this flower fheddeth not his leaues in a great while) it will change fomewhat whitifh; and therefore diuers haue ignorantly called it, the double white Peony : the feedes, which fometimes it beareth, and rootes, are like vnto the former female kindes, but fomewhat longer, and of a brighter colour on the outfide.

\section{Paonia famina Byzantina. The fingle red Peony of Conftantinople.}

This red Peony of Conftantinople is very like in all things vnto the double red Peonie, but that the flowers hereof are fingle, and as large as the laft, and that is larger then either the fingle female, or the male kinde, confifting of eight leaues, of a deeper red colour then either the fingle or double Peonies, and not purplifh at all, but rather of the colour of an ordinary red Tulipa, ftanding clofe and round together : the roots of this kinde haue longer clogs, and not fo thort as of the ordinary female kinde, and of a paler colour on the outfide.

\section{The Place.}

All thefe Peonies haue beene fent or brought from diuers parts beyond the Seas; they are endenized in our Gardens, where wee cherifh them for the beauty and delight of their goodly flowers, as well as for their Phyficall vertues.

The Time.

They all flower in May, but fome (as I faid) abide a fmall time, and others many weekes.

\section{The Names.}

The name Pconia is of all the later Writers generally giuen to thefe plants, although they haue had diuers other names giuen by the elder W riters, as Rofa fatuina, Idaus dactylus, Aglaophotis, and others, whereof to fet 


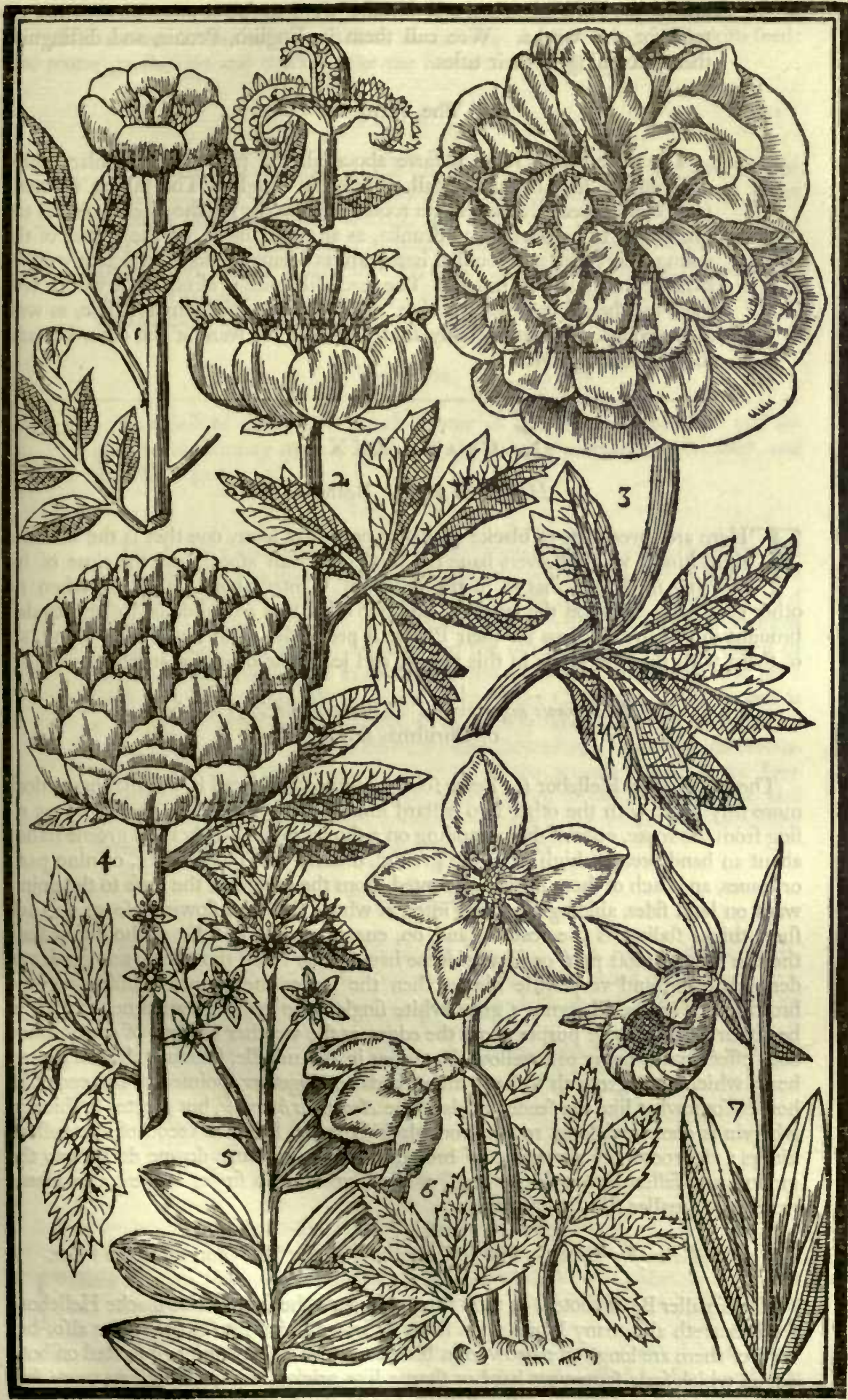

1 Peonia mas com fomire. The male Peony \& the feed. 2 Paonia famina Bysantins. The female red Peony of Conftantinopic. 3 Paomia famina Alore pleno vwlgaris. The ordinary double Peony. 4 Paomia fore pleno albirante. The double white Peony. 5 Helleborus sernus atronbente Rors. The early white Ellebor with a darke red Rower. 6 Helleborus niger rerus. The Chriftmas flower. 7 Calecolws Mnria. Our Ladies Slipper. 
downe the caufes, reafons, and errours, were to fpend more time then I intend for this worke. Wee call them in Englifh, Peonie, and diftinguifh them according to their titles.

The Vertues.

The male Peony roote is farre aboue all the reft a moft.fingular approued remedy for all Epilepticall difeafes, in Englifh, The falling fickneffe (and more efpecially the greene roote then the dry) if the difeafe be not too inueterate, to be boyled and drunke, as alfo to hang about the neckes of the younger fort that are troubled herewith, as I haue found it fufficiently experimented on many by diuers. The feede likewife is of efpeciall vfe for women, for the rifing of the mother. The feede of the female kinde, as well as the rootes, are moft vfually fold, and may in want of the other be (and fo are generally) vfed.

\section{C н А P. L XXXI.}

\section{Helleborus niger. Beares foote.}

T Here are three forts of blacke Hellebor or Beares foote, one that is the true and right kinde, whofe flowers haue the moft beautifull afpect, and the time of his flowring moft rare, that is, in the deepe of Winter about Chriftmas, when no other can bee feene vpon the ground : and two other that are wilde or baftard kindes, brought into many Gardens for their Phyficall properties; but I will only ioyne one of them with the true kinde in this worke, and leaue the other for another.

\section{Helleborus niger verus. The true blacke Hellebor, or Chriftmas flower.}

The true blacke Hellebor (or Beare foote as fome would call it, but that name doth more fitly agree with the other two baftard kindes) hath many faire greene leaues rifing from the roote, each of them ftanding on a thicke round flefhly ftiffe greene ftalke, about an hand breadth high from the ground, diuided into feuen, eight, or nine parts or leaues, and each of them nicked or dented, from the middle of the leafe to the pointward on both fides, abiding all the Winter, at which time the flowers rife vp on fuch fhort thicke ftalkes as the leaues ftand on, euery one by it felfe, without any leafe thereon for the moft part, or very feldome hauing one fmall thort leafe not much vnder the flower, and very little higher then the leaues themfelues, confifting of fiue broad white leaues, like vnto a great white fingle Rore (which fometimes change to be either leffe or more purple about the edges, as the weather or time of continuance doth effect) with many pale yellow thrummes in the middle, ftanding about a greene head, which after groweth to have diuers cods fet together, pointed at the ends like hornes, fomewhat like the feede veffels of the Aconitum hyemale, but greater \& thicker, wherein is contained long, round, and blackifh feede, like the feede of the baftard kindes: the rootes are a number of brownifh ftrings running downe deepe into the ground, and faftened to a thicke head, of the bigneffe of a finger at the toppe manie times, and fmaller ftill downewards.

\section{Helleborafter minor. The leffer baftard blacke Hellebor, or Beare foote.}

The fmaller Beare foote is in moft things like vnto the former true blacke Hellebor; for it beareth alfo many leaues vpon thort ftalkes, diuided into many leaues alfo, but each of them are long and narrow, of a blacker greene colour, fnipt or dented on both edges, which feele fomewhat hard or Tharpe like prickes, and perifh euery yeare, but rife againe the next Spring: the flowers hereof ftand on higher ftalkes, with fome leaues on them alfo, although but very few, and are of a pale greene colour, like in 
forme vnto the flowers of the former, but fmaller, hauing alfo many greenifh yellow threads or thrums in the middle, and fuch like heads or feede veffels, and blackifh feed: the rootes are ftringie and blackifh like the former.

\section{The Place.}

The firft groweth onely in the Gardens of thofe that are curious, and delight in all forts of beautifull flowers in our Countrey, but wilde in many places of Germany, Italy, Greece, \&c.

The other groweth wilde in many places of England, as well as the other greater fort, which is not here defcribed; for befides diuers places within eight or ten miles from London, I haue feen it in the Woods of Northamptonfhire, and in other places.

\section{The Time.}

The firft of thefe plants doth flower in the end of December, and beginning of Ianuary moft vfually, and the other a moneth or two after, and fometime more.

\section{The Names.}

The firft is called Helleborus, or Elleborus niger verus, and is the fame that both Theophraftus and Diofcorides haue written of, and which was called Melampodion, of Melampus the Goateheard, that purged and cured the mad or melancholicke daughters of Prætus with the rootes thereof. Dodonæus calleth it Veratrum nigrum primum, and the other fecundum: Wee call it in Englifh, The true blacke Hellebor, or the Chriftmas flower, becaufe (as I faid) it is moft commonly in flower at or before Chriftmas. The fecond is a baftard or wilde kinde thereof, it fo nearely refembleth the true, and is called of moft of the later Writers, P feudoelleborus niger minor, or Helleborafer minor, for a diftinction betweene it and the greater, which is not here defcribed: and is called in Englifh, The fmaller or leffer Beare foote, and moft vfed in Phyficke, becaufe it is more plentifull, yet it is more churlifh and ftrong in operation then the true or former kinde.

\section{The Vertues.}

The rootes of both thefe kindes are fafe medecines, being rightly prepared, to be vfed for all Melancholicke difeafes, whatfoeuer others may feare or write, and may be without danger applied, fo as care and skill, and not temerary rafhneffe doe order and difpofe of them.

The powder of the dryed leaues, efpecially of the baftard kinde, is a fure remedy to kill the wormes in children, moderately taken.

\section{Ch A P. L X X XII.}

\section{Elleborus albus. White Ellebor or Neefewort.}

Here are two forts of great white Ellebors or Neefeworts, whereas there was but one kinde knowne to the Ancients; the other being found out of later dayes: And although neither of both thefe haue any beauty in their flowers, yet becaufe their leaues, being faire and large, haue a goodly profpect, I haue inferted them in this place, that this Garden fhould not be vnfurnifhed of them, and you not vnacquainted with them. 


\section{Elleborus albus vulgaris. White Ellebor or Neefing roote.}

The firft great white Ellebor rifeth at the firft out of the ground, with a whitifh greene great round head, which growing vp, openeth it felfe into many goodly faire large greene leaues, plaited or ribbed with eminent ribbes all along the leaues, compaffing one another at the bottome, in the middle whereof rifeth vp a ftalke three foot high or better, with diuers fuch like leaues thereon, but fmaller to the middle thereof; from whence to the toppe it is diuided into many branches, hauing many fnall yellowifh, or whitifh greene ftarre-like flowers all along vpon them, which after turne into fmall, long, three fquare whitifh feede, ftanding naked, without any huske to containe them, although fome haue written otherwife : the roote is thicke and reafonable great at the head, hauing a number of great white ftrings running downe deepe into the ground, whereby it is ftrongly faftened.

2. Elleborus albus pracox fue atrorubente flore.

The early white Ellebor with reddifh flowers.

This other Ellebor is very like the former, but that it fpringeth vp a moneth at the leaft before it, and that the leaues are not fully fo thicke or fo much plaited, but as large or larger, and doe fooner perioh and fall away from the plant: the ftalke hereof is as high as the former, bearing fuch like ftarry flowers, but of a darke or blackifh red colour: the feede is like the other: the roote hath no fuch head as the other (fo farre as I haue obferued, both by mine own and others plants) but hath many long white ftrings faftened to the top, which is as it were a long bulbous fcaly head, out of which fpring the leaues.

\section{The Place.}

The firft groweth in many places of Germany, as alfo in fome parts of Ruffia, in that aboundance, by the relation of that worthy, curious, and diligent fearcher and preferuer of all natures rarities and varieties, my very good friend, Iohn Tradefcante, often heretofore remembred, that, as hee faid, a good thip might be loaden with the rootes hereof, which hee faw in an Inand there.

The other likewife groweth in the vpland wooddy grounds of Germanie, and other the parts thereabouts.

The Time.

The firf springeth vp in the end or middle of March, and flowreth in Iune. The fecond fpringeth in February, but flowreth not vntill Iune.

\section{The Names.}

The firft is called Elleborus albus, or Helleborus albus, the letter $H$, as all Schollers know, being but aspirationis nota: and Veratrum album flore viridante, of fome Sanguis Herculis. The other is called Elleborus albus pracox, and flore atrorubente, or atropurpurante. We call the firt in Englifh, White Ellebor, Neefewort, or Neefing roote, becaufe the powder of the roote is vfed to procure neefing; and I call it the greater, in regard of thofe in the next Chapter. The other hath his name according to the Latine title, moft proper for it.

\section{The Vertues.}

The force of purging is farre greater in the roote of this Ellebor, then in the former; and therefore is not carelefly to bee vfed, without extreame danger; yet in contumatious and ftubborne difeafes it may bee vfed with 
good caution and aduice. There is a Syrupe or Oxymel made hereof in the Apothecaries fhops, which as it is dangerous for gentle and tender bodies, fo it may be very effectuall in ftronger conftitutions. Paufanias in Phocicis, recordeth a notable ftratagen that Solon ved in befieging the Citie of Cirrheus, vir. That hauing cut off the riuer Pliftus from running into the Citie, he caufed a great inany of thefe rootes to be put into a quantity thereof, which after they had fteeped long enough therein, and was fufficiently infected therewith, he let paffe into the Citic againe: whereof when they had greedily drunke, they grew fo weake and feeble by the fuperpurgation thereof, that they were forced to leaue their wals vnmand, and not guarded, whereby the Amphyctions their enemies became mafters of their Citie. The like ftratagems are fet downe by diuers other Authors, performed by the helpe of other herbes.

\section{Ch A P. L X X XIII.}

\section{Elleborine. Small or wilde white Ellebor.}

7 He likeneffe of the leaues of thefe plants, rather then any other faculty with the former white Ellebor, hath caufed them to be called Elleborine, as if they were funaller white Ellebors. And I for the fame caufe have ioyned them next, whereof there are found many forts: One which is the greater kinde, is of greateft beauty; the other which are leffer differ not much one from another, more then in the colour of the flowers, whereof I will onely take three, being of the molt beautie, and leaue the reft to another worke.

\section{Helleborine vel Elleborine maior, fune Calceolus Maria. Our Ladies Slipper.}

This moft beautifull plant of all thefe kindes, rifeth vp with diuers ftalkes, a foote and a halfe high at the moft, bearing on each fide of them broad greene leaues, fomewhat like in forme vnto the leaues of the white Ellebor, but fmaller and not fo ribbed, compaffing the ftalke at the lower end; at the tops of the ftalkes come forth one, or two, or three flowers at the moft, one aboue another, vpon Imall fhort foote-ftalkes, with a fmall leafe at the foote of euery ftalke: each of thefe flowers are of a long ouall forme, that is, more long then round, and hollow withall, efpecially at the vpper part, the lower being round and fwelling like a belly: at the hollow part there are two finall peeces like eares or flippets, that at the firft doe couer the hollow part, and after ftand apart one from another, all which are of a fine pale yellow colour, in all that $I$ haue feene (yet it is faid there are fome found, that are more browne or tending to purple) there are likewife foure long, narrow, darke coloured leaues at the fetting on of the flower vnto the ftalke, wherein as it were the flower at the firft ftandeth : the whole flower is of a pretty fmall fent : the feede is very fmall, very like vnto the feede of the Orchides or Satyrions, and contained in fuch like long pods, but bigger : the roots are compofed of a number of ftrings enterlacing themfelues one within another, lying within the vpper cruft of the earth, \& not fpreading deep, of a darke brownifh colour.

\section{Elleborine minor flore albo.}

The fmall or wilde white Ellebor with a white flower.

This fimaller wilde white Ellebor rifeth vp in the like manner vnto the former, and not much lower, bearing fuch like leaues, but fmaller, and of a whiter greene colour, almoft of the colour and fafhion of the leaues of Lilly Conually; the top of the ftalke hath many more flowers, but leffer, growing together, [pike-fanion, with fmall fhort leaues at the ftalke of euery flower, which confifteth of fue Imall white leaues, with a fmall clofe hood in the middle, without any fent at all : the feede and feede veffels are 
like vnto the former, but fmaller: the rootes are many fmall ftrings, difperfing themfelues in the ground.

\section{Ellebarine minor flore purpurante.}

The frnall or wilde white Ellebor with blufh flowers.

The leaues of this kinde are like vnto the laft defcribed, but fomewhat narrower: the ftalkes and flowers are alike, but fmaller alfo, and of a pale purplifh or blufh colour, which caufeth the difference.

\section{The Place.}

The firt groweth in very many places of Germany, and in other Countries alfo. It groweth likewife in Lancafhire, neare vpon the border of Yorkefhire, in a wood or place called the Helkes, which is three miles from Ingleborough, the higheft Hill in England, and not farre from Ingleton, as I am enformed by a courteous Gentlewoman, a great louer of thefe delights, called Miftris Thomafin Tunftall, who dwelleth at Bull-banke, neare Hornby Caftle in thofe parts, and who hath often fent mee vp the rootes to London, which haue borne faire flowers in my Garden. The fecond groweth in many places of England, and with the fame Gentlewoman alfo before remembred, who fent me one plant of this kinde with the other. The laft I haue not yet knowne to growe in England; but no doubt many things doe lye hid, and not obferued, which in time may bee difcouered, if our Country Gentlemen and women, and others, in their feuerall places where they dwell, would be more carefull and diligent, and be aduertifed either by themfelues, or by others capable and fit to be imployed, as occafion and time might ferue, to finde out fuch plants as growe in any the circuits or limits of their habitations, or in their trauels, as their plearures or affaires leade them. And becaufe ignorance is the chiefe caufe of neglect of many rare things, which happen to their view at fometimes, which are not to be feene againe peraduenture, or not in many yeares after, I would heartily aduife all men of meanes, to be ftirred vp to bend their mindes, and fpend a little more time and trauell in thefe delights of herbes and flowers, then they haue formerly done, which are not onely harmleffe, but pleafurable in their time, and profitable in their vfe. And if any would be better enformed, and certified of fuch things they know not, I would be willing and ready to my beft skill to aduertife them, that fhall fend any thing vp to me where I dwell in London. Thus farre I haue digreffed from the matter in band, and yet not without fome good vfe I hope, that others may make of it.

\section{The Time.}

The two firft flower earlier then the laft, and both the firft about one time, that is, in the end of Aprill, or beginning of May. The laft in the end of May, or in Iune.

\section{The Names.}

The firt is called Elleborine recentiorum maior, and Calceolus Maria: Of fome thought to be Cofmofandalos, becaufe it is Sandali forma. In Englin we call it our Ladies Slipper, after the Dutch name. The other two leffer kinds haue their names in their titles: I haue thought it fit to adde the title of fmall white Ellebors vnto thefe, for the forme fake, as is before faid.

The Vertues.

There is no vfe of thefe in Phyficke in our dayes that I know.

CH A P. 


\section{CH A P. L X X XIIII.}

\section{Lilium Conuallium. Lilly Conually.}

T He remembrance of the Conuall Lilly, fpoken of in the precedent Chapter, hath caufed me to infert thefe plants among the reft, although differing both in face and properties; but left it fhould lofe all place, let it keepe this. It is of two forts, differing chiefly in the colour of the flowers, the one being white, and the other reddifh, as fhall be fhewed in their defcriptions following.

\section{Lilium Conuallium flore albo. The white Lilly Conually.}

The white Conuall or May Lilly, hath three or foure leaues rifing together from the roote, one enclofed within another, each whereof when it is open is long and broad, of a grayifh fhining greene colour, fomewhat refembling the leaues of the former wilde Neefewort, at the fide whereof, and fometime from the middle of them, rifeth vp a fmall fhort naked foote-ftalke, an hand breadth high or fomewhat more, bearing at the toppe one aboue another many fmall white flowers, like little hollow bottles with open mouths, nicked or cut into fiue or fix notches, turning all downewards one way, or on one fide of the ftalke, of a very ftrong fweete fent, and comfortable for the memory and fenfes, which turne into fmall red berries, like vnto Afparagus, wherein is contained hard white feede : the rootes runne vnder ground, creeping euery way, confifting of many fmall white ftrings.

\section{Lilium Conuallium flore rubente. May Lillies with red flowers.}

This other May Lilly differeth neither in roote, leafe, nor forme of flower from that before, but onely in the colour of the flower, which is of a fine pale red colour, being in my iudgement not altogether fo fweet as the former.

\section{The Place.}

The firft groweth aboundantly in many places of England. The other is a ftranger, and groweth only in the Gardens of thofe that are curious louers of rarities.

The Time.

They both flower in May, and the berries are ripe in Auguft.

The Names.

The Latines haue no other name for this plant but Lilium Conuallium, although fome would have it to be Lilium vernum of Theophraftus, and others Oenanthe of the fame Author. Gefner thinketh it to be Callionymus. Lonicerus to be Cacalia, and Fuchfius to be Ephemerum non lethale: but they are all for the moft part miftaken. We call it in Englifh Lilly Conually, May Lilly, and of fome Liriconfancie.

\section{The Vertues.}

The flowers of the white kinde are often vfed with thofe things that help to ftrengthen the memory, and to procure eafe to Apoplecticke perfons. Camerarius fetteth downe the manner of making an oyle of the flowers hereof, which he faith is very effectuall to eafe the paines of the Goute, and fuch like difeafes, to be vfed outwardly, which is thus: Hauing filled a glaffe with the flowers, and being well ftopped, fet it for a moneths fpace in an Ants hill, and after being drayned cleare, fet it by to vfe. 


\section{CH A P. LXXXV.}

\section{Gentiana. Gentian or Fell-wort.}

$\mathrm{T}$

Here are diuers forts of Gentians or Fell-wortes, fome greater, others leffer, and fome very fmall; many of them haue very beautifull flowers, but becaufe fome are very fuddenly paft, before one would thinke they were blowne open, and others will abide no culture and manuring, I will onely fet forth vnto you two of the greater forts, and three of the leffer kindes, as fitteft, and more familiarly furnifhing our gardens, leauing the reft to their wilde habitations, and to bee comprehended in a generall Worke.

\section{Gentiana maior flore faus. The great Gentian.}

The great Gentian rifeth vp at the firt, with a long, round and pointed head of leaues, clofing one another, which after opening themfelues, lye vpon the ground, and are faire, long and broad, fomewhat plaited or ribbed like vnto the leaues of white Ellebor or Neefeworte, but not fo fairely or eminently plaited, neyther fo ftiffe, but rather refembling the leaues of a great Plantane: from among which rifeth vp a ftiffe round ftalke, three foote high or better, full of ioynts, hauing two fuch leaues, but narrower and fmaller at euery ioynt, fo compaffing about the ftalke at the lower end of them, that they will almoft hold water that falleth into them: from the middle of the ftalke to the toppe, it is garnifhed with many coronets or rundles of flowers, with two fuch greene leaues likewife at euery ioynt, and wherein the flowers doe ftand, which are yellow, layd open like ftarres, and rifing out of fmall greenifh huskes, with fome threds in the middle of them, but of no fent at all, yet ftately to behold, both for the order, height and proportion of the plant: the feede is browne and flat, contained in round heads, fomewhat like vnto the feede of the Fritillaria, or checkerd Daffodill, but browner: the rootes are great, thicke and long, yellow, and exceeding bitter.

\section{Gentiana maior folio Afclepiadis. Swallow-wort Gentian.}

This kinde of Gentian hath many ftalkes rifing from the roote, neere two foote high, whereon grow many faire pale greene leaues, fet by couples, with three ribs in euery one of them, and doe fomewhat refemble the leaues of Afclepias or Swallowwort, that is, broade at the bottome, and fharpe at the point: the flowers grow at the feuerall ioynts of the ftalkes, from the middle vpwards, two or three together, which are long and hollow, like vnto a bell flower, ending in fiue corners, or pointed leaues, and folded before they are open, as the flowers of the Bindeweedes are, of a faire blew colour, fometimes deeper, and fometimes paler : the heads or feede veffels haue two points or hornes at the toppes, and containe within them flat grayifh feed, like vnto the former, but leffe: the rootes hereof are nothing fo great as the former, but are yellow, fmall and long, of the bigneffe of a mans thumbe.

\section{Gentiana minor Cruciata. Croffe-wort Gentian.}

This fmall Gentian hath many branches lying vpon the ground, fcarce lifting themfelues vpright, and full of ioynts, whereat grow vfually foure leaues, one oppofite vnto another, in manner of a Croffe, from whence it tooke his name, in thape very like vnto Saponaria or Sopewort, but fhorter, and of a darker greene colour: at the tops of the ftalkes ftand many flowers, thick thrufting together, and likewife at the next ioynt vnderneath, euery one of them ftanding in a darke blewifh greene huske, and confifting of fiue fmall leaues, the points or ends whereof only appeare aboue the huskes wherein they ftand, and are hardly to be feene, but that they are of a fine pale blew colour, and that many grow together : the feed is fmall and brown, hard, and fomewhat 


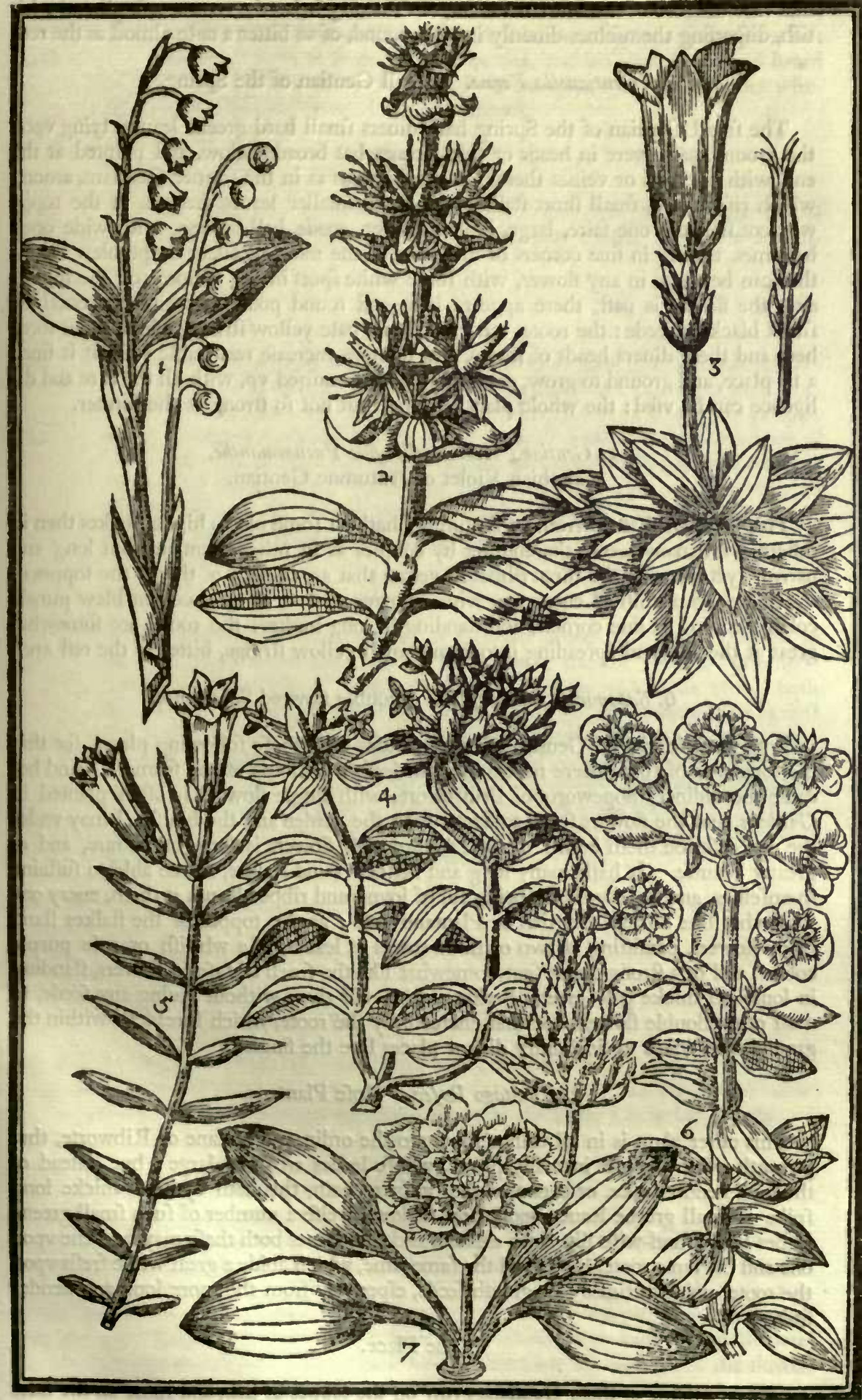

2 Lilixm Conuallium. Liricon fancy or Lilly Consally. 2 Gentiama maior. The great Gentian. 3 Gentianella verne. Small Gentian of the Spring. 4 Gentiana Cruciala. Croflewort Gencian. 5 Pweumonawlhe fon Gentiana Aulumnalis. Autumne 
like vnto the feed of the Marian Violets, or Couentry bels: the roots are fmall and whitifh, difperfing themfelues diuerly in the ground, of as bitter a tafte almoft as the reft.

\section{Gentianella Verna. Small Gentian of the Spring.}

The fmall Gentian of the Spring hath diuers fmall hard greene leaues, lying vpon the ground, as it were in heads or tufts, fomewhat broade below, and pointed at the end, with fiue ribs or veines therein, as confpicuous as in the former Gentians, among which rifeth vp a fmall fhort ftalke, with fome fmaller leaues thereon, at the toppe whereof ftandeth one faire, large, hollow flower, made bell fafhion, with wide open brimmes, ending in fiue corners or diuifions, of the moft excellent deepe blew colour that can be feene in any flower, with fome white fpots in the bottome on the infide: after the flower is paft, there appeare long and round pods, wherein are contained fmall blackifh feede: the rootes are finall, long, pale yellow ftrings, which fhoot forth here and there diuers heads of leaues, and thereby encreafe reafonable well, if it finde a fit place, and ground to grow, or elfe will not be nourfed vp, with all the care and diligence can be vfed: the whole plant is bitter, but not fo ftrong as the former.

\section{Gentiana Autumnalis fuce Pneumonanthe. \\ Calathian Violet or Autumne Gentian.}

This Gentian that flowreth in Autumne, hath in fome places higher ftalkes then in others, with many leaues thereon, fet by couples as in other Gentians, but long and narrow, yet fhewing the three ribbes or veines that are in each of them: the toppes of the ftalkes are furnifhed euery one with a flower or two, of an excellent blew purple colour, ending in fiue corners, and ftanding in long huskes: the rootes are fomewhat great at the top, and fpreading into many fmall yellow ftrings, bitter as the reft are.

\section{Saponaria flore duplici. Double flowred Sopeworte.}

Vnto thefe kindes of Gentians, I muft needes adde thefe following plants, for that the former is of fome neere refemblance in leafe with fome of the former. And becaufe the ordinary Sopeworte or Bruifeworte with fingle flowers is often planted in Gardens, and the flowers ferue to decke both the garden and the houfe ; I may vnder the one defcribe them both: for this with double flowers is farre more rare, and of greater beautie. It hath many long and flender round ftalkes, fcarce able to fuftaine themfelues, and ftand vpright, being ful of ioynts and ribbed leaues at them, euery one fomewhat like a fmall Gentian or Plantane leafe : at the toppes of the ftalkes ftand many flowers, confifting of two or three rowes of leaues, of a whitifh or pale purple colour, and of a ftrong fweet fent, fomewhat like the fmell of Iafmin flowers, ftanding in long and thicke pale greene huskes, which fall away without giuing any feede, as moft other double flowers doe that encreafe by the roote, which fpreadeth within the ground, and rifeth vp in fundry diftant places like the fingle.

\section{Plantago Rofea. Rofe Plantane.}

This other plant is in all things like vnto the ordinary Plantane or Ribworte, that groweth wilde abroade in many places, whofe leaues are very large : but inftead of the long flender fpike, or eare that the ordinary hath, this hath eyther a thicke long fpike of fmall greene leaues vpon thort ftalkes, or elfe a number of fuch fmall greene leaues layd round-wife like vnto a Rofe, and fometimes both thefe may be feene vpon one and the fame roote, at one and the fame time, which abide a great while frefh vpon the roote, and fometimes alfo giueth feede, efpecially from the more long and flender fpikes.

The Place.

Some of thefe Gentians grow on the toppes of hils, and fome on the fides and foote of them in Germany and other Countreyes: fome of them alfo vpon barren heaths in thofe places, as alfo in our owne Countrey, efpecial- 
ly the Autumne Gentian, and as it is reported, the Vernall likewife. The fingle or ordinary Sopeworte is found wilde in many places with vs, but the double came to vs from beyond the Sea, and is fcarce known or heard of in England. The Rofe Plantaine hath beene long in England, but whether naturall thereof or no, I am not affured.

\section{The Time.}

They flower for the moft part in Iune and Iuly, but the fmall Gentian of the Spring flowreth fomewhat earlier, and that of the Autumne in Auguft and September.

\section{The Names.}

Gentiana is the generall name giuen to the Gentians. We call them in Englifh Gentian, Fellworte, Bitterwort, and Baldmoney. Saponaria taketh his name from the fcouring qualitie it hath: Wee call it in Englifh Sopewort, and in fome places Bruifewort. Some haue thought it to bee Struthium of Diofcorides, or at leaft haue vfed it for the fame caufes, but therein they are greatly deceiued, as Matthiolus hath very well obferued thereon, and fo is Dodonæus, that thought it to be Alifma. The Rofe Plantaine is fo called of the double fpikes it carrieth.

\section{The Vertues.}

The wonderfull 'wholfomneffe of Gentian cannot bee eafily knowne to vs, by reafon our daintie taftes refufe to take thereof, for the bitterneffe fake: but otherwife it would vndoubtedly worke admirable cures, both for the liuer, ftomacke and lunges. It is alfo a fpeciall counterpoifon againft any infection, as alfo againft the violence of a mad dogges tooth: wilde Sopewort is vfed in many places, to fcoure the countrey womens treen, and pewter veffels, and phyfically fome make great boaft to performe admirable cures in Hydropicall difeafes, becaufe it is diureticall, and in Lue Veneria, when other Mercuriall medicines haue failed. The Rofe Plantaine no doubt hath the fame qualities that the ordinary hath.

\section{Ch A P. L XXXVI.}

\section{Campanula. Bell-flowers.}

$\mathrm{V}$ Nder the title of Bell-flowers are to bee comprehended in this Chapter, not only thofe that are ordinarily called Campanula, but Viola Mariana, and Trachelium alfo, whereof the one is called Couentry, the other Canterbury Bells.

\section{Campanula Per ficifolia alba, vel carulea.}

Peach-leafed Bell-flowers white or blew.

The Peach-leafed Bell-flower hath many tufts, or branches of leaues lying vpon the ground, which are long and narrow, fomewhat like vnto the leafe of an Almond or Peach tree, being finely nicked about the edges, and of a fad greene colour, from among which rife vp diuers ftalkes, two foote high or more, fet with leaues to the middle, and from thence vpwards, with many flowers ftanding on feuerall fmall footeftalkes, one aboue another, with a fmall leafe at the foote of euery one: the flowers ftand in fmall greene huskes, being fmall and round at the bottome, but wider open at the brimme, and ending in fiue corners, with a three forked clapper in the middle, fet about with fome fmall threds tipt with yellow, which flowers in fome plants are pure 
white, and in others of a pale blew or watchet colour, hauing little or no fent at all: the feede is fmall, and contained in round flat heads, or feede veffels: the roote is very fmall, white and threddy, creeping vnder the vpper cruft of the ground, fo that oftentimes the heat and drought of the Summer will goe near to parch and wither it vtterly: it requireth therefore to be planted in fome fhadowie place.

\section{Campanula maior, fue Pyramidalis.}

The great or fteeple Bell-flower.

This great Bell-flower hath diuers ftalkes, three foote high or better, whereon grow diuers fmooth, darke, greene leaues, broade at the bottome, and fmall at the point, fomewhat vneuenly notched about the edges, and ftanding vpon longer footeftalkes below then thofe aboue: the flowers are blew, and in fome white, not fo great or large as the former, but neare of the fame fafhion, growing thicker and more plentifully together, with fmaller leaues among them, buhing thicke below, and rifing fmaller and thinner vp to the toppe, in fafhion of a Pyramis or fpeere Steeple: the roote is thicke and whitifh, yeelding more ftore of milke being broken (as the leaues and ftalks alfo doe) then any other of the Bell-flowers, euery one whereof doe yeelde milke, fome more and fome leffe.

\section{Viola Mariana flore albido vel purpureo.}

Couentry Bels white or purple.

The leaues of Couentry Bels are of a pale or frefh greene colour, long, and narrow next vnto the bottome, and broader from the middle to the end, and fomewhat round pointed, a little hairy all ouer, and fnipt about the edges: the ftalkes rife vp the yeare after the fowing, being fomewhat hairy alfo, and branching forth from the roote, into diuers parts, whereon ftand diuers leaues, fmaller then the former, and of a darker greene colour: at the end of euery branch ftand the flowers, in greene huskes, from whence come large, round, hollow Bels, fwelling out in the middle, and rifing fomewhat aboue it, like the necke of a pot, and then ending in fiue corners, which are either of a faire or faint white, or of a pale blew purplinh colour, and fometimes of a deeper purple or violet: after the flowers are paft, there rife vp great fquare, or cornered feede veffels, wherein is contained in diuers diuifions, fmall, hard, fhining, browne, flat feeds: the roote is white, and being young as in the firt yeares fowing, is tender, and often eaten as other Rampions are; but the next yeare, when it runneth vp to feede, it groweth hard, and perifheth: fo that it is to be continued by euery other yeares fowing.

\section{Trachelium maius flore albo vel purpureo.}

Great Canterbury Bels white or purple.

The greater Canterbury Bels, or Throateworte, hath many large rough leaues, fomewhat like vnto Nettle leaues, being broad and round at the bottome, and pointed at the end, notched or dented on the edges, and euery one ftanding on a long footftalk: among thefe leaues rife vp diuers fquare rough ftalkes, diuided at the toppe into diuers branches, whereon grow the like leaues as grow below, but leffer; toward the ends of the branches ftand the flowers, mixed with fome longer leaues, euery one in his feuerall huske, which are hollow, long and round, like a bell or cup, wide open at the mouth, and cut at the brimme into fiue corners, or diuifions, fomewhat leffer then the $\mathrm{Co}$ uentry Bels, in fome of a pure white, and others of a faire deepe purple violet colour, and fometimes paler: after the flowers are paft, come fmaller and rounder heades then in the former, containing flat feede, but blacker, and not fo redde as the laft: the roote is hard and white, difperfing it felfe into many branches vnder ground, not perifhing euery yeare as the former (although it lof eth all the leaues in winter) but abiding many yeares, and encreafing into diuers heades or knobs, from whence fpring new leaues and branches. 


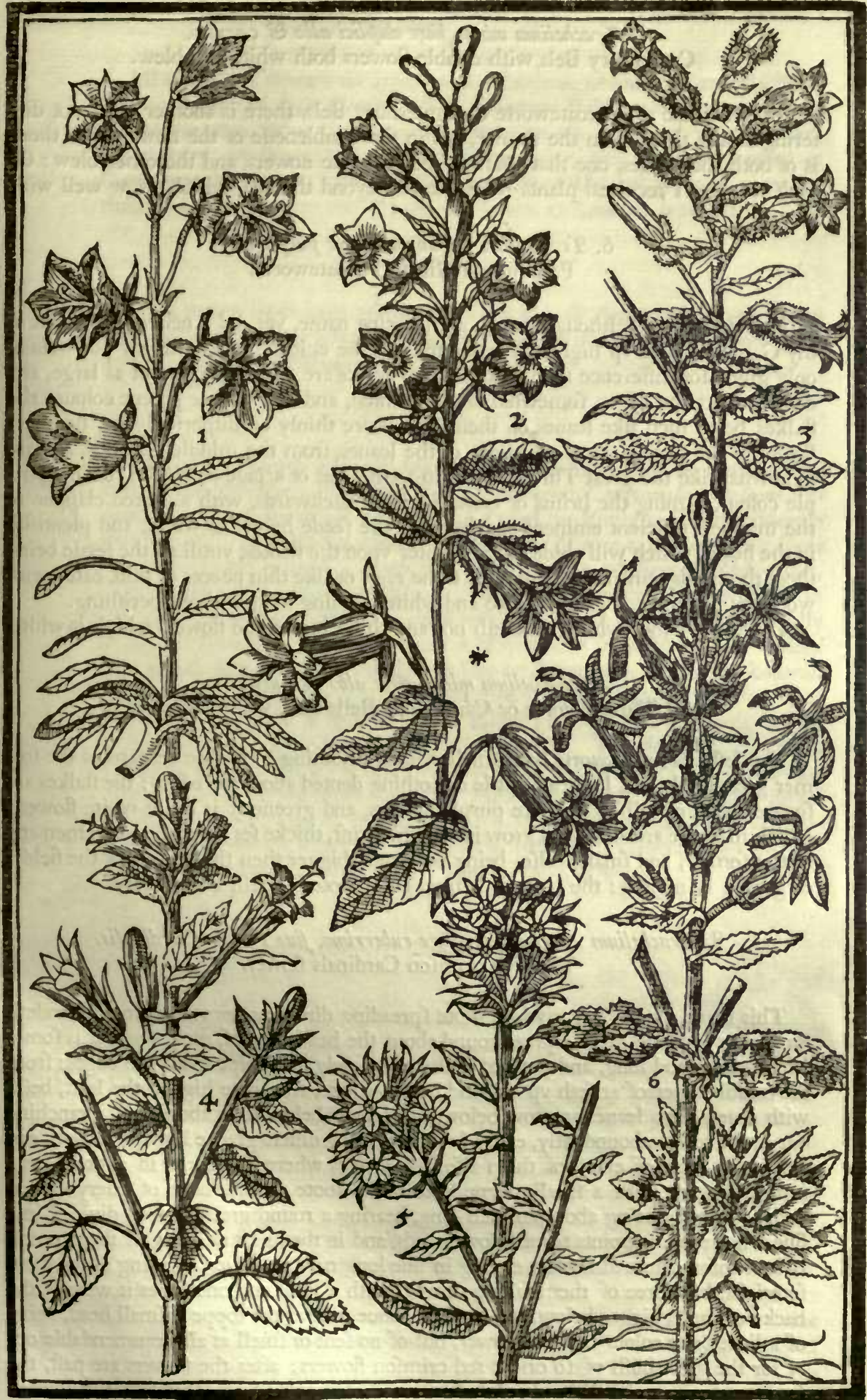

I Campanule porficifolia. Peach leafed Bell-flower. 2 Trackelium maius fimplex. Canterbury Bels. - Trachelium flore duplici. Double Canterbury Bels. 3 Viola Mariana. Couentry Bels. \& Trachelium Giganteum. Giants Throatewort. Trachlium minus. The leffer Throatewort. 6 Trachelium Americanum fius Cardinalis planla. The rich crimfon Cardinals 


\section{Trachelium maius fore duplici albo \&o caruleo.}

Canterbury Bels with double flowers both white and blew.

Of this kinde of Throateworte or Canterbury Bels, there is another fort, not differing in any thing from the former, but in the doubleneffe of the flower: For there is of both the kindes, one that beareth double white flowers, and the other blew: Of each whereof I receiued plants from friends beyond the Sea, which grow well with me.

\section{Trachelium Giganteum flore purpurante. Pale purple Giants Throateworte.}

This Bell-flower, although it hath a Gigantine name, yet did I neuer perceiue it in my Garden, to rife vp higher then the former, the epithite beeing in my perfwafion, only giuen for difference fake: the leaues whereof are not fo rough, but as large, and dented about the edges, fomewhat larger pointed, and of a frefher greene colour: the ftalkes beare fuch like leaues on them, but more thinly or difperfedly fet, hauing a flower at the fetting on of euery one of the leaues, from the middle vpwards, and are fomewhat like the great Throateworte in forme, but of a pale or bleake reddifh purple colour, turning the brims or corners a little backwards, with a forked clapper in the middle, fufficient eminent and yellow: the feede hereof is white, and plentifull in the heads, which will abide all the winter vpon the ftalkes, vntill all the feede being fhed, the heads remaining feeme like torne rags, or like thin peeces of skin, eaten with wormes: the roote is great, thicke and white, abiding long without perifhing.

Flore albo. There is another which differeth not any thing but in the flower, which is white.

\section{Trachelium minus fore albo \& purpureo.}

Small Throateworte or Canterbury Bells both white and purple.

The leffer Throateworte hath fmaller leaues, nothing fo broade or hard as the former great kinde, but long, and little or nothing dented about the edges: the ftalkes are fquare and brownilh, if it beare purple flowers, and greene if it beare white flowers, which in forme are alike, and grow in a bufh or tuft, thicke fet together, more then any of the former, and fmaller alfo, being not much bigger then the flowers of the fielde, or garden Rampions: the roote is lafting, and thooteth afrefh euery yeare.

\section{Trachelium Americanum fore ruberrimo, fue Planta Cardinalis.}

The rich crimfon Cardinals flower.

This braue plant, from a white roote fpreading diuers wayes vnder ground, fendeth forth many greene leaues, fpread round about the head thereof, each whereof is fomewhat broade and long, and pointed at the end, finely alfo fnipt about the edges: from the middle whereof arifeth $\mathrm{vp}$ a round hollow ftalke, two foote high at the leaft, befet with diuers fuch leaues as grow below, but longer below then aboue, and branching out at the toppe aboundantly, euery branch bearing diuers greene leaues on them, and one at the foote of euery of them alfo, the toppes whereof doe end in a great large tuft of flowers, with a fmall greene leafe at the foote of the ftalke of euery flower, each footeftalke being about an inch long, bearing a round greene huske, diuided into fiue long leaues or points turned downwards, and in the midit of euery of them a moft rich crimfon coloured flower, ending in fiue long narrow leaues, ftanding all of them foreright, but three of them falling downe, with a long vmbone fet as it were at the backe of them, bigger below, and fmaller aboue, and at the toppe a fmall head, being of a little paler colour then the flower, but of no fent or fmell at all, commendable only for the great bufh of fo orient red crimfon flowers: after the flowers are paft, the feede commeth in fmall heads, clofed within thofe greene husks that held the flowers, which is very like vnto the feede veffels of the Viola Mariana, or Couentry Bels, and is fmall and brownith. 


\section{The Place.}

All thefe Bell-flowers do grow in our Gardens, where they are cherifhed for the beautie of their flowers. The Couentry Bels doe not grow wilde in any of the parts about Couentry, as I am credibly informed by a faithfull Apothecary dwelling there, called Mafter Brian Ball, but are nourfed in Gardens with them, as they are in other places. The laft groweth neere the riuer of Canada, where the French plantation in America is feated.

\section{The Time.}

They flower from May vntill the end of Iuly or Auguft, and in the mean time the feed is ripe : But the Peache-leafed Bell-flowers, for the moft part, flower earlier then the other.

The Names.

The firft is generally called Campanula Perficifolia, in Englifh Peach-leafed Bell-flower. The fecond is called Campanula maior, Campanula lacte fcens Pyramidalis, and Pyramidalis Lutetiana of Lobel, in Englifh, Great or Steeple Bell-flower. The third is vfually called Viola Mariana, and of fome Viola Marina. Lobel putteth a doubt whether it be not Medium of Diofcorides, as Matthiolus and others doe thinke; but in my opinion the thickneffe of the roote, as the text hath it, contradicteth all the reft. We call it generally in Englifh Couentry Bels. Some call it Marian, and fome Mercuries Violets. The fourth and fift are called Trachelium or Ceruicaria, of fome Vvularia, becaufe many haue vfed it to good purpofe, for the paines of the Vvula, or Throate: Yet there is another plant, called alfo by fome Vvularia, which is Hippoglo/fum, Horfe tongue, or Double tongue. The fixt hath his title to defcipher it out fufficiently, as is declared. The feuenth is called Trachelium minus, and Ceruicaria minor, of fome Saponaria altera ; in Englifh, Small Throateworte, or Small Canterbury Bels. The laft hath his name in the title, as it is called in France, from whence I receiued plants for my Garden with the Latine name : but I haue giuen it in Englifh.

\section{The Vertues.}

The Peach-Bels as well as the others may fafely bee vfed in gargles and lotions for the mouth, throate, or other parts, as occafion ferueth. The rootes of many of them, while they are young, are often eaten in fallets by diuers beyond the Seas.

\section{CH A P. L X X X VII.}

\section{Campana Carulea fue Convolvulus Caruleus.} Blew Bell flowers, or blew Bindeweede.

$T$ Here are two other kindes of Bell-flowers, much differing from the Tribe or Familie of the former, becaufe of their climbing or winding qualitie, which I muft needes place next them, for the likeneffe of the flowers, although otherwife they might haue beene placed with the other clamberers that follow. Of thefe there is a greater, and a leffer, and of each likewife fome difference, as fhall be declared. 


\section{Convolvulus caruleus maior rotundifolius.}

The greater blew Bindweede, or Bell-flower with round leaues.

This goodly plant rifeth vp with many long and winding branches, whereby it climbeth and windeth vpon any poles, herbes, or trees, that ftand neare it within a great compaffe, alwaies winding it felfe contrary to the courfe of the Sunne: on thefe branches doe growe many faire great round leaues, and pointed at the end, like vnto a Violet leafe in fhape, but much greater, of a fad greene colour : at the ioynts of the branches, where the leaues are fet, come forth flowers on pretty long ftalkes, two or three together at a place, which are long, and pointed almoft like a finger, while they are buds, and not blowne open, and of a pale whitilh blew colour, but being blowne open, are great and large bels, with broad open mouths or brims ending in fine corners, and fmall at the bottome, ftanding in fmall greene huskes of fine leaues : thefe flowers are of a very deepe azure or blew colour, tending to a purple, very glorious to behold, opening for the moft part in the euening, abiding fo all the night and the next morning, vntill the Sunne begin to growe fomewhat hot vpon them, and then doe clofe, neuer opening more : the plant carrieth fo many flowers, if it ftand in a warme place, that it will be replenifhed plentifully, vntill the cold ayres and euenings ftay the luxury thereof: after the flowers are paft, the ftalkes whereon the flowers did ftand, bend downwards, and beare within the huskes three or foure blacke feedes, of the bigneffe of a Tare or thereabouts: the rootes are ftringy, and perifh euery yeare.

\section{Convolvulus trifolius fiue hederaceus purpureus.}

The greater purple Bindeweede, or Bell-flower with cornered leaues.

The growing and forme of this Bindeweede or Bell-flower, is all one with the former, the chiefert differences confifting in the forme of the leafe, which in this is three cornered, like vnto an Iuie leafe with corners; and in the flower, which is of a deeper blew, tending more to a deepe purple Violet, and fomewhat more reddifh in the fiue plaites of each flower, as alfo in the bottomes of the flowers.

\section{Convolvulus tenuifolius Americanus. The red Bell-flower of America.}

Although this rare plant (becaufe wee feldome haue it, and can as hardly keepe it) be fcarce knowne in thefe cold Countries, yet I could not but make mention of it, to incite thofe that haue conueniencie to keepe it, to be furnifhed of it. It fpringeth vp at the firft from the feede with two leaues, with two long forked ends, which abide a long time before they perifh, betweene which rifeth vp the ftalke or ftemme, branching forth diuers waies, being of a brownifh colour, which windeth it felfe as the former great Bell-flower doth, whereon are fet at feuerall ioynts diuers winged leaues, that is to fay, many fmall narrow and long leaues fet on both fides of the middle ribbe, and one at the end : from thefe ioynts arife long ftalkes, at the ends whereof ftand two or three fmall, long, hollow flowers, fafhioned very like vnto the flowers of a Bindeweede, or the flowers of Tabacco, and ending in the like manner in fiue points, but not fo much laide open, being of a bright red colour, plaited as the Bindeweedes or Bell-flowers before they be open, with fome few threads in the middle, which turne into long pointed cods, wherein is contained long and blacke feede, tafting hot like Pepper : the roote is fmall and ftringy, perifhing euery yeare, and with vs will feldome come to flower, becaufe our cold nights and frofts come fo foone, before it cannot haue comfort enough of the Sun to ripen it.

\section{Convolvulus caruleus minor Hippanicus.}

The Spanifh fmall blew Bindeweede.

This fmall Bindeweede hath fmall long leaues, fomewhat broader then the next that followeth, and not fo broad as the common fmall Bindeweede (that groweth 
euery where wilde on the bankes of fields abroad) fet vpon the fmall trayling branches, which growe aboue two or three foote high: from the middle of thefe branches, and fo vnto the toppes of them, come forth the flowers at the ioynts with the leaues, folded together at the firft into fiue plaites, which open into fo many corners, of a moft excellent faire skie coloured blew (fo pleafant to behold, that often it amazeth the (pectator) with white bottomes, and yellowith in the middle, which turne into fmall round white heads, wherein are contained fimall blackilh cornered feede, fomewhat like the former, but fmaller: the roote is fmall and threddy, perifhing as the former euery yeare: this neuer windeth it felfe about any thing, but leaneth by reafon of the weakneffe of the branches, and dyeth euery yeare after feede time, and not to be fowne againe vntill the next Spring.

\section{Corvolvulus purpureus Spicrefolius. Lauander leafed Bindeweede.}

This fmall purple Bindeweede, where it naturally groweth, is rather a plague then a pleafure, to whatfoeuer groweth with it in the fields; yet the beauty of the flower hath caufed it to be receiued into Gardens, bearing longer and finaller leaues then the laft, and fuch like finall Bell-flowers, but of a fad purple colour: the roote is liuing, as the common kinds are, and fpringeth againe where it hath been once fowne, without feare of perifhing.

\section{The Place.}

The firt two greater kindes haue beene fent vs out of Italy, but whether they had them from the Eaft Indies, or from fome of the Eafterne Countries on this fide, wee know not : but they thriue reafonable well in our Country, if the yeare be any thing kindly. The next came out of America, as his name teftifieth. The leffer blew kinde groweth naturally in many places both of Spaine and Portugall (from whence I firt receiued feedes from Guillaume Boel, heretofore remembred.) The laft groweth wilde in the fields, about Dunmowe in Effex, and in many other places of our owne Countrey likewife.

\section{The Time.}

The three firft greater kindes flower not vntill the end of Auguft, or thereabouts, and the feede ripeneth in September, if the colds and frofts come not on too fpeedily. The leffer kindes flower in Iune and Iuly.

\section{The Names.}

The firt is called of fome Campana Lazura, as the Italians doe call it, or Campana carulea, of others Corrolvulus caruleus maior, fue Indicus, and Flos noctis. Of fome Nil Auicenne. The fecond is called Comvolvulus trifolius, or hederaceus, for the diftinction of the leaues. In Englin wee call them eyther Great blew Bell flowers, or more vfually, Great blew Bindeweedes. That of America is diuerly called by diuers. It is called Quamoclit of the Indians, and by that name it was fent to Ioachinus Camerarius out of Italy, where it is fo called ftill, as Fabius Columna fetteth it downe, and as my felfe alfo can witneffe it, from thence being fo fent vito inee: but Andras Cxfalpinus calleth it, Iafminum folio Millefolij, fuppofing it to be a Iafmine. Camerarius faith, it may not vnfitly be called Comoslvulus temuifolius, accounting it a kinde of Bindeweede. Columna entituleth it Comolvulus pennatus exoticus rarior, and faith it cannot bee referred to any other kinde of plant then to the Bindeweedes. Hee that publifhed the Cura poferiores of Clufius, giveth it the name of Iafminum Americanum, which I would doe alro, if I thought it might belong to that Family; but feeing the face and forme of the plant better agreeing with the Bindeweedes or Bell-flowers, 
I have (as you fee) inferted it among them, and giuen it that name may bee moft fit for it, efpecially becaufe it is but an annuall plant. The leffer kindes haue their names fufficiently expreffed in their titles.

The Vertues.

We know of no vfe thefe haue in Phyficke with vs, although if the firft be Nil of Auicen, both he and Serapio fay it purgeth ftrongly.

C н а P. L XXX V I I I.

Stramonium. Thorne-Apple.

$\mathrm{V}$ Nto the Bell-flowers, I muft adioyne three other plants, in the three feuerall Chapters following, for fome affinity of the flowers: and firt of the ThorneApples, whereof there are two efpeciall kindes, that is, a greater and a leffer, and of each fome diuerfity, as thall be fet downe.

I. Stramonium maius album. The great white flowred Thorne-Apple.

The greater Thorne-Apple hath a great, ftrong, round greene ftalke, as high as any man, if it be planted in good ground, and of the bigneffe of a mans wreft almoft at the bottome, fpreading out at the toppe into many branches, whereon ftand many very large and broad darke greene leaues, cut in very deeply on the edges, and hauing manie points or corners therein: the flowers come forth at the ioynts, betweene two branches towards the toppe of them, being very large, long, and wide open, ending in fiue points or corners, longer and larger then any other Bell-flowers whatfoeuer : after the flowers are paft, come the fruit, which are thorny long heads, more prickly and greene then the leffer kindes, which being ripe openeth it felfe into three or foure parts, hauing a number of flat blackifh feede within them: the roote is aboundant in fibres, whereby it ftrongly taketh hold in the ground, but perifheth with the firft frofts; yet the feede that is fhed when the fruit is ripe, commeth vp the next yeare.

\section{Stramonium maius purpureum.}

The great purple flowred Thorne-Apple.

This purple Thorne-Apple is in largeneffe of leaues, thickneffe and height of ftalke, greatneffe and forme of flowers and fruit, euery way equall and correfpondent vnto the former, the chiefe differences be thefe : the ftalke is of a darke purple colour; the leaues are of a darker greene, fomewhat purplifh, and the flowers are of light purple or pale Doue colour, enclining to white, and whiter at the bottome.

\section{Stramonium minus feu Nux Metel flore albo.}

The fmaller Thorne-Apple with a white flower.

The fmaller Thorne-Apple rifeth vp with one round ftalke, of the bigneffe of a mans finger, and neuer much aboue two foote high with vs, bearing a few large, broad, fmooth leaues thereon, without any branches at all, which are vneuenly rent or torne about the edges, with many ribs, and fmaller veines running through them, yet leffer by much then the greater kinde: at the ioynts where the leaues ftand, come forth long and large white flowers, with broad or wide open brims, folded together before their opening, as the other former Bell-flowers or Bindeweedes, but hauing their fiue corners more pointed or horned then either they, or the former Thorne-Apples: after the flowers are paft, fucceed fmall fruit, rounder and harder, fet with harder, but blunt prickes then the former, wherein is contained brownifh yellow flat feede, 


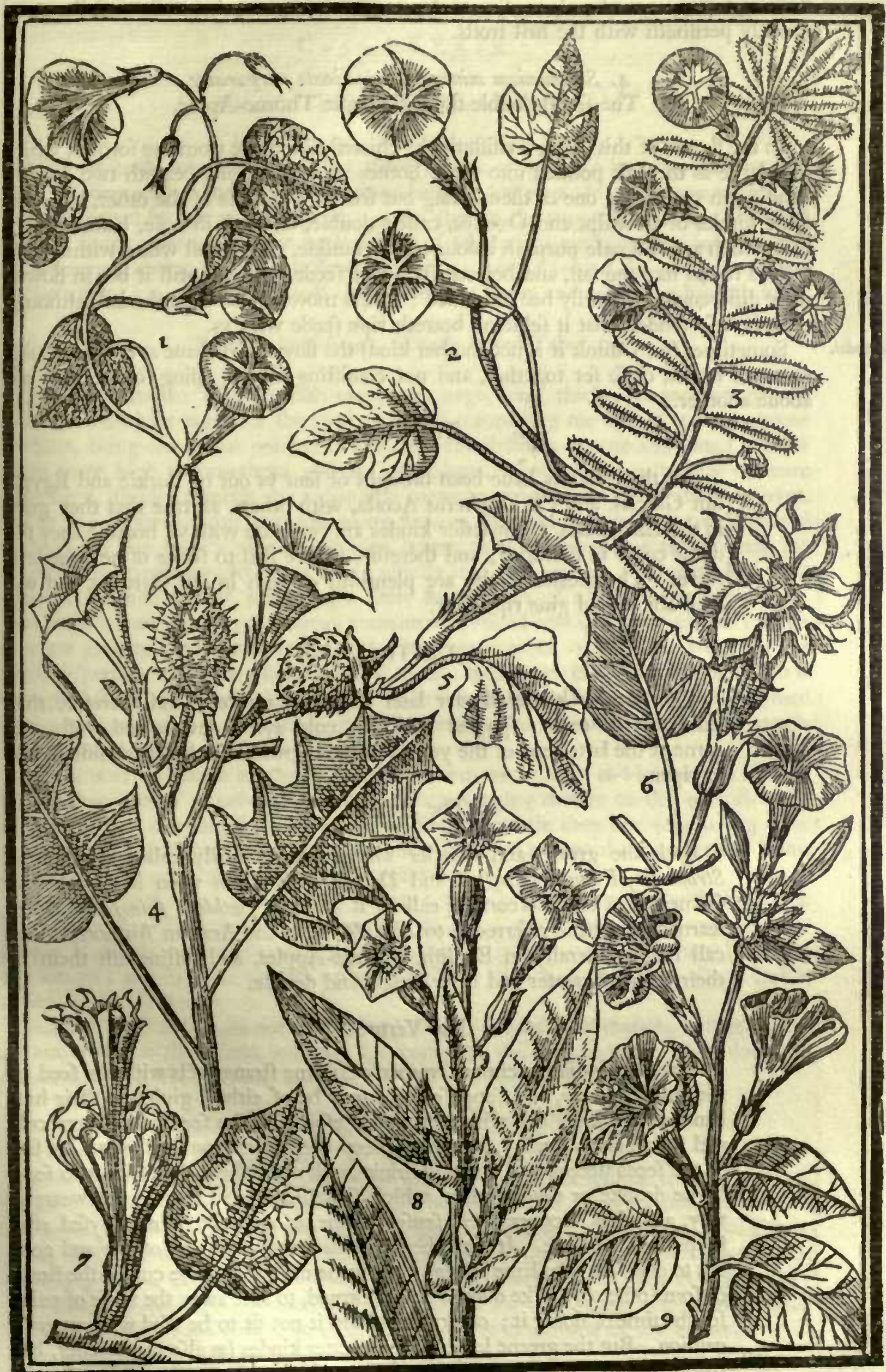

I Conoolvulus major carulcus. The greater blew Bindweed or Bell fower. 2 Convolvulus trifolius feu hederaceus. The great purple Bindeweed. 3 Cosvolewlus minor carulews. Hifpanieus. The Spanifh imall blew Bindweed. 1 Stramonium maius fou Pomum

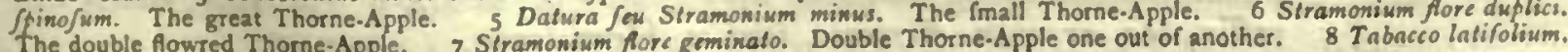
Broad-leafed Tabacco. I Mirabilia Pcruana. The Meruaile of the world. 
fticking to the inward pulpe : the roote is not very great, but full of ftrings, and quickly perifheth with the firt frofts.

4. Stramonium minus flore geminato purpurante.

The fmall double flowred purple Thorne-Apple.

In the flower of this plant, confifteth the chiefeft difference from the former, which is as large as the laft, pointed into more hornes or corners, and beareth two flowers, ftanding in one huske, one of them rifing out from the middle of the other, like vnto thofe kindes of Cowlips and Oxelips, called double, or Hofe in hofe, before defcribed, which are of a pale purplin colour on the outfide, and almoft white within : the fruit is round like the laft, and beareth fuch like feede, fo that vntill it bee in flower, their difference can hardly bee difcerned: this is more tender then the laft, although euen it is fo tender, that it feldome beareth ripe feede with vs.

Sometimes (for I think it is not another kind) the flower will haue as it were double rowes of leaues, clofe fet together, and not confifting of two, rifing fo diftinctly one aboue another.

The Place.

All thefe kindes haue been brought or fent vs out of Turkie and Egypt; but Garcias, and Chriftopherus Acofta, with others, affirme that they grow in the Eaft Indies. The leffer kindes are very rare with vs, becaufe they feldome come to maturity; and therefore we are ftill to feeke of new feede to fowe. The greater kindes are plentifull enough in our Gardens, and will well abide, and giue ripe fruit.

\section{The Time.}

The fmaller kindes flower later then the greater; and therefore their fruit are the sooner fpoyled with the cold ayres, dewes, and frofts, that come at the latter end of the yeare : but the greater kinds neuer miffe lightly to ripen.

\section{The Names.}

Both the greater and fmaller kindes are generally called Stramonium, Stramonia, Pomum Jpinofum, and Datura. Bauhinus vpon Matthiolus his Comentaries on Diofcorides, calleth it Solanum fatidum fpinofum. Some learned men haue referred it to Nux Metel, of the Arabian Authors. Wee call them generally in Englifh, Thorne-Apples, and diftinguilh them by their titles of greater and leffer, fingle and double.

\section{The Vertues.}

The Eaft Indian lafciuious women performe ftrange acts with the feed (of the fmaller kinde, as I fuppofe, or it may be of either) giuing it their hufbands to drinke. The whole plant, but efpecially the feed, is of a very cold and foporiferous quality, procuring neep and diftraction of fenfes. A few of the feeds fteeped and giuen in drinke, will caufe them that take it to feem ftarke drunke or dead drunke, which fit will within a few houres weare away, and they recouer their fenfes againe, as a drunken man rayfed after fleep from his wine. It may therefore (in my opinion) be of fafe and good vfe to one, that is to have a legge or an arme cut off, or to be cut for the ftone, or fome other fuch like cure to be performed, to take away the fenfe of paine for the time of doing it ; otherwife I hold it not fit to be vfed without great caution. But the greene leaues of the greater kindes (as alfo of the leffer, but that with vs they are not fo plentifull) are by tryed experience, found to be excellent good for any fcalded or burned part, as alfo to take away any hot inflammations, being made vp into a falue or ointment with fuet, waxe, and roffin, \&c. or with Axungia, that is, Hogs larde. 


\section{CHAP. LXXXIX.}

\section{Tabacco. Indian Henbane, or Tabacco.}

$\mathrm{T}$

Here hath beene formerly but three kindes of 'Tabacco knowne vnto vs, two of them called Indian, and the third Englifh Tabacco. In thefe later yeares, we haue had in our gardens about London (before the fupprefling of the planting) three or foure other forts at the leaft, and all of the Indian kinde, having fome efpeciall difference, eyther in leafe, or flower, or both: And in regard the flowers of fome of thefe carry a pretty thew, I hall only entreate of them, and not of the Englilh kind.

\section{Tabacco latifolium. Broade leafed Tabacco.}

The great Indian Tabacco hath many very large, long, thicke, fat and faire greene leaues, ftanding foreright for the moft part, and compaffing the ftalkes at the bottome of them, being fomewhat pointed at the end: the ftalke is greene and round, fixe or feuen foote high at fometimes, and in fome places, in others not paft three or foure foote high, diuided towards the toppe into many branches, with leaues at euery ioynt, and at the toppes of the branches many flowers, the bottomes hereof are long and hollow, and the toppes plaited or folded before they are open, but being open, are diuided fometimes into foure, or more vfually into fiue corners, fomewhat like vnto other of the Bell-flowers, but lying a little flatter open, of a light carnation colour. The feede is very fmall and browne, contained in round heads, that are clammy while they are greene, and pointed at the end: the roote is great, whitifh, and woody at the head, difperfing many long branches, and fmall fibres vnder the ground, whereby it is ftrongly faftened, but perifheth with our violent frofts in the winter, if it be left abroad in the garden, but if it be houfed, or fafely prouided for againt the froftes, the rootes will liue, and fpring afrefh the next yeare.

There is of this kinde another fort, whofe leaues are as large and long as the former, but thicker, and of a more dead greene colour, hanging downe to the ground-ward, and fcarce any ftanding forth-right, as the former, vnleffe they bee very young: the flowers of this kinde are almoft whole, without any great thew of corners at the brims or edges, in all other things there is no difference.

There is another, whofe large and thicke flat leaues doe compaffe the ftalke at the bottone, and are as it were folded together one fide vnto another: the flowers are of a deeper blufh, or carnation colour, and with longer points and corners then in any of the former; and in thefe two things confifteth the difference from the others, and is called Verines Tabacco.

Another hath his leaues not fo large and long as the firt, and thefe haue fhort footeitalkes, whereon they ftand, and doe not compaffe the ftalke as the other doe: the flower hereof is like the firt, but fmaller, and of a little paler colour.

Tabacco angufifolium. Narrow leafed Tabacco.

This kinde of Tabacco hath fomewhat lower, and fmaller ftalkes, then any of the former: the leaues hereof are fmaller and narrower, and not altogether fo thicke, but more pointed, and euery one ftanding vpon a footftalke, an inch and a halfe long at the leaft : the flowers hereof ftand thicker together, vpon the fmall branches, fomewhat larger, of a deeper blufh colour, and more eminent corners then in any the former: the feed and roots are alike, and perifh in like inanner, vnleffe it be brought into a cellar, or other fuch couert, to defend it from the extremitie of the Winter.

The Place.

America or the Weft Indies is the place where all thefe kindes doe grow naturally, forne in one place, and fome in another, as in Peru, Trinidado, 
Hifpaniola, and almoft in euery Iland and Countrey of the continent thereof: with vs they are cherifhed in gardens, as well for the medicinable qualities, as for the beauty of the flowers.

\section{The Time.}

It flowreth in Auguft, feldome before, and the feede is ripe quickly after. If it once fowe it felfe in a Garden, it will giue next year after young plants: but for the moft part they will fpring vp late, and therefore they that would haue them more early, haue fowen the feede vpon a bed of dung, and tranfplanted them afterwards.

\section{The Names.}

This plant hath gotten many names. The Indians call it in fome places Petum, in others, Picielt, and Perebecenuc, as Ouiedus and others doe relate. The Spaniards in the Indies firft called it $\mathcal{T}_{a}$ abacco, of an Iland where plenty of it grew. It hath in Chriftendome receiued diuers other names, as Nicotiana, of one Nicot a French man, who feeing it in Portugall, fent it to the French Queene, from whom it receiued the name of Herba Regina. Lobel calleth it Sancta herba, \& Sana fancta Indorum. Some haue adiudged it to be an Hiofcyamus, and therefore call it Peruvianus. The moft vfuall name wherby we call it in Englifh, is Tabacco.

The Vertues.

The herbe is, out of queftion, an excellent helpe and remedy for diuers difeafes, if it were rightly ordered and applyed, but the continuall abufe thereof in fo many, doth almoft abolifh all good vfe in any. Notwithftanding if men would apply their wits to the finding out of the vertues, I make no doubt but many ftrange cures would bee performed by it, both inward and outward. For outward application, a Salue made hereof (as is before recited of the Thorne apple leaues) cureth vlcers, and wounds of hard curation: And for inward helpes, a Syrupe made of the iuice and fugar, or honey, procureth a gentle vomit (but the dryed leafe infufed in wine much more) and is effectuall in aftmaticall difeafes, if it bee carefully giuen. And likewife cleanfeth cankers and fiftulaes admirably, as hath beene found by late experience. The afhes of Tabacco is often vfed, and with good fucceffe, for cuts in the hands, or other places, and for other fmall greene wounds.

\section{C н A P. X C.}

\section{Mirabilia Peruviana. The Meruaile of Peru.}

$\mathrm{T}$

His plant yeeldeth in our Gardens fiue or fixe feuerall varieties of beautifull flowers, as pure white, pure yellow, pure red, white and red fpotted, and red and yellow fpotted. But befides thefe, I haue had fome other forts, among which was one, of a pale purple or peach colour: all which, comming vnto mee out of Spaine with many other, feedes in an vnkindly yeare (an early winter following a cold fummer) perifhed with mee; yet I plainely might difcerne by their leaues, and manner of growing, to be diuers from them that we now haue and keepe. I thall need therefore (becaufe the chiefeft difference confifteth almoft in the flowers) to give only one defcription of the plant, and therein thew the varieties as is before declared.

Admirabilis. The Meruaile of the World.

The ftalke of this meruellous plant is great and thick, bigger then any mans thumbe, bunched 
bunched out or fwelling at euery ioynt, in fome the ftalkes will bee of a faire greene colour, and thore will bring white, or white and red flowers: in others they will bee reddifh; and more at the ioynts, and thofe giue red flowers; and in fome of a darker greene colour, which gine yellow flowers; the ftalkes and ioynts of thofe that will giue red and yellow flowers fpotted, are fomewhat brownifh, but not fo red as thofe that giue wholly red flowers: vpon thefe ftalkes that fpread into many branches, doe grow at the ioynts vpon feuerall footeftalkes, faire greene leaues, broad at the ftalke, and pointed at the end: at the ioynts likewife toward the vpper part of the branches, at the foote of the leaues, come forth feuerall flowers vpon fhort footeftalkes, euery one being fmall, long and hollow from the bottome to the brimme, which is broade fpread open, and round, and confilt but of one leafe without diuifion, like vnto a Bell flower, but not cornered at all: which flowers, as I faid, are of diuers colours, and diuerlly marked and Spotted, fome being wholly white, without any fpot ir them for the moft part, through all the flowers of the plant; fo likewife fome being yellow, and fome wholly red; fome plants againe being mixed and fpotted, fo variably either white and red, or purple, (except here and there fome may chance to be wholly white, or red or purple among the reft) or red and yellow through the whole plant, (except as before fome may chance in this kinde to be eyther wholly red, or wholly yellow) that you thall hardly finde two or three flowers in a hundred, that will bee alike rpotted and marked, without fome diuerfitie, and fo likewife euery day, as long as they blow, which is vitill the winters, or rather autumnes cold blaftes do ftay their willing proneneffe to flower: And I haue often alfo obferued, that one fide of a plant will give fairer varieties then another, which is moft commonly the Eafterne, as the more temperate and thadowie fide. All thefe flowers doe open for the moft part, in the euening, or in the night time, and fo ftand blowne open, vntill the next mornings fun beginne to grow warme vpon them, which then clofe themfelues together, all the brims of the flowers thrinking into the middle of the long necke, much like vnto the blew Bindeweede, which in a manner doth fo clofe vp at the funnes warme heate: or elfe if the day be temperate and milde, without much funne fhining vpon them, the flowers will not clofe vp for the inoft part of that day, or vntill toward night: after the flowers are palt, come feuerall feedes, that is, but one at a place as the flowers ftood before, of the bigneffe (fometimes) of peafe, but not fo round, ftanding within the greene huskes, wherein the flowers ftood before, being a little flat at the toppe, like a crowne or head, and round where it is faftened in the cup, of a blacke colour when it is ripe, but elfe greene all the while it groweth on the ftalke, and being ripe is foone thaken downe with the wind, or any other light fhaking : the roote is long and round, greater at the head, and fmaller downwards to the end, like vnto a Reddilh, fpreading into two or three, or more branches, blackifh on the outfide and whitifh within. Thefe rootes I haue often preferued by art a winter, two or three (for they will perifh if they be left out in the garden, vnleffe it be vnder a houfe fide) becaufe many times, the yeare not falling out kindely, the plants giue not ripe feede, and fo we fhould be to feeke both of feede to fow, and of rootes to fet, if this or the like art to keep them, were not vfed; which is in this manner: Within a while after the firft frofts haue taken the plants, that the leaues wither and fall, digge vp the rootes whole, and lay them in a dry place for three or foure dayes, that the fuperfluous moyiture on the outfide, may be fpent and dryed, which done, wrap them vp feuerally in two or three browne papers, and lay them by in a boxe, cheft or tub, in fome conuenient place of the houfe all the winter time, where no winde or moift ayre may come vnto them; and thus you thall haue thefe rootes to fpring a frefh the next yeare, if you plant them in the beginning of March, as I haue fufficiently tryed. But fome haue tryed to put them vp into a barrell or firkin of fand, or afhes, which is alfo good if the fand and afhes be thorough dry, but if it bee anything moift, or if they giue againe in the winter, as it is vfuall, they haue found the moifture of the rootes, or of the fand, or both, to putrefie the rootes, that they haue beene nothing worth, when they haue taken them forth. Take this note alfo for the fowing of your feede, that if you would haue variable flowers, and not all of one colour, you muft choofe out fuch flowers as be variable while they grow, that you may haue the feede of them: for if the flowers bee of one entire colour, you thall haue for the moft part from thofe feedes, plants that will bring flowers all of that colour, whether it be white, red or yellow. 


\section{The Place.}

Thefe plants grow naturally in the Weft Indies, where there is a perpetuall fummer, or at the leaft no cold frofty winters, from whence the feede hath been fent into thefe parts of Europe, and are difperfed into euery garden almoft of note.

The Time.

Thefe plants flower from the end of Iuly fometimes, or Auguft, vntill the frofts, and cold ayres of the euenings in October, pull them down, and in the meane time the feed is ripe.

\section{The Names.}

Wee haue not receiued the feedes of this plant vnder any other name, then Mirabilia Peruviana, or Admirabilis planta. In Englifh wee call them, The meruaile of Peru, or the meruaile of the world: yet fome Authors haue called it Gelfeminım, or Iafminum rubrum, E Indicum: and Bauhinus Solanum Mexicanum fore magno.

The Vertues.

We haue not knowne any vfe hereof in Phyficke.

\section{CH A P. X C I.}

\section{Malua. Mallowes.}

$\mathrm{F}$ the kindred of Mallowes there are a great number, fome of the gardens, others wilde, fome with fingle flowers, others with double, fome with whole leaues, others with cut or diuided: to entreate of them all is not my purpofe, nor the fcope of this worke, but onely of fuch whofe flowers, hauing beatie and rerpect, are fit to furnifh this garden, as ornaments thereunto. And firft of thofe fingle kindes, whofe flowers come neereft vnto the fafhion of the former Bell-flowers, and after to the double ones, which for their brauery, are entertained euery where into euery Countrey womans garden.

\section{Malua Hifpanica flore carneo amplo.} The Spanifh blufh Mallow.

The Spanifh Mallow is in forme and manner of growing; very like vnto our common fielde Mallow, hauing vpright ftalkes two or three foote high, fpread into diuers branches, and from the bottome to the toppe, befet with round leaues, like vnto our Mallowes, but fomewhat fmaller, rounder, and leffe diuided, yet larger below then aboue: the flowers are plentifully growing vpon the fmall branches, folding or writhing their leaues one about another before they bee blowne, and being open confift of fiue leaues, with a long forked clapper therein, of the fame colour with the flower: the chiefert difference from the common confifteth in this, that the leaues of thefe flowers are longer, and more wide open at the brimmes (almoft like a Bell flower) and of a faire blufh or light carnation colour, clofing at night, and opening all the day: after the flowers are paft, there come fuch like round heads, with fmall blacke feede, like vnto the common kinde, but fomewhat fmaller: the roote is fmall and long, and perifheth euery yeare.

2. Alcea vulgaris flore carneo. Vervaine Mallow with blufh flowers.

There is a Mallow that hath long ftalkes, and flowers like vnto the common wilde 
19.

(A)

Ima i 1 120 15.

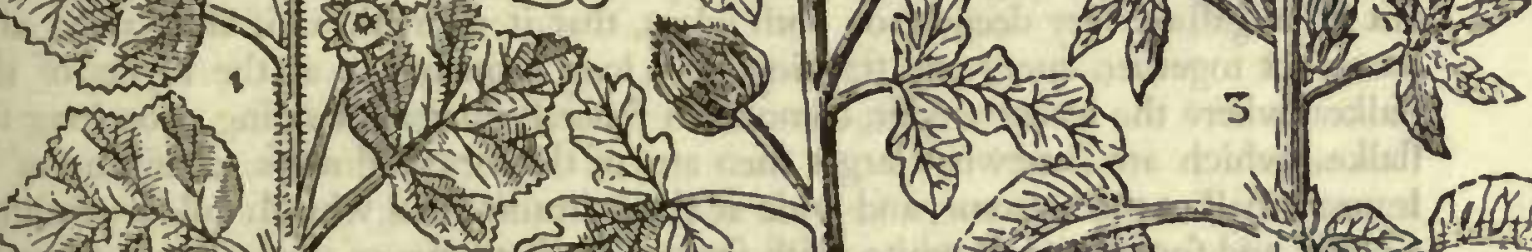

1.

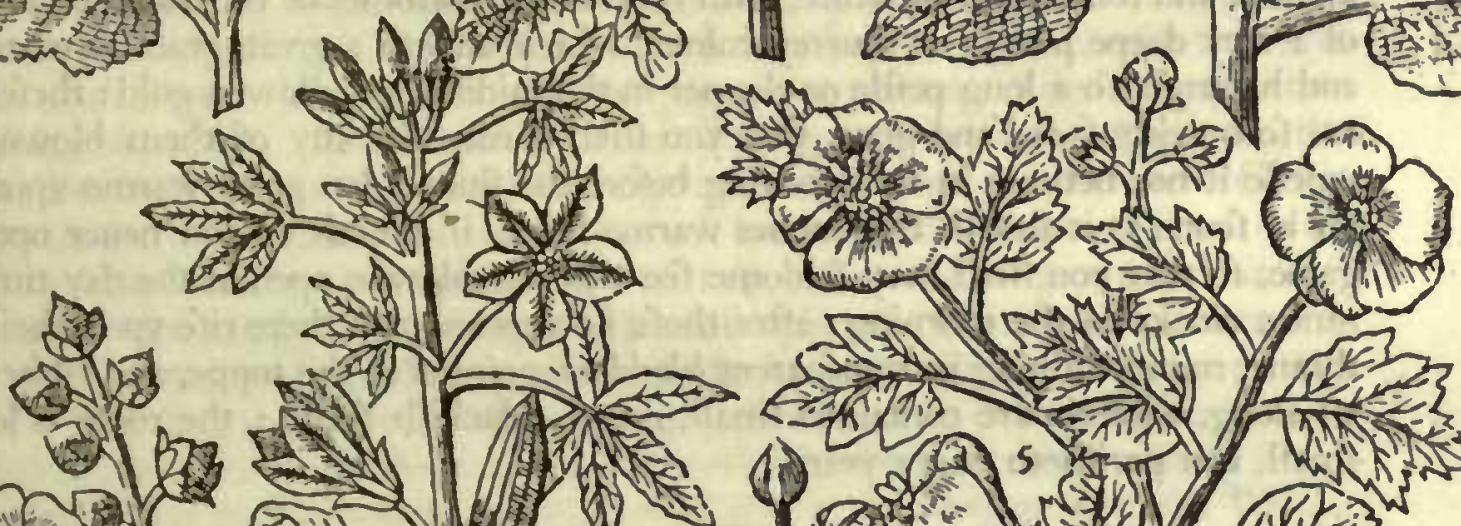
9. T. 2. $35-2$.

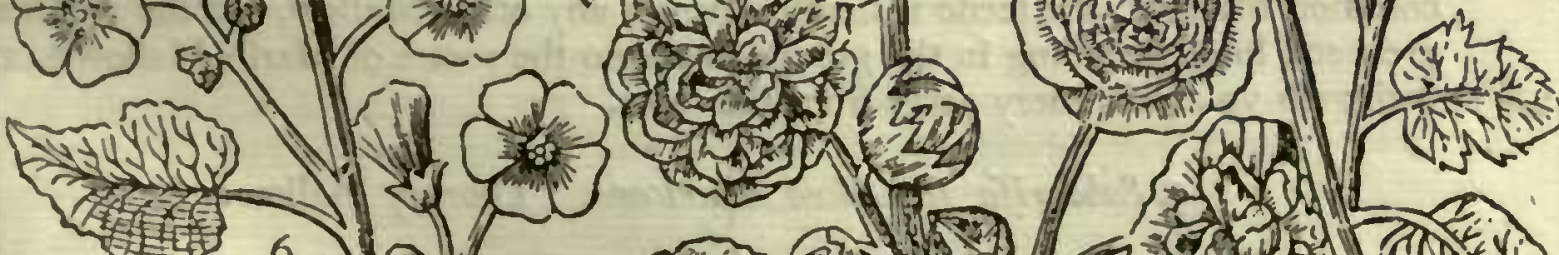
-

I Malwa Hifpanica fore cameo amplo. The Spanim Mallow. 2 Alcea Veneta. The Venice Mallow. 3 Alcea Americana. Thorney Mallow. + Alesa Aigyptia. The Mallow of Egypt. 5 Atshea frutex. The mrubbe Mallow. 6 Malua hortenfis fimplex. Single Hollihockes. 7 Malwa rofra muitiplex. Double Hollibockes. 
Mallow, and of the fame deepe colour with it, fo that you can hardly know it from the ordinary kinde, which is found growing wilde together with it, but onely by the leafe, which is as round and as large as the former, but cut into many fine diuifions, euen to the ftalke that vpholdeth it, that it feemeth to confint onely of ragges, or peeces of leaues: Of this kinde I take a plante for this garden, growing in all refpects like vnto it, but differing onely in the colour of the flowers, which are of the fame blufh or light carnation colour, or not much differing from the former Spanifh kinde, with fome veines therein of a deeper colour: the root hereof liueth, as the root of the common wilde kinde doth.

\section{Alcea peregrina fiue veficaria.}

Venice Mallow, or Good night at noone.

The Venice Mallow hath long and weake ftalkes, moft vfually lying or leaning vpon the ground, hauing here and there vpon them long leaues and fomewhat broad, cut in or gafhed very deepely on both edges, that it feemeth as if they were diuers leaues fet together, euery one ftanding on a long footeftalke: at the ioynts of thefe ftalkes, where the leaues are fet, come forth feuerall flowers, ftanding vpon long footftalkes, which are fomewhat larger then any of the former flowers, confifting of fiue leaues, fmall at the bottome, and wide at the brimmes, of a whitifh colour tending to a blurh, and fometimes all white, with fpots at the bottomes of the leaues on the infide, of a very deepe purple or murrey colour, which addeth a great grace to the flower, and hauing alfo a long peftle or clapper in the middle, as yellow as gold: thefe flowers are fo quickly faded and gone, that you thall hardly fee any of them blowne open, vnleffe it bee betimes in the morning before the Sunne doe grow warme vpon them, for as foone as it feeleth the Sunnes warme heate, it clofeth vp and neuer openeth againe, fo that you thall very feldome fee a flower blowne open in the day time, after nine a clocke in the morning: after thefe flowers are paft, there rife vp in their places thinne, round, thining or tranfparent bladders, pointed at the toppe, and ribbed down all along, wherein are contained fmall, round, blackifh feede : the roote is long and fmall, and perifheth euery yeare.

\section{Alcea fruticofa pentaphyllea. Cinquefoile Mallow.}

The ftalkes of this Mallow are very long, hard or wooddy, more then of any of the other Mallowes : at the lower part whereof, and vp to the middle, ftand diuers leaues vpon long footeftalkes, parted or diuided into fiue parts or leaues, and dented about the edges; but vpwards from the middle to the toppe, the leaues haue but three diuifions: among thefe leaues ftand large wide open flowers, of the colour of the common Mallow: the feede is fmaller then in any other Mallow, but the rootes are great and long, fpreading in the ground like vnto the rootes of Marh Mallowes, and fpringeth vp afrefh euery yeare from the roote.

\section{Sabdarifa Jeu Alcea Americana. Thorney Mallowe.}

This Thorney Mallowe hath greene leaues next vnto the ground, that are almoft round, but pointed at the end, and dented very much about the edges; the other leaues that growe vpon the ftalke are diuided into three parts, like vnto a trefoile, and fome of them into fiue diuifions, all of them dented about the edges: the ftalke is reddifh, with fome harmeleffe prickles in fundry places thereon, and rifeth vp three or foure foote high in a good ground, a fit place, and a kindly yeare, bearing plenty of flowers vpon the ftalkes, one at the foote of euery leafe, the toppe it felfe ending in a long rpike, as it were of buddes and leaues together: the flowers are of a very pale yellow, tending to a white colour, fpotted in the bottome of each of the fiue leaues, with a deepe purple fpot, broad at the lower part, and ending in a point about the middle of the leafe, which are quickly fading, and not abiding aboue one day, with a long peftle in the middle diuided at the toppe: after the flower is paft, commeth vp a fhort prickly podde, fet within a fmall greene huske or cup that bore the flower, wherein is contai- 
ned whitifh, or rather brownifh yellow feede, flat and fomewhat round, like vnto the feedes of Hollyhocke: the roote is ftringie, and quickly perifheth; for it will hardly endure in our cold Country to giue flowers, much leffe feede, vnleffe (as I faid before) it happen in a kindly yeare, and be well planted and tended.

\section{Bamia feu Alcen Agyptia. The Mallow of Egypt.}

This Mallow is alfo as tender to nourfe vp as the laft, hauing the lower leaues broad like a Marfh Mallow, and of a frefh greene colour; but thofe that growe vpon the Italke, and vp to the toppe, are diuided into fiue parts or points, but are not cut in to the middle ribbe, like the former Thorney Mallow, yet dented about the edges like visto them : the flowers growe at the fetting to of the leaues, like vnto a Mallow for forme, but of a whitith colour; after which come long fue fquare pointed pods, with hard thels, wherein are contained round blackifh gray feede, as bigge as a Vetch or bigger: the roote perifheth quickly with vs, euen with the firft frofts.

\section{Althan frutex fore albo vel purpureo.}

Shrubbe Mallow with a white or purple flower.

There are diuers forts of fhrubbe Mallowes, whereof fome that haue their ftemmes or ftalkes leffe wooddy, dye downe to the ground euery yeare, and others that abide alwayes, are more wooddy: Of the former forts I intend not to fpeake, referring them to a fitter place; and of the other, I will onely giue you the knowledge of one or two in this place, although I doe acknowledge their fitteft place had been to be among the Ahrubbes; but becaure they are Mallowes, I pray let them paffe with the reft of their kindred, and their defcriptions in this manner: Thefe wooddy kindes of thrub Mallowes haue fomewhat large, long, and diuided leaues, of a whitifh greene colour, foft alfo, and as it were woolly in handling, fet difperfedly on the whitifh hard or wooddy ftalkes : their flowers are large, like vnto a fingle Rofe or Hollyhocke, in the one being white with purple fpots in the bottome; in the other either of a deepe red colour, or elfe of a paler purple, with a deeper bottome, and with veines running in euery leafe: they are fomewhat tender, and would not be fuffered to be vncouered in the Winter time, or yet abroad in the Garden, but kept in a large pot or tubbe, in the houre or in a warme cellar, if you would haue them to thriue.

\section{Malua hortenfis rofea fimplex E multiplex diuer forum colorum. \\ Hollihockes fingle and double of feuerall colours.}

I thall not neede to make many defcriptions of Hollihockes, in regard the greateft difference confifteth in the flowers, which are in fome fingle, in fome double, in fome of one colour, and in others of other colours: for the loweft leaues of Hollihockes are all round, and fomewhat large, with many corners, but not cut in or diuided, foft in handling; but thofe that growe vp higher are much more diuided into many corners: the ftalkes fometimes growe like a tree, at the leaft higher then any man, witl diuers fuch diuided leaues on them, and flowers from the middle to the toppe, where they ftand as it were a long fpike of leaues and buds for flowers together: the flowers are of diuers colours, both fingle and double, as pure white, and pale blufh, almoft like a white, and more blufh, frefh and liuely, of a Rofe colour, Scarlet, and a deeper red like a crimfon, and of a darke red like blacke bloud; thefe are the moft ef peciall colours both of fingle and double flowers that I haue feene: the fingle flowers confit of fiue broad and round leaues, ftanding round like vnto fingle Rofes, with a middle long ftile, and fome chiues aboue them: the double flowers are like vinto double Rofes, very thicke, fo that no ftile or vmbone is feene in the middle, and the outermoft rowe of leaues in the flowers are largeft, the innermoft being finaller and thicke fet together: after the flowers are paft, there come vp as well in the double as fingle, flat round heads, like flat cakes, round about the bottomes whereof growe flat whitifh feede: the roote is long and great at the head, white and tough, like the roote of the common Mallowes, but greater, and will reafonably well abide the Winter. 
The Place.

The firft groweth wilde in Spaine. The fecond in our owne Countrey. The third is thought to growe in Italy and Venice; but Lobel denieth it, faying, that it is there onely in Gardens, and is more plentifull in thefe parts then with them. The fourth Clufius faith he found in many places of Germany. The fifth is fuppofed to be firft brought out of the Weft Indies, but an Arabicke name being giuen it, maketh me fomewhat doubtfull how to beleeue it. The fixth groweth in Egypt, where it is of great vfe, as Profper Alpinus hath fet downe in his Booke of Egyptian plants. The feuenth groweth in fome parts both of Spaine and France. The laft is not found but in Gardens euery where.

The Time.

The firf, fecond, third, fourth, and laft, doe flower from Iune vntill the end of Iuly and Auguft. The reft flower very late, many times not vntill September or October.

\section{The Names.}

The firft and fecond haue their names fufficiently expreffed in their titles. The third is diuerfly called, as Malua horaria, Alcea verficaria, Alcea Veneta, Alcea Peregrina, and of Matthiolus, Hypecoum. The moft vfuall Englifh name is Venice Mallow. The fourth is called Alcea fruticofa pentaphyllea, and Cannabinifolio, or Pentaphyllifolio: In Englin, Cinquefoile Mallow. The fifth hath been fent vnder the name of Sabdarifa, and Sabdariffa, and (as I faid) is thought to be brought from America, and therefore it beareth the name of that Country. The fixth is called in Egypt, Bamia, or Bammia, and by that name fent with the addition del Cayro vnto it: In Englifh, Egyptian Mallow, or Mallow of Egypt. The feuenth is called Althea frutex, and of fome Althea arborea: In Englifh, Shrubbe Mallow, becaufe his ftemme is wooddie, and abideth as hrubbes and trees doe. The eight and laft is called Malua horten fis, Malua Rofea, and of fome Rofa vltra marina: In Englifh, of fome Hockes, and vfually Hollihockes.

\section{The Vertues.}

All forts of Mallowes, by reafon of their vifcous or flimie quality, doe helpe to make the body foluble, being vfed inwardly, and thereby helpe alfo to eafe the paines of the ftone and grauell, caufing them to be the more eafily voided: being outwardly applyed, they mollifie hard tumours, and helpe to eafe paines in diuers parts of the body; yet thofe that are of moft vfe, are moft common. The reft are but taken vpon credit.

\section{Cн А P. X C I I.}

Amaranthus. Flower-gentle.

W

haue foure or fiue forts of Flower-gentle to trimme vp this our Garden withall, which doe differ very notably one from another, as nhall be declared in their feuerall defcriptions; fome of which are very tender, and muft be carefully regarded, and all little enough to caufe them beare feede with vs, or elfe wee fhall bee to feeke euery yeare: others are hardy enough, and will hardly be loft out of the Garden. 


\section{Amaranthus purpureus minor. The linall purple Flower-gentle.}

This gallant purple Veluet flower, or Flower-gentle, hath a crefted Italke two foote high or more, purplin at the bottome, but greene to the toppe, whereout groweth many fmall branches, the leaues on the ftalkes and branches are fomewhat broad at the bottome, and tharpe pointed, of a full greene colour, and often fomewhat reddifh withall, like in forme vnto the leaues of Blites (whereof this and the reft are accounted (pecies, or forts) or fmall Beetes : the flowers are long, fpikie, foft, and gentle tufts of haires, many as it were growing together, broad at the bottome, and fmall vp at the toppe, pyramis or fteeple-fathion, of fo excellent a Mining deepe purple colour, tending to a murrey, that in the moft excellent coloured Veluet, cannot be feene a more orient colour, (and I thinke from this refpect, the French call it Pafje velours, that is to fay, paffing Veluet in colour) without any fmell at all, which being bruifed giueth the fame excellent purple colour on paper, and being gathered in his full ftrength and beauty, will abide a great time (if it be kept out of the winde and funne in a dry place) in the fane grace and colour: among thefe tufts lye the feede fcattered, which is (mall, very blacke, and thining : the rootes are a few threddy ftrings, which quickly perifh, as the whole plant doth, at the firft approach of Winter weather.

\section{Amaranthus Coccineus. Scarlet Flower-gentle.}

The leaues of this Flower-gentle are longer, and fomewhat narrower then the former ; the ftalke groweth fomewhat higher, bearing his long tufts at feuerall leaues, as alfo at the toppe of the ftalkes, many being fet together, but feparate one from another, and each bowing or bending downe his head, like vnto a Feather, fuch as is worn in our Gallants and Gentlewomens heads, of an excellent bloudy Scarlet colour : the feede is blacke, like vnto the former: the roote perifheth quicklier, becaufe it is more tender.

\section{Amaranthus tricolor. Spotted or variable Flower-gentle.}

The chiefeft beauty of this plant confilteth in the leaues, and not in the flowers; for they are fmall tufts growing along the ftalke, which is nothing fo high as the former, efpecially with vs, and at the ioynts with the leaues: the leaues hereof are of the fame fafhion that the former are, and pointed alfo; but euery leafe is to be feene parted into greene, red, and yellow, very orient and frefh (efpecially if it come to his full perfection, which is in hot and dry weather) diuided not all alike, but in fome leaues, where the red or yellow is, there will be greene, and fo varying, that it is very pleafant to behold : the feede hereof is blacke and fhining, not to bee knowne from the former.

\section{Amaramthus Carnea Spica. Carnation Flower-gentle.}

There is another more rare then all the reit, whofe leaues are fomewhat longer, and narrower then the firt, and like vnto the fecond kinde : the fpikes are fhort, many fet together, like branches full of heads or eares of corne, euery one whereor hath fome long haires fticking out from them, of a deep blufh, tending to a carnation colour.

5. Amaranthus purpureus maior paniculis Sparfis. Great Floramour, or purple Flower-gentle.

The great Floramour hath one thicke, tall, crefted, browne red ftalke, fiue or fix foote high, from whence fpring many great broad leaues, like vnto the former for the forme, but much larger \& redder for the moft part, efpecially the loweft, which brancheth forth into diuers parts, \& from between thefe leaues, \& the ftalks or branches, as alfo at the tops of them, ftand long, [pikie, round, \& fomewhat flat tufts, of a more reddifh purple colour then the firt, and diuided alfo into feuerall parts, wherin when they 
are full ripe, are to be feen an innumerable company of white feed, ftanding out among the fhort thrums, and do then eafily fall away with a little touching; euery one of thefe white feed hath as it were an hole halfe bored through therin : the root is a great bufh of ftrings, fpreading in the ground, whereby it is ftrongly faftened, yet perifheth euery yeare, after it hath giuen his feede.

The Place.

All thefe plants growe in the Eafterne Countries, as Perfia, Syria, Arabia, \&c. except the greateft, which hath been brought out of the Weft Indies, where it is much vfed, efpecially the feede : they are all, except it, nourfed $v p$ with much care in our Gardens, and yet in a backward or cold yeare they will not thriue, for that they defire much heate : but the greateft doth alwayes giue ripe feede euery yeare.

\section{The Time.}

They beare their gallant tufts or fpikes for the moft part in Auguft, and fome not vntill September.

\section{The Names.}

The name Amaranthus is giuen to all thefe plants, taken from the Greeke word a ${ }^{2}$ apavrivos, non marcefcens, or non fenefcens, that is, neuer waxing old, and is often alfo impofed on other plants, who haue the fame property, that is, that their flowers being gathered in a fit feafon, will retaine their natiue colour a long time, as thall be thewed in the Chapter following. Diuers do thinke the firft to be Phlox, or Flamma of Theophraftus. The third is called Gelofia, or Celofia of Tragus. Spigelius in his Ifagoges faith, it is generally taken to be Sophonia, whereof Plinie maketh mention; and Lobel, to bee the Perfians Theombroton of Plinie. The Italians, from whom I had it (by the meanes of $\mathrm{M}^{\mathrm{r}}$. Doctor Iohn More, as I haue had many other rare fimples) call it, Blito di tre colori, A three coloured Blite. The fifth, which is the greateft, hath been fent from the Weft Indies by the name of Quinuia, as Clufius reporteth. The name Flower-gentle in Englifh, and Floramour, which is the French, of Flos amoris, and Pafe velours, as is before faid, or Veluet flower, according to the Italian, Flor veluto, are equally giuen to all thefe plants, with their feuerall diftinctions, as they are expreffed in their titles.

\section{The Vertues.}

Diuers fuppofe the flowers of thefe plants doe helpe to ftay the fluxe of bloud in man or woman, becaufe that other things that are red or purple doe performe the fame. But Galen difproueth that opinion very notably, in lib. 2. E 4. de fimpl. medicament. facultatibus.

\section{CH A P. X C I I I.}

HelichryJum, fue Amaranthus luteus.

Golden Flower-gentle, Goldilockes, or Gold-flower.

T

He propinquity of property (as I before faid) hath caufed the affinity in name, and fo in neighbourhood in thefe plants, wherein there are fome diuerfity; and although they differ from them before in many notable points, yet they all agree with themfelues in the golden, or filuer heads or tufts they beare; and therefore I 


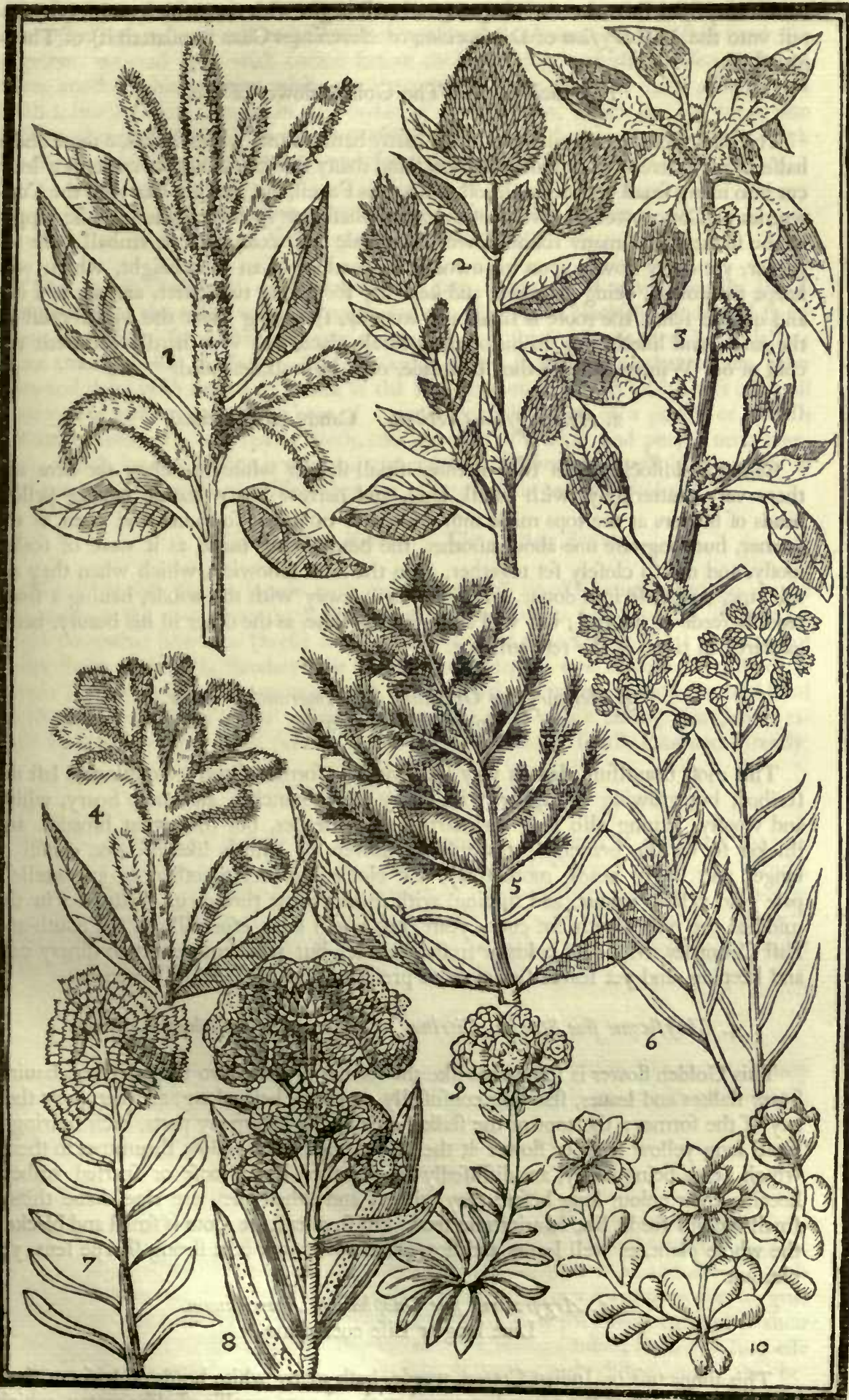

I Amarasthus purpureus maior. The great purple Flower gentle. 2 Amaranthus purpurens minor. The leffer purple Flower gente. 3 Amaranthus tricolor. Variable Flower gentle. 4 A Amaranthus Coccincus. Scarlet lilower gintle. 5 Amaranthus 8 Gmaphalium Americanum. Liuelong or Life euerlafting. 9 Graphalium monlanwm. Cats foote. ro Gnaphalium rofenm, The Cotion Role. 
haue comprifed them in one Chapter, and will begin with that which commeth neareft vnto the Helichryfum of Diofcorides, or Aurelia (as Gaza tranflateth it) of Theophraftus.

\section{Helichryfum. The Golden flower of life.}

This firft Golden tuft rifeth vp with many hard, round, white ftalkes, a foote and a halfe high, whereon at certaine diftances ftand many fine cut leaues, or rather one leafe cut into many fmall fine parts, almoft as fmall as Fenell, but grayinh, like vnto the Cudweedes or Cotton-weedes (whereof certainly thefe are fpeciall kindes) at the toppes of the ftalkes ftand many round flowers, of a pale gold colour, in an vmbell clofe together, yet euery flower vpon his owne ftalke, and all of an euen height, which will keepe the colour, being gathered, and kept dry for a long time after, and are of a hot and quicke fent: the roote is fmall and wooddy, fpreading vnder the vpper cruft of the earth, and liueth long in his owne naturall place, but very hardly endureth the cold of our Winters, vnleffe they be milde, or it be well defended.

\section{Helichryfum Creticum. Candy Goldilockes.}

Candy Goldilockes hath two or three fmall flender white branches, fet here and there very fcatteringly, with fmall, long, and narrow hoary leaues, hauing yellow heads of flowers at the tops made into vmbels or tufts, not fo round and euen as the former, but longwife one aboue another, the heads being made as it were of fcales, loofly, and not fo clofely fet together, as in the next following, which when they are full ripe, doe paffe into doune, and are blowne away with the winde, hauing a fmall reddifh feede at the end; but will abide a long time, as the other in his beauty, being gathered in time, as the reft will doe.

\section{Helichryfum Orientale fure Amaranthus luteus. Golden Flower-gentle.}

This moft beautifull plant is very like vnto the former Candy Goldilockes laft defcribed, but growing vp higher, with many more branches, and more hoary, white, and woolly, hauing alfo long and narrow white leaues, but fomewhat broader, and thicker fet on the branches : the tufts of flowers or vmbels likewife doe confift of longer and larger heads, more fcaly, and clofer compact together, of an excellent pale gold yellow colour, and fhining, with fome yellow threads or thrummes in the middle: the roote dyeth not euery yeare, but liueth long, efpecially in the South and Eaft Countries, where no colds or frofts are felt; but will require extraordinary care and keeping, and yet fcarce fufficient to preferue it in thefe cold Countries.

\section{Chryfocome fuue Stachas Citrina. Golden tufts or Golden Caffidony.}

This Golden flower is fomewhat like the former of thefe two laft defcribed, hauing hoary ftalkes and leaues, ftanding confufedly on them, being long, and narrower then any of the former: the tops of the ftalkes are diuided into many parts, each bearing a fmall long yellow head or flower at the toppe, with fome yellow thrummes in them, which heads being many, are diffufedly fet together, like a loofe or fparfed vmbell, keeping their colour long before they wither, and when they are ripe, haue thinne fmall reddifh feede, like Mariorome feede, but fmaller; the roote is fmall and blacke: the whole plant, as well leaues and flowers, as rootes, are of a ftrong fharpe fent, yet pleafant.

\section{Argyrocome fuue Gnaphalium Americanum.} Liue long or Life euerlafting.

This filuer tuft or Indian Cotton weede, hath many white heads of leafes at their firft fpringing out of the ground, couered with a hoary woollineffe like cotton, which rifing into hard, thicke round ftalkes, containe ftill the fame hoarineffe vpon them, as alfo vpon the long and narrow leaues which are fet thereon, efpecially on the vnder 
fide, for the vpper fides are of a darke fhining greene colour : the ftalkes are diuided at the toppe into many fmall branches, each whereof haue many faly tufted heads fet together, couered ouer with cotton before their opening, and then diffcuering one from another, abiding very white on the outfide, when they are fully growne, but with a fmall yellow thrume in the midde of euery flower, which in time turne into yellow doune, apt to be blowne away with euery winde: the roots are long and black on the outfide, creeping vinder ground very much.

\section{Gnaphalium montanum flore albo Es fore purpureo. \\ White and purple Cats foote.}

This frnall Cudweede or Cottonweede, hath many fmall white woolly leaues growing from the roote, which is compofed of a few fmall blackifh threds, and lying vpon the ground fomewhat like vnto the leaues of a fmall Moufe eare, but fmaller; from among which rifeth vp a fmall ftalke of halfe a foote high or thereabouts, befet here and there with fome few leaues, at the top whereof commeth forth a tuft of fmall flowers, fet clofe together, in fome of a pure white, in others of a purple or reddith colour, in fome of a pale red or blufh, and in others of a white and purple mixt together, which for the beauty is much commended and defired, but will hardly abide to be kept in Gardens, fo vnwilling they are to leaue their naturall abiding.

\section{Graphalium Rofeum. The Cotton Rofe.}

This little rofe Cotton weede hath many fuch like woolly leaues, growing as the former from the roote vpon fmall fhort branches, not full an hand breadth high, in fafhion fomewhat like vnto Dayfie leaues, but leffer, and round pointed: at the toppe of euery ftalke or branch, ftandeth one flower, compofed of two rowes of fmall white lenues, layd open like a Starre or a Rofe, as it beareth the name, hauing a round head in the middle made of many yellow threds or thrumes, which falling away, there rifeth vp a fmall round head, full of fmall feedes: the root is fmall, long and threddy.

The Place.

The foure firf plants doe grow naturally in many of the hot Countries of Europe, as Spaine, Italie, and Prouince in France; as alfo in Candy, Barbary, and other places, and muft be carefully kept with vs in the winter time. The Liue long was brought out of the Weft Indies, and groweth plentifully in our gardens. The two laft doe grow as well in the colder Countries of Germany, as in France and other places.

\section{The Time.}

They all flower in the end of September, if they will thew out their beauty at all with vs, for fometimes it is fo late, that they haue no faire colour at all, efpecially the foure firft forts.

The Names.

Variable and many are the names that feuerall Writers do call thefe foure firt forts of plants, as Helichryfum, Heliochry. fum, or Elichryfum, Eliochryfum, Chry focome, Coma aurea, Amaranthus luteus, Stocchas Citrina, and Aurelia, with others, needleffe here to be recited: it is fufficient for this worke, to giue you knowledge that their names are fufficient as they are expreffed in their titles: The fift is called Gnaphalium by Carolus Clufius, from the likeneffe of the vmbels or tufts of heads, though greater and white: for as I faid before, the Cotton weedes are of kindred with the golden tufts: It hath been called by our Englifh Gentlewomen, Liue long, and Life euerlafting, becaure of the durabilitie of the flowers in their beautie. The two laft are cal- 
led Gnaphalium, according to their titles; and in Englifh they may paffe vnder thofe names are fet downe with them.

The Vertues.

The foure firft are accounted to bee hot and dry, and the three laft to bee cold and dry: yet all of them may to fome good purpofe bee applyed to rheumaticke heads. The former foure are likewife vfed to caufe vrine, and in baths to comfort and heate cold parts. They are alfo layd in cheits and wardrobes, to keepe garments from moths; and are worne in the heads and armes of Gentiles and others, for their beautifull afpect.

\section{Ch A P. X C I I I I.}

Canna Indica. The Indian flowring Reede.

$\mathrm{T}$

Here are two kindes or forts of this beautifull plant, the one with a red flower, the other with a yellow, fpotted with reddin fpots, both which in fome kindly yeares haue borne their braue flowers, but neuer any ripe feede, and doth not abide the extremities of our winters, eyther abroade or vnder couert, vnleffe it meete with a ftoue or hot-houfe, fuch as are vfed in Germany, or fuch other like place : For neyther houfe nor cellar will preferue it, for want of heate.

\section{Canna Indica flore rubro. Red flowred Indian Reede.}

This beautifull plant rifeth vp with faire greene, large, broade leaues, euery one rifing out of the middle of the other, and are folded together, or writhed like vnto a paper Coffin (as they call it) fuch as Comfitmakers and Grocers vfe, to put in their Comfits and Spices, and being fpread open, another rifeth from the bottome thereof, folded in the fame manner, which are fet at the ioynts of the ftalke when it is rifen vp, like vnto our water Reede, and growing (if it runne vp for flower) to be three or foure foote high, as I haue obferued in mine owne garden : the flowers grow at the toppe of the ftalke one aboue another, which before their opening are long, fmall, round, and pointed at the end, very like vnto the claw of a Crauife or Sea-Crab, and of the fame red or crimfon colour, but being open, are very like vnto the flower of Gladiolus or Corne-flagge, but of a more orient colour then at the firft, and ftanding in a rough huske, wherein afterwards ftandeth a three fquare head, containing therein round blacke feede, of the bigneffe of a peafe : the roote is white and tuberous, growing into many knobs, from whence arife fuch other leaues and ftalkes, whereby it encreafeth very much, if it be rightly kept and defended.

\section{Ganna Indica flore flauo punctato. Yellow fpotted Indian Reede.}

This Reede groweth vp with leaues and flowers, in all points fo like vnto the former, that it cannot bee knowne from it, vntill it come to flower, which is of a yellow colour, fpotted with reddifh fpots, without any other difference.

\section{The Place.}

Thefe plants grow naturally in the Weft Indies, from whence they were firt fent into Spaine, and Portugall, where Clufius faith he faw them planted by the houfes fides, flowring in winter, which might be in thofe warme Countreyes. We preferue them with great care in our gardens, for the beautifull af pect of their flowers. 
The Time. neft.

They flower not with vs vntill the end, or middle of Auguft, at the foo-

The Names.

They are called of fome Canna Indica, and Arundo Indica, of others Cannacorus, and of fome Flos Cancri, becaufe the colour of the flowers, as well as the forme of the buds, are fo like vnto a Sea-Crabs cle, or claw.

\section{The Vertues.}

There is not any vfe of thefe in Phyficke that I know.

\section{CHA P. XCV.}

Mandragoras. Mandrake.

The Mandrake is diftinguifhed into two kindes, the male and the female; the male hath two forts, the one differing from the other, as fhall be fhewed; but of the female I know but one: The male is frequent in many gardens, but the female, in that it is more tender and rare, is nourfed vp but in a few.

\section{Mandragoras mas. The male Mandrake.}

The male Mandrake thrufteth vp many leaues together out of the ground, which being full growne, are faire, large and greene, lying round about the roote, and are larger and longer then the greateft leaues of any Lettice, whereunto it is likened by Diofcorides and others: from the middle, among thefe leaues, rife vp many flowers, euery one vpon a long flender ftalke, ftanding in a whitifh greene huske, confifting of fiue pretty large round pointed leaues, of a greenifh white colour, which turne into fmall round apples, greene at the firft, and of a pale red colour when they are ripe, very fmooth and fhining on the outfide, and of a heady or ftrong ftuffing fmell, wherein is contained round whitifh flat feede: the roote is long and thicke, blackifh on the outfide, and white within, confifting many times but of one long roote, and fometimes diuided into two branches a little below the head, and fometimes into three or more, as nature lifteth to beftow vpon it, as my felfe haue often feene, by the tranfplanting of many, as alfo by breaking and cutting off of many parts of the rootes, but neuer found harme by fo doing, as many idle tales haue beene fet downe in writing, and deliuered alfo by report, of much danger to happen to fuch, as fhould digge them vp or breake them; neyther haue I euer feene any forme of man like or woman-like parts, in the rootes of any: but as I faid, it hath oftentimes two maine rootes running down right into the ground, and fometimes three, and fometimes but one, as it likewife often happeneth to Parfneps, Carrots, or the like. But many cunning counterfeit rootes haue bin fhaped to fuch formes, and publickly expofed to the view of all that would fee them, and haue been tolerated by the chiefe Magiftrates of the Citie, notwithftanding that they haue beene informed that fuch practices were meere deceit, and vnfufferable; whether this happened through their ouer-credulitie of the thing, or of the perfons, or through an opinion that the information of the truth rofe vpon enuy, I know not, I leaue that to the fearcher of all hearts: But this you may bee bold to reft vpon, and affure your felues, that fuch formes as haue bin publickly expofed to be feene, were neuer fo formed by nature, but only by the art and cunning of knaues and deceiuers, and let this be your Galeatum againft all fuch vaine, idle and ridiculous toyes of mens inuentions. 
There is likewife another fort of thefe male Mandrakes, which I firft faw at Canterbury, with my very louing and kinde friende Iohn Tradefcante, in the garden of the Lord Wotton, whofe gardiner he was at that time; the leaues whereof were of a more grayifh greene colour, and fomewhat folded together, when as the former kind that grew hard by it, was of the fame forme that is before defcribed, and ordinary in all others: but whether the apples were differing from the other, I know not, nor did they remember that euer it had borne any.

Mandragoras famina. The female Mandrake.

The female Mandrake doth likewife put vp many leaues together, from the head of the roote, but they are nothing fo large, and are of a darker greene colour, narrower alfo and thining, more crumpled, and of a ftronger fent : the flowers are many, rifing $\mathrm{vp}$ in the middle of the leaues, vpon flender ftalkes, as in the male kind, but of a blewifh purple colour, which turne into fmall round fruite or apples, and not long like a peare (as Clufius reporteth that faw them naturally growing in Spaine) greene at the firf, and of a pale yellowifh colour, when they are full ripe; of a more pleafing, or if you will, of a leffe heady fent then the apples of the male, wherein is contained fuch like feede, but fmaller and blacker : the rootes are like the former, blacke without and white within, and diuided in the fame manner as the male is, fometimes with more, and fometimes with fewer parts or branches.

\section{The Place.}

They grow in many places of Italie, as Matthiolus reporteth, but efpecially on Mount Garganus in Apulia. Clufius faith hee found the female in many wet grounds of Spaine, as alfo in the borders of thofe medowes that lye neere vnto riuers and water courfes. The male is cherifhed in many Gardens, for pleafure as well as for vfe: but the female as is faid, is both very rare, and farre more tender.

\section{The Time.}

The Male flowreth in March, and the fruit is ripe in Iuly. The Female, if it be well preferued, flowreth not vntill Auguft, or September; fo that without extraordinary care, we neuer fee the fruite thereof in our gardens.

\section{The Names.}

Mandragoras mas is called albus, as the Famina is called niger, which titles of blacke and white, are referred vnto the colour of the leaues: the female is called alfo Thridacias, from the likeneffe of Lettice, whereunto they fay in forme it doth carry fome fimilitude. Diofcorides faith, that in his time the male was called Morion, and both of them Antimelum, and Circaa. Wee call them in Englifh, The male, and the female Mandrake.

\section{The Vertues.}

The leaues haue a cooling and drying qualitie, fit for the oyntment $P_{0-}$ puleon, wherein it is put. But the Apples haue a foporiferous propertie, as Leuinus Lemnius maketh mention in his Herball to the Bible, of an experiment of his owne. Befides, as Diofcorides firft, and then Serapio, Auicen, Paulus Ægineta, and others alfo do declare, they conduce much to the cooling and cleanfing of an hot matrix. And it is probable, that Rachel knowing that they might be profitable for her hot and dry body, was the more earneft with Leah for her Sonne Rubens Apples, as it is fet downe Genefis 30. ver $\int e$ 14. The ftrong fent of thefe apples is remembred alfo, Cant. 7. 13. although fome would diuert the fignification of the Hebrew word, דודאיפ, 
vnto Violets, or fome other fweet flowers, in the former place of Genefis, and the fruit of $M u f a$, or Adams Apples in this place of the Canticles. Hamilcar the Carthaginian Captaine is faid to haue infected the wine of the Lybians (his enemies againft whom he fought) with the apples of Mandrake, whereby they being made exceeding drowfie, he obtained a famous victory ouer them.

\section{Cна Р. X C V I.}

\section{Pomum Amoris. Loue Apples.}

A Lthough the beautie of this plant confifteth not in the flower, but fruit, yet giue me leaue to infert it here, left otherwife it have no place: whereof there are two efpeciall forts, which wee comprehend in one Chapter, and diftinguifh them by maius and minus, greater and fmaller: yet of the greater kinde, we haue nourfed vp in our Gardens two forts, that differ only in the colour of the fruite, and in nothing elfe.

\section{Pomum Amoris maius fructu rubro.}

Great Apple of Loue the ordinary red fort.

This greater kinde of Loue Apples, which hath beene moft frequently cherifhed with vs, hath diuers long and trayling, branches, leaning or fpreading vpon the ground, not able to fuftaine themfelues, whereon doe grow many long winged leaues, that is, many leaues fet on both fides, and all along a middle ribbe, fome being greater, and others leffe, iagged alfo and dented about the edges, of a grayifh ouer-worne greene colour, fomewhat rough or hairy in handling; from among the leaues and the branches come forth long ftalkes, with diuers flowers fet thereon, vpon feuerall thort footftalks, confifting of fixe, and fometimes of eight fmall long yellow leaues, with a middle pricke or vmbone, which after the flowers are fallen, rifeth to be the fruite, which are of the bigneffe of a fmall or meane Pippin, vneuenly bunched out in diuers places, and fcarce any full round without bunches, of a faire pale reddifh colour, or fomewhat deeper, like vnto an Orenge, full of a flimie iuice and watery pulpe, wherein the feede lyeth, which is white, flat and fomewhat rough: the roote fhooteth with many fmall ftrings and bigger branches vnder ground, but perifheth at the firft feeling of our winter weather. The fruite hereof by often fowing it in our Land, is become much fmaller then I haue here defcribed it : but was at the firft, and fo for two or three yeares after, as bigge as I haue related it.

\section{Pomum Amoris maius fructu luteo. Yellow Amorous Apples.}

Of the fame kinde is this other fort of Amorous Apples, differing in nothing but the colour of the fruite, which is of a pale yellow colour, hauing bunches or lobes in the fame manner, and feede alfo like the former.

\section{Pomum Amoris minus, fue Mala Ethiopica parua. Small Loue Apples.}

The fmall Apples of Loue in the very like manner, haue long weake trayling branches, befet with fuch like leaues as the greater kinde hath, but fmaller in euery part: the flowers alfo ftand many together on a long ftalke, and yellow as the former, but much fmaller: the fruite are fmall, round, yellowifh red berries, not much bigger then great grapes, wherein are contained white flat feede, like the other, but fmaller : the roote perifheth in like manner euery yeare, and therefore muft bee new fowen euery fpring, if you will haue the pleafure of their fight in the garden; yet fome yeares $I$ haue known them rife of their owne fowing in my garden. 
The Place.

They growe naturally in the hot Countries of Barbary, and Ethiopia; yet fome report them to be firft brought from Peru, a Prouince of the Weft Indies. Wee onely haue them for curiofity in our Gardens, and for the amorous afpect or beauty of the fruit.

\section{The Time.}

They flower in Iuly and Auguft, and their fruit is ripe in the middle or end of September for the moft part.

\section{The Names.}

The firft is named diuerny by diuers Authors; for Lobel, Camerarius, and others, call them Poma amoris. Dodonæus Aurea Mala. Gefnerus firft, and Bauhinus after him, make it to be a kinde of Solanum Pomiferum. Anguillara taketh it to be Lycoperficum of Galen. Others thinke it to bee Glaucium of Diofcorides. The laft is called Mala Ethiopica parua, and by that title was firft fent vnto vs, as if the former were of the fame kinde and country. We call them in Englifh, Apples of Loue, Loue-Apples, Golden Apples, or Amorous Apples, and all as much to one purpofe as another, more then for their beautifull afpect.

The Vertues.

In the hot Countries where they naturally growe, they are much eaten of the people, to coole and quench the heate and thirft of their hot ftomaches. The Apples alfo boyled, or infufed in oyle in the funne, is thought to be good to cure the itch, affuredly it will allay the heate thereof.

\section{Сна Р. X C VII.}

\section{Digitalis. Foxegloue.}

$\mathrm{T}$ Here are three principall forts of Foxegloues, a greater, a middle or meane fort, and a leffer, and of them, three efpeciall colours, that is, purple, white, and yellow; the common purple kinde that groweth abroad in the fields, I leaue to his wilde habitation: and of the reft as followeth.

\section{Digitalis maxima ferruginea. Dun coloured Foxegloues.}

The leaues of this Foxegloue are long and large, of a grayifh green colour, finely cut or dented about the edges, like the teeth of a fine fawe; among which commeth vp a ftrong tall ftalke, which when it was full growne, and with ripe feede thereon, I haue meafured to be feuen foot high at the leaft, whereon grow an innumerable company (as I may fo fay, in refpect of the aboundance) of flowers, nothing fo large as the common purple kinde, that groweth wilde euery where in our owne Countrey, and of a kinde of browne or yellowifh dunne colour, with a long lippe at euery flower; after them come feede, like the common kinde, but in fmaller heads: the rootes are ftringie like the ordinary, but doe vfually perifh, or feldome abide after it hath giuen feed.

\section{Digitalis maior flore carneo. Bluph coloured Foxegloues.}

This kinde of Foxegloues hath reafonable large leaues, yet not altogether fo large 


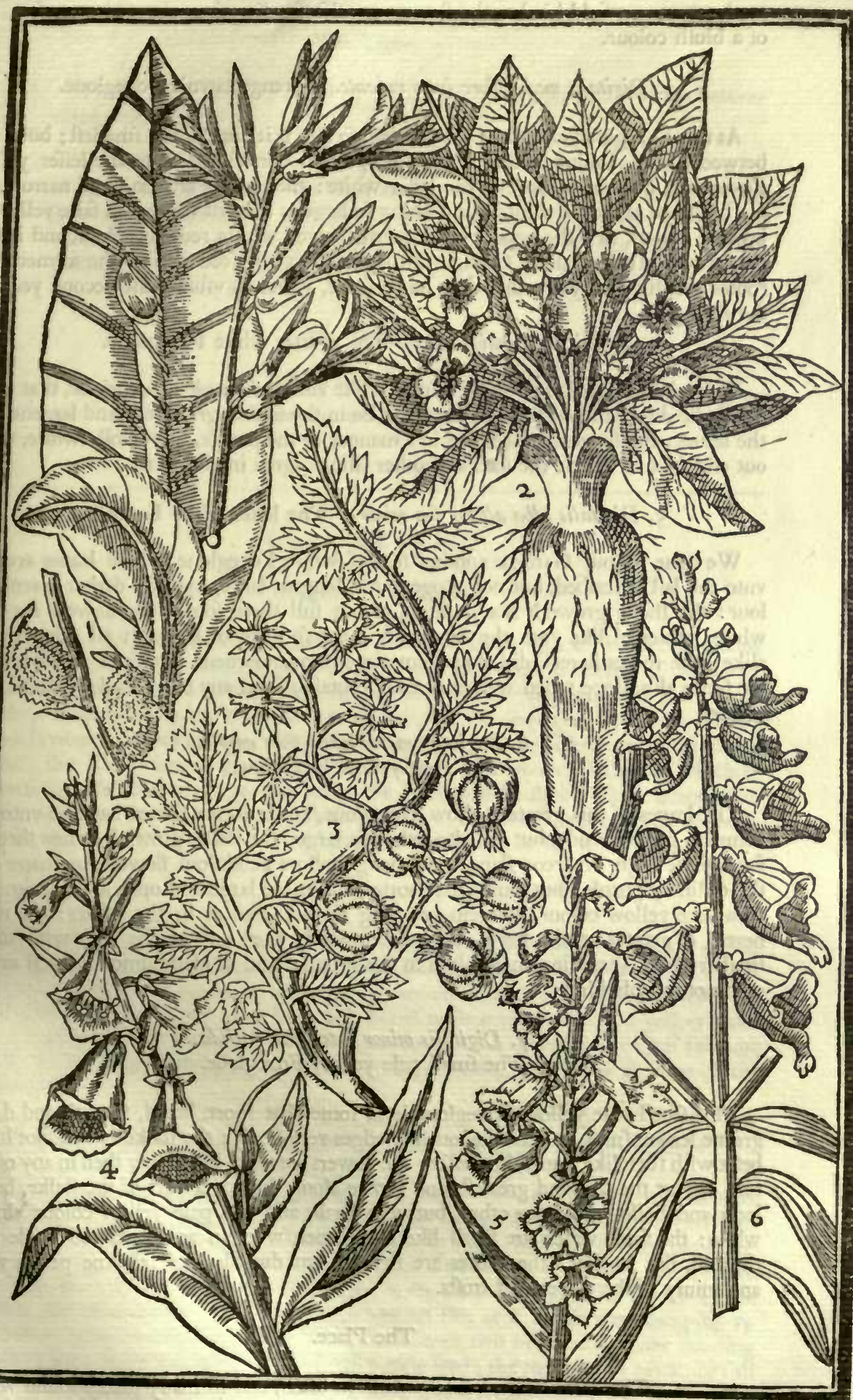

Canna Indica. The Indian Reed. 2 Mandragoras mas. The male Mandrake. 3 Pomum amoris mains. Great Apples of loue. 4 Digitalis maior flore luteo amplo. The great yellow Foxegloue. 5 Digitalis mediu flore luteo rubentc. Orenge tawny Foxegloues. 6 Digitalis maxima ferruginca. Dun coloured l'oxegloues. 
as the common field kinde: the flowers are alfo fmaller then the common fort, but of a blufh colour.

\section{Digitalis media flore luteo rubente. Orenge tawnie Foxegloue.}

As this Foxegloue is none of the greateft, fo alfo is it none of the fmalleft; but a fort betweene both, hauing leaues in fome proportion correfpondent to the leffer yellow Foxegloue, but not fo large as the leffer white: the flowers are long and narrow, almoft as large as the laft white, but nothing fo large as the firft white, of a faire yellowifh browne colour, as if the yellow were ouerfhadowed with a reddifh colour, and is that colour wee vfually call an Orenge tawnie colour: the feede is like the former: the rootes perifh euery yeare that they beare feede, which is vfually the fecond yeare of the fpringing.

\section{Digitalis maior alba. The greater white Foxegloue.}

This white Foxegloue is in all things fo like vnto the purple wilde kinde, that it can hardly be diftinguifhed from it, vnleffe it be in the frefher greenneffe and largeneffe of the leaues: the flowers are as great in a manner as the purple, but wholly white, without any fpot in them: the feed and other things agree in all points.

\section{Digitalis alba altera feu minor. The leffer white Foxegloue.}

We have in our Gardens another fort of white Foxegloue, whofe leaues are like vnto the laft defcribed, but not altogether fo long or large, and of a darker greene colour: the ftalke groweth not fo high, as not full three foote: the flowers are pure white, fafhioned like vnto the former, but not fo great or large, in all other things alike: the rootes hereof did abide fometime in our Gardens, but fince perifhed, and the feede alfo, fince when we neuer could obtaine from any our friends of that kinde againe.

\section{Digitalis maior lutea flore amplo.}

The great yellow Foxegloue.

The leaues of this greater yellow Foxegloue, are in forme fomewhat like vnto the common purple kinde, but not altogether fo large: the ftalke groweth to bee three or foure foote high, whereon ttand many long hollow pendulous flowers, in fhape like the ordinary purple: but fomewhat fhorter, and more large and open at the brimmes, of a faire yellow colour, wherein are long threads, like as in the others: the roote hereof is greater at the head, and more wooddy then any of the reft, with many fmaller fibres, fpreading themfelues in the ground, and abideth almoft as well as our common purple kinde.

\section{Digitalis minor lutea fue pallida.}

The fmall pale yellow Foxegloue.

This fmall pale yellow Foxegloue hath fomewhat fhort, broad, fmooth and darke greene leaues, fnipt or dented about the edges very finely: the ftalke is two foot high, befet with fuch like leaues, but leffer: the flowers are more in number then in any of the reft, except the firft and greateft, and growe along the vpper part of the ftalke, being long and hollow, like the other, but very fnall, and of a pale yellow colour almoft white: the feede veffels are fmall like the former, wherein are contained feede like the reft, but fmaller: the rootes are ftringy, but durable, and feldome perifh with any iniury of the extreameft frolts.

The Place.

The great white kinde hath been often, and in many places found wilde in our owne Country, among or hard by the common purple kinde. All the reft are ftrangers, but cherifhed in our Gardens. 


\section{The Time.}

They flower in Iune and Iuly, and fome in Auguft, their feede becomming ripe quickly after.

\section{The Names.}

Onely the name Digitalis, is of all Writers giuen vnto thefe plants ; for it is not knowne to bee remembred of any of the old Authors. Wee call them generally in Englifh, Foxegloue ; but fome (as thinking it to bee too foolifh a name) doe call them Finger-flowers, becaufe they are like vnto the fingers of a gloue, the ends cut off.

\section{The Vertues.}

Foxegloues are not vfed in Phyficke by any iudicious man that I know ; yet fome Italians of Bononia, as Camerarius faith, in his time vfed it as a wound herbe.

\section{Cна н, X CVIII.}

\section{Verbafcum. Mullein.}

,

T

Here be diuers kindes of Mullein, as white Mullein, blacke Mullein, wooddy Mullein, bafe Mullein, Moth Mullein, and Ethiopian Mullein, all which to diftinguifh or to defcribe, is neither my purpofe, nor the intent of this worke, which is to ftore a Garden with flowers of delight, and fequefter others not worthy of that honour. Thofe that are fit to bee brought to your confideration in this place, are firft, the Blattarias, or Moth Mulleins, and then the wooddy Mullein, which otherwife is called French Sage, and laftly, the Ethiopian Mullein, whofe beauty confifteth not in the flower, but in the whole plant; yet if it pleafe you not, take it according to his Country for a Moore, an Infidell, a Slaue, and fo vfe it.

\section{Blattaria lutea odorata. Sweete yellow Moth Mullein.}

The yellow Moth Mullein whofe flower is fweete, hath many hard grayifh greene leaues lying on the ground, fomewhat long and broad, and pointed at the end: the ftalks are two or three foot high, with fome leaues on them, \& branching out from the middle vpwards into many long branches, ftored with many fmall pale yellow flowers, of a pretty fweete fent, fomewhat ftronger then in the other forts, which feldome giueth feede, but abideth in the roote, liuing many yeares, which few or none of the others doe.

\section{Blattaria lutea maior fue Hifpanica. The great yellow Moth Mullein.}

This Spanifh kinde hath larger and greener leaues then the former, and rounder and larger then the next that followeth: the ftalke is higher then in any of the Moth Mulleins, being for the moft part foure or fiue foote high, whereon toward the toppe growe many goodly yellow flowers, confifting of fiue leaues, as all the reft doe, not fo thicke fet as the former, but much larger, with fome fmall purplifh threads in the middle: the ends whereof are fafhioned fomewhat like as if a Flie were creeping vp the flower, which turne into round heads, fometimes two or three or more ftanding together, but vfually one, wherein lye fmall duskie feed: the roote is not great nor full of threads, and doth perifh moft yfually hauing giuen feede, except the Winter bee very milde, 


\section{Blattaria lutea altera vulgatior. The ordinary yellow Moth Mullein.}

This yellow Moth Mullein (which is the moft frequent in our Gardens) hath longer, and narrower leaues then any of the former, and roundly notched or dented on the edges, of a darke greene colour: the ftalke is fometimes branched, but moft vfually fingle, whereon ftand many gold yellow flowers, not fully fo large as the Spanifh kinde, but with the like purple threads in the middle: the feede is fmall, and contained in the like round heads, but alwaies euery one fingle by it felfe: the roote perifheth euery yeare that it beareth feede.

\section{Blattaria flore luteo purpurafcente. Cloth of gold Moth Mullein.}

The greatert point of difference betweene this and the laft defcribed, confifteth chiefly in the colour of the flower, which in this is of the colour of cloth of gold, that is, the ground yellow, and ouerhadowed with a bright crimfon colour, which is a fine colour of much delight: the threads in the middle are not fo purple red as in the former, but much about the colour of the flower: this is not fo willing to giue feede, and will as hardly abide in the roote, and hath out of quettion rifen from the feede of the former.

\section{Blattaria flore albo. White Moth Mullein.}

The leaues of the white Moth Mullein are fomewhat like vnto the yellow, yet not altogether fo much roundly notched about the edges, but rather a little dented, with fharper notches: the ftalke rifeth as high as the yellow, and hath now and then fome branches about it: the flowers hereof are pure white, as large and great as the ordinary yellow, or fomewhat larger, with the like purple threads in the middle, as are in the yellow : the feed is like the other; the root perifheth in like manner, and will not endure.

\section{Blattaria flore purpureo. Purple Moth Mullein.}

The Purple Moth Mullein hath his leaues lying on the ground, broader and thorter then any of the other, of a more grayifh greene colour, and without any denting for the moft part about the edges, tharpe pointed alfo at the end of the leafe; among the leaues rifeth vp the ftalke, not fo high as either the white or the yellow, and many times branched, bearing many flowers thereon, of the fame fafhion, and no whit fmaller, of a faire deepe blewifh colour tending to redneffe, the threads in the middle of the flowers being yellow: the feede veffels hereof are fomewhat fmaller then any of the former, except the firft fweete yellow kinde: the roote hereof is long, thicke, and blackifh on the outfide, abiding very well from yeare to yeare, and rifeth well alfo from the fowing of the feede.

\section{Blattaria flore caruleo. Blew Moth Mullein.}

This blew Moth Mullein is in all refpects like vnto the former purple kinde, fauing onely in the colour of the flower, which is of a blewifh violet colour, and is not much inferiour either in greatneffe of the plant, or in the largeneffe of the flower, vnto the former purple kinde, and endureth many yeares in the like manner. And thefe be all the forts of this kinde of Moth Mullein, that I have feene and nourfed vp for this my Garden, without interpofing any vnknowne, not feene, or vnworthy.

\section{Verbafcum filueftre fue quartum Matthioli.} Wooddy Mullein or French Sage.

Wooddy Mullein or French Sage, hath diuers wooddy branches two or three foot high, very hoary or white, whereon at feuerall ioynts ftand diuers thicke leaues, white alfo and hoary, long, fomewhat broad, round pointed, and rough, fomewhat refembling the leaues of Sage in the forme and roughneffe, but not in the fent, whereof our 
people gaue it the name of Sage, calling it French Sage (when as it is as great a ftranger in France as in England, yet they doe with this as with many other things, calling them French, which come from beyond the Seas; as for example, all or moft of our bulbous flowers, they call French flowers, \&rc.) at the toppes of the ftalkes and branches, at certaine diftances, are placed round about them many gaping flowers, like vnto the flowers of Sage, but yellow: after which now and then come feede, fomewhat bigger then the Moth Mulleins, and leffe then the next Mullein of Ethiopia: the roote is wooddy at the toppe, with diuers blackifh ftrings growing from it, and endureth as well aboue ground with his lenues, as vnder it with his rootes.

\section{Athiopis. Ethiopian Mullein.}

This Mullein of Ethiopia hath many great, broad, and large leaues lying on the ground, rent or torne in diuers of them very much on the fides, of fo hoary a white greene colour, that it farre paffeth any of the white Mulleins, that growe wilde abroad in our owne Country ; for they are of a yellowith white hoarineffe, nothing fo pleafant to looke on as this: in the middle of thefe leaues rifeth vp a fquare ftrong ftalke, foure or fiue foote high, fet full of fuch like leaues as growe belowe, but much leffer, and leffer ftill vp to the toppe, all hoary and woolly, as the reft, and diuided into manie branches, fpreading farre, and taking vp a great compaffe of ground, more then any one roote of Garden Clary, or other fuch like plant : at each of the ftalkes and branches are fet two fmall leaues, and with them, round about the ftalkes, ftand many finall gaping flowers, of a pale bleake blew colour : the feede is almoft as large as Garden Clary feede, and of the fame forme and colour: the roote is wooddy, and peritheth as foone as it hath borne feede, which is vfually the fecond yeare after the fowing; for the firft yeare it feldome runneth vp to flower.

\section{Lamium Pannonicum fue Galeopfis Pannonica.} Hungary dead Nettle or the Dragon flower.

Let mee thruft this plant into this place, rather then make a peculiar Chapter, becaufe I haue no other of the fame ftocke or kindred to be ioyned with it, and is a pretty ornament in a Garden. The leaues whereof are very large, round, and great, rough or full of veines, which make it feeme crumpled, dented or deepely notched about the edges, and of a very darke greene colour, and fometimes brownin, or of a darke reddifh colour withall, euery one ftanding on a long foote-ftalke, very like in forme vnto the great white Arch-Angell leaues, but farre larger and blacker: the ftalkes are great and foure fquare, hauing leaues and flowers ftanding round about them at the ioynts like coronets, which flowers are very great, long, and wide gaping open, of a darke red or purple colour, with fome whiteneffe or fpots in the iawes, and fome hairineffe alfo on the fides, which ftand in full flower two or three moneths moft vfually, and fometimes longer, after which come brownifh feede: the roote is a great tuft or bufh of long whitifh ftrings, and encreafeth euery yeare, not fearing the greateft iniuries of our coldeft and extreameft Winters.

The Place.

All thefe plants are Atrangers in our Countrey, and onely preferued in Gardens, to furnifh them with variety; but (as I faid) the cloth of gold Moth Mullein hath been raifed from feed in our owne Country.

\section{The Time.}

The laft flowreth firft, before all the reft, beginning in Aprill. The Moth Mulleins in May and Iune. The French Sage in Iuly.

The Names.

All the forts of Blattaria may bee comprehended vnder the kindes of 
Verbafcum nigrum, as any one but meanely exercifed in the knowledge of plants, may difcerne. And although Plinie faith, that Moths doe moft frequently haunt where Blattaria either groweth, or is laid, yet it is not obferued fufficiently in our Country fo to doe, notwithftanding the name of Moth Mullein is generally giuen them. The laft is generally called with vs Lamium Pannonicum, but certainely it is the Galeofis maxima Pannonica of Clufius.

The Vertues.

Other qualities I haue not found hath been alloted vnto the Blattaria or Moth Mullein, then thofe of Plinie, to engender Moths. Wee vfe none of thefe plants in Phyficke in thefe daies.

\section{Ch A P. XCIX.}

\section{Valeriana. Valerian.}

$\mathrm{T}$ He many forts of Valerian (or Set-wall as many doe call them) are fitter for a generall worke, or a generall Phyficall Garden of Simples, then this of delightfull flowers. I will therefore felect out a few, worthy of the place, and offer them to your confiderations.

\section{Valeriana rubra Dodonai. Red Valerian.}

This Valerian hath diuers hard, but brittle whitifh greene ftalkes, rifing from the roote, full of tuberous or fwelling ioynts, whereat ftand two leaues, on each fide one, and now and then fome fmall leaues from betweene them, which are fomewhat long and narrow, broadeft in the middle, and rmall at both ends, without either diuifion or incifure on the edges, of a pale greene colour: the ftalkes are branched at the top into diuers parts, at the ends whereof ftand many flowers together, as it were in an vmbell or tuft, fomewhat like vnto the flowers of our ordinary Valerian, but with longer neckes, and of a fine red colour, very pleafant to behold, but of no fent of any Valerian: after thefe flowers haue ftood blowne a very great while, they fodainely fall away, and the feede is ripe very quickly after, which is whitirh, ftanding vpon the branches naked, as the Valerians doe, and very like vnto them, with a little white doune at the end of euery one of them, whereby they are foone carried away with the winde: the roote is great, thicke, and white, continuing long, and fhooting out new branches euery yeare, and fmelling fomewhat like a Valerian.

\section{Nardus Montana tuberofa. Knobbed Mountaine Valerian.}

This kinde of Valerian or Spiknard, if you will fo call it, hath his firft leaues lying on the ground, without any diuifion in them at all, being fmooth, and of a darke greene colour, which fo abide all the winter ; but thofe that fpring vp after, and when it runneth vp to flower, are cut in on the edges, very like vnto the iagged leaues of the great garden Valerian, and fo the elder they grow, the more cut and iagged they are: the ftalke and flowers are very like the ftalke with flowers of the garden Valerian, but of a darke or deepe red colour, and more ftore of them thruft together, by double the number almoft : the feede is like the feede of the great Valerian: the root is tuberous, or knobbed in many parts, round about, aboue and below alfo, with fome fibres fhooting from them, whereby it is encreafed, and fmelleth very like the roote of the garden Setwall, or not altogether fo ftrong. 


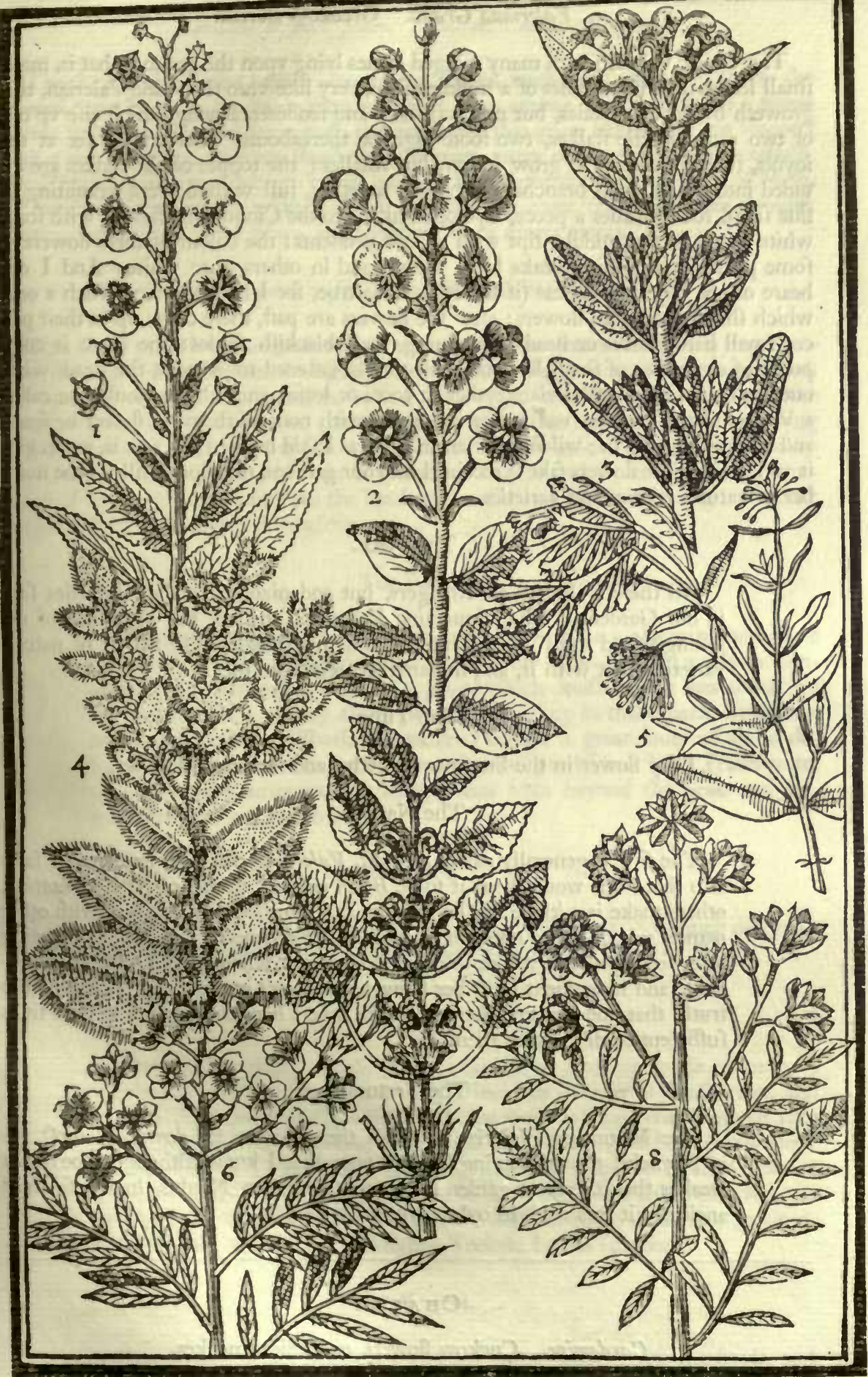

Blaltaria flore albo. Moth Mullein with a white flower. 2 Blallario fore purfurco. Moth Mullein with a purple flower. Verbafism quartum 3rathioli. French Sage. + Ethiopis. Etbiopian Mlullein. 5 Valeriara rubro Dodonai. Red alerian. 6 Valeriana Graca. Greek Valerian. Double Cuckowe flower or Ladies fmocks. 


\section{Valeriana Graca. Greeke Valerian.}

The Greek Valerian hath many winged leaues lying vpon the ground, that is, many fmall leaues fet on both fides of a middle ribbe, very like vnto the wilde Valerian, that groweth by the ditch fides, but much fmaller and tenderer, among which rife vp one or two round brittle ftalkes, two foote high or thereabouts, whereon are fet at the ioynts, fuch like leaues as grow below, but fmaller: the toppes of the ftalkes are diuided into many fmall branches, thicke fet together, full with flowers, confifting of fiue fmall round leaues a peece, layd open like vnto the Cinquefoile flower, with fome white threds in the middle, tipt with yellow pendents: the colour of thefe flowers in fome plants, is of a faire bleake blew colour, and in others pure white: And I doe heare of one beyond the Seas (if the report bee true, for I haue not feene fuch a one) which fhould beare red flowers: after the flowers are paft, there come vp in their places fmall hard huskes or heads, containing fmall blackifh feedes: the roote is compofed of a number of fmall long blackifh threds, faftened together at the head, without any fent at all of a Valerian, eyther in roote or leafe; and why it fhould bee called a Valerian I fee no great reafon, for it agreeth with none of them, in flower or feede, and but onely with the wilde Valerian in leafe, as I faid before: but as it is, we fo giue it you, and for the flowers fake is receiued into our gardens, to helpe to fill vp the number of natures rarities and varieties.

The Place.

All thefe Valerians are ftrangers, but endenizond for their beauties fake in our Gardens. The Mountaine Valerian I had of the liberalitie of my louing friend Iohn Tradefcante, who in his trauaile, and fearch of natures varieties, met with it, and imparted thereof vnto me.

The Time.

They flower in the Summer moneths, and feed quickly after.

\section{The Names.}

The firft is generally called of moft, Valeriana rubra Dodonai, who faith alfo that fome would haue it to be Behen rubrum. Some call it Valerianthon, others make it a kinde of Ocimaftrum, and fome Saponaria altera, with other names, which are to no great purpofe to fet downe in this place, it beeing fitter for a generall worke to difcuffe of names, wherein both reading, knowledge and iudgement muft bee fhewen, to correct errours, and fet downe the truth, that one may reft thereon. The others haue their names in their titles fufficient to diftinguilh them.

The Vertues.

The Mountaine Valerian is of all the reft here fet downe of moft vfe in Phyficke, the reft hauing little or none that I know, although it be much weaker then the great garden kinde, or the Indian Nardus, in whofe fteed anciently it was vfed, in oyles, oyntments, \&cc.

\section{C н A P. C.}

Cardamine. Cuckow flowers, or Ladies fmockes.

$F$ the common forts of Cuckow flowers that grow by ditch-fides, or in moift medowes, \& wet grounds, it is not my purpore here to write, but of one or two other, the moft fpecious or faire of all the tribe, that doe beft befit this garden. 


\section{Cardamine flore pleno. Double Cuckow flowers.}

The double Cardamine hath a few winged leaues, weake and tender, lying on the ground, very like vnto the fingle medow kinde; from among which rifeth vp a round greene ftalke, fet here and there, with the like leaues that grow below, the top whereof hath a few branches, whereon ftand diuers flowers, euery one vpon a fmall footeftalk, confifting of many fmall whitifh round leaues, a little dafht ouer with a fhew of blufh, fet round together, which make a double flower: the roote creepeth vnder ground, fending forth fmall white fibres, and fhooteth vp in diuers places.

\section{Cardamine trifolia. Trefoile Ladies fmockes.}

This fmall plant hath diuers hard, darke round greene leaues, fomewhat vneuen about the edges, alwayes three fet together on a blackifh fmall footftalke, among which rife vp fmall round blackifh ftalkes, halfe a foote high, with three fmall leaues at the ioynts, where they branch forth; at the toppes whereof ftand many flowers, confifting of foure leaues a peece, of a whitifh or blufh colour very pale : after which come vp fmall, thicke and long pods, wherein is contained fmall round feede : the root is compofed of many white threds, from the heads whereof runne out fmall ftrings, of a dark purple colour, whereby it encreafeth.

\section{The Place.}

The firft with the double flower is found in diuers places of our owne Countrey, as neere Micham about eight miles from London; alfo in Lancafhire, from whence I receiued a plant, which perifhed, but was found by the induftrie of a worthy Gentlewoman, dwelling in thofe parts heretofore remembred, called Miftreffe Thomafin Tunftall, a great louer of thefe delights. The other was fent me by my efpeciall good friend Iohn Tradefcante, who brought it among other dainty plants from beyond the Seas, and imparted thereof a roote to me.

\section{The Time.}

The laft moft vfually flowreth before the former, yet not much differing, that is, in the end of Aprill or in May.

\section{The Names.}

The firt is a double kinde of that plant, that growing wilde abroade, is vfually called Cardamine altera, and Sifymbrium alterum of Diofcorides, and of fome Flos cuculi, but not fitly; for that name is more vfually giuen vnto the wilde featherd Campions, both fingle and double, as is before expreffed: yet for want of a fitter name, wee may call it in Englifh, eyther Cuckowe flower, or Ladyes fmockes, which you will. The fecond hath beene fent vnder the name of Sanicula trifolia, but the moft frequent name now received, is Cardamine trifolia, and in Englifh Trefoile Ladies fmockes.

\section{The Vertues.}

The double Ladies fmockes are of the fame qualitie with the fingle, and is thought to be as effectuall as Watercreffes. The propertie of the other I thinke is not much knowne, although fome would make it a wound herbe. 


\section{C н A P. C I.}

Thlaspi Creticum. Candy Tufts.

F the many forts of Thla/pi it is not the fcope of this worke to relate, I will felect but onely two or three, which for their beautie are fit to bee inferted into this garden.

\section{Thlaspi Creticum vmbellatum flore albo E purpureo. \\ Candy Tufts white and purple.}

This fmall plant rifeth feldome aboue a foote and a halfe high, hauing Imall, narrow, long and whitifh greene leaues, notched or dented with three or foure notches on each fide, from the middle to the point-wards; from among which rife vp the ftalkes, branched from the bottome almoft into diuers fmall branches, at the toppes whereof ftand many fmall flowers, thick thruft together in an vmbell or tuft, making them feeme to be fmall, round, double flowers of many leaues, when as euery flower is fingle, and ftandeth a part by it felfe, of a faire white colour in fome plants, without any fpot, and in others with a purplifh fpot in the centre or middle, as if fome of the middle leaues were purple; in others agane the whole flower is purplinh all ouer, which make a pretty thew in a garden : the feede is contained in many fmall and flat feed veffels, which ftand together in an vmbell, as the flowers did, in which are contained fomewhat reddifh feede, like vnto fome other forts of Thla/pi, called Treakle Muftards: the roote is Imall and hard, and perifheth euery yeare hauing giuen feede.

Thlafpi Mari- We haue another fort, whofe leaues before it fendeth forth any. ftalke, are a little num Baticum. toothed, or finely dented about the edges, and brancheth not fo much out, but carryeth an vmbell of purplifh flowers like vnto the former, and paler yellow feede.

\section{The Place.}

Thefe doe grow in Spaine and Candie, not farre from the Sea fide.

\section{The Time.}

Thefe Thlaspi giue not their flowers vntill the end of Iune, or beginning of Iuly, and the feed is ripe foone after.

\section{The Names.}

The firft is named by fome, Draba, or Arabis, as Dodonæus, but Draba is another plant differing much from this. Wee call one fort, Thlajpi Creticum, and the other Thlaspi Baticum marinum, becaufe the one came from Spaine, and the other from Candy; we giue it in Englin, the name of Tufts, becaufe it doth fit the forme of the flowers beft, although ordinarily all the Thlaspi are Englinhed Wilde Murtardes.

\section{The Vertues.}

Candy, or Spanifh Tufts, is not fo tharpe biting in tafte, as fome other of the Thlafpies are, and therefore is not to be vfed in medicines, where Thlaspi hould be in the ftead thereof. 


\section{CHAP. CII.}

\section{Glematis. Clamberers, or Creepers.}

$\mathrm{H}$ Auing fhewed you all my ftore of herbes bearing fine flowers, let mee now bring to your confideration the reft of thofe plants, be they Shrubs or Trees, that are cherifhed in our garden, for the beauty of their flowers chiefly, or for fome other beautifull refpect : and firft I will begin with fuch as creepe on the ground, without climing, and then fuch as clime vp by poles, or other things, that are fet or grow neere them, fit to make Bowers, and Arbours, or elfe are like them in forme, in name, or fome other fuch qualitie or propertie.

\section{Clematis Daphnoides, fue Vinca peruinca fimplex minor diuer forum colorum. Single Perwinkle of diuers colours.}

The fmaller Perwinkle which not onely groweth wilde in many places, but is moft vfuall in our Gardens, hath diuers creeping branches, trayling or running vpon the ground, fhooting out fmall fibres at the ioynts, as it creepeth, taking thereby hold in the ground, and rooteth in diuers places: at the ioynts of thefe branches ftand two fmall darke greene fhining leaues, fomewhat like vnto fmall Baye leaues, but fmaller, and at the ioynts likewife with the leaues, come forth the flowers, one at a ioynt, ftanding vpon a tender footeftalke, being fomewhat long and hollow, parted at the brims, fometimes into foure leaues, and fometimes into fiue, the moft ordinary fort is of a pale or bleake blew colour, but fome are pure white, and fome of a darke reddifh purple colour : the root is in the body of it, little bigger then a rufh, bufhing in the ground, and creeping with his branches farre about, taking roote in many places, whereby it quickely poffeffeth a great compaffe; and is therefore moft vfually planted vnder hedges, or where it may haue roome to runne.

\section{Vinca peruinca flore duplici purpureo.}

Double purple Perwinkle.

The double Perwinkle is like vnto the former fingle kinde, in all things except in the flower, which is of that darke reddifh purple colour that is in one of the fingle kindes; but this hath another row of leaues within the flower, fo that the two rowes of leaues caufeth it to be called double, but the leaues of thefe are leffer then the fingle. I haue heard of one with a double white flower, but I have not yet feene it.

\section{Clematis Daphnoides fue Peruinca maior. \\ The greater Perwinkle.}

This greater Perwinkle is fomewhat like the former, but greater, yet his branches creepe not in that manner, but ftand more vpright, or leffe creeping at the leaft: the leaues alfo hereof ftand by couples at the ioynts, but they are broader and larger by the halfe: the flowers are larger, confifting of fiue leaues that are blew, a little deeper then the former blew : this plant is farre tenderer to keepe then the other, and therefore would ftand warme, as well as in a moift fhadowie place.

\section{Clematis altera fue vrens flore albo. Burning Clamberer, or Virgins Bower.}

This Caufticke or burning Climer, hath very long and climing tender branches, yet fomewhat woody below, which winde about thofe things that ftand neere it, couered with a brownih greene barke, from the ioynts whereof fhoote forth many winged leaues, confifting for the moft part of fiue fingle leaues, that is, two and two together, and one at the end, which are a little cut in or notched on the edges here and 
there, but euery part of them is leffer then the leaues of the next following Climer, without any clafping tendrels to winde about any thing at all : towards the vpper part of the branches, with the faid leaues, come forth long ftalks, whereon ftand many white flowers cluftering together, opening the brims into fixe or eight fmall leaues, fpreading like a ftarre, very fweet of fmell, or rather of a ftrong heady fent, which after turne into flattifh and blackifh feede, plumed at the head, which plume or feather flyeth away with the winde after it hath ftood long, and leaueth the feede naked or bare: the roote is white and thicke, flefhie and tender, or eafie to be broken, as my felfe can well teftifie, in that defiring to take a fucker from the roote, I could not handle it fo tenderly, but that it broke notwithftanding all my care. Mafter Gerard in his Herball maketh mention of one of this kinde with double white flowers, which hee faith he recouered from the feede was fent him from Argentine, that is Strasborough, whereof hee fetteth forth the figure with double flowers: but I neuer faw any fuch with him, neither did I euer heare of any of this kinde with double flowers. Clufius indeed faith, that hee receiued from a friend fome feede vnder the name of Clematis flore albo pleno: but he doubteth whether there bee any fuch: the plants that fprang with him from that feede, were like vnto the vpright kinde called Flammila Matthioli, or Iouis crefta, as he there faith : but affuredly I haue beene informed from fome of my efpeciall friends beyond Sea, that they haue a double white Clematis, and haue promifed to fend it; but whether it will be of the climing or vpright fort, I cannot tell vntill I fee it: but furely I doe much doubt whether the double will giue any good feede.

\section{Clematis altera fue peregrina fore rubro. Red Ladies Bower.}

This Climer hath many limber and weake climing branches like the former, couered with a browne thin outer barke, and greene vnderneath: the leaues ftand at the ioynts, confifting but of three leaues or parts, whereof fome are notched on one fide, and fome on both, without any clafping tendrels alfo, but winding with his branches about any thing ftandeth next vnto it: the flowers in like manner come from the fame ioynts with the leaues, but not fo many together as the former vpon long footftalkes, confifting of foure leaues a peece, ftanding like a croffe, of a darke red colour; the feed is flat and round, and pointed at the end, three or foure or more ftanding clofe together vpon one ftalk, without any doune vpon them at all, as in the former: the roots are a bundell of brownifh yellow ftrong ftrings, running down deep into the ground, from a bigge head aboue.

\section{Clematis peregrina flore purpureo fimplici.} Single purple Ladies Bower.

This Ladies Bower differeth in nothing from the laft defcribed, but onely in the colour of the flower, which is of a fad blewifh purple colour; fo that the one is not poffible to be known from the other, vntill they be in flower.

\section{Glematis peregrina fore purpureo pleno.}

Double flowred purple Ladies Bower.

This double Clematis hath branches and leaues fo neere refembling the fingle kinds, that there can be knowne no difference, vnleffe it be, that this groweth more goale and great, and yeeldeth both more ftore of branches from the ground, and more fpreading aboue: the chiefert marke to diftinguifh it is the flower, which in this is very thicke and double, confifting of a number of fmaller leaues, fet clofe together in order in the middle, the foure outermoft leaues that encompaffe them, being much broader and larger then any of the inward, but all of a dull or fad blewifh purple colour, the points or ends of the leaues feeming a little darker then the middle of them: this beareth no feede that euer I could fee, heare of, or learne by any of credit, that haue nourfed it a great while; and therefore the tales of falfe deceitfull gardiners, and others, that diliuer fuch for truth, to deceiue perfons ignorant thereof, muft not bee credulouly entertained. 
In the great booke of the Garden of the Bifhop of Eyftot (which place is neere clematisperevnto Noromberg) in Germany, I reade of a Clematis of this former kinde, whofe fi-grina fore car. gure is thereto alfo annexed, with double flowers of an incarnate, or pale purple ten-" ding to a blufh colour, whereof I haue not heard from any other place.

\section{Flammula Iowis ereda. Vpright Virgins Bower.}

This kinde of Clematis hath diuers more vpright ftalkes then any of the foure laft defcribed, fometimes foure or fiue foote high, or more : yet leaning or bending a little, io that it had fome neede of fuftaining, couered with a brownifh barke; from whence come forth on all fides diuers winged leaues, confifting of fiue or feuen leaues, fet on both lides of a middle ribbe, whereof one is at the end : the tops of the ftalkes are diuided into many branches, bearing many white fweet finelling flowers on them, like in fafhion vnto the white Virgins Bower; after which corne fuch like feather topt feede, which remaine and fhew themfelues, being flat like the other, when the plumes are blowne abroad : the roote \{preadeth in the ground from a thicke head, into many long ftrings, and fafteneth it felfe ftrongly in the earth; but all the ftalkes dye downe euery yeare, and fpring afrefh in the beginning of the next.

\section{Clematis carulea Pannonica. The Hungarian Climer.}

The ftalks of this plant ftand vpright, \& 2 are foure fquare, bearing at euery ioynt two leaues, which at the firft are clofed together, and after they are open, are fomewhat like vnto the leaues of Afclepias, or Swallow-wort : from the tops of the ftalks, and fometimes alfo from the fides by the leaues 'commeth forth one flower, bending the head downward, confifting of foure leaues, fomewhat long \& narrow, ftanding like a croffe, and turning $v p$ their ends a little againe, of a faire blew or skie colour, with a thicke pale yellow thort thrumme, made like a head in the middle : after the flower is part, the head turneth into fuch a like round feather topt ball, as is to be feene in the Trauellers ioy, or Viorna (as it is called) that groweth plentifully in Kent, and in other places by the way fides, and in the hedges, wherein is included fuch like flat feede. Thefe ftalkes (like as the laft) dye downe to the ground euery yeare, and rife againe in the Spring following, fhooting out new branches, and therby encreafeth in the root.

\section{Maracoc fune Clematis Virginiana. The Virginia Climer.}

Becaufe this braue and too much defired plant doth in fome things refemble the former Climers, fo that vnto what other family or kindred I might better conioyne it I know not; let me I pray infert it in the end of their Chapter, with this defcription. It rifeth out of the ground (very late in the yeare, about the beginning of May, if it be a plant hath rifen from the feed of our owne fowing, and if it be an old one, fuch as hath been brought to vs from Virginia, not till the end thereof) with a round ftalke, not aboue a yard and a halfe high (in any that I haue feene) but in hotter Countries, as fome Authors have fet it downe, much higher, bearing one leafe at euery ioynt, which from the ground to the middle thereof hath no clafpers, but from thence vpwards hath at the fame ioynt with the leafe both a fmall twining clafper, like vnto a Vine, and a flower alfo : euery leafe is broad at the ftalke thereof, and diuided about the middle on both fides, making it fornewhat refemble a Figge leafe, ending in three points, whereof the middlemolt is longelt : the bud of the flower, before it doe open, is very like vnto the head or feede veffell of the ordinary fingle Nigella, hauing at the head or top fiue frnall crooked hornes, which when this bud openeth, are the ends or points of fiue leaues, that are white on the infide, and lay themfelues flat; like vnto an Anemone, and are a little hollow like a fcoope at the end, with fiue other fmaller leaues, and whiter then they lying betweene them, which were hid in the bud before it opened, fo that this flower being full blowne open, confifteth of ten white leaues, laide in order round one by another : from the bottome of thefe leaues on the infide, rife diuers twined threads, which fpread and lay themfelues all ouer thefe white leaues, reaching beyond the points of them a little, and are of a reddifh peach colour : towards the bot- 
tomes likewife of thefe white leaues there are two red circles, about the breadth of an Oten ftrawe, one diftant from another (and in fome flowers there is but one circle feen) which adde a great grace vnto the flower ; for the white leaues thew their colour through the peach coloured threads, and thefe red circles or rings vpon them being alfo perfpicuous, make a tripartite thew of colours moft delightfull : the middle part of this flower is hollow, and yellowifh ; in the bottome whereof rifeth vp an vmbone, or round ftile, fomewhat bigge, of a whitifh greene colour, fpotted with reddifh fpots like the ftalkes of Dragons, with fiue round threads or chiues, fpotted in the like manner, and tipt at the ends with yellow pendents, ftanding about the middle part of the faid vmbone, and from thence rifing higher, endeth in three long crooked hornes moft vfually (but fometimes in foure, as hath beene obferued in Rome by $\mathrm{D}^{\mathrm{r}}$. Aldine, that fet forth fome principall things of Cardinall Farnefius his Garden) fpotted like the reft, hauing three round greene buttons at their ends: thefe flowers are of a comfortable fweete fent, very acceptable, which perifh without yeelding fruit with vs, becaufe it flowreth fo late: but in the naturall place, and in hot Countries, it beareth a fmall round whitifh fruit, with a crowne at the toppe thereof, wherein is contained (while it is

The Iefuites Figure of the Maracoc.

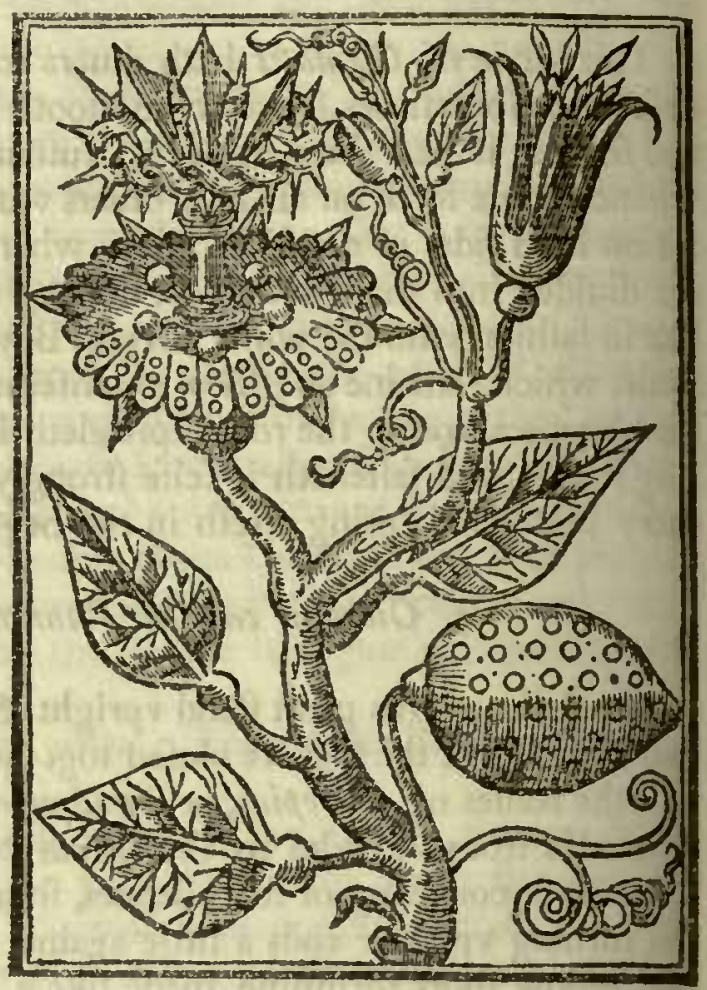

GRANADILLVS FrVTEX INDICVS Christi Passionis IMAgo. frefh, and before it be ouer dried) a fweet liquor, but when it is dry, the feede within it, which is fmall, flat, fomewhat rough and blacke, will make a ratling noire: the rootes are compofed of a number of exceeding long and round yellowilh browne ftrings, fpreading farre abroad vnder the ground (I haue feene fome rootes that haue beene brought ouer, that were as long as any rootes of Sar Saparilla, and a great deale bigger, which to be handfomely laid into the ground, were faine to be coyled like a cable) and fhooting vp in feuerall places a good diftance one from another, whereby it may be well encreafed.

The Place.

The firft blew Perwinkle groweth in many Woods and Orchards, by the hedge fides in England, and fo doth the white here and there, but the other fingle and double purple are in our Gardens onely. The great Perwinkle groweth in Prouence of France, in Spaine, and Italy, and other hot Countries, where alfo growe all the twining Clamberers, as well fingle as double: but both the vpright ones doe growe in Hungary and there abouts. The furpaffing delight of all flowers came from Virginia. Wet preferue them all in our Gardens.

The Time.

The Perwinkles doe flower in March and Aprill. The Climers not vn till the end of Iune, or in Iuly, and fometimes in Auguft. The Virginiar fomewhat later in Auguft; yet fometimes I haue knowne the flower to fhev it felfe in Iuly.

The Names.

The firt is out of queftion the firft Clematis of Diofcorides, and called c 


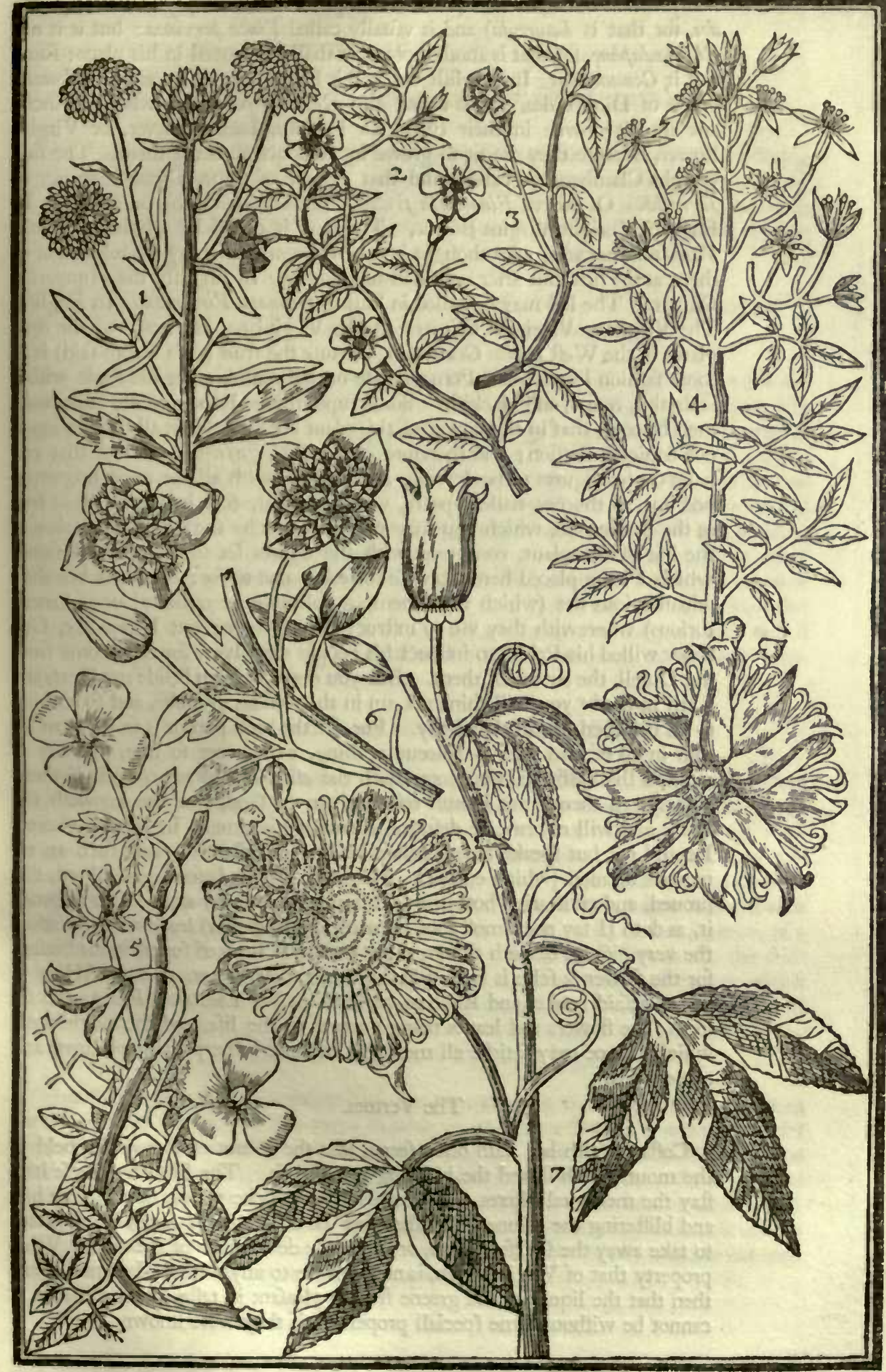

2.Thla/pi Cretiown. Candy iufts, 2 Vinca perwinca fore fimplici. Single Perwinkle. 3 Vinca perwinca flore duplici. Double Clemalis peregrina fore pleno purpwrro. Dooble dowred Ladies Bower. 7 Maracor fiwe Clemalis Virginiana. The Virginian Climes. 
many Clematis Daphnoides (but not that plant that is fimply called Daphnoides, for that is Laureola) and is vfually called Vinca pervinca: but it is not Chamadaphne, for that is another plant, as fhall be fhewed in his place; fome call it Centunculus: In Englifh wee call it Perwinkle. The other is Clematis altera of Diofcorides, and is called alfo Clematis peregrina, whofe diftinctions are fet downe in their titles: In Englifh, Ladies Bower, or Virgins Bower, becaufe they are fit to growe by Arbours, to couer them. The firft vpright Clamberer is called, and that rightly of fome, Clematis erecta, or furrecta. Of others, Flammula frutex, and Flammula Iouis, or Jurrecta: In Englifh, Vpright Virgins Bower. The next is called by Clufius, Clematis Pannonica carulea, who thought it to be Climeni Species, by the relation of others, at the firft, but after entituled it, Clematis: In Englin, the Hungarian Climer. The laft may be called in Latine, Clematis Virginiana: In Englifh, The Virgin or Virginian Climer; of the Virginians, Maracoc: of the Spaniards in the Weft Indies Granadillo, becaufe the fruit (as is before faid) is in fome fafhion like a fmall Pomegranate on the outfide; yet the feede within is flattifh, round, and blackifh. Some fuperftitious Ief uite would faine make men beleeue, that in the flower of this plant are to be feene all the markes of our Sauiours Paffion; and therefore call it Flos Pa/sionis: and to that end haue caufed figures to be drawne, and printed, with all the parts proportioned out, as thornes, nailes, fpeare, whippe, pillar, \&c. in it, and all as true as the Sea burnes, which you may well perceiue by the true figure, taken to the life of the plant, compared with the figures fet forth by the Iefuites, which I haue placed here likewife for euery one to fee: but thefe bee their aduantagious lies (which with them are tolerable, or rather pious and meritorious) wherewith they vfe to inftruct their people; but I dare fay, God neuer willed his Priefts to inftruct his people with lyes: for they come from the Diuell, the author of them. But you may fay I am befide my Text, and I am in doubt you will thinke, I am in this befides my felfe, and fo nothing to be beleeued herein that I fay. For, for the moft part, it is an inherent errour in all of that fide, to beleeue nothing, be it neuer fo true, that any of our fide fhall affirme, that contrarieth the affertions of any of their Fathers, as they call them: but I muft referre them to God, and hee knoweth the truth, and will reforme or deforme them in his time. In regard whereof I could not but fpeake (the occafion being thus offered) againft fuch an erroneous opinion (which euen $\mathrm{D}^{\mathrm{r}}$. Aldine at Rome, before remembred, difproued, and contraried both the faid figures and name) and feek to difproue it, as doth (I fay not almoft, but I am affraid altogether) leade many to adore the very picture of fuch things, as are but the fictions of fuperfitious brains: for the flower it felfe is farre differing from their figure, as both Aldine in the aforefaid booke, and Robinus at Paris in his Theatrum Flora, doe fet forth; the flowers and leaues being drawne to the life, and there exhibited, which I hope may fatisfie all men, that will not be perpetually obftinate and contentious.

\section{The Vertues.}

Coftxus faith hee hath often feene, that the leaues of Perwinkle held in the mouth, hath ftayed the bleeding at the nofe. The French doe vfe it to ftay the menftruall fluxes. The other are caufticke plants, that is, fiery hot, and bliftering the skinne; and therefore (as Diofcorides faith) is profitable to take away the fcurfe, leprye, or fuch like deformities of the skin. What property that of Virginia hath, is not knowne to any with vs I thinke, more then that the liquor in the greene fruit is pleafant in tafte; but affuredly it cannot be without fome Ipeciall properties, if they were knowne. 
CHА P. CIII.

Chamelce. Dwarfe Spurge Oliue, or Dwarfe Baye.

Taue three forts of Chameleen to bring to your confideration, euery one differing notably from other; two of them of great beauty in their flowers, as well as in the whole plant: the third abiding with greene leaues, although it haue no beauty in the flower, yet worthy of the place it holds. And vnto thefe I muft adioyne another plant, as comming neareft vnto them in the brauery of the flowers.

1. Chamelea Germanica fue Mezereon floribus dilutioris coloris \& faturatioris. Dwarfe Bay, or flowring Spurge Oliue.

We haue two forts of this Spurge Oliue or Dwarfe Baye, differing onely in the colour of the flowers. They both rife vp with a thicke wooddy ftemme, fiue or fix foot high fometimes, or more, and of the thickneffe (if they be very old) of a mans wreft at the ground, fpreading into many flexible long branches, couered with a tough grayith harke, befet with fmall long leaues, fomewhat like vnto Priuet leaues, but fmaller and paler, and in a manner round pointed : the flowers are fmall, confifting of foure leaues, many growing together fometimes, and breaking out of the branches by themfelues: in the one fort of a pale red at the firft blowing, and more white afterwards; the other of a deeper red in the bloffome, and continuing of a deeper red colour all the time of the flowring, both of them very fweete in fmell : after the flowers are paft, come the berries, which are greene at the firft, and very red afterwards, turning blackifh red, if they ftand too long vpon the branches: the rootes fpread into many tough long branches, couered with a yellowifh barke.

\section{Chamalaen Alpina. Mountaine Spurge Oliue.}

This Mountaine Laurell rifeth vp with a fmall wooddy ftemme, three or foure foot high, or more, branching forth towards the vpper parts into many flender and tough branches, couered with a rough hoary greene barke, befet at the ends thereof with flatter, fuller, and fmaller round pointed leaues then the former, of a grayilh greene colour on the vpperfide, and hoary vnderneath, which abide on the branches in Winter, and fall not away as the former: the flowers are many fet together at the ends of the branches, greater then the former, and confifting of foure leaues a peece, of a light blufh colour, ftanding in fmall gravifh huskes, of little or no fent at all: the fruit followeth, which are fmall long graines or berries, of an excellent red colour, which afterwards turne blacke : the roote is long, and fpreadeth about vnder the vpper part of the earth.

\section{Chamelan tricoccos. Widowe Wayle.}

This three berried Spurge Oliue hath no great ftemme at all, but the whole plant spreadeth from the ground into many flexible tough greene branches, whereon are fet diuers narrow, long, darke greene leaues all along the branches, which abide greene all the Winter: the flowers are very fmall, fcarce to be feene, and come forth between the leaues and the ftalke, of a pale yellow colour, made of three leaues; after which come fmall blackifh berries, three vfually fet together: the roote fpreadeth it felfe in the ground not very farre, being hard and wooddy, and often dyeth, if it bee not well defended from the extremity of our tharpe Winters.

\section{Cneorum Matthioli. Small Rocke Rofes.}

I was long in doubt in what place I fhould difpofe of this plant, whether among the Campions, as Bauhinus, or among thefe, as Clufius doth; but left my Garden fhould want it wholly, let it take vp roome for this time here. This gallant plant hath diuers 
long, weake, flender, but yet tough branches lying vpon the ground, diuided vfually into other fmaller branches, whereon growe many, fmall, long, and fomewhat thicke leaues, fomewhat like vnto the leaues of the former Mezereon, fet without any order to the very tops, from whence doe come forth a tuft of many fmall flowers together, made or confifting of foure leaues a peece, of a bright red or carnation colour, and very fweete withall, which turne into fmall round whitifh berries, wherein is contained fmall round feede, couered with a grayifh coate or skinne: the roote is long and yellowifh, fpreading diuers wayes vnder the ground, and abideth many yeares thooting forth new branches.

It hath beene obferued in fome of thefe plants, to bring forth white flowers, not differing in any thing elfe.

The Place.

The firft forts growe plentifully in many places of Germany. The fecond in the mountaines by Sauoye. The third in Prouence and Spaine. The laft in diuers parts of Germany, Bohemia, and Auftria, and about Franckford.

\section{The Time.}

The two firft forts are moft vfually in flower about Chriftmas, or in Ianuary, if the weather be not violent, and fometimes not vntill February. The fecond flowreth not vntill Aprill. The third in May. The berries of them ripen fome in Iune and Iuly; fome in Auguft and September, as their flowring is earlier or later. The laft flowreth as well in the Spring as in Autumne, fo apt and plentifull it is in bearing, and the feede at both times doth ripen foone after.

\section{The Names.}

The firf is called of fome Chamalca, with this addition Germanica, that it may differ from the third, which is the true Chamalaa of Diofcorides, as all the beft Authors doe agree, and is alfo called Piper montanum of the Italians. It is generally called Mezereon, and is indeede the true Mezereon of the Arabians, and fo vfed in our Apothecaries fhops, wherefoeuer the Arabians Mezereon is appointed, although the Arabians are fo intricate and vncertaine in the defcriptions of their plants, confounding Chamalaa and Thymalcea together. Matthiolus maketh it to be Daphnoides of Diofcorides; but in my opinion he is therein miftaken: for all our beft moderne Writers doe account our Laureola, which hath blacke berries, to bee the true Daphnoides: the errour of his Countrey might peraduenture drawe him thereunto; but if hee had better confidered the text of Diofcorides, that giueth black berries to Daphnoides, and red to Chamadaphne, he would not fo haue written; and truly, I fhould thinke (as Lobel doth) with better reafon, that this Chamalaa were Diofcorides Chamadaphne, then hee to fay it were Daphnoides: for the defcription of Chamadaphne, may in all parts be very fitly applyed to this Chamalca: and euen thefe words, Semen annexum folijs, wherein may be the greateft doubt in the defcription, may not vnfitly bee conftrued, that as is feene in the plant, the berries growe at the foote of the leaues, about the branches: the faculties indeede that Diofcorides giueth to Chamadapline, are (if any repugnancie be) the greateft let or hinderance, that this Chamalca hould not be it: but I leaue the difcuffing of thefe and others of the like nature, to our learned Phyfitians; for I deale not fo much with vertues as with defcriptions. The fecond is called of Lobel Chamalaa Alpine incana, of Clufius Chamcelca fecunda, and faith hee had it out of Italy. Wee may call it in Englifh, Mountaine Spurge Oliue, as it is in the defcription, or Mountaine Laurell, which you will. The laft hath the name of Cneorum, firft giuen it by Matthiolus, which fince is continued by all others. Bauhinus (as I faid) referreth it to the Mountaine Campions, but Clufius 


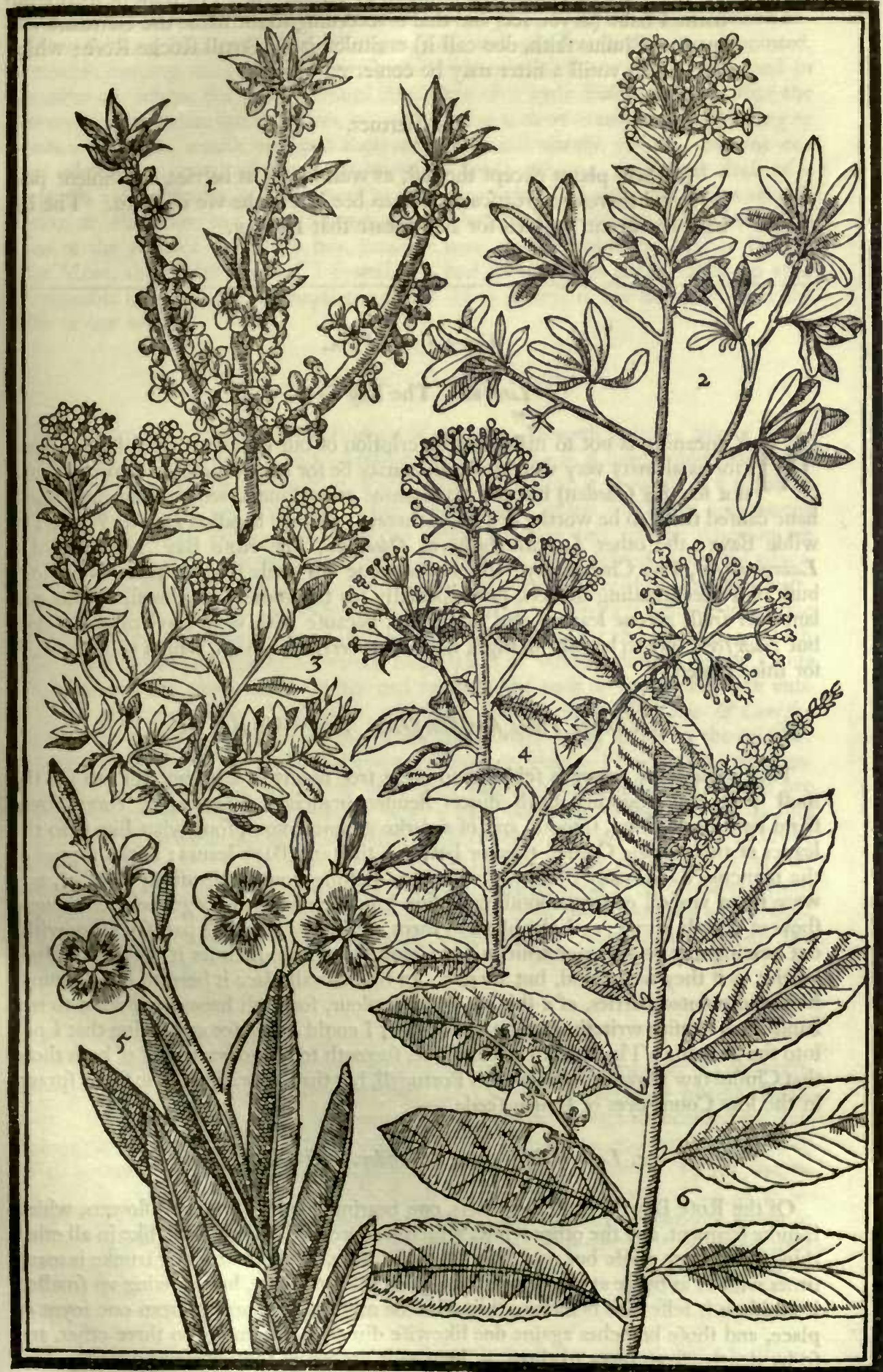

I Chamalea Germanica feu Mezerean. Mezereon or Dwarfe Bay. 2 Chamalaa Alpina. Mountain or Spurge Olive.

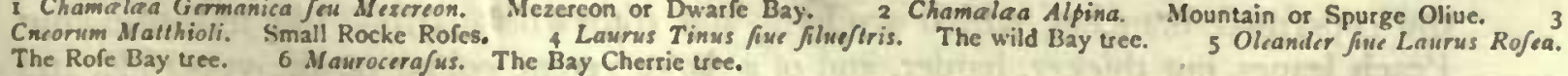


(as I doe) to the kindes of Chamalaa or Thymalaa. For want of an Englifh name I have (as you fee, and that is according to the name the Germane women, as Clufius faith, doe call it) entituled it the Small Rocke Rofe; which may abide vntill a fitter may be conferred vpon it.

\section{The Vertues.}

All thefe plants except the laft, as well leaues as berries, are violent purgers, and therefore great caution is to bee had in the vfe of them. The laft hath not beene applyed for any difeare that I know.

\section{С н а P. C I I I A.}

\section{Laurus. The Bay Tree.}

$\mathrm{M}$

$\mathrm{Y}$ meaning is not to make any defcription of our ordinary Bayes in this place (for as all may very well know, they may be for an Orchard or Courtyard, and not for this Garden) but of two or three other kindes, whofe beautifull afpect haue caufed them to be worthy of a place therein : the one is called Laurus Tinus, The wilde Baye: the other Laurus Rofea or Oleander, The Rofe Bay: and a third is Laurocerafus, The Cherry Bay; which may haue not onely fome refpect for his long bufh of fweet fmelling flowers, but efpecially for the comely ftatelineffe of his gallant euer frefh greene leaues; and the rather, becaufe with vs in moft places, it doth but frute fcere, vfe to bee Shrub high, not arborefcere, Tree high, which is the more fit for this Garden.

\section{Laurus Tinus fue filueftis. The wilde Bay tree.}

This wilde Baye groweth feldome to bee a tree of any height, but abideth for the moft part low, fhooting forth diuers flender branches, whereon at euery ioynt ftand two leaues, long, fmooth, and of a darke greene colour, fomewhat like vnto the leaues of the Female Cornell tree, or between that and Baye leaues: at the toppes of the branches ftand many fmall white fweete fmelling flowers, thrufting together, as it were in an vmbell or tuft, confifting of fiue leaues a peece, the edges whereof haue a fhew of a wafh purple, or light blufh in them, which for the moft part fall away without bearing any perfect ripe fruit in our Countrey: Yet fometimes it hath fmall black berries, as if they were good, but are not. In his naturall place it beareth fmall, round, hard and pointed berries, of a fhining blacke colour, for fuch haue come often to my hands (yet Clufius writeth they are blew); but I could neuer fee any fpring that I put into the ground. This that I here defcribe, feemeth to me to be neither of both thofe that Clufius faw growing in Spain and Portugall, but that other, that (as he faith) fprang in the low Countreyes of Italian feede.

\section{Laurus Rofea fiue Oleander. The Rofe Bay.}

Of the Rofe Bay there are two forts, one bearing crimfon coloured flowers, which is more frequent, and the other white, which is more rare. They are fo like in all other things, that they neede but one defcription for both. The ftemme or trunke is many times with vs as bigge at the bottome as a good mans thumbe, but growing vp fmaller, it diuideth it felfe into branches, three for the moft part comming from one ioynt or place, and thofe branches againe doe likewife diuide themfelues into three other, and fo by degrees from three to three, as long as it groweth: the loweft of thefe are bare of leaues, hauing thed or loft them by the cold of winters, keeping onely leaues on the vppermoft branches, which are long, and fomewhat narrow, like in forme vnto Peach leaues, but thicker, harder, and of a darke greene colour on the vpperfide, and 
yellowifh greene vnderneath: at the tops of the young branches come forth the flowers, which in the one fort before they are open, are of an excellent bright crimfon colour, and being blowen, confift of foure long and narrow leaues, round pointed, fomewhat twining themfelues, of a paler red colour, almoft tending to blufh, and in the other are white, the greene lenues alfo being of a little frefher colour: after the flowers are paft, in the hot countries, but neuer in ours, there come vp long bending or crooked flat pods, whofe outward Thell is hard, almoft woody, and of a browne colour, wherein is contained finall flat brownifh feede, wrapped in a great deale of a brownifh yellow doune, as fine almoft as filke, fomewhat like vnto the huskes of $\mathrm{Af}$ clepias, or Periploca, but larger, flatter and harder; as my felfe can teftifie, who had fome of the pods of this Rofe bay, brought mee out of Spaine, by Mafter Doctor Iohn More, the feedes whereof I fowed, and had diuers plants that I raifed vp vnto a reafonable height, but they require, as well old as young, to bee defended from the colde of our winters.

\section{Laurocerafius. The Bay Cherry.}

This beautifull bay in his naturall place of growing, groweth to bee a tree of a reafonable bigneffe and height, and oftentimes with vs alro if it bee pruined from the lower branches; but more vfually in thefe colder Countries, it groweth as a thrub or hedge bufh, hooting forth many branches, whereof the greater and lower are couered with a darke grayinh greene barke, but the young ones are very greene, whereon are fet many goodly, faire, large, thicke and long leaues, a little dented about the edges, of a more excellent frefh fhining greene colour, and farre larger then any Bay leafe, and compared by many to the leaues of the Pomeritron tree (which becaufe wee haue none in our Countrey, cannot be fo well known) both for colour and largeneffe, which yeeld a moft gracefull afpect : it beareth long ftalkes of whitifh flowers, at the ioynts of the leaues both along the branches and towards the ends of them alfo, like vnto the Birds Cherry or Padus Theophrafti, which the French inen call Putier EO Cerifier blanc, but larger and greater, confifting of fiue leaues with many threds in the middle: after which commeth the fruite or berries, as large or great as Flanders Cherries, many growing together one by another on a long ftalke, as the flowers did, which are very blacke and Thining on the outfide, with a little point at the end, and reafonable fweete in tafte, wherein is contained a hard round ftone, very like vnto a Cherry ftone, as I haue obferued as well by thofe I receiued out of Italie, as by them I had of Mafter Iames Cole a Merchant of London lately deceafed, which grew at his houfe in Highgate, where there is a faire tree which hee defended from the bitterneffe of the weather in winter by cafting a blanket ouer the toppe thereof euery yeare, thereby the better to preferue it.

\section{The Place.}

The firf is not certainly knowne from whence it came, and is communicated by the fuckers it yeeldeth. The fecond groweth in Spaine, Italie, Grece, and many other places: that with white flowers is recorded by Bellonius, to grow in Candy. The laft, as Matthiolus, and after him Clufius report, came firt from Conftantinople: I had a plant hereof by the friendly gift of Mafter Iames Cole, the Merchant before remembred, a great louer of all rarities, who had it growing with him at his countrey houfe in Highgate aforefaid, where it hath flowred diuers times, and borne ripe fruit alfo.

\section{The Time.}

The firft flowreth many times in the end of the yeare before Chriftmas, and often alfo in Ianuary, but the moft kindly time is in March and Aprill, when the flowers are fweeteft. The fecond flowreth not vntill Iuly. The laft in May, and the fruit is ripe in Auguft and September. 


\section{The Names.}

The firt is called Laurus fluefris, and Laurus Tinus: in Englifh Wilde Bay, or Sweete flowring Bay. The fecond is called Laurus Rofea, Oleander, Nerium, and Rhododendros: in Englifh The Rofe Bay, and Oleander. The laft was fent by the name of Trebezon Curma fi, that is to fay, Dactylus Trapezuntina, but not hauing any affinitie with any kinde of Bay. Bellonius as I thinke firft named it Laurocerafus, and Cerafus Trapezuntina. Dalechampius thinketh it to bee Lotus Aphricana, but Clufius refuteth it. Thofe ftones or kernels that were fent me out of Italie, came by the name of Laurus Regia, The Kings Bay. Wee may moft properly call it according to the Latine name in the title, The Cherry bay, or Bay Cherry, becaufe his leaues are like vnto Bay-leaues, and both flowers and fruit like vnto the Birdes Cherry or Clufter Cherry, for the manner of the growing; and therefore I might more fitly I confeffe haue placed it in my Orchard among the forts of Cherries: but the beautifulneffe of the plant caufed mee rather to infert it here.

\section{The Vertues.}

The wilde Bay hath no propertie allotted vnto it in Phyficke, but that it is not to be endured, the berries being chewed declare it to be fo violent hot and choking. The Rore Bay is faid by Diofcorides, to be death to all foure footed beafts, but contrariwife to man it is a remedie againft the poifon of Serpents, but efpecially if Rue bee added vnto it. The Cherry Bay is not knowne with vs to what phyficke vfe it may be applyed.

\section{CH A P. C I I I I.}

Cerafus flore multiplici. The Rofe or double bloffomd Cherry. Malus flore multiplici. The double bloffomd Apple tree. And Malus Perfica flore multiplici. The double bloffomd Peach tree.

$\mathrm{T}$

He beautifull hew of thefe three forts of flowers, hath made me to infert them into this garden, in that for their worthineffe I am vnwilling to bee without them, although the reft of their kindes I haue transferred into the Orchard, where among other fruit trees, they fhall be remembred : for all thefe here fet downe, feldome or neuer beare any fruite, and therefore more fit for a Garden of flowers, then an Orchard of fruite.

\section{Cerafus flore pleno vel multiplici.}

The Rofe Cherry, or double bloffomd Cherry.

The double bloffomed Cherry tree is of two forts for the flower, but not differing in any other part, from the ordinary Englifh or Flanders Cherry tree, growing in the very like manner: the difference confifteth in this, that the one of thefe two forts hath white flowers leffe double, that is, of two rowes or more of leaues, and the other more double, or with more rowes of leaues, and befides I haue obferued in this greater double bloffomd Cherry, that fome yeares moft of the flowers haue had another fmaller and double flower, rifing vp out of the middle of the other, like as is to bee feene in the double Englifh Crow-foote, and double redde Ranunculus or Crowfoote, before defcribed : this I fay doth not happen euery yeare, but fometimes. Sometimes alfo thefe trees will giue a few berries, here and there fcattered, and that with leffe double flowers more often, which are like vnto our Englifh Cherries both for tafte and bigneffe. Thefe be very fit to be fet by Arbours. 


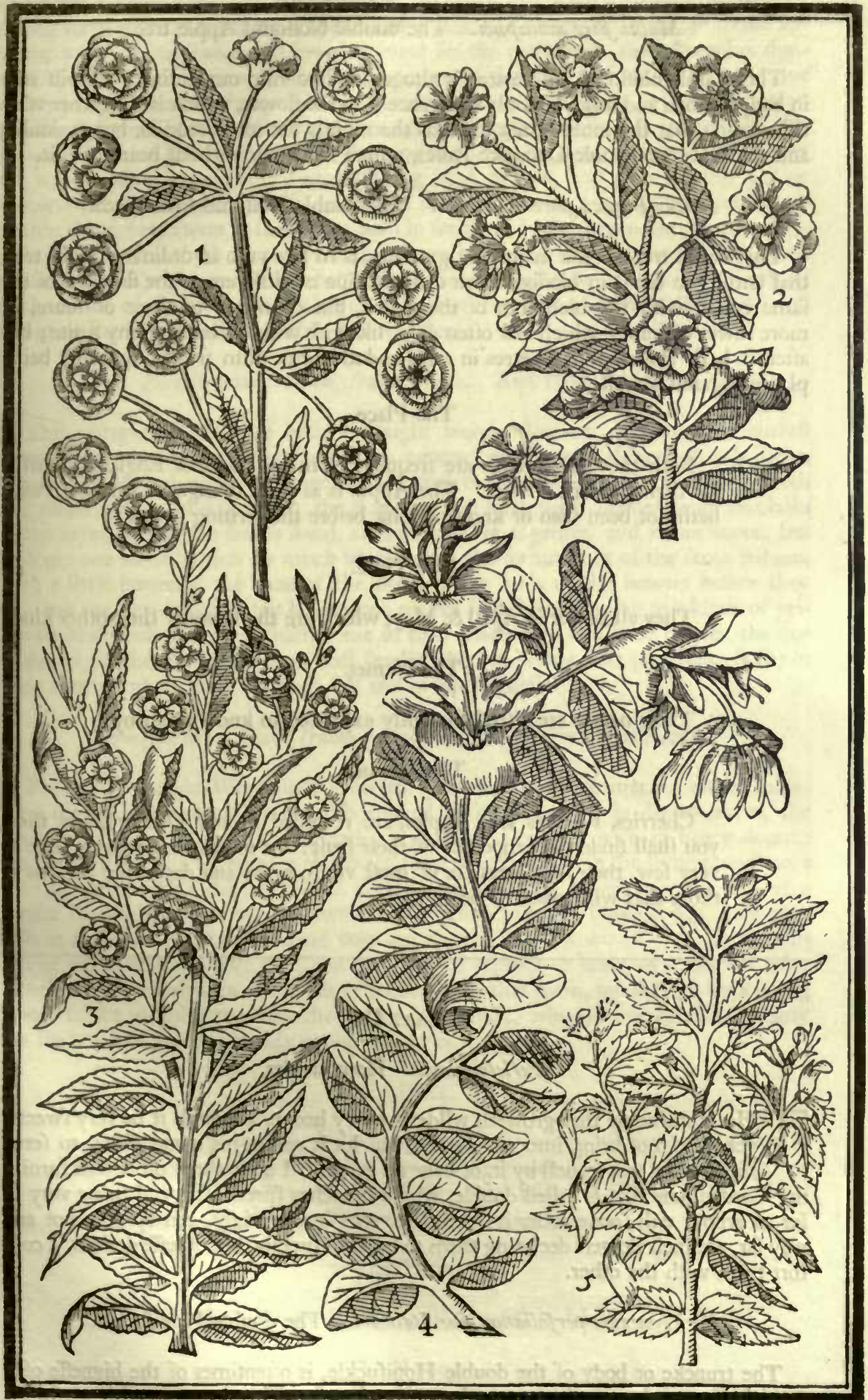

- Cerafus fore fleno. The double blofiond Cherry tree. Perfica flone pleno. The double blolfomd Peach tree.

2 Malus flore multiplici. The double bloflomd Apple tree. 3 Malus rectum. Viprigbt Honifuckle. 
Malus flore multiplici. The double bloffomd Apple tree.

This double bloffomd Apple tree is altogether like vnto our ordinary Pippin tree in body, branch and leafe, the only difference is in the flower, which is altogether whitifh, fauing that the inner leaues towards the middle are more reddifh, but as double and thicke as our double Damaske Rofes, which fall away without bearing fruit.

Malus Perfica flore multiplici. The double bloffomd Peach tree.

This Peach tree for the manner of growing, is fo like vnto an ordinary Peach tree, that vntill you fee it in bloffome you can perceiue no difference: the flower is of the fame colour with the bloffomes of the Peach, but confifting of three or foure, or more rowes of leaues, which fall often away likewife without bearing any fruite; but after it hath abiden fome yeares in a place doth forme into fruite, efpecially being planted againit a wall.

\section{The Place.}

Both the Cherry trees are frequent in many places of England, nourfed for their pleafant flowers. The Apple is as yet a ftranger. And the Peach hath not been feen or knowne, long before the writing hereof.

The Time.

They all flower in April \& May, which are the times of their other kinds.

The Names.

Their names are alfo fufficiently expreffed to know them by.

The Vertues.

Cherries, Peaches and Apples, are recorded in our Orchard, and there you fhall finde the properties of their fruit: for in that thefe beare none or very few, their bloffomes are of moft vfe to grace and decke the perfons of thofe that will weare or beare them.

\section{H A. P. C V.}

\section{Periclymenum. Honyfuckles.}

T He Honifuckle that groweth wilde in euery hedge, although it be very fweete, yet doe I not bring into my garden, but let it reft in his owne place, to ferue their fenfes that trauell by it, or haue no garden. I haue three other that furnifh my Garden, one that is called double, whofe branches fpreade far, and being very fit for an arbour will foone couer it: the other two ftand vpright, and fpreade not any way far, yet their flowers declaring them to be Honifuckles, but of leffe delight, I confort them with the other.

Periclymenum perfoliatum fue Italicum. The double Honifuckle.

The truncke or body of the double Honifuckle, is oftentimes of the bigneffe of a good ftaffe, running out into many long fpreading branches, couered with a whitifh barke, which had neede of fome thing to fuftaine them, or elfe they will fall down to the ground (and therefore it is vfually planted at an arbour, that it may run thereon, 
or againft a houfe wall, and faftened thereto in diuers places with nailes) from whence fpring forth at feuerall diftances, and at the ioynts, two leaues, being like in forme vnto the wilde Honifuckles, and round pointed for the moft part; thefe branches diuiding themfelues diuers wayes, haue at the toppes of them many flowers, fet at certaine diftances one aboue another, with two greene leaues at euery place, where the flowers doe ftand, ioyned fo clofe at the bottome, and fo round and hollow in the middle, that it feemeth like a hollow cuppe or fawcer of flowers: the flowers ftand round about the middle of thefe cuppes or fawcers, being long, hollow, and of a whitifh yellow colour, with open mouthes dafht ouer with a light thew of purple, and fome threds within them, very fweet in fmell, like both in forme and colour vnto the common Honifuckles, but that thefe cuppes with the flowers in them are two or three ftanding one aboue another (which make a far better fhew then the common, which come forth all at the heade of the branches, without any greene leaues or cuppes vnder them) and therefore thefe were called double Honifuckles.

\section{Periclymenum rectum fructu rubro. Red Honifuckles.}

This vpright Woodbinde hath a ftraight woody ftemme, diuided into feuerall branches, about three or foure foote high, couered with a very thinne whitifh barke, whereon ftand two leaues together at the ioynts, being leffer then the former, fmooth and plaine, and a little pointed: the flowers come forth vpon flender long footftalks at the ioynts where the leaues ftand, alwayes two fet together, and neuer more, but feldome one alone, which are much fmaller then the former, but of the fame fafhion, with a little button at the foote of the flower; the buds of the flowers before they are open are very reddifh, but being $\rho$ pen are not fo red, but tending to a kinde of yellowifh blufh colour : after which come in their places two fmall red berries, the one withered for the moft part, or at leaft fmaller then the other, but (as Clufius faith) in their naturall places they are both full and of one bigneffe.

\section{Periclymenum rectum fructu caruleo. Blew berried Honifuckles.}

This other vpright Woodbinde groweth vp as high as the former, or rather fomewhat higher, couered with a blackifh rugged barke, chapping in diuers places, the younger branches whereof are fomewhat reddifh, and couered with an hoary doune: the leaues ftand two together at the ioints, fomewhat larger then the former, and more whitifh vnderneath: the flowers are likewife two ftanding together, at the end of a flender footeftalke, of a pale yellowifh colour when they are blowne, but more reddifh in the bud: the berries ftand two together as the former, of a darke blewifh colour when they are fully ripe, and full of a red liquour or iuice, of a pleafant tafte, which doth not only dye the hands of them that gather them, but ferueth for a dying colour to the inhabitants where they grow plentifully, wherein are contained many flat feede : The roote is woody as the former is.

The Place.

The firft groweth in Italie, Spaine, and Prouence of France, but not in the colder countreyes, vnleffe it be there planted, as is moft frequent in our countrey. The others grow in Auftria, and Stiria, as Clufius faith, and are entertained into their gardens onely that are curious.

\section{The Time.}

The firft flowreth vfually in Aprill, the reft in May.

The Names.

The firf is called Periclymenum, Caprifolium perfoliatum, and Italicum, as a difference from the common kinde: In Engliph Double Woodbinde, 
or double Honifuckles. The others, as they are rare, and little knowne, fo are their names alfo: yet according to their Latine, I haue giuen them Englifh names.

\section{The Vertues.}

The double Honifuckle is as effectuall in all things, as the fingle wilde kinde, and befides, is an efpeciall good wound herbe for the head or other parts. I haue not knowne the vpright kindes vfed in Phyficke.

\section{CH A P. CVI.}

\section{Iafminum fue Gelfeminum. Iafmine or Gefmine.}

W $\mathrm{E}$ haue but one fort of true Iafmine ordinarily in our Gardens throughout the whole Land; but there is another greater fort, which is farre more tender, brought out of Spaine, and will hardly endure any long time with vs, vnleffe it be very carefully preferued. Wee haue a third kinde called a yellow Iafmine, but differeth much from their tribe in many notable points: but becaufe the flowers haue fome likeneffe with the flowers of the true Iafmine, it hath been vfually called a Iafmine; and therefore I am content for this Garden to conioyne them in one Chapter.

\section{Ia minum album. The white Iafmine.}

The white Iafmine hath many twiggy flexible greene branches, comming forth of the fundry bigger boughes or ftems, that rife from the roote, which are couered with a grayinh darke coloured barke, hauing a white pith within it like the Elder, but not fo much : the winged leaues ftand alwaies two together at the ioynts, being made of manie fmall and pointed leaues, fet on each fide of a middle ribbe, fix moft vfually on both fides, with one at the end, which is larger, more pointed then any of the reft, and of a darke greene colour : at the toppes of the young branches ftand diuers flowers together, as it were in an vmbell or tuft, each whereof ftandeth on a long greene ftalke, comming out of a fmall huske, being fmall, long, and hollow belowe, opening into fiue white fmall, pointed leaues, of a very ftrong fweete fmell, which fall away without bearing any fruit at all, that euer I could learne in our Country; but in the hot Countries where it is naturall, it is faid to beare flat fruit, like Lupines: the rootes fpread farre and deepe, and are long and hard to growe, vntill they haue taken ftrong hold in the ground.

\section{Iafminum Catalonicum. The Spanifh Iafmine.}

This Catalonia Iafmine groweth lower then the former, neuer rifing halfe fo high, and hath Render long greene branches, rifing from the toppe of the wooddy ftemme, with fuch like leaues fet on them as the former, but fomewhat fhorter and larger : the flowers alfo are like vnto the former, and ftand in the fame manner at the end of the branches, but are much larger, being of a blufh colour before they are blowne, and white with blufh edges when they are open, exceeding fweete of fmell, more ftrong then the former.

\section{Iafminum luteum, fiue Trifolium fruticans alijs Polemonium.}

\section{The yellow Iarmine.}

This that is called the yellow Iafmine, hath many long flender twiggy branches rifing from the roote, greene at the firft, and couered with a darke grayifh barke afterwards, whereon are fet at certaine diftances, three fmall darke greene leaues together, the end leafe being alwaies the biggeft : at the ioynts where the leaues come forth, 
ftand long ftalkes, bearing long hollow flowers, ending in fiue, and fome in fix leaues, very like vnto the flowers of the firft Iafmine, but yellow, whereupon it is vfually called the Yellow Iafmine : after the flowers are paft, there come in their places round blacke fhining berries, of the bigneffe of a great Peafe, or bigger, full of a purplifh iuyce, which will dye ones fingers that bruife them but a little : the roote is tough, and white, creeping farre about vnder the ground, fhooting forth plentifully, whereby it greatly encreafeth.

The Place.

The firft is verily thought to haue been firft brought to Spaine out of Syria, or thereabouts, and from Spaine to vs, and is to be feene very often, and in many of our Country Gardens. The fecond hath his breeding in Spaine alfo, but whether it be his originall place we know not, and is fcarce yet made well acquainted with our Englifh ayre. The third groweth plentifully about Mompelier, and will well abide in our London Gardens, and any where elfe.

\section{The Time.}

The firft flowreth not vntill the end of Iuly. The fecond fomewhat earlier. The third in Iuly alfo.

\section{The Names.}

The firft is generally called Iafminum album, and Gelfeminum album : In Englifh, The white Iafmine. The fecond hath his name in his title, as much as may be faid of it. The third hath been taken of fome to be a Cytifus, others iudge it to be Polemonium, but the trueft name is Trifolium fruticans, although many call it Ia/minum luteum: In Englifh moft vfually, The yellow Iafmine, for the reasons aforefaid; or elfe after the Latine name, Shrubbie Trefoile, or Make-bate.

\section{The Vertues.}

The white Iafmines haue beene in all times accepted into outward medicines, eyther for the pleafure of the fweete fent, or profit of the warming properties. And is in thefe dayes onely vfed as an ornament in Gardens, or for fent of the flowers in the houfe, \&cc. The yellow Iafmine, although fome haue adiudged it to be the Polemonium of Diofcorides, yet it is not vfed to thofe purpofes by any that I know.

\section{CH A P. CVII.}

Syringa. The Pipe tree.

$\mathrm{V}$

Nder the name of Syringa, is contained two fpeciall kinds of Shrubs or Trees, differing one from another ; namely, the Lilac of Matthiolus, which is called Syringa carulea, and is of two or three forts: And the Syring a alba, which alfo is of two forts, as fhall bee declared.

\section{Lilac fiue Syringa carulea. The blew Pipe tree.}

The blew Pipe tree rifeth fometimes to be a great tree, as high and bigge in the bodie as a reafonable Apple tree (as I haue in fome places feene and obferued) but moft vfually groweth lower, with many twigs or branches rifing from the roote, hauing as much pith in the middle of them as the Elder hath, couered with a grayifh greene 
barke, but darker in the elder branches, with ioynts fet at a good diftance one from another, and two leaues at euery ioynt, which are large, broad, and pointed at the ends, many of them turning or folding both the fides inward, and ftanding on long foote ftalkes : at the toppes of the branches come forth many flowers, growing fpike-fafhion, that is, a long branch of flowers vpon a ftalke, each of thefe flowers are fmall, long, and hollow belowe, ending aboue in a pale blewilh flower, confinting of foure fmall leaues, of a pretty fmall fent : after the flowers are paft, there come fometimes (but it is not often in our Country, vnleffe the tree haue ftood long, and is grown great, the fuckers being continually taken away, that it may growe the better) long and flat cods, confifting as it were of two fides, a thin skinne being in the midrt, wherein are contained two long flattifh red feede: the rootes are ftrong, and growe deepe in the ground.

\section{Syringa flore lacteo fiue argenteo.}

The filuer coloured Pipe tree.

This Pipe tree differeth not from the former blew Pipe tree, either in ftemme or branches, either in leaues or flowers, or manner of growing, but onely in the colour of the flower, which in this is of a milke, or filuer colour, which is a kinde of white, wherein there is a thinne wafh, or light thew of blew thed therein, comming fomewhat neare vnto an afh-colour.

\section{Lilac lacimatis folijs. The blew Pipe tree with cut leaues.}

This Pipe tree fhould not differ from the firft in any other thing then in the leaues, which are faid to be cut in on the edges into feuerall parts, as the relation is giuen $a v i-$ ris fide dignis; for as yet I neuer faw any fuch; but I here am bold to fet it downe, to induce and prouoke fome louer of plants to obtaine it for his pleafure, and others alfo.

\section{Syringa flore albo fimplici. The fingle white Pipe tree.}

The fingle white Pipe tree or bufh, neuer commeth to that height of the former, but abideth alwaies like a hedge tree or bufh, full of fhootes or fuckers from the roote, much more then the former: the young thootes hereof are reddifh on the outfide, and afterward reddifh at the ioynts, and grayifh all the reft ouer: the young as well as the old branches, haue fome pith in the middle of them, like as the Elder hath : the leaues ftand two at a ioynt, fomewhat like the former, but more rugged or crumpled, as alfo a little pointed, and dented about the edges: the flowers growe at the toppes of the branches, diuers ftanding together, confifting of foure white leaues, like vnto fmall Muske Rofes, and of the fame creame colour, as I may call it, with many fmall yellowifh threads in the middle, and are of a ftrong, full, or heady fent, not pleafing to a great many, by reafon of the ftrange quickneffe of the fent: the fruit followeth, being flat at the head, with many leafie fhels or fcales compaffing it, wherein is enclofed fmall long feede : the rootes runne not deepe, but fpread vnder the ground, with many fibres annexed vnto them.

\section{Syringa Arabica flore albo duplici.}

The double white Pipe tree.

This Pipe tree hath diuers long and flender branches, whereon growe large leaues, fomewhat like vnto the leaues of the former fingle white kinde, but not fo rough or hard, and not at all dented about the edges, two alwaies ftanding one againft another at euery ioynt of the ftalke, but fet or difpofed on contrary fides, and not all vpon one fide; at the ends whereof come forth diuers flowers, euery one ftanding on his owne foote-ftalke, the hofe or huske being long and hollow, like vnto the white Iafmine, and the flowers therein confifting of a double rowe of white and round pointed leaues, fiue or fix in a rowe, with fome yellowneffe in the middle, which is hollow, of a very ftrong and heady fweet fent, and abiding a long time flowring, ef pecially in the hotter Countries, but is very tender, and not able to abide any the leaft cold weather with vs; 


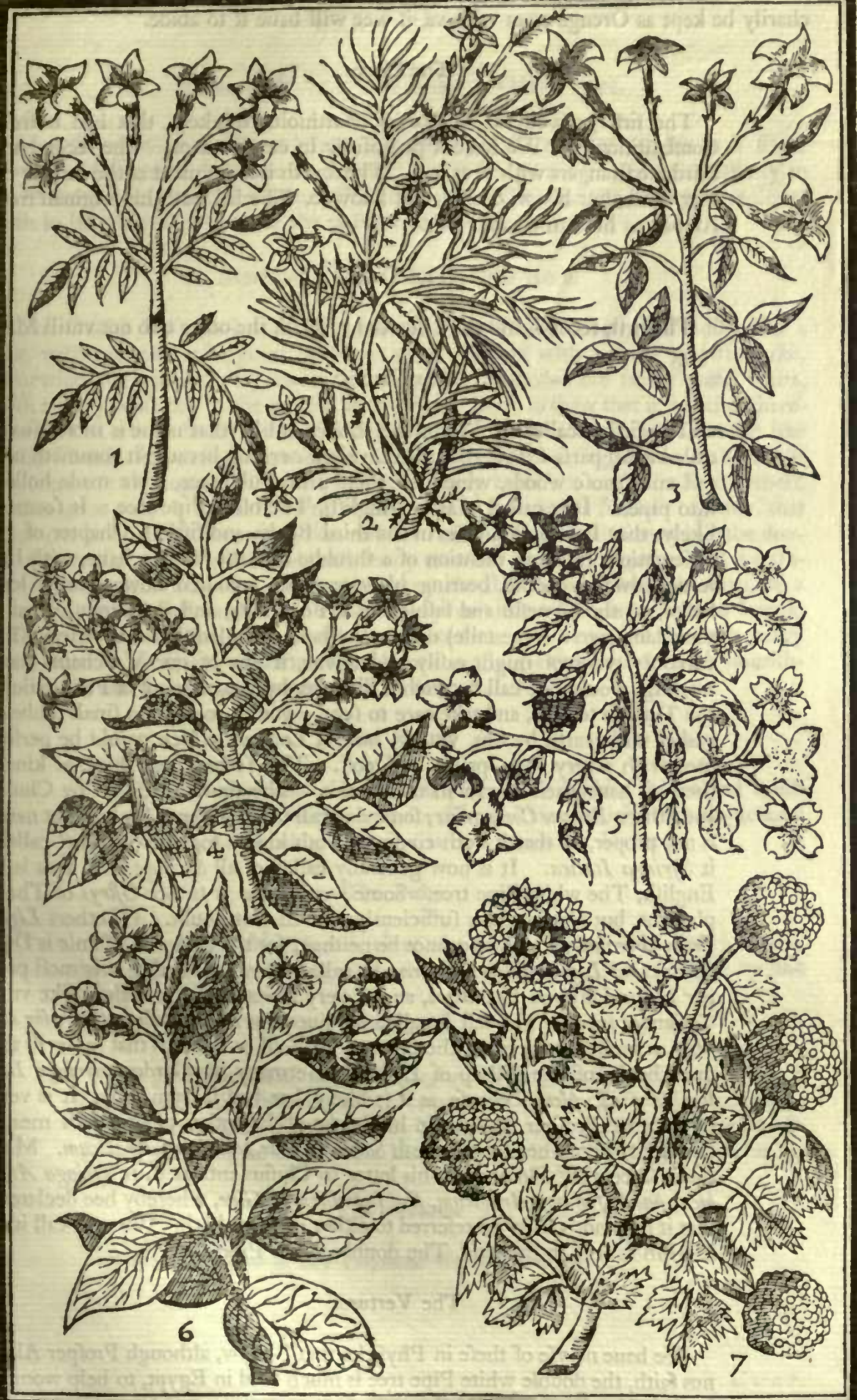

1 Iofminum album sulgare. The ordinary white Iafmine. 2 Iafminum Americanum fue Contoloulus Americanus. The Iafmine or Bindweed of America. 3 Iafminum lwteum tulgare. The yellow Iafmine. 4 Lilac fou Syringa carwlea. The blew Pipe tree. 5 Syringa albra ougaris. The fingle whit 
for the cold windes will (as I vnderftand) greatly moleft it: and therefore muft as charily be kept as Orenge trees with vs, if wee will haue it to abide.

\section{The Place.}

The firt groweth in Arabia (as Matthiolus thinketh, that had it from Conftantinople.) We have it plentifully in our Gardens. The fecond and third are ftrangers with vs as yet. The fourth is as frequent as the firft, or rather more, but his originall is not knowne. The laft hath his originall from Arabia, as his name importeth.

The Time.

The firft, fecond, and third flower in Aprill, the other two not vntill May.

\section{The Names.}

The firt is called of Mattbiolus Lilac, and by that name is moft vfually called in all parts. It is alfo called Syringa carulea, becaufe it commeth neareft vnto thofe woods, which for their pithy fubftance, were made hollow into pipes. It is called of all in Englifh, The blew Pipe tree. It feemeth likely, that Petrus Bellonius in his third Booke and fiftieth Chapter of his obferuations (making mention of a fhrubbe that the Turkes haue, with Iuie leaues alwaies greene, bearing blew or violet coloured flowers on a long ftalke, of the bigneffe and farhion of a Foxe taile, and thereupon called in their language a Foxe taile) doth vnderftand this plant here expreffed. The certainty whereof might eafily be knowne, if any of our Merchants there refiding, would but call for fuch a Mrubbe, by the name of a Foxe taile in the Turkifh tongue, and take care to fend a young roote, in a fmall tubbe or basket with earth by Sea, vnto vs here at London, which would be performed with a very little paines and cort. The fecond and third, as kindes thereof, have their names in their titles. The fourth is called by Clufius and others, Frutex Coronarius; fome doe call it Lilac flore albo, but that name is not proper, in that it doth confound both kindes together. Lobel calleth it Syringa Italica. It is now generally called of all Syringa alba, that is in Englifh, The white Pipe tree. Some would haue it to bee Oftrys of Theophraftus, but Clufius hath fufficiently cleared that doubt. Of others Ligufrum Orientale, which it cannot be neither; for the Cyprus of Plinie is Diofcorides his Liguftrum, which may be called Orientale, in that it is moft proper to the Eafterne Countries, and is very fweete, whore feede is like vnto Coriander feede. The laft is called by diuers Syringa Arabica flore albo duplici, as moft fitly agreeing thereunto. Of Bafilius Beflerus that fet forth the great booke of the Bifhop of Eyftot in Germany his Garden, Syringa Italica flore albo pleno, becaure, as it is likely, hee had it from Italy. It is very likely, that Profper Alpinus in his booke of Egyptian plants, doth meane this plant, which hee there calleth Sambach, fue Iafminum Arabicum. 'Matthrus Caccini of Florence in his letter to Clufius entituleth it Syringa Arabica, fue Iafminum Arabicum, fue Iafminum ex Gine, whereby hee declareth that it may not vnfitly be referred to either of them both. We may call it in Englifh as it is in the title, The double white Pipe tree.

The Vertues.

We haue no vfe of thefe in Phyficke that I know, although Profper Alpinus faith, the double white Pipe tree is much vfed in Egypt, to help women in their trauailes of childbirth. 


\title{
CHAP. CVIII.
}

Sambucus Rofea. The Elder or Gelder Rofe.

\begin{abstract}
Lthough there be diuers kindes of Elders, yet there is but one kinde of Elder Rofe, whereof I meane to intreate in this Chapter, being of neare affinity in fome things vnto the former Pipe trees, and which for the beauty of it deferueth to be remembred among the delights of a Garden.
\end{abstract}

\section{Sambucus Rofea. The Gelder Rofe.}

The Gelder Rofe (as it is called) groweth to a reafonable height, ftanding like a tree, with a trunke as bigge as any mans arme, couered with a darke grayifh barke, fomewhat rugged and very knotty: the younger branches are fmooth and white, with a pithy fubftance in the middle, as the Elders haue, to thew that it is a kind thereof, whereon are fet broad leaues, diuided into three parts or diuifions, fomewhat like vnto a Vine leafe, but fmaller, and more rugged or crumpled, iagged or cut alfo about the edges: at the toppes of euery one of the young branches, moft vfually commeth forth a great tuft, or ball as it were, of many white flowers, fet fo clofe together, that there can be no diftinction of any feuerall flower feene, nor doth it feeme like the double flower of any other plant, that hath many rowes of leaues fet together, but is a clufter of white leaued flowers fet together vpon the ftalke that vpholdeth them, of a fmall fent, which fall away without bearing any fruit in our Country, that euer I could obferue or learne: The roote f preadeth neither farre nor deepe, but thooteth many fmall rootes and fibres, whereby it is faftened in the ground, and draweth nourifhment to it, and fometimes yeeldeth fuckers from it.

The Place.

It fhould feeme, that the naturall place of this Elder is wet and moift grounds, becaufe it is fo like vnto the Marfh Elder, which is the fingle kind hereof. It is onely nourfed vp in Gardens in all our Country.

The Time.

It flowreth in May, much about the time of the double Peony flower, both which being fet together, make a pleafant variety, to decke vp the windowes of a houfe.

The Names.

It is generally called Sambucus Rofea : In Englifh, The Elder Rofe, and more commonly after the Dutch name, the Gelder Rofe. Dalechampius feemeth to make it Thraupalus of Theophraftus, or rather the fingle Marfh Elder; for I thinke this double kinde was not knowne in Theophraftus his time.

The Vertues.

It is not applyed to any Phyficall vfe that I know. 


\section{С н А. C I X.}

Rofa. The Rofe tree or bufh.

T He great varietie of Rofes is much to be admired, beeing more then is to bee feene in any other thrubby plant that I know, both for colour, forme and fmell. I haue to furnifh this garden thirty forts at the leaft, euery one notably differing from the other, and all fit to be here entertained: for there are fome other, that being wilde and of no beautie or fmell, we forbeare, and leaue to their wilde habitations. To diftinguifh them by their colours, as white, red, incarnate, and yellow, were a way that many might take, but I hold it not fo conuenient for diuers refpects : for fo I thould confound thofe of diuers forts one among another, and I thould not keepe that methode which to me feemeth moft conuenient, which is, to place and ranke euery kinde, whether fingle or double, one next vnto the other, that fo you may the better vnderftand their varieties and differences: I will therefore beginne with the moft ancient, and knowne Rofes to our Countrey, whether naturall or no I know not, but affumed by our precedent Kings of all others, to bee cognifances of their dignitie, the white Rofe and the red; whom fhall follow the damaske, of the fineft fent, and moft vfe of all the other forts, and the reft in their order.

\section{Rofa Anglica alba. The Englifh white Rofe.}

The white Rofe is of two kindes, the one more thicke and double then the other: The one rifeth vp in fome fhadowie places, vnto eight or ten foote high, with a ftocke of a great bigneffe for a Rofe. The other growing feldome higher then a Damaske Rofe. Some doe iudge both thefe to be but one kinde, the diuerfitie happening by the ayre, or ground, or both. Both thefe Rofes haue fomewhat fmaller and whiter greene leaues then in many other Rofes, fiue moft vfually fet on a ftalke, and more white vnderneath, as alfo a whiter greene barke, armed with fharpe thornes or prickles, whereby they are foone known from other Rofes, although the one not fo eafily from the other: the flowers in the one are whitifh, with an eye or flew of a blufh, efpecially towards the ground or bottome of the flower, very thicke double, and clofe fet together, and for the moft part not opening it felfe fo largely and fully as eyther the Red or Damaske Rofe. The other more white, leffe thicke and double, and opening it felfe more, and fome fo little double as but of two or three rowes, that they might be held to be fingle, yet all of little or no fmell at all. To defcribe you all the feuerall parts of the Rofe, as the bud, the beards, the threds \&c. were needleffe, they are fo conuerfant in euery ones hand, that I thall not neede but to touch the moft fpeciall parts of the varieties of them, and leaue a more exact relation of all things incident vnto them, vnto a generall worke.

\section{Rofa Incarnata. The Carnation Rofe.}

The Carnation Rofe is in moft things like vnto the leffer white rofe, both for the growing of the ftocke, and bigneffe of the flower, but that it is more fpreade abroade when it is blown then the white is, and is of a pale blufh colour all the flower thoroughout, of as fmall a fent as the white one is almoft.

This kinde of Rofe is not very great, but very thicke and double, and is very variable in the flowers, in that they will be fo different one from another : fome being paler then others, and fome as it were blafted, which commeth not cafually, but naturally to this rofe: but the beft flowers (whereof there will bee ftill fome) will be of a bright pale murrey colour, neere vnto the Veluet rofe, but nothing fo darke a colour.

3. Rofa Anglica rubra. The Englifh red Rofe.

The red Rofe (which I call Englifh, not only for the reafon before expreffed, but becaufe 
caufe (as I take it) this Rofe is more frequent and vfed in England, then in other places) neuer groweth fo high as the damaske Rofe bufh, but moft vfually abideth low, and fhooteth forth many branches from the roote (and is but feldome fuffered to grow vp as the damaske Rofe into ftandards) with a greene barke, thinner fet with prickles, and larger and greener leaues on the vpperfide then in the white, yet with an eye of white vpon them, fiue likewife moft vfually fet vpon a ftalke, and grayifh or whitifh vnderneath. The Rofes or Flowers doe very much vary, according to their fite and abiding; for fome are of an orient, red or deepe crimfon colour, and very double (although neuer fo double as the white) which when it is full blowne hath the largeft leaues of any other Rofe; forne of them againe are paler, tending fome what to a damaske; and fome are of fo pale a red, as that it is rather of the colour of the canker Rofe, yet all for the moft part with larger leaues then the damaske, and with many more yellow threds in the middle : the fent hereof is much better then in the white, but not comparable to the excellencie of the damaske Rofe, yet this Rofe being well dryed and well kept, will hold both colour and fent longer then the damaske, bee it neuer fo well kept.

\section{Rofa Damafcena. The Damaske Rofe.}

The Damaske Rofe bufh is more vfually nourfed vp to a competent height to ftand alone, (which we call Standards) then any other Rofe: the barke both of the ftocke and branches, is not fully fo greene as the red or white Rofe: the leaues are greene with an eye of white vpon them, fo like vnto the red Rofe, that there is no great difference betweene them, but that the leaues of the red Rofe feeme to bee of a darker greene. The flowers are of a fine deepe blufh colour, as all know, with fome pale yellow threds in the middle, and are not fo thicke and double as the white, not being blowne, with fo large and great leaues as the red, but of the moft excellent fweet pleafant fent, far furpaffing all other Rofes or Flowers, being neyther heady nor too ftrong, nor ftuffing or vnplealant fweet, as many other flowers.

\section{Rofa Prouincialis fue Hollandica Damafcena.}

The great double Damaske Prouince or Holland Rofe.

This Rore (that fome call Centifolia Batauica incarnata) hath his barke of a reddifh or browne colour, whereby it is foone difcerned from other Rofes. The leaues are likewife more reddifh then in others, and fomewhat larger, it vfually groweth very like the Damaske rofe, and much to the fame height: the flowers or rofes are of the fame deepe blufh colour that the damaske rofes are, or rather fomewhat deeper, but much thicker, broader, and more double, or fuller of leaues by three parts almoft, the outer leaues turning themfelues backe, when the flower hath ftood long blowne, the middle part it felfe (which in all other rofes almoft haue fome yellow threds in them to be feene) being folded hard with fmall leaues, without any yellow alinoft at all to be feene, the fent whereof commeth neereft vnto the damaske rofe, but yet is fhort of it by much, howfoeuer many doe thinke it as good as the damask, and to that end I haue known fome Gentlewomen haue caufed all their damaske ftockes to bee grafted with prouince Rofes, hoping to haue as good water, and more ftore of them then of damask Rofes; but in my opinion it is not of halfe fo good a fent as the water of damaske Rofes: let euery one follow their own fancie.

\section{Rofa Prouincialis rubra. The red Prouince Rofe.}

As the former was called incarnata, fo this is called Batauica centifolia rubra, the difference being not very great: the ftemme or ftocke, and the branches alfo in this, feeming not to be fo great but greener, the barke being not fo red; the leaues of the fame largeneffe with the former damaske Prouince. The flowers are not altogether fo large, thicke and double, and of a little deeper damaske or blufh colour, turning to a red Rofe, but not comming neere the full colour of the beft red Rofe, of a fent not fo fweete as the damaske Prouince, but comming fomewhat neere the fent of the or- 
dinary red rofe, yet exceeding it. This rofe is not fo plentifull in bearing as the damaske Prouince.

\section{Rofa Prouincialis alba. The white Prouince Rofe.}

It is faid of diuers, that there is a white Prouince Rofe, whereof I am not oculatus tefits, and therefore I dare not give it you for a certaintie, and indeed I haue fome doubt, that it is the greater and more double white rofe, whereof I gaue you the knowledge in the beginning: when I am my felfe better fatisfied, I fhall bee ready to fatisfie others.

\section{Rofa verffcolor. The party coloured Rofe, of fome Yorke and Lancafter.}

This Rofe in the forme and order of the growing, is neereft vnto the ordinary damaske rofe, both for ftemme, branch, leafe and flower: the difference confifting in this, that the flower (being of the fame largeneffe and doubleneffe as the damask rofe) hath the one halfe of it, fometimes of a pale whitifh colour, and the other halfe, of a paler damaske colour then the ordinary; this happeneth fo many times, and fometimes alfo the flower hath diuers ftripes, and markes in it, as one leafe white, or ftriped with white, and the other halfe blufh, or ftriped with blufh, fometimes alfo all ftriped, or fpotted ouer, and other times little or no ftripes or markes at all, as nature lifteth to play with varieties, in this as in other flowers: yet this I have obferued, that the longer it abideth blowen open in the fun, the paler and the fewer ftripes, markes or fpots will be feene in it: the fmell whereof is of a weake damaske rofe fent.

\section{Rofea Cliryfallina. The Chryftall Rofe.}

This Rofe is very like vnto the laft defcribed, both for ftocke, branch and leafe: the flower hereof is not much different from it, being no great large or double Rofe, but of a meane fize, ftriped and marked with a deeper blufh or red, vpon the pale coloured leafe, that it feemeth in the marking and beauty thereof, to bee of as much delight as the Chryftall Gilloflower: this, euen like the former, foone fadeth and paffeth away, not yeelding any great ftore of flowers any yeare.

\section{Ro fa rubra humilis fue pumilio.}

The dwarfe red Rofe, or Gilloflower Rofe.

This Rofe groweth alwayes low and fmall, otherwife in moft refpects like vnto the ordinary redde Rofe, and with few or no thornes vpon it: the Flowers or Rores are double, thicke, fmall and clofe, not fo much fpread open as the ordinary red, but fomewhat like vnto the firft double white Rofe before expreffed; yet in fome places I have feene them more layde open then thefe, as they grew in my garden, being fo euen at the toppes of the leaues, as if they had been clipt off with a paire of theeres, and are not fully of fo red a colour as the red Prouince Rofe, and of as fmall or weak fent as the ordinary red Rofe, or not fo much.

\section{Rofa Francafurtenfis. The Franckford Rore.}

The young thootes of this Rofe are couered with a pale purplifh barke, fet with a number of fmall prickes like haires, and the elder haue but very few thornes: the flower or rofe it felfe hath a very great bud or button vnder it, more then in any other rofe, and is thicke and double as a red rofe, but fo ftrongly fwelling in the bud, that many of them breake before they can be full blowen, and then they are of a pale red rofe colour, that is, betweene a red and a damaske, with a very thicke broade and hard vmbone of fhort yellow threds or thrumes in the middle, the huske of the flower hauing long ends, which are called the beards of the rofe, which in all other are iagged in fome of them, in this hath no iagge at all : the fmell is neereft vnto a red Rofe. 


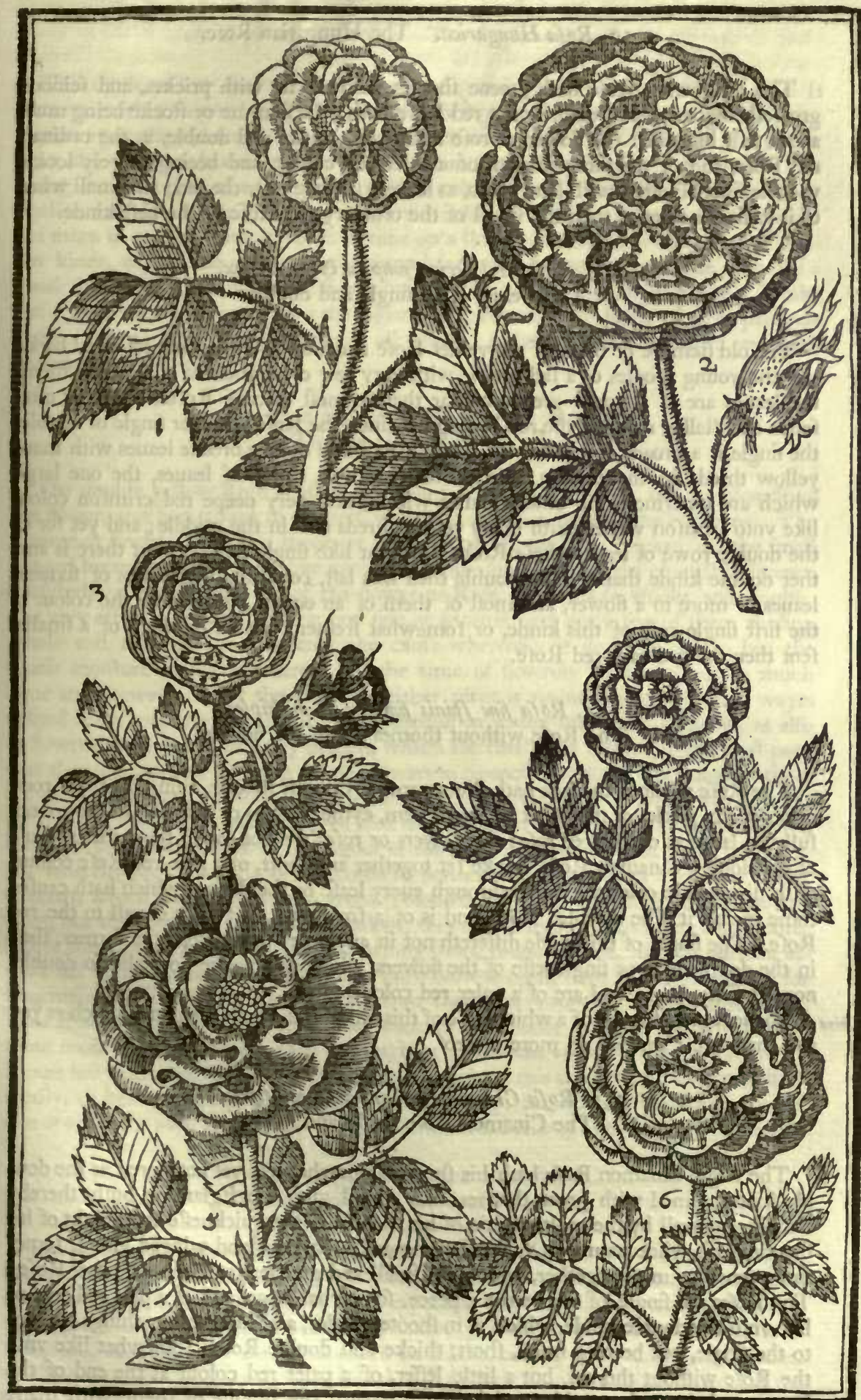

I Rofa Damafecna. The Damaske Role. 2 Rofa Prouincialis fime ITollandica. The great Province Rofe. 3 Rofa Franca. 6 Rofa intea multiplex. The great double yellow Rofe. 


\section{Rofa Hungarica. The Hungarian Rofe.}

The Hungarian Rofe hath greene fhootes flenderly fet with prickes, and feldome groweth higher then ordinarily the red Rofe doth; the ftemme or ftocke being much about that bigneffe: the flower or rofe is as great, thicke and double, as the ordinary red Rofe, and of the fame fafhion, of a paler red colour, and beeing neerely looked vpon is finely fpotted with faint fpots, as it were fpreade ouer the red; the fmell wherof is fomewhat better then the fmell of the ordinary red Rofe of the beft kinde.

\section{I3. Rofa Holoferica fimplex \& multiplex.}

The Veluet Rofe fingle and double.

The old ftemme or ftock of the veluet Rofe is couered with a dark coloured barke, and the young thootes of a fad greene with very few or no thornes at all vpon them: the leaues are of a fadder greene colour then in moft forts of Rofes, and very often feuen on a ftalke, many of the reft hauing but fiue : the Rofe is eyther fingle or double: the fingle is a broade fpread flower, confifting of fiue or fixe broade leaues with many yellow threds in the middle: the double hath two rowes of leaues, the one large, which are outermoft, the other fmaller within, of a very deepe red crimfon colour like vnto crimfon veluet, with many yellow threds alfo in the middle; and yet for all the double rowe of leaues, thefe Rofes ftand but like fingle flowers: but there is another double kinde that is more double then this laft, confifting oftentimes of fixteene leaues or more in a flower, and moft of them of an equall bigneffe, of the colour of the firft fingle rofe of this kinde, or fomewhat frefher; but all of them of a fmaller fent then the ordinary red Rofe.

14. Rofa fine fpinis fimplex \& multiplex.

The Rofe without thornes fingle and double.

The Rofe without thornes hath diuers greene fmooth fhootes, rifing from the root, without any pricke or thorne at all vpon them, eyther young or old: the leaues are not fully fo large as of the red rofe: the flowers or rofes are not much bigger then thofe of the double Cinamon Rofe, thicke fet together and fhort, of a pale red Rofe colour, with diuers pale coloured veines through euery leafe of the flower, which hath caufed fome to call it The marbled Rofe, and is of a fmall fent, not fully equall to the red Rofe. The fingle of this kinde differeth not in any other thing from the former, then in the doubleneffe or fingleneffe of the flowers, which in this are not halfe fo double, nor yet fully fingle, and are of a paler red colour.

Rofa fiue Jpina I haue heard likewife of a white Rofe of this kinde, but I haue feene none fuch as yet, flore albo. and therefore I can fay no more thereof.

\section{Rofa Cinamomea fimplex \& multiplex.}

The Cinamon Rofe fingle and double.

The fingle Cinamon Rofe hath his thootes fomewhat red, yet not fo red as the double kinde, armed with great thornes, like almoft vnto the Eglantine bufh, thereby thowing, as well by the multiplicitie of his thootes, as the quickneffe and height of his fhooting, his wilde nature: On the ftemme and branches ftand winged leaues, fometimes feuen or more together, which are fmall and greene, yet like vnto other Rofes. The Rofes are fingle, of fiue leaues a peece, fomewhat large, and of a pale red colour, like vnto the double kinde, which is in fhootes redder, and in all other things like vnto the fingle, but bearing fmall, fhort, thicke and double Rofes, fomewhat like vnto the Rofe without thornes, but a little leffer, of a paler red colour at the end of the leaues, and fomewhat redder and brighter toward the middle of them, with many yellow fhort thrumes; the fmall fent of Cinamon that is found in the flowers hath caufed it to beare the name. 


\section{Rofa luter fimplex. The fingle yellow Rofe.}

This fingle yellow Rofe is planted rather for variety then any other good vfe. It often groweth to a good height, his ftemme being great and wooddy, with few or no prickes vpon the old wood, but with a number of fmall prickes like haires, thicke fet, vpon the younger branches, of a darke colour fomewhat reddifh, the barke of the young thootes being of a lad greene reddifh colour: the leaues of this Rofe bufh are finaller, rounder pointed, of a paler greene colour, yet finely fnipt about the edges, and more in number, that is, feuen or nine on a ftalke or ribbe, then in any other Garden kinde, except the double of the fame kinde that followeth next: the flower is a fimall fingle Rofe, confifting of fiue leaues, not fo large as the fingle Spanifh Muske Rofe, but fornewhat bigger then the Eglantine or fweete Briar Rofe, of a fine pale yellow colour, without any great fent at all while it is frefh, but a little more, yet fmall and weake when it is dryed.

\section{Rofa lutea multiplex fuue flore pleno.}

The double yellow Rofe.

The double yellow Rofe is of great account, both for the rarity, and doubleneffe of the flower, and had it fent to the reft, would of all other be of higheft efteeme. The ftemme or ftocke, the young fhoots or branches, the fmall hairy prickes, and the fmall winged leaues, are in all parts like vnto the former fingle kinde; the chiefeft difference confifteth in the doubleneffe of the flower or Rofe, which is fo thicke and double, that very often it breaketh out on one fide or another, and but a few of them abiding whole and faire in our Countrey, the caufe whereof wee doe imagine to bee the much moifture of our Countrey, and the time of flowring being fubiect to much raine and fhowers; many therefore doe either plant it againft a wall, or other wayes defend it by couering: againe, it is fo plentifull in young fhootes or branches, as alro in flowers at the toppe of euery branch, which are fmall and weake for the moft part, that they are not able to bring all the flowers to ripeneffe; and therefore molt of them fall or wither away without comming to perfection (the remedy that many doe vfe for this inconuenience laft recited is, that they nippe away moft of the buds, leauing but fome few vpon it, that fo the vigour of the plant may be collected into a few flowers, whereby they may the better come to perfection, and yet euen thus it is hardly effected) which are of a yellowinh greene colour in the bud, and before they be blowne open, but then are of a faire yellow colour, very full of leaues, with many hort haires rather then leaues in the middle, and hauing fhort, round, greene, fmooth buttons, almoft flat vnder them : the flower being faire blowne open, doth fcarce give place for largeneffe, thickneffe, and doubleneffe, vnto the great Prouence or Holland Rofe. This Rofe bufh or plant is very tender with vs here about London, and will require fome more care and keeping then the fingle of this kinde, which is hardy enough; for I haue lof many my felfe, and I know but a few about this towne that can nourfe it vp kindly, to beare or fcarce to abide without perifhing; but abideth well in euery free aire of all or the moft parts of this Kingdome: but (as I heare) not fo well in the North.

\section{Rofa Mofchata fimplex E multiplex.}

The Muske Rore fingle and double.

The Muske Rofe both fingle and double, rife vp oftentimes to a very great height, that it ouergroweth any arbour in a Garden, or being fet by an houfe fide, to bee ten or twelue foote high, or more, but more efpecially the fingle kinde, with many green farre fpread branches, armed with a few Mharpe great thornes, as the wilder forts of Rofes are, whereof thefe are accounted to be kindes, hauing fmall darke greene leaues on them, not much bigger then the leaues of Eglantine: the flowers come forth at the toppes of the branches, many together as it were in an vmbell or tuft, which for the molt part doe flower all at a time, or not long one after another, euery one ftanding on a pretty long ftalke, and are of a pale whitifh or creame colour, both the fingle and 
the double; the fingle being fmall flowers, confifting of fiue leaues, with many yellow threads in the middle: and the double bearing more double flowers, as if they were once or twice more double then the fingle, with yellow thrummes alfo in the middle, both of them of a very fweete and pleafing fmell, refembling Muske : fome there be that haue auouched, that the chiefeft fent of thefe Rofes confifteth not in the leaues, but in the threads of the flowers.

\section{Rofa Mofchata multiplex altera: alijs Damafcena alba, vel verifimilior Cinamomea flore pleno albo. \\ The double white Damaske Muske Rofe.}

This other kinde of Muske Rofe (which with fome is called the white Damaske Muske, but more truely the double white Cinamon Rofe) hath his ftemme and branches alfo fhorter then the former, but as greene: the leaues are fomewhat larger, and of a whiter greene colour; the flowers alfo are fomewhat larger then the former double kinde, but ftanding in vmbels after the fame manner, or fomewhat thicker, and of the fame whitifh colour, or a little whiter, and fomewhat, although but a little, neare the fmell of the other, but nothing fo ftrong. This flowreth at the time of other Rofes, or fomewhat later, yet much before the former two forts of Muske Rofes, which flower not vntill the end of Summer, and in Autumne; both which things, that is, the time of the flowring, and the fent being both different, thew plainly it cannot be of the tribe of the Muske Rofes.

\section{Rofa Hifpanica Mofchata fimplex. The Spanifh Muske Rofe.}

This Spanifh Rofe rifeth to the height of the Eglantine, and fometimes higher, with diuers great greene branches, the leaues whereof are larger and greener then of the former kindes: the flowers are fingle Rofes, confifting of fiue whiter leaues then in any of the former Muske Rofes, and much larger, hauing fometimes an eye of a blufh in the white, of a very fweete fmell, comming neareft vnto the laft recited Muske Rofe, as alfo for the time of the flowring.

\section{Rofa Pomifera maior. The great Apple Rofe.}

The ftemme or ftocke of this Rofe is great, couered with a darke grayinh barke, but the younger branches are fomewhat reddifh, armed here and there with great and fharpe thornes, but nothing fo great or plentifull as in the Eglantine, although it be a wilde kinde: the leaues are of a whitifh greene colour, almoft like vnto the firft white Rofe, and fiue alwaies fet together, but feldome feuen : the flowers are fmall and fingle, confifting of fiue leaues, without any fent, or very little, and little bigger then thofe of the Eglantine bufh, and of the very fame deepe blufh colour, euery one ftanding vpon a rough or prickly button, bearded in the manner of other Rofes, which when the flowers are fallen growe great, fomewhat long and round, peare-fafhion, bearing the beards on the tops of them; and being full ripe are very red, keeping the fmall prickles ftill on them, wherein are many white, hard, and roundifh feedes, very like vnto the feede of the Heppes or Eglantine Berries, lying in a foft pulpe, like vnto the Hawthorne berries or Hawes: the whole beauty of this plant confifteth more in the gracefull afpect of the red apples or fruit hanging vpon the bufhes, then in the flowers, or any other thing. It feemeth to be the fame that Clufius calleth Rofa Pumila, but that with me it groweth much higher and greater then he faith his doth.

\section{Rofa flueftris odora fue Eglenteria fimplex.}

The fingle Eglantine or fweete Briar bufh.

The fweete Briar or Eglantine Rofe is fo well knowne, being not onely planted in Gardens, for the fweeteneffe of the leaues, but growing wilde in many woods and hedges, that I thinke it loft time to defcribe it; for that all know it hath exceeding long greene thootes, armed with the cruelleft fharpe and ftrong thornes, and thicker fet 


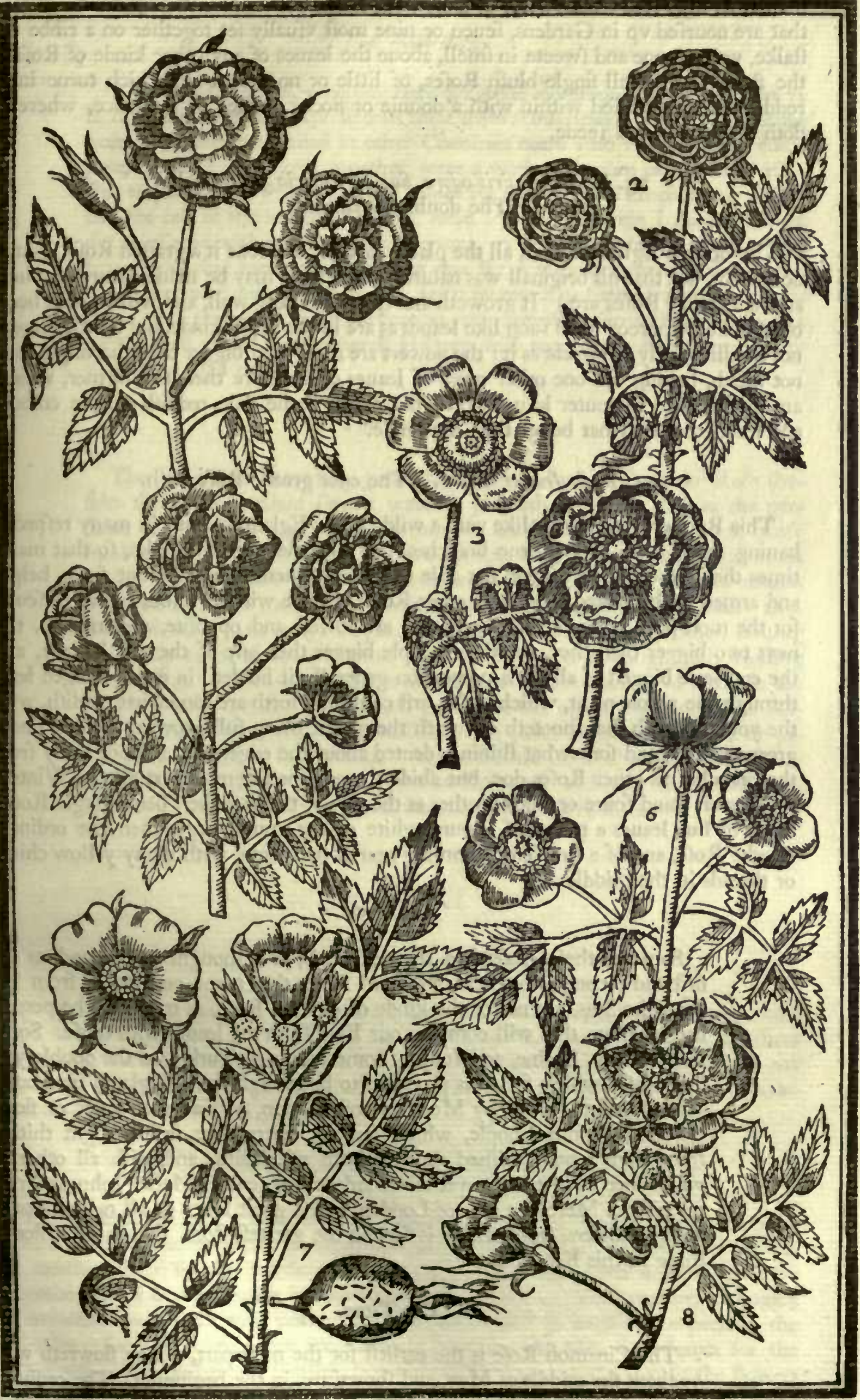

1 Rofa fine spinis multiplex. The double Rofe without thorns. 2 Rofa Cinamomea flore pleno. The double Cinamon Rofe. 3 Rofa Holoferica fimplex. The lingle Veluet Rofe. 4 Rofa Holoferica dwplex. The double Veluet Rofe. 5 Rofa Mofchata
multiplex. The double Muske Rofe. 6 Rofa Mofchata Hijpanica fimplex. The fingle Spanifh Muske Rofe. fera maior. The great Apple Rofe. 8 Rofa flwefiris foue Eglanteria dxplex. The double Eglantine Rofe. 
then is in any Rofe either wilde or tame : the leaues are fmaller then in moft of thofe that are nourfed vp in Gardens, feuen or nine moft vfually fet together on a ribbe or ftalke, very greene and fweete in fmell, aboue the leaues of any other kinde of Rofe : the flowers are fmall fingle blufh Rofes, of little or no fent at all, which turne into reddifh berries, ftuffed within with a dounie or flocky matter or fubftance, wherein doth lye white hard feede.

\section{Rofa filuefris odora fiue Eglenteria flore duplici. The double Eglantine.}

The double Eglantine is in all the places that I haue feene it a grafted Rofe, (but I doubt not, but that his originall was naturall, and that it may be made naturall againe, as diuers other Rofes are.) It groweth and fpreadeth very well, and with a great head of branches, whereon ftand fuch like leaues as are in the fingle kinde, but a little larger, not fmelling fully fo fweete as it : the flowers are fomewhat bigger then the fingle, but not much, hauing but one other rowe of leaues onely more then the former, which are fmaller, and the outer leaues larger, but of the fame pale reddifh purple colour, and fmelleth fomewhat better then the fingle.

\section{Rofa femper virens. The euer greene Rofe bufh.}

This Rofe or bufh is very like vnto a wilde fingle Eglantine bufh in many refpects, hauing many very long greene branches, but more flender and weake, fo that many times they bend downe againe, not able to fuftaine themfelues without fome helpe, and armed with hooked thornes as other Rofes be; the winged leaues confift of feuen for the moft part, whereof thofe two that are loweft and oppofite, are fmalleft, the next two bigger then they, the third couple bigger then any of the reft belowe, and the end leafe biggeft of all : this proportion generally it holdeth in euery winged leafe through the whole plant, which at the firf comming forth are fomewhat reddifh, with the young branch that hooteth out with them, but being full growne, are of a deepe greene colour, and fomewhat thining, dented about the edges, and fall not away from the branches as other Rofes doe, but abide thereon for the moft part all the Winter: the flowers ftand foure or fiue together at the tops of the branches, being fingle Rofes, made of fiue leaues a peece, of a pure white colour, much larger then the ordinary Muske Rofe, and of a fine fent, comming neareft thereunto, with many yellow chiues or threads in the middle.

\section{The Place.}

Some of thefe Rofes had their originall, as is thought in England, as the firft and fecond ; for thefe dryed red Rofes that come ouer to vs from beyond the Seas, are not of the kinde of our red Rofe, as may well be perceiued by them that will compare our Englifh dryed leaues with thofe. Some in Germany, Spaine, and Italy. Some againe in Turkie, as the double yellow Rore, which firft was procured to be brought into England, by Mafter Nicholas Lete, a worthy Merchant of London, and a great louer of flowers, from Conftantinople, which (as wee heare) was firft brought thither from Syria; but perifhed quickly both with him, and with all other to whom hee imparted it : yet afterwards it was fent to Mafter Iohn de Franqueuille, a Merchant alfo of London, and a great louer of all rare plants, as well as flowers, from which is f prung the greateft ftore, that is now flourifhing in this Kingdome.

\section{The Time.}

The Cinamon Rofe is the earlieft for the moft part, which flowreth with vs about the middle of May, and fometimes in the beginning. The ordinary Muske Rofes both fingle and double flower lateft, as is faid. All the other flower much about one time, in the beginning of Iune, or thereabouts, and continue flowring all that moneth, and the next throughout for the moft part, and the red vntill Auguft be halfe paft. 


\section{The Names.}

The feuerall names, whereby they are moft commonly knowne vnto vs in this Countrey, are exprefled in their titles; but they are much differing from what they are called in other Countries neare vnto vs, which to compare, conferre, and agree together, were a worke of more paines then vfe : But to proportion them vnto the names fet downe by Theophraftus, Pliny, and the reft of the ancient Authors, were a worke, wherein I might be fure not to efcape without falling into errour, as I verily beleeue many others haue done, that haue vndertaken to doe it: I will therefore for this worke defire that you will reft contented, with fo much as hath already been deliuered, and expect an exact definition and complete fatisfaction by fuch a methodicall courfe as a generall Hiftory will require, to be performed by them that fhall publifh it.

The Vertues.

The Rofe is of exceeding great vfe with vs; for the Damaske Rofe (befides the fuperexcellent fweete water it yeeldeth being diftilled, or the perfume of the leaues being dryed, feruing to fill fweete bags) ferueth to caufe folubleneffe of the body, made into a Syrupe, or preferued with Sugar moift or dry candid. The Damaske Prouince Rofe, is not onely for fent neareft of all other Rofes vnto the Damaske, but in the operation of folubility alfo. The red Rofe hath many Phyficall vfes much more then any other, feruing for many forts of compofitions, both cordiall and cooling, both binding and loofing. The white Rofe is much vfed for the cooling of heate in the eyes: diuers doe make an excellent yellow colour of the iuyce of white Rofes, wherein fome Allome is diffolued, to paint or colour flowers or pictures, or any other fuch things. There is little vfe of any other fort of Rofes; yet fome affirme, that the Muske Rofes are as ftrong in operation to open or loofen the belly as the Damaske Rofe or Prouince.

\section{CH A P. CXI.}

\section{Ciftus. The Holly Rofe or Sage Rofe.}

7 Here are three principall kindes of Ciftus, the male, the female, and the gumme or fweete fmelling Ciftus bearing Ladanum, called Ledon. Of each of thefe three there are alfo diuers forts: Of them all to intreate in this worke is not my minde, I will onely felect out of the multitude fome few that are fit for this our Garden, and leaue the reft to a greater.

The male Ciffus that is moft familiar vnto our Countrey, I meane that will beft abide, is a fmall fhrubby plant, growing feldome aboue three or foure foote high with vs, hauing many flender brittle wooddy branches, couered with a whitifh barke, whereon are fet many whitifh greene leaues, long and fomewhat narrow, crumpled or wrinckled as it were with veines, and fomewhat hard in handling, efpecially the old ones; for the young ones are fofter, fomewhat like vnto Sage leaues for the forme and colour, but much fmaller, two alwaies fet together at a ioynt : the flowers ftand at the toppe of the branches, three or foure together vpon feuerall flender footftalkes, confifting of fiue fmall round leaues a peece, fomewhat like vnto a fmall fingle Rofe, of a fine reddifh purple colour, with many yellow threads in the middle, with- 
out any fent at all, and quickly fading or falling away, abiding feldome one whole day blowne at the moft : after the flowers are paft, there come vp round hard hairie heads in their places, containing fmall brownifh feede : the roote is wooddy, and will abide fome yeares with vs, if there be fome care had to keepe it from the extreamity of our Winters froftes, which both this, and many of the other forts and kinds, will not abide doe what we can.

\section{Ciftus famina. The female Holly Rofe.}

The female Holly Rofe groweth lower, and fmaller then the former male kinde, hauing blackifh branches, leffe woody, but not leffe brittle then it: the leaues are fomewhat rounder and greener, but a little hard or rough withall, growing in the fame manner vpon the branches by couples: the flowers grow at the toppes of the branches, like vnto the former, confifting of fiue leaues, but fomewhat leffer, and wholly white, with yellow threds in the middle, as quickly fading, and of as little fent as the former: the heads and feede are fomewhat bigger then in the former.

\section{Chamacifus Frificus. The dwarfe Holly Rofe of Frifeland.}

This dwarfe Ciftus is a fmall low plant, hauing diuers fhootes from the rootes, full of leaues that are long and narrow, very like vnto the leaues of the French Spikenard or Spica Celtica ; from among which leaues fhoote forth Thort ftalkes, not aboue a fpan high, with a few fmaller leaues thereon; and at the toppes diuers fmall flowers one aboue another, confifting of fix fmall round leaues, of a yellow colour, hauing two circles of reddinh fpots round about the bottome of the leaues, a little diftant one from another, which adde much grace to the flower : after the flowers are paft, there come in their places fmall round heads, being two forked at the end containing within them fmall brownifh chaffie feede : the roote is fmall and flender, with many fibres thereat creeping vnder ground, and thooting forth in diuers places, whereby it much encreafeth : the whole plant, and euery part of it, fmelleth ftrong without any pleafant fent.

\section{Ciftus annuus. The Holly Rofe of a yeare.}

This fmall Ciftus that endureth but a year (and will require to be fowne euery year, if ye will have it) rifeth vp with ftraight, but flender hard ftalkes, fet here and there confufedly with long and narrow greenifh leaues, very like vnto the leaues of the Gum Ciftus or Ledon, being a little clammy withall : at the toppe of the ftalkes, and at the ioynts with the leaues, ftand two or three pale yellow, flowers, confifting of fiue leaues a peece, with a reddifh fpot neere the bottome of euery leafe of the flower, as quickely fading as any of the former : after which follow fmall three fquare heades, containing fmall feede, like vnto the firft female kinde, but fomewhat paler or yellower : the root is Small and woody, and perifheth as foone as it hath borne feede.

\section{Ciftus Ledon. The Gum Ciftus, or Sweete Holly Rofe.}

This fweete Holly Rofe or Gum Ciftus, rifeth higher, and fpreadeth larger then the former male kind doth, with many blackifh woody branches, whereon are fet diuers long and narrow darke greene leaues, but whitifh vnderneath, two alwayes ftanding together at a ioint, both ftalks and leaues bedeawed as it were continually with a clammy fweete moifture (which in the hot Countries is both more plentifull, and more fweet then in ours) almoft tranfparent, and which being gathered by the inhabitants, with certaine inftruments for that purpore (which in fome places are leather thongs, drawne ouer the burhes, and after fcraped off from the thongs againe, and put together) is that kind of blacke fweet gum, which is called Ladanum in the Apothecaries fhops: at the tops of the branches ftand fingle white flowers, like vnto fingle Rofes, being larger then in any of the former kindes, confifting of fiue leaues, whereof euery one hath at the bottome a dark purplifh fpot, broad below, and fmall pointed vpwards, with fome yellow threds in the middle: after which are paft, there arife cornered 


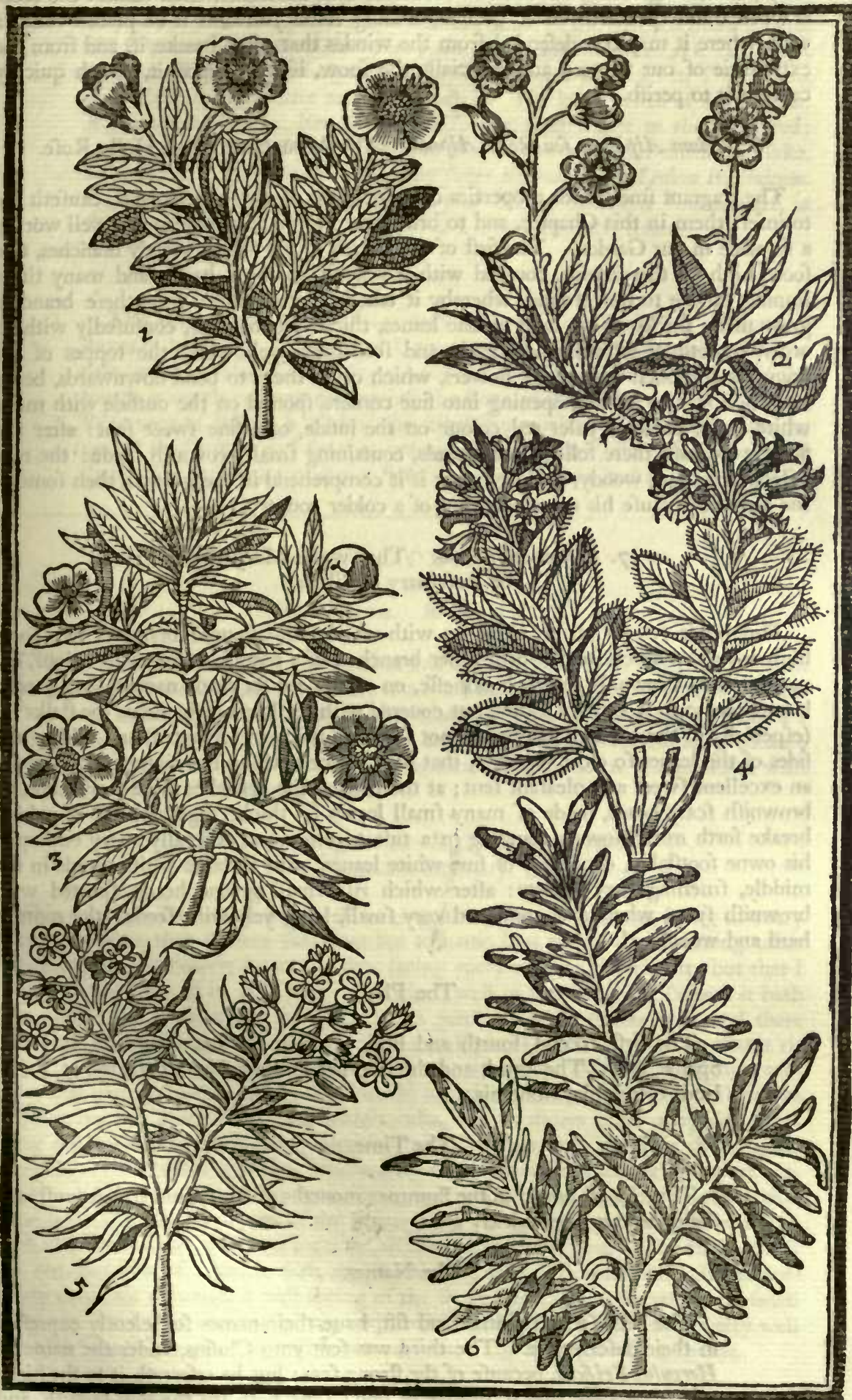

1 Ciflus mas. The male Holly Rofe. 2 Chamaciflus Frifucus. The dwarfe Holly Rofe of Frifia. 3 Ciflus Ledon. The Rofe of Silefa. or gumme Ciftus. 4 Ledum Alpinum. The mountaine llolly Rofe. 5 Ledum Silefiacum. The fweet Mary 
heads, containing fuch fmall brownifh feede as is in the former male kinde: the roote is woody, and fpreadeth vnder ground, abiding fome yeares, if it be placed vnder a wall, where it may bee defended from the windes that often breake it, and from the extremitie of our winters, and efpecially the fnow, if it lye vpon it, which quickly caufeth it to perifh.

\section{Ledum Alpinum feu Rofa Alpina. The Mountaine fweet Holly Rofe.}

The fragrant fmell with properties correfpondent of two other plants, caufeth me to infert them in this Chapter, and to bring them to your knowledge, as well worthy a fit place in our Garden. The firft of them hath diuers flender woody branches, two foote high or thereabouts, couered with a grayifh coloured barke, and many times leaning downe to the ground, whereby it taketh roote againe: vpon thefe branches grow many thicke, thort, hard greene leaues, thicke fet together, confufedly without order, fometimes whitifh vnderneath, and fometimes yellowifh: the toppes of the branches are loden with many flowers, which caufe them to bend downwards, being long, hollow and reddifh, opening into fue corners, fpotted on the outfide with many white fpots, and of a paler red colour on the infide, of a fine fweet fent: after the flowers are paft, there follow fmall heads, containing fmall brownifh feede: the root is long, hard and woody, abiding better if it comprehend in the ground, then fome of the former, becaufe his originall is out of a colder country.

\section{Ledum Silefracum. The fweete Mary Rofe, or Rofemary of Silefia.}

This other fweete plante rifeth vp with woody afh-coloured branches two foote high or more, which fhoote forth other branches, of a reddifh or purplifh colour, couered with a brownifh yellow hoarineffe, on which are fet many narrow long greene leaues, like vnto Rofemary leaues, but couered with the like hoarineffe as the ftalks are (efpecially in the naturall places, but not fo much being tranfplanted) and folding the fides of the leaues fo clofe together, that they feeme nothing but ribbes, or ftalkes, of an excellent fweet and pleafant fent; at the ends of the branches there grow certaine brownifh fcaly heads, made of many fmall leaues fet thicke together, out of which breake forth many flowers, ftanding in a tuft together, yet feuerally euery one vpon his owne footftalke, confifting of fiue white leaues, with certaine white threds in the middle, fmelling very fweete: after which rife fmall greene heads, fpotted with brownifh fpots, wherein is contained very fmall, long, yellowifh feede: the roote is hard and woodie.

\section{The Place.}

The firt, fecond, fourth and fifth, grow in the hot Countries, as Italie, Spaine, \&c. The third, and the two laft in the colder Countries, as Frifeland, Germanie, Bohemia.

\section{The Time.}

They do all flower in the Summer moneths of Iune, Iuly and Auguft, and their feede is ripe quickly after.

\section{The Names.}

The firf, fecond, fourth and fift, haue their names fufficiently expreffed in their defcriptions. The third was fent vnto Clufius, vnder the name of Herculus Frificus, becaufe of the ftrong fent : but he referreth it to the kinds of Chamaciftus, that is, dwarfe or low Ciffus, both for the low growth, and for the flowers and feede fake. The fixt is diuerly called; for Ciufius calleth it Ledum Alpinum: others, Nerium Alpinum, making it to bee a Rofe Bay. 
Gefner according to the Countrey peoples name, $R \circ f_{a} A$ /pina, and $R \circ f_{a}$ Montona. Lobel calleth it Balfomum Alpinum, of the fragrant fmell it hath, and Chamerhododendros Chamelerefolio. And fome haue called it Exronymus, without all manner of iudgement. In Englifh wee may call it, The Mountaine Rofe, vntill a fitter name be giuen it. The latt is called of Matthiolus, Rofinarinum filueftre, but of Clufius Ledum, referring it to their kindred; and Sile facum, becaufe he found it in that Countrey; or for diftinction fake, as he faith, it may bee called, Ledum folijs Rofmarini, or Ledum Bohemicum. Cordus, as it feemeth in his Hiftory of Plants, calleth it Chameepence, as though he did account it a kinde of low Pine, or Pitch tree.

\section{The Vertues.}

The firft, fecond, and fift, are very aftringent, effectuall for all forts of fluxes of humours. The fweet Gum called Lodanum, made artificially into oyle, is of fingular vfe for Alopecia, or falling of the haire. The feed of the fourth is much commended againt the ftone of the Kidneyes. The fweete Rofemary of Silefia is vfed of the inhabitants, where it naturally groweth, againft the fhrinking of fnewes, crampes, or other fuch like difeafes, whereof their daily experience makes it familiar, being vfed in bathing or otherwife.

\section{CH A P. CXII.}

\section{Rofmarinum. Rofemary.}

T Here hath beene vfually knowne but one fort of Rofemary, which is frequent through all this Country: but there are fome other forts not fo well known; the one is called Gilded Rofemary; the other broade leafed Rofemary; a third I will adioyne, as more rare then all the other, called Double flowred Rofmary, becaufe few haue heard thereof, much lefle feene it, and my felfe am not well acquainted with it, but am bold to deliuer it vpon credit.

\section{Libanotis Coronaria fuve Rofmarinum vulgare. \\ Our Common Rofmary.}

This common Rofemary is fo well knowne through all our Land, being in euery womans garden, that it were fufficient but to name it as an ornament among other fweete herbes and flowers in our Garden, feeing euery one can defcribe it : but that I may fay fomething of it, It is well obferued, as well in this our Land (where it hath been planted in Noblemens, and great mens gardens againft bricke wals, and there continued long) as beyond the Seas, in the naturall places where it groweth, that it rifeth $\mathrm{vp}$ in time vnto a very great height, with a great and woody ftemme (of that compaffe, that (being clouen out into thin boards) it hath ferued to make lutes, or fuch like inftruments, and here with vs Carpenters rules, and to diuers other purpofes) branching out into diuers and fundry armes that extend a great way, and from them againe into many other fmaller branches, whereon are fet at feueral diftances, at the ioynts, many very narrow long leaues, greene aboue, and whitifh vnderneath; among which come forth towards the toppes of the ftalkes, diuers fweet gaping flowers, of a pale or bleake blewifh colour, many fet together, ftanding in whitifh huskes; the feed is fmall and red, but thereof feldome doth any plants arife that will abide without extraordinary care; for although it will fpring of the feede reafonable well, yet it is fo fmall and tender the firft yeare, that a Tharpe winter killeth it quickly, vnleffe it be very well defended: the whole plant as well leaues as flowers, fmelleth exceeding fweete.

\section{Rofmarinum friotum, fue aureum. Gilded Rofemary.}

This Rofemary differeth not from the former, in forme or manner of growing, nor 
in the forme or colour of the flower, but only in the leaues, which are edged, or ftriped, or pointed with a faire gold yellow colour, which fo continueth all the yeare throughout, yet frefher and fairer in Summer then in Winter; for then it will looke of a deader colour, yet fo, that it may be difcerned to be of two colours, green \& yellow.

\section{Rofmarinum latifolium. Broade leafed Rofemary.}

This broad leafed Rofemary groweth in the fame manner that the former doth, but that we haue not feene it in our Countrey fince we had it to grow fo great, or with fuch woody ftemmes: the leaues ftand together vpon the long branches after the fame fafhion, but larger, broader and greener then the other, and little or nothing whitifh vnderneath: the flowers likewife are of the fame forme and colour with the ordinary, but larger, and herein confifteth the difference.

\section{Rofmarinum flore duplici. Double flowred Rormary.}

The double flowred Rormary thus far differeth from the former, that it hath ftronger ftalkes, not fo eafie to breake, fairer, bigger and larger leaues, of a faire greene colour, and the flowers are double, as the Larkes heele or fpurre: This I haue onely by relation, which I pray you accept, vntill I may by fight better enforme you.

\section{The Place.}

Our ordinary Rofmary groweth in Spaine, and Prouence of France, and in others of thofe hot Countryes, neere the Sea fide. It will not abide (vnleffe kept in ftoues) in many places of Germany, Denmarke, and thofe colder Countries. And in fome extreame hard winters, it hath well neere perifhed here in England with vs, at the leaft in many places: but by flipping it is vfually, and yearly encreafed, to replenifh any garden.

\section{The Time.}

It flowreth oftentimes twice in the yeare; in the Spring firft, from April vntill the end of May or Iune, and in Auguft and September after, if the yeare before haue been temperate.

\section{The Names.}

Rofmary is called of the ancient Writers, Libanotis, but with this diftinction, Stephanomatica, that is, Coronaria, becaufe there were other plants called Libanotis, that were for other vfes, as this for garlands, where flowers and fweete herbes were put together. The Latines call it Rofmarinum. Some would make it to be Cneorum nigrum of Theophraftus, as they would make Lauander to bee his Cneorum album, but Matthiolus hath fufficiently confuted that errour.

\section{The Vertues.}

Rormary is almoft of as great vfe as Bayes, or any other herbe both for inward and outward remedies, and as well for ciuill as phyficall purpores. Inwardly for the head and heart; outwardly for the finewes and ioynts: for ciuill vfes, as all doe know, at weddings, funerals, \&c. to beftow among friends: and the phyficall are fo many, that you might bee as well tyred in the reading, as $I$ in the writing, if $I$ fhould fet down all that might be faid of it. I will therefore onely giue you a tafte of fome, defiring you will be content therewith. There is an excellent oyle drawne from the flowers alone by the heate of the Sunne, auaileable for many difeases both inward and outward, and accounted a foueraigne Balfame: it is alfo good to helpe dim- 
neffe of fight, and to take away fpots, markes and fcarres from the skin; and is made in this manner. Take a quantitie of the flowers of Rofemary, accosding to your owne will eyther more or leffe, put them into a ftrong glaffe clofe ftopped, fet them in hot horfe dung to digeft for fourteene dayes, which then being taken forth of the dung, and vnitopped, tye a fine linnen cloth ouer the mouth, and turne downe the mouth thereof into the mouth of another ftrong glaffe, which being fet in the hot Sun, an oyle will diftill downe into the lower glaffe; which preferue as precious for the vfes before recited, and many more, as experience by practice may enforme diuers.

There is another oyle Chymically drawne, auaileable in the like manner for many the fame inward and outward difeases, viz. for the heart, rheumaticke braines, and to ftrengthen the memory, outwardly to warme and comfort cold benummed finewes, whereof many of good iudgement haue had much experience.

\section{CHAP. CXIII.}

\section{Myrtus. The Mirtle tree or bufh.}

I $\mathrm{N}$ the hot Countreyes, there haue been many forts of Mirtles found out, naturally growing there, which will not fructifie in this of ours, nor yet abide without extraordinary care, and conueniencie withall, to preferue them from the fharpeneffe of our winters. I thall only bring you to view three forts in this my Garden, the one with a greater, the other two with leffet leaues, as the remainder of others which wee haue had, and which are preferued from time to time, not without much paine and trouble.

\section{Myrtus latifolia. The greater leafed Mirtle.}

The broader leafed Mirtle rifeth vp to the height of foure or fiue foote at the moft with vs, full of branches and leaues growing like a fmall bufh, the ftemme and elder branches whereof are couered with a dark coloured bark, but the young with a green, and fome with a red, efpecially vpon the firft thooting forth, whereon are fet many freth greene leaues, very fweet in Imell, and very pleafant to behold, fo neer refembling the leaues of the Pomegranate tree that groweth with vs, that they foone deceiue many that are not expert therein, being fomewhat broade and long, and pointed at the ends, abiding alwaies green : at the ioynts of the branches where the leaues ftand, come forth the flowers vpon fmall footeftalkes, euery one by it felfe confifting of fiue fmall white leaues, with white threds in the middle, fmelling alfo very fweet: after the flowers are paft, there doe arife in the hot Countries, where they are naturall, round blacke berries, when they are ripe, wherein are contained many hard white crooked feedes, but neuer in this Countrey, as I faid before: the roote difperfeth it felfe into many branches, with many fibres annexed thereto.

\section{Myrtus minor, feu minore folio. The fmaller leafed Mirtle.}

The fmaller leafed Mirtle is a low thrub or bufh, like vnto the former, but fcarce rifing fo high, with branches fpreading about the ftemme, much thicker fet with leaues then the former, fmaller alfo, and pointed at the ends, of a little deeper greene colour, abiding greene alfo winter and fummer, and very fweete likewife: the flowers are white like vnto the former, and as fweete, but thew not themfelues fo plentifull on the branches: the fruit is blacke in his naturall places, with feedes therein as the former.

3. Myrtus minor rotundiore folio. Boxe Mirtle.

Wee haue another fort of this fmall kinde of Mirtle, fo like vnto the former both for fmalneffe, deepe greene colour of the leaues, and thicke growing of the branches, 
that it will be thought of moft, without good heede, and comparing the one with the other, to be the very fame with the former: but if it bee well viewed, it will thew, by the roundneffe at the ends of the leaues very like vnto the fmall Boxe leaues, to be another differing kinde, although in nothing elfe. Wee nourfe them with great care, for the beautifull afpect, fweete fent and raritie, as delights and ornaments for a garden of pleafure, wherein nothing fhould be wanting that art, care and coft might produce and preferue: as alfo to fet among other euer greene plants to fort with them.

The Place.

Thefe, and many other forts of Mirtles grow in Spaine, Portugall, Italie, and other hot Countries in great aboundance, where they make their hedges of them: wee (as I faid) keepe them in this Countrey, with very great care and diligence.

\section{The Time.}

The Mirtles doe flower very late with vs, not vntill Auguft at the fooneft, which is the caufe of their not fructifying.

\section{The Names.}

They are called in Latine Myrtus, and in Englifh Mirtle tree, without any other diuerfitie of names, for the generall title. Yet the feuerall kindes haue had feuerall denominations, in Plinies time, and others, as Romana, Coniugala, Terentina, Egyptia, alba, nigra, $\Xi^{2} c$. which have noted the differences, euen then well obferued.

\section{The Vertues.}

The Mirtle is of an aftringent qualitie, and wholly vfed for fuch purpofes.

\section{С н А. C X I I I I.}

\section{Malus Punica fue Granata. The Pomegranet tree.}

$\mathrm{T}$

Here are two kindes of Pomegranet trees, The one tame or manured, bearing fruit, which is diftinguifhed of fome into two forts, of others into three, that is, into fower, and fweet, and into fower fweete. The other wilde, which beareth no fruite, becaufe it beareth double flowers, like as the Cherry, Apple, and Peach tree with double bloffomes, before defcribed, and is alfo diftinguifhed into two forts, the one bearing larger, the other leffer flowers. Of the manured kinde wee haue onely one fort (fo farre as we know) for it neuer beareth ripe fruit in this our Countrey) which for the beautifull afpect, both of the greene verdure of the leaues, and faire proportion and colour of the flowers, as alfo for the raritie, are nourfed in fome few of their gardens that delight in fuch rarities: for in regard of the tenderneffe, there is neede of diligent care, that is, to plant it againft a brick wall, and defend it conueniently from the tharpeneffe of our winters, to giue his Mafter fome pleafure in feeing it beare flowers: And of the double kinde we haue as yet obtained but one fort, although I thall giue you the knowledge and defcription of another.

\section{Malus Punica fatiua. The tame Pomegranet tree.}

This Pomegranet tree groweth not very high in his naturall places, and with vs fomtimes it thooteth forth from the roote many brownifh twigges or branches, or if it bee pruned from them, and fuffered to grow vp, it rifeth to bee feuen or eight foote high, 


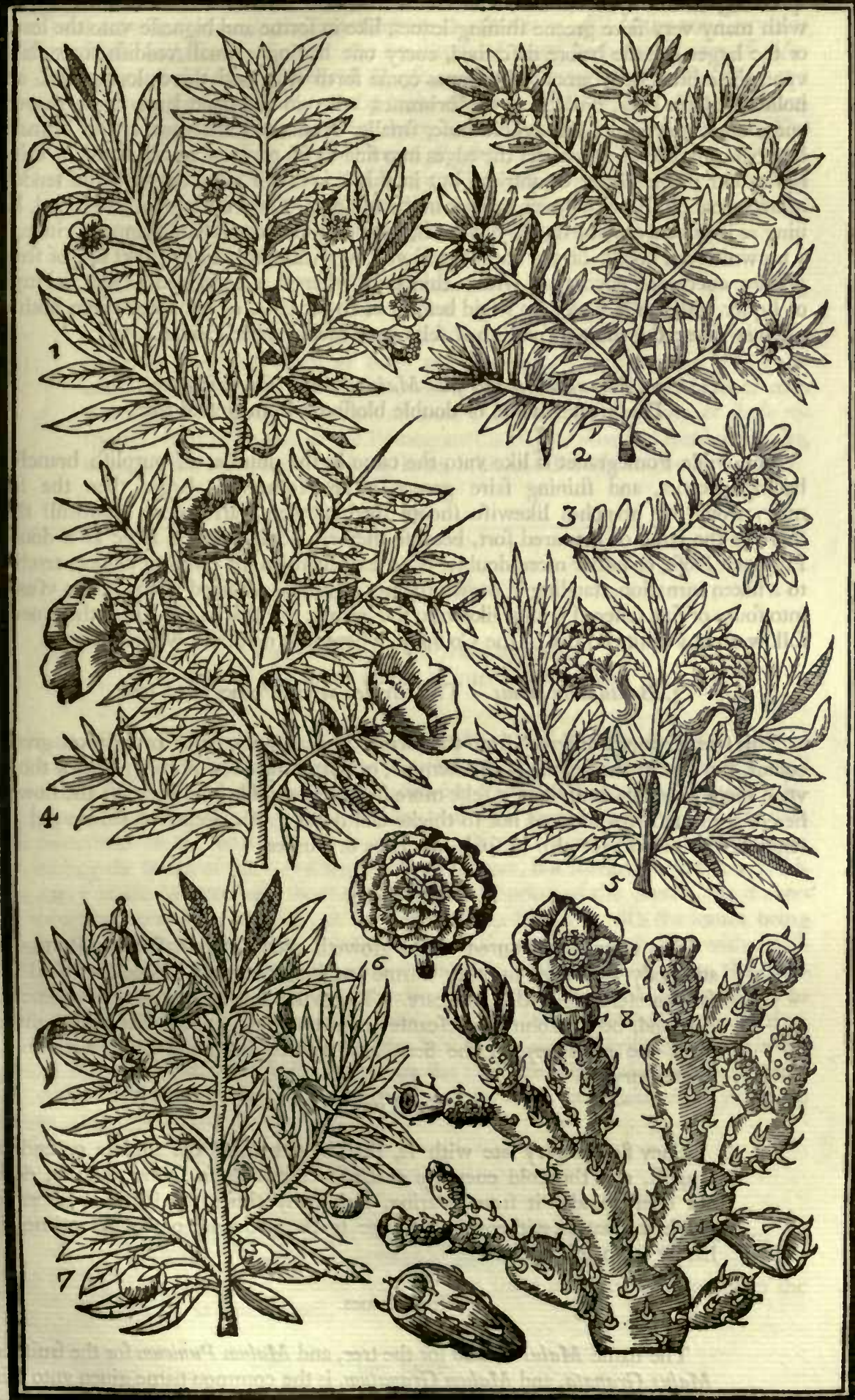

I. Ujrius latifolia maior. The broad leafed Myrtle. 2 Myrtus anguftifolia minor. The fmall leafed Myrtie. 3 Myrtus buxifolia minor. The Boxe leafed Myrtle. 4 Malus Granatus fimplici flore. The ordinary Pomegranet tree. 5 Balauftium lowred Pomegranet. Indian Figgetree and his fruit. 
fpreading into many fmall and flender branches, here and there fet with thornes, and with many very faire greene fhining leaues, like in forme and bigneffe vnto the leaues of the larger Myrtle before defcribed, euery one hauing a fmall reddifh foote-ftalke vpon thefe branches: among the leaues come forth here and there, long, hard, and hollow reddifh cups, diuided at the brimmes, wherein doe ftand large fingle flowers, euery one confifting of one whole leafe, fmaller at the bottome then at the brimme, like bels, diuided as it were at the edges into fiue or fix parts, of an orient red or crimfon colour in the hotter Countries; but in this it is much more delayed, and tendeth neare vnto a blufh, with diuers threads in the middle. The fruit is great and round, hauing as it were a crowne on the head of it, with a thicke tough hard skinne or rinde, of a brownifh red colour on the outfide, and yellow within, ftuffed or packt full of fmall graines, euery one encompaft with a thin skin, wherein is contained a clear red iuyce or liquor, either of a fweet (as I faid before) or fower tafte, or betweene them both of a winie tafte : the roote difperfeth it felfe very much vnder ground.

\section{Balaufium maius fiue Malus Punica flueftris maior.}

The greater wilde or double bloffomd Pomegranet tree.

The wilde Pomegranet is like vnto the tame in the number of purplifh branches, hauing thornes, and thining faire greene leaues, fomewhat larger then the former : from the branches likewife fhoote forth flowers, farre more beautifull then thofe of the tame or manured fort, becaufe they are double, and as large as a double Prouince Rofe, or rather more double, of an excellent bright crimfon colour, tending to a filken carnation, ftanding in brownifh cups or huskes, diuided at the brims vfually into foure or fiue feuerall points, like vnto the former, but that in this kinde there neuer followeth any fruit, no not in the Country, where it is naturally wilde.

\section{Balauftium minus. The fmaller wilde Pomegranet tree.}

This imaller kinde differeth from the former in his leaues, being of a darker greene colour, but not in the height of the ftemme, or purplifhneffe of his branches, or thorns vpon them; for this doth thew it felfe more like vnto a wilde kind then it : the flowers hereof are much fmaller, and not fo thicke and double, of a deeper or fadder red Orenge tawny colour, fet alfo in fuch like cups or huskes.

The Place.

The tame or manured kinde groweth plentifully in Spaine, Portugall, and Italy, and other in other warme and hot countries. Wee (as I faid before) preferue it with great care. The wilde I thinke was neuer feene in England, before Iohn Tradefcante my very louing good friend brought it from the parts beyond the Seas, and planted it in his Lords Garden at Canterbury.

\section{The Time.}

They flower very late with vs, that is, not vntill the middle or end of Auguit, and the cold euenings or frofts comming fo foone vpon it, doth not onely hinder it from bearing, but many times the tharpe winters fo pinch it, that it withereth it downe to the ground, fo that oftentimes it hardly fpringeth againe.

\section{The Names.}

The name Malus Punica for the tree, and Malum Punicum for the fruit, or Malus Granata, and Malum Granatum, is the common name giuen vnto this tree, which is called in Englin the Pomegarnet or Pomegranet tree. The flowers of the tame kinde are called Cytini, as Diofcorides faith, although Plinie feemeth either to make Cytinus to be the flower of the wilde kinde, or 
Balauftium to be the flower of both tame and wilde kinde: but properly, as I take it, Cytinus is the cup wherein the flower as well of the tame as wilde kinde doth ftand ; for vnto the fimilitude of them, both the flowers of $A J a$ rum, and the feede veffels of Hyofciamus are compared and refembled, and not vnto the whole flower : the barke or rinde of the fruit is called of diuers Sidion, and in the Apothecaries fhops Pfidium, and cortex Granatorum. The wilde kinde is called Malus Punica filueftris: In Englifh, The wilde Pomegranet tree ; the flower thereof is properly called Balauftium. The leffer kind is vfually called Balauftium Romanum, as the greater is called Creticum and Cyprinum, becaufe they growe in Candy and Cyprus.

\section{The Vertues.}

The vfe of all thefe Pomegranets is very much in Phyficke, to coole and binde all fluxibility both of body and humours: they are alfo of fingular effect in all vlcers of the mouth, and other parts of the body, both of man and woman. There is no part of them but is applyed for fome of thefe refpects. The rinde alfo of the Pomegranet is vfed of diuers in ftead of Gaules, to make the beft fort of writing Inke, which is durable to the worlds end.

\section{Cha , CXV.}

\section{Amonum Plinij feu Pfeudocapficum.}

Tree Night fhade or the Winter Cherry tree.

I Haue adioyned this plant, for the pleafurable beauty of the greene leaues, and red berries. It groweth vp to be a yard or foure foote high at the moft, hauing a fmall wooddy ftemme or ftocke, as bigge as ones finger or thumbe, couered with a whitifh greene barke, fet full of greene branches, and faire greene leaues, fomewhat vneuen fometimes on the edges, narrower then any Night fhade leaues, and very neare refembling the leaues of the Capficum, or Ginny pepper, but fmaller and narrower, falling away in the Winter, and fhooting frefh in the Spring of the yeare: the flowers growe often two or three together, at the ioynts of the branches with the leaues, being white, opening ftarre-fafhion, and fometimes turning themfelues backe, with a yellow pointell in the middle, very like vnto the flowers of Night fhade : after the flowers are paft, come forth in their ftead fmall greene buttons, which after turne to be pleafant round red berries, of the bigneffe of fmall Cherries when they are ripe, which with vs vfually ripen not vntill the Winter, or about Chriftmas, wherein are contained many fmall whitifh feede that are flat : all the whole plant, as well leaues and flowers as feede, are without either fmell or tafte : the roote hath many yellowifh ftrings and fibres annexed vnto it.

The Place.

The originall place hereof is not well knowne, but is thought to bee the Weft Indies. It hath been planted of long time in moft of thefe Countries, where it abideth reafonable well, fo that fome care bee had thereof in the extreamity of the $\mathrm{W}$ inter.

\section{The Time.}

It flowreth fometimes in Iune, but vfually in Iuly and Auguft, and the fruit is not ripe (as is faid) vntill the Winter. 


\section{The Names.}

This plant hath diuers names; for it is thought to be that kinde of Amomum that Plinie fetteth downe. Dodonæus calleth it Pfeudocapficum, for fome likeneffe in the leafe and fruit vnto the fmall Capficum or Ginnie Pepper, although much vnlike in the tafte and property. Others doe call it Strichnodendron, that is, Solanum arborefcens, and wee in Englifh according thereunto, Tree Night thade. But fome Latine affes corrupting the Latine word Amomum, doe call it the Mumme tree. Dalechampius calleth it Solanum Americum, feu Indicum, and faith the Spaniards call it in their tongue, Guindas de las Indias, that is, Cerafa Indiana, Indian Cherries, which if any would follow, I would not bee much againft it : but many Gentlewomen doe call them Winter Cherries, becaufe the fruit is not throughly ripe vntill Winter.

The Vertues.

I finde no phyficall property allotted vnto it, more then that by reafon of the infipidity, it is held to be cooling.

\section{Ch A P. CXVI.}

Ficus Indica minor. The fmaller Indian Figge tree.

$\mathrm{T}$ His Indian Figge tree, if you will call it a tree (becaufe in our Country it is not fo, although it groweth in the naturall hot Countries from a wooddy ftemme or body into leaues) is a plant confifting only of leaues, one fpringing out of another, into many branches of leaues, and all of them growing out of one leafe, put into the ground halfe way, which taking roote, all the reft rife out thereof, thofe belowe for the moft part being larger then thofe aboue; yet all of them fomewhat long, flat, and round pointed, of the thickneffe of a finger vfually, and fmalleft at the lower end, where they are ioyned or fpring out of the other leaues, hauing at their firft breaking out a fhew of fmall, red, or browne prickes, thicke fet ouer all the vpper fide of the leaues, but with vs falling away quickly, leauing onely the markes where they ftood: but they haue befides this hew of great prickes, a few very fine, and fmall, hard, white, and fharpe, almoft infenfible prickes, being not fo bigge as haires on the vnderfide, which will often fticke in their fingers that handle them vnaduifedly, neither are they to be difcerned vnleffe one look precifely for them: the leaues on the vnderfide hauing none of thofe other great pricks or marks at all, being of a faire frefh pale green colour: out of the vppermolt leaues breake forth certaine greene heads, very like vnto leaues (fo that many are deceiued, thinking them to be leaues, vntill they marke them better, and be better experienced in them) but that they growe round and not flat, and are broad at the toppe ; for that out of the tops of euery of them fhooteth out a pale yellow flower, confifting of two rowes of leaues, each containing fiue leaues a peece, laid open with certaine yellow threads, tipt with red in the middle : this greene head, vntill the flower be paft, is not of halfe that bigneffe that it attaineth vnto after, yet feldome or neuer commeth vnto perfection with vs, being long and round, like vnto a Figge, fmall belowe, and greater aboue, bearing vpon the flat or broad head the marke of the flower ; fome holding ftill on them the dryed leaues, and others hauing loft them, Thew the hollowneffe which they haue in the toppe or middle of the head, the fides round about being raifed or ftanding vp higher : this head or figge in our Country abideth greene on the outfide, and little or nothing reddifh within (although it abide all the Winter, and the Summer following, as fometimes it doth) for want of that heate and comfort of the Sunne it hath in his naturall place, where it groweth 
reddifh on the outfide, and containing within it a bloudy red clammy iuyce, making the vrine of them that eate of them as red as bloud, which many feeing, were in doubt of themfelues, left their vrine were not very bloud; of what fweetneffe, like a figge, in the naturall places, I am not well affured, yet affirmed : but thofe that haue beene brought vnto me, whofe colour on the outfide was greenifh, were of a reddifh purple within, and contained within them round, fmall, hard feede, the tafte was flat, waterifh, or infipide : the roote is neither great, nor difperfeth it felfe very deepe or farre, but fhooteth many fmall rootes vnder the vpper cruft of the earth.

There is a greater kinde hereof, whofe leaues are twice or thrice as bigge, which hauing been often brought vs, will feldome abide more then one Summer with vs, our Winters alwaies rotting the leaues, that it could not be longer kept.

The Place.

This Indian Figge tree groweth difperfedly in many places of America, generally called the Weft Indies: The greater kinde in the more remote and hot Countries, as Mexico, Florida, \&c. and in the Bermudas or Summer Iflands, from whence wee haue often had it. The leffer in Virginia, and thofe other Countries that are nearer vnto vs, which better endureth with vs.

\section{The Time.}

It flowreth with vs fometimes in May, or Iune; but (as I faid) the fruit neuer commeth to perfection in this Country.

\section{The Names.}

Diuers doe take it to bee Opuntia Plinij, whereof hee fpeaketh in the 21 . Booke and 17. Chapter of his Naturall Hiftory : but he there faith, Opuntia is an herbe, fweete and pleafant to be eaten, and that it is a wonder that the roote fhould come from the leafe, and fo to growe ; which words although they defcipher out the manner of the growing of this plant, yet becaufe this is a kinde of tree, and not an herbe, nor to be eaten, it cannot bee the fame : but efpecially becaufe there is an herbe which groweth in the fame manner, or very neare vnto it, one leafe ftanding on the toppe or fide of another, being a Sea plant, fit to be eaten with vinegar and oyle (as many other herbes are that growe in the falt marfhes, or neare the Sea, whereof Sea Purflane is one) which Clufius calleth Lychen Marinus, and (as Clufius faith) Cortufus very fitly called Opuntia marina, and out of doubt is the verie fame Opuntia that Theopraftus maketh mention of, and Plinie out of him. Our Englifh people in Virginia, and the Bermuda Ifland, where it groweth plentifully, becaufe of the form of the fruit, which is fomewhat like to a Peare, \& not being fo familiarly acquainted with the growing of Figs, fent it vnto vs by the name of the prickly Peare, from which name many haue fuppofed it to be a Peare indeede, but were therein deceined.

\section{The Vertues.}

There is no other efpeciall property giuen hereunto, by any that have written of the Weft Indies, then of the colouring of the vrine, as is before faid. 


\section{C н А P. C X VII.}

ruca fue Iucca. The fuppofed Indian Iucca.

T His rare Indian plant hath a great thicke tuberous roote (fpreading in time into many tuberous heads) from the head whereof (hooteth forth many long, hard, and guttured leaues, very tharpe pointed, compaffing as it were one another at the bottome, of a grayin greene colour, which doe not fall away, but abide euer greene on the plant ; from the middle whereof fpringeth forth (now and then, but not euery yeare) a ftrong round ftalke, diuided into diuers branches, whereon ftand diuers white, and fomewhat large flowers, hanging downe their heads, confifting of fix leaues, with diuers veines, of a weake reddifh or blufh colour, fpread on the backe of the three outer leaues, efpecially from the middle of the leaues to the bottome, and not rifing to the edge of the leafe of any flower, which fall away without bearing any feede in our Country, as farre as euer could be obferued either in the plant that Mafter Gerard kept a long time by him, or by Robinus at Paris his plant, which Mafter Gerard fent vnto him, or yet by that plant, that Vefpafian Robin the fonne of old Robin fent vnto Mafter Iohn de Franqueuille, and now abideth and flourifheth in my Garden.

\section{The Place.}

It was firft brought into England (as Mafter Gerard faith) from the Weft Indies, by a feruant of Mafter Thomas Edwards, an Apothecary of Exeter, and imparted to him, who kept it vnto his death : but perifhed with him that got it from his widow, intending to fend it to his Country houfe.

\section{The Time.}

It flowreth not vntill Iuly, and the flowers fall away fodainely, after they haue beene blowne open a while.

\section{The Names.}

Mafter Gerard firft as I thinke called it Iucca, fuppofing it to bee the true ruca of Theuet, wherewith the Indians make bread, called Caffana: but the true Iucca is defcribed to haue a leafe diuided into feuen or nine parts, which this hath not: Yet not knowing by what better name to call it, let it hold ftill his firft impofition, vntill a fitter may be giuen it.

\section{The Vertues.}

Wee haue not heard of any, that hath either read, heard, or experimented the faculties hereof, nor yet whether it hath good or euill tafte ; for being rare, and poffeffed but by a few, they that have it are loth to cut any thereof, for feare of fpoiling and lofing the whole roote.

Some haue affirmed, that in fome parts of Turkie, where as they fay this plant groweth, they make a kinde of cloth from the threads are found running through the leaues; but I finde the threads are fo ftrong and hard, that this cannot be that plant the relators meane is vfed in that manner. 


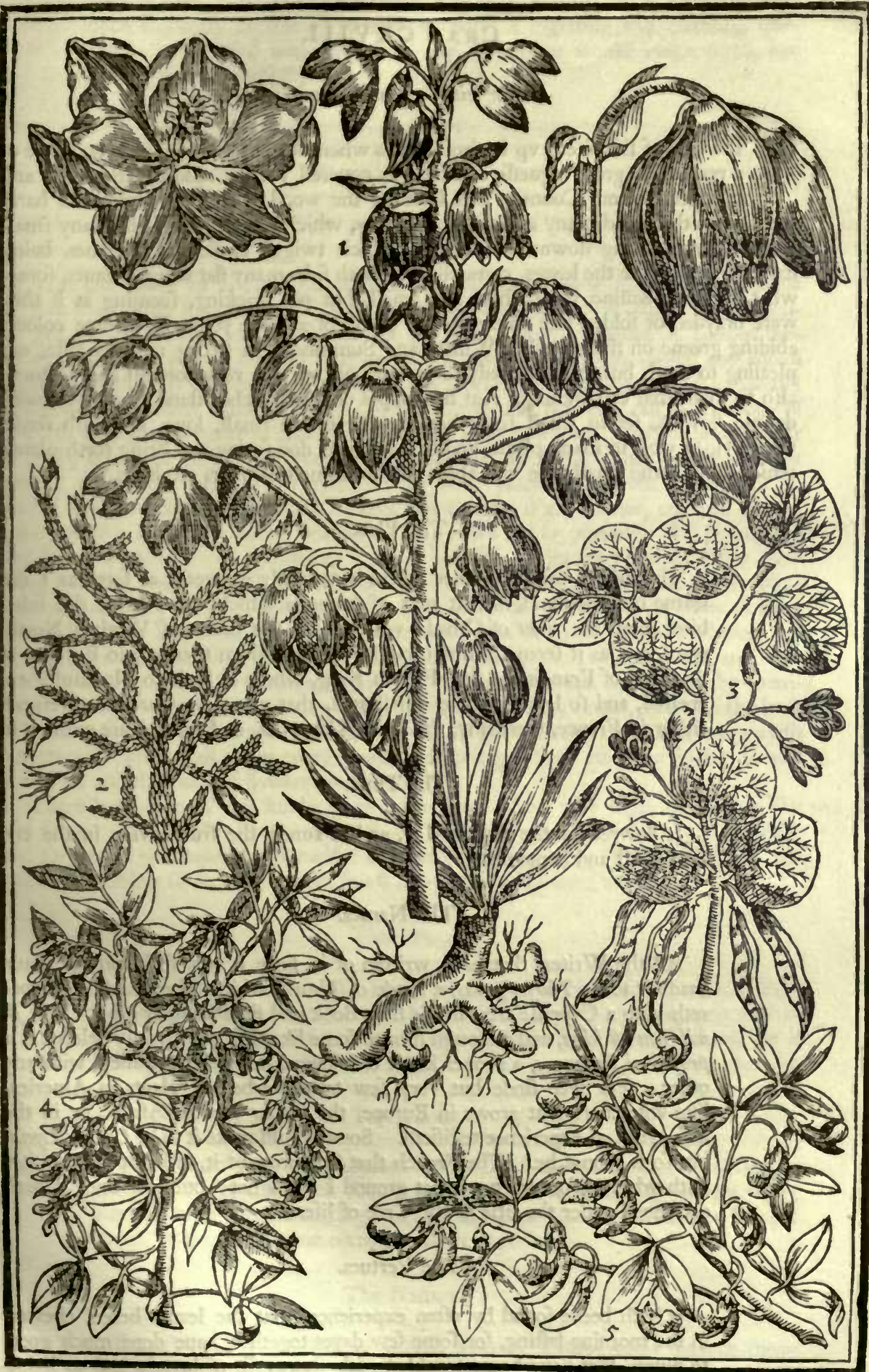

1. Ywea fiue Iucea. The Indian Iucea. Trefoile. 5 Cylifus. Tree Trefoile. 


\section{Cн А P. CXVIII.}

Arbor vite. The tree of life.

$\mathrm{T}$

He tree of life rifeth vp in fome places where it hath ftood long, to be a tree of a reafonable great bigneffe and height, couered with a redder barke then any other tree in our Country that I know, the wood whereof is firme and hard, and fpreadeth abroad many armes and branches, which againe fend forth many fmaller twigges, bending downewards; from which twiggy or flender branches, being flat themfelues like the leaues, come forth on both fides many flat winged leaues, fomewhat like vnto Sauine, being thort and fmall, but not pricking, feeming as if they were brayded or folded like vnto a lace or point, of a darke yellowifh greene colour, abiding greene on the branches Winter and Summer, of a ftrong refinous tafte, not pleafing to moft, but in fome ready to procure cafting, yet very cordiall and pectorall alfo to them that can endure it : at the toppes of the branches ftand fmall yellowith dounie flowers, fet in fmall fcaly heads, wherein lye fmall, long, brownifh feede, which ripen well in many places, and being fowne, doe fpring and bring forth plants, which with fome fmall care will abide the extreameft Winters we haue.

The Place.

The firft or originall place where it naturally groweth, as farre as I can learne or vnderftand, is that part of America which the French doe inhabite, about the riuer of Canada, which is at the backe of Virginia Northward, and as it feemeth, firft brought by them from thence into Europe, in the time of Francis the firft French King, where it hath fo plentifully encreafed, and fo largely beene diftributed, that now few Gardens of refpect, either in France, Germany, the Lowe Countries, or England, are without it.

The Time.

It flowreth in the end of May, and in Iune; the fruit is ripe in the end of Auguft and September.

\section{The Names.}

All the Writers that haue written of it, fince it was firft knowne, haue made it to be Thuyce genus, a kinde of Thuya, which Theophraftus compareth vnto a Cypreffe tree, in his fifth Book and fifth Chapter : but Omne fo mile non eft idem, and although it haue fome likeneffe, yet I verily beleeue it is proprium fui genus, a proper kinde of it owne, not to bee paralleld with any other. For wee finde but very few trees, herbes, or plants in America, like vnto thofe that growe in Europe, the hither part of Africa, or in the leffer Afia, as experience teftifieth. Some would make it to be Cedrus Lycia, but fo it cannot be. The French that firf brought it, called it Arbor vita, with what reafon or vpon what ground I know not : but euer fince it hath continued vnder the title of the Tree of life.

\section{The Vertues.}

It hath beene found by often experience, that the leaues hereof chewed in the morning fafting, for fome few dayes together, haue done much good to diuers, that haue beene troubled with fhortneffe of breath, and to helpe to expectorate thinne purulentous matter ftuffing the lungs. Other properties I haue not heard that it hath; but doubtleffe, the hot refinous fmell and 
tafte it hath, both while it is frefh, and after it hath beene long kept dry, doth euidently declare his tenuity of parts, a digefting and cleanfing quality it is poffeffed with, which if any induftrious would make tryall, hee fhould finde the effects.

\section{Снан. C X I X.}

\section{Arbor Iuda. Iudas tree.}

I

Vdas tree rifeth vp in fome places, where it ftandeth open from a wall, and alone free from other trees (as in a Garden at Battherfey, which fometimes agoe belonged to Mafter Morgan, Apothecary to the late Queene Elizabeth of famous memory) to be a very great and tall tree, exceeding any Apple tree in height, and equall in bigneffe of body thereunto (as my felfe can teftifie, being an eye witneffe thereof) when as it had many ftalkes of flowers, being in the bud, breaking out of the body of the tree through the barke in diuers places, when as there was no bough or branch near them by a yard at the leaft, or yet any leafe vpon the tree, which they gathered to put among other flowers, for Nofegayes) and in other places it groweth to bee but an hedge bufh, or plant, with many fuckers and fhootes from belowe, couered with a darke reddifh barke, the young branches being more red or purplifh: the flowers on the branches come forth before any fhew or budding of leaues, three or foure ftanding together vpon a fmall foote-ftalke, which are in fafhion like vnto Peafe bloffomes, but of an excellent deepe purplifh crimfon colour: after which come in their places fo many long, flat, large, and thirine cods, of a brownifh colour, wherein are contained fmall, blackifh browne, flat, and hard feede: the roote is great, and runneth both deepe, and farre fpreading in the earth: the leaues come forth by themfelues, euery one ftanding on a long ftalke, being hard \& very round, like vnto the leafe of the largeft $A$ farum, but not fo thick, of a whitifh green on the vpper fide, and grayifh vnderneath, which fall away euery yeare, and fpring a frefh after the Spring is well come in, and the buds of flowers are fprung.

There is another of this kinde, growing in fome places very high, fomewhat like Flore albo. the former, and in other places alfo full of twiggy branches, which are greener then the former, as the leaues are likewife: the flowers of this kinde are wholly white, and the cods nothing fo red or browne, in all other things agreeing together.

\section{The Place.}

The former groweth plentifully in many places of Spaine, Italy, Prouence in France, and in many other places. The other hath beene fent vs out of Italy many times, and the feede hath fprung very well with vs, but it is fomewhat tender to keepe in the Winter.

\section{The Time.}

The flowers (as I faid) appeare before the leaues, and come forth in Aprill and May, and often fooner alfo, the leaues following fhortly after; but neither of them beareth perfect feede in our Country, that euer I could learne, or know by mine owne or others experience.

\section{The Names.}

Some would referre this to Cercis, whereof Theophraftus maketh mention in his firft Booke and eighteenth Chapter, among thofe trees that beare their fruit in cods, like as Pulfe doe: and hee remembreth it againe in the fourteenth Chapter of his third Booke, and maketh it not vnlike the white 
Poplar tree, both in greatneffe and whiteneffe of the branches, with the leafe of an Iuie, without corners on the one part, cornered on the other, and Tharpe pointed, greene on both fides almoft alike, hauing fo flender long footeftalkes that the leaues cannot ftand forthright, but bend downwards, with a more rugged barke then the white Poplar tree. Clufius thinketh this large defcription is but an ample defcription of the third kinde of Poplar, called Lybica, the Afpen tree, which Gaza tranlateth Alpina : but who fo will well confider it, fhall finde it neyther anfwerable to any Poplar tree, in that it beareth not cods as Cercis doth; nor vnto this Arbor Iudee, becaufe it beareth not white branches. Clufius faith alfo, that the learned of Mompelier in his time, referred it to Colytea of Theophraftus in his third booke and feuenteenth chapter, where he doth liken it to the leaues of the broadeft leafed Bay tree, but larger and rounder, green on the vpperfide, and whitifh vnderneath, and whereunto (as he faith) Theophraftus giueth cods in the fourteenth chapter of the fame third booke: and by the contracting of their defcriptions both together, faith, they agree vnto this Iudas tree. But I find fome doubts and differences in thefe places: for the Colutea that Diofcorides mentioneth in the faid fourteenth chapter of his third booke, hath (as he faith there) a leafe like vnto the Willow, and therefore cannot bee the fame Colutea mentioned in the feuenteenth chapter of the fame third book, which hath a broade Bay leafe: indeede hee giueth feede in cods: but that with broade Bay leaues is (as he faith) without eyther flower or fruite; and befides all this, he faith the rootes are very yellow, which is not to bee found in this Arbor Iuda, or Iudas tree: let others now iudge if thefe things can bee well reconciled together. Some haue for the likeneffe of the cods vnto Beane cods, called it Fabago. And Clufius called it Siliqua fluefris. It is generally in thefe dayes called Arbor Iuda, and in Englifh after the Latine name, vntill a fitter may be had, Iudas tree.

\section{The Vertues.}

There is nothing extant in any Author of any Phyficall vfe it hath, neyther hath any later experience found out any.

\section{C н А P. CXX.}

\section{Laburnum. Beane Trefoile.}

T

Here be three forts of thefe codded trees or plants, one neere refembling another, whereof Anagyris of Diofcorides is one. The other two are called $\mathrm{La}$ burnum; the larger whereof Matthiolus calleth Anagyris altera, and fo doe fome others alfo: the third is of the fame kinde with the fecond, but fmaller. I thall not for this our Garden trouble you or my felfe with any more of them then one, which is the leffer of the two Liburnum, in that it is more frequent, and that it will far better abide then the Anagyris, which is fo tender, that it will hardly endure the winters of our Countrey: and the greater Laburnum is not fo eafily to be had.

\section{Laburnum. Beane Trefoile.}

This codded tree rifeth vp with vs like vnto a tall tree, with a reafonable great body, if it abide any long time in a place, couered with a fmooth greene barke; the branches are very long, greene, pliant, and bending any way, whereon are fet here and there diuers leaues, three alwaies ftanding together vpon a long ftalk, being fomewhat long, and not very narrow, pointed at the ends, greene on the vpperfide, and of a filuer fhining colour vnderneath, without any fmell at all: at the ioynts of thefe branches, where the leaues ftand, come forth many flowers, much like vnto broome flowers, but not fo 
large or open, growing about a very long branch or ftalke, fometimes a good fpan or more in length, and of a faire yellow colour, but not very deepe; after which come flat thin cods, not very long or broade, but as tough and hard as the cods of Broome; wherein are contained blackifh feede, like, but much leffe then the feede of Anagyris vera (which are as big as a kidney beane, purplifh and fpotted) : the roote thrufteth down deepe into the ground, fpreading alfo farre, and is of a yellowith colour.

\section{The Place.}

This tree groweth naturally in many of the woods of Italie, and vpon the Alpes alfo, and is therefore ftill accounted to be that Laburnum that Plinie calleth Arbor Alpina. It groweth in many gardens with vs.

\section{The Time.}

It flowreth in May, the fruit or cods, and the feedes therein are ripe in the end of Auguft, or in September.

\section{The Names.}

This tree (as I faid before) is called of Matthiolus Anagyris altera, fue fecunda, of Cordus, Gefner and others, efpecially of moft now adayes, Laburnum. It is probable in my opinion, that this fhould bee that Colutcea of Theophraftus, mentioned in the fourteenth Chapter of his third book with the leafe of a Willow; for if you take any one leafe by it felfe, it may well refemble a Willow leafe both for forme and colour, and beareth fmall feed in cods like vnto pulfe as that doth. Of fome it hath beene taken for a kinde of Cytifus, but not truely. We call it in Englifh, Beane Trefoile, in regard of his cods and feede therein, fomewhat like vnto Kidney Beanes, and of the leaues, three alwayes ftanding together, vntill a more proper name may bee giuen it.

\section{The Vertues.}

There is no vfe hereof in Phyficke with vs, nor in the naturall place of the growing, faue only to prouoke a vomit, which it will doe very ftrongly.

\section{CH A P. CXXI.}

\section{Cytifus. Tree Trefoile.}

T Here are fo many forts of Cytifus or Tree trefoiles, that if I fhould relate them all, I fhould weary the Reader to ouerlooke them, whereof the moft part pertaine rather to a generall worke then to this abftract. I fhall not therefore trouble you with any fuperfluous, but only with two, which we haue nourfed vp to furnifh wafte places in a garden.

\section{Cytifus Maranthe. Horned Tree Trefoile.}

This Tree Trefoile which is held of moft Herbarifts to bee the true Cytifus of Diofcorides, rifeth vp to the height of a man at the moft, with a body of the bigneffe of a mans thumbe, couered with a whitifh bark, breaking forth into many whitifh branches fpreading farre, befet in many places with fmall leaues, three alwayes fet together vpon a fmall fhort footeftalke, which are rounder, and whiter then the leaues of Beane Trefoile: at the ends of the branches for the moft part, come forth the flowers three or foure together, of a fine gold colour, and of the fafhion of Broome flowers, but 
not fo large : after the flowers are paft, there come in their places crooked flat thinne cods, of the fafhion of a halfe moone, or crooked horne, whitifh when they are ripe, wherein are contained blackifh feede: the roote is hard and woody, fpreading diuers wayes vnder the ground: the whole plant hath a pretty fmall hot fent.

\section{Cytifus vulgatior. The common Tree Trefoile.}

This Cytifus is the moft common in this Land, of any the other forts of tree trefoiles, hauing a blackifh coloured barke, the ftemme or body whereof is larger then the former, both for height and fpreading, bearing alfo three leaues together, but fmaller and greener then the former: the flowers are fmaller, but of the fame fafhion and colour: the cods blackifh and thin, and not very long, or great, but leffer then Broome cods, wherein there lyeth fmall blackifh hard feede : the roote is diuerfly difperfed in the ground.

The Place.

The firf groweth in the kingdome of Naples, and no doubt in many other places of Italie, as Matthiolus faith. The other groweth in diuers places of France.

The Time.

They flower for the moft part in May or Iune: the feede is ripe in Auguit or September.

\section{The Names.}

The firft (as I faid) is thought of moft to be the true Cytifus of Diof corides, and as is thought, was in thefe later dayes firft found by Bartholomæus Maranta of Naples, who fent it firft to Matthiolus, and thereupon hath euer fince beene called after his name, Cytifus Marantha. Some doe call it Cytifus Lunatus, becaure the cods are made fomewhat like vnto an halfe Moone. We call it in Englifh, Horned Tree Trefoile. The other is called Cytifus vulgaris or vulgatior; in Englifh, The common Tree Trefoile, becaufe we haue not any other fo common.

The Vertues.

The chiefeft vertues that are appropriate to thefe plants, are to procure milke in womens brealts, to fatten pullen, fheep \&c. and to be good for bees.

\section{CH A P. C X XII.}

\section{Colutea. The Baftard Sena Tree.}

W

Ee have in our Gardens two or three forts of the Baftard Sena tree; a greater as I may fo call it, and two leffer: the one with round thin tranfparent skins like bladders, wherein are the feede: the others with long round cods, the one bunched out or fwelling in diuers places, like vnto a Scorpions tale, wherein is the feede, and the other very like vnto it, but fmaller.

\section{Colutea Veficaria. The greater Baftard Sena with bladders.}

This fhrub or tree, or fhrubby tree, which you pleafe to call it, rifeth vp to the height of a pretty tree, the ftemme or ftock being fometimes of the bigneffe of a mans arme, couered with a blackifh greene rugged barke, the wood whereof is harder then of an 
Elder, but with an hollowneffe like a pith in the heart or middle of the branches, which are diuided many wayes, and whereon are fet at feucrall diftances, diuers winged leaues, compofed of many fmall round pointed, or rather flat pointed leaues, one fet againlt another, like vnto Licoris, or the Hatchet Fitch; among thefe leaues come forth the flowers, in fafhion like vnto Broome flowers, and as large, of a very yellow colour : after which appeare cleare thinne fwelling cods like vnto thinne tranfparent bladders, wherein are contained blacke feede, fet vpon a middle ribbe or finew in the middle of the bladder, which if it be a little crufhed betweene the fingers, will giue a cracke, like as a bladder full of winde. The roote groweth branched and woody.

2. Colutea Scorpioides maior. The greater Scorpion podded Baftard Sena.

This Baftard Sena groweth nothing fo great or tall, but fhooteth out diuerfly, like vnto a fhrub, with many fhoots fpringing from the root : the branches are greener, but more rugged, hauing a white barke on the beft part of the elder growne branches; for the young are greene, and haue fuch like winged leaues fet on them as are to be feen in the former, but fmaller, greener, and more pointed: the flowers are yellow, but much fmaller, fafhioned fomewhat like vnto the former, with a reddifh ftripe downe the backe of the vppermoft leafe : the long cods that follow are fmall, long and round, diftinguifhed into many diuifions or dents, like vnto a Scorpions tayle, from whence hath rifen the name: in thefe feuerall diuifions lye feuerall blacke feede, like vnto the feede of Fenigrecke : the roote is white and long, but not fo woody as the former.

\section{Colutea Scorpioides minor. The leffer Scorpion Baftard Sena.}

This lefier Baftard Sena is in all things like the former, but fomewhat lower, and fmaller both in leafe, flower, and cods of feede, which haue not fuch eminent bunches on the cods to be feene as the former.

\section{The Place.}

They grow as Matthiolus faith about Trent in Italie, and in other places: the former is frequent enough through all our Countrey, but the others are more rare.

\section{The Time.}

They flower about the middle or end of May, and their feede is ripe in Augurt. The bladders of the firt will abide a great while on the tree, if they be fuffered, and vntill the winde caufe them to rattle, and afterwards the skins opening, the feede will fall away.

\section{The Names.}

The name Colutrea is impofed on them, and by the iudgement of moft writers, the firf is taken to bee that Colutea of Lipara that Theophraftus maketh mention of, in the feuenteenth chapter of his third booke. But I fhould rather thinke that the Scorpioides were the truer Colutae of Theophraftus, becaufe the long pods thereof are more properly to bee accounted filiqua, then the former which are veficre tumentes, windy bladders, and not fliqua: and no doubt but Theophraftus would haue giuen fome peculiar note of difference if he had meant thofe bladders, and not thefe cods. Let others of iudgement be vmpeeres in this cafe; although I know the currant of writers fince Matthiolus, doe all hold the former Colutaa vefacaria to be the true Colutca Lipara of Theophraftus. Wee call it in Englifh, Baftard Sena, from Ruellius, who as I thinke firft called it Sena, from the forme of the leaues. The fecond and third (as I faid before) from the forme of the cods receiued their names, as it is in the titles and defcriptions; yet they may as properly be called Siliguofa, for that their fruite are long cods. 


\title{
The Vertues.
}

Theophraftus faith it doth wonderfully helpe to fatten fheepe: But fure it is found by experience, that if it be giuen to man it caufeth ftrong caftings both vpwards and downwards; and therefore let euery one beware that they vfe not this in fteede of good Sena, left they feele to their coft the force thereof.

\section{Сна Р. CXXIII.}

\section{Spartum Hifpanicum frutex. Spanifh Broome.}

\begin{abstract}
1 Lthough Clufius and others haue found diuers forts of this Ahrubby Spartum or Spanifh Broome, yet becaufe our Climate will nourfe vp none of them, and euen this very hardly, I fhall leaue all others, and defcribe vnto you this one only in this manner : Spanifh Broome groweth to bee fiue or fixe foote high, with a woody ftemme below, couered with a darke gray, or afh-coloured barke, and hauing aboue many pliant, long and flender greene twigs, whereon in the beginning of the yeare are fet many fmall long greene leaues, which fall away quickly, not abiding long on; towards the tops of thefe branches grow the flowers, fafhioned like vnto Broom flowers, but larger, as yellow as they, and fmelling very well; after which come fmall long cods, crefted at the backe, wherein is contained blackifh flat feede, fafhioned very like vnto the Kidney beanes: the roote is woody, difperfing it felfe diuers waies.
\end{abstract}

\section{The Place.}

This groweth naturally in many places of France, Spaine and Italie, wee haue it as an ornament in our Gardens, among other delightfull plants, to pleafe the fenfes of fight and fmelling.

\section{The Time.}

It flowreth in the end of May, or beginning of Iune, and beareth feede, which ripeneth not with vs vntill it be late.

\section{The Names.}

It is called Spartium Gracorum, and Spartum frutex, to diftinguifh it from the fedge or rufh, that is fo called alfo. Of fome it is called Genifta, and thought not to differ from the other Genifta, but they are much deceiued; for euen in Spaine and Italie, the ordinary Genifa or Broome groweth with it, which is not pliant, and fit to binde Vines, or fuch like things withall as this is.

\section{The Vertues.}

There is little vfe hereof in Phyficke, by reafon of the dangerous qualitie of vomiting, which it doth procure to them that take it inwardly: but being applyed outwardly, it is found to helpe the Sciatice, or paine of the hippes. 


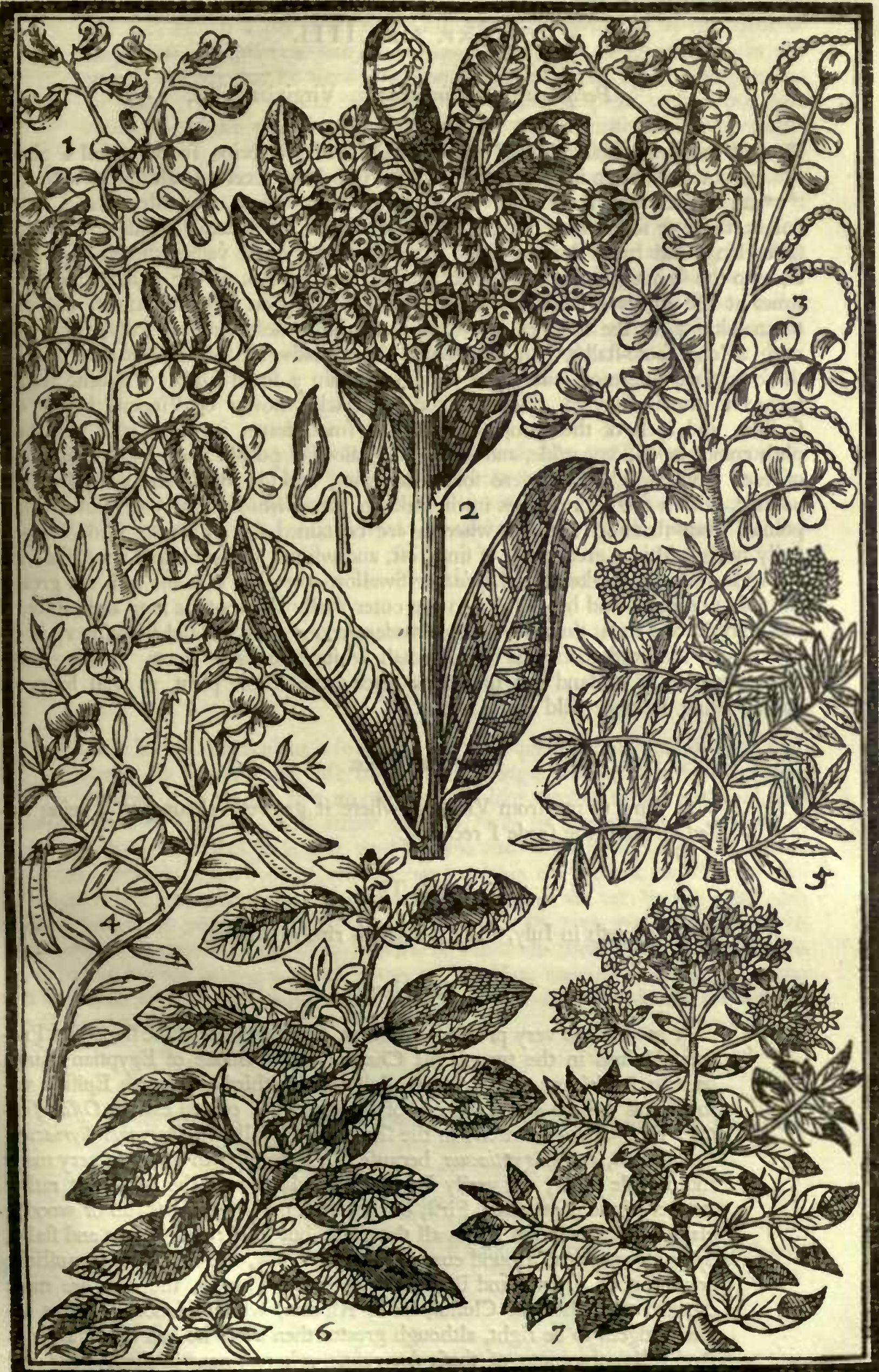

I Colutaa oulgaris. Ordinary baftard Sene. 2 Pcriploca rena Virginiana. Virginian Silke. 3 Colutan Scorpioides. Scorpion baflard Sene. I Spartum Hifparicum. Spanith Broome.

y Maiorana aurea. Guilded Marierome. 
CH A P. CXXIIII.

\section{Periploca recta Virginiana. Virginian Silke.}

Ent this ftranger fhould find no horpitality with vs, being fo beautifull a plant, or not finde place in this Garden, let him be here receiued, although with the

laft, rather then not at all. It rifeth vp with one or more ftrong and round ftalkes, three or foure foote high, whereon are fet at the feuerall ioynts thereof two faire, long, and broad leaues, round pointed, with many veines therein, growing clofe to the ftemme, without any foote-ftalke: at the tops of the ftalkes, and fome times at the ioynts of the leaues, groweth forth a great bufh of flowers out of a thinne skinne, to the number of twenty, and fometimes thirty or forty, euery one with a long foote-ftalke, hanging downe their heads for the moft part, efpecially thofe that are outermoft, euery one ftanding within a fmall huske of greene leaues, turned to the ftalkeward, like vnto the Lyfimachia flower of Virginia before defcribed, and each of them, confifting of fiue fmall leaues a peece, of a pale purplifh colour on the vpperfide, and of a pale yellowih purple vnderneath, both fides of each leafe being as it were folded together, making them feeme hollow and pointed, with a few thort chiues in the middle: after which come long and crooked pointed cods ftanding vpright, wherein are contained flat brownifh feede, difperfedly lying within a great deale of fine, foft, and whitifh browne filke, very like vnto the cods, feede, and filke of Afclepias, or Swallow-wort, but that the cods are greater and more crooked, and harder allo in the outer thell : the roote is long and white, of the bigneffe of a mans thumbe, running vnder ground very far, and fhooting vp in diuers places, the heads being fet full of fmall white grumes or knots, yeelding forth many branches, if it ftand any time in a place : the whole plant, as well leaues as ftalkes, being broken, yeeld a pale milke.

\section{- The Place.}

It came to me from Virginia, where it groweth aboundantly, being raifed vp from the feede I receiued.

The Time.

It flowreth in Iuly, and the feede is ripe in Augutt.

The Names.

It may feeme very probable to many, that this plant is the fame that Profper Alpinus in the twenty fift Chapter of his Booke of Egyptian plants, nameth Beidelfar; and Honorius Bellus in his third and fourth Epiftles vnto Clufius (which are at the end of his Hiftory of plants) calleth O far frutex: And Clufius himfelfe in the fame Booke calleth Apocynum Syriacum, Palaffinum, and Egyptiacum, becaufe this agreeth with theirs in very many and notable parts; yet verily I thinke this plant is not the fame, but rather another kinde of it felfe: Firft, becaufe it is not frutex, a fhrub or wooddy plant, nor keepeth his leaues all the yeare, but lofeth both leaues and ftalks, dying down to the ground euery yeare: Secondly, the milke is not caufticke or violent, as Alpinus and Bellus fay O/far is: Thirdly, the cods are more crooked then thofe of Clufius, or of Alpinus, which Honorius Bellus acknowledgeth to be right, although greater then thofe he had out of Egypt : And lartly, the rootes of thefe doe runne, whereof none of them make any mention. Gerard in his herball giueth a rude figure of the plant, but a very true figure of the cods with feede, and faith the Virginians call it Wijanck, and referreth it to the $A$ clepias, for the likeneffe of the cods ftuffed with 
filken doune. But what reafon Cafpar Bauhinus in his Pinax Theatri Botanici had, to call it (for it is Clufius his Apocynum Syriacum) by the name of Lapathum Egyptiacum lackefcens filiqua Afclepiadis, I know none in the world: for but that he would fhew an extreame fingularity in giuing names to plants, contrary to all others (which is very frequent with him) how could he thinke, that this plant could haue any likeneffe or correfpondencie, with any of the kindes of Dockes, that euer he had feene, read, or heard of, in face, or thew of leaues, flowers, or feede; but ef pecially in giuing milke. I haue you fee (and that not without iuft and euident caufe) giuen it a differing Latine name from Gerard, becaufe the $A$ fclepias giueth no milke, but the Periploca or Apocymum doth; and therefore fitter to be referred to this then to that. And becaufe it fhould not want an Englifh name anfwerable to fome peculiar property thereof, I have from the filken doune called it Virginian Silke: but I know there is another plant growing in Virginia, called Silke Graffe, which is much differing from this.

\section{The Vertues.}

I know not of any in our Land hath made any tryall of the properties hereof. Captaine Iohn Smith in his booke of the difcouery and defcription of Virginia, faith, that the Virginians vfe the rootes hereof (if his be the fame with this) being bruifed and applyed to cure their hurts \& difeafes.

\section{CHA. CXXV.}

\section{Liguftrum. Primme or Priuet.}

B Ecaufe the vfe of this plant is fo much, and fo frequent throughout all this Land, although for no other purpofe but to make hedges or arbours in Gardens, \&c. whereunto it is fo apt, that no other can be like vnto it, to bee cut, lead, and drawne into what forme one will, either of beafts, birds, or men armed, or otherwife: I could not forget it, although it be fo well knowne vnto all, to be an hedge bufh growing from a wooddy white roote, fpreading much within the ground, and bearing manie long, tough, and plyant fprigs and branches, whereon are fet long, narrow, and pointed fad greene leaues by couples at euery ioynt: at the tops whereof breake forth great tufts of fweete fmelling white flowers, which when they are fallen, turne into fmall blacke berries, hauing a purple iuyce within them, and fmall feede, flat on the one fide, with an hole or dent therein : this is feene in thofe branches that are not cut, but fuffered to beare out their flowers and fruit.

\section{The Place.}

This bufh groweth as plentifully in the Woods of our owne Countrey, as in any other beyond the Seas.

\section{The Time.}

It flowreth fometimes in Iune, and in Iuly; the fruit is ripe in Auguft and September.

\section{The Names.}

There is great controuerfie among the moderne Writers concerning this

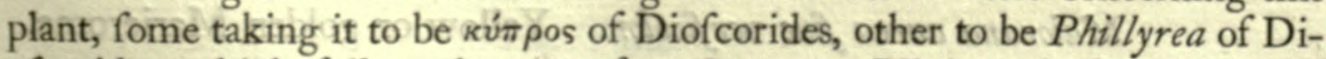
of corides, which followeth next after Cyprus. Plinie maketh mention of Cyprus in two places; in the one he faith, Cyprus hath the leafe of Ziziphus, 
or the Iuiube tree: in the other he faith, that certain do affirme, that the Cyprus of the Eaft Country, and the Liguftrum of Italy is one and the fame plant: whereby you may plainly fee, that our Priuet which is Liguftrum, cannot be that Cyprus of Plinie with Iuiube leaues: Befides, both Diof corides \& Plinie fay, that Cyprus is a tree; but all know that Liguftrum, Priuet, is but an hedge bufh: Againe, Diofcorides faith, that the leaues of Cyprus give a red colour, but Priuet giueth none. Bellonius and Profper Alpinus haue both recorded, that the true Cyprus of Diofcorides groweth plentifully in Egypt, Syria, and thofe Eafterne Countries, and nourfed vp alfo in Conftantinople, and other parts of Greece, being a merchandife of much worth, in that they tranfport the leaues, and young branches dryed, which laid in water giue a yellow colour, wherewith the Turkifh women colour the nailes of their hands, and fome other parts of their bodies likewife, delighting much therein: and that it is not our Liguftrum, or Priuet, becaufe Cyprus beareth round white feede, like Coriander feede, and the leaues abide greene alwaies vpon the tree, which groweth (if it bee not cut or pruined) to the height of the Pomegranet tree. I haue (I confeffe) beyond the limits I fet for this worke fpoken concerning our Priuet, becaufe I haue had the feede of the true Cyprus of Diofcorides fent mee, which was much differing from our Priuet, and although it fprang vp, yet would not abide any time, whereas if it had beene our Priuet, it would haue beene familiar enough to our Countrey.

The Vertues.

It is of fmall vfe in phyficke, yet fome doe vfe the leaues in Lotions, that ferue to coole and dry fluxes or fores in diuers parts.

\section{C н A P. CXXVI.}

Saluia variegata. Party coloured Sage. And Maiorana verficolor fue aurea. Yellow or golden Marierome.

$\mathrm{V}$

Nto all thefe flowers of beauty and rarity, I muft adioyne two other plants, whofe beauty confifteth in their leaues, and not in their flowers : as alfo to feparate them from the others of their tribe, to place them here in one Chapter, before the fweete herbes that thall follow, as is fitteft to furnilh this our Garden of pleafure. This kinde of Sage groweth with branches and leaues, very like the ordinary Sage, but fomewhat fmaller, the chiefeft difference confifteth in the colour of the leaues, being diuerly marked and fpotted with white and red among the greene: for vpon one branch you thall haue the leaues feuerally marked one from another, as the one halfe of the leafe white, and the other halfe greene, with red fhadowed ouer them both, or more white then greene, with fome red in it, either parted or fhadowed, or dafht here and there, or more greene then white, and red therein, eyther in the middle or end of the leafe, or more or leffe parted or ftriped with white and red in the greene, or elfe fometimes wholly greene the whole branch together, as nature lifteth to play with fuch varieties: which manner of growing rifing from one and the fame plant, becaufe it is the more variable, is the more delightfull and much refpected.

There is another fpeckled Sage parted with white and greene, but it is nothing of that beauty to this, becaufe this hath three colours euidently to bee difcerned in euery leafe almont, the red adding a fuperaboundant grace to the reft.

\section{Maiorana aurea fiue verficolor. Yellow or golden Marierome.}

This kinde of Marierome belongeth to that fort is called in Latine Maiorana latifo- 
Ita, which Lobel fetteth forth for Hy.Jopus Gracorum genuina : In Englifh Winter Marierome, or pot Marierome : for it hath broader and greater leaues then the fweete Marierome, and a different vmbell or tuft of flowers. The difference of this from that fet forth in the Kitchin Garden, confifteth chiefly in the leaues, which are in Summer wholly yellow in fome, or but a little greene, or parted with yellow and greene more or leffe, as nature lifteth to play : but in Winter they are of a darke or dead greene colour, yet recouering it felfe againe : the fent hereof is all one with the pot Marierome. former.

Wee haue another parted with white and greene, much after the manner with the

The Place, Time, Names, and Vertues of both thefe plants, fhall be declared where the others of their kindes are fpecified hereafter, and in the Kitchen Garden; for they differ not in properties.

\section{CHA P. CX XVII.}

\section{Lauendula. Lauender Spike.}

Fter all thefe faire and fweete flowers before fpecified, I muft needes adde a few fweete herbes, both to accomplifh this Garden, and to pleafe your fenfes, by placing them in your Nofegays, or elfe where, as you lift. And although I bring them in the end or laft place, yet are they not of the leaft account.

\section{Lauendula maior." Garden Lauender.}

Our ordinary Garden Lauender rifeth vp with a hard wooddy ftemme aboue the ground, parted into many fmall branches, whereon are fet whitifh, long, and narrow leaues, by couples one againft another ; from among which rifeth vp naked fquare ftalkes, with two leaues at a ioynt, and at the toppe diuers fmall huskes ftanding round about them, formed in long and round heads or fpikes, with purple gaping flowers fpringing out of each of them : the roote is wooddy, and fpreadeth in the ground: The whole plant is of a ftrong fweete fent, but the heads of flowers much more, and more piercing the fenfes, which are much vfed to bee put among linnen and apparrell.

There is a kinde hereof that beareth white flowers, and fomewhat broader leaues, Flore albo. but it is very rare, and feene but in few places with vs, becaufe it is more tender, and will not fo well endure our cold Winters.

\section{Lauendula minor feu Spica. Small Lauender or Spike.}

The Spike or fmall Lauender is very like vnto the former, but groweth not fo high, neither is the head or fpike fo great and long, but fhorter and fmaller, and of a more purplifh colour in the flower : the leaues alfo are a little harder, whiter, and fhorter then the former ; the fent alfo is fomewhat fharper and ftronger. This is not fo frequent as the firft, and is nourifhed but in fome places that are warme, and where they delight in rare herbes and plants.

The Place.

Lauender groweth in Spaine aboundantly, in many places fo wilde, and little regarded, that many haue gone, and abiden there to diftill the oyle thereof whereof great quantity now commeth ouer from thence vnto vs: and alfo in Lanquedocke, and Prouence in France.

The Time. Iuly.

It flowreth early in thofe hot Countries, but with vs not vntill Iune and 


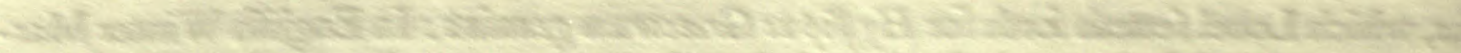

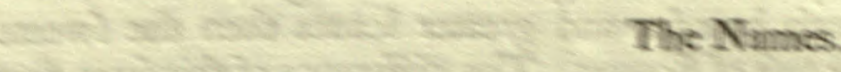

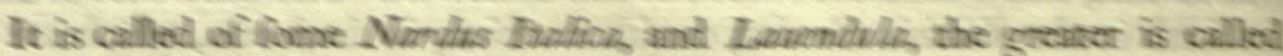
Ferminus, and the leffer Mas, Me doe call them generallit Lanender, or Li2wender Spikts and the leffer Spikts, without any orther abdition.

\section{The Vercues.}

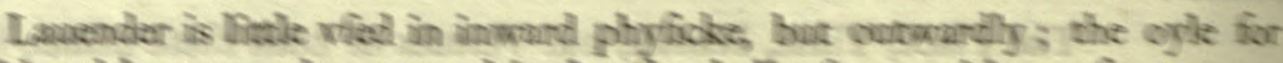
cold and benummed parts and is almoit wholly fipent with ws, for to per-

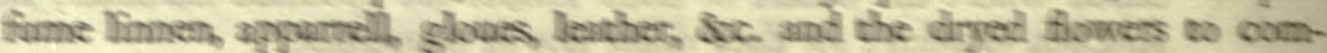
fort and Ary vp the moikture of a cold bruine.

\section{CaAm CXXVIII.}

\section{Sreechuss. Stiondoue, Ciffidony, or French Luvender-}

C

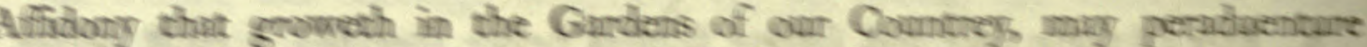
iomevitur differ in collour, as well as in firength, from that which growech in

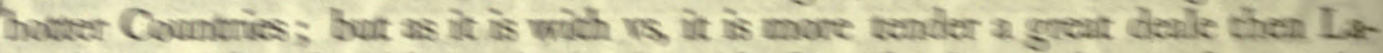
mender, and growech rather like an herbe then a buth or ihrulb, mor about a focte and a halfe high, or therealbouts, having muny marrow long greene levues like Luvender, but

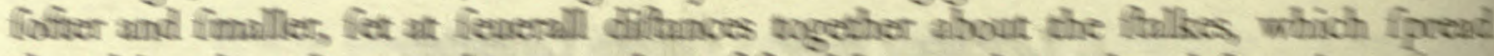
abrouat into brunches: at the topss whereoffland long and round, and fometimes foure figure heats of a durke greenith purple colbur, companct of many foules fet togecther; from annong which come forth the flowers of a blemilh purple collours, afier which follow feede veffels, which are fomewhat whitih when they are rijes contrining

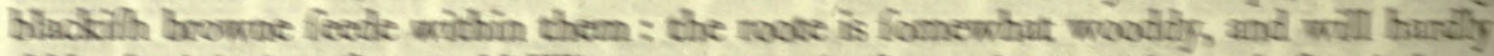
ahide the imiuries of our colld Winsers, except in fome places onelys or befort it hrue flowred: The whole plune is fomewhat fweete, bot noching is much as Lravender.

\section{The Place.}

Cuffilong gremech in the Whands Strechades, which are ouer aguinit Murfelles and in Aruhin alfo: we ketp it with grent curt in our Gurtens.

\section{The Time}

It flowrech the next yeure afier it is fowne, in the end of Mars which is a monech before any Lanender.

\section{The Nimes.}

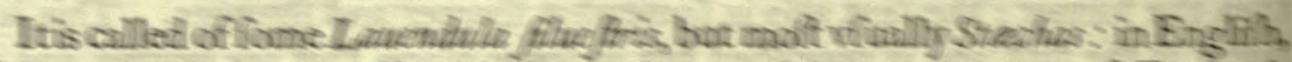
of forme Stichudisues or French Leveender; and in muny purss of Englund. Caffidons:

The Vertues.

It is of mach more vit in phrifcke then Lauender, and is much vied fir

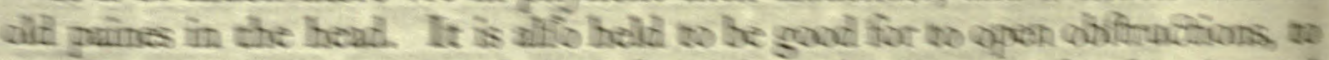
expell meturchols, to cleanie and ffrengehen the fruer, and obther invurt purts and as be a Pectorill allo.

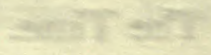




\section{С А Р. CXXIX.}

Abrotanum famina fue Santolina. Lauender Cotton.

THis Lauender Cotton hath many wooddy, but brittle branches, hoary or of a whitifh colour, whereon are fet many leaues, which are little, long, and foure fquare, dented or notched on all edges, and whitifh alfo: at the tops of thefe branches ftand naked ftalkes, bearing on euery one of them a larger yellow head or flower, then eyther Tanfie or Maudeline, whereunto they are fornewhat like, wherein is contained fmall darke coloured feede: the roote is hard, and fpreadeth abroad with many fibres : the whole plant is of a ftrong fweete fent, but not vnpleafant, and is in many places planted in Gardens, to border knots with, for which it will abide to be cut into what forme you thinke beft; for it groweth thicke and bufhy, very fit for fuch workes, befides the comely fhew the plant it felfe thus wrought doth yeeld, being alwayes greene, and of a fweet fent; but becaufe it quickly groweth great, and will foone runne out of forme, it muft be euery fecond or third yeare taken vp, and new planted.

The Place.

It is onely planted in Gardens with vs, for the vfes aforefaid efpecially.

\section{The Time.}

It flowreth in Iuly, and ftandeth long in the hot time of the yeare in his colour, and fo will doe, if it be gathered before it haue ftood ouer long.

\section{The Names.}

Diuers doe call it as Matthiolus doth, Abrotanum famina, and Santolina; and fome call it Chamacypariffus, becaufe the leaues thereof, are fomewhat like the leaues of the Cypreffe tree: Wee call it in Englifh generally Lauender Cotton.

\section{The Vertues.}

This is vfually put among other hot herbes, eyther into bathes, ointments, or other things, that are vfed for cold caufes. The feede alfo is much vied for the wormes.

\section{Cн А . $\mathrm{CXXX}$.}

\section{Ocimum. Baffill.}

$\mathrm{B}$

Affill is of two forts (befides other kindes) for this our Garden, the one whereof is greater, the other leffe in euery part thereof, as fhall be fhewed.

\section{Ocimum Citratum. Common Baffill.}

Our ordinary Garden Baffill hath one ftalke rifing from the root, diuerlly branched out, whereon are fet two leaues alwayes at a ioynt, which are broad, fornewhat round, and pointed, of a pale greene colour, but freih, a little fnipt or dented about the edges, and of a ftrong or heady fent, fomewhat like a Pomecitron, as many have compared it; and thereof call it Citratum : the flowers are fmall and white, ftanding at the tops of the branches, with two fmal leaues at euery ioynt vnder them, in fome plants green, in o- 
thers browne vnder them : after which commeth blacke feede : the roote perifheth at the firft approach of winter weather, and is to be new fowen euery yeare.

\section{Ocimum minimum fue Gariophyllatum. Bufh Bafill.}

The bufh Bafill groweth not altogether fo high, but is thicker fpreade out into branches, whereon grow fmaller leaues, and thicker fet then the former, but of a more excellent and pleafant fmell by much : the flowers are white like the former, and the feede blacke alfo like it, and perifheth as fuddenly, or rather fooner then it, fo that it requireth more paines to get it, and more care to nourfe it, becaufe we feldome or neuer haue any feede of it.

\section{Ocimum Indicum. Indian Bafill.}

The Indian Bafill hath a fquare reddifh greene ftalke, a foote high or better, from the ioynts whereof fpreade out many branches, with broade flat leaues fet thereon, two alwayes together at the ioynt, one againft another, as other Bafils haue, but fomewhat deepely cut in on the edges, and oftentimes a little crumpled, ftanding vpon long reddifh footeftalkes, of a darke purple colour, fpotted with deeper purple fpots, in fome greater, in others leffer: the flowers ftand at the tops of the ftalkes fpike-fafhion, which are of a white colour, with reddifh ftripes and veines running through them, fet or placed in darke purple coloured huskes: the feede is greater and rounder then the former, and fomewhat long withall : the roote perifheth in like manner as the other former doe. The whole plant fmelleth ftrong, like vnto the other Bafils.

The Place.

The two laft forts of Bafils are greater ftrangers in our Country then the firft which is frequent, and only fowen and planted in curious gardens. The laft came firft out of the Weft Indies.

The Time.

They all flower in Auguit, or Iuly at the fooneft, and that but by degrees, and not all at once.

\section{The Names.}

The firf is vfually called Ocimum vulgare, or vulgatius, and Ocinum Citratum. In Englifh, Common or Garden Bafill. The other is called Ocimum minimum, or Gariophyllatum, Cloue Bafill, or Bufh Bafill. The laft eyther of his place, or forme of his leaues, being fpotted and curled, or all, is called Ocimum Indicum maculatum, latifolium E crifpum. In Englifhaccording to the Latine, Indian Bafill, broade leafed Bafill, fpotted or curled Bafill, which you pleafe.

\section{The Vertues.}

The ordinary Bafill is in a manner wholly fpent to make fweet, or wafling waters, among other fweet herbes, yet fometimes it is put into nofegayes. The Phyficall properties are, to procure a cheerefull and merry heart, whervnto the feede is chiefly vfed in pouder, \&c. and is moft vfed to that, and to no other purpofe. 


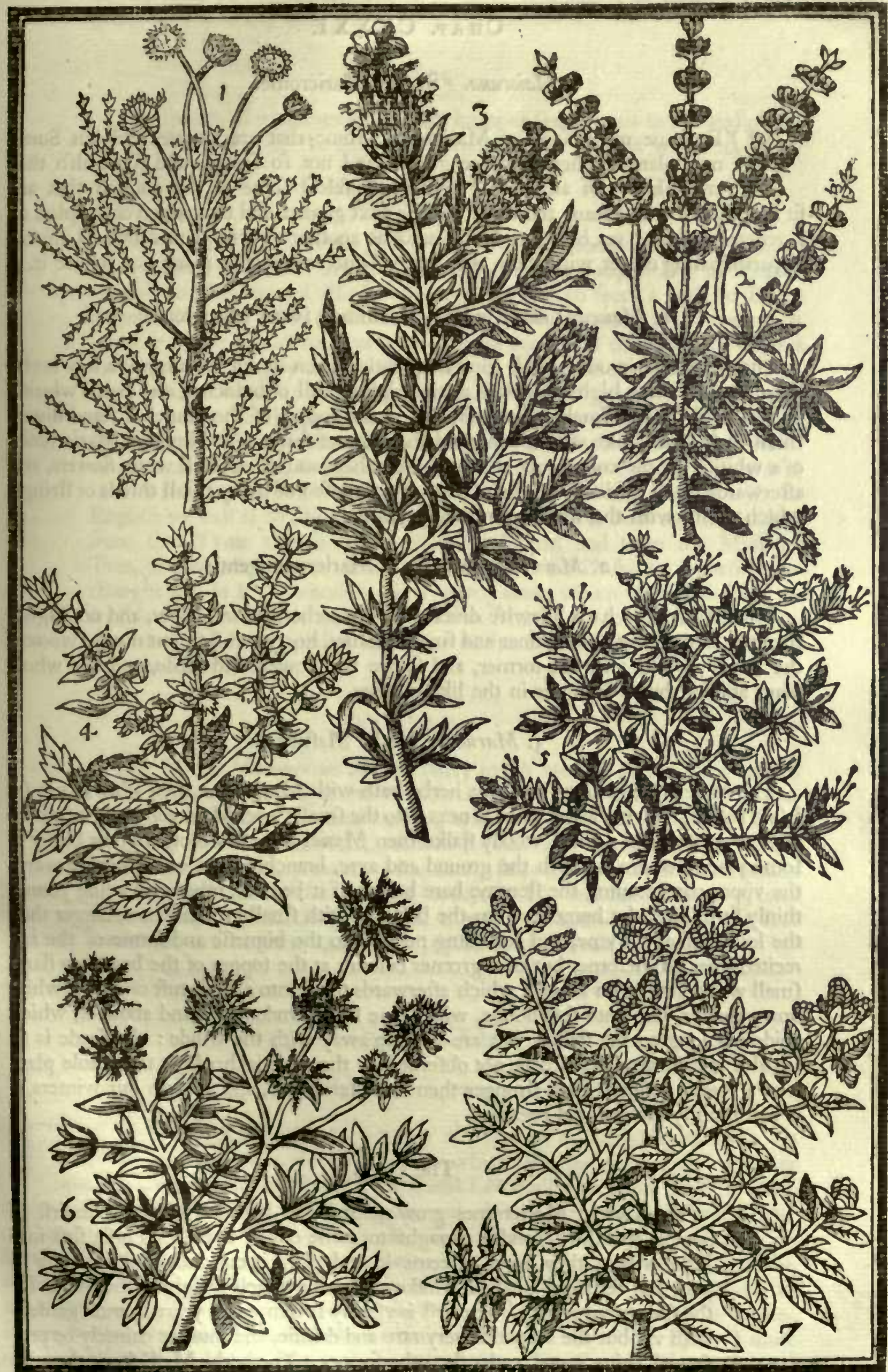

I Santolina. Lauender Cotton. 2 Lausmiula. Lauender Spike. 3 Stachas. Caffidony. Ucimum minus. Fine Bafill. 6 Marwm. Herbe Mafticke. , Maiorana. Sweete Marierome. 


\section{С н а Р. C X XXI.}

\section{Maiorana. Sweete Marierome.}

W Ee haue many forts of Marierome; fome that are fweete, and but Summer plants; others that are greater and not fo fweet; and fome alfo that are wilde. Of all thefe I will onely felect fome of the choifert that are fit for this place, and leaue the other for the next garden, and the garden of fimples, or a generall worke : yet hereunto I will adioyne another fweete plant called Mafticke, as participating neerer with them then with Time, whereunto many doe referre it.

\section{Maiorana maior aftiua. Common fweet Marierome.}

The fweet Marierome that is moft frequently fowen in our Country, is a low herbe little aboue a foote high when it is at the higheft, full of branches, and rmall whitifh foft roundifh leaues, fmelling very fweet : at the toppes of the branches ftand diuers fmall fcaly heads, like vnto knots, (and therefore of fome called knotted Marierome) of a whitith greene colour, out of which come here and there fmall white flowers, and afterwards fmall reddifh feede : the roote is compofed of many fmall threds or ftrings, which perifh with the whole plant euery yeare.

\section{Maiorana tenuifolia. Marierome gentle.}

This Marierome hath likewife diuers fmall branches, growing low, and not higher then the former, but hauing finer and fmaller leaues, hoary and foft, but much fweeter: the heads are like vnto the former, and fo are the flowers and feede, and the whole plant abiding but a Summer in the like manner.

\section{Marum. Herbe Mafticke.}

The neerer refemblance that this herbe hath with Marierome then with Tyme (as I faid before) hath made me place it next vnto the $\mathrm{fmall} f$ weet Marierome. It rifeth vp with a greater, and a more woody ftalke then Marierome, two foote high or better in fome places, where it liketh the ground and ayre, branching out on all fides towards the vpper part, leauing the ftemme bare below, if it bee old, otherwife being young, thinly furnifhing the branches from the bottome with fmall greene leaues, bigger then the leaues of any Tyme, and comming neere vnto the bigneffe and forme of the lant recited finer Marierome, but of a greener colour: at the toppes of the branches ftand fmall white flowers on a head, which afterwards turne into a loofe tuft of a long white hoary matter, like vnto foft doune, with fome leaues vnderneath and about it, which abide not long on the ftalkes, but are blowne away with the winde : the feede is fo fmall if it haue any, that I haue not obferued it : the roote is threddy : the whole plant is of a fweete refinous fent, Atronger then the Marierome, and abideth our winters, if it be carefully planted and regarded.

The Place.

The fweete Marieromes grow naturally in hot Countreyes: the firft in Spaine \&c. the fecond is thought to come out of Syria, or Perfia firft into Italie, where they much efteeme it, and plant it curioufly and carefully in pots, and fet them in their windowes, beeing much delighted therewith for the fweet fent it hath. The firft is vfually fowen euery yeare in moft gardens with vs: but the fecond is very rare and daintie, and muft as daintely be preferued, being more tender then the former. The herbe Mafticke is thought to be firft brought out of Candie, Clufius faith he found it in Spaine: It is planted by lippes, (and not fowen) in many gardens, and is much replanted 
for increafe, but profpereth onely, or more frequently, in loamie or clay grounds then in any other foyle.

\section{The Time.}

The fweete Marieromes beare their knots or fcaly heads in the end of Iuly, or in Auguft. Herbe Mafticke in Iune many times, or in the beginning of Iuly.

\section{The Names.}

The firft of the two fweet Marieromes called Maiorana in Latine à maiore cura, is taken of mott writers to be the Amaracus or Sampfuchum of Diofcorides, Theophraftus and Plinie, although Galen doth feem a little to diffent therefrom. The other fweet Marierome hath his name in his title as much as can be faid of it. The next is thought by the beft of the moderne Writers to be the true Marum that Galen preferreth for the excellent fweetneffe, before the former Marierome in making the Oleum, or vnguentum Amaricinum, and feemeth to incline to their opinion that thought Amaracus was deriued from Marum. It is the fame alfo that Galen and others of the ancient Writers make mention of, to go into the compofition of the Trochifci Hedychroi, as well as Amaracus among the ingredients of the Theriaca Andromachi. In Englifh we call it Mafticke fimply, or Herbe Maftick, both to diftinguifh it from that Tyme that is called Mafticke Tyme, and from the Mafticke Tree, or Gum, fo called. Some of later times, and Clufius with them, haue thought this to be Diofcorides his Tragoriganum, which doth fomewhat refemble it : but there is another, plant that Matthiolus fetteth forth for $\mathrm{Ma}$ rum, that in Lobels opinion and mine is the trueft Tragoriganum, and this the trueft Marum.

\section{The Vertues.}

The fweete Marieromes are not onely much vfed to pleafe the outward fenfes in nofegayes, and in the windowes of houfes, as alfo in fweete pouders, fweete bags, and fweete wafhing waters, but are alfo of much vfe in Phyficke, both to comfort the outward members, or parts of the body, and the inward alfo: to prouoke vrine being ftopped, and to eafe the paines thereof, and to caufe the feminine courfes. Herbe Mafticke is of greater force to helpe the ftopping of vrine, then the Marierome, and is put into Antidotes, as a remedie againft the poyfon of venemous Beafts.

\section{Cн а P. C X X XI.}

Thymum. Tyme.

7 Here are many kindes of Tyme, as they are vfually called with vs, fome are called of the garden, and others wilde, which yet for their fweetneffe are brought into gardens, as Muske Tyme, and Lemon Tyme ; and fome for their beauty, as embroidered or gold yellow Tyme, and white Tyme. But the true Tyme of the ancient Writers, called Gapitatum, as a fpeciall note of diftinction from all other kindes of Tyme, is very rare to be feene with vs here in England, by reafon of the tenderneffe, that it will not abide our Winters. And all the other forts that with vs are called garden Tymes, are indeede but kindes of wilde Tyme, although in the defect or want of the true Tyme, they are vfed in the ftead of it. With the Tymes I muft doe as I did with the Marieromes in the Chapter before, that is, referue the moft common in vfe, for the common vfe of the Kitchen, and fhew you only thofe here, that are not put to that vfe : and firft with the true Tyme, becaufe it is knowne but to a few. 


\section{Thymum legitimum capitatum. The true Tyme.}

The true Tyme is a very tender plant, hauing hard and hoary brittle branches, fpreading from a fmall wooddy ftemme, about a foote and a halfe high, whereon are fet at feuerall ioynts, and by fpaces, many fmall, long, whitifh, or hoary greene leaues, of a quicke fent and tafte: at the tops of the branches ftand fmall long whitifh greene heads, fomewhat like vnto the heads of Stachas, made as it were of many leaues or fcales, out of which ftart forth fmall purplifh flowers (and in fome white, as Bellonius faith) after which commeth fmall feede, that foone falleth out, and if it be not carefully gathered, is foone loft, which made (I thinke) Theophraftus to write, that this Tyme was to be fowne of the flowers, as not hauing any other feede: the root is fmall and wooddy. This holdeth not his leaues in Winter, no not about Seuill in Spaine, where it groweth aboundantly, as Clufius recordeth, finding it there naked or fpoiled of leaues. And will not abide our Winters, but perifheth wholly, roote and all.

\section{Serpillum hortenfe fue maius. Garden wilde Tyme.}

The wilde Tyme that is cherifhed in gardens groweth vpright, but yet is lowe, with diuers flender branches, and fmall round greene leaues, fomewhat like vnto (mall fine Marierome, and fmelling fomewhat like vnto it : the flowers growe in roundels at the toppes of the branches, of a purplifh colour : And in another of this kinde they are of a pure white colour.

There is another alfo like hereunto, that fmelleth fomewhat like vnto Muske; and therefore called Muske Tyme, whofe greene leaues are not fo fmall as the former, but larger and longer.

\section{Serpillum Citratum. Lemon Tyme.}

The wilde Tyme that fmelleth like vnto a Pomecitron or Lemon, hath many weake branches trayling on the ground, like vnto the firft defcribed wilde Tyme, with fmall darke greene leaues, thinly or fparfedly fet on them, and fmelling like vnto a Lemon, with whitifh flowers at the toppes in roundels or fpikes.

\section{Serpillum aureum fine verficolor. Guilded or embroidered Tyme.}

This kinde of wilde Tyme hath fmall hard branches lying or leaning to the ground, with fmall party coloured leaues vpon them, diuided into ftripes or edges, of a gold yellow colour, the reft of the leafe abiding greene, which for the variable mixture or placing of the yellow, hath caufed it to be called embroidered or guilded Tyme.

The Place.

The firft groweth as is faid before, about Seuill in Spaine, in very great aboundance as Clufius faith; and as Bellonius faith, very plentifully on the mountaines through all Greece. The others growe fome in this Country, and fome in others: but wee preferue them with all the care wee can in our gardens, for the fweete and pleafant fents and varieties they yeeld.

\section{The Time.}

The firft flowreth not vntill Auguft ; the reft in Iune and Iuly.

\section{The Names.}

Their names are feuerally fet downe in their titles, as is fufficient to diftinguifh them; and therefore I fhall not neede to trouble you any further with them. 


\section{The Vertues.}

The true Tyme is a fpeciall helpe to melancholicke and fpleneticke difeafes, as alfo to flatulent humours, either in the vpper or lower parts of the body. The oyle that is Chimically drawne out of ordinary Tyme, is vfed (as the whole herbe is, in the ftead of the true) in pils for the head and ftomach. It is alfo much vfed for the toothach, as many other fuch like hot oyles are.

\section{Ch A P. CX X XII.}

\section{Hy. Jopus. Hyffope.}

7 Here are many varieties of Hyffope, befide the common or ordinary, which I referue for the Kitchen garden, and intend onely in this place to giue you the knowledge of fome more rare: viz. of fuch as are nourfed vp by thofe that are curious, and fit for this garden : for there are fome other, that muft be remembred in the Phyficke garden, or Garden of Simples, or elfe in a generall worke.

\section{Hy.Jopus folijs niueis. White Hyffope.}

This white Hyffope is of the fame kinde and fmell with the common Hyffope ; but differeth, in that this many times hath diuers leaues, that are wholly of a white colour, with part of the ftalke alfo : others are parted, the one halfe white, the other halfe greene, and fome are wholly greene, or with fome fpots or ftripes of white within the greene, which makes it delightfull to moft Gentlewomen.

\section{Hy.Jopus folijs cinereis. Ruffet Hyffope.}

As the laft hath party coloured leaues, white and greene, fo this hath his leaues of an afh-colour, which of fome is called ruffet ; and hath no other difference either in forme or fmell.

3. Hy.Jopus aureus. Yellow or golden Hyffope.

All the leaues of this Hyffope are wholly yellow, or but a little greene in them, and are of fo pleafant a colour, efpecially in Summer, that they prouoke many Gentlewomen to weare them in their heads, and on their armes, with as much delight as many fine flowers can giue : but in Winter their beautifull colour is much decayed, being of a whitifh greene, yet recouer themfelues againe the next Summer.

\section{Hy Jopus furculis denfis. Double Hyffope.}

As this kinde of Hyffope groweth lower then the former or ordinary kinde, fo it hath more branches, flenderer, and not fo wooddy, leaning fomewhat downe toward the ground, fo wonderfully thicke fet with leaues, that are like vnto the other, but of a darker greene colour, and fomewhat thicker withall, that it is the onely fine fweete herbe, that I know fitteft (if any be minded to plant herbes) to fet or border a knot of herbes or flowers, becaufe it will well abide, and not growe too wooddy or great, nor be thinne of leaues in one part, when it is thicke in another, fo that it may be kept with cutting as fmooth and plaine as a table. If it be fuffered to growe vp of it felfe alone, it rifeth with leaues as before is fpecified, and flowreth as the common doth, and of the fame fent alfo, not differing in any thing, but in the thickneffe of the leaues on the ftalkes and branches, and the aptneffe to be ordered as the keeper pleafeth. 


\section{Chamadrys. Germander.}

Left Germander fhould be vtterly forgotten, as not worthy of our Garden, feeing many (as I faid in my treatife or introduction to this Garden) doe border knots therewith : let me at the leaft giue it a place, although the laft, being more vfed as a ftrewing herbe for the houfe, then for any other vfe. It is (I thinke) fufficiently knowne to haue many branches, with fmall and fomewhat round endented leaues on them, and purplifh gaping flowers: the rootes fpreading far abroad, and rifing vp againe in many places.

\section{The Place.}

Thefe Hyffopes haue beene moft of them nourfed $v p$ of long time in our Englifh Gardens, but from whence their firt originall fhould be, is not well knowne. The Germander alfo is onely in Gardens, and not wilde.

\section{The Time.}

They flower in Iune and Iuly.

\section{The Names.}

The feuerall names whereby they are knowne to vs, are fet forth in their titles; and therefore I neede not here fay more of them then onely this, that neyther they here fet downe, nor the common or ordinary fort, nor any of the reft not here expreffed, are any of them the true Hyffope of the ancient Greeke Writers, but Suppofititice, vfed in the ftead thereof. The Germander, from the forme of the leaues like vnto fmall oaken leaues, had the name Chamadrys giuen it, which fignifieth a dwarfe Oake.

\section{The Vertues.}

The common Hyffope is much vfed in all pectorall medicines, to cut fleagme, and to caufe it eafily to be auoided. It is vfed of many people in the Country, to be laid vnto cuts or frefh wounds, being bruifed, and applyed eyther alone, or with a little Sugar. It is much vfed as a fweet herbe, to be in the windowes of an houfe. I finde it much commended againt the Falling Sickneffe, efpecially being made into Pils after this manner: Of Hyflope, Horhound, and Caftor, of each halfe a dramme, of Peony rootes (the male kinde is onely fit to be vfed for this purpofe) two drams, of $A / \int a$ fatida one fcruple: Let them be beaten, and made into pils with the iuyce of Hyffope ; which being taken for feuen dayes together at night going to bed, is held to be effectual to giue much eafe, if not thoroughly to cure thofe that are troubled with that difeafe. The vfe of Germander ordinarily is as Tyme, Hyffope, and other fuch herbes, to border a knot, whereunto it is often appropriate, and the rather, that it might be cut to ferue (as I faid) for a ftrewing herbe for the houfe among others. For the phyficall vfe it ferueth in difeafes of the fplene, and the ftopping of vrine, and to procure womens courfes.

Thus have I led you through all my Garden of Pleafure, and fhewed you all the varieties of nature nourfed therein, pointing vnto them, and defcribing them one after another. And now laftly (according to the vfe of our old ancient Fathers) I bring you to reft on the Graffe, which yet fhall not be without fome delight, and that not the leaft of all the reft. 


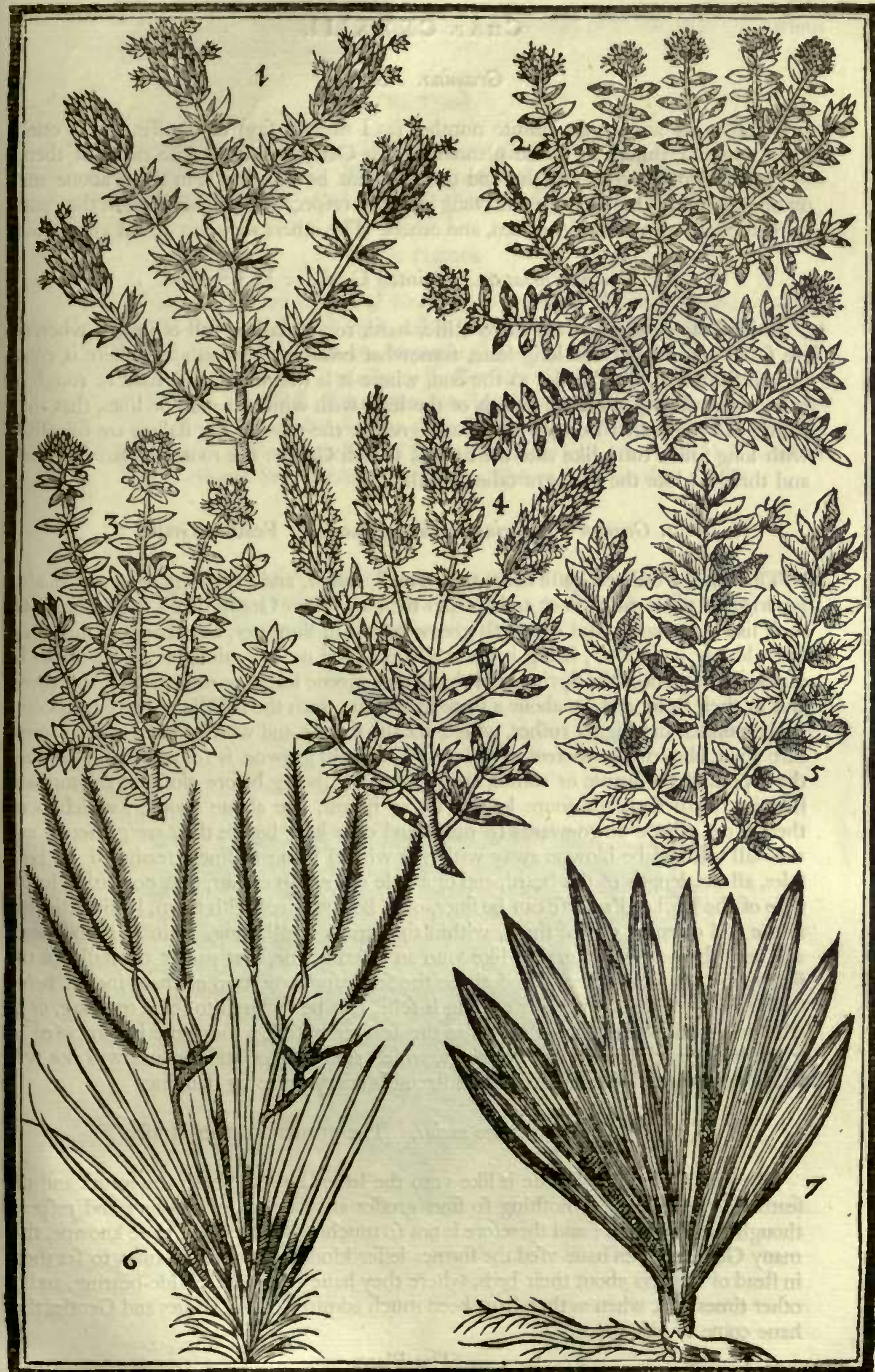

1 Thymum legitimum. The true Tyme. 2 Serpillum maius hortenfe. Gasden wilde Tyme. 3 Serpillum Citratum. Lemon Tyme, 4 HyJopus verficolor fiue aureus. Golden IIyflope. 5 Chamedrys. Germander. 6 Spartum Arftriatum fiue Gramen plumarium minus. The leffer feather Graffe. 7 Gramen Friatum vel fulcalum. Painted Graffe or Ladies Laces. 


\section{C н А P. C X X X I I I.}

\section{Gramina. Graffes.}

T Here are among an infinite number (as I may fo fay) of Graffes, a few onely which I thinke fit to be planted in this Garden, both for the rarity of them, and alfo for your delight, and the excellent beauty that is in them aboue many other plants. One of them hath long agoe bin refpected, and cherifhed in the country gardens of many Gentlewomen, and others. The others are knowne but vnto a few.

\section{Gramen friatum. Painted Graffe or Ladies laces.}

This kinde of Graffe hath many ftiffe, hard, round ftalkes, full of ioynts, whereon are fet at euery ioynt one long leafe, fomewhat broad at the bottome, where it compaffeth the ftalke, and fmaller to the end, where it is fharpe pointed, hard or rough in handling, and ftriped all the length of the leafe with white ftreakes or lines, that they feeme party coloured laces of white and greene: the tops of the ftalkes are furnifhed with long fpikie tufts, like vnto the tufts of Couch Graffe: the rootes are fmall, white, and threddy, like the rootes of other Graffes.

\section{Gramen Plumarium minus. The leffer Feather-Graffe.}

This leffer Feather-Graffe hath many fmall, round, and very long leaues or blades, growing in tufts, much finer and fmaller then any other Graffe that I know, being almoft like vnto haires, and of a frefh greene colour in Summer, but changing into gray, like old hay in Winter, being indeede all dead, and neuer reuiuing; yet hardly to be plucked away vntill the Spring, and then other greene leaues or rufhes rife vp by them, and in their ftead, and are aboue a foote in length: from the middle of thefe tufts come forth rounder and bigger rufhes, which are the ftalkes, and which haue a chaffie round eare about the middle thereof, which when it is full growne, is fomewhat higher then the toppes of the leaues or rufhes, opening it felfe (being before clofe) at the top, and fhewing forth three or foure long ayles or beards, one aboue another, which bend themfelues a little downewards (if they ftand ouer long before they are gathered, and will fall off, and be blowne away with the winde) being fo finely feathered on both fides, all the length of the beard, and of a pale or grayinh colour, that no feather in the taile of the Bird of Paradife can be finer, or to be compared with them, hauing fticking at the end of euery one of them, within the eare, a fmall, long, whitifh, round, hard, and very tharpe pointed graine, like vnto an oaten graine, that part of the ftalke of the feather that is next vnder it, and aboue the feede for fome two or three inches, being ftiffe and hard, and twining or curling it felfe, if it be fuffered to ftand too long, or to fall away, otherwife being ftraight as the feather it felfe: the roote is compofed of many long, hard, fmall threddy ftrings, which runne deepe and far, and will not willingly be remoued, in that it gaineth ftrength euery yeare by ftanding.

\section{Gramen Plumarium maius. The greater Feather-Graffe.}

The greater Feather-Graffe is like vnto the leffer, but that both the leaues and the feathers are greater, and nothing fo fine, groffer alfo; and of leffe beauty and refpect, though whiter then it; and therefore is not fo much regarded: for I haue knowne, that many Gentlewomen haue vfed the former leffer kinde, being tyed in tufts, to fet them in ftead of feathers about their beds, where they haue lyen after childe-bearing, and at other times allo, when as they haue been much admired of the Ladies and Gentles that haue come to vifit them.

The Place.

The firt of thefe Graffes, as Lobel faith, groweth naturally in the woods and hils of Sauoy. It hath long agoe beene receiued into our Englifh gar- 
dens. The fecond, as Clufius faith, in Auftria, from whence alfo (as I take it) the greater came, and are both in the gardens of thofe, that are curious obferuers of thefe delights.

The Time.

The firft is in its pride for the leaues all the Spring and Summer, yeelding his bufh in Iune. The other giue their feather-like fprigs in Iuly and Auguft, and quickly (as I faid) are fhed, if they be not carefully gathered.

The Names.

The firft is called by Lobel Gramen fulcatum, or ftriatum album; of others Gramen pictum. The French call it Aiguellettes d'armes, of the fafhion that their Enfignes, Pennons, or Streamers vfed in wars were of, that is, like vnto a party coloured curtaine. In Englifh vfually Ladies laces, and Painted Graffe. The firft of the other two is called Gramen plumarium or plumofum, and minus is added for the diftinction of it. Clufius calleth it Spartum Aufriacum, of the likenefle and place where he found it. The laft is called Gramen plumarium, or plumofum maius, The greater Feather-Graffe.

The Vertues.

Thefe kindes of Graffes are not in any time or place that I doe heare of applyed to any Phyficall vfe ; and therefore of them I will fay no more : but here I will end the prime part of this worke.

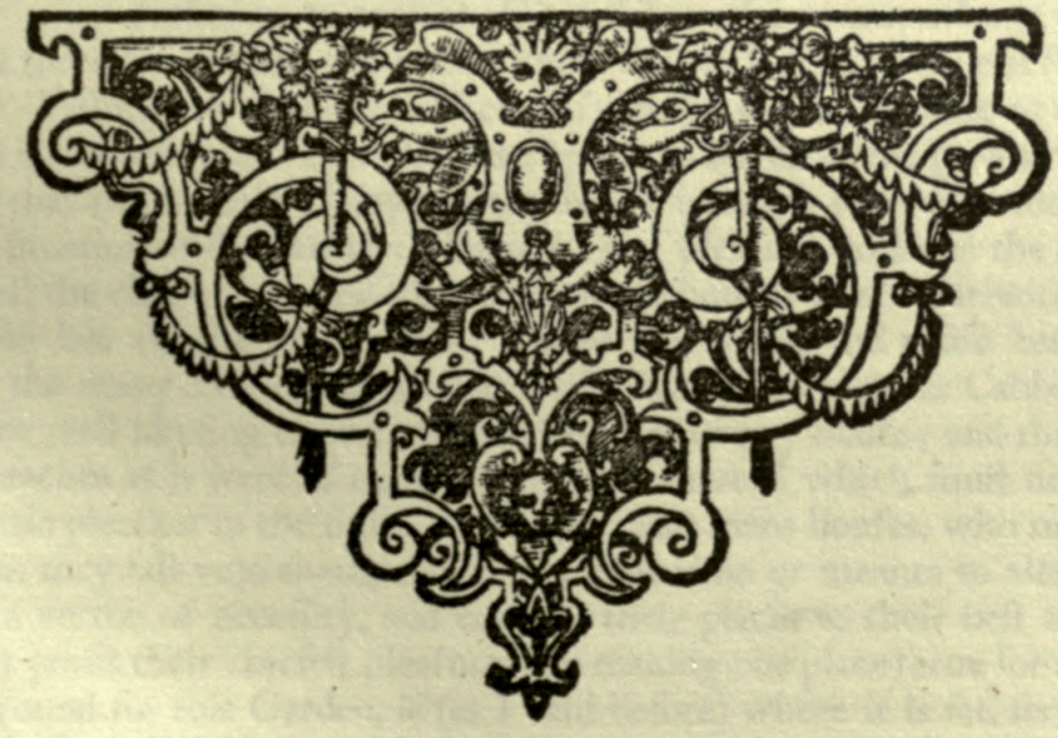




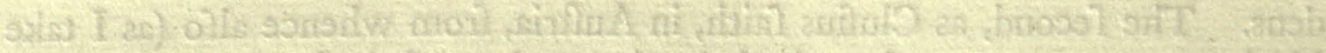

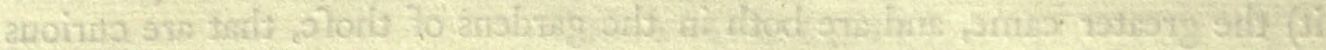

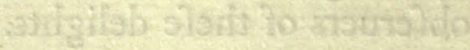

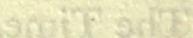

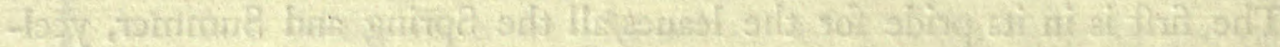

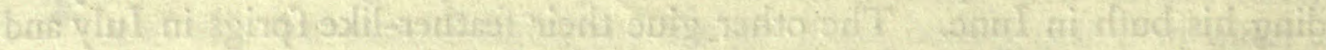

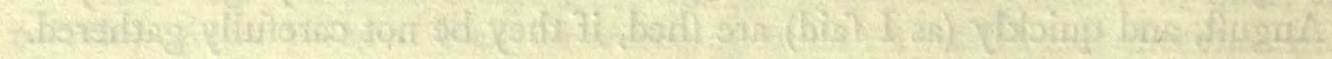

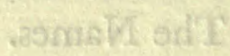

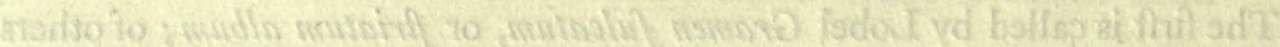

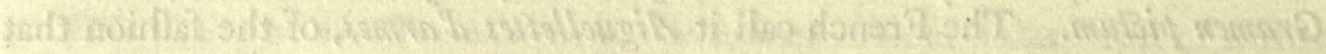

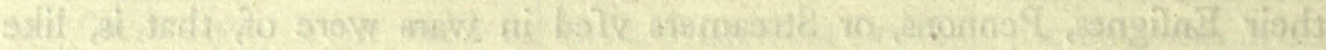

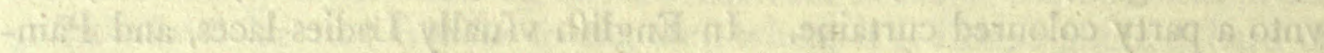

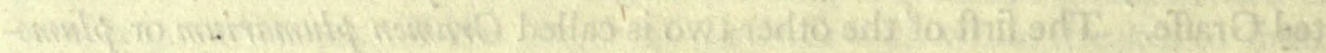

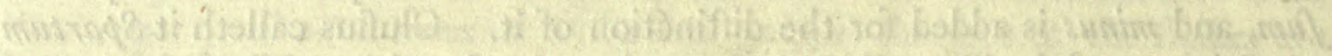

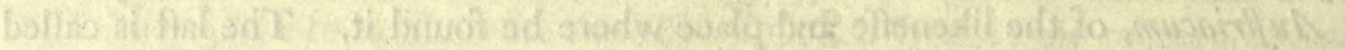

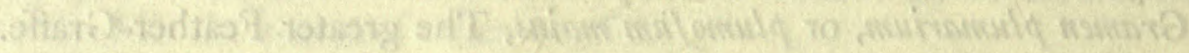

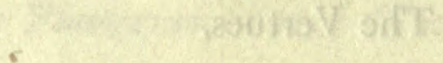

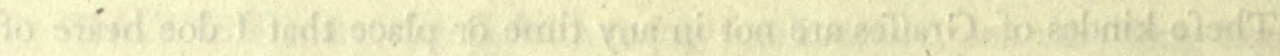

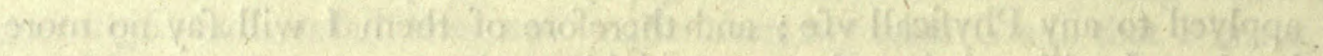

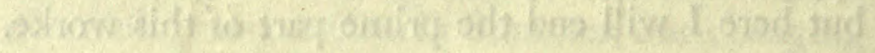

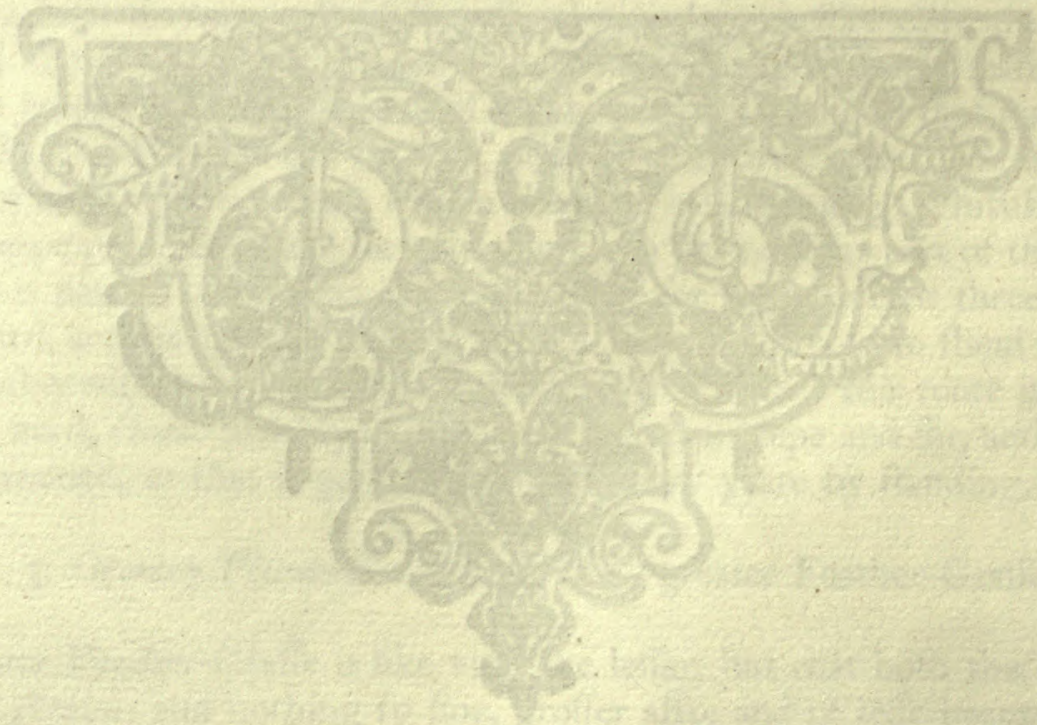

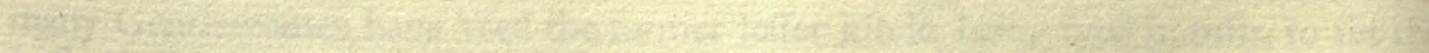

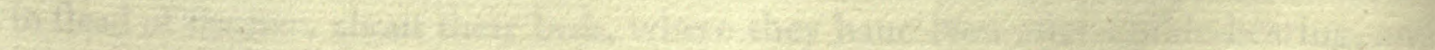




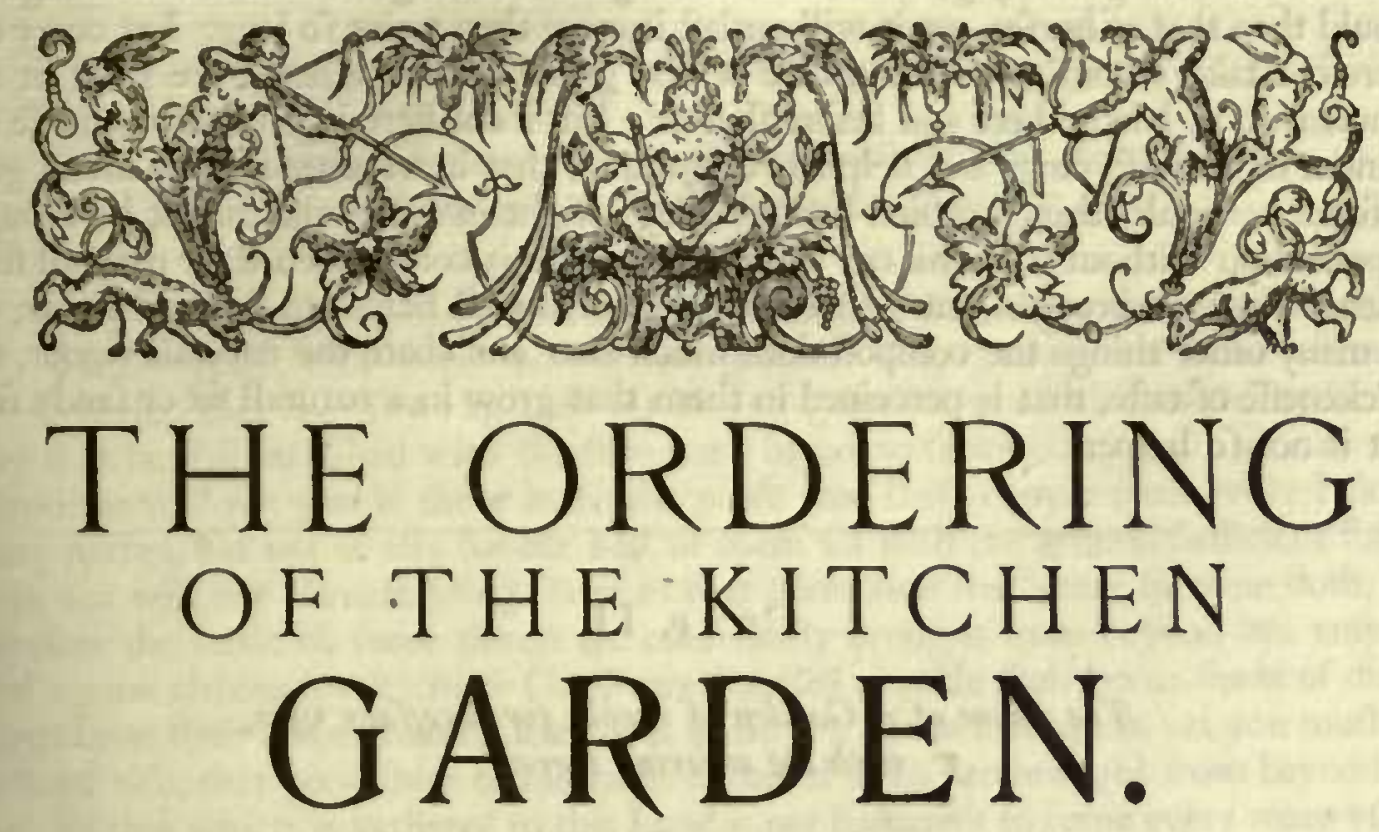

Cн A P. I.

The fituation of a Kitchen Garden, or Garden of Herbes, and what fort of manure is fitteft to helpe the decaying of the Soyle thereof.

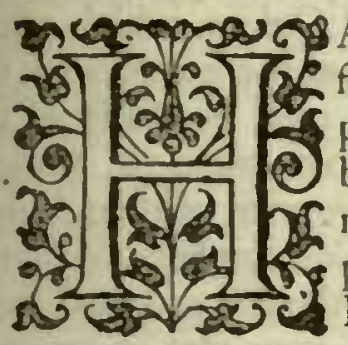
Auing giuen you the beft rules and inftructions that I can for your
flower Garden, and all the flowers that are fit to furnifh it, I now proceede to your herbe garden, which is not of the leaft refpect belonging to any mans houfe, nor vtterly to bee neglected for the f many vtilities are to be had from it, both for the Malters profit and pleafure, and the meynies content and nourifhment: all which if I thould here fet down, I had a large field to wander in, and matter fufficient to entreat of, but this worke permitteth not that libertie: and I thinke there are but few but eyther know it already, or conceiue it fufficiently in their minds. Paffing therefore no further in fuch difcourfes, I come to the matter in hand, which is to thew you where the fitteft place is for an herbe garden. As before I thewed you that the beautie of any worthy houfe is much the more commended for the pleafant fituation of the garden of flowers, or of pleafure, to be in the fight and full profpect of all the chiefe and choifeft roomes of the houfe; fo contrariwife, your herbe garden thould bee on the one or other fide of the houfe, and thofe beft and choyfe roomes: for the many different fents that arife from the herbes, as Cabbages, Onions, \&c. are fcarce well pleafing to perfume the lodgings of any houfe; and the many ouertures and breaches as it were of many of the beds thereof, which muft neceffarily bee, are alfo as little pleafant to the fight. But for priuate mens houfes, who muft like their habitations as they fall vnto them, and cannot haue time or meanes to alter them, they muft make a vertue of neceffity, and conuert their places to their beft aduantage, by making their profit their chiefeft pleafure, and making one place ferue for all vfes. The choyce of ground for this Garden, is (as I faid before) where it is fat, fertill and good, there needeth the leffe labour and coft : and contrariwife, where it is cold, wet, dry or barren, there muft bee the more helpes ftill added to keepe it in heart. For this Garden by reafon of the much and continuall ftirring therein, the herbes and rootes drawing out the fubftance of the fertilitie thereof more aboundantly then in the former, mult be continually holpen with foyle, or elfe few things of goodneffe or worth will come forward therein. The ftable foyle of horfes is beft and more proper for any colde grounds, for being the hotteft, it will caufe any the feedes for this Garden to profper well, and be more forward then in any other ground that is not fo holpen. The ftable foyle of Cattell is of a colder and moifter nature, and is therefore more proper for 
the hot fandy or grauelly grounds, and although it bee longer before it bee brought to mould then that of horfes, yet it will outlaft it more then twice fo long. Let euery one therefore take according to the nature of the ground fuch helpes as are moft fit and conuenient, as I haue here and before thewed. But I doe here ingenuoufly confeffe my opinion of thefe forcings and helpings of ground, that howfoeuer it doth much good to fome particular things, which becaufe they delight in heate, and cannot be brought to perfection without it in this our Countrey, which is colder then their naturall from whence they are brought, muft therefore haue artificiall helpes to forward them; yet for many other things the compoft doth much alter and abate the naturall vigour, and quickeneffe of tafte, that is perceiued in them that grow in a naturall fat or fandy foile that is not fo holpen.

\section{Ch A P. II.}

The forme of a Garden of herbes for necelfary $v$ fes, with the ordering thereof.

$\mathrm{A}$ $S$ our former Garden of pleafure is wholly formable in euery part with fquares, trayles, and knots, and to bee ftill maintained in their due forme and beautie: fo on the contrary fide this Garden cannot long conferue any forme, for that euery part thereof is fubiect to mutation and alteration. For although it is conuenient that many herbes doe grow by themfelues on beds, caft out into fome proportion fit for them, as Tyme, Hiffope, Sage, \&c. yet many others may bee fowen together on a plot of ground of that largeneffe that may ferue euery mans particular vfe as he Thall haue occafion to employ it, as Reddin, Lettice and Onions, which after they are growne vp together may be drawne vp and taken away, as there is occafion to fpend them : but Carrots or Parfneps being fowen with others muft bee fuffered to grow laft, becaufe they require a longer time before they be fit to be taken vp. Other herbes require fome large compaffe of ground whereon they may grow of themfelues without any other herbes growing among them, as Artichokes, Cowcumbers, Melons, Pompions. And fome will doe fo with their Cabbages alfo, but the beft and moft frugall way now vfed, is to plant them round about the border of your plot or ground whereon you plant Cowcumbers, Pompions, or other things, in that by this meanes fo much ground will be well faued, and the other things be no whit hindered thereby, which elfe a great deale of ground muft be employed for them apart. So that by this that I haue here faid, you may perceiue the forme of this Garden is for the moft part, to bee ftill out of forme and order, in that the continuall taking vp of the herbes and rootes that are fowen and planted, caufeth the beds or parts:of this Garden to lye broken, difmembered, and out of the order that at the firft it was put into. Remember herewithall that (as I faid before) this Garden requireth the continuall helpe of foyle to be brought.into it, in that the plenty of thefe manner of herbes and rootes doe fo much wafte the fertilitie and fatneffe of the ground, that without continuall refrefhing it would quickly become fo poore and barren, that it would not yeelde the worth of the feede. The ordinary time to foyle a Garden, is to bring in manure or dung before Chriftmas, and eyther bury it fome fmall depth, not too deepe, or elfe to lay it vpon the ground that the winter froftes may pierce it, and then turne it fhallow into the ground to fow your. feeds in the Spring.

CHAP. 


\section{A P. III.}

\section{How to order diwers Garden herbes, both for their fonving, Ipending, and gathering of thic Jeede.}

$\mathrm{O}$ $V_{r}$ chiefelt and greateft Gardiners now adaies, doe fo prouide for themfelues euery yeare, that from their owne grounds they gather the feede of many herbes that they fowe againe: for hauing gained the beft kind of diuers herbes, they will be ftill furnifhed with the fame, and be not to feeke euery yeare for new that oftentimes will not yeelde them halfe the profit that their choyce feede will : I fay of many herbes, but not of all ; for the beft of them all hath not ground fufficient for all forts, nor will our climate bring fome to that perfection that other forraine doth, and therefore the feede of fome things are continually brought from beyond Sea visto vs. And againe although our chiefe Gardiners doe ftill prouide their owne feede of diuers things from their owne ground, becaufe as I faid it is of the beft kinde, yet you muft vnderftind alfo, that good ftore of the fame fortes of feeds are brought from beyond the Seas, for that which is gathered in this Land is not fufficient to ferue euery mans vfe in the whole Kingdome by many parts; yet ftill it is true, that our Englifh feede of many things is better then any that commeth from beyond the Seas : as for example, Reddifh, Lettice, Carrots, Parfneps, Turneps, Cabbages, and Leekes, of all which I intend to write in this place; for thefe are by them fo husbanded, that they doe not fow their owne grounds with any other feede of thefe forts but their owne : which that you may know the manner how to doe, I will here fet it downe, that euery one may haue the beft directions if they will follow them. Of Reddifh there are two forts, one more early then the other: they vfe therefore to fow their early Reddin firft, that they may haue the earlieft profit of them, which is more worth in one fortnight, then in a moneth after. And to effect this they haue fome artificiall helps alfo; which are thefe: They vfe to digge vp a large plot of ground where they intend to fow their feede a litthe before or after Chriftmas, cafting it into high balkes or ridges fiue or fixe foote afunder, which they fuffer to lye and take all the extreame frofts in Ianuary to mellow the earth, and when the froftes are paft, they then beginne to bring into it good ftore of frefh itable dung, which they laye neyther too deepe nor too thicke, and couer it with the mould a hand breadth thickneffe aboue the dung, which doth giue fuch a warmith and comfort to whatfoeuer is fowen thereon, that it forceth it forward much fooner then any other way can doe: And to preuent both the froftes, and the cold bitter windes which often fpoyle their feede new fprung vp, they vfe to fet great high and large mattes made of reedes, tyed together, and faftened vnto itrong ftakes, thruft into the ground to keepe them vp from falling, or being blowne down with the winde; which mattes they place on the North and Ealt fide to breake the force of thefe winds, and are fo fure and fafe a defence, that a bricke wall cannot better defend anything vnder it, then this fence will. In this manner they doe euery yeare to bring forward their feede to gaine the more by them, and they that will haue Reddifh early, muft take the fame courfe. The other fort of Reddifh for the inoft part is fowen in Februarie, a fortnight after the other at the leaft, and likewife euery moneth after vito September, that they may haue young continually. For the blacke Reddifh, although many in many places doe fowe it in the fame time, and in the fane manner that the ordinary is fowen, yet the nature thereof is to runne vp to feede more fpeedily then the other, if it haue fo rich ground to grow vpon, and therefore the beft time to fow it is in Augult, that fo it may abide all winter, wherein is the chiefeft time for the fpending thereof, and to keepe $i t$ vntill the beginning of the next yeare from running vp to feed: the gathering whereof, as alfo of the other fort, is all after one manner, that is, to be pulled vp when the pods change whitifh, and then hanged vpon bufhes, pales, or fuch other thing, vntill they bee thorough dry, and then beaten or thrafied out vpon a finooth plancher, or vpon clothes, as euery ones ftore is, and their conueniencic. Lettice is fowen oftentimes with the early Reddifh, in the fame manner before faid, that they may haue Lettice likewife as early as the time of the year will perınit them, which 
they pull vp where they grow too thicke, fpending them firft, and fo taking vp from time to time, vntill they ftand two foote in funder one from another, and beginne to fpindle and thoote vp for feede. In this is vfed fome arte to make the plants ftrong to giue the better feede without danger of rotting or fpoyling with the wet, which often happeneth to thofe about whom this caution is not obferued: Before your Lettice is fhot vp, marke out the choyfeft and ftrongeft plantes which are fitteft to grow for feede, and from thofe when they are a foote high, Atrippe away with your hand the leaues that grow loweft vpon the ftalke next the ground, which might rot, fpoyle or hinder them from bearing fo good feede; which when it is neere to be ripe, the ftalkes mult be cut off about the middle, and layde vpon mats or clothes in the Sunne, that it may there fully ripen and be gathered; for it would be blowne away with the winde if it fhould be fuffered to abide on the ftalkes long. Parfneps muft be fowen on a deep trenched mellow ground, otherwife they may run to feede the firft yeare, which then are nothing worth: or elfe the rootes will be fmall ftaruelings and fhort, and runne into many fpires or branches, whereby they will not bee of halfe the worth. Some vfe to fow them in Auguif and September, that fo they may bee well growne to ferue to fpend in Lent following, but their beft time is in February, that the Summers growth may make them the fairer and greater. When they runne vp to feede you fhall take the principall or middle heades, for thofe carry the Mafter feede, which is the beft, and will produce the faireft rootes againe. You hall hardly haue all the feede ripe at one inftant, for vfually the chiefeft heads will be fallen before the other are ripe: you muft therefore ftill looke them ouer, and cut them as they ripen. Carrots are vfually fowen in March and Aprill, and if it chance that fome of them doe runne vp for feede the fame year, they are to be weeded out, for neyther the feed nor roots of them are good: You muft likewife pull them $\mathrm{vp}$ when they are too thicke, if you will haue them grow fair, or for feed, that they may grow at the leaft three or foure foot in funder : the ftalkes of Carrots are limber, and fall downe to the ground; they muft therefore be fuftained by poles layde acroffe on ftalkes thruft into the ground, and tyed to the poles and ftalkes to keepe them vp from rotting or fpoyling vpon the ground : the feed hereof is not all ripe at once, but muft be tended and gathered as it ripeneth, and layd to dry in fome dry chamber or floore, and then beaten out with a ftick, and winnowed from the refure. Turneps are fowne by themfelues vpon a good ground in the end of Iuly, and beginning of Auguft, to haue their rootes beft to fpend in winter; for it often happeneth that thofe feedes of Turneps that are fowen in the Spring, runne vp to feede the fame yeare, and then it is not accounted good. Many doe vfe to fow Turneps on thofe grounds from whence the fame yeare they haue taken off Reddifh and Lettice, to make the greater profit of the ground, by hauing two crops of increafe in one yeare. The ftalkes of Turneps will bend downe to the ground, as Carrots doe, but yet muft not be bound or ordered in that manner, but fuffered to grow without ftaking or binding, fo as they grow of fome good diftance in funder: when the feede beginneth to grow ripe, be very carefull to preferue it from the birds, which will be moft bufie to deuour them. You hall vnderftand likewife that many doe account the beft way to haue the faireft and moft principall feede from all thefe fore-recited herbes, that after they are fowen and rifen to a reafonable growth, they be tranf planted into frefh ground. Cabbages alfo are not only fowen for the vfe of their heads to fpend for meat, but to gather their feede likewife, which howfoeuer fome haue endeauoured to doe, yet few haue gained good feede, becaufe our harpe hard froftes in winter haue fpoyled and rotted their ftockes they preferued for the purpofe ; but others haue found out a better and a more fure way, which is, to take vp your ftocks that are fitteft to be preferued, and bring them into the houfe, and there wrap them eyther in clothes, or other things to defend them from the cold, and hang them vp in a dry place, vntill the beginning of March following, then planting them in the ground, and a little defend them at the firft with ftraw caft ouer them from the cold nights, thereby you may be fure to haue perfect good feede, if your kinde be of the beft: Sowe your feed in the moneths of February or March, and tranfplant them in May where they may ftand to grow for your vfe, but be carefull to kill the wormes or Caterpillers that elfe will deuoure all your leaues, and be carefull alfo that none of the leaues bee broken in the planting, or otherwife rubbed, for that oftentimes hindereth the well clofing of them. Leekes are 
for the moft part wholly nourfed vp from the feede that is here gathered; and becaufe there is not fo much ftore of them either fowne or fpent, as there is of Onions by the twentieth part, we are ftill the more carefull to be prouided from our owne labours; yet there be diuers Gardiners in this Kingdome, that doe gather fome fmall quantity of Onion feede alfo for their owne or their priuate friends fpending. The fowing of them both is inuch about one time and manner, yet inoft vfually Leeks are fowne later then Onions, and both before the end of March at the furtheft; yet fome fowe Onions from the end of Iuly to the beginning of September, for their Winter prouifion. Thofe that are fowne in the Spring, are to be taken vp and tranfplanted on a frefh bed prepared for the purpofe, or elfe they will hardly abide a Winter; but hauing taken roote before W $\mathrm{W}$ inter, they will beare good feede in the Summer following: You muft ftake both your Leekes and your Onion beds, and with poles laid a croffe, binde your lopple headed ftalkes vnto them, on high as well as belowe, or elfe the winde and their owne weight will beare them downe to the ground, and fpoile your feede. You muft thinne them, that is, pull vp continually after they are firt fprung vp thofe that growe too thicke, as you doe with all the other herbes before fpoken of, that they may haue the more roome to thriue. Of all thefe herbes and rootes before fpoken of, you muft take the likelieft and faireft to keepe for your feede; for if you thould not take the beft, what hope of good feede can you expect? The time for the fpending of thefe herbes and rootes, not particularly mentioned, is vntill they begin to runne vp for feede, or vitill they are to bc tranfplanted for feede, or elfe vntill Winter, while they are good, as euery one thall fee caufe.

\section{Cи а P. II I I.}

\section{How to order Artichokes, Melons, Concumbers, and Pompions.}

T

Here are certaine other herbes to be fpoken of, which are wholly nourfed vp for their fruit fake, of whom I fhall not need to fay much, being they are fo frequent in euery place. Artichokes being planted of faire and large lips, taken from the roote in September and October (yet not too late) will moft of them beare fruit the next yeare, fo that they be planted in well dunged ground, and the earth raifed vp like vnto an Anthill round about each roote, to defend them the better from the extreame frofts in Winter. Others plant nips in March and Aprill, or fooner, but although forne of them will beare fruit the fame yeare, yet all will not. And indeede many doe rather choofe to plant in the fpring then in the fall, for that oftentimes an extreame hard Winter following the new fetting of flips, when they haue not taken fufficient heart and roote in the ground, doth vtterly pierce and perifh them, when as they that are fet in the Spring haue the whole Summers growth, to make them Atrong before they feele any tharpe frofts, which by that time they are the better able to beare. Muske Melons haue beene begun to bee nourfed vp but of late dayes in this Land, wherein although many haue tryed and endeauoured to bring them to perfection, yet few haue attained vnto it : but thofe rules and orders which the beft and skilfulleft haue vfed, I will here fet downe, that who fo will, may haue as good and ripe Melons as any other in this Land. The firf thing you are to looke vnto, is to prouide you a peece of ground fit for the purpofe, which is either a floping or fheluing banke, lying open and oppofite to the South Sunne, or fome other fit place not theluing, and this ground alfo you muft fo prepare, that all the art you can vfe about it to make it rich is little enough ; and therefore you muft raife it with meere ftable foyle, thorough rotten \& well turned $v p$, that it may be at the leaft three foote deepe thereof, which you muft caft alfo into high beds or balkes, with deepe trenches or furrowes betweene, fo as the ridges may be at the leaft a foot and a halfe higher then the furrowes; for otherwife it is not poffible to haue good Melons growe ripe. The choife of your feede alfo is another thing of efpeciall regard, and the beft is held to be Spanifh, and not French, which hauing once gained, be fure to haue ftill of the farne while they laft 
good, that you may haue the feede of your owne ripe Melons from them that haue eaten them, or faue fome of the beft your felfe for the purpofe. I fay while they laft good ; for many are of opinion, that no feede of Muske Melons gathered in England, will endure good to fowe againe here aboue the third yeare, but ftill they muft be renewed from whence you had your choifeft before. Then hauing prepared a hot bed of dung in Aprill, fet your feedes therein to raife them vp, and couer them, and order them with as great care or greater then Cowcumbers, \&c. are vfed, that when they are ready, they may be tranfplanted vpon the beds or balkes of that ground you had before prepared for them, and fet them at the leaft two yards in funder, euery one as it were in a hole, with a circle of dung about them, which vpon the fetting being watered with water that hath ftood in the Sunne a day or two, and fo as often as neede is to water, couer them with ftrawe (fome vfe great hollow glaffes like vnto bell heads) or fome fuch other things, to defend them both from the cold euenings or dayes, and the heate of the Sunne, while they are young and new planted. There are fome that take vpon them great skill, that millike of the raifing vp of Melons, as they doe alfo of Cowcumbers, on a hot bed of horfe dung, but will put two or three feedes in a place in the very ground where they hall ftand and growe, and thinke without that former manner of forcing them forwards, that this their manner of planting will bring them on faft and fure enough, in that they will plucke away fome of the worft and weakeft, if too many rife vp together in a place; but let them know for certaine, that howfoeuer for Cowcumbers their purpofe and order may doe reafonable well, where the ground is rich and good, and where they ftriue not to haue them fo early, as they that vfe the other way, for Muske Melons, which are a more tender fruit, requiring greater care and trouble in the nourfing, and greater and Atronger heate for the ripening, they muft in our cold climate haue all the art vfed vnto them that may be, to bring them on the more early, and haue the more comfort of the Sunne to ripen them kindly, or elfe they will not bee worth the labour and ground. After you haue planted them as aforefaid, fome of good skill doe aduife, that you be carefull in any dry feafon, to giue them water twice or thrice euery weeke while they are young, but more afterward when they are more growne, and that in the morning efpecially, yea and when the fruit is growne fomewhat great, to water the fruit it felfe with a watering pot in the heate of the day, is of fo good effect, that it ripeneth them much fafter, and will give them the better tafte and fmell, as they fay. To take likewife the fruit, and gather it at the full time of his ripeneffe is no fmall art; for if it be gathered before his due time to be prefently eaten, it will be hard and greene, and not eate kindly; and likewife if it be fuffered too long, the whole goodneffe will be loft: You fhall therefore know, that it is full time to gather them to fpend prefently, when they begin to looke a little yellowish on the outfide, and doe fmell full and ftrong; but if you be to fend them farre off, or keepe them long vpon any occafion, you thall then gather them fo much the earlier, that according to the time of the carriage and $r$ pending, they may ripen in the lying, being kept dry, and couered with woollen clothes: When you cut one to eate, you fhall know it to be ripe and good, if the feede and pulpe about them in the middle be very waterifh, and will eafily be feparated from the meate, and likewife if the meate looke yellow, and be mellow, and not hard or greene, and tafte full and pleafant, and not waterifh: The vfuall manner to eate them is with pepper and falt, being pared and fliced, and to drowne them in wine, for feare of doing more harme. Cowcumbers and Pompions, after they are nourfed vp in the bed of hot dung, are to be feuerally tranfplanted, each of them on a large plot of ground, a good diftance in funder: but the Pompions more, becaufe their branches take vp a great deale more ground, \& befides, will require a great deale more watering, becaufe the fruit is greater. And thus haue you the ordering of thofe fruits which are of much efteeme, ef pecially the two former, with all the better fort of perfons; and the third kinde is not wholly refufed of any, although it ferueth moft vfually for the meaner and poorer fort of people, after the firft early ripe are fpent. 


$$
\begin{aligned}
& \text { CH A P. V. } \\
& \text { The ordering of diuers forts of herbes for the pot, for meate, } \\
& \text { and for the table. }
\end{aligned}
$$

$T$

Yme, Sauory, and Hyffope, are vfually fowne in the Spring on beds by themfelues, euerie one a part; but they that make a gaine by felling to others the young rootes, to fet the knots or borders of Gardens, doe for the moft part fowe them in Iuly and Augurt, that fo being fprung vp before Winter, they will be the fitter to be taken vp in the Spring following, to ferue any mans vfe that would haue them. Sage, Lauender, and Rofemary, are altogether fet in the Spring, by Nipping the old ftalkes, and taking the youngeft and likelieft of them, thrufting them either twined or otherwife halfe a foote deepe into the ground, and well watered vpon the fetting; if any feafonable weather doe follow, there is no doubt of their well thriuing : the hot Sunne and piercing drying Windes are the greatelt hinderances to them; and therefore I doe aduife none to fet too foone in the Spring, nor yet in Autumne, as many doe practife : for I could neuer fee fuch come to good, for the extremity of the Winter comming vpon them fo foone after their fetting, will not fuffer their young thootes to abide, not hauing taken fufficient ftrength in the ground, to maintain themfelues againft fuch violence, which doth often pierce the ftrongeft plants. Marierome and Baffill are fowne in the Spring, yet not too early; for they are tender plants, and doe not fpring vntill the weather bee fomewhat warme : but Baffill would bee fowne dry, and not haue any water of two or three daies after the fowing, elfe the feede will turne to a gelly in the ground. Some vfe to fowe the feed of Rofemary, but it feldome abideth the firt $W$ inter, becaufe the young plants being fmall, and not of fufficient itrength, cannot abide the fharpneffe of fome Winters, notwithftanding the couering of them, which killeth many old plants; but the vfuall way is to flippe and fet, and fo they thriue well. Many doe vfe to fowe all or the moft forts of Pot-herbes together on one plot of ground, that they neede not to goe farre to gather all the forts they would vfe. There are many forts of them well knowne vnto all, yet few or none doe vfe all forts, but as euery one liketh; forne vfe thofe that others refure, and fome efteem thofe not to bee wholefome and of a good rellifh, which others make no fcruple of. The names of them are as followeth, and a fhort relation of their fowing or planting.

Rofemary, Tyme, and Sauorie are fpoken of before, and Onions and Leekes.

Mints are to bee fet with their rootes in fome by-place, for that their rootes doe creepe fo farre vnder ground, that they quickly fill vp the places neare adioyning, if they be not puld vp.

Clarie is to be fowne, and feedeth and dyeth the next yeare, the herbe is itrong, and therefore a little thereof is fufficient.

Nep is fowne, and dyeth often after feeding, few doe vfe it, and that but a little at a time: both it and Clarie are more vfed in Tanfies then in Broths.

Coftmarie is to be fet of rootes, the leaues are vfed with forne in their Broths, but with more in their Ale.

Pot Marierome is fet of rootes, being feparated in funder.

Penniroyall is to be fet of the fmall heads that haue rootes, it creepeth and fpreadeth quickly.

Allifanders are to be fowne of feede, the tops of the rootes with the greene leaues are vfed in Lent efpecially.

Parley is a common herbe, and is fowne of feede, it feedeth the next yeare and dyeth: the rootes are more vfed in broths then the leaues, and the leaues almoft with all forts of meates.

Fennell is fowne of feede, and abideth many yeares yeelding feede : the rootes alfo are ved in broths, and the leaues more feldome, yet ferue to trimme vp many fifh meates.

Borage is fowne of feede, and dyeth the next yeare after, yet once being fuffered to feede in a Garden, will ltill come of it owne thedding. 
Bugloffe commeth of feede, but abideth many yeares after it hath giuen feede, if it ftand not in the coldeft place of the Garden.

Marigolds are fowne of feede, and may be after tranfplanted, they abide two or three yeares, if they be not $f e t$ in too cold a place : the leaues and flowers are both vfed.

Langedebeefe is fowne of feede, which thedding it felfe will hardly be deftroyed in a Garden.

Arrach is to be fowne of feede, this likewife will rife euery yeare of it owne feed, if it be fuffered to thed it felfe.

Beetes are fowne of feede, and abideth fome yeares after, ftill giuing feede.

Blites are vfed but in fome places, for there is a generall opinion held of them, that they are naught for the eyes: they are fowne euery yeare of feede.

Bloodwort once fowne abideth many yeares, if the extremity of the frofts kill it not, and feedeth plentifully.

Patience is of the fame nature, and vfed in the fame manner.

French Mallowes are to be fowne of feede, and will come of it owne fowing, if it be fuffered to thed it felfe.

Ciues are planted onely by parting the rootes; for it neuer giueth any feede at all.

Garlicke is ordered in the fame manner, by parting and planting the rootes euerie yeare.

Thefe be all the forts are vfed with vs for that purpore, whereas I faid before, none vfeth all, but euery one will vfe thofe they like beft : and fo much thall fuffice for potherbes.

\section{H A P. V I. \\ The manner and ordering of many forts of herbes and rootes for Sallets.}

T

F I thould fet downe all the forts of herbes that are vfually gathered for Sallets, I fhould not onely fpeake of Garden herbes, but of many herbes, \&c. that growe wilde in the fields, or elfe be but weedes in a Garden; for the vfuall manner with many, is to take the young buds and leaues of euery thing almoft that groweth, as well in the Garden as in the Fields, and put them all together, that the tafte of the one may amend the rellifh of the other: But I will only fhew you thofe that are fown or planted in gardens for that purpofe. Afparagus is a principall \& delectable Sallet herbe, whofe young thootes when they are a good handfull high aboue the ground, are cut an inch within the ground, which being boyled, are eaten with a little vinegar and butter, as a Sallet of great delight. Their ordering with the beft Gardiners is on this wife : When you haue prouided feede of the beft kinde, you muft fowe it either before Chriftmas, as moft doe, or before the end of February ; the later you fowe, the later and the more hardly will they fpring: after they are growne vp, they are to be tranfplanted in Autumne on a bed well trenched in with dung; for elfe they will not bee worth your labour, and fet about a foote diftance in funder, and looke that the more.carefull you are in the replanting of them, the better they will thriue, and the fooner growe great : after fiue or fix yeares ftanding they vfually doe decay; and therefore they that ftriue to haue continually faire and great heads, doe from feede raife vp young for their ftore. You muft likewife fee that you cut not your heads or young thoote too nigh, or too much, that is, to take away too many heads from a roote, but to leaue a fufficient number vncut, otherwife it will kill the heart of your rootes the fooner, caufing them to dye, or to giue very fmall heads or thootes; for you may well confider with your felfe, that if the roote have not head enough left it aboue the ground to thoote greene this yeare, it will not, nor cannot profper vnder ground to giue encreafe the next yeare. The ordering of Lettice I haue fpoken of before, and fhall not neede here to repeate what hath beene already faid, but referre you thereunto for the fowing, planting, \&c. onely I will here thew you the manner of ordering them for Sallets. There are fome forts of Lettice that growe very great, and clofe their heads, which are called Cab- 
bage Lettice, both ordinary and extraordinary, and there are other forts of great Lettice that are open, and clofe not, or cabbage not at all, which yet are of an excellent kinde, if they be vfed after that ef peciall manner is fit for them, which is, That when they are planted (for after they are fowne, they muft be tranfplanted) of a reafonable diftance in funder, and growne to be of fome bigneffe, euery one of them muft bee tyed together with baft or thread toward the toppes of the leaues, that by this meanes all the inner leaues may growe whitifh, which then are to be cut vp and vfed: for the keeping of the leaues clofe doth make them tafte delicately, and to bee very tender. And thefe forts of Lettice for the moft part are fpent after Summer is paft, when other Lettice are not to be had. Lambes Lettice or Corne Sallet is an herbe, which abiding all Winter, is the firt Sallet herbe of the yeare that is vfed before any ordinarie Lettice is ready; it is therefore vfually fowne in Auguft, when the feede thereof is ripe. Purflane is a Summer Sallet herbe, and is to be fowne in the Spring, yet fomewhat late, becaufe it is tender, and ioyeth in warmth; and therefore diuers haue fowne it vpon thofe beddes of dung, whereon they nourfed vp their Cowcumbers, Scc. after they are taken away, which being well and often watered, hath yeclded Sallet vntill the end of the yeare. Spinach is fowne in the Spring, of all for the molt part that vfe it, but yet if it be fowne in Summer it will abide greene all the Winter, and then feedeth quickly: it is a Sallet that hath little or no tafte at all therein, like as Lettice and Purflane, and therefore Cookes know how to make many a good difh of meate with it, by putting Sugar and Spice thereto. Coleworts are of diuers kinds, and although fome of them are wholly fpent among the poorer fort of people, yet fome kindes of them may be dreffed and ordered as may delight a curious palate, which is, that being boyled tender, the middle ribs are taken cold, and laid in difhes, and vinegar and oyle poured thereon, and fo eaten. Coleflowers are to be had in this Countrey but very feldome, for that it is harde to meete with good feede : it muft bee fowne on beds of dung to force it forward, or elfe it would perifh with the froft before it had giuen his head of flowers, and tranf planted into verie good and rich ground, left you lofe the benefit of your labours. Endiue is of two forts, the ordinary, and another that hath the edges of the leaues curld or crumpled; it is to be whited, to make it the more dainty Sallet, which is vfually done in this manner: After they are grown to fome reafonable greatneffe (but in any cafe before they fhoote forth a ftalke in the midnt for feede) they are to be taken vp, and the rootes being cut away, lay them to dry or wither for three or foure houres, and then bury them in fand, fo as none of them lye one vpon another, or if you can, one to touch another, which by this meanes will change whitifh, and thereby become verie tender, and is a Sallet both for Autumne and Winter. Succorie is vfed by fome in the fame manner, but becaufe it is more bitter then Endiue, it is not fo generally vfed, or rather vfed but of a verie few: and whereas Endiue will feede the fame yeare it is fowne, and then dye, Succorie abideth manie yeares, the bitternefle thereof caufing it to be more Phyficall to open obftructions; and therefore the flowers pickled vp, as divers other flowers are vfed to be now adaies, make a delicate Sallet at all times when there is occafion to vfe them. Of red Beetes, the rootes are onely vfed both boyled and eaten cold with vinegar and oyle, and is alfo vfed to trimme vp or garnilh forth manie forts of difhes of meate: the feede of the beft kinde will not abide good with vs aboue three yeares, but will degenerate and growe worfe; and therefore thofe that delight therein muft be curious, to be prouided from beyond Sea, that they may haue fuch as will giue delight. Sorrell is an herbe fo common, and the vfe fo well kriowne, both for fawce, and to feafon broths and meates for the found as well as ficke perfons, that I fhall not neede to fay anie more thereof. Cheruill is a Sallet herbe of much vfe, both with French and Dutch, who doe much more delight in herbes of ftronger tafte then the Englifh doe: it is fowne early, and vfed but a while, becaufe it quickly runneth vp to feede. Swcete Cheruill, or as fome call it, Sweete Cis, is fo like in tafte vnto Anife feede, that it much delighteth the tafte among other herbes in a Sallet : the feede is long, thicke, blacke, and cornered, and muft be fowne in the end of Autumne, that it may lye in the ground all the Winter, and then it will thoote out in the Spring, or elfe if it be fowne in the Spring, it will not fpring vp that yeare vntill the next : the leaues (as I faid before) are vfed among other herbes: the rootes likewife are not onely cordiall, but alio held to be preferuatiue againt the Plague, either greene, dryed, or preferued 
with fugar. Rampion rootes are a kinde of Sallet with a great many, being boyled tender, and eaten cold with vinegar and pepper. Creffes is an herbe of eafie and quick growth, and while it is young eaten eyther alone, or with parley and other herbes: it is of a ftrong tafte to them that are not accuftomed thereunto, but it is much vfed of ftrangers. Rocket is of the fame nature and qualitie, but fomewhat ftronger in tafte: they are both fowen in the Spring, and rife, feede and dye the fame yeare. Tarragon is an herbe of as ftrong a tafte as eyther Rocket or Creffes, it abideth and dyeth not euery yeare, nor yet giueth ripe feede (as far as euer could bee found with vs) any yeare, but maketh fufficient increafe within the ground, fpreading his roots all abroad a great way off. Muftard is a common fawce both with fifh and fleeh, and the feede thereof (and no part of the plant befides) is well knowne how to be vfed being grownded, as euery one I thinke knoweth. The rootes of horfe Radifh likewife beeing grownd like Muftard, is vfed both of ftrangers and our owne nation, as fawce for fifh. Tanfie is of great vfe, almoft with all manner of perfons in the Spring of the yeare: it is more vfually planted of the rootes then otherwife; for in that the rootes fpread far and neere they may be eafily taken away, without any hurt to the reft of the rootes. Burnet, although it be more vfed in wine in the Summer time then any way elfe, yet it is likewife made a fallet herbe with many, to amend the harfh or weak rellifh of fome other herbs. Skirrets are better to be fowen of the feed then planted from the roots, and will come on more fpeedily, and be fairer rootes : they are as often eaten cold as a Sallet, being boyled and the pith taken out, as ftewed with butter and eaten warme. Let not Parlley and Fenell be forgotten among your other Sallet herbes, whereof I haue fpoken before, and therefore need fay no more of them. The flowers of Marigolds pickt cleane from the heads, and pickled vp againft winter, make an excellent Sallet when no flowers are to be had in a garden. Cloue Gilloflowers likewife preferued or pickled vp in the fame Inanner (which is Aratum fuper fratum, a lay of flowers, and then ftrawed ouer with fine dry and poudered Sugar, and fo lay after lay ftrawed ouer, vntill the pot bee full you meane to keepe them in, and after filled vp or couered ouer with vinegar) make a Sallet now adayes in the higheft elteeme with Gentles and Ladies of the greateft note : the planting and ordering of them both is fpoken of feuerally in their proper places. Goates bearde that groweth in Gardens only, as well as that which groweth wilde in Medowes, \&cc. bearing a yellow flower, are vfed as a Sallet, the rootes beeing boyled and pared are eaten cold with vinegar, oyle and pepper; or elfe ftewed with butter and eaten warme as Skirrets, Parfneps \&cc. And thus haue you here fet downe all thofe moft vfuall Sallets are vfed in this Kingdome: I fay the moft vfuall, or that are nourfed vp in Gardens; for I know there are fome other wilde herbes and rootes, as Dandelion \&c. but they are vfed onely of ftrangers, and of thofe whofe curiofitie fearcheth out the whole worke of nature to fatisfie their defires.

\section{С н А P. VII. \\ Of diuers Phyficall herbes fit to be planted in Gardens, to ferue for the especiall ves of a familie.}

$\mathrm{H}$ Auing thus fhewed you all the herbes that are moft vfually planted in Kitchen Gardens for ordinary vfes, let mee alfo adde a few other that are alfo nourfed vp by many in their Gardens, to preferue health, and helpe to cure fuch fmall difeafes as are often within the compaffe of the Gentlewomens skils, who, to helpe their owne family, and their poore neighbours that are farre remote from Phyfitians and Chirurgions, take much paines both to doe good vito them, and to plant thofe herbes that are conducing to their defires. And although I doe recite fome that are mentioned in other places, yet I thought it meete to remember them altogether in one place. Angelica, the garden kinde, is fo good an herbe, that there is no part thereof but is of much vfe, and all cordiall and preferuatiue from infectious or contagious difeafes, whether you will diftill the water of the herbe, or preferue or candie the rootes or the greene ftalkes, or vfe the feede in pouder or in dittillations, or decoctions with other things : it is fowen of feede, and will abide vntill 
it giue feede, and then dyeth. Rue or Herbe grace is a ftrong herbe, yet vfed inwardly againt the plague as an Antidote with Figs and Wall-nuts, and helpeth much againft windy bodies: outwardly it is vfed to bee layde to the wreftes of the hands, to driue away agues : it is more vfually planted of nips then raifed from feede, and abideth long if tharpe froftes kill it not. Dragons being diftilled are held to be good to expell any euill thing from the heart : they are altogether planted of the rootes. Setwall, Valerian, or Capons tayle, the herbe often, but the roote much better, is vfed to prouoke fweating, thereby to expell euill vapours that might annoy the heart : it is only planted of the rootes when they are taken vp, and the young replanted. Afarabacca, the leaues are often vfed to procure vomiting being ftamped, and the ftrained iuice to a little quantitie, put into a draught of ale and drunke, thereby to eafe the ftomacke of many euill and groffe humours that there lye and offend it ; diuers alfo take the leaues and rootes a little boyled in wine, with a little fpice added thereunto, to expell both tertian and quartan agues: the rootes of our Englifh growing is more aunileable for chefe purpofes then any outlandifh : it is planted by the roote; for I could neuer fee it fpring of feede. Mafterwort commeth fomewhat neere in propertie unto Angelica, and befides very effectuall to difperfe winde in the bodie, whether of the colicke or otherwife ; as alfo very profitable to comfort in all cold caufes : it yeeldeth feede, but yet is more vfually planted from the rootes being parted. Balme is a cordiall herbe both in fmell and tafte, and is wholly vfed for thofe purpofes, that is, to comfort the heart being diftilled into water either fimple or compound, or the herbe dryed and vfed : it is fet of the rootes being parted, becaufe it giueth no feede that euer I could obferue. Camomill is a common herbe well knowne, and is planted of the rootes in alleyes, in walkes, and on bankes to fit on, for that the more it is troden on, and preffed downe in dry weather, the clofer it groweth, and the better it will thriue : the vfe thereof is very much, both to warme and comfort, and to eafe paines being applyed outwardly after many fafhions: the decoction alfo of the flowers prouoketh fweat, and they are much vfed againft agues. Featherfew is an herbe of greater vfe for women then for men, to diffolue flatulent or windy humours, which caufeth the paines of the mother : fome vfe to take the iuice thereof in drinke for agues: it is as well fowen of the feede as planted of the rootes. Coftmary is vfed among thofe herbes that are put into ale to caufe it have a good rellifh, and to be fomewhat phyficall in the moneth of May, and doth helpe to prouoke vrine: it is fet of the rootes being parted. Maudlin is held to be a principall good herbe to open and cleanfe the liuer, and for that purpore is vfed many wayes, as in ale, in tanfies, and in broths \&c. the feed alfo is vfed, and fo is the herbe alfo formetimes, to kill the wormes in children: it is fowen of the feede, and planted alfo of the feparated rootes. Caffidonie is a fmall kinde of Lauender, but differing both in forme and qualitie : it is much vfed for the head to eafe paines thereof, as alfo put among other things to purge melancholicke difeafes: it is fowen of feede, and abideth not a winter vnleffe it bee well defended, and yet hardly giueth ripe feede againe with vs. Smallage is a great opening herbe, and much more then eyther Parfley or Fenell, and the rootes of them all are often vfed together in medicines: it is fowen of feede, and will not bee wanting in a Garden if once you fuffer it to fow it felfe. Cardus Benedictus, or the Bleffed Thifte, is much vfed in the time of any infection or plague, as alfo to expell any euill fymptome from the heart at all other times. It is vfed likewife to be boyled in poffet drink, \& giuen to them that haue an ague, to help to cure it by fweating or otherwife. It is vfually fowen of feed, and dyeth when it hath giuen feed. Winter Cherries are likewife nurfed vp in diuers gardens, for that their propertie is to give helpe to them that are troubled eyther with the ftopping or heate of their vrine: the herbe and berries are often diftilled, but the berries alone are more often vfed: after it is once planted in a garden it will runne vnder ground, \& abide well enough. Celondine is held to bee good for the iaundife, it is much vfed for to cleere dim eyes, eyther the iuice or the water dropped into them : it is fowen of feede, and being once brought into a garden, will hardly be weeded out ; the feede that fheddeth will fo fow it felfe, and therefore fome corner in a garden is the fitteft place for it. Tabacco is of two forts, and both vfed to be planted in Gardens, yet the Englifh kinde (as it is called) is more to be found in our Countrey Gardens then the Indian fort: the leaues of both forts indifferently, that is, of eyther of which is next at hand, being ftamped and boy- 
led eyther by it felfe, or with other herbes in oyle or hogs fuet, doe make an excellent falue for greene wounds, and alfo to clenfe old vlcers or fores; the iuice of the greene leaues drunke in ale, or a dryed leafe fteeped in wine or ale for a night, and the wine or ale drunke in the morning, prouoketh to caft, but the dryed leafe much ftronger then the greene: they are fowen of feede, but the Indian kinde is more tender, and will not abide a winter with vs abroade. Spurge that vfually groweth in Gardens, is a violent purger, and therefore it is needfull to be very carefull how it is vfed : the feede is more ordinarily vfed then any other part of the plant, which purgeth by vomiting in fome, and both vpwards and downwards in many; the iuice of the herbe, but ef pecially the milke thereof, is vfed to kill wartes : it is fowen of feede, and when it doth once fhed it felfe, it will ftill continue fpringing of the fallen feede. Bearefoote is fowen of feed, and will hardly abide tranfplanting vnleffe it bee while it is young; yet abideth diuers yeares, if it ftand not in too cold a place. This I fpeake of the greater kinde; for the lower fmall wilde kinde (which is the moft ordinary in this land) will neuer decay : the leaues are fometimes vfed greene, but moft vfually dryed and poudered, and giuen in drinke to them that haue the wormes: it purgeth melancholy, but efpecially the roots. In many Countries of this Land, and elfewhere, they vfe to thruft the ftalk of the great kinde through the eare or dewlap of Kine and Cattell, to cure them of many difeafes. Salomons Seale, or (as fome call it) Ladder to heauen, although it doth grow wilde in many places of this Land, yet is planted in Gardens: it is accounted an excellent wound herbe to confolidate, and binde, infomuch that many vfe it with good fucceffe to cure ruptures, and to ftay both the white and the red fluxe in women: it is planted altogether of the rootes, for I could neuer finde it fpring from the feede, it is fo ftrong. Comfry likewife is found growing wilde in many places by ditch fides, and in moift places, and therefore requireth fome moift places of the garden: it is wholly vfed for knitting, binding, and confolidating fluxes and wounds, to be applyed either inwardly or outwardly: The rootes are ftronger for thofe purpofes then any other parts of the plant. Licoris is much vfed now adaies to bee planted in great quantitie, euen to fill many acres of ground, whereof rifeth a great deale of profit to thofe that know how to order it, and haue fit grounds for it to thriue in ; for euery ground will not be aduantagious: It will require a very rich, deepe and mellow ground, eyther naturall or artificiall; but for a priuate houfe where a fmall quantitie will ferue, there needeth not fo much curiofitie: it is vfually planted of the top heads, when the lower rootes (which are the Licoris that is vfed) and the runners are cut from them. Some vfe to make an ordinary drinke or beuerage of Licoris, boyled in water as our vfuall ale or beere is with malt, which fermented with barme in the fame manner, and tunned vp, ferueth in ftead thereof, as I am credibly informed : It is otherwife in a manner wholly fpent for colds, coughes and rheumes, to expectorate flegme, but vfed in diuers formes, as in iuice, in decoctions, fyrrups, roules, trochifces, and the greene or dryed roote of it felfe.

And thefe are the molt ordinary Phyficall herbes that are vfed to be planted in gardens for the vfe of any Country familie, that is (as I faid before) farre remote from Phyfitians or Chirurgions abidings, that they may vfe as occafion ferueth for themfelues or their neighbours, and by a little care and paines in the applying may doe a great deale of good, and fometimes to them that haue not wherewith to fpend on themfelues, much leffe on Phyfitians or Chirurgions, or if they haue, may oftentimes receiue leffe good at their hands then at others that are taught by experience in their owne families, to be the more able to giue helpe to others. 

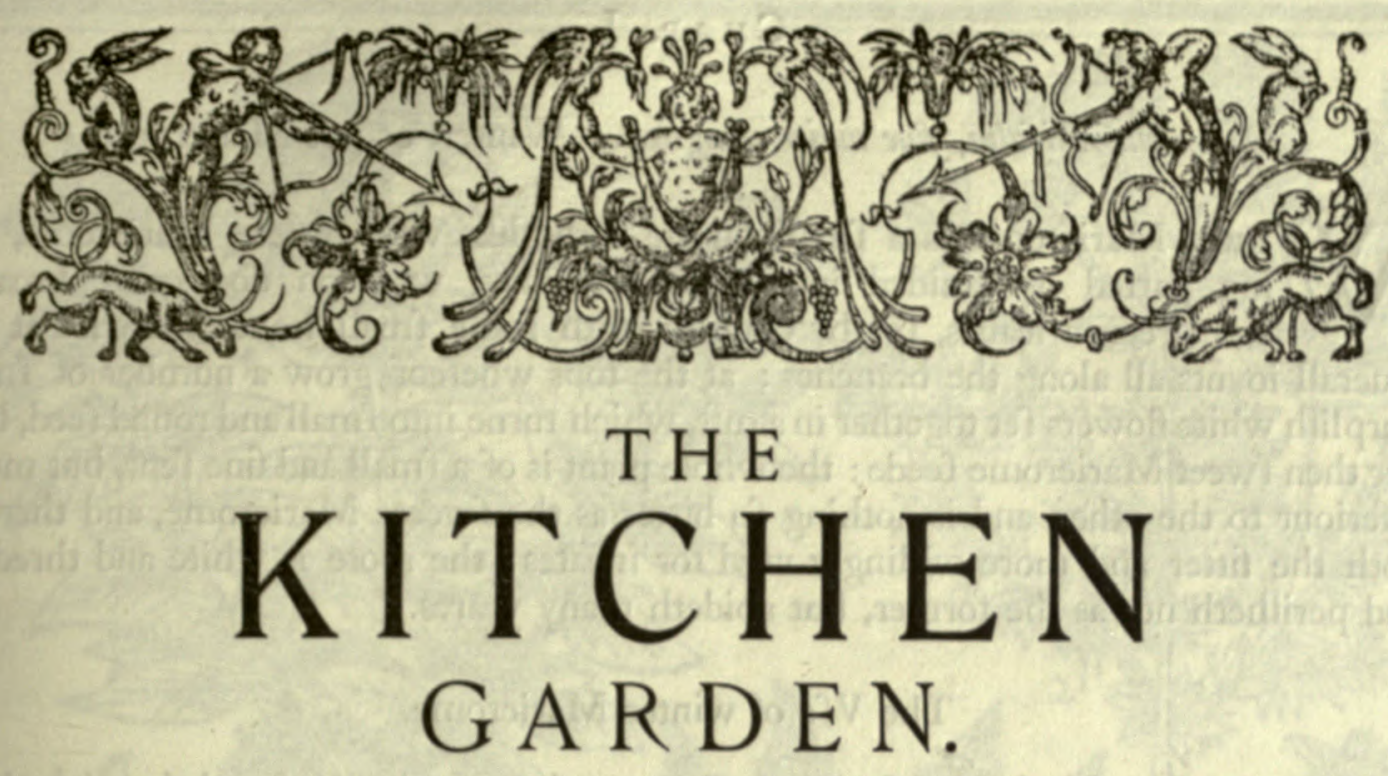

THE SECOND PART,

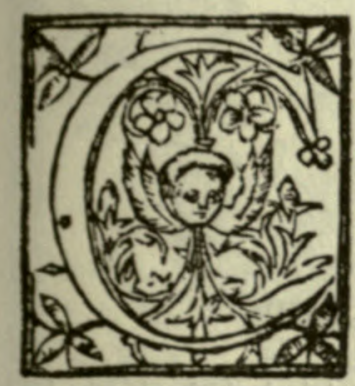

Ontaining as well all forts of herbes, as rootes and fruits, that are vfually planted in Gardens, to ferue for the vfe of the Table whether of the poore or rich of our Countrey: but herein I intend not to bring any fruite bearing trees, fhrubbes, or bufhes; for I referue them for my Orchard, wherin they fhal be fet forth. So that in thefe three parts, I fuppofe the exquifite ornament of any worthy houfe is confummate for the exteriour bounds, the benefit of their riches extending alfo to the furnifhing of the moft worthy inward parts thereof : but becaufe many take pleafure in the fight and knowledge of other herbes that are Phyficall, and much more in their properties and vertues, if vnto thefe three I fhould adde a Phyficke Garden, or Garden of Simples, there would be a quadripartite complement, of whatfoeuer arte or nature, neceffitie or delight could affect : which to effect (as many my friends haue intreated it at my hands) will require more paines and time then all this worke together : yet to fatisfie their defires and all others herein, that would bee enformed in the truth, and reformed of the many errours and flips fet forth and publifhed heretofore of plants by diuers, I thall (God affifting and granting life) labour to performe, that it may fhew it felfe to the light in due conueniencie, if thefe bee well and gratefully accepted. And becaufe I ended with fome fweete herbes in the former part, I will in this part beginne with the reft, which I referued for this place, as fitter for the pot and kitchen then for the hand or bofome, and fo defcend to other herbes that are for meat or fallets : and after them to thofe rootes that are to be eaten, as meate or as fallets: and laftly the fruits that grow neere, or vpon the ground, or not much aboue it; as the Artichoke, \&c. in which I make a fhorter defcription then I did in the former, rather endeauouring to fhew what they are, and whereunto they are vfed, then the whole varietie or any exact declaration: which methode, although in fome fort it may bee fitting for this purpofe, yet it is not for an hiftory or herball : I fhall therefore require their good acceptance for whofe fake I doe it, not doubting, but that I, or others, if they write againe of this fubiect, may polifh and amende what formerly hath beene eyther mif fet, or not fo thoroughly expreffed, befides fome additions of new conceits; feeing I treade out a new path, and therefore thofe that follow may the eafilier fee the Meanders, and fo goe on in a direct line. 
Снар. I.

Maiorana latifolia, fue maior Anglica. Winter, or pot Marierome.

W

Inter Marierome is a fmall bufhie herbe like vnto fweete Marierome, being parted or diuided into many branches, whereon doe grow broader and greener leaues, fet by couples, with fome fmall leaues likewife at the feuerall ioynts all along the branches: at the tops whereof grow a number of fmall purplifh white flowers fet together in a tuft, which turne into fmall and round feed, bigger then fweet Marierome feede: the whole plant is of a fmall and fine fent, but much inferiour to the other, and is nothing fo bitter as the fweete Marierome, and thereby both the fitter and more willingly vfed for meates: the roote is white and threddy, and perifheth not as the former, but abideth many yeares.

\section{The Vfe of winter Marierome.}

The vfe of this Marierome is more frequent in our Land then in others, being put among other pot-herbes and farfing (or fafeting herbes as they are called) and may to good profit bee applyed in inward as well as outward griefes for to comfort the parts, although weaker in effect then fweete Marieromes.

\section{CH A P. I I.}

\section{Thymum vulgatius fue durius. Ordinary Garden Tyme.}

T He ordinary Garden Tyme is a fmall low wooddy plant with brittle branches, and fmall hard greene leaues, as euery one knoweth, hauing fmall white purplifh flowers, ftanding round about the tops of the ftalkes: the feed is fmall and browne, darker then Marierome feed : the root is woody, and abideth well diuers Winters.

\section{Thymum latifolium. Mafticke Tyme.}

This Tyme hath neyther fo wooddy branches, nor fo hard leaues, but groweth lower, more fpreading; and with fomewhat broader leaues: the flowers are of a purplifh white colour, ftanding in roundles round about the ftalkes, at the ioynts with leaues at them likewife. This Tyme endureth better and longer then the former, and by fpreading it felfe more then the former, is the more apt to bee propagated by nipping, becaufe it hath beene feldome feene to giue feede : It is not fo quicke in fent or tafte as the former, but is fitter to fet any border or knot in a garden, and is for the moft part wholly employed to fuch vfes.

\section{The Vfe of Tyme.}

To fet downe all the particular vfes whereunto Tyme is applyed,.were to weary both the Writer and Reader; I will but only note out a few: for befides the phyficall vfes to many purpofes, for the head, ftomacke, fplene, \&cc. there is no herbe almoft of more vfe, in the houfes both of high and low, rich and poore, both for inward and outward occafions; outwardly for bathings among other hot herbes, and among other fweete herbes for ftrewings: inwardly in moft forts of broths, with Rofmary, as alfo with other fafeting (or rather farfing) herbes, and to make fawce for diuers forts both firh and flefh, as to ftuffe the belly of a Goofe to bee rofted, and after put into the fawce, and the pouder with breade to ftrew on meate when it 


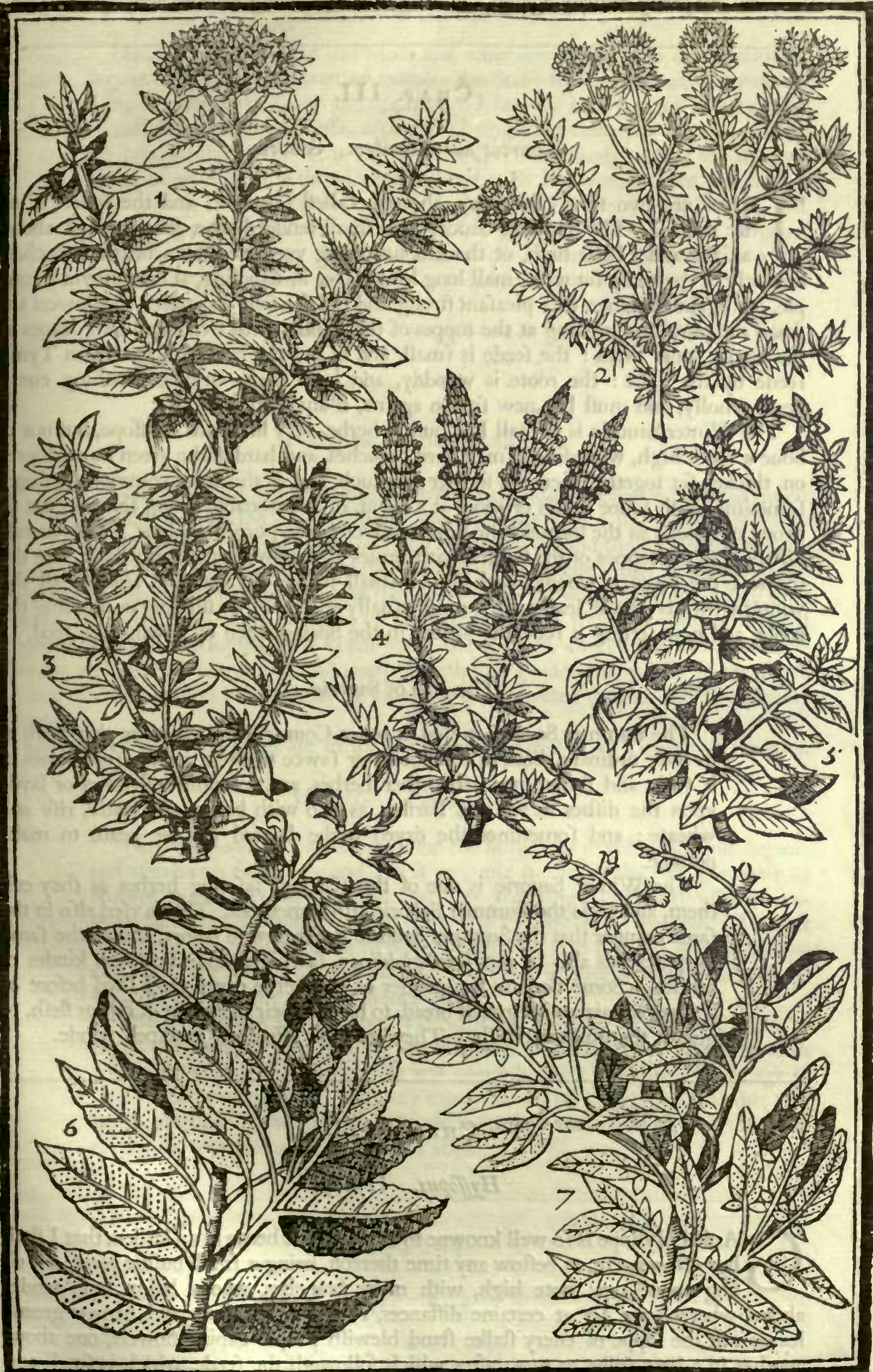

Maiorara maior Anglia. Pot Marierome Salurcia. Sauorie. Hyflope. 5 Pulegium. Penniroyall. 6 Saluia maior. Common Sage. 7 Saluia minor primala. Sage of vertue. 
is rofted, and fo likewife on rofted or fryed fifh. It is held by diuers to bee a fpeedy remedy againft the fting of a Bee, being bruifed and layd thereon.

\section{C н A P. I I I.}

Satureia fiue Thymbra. Sauorie.

T Here are two forts of Sauory, the one called Summer, and the other Winter Sauorie: The Summer Sauory is a fmall tender herbe, growing not aboue a foote and a halfe high, or thereabouts, rifing vp with diuers brittle branches, flenderly or fparfedly fet with fmall long leaues, foft in handling, at euery ioynt a couple, one againft another, of a pleafant ftrong and quicke fent and tafte: the flowers are fmall and purplifh, growing at the toppes of the ftalkes, with two fmall long leaues at the ioynts vnder them : the feede is fmall, and of a darke colour, bigger then Tyme feede by the halfe : the roote is wooddy, and hath many ftrings, perining euery yeare wholly, and muft bee new fowen againe, if any will haue it.

The Winter Sauorie is a fmall low bufhie herbe, very like vnto Hyffope, but not aboue a foote high, with diuers fmall hard branches, and hard darke green leaues thereon, thicker fet together then the former by much, and as thicke as common Hyffope, fometimes with foure leaues or more at a ioynt, of a reafonable ftrong fent, yet not $\mathrm{Co}_{0}$ ftrong or quicke as the former : the flowers are of a pale purplifh colour, fet at feuerall diftances at the toppes of the ftalkes, with leaues at the ioynts alfo with them, like the former: the roote is woody, with diuers fmall ftrings thereat, and abideth all the winter with his greene leaues: it is more vfually encreafed by flipping or diuiding the roote, and new fetting it feuerally againe in the Spring, then by fowing the feed.

The Vfe of Sauorie.

The Summer Sauorie is vfed in other Countryes much more then with vs in their ordinary diets, as condiment or fawce to their meates, fometimes of it felfe, and fometimes with other herbes, and fometimes ftrewed or layde vpon the difhes as we doe Parley, as alfo with beanes and peafe, rife and wheate; and fometimes the dryed herbe boyled among peafe to make pottage.

The Winter Sauorie is one of the (farfing) fafeting herbes as they call them, and fo is the Summer Sauorie alfo fometimes. This is vfed alfo in the fame manner that the Summer Sauorie is, fet downe before, and to the fame purpofes: as alfo to put into puddings, fawfages, and fuch like kindes of meates. Some doe vfe the pouder of the herbe dryed (as I fayd before of Tyme) to mixe with grated bread, to breade their meate, be it fifh or flefh, to giue it the quicker rellifh. They are both effectuall to expell winde.

\section{CH A P. I I I I.}

\section{Hydopus. Hyffope.}

G

Arden Hyffope is fo well knowne to all that haue beene in a Garden, that I thall but actum agere, to beftow any time thereon, being a fmall bufhie plant, not rifing aboue two foote high, with many branches, woody below, and tender aboue, whereon are fet at certaine diftances, fundry fmall, long and narrow greene leaues: at the toppe of euery ftalke fand blewifh purple gaping flowers, one aboue another in a long fpike or eare: after which followeth the feede, which is fmall and blackifh : the rootes are compofed of many threddy ftrings; the whole plant is of a frong fweet rent. 
The Vfe of Hyffope.

Hyffope is much vfed in Ptifans and other drinkes, to help to expectorate flegme. It is many Countrey peoples medicine for a cut or greene wound, being bruifed with fugar and applyed. I finde it is alfo much commended againft the falling fickeneffe, ef pecially being made into pils after the manner before rehearfed. It is accounted a fpeciall remedy againft the fting or biting of an Adder, if the place be rubbed with Hyffope, bruifed and mixed with honey, falt and cummin feede. A decoction thereof with oyle, and annointed, taketh away the itching and tingling of the head, and vermine alfo breeding therein. An oyle made of the herbe and flowers, being annointed, doth comfort benummed finewes and ioynts.

\section{C н А P. V.}

\section{Pulegium. Pennyroyall.}

Ennyroyall alfo is an herbe fo well knowne, that I fhall not neede to fpend much time in the defcription of it : hauing many weake round ftalkes, diuided into fundry branches, rather leaning or lying vpon the ground then ftanding vpright, whereon are fet at feuerall ioynts, fmall roundifh darke greene leaues: the flowers are purplifh that grow in gardens, yet fome that grow wilde are white, or more white then purple, fet in roundles about the tops of the branches; the ftalkes fhoote forth fmall fibres or rootes at the ioynts, as it lyeth vpon the ground, thereby faftening it felfe therein, and quickly increafeth, and ouer-runneth any ground, ef pecially in the fhade or any moift place, and is replanted by breaking the fprouted ftalkes, and fo quickely groweth.

Other forts of Pennyroyall are fit for the Phyficke Garden, or Garden of Simples.

\section{The Vfe of Pennyroyall.}

It is very good and wholefome for the lunges, to expell cold thin flegme, and afterwards to warme and dry it vp: and is alfo of the like propertie as Mintes, to comfort the ftomacke, and ftay vomiting. It is alfo vfed in womens baths and wafhings: and in mens alfo to comfort the finewes. It is yet to this day, as it hath beene in former times, vfed to bee put into puddings, and fuch like meates of all forts, and therefore in diuers places they know it by no other name then Pudding-graffe.

The former age of our great Grandfathers, had all thefe hot herbes in much and familiar vfe, both for their meates and medicines, and therewith preferued themfelues in long life and much health: but this delicate age of ours, which is not pleafed with any thing almoft, be it meat or medicine, that is not pleafant to the palate, doth wholly refufe thefe almoft, and therefore cannot be partaker of the benefit of them.

\section{CHA P. VI. \\ Salvia. Sage.} dinary vfe, whereof I intend to write in this place, leauing the reft to his fitter place. Our ordinary Sage is reckoned to bee of two forts, white and red, 
both of them bearing many foure fquare wooddy ftalkes, in fome whiter, in others redder, as the leaues are alfo, ftanding by couples at the ioynts, being long, rough, and wrinkled, of a ftrong fweete fent : at the tops of the ftalkes come forth the flowers, fet at certaine fpaces one aboue another, which are long and gaping, like vnto the flowers of Clary, or dead Nettles, but of a blewifh purple colour; after which come fmall round feede in the huske that bore the flower: the roote is wooddy, with diuers ftrings at it: It is more vfually planted of the flips, pricked in the Spring time into the ground, then of the feed.

\section{Saluia minor fuce pinnata. Small Sage or Sage of vertue.}

The leffer Sage is in all things like vnto the former white Sage, but that his branches are long and flender, and the leaues much fmaller, hauing for the moft part at the bottome of each fide of the leafe a peece of a leafe, which maketh it thew like finns or eares: the flowers alfo are of a blewifh purple colour, but leffer. Of this kinde there is one that beareth white flowers.

The Vfe of Sage.

Sage is much vfed of many in the moneth of May fafting, with butter and Parley, and is held of moft much to conduce to the health of mans body.

It is alfo much vfed among other good herbes to bee tund vp with Ale, which thereupon is termed Sage Ale, whereof many barrels full are made, and drunke in the faid moneth chiefly for the purpofe afore recited: and alfo for teeming women, to helpe them the better forward in their childebearing, if there be feare of abortion or mifcarrying.

It is alfo vfed to be boyled among other herbes, to make Gargles or waters to wafh fore mouths and throates: As alfo among other herbes, that ferue as bathings, to warh mens legs or bodies in the Summer time, to comfort nature, and warme and Atrengthen aged cold finewes, and lengthen the ftrength of the younger.

The Kitchen vfe is either to boyle it with a Calues head, and being minced, to be put with the braines, vinegar and pepper, to ferue as an ordinary fawce thereunto: Or being beaten and iuyced (rather then minced as manie doe) is put to a rofted Pigges braines, with Currans for fawce thereunto. It is in fmall quantity (in regard of the ftrong tafte thereof) put among other fafting herbes, to ferue as fawce for peeces of Veale, when they are farfed or ftuffed therewith, and rofted, which they call Olliues.

For all the purpofes aforefaid, the fmall Sage is accounted to be of the more force and vertue.

\section{CнA P. VII.}

\section{Horminum Jativum. Garden Clary.}

$\mathrm{T}$ Here is but one fort of Garden Clary, though many wilde, which hath foure fquare Atalks, with broad rough wrinkled whitifh leaues, fomewhat vneuenly cut in on the edges, and of a ftrong fweete fent, growing fome next the ground, $\&$ fome by couples vpon the ftalkes: the flowers growe at certaine diftances, with two fmall leaues at the ioynts vnder them, fomewhat like vnto the flowers of Sage, but leffer, and of a very whitifh or bleake blew colour: the feede is of a blackith browne colour, fomewhat flat, and not fo round as the wilde: the rootes fpread not farre, and perifh euery yeare that they beare flowers and feede. It is altogether to bee fowne of feed in the Spring time, yet fometimes it will rife of it owne fowing. 


\section{The Vfe of Clary.}

The moft frequent and common vfe of Clary, is for men or women that haue weake backes, to helpe to comfort and ftrengthen the raines, being made into Tanfies and eaten, or otherwife. The feede is vfed of fome to be put into the corner of the eye, if any mote or other thing haue happened into it: but affuredly although this may peraduenture doe fome good, yet the feede of the wilde will doe much more. The leaues taken dry, and dipped into a batter made of the yolkes of egges, flower, and a little milke, and then fryed with butter vntill they be crifpe, ferue for a difh of meate accepted with manie, vnpleafant to none.

\section{Cha P. VIII.}

\section{Nepeta. Nep.}

Lthough thofe that are Herbarifts do know three forts of Nep, a greater \& two leffer, yet becaufe the leffer are not vfuall, but in the Gardens of thofe that delight in natures varieties, I do not here fhew you them. That which is vfuall (and called of manie Cat Mint) beareth fquare ftalkes, but not fo great as Clarie, hauing two leaues at euery ioynt, fomewhat like vnto Balme or Speare Mintes, but whiter, fofter, and longer, and nicked about the edges, of a ftrong fent, but nothing fo ftrong as Clary : the flowers growe at the toppes of the ftalkes, as it were in long fpikes or heads, fomewhat clofe together, yet compaffing the ftalkes at certaine ioynts, of a whitifh colour, for forme and bigneffe like vnto Balme, or fomewhat bigger: the rootes are compofed of a number of ftrings, which dye not, but keepe greene leaues vpon them all the Winter, and fhoote anew in the Spring. It is propagated both by the feede, and by flipping the rootes.

\section{The Vfe of Nep.}

Nep is much vfed of women either in baths or drinkes to procure their feminine courfes: as alfo with Clarie, being fryed into Tanfies, to ftrengthen their backes. It is much commended of fome, if the iuyce thereof be drunke with wine, to helpe thofe that are bruifed by fome fall, or other accident. A decoction of Nep is auaileable to cure the fcabbe in the head, or other places of the body.

\section{CHAP. I X.}

\section{Meliffa. Baulme.}

$7 \mathrm{He}$ Garden Baulme which is of common knowne vfe, hath diuers fquare blackifh greene ftalkes, and round, hard, darke, greene pointed leaues, growing thereon by couples, a little notched about the edges, of a pleafant fweete fent, drawing neareft to the fent of a Lemon or Citron; and therefore of fome called $\mathrm{Ci}$ trago: the flowers growe about the toppes of the ftalkes at certaine diftances, being fmall and gaping, of a pale carnation colour, almoft white: the rootes faften themfelues ftrongly in the ground, and endure many yeares, and is encreafed by diuiding the rootes; for the leaues dye downe to the ground euery yeare, leauing no fhew of leafe or ftalke in the Winter. 


\section{The Vfe of Baulme.}

Baulme is often vfed among other hot and fweete herbes, to make baths and wafhings for mens bodies or legges, in the Summer time, to warme and comfort the veines and finewes, to very good purpofe and effect, and hath in former ages beene of much more vfe then now adaies. It is alfo vfed by diuers to be ftilled, being fteeped in Ale, to make a Baulme water, after the manner they haue beene taught, which they keepe by them, to vfe in the ftead of Aqua vita, when they haue any occafion for their owne or their neighbours Families, in fuddaine qualmes or paffions of the heart: but if they had a little better direction (for this is fomewhat too rude) it would doe them more good that take it: For the herbe without all queftion is an excellent helpe to comfort the heart, as the very fmell may induce any fo to beleeue. It is alfo good to heale greene wounds, being made into falues: and I verily thinke, that our forefathers hearing of the healing and comfortable properties of the true naturall Baulme, and finding this herbe to be fo effectuall, gaue it the name of Baulme, in imitation of his properties and vertues. It is alfo an herbe wherein Bees doe much delight, as hath beene found by experience of thofe that haue kept great ftore; if the Hives bee rubbed on the infide with fome thereof, and as they thinke it draweth others by the fmell thereof to refort thither. Plinie faith, it is a prefent remedy againt the ftinging of Bees.

\section{CH A P. X.}

\section{Mentha. Mintes.}

T

Here are diuers forts of Mints, both of the garden, and wilde, of the woods, mountaines, and ftanding. pooles or waters: but I will onely in this place bring to your remembrance two or three forts of the molt vfuall that are kept in gardens, for the vfes whereunto they are proper.

Red Mint or browne Mint hath fquare brownifh ftalkes, with fomewhat long and round pointed leaues, nicked about the edges, of a darke greene colour, fet by couples at euery ioynt, and of a reafonable good fent : the flowers of this kinde are reddifh, ftanding about the toppes of the ftalkes at diftances: the rootes runne creeping in the ground, and as the reft, will hardly be cleared out of a garden, being once therein, in that the fmalleft peece thereof will growe and encreafe apace.

Speare Mint hath a fquare greene ftalke, with longer and greener leaues then the former, fet by couples, of a better and more comfortable fent, and therefore of much more vfe then any other: the flowers hereof growe in long eares or fpikes, of a pale red or blufh colour: the rootes creepe in the ground like the other.

Party coloured or white Mint hath fquare greene ftalkes and leaues, fomewhat larger then Speare Mint, and more nicked in the edges, whereof many are parted, halfe white and halfe greene, and fome more white then greene, or more green then white, as nature lifteth: the flowers ftand in long heads clofe fet together, of a blufh colour: the rootes creepe as the reft doe.

\section{The Vfe of Mintes.}

Mintes are oftentimes vfed in baths, with Baulme and other herbes, as a helpe to comfort and ftrengthen the nerues and finewes.

It is much vfed either outwardly applyed, or inwardly drunke, to itrengthen and comfort weake ftomackes, that are much giuen to cafting: as alfo for feminine fluxes. It is boyled in milke for thofe whofe ftomackes are 


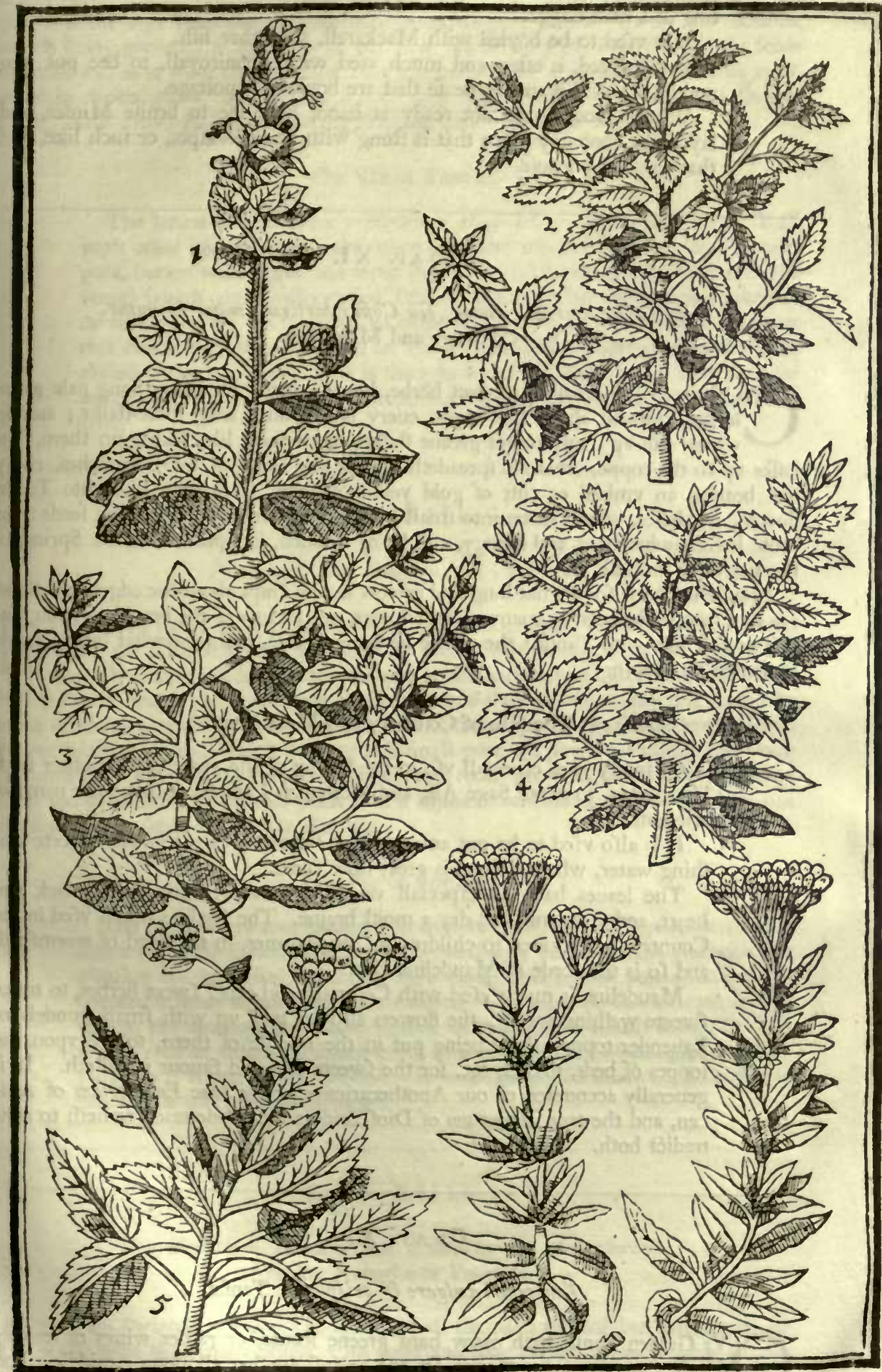

1 Horminum jatisum. Garden Clary. 2 Nepela. Nep. 3 Meliffa. Baulme. 4 Mentha Fatiua. Garden Mintes. Balfamita mas, 'ex Cofius hortorum. Coftmary. 6 Agcrurum. Maudeline, 
apt to caure it to curdle. And applyed with falt, is a good helpe for the biting of a mad dogge.

It is vfed to be boyled with Mackarell, and other filh.

Being dryed, is often and much vfed with Penniroyall, to bee put into puddings : as alfo among peafe that are boyled for pottage.

Where Dockes are not ready at hand, they vfe to bruife Mintes, and lay them vpon any place that is ftung with Bees, Waipes, or fuch like, and that to good purpofe.

\section{Cн A P. X I.}

\section{Balfamita mas E famina, feu Coftus hortorum maior E' minor. Coftmary and Maudeline.}

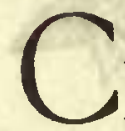
Oftmary or Alecoaft is a fweet herbe, bearing many broad and long pale green leaues, fnipped about the edges, euery one vpon a long foote-ftalke; among which rife vp many round greene ftalkes, with fuch like leaues on them, but leffer vp to the toppe, where it fpreadeth it felfe into three or foure branches, euery one bearing an vmbell or tuft of gold yellow flowers, fomewhat like vnto Tanfie flowers, but leffer, which turne into fmall heads, containing fmall flat long feede: the roote is fomewhat hard and Atringy, and being diuided, is replanted in the Spring of the yeare for increafe.

Maudeline hath fomewhat long and narrow leaues, fnipt about the edges: the ftalks are two foot high, bearing many yellow flowers on the tops of the branches, in an vmbell or tuft like vnto Tanfie: the whole herbe is fweete, and fomewhat bitter, and is replanted by nipping.

The Vfe of Coftmary and Maudeline.

Coftmary is of efpeciall vfe in the Spring of the yeare, among other fuch like herbes, to make Sage Ale, and thereupon I thinke it tooke the name of Alecoaft.

It is alfo vfed to be put among other fweete herbes, to make fweete wafhing water, whereof there is great ftore fpent.

The leaues haue an efpeciall vertue to comfort both the ftomack and heart, and to warme and dry a moift braine. The feede is much vfed in the Country, to be giuen to children for the wormes, in the ftead of wormfeed, and $f_{0}$ is the feede of Maudeline alfo.

Maudeline is much vfed with Coftmary and other fweet herbes, to make fweete wafhing water : the flowers alfo are tyed vp with fmall bundels of Lauender toppes, thefe being put in the middle of them, to lye vpon the toppes of beds, preffes, \&c. for the fweete fent and fauour it cafteth. It is generally accounted of our Apothecaries to be the true Eupatorium of Auicen, and the true Ageratum of Diofcorides; but Dodonæus feemeth to contradict both.

\section{CH A P. XII.}

Tanacetum vulgare E crippum. Tanfie. 
fie, in others thinner and more fparfedly: It rifeth vp with many hard ftalks, whereon growe at the tops vpon the feuerall fmall branches gold yellow flowers like buttons, which being gathered in their prime, will hold the colour frefh a long time: the feede is fmall, and as it were chaffie: the roote creepeth vnder ground, and fhooteth vp againe in diuers places: the whole herbe, both leaues and flowers, are of a fharpe, ftrong, bitter fmell and tafte, but yet pleaf ant, and well to be endured.

\section{The Vfe of Tanfie.}

The leaues of Tanfie are vfed while they are young, either fhred fmall with other herbes, or elfe the iuyce of it and other herbes fit for the purpofe, beaten with egges, and fryed into cakes (in Lent and the Spring of the yeare) which are vfually called Tanfies, and are often eaten, being taken to be very good for the ftomack, to helpe to digeft from thence bad humours that cleaue thereunto: As alfo for weak raines and kidneyes, when the vrine paffeth away by drops: This is thought to be of more vfe for men then for women. The feed is much commended againft all forts of wormes in children.

\section{CHA P. XIII.}

\section{Pimpinella fue Sanguiforba. Burnet.}

B Vrnet hath many winged leaues lying vpon the ground, made of many fmall, round, yet pointed greene leaues, finely nicked on the edges, one fet againft another all along a middle ribbe, and one at the end thereof; from among which rife vp diuers round, and fometimes crefted browne ftalkes, with fome few fuch like leaues on them as growe belowe, but fmaller: at the toppes of the ftalkes growe fmall browne heads or knaps, which fhoote forth fmall purplifh flowers, turning into long and brownifh, but a little cornered feede: the roote groweth downe deepe, being fmall and brownifh : the whole plant is of a ftipticke or binding tafte or quality, but of a fine quicke fent, almoft like Baulme.

The Vfe of Burnet.

The greateft vfe that Burnet is commonly put vnto, is to put a few leaues into a cup with Claret wine, which is prefently to be drunke, and giueth a pleafant quicke tafte thereunto, very delightfull to the palate, and is accounted a helpe to make the heart merrie. It is fometimes alfo while it is young, put among other Sallet herbes, to giue a finer rellifh thereunto. It is alfo vfed in vulnerary drinkes, and to ftay fluxes and bleedings, for which purpofes it is much commended. It hath beene alfo much commended in contagious and peftilentiall agues.

\section{CHAP. X I I II.}

\section{Hippolapathum fativum, fue Rhabarbarum Monachorum.}

Monkes Rubarbe or Patience.

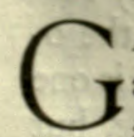

Arden Patience is a kinde of Docke in all the parts thereof,"but that it is larger and taller then many others, with large and long greene leaues, a great, ftrong, and high ftalke, with reddifh or purplifh flowers, and three fquare feede, like as all other Dockes haue : the roote is great and yellow, not hauing any fhew of flefh coloured veines therein, no more then the other kinde with great round thin leaues, 
commonly called Hippolapathum rotundifolium, Baftard Rubarbe, or Monkes Rubarbe, the properties of both which are of very weake effect : but I haue a kinde of round leafed Dock growing in my Garden, which was fent me from beyond Sea by a worthy Gentleman, $M^{r}$. D ${ }^{r}$. Matth. Lifter, one of the Kings Phyfitians, with this title, Rhaponticum verum, and firft grew with me, before it was euer feen or known elfewhere in England, $w^{\text {ch }}$ by proof I haue found to be fo like vnto the true Rubarbe, or the Rha of Pontus, both for forme and colour, that I dare fay it is the very true Rubarbe, our climate only making it leffe ftrong in working, leffe heauy, and leffe bitter in tafte: For this hath great and thicke rootes, as diuerfly difcoloured with flefh coloured veines as the true Rubarbe, as I have to thew to any that are defirous to fee and know it ; and alfo other fmaller fprayes or branches of rootes, fpreading from the maine great roote, which fmaller branches may well be compared to the Rhaponticum which the Merchants haue brought vs, which we haue feene to be longer and flenderer then Rubarbe, but of the very fame colour : this beareth fo goodly large leaues, that it is a great beauty in a garden to behold them : for I haue meafured the ftalke of the leafe at the bottome next the roote to bee of the bigneffe of any mans thumbe; and from the roote to the leafe it felfe, to bee two foote in length, and fometimes more; and likewife the leafe it felfe, from the lower end where it is ioyned to the ftalke, to the end or point thereof, to bee alfo two foote in length, and fometimes more; and alfo in the broadeft part of the leafe, to be two foote or more ouer in breadth: it beareth whitifh flowers, contrary to all other Dockes, and three fquare brownifh feede as other Dockes doe, but bigger, and therefore affuredly it is a Docke, and the true Rubarbe of the Arabians, or at the leaft the true Rhaponticum of the Ancients. The figure of the whole plant I haue caufed to be cut, with a dryed roote as it grew in my garden by it felfe, and haue inferted it here, both becaufe Matthiolus giueth a falfe figure of the true Rubarbe, and that this hath not been expreffed and fet forth by any before.

The Vfe of Patience, and of the Rubarbe.

The leaues of Patience are often, and of many vfed for a pot-herbe, and feldome to any other purpofe: the roote is often vfed in Diet-beere, or ale, or in other drinkes made by decoction, to helpe to purge the liuer, and clenfe the blood. The other Rubarbe or Rhaponticum, whereof I make mention, and giue you here the figure, I haue tryed, and found by experience to purge gently, without that aftriction that is in the true Rubarbe is brought vs from the Eaft Indies, or China, and is alfo leffe bitter in tafte; whereby I coniecture it may bee vfed in hot and feauerifh bodies more effectually, becaufe it doth not binde after the purging, as the Eaft India Rubarbe doth : but this muft bee giuen in double quantitie to the other, and then no doubt it will doe as well: The leaues haue a fine acide tafte: A ryrrupe therefore made with the iuice and fugar, cannot but be very effectuall in deiected appetites, and hot fits of agues; as alfo to helpe to open obftructions of the liuer, as diuers haue often tryed, and found auaileable by experience.

\section{Cна Р. XV. \\ Lapathum Sanguineum. Blood-wort.}

Mong the forts of pot-herbes Bloode-worte hath alwayes beene accounted a
principall one, although I doe not fee any great reafon therein, efpecially fee-
ing there is a greater efficacie of binding in this Docke, then in any of the o-
ther : but as common vfe hath receiued it, fo I here fet it downe. Blood-worte is one
of the forts of Dockes, and hath long leaues like vnto the fmaller yellow Docke, but
ftriped with red veines, and ouer-fhadowed with red vpon the greene leafe, that it fee-
meth almoft wholly red fometimes: the ftalke is reddifh, bearing fuch like leaues, but
fmaller 


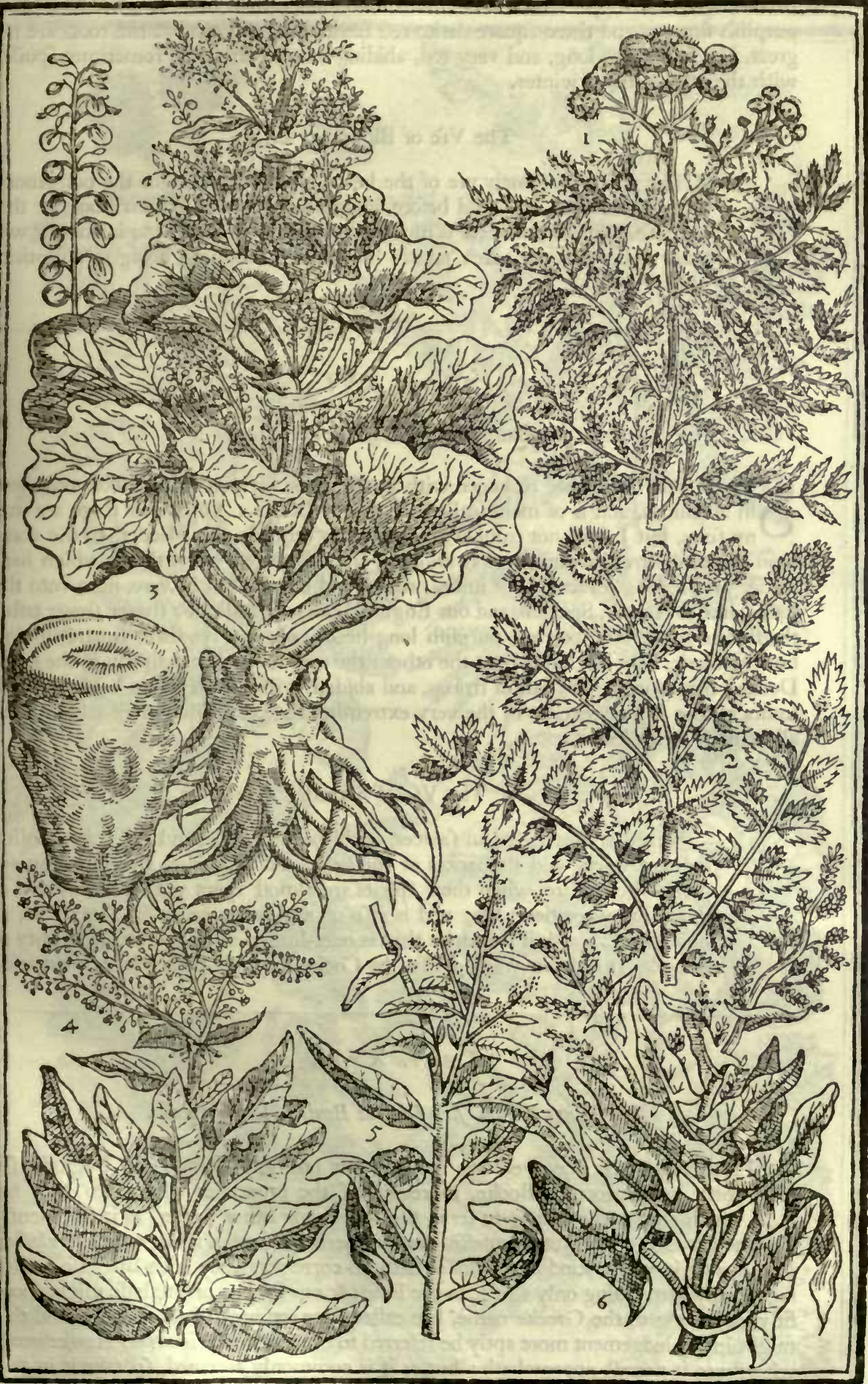

I Tanacelum. Tanfie. 2 Pimpinella. Burnet. 3 Rhapanticum zerum fou patiws Rhabarbarum verum. True Raponticke of rather true Rubarbe. +Lapathwm fatirum Seu Palientia. Monkes Rubarbe or Patience. 5 Lapalhum fanguinenm. Bloudwort. 
fmaller vp to the toppe, where it is diuided into diuers fmall branches, whereon grow purplifh flowers, and three fquare darke red feede, like vnto others: the roots are not great, but fomewhat long, and very red, abiding many yeares, yet fometimes fpoiled with the extremitie of winter.

The Vfe of Blood-worte.

The whole and onely vfe of the herbe almoft, ferueth for the pot, among other herbes, and, as I faid before, is accounted a moft ef peciall one for that purpofe. The feede therof is much commended for any fluxe in man or woman, to be inwardly taken, and fo no doubt is the roote, being of a ftipticke qualitie.

\section{C н А P. X VI.}

\section{Oxalis fue Acetofa. Sorrell.}

Orrell muft needes bee reckoned with the Dockes, for that it is fo like vnto them

S in all things, and is of many called the fower Docke. Of Sorrels there are many forts, but I thall not trouble you with any other in this place, then the common Garden Sorrell, which is moft knowne, and of greateft vfe with vs; which hath tender greene long leaues full of iuice, broade, and bicorned as it were, next vnto the ftalke, like as Arrach, Spinach, and our Englifh Mercurie haue, of a Sharpe fower tafte: the ftalkes are flender, bearing purplifh long heads, wherein lye three fquare fhining browne feede, like, but leffer then the other: the root is fmaller then any of the other Dockes, but browne, and full of ftrings, and abideth without decaying, hauing greene leaues all the winter, except in the very extremitie thereof, which often taketh away all or moft of his leaues.

The Vfe of Sorrell.

Sorrell is much vfed in fawces, both for the whole, and the ficke, cooling the hot liuers, and ftomackes of the ficke, and procuring vnto them an appetite vnto meate, when their fpirits are almoft fpent with the violence of their furious or fierie fits; and is alfo of a pleafant relifh for the whole, in quickning vp a dull ftomacke that is ouer-loaden with euery daies plenty of difhes. It is diuers waies dreffed by Cooks, to pleafe their Mafters ftomacks.

\section{Cна н. X VII.}

Buglofum luteum, fue Lingua Bouis. Langdebeefe.

$\mathrm{V}$ Nto this place may well bee referred our ordinary Borage and Bugloffe, fet forth in the former Booke, in regard of the properties whereunto they are much employed, that is, to ferue the pot among other herbes, as is fufficiently knowne vnto all. And yet I confeffe, that this herbe (although it bee called Buglo/fum luteum, as if it were a kind of Bugloffe) hath no correfpondency with Bugloffe or Borage in any part, fauing only a little in the leafe; \& our Borage or Bugloffe might more fitly, according to the Greeke name, bee called Oxe tongue or Langdebeefe; and this might in my iudgement more aptly be referred to the kinds of Hieratium Hawkeweed, whereunto it neereft approacheth: but as it is commonly receiued, fo take it in this place, vntill it come to receiue the place is proper for it. It hath diuers broad and long darke green leaues, lying vpon the ground, very rough in handling, full of fmall haires or prickes, ready to enter into the hands of any that handle it; among which rifeth 


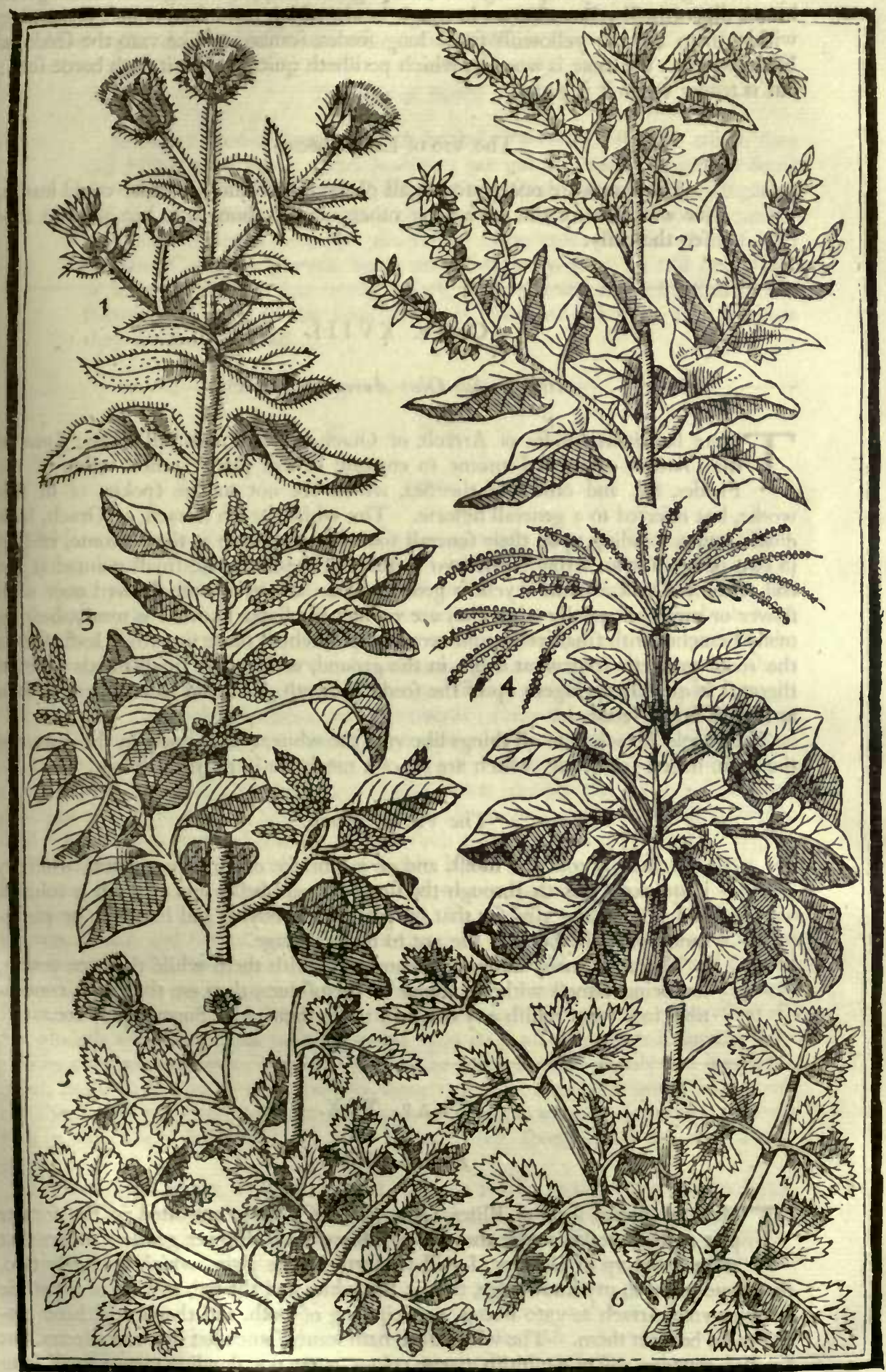


vp a round greene hairy or prickly ftalk, bearing at the toppe, among a few fmall green leaues, diuers fmall yellow flowers in rough heads, which turne into doune, containing within them browne yellowifh fmall long feedes, fomewhat like vnto the feede of Hawkeweede: the roote is wooddy, which perifheth quickly after it hath borne feed; but is tender while it is young.

The Vfe of Langdebeefe.

The leaues are onely vfed in all places that I know, or euer could learne, for an herbe for the pot among others, and is thought to bee good to loofen the belly.

\section{C н A P. X'V I I I.}

\section{Atriplex fue Olus Aureum. Arrach.}

$\mathrm{T}$ Here be diuers kindes of Arrach, or Orach, as fome doe call them; fome of the Garden, whereof I meane to entreate in this place; others wilde of the Fieldes, \&c. and others of the Sea, which are not to bee fpoken of in this worke, but referred to a generall hiftorie. The white garden Arrach, or Orach, hath diuers leaues, ftanding vpon their feuerall footeftalkes, broade at the bottome, ending in two points like an arrow, with two feathers at the head, and fmall pointed at the end of the leafe, of a whitifh yellow greene colour, and as it were ftrewed ouer with flower or meale, efpecially while they are young: the ftalke likewife is mealy, bearing many branches with fmall yellow flowers on them, which turne into fmall leafie feeds: the roote groweth fomewhat deepe in the ground, with many fmall threds faftened thereto: it quickly $f$ pringeth vp of the feede, groweth great, and fadeth away as foon as it hath borne feede.

The purple Arrach is in all things like vnto the white, fauing onely in the colour of the leafe, ftalke, feede, \&c. which are all of a mealy dufty purplifh colour.

The Vfe of Arrach.

Arrach is cold and moift, and of a lubricke or flippery qualitie, whereby it quickely paffeth through the ftomacke and belly, and maketh it foluble, and is of many vfed for that purpofe, being boyled and buttered, or put among other herbes into the pot to make pottage.

There are many difhes of meate made with them while they are young, for being almoft without fauour of themfelues, they are the more conuertible into what rellifh any one will make them with Sugar, Spice \&c.

\section{C н А P. XIX.}

\section{Blitum. Blites.}

7 Here be diuers forts of Blites, fome whereof I haue entreated in the former part of this worke, vnder the title of Amaranthus, Flower gentle: others that are nourfed $\mathrm{vp}$ in Gardens, I will fet forth in this place, which are onely two, that haue come to my knowledge, that is, the white and the red, and are of a qualitie as neere vnto Arrach as vnto Beetes, participating of both, and therefore I haue placed them betwixt them. The white Blite hath leaues fomewhat like vnto Beetes, but fmaller, rounder, and of a whitifh greene colour, euery one ftanding vpon a fmall long footeftalke: the ftalke rifeth vp two or three foote high, with many fuch like leaues thereon: the flowers grow at the top in long round tufts or clufters, wherein are con- 
tained fmall round feede : the roote is very full of threds or frings.

The red Blite is in all things like the white, but that his leaues and tufted heades are exceeding red at the firt, and after turne more purplifh.

The Vfe of Blites.

Blites are vfed as Arrach, eyther boyled of it felfe or ftewed, which they call Loblolly, or among other herbes to bee put into the pot; and yet fome doe vtterly refufe it, becaufe in diuers it prouoketh caftings. It is altogether infipide or without tafte, but yet by reafon of the moift nipperie qualitie it hath, it helpeth to loofen the belly. The vnfauorineffe whereof hath in many Countries growne into a prouerbe, or by-word, to call dull, flow, or lazie perfons by that name: They are accounted more hurtfull to the Itomacke, and fo to the head and eyes, then other herbes, and therefore they are the leffe vfed.

Cи A P. XX.

\section{Beta. Beetes.}

7 Here are many diuerfities of Beetes, fome growing naturally in our own Country, others brought from beyond Sen; whereof fome are white, fome greene, fome yellow, fome red: the leaues of fome are of vfe only, and the root not vfed : others the roote is only vfed, and not the leaues: and fome againe, both roote and leafe. The ancient Authors, as by their workes appeare, knew but two forts, the white and the blacke Beete, whereof the white is fufficiently known, and was of thein termed Sicula, of the later Phyfitians Sicla, becaufe it was thought firft to be brought from Sicilie : the blacke abideth fome controuerfie; fome thinking that our common greene Beete, becaufe it is of a darke greene colour, was that they called the blacke Beete; others that our fmall red Beete, which is of a darke red colour, was their black Beete, which in my opinion is the more likely : But to come to the matter in hand, and giue you the defcriptions of them which are in vfe with vs, and leaue controuerfies to fuch a worke as is fit for them, wherein all fuch matters may be difcuffed at large.

The common white Beete hath many great leaues next the ground (in fome hot Countries growing to be three foote long, and very broade, in our Countrey they are very large, but nothing neere that proportion) of a whitifh greene colour; the ftalke is great, ftrong, and ribbed or crefted, bearing great ftore of leaues vpon it vp to the very toppe almoft: the flowers grow in very long tufts, fmall at the ends, and turning down their heads, which are fmall pale greenifh yellow burres, giuing cornered prickly feede : the roote is great, long and hard, when it hath given feede, of no vfe at all, but abideth a former winter with his leaues vpon it, as all other forts following doe.

The common red Beet differeth not from the white Beete, but only that it is not fo great, and both the leaues and rootes are fornewhat red : the leaues bee in fome more red then in others, which haue but red veines or ftrakes in them, in fome alfo of a frefh red, in others very darke red: the roote hereof is red, fpongy, and not vfed to bee eaten.

The common greene Beete is alfo like vnto the white Beete, but of a darke greene colour. This hath beene found neere the falt Marfhes by Rochefter, in the foote-ivay going from the Lady Levefons houfe thither, by a worthy, diligent and painefull obferuer and preferuer both of plants and all other natures varieties, often remembred before in this worke, called Iohn Tradefcante, who there finding it, gaue me the knowledge thereof, and I haue vpon his report fet it here down in this manner:

The Romane red Beete, called Beta rapofa, is both for leafe and roote the moft excellent Beete of all others : his rootes bee as great as the greateft Carrot, exceeding red both within and without, very fweete and good, fit to bee eaten : this Beete groweth higher then the laft red Beete, whole rootes are not vfed to bee eaten: the leaues like- 
wife are better of tafte, and of as red a colour as the former red Beete : the roote is fometimes thort like a Turnep, whereof it took the name of Rapa or rapofa; and fometimes as I faid before, like a Carrot and long: the feede is all one with the leffer red Beete.

The Italian Beete is of much refpect, whofe faire greene leaues are very large and great, with great white ribbes and veines therein: the ftalke in the Summer time, when it is growen vp to any height, is fix fquare in fhew, and yellowith withall, as the heades with feede vpon them feeme likewife.

The great red Beete that Mafter Lete a Merchant of London gaue vnto Mafter Gerrard, as he fetteth it downe in his Herball, feemeth to bee the red kinde of the laft remembred Beete, whofe great ribbes as he faith, are as great as the middle ribbe of the Cabbage leafe, and as good to bee eaten, whofe ftalke rofe with him to the height of eight cubits, and bore plenty of feede.

\section{The Vfe of Beetes.}

Beetes, both white, greene and red, are put into the pot among other herbes, to make pottage, as is commonly known vnto all, and are alfo boyled whole, both in France vfually with moft of their boyled meates, and in our Countrey, with diuers that delight in eating of herbes.

The Italian Beete, and fo likewife the laft red Beete with great ribbes, are boyled, and the ribbes eaten in fallets with oyle, vinegar and pepper, and is accounted a rare kinde of fallet, and very delicate.

The roote of the common red Beete with fome, but more ef pecially the Romane red Beete, is of much vfe among Cookes to trimme or fet out their difhes of meate, being cut out into diuers formes and fafhions, and is grown of late dayes into a great cuftome of feruice, both for firh and flefh.

The rootes of the Romane red Beete being boyled, are eaten of diuers while they are hot with a little oyle and vinegar, and is accounted a delicate fallet for the winter; and being cold they are fo vfed and eaten likewife.

The leaues are much vfed to mollifie and open the belly, being vfed in the decoction of Glifters. The roote of the white kinde fcraped, and made vp with a little honey and falt, rubbed on and layd on the belly, prouoketh to the ftoole. The vie of eating Beetes is likewife held to bee helpefull to fpleneticke perfons.

\section{Cн А . XXI.}

\section{Hippofelinum, fue Olus atrum. Alifanders.}

A Lifanders hath beene in former times thought to be the true Macedonian Parnley, and in that errour many doe yet continue : but this place giueth not leaue to difcuffe that doubt : but I muft here only thew you, what it is, and to what vfe it is put ordinarily for the Kitchen. The leaues of Alifanders are winged or cut into many parts, fomewhat refembling Smallage, but greater, broader, and more cut in about the edges : the ftalkes are round and great, two foote high or better, bearing diuers leaues on them, and at the toppe fpokie roundles of white flowers on feuerall fmall branches, which turne into blacke feede, fomewhat cornered or crefted, of an aromaticall bitter tafte: the roote is blacke without, and white within, and abideth well the firft year of the fowing, perifhing after it hath borne feed.

\section{The Vfe of Alifanders.}

The tops of the rootes, with the lower part of the ftalkes of Alifanders, are vfed in Lent ef pecially, and Spring of the yeare, to make broth, which although it be a little bitter, yet it is both wholfome, and pleafing to a great 
many, by reafon of the aromaticall or fpicie tafte, warming and comforting the ftomack, and helping it digeft the many waterifh and flegmaticke meates are in thofe times much eaten. The rootes alfo either rawe or boyled are often eaten with oyle and vinegar. The feede is more vfed phyfically then the roote, or any other part, and is effectuall to prouoke plenty of vrine in them that piffe by drops, or haue the Strangury: It helpeth womens courfes, and warmeth their benummed bodies or members, that haue endured fierce cold daies and nights, being boyled and drunke.

\section{Cна Р. XXII.}

\section{Selinum dulce. Sweete Parfley or fweete Smallage.}

This kinde of fweete Parfley or Smallage, which foeuer you pleafe to call it, for it refembleth Smallage as well in the largeneffe of the leaues, as in the tafte, yet fweeter and pleafanter, is (as I take it) in this like vnto fweete Fennell (that hath his fweetneffe from his naturall foyle and clymate; for howfoeuer it bee reafonable fweete the firft yeare it is fowne with vs, yet it quickly doth degenerate, and becommeth no better then our ordinarie Fennell afterwards). The firft yeare it is fowne and planted with vs (and the firft that euer I faw, was in a Venetian Ambaffadours Garden in the Spittle yard, neare Bifhops gate ftreete) is fo fweete and pleafant, ef pecially while it is young, as if Sugar had beene mingled with it: but after it is growne vp high and large, it hath a ftronger tafte of Smalladge, and fo likewife much more the next yeare; that it groweth from the feed was gathered here: the leaues are many, fpreading farre about the roote, broader and of a frefher greene colour then our ordinary Smalladge, and vpon longer ftalkes: the feed is as plentifull as Parfley, being fmall and very like vnto it, but darker of colour.

\section{The Vfe of fweete Parfley.}

The Venetians vfe to prepare it for meate many waies, both the herbe and the roote eaten rawe, as many other herbes and rootes are, or boyled or fryed to be eaten with meate, or the dryed herbe poudered and ftrewed vpon meate; but moft vfually either whited, and fo eaten rawe with pepper and oyle, as a dainty Sallet of it felfe, or a little boyled or ftewed: the tafte of the herbe being a little warming, but the feede much more, helpeth cold windy ftomackes to digeft their meate, and to expell winde.

\section{CHA P. X XIII.}

\section{Petrofolinum \& Apium. Parfley and Smalledge.}

W E haue three forts of Parfley in our Gardens, and but one of Smalladge: Our common Parfley, Curld Parfley, and Virginia Parfley; which laft, although it be but of late knowne, yet it is now almoft growne common, and of as good vfe as the other with diuers. Our common Parfley is fo well knowne, that it is almoft needleffe to defcribe it, hauing diuers frefh greene leaues, three alwaies placed together on a ftalke, and fnipt about the edges, and three ftalkes of leaues for the moft part growing together: the ftalkes growe three or foure foote high or better, bearing fpikie heads of white flowers, which turne into fmall feede, fomewhat fharpe and hot in tafte: the roote is long and white.

Curld Parfley hath his leaues curled or crumpled on the edges, and therein is the onely difference from the former. 
Virginia Parney is in his leafe altogether like vnto common Parfley for the forme, confifting of three leaues fet together, but that the leaues are as large as Smallage leaues, but of a pale or whitifh greene colour, and of the fame tafte of our common Parley: the feede hereof is as the leaues, twice if not thrice as bigge as the ordinary Parfley, and perifheth when it hath giuen feede, abiding vfually the firft yeare of the fowing.

Smallage is in forme fomewhat like vnto Parfley, but greater and greener, and leffe pleafant, or rather more bitter in tafte: the feede is fmaller, and the root more ftringy.

\section{The Vfe of Parnley.}

Parfley is much vfed in all forts of meates, both boyled, roafted, fryed, ftewed, \&c. and being greene it ferueth to lay vpon fundry meates, as alfo to draw meate. withall. It is alfo thred and ftopped into poudered beefe, as alfo into legges of Mutton, with a little beefe fuet among it, \&cc.

The rootes are often vfed to be put into broth, to helpe to open obftructions of the liuer, reines, and other parts, helping much to procure vrine.

The rootes likewife boyled or ftewed with a legge of Mutton, ftopped with Parney as aforefaid, is very good meate, and of very good rellifh, as I haue proued by the tafte; but the rootes muft bee young, and of the firft yeares growth, and they will haue their operation to caufe vrine.

The feed alfo is vfed for the fame caufe, when any are troubled with the ftone, or grauell, to open the paffages of vrine.

Although Smallage groweth in many places wilde in moift grounds, yet it is alfo much planted in Gardens, and although his euill tafte and fauour doth caufe it not to be accepted into meates as Parfley, yet it is not without many fpeciall good properties, both for outward and inward difeafes, to helpe to open obftructions, and prouoke vrine. The iuyce cleanfeth vlcers; and the leaues boyled with Hogs greafe, healeth felons on the ioynts of the fingers.

\section{CH A.P. X XIIII.}

\section{Faniculum. Fenell.}

T Here are three forts of Fenell, whereof two are fweete. The one of them is the ordinary fweete Fenell, whofe feedes are larger and yellower then the common, and which (as I faid before in the Chapter of fweete Parlley) doth foone degenerate in this our Country into the common. The other fweete Fenell is not much knowne, and called Cardus Fenell by thofe that fent it out of Italy, whofe leaues are more thicke and bufhie then any of the other. Our common Fenell, whereof there is greene and red, hath many faire and large fpread leaues, finely cut and diuided into many fmall, long, greene, or reddifh leaues, yet the thicker tufted the branches be, the fhorter are the leaues: the ftalkes are round, with diuers ioynts and leaues at them, growing fiue or fix foot high, bearing at the top many fpoakie rundels of yellow flowers; the Common, I meane, doth turne into a darke grayilh flat feede, and the Sweete into larger and yellower: the roote is great, long, and white, and endureth diuers yeares.

\section{The Vfe of Fenell.}

Fenell is of great vfe to trimme vp, and ftrowe vpon fifh, as alfo to boyle or put among fifh of diuers forts, Cowcumbers pickled, and other fruits, \&c. The rootes are vfed with Parfley rootes, to be boyled in broths and drinkes to open obftructions. The feed is of much vfe with other things to expell winde. The feede alfo is much vfed to be put into Pippin pies, and diuers 


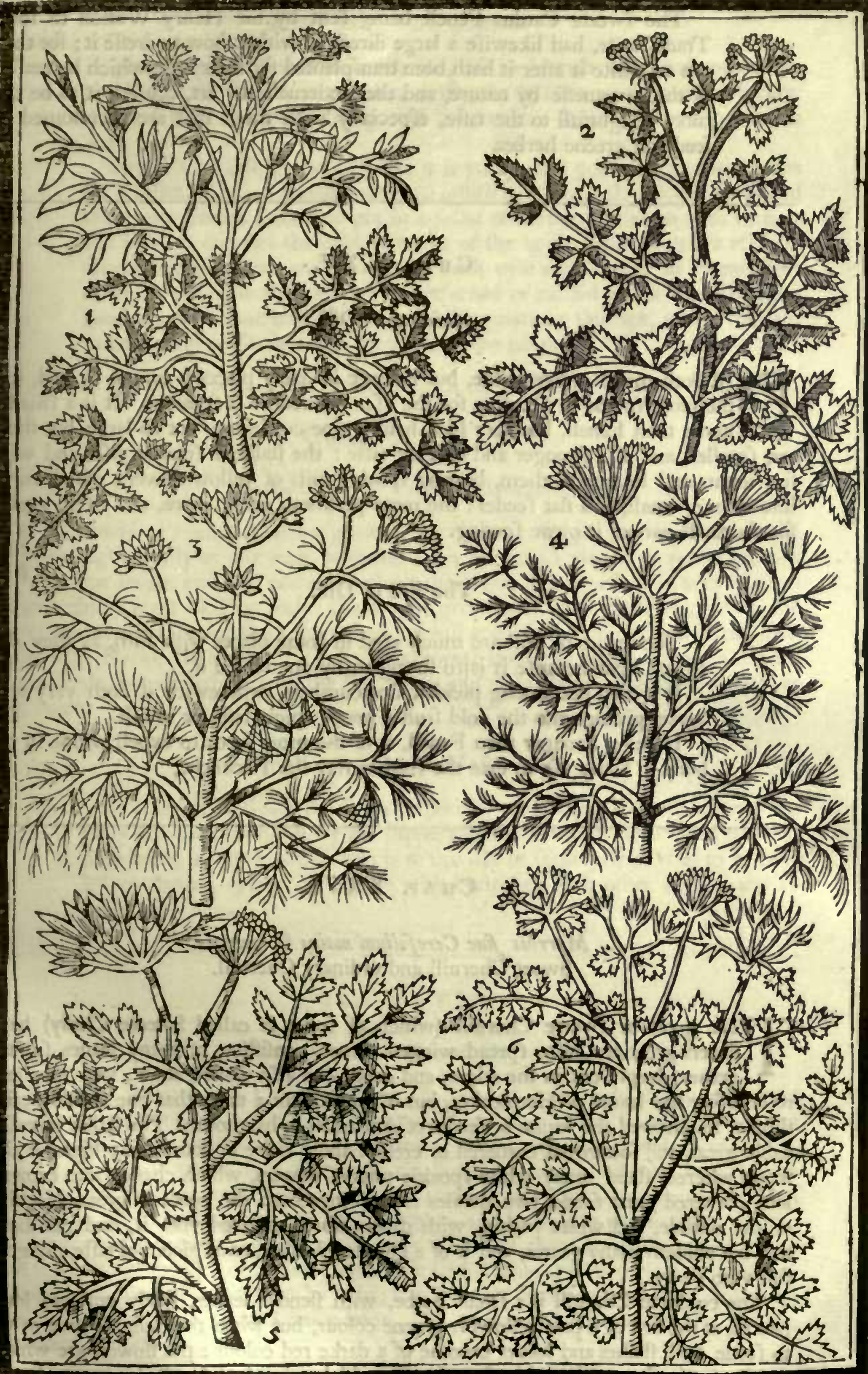

1 Petrofolinum. Particy. 2 Afium. Smallage.

Ficuiculum, Fenell. A Arethum, Dill.

5 Mfyrrlis fue Cerefolium magnum. Sweete Cheruill. 6 Cerefolium sulgare. Common Cheruill, 
other fuch baked fruits, as alfo into bread, to giue it the better rellifh.

The fweete Cardus Fenell being fent by Sir Henry Wotton to Iohn Tradefcante, had likewife a large direction with it how to dreffe it; for they vfe to white it after it hath been tranfplanted for their vfes, which by reafon of the fweetneffe by nature, and the tenderneffe by art, caufeth it to be the more delightfull to the tafte, ef pecially with them that are accuftomed to feede on greene herbes.

C H A P. XXV.

Anethum. Dill.

$\mathrm{D}$

Ill doth much growe wilde, but becaufe in many places it cannot be had, it is therefore fowne in Gardens for the vfes whereunto it ferueth. It is a fmaller herbe then Fenell, but very like, hauing fine cut leaues, not fo large, but fhorter, fmaller, and of a ftronger and quicker tafte: the ftalke is fmaller alfo, and with few ioynts and leaues on them, bearing fpoakie tufts of yellow flowers, which turne into thinne, fmall, and flat feedes: the roote perifheth euery yeare, and rifeth againe for the molt part of it owne fowing.

The Vfe of Dill.

The leaues of Dill are much vfed in fome places with Fifh, as they doe Fenell; but becaufe it is fo ftrong many doe refufe it.

It is alfo put among pickled Cowcumbers, wherewith it doth very well agree, giuing vnto the cold fruit a pretty f picie tafte or rellifh.

It being ftronger then Fenell, is of the more force to expell winde in the body. Some vfe to eate the feed to ftay the Hickocke.

\section{Cн н P. XX V I.}

\section{Myrrhis fiue Cerefolium maius E vulgare. Sweet Cheruill and ordinary Cheruill.}

$\mathrm{T}$

He great or fweete Cheruill (which of fome is called Sweete Cicely) hath diuers great and faire fpread winged leaues, confifting of many leaues fet together, deeply cut in the edges, and euery one alfo dented about, very like, and refembling the leaues of Hemlockes, but of fo pleafant a tafte, that one would verily thinke, he chewed the leaues or feedes of Anifeedes in his mouth: The ftalke is reafonable great, and fomewhat cornered or crefted about three or foure foote high, at the toppe whereof ntand many white fpoakie tufts of flowers, which change into browne long cornered great feede, two alwaies ioyned together: the roote is great, blackifh on the outfide, and white within, with diuers fibres annexed vnto it, and perifheth not, but abideth many yeares, and is of a fweete, pleafant, and fpicie hot tafte, delightfull vnto inany.

The common Cheruill is a fmall herbe, with flender leaues, finely cut into long peeces, at the firt of a pale yellowin greene colour, but when the ftalke is growne vp to feede, both ftalkes and leaues become of a darke red colour : the flowers are white, ftanding vpon fcattered or thin fpread tufts, which turne into fmall, long, round, and fharpe pointed feedes, of a brownifh blacke colour : the roote is fmall, with diuers long flender white ftrings, and perifheth euery yeare. 
The Vfes of thefe Cheruils.

The common Cheruill is much vfed of the French and Dutch people, to bee boyled or ftewed in a pipkin, eyther by it felfe, or with other herbes, whereof they make a Loblolly, and fo eate it. It is vfed as a pot-herbe with vs.

Sweete Cheruill, gathered while it is young, and put among other herbes for a fallet, addeth a meruellous good rellifh to all the reft. Some commend the greene feedes fliced and put in a fallet of herbes, and eaten with vinegar and oyle, to comfort the cold ftomacke of the aged. The roots are vfed by diuers, being boyled, and after eaten with oyle and vinegar, as an excellent fallet for the fame purpofe. The preferued or candid rootes are of fingular good vfe to warme and comfort a cold flegmaticke ftomack, and is thought to be a good preferuatiue in the time of the plague.

\section{CHA P. X XVII.}

\section{Malua Crifpa. French Mallowes.}

$\mathrm{T}$ He curld or French Mallow groweth vp with an vpright greene round ftalke, as high vfually as any man, whereon from all fides grow forth round whitifh greene leaues, curld or crumpled about the edges, like a ruffe, elfe very like vnto an ordinary great Mallow leafe : the flowers grow both vpon the ftalke, and on the other branches that fpring from them, being fmall and white; after which come fmall cafes with blacke feede like the other Mallowes: the roote perifheth when it hath borne feede, but abideth vfually the firft yeare, and the fecond runneth vp to flower and feede.

\section{The Vfe of French Mallowes.}

It is much vfed as a pot-herbe, efpecially when there is caufe to moue the belly downward, which by his flippery qualitie it doth helpe forward. It hath beene in times paft, and fo is to this day in fome places, vfed to be boyled or ftewed, eyther by it felfe with butter, or with other herbes, and fo eaten.

\section{Снар. XXVIII.}

Imtubum. Succorie and Endiue.

I Put both Succorie and Endiue into one chapter and defcription, becaufe they are both of one kindred; and although they differ a little the one from the other, yet they agree both in this, that they are eaten eyther greene or whited, of many.

Endiue, the fmooth as well as the curld, beareth a longer and a larger leafe then Succorie, and abideth but one yeare, quickely running vp to ftalke and feede, and then perifheth: whereas Succorie abideth many years, and hath long and narrower leaues, fomewhat more cut in, or torne on the edges: both of them haue blew flowers, and the feede of the fmooth or ordinary Endiue is fo like vnto the Succorie, that it is very hard to diftinguifh them af under by fight ; but the curld Endiue giueth blackifh and flat feede, very like vnto blacke Lettice feede : the rootes of the Endiue perifh, but the Succorie abideth.

The Vfe of Succory and Endiue.

Although Succorie bee fomewhat more bitter in tafte then the Endiues, 
yet it is oftentimes, and of many eaten greene, but more vfually being buried a while in fand, that it may grow white, which caufeth it to lofe both fome part of the bitterneffe, as alfo to bee the more tender in the eating; and Horace fheweth it to be vfed in his time, in the 32 . Ode of his firft Book, where he faith,

\section{Me pafcunt Oliuce, me Githorea leuefge Malua.}

Endiue being whited in the fame, or any other manner, is much vfed in winter, as a fallet herbe with great delight ; but the curld Endiue is both farre the fairer, and the tenderer for that purpofe.

\section{Ch A P. XXIX.}

\section{Spinachia, fiue Olus Hifpanicum. Spinach.}

$\mathrm{S}$ Pinach or Spinage is of three forts (yet fome doe reckon of foure, accounting that herbe that beareth no feede to be a fort of it felfe, when it is but an accident of nature, as it falleth out in Hempe, Mercury, and diuers other herbes) two that bear prickly feed, the one much greater then the other: the third that beareth a finooth feede, which is more daintie, and nourfed vp but in few Gardens: The common Spinach which is the leffer of the two prickly forts, hath long greene leaues, broad at the ftalke, and rent, or torne as it were into foure corners, and fharpe pointed at the ends: it quickly runneth vp to ftalke, if it be fowen in the Spring time; but elfe, if at the end of Summer, it will abide all the winter green, and then fuddenly in the very beginning of the Spring, runne vp to ftalke, bearing many leaues both below and at the toppe, where there doth appeare many fmal greenilh flowers in clufters, and after them prickly feede: The other greater fort that hath prickly feede, is in all things like the former, but larger both in ftalke, leafe and feede. The fmooth Spinach hath broader, and a little rounder pointed leaues then the firft, efpecially the lower leaues; for thore that grow vpwards vpon the ftalke, are more pointed, and as it were three fquare, of as darke a greene colour as the former: at the feuerall ioynts of the ftalkes and branches, ftand cluftering many fmall greenifh flowers, which turne into clufters of round whitifh feede, without any prickles at all vpon them: the roote is long, white and rmall, like vnto the other, with many fibres at it: If it be often cut, it will grow the thicker, or elfe f pindle vp very thinly, and with but few leaues vpon the ftalke.

The Vfe of Spinage.

Spinage is an herbe fit for fallets, and for diuers other purpores for the table only; for it is not knowne to bee vfed phyfically at all. Many Englifh that haue learned it of the Dutch people, doe ftew the herbe in a pot or pipkin, without any other moifture then it owne, and after the moifture is a little preffed from it, they put butter, and a little spice vnto it, and make therewith a difh that many delight to eate of. It is vfed likewife to be made into Tartes, and many other varieties of difhes, as Gentlewomen and their Cookes can better tell then my felfe; vnto whom I leaue the further ordering of thefe herbes, and all other fruits and rootes of this Garden : For I intend only to giue you the knowledge of them, with fome briefe notes for their vfe, and no more. 


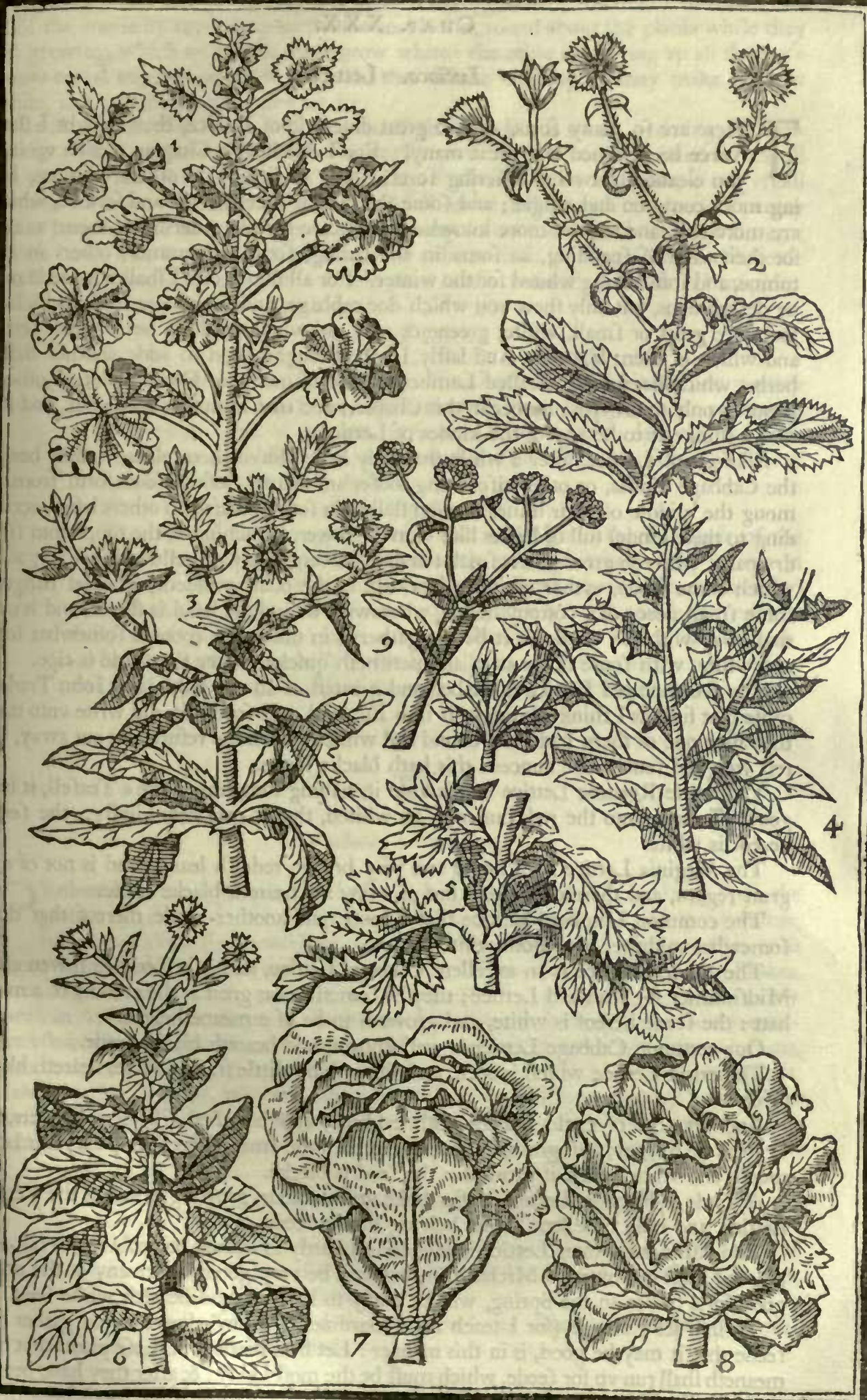

1 Malma griffa. French Mallowes. 2 Endimia. Endive. 3 Cichoriwm. Succory. 4 Spinachia. Spinach. 5 Laßnco crifpa. Curld Lettice. 6 Laßnca paimla. An open Lettice. 7 LaAuca capitata on/garis. Ordinary cabbage Lettice. Lactuca cafitale Romana. The great Romane cabbage Lettice. 9 Lalluca agromo. Corne Sallet or Lambes Lettice. 
С н А Р. X XX.

\section{Lactuca. Lettice.}

7 Here are fo many forts, and fo great diuerfitie of Lettice, that I doubt I thall fcarce be beleeued of a great many. For I doe in this Chapter reckon vp into you eleauen or twelue differing forts; fome of little vfe, others of more, being more common and vulgar ; and fome that are of excellent vfe and feruice, which are more rare, and require more knowledge and care for the ordering of them, as alfo for their time of fpending, as fome in the fpring, fome in fummer, others in autumne, and fome being whited for the winter. For all thefe forts I thall not neede many def criptions, but only fhew you which doe cabbage, and which are loofe, which of them are great or fmall, white, greene or red, and which of them beare white feeds, and which of them blacke. And laftly I haue thought good to adde another Sallet herbe, which becaufe it is called Lambes Lettice of many, or Corne Sallet of others, is put in only to fill vp a number in this Chapter, and that I muft fpeake of it, and not that I thinke it to be any of the kindes of Lettice.

All forts of Lettice, after a while that they haue clofed themfelues, if they bee of the Cabbage kindes, or otherwife being loofe, and neuer clofing, fend forth from among the middle of their leaues a round ftalke (in fome greater, in others leffer, according to their kinde) full of leaues like vnto the lower, branching at the toppe into fundry parts, whereon grow diuers fmall ftar-like flowers, of a pale yellowifh colour; after which come feede, eyther white or blackifh, as the plant yeeldeth, whereat hangeth fome fmall peece of a cottony doune, wherewith the whole head is ftored, and is carried away with the winde, if it be not gathered in time : the roote is fomewhat long and white, with fome fibres at it, and perifheth quickely after the feede is ripe.

The Romane red Lettice is the beft and greateft of all the reft. For Iohn Tradefcante that firft, as I thinke, brought it into England, and fowed it, did write vnto mee, that after one of them had been bound and whited, when the refufe was cut away, the reft weighed feuenteene ounces: this hath blacke feede.

The white Romane Lettice is like vnto it, hauing long leaues like a Teafell, it is in goodneffe next vnto the red, but muft be whited, that it may eate kindly: the feede hereof is white.

The Virginia Lettice hath fingle and very broade reddifh leaues, and is not of any great regard, and therefore is kept but of a few : it beareth blacke feede.

The common Lumbard Lettice that is loofe, and another kinde thereof that doth fomewhat cabbage, haue both white feedes.

The Venice Lettice is an excellent Cabbage Lettice, and is beft to bee fowen after Midfummer for lateward Lettice; they be fometimes as great as the crowne of a mans hatt : the feede hereof is white, and groweth to be of a meane height.

Our common Cabbage Lettice is well known, and beareth blacke feede.

The curld Lettice which is open, and differeth but little from Endiue, beareth black reede.

Another fort of curld Lettice doth cabbage, and is called Flanders Cropers, or Cropers of Bruges; this groweth loweft, and hath the fmalleft head, but very hard and round, and white while it groweth : the feed is blacke.

A kinde of Romane Lettice is of a darke green colour, growing as low as the Venice Lettice, and is an excellent kinde, bearing blacke feede.

And laftly our winter Lettice is wonderfull hardy to endure our cold : It is but fingle, and muft be fowen at Michaelmas, but will be very good, before any of the other good forts fowen in the Spring, will be ready to be vfed, and beareth white feed.

To inftruct a nouice (for I teach not a Gardiner of knowledge) how to gather his feede that it may be good, is in this manner : Let him marke out thofe plants that hee meaneth fhall run vp for feede, which muft be the moft likely; $\&$ after they haue begun to fhoote forth ftalkes, ftrip away the lower leaues, for two or three hands breadth aboue the ground, that thereby in taking away the loweft leaues, the ftalke doe not rot, nor the feed be hindered in the ripening. 
There are two manner of wayes to whiten Lettice to make them eate the more tender : the one is by rayfing vp earth like moale hils, round about the plants while they are growing, which will make them grow white: the other is by tying vp all the loofe leaues round together while it groweth, that fo the clofe tying may make it grow white, and thereby be the more tender.

Lambes Lettice or Corne Sallet is a fmall plant while it is young, growing clofe vpon the ground, with many whitifh greene, long and narrow, round pointed leaues, all the winter, and in the beginning of the fpring (if it bee fowen in autumne, as it is vfuall to ferue for an early fallet) rifeth vp with fmall round ftalkes, with two leaues at euery ioynt, branching forth at the toppe, and bearing tufts of fmall bleake blew flowers, which turne into fmall round whitifh feede : the roote is fmall and long, with fome fmall threds hanging thereat : the whole plant is of a waterifh tafte, almoft infipide.

\section{The Vfe of Lettice.}

All forts of Lettice are fpent in fallets, with oyle and vinegar, or as euery one pleafe, for the moft part, while they are frefh and greene, or whited, as is declared of fome of the forts before, to caufe them to eate the more delicate and tender. They are alfo boyled, to ferue for many forts of difhes of meate, as the Cookes know beft.

They all coole a hot and fainting ftomacke.

The iuice of Lettice applyed with oyle of Rofes to the foreheads of the ficke and weake wanting fleepe, procureth reft, and taketh away paines in the head: bound likewife to the cods, it helpeth thofe that are troubled with the Colts euill. If a little camphire be added, it reftraineth immoderate luft : but it is hurtfull to fuch as are troubled with the fhortneffe of breath.

Lambes Lettice is wholly fpent for fallets, in the beginning of the yeare, as I faid, before any almoft of the other forts of Lettice are to be had.

\section{CHA P. XXXI.}

\section{Portulaca. Purflane.}

Drflane hath many thicke round fhining red ftalkes, full of iuice, lying vpon the ground for the moft part; whereon are fet diuers long, thicke, pale green leaues, fometimes alone by themfelues, and fometimes many fmall ones together with them; among which grow fmall yellow flowers, which ftand in little greene huskes, containing blacke feede: the roote is $\mathrm{fmall}$, and perifheth euery yeare, and muft be new fowen in Aprill, in the alleyes of the Garden betweene the beds, as fome haue heretofore vfed, where it may haue the more moifture, or, as I haue feene in fome Gardens, vpon thofe beds of dung that Gardiners haue vfed to nourfe vp their Cowcumbers, Melons, and Pompions, whereon after they haue been taken away, they haue fowen Purflane, where if it be much watered, the warmth of the dung, and the water giuen it, the Purflane hath grown great and large, and continued vntill winter.

\section{The Vfe of Purflane.}

It is vfed as Lettice in fallets, to coole hot and faint ftomackes in the hot time of the yeare, but afterwards if only for delight, it is not good to bee too prodigall in the vfe thereof.

The feede of Purlane doth coole much any inflammation inward or outward, and doth a little binde withall. 


\section{CHA.P. XXXII.}

\section{Dracoherba fue Tarchon \& Dracunculus hortenfis. Tarragon.}

T Arragon hath long and narrow darke greene leaues, growing on flender and brittle round ftalkes, two or three foote high, at the tops whereof grow forth long flender fpikes of fmall yellowifh flowers, which feldome giue any good feede, but a duftie or chaffie matter, which flieth away with the winde: the roote is white, and creepeth about vnder ground, whereby it much encreafeth : the whole herbe is of a hot and biting tafte.

The Vfe of Tarragon.

It is altogether vfed among other cold herbes, to temper their coldneffe, and they to temper its heate, fo to giue the better rellifh vnto the Sallet; but many doe not like the tafte thereof, and fo refure it.

There are fome Authors that haue held Tarragon not to be an herbe of it owne kinde, but that it was firt produced, by putting the feede of Lin or Flaxe into the roote of an Onion, being opened and fo fet into the ground, which when it hath fprung, hath brought forth this herbe Tarragon, which abfurd and idle opinion, Matthiolus by certaine experience faith, hath been found falfe.

\section{C н А P. X X XIII.}

\section{Nasturtium hortenfe. Garden Creffes.}

$\bigcirc$ Arden Creffes growe vp to the height of two foote or thereabouts, hauing many fmall, whitifh, broad, endented, torne leaues, fet together vpon a middle ribbe next the ground, but thofe that growe higher vpon the ftalkes are fmaller and longer: the tops of the ftalkes are ftored with white flowers, which turne into flat pods or pouches, like vnto Shepheard purfe, wherein is contained flat reddifh feede: the roote perifheth euery yeare: the tafte both of leaues and feedes are fomewhat ftrong, hot, and bitter.

\section{The Vfe of Creffes.}

The Dutchmen and others vfe to eate Creffes familiarly with their butter and bread, as alfo ftewed or boyled, either alone or with other herbes, whereof they make a Hotch potch, and fo eate it. Wee doe eate it mixed among Lettice or Purflane, and fometimes with Tarragon or Rocket, with oyle and vinegar and a little falt, and in that manner it is very fauoury to fome mens ftomackes.

The vfe of Creffes phyfically is, it helpeth to expectorate tough flegme, as allo for the paines of the breaft; and as it is thought taketh away fpots, being laid to with vinegar. The feede is given of many to children for the wormes. 


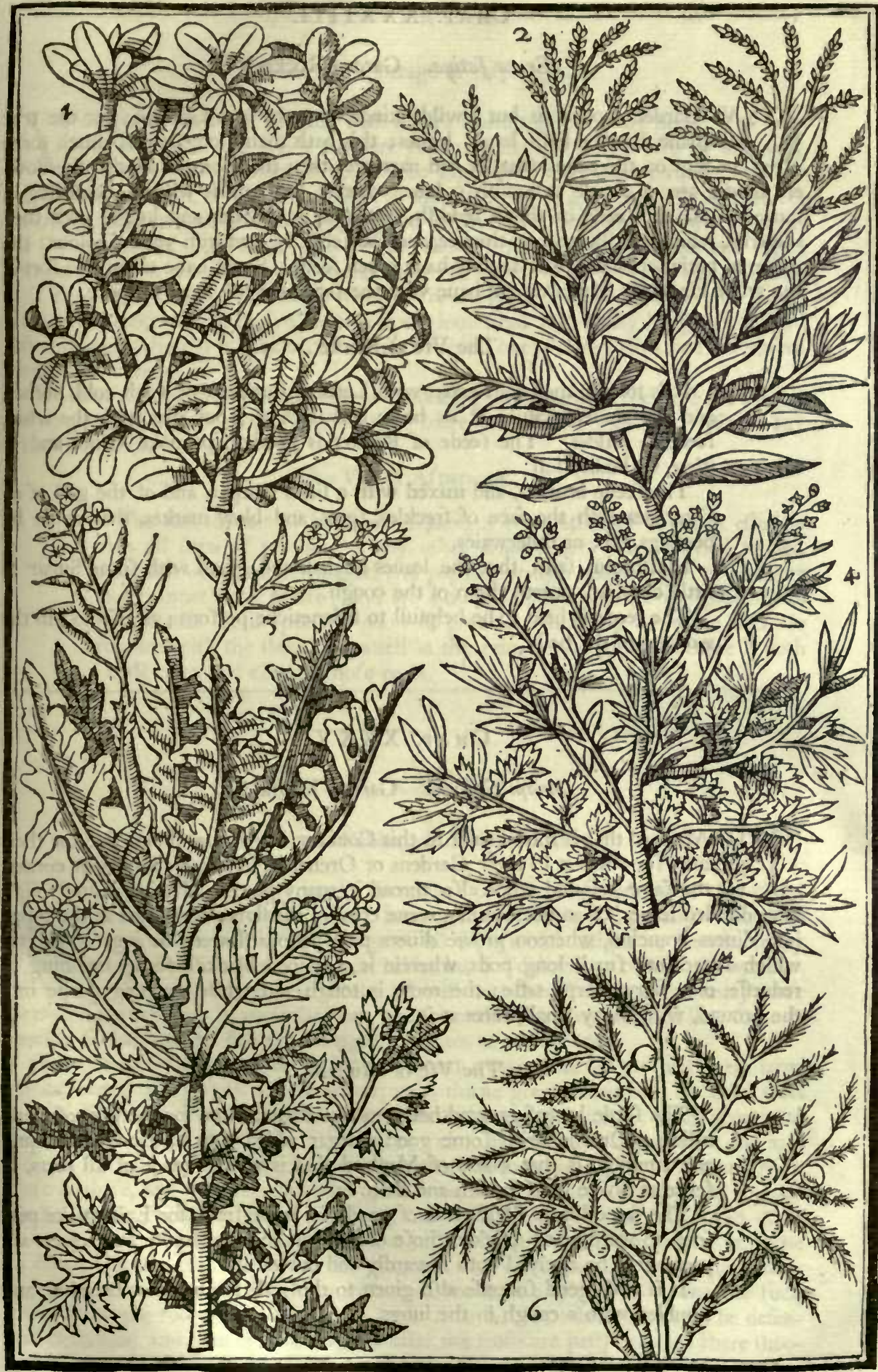

I Parlulaca. Purflane. 2 Drachoherba fen Tarchon. Tarragon. 3 Eruca fatiwa. Garden Rocket, 4 Nafiurlium fativum. Garden Crefles. 5 Sinapi. Muftard. 6 Afparagus. Afparagus or Sperage. 


\section{Ch а P. XXXIIII.}

\section{Eruca fatiua. Garden Rocket.}

$\mathrm{O}$

Vr Garden Rocket is but a wilde kinde brought into Gardens; for the true Romane Rocket hath larger leaues; this hath many long leaues, much torne or rent on the edges, fmaller and narrower then the Romane kinde: the flowers hereof are of a pale yellowith colour, whereas the true is whitifh, confinting of foure leaues: the feede of this is reddirh, contained in fmaller and longer pods then the true, which are fhorter and thicker, and the feede of a whitifh yellow colour: the rootes of both perifh as foone as they haue giuen feede. Some haue taken one fort of the wilde kinde for Muftard, and haue vfed the feede for the fame purpofe.

\section{The Vfe of Rocket.}

It is for the moft part eaten with Lettice, Purflane, or fuch cold herbes, and not alone, becaufe of its heate and ftrength; but that with the white feede is milder. The feede of Rocket is good to prouoke vrine, and to ftirre vp bodily luft.

The feede bruifed, and mixed with a little vinegar, and of the gall of an Oxe, cleanfeth the face of freckles, fpots, and blew markes, that come by beatings, fals, or otherwaies.

Matthiolus faith, that the leaues boyled, and giuen with fome Sugar to little children, cureth them of the cough.

The feede is held to be helpfull to fpleneticke perfons; as alfo to kill the wormes of the belly.

\section{Ch а т. XXXV.}

\section{Sinapi fativum. Garden Muftard.}

He Muftard that is moft vfuall in this Country, howfoeuer diuers doe for their priuate vfes fowe it in their Gardens or Orchards, in fome conuenient corner, yet the fame is found wilde alfo abroad in many places. It hath many rough long diuided leaues, of an ouerworne greene colour: the ftalke is diuided at the toppe into diuers branches, whereon growe diuers pale yellow flowers, in a great length, which turne into fmall long pods, wherein is contained blackifh feede, inclining to redneffe, of a fiery fharpe tafte: the roote is tough and white, running deepe into the ground, with many fmall fibres at it.

\section{The Vfe of Muftard.}

The feede hereof grownd between two ftones, fitted for the purpofe, and called a Querne, with fome good vinegar added vnto it, to make it liquid and running, is that kinde of Muftard that is vfually made of all forts, to ferue as fawce both for fifh and flefh.

The fame liquid Muftard is of good vfe, being frefh, for Epilepticke perfons, to warme and quicken thofe dull fpirits that are fopite and fcarce appeare, if it be applyed both inwardly and outwardly.

It is with good fucceffe alfo giuen to thofe that haue fhort breathes, and troubled with a cough in the lungs. 


\section{C и A Р. XXXVI.}

\section{ASparagus. Sperage or Afparagus.}

Sparagus rifeth vp at the firft with diuers whitifh greene fcaly heads, very britA tle or eafie to breake while they are young, which afterwards rife vp into very long and llender greene ftalkes, of the bigneffe of an ordinary riding wand at the bottome of moft, or bigger or leffer, as the rootes are of growth, on which are fet diuers branches of greene leaues, Morter and fmaller then Fennell vp to the toppe, at the ioynts whereof come forth fmall moflie yellowifh flowers, which turne into round berries, greene at the firft, and of an excellent red colour when they are ripe, fhewing as if they were beades of Corrall, wherein are contained exceeding hard and blacke feede : the rootes are difperfed from a fpongious head into many long, thicke, and round ftrings, whereby it fucketh much nourilhment out of the ground, and encreafeth plentifully thereby.

We haue another kinde hereof that is of much greater account, becaufe the fhootes are larger, whiter, and being dreffed tafte more (weete and pleafant, without any other difference.

\section{The Vfe of Afparagus.}

The firt thootes or heads of Afparagus are a Sallet of as much efteeme with all forts of perfons, as any other whatfoeuer, being boyled tender, and eaten with butter, vinegar, and pepper, or oyle and vinegar, or as euery ones manner doth pleafe; and are almoft wholly fpent for the pleafure of the pallate. It is fpecially good to prouoke vrine, and for thofe that are troubled with the ftone or grauell in the reines or kidneyes, becaufe it doth a little open and cleanfe thofe parts.

\section{CH A P. X X X V I I.}

\section{Brafsica. Cabbages and Coleworts.}

T

Here is greater diuerfity in the forme and colour of the leaues of this plant, then there is in any other that I know groweth vpon the ground. But this place requireth not the knowledge of all forts which might be fhewen, many of them being of no vfe with vs for the table, but for delight, to behold the wonderfull variety of the workes of God herein. I will here therefore thew you onely thofe forts that are ordinary in moft Gardens, and fome that are rare, received into fome efpeciall Gardens : And firft of Cabbages, and then of Coleworts.

Our ordinary Cabbage that cloreth hard and round, hath at the firt great large thicke leaues, of a grayilh greene colour, with thicke great ribbes, and lye open moft part of the Summer without clofing, but toward the end of Summer, being growne to haue inany leaues, it then beginneth to growe clofe and round in the middle, and as it cloreth, the leaues growe white inward; yet there be fome kindes that will neuer be fo clore as thefe, but will remaine halfe open, which wee doe not account to be fo good as the other: in the middle of this head, the next yeare after the fowing, in other Countries efpecially, and fometimes in ours, if the Winter be milde, as may be feene in diuers Gardens (but to preuent the danger of our Winter frofts, our Gardiners now doe vfe to take vp diuers Cabbages with their rootes, and tying a cloth or fome fuch thing about the rootes, doe hang them $v p$ in their houfes, where they may be defended from cold, and then fet them againe after the frofts are paft) and then there fhooteth out a great thicke ftalke, diuided at the toppe into many branches, bearing thereon diuers fmall flowers, fometime white, but moft commonly yellow, made of foure leaues, which turne into long, round, and pointed pods, containing therein fmall 
round feede, like vnto Turnep feede: the roote fpreadeth not farre nor deepe, and dyeth vfually in any great frofte ; for a fmall froft maketh the Cabbage eate the tenderer.

The red Cabbage is like vnto the white, laft fpoken of, but differing in colour and greatneffe; for it is feldome found fo great as the white, and the colour of the leaues is very variable, as being in fome ftript with red, in others more red, or very deepe red or purple.

The fugar loafe Cabbage, fo called becaufe it is fmaller at the toppe then it is the bottome, and is of two forts, the one white, the other greene.

The Sauoy Cabbadge, one is of a deepe greene coloured leafe, and curld when it is to be gathered; the other is yellowifh: neyther of both thefe doe clofe fo well as the firft, but yet are vfed of fome, and accounted good.

The Cole flower is a kinde of Coleworte, whofe leaues are large, and like the Cabbage leaues, but fomewhat fmaller, and endented about the edges, in the middle wherof, fometimes in the beginning of Autumne, and fometimes much fooner, there appeareth a hard head of whitifh yellow tufts of flowers, clofely thruft together, but neuer open, nor fpreading much with vs, which then is fitteft to be vfed, the green leaues being cut away clofe to the head : this hath a much pleafanter tafte then eyther the Coleworte, or Cabbage of any kinde, and is therefore of the more regard and refpect at good mens tables.

The ordinary Coleworte is fufficiently knowne not to clofe or cabbage, and giueth feede plentifully enough.

The other Colewortes that are nourfed vp with thofe that delight in curiofities, befides the aforefaid ordinary greene, which is much vfed of Dutchmen, and other ftrangers, are thefe: The Curld Coleworte eyther wholly of a greene colour, or of diuers colours in one plant, as white, yellow, red, purple or crimfon, fo variably mixed, the leaues being curld on the edges, like a ruffe band, that it is very beautifull to behold.

There is alfo another curld Colewort of leffe beauty and refpeet, being but a little curld on the edges, whofe leaues are white, edged with red, or green edged with white.

Two other there are, the one of a popingaye greene colour: the other of a fine deepe greene, like vnto the Sauoyes.

Then there is the Cole rape, which is alfo a kinde of Coleworte, that beareth a white heade, or headed ftalke aboue the ground, as bigge as a reafonable Turnep, but longer, and from the toppe thereof fpringeth out diuers great leaues, like vnto Colewortes; among which rife diuers ftalkes that beare yellow flowers, and feede in pods, almoft as fmall as Muftard feede : the roote is fomewhat long, and very bufhie with threds.

\section{The Vfe of Cabbages and Colewortes.}

They are moft vfually boyled in poudered beefe broth vntil they be tender, and then eaten with much fat put among them.

The great ribs of the Popingay, and deepe greene Colewortes, beeing boyled and layde into difhes, are ferued to the table with oyle and vinegar in the Lent time for very good fallets.

In the cold Countries of Ruffia and Mufcouia, they pouder vp a number of Cabbages, which ferue them, efpecially the poorer fort, for their moft ordinary foode in winter; and although they ftinke moft grieuoufly, yet to them they are accounted good meate.

It is thought, that the vfe of them doth hinder the milke in Nurfes breafts, caufing it to dry vp quickely: but many women that haue giuen fucke to my knowledge haue denyed that affertion, affirming that they haue often eaten them, and found no fuch effect. How it might proue in more delicate bodies then theirs that thus faid, I cannot tell : but Matthiolus auerreth it to encreafe milke in Nurfes breaftes; fo differing are the opinions of many. The feede groffely bruifed and boyled a little in flefh broth, is a prefent remedie for the Collicke; the feede and the broth being taken together, eafing them that are troubled therewith of all griping paines: as alfo for the ftone in the kidneyes. A Lohoc or licking Electuary made of the pulpe of 


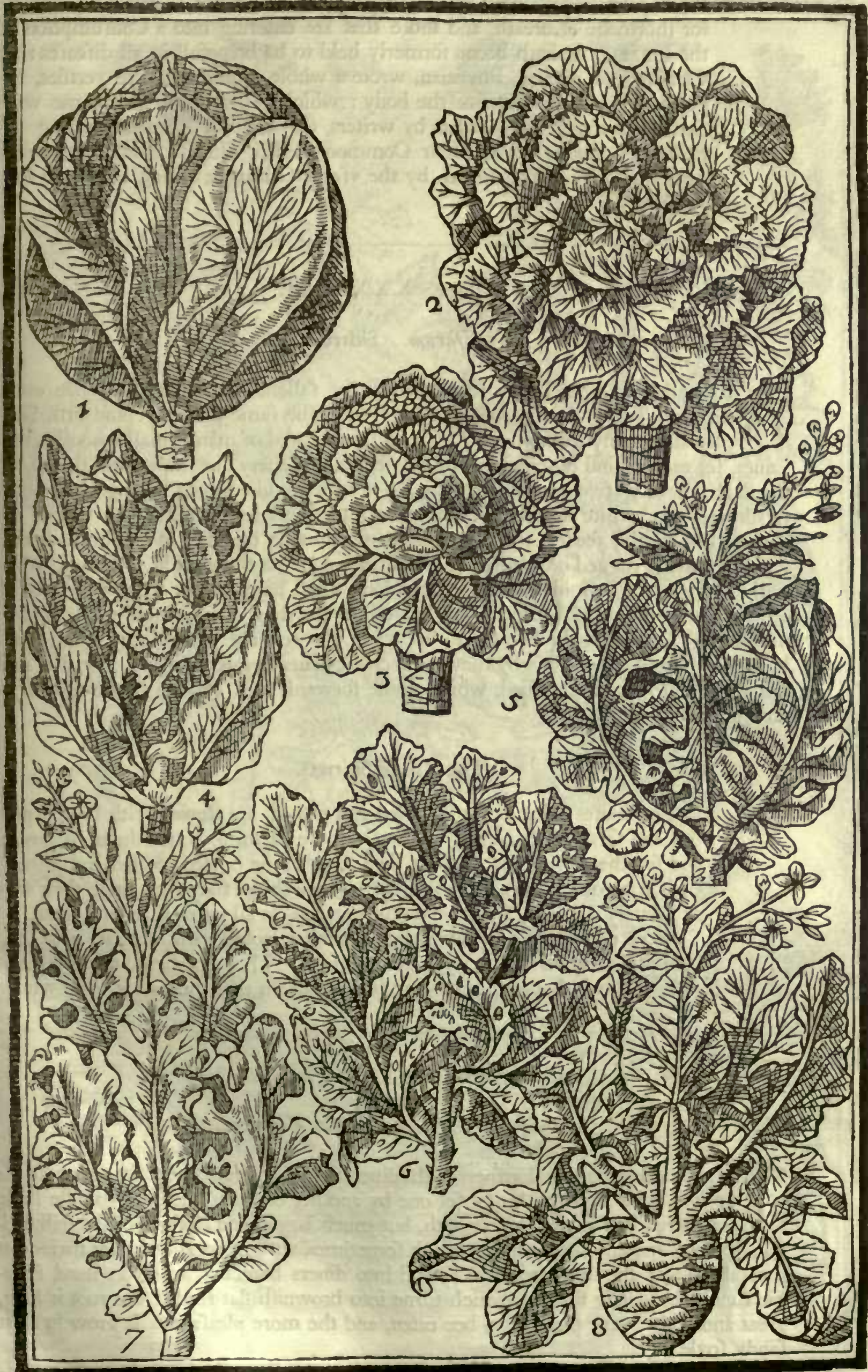

1 Brafsica capilala. Clofe Cabbage.

2 Brafsica falula. Open Cabbage. 3 Brafsica Sabaudica crifpa. Curld Sauoye Colewort. Caulis florida. Cole flower. Colewor, 7 Rapocaulis. Cole rape. 
the boyled ftalkes, and a little honey and Almond milke, is very profitable for thortneffe of breath, and thofe that are entering into a Confumption of the lunges. It hath beene formerly held to be helpefull in all difeafes : for Crifippus, an ancient Phyfitian, wrote a whole Volume of the vertues, applying it to all the parts of the body : which thing neede not feeme wonderfull, in that it is recorded by writers, that the old Romanes hauing expelled Phyfitians out of their Common-wealth, did for many hundred of yeares maintaine their health by the vfe of Cabbages, taking them for euery difeafe.

\section{Ch A P. X XXVIII.}

\section{Sifarum. Skirrets.}

A Fter all the herbes before rehearfed, fit for fallets, or otherwife to bee eaten, there mutt follow fuch rootes as are vfed to the fame purpofe : and firt, Skirrets haue many leaues next the ground, compofed of many fmall fmooth green leaues, fet each againft other vpon a middle ribbe, and euery one fnipt about the edges: the ftalke rifeth vp two or three foote high, fet with the like leaues, hauing at the toppe fpoakie tufts of white flowers, which turne into fmall feede, fomewhat bigger and darker then Parfley feede : the rootes be many growing together at one head, beeing long, flender, \& rugged or vneuen, of a whitifh colour on the outfide, and more white within, hauing in the middle of the roote a long fmall hard pith or ftring: thefe heads are vfually taken vp in February and March, or fooner if any fo pleafe, the greater number of them being broken off to bee vfed, the reft are planted againe after the heads are feparated, and hereby they are encreafed euery yeare by many; but it is now adayes more fowen of the feed, which come forwards well enough if the ground be fat and good.

\section{The Vfe of Skirrets.}

The rootes being boyled, peeled and pithed, are ftewed with butter, pepper and falt, and fo eaten; or as others vfe them, to roule them in flower, and fry them with butter, after they haue beene boyled, peeled and pithed: each way, or any way that men pleafe to vfe them, they may finde their tafte to be very pleafant, far beyond any Parfnep, as all agree that tafte them.

Some doe vfe alfo to eate them as a fallet, colde with vinegar, oyle, \&cc. being firft boyled and dreffed as before faid. They doe helpe to prouoke vrine, and as is thought, to procure bodily luft, in that they are a little windy.

\section{CH A P. X XXIX.}

\section{Pafinaca fatiua latifolia. Parfneps.}

$\mathrm{T}$ He common garden Parfnep hath diuers large winged leaues lying vpon the ground, that is, many leaues fet one by another on both fides of a middle ftalk, fomewhat like as the Skirret hath, but much larger, and clofer fet: the ftalke rifeth vp great and tall, fiue or fix foot high fometimes, with many fuch leaues thereon at feuerall ioynts; the top whereof is fpread into diuers branches, whereon ftand fpoakie rundles of yellow flowers, which turne into brownifh flat feede : the root is long, great and white, very pleafant to bee eaten, and the more pleafant if it grow in a fat fandy foyle.

There is another fort of garden Parfnep, called the Pine Parfnep, that is not common in euery Garden, and differeth from the former in three notable parts. The root is not fo long, but thicker at the head and fmaller below ; the ftalke is neither fo bigge, 


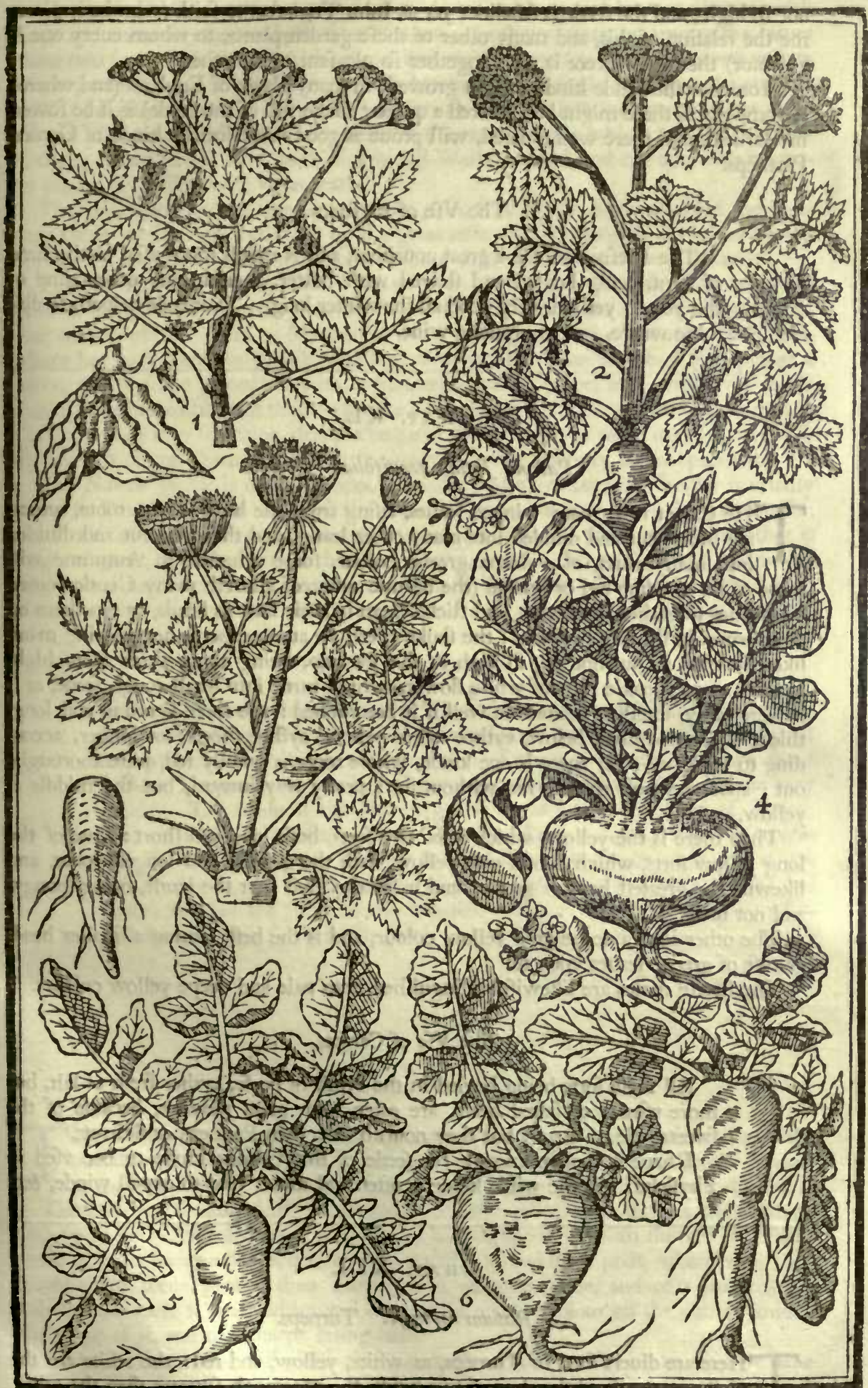

Sifarum. Skirrets. 2 Paftinaca latifolia. Parfoeps. 3 Paflinasa tenuifolia. Carrets. 4 Kapsum
Napus fatiuns. Navewes. 6 Raphanus niger. Blacke Raddin. 7 Raphanus voulgaris. Comon Raddifh. 
nor fo high; and the feede is fmaller : yet as Iohn Tradefcante faith (who hath giuen me the relation of this, and many other of thefe garden plants, to whom euery one is a debtor) the roote hereof is not altogether fo pleafant as the other.

Moreouer the wilde kinde, which groweth in many places of England (and wherof in fome places there might be gathered a quarter facke full of the feede) if it be fowen in Gardens, and there well ordered, will proue as good as the former kinde of Garden Parfneps.

The Vfe of Parfneps.

The Parfnep root is a great nourifher, and is much more vfed in the time of Lent, being boyled and ftewed with butter, then in any other time of the yeare; yet it is very good all the winter long. The feede helpeth to diffolue winde, and to prouoke vrine.

\section{CHA P. XL.}

\section{Pastina fatiua tenuifolia. Carrots.}

$\mathrm{T}$ He Carrot hath many winged leaues, rifing from the head of the roote, which are much cut and diuided into many other leaues, and they alfo cut and diuided into many parts, of a deepe greene colour, fome whereof in Autumne will turne to be of a fine red or purple (the beautie whereof allureth many Gentlewomen oftentimes to gather the leaues, and fticke them in their hats or heads, or pin them on their armes in ftead of feathers) : the ftalke rifeth vp among the leaues, bearing many likewife vpon it, but nothing fo high as the Parfnep, being about three foote high, bearing many fpoakie tufts of white flowers, which turne into fmall rough feede, as if it were hairy, fmelling reafonable well if it bee rubbed : the roote is round and long, thicke aboue and fmall below, eyther red or yellow, eyther fhorter or longer, according to bis kinde; for there is one kinde, whofe roote is wholly red quite thoroughout ; another whofe roote is red without for a pretty way inward, but the middle is yellow.

Then there is the yellow, which is of two forts, both long and fhort: One of the long yellow forts, which is of a pale yellow, hath the greateft and longeft roote, and likewife the greateft head of greene, and is for the molt part the worlt, being fpongy, and not firme.

The other is of a deepe gold yellow colour, and is the beft, hauing a fmaller head, or tuft of greene leaues vpon it.

The fhorte rootes are likewife diftinguifhed, into pale and deepe yellow colours.

The Vfe of Carrots.

All thefe forts being boyled in the broth of beefe, eyther frefh or falt, but more vfually of falted beefe, are eaten with great pleafure, becaufe of the fweeteneffe of them : but they nourifh leffe then Parfneps or Skirrets.

I haue not often knowne the feede of this Garden kinde to bee vfed in Phyficke : but the wilde kinde is often and much vfed to expell winde, \&c.

\section{Сна Р. XLI.}

Rapum hortenfe. Turneps.

$\mathrm{T}$ Here are diuers forts of Turneps, as white, yellow, and red: the white are the moft common, and they are of two kinds, the one much fweeter then the other.

The yellow and the red are more rare, and nourfed vp only by thofe that are curious: as alfo the Navewe, which is feene but with very few. 
The ordinary Garden Turnep hath many large, and long rough greene leaues, with deepe and vneuen gafhes on both fides of them: the ftalke rifeth vp among the leaues about two foote high, fpread at the toppe into many branches, bearing thereon yellow flowers, which turne into long pods, with blackifh round feede in them : the roote is round and white, fome greater, fome fmaller; the beft kinde is knowne to be flat, with a fmall pigges tale-like roote vnderneath it; the worfer kinde which is more common in many places of this land, both North and Weft, is round, and not flat, with a greater pigges tayle-like roote vnderneath.

The yellow kinde doth often grow very great, it is hardly difcerned from the ordinary kinde while it groweth, but by the greatneffe and fpreading of the leaues beeing boyled, the roote changeth more yellow, fomewhat neare the colour of a Carrot.

The red Turnep groweth vfually greater then any of the other, efpecially in a good ground, being of a faire red colour on the outfide, but being pared, as white as any ather on the infide. This, as Matthiolus faith, doth grow in the Countrey of Anania, where hee hath feene an infinite number of them that haue waighed fifty pound a peece, and in forne places hee faith, a hundred pound a peece, both which we would thinke to be incredible, but that we fee the kind is greatly giuen to grow, and in warme Countries they may fo thriue, that the bulke or bigneffe of the roote may fo farre paffe the growth of our Countrey, as that it may rife to that quantity aboue fpecified.

The Navew gentle is of two kindes, a fmaller and a greater; the fmaller is vfually called in France, Navean de Cane, the roote is fornewhat long with the roundneffe; this kinde is twice as bigge as a mans thumbe, and many of them leffe: The other is long and great, almoft as big as the fhort Carrot, but for the moft part of an vneuen length, and roundneffe vnto the very end, where it fpreadeth into diuers fmall long fibres : neyther of them doth differ much from the Turnep, in leafe, flower or feed.

\section{The Vfe of Turneps.}

Being boyled in falt broth, they all of them eate moft kindly, and by reafon of their fweetneffe are much efteemed, and often feene as a difh at good mens tables: but the greater quantitie of them are fpent at poore mens feafts. They nourith much, and engender moift and loofe flefh, and are very windy. The feede of the Navew gentle is (as I take it) called of Andromachus in the compofition of his Treakle, Bunias dulcis : for Diofcorides and Plinie doe both fay, that the feede of the tame Bunias or Napus is put into Antidotes, and not the feede of the wilde, which is more fharpe and bitter; neyther the feede of the Turnep, which is called in Greeke yoyúd $\eta$, in Latine Rapum, becaufe the feede is not fweete.

\section{ChA P. XLII.}

\section{Raphanus. Raddifl.}

$\mathrm{T}$ Here are two principall kindes of Garden Raddifh, the one is blackifh on the outfide, and the other white; and of both thefe there is fome diuifion againe, as fhall be thewed. Dittander and horfe Raddifh be reckoned kinds thereof.

The ordinary Raddi?h hath long leaues, vneuenly gafhed on both fides, the ftalke rifeth vp to the height of three or foure foote, bearing many purplifh flowers at the top, made of foure leaues a peece, which turne into thicke and hort pods, wherein are contained round feede, greater then Turnep or Coleworte feede, and of a pale reddilh colour : the roote is long, white, and of a reddifh purple colour on the outfide toward the toppe of it, and of a fharpe biting tafte.

There is a fmall kind of Raddifh that commeth earlier then the former, that we hauc had out of the low Countries, not differing in any thing elfe.

The blacke Raddifh I have had brought me out of the lowe Countries, where they fell them in fome places by the pound, and is accounted with them a rare winter fallet: 
the roote of the beft kinde is blackifh on the outfide (and yet the feede gathered from fuch an one, hath after the fowing againe, giuen rootes, whereof fome haue beene blacke, but the moft part white on the outfide) and white within, great and round at the head, almoft like a Turnep, but ending fhorter then a Raddifh, and longer then a Turnep, almoft peare-fafhion, of a firmer and harder fubftance then the ordinary Raddifh, but no leffe fharpe and biting, and fomewhat ftrong withall; the leaues are fomewhat fmaller, and with deeper ganhes, the flower and feede are like the former, but fmaller.

Another fort of blacke Raddifh is like in leafe and feede to the former, but the flower is of a lighter purple colour : the roote is longer and fmaller, and changeth alfo to bee white as the former doth, fo that I thinke they haue both rifen from one kinde.

The Horfe Raddifh is a kinde of wilde Raddifh, but brought into Gardens for the vfe of it, and hath great large and long greene leaues, which are not fo much diuided, but dented about the edges: the roote is long and great, much ftronger in tafte then the former, and abideth diuers yeares, fpreading with branches vnder ground.

Dittander is likewife a wilde kinde hereof, hauing long pointed blewifh greene leaues, and a roote that creepeth much vnder ground: I confeffe this might haue bin placed among the herbes, becaufe the leaues and not the rootes are vfed; but let it paffe now with the kindes of Raddifh.

\section{The Vfe of thefe Raddifhes.}

Raddifhes doe ferue vfually as a fimulum before meat, giuing an appetite thereunto; the poore eate them alone with bread and falt. Some that are early fowen, are eaten in Aprill, or fooner if the feafon permit ; others come later; and fome are fowen late to ferue for the end of Summer: but (as of all things elfe) the earlier are the more accepted.

The blacke Raddithes are moft vfed in the winter, (yet fome in their naturall and not forc'd grounds, haue their rootes good moft part of the Summer) and therefore muft bee fowen after Midfomer; for if they thould bee fowen earlier, they would prefently runne vp to ftalke and feed, and fo lofe the benefit of the roote. The Phyficall propertie is, it is often vfed in medicines that helpe to breake the ftone, and to auoyde grauell.

The Horfe Raddifh is vfed Phyfically, very much in Melancholicke, Spleneticke and Scorbuticke difeafes. And forne vfe to make a kinde of Muftard with the rootes, and eate it with fifh.

Dittander or Pepperworte is vfed of fome cold churlifh ftomackes, as a fawce or fallet fometimes to their meate, but it is too hot, bitter and ftrong for weake and tender ftomackes.

Our Gardiners about London vfe great fences of reede tyed together, which feemeth to bee a mat fet vpright, and is as good as a wall to defend the cold from thofe things that would be defended, and to bring them forwards the earlier.

\section{CH A P. X L I I I.}

\section{Cepa. Onions.}

W Ee have diuers forts of Onions, both white and red, flat, round and long, as fhall be prefently thewed : but I will doe with thefe as I doe with the reft, only give you one defcription for them all, and afterwards their feuerall names and varieties, as they are to be known by.

Our common. Garden Onion hath diuers long greene hollow leaues, feeming halfe flat; among which rifeth vp a great round hollow ftalke, bigger in the middle then any where elfe, at the toppe whereof ftandeth a clofe round head, couered at the firft with a thin skinne, which breaketh when the head is growne, and fheweth forth a great vm- 


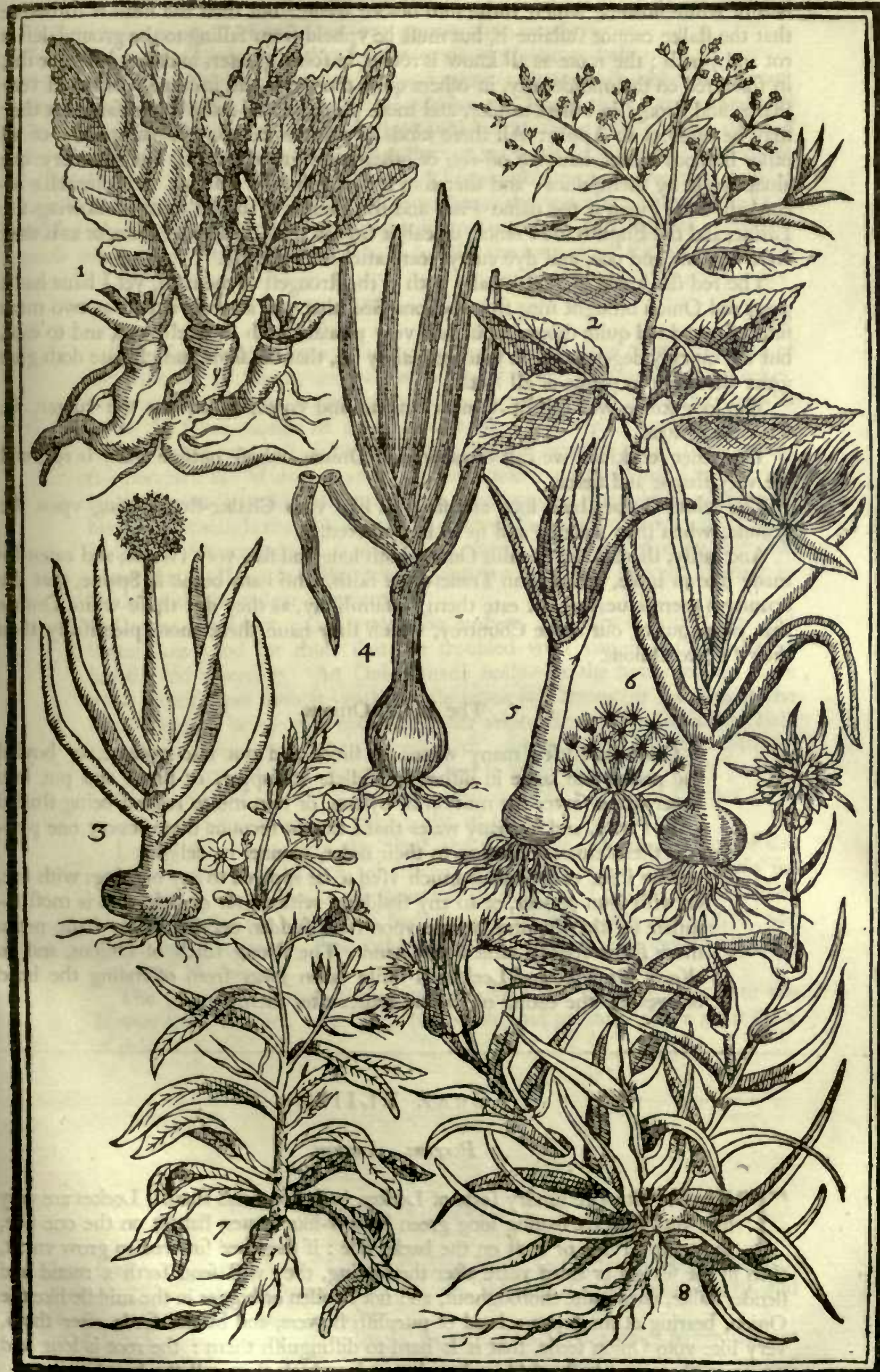

1 Raphanus rufticanus. Horfe Raddifh. 2 Lipidium foue Piperitis. Dittander. 3 Cepa rotwuda. Round Onions. 4 Cepa longa. Long Onions. 5 Pornum. Leekes. 6 Alliwm. Garlicke. 7 Rapuncwlus. Rampions. 8 Tragopogon. Goates 
bell of white flowers, which turne into blacke feede : but then the head is fo heauie that the ftalke cannot fuftaine it, but muft be vpheld from falling to the ground, left it rot and perifh : the roote as all know is round, in fome greater, in others leffer, or flat, in fome red on the outfide only, in others quite thorough out, in forne white, and very fharpe and ftrong, in others milder, and more pleafant, and fome fo pleafant that they may be eaten as an Apple: All thefe kinds of Onions, contrary to the nature of all other bulbous rootes, haue no off-fet, or other roote growing to it, but are euery one alone fingle by themfelues; and therefore it feemeth, the Latines, as Columella recordeth, haue giuen it the name Vnio, and the French it fhould feeme following the Latine, and the Englifh the French, do call it Oignon and Onion, as an vnite, or as if they were but one and one, and dye euery yeare after feed bearing.

The red flat kinde is moft vfually with vs the ftrongeft of them all, yet I haue had a great red Onion brought mee from beyond Sea, that was as great almoft as two mens fiftes, flat and red quite thoroughout, and very pleafant both to fmell vnto, and to eate, but did quickly degenerate; fo that we plainly fee, that the foyle and climate doth giue great alteration to plants of all forts.

The long kinde wee call St. Omers Onions, and corruptly among the vulgar, St. Thomas Onions.

The other red kinde we call Strasborough Onions, whofe outfide onely is red, and are very tharpe and fierce.

The white Onions both long and flat, are like vnto Chalke-ftones lying vpon the ground, when they are ripe and fit to be gathered.

And laftly, there is the Spanifh Onion, both long and flat, very fweete, and eaten by many like an apple, but as Iohn Tradefcante faith, who hath beene in Spaine, that the Spaniards themfelues doe not eate them fo familiarly, as they doe thofe white Onions that come out of our owne Countrey, which they haue there more plentifully then their fweete Onions.

\section{The Vfe of Onions.}

Onions are vfed many wayes, as fliced and put into pottage, or boyled and peeled and layde in difhes for fallets at fupper, or fliced and put into water, for a fawce for mutton or oyfters, or into meate roafted being ftuffed with Parfly, and fo many waies that I cannot recount them, euery one pleafing themfelues, according to their order, manner or delight.

The iuice of Onions is much vfed to be applyed to any burnings with fire, or with Gun-pouder, or to any fcaldings with water or oyle, and is moft familiar for the Country, where vpon fuch fudden occafions they haue not a more fit or fpeedy remedie at hand: The ftrong fmell of Onions, and fo alfo of Garlicke and Leekes, is quite taken away from offending the head or eyes, by the eating of Parfley leaues after them.

\section{Сн A P. X L I I I I.}

\section{Porrum. Leekes.}

$\mathrm{T}$ Here be likewife fundry forts of Leekes, both great and fmall. Leekes are very like vnto Onions, hauing long green hollow-like leaues, flattifh on the one fide, and with a ridge or creft on the backe fide : if they bee fuffered to grow vncut, then in the fecond or third yeare after the fowing, they will fend forth a round and flender ftalke, euen quite thoroughout, and not fwollen or bigger in the middle like the Onion, bearing at the toppe a head of purplifh flowers, and blacke feede after them, very like vnto Onion feede, that it is hard to diftinguifh them : the root is long and white, with a great bufh of fibres hanging at it, which they call the beards.

The vnfet Leeke hath longer and flenderer roots then the other, which being tranfplanted, groweth thicker and greater. 
The French Leeke, which is called the Vine Leeke, is the beft of all others.

Our common kinde is of two forts, one greater then another.

Another fort encreafeth altogether by the roote, as Garlicke doth.

And then Ciues, which are the fmalleft, and encreafe aboundantly only by the root.

Some doe account Scalions to be rather a kinde of Onions then Leekes, and call them Cepa Afcalonica, or Afcalonitides, which will quickly fpend it felfe, if it befuffered to be vncut; but all Authors affirme, that there is no wilde kinde of Onion, vnleffe they would have it to be Gethyum, whereof Theophraftus maketh mention, faying, that it hath a long necke (and fo thefe Scalions haue) and was alfo of fome called Gethyllides, which antiquity accounted to be dedicated to Latona, the mother of Apollo, becaufe when fhe was bigge with childe of Apollo, the longed for thefe Leekes.

\section{The Vfe of Leekes.}

The old World, as wee finde in Scripture, in the time of the children of Ifraels being in Egypt, and no doubt long before, fed much vpon Leekes, Onions, and Garlicke boyled with flefh; and the antiquity of the Gentiles relate the fame manner of feeding on them, to be in all Countries the like, which howfoeuer our dainty age now refufeth wholly, in all forts except the pooreft ; yet Mufcouia and Ruffia vfe them, and the Turkes to this day, (as Bellonius writeth) obferue to haue them among their difhes at their tables, yea although they be Bafbas, Cades, or Vaiuodas, that is to fay, Lords, Iudges, or Gouernours of countries and places. They are vfed with vs alfo fometimes in Lent to make pottage, and is a great and generall feeding in Wales with the vulgar Gentlemen.

Onions boyled or rofted vnder the embers, and mixed with fugar and butter, are good for thofe that are troubled with coughes, fhortneffe of breath, and wheefing. An Onion made hollow at the bottome, and fome good Treakle put into it, with a little iuyce of Citrons (or Lemons in the ftead thereof) being well baked together vnder the embers, after the hole is ftopped againe, and then ftrained forth, and giuen to one that hath the plague, is very helpefull, fo as hee be laid to fweate vpon it.

Ciues are vfed as well to be fhred among other herbes for the pot, as to be put into a Sallet among other herbs, to giue it a quicker relifh.

Leekes are held to free the cheft and lungs from much corruption and rotten flegme, that fticketh faft therein, and hard to be auoided, as alfo for them that through hoarfeneffe haue loft their voice, if they be eyther taken rawe, or boyled with broth of barley, or fome fuch other fupping, fit and conducing thereunto. And baked vnder hot embers is a remedy againft a furfeit of Mufhromes.

The greene blades of Leekes being boyled and applyed warme to the Hemorrhoides or piles, when they are fwolne and painfull, giue a great deale of eafe.

\section{Cна P. XLV.}

\section{Allium. Garlicke.}

I Haue fpoken of diuers forts of Garlicke called Moly, in the former booke: I thall neede in this place to fhew onely thofe kindes, that this Garden nourfeth vp, and leaue the reft to his fit time and place.

Garlicke hath many long greene leaues, like vnto Onions, but much larger, and?not hollow at all as Onions are : the ftalke rifeth vp to be about three foote high, bearing fuch a head at the toppe thereof as Onions and Leekes doe, with purplifh flowers, and blacke feede like Leekes: the roote is white within, couered ouer with many pur- 
plifh skins, and is diuided into many parts or cloues, which ferue both to fet againe for increafe, and alfo to vfe as neede fhall require, and is of a very ftrong fmell and tafte, as euery one knoweth, paffing either Onions or Leekes, but exceeding wholfome withall for them that can take it.

\section{Allium Vrfinum. Ramfons.}

Ramfons are another kinde of Garlicke, and hath two or three faire broade leaues, of a frefh or light greene colour, pointed at the end: the ftalke groweth about an hand length high, bearing many fmall and pure white ftarre-like flowers at the toppe, and afterwards fmall, blacke, and fmooth round feede : the roote is alfo diuided into many parts, whereby it is much encreafed, and is much milder then the former, both in fmell and tafte.

\section{The Vfe of Garlicke.}

It being well boyled in falt broth, is often eaten of them that haue ftrong ftomackes, but will not brooke in a weake and tender ftomacke.

It is accounted, and fo called in diuers Countries, The poore mans Treakle, that is, a remedy for all difeafes. It is neuer eaten rawe of any man that I know, as other of the rootes aforefaid, but fodden alwaies and fo taken.

Ramfons are oftentimes eaten with bread and butter, and otherwife alfo, as euery mans affection and courfe of life leadeth him to vfe.

\section{CHA P. XLVI. \\ Rapunculus fue Rapuntium. Rampions.}

Arden Rampions are of two forts, the one greater, the other leffer: the leaues of Rampions are in the one fomewhat broad like a Beete, in the other fomewhat long and narrow, and a little broader at the end, of a light greene colour, lying flat vpon the ground all the firft winter, or yeare of the fpringing, and the next Spring thooteth forth ftalkes two or three foote high, bearing at the toppe, in the bigger fort, a long flender f pike of fmall horned or crooked flowers, which open their brimmes into foure leaues; in the leffer many fmall purplifh bels, ftanding vpon feuerall fmall foote-ftalkes, which turne into heads, bearing fmall blackifh feede : the root is white, branched into two or three rootes, of the bigneffe and length of a mans finger or thumbe.

The Vfe of Rampions.

The rootes of both are vfed for Sallets, being boyled, and then eaten with oyle and vinegar, a little falt and pepper.

\section{CH A P. XLVII.}

\section{Tragopogon. Goates beard.}

Or Oates beard hath many long and narrow leaues, broader at the bottome, and Tharper at the end, with a ridge downe the backe of the leafe, and of a pale greene colour; among which rifeth vp a falke of two or three foote high, fmooth and hollow, bearing thereon many fuch like leaues, but fmaller and horter, and at the toppe thereof on euery branch a great double yellow flower, like almoft vnto the flower of a Dandelion, which turneth into a head, ftored with doune, and long whitifh feede therein, hauing on the head of euery one fome part of the doune, 
and is carried away with the winde if it bee neglected : the roote is long and round, fomewhat like vnto a Parfnep, but farre fmaller, blackifh on the outfide, and white within, yeelding a milkie iuyce being broken, as all the reft of the plant doth, and of a very good and pleafant tafte. This kinde, as alfo another with narrower leaues, almoft like graffe, growe wilde abroad in many places, but are brought into diuers Gardens. The other two kindes formerly defcribed in the firft part, the one with a purple flow$\mathrm{er}$, and the other with an afh-coloured, haue fuch rootes as thefe here defcribed, and may ferue alfo to the fame purpofe, being of equall goodneffe, if any will vfe them in the fame manner; that is, while they are young, and of the firft yeares fowing, elfe they all growe hard, in running vp to feede.

\section{The Vfe of Goates beard.}

If the rootes of any of thefe kindes being young, be boyled and dreffed as a Parfnep, they make a pleafant difh of meate, farre paffing the Parfnep in many mens iudgements, and that with yellow flowers to be the beft.

They are of excellent vfe being in this manner prepared, or after any other fit and conuenient way, to ftrengthen thofe that are macilent, or growing into any confumption.

\section{ChAP. XLVIII. \\ Carum. Carawayes.}

Arawayes hath many very fine cut and diuided leaues lying on the ground, being alwaies greene, fomewhat refembling the leaues of Carrots, but thinner, and more finely cut, of a quicke, hot, and fpicie tafte: the ftalke rifeth not much higher then the Carrot ftalke, bearing fome leaues at the ioynts along the ftalke to the toppe, where it brancheth into three or foure parts, bearing fpoakie vmbels of white flowers, which turne into fmall blackifh feede, fmaller then Anifeede, and of a hotter and quicker tafte : the roote is whitifh, like vnto a Parfnep, but much fmaller, more fpreading vnder ground, and a little quicke in tafte, as all the reft of the plant is, and abideth long after it hath giuen feede.

\section{The Vfe of Carawayes.}

The rootes of Carawayes being boyled may be eaten as Carrots, and by reafon of the fpicie tafte doth warme and comfort a cold weake ftomacke, helping to diffolue winde (whereas Carrots engender it) and to prouoke vrine, and is a very welcome and delightfull difh to a great many, yet they are fomewhat ftronger in tafte then Parfneps.

The feede is much vfed to bee put among baked fruit, or into bread, cakes, \&c. to giue them a rellifh, and to helpe to digeft winde in them are fubiect thereunto.

It is alfo made into Comfits, and put into Trageas, or as we call them in Englifh, Dredges, that are taken for the cold and winde in the body, as alfo are ferued to the table with fruit. 


\section{C н А P. X L I X.}

\section{Pappas fiue Battatas. Potatoes.}

1 Hree forts of Potatoes are well knowne vinto vs, but the fourth I reft doubtfull of, and dare not affirme it vpon fuch termes as are giuen vnto it, vntill I may be better informed by mine owne fight.

The Spanifh kinde hath (in the Iflands where they growe, either naturally, or planted for increafe, profit, and vfe of the Spaniards that nourfe them) many firme and verie fweete rootes, like in thape and forme vnto Afphodill rootes, but much greater and longer, of a pale browne on the outfide, and white within, fet together at one head; from whence rife vp many long branches, which by reafon of their weight and weakneffe, cannot ftand of themfelues, but traile on the ground a yard and a halfe in length at the leaft (I relate it, as it hath growne with vs, but in what other forme, for flower or fruit, we know not) whereon are fet at feuerall diftances, broad and in a manner three fquare leaues, fomewhat like triangled Iuie leaues, of a darke greene colour, the two fides whereof are broad and round, and the middle pointed at the end, ftanding reafonable clofe together: thus much we haue feene growe with vs, and no more: the roote rather decaying then increafing in our country.

The Potatoes of Virginia, which fome foolifhly call the Apples of youth, is another kinde of plant, differing much from the former, fauing in the colour and tafte of the roote, hauing many weake and fomewhat flexible branches, leaning a little downwards, or eafily borne downe with the winde or other thing, befet with many winged leaues, of a darke grayifh greene colour, whereof diuers are fmaller, and fome greater then others: the flowers growe many together vpon a long ftalke, comming forth from betweene the leaues and the great ftalkes, euery one feuerally vpon a fhort footftalke, fomewhat like the flower of Tabacco for the forme, being one whole leafe fix cornered at the brimmes, but fomewhat larger, and of a pale blewifh purple colour, or pale doue colour, and fome almoft white, with fome red threads in the middle, ftanding about a thicke gold yellow pointell, tipped with greene at the end: after the flowers are paft, there come vp in their places fmall round fruit, as bigge as a Damfon or Bulleis, greene at the firft, and fomewhat whitifh afterwards, with many white feedes therein, like vnto Nightfhade: the rootes are rounder and much fmaller then the former, and fome much greater then others, difperfed vnder ground by many fmall threads or ftrings from the rootes, of the fame light browne colour on the outfide, and white within, as they, and neare of the fame tafte, but not altogether fo pleafant.

The Potatos of Canada, (which hath diuers names giuen it by diuers men, as Bau hinus vpon Matthiolus calleth it, Solanum tuberofum ef culentum, Pelleterius of Middleborough in his Plantarum Synonimia, Heliotropium Indicum tuberofum, Fabius Columna in the fecond part of his Phytobafanos, Flos Solis Farnefanus, fuue After Peruanus tuberofus: We in England, from fome ignorant and idle head, haue called them Artichokes of Ierufalem, only becaufe the roote, being boyled, is in tafte like the bottome of an Artichoke head: but they may moft fitly be called, Potatos of Canada, becaufe their rootes are in forme, colour and tafte, like vnto the Potatos of Virginia, but greater, and the French brought them firft from Canada into thefe parts) rifeth vp with diuers ftiffe, round ftalkes, eight or tenne foote high in our Country, where they haue fcarce Thewed their flowers, whereas the very head of flowers in other Countries, as Fabius Columna expreffeth it, being of a Pyramis or Sugar loafe fafhion, broade fpreading below, and fmaller pointed vpwards towards the toppe, is neere of the fame length, whereon are fet large and broade rough greene leaues, very like vnto the leaues of the flower of the Sunne, but fmaller, yet growing in the very fame manner, round about the ftalkes: at the very later end of Summer, or the beginning of Autumne, if the roote bee well planted and defended, it will giue a hew of a few fmall yellow flowers at the top, like vnto the flowers of $A$ fer or Starre-worte, and much fmaller then any flower of the Sunne, which come to no perfection with vs: the roote, while the plant 


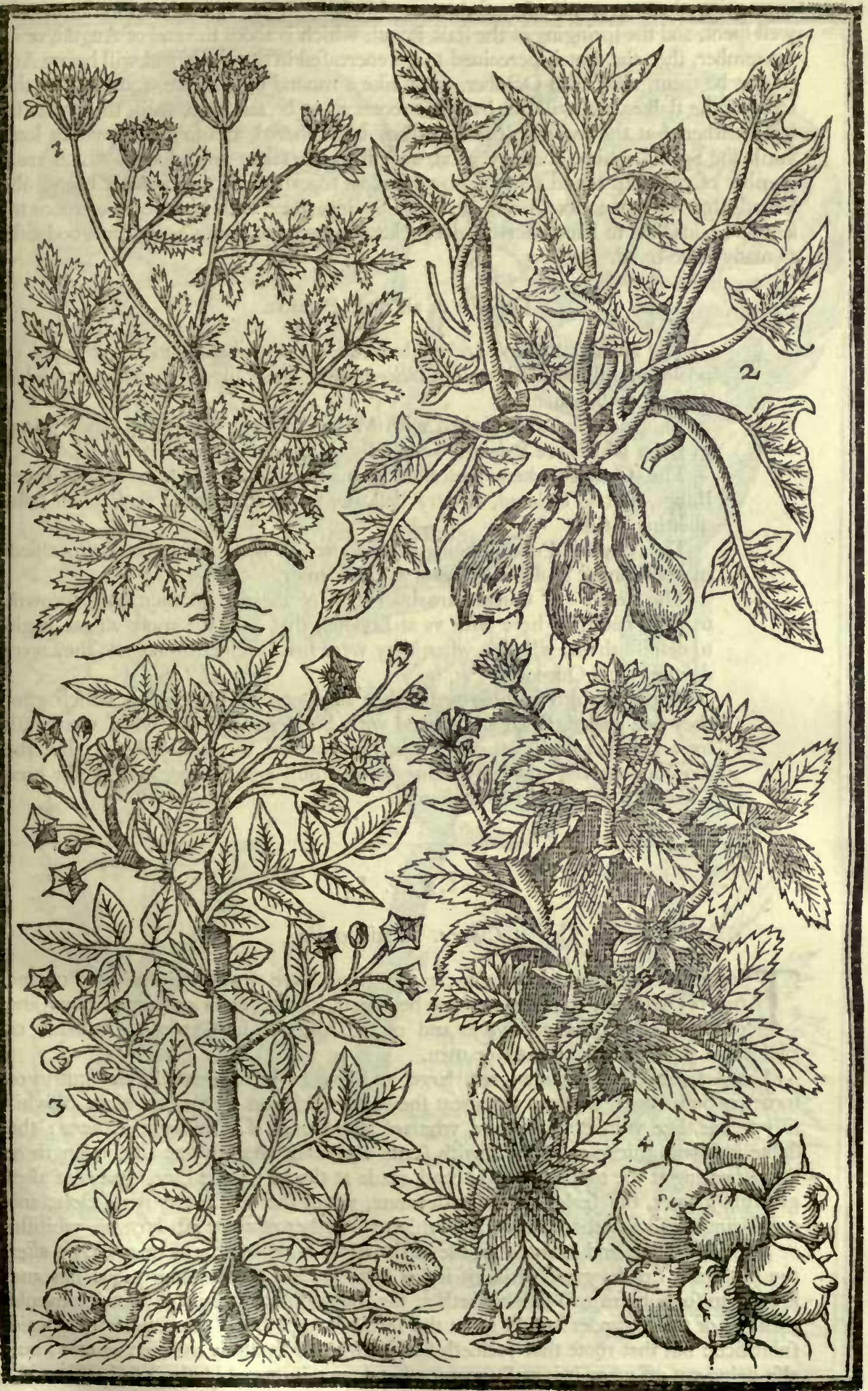

I Carum. Carawayes. 2 Bullalas Hifpanorum. Spanifh Potatoes

3 Papas fen Ballalas Virginianurum. Virginia Potatoes, 4 Ballatus de Canada. Potatoes of Canada, or Artichokes of Ierulalem. 
is growing aboue ground, encreafeth not to his full growth, but when the Summer is well fpent, and the fpringing of the ftalk is paft, which is about the end of Auguft, or in September, then the root is perceiued to be encreafed in the earth, and will before Autumne be fpent, that is, in October, fwell like a mound or hillocke, round about the foote of the ftalkes, and will not haue his rootes fit to be taken vp, vntill the fralkes be halfe withered at the fooneft; but after they be withered, and fo all the winter long vntill the Spring againe, they are good, and fit to bee taken vp and vfed, which are a number of tuberous round rootes, growing clofe together; fo that it hath beene obferued, that from one roote, being fet in the Spring, there hath been forty or more taken vp againe, and to haue ouer-filled a pecke meafure, and are of a pleafant good tafte as many haue tryed.

The Vfe of all thefe Potato's.

The Spanifh Potato's are roafted vnder the embers, and being pared or peeled and fliced, are put into facke with a little fugar, or without, and is delicate to be eaten.

They are vfed to be baked with Marrow, Sugar, Spice, and other things in Pyes, which are a daintie and contly difh for the table.

The Comfit-makers preferue them, and candy them as diuers other things, and fo ordered, is very delicate, fit to accompany fuch other banquetting difhes.

The Virginia Potato's being dreffed after all thefe waies before fpecified, maketh almolt as delicate meate as the former.

The Potato's of Canada are by reafon of their great increafing, growne to be fo common here with vs at London, that euen the mort vulgar begin to defpife them, whereas when they were firft receiued among vs, they were dainties for a Queene.

Being put into feething water they are foone boyled tender, which after they bee peeled, fliced and ftewed with butter, and a little wine, was a difh for a Queene, beeing as pleafant as the bottome of an Artichoke : but the too frequent vfe, efpecially being fo plentifull and cheape, hath rather bred a loathing then a liking of them.

\section{CH А P. L.}

\section{Ginara. Artichokes.}

T He fruits that grow vpon or neere the ground, are next to be entreated of, and firt of Artichokes, whereof there be diuers kindes, fome accounted tame and of the Garden, others wilde and of late planted in Gardens, Orchards or Fieldes, of purpore to be meate for men.

The Artichoke hath diuers great, large, and long hollowed leaues, much cut in or torne on both edges, without any great fhew of prickles on them, of a kinde of whitifh greene, like vnto an afh colour, whereof it tooke the Latine name Cinara: the ftalke is ftrong, thicke and round, with fome skins as it were downe all the length of them, bearing at the toppe one fcaly head, made at the firft like a Pine-apple, but after growing greater, the fcales are more feparate, yet in the beft kindes lying clofe, and not ftaring, as fome other kindes doe, which are eyther of a reddifh browne, whitifh, or greenifh colour, and in fome broade at the ends, in others fharpe or prickly : after the head hath ftood a great while, if it bee fuffered, and the Summer proue hot and kindly, in fome there will breake forth at the toppe thereof, a tuft of blewifh purple thrumes or threds, vnder which grow the feede, wrapped in a great deale of dounie fubftance : but that roote that yeeldeth flowers will hardly abide the next winter ; but elfe being cut off when it is well growne, that dounie matter abideth clofe in the middle of the head, hauing the bottome thereof flat and round, which is that matter or fubftance that is vfed to be eaten : the roote fpreadeth it felfe in the ground reafona- 


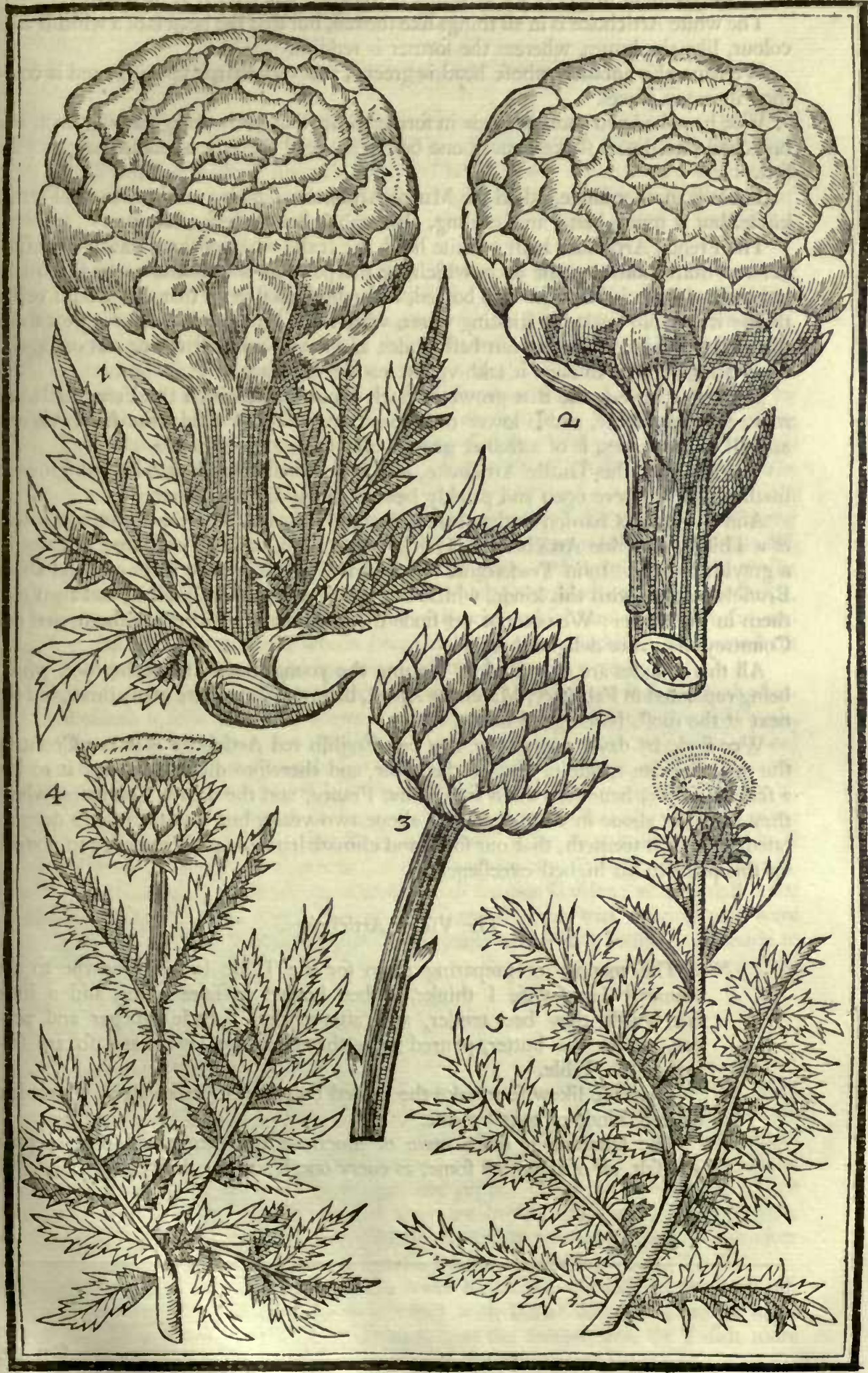

I Cinara faliua rubra. The sed Artichoke. 2 Cinara fatiwa alba. The white Artichoke.

Cimara palula. The French Artichole. + Cinara filwefiris. The Thitle Artichoke. 
ble well, yeelding diuers heads of leaues or fuckers, whereby it is increafed.

The white Artichoke is in all things like the red, but that the head is of a whitifh afhe colour, like the leaues, whereas the former is reddifh.

We haue alfo another, whofe head is greene, and very fharpe vpwards, and is common in many places.

Wee haue had alfo another kinde in former times that grew as high as any man, and branched into diuers ftalkes, euery one bearing a head thereon, almoft as bigge as the firft.

There is another kinde, called the Muske Artichoke, which groweth like the French kinde, but is much better in fpending, although it haue a leffer bottome.

The French Artichoke hath a white head, the fcales whereof ftand ftaring far afunder one from another at the ends, which are tharpe: this is well known by this qualitie, that while it is hot after it is boyled, it fmelleth fo Atrong, that one would verily thinke it had bin boyled in ftinking water, which was brought ouer after a great frofte that had well nigh confumed our beft kindes, and are now almoft cleane caft out again, none being willing to haue it take vp the roome of better.

There is a lowe kinde that groweth much about Paris, which the French efteeme more then any other, and is lower then the former French kinde, the head whereof as well as the leaues, is of a frefher greene colour, almoft yellowifh.

Then there is the Thiftle Artichoke, which is almoft a wilde kinde, and groweth fmaller, with a more open and prickly head then any of the former.

And laftly, the Chardon as they call it, becaufe it is almoft of the forme and nature of a Thiftle, or wilde Artichoke. This groweth high, and full of tharpe prickles, of a grayilh colour. Iohn Tradefcante affured mee, hee faw three acres of Land about Bruffels planted with this kinde, which the owner whited like Endiue, and then fold them in the winter: Wee cannot yet finde the true manner of dreffing them, that our Countrey may take delight therein.

All thefe kindes are encreafed by flipping the young fhootes from the root, which being replanted in February, March, or Aprill, haue the fame yeare many times, but the next at the moft, borne good heads.

Wee finde by dayly experience, that our Englifh red Artichoke is in our Countrey the moft delicate meate of any of the other, and therefore diuers thinking it to bee a feuerall kinde, haue fent them into Italie, France, and the Lowe Countries, where they haue not abode in their goodneffe aboue two yeare, but that they haue degenerated; fo that it feemeth, that our foyle and climate hath the preheminence to nourith vp this plant to his higheft excellencie.

The Vfe of Artichokes.

The manner of preparing them for the Table is well knowne to the youngeft Houfewife I thinke, to bee boyled in faire water, and a little falt, vntill they bee tender, and afterwardes a little vinegar and pepper, put to the butter, poured vpon them for the fawce, and fo are ferued to the Table.

They vfe likewife to take the boyled bottomes to make Pyes, which is a delicate kinde of baked meate.

The Chardon is eaten rawe of diuers, with vinegar and oyle, pepper and falt, all of them, or fome, as euery one liketh for their delight. 
C н А P. L I.

\section{Fabre Es Phafeoli. Garden and French Beanes.}

$\mathrm{T}$

He Garden Beane is of two colours, red or blacke, and white, yet both rife from one; the finall or fielde Beanes I make no mention of in this place; but the French or Kidney Beane is almoft of infinite forts and colours: we doe not for all that intend to trouble you in this place, with the knowledge or relation of any more then is fit for a Garden of that nature, that I have propounded it in the beginning.

Our ordinary Beanes, feruing for foode for the poorer fort for the moft part, are planted as well in fieldes as in gardens, becaufe the quantity of them that are fpent taketh vp many acres of land to be planted in, and rife vp with one, two or three ftalks, according to the fertilitie of the foyle, being fmooth and fquare, higher then any man oftentimes, whereon are fet at certaine diftances, from the very bottome almoft to the toppe, two long fmooth flefhy and thicke leaues almoft round, one ftanding by another at the end of a fmall footeftalke : betweene thefe leaues and the ftalke, come forth diuers flowers, all of them looking one way for the moft part, which are clofe a little turned vp at the brimmes, white and fpotted with a blackin fpot in the middle of them, and fomewhat purplifh at the foot or bottome, of the forme almoft of Broome or Peafe flowers, many of which that grow vpward toward the toppe, doe feldome beare fruit, and therefore are gathered to diftill, and the toppes of the ftalkes cut off, to caufe the reft to thriue the better; after which grow vp long great fmooth greene pods, greater then in any other kinde of Pulfe, which grow blacke when they are ripe, and containe within them two, three or foure Beanes, which are fomewhat flat and round, eyther white or reddifh, which being full ripe grow blackifh: the roote hath diuers fibres annexed vnto the maine roote, which dyeth euery yeare.

The French or Kidney Beane rifeth vp at the firft but with one ftalke, which afterwards diuideth it felfe into many armes or branches, euery one of them being fo weak, that without they be fuftained with ftickes or poles, whereon with their winding and clafpers they take hold, they would lye fruitleffe vpon the ground : vpon thefe branches grow forth at feuerall places long footeftalkes, with euery of them three broade, round and pointed greene leaues at the end of them, towards the tops whereof come forth diuers flowers, made like vnto Peafe bloffomes, of the fame colour for the molt part that the fruit will be of, that is to fay, eyther white, or yellow, or red, or blackinh, or of a deepe purple \&c. but white is moft vfuall for our Garden; after which come long and flender flat pods, fome crooked, and fome. ftraight, with a ftring as it were running downe the backe thereof, wherein are contained flattifh round fruit, made to the fafhion of a kidney: the roote is long, and fpreadeth with many fibres annexed vnto it, perifhing euery yeare.

\section{The Vfe of thefe Beanes.}

The Garden Beanes ferue (as I faid before) more for the vfe of the poore then of the rich: I thall therefore only thew you the order the poore take with them, and leaue curiofity to them that will beftow time vpon them. They are only boyled in faire water and a little falt, and afterwards ftewed with fome butter, a little vinegar and pepper being put vnto them, and fo eaten : or elfe eaten alone after they are boyled without any other fawce. The water of the bloffomes diftilled, is vfed to take away fpots, and to cleer the skin. The water of the greene huskes or cods is good for the ftone.

The Kidney Beanes boyled in water huske and all, onely the ends cut off, and the ftring taken away, and ftewed with butter \&c. are efteemed more fauory meate to many mens pallates, then the former, and are a difh more oftentimes at rich mens Tables then at the poore. 
Ch A P. LII.

Pifum. Peafe.

$\mathrm{T}$ Here is a very great variety of manured Peafe known to vs, and I think more in our Country then in others, whereof fome profper better in one ground and country, and fome in others: I thall give you the defcription of one alone for all the reft, and recite vnto you the names of the reft.

Garden Peafe are for the moft part the greateft and fweetert kinds, and are furtained with ftakes or bufhes. The Field Peafe are not fo vfed, but growe without any fuch adoe. They fpring vp with long, weake, hollow, and brittle (while they are young and greene) whitifh greene ftalkes, branched into diuers parts, and at euery ioynt where it parteth one broad round leafe compaffing the ftalke about, fo that it commeth as it were thorough it: the leaues are winged, made of diuers fmall leaues fet to a middle ribbe, of a whitifh greene colour, with clafpers at the ends of the leaues, whereby it taketh hold of whatfoeuer ftandeth next vnto it: betweene the leaues and the ftalkes come forth the flowers, ftanding two or three together, euery one by it felfe on his owne feuerall ftalke, which are either wholly white, or purple, or mixed white and purple, or purple and blew: the fruit are long, and fomewhat round cods, whereof fome are greater, others leffer, fome thicke and fhort, fome plaine and fmooth, others a little crooked at the ends; wherein alfo are contained diuers formes of fruit or peafe; fome being round, others cornered, fome fmall, fome great, fome white, others gray, and fome fpotted: the roote is fmall, and quickly perifheth.

The kindes of Peafe are thefe :

The Rounciuall.

The greene Hafting.

The Sugar Peafe.

The fpotted Peafe.

The gray Peafe.

The white Hafting.

The Peafe without skins.

The Scottifh or tufted Peafe, which fome call the Rofe Peafe, is a good white Peafe fit to be eaten.

The early or French Peafe, which fome call Fulham Peafe, becaufe thofe grounds thereabouts doe bring them fooneft forward for any quantity, although fometimes they mifcarry by their hafte and earlineffe.

\section{Cicer Arietinum. Rams Ciches.}

This is a kinde of Pulfe, fo much vfed in Spaine, that it is vfually one of their daintie difhes at all their feafts: They are of two forts, white and red; the white is onely vfed for meate, the other for medicine. It beareth many vpright branches with winged leaues, many fet together, being fmall, almoft round, and dented about the edges : the flowers are either white or purple, according to the colour of the Peafe which follow, and are fomewhat round at the head, but cornered and pointed at the end, one or two at the mort in a fmall roundifh cod.

\section{The Vfe of Peafe.}

Peafe of all or the molt of thefe forts, are either vfed when they are greene, and be a dirh of meate for the table of the rich as well as the poore, yet euery one obferuing his time, and the kinde : the faireft, fweeteft, youngeft, and earlieft for the better fort, the later and meaner kindes for the meaner, who doe not giue the deereft price: Or

Being dry, they ferue to boyle into a kinde of broth or pottage, wherein many doe put Tyme, Mints, Sauory, or fome other fuch hot herbes, to giue it the better rellifh, and is much vied in Towne and Countrey in the Lent 


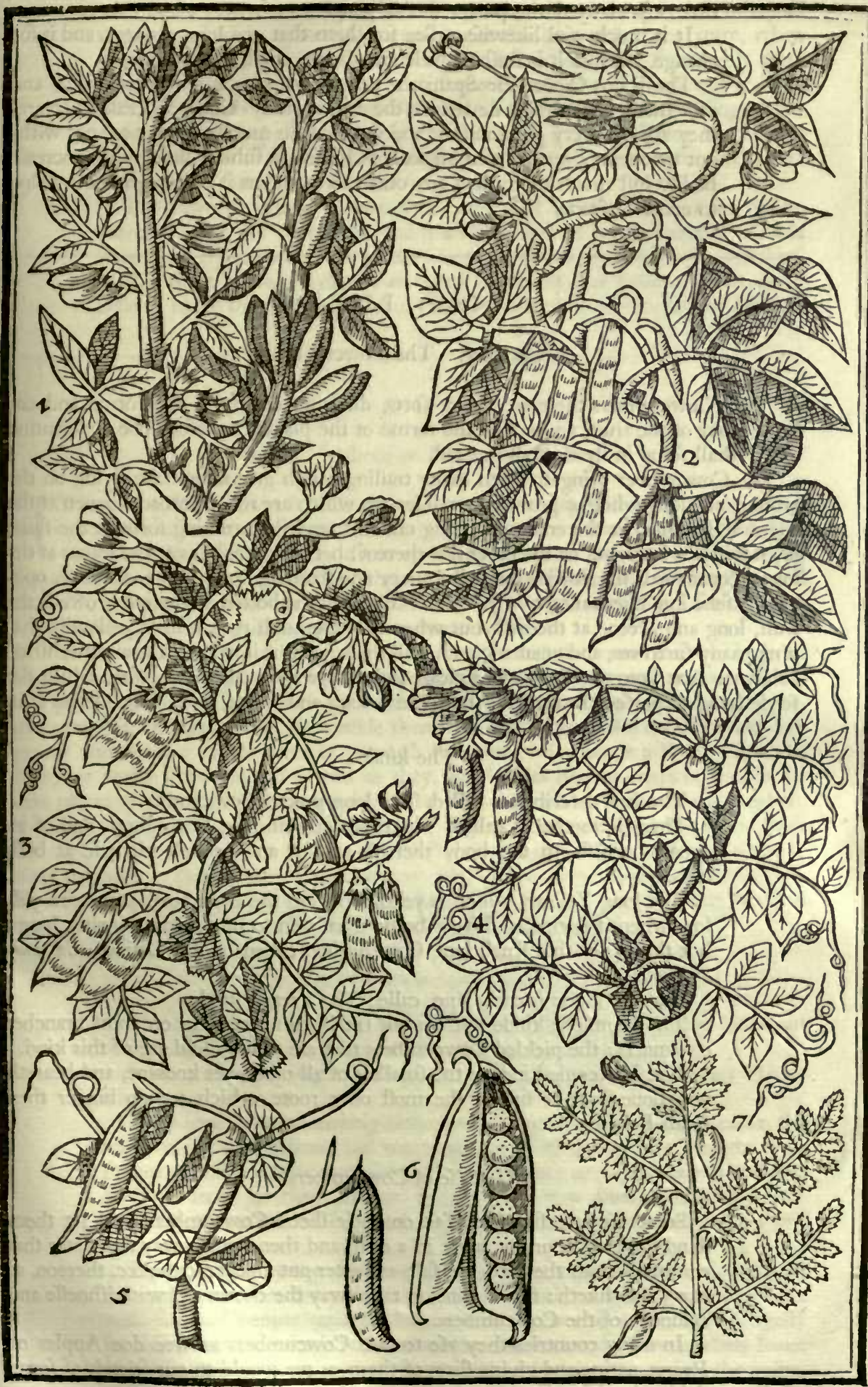

1 Faba fativa. Garden Beanes. 2 Phafcoli fatiui. French Beanes. 3 Pifom sulgare. Garden Peafe. 4 Pj/um smbollatum fiwe Rofoum. Rufe Peafe or Scottin Peafe. 5 Pifum Saccharalum. Sugar Peafe. 6 Pifum maculatum. Spotted Peafe. 7 Cicer Arictinum. Rams Ciches or Cicers. 
time; efpecially of the poorer fort of people.

It is much vfed likewife at Sea for them that goe long voyages, and is for change, becaufe it is frefh, a welcome diet to moft perfons therein.

The Rams Ciches the Spaniards call Grauancos, and Garauancillos, and eate them boyled and ftewed as the moft dainty kinde of Peafe that are, they are of a very good rellifh, and doe nourifh much; but yet are not without that windy quality that all forts of Pulfe are fubiect vnto: they increafe bodily luft much more then any other forts, and as it is thought, doth helpe to encreafe feede.

\section{Ch A P. L I I I.}

\section{Cucumer. The Cowcumber.}

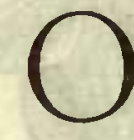

F Cowcumbers there are diuers forts, differing chiefly in the forme and colour of the fruit, and not in the forme of the plant; therefore one defcription fhall ferue in ftead of all the reft.

The Cowcumber bringeth forth many trailing rough greene branches lying on the ground, all along whereof growe feuerall leaues, which are rough, broad, vneuen at the edges, and pointed at the ends, with long crooked tendrils comming forth at the fame ioynt with the leafe, but on the other fide thereof: between the ftalks \& the leaues at the ioynts come forth the flowers feuerally, euery one ftanding on a fhort foot-ftalke, opening it felfe into fiue leaues, of a yellowifh colour, at the bottome whereof groweth the fruit, long and greene at the firft, but when it is thorough ripe, a little yellowifh, hauing many furrowes, and vneuen bunches all the length of it, wherein is a white firme fubftance next vnto the skin; and a cleare pulpe or watery fubftance, with white flat feede lying difperfed through it: the roote is long and white, with diuers fibres at it.

\section{The kindes.}

The firft defcribed is called, The long greene Cowcumber.

There is another is called, The fhort Cowcumber, being thort, and of an equall bigneffe in the body thereof, and of an vnequall bigneffe at both ends.

The long Yellow, which is yellowifh from the beginning, and more yellow when it is ripe, and hath beene meafured to be thirteene inches long : but this is not that fmall long Cowcumber, called of the Latines, Cucumis anguinus.

Another kinde is early ripe, called The French kinde.

The Dantficke kinde beareth but fmall fruit, growing on fhort branches or runners: the pickled Cowcumbers that are vfually fold are of this kind.

The Mufcouie kinde is the fmalleft of all other, yet knowne, and beareth not aboue foure or fiue at the mort on a roote, which are no bigger then fmall Lemons.

\section{The Vfe of Cowcumbers.}

Some vfe to caft a little falt on their fliced Cowcumbers, and let them ftand halfe an houre or more in a difh, and then poure away the water that commeth from them by the falt, and after put vinegar, oyle, \&c. thereon, as euery one liketh : this is done, to take away the ouermuch waterifhneffe and coldneffe of the Cowcumbers.

In many countries they vfe to eate Cowcumbers as wee doe Apples or Peares, paring and giuing flices of them, as we would to our friends of fome dainty Apple or Peare.

The pickled Cowcumbers that come from beyond Sea, are much vfed 
with vs for fawce to meate all the Winter long. Some haue ftriuen to equall them, by pickling vp our Cowcumbers at the later end of the yeare, when they are cheapeft, taking the little ones and fcalding them thoroughly well, which after they put in brine, with fome Dill or Fenell leaues and italkes: but thefe are nothing comparable to the former, wee either miffing of the right and orderly pickling of them, or the kinde it felfe differing much from ours (as I faid of the Dantficke kinde) for ours are neither fo tender and firme, nor fo fauoury as the other.

The rawe or greene Cowcumbers are fitteft for the hotter time of the yeare, and for hot ftomackes, and not to be vfed in colder weather or cold Itomackes, by reafon of the coldneffe, whereby many haue been oucrtaken.

The feede is vfed phyfically in many medicines that ferue to coole, and a little to make the paffages of vrine Mippery, and to giue eafe to hot difeafes.

\section{CH A P. L I I I I.}

\section{Melo. Milions or Muske Melons.}

7 Here bee diuers forts of Melons found out at this day, differing much in the goodneffe of tafte one from another. This Countrey hath not had vntill of late yeares the skill to nourfe them vp kindly, but now there are many that are fo well experienced therein, and haue their ground fo well prepared, as that they will not miffe any yeare, if it be not too extreme vnkindly, to haue many ripe ones in a reafonable time: yet fome will be later then others alwayes.

The Melon is certainly a kinde of Cowcumber, it doth fo neere refemble it, both in the manner of his growing, hauing rough trailing branches, rough vneuen leaues, and yellow flowers: after which come the fruit, which is rounder, thicker, bigger, more rugged, and fpotted on the outfide then the Cowcumber, of a ruffet colour, and greene vnderneath, which when it groweth full ripe, will change a little yellowifh, being as deepe furrowed and ribbed as they, and befides hauing chaps or rifts in diuers places of the rinde : the inward hard fubftance is yellow, which onely is eaten: the feede which is bigger, and a little yellower then the Cowcumber, lying in the middle onely among the moifter pulpe : the fmell and changing of his colour, fore-fhew their ripeneffe to them that are experienced: the roote is long, with many fibres at it. The fruit requireth much watering in the hot time of the day, to caufe them to ripen the fooner, as I haue obferued by diuers of the beft skill therein.

\section{The Vfe of the kindes of Melons.}

The beft Melon feede doe come to vs out of Spaine, fome haue come out of Turkie, but they haue been nothing fo good and kindly.

Some are called Sugar Melons, others Peare Melons, and others Muske Melons.

They haue beene formerly only eaten by great perfonages, becaufe the fruit was not only delicate but rare; and therefore diuers were brought from France, and fince were nourfed vp by the Kings or Noblemens Gardiners onely, to ferue for their Mafters delight : but now diuers others that have skill and conueniencie of ground for them, doe plant them and make them more common.

They paire away the outer rinde; and cut out the inward pulpe where the feede lyeth, nice the yellow firme inward rinde or fubftance, \& fo eate it with falt and pepper (and good ftore of wine, or elfe it will hardly digeft) for this is firmer, \& hath not that moifture in it that the Cowcumbers haue. It is alfo more delicate, and of more worth, which recompenfeth the paine.

The feed of thefe Melons are vied as Cowcumbers phyfically, and together with them moft vfually. 
CHAP. L V.

Pepo. Pompions.

W E have but one kinde of Pompion (as I take it) in all our Gardens, notwithftanding the diuerfities of bigneffe and colour.

The Pompion or great Melon (or as fome call it Milion) creepeth vpon the ground (if nothing bee by it whereon it may take hold and climbe) with very great, ribbed, rough, and prickly branches, whereon are fet very large rough leaues, cut in on the edges with deepe gafhes, and dented befides, with many clafpers alfo, which winde about euery thing they meete withall : the flowers are great and large, hollow and yellow, diuided at the brims into fiue parts, at the bottome of which, as it is in the reft, groweth the fruit, which is very great, fometimes of the bigneffe of a mans body, and oftentimes leffe, in fome ribbed or bunched, in others plaine, and either long or round, either greene or yellow; or gray, as Nature lifteth to fhew her felfe; for it is but wafte time, to recite all the formes and colours may be obferued in them: the inner rinde next vnto the outer is yellowifh and firme: the feede is great, flat, and white, lying in the middle of the watery pulpe : the roote is of the bigneffe of a mans thumbe or greater, difperfed vnder ground with many fmall fibres ioyned thereunto.

Gourds are kindes of Melons; but becaufe wee haue no vfe of them, wee leaue them vnto their fit place.

The Vfe of Pompions.

They are boyled in faire water and falt, or in powdered beefe broth, or fometimes in milke, and fo eaten, or elfe buttered. They vfe likewife to take out the inner watery fubftance with the feedes, and fill vp the place with Pippins, and hauing laid on the couer which they cut off from the toppe, to take out the pulpe, they bake them together, and the poore of the Citie, as well as the Country people, doe eate thereof, as of a dainty difh.

The feede hereof, as well as of Cowcumbers and Melons, are cooling; and ferue for emulfions in the like manner for Almond milkes, \&c. for thofe are troubled with the ftone.

\section{Cна а. LVI.}

Fragaria. Strawberries.

T Here be diuers forts of Strawberries, whereof thofe that are nourfed vp in Gardens or Orchards I intend to giue you the knowledge in this place, and leaue the other to a fitter ; yet I muft needs thew you of one of the wilde forts, which for his ftrangeneffe is worthy of this Garden: And I muft alfo enforme you, that the wilde Strawberry that groweth in the Woods is our Garden Strawberry, but bettered by the foyle and tranfplanting.

The Strawberry hath his leaues clofed together at the firf fpringing $v p$, which afterwards fpread themfelues into three diuided parts or leaues, euery one ftanding vpon a frmall long foote-italke, greene on the vpperfide, grayifh vnderneath, and fnipped or dented about the edges; among which rife vp diuers fmall ftalkes, bearing foure or fiue flowers at the tops, confifting of fiue white round pointed leaues, fomewhat yellowifh in the bottome, with fome yellow threads therein; after which come the fruit, made of many fmall graines fet together, like vnto a fmall Mulberry or Rafpis, reddifh when it is ripe, and of a pleafant winy tafte, wherein is enclof ed diuers fmall blackifh feede : the roote is reddifh and long, with diuers fmall threads at it, and fendeth 


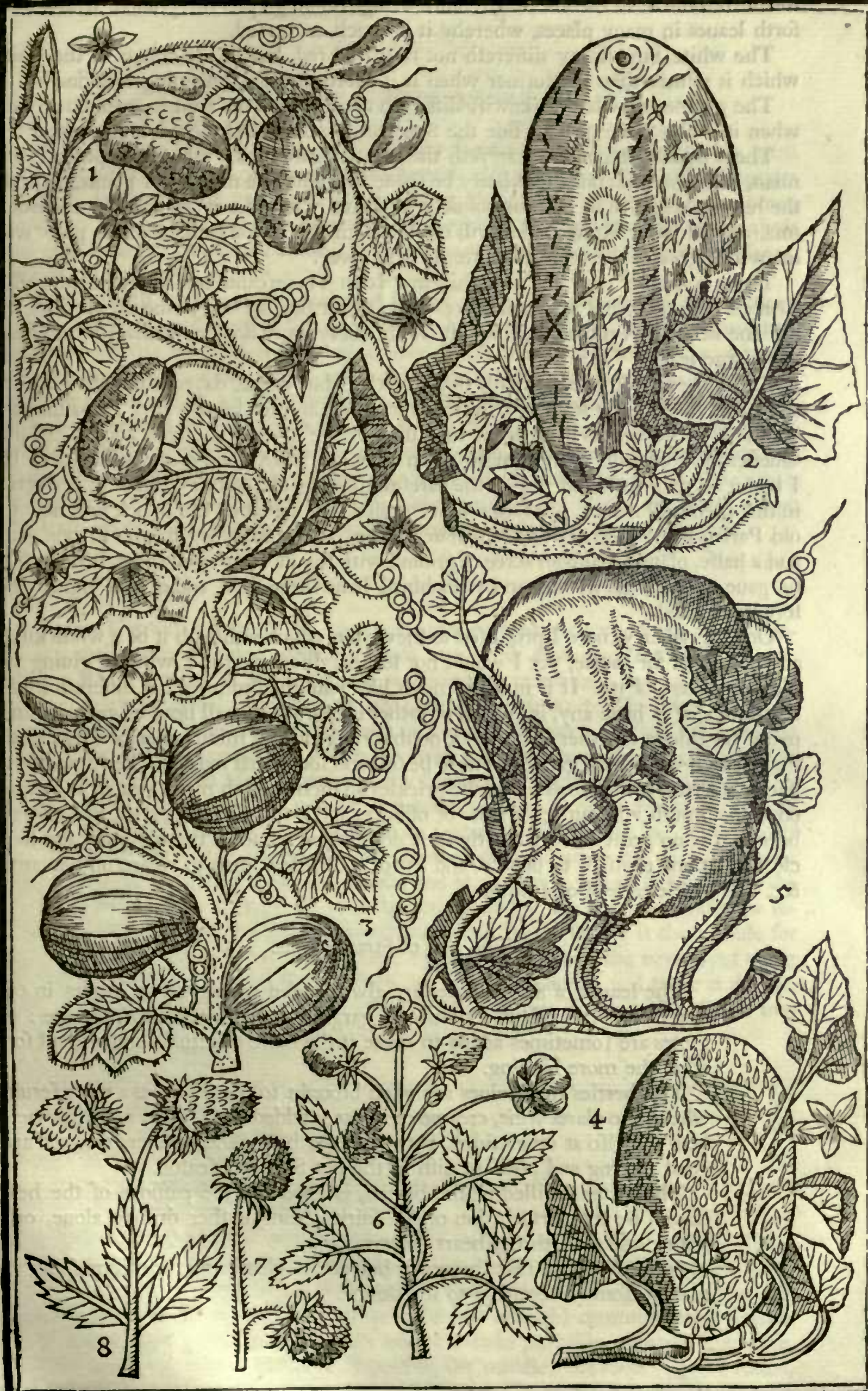

I Cucumis longus vulgaris. The ordinary Cowcumber. 2 Cucumis Hifpanicus. The long yellow Spanifh Cowcumber. 3 Mrlo sulgaris. The ordinary Melon. 4 Melo maximus optimus. The greatêt Muske Melon. 5 Pepo. The Pompion. 6 Fragari
vulgaris. Common Strawberries. 7 Fragari Bohemica maxima. The great Bohemia Strawberrics. 8 Fragari aculcala. The prickly Strawberry. 
forth from the head thereof long reddifh ftrings running vpon the ground, which thoot forth leaues in many places, whereby it is much encreafed.

The white Strawberry differeth not from the red, but in the colour of the fruite, which is whiter then the former when it is thorough ripe, enclining to redneffe.

The greene Strawberry likewife differeth not, but that the fruit is green on all fides when it is ripe, faue on that fide the Sun lyeth vpon it, and there it is fomewhat red.

The Virginia Strawberry carryeth the greateft leafe of any other, except the Bohemian, but fcarce can one Strawberry be feene ripe among a number of plants; I thinke the reafon thereof to be the want of skill, or induftry to order it aright. For the Bohemia, and all other Strawberries will not beare kindly, if you fuffer them to grow with many ftrings, and therefore they are ftill cut away.

There is another very like vnto this, that Iohn Tradefcante brought with him from Bruffels long agoe, and in feuen yeares could neuer fee one berry ripe on all fides, but ftill the better part rotten, although it would euery yeare flower abundantly, and beare very large leaues.

The Bohemia Strawberry hath beene with vs but of late dayes, but is the goodlieft and greateft, both for leafe next to the Virginian, and for beauty farre furpafing all; for fome of the berries haue beene meafured to bee neere fiue inches about. Mafter Quefter the Poftmafter firft brought them ouer into our Country, as I vnderftand, but I know no man fo induftrious in the carefull planting and bringing them to perfection in that plentifull maner, as Mafter Vincent Sion who dwelt on the Banck fide, neer the old Paris garden ftaires, who from feuen rootes, as hee affirmed to me, in one yeare and a halfe, planted halfe an acree of ground with the increafe from them, befides thofe he gaue away to his friends, and with him I have feene fuch, and of that bigneffe before mentioned.

One Strawberry more I promifed to thew you, which although it be a wilde kinde, and of no vfe for meate, yet I would not let this difcourfe paffe, without giuing you the knowledge of it. It is in leafe much like vnto the ordinary, but differeth in that the flower, if it haue any, is greene, or rather it beareth a fmall head of greene leaues, many fet thicke together like vnto a double ruffe, in the midft whereof ftandeth the fruit, which when it is ripe, Theweth to be foft and fomewhat reddirh, like vnto a Strawberry, but with many fmall harmleffe prickles on them, which may be eaten and chewed in the mouth without any maner of offence, and is fomewhat pleafant like a Strawberry : it is no great bearer, but thore it doth beare, are fet at the toppes of the ftalks clofe together, pleafant to behold, and fit for a Gentlewoman to weare on her arme, \&c. as a raritie inftead of a flower.

\section{The Vfe of Strawberries.}

The leaues of Strawberries are alwaies vfed among other herbes in cooling drinkes, as alfo in lotions, and gargles for the mouth and throate : the rootes are fometimes added to make it the more effectuall, and withall fomwhat the more binding.

The berries themfelues are often brought to the Table as a reare feruice, whereunto claret wine, creame or milke is added with fugar, as euery one liketh; as alfo at other times, both with the better and meaner fort, and are a good cooling and pleafant difh in the hot Summer feafon.

The water diftilled of the berries, is good for the paffions of the heart, caufed by the perturbation of the fpirits, being eyther drunke alone, or in wine ; and maketh the heart merry.

Some doe hold that the water helpeth to clenfe the face from fpots, and to adde fome cleereneffe to the skinne. 


\section{CH A P. L V I I.}

\section{Angelica. Garden Angelica.}

I Auing thus furnifhed you out a Kitchen Garden with all forts of herbes, roots $\&$ fruits fit for it, and for any mans priuate vfe, as I did at the firft appropriate it; let we a little tranfcend, and for the profit \& vfe of Country Gentlewomen and others, furnifh them with fome few other herbes, of the moft efpeciall vfe for thofe thall need them, to be planted at hand in their Gardens, to fpend as occafion fhall ferue, and firft of Angelica.

Angelica hath great and long winged leaues, made of many broade greene ones, diuided one from another vpon the ftalk, which is three foot long or better fomtimes, among which rife vp great thicke and hollow ftalkes with fome few ioynts, whereat doth alwayes ftand two long leaues compaffing the ftalke at the bottome, in fome places at the ioynts fpring out other ftalkes or branches, bearing fuch like leaues but fmaller, and at the tops very large vinbels of white flowers, that turne into whitifh feede fomewhat thicke: the roote groweth great with many branches at it, but quickly perifheth after it hath borne feede : to preferue the roote therefore the better, they vfe to cut it often in the yeare, thereby to hinder the running vp to feede: the whole plant, both leafe, roote and feede, is of an excellent comfortable fent, fauour and tafte.

\section{The Vfe of Angelica.}

The diftilled water of Angelica, eyther fimple or compound, is of efpeciall vfe in deliquium animi, vel cordis tremores $E^{2}$ pa fsiones, that is, fwounings, when the fpirits are ouercome and faint, or tremblings and paffions of the heart, to expell any windy or noyfome vapours from it. The green ftalkes or the young rootes being preferued or candied, are very effectuall to comfort and warme a colde and weake ftomacke : and in the time of infection is of excellent good vfe to preferue the fpirits and heart from infection. The dryed roote made into pouder, and taken in wine or other drinke, will abate the rage of luft in young perfons, as I haue it related vnto me vpon credit: A Syrupe made thereof in this manner, is very profitable to expectorate flegme out of the cheft and lunges, and to procure a fweete breath. Into the greene ftalke of Angelica as it ftandeth growing, make a great gafhe or incifion, wherein put a quantitie of fine white Sugar, letting it there abide for three dayes, and after take it forth by cutting a hole at the next ioynt vnder the cut, where the Syrupe refteth, or cut off the ftalke, and turne it downe, that the Syrrupe may drayne forth; which keepe for a moft delicate medicine.

\section{C н A P. L V I I I.}

\section{Dracunculus hortenfis fue Serpentaria. Dragons.}

D Ragons rifeth out of the ground with a bare or naked round whitifh ftalke, fpotted very much with purplifh fpots and ftrakes, bearing at the toppe therof a few greene leaues very much diuided on all fides, ftanding vpon long footeftalkes, in the middle whereof (if the roote be old enough) commeth forth a great long huske or hofe, green on the outfide, and of a darke purplifh colour on the infide, with a flender long reddifh peftell or clapper in the middle: the roote is great, round, flat and whitifh on the outfide, and whiter within, very like vnto the rootes of Arum, or Wakerobin, and tafting fomewhat fharpe like it. 
The Vfe of Dragons.

The chiefe vfe whereunto Dragons are applyed, is, that according to an old receiued "cuftome and tradition (and not the iudgement of any learned Author) the diftilled water is giuen with Mithridatum or Treakle to expell noyfome and peftilentiall vapours from the heart.

\section{Ch A.P. LIX.}

\section{Ruta. Garden Rue, or Herbe Grace.}

Arden Rue or Herbe Grace groweth vp with hard whitifh wooddy ftalkes, whereon are fet diuers branches of leaues, being diuided into many fmall ones, which are fomewhat thicke and round pointed, of a blewifh greene colour: the flowers ftand at the tops of the ftalkes confifting of foure fmall yellow leaues, with a greene button in the middle, and diuers fmall yellow threds about it, which growing ripe, containe within them fmall blacke feede: the roote is white and wooddy, fpreading farre in the ground.

\section{The Vfe of Rue.}

The many good properties whereunto Rue ferueth, hath I thinke in former times caufed the Englifh name of Herbe Grace to be giuen vnto it. For without doubt it is a moft wholefome herbe, although bitter and ftrong, and could our dainty ftomackes brooke the vfe thereof, it would worke admirable effects being carefully and skilfully applyed, as time and occafion did require: but not vndifcreetly or hand ouer head, as many vfe to doe that haue no skill. Some doe rippe vp a beade rowle of the vertues of Rue, as Macer the Poet and others, in whom you fhall finde them fet downe, to bee good for the head, eyes, breaft, liuer, heart, fpleene, \&c. In fome places they vfe to boyle the leaues of Rue, and keep them in pickle, to eate them as Sampire for the helpe of weake eyes. It is very auaileable in glifters or drinkes againft the winde or the collicke, and to procure vrine that is ftayed by the paines therof. The diftilled water is often vfed for the fame purpofes aforefaid: but beware of the too frequent or ouermuch vfe thereof, becaufe it heateth exceedingly, and wafteth nature mightily.

\section{CHAP. LX.}

Carduus Benedictus. The Bleffed Thiftle.

$\mathrm{C}$ Arduus benedictus or the bleffed Thiftle, hath many weake tender branches lying for the moft part on the ground, whereon are fet long and narrow leaues, much cut in or waued about the edges, hairy or rough in handling, yet without any hard or fharpe thornes or prickles at all, that the tendereft hand may touch them without harme: but thofe that grow toward the toppes of the ftalkes are fomewhat more prickly, and the heads which grow on the tops of the feuerall branches are fomewhat fharpe, fet with prickles like a Thiftle: the flower is yellow, and the feede lying within the woolly or flocky doune like to all other thiftles, are blackifh, long and round, with a few haires on the head of them: the roote is white, and perifheth euery yeare after it hath giuen feede.

\section{The Vfe of the bleffed Thifle.}

The diftilled water hereof is much vfed to be drunke againf agues of all fortes, eyther peftilentiall or humorall, of long continuance or of leffe: 


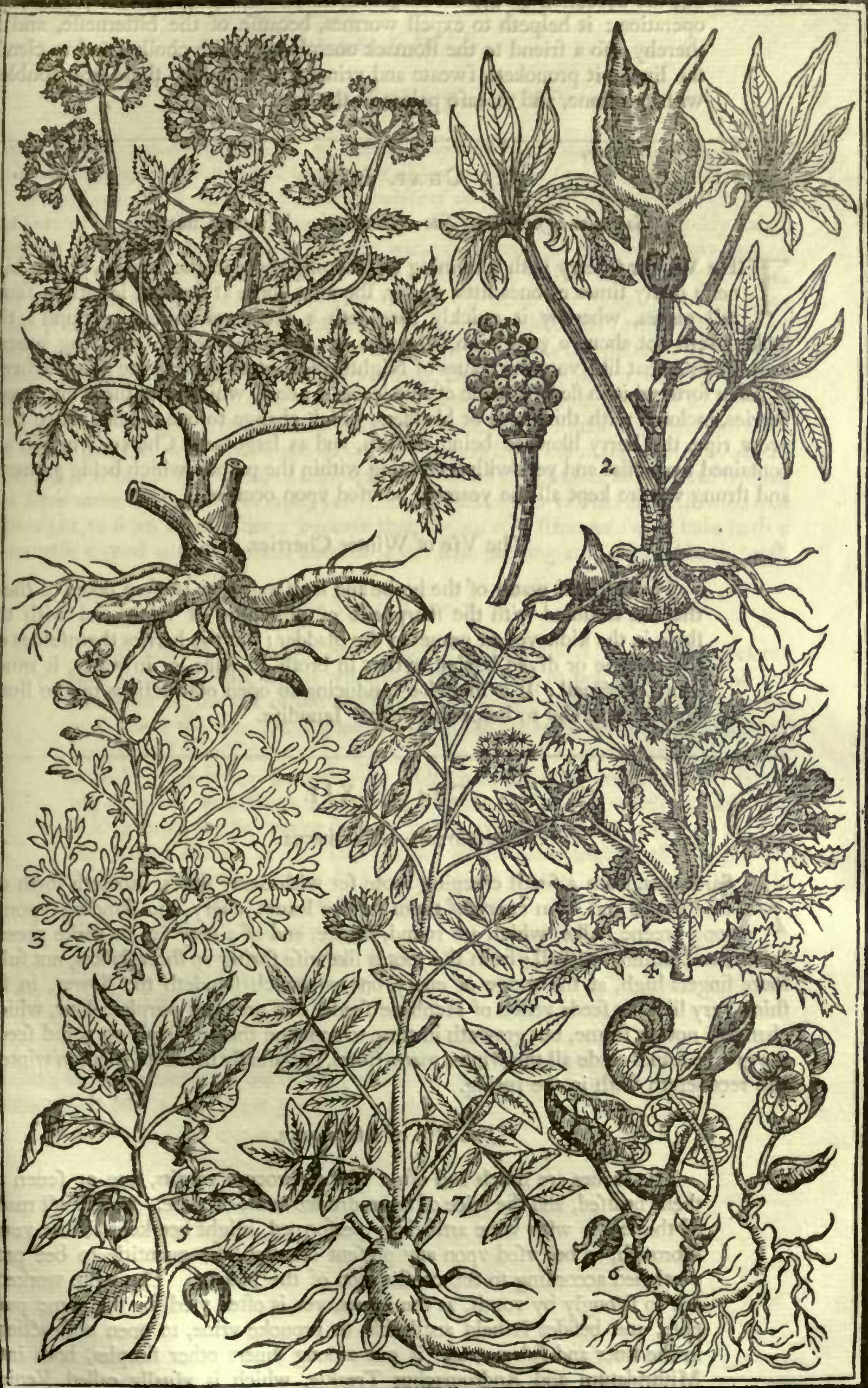

I Angellica. Angellica. 2 Dracuneulus hortonfis. Dragone, 3 Rula horkenfis. Garden Rue, Or II erbegrace. 4 Carduns benedians. The blefied 
but the decoction of the herbe giuen in due time, hath the more forcible operation : it helpeth to expell wormes, becaufe of the bitterneffe, and is thereby alfo a friend to the ftomack ouercharged with chollar, and to clenfe the liuer: it prouoketh fweate and vrine, is helpefull to them are troubled with the ftone, and to eafe paines in the fides.

\title{
C н а P. LXI.
}

\section{Solanum veficarium, fiue Alkakengi. Winter Cherries.}

$\mathrm{T}$

He Winter Cherry hath a running or creeping roote in the ground, of the bigneffe many times of ones little finger, thooting forth at feuerall ioynts in feuerall places, whereby it quickly fpreadeth a great compaffe of ground : the ftalke rifeth not aboue a yard high, whereon are fet many broade and long greene leaues, fomewhat like vnto the leaues of Nighthade, but larger : at the ioynts whereof come forth whitith flowers made of fiue leaues a peece, which after turne into green berries, inclofed with thin skins or bladders, which change to bee reddifh when they grow ripe, the berry likewife being reddifh, and as large as a Cherry, wherein are contained many flat and yellowifh feed lying within the pulpe: which being gathered and ftrung vp, are kept all the yeare to be vfed vpon occafion.

\section{The Vfe of Winter Cherries.}

The diftilled water of the herbe and fruit together, is often taken of them that are troubled with the Tharpneffe or difficultie of vrine, and with the ftone in the kidneyes, or grauel in the bladder : but the berries themfelues either greene or dryed boyled eyther in broth, in wine, or in water, is much more effectuall : It is likewife conducing to open obftructions of the liuer, $\& c$. and thereby to helpe the yellow Iaundife.

\section{Ch A P. LXII.}

\section{Afarum. Afarabacca.}

\begin{abstract}
Sarabacca, from a fmall creeping roote fet with many fibres, thooteth forth diuers heads, and from euery of them fundry leaues, euery one ftanding vpon a long greene ftalke, which are round, thicke, and of a very fad or darke greene colour, and fhining withall : from the rootes likewife fpring vp fhort ftalkes, not fully foure fingers high, at the toppe of euery one of which ftandeth the flower, in fathion very like the feede veffell of Henbane feede, of a greenifh purple colour, which changeth not his forme, but groweth in time to containe therein fmall cornered feed: the greene leaues abide all the winter many times, but vfually fheddeth them in winter, and recouereth frefh in the fpring.
\end{abstract}

\section{The Vfe of Afarabacca.}

The leaues are much and often vfed to procure vomits, fiue or feuen of them bruifed, and the iuice of them drunke in ale or wine. An extract made of the leaues with wine artificially performed, might bee kept all the yeare thorough, to bee vfed vpon any prefent occafion, the quantitie to bee proportioned according to the conftitution of the patient. The roote worketh not fo ftrongly by vomit, as the leaues, yet is often vfed for the fame purpofe, and befides is held auaileable to prouoke vrine, to open obitructions in the liuer and fpleene, and is put among diuers other fimples, both into Mithridatum and Andromachus Treakle, which is vfually called Venice Treakle. A dram of the dryed roots in pouder giuen in white wine a little before the fit of an ague, taketh away the fhaking fit, \& therby caufe the hot fit to be the more remiffe, and in twice taking expell it quite.

C H A P. 


\section{CH A P. L X I I I.}

\section{Glycyrrhiza fue Liqueritia. Licorice.}

A Lthough there are two forts of Licorice fet downe by diuers Authors, yet becaufe this Land familiarly is acquainted but with one fort, I thall not neede for this Garden, to make any further relation of that is vnknowne, but onely of that fort which is fufficiently frequent with vs. It rifeth vp with diuers wooddy ftalks, whereon are fet at feuerall diftances many winged leaues, that is to fay, many narrow long greene leaues fet together on both fides of the ftalke, and an odde one at the end, very well refembling a young Afhe tree fprung vp from the feede: this by many yeares continuance in a place without remouing, and not elfe, will bring forth flowers many ftanding together fpike-fafhion one aboue another vpon the ftalkes, of the forme of Peafe bloffomes, but of a very pale or bleake blew colour, which turne into long fomewhat flat and fmooth cods, wherein is contained fmall round harde feede : the roote runneth downe exceeding deep into the ground, with diuers other fmaller roots and fibres growing with them, and fhoote out fuckers from the maine rootes all about, whereby it is much encreafed, of a brownifh colour on the outfide, and yellow within, of a farre more weake fweete tafte, yet far more pleafing to vs then that Licorice that is brought vs from beyond Sea ; becaufe that, being of a ftronger fweet tafte hath a bitterneffe ioyned with it, which maketh it the leffe pleafing and acceptable to moft.

\section{The Vfe of Licorice.}

Our Englifh Licorice is now adaies of more familiar vfe (as I faid before) then the outlandifh, and is wholly fpent and vfed to helpe to digeft and expectorate flegme out of the cheft and lunges, and doth allay the fharpeneffe or faltneffe thereof. It is good alfo for thofe are troubled with fhortneffe of breath, and for all forts of coughes. The iuice of Licorice artificially made with Hyffope water, ferueth very well for all the purpofes aforefaid. It being diffolued with Gum Tragacanth in Rofe water, is an excellent Lohoc or licking medicine to breake flegme, and to expectorate it, as alfo to avoyde thin frothy matter, or thin falt flegme, which often fretteth the lungs. It doth alfo lenifie exulcerated kidneyes, or the bladder, and helpeth to heale them. It is held alfo good for thofe that cannot make their water but by drops, or a fmall deale at a time.

The dryed root finely minced, is a fpeciall ingredient into all Trageas or Dredges, feruing for the purpofes aforefaid, but the vfe of them is almoft wholly left now adaies with all forts.

Thus haue I fhewed you not only the herbes, rootes and fruites, nourfed vp in this Garden, but fuch herbes as are of moft neceffary vfes for the Country Gentlewomens houfes: And now I will thew you the Orchard alfo. 


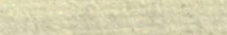 \\ IITXI $A+E^{2}$}

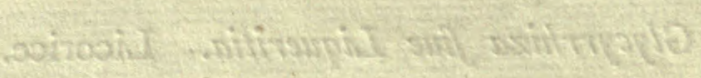

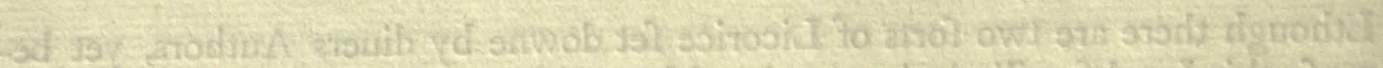

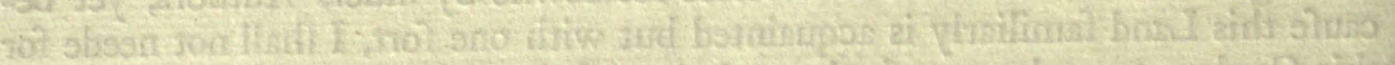

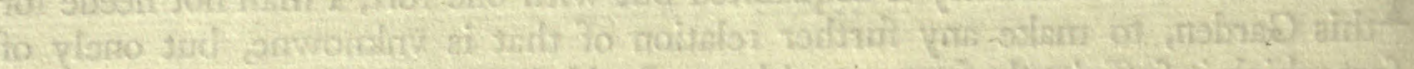

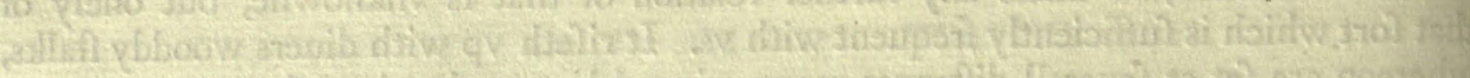

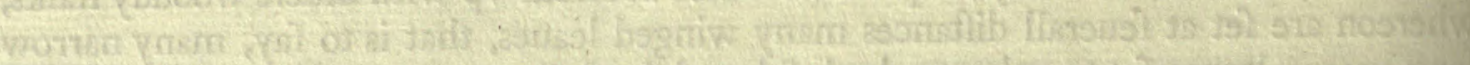

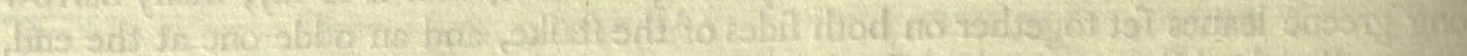

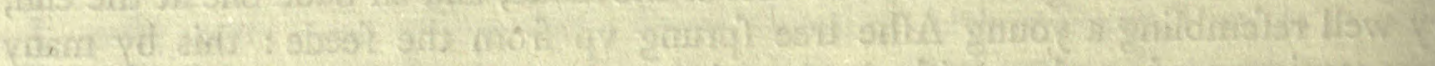

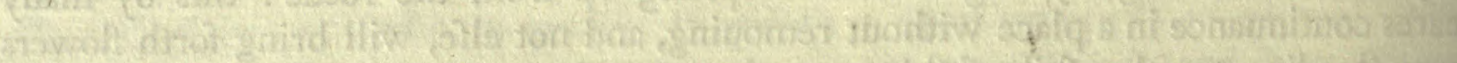

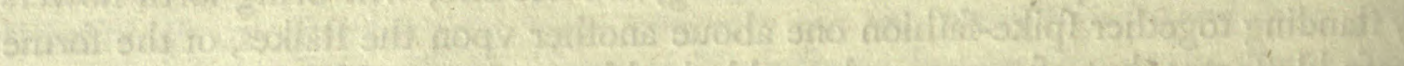

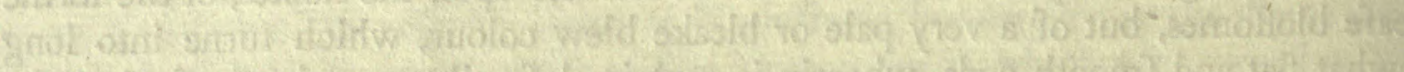

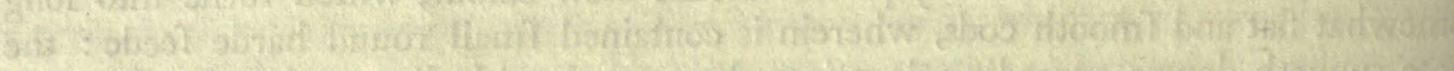

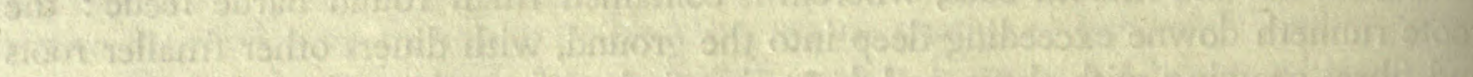

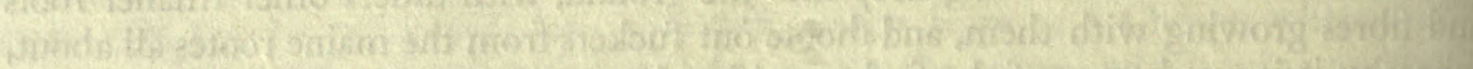

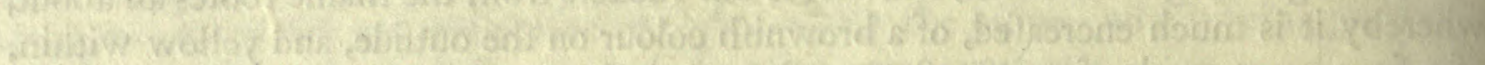

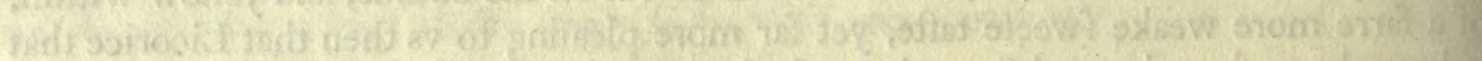

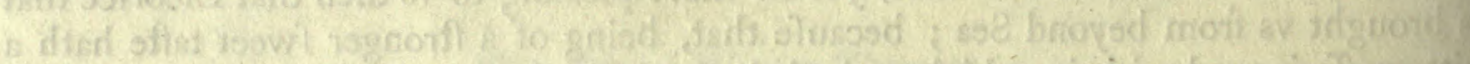

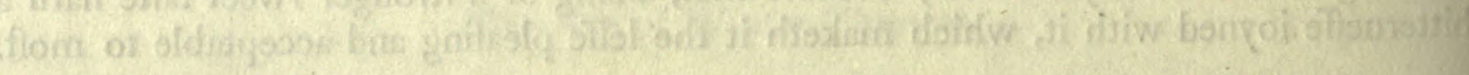

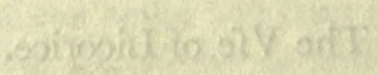

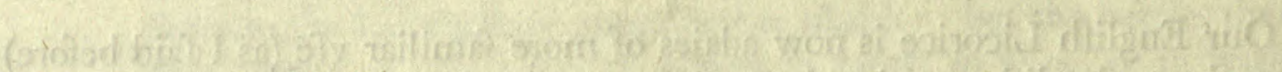

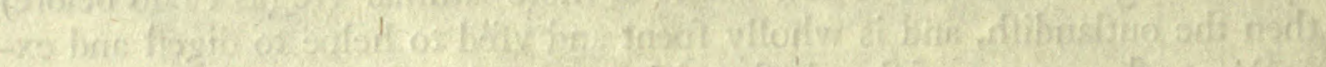

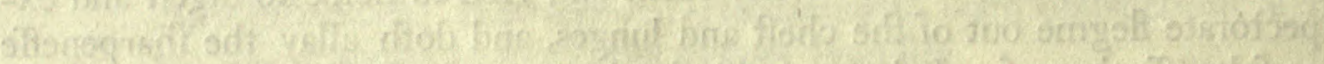

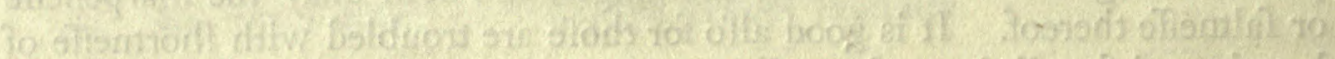

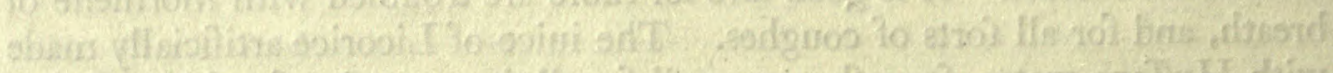

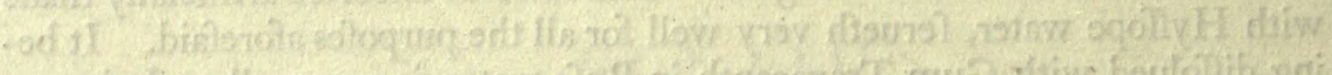

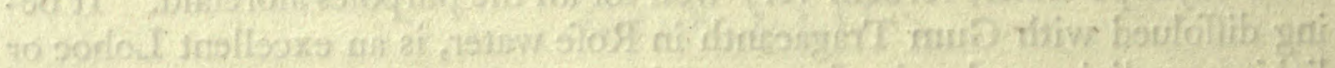

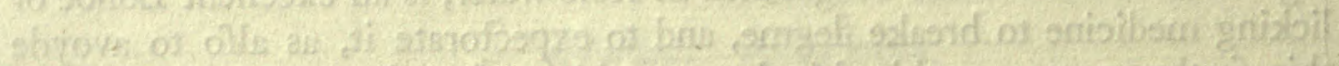

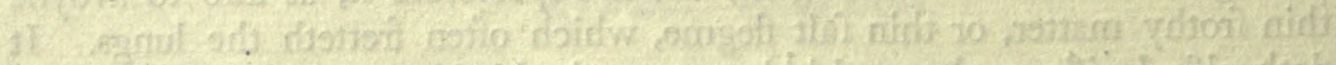

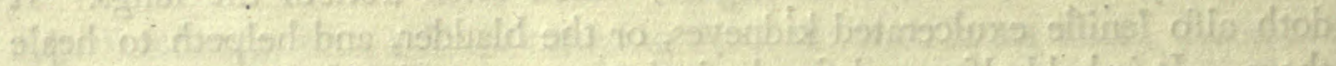

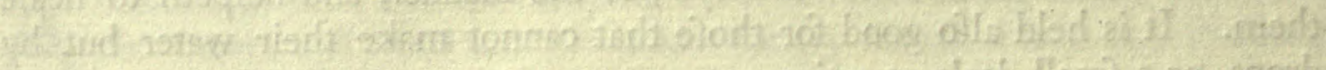

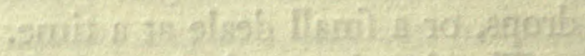

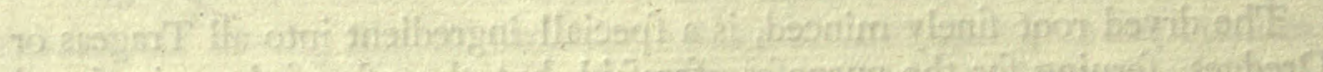

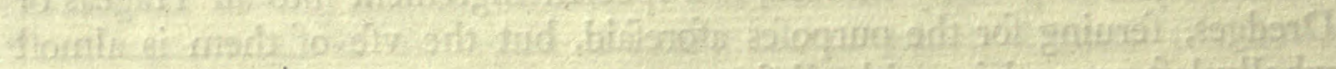

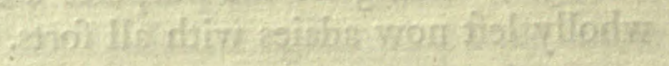

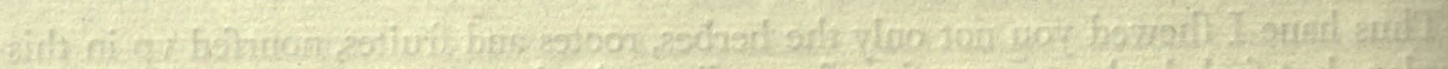

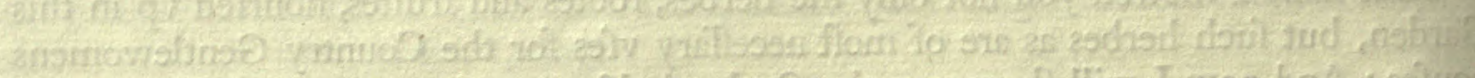

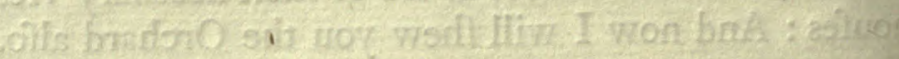




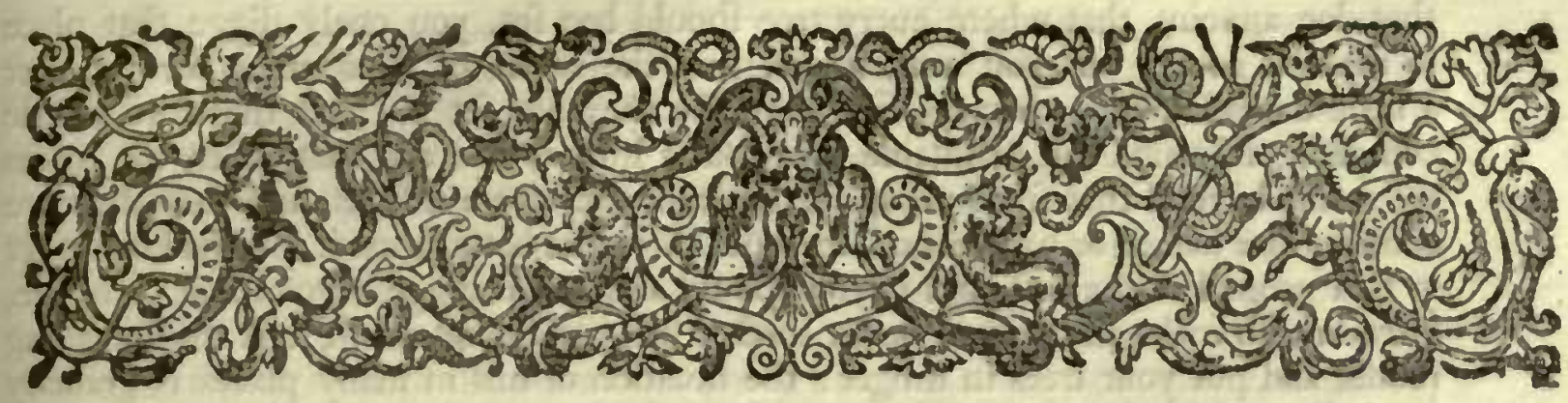

T H E

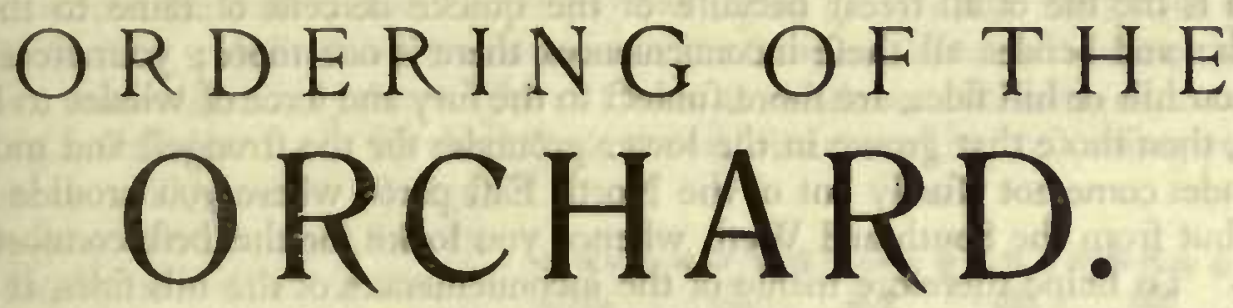

The third part, or ORCHARD.

Chap. I.

The filuation of an Orchard for fruit-bearing trees, and how to amend the defects of many grounds.

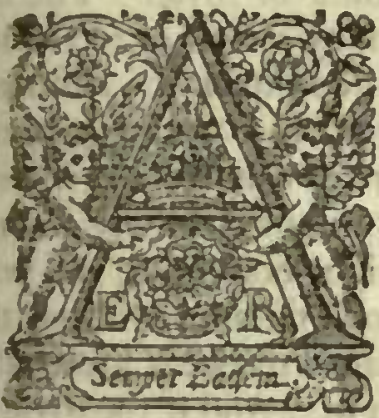

S I baue done in the two former parts of this Treatife, fo I meane to proceede in this; firft to fet downe the fituation of an Orchard, and then other things in order : And firt, I hold that an Orchard which is, or thould bee of fome reafonable large extent, hould be fo placed, that the houfe fhould have the Garden of Alowers iuft before it open vpon the South, and the Kitchen Garden on the one fide thereof, thould allo haue the Orchard on the other fide of the Garden of Pleafure, for many good reafons: Firft, for that the fruit trees being grown great and tall, will be a great Thelter from the North and Eaft windes, which may offend your chiefeft Garden, and although that your Orchard itand a little bleake vpon the windes, yet trees rather endure thefe ftrong bitter blafts, then other fmaller and more tender thrubs and herbes can doe. Secondly, if your Orchard thould ftand behinde your Garden of flowers more Southward, it would thadow too much of the Garden, and befides, would fo binde in the North and Eaft, and North and Weft windes vpon the Garden, that it would rpoile many tender things therein, and fo much abate the edge of your pleafure thereof, that you would willingly wirh to have no Orchard, rather then that it fhould fo much annoy you by the fo ill ftanding thereof. Thirdly, the falling leaues being ftill blowne with the winde fo aboundantly into the garden, would either fpoile many things, or haue one daily and continuall attending thereon, to cleanfe and fweepe them away. Or elfe to auoide thefe great inconueniences, appoint out an Orchard the farther off, and fet a greater diftance of ground betweene. For the ground or foile of the Orchard, what I haue fpoken concerning the former Garden for the bettering of the feuerall grounds, may very well ferue and be applyed to this purpofe. But obferue this, that whereas your Gardens before f poken of may be turned vp, manured, and bettered with foile if they growe out of heart, your Orchard is not fo eafily done, but mult abide many yeares without altering; and therefore if the ground be barren, or not good, it had the more neede to bee amended, or wholly made good, before you make an Orchard of it; yet, fome there be 
that doe appoint, that where every tree thould bee fet, you onely digge that place (t) make if grood: but you mut know, that the rootes of eress rume further after a little rimes flanding, then the firt compantic they are fet in; and therefore a litele computie of ground can maintuine them but a little while, and that when the moses are rumne beyond that funall compalle wherein they were firt fet, and that they are come to the barren or bad ground, they can thrine no better then if they had beene iet in that ground at the firtt, and if you thould atterwards digge beyond that compatie, intending to make the ground better furcher off, you llould unuch hurt the fprending reores and put your trees in danger: the fituntion of hils in many places is grauelly or chalky, which is not good for trees becaule they are both two Itonie, and lacke mellow earth, wherein a tree doth molt ioy and profper, and want moitture alio (which is the life of all trees) becaufe of the quicke defent of raine to the lower grounds: and betides all theie inconueniences there is one more: your trees planted either on hils or hill fides sre more lubiect to the fury and force of windes to be ouerturned, then thofe that growe in the lower grounds; for the ftrongelt and mout forcible windes come not viully out of the North Eatt parts where you prouide beit defence, but from the South and Weft, whence you looke for the bett comtort of the Sunne. To helpe therefore manie of the inconueniences of the hils fides it were tit to caufe manie leauels to bee made thereon, by raifing the lower grounds with groxt earth, and futtaining them with bricke or ftone wals, which although chargeable, will counteruaile your colt. befide the plenfure of the walkes and profpect of fo worthy a worke. The plaine or leuell grounds as they are the molt frequent, fo they are the molt commendable for an Orchard, becauie the moulds or earths are more rich, or may better and ionerer be made fo; and cherefore the profis are the more may be raifert from them. A ftiffe clay doth nourith trees well, by reafon it contuineth moifture; but in regard of the coldnefie thereof, it killeth for the mott part all tender and early things therein: fea-role alhes therefore, bucke athes Itreete foyle, chaulke after it hath lyen abrowd and heen broken with many yeares frolts and naine, and theepes dung, are the molt proper and fittelt manure to helpe this kinde of foyle. The dry fandy toile, and gramelly ground are on the contrary lide as bad, by reaton of $t(x)$ much heare and lacke of moilture: the dung of kine or cattell in good quantity beltuwert therom, will much helpe them. The amending or bettering of other forts of grounds is fet down toward the end of the fint Chapter of the firt part of this worke, whereviso I will referre you, not willing to repeate againe the faume things there fet downe. The bett way to anoide and amend the incommeniences of high, boifterous and cold windes is to phant Walnut trees Elmes, Oakes or Afhes a good difturce without the compatie of your Orchard, which after they are growne grest, will bee a great laic guwn theremito, by breaking the violence of the windes from it. And if the foyle of your Orchant want moifture, the conneying of the finke of the houle, as alfo any or ther draine of water thereinto, if it may be, will much helpe it.

C. A P. II.

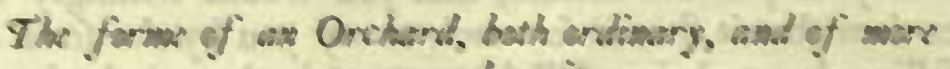
graver was rariaty.

$\mathrm{A}$ Coonding to the fituation of mens grounds fo mutt the planmtion of them of netesitic be slio: and if the groumd be in forme, you thatl haue a formall Orchand: if osherwife, it can haue little grace or forme. And indent in the elder sges there wss limall care or herte niken for the firmality; for euery tree for the mut? purt was planted without onder, euen where the madter or kefere found a vacant place to plant than in fo that offentimes the ill placing of tress without litficient lpwer botwewne them, axd negligence in not loxking to vphold thesus. procurol more walte and ipoile of fruit, then any sccident of winde or weather coukt doe. Orchants in moutt pleces have not bricke or ftone wals to fecure them. hewute the extent therevi being 
larger then of a Garden, would require more coft, which euery one cannot vndergoe; and thercfore mud wals, or at the beft a quicke fet hedge, is the ordinary and inoft vfuall defence it findeth almoft in all places: but with thofe that are of ability to compaffe it with bricke or ftone wals, the gaining of ground, and profit of the fruit trees planted there againft, will in thort time recompenfe that charge. If you make a doubt how to be fure that your Orchard wall fhall have fufficient comfort of the Sunne to ripen the fruits, in regard the trees in the Orchard being fo nigh thereunto, and fo high withall, will fo much fhadow the wall, that nothing will ripen well, becaufe it will want the comfort of the Sunne: you may follow this rule and aduice, to remedy thofe inconueniences. Hauing an Orchard containing one acre of ground, two, three, or more, or leffe, walled about, you may fo order it, by leauing a broad and large walke betweene the wall and it, containing twenty or twenty foure foote (or yards if you will) that the wall thall not be hindered of the Sun, but haue fufficient comfort for your trees, notwithftanding the height of them, the diftance betweene them and the wall being a fufficient fpace for their hadow to fall into: and by compaffing your Orchard on the infide with a hedge (wherein may bee planted all forts of low fhrubs or bufhes, as Rofes, Cornellian Cherry trees plafhed lowe, Goofeberries, Curran trees, or the like) you may enclofe your walke, and keepe both it and your Orchard in better forme and manner, then if it lay open. For the placing of your trees in this Orchard, firf for the wals: Thofe fides that lye open to the South \& Southweft Sunne, are fitteft to bee planted with your tendereft and earlieft fruits, as Apricockes, Peaches, Nectarius, and May or early Cherries: the Eaft, North and Weft, for Plums and Quinces, as you thall like beft to place them. And for the Orchard it felfe, the ordinary manner is to place them without regard of meafure or difference, as Peares among Apples, and Plums among Cherries promifcuouly; but fome keepe

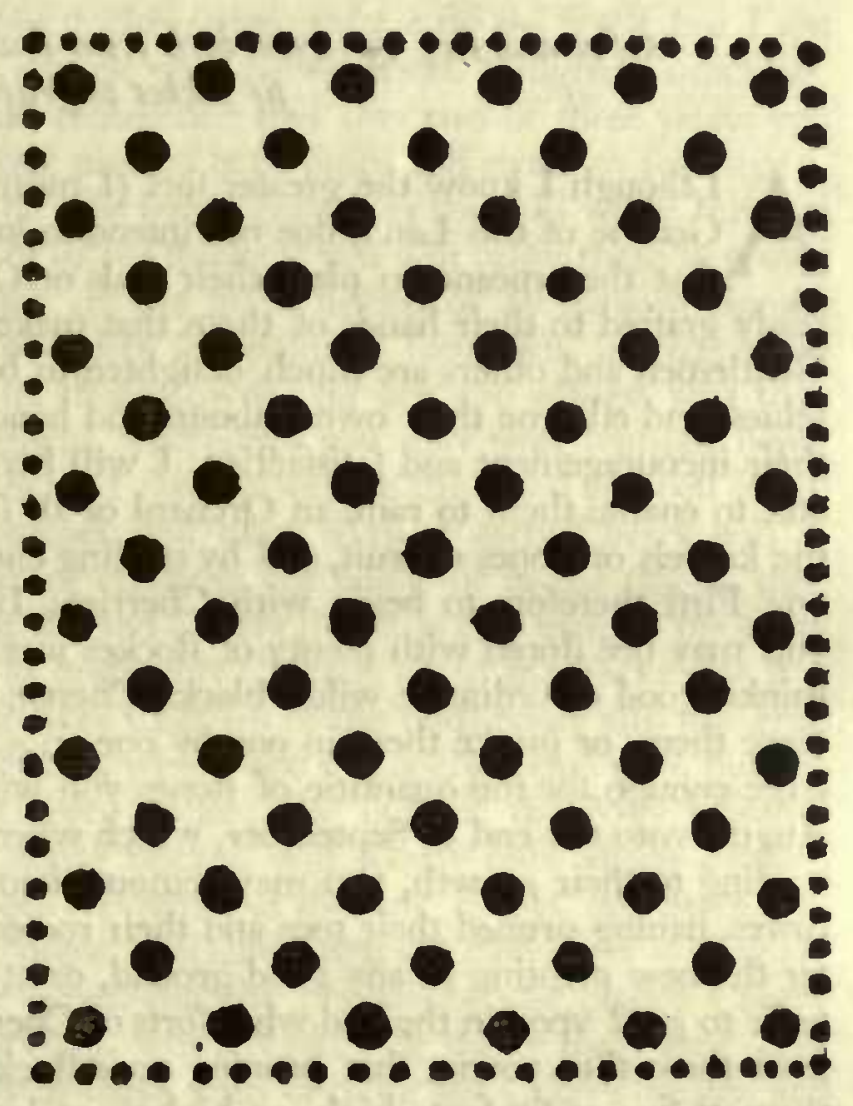
both a diftance and a diuifion for euery fort, without intermingling: yet the moft gracefull Orchard containeth them all, with fome others, fo as they be placed that one doe not hinder or fpoile another; and therefore to defcribe you the inodell of an Orchard, both rare for comelineffe in the proportion, and pleafing for the profitableneffe in the vfe, and alfo durable for continuance, regard this figure is here placed for your direction, where you muft obferue, that your trees are here fet in fuch an equall diftance one from another euery way, \& as is fitteft for them, that when they are grown great, the greater branches fhall not gall or rubbe one againft another; for which purpofe twenty or fixteene foot is the leaft to be allowed for the diftance euery way of your trees, \& being fet in rowes euery one in the middle diftance, will be the moft gracefull for the plantation, and befides, giue you way fufficient to paffe through them, to pruine, loppe, or dreffe them, as need thall require, and may alfo bee brought (if you pleare) to that gracefull delight, that euery alley or diftance may be formed like an arch, the branches of either fide meeting to be enterlaced together. Now for the feuerall forts of fruit trees that you fhall place in this modell, your beft direction is to fet Damfons, Bulleis, and your taler growing Plums on the outfide, and your lower Plums, Cherries, and Apples on the infide, hauing regard, that you place no Peare tree to the Sunward, of any other tree, left it ouer- 
Thadow them: Let your Peare trees therefore be placed behinde, or on the one fide of your lower trees, that they may be as it were a fhelter or defence on the North \& Eaft fide. Thus may you alfo plant Apples among Plums and Cherries, fo as you fuffer not one to ouer-growe or ouer-toppe another; for by pruning, lopping, and thredding thofe that growe too faft for their fellowes, you may itill keepe your trees in fuch a conformity, as may be both moft comely for the fight, and moft profitable for the yeelding of greater and better ftore of fruit. Other forts of fruit trees you may mixe among there, if you pleafe, as Filberds, Cornellian Cherries in ftanderds, and Medlers: but Seruice trees, Baye trees, and others of that high fort, muft be fet to guard the reft. Thus haue I given you the faireft forme could as yet be deuifed; and from this patterne, if you doe not follow it precifely, yet by it you may proportion your Orchard, be it large or little, be it walled or hedged.

CH A P. II I.

\section{Of a nourfery for trees, both from fowing the kernels, and planting} fit fockes to graft upon.

A Lthough I know the greater fort (I meane the Nobility and better part of the Gentrie of this Land) doe not intend to keepe a Nurfery, to raife vp thofe trees that they meane to plant their wals or Orchards withall, but to buy them already grafted to their hands of them that make their liuing of it : yet becaufe many Gentlemen and others are much delighted to beftowe their paines in grafting themfelues, and efteeme their owne labours and handie worke farre aboue other mens: for their incouragement and fatisfaction, I will here fet downe fome conuenient directions, to enable them to raife an Orchard of all forts of fruits quickly, both by fowing the kernels or ftones of fruit, and by making choife of the beft forts of ftockes to graft on: Firft therefore to begin with Cherries; If you will make a Nurfery, wherein you may bee ftored with plenty of ftockes in a little fpace, take what quantitie you thinke good of ordinarie wilde blacke Cherrie ftones, cleanfed from the berries, and fowe them, or pricke them in one by one on a peece of ground well turned vp, and large enough for the quantitie of ftones you will beftowe thereon, from the midft of Auguft vnto the end of September, which when they are two or three yeares old, according to their growth, you may remoue them, and fet them anew in fome orderly rowes, hauing pruned their tops and their rootes, which at the next yeares growth after the new planting in any good ground, or at the fecond, will be of fufficient bigneffe to graft vpon in the bud what forts of Cherries you thinke beft : and it is fitteft to graft them thus young, that pruning your ftockes to raife them high, you may graft them at fiue or fix foote high, or higher, or lower, as you thall fee good, and being thus grafted in the bud, will both more fpeedily and fafely bring forward your grafts, and with leffe danger of lofing your ftockes, then by grafting them in the ftocke: for if the bud take not by inoculating the firf yeare, yet your tree is not loft, nor put in any hazzard of loffe; but may be grafted anew the yeare following, if you will, in an other place thereof, whereas if you graft in the ftocke, and it doe not take, it is a great chance if the ftocke dye not wholly, or at leaft be not fo weakened both in ftrength and height, that it will not bee fit to bee grafted a yeare or two after. In the fame manner as you doe with the blacke, you may deale with the ordinary Englifh red Cherrie ftones, or kernels, but they are not fo apt to growe fo ftraight and high, nor in fo thort a time as the blacke Cherrie ftones are, and befides are fubiect in time to bring out fuckers from the rootes, to the hinderance of the ftockes and grafts, or at the leaft to the deformitie of your Orchard, and more trouble to the Gardiner, to pull or digge them away. Plumme ftones may bee ordered in this manner likewife, but you muft make choife of your Plums; for although euery Plumme is not fo fit for this purpore, as the white Peare Plumme, becaufe it groweth the goaleft and freeft, the barke being fmooth and apteft to be raifed, that they may be grafted vpon; yet diuers other Plummes may be taken, if they be not at hand, or to be had, as the blacke and red Peare Plumme, the 
white and red Wheate Plumme, becnufe they are neareft in goodneffe vnto it. Peach ftones will be foone raired vp to graft other forts of l'eaclies or Nectorins vpon, but the nature of the Peach roote being fpongie, is not to abide long. As for Almonds, they will be raifed from their ftones to be trees of themfelues; but they will hardly abide the remouing, and leffe to bee grafted vpon. Apricocke ftones are the worlt to deale withall of any fort of ftone fruit; for although the Apricocke branches are the fitteft ftockes to graft Nectorins of the beft forts vpon, yet thofe that are raifed from the kernels or itones will neuer thriue to be brought on for this purpore; but will ftarue and dye, or hardly grow in a long time to be a ftraight and fit ftocke to be grafted, if it be once remoued. Your Cornellian Cherrie trees are wholly, or for the moft part raifed from the ftones or kernels; yet I know diuers doe increale them, by laying in their loweft branches to take roote: and thus much for ftone fruits. Now for Apples and Peares, to be dealt withall in the fame manner as aforefaid. They vfe to take the preffing of Crabs whereas Veriuyce is made, as alfo of Cidar and Perry where they are made, and fowing them, doe raife vp great ftore of ftockes; for although the beating of the fruit doth fpoile many kernels, yet there will bee enough left that were neuer toucht, and that will fpring: the Crabbe ftockes fome preferre for the fitteit, but I am fure, that the better Apple and Peare kernels will growe fairer, ftraighter, quicklier, and better to be grafted on. You muft remember, that after two or three yeares you take vp thefe ftockes, and when you have pruned both toppe and roote, to fet them againe in a thinner and fitter order, to be afterwards grafted in the bud while they are young, as I thall fhew you by and by, or in the ftocke if you will fuffer them to growe greater. Now likewife to know which are the fitteft ftockes of all forts to choore, thereon to graft euery of thefe forts of fruits, is a point of fome skill indeede; and therefore obferue them as I doe here fet them dowrie: for bee you alfured, that they are certaine rules, and knowne experiences, whereunto you may truft without being deceiued. Your blacke Cherrie ftockes (as' I faid before) are the fittéft and beft for all' forts of Cherries long to abide and prófper, and euen May' ot early Cherry will abide or liue longer, being grafted thereon, either in the budde of in the ftocke, then on the ordinary red Cherry ftocke; but the red Cherry ftocke is in a manner the onely tree that.moft Nurfery men doe take to graft May Cherries on in the ftocke (for it is but a late experience of many, to graft May Cherries in the bud) many alfo doe graft May Cherries on Gafcoigne Cherry ftockes; which doe not onely thriue well, but endure longer then vpon any ordinary Cherry ftocke: For indeede the May Cherries that are grafted vpon ordinary red Cherrie ftockes, will hardly' hold aboue a dozen yeares bearing well, although they come forwarder at the firt, that is, doe beare fooner then thofe that are grafted on Gafcoigne or blacke Cherry ftockes; but as they are earlier in bearing, fo they are fooner fpent, and the Gafcoigne and blacke Cherry itockes that are longer in comming forward; will laft twice or thrice their time; but many more grafts will miffe in grafting of thefe, then of thofe red Cherry ftockes, and befides, the natures of the Gafcoigne and blacke Cherry ftockes are to rife higher, and make a goodlier tree then the ordinary red ftocke will, which for the moft part fpreadeth wide, but rifeth not very high. The Englinh red Cherry'ftocke will ferue very well to graft any other fort of Cherry vpon, and is vfed in mort places of this Land, and I know no other greater inconuenience in it, then that it mooteth out many fuckers from the roote, which yet by looking vnto may foone bee remoud from doing any harme, and that it will not laft fo long as the Gafcoigne or blacke Cherry ftocke will. May Cherries thus grafted lowe, doe mott vfually ferue to be planted againft a wall, to bring on the fruit the earlier; yet fome graft them high vpon ftandards, althougl not many, and it is, I thinke, rather curiofity (if they that doe it have any wals) then anie other matter that caufeth them thus to doe: for the fruit is naturally fmall, though early, and the ftandard Cherries are alwaies later then the wall Cherries, fo that if they can fpare any roome for them at their wals, they will not plant many in ftandards. Now concerning Plummes (as I faid before) for the fowing or fetting of the ftones, fo I fay here for their choife in grafting of them, either in the budde or ftocke. The white Peare Plumme ftocke, and the other there mentioned, but efpecially the white Peare Plumme is the goodlieft, freeft, and fitteft of all the reft, as well to graft all fort of Plummes vpon, as alfo to graft Apricockes, which can be handfomely, and to any 
good purpofe grafted vpon no other Plum ftocke, to rife to bee worth the labour and paine. All forts of Plums may be grafted in the ftocke, and fo may they alfo in the bud; for I know none of them that will refufe to be grafted in the bud, if a cunning hand performe it well; that is, to take off your bud cleanely and well, when you haue made choice of a fit cyon: for, as I thal fhew you anon, it is no fmall peece of cunning to chufe your cyon that it may yeeld fit buds to graft withall, for euery plum is not of a like aptnes to yeeld them : But Apricocks cannot be grafted in the ftock for any thing that euer I could heare or learne, but only in the bud, and therefore let your Plum ftocke bee of a reafonable fize for Apricockes efpecially, and not too fmall, that the graft ouergrow not the ftocke, and that the ftocke bee large enough to nourifh the graft. As your Plum ftockes ferue to graft both Apricockes and Plummes, fo doe they ferue alfo very well to graft Peaches of all forts; and although Peach ftockes will ferue to be grafted with Peaches againe, yet the Peach ftocke (as I faid before) will not endure fo long as the Plumme ftocke, and therefore ferueth but for neceffity if Plum Ptocks be not ready, or at hand, or for the prefent time, or that they afterwards may graft that fort of Peach on a Plumme ftocke: for many might lofe a good fruit, if when they meete with it, and haue not Plumme ftockes ready to graft it on, they could not be affured that it would take vpon another Peach ftocke or branch, or on the branch of an Apricocke eyther. Plumme ftockes will ferue likewife very well for fome forts of Nectorins; I fay, for fome forts, and not for all : the greene and the yellow Nectorin will beft thriue to be grafted immediately on a Plumme ftocke; but the other two forts of red Nectorins muft not be immediately grafted on the Plumme ftocke, but vpon a branch of an Apricocke that hath beene formerly grafted on a Plumme ftocke, the nature of thefe Nectorins being found by experience to be fo contrary to the Plum ftocke, that it will fterue it, and both dye within a yeare, two or three at the moft: Diuers haue tryed to graft thefe red Nectorins vpon Peach ftockes, and they haue endured well a while; but feeing the Peach ftocke will not laft long it felfe, being ouerweake, how can it hold fo ftrong a nature as thefe red Nectorins, which will (as I faid before) Iterue a Plum ftocke that is fufficient durable for any other Plumme?

Apricocke ftockes from the ftones are hardly nurfed vp, and worfe to be remoued, and if a red Nectorin fhould be grafted on an Apricock rayfed from the ftone, and not remoued, I doubt it might happen with it as it doth with many other trees raifed from ftones or kernels, and not remoued, that they would hardly beare fruit: for the nature of moft trees raifed from ftones or kernels, and not remoued, is to fend great downeright rootes, and not to fpread many forwards; fo that if they be not cut away that others may fpreade abroad, I haue feldome feene or known any of them to beare in any reafonable time; and therefore in remouing, thefe great downe-right rootes are alwayes $\mathrm{fhred}$ away, and thereby made fit to thoote others forwards. Hereby you may perceiue, that thefe red Nectorins will not abide to bee grafted vpon any other ftocke well, then vpon an Apricocke branch, although the green and the yellow (as I faid before) will well endure and thriue vpon Plums. The fuckers or thootes both of Plums and Cherries that rife from their rootes, eyther neare their ftockes, or farther off, fo that they bee taken with fome fmall rootes to them, will ferue to bee ftockes, and will come forward quickly; but if the fuckers haue no fmall roots whereby they may comprehend in the ground, it is almoft impoffible it fhould hold or abide. There is another way to rayfe vp eyther ftockes to graft on, or trees without grafting, which is, by circumcifing a faire and fit branch in this manner: About Midfomer, when the fappe is thoroughly rifen (or before if the yeare be forward) they vfe to binde a good quantity of clay round about a faire and ftraight branch, of a reafonable good fize or bigneffe, with fome conuenient bands, whether it be ropes of hey, or of any other thing, about an handfull aboue the ioynt, where the branch fpreadeth from the tree, and cutting the barke thereof round about vnder the place where the clay is bound, the fap is hereby hindered from rifing, or defcending further then that place fo circumcifed, whereby it will thoote out $\mathrm{fmall}$ knubs and rootes into the clay, which they fuffer fo to abide vntill the beginning of winter, whenas with a fine Sawe they cut off that branch where it was circumcifed, and afterwardes place it in the ground where they would have it to grow, and ftake it, and binde it faft, which will fhoote forth rootes, and will become eyther a faire tree to beare fruite without grafting, or elfe a fit ftocke to graft on accor- 
ding to the kinde : but oftentimes this kinde of propagation miffeth, in that it fendeth not forth rootes fufficient to caure it to abide any long time. Let me yet before I leaue this narration of Plummes, gitue you one admonition more, that vpon whatfoeuer Plumune ftocke you doe graft, yet vpon a Damfon ftocke that you neuer itriue to graft, for it (aboue all other forts of Plumme ftockes) will neuer giue you a tree worth your labour. It remaineth only of ftone fruit, that I fpeake of Cornelles, which as yet I neuer faw grafted vpon any itocke, being as it fhould feeme vtterly repugnant to the nature thereof, to abide grafting, but is wholly rayfed vp (as I faid before) eyther from the ftones, or from the fuckers or layers. For Peares and Apples your vfuall ftockes to graft on are (as I faid before, fpeaking of the nurfing vp of trees from the kernels) your Crabbe ftockes, and they bee accepted in euery Countrey of this Land as they may contueniently be had, yet many doe take the ftockes of better fruit, whether they bee fuckers, or ftockes rayfed from the kernels (and the moft common and knowne way of grafting, is in the ftocke for all forts of them, although forne doe vfe whipping, packing on, or incifing, as euery one lift to call it : but now we doe in many places begin to deale with Peares and Apples as with other ftone fruit, that is, graft them all in the bud, which is found the moft compendious and fafeft way both to preferue your ftocke from perifhing, and to bring them the fooner to couer the ftock, as alfo to make the goodlier and ftraighter tree, being grafted at what height you pleafe :) for thofe Ptockes that are rayfed from the kernels of good fruit (which are for the mort part eafily knowne from others, in that they want thofe thornes or prickles the wilde kindes are armed withall:) I fay for the moft part; for I know that the kernels of fome good fruite hath giuen ftockes with prickles on them (which, as I thinke, was becaufe that good fruite was taken from a wilde ftocke that had not beene long enough grafted to alter his wilde nature; for the longer a tree is grafted, the more ftrength the fruite taketh from the graft, and the leffe ftill from the ftocke) being fmoother and fairer then the wilde kinds, mult needes make a goodlier tree, and will not alter any whit the tafte of your fruit that is grafted thereon, but rather adde fome better rellifh thereunto; for the Crabbe ftockes yeelding harfh fruite, muft giue part of their nature to the grafts are fet thereon, and therefore the tafte or rellifh, as well as fome other naturall properties of moft fruits, are fomewhat altered by the ftocke. Another thing I would willingly giue you to vnderftand concerning your fruits and ftockes, that whereas diuers for curiofity and to try experiments haue grafted Cherries vpon Plumme ftockes, or Plums on Cherry ftockes, Apples vpon Peare Itockes, and Peares vpon Apple ftockes, fome of thefe haue held the graft a yeare, two or three peraduenture, but I neuer knew that euer they held long, or to beare fruite, much leffe to abide or doe well : beftow not therefore your paines and time on fuch contrary natures, vnleffe it be for curiofitie, as others haue done: Yet I know that they that graft peares on a white thorne ftocke haue had their grafts feeme to thriue well, and continue long, but I haue feldome feenc the fruite thereof anfwerable to the naturall wilde Peare ftocke; yet the Medlar is knowne to thriue beft on a white thorne. And laftly, whereas diuers doe affirme that they may haue not only good ftockes to graft vpon, but alfo faire trees to bear ftore of fruit from the kernels of Peares or Apples being prickt into the ground, and fuffered to grow without remouing, and then eyther grafted or fuffered to grow into great trees vngrafted; and for their bearing of fruite, affigne a dozen or twenty yeares from the firft fetting of the kernels, and abiding vngrafted, I haue not feene or heard that experience to hold certaine, or if it thould be fo, yet it is too long time loft, and too much fruit alfo, to waite twenty yeares for that profit may be gained in a great deale of leffe time, and with more certainty. Vnto thefe inftructions let mee adde alfo one more, which is not much known and vfed, and that is, to haue fruit within foure or fiue years from the firft fowing of your ftones or kernels in this manner: After your ftones or kernels are two or three yeares old, take the faireft toppe or branch, and graft it as you would doe any other cyon taken from a bearing tree, and looke what rare fruite, eyther Peare or Apple, the kernell was of that you fowed, or Peach or Plum \&cc. the ftone was fet, fuch fruite fhall you haue within two or three yeares at the moft after the grafting, if it take, and the ftocke be good. And thus may you fee fruit in farre leffe time then to ftay vntill the tree from a kernell or ftone beareth fruit of it felfe. 


\section{C н A P. I I I I.}

The diuers manners of grafting all forts of fruits
ved in our Land.

$\mathrm{T}$ He moft vfuall manner of grafting in the ftocke is fo common and well known in this Land to euery one that hath any thing to doe with trees or an Orchard, that I think I thall take vpon mee a needleffe worke to fet downe that is fo well knowne to molt; yet how common foeuer it is, fome directions may profit euery one, without which it is not eafily learned. And I doe not fo much fpend my time and paines herein for their fakes that haue knowledge, but for fuch as not knowing would faine be taught priuately, I meane, to reade the rules of the arte fet downe in priuate, when they would refufe to learne of a Gardiner, or other by fight : and yet I difcommend not that way vnto them to learne by fight; for one may fee more in an inftant by fight, then he fhall learn by his own practice in a great while, efpecially if he be a little practifed before he fee a cunning hand to doe it. There are many other kindes of grafting, which thall be fpoken of hereafter, and peraduenture euen they that know it well, may learne fomething they knew not before.

1. The grafting in the ftocke, is, to fet the fprigge of a good fruit into the body or ftocke of another tree, bee it wilde or other, bee it young or old, to caufe that tree to bring forth fuch fruit as the tree bore from whence you took the fprigge, and not fuch as the ftocke or tree would haue borne, if it had not beene grafted, and is performed in this manner : Looke what tree or ftocke you will chufe to graft on, you muft with a fmall fine fawe and very fharpe, whip off, or cut off the head or toppe thereof at what height you eyther thinke beft for your purpofe, or convenient for the tree : for if you graft a great tree, you cannot without endangering the whole, cut it downe fo low to the ground, as you may without danger doe a fmall tree, or one that is of a reafonable fize; and yet the lower or neerer the ground you graft a young tree, the fafer it is both for your ftocke and graft, becaufe the fappe fhall not afcend high, but foone giue vigour to the graft to take and fhoote quickly : After you haue cut off the toppe of your ftocke, cut or fmooth the head thereof with a tharpe knife, that it may be as plaine and fmooth as you can, and then cleaue it with a hammer or mallet, and with a ftrong knife, cleauer or cheffell, either in the middle of it if it be fmall, or of a reafonable fize, or on the fides an inch or more within the barke, if it be great : into both fides of the cleft put your grafts, or into one if the ftocke bee fmaller; which grafts muft bee made fit for the purpofe on this fafhion: Hauing made choife of your grafts from the toppe branches efpecially, or from the fides of that tree whereof you would have the fruit, and that they be of a reafonable good fize, not too fmall or too great for your ftockes, and of one or the fame yeares fhoote; (and yet many doe cut an inch or more of the olde wood with the fprigge of the laft yeares growth; and fo graft the old and young together (but both are good, and the old wood no better then the young) cut your graft not too long, but with two, three or foure eyes or buds at the moft, which at the lower or bigger end for an inch long or more (for the greater ftockes, and an inch or leffe for the leffer fort) muft be fo cut, that it be very thin on the one fide from the fhoulders downward, and thicker on the other, and thin alfo at the end, that it may goe downe clofe into the cleft, and reft at the fhoulders on the head of the ftocke: but take heede that in cutting your grafts your knife bee very tharpe that you doe not rayfe any of the barke, eyther at the fides or the end, for feare of lofing both your paines and graft, and itocke too peraduenture; and let not your grafts bee made long before you fet them, or elfe put the ends of them in water to keepe them frefh and cleane: when you fet them you muft open the cleft of your ftocke with a wedge or cheffell as moft doe, that the graft may goe eafily into it, and that the barke of both graft and ftocke may ioyne clofe the one to the other, which without ftirring or difplacing muft bee fo left in the cleft, and the wedge or cheffell gently pulled forth; but becaufe in the doing hereof confifteth in a manner the whole loffe or gaine of your paines, graft and ftocke, to preuent which inconuenience I doe vfe an iron Inftument, the forme whereof is thowne in the fol- 
lowing page, marked with the letter $A$, crooked at both ends, and broade like vnto a cheffell, the one bigger, and the other leffer, to fit all forts of ftockes, and the iron handle fomewhat long betweene them both, that heing thruft or knocked downe into the cleft, you may with your left hand open it as wide as is fit to let in your graft, without ftrayning, which being placed, this iron may bee pulled or knocked vp againe without any mouing of your graft : when you haue thus done, you munt lay a good handfull or more (according to the bigneffe of your ftocke) of foft and well moiftned clay or loame, well tempered together with hort cut hey or horfe dung, vpon the head of your ftocke, as lowe or fomewhat lower then the cleft, to keepe out all winde, raine or ayre from your graft vntill Midfomer at the leaft, that the graft be fhot forth fomewhat ftrongly, which then if you pleafe may be remoued, and the cleft at the head only filled with a little clay to keepe out earewigs, or other things that may hurt your graft.

A. The Iron Inftrument with cheffels at each end, the one bigger and the other leffer, to keepe the cleft of the Tree open vntill the graft bee placed in the ftocke, which with a knock vpwards will be eafily taken away.

B. The fmall Penne-knife with a broad and thinne ended hafte, to raife the fides both of the bud and the down-right Mit in the body or arme of a Tree to be grafted in the bud.

C. A pen or quil cut halfe round to take of a bud from the branch.

D. An Iuory Inftrument made to the fame fafhion.

E. A thielde of braffe made hollow before to be put into the fit, to keepe it open vntill the bud be put into its place.

F. The manner of grafting called incifing or fplicing.

G. A Ladder made with a Atoole at the toppe, to ferue both to graft higher or lower, and alfo to gather fruit without fpoyling or hurting any buddes or branches of Trees.
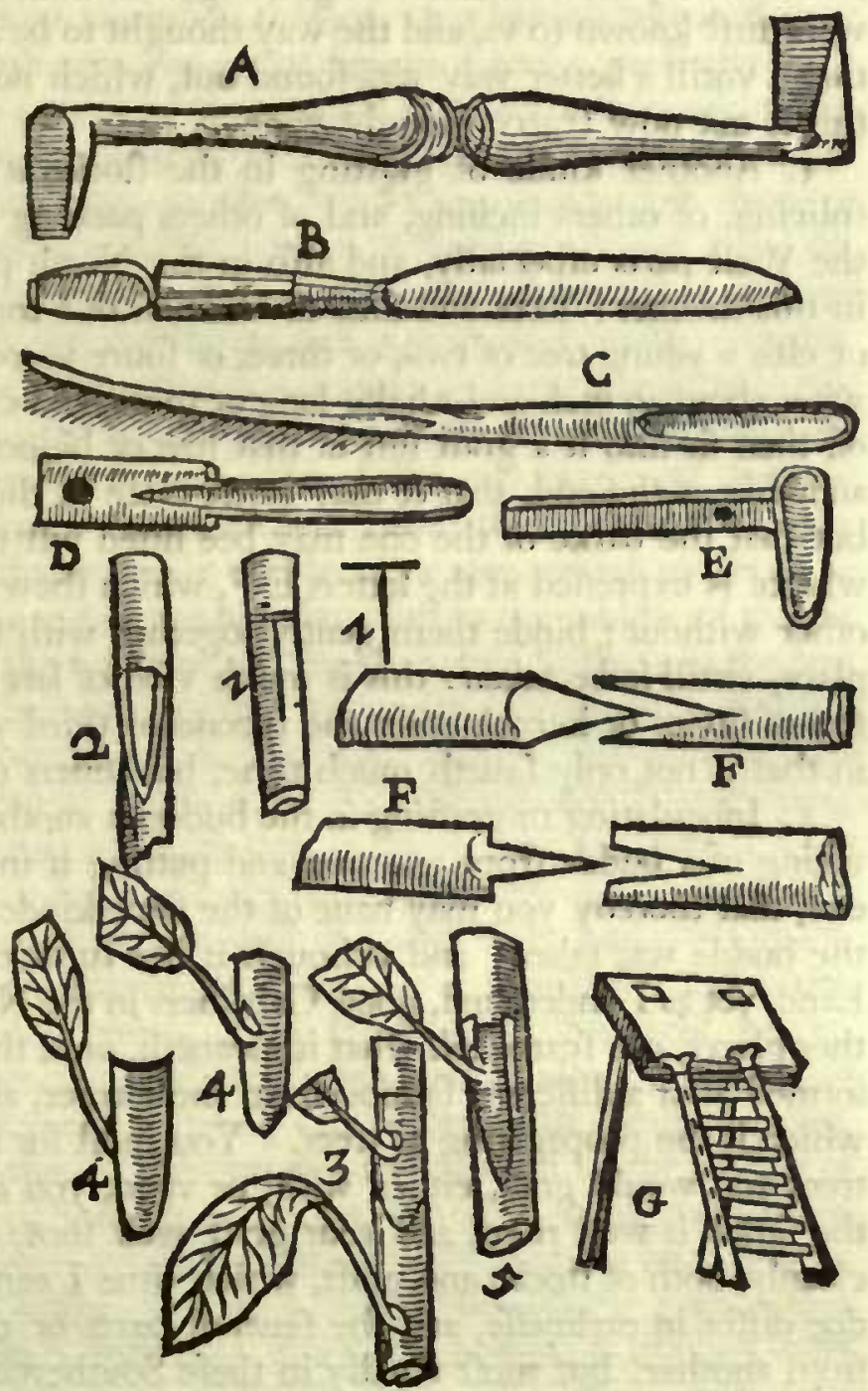

1. The firft Mit in the body or arme of a Tree to be grafted in the bud with the croffe cut at the head.

2. The fame flit opened on both fides, ready to receiue the budde fhould be put therein: thefe fmall peeces ferue as well as trees to fhew the manner and order of the grafting.

3. The branch of a Tree with one budde cut ready to be taken off, and another not yet touched.

4. The bud cleane taken off from the branch, both the forefide and backfide.

5. The graft or bud now put into the ftocke or tree you intend to be grafted : but the binding thereof is omitted.

2. Inarching is another manner of grafting in the ftocke, and is more troublefome, and more cafuall alfo then the former, and is rather a curiofity then any way of good fpeede, certainety or profit, and therefore vied but of a few. Yet to thew you, the 
manner thereof, it is thus: Hauing a tree well growne, bee it high or low, yet the lower the better, with young branches well fpread, they vfe to fet ftockes round about it, or on the one fide as you pleafe; into which ftockes they ingraft the young branches of the well growne tree as they are growing (before they cut them from the tree) by bowing downe the branch they intend to graft, and putting it into the ftocke, hauing firft cut off the head thereof, and cut a notch in the middle of the head a little flope on both fides, wherein the branch muft be fitted: let the branch be cut thinne on the vnderfide, only of that length as may fuffice to fit the notch in the ftocke, leauing about halfe a yarde length of the branch, to rife aboue or beyond the ftocke, which beeing bound on, and clayed ouer or couered with red or greene foft waxe, they let fo abide, that if it take in the ftocke they cut off the branch a little below the grafting place in Nouember following, and remouing the ftocke, they haue thus gained a grafted and growne tree the firft yeare : but it is vfually feene, that where one branch taketh, three doe miffe : yet this manner of grafting was much in vfe for May Cherries, when they were firft known to vs, and the way thought to be a rare manner of grafting to encreafe them, vntill a better way was found out, which now is fo common and good alfo, that this is not now fcarce thought vpon.

3. Another kinde of grafting in the ftocke is called of fome whipping, of fome fplicing, of others incifing, and of others packing on (and as I heare, is much vfed in the Weft parts efpecially, and alfo in the North parts of this Land) and is performed in this manner: Take and flice the branch of a tree (fo as the branch be not too bigge) or elfe a young tree of two, or three, or foure yeares growth at the moft, quite off flope wife, about an inch and a halfe long or more, and cut a deep notch in the middle thereof, then fit into it a graft iuft of that fize or bigneffe, cut on both fides with fhoulders, and thin at the end, that it may ioyne clofe in the notch, and neyther bigger or leffer, but that the barke of the one may bee fitted iuft to the barke of the other, the figure wherof is expreffed at the letters E.F. which thew the one to be with a fhoulder \& the other without ; binde them gently together with baft, and put clay or waxe ouer the place, vntill it be taken : this is much vfed of late dayes for fuch young trees as are rifen of ftones or kernels after the fecond or third yeares growth, and thriue very well in that it not only faueth much time, but diuers checks by remouing and grafting.

4. Inoculating or grafting in the budde is another manner of grafting, which is the taking of a budde from one tree, and putting it into the barke of another tree, to the end, that thereby you may haue of the fame kinde of fruit the tree bare from whence the budde was taken; and although it bee fufficiently knowne in many places of this Land, yet as I vnderftand, good Gardiners in the North parts, and likewife in fome other places, can fcarce tell what it meaneth, or at the leaft how to doe it well. It is performed after a different fafhion from the former, although they all tend vnto one end, which is the propagating of trees. You muft for this purpofe obferue, that for thofe trees you would graft, either with, or vpon, you choofe a fit time in Summer, when the fappe is well rifen, and your graft well hot, that the barke will rife eafily and cleanly, both of ftocke and graft, which time I cannot appoint, becaufe both the years doe differ in earlineffe, and the feuerall parts or countries of this Land likewife one from another, but moft vfually in thefe Southerne parts, from the beginning of Iune vnto the end of it, or to the middle of Iuly, or either fomewhat before or after. Firft (as I faid) hauing taken the fittert time of the yeare, you muft take ef peciall care, that your grafts be well growne, and of the fame yeares fhoote, and alfo that the buds or eyes haue but fingle leaues at them, as neere as you can: for I would vtterly. refufe thofe buds that haue aboue two leaues as vnprofitable, either in Peaches or any other fruit; and therefore fee that your grafts or cyons bee taken from the chiefert place of the tree, that is, either from the toppe, or from a funnie fide thereof, and not from the contrarie fide if you may otherwife, nor from any vnder-boughes; for feeing your graft is fo fmall a thing, you had neede take the more care that it be the beft and faireft. You muft to take off this eye or budde from the fprigge, haue a fmall harpe pen-knife, the end of the haft being made flat and thinne, like a cheffell or wedge, the figure whereof is fet forth at the letter $\mathrm{B}$, and a pen or goofe quill cut, to be leffe then halfe round, and to be broad at the end, but not tharpe pointed like a penne, or elfe fuch a peece of bone or Iuorie made in that farhion as the quill is, to bee thinne, hollow, or 
halfe round, the figures of both which are marked with the letters $C$, D, with your knife cut the barke of the bud (hauing firft cut off the leafe, leauing onely the fhort foote-ftalke thereof at the bud) about a ftrawes breadth aboue the eye thereof halfe round, and then from that round or ouerthwart cut, with your knife cut it downe on both fides of the eye, clofe to the bud nopewife about an inch long or thereabouts, that it bee broad at the head aboue the eye, and pointing at the end like a theild or fcutcheon; and then cutting away the reft of the barke from about it, with the thinne flat end of the haft of your knife raife vp both fides of your bud a little, and with your quill or bone put vnder the barke, raife your budde, and thruft it quite off, beginning at the toppe or head of your eye; but fee that you thruft it off clofe to the wood of the branch or Sprigge, and that you doe not leaue the eye of the budde behinde fticking vpon the branch; for if that eye be left or loft, your bud is worth nothing; you muft caft it away, and cut another that may have that eye abiding within the budde on the infide: you may perceiue if that eye be wanting, if you fee an emptie hole in the place where the eye fhould be, to fill it vp on the infide thereof; thus hauing taken off your bud well and cleanly, which is fet forth vnto you at the figures 3 and 4 . prefently fet it on the tree you would graft (for your fmall budde can abide no delay, left by taking the ayre too long it become dry, and nothing worth) in this manner: Cut the barke of your tree you would graft in a fmooth place, at what height you pleafe, firft aboue or ouerthwart, and then downe right in the middle thereof, more then an inch long, the figure whereof you thall haue at the figure 1 . and then raife vp both fides of the barke, firft one, and then another, with the flat and thinne haft end of your knife, a prettie way inwards (for if the barke will not rife eafily, the ftocke is not then fit to graft vpon) put in your budde into the cleft with the point downewards, holding the ftalke of the leafe that is with the budde betweene your fingers of the one hand, and opening the cleft with the flat end of your knife with the other hand, that the head of your bud may be put clofe vnder the ouerthwart cut in the ftocke or tree (which muft not be raifed or ftirred as the fides are) \& the eye of the bud ftand iuft in the middle of the nit that is downeright, and then clofing the barke of the ftocke or tree foftly vnto the bud thus put in with your fingers, let it be bound gently with a fmall long peece of bafte, or other fuch like foft thing, firft aboue the eye, \& then compaffing it belowe as clofe as you can, but not too hard in any cafe, vntil you haue bound it all ouer the flit you made, efpecially the lower end, left any winde get in to dry and fpoile it; and hauing tyed both ends thereof faft, leaue it fo for a fortnight or fomewhat more, in which fpace it will take and hold, if it be well done, which you thall perceiue, if the bud abide green, and turne not blacke, when you haue vnloofed the tying; for if it hold faft to the tree, and be frefh and good, tye it vp gently againe, and fo leave it for a fortnight longer, or a moneth if you will, and then you may take away your binding cleane: this.budde will (if no other mifchance happen vnto it) fpring and thoote forth the next yeare, (and fometimes the fame yeare, but that is feldome) and therefore in the beginning of the yeare, cut off the head of the grafted tree about an handfull aboue the grafted place, vntill the graft be growne ftrong, and then cut it off clofe, that the head may be couered with the graft, and doe not fuffer any buds to fprout befides the graft, either aboue or belowe it. If you graft diuers buds vpon one ftocke (which is the beft way) let that onely remaine and abide that thooteth beft forth, and rubbe off, or take away the other: the feuerall parts of this grafting I haue caufed to be expreffed for your. further information.

5. Grafting in the fcutcheon is accounted another kinde of grafting, and differeth verie little from grafting in the budde: the difference chiefly confifteth in this, that in ftead of the downe right nit, and that aboue ouerthwart, they take away iuft fo much barke of the great tree, as your budde is in bigneffe, which vfually is a littlc larger then the former, and placing it therein, they binde it as formerly is faid: fome vfe for this purpore a paire of compaffes, to giue the true meafure both of bud and ftocke; this manner of grafting is moft vfed vpon greater trees, whofe young branches are too high to graft vpon in the former maner, and whofe tops they cut off (for the moft part) at the latter end of the next yeare after the bud is taken: both thefe waies were inuented to faue the loffe of trees, which are more endangered by grafting in the ftocke, 
then any of thefe waies; and befides, by thefe waies you may graft at a farre greater height without loffe.

\section{C н A P. V. \\ Of the manner of grafting and propagating all forts of Rofes.}

$\mathrm{H}$ Auing now fpoken of the grafting of trees, let mee adioyne the properties of Rofes, which although they better fit a Garden then an Orchard, yet I could not in a fitter place expreffe them then here, both for the name and affinity of grafting, \& becaufe I do not expreffe it in the firft part. All forts of Rofes may be grafted (although all forts are not, fome feruing rather for ftockes for others to be grafted on) as eafily as any other tree, \& is only performed, by inoculating in the fame maner I haue fet downe in the former Chapter of grafting trees in the bud; for both ftocke and budde muft bee dealt with after the fame fafhion. And although fome haue boafted of grafting Rofes by flicing or whipping, as they call it, or in the ftocke, after the firft manner, fet downe in the former Chapter, yet I thinke it rather a bragge, not hauing feene or heard any true effect proceede from that relation. The fweete Briar or Eglantine, the white and the Damaske Rofes, are the chiefeft ftockes to graft vpon. And if you graft lowe or neare the ground, you may by laying downe that graft within the ground, after it hath bin thot out well, and of a years growth, by pinning it faft downe with fhort ftickes, a thwart or acroffe, caufe that grafted branch, by taking roote, to become a naturall Rofe, fuch as the graft was, which being feparated and tranfplanted after it hath taken root wel, will profper as well as any naturall fucker. And in this maner, by laying downe branches at length into the ground, if they be full of fpreading fmall branches, you may increafe all forts of Rofes quickly and plentifully; for they will thoote forth rootes at the ioynts of euery branch : But as for the manner of grafting white Rofes or Damaske vpon Broome ftalkes or Barbary bufhes, to caufe them to bring forth double yellow Rofes, or vpon a Willowe, to beare greene Rofes, they are all idle conceits, as impoffible to be effected, as other things, whereof I haue fpoken in the ninth Chapter of my firt part, concerning a Garden of flowers, vnto which I referre you to be fatisfied with the reafons there alledged. And it is the more needleffe, becaufe we haue a naturall double yellow Rofe of it owne growing. The fowing of the feedes of Rofes (which are fometimes found vpon moft forts of Rofes, although not euery yeare, and in euerie place) hath bin formerly much vfed; but now the laying downe of the young thootes is a way for increafe fo much vfed, being fafe and verie fpeedie to take, ef pecially for thofe Rofes that are not fo apt to giue fuckers, that it hath almoft taken quite away the vfe of fowing of the feedes of Rofes, which yet if anie one be difpofed to make the triall, they muft gather the feede out of the round heads, from amongt the doune, wherein they lye verie like vnto the berries of the Eglantine or fweete Briar burh, and ef pecially of thofe Rofes that bee of the more fingle kindes, which are more apt to giue berries for feed then the more double, although fometimes the double Rofes yeeld the like heads or berries. Their time of fowing is in the end of September (yet fome referue them vntill February) and their manner of nourfing is to bee tranfplanted, after the firft or fecond yeares growth, and tended carefully, that while they are young they be not loft for want of moifture in the dry time of Summer. 
C 1 A P. VI.

\section{Certaine rules and obferwations in and after grafting, not remembred in the former Chapter.}

T He time of fome manners of grafting being not mentioned before, muft here be fpoken of. For the grafting of all forts of trees in the ftocke, the moft vfuall time is from the middle of February vntill the middle of March, as the yeare and the countrie is more forward or backward, with vs about London wee neuer paffe midde March : but becaufe the May Cherrie is firf ripe, and therefore of a very forward nature, it doth require to be grafted fomewhat fooner then others. The time of gathering likewife, or cutting your grafts for grafting in the ftocke, is to be obferued, that they bee not long gathered before they bee grafted, for feare of being too dry, which I commend, howfoeuer diuers fay, if they be long kept they are not the worfe; and therefore if you be forced to haue your grafts from farre, or by fome other chance to keepe them long, be carefull to keepe them moift, by keeping their ends ftucke in moilt clay; but if neare hand, neglect no time I fay after the cutting of them for their grafting, but either the fame, or the next day, or verie fpeedily after, in the meane time being put into the ground to keepe them frefh. The grafts taken from old trees, becaufe they are ftronger, and fhoote forth fooner, are to bee fooner grafted then thofe that are taken from younger trees: of a good branch may bee made two, and fometimes three grafts fufficient for anie reafonable ftocke. For whipping, the time is fomewhat later ther grafting in the ftocke, becaufe it is performed on younger trees, which (as I faid before) doe not fo early bud or fhoote forth as the elder. Inarching likewife is performed much about the later end of the grafting time in the ftocke; for being both kindes thereof they require the fame time of the yeare. The times of the other manners of graftings are before expreffed, to bee when they have fhot forth young branches, from whence your buds mut be taken; and therefore need not here againe to be repeated. If a graft in the ftocke doth happen not to fhoote forth when others do (fo as it holdeth green) it may perchance fhoot out a moneth or two after, \& do well, or elfe after Midfummer, when a fecond time of fhooting, or the after Spring appeareth : but have an ef peciall care, that you take not fuch a graft that fhal have nothing but buds for flowers vpon it, and not an eye or bud for leaues (which you muft be carefull to diftinguifh) for fuch a graft after it hath hot out the flowers muft of neceflitie dye, not hauing wherewith to maintaine it felfe. Alfo if your good graft doe miffe, and not take, it doth hazzard your ftocke at the firft time, yet manie ftockes doe recouer to be grafted the fecond time; but twice to faile is deadly, which is not fo in the inoculating of buds in the greene tree : for if you faile there in three, or three times three, yet euerie wound being Imall, and the tree ftill growing greene, will quickly recouer it, and not be afterwards feen. Some vfe to graft in the ftocke the fame yeare they remoue the ftocke, to faue time, \& a fecond checke by grafting; but I like better both in grafting in the ftocke, and in the bud alfo, that your trees might be planted in the places where you would haue them growe, for a yeare or two at the leaft before you graft them, that after grafting there fhould be no remouall, I neede not be tedious, nor yet I hope verie follicitous to remember many other triuiall, or at the leaft common knowne things in this matter. Firft, for the time to remoue trees, young or old, grafted or vngrafted, to be from a fortnight after Michaelmas vntill Candlemas, or if neede be, fomewhat after, yet the fooner your remoue is, the better your trees will thriuc, except it be in a very moift ground. For the manner or way to fet them: viz. in the high and dry grounds fet them deeper, both to have the more moifture, and to be the better defended from windes; and in the lower and moifter grounds thallower, and that the earth be mellow, well turned vp, and that the finer carth bee put among the finall rootes, wherein they may fpread, and afterwards gently troden downe, that no hollowneffe remaine among the rootes: as alfo that after fetting (if the time be not ouermoift) there may be fome water powred to the rootes, to moiften and faften them the better; and in the dry time of Summer, after the fetting, let them not want moifture, if you will 
haue them thriue and profper; for the want thereof at that time, hath often killed manie a likely tree. To ftake and fence them alfo if neede bee after they are new fet, and fo to continue for two or three yeares after, is verie expedient, left windes or other cafualties fpoile your paines, and ouerthrow your hopes. And likewife to defend your grafts from birds lighting on them, to breake or difplace them, to fticke fome prickes or fharpe pointed ftickes longer then your graft into your clay, that fo they may be a fure defence of it: As alfo to tye fome woollen cloathes about the lower end of your ftockes, or thruft in fome thornes into the ground about the rootes, to defend them from hauing their barkes eaten by Conies, or hurt by fome other noifome vermine.

\section{CH A P. VII. \\ Obferuations for the drefsing and well keeping of Trees and an Orchard in good order.}

T Here are two manner of waies to dreffe and keepe trees in good order, that they may bee both gracefull and fruitfull; the one is for wall-trees, the other is for iftandards: for as their formes are different, fo is their keeping or ordering. Wall trees, becaufe they are grafted lowe, and that their branches muft be plafht or tackt vnto the wall to faften them, are to be fo kept, that all their branches may be fuffered to growe, that fhoote forth on either fide of the bodie, and led either along the wall, or vpright, and one to lappe ouer or vnder another as is conuenient, and fill with peeces of lifts, parings of felt, peeces of foft leather, or other fuch like foft thing compaffing the armes or branches, faftened with fmall or great nailes, as neede requireth, to the wals, onely thofe buds or branches are to be nipped or cut off, that fhoot forward, and will not fo handfomely be brought into conformity, as is fitting; yet if the branches growe too thicke, to hinder the good of the reft, or too high for the wall, they may, nay they muft be cut away or lopped off: and if anie dead branches alfo happen to be on the trees, they muft be cut away, that the reft may haue the more libertie to thriue. Diuers alfo by carefully nipping away the wafte and fuperfluous buds, doe keepe their trees in conformity, without much cutting. The time to pruine or plafh, or tye vp wall trees, is vfually from the fall of the leafe, to the beginning of the yeare, when they begin to bloffome, and moft efpecially a little before or after Chriftmas : but in any cafe not too late, for feare of rubbing off their buds. Some I know doe plafh and tye vp their wall trees after bearing time, while the leaues are greene, and their reafon is, the buds are not fo eafie or apt to bee rubbed from the branches at that time, as at Chriftmas, when they are more growne: but the leaues muft needes be very cumberfome, to hinder much both the orderly placing, and clofe faftening of them to the wall. This labour you muft performe euery yeare in its due time; for if you thall neglect and ouerlip it, you fhall haue much more trouble, to bring them into a fit order againe, then at the firft. The ftandard trees in an Orchard muft be kept in another order; for whereas the former are fuffered to fpread at large, thefe muft be pruined both from fuperfluous branches that ouerload the trees, \& make them leffe fruitfull, as well as leffe fightly, and the vnder or water boughes likewife, that drawe much nourifhment from the trees, and yet themfelues little the better for it, I meane to giue fruit. If therefore your Orchard conffit of young trees, with a little care and paines it may bee kept in that comely order and proportion it was firft deftined vnto; but if it confift of old growne trees, they will not without a great deale of care and paines be brought into fuch conformitie, as is befitting good and comely trees: for the marke of thofe boughes or branches that are cut off from young trees, will quickly be healed againe, the barke growing quickly ouer them, whereby they are not worfe for their cutting; but an old tree if you cut off a bough, you muft cut it clofe and cleanly, and lay a fearcloth of tallow, waxe, and a little pitch melted together vpon the place, to keepe off both the winde, funne, and raine, vntill the barke haue couered it ouer againe: and in this manner you muft deale with all fuch fhort ftumps of branches, as are either broken fhort off with the winde, or by carelefneffe or 
want of skill, or elfe fuch armes or branches as are broken off clofe, or fliued from the body of the tree: for the raine beating and falling into fuch a place, will in fhort time rotte your tree, or put it in danger, befides the deformity. Some vfe to fill vp fuch an hole with well tempered clay, and tacke a cloth or a peece of leather ouer it vntill it be recouered, and this is alfo not amiffe. Your young trees, if they ftand in anie good ground, will bee plentifull enough in thooting forth branches; bee carefull therefore if they growe too thicke, that you pruine away fuch as growe too clofe (and will, if they be fuffered, (poile one another) as they may be beft fpared, that fo the funne, ayre, and raine may haue free acceffe to all your branches, which will make them beare the more plentifully, and ripen them the fooner and the more kindly. If anie boughes growe at the toppe too high, cut them alfo away, that your trees may rather fpread then growe too high. And fo likewife for the vnder boughes, or anie other that by the weight of fruit fall or hang downe, cut them off at the halfe, and they will afterwards rife and thoote vpwards. You fhall obferue, that at all thofe places where anie branches haue been cut away, the fappe will euer bee readie to put forth : if therefore you would haue no more branches rife from that place, rubbe off or nippe off fuch buddes as are not to your minde when they are new fhot: and thus you may keep your trees in good order with a little paines, after you haue thus pruined and dreffed them. One other thing I would aduertife you of, and that is how to preferue a fainting or decaying tree which is readie to perifh, if it be not gone too farre or paft cure, take a good quantitie of oxe or horfe bloud, mixe therewith a reafonable quantitie of fleepe or pigeons dung, which being laid to the roote, will by the often raines and much watering recouer it felfe, if there bee anie poffibilitie; but this muft bee done in Ianuaric or Februarie at the furtheft.

\section{С н А P. VI I I.}

\section{Diwers other obferuations to be remembred in the well keeping of an Orchard.}

7 Here be diuers other things to be mentioned, whereof care muft be had, either to doe or auoide, which I thinke fit in this Chapter promifcuoufly to fet down, that there may be nothing wanting to furnilh you with fufficient knowledge of the care, paines, and cafualties that befall an Orchard: for it hath many enemies, and euery one laboureth as much as in them lye, to fpoile you of your pleafure, or profit, or both, which muft bee both fpeedily and carefully preuented and helped; and they are thefe: Moffe, Caterpillars, Ants, Earwigs, Snailes, Moales, and Birds. If Moffe begin to ouergrowe your trees, looke to it betimes, left it make your trees barren: Some vfe to hacke, and croffehacke, or cut the barke of the bodies of their trees, to caufe it fall away; but I feare it may endanger your trees. Others do either rubbe it off with a haire cloth, or with a long peece of wood formed like a knife, at the end of a long fticke or pole, which if it bee vfed cauteiounly without hurting the buds, I like better. Caterpillars, fome f moake them with burning wet ftrawe or hay, or fuch like ftuffe vnder the trees; but I doe not greatly like of that way: others cut off the boughes whereon they breed, and tread them vider their feete, but that will fpoile too manic branches; and fome kill them with their hands: but fome doe vfe a new deuifed way, that is, a pompe made of lattin or tin, Spout-fafhion, which being fet in a tubbe of water vnder or neare your trees, they will caufe the water to rife through it with fuch a force, and through the branches, that it will wafh them off quickly. To deftroy Ants, that eate your fruit before and when it is ripe, fome vfe to annoint the bodies of their trees with tarre, that they may not creepe vp on the branches; but if that doe not helpe, or you will not vfe it, you muft be carefull to finde out their hill, and turne it vp, pouring in fcalding water, either in Summer, but efpecially if you can in Winter, and that will furely deftroy them. I haue f poken of Earwigs in the firt part of this worke, entreating of the annoyances of Gilloflowers, and therefore I referre you thereunto: yet one way more I 
will here relate which fome doe vfe, and that is with hollow canes of halfe a yard long or more, open at both ends for them to creepe in, and ftucke or laid among the branches of your trees, will foone drawe into them many Earwigs, which you may foone kill, by knocking the cane a little vpon the ground, and treading on them with your foote. Snailes muft be taken with your hands, and that euerie day, efpecially in the morning when they will be creeping abroad. Moales by running vnder your trees make them leffe fruitfull, and alfo put them in danger to be blowne downe, by leauing the ground hollow, that thereby the rootes haue not that ftrength in the ground, both to fhoote and to hold, that otherwife they might haue. Some haue vfed to put Garlicke, and other fuch like things into their holes, thinking thereby to driue them away, but to no purpofe: others haue tryed manie other waies; but no way doth auaile anie thing, but killing them either with a Moale fpade, or a trappe made for the purpofe as manie doe know: and they mut bee watched at their principall hill, and trenched round, and fo to be caught. Birds are another enemie both to your trees and fruit; for the Bullfinch will deftroy all your ftone fruit in the budde, before they flower, if you fuffer them, and Crowes, \&cc. when your Cherries are ripe : for the fmaller birds, Lime twigs fet either neare your trees, or at the next water where they drinke, will helpe to catch them and deftroy them. And for the greater birds, a ftone bowe, a birding or fowling peece will helpe to leffen their number, and make the reft more quiet : or a mill with a clacke to fcarre them away, vntill your fruit be gathered. Some other annoyances there are, as fuckers that rife from the rootes of your trees, which muft be taken away euerie yeare, and not fuffered to growe anie thing great, for feare of robbing your trees of their liuelihood. Barke bound, is when a tree doth not thoote and increafe, by reafon the barke is as it were drie, and will not fuffer the fappe to paffe vnto the branches: take a knife therefore, and flit the barke downe almoft all the length of the tree in two or three places, and it will remedy that euill, and the tree will thriue and come forward the better after. Barke pilled is another euill that happeneth to fome trees, as well young as old, either by reafon of cafuall hurts, or by the gnawing of beafts, howfoeuer it bee, if it bee anie great hurt, lay a plaifter thereon made of tallow, tarre, and a little pitch, and binde it thereto, letting it fo abide vntill the wound bee healed: yet fome doe only apply a little clay or loame bound on with ropes of hay. The Canker is a Ahrewd difeafe when it happeneth to a tree; for it will eate the barke round, and fo kill the very heart in a little fpace. It muft be looked vnto in time before it hath runne too farre; molt men doe wholly cut away as much as is fretted with the Canker, and then dreffe it, or wet it with vinegar or Cowes piffe, or Cowes dung and vrine, \&c. vntill it be deftroyed, and after healed againe with your falue before appointed. There are yet fome other enemies to an Orchard : for if your fence be not of bricke or ftone, but either a mudde wall, or a quicke fet or dead hedge, then looke to it the more carefully, and preuent the comming in of either horfe, or kine, theepe, goates, or deere, hare, or conie; for fome of them will breake through or ouer to barke your trees, and the leaft hole almoft in the hedge will giue admittance to hares and conies to doe the like. To preuent all which, your care muft be continuall to watch them or auoide them, and to ftoppe vp their entrance. A dogge is a good feruant for many fuch purpofes, and fo is a ftone bowe, and a peece to make vfe of as occafion thall ferue. But if you will take that medicine for a Canker fpoken of before, which is Cowes dung and vrine mixed together, and with a brufh wafh your trees often to a reafonable height, will keepe hares and conies from eating or barking your trees. Great and cold windes doe often make a great fpoile in an Orchard, but great trees planted without the compaffe thereof, as Wall-nuts, Oakes, Elmes, Afhes, and the like, will ftand it in great ftead, to defend it both early and late. Thus haue I hewed you moft of the euils that may happen to an Orchard, and the meanes to helpe them, and becaufe the number is great and daily growing, the care and paines muft be continuall, the more earneft and diligent, left you lofe that in a moment that hath been growing many yeares, or at the leaft the profit or beauty of fome yeares fruit. 


\section{A P. I X.}

\section{The manner and way how to plant, order, and keepe other trees that beare greene leaues continually.}

$\mathrm{T}$

He way to order thofe trees that beare their leaues greene continually, is differing from all others that doe not fo: for neyther are they to bee planted or remoued at the time that all other trees are fet, nor doe they require that manner of dreffing, pruining and keeping, that others doe. And although many ignorant perfons and Gardiners doe remoue Bay trees, and are fo likewife perfwaded that all other trees of that nature, that is, that carry their greene leaues continually, may bee remoued in Autumne or Winter, as well as all other trees may bee, yet it is certaine it is a great chance if they doe thriue and profper that are fet at that time, or rather it is found by experience, that fcarce one of ten profpereth well that are fo ordered. Now in regard that there be diuers trees and fhrubs mentioned here in this booke that beare euer greene leaues, wherein there is very great beauty, and many take pleafure in them; as the ordinary Bay, the Rofe Bay, and the Clserry Bay trees, the Indian Figge, the Cypreffe, the Pine tree, the Mirtle and dwarfe Boxe, and many others; I will here fhew you how to plant and order them, as is fitteft for them. For in that they doe not thed their greene leaues in winter as other trees doe, you may in reafon be perfwaded that they are of another nature; and fo they are indeede: for feeing they all grow naturally in warme Countries, and are from thence brought vnto vs, we muft both plant them in a warmer place, and tranfplant them in a warmer time then other trees be, or elfe it is a great hazzard if they doe not perifh and dye, the cold and frofts in the winter being able to pierce them through, if they fhould bee tranfplanted in winter, before they haue taken roote. You muft obferue and take this therefore for a certaine rule, that you alwaies remoue fuch trees or fhrubbes as are ener greene in the fpring of the yeare, and at no time elfe if you will doe well, that is, from the end of March, or beginning of Aprill, vnto the middle or end of May, efpecially your more dainty and tender plants, fhadowing them alfo for a while from the heate of the Sun, and giuing them a little water vpon their planting or tranfplanting; but fuch water as hath not perfently been drawn from a Well or Pumpe, for that will go neer to kill any plant, but fuch water as hath ftood in the open ayre for a day at the leaft, if not two or three. Yet for dwarfe Boxe I confeffe it may endure one moneth to be earlier planted then the reft, becaufe it is both a more hardy and lowe plant, and thereby not fo much fubiect to the extremitie of the colde : but if you fhould plant it before winter, the frofts would raife it out of the ground, becaufe it cannot fo foone at that time of the yeare take roote, and thereby put it in danger to be loft. Moreouer all of them will not abide the extremitie of our winter frofts, and therefore you muft of neceffity houfe forne of them, as the Rofe Bay, Mirtle, and fome others, but the other forts being fet where they may bee fomewhat defended from the cold windes, froftes, and fnow in winter, with fome couering or fhelter for the time, will reafonably well endure and beare their fruit, or the moft of them. If any be defirous to be furnifhed with ftore of thefe kinds of trees that will be nourfed vp in our Country, he may by fowing the feed of them in fquare or long woodden boxes or chefts made for that purpore, gaine plenty of them: but hee muft be carefull to couer them in winter with fome ftraw or fearne, or beane hame, or fuch like thing layd vpon croffe fticks to beare it vp from the plants, and after two or three yeares that they are growne fomewhat great and ftrong, they may bee tranfplanted into fuch places you meane they fhall abide : yet it is not amiffe to defend them the firt yeare after they are tranfplanted, for their inore fecuritie : the feedes that are moft vfually fowen with vs, are, the Cypreffe tree, the Pine tree, the Baye, the Pyracantha or prickly Corall tree, and the Mirtle: the Rofe Bay I haue had alfo rifen from the feede that was frefh, and brought me from Spaine. But as for Orenge trees, becaufe they are fo hardly preferued in this our cold climate (vnleffe it bee with fome that doe beftow the houfing of them, befides a great deale more of care and refpect vnto them) from the bitterneffe of our cold long winter weather (although their 
kernels being put into the ground in the Spring or Summer, and if care bee had of them and conuenient keeping, will abide, and by grafting the good fruite on the crab ftocke they may bee in time nurfed vp) I doe not make any other ef peciall account of them, nor giue you any further relation of their ordering. Now for the ordering of thefe trees after they are eyther planted of young fets, or tranfplanted from the feede, it is thus: Firft for Bay trees, the moft vfuall way is to let them grow vp high to bee trees, and many plant them on the North or Eaft fide of their houfes that they may not bee fcorched with the Sunne; but the bitter winters which we often haue, doe pinch them fhrewdly, infomuch that it killeth euen well growne trees fometimes downe to the roote : but fome doe make a hedge of them being planted in order, and keep them low by lopping of them continually, which will make them bufh and fpread. 'The Cypreffe tree is neuer lopped, but fuffered to grow with all the branches from a foote aboue the ground, if it may be, ftraight vpright; for that is his natiue grace and greateft beautie, and therefore the more branches doe dye that they muft bee cut away, the more you deforme his propertie. The Pine tree may be vfed in the fame manner, but yet it wil better endure to fuftaine pruining then the Cypreffe, without any fuch deformitie. The Laurocerafus or Cherry Bay may be diuerfly formed, that is, it may be either made to grow into a tall tree by fhredding ftill away the vnder branches, or elfe by fuffering all the branches to grow to be a low or hedge bufh, and both by the fuckers and by laying downe the lower branches into the earth, you may foone haue much increafe; but this way will caufe it to bee the longer before it beare anie fruit. The Rofe Baye will verie hardlie bee encreafed either by fuckers or by layers, but muft bee fuffered to grow without lopping, topping or cutting. The Pyracantha or Prickly Corall tree may bee made to grow into a reafonable tall tree by firedding away the lower branches, or it may be fuffered to grow lowe into an hedge bufh, by fuffering all the branches to grow continually, you may alfo propagate it by the fuckers, or by laying downe the lower branches. The Myrtle of all forts abideth a low bufh fpreading his branches full of fweete leaues and flowers, without anie great encreafe of it felfe, yet fometimes it giueth fuckers or thootes from the rootes: but for the more fpeedie propagating of them, fome doe put the cuttings of them into the earth, and thereby increafe them. There are fome other trees that are not of any great refpect, as the Yew tree, and the Savine bufh, both which may be encreafed by the cuttings, and therefore I need not make any further relation or amplification of them, and to fay thus much of them all, is (I thinke) fufficient for this Worke.

CH A P. X.

The ordering, curing, and propagating Vines of all forts.

$\mathrm{N}$ moft places of this countrie there is fmall care or paines taken about the ordering of Vines : it fufficeth for the moft part with them that haue anie, to make a frame for it to fpread vpon aboue a mans height, or to tacke it to a wall or window, \&cc. and fo to let it hang downe with the branches and fruit, vntill the weight thereof, and the force of windes doe teare it downe oftentimes, and fpoile the grapes: and this way doth fomewhat refemble that courfe that the Vineyard keepers obferue in the hot countries of Syria, Spaine, and Italy, and in the fartheft parts of France as I hear likewife : for in moft of thefe hot countries they vfe to plant an Oliue betweene two Vines, and let them runne thereupon. But manie of the other parts of France, \&c. doe not fuffer anie trees to growe among their Vines; and therefore they plant them thicke, and pruine them much and often, and keepe them lowe in comparifon of the other way, faftening them to pearches or poles to hold them vp. And according to that fafhion may haue aduentured to make Vineyards in England, not onely in thefe later daies, but in ancient times, as may wel witneffe the fundrie places in this Land, entituled by the name of Vineyards; and I haue read that manie Monafteries in this Kingdome hauing Vineyards, had as much wine made therefrom, as fufficed their conuents yeare by yeare : but long fince they haue been deftroyed, and the knowledge how to order a Vineyard is alfo vtterly perifhed with them. For although diuers, both No- 
bles and Gentlemen, haue in thefe later times endeauoured to plant and make Vineyards, and to that purpore haue caufed French men, being skilfull in keeping and dreffing of Vines, to be brought ouer to performe it, yet either their skill failed them, or their Vines were not good, or (the moft likely) the foile was not fitting, for they could neuer make anie wine that was worth the drinking, being fo fmall and heartleffe, that they foone gaue ouer their practice. And indeede the foile is a maine matter to bee chiefly confidered to feate a Vineyard vpon: for euen in France and other hot countries, according to the nature of the foile, fo is the rellih, ftrength, and durabilitie of the wine. Now although $I$ think it a fruitleffe labour for any man to ftriue in thefe daies to make a good Vineyard in England, in regard not only of the want of knowledge, to make choife of the fitteft ground for fuch Vines as you would plant thereupon but alfo of the true maner of ordering them in our country ; but moft chiefly \& aboue all others, that our years in thefe times do not fal out to be fo kindly and hot, to ripen the grapes, to make anie good wine as formerly they haue done; yet I thinke it not amiffe, to giue you inftructions how to order fuch Vines as you may nourfe vp for the pleafure of the fruit, to eate the grapes being ripe, or to preferue and keepe them to bee eaten almoft all the winter following: And this may be done without any great or extraordinarie paines. Some doe make a lowe wall, and plant their Vines againft it, and keepe them much about the height thereof, not fuffering them to rife much higher: but if the high bricke or ftone wals of your Garden or Orchard haue buttreffes thereat, or if you caufe fuch to bee made, that they bee fomewhat broade forwards, you may the inore conueniently plant Vines of diuers forts at them, and by fticking down a couple of good ftakes at euery buttreffe, of eight or ten foot high aboue ground, tacking a few lathes acroffe vpon thofe ftakes, you may thereunto tye your Vines, \& carry them theron at your pleafure : but you muft be carefull to cut them euery year, but not too late, and fo keepe them downe, and from farre Spreading, that they neuer runne much beyond the frame which you fet at the buttreffes: as alfo in your cutting you neuer leaue too many ioynts, nor yet too few, but at the third or fourth ioint at the moft cut them off. I doe aduife you to thefe frames made with ftakes and lathes, for the better ripening of your grapes: for in the blooming time, if the branches of your vines bee too neare the wall, the reflection of the Sunne in the day time, and the colde in the night, doe oftentimes f poile a great deale of fruit, by piercing and withering the tender footftalkes of the grapes, before they are formed, whereas when the bloffomes are paft, and the fruit growing of fome bigneffe, then all the heate and reflection you can giue them is fit, and therefore cut away fome of the branches with the leaues, to admit the more Sunne to ripen the fruit. For the divers forts of grapes I haue fet them downe in the Booke following, with briefe notes vpon euerie of them, whether white or blacke, finall or great, early or late ripe; fo that I neede not here make the fame relation again. There doth happen forne difeafes to Vines fometimes, which that you may helpe, I thinke it conuenient to informe you what they are, and how to remedy them when you thall be troubled with any fuch. The firft is a luxurious fpreading of branches and but little or no fruit: for remedie whereof, cut the branches fomewhat more neere then vfuall, and bare the roote, but take heed of wounding or hurting it, and in the hole put either fome good old rotten ftable dung of Horfes, or elfe fome Oxe blood new taken from the beafts, and that in the middle of Ianuarie or beginning of Februarie, which being well tempered and turned in with the earth, let it fo abide, which no doubt, when the comfort of the blood or dung is well foaked to the bottome by the raines that fall thereon, will caufe your Vine to fructifie againe. Another fault is, when a Vine doth not bring the fruit to ripeneffe, but either it withereth before it be growne of any bigneffe, or prefently after the blooming: the place or the earth where fuch a Vine ftandeth, affuredly is too cold, and therefore if the fault bee not in the place, which cannot bee helped without remouing to a better, digge out a good quantity of that earth, and put into the place thereof fome good frefh ground well heartned with dung, and fome fand mixed therewith (but not falt or falt water, as fome doe aduife, nor yet vrine as others would haue) and this will hearten and ftrengthen your Vine to beare out the fruit vnto maturitic. When the leaues of a Vine in the end of Summer or in Autumne, vntimely doe turne either yellow or red, it is a great figne the earth is 
too hot and drie; you muft therefore in ftead of dung and fand, as in the former defect is faid, put in fome frefh loame or fhort clay, well mixed together with fome of the earth, and fo let them abide, that the frofts may mellow them. And laftly, a Vine fometimes beareth fome ftore of grapes, but they are too many for it to bring to ripeneffe; you thall therefore helpe fuch a Vine (which no doubt is of fome excellent kinde, for they are moft vfually fubiect to this fault) by nipping away the bloffomes from the branches, and leauing but one or two bunches at the moft vpon a branch, vntill the Vine be growne older, and thereby ftronger, and by this meane inured to beare out all the grapes to ripeneffe. Thefe be all the difeafes I know doe happen to Vines: for the bleeding of a Vine it feldome happeneth of it felfe, but commeth either by cutting it vntimely, that is, too late in the yeare, (for after Ianuarie, if you will be well aduifed, cut not any Vine) or by fome cafuall or wilfull breaking of an arme or a branch. This bleeding in fome is vnto death, in others it ftayeth after a certaine fpace of it felfe: To helpe this inconuenience, fome have feared the place where it bleedeth with an hot iron, which in many haue done but a little good; others haue bound the barke clofe with packe-thred to ftay it; and fome haue tied ouer the place, being firft dried as well as may bee, a plaifter made with waxe roffen and turpentine while it is warme. Now for the propagating of them: You muft take the faireft and goaleft thot branches of one yeares growth, and cut them off with a peece of the old wood vnto it, and thefe being put into the ground before the end of Ianuarie at the furtheit, will fhoote forth, and take roote, and fo become Vines of the fame kinde from whence you tooke them. This is the moft fpeedy way to haue increafe: for the laying downe of branches to take roote, doth not yeelde fuch ftore fo plentifully, nor doe fuckers rife from the rootes fo aboundantly; yet both thefe waies doe yeelde Vines, that being taken from the old ftockes will become young plants, fit to bee difpofed of as any fhall thinke meete.

С н А. X $\mathrm{X}$.

The way to order and preferue grapes, fit to be eaten almoft all the Winter long, and fometimes vnto the Spring.

$\Lambda^{2}$

Lthough it bee common and vfuall in the parts beyond the Sea to dry their grapes in the Sunne, thereby to preferue them all the year, as the Raifins of the Sunne are, which cannot bee done in our Countrie for the want of fufficient heate thereof at that time : or otherwife to fcald them in hot water (as I heare) and afterwards to dry them, and fo keepe them all the yeare, as our Malaga Raifins are prepared that are packed vp into Frayles: yet I doe intend to thew you fome other waies to preferue the grapes of our Countrie frefh, that they may be eaten in the winter both before and after Chriftmas with as much delight and pleafure almort, as when they were new gathered. One way is, when you haue gathered your grapes you intend to keepe, which muft be in a dry time, and that all the fhrunke, dried, or euill grapes in euery bunch be picked away, and hauing prouided a veffell to hold them, be it of wood or ftone which you will, and a fufficient quantitie of faire and cleane drie fand; make fratum fuper ftratum of your grapes and the fand, that is, a lay of fand in the bottome firft, and a lay of grapes vpon them, and a lay or ftrowing againe of fand vpon thofe grapes, fo that the fand may couer euery lay of grapes a fingers breadth in thickneffe, which being done one vpon another vntill the veffell be full, and a lay of fand vppermoft, let the veffell be ftopped clofe, and fet by vntill you pleafe to fpend them, being kept in fome drie place and in no fellar: let them bee wafhed cleane in faire water to take away the fand from fo many you will fpend at a time. Another way is (which Camerarius fetteth downe he was informed the Turkes vfe to keepe grapes all the winter vnto the next fummer) to take fo much meale of Muftard feede, as will ferue to ftrow vpon grapes, vntill they haue filled their veffels, whereon afterwards they poure new wine before it hath boiled, to fill vp their veffels therwith, and being ftopped vp clofe, they keepe them a certaine time, and felling them with their liquour to them that will 
vfe them, they doe wafh the feedes or meale from them when they vfe them. Another way is, that hauing gathered the faireft ripe grapes, they are to be caft vpon threds or ftrings that are faftened at both ends to the fide walks of a chamber, neere vnto the feeling thereof, that no one bunch touch another, which will bee fo kept a great while, yet the chamber muft be well defended from the frofts, and cold windes that pierce in at the windowes, left they perifh the fooner: and fome will dippe the ends of the branches they hang vp firt in molten pitch, thinking by fearing vp the ends to keepe the bunches the better; but I doe not fee any great likelihood therein. Your chamber or clofet you appoint out for this purpofe muft alfo bee kept fomewhat warme, but efpecially in the more cold and froftie time of the yeare, left it fpoile all your coft and paines, and fruftrate you of all your hopes: but although the frofts fhould pierce and fpoile fome of the grapes on a bunch, yet if you be carefull to keepe the place warme, the fewer will be fpoiled. And thus haue I fhewed you the beft directions to order this Orchard rightly, and all the waies I know are vfed in our Countrie to keep grapes good anie long time after the gathering, in regard wee haue not that comfort of a hotter Sun to preferue them by its heate.

The fruits themfelues fhall follow euerie one in their order; the lower fhrubbes or bufhes firft, and the greater afterwards.

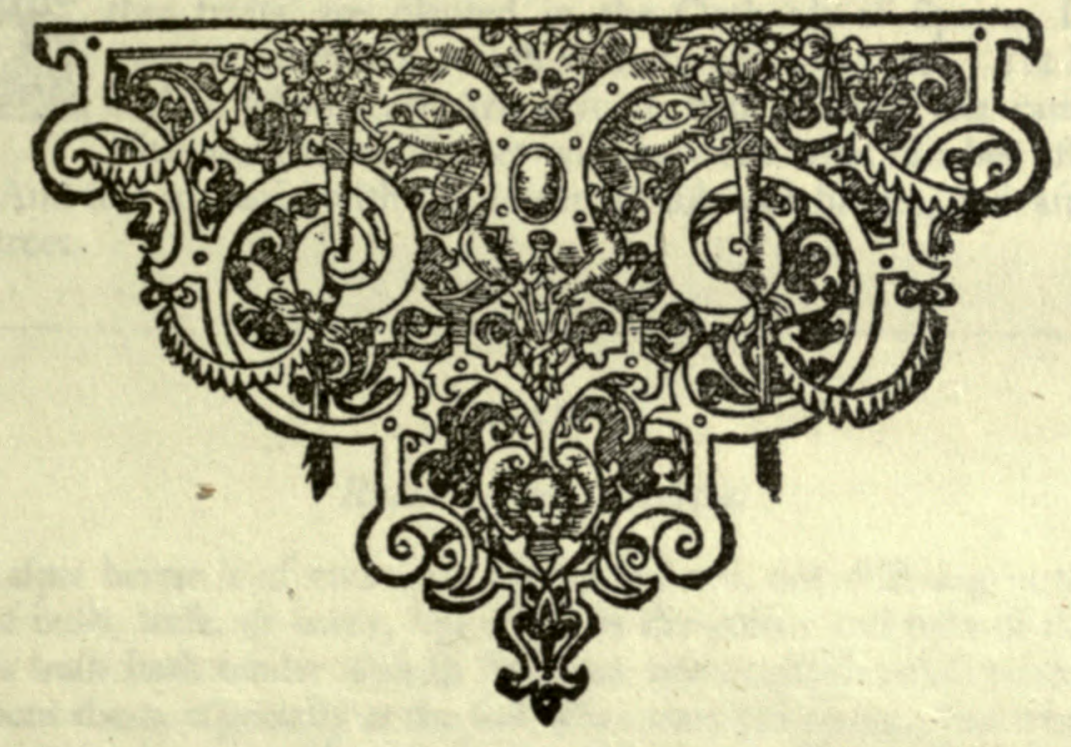




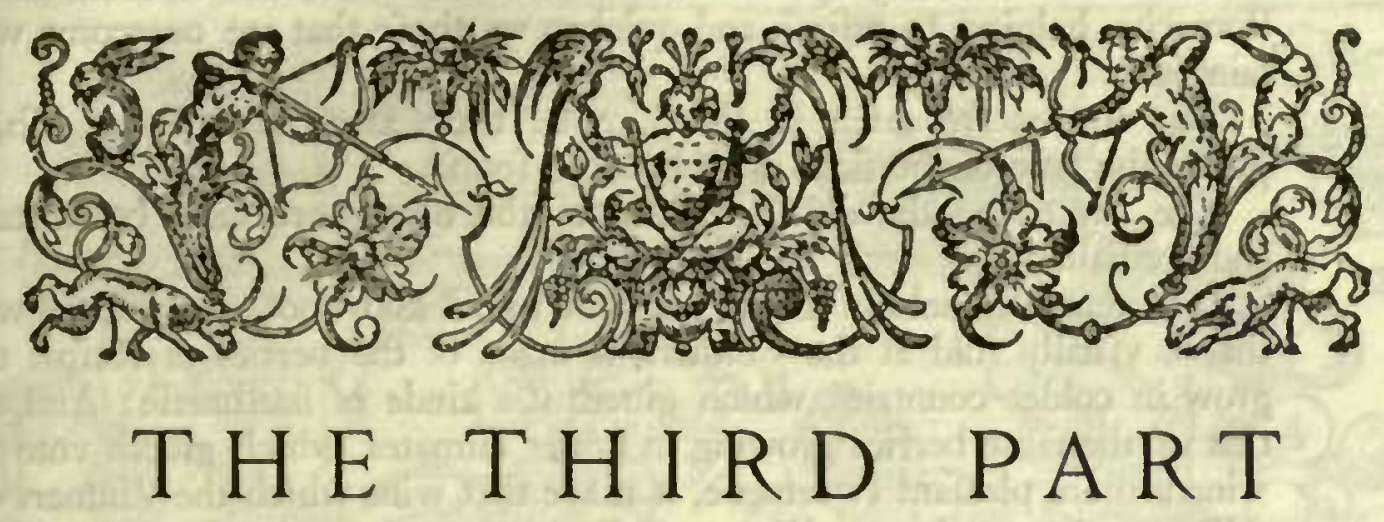
CALLED
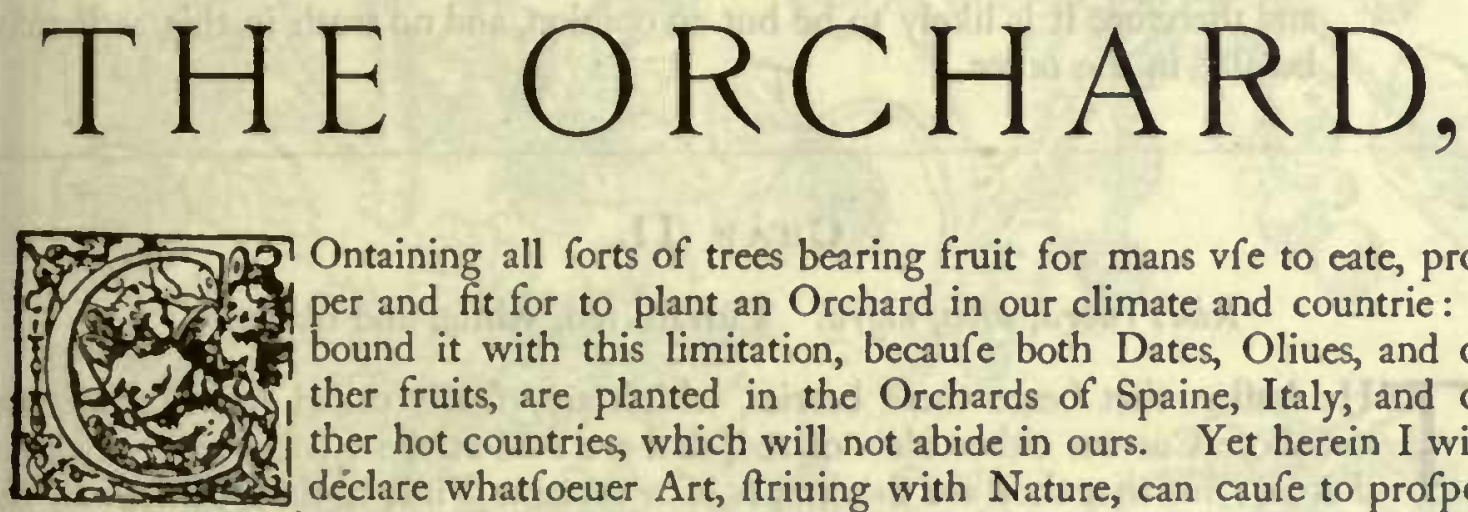

Ontaining all forts of trees bearing fruit for mans vfe to eate, proper and fit for to plant an Orchard in our climate and countrie: I bound it with this limitation, becaufe both Dates, Oliues, and other fruits, are planted in the Orchards of Spaine, Italy, and other hot countries, which will not abide in ours. Yet herein I will declare whatfoeuer Art, ftriuing with Nature, can caufe to profper with vs, that whofoeuer will, may fee what can bee effected in our countrie. And firt to begin with the lower Shrubbes or burhes, and after afcend to the higher trees.

\section{CH A.P. I.}

\section{Rubus Idaus. Rafpis.}

7 He Rafpis berrie is of two forts, white and red, not differing in the forme either of bufh, leafe, or berry, but onely in the colour and tafte of the fruit. The Rafpis bufh hath tender whitifh ftemmes, with reddifh Imall prickes like haires fet round about them, ef pecially at the firft when they are young; but when they grow old they become more wooddy and firme, without any hew of thornes or prickles vpon them, and hath onely a little hairineffe that couereth them : the leaues are fomewhat rough or rugged, and wrinkled, ftanding three or fiue vpon a ftalke, fomewhat like vnto Rofes, but greater, and of a grayer greene colour: the flowers are [mall, made of fine whitilh round leaues, with a dah as it were of blufh caft ouer them, many ftanding together, yet euery one vpon his owne ftalke, at the tops of the branches; after which come vp fmall berries, fomewhat bigger then Strawberries, and longer, either red or white, made of many graines, more eminent then in the Strawberry, with a kinde of dounineffe caft ouer them, of a pleafant tafte, yet fomewhat fowre, and nothing fo pleafant as the Strawberrie. The white Rafpis is a little more pleafant then the red, wherein there is fmall feede inclofed : the rootes creepe vnder ground veric farre, and thoote vp againe in many places, much encreafing thereby.

There is another whofe ftemme and branches are wholly without prickles: the fruit is red, and fomewhat longer, and a little more fharpe.

The Vfe of Rafpis.

The leaues of Rafpis may be vfed for want of Bramble leaues in gargles, and other decoctions that are cooling and drying, although not fully to that effect. 
The Conferue or Syrupe made of the berries, is effectuall to coole an hot ftomacke, helping to refrefh and quicken vp thofe that are ouercome with faintneffe.

The berries are eaten in the Summer time, as an afternoones difh, to pleafe the tafte of the ficke as well as the found.

The iuyce and the diftilled water of the berries are verie comfortable and cordiall.

It is generally held of many, but how true I know not, that the red wine that is vfually fold at the Vintners, is made of the berries of Rafpis that grow in colder countries, which giueth it a kinde of harhneffe: And alfo that of the fame berries growing in hotter climates, which giueth vnto the wine a more pleafant fweetneffe, is made that wine which the Vintners call Alligant: but we haue a Vine or Grape come to vs vnder the name of the Alligant Grape, as you fhall finde it fet downe hereafter among the Grapes; and therefore it is likely to be but an opinion, and no truth in this, as it may be alfo in the other.

\section{C н A P. I I.}

Ribes rubra, alba, nigra. Currans red, white, and blacke.

T He bufhes that beare thofe berries, which are vfually called red Currans, are not thofe Currans either blew or red, that are fold at the Grocers, nor any kind thereof; for that they are the grapes of a certaine Vine, as thall be thewed by and by: but a farre differing kinde of berry, whereof there are three forts, red, white, and blacke.

The red Curran bufh is of two forts, and groweth to the height of a man, hauing fometimes a ftemme of two inches thickneffe, and diuers armes and branches, couered with a fmooth, darke, brownifh barke, without anie pricke or thorne at all vpon anie part thereof, whereon doe growe large cornered blackifh greene leaues, cut in on the edges, feeming to be made of fiue parts, almoft like a Vine leafe, the ends a little pointing out, and ftanding one aboue another on both fides of the branches: the flowers are little and hollow, comming forth at the ioynts of the leaues, growing many together on a long ftalke, hanging downe aboue a fingers length, and of an herbie colour : after which come fmall round fruit or berries, greene at the firft, and red as a Cherry when they are ripe, of a pleafant and tart tafte: the other differeth not in anie other thing then in the berries, being twice as bigge as the former: the roote is wooddy, and fpreadeth diuerlly.

The white Curran bufh rifeth vfually both higher then the red, and ftraighter or more vpright, bigger alfo in the ftemme, and couered with a whiter barke: the leaues are cornered, fomewhat like the former, but not fo large: the flowers are fmall and hollow like the other, hanging downe in the fame manner on long ftalkes, being of a whiter colour: the berries likewife growe on the long ftalkes, fomewhat thicker fet together, and of a cleare white colour, with a little blacke head, fo tranfparent that the feedes may be eafily feene thorough them, and of a more pleafant winie tafte then the red by much.

The blacke Curran bufh rifeth higher then the white, with more plentifull branches, and more pliant and twiggie: the ftemme and the elder branches being couered with a brownifh barke, and the younger with a paler: the flowers are alfo like vnto little bottles as the others be, of a greenifh purple colour, which turne into blacke berries, of the bigneffe of the fmaller red Currans: the leaues are fomewhat like vnto the leaues of the red Currans, but not fo large : both branches, leaues, and fruit haue a kind of ftinking fent with them, yet they are not vnwholfome, but the berries are eaten of many, without offending either tafte or fmell.

\section{The Vfe of Currans.}

The red Currans are vfually eaten when they are ripe, as a refrefhing to an 


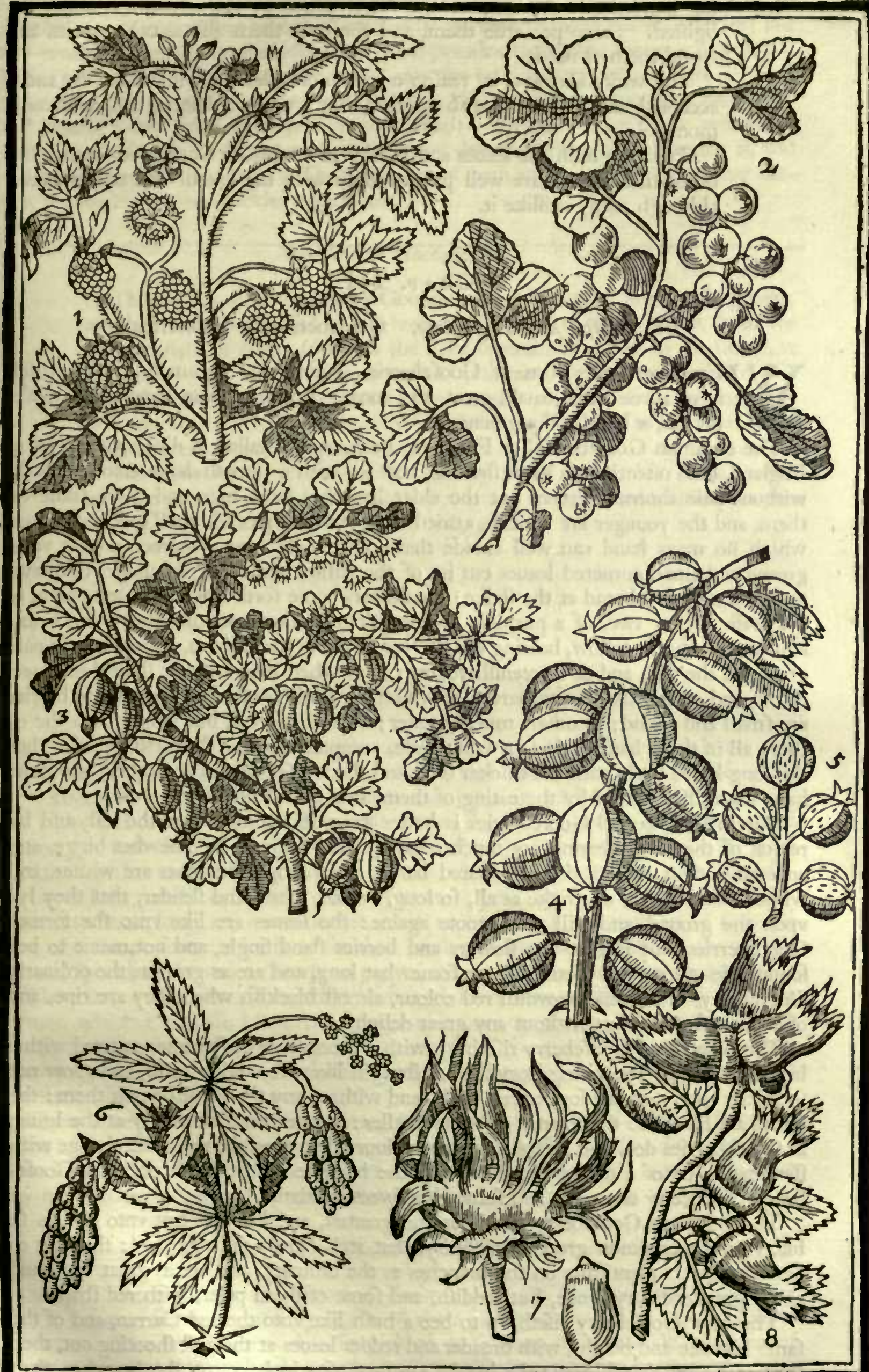

I Rubus Idaus. The Rafpis. 2 Ribes frulau rubro zel albo. White or red Currans, 3 Grolfularia vwlgaris. The ordinary Gooleberry. Grofjulariu frufiu rubro. The great red Goofeberry. 5 GrofJularia arwlala. The prickly Goofeberry. $60 x y a c a n t h a$
fem Berberis. The Barbary bufh. Filberd. 
hot ftomacke in the heate of the yeare, which by the tartneffe is much delighted. Some preferue them, and conferue them alfo as other fruits, and fpend them at neede.

The white Currans, by reafon of the more pleafant winie tafte, are more accepted and defired, as alfo becaufe they are more daintie, and leffe common.

Some vfe both the leaues and berries of the blacke Currans in fawces, and other meates, and are well pleafed both with the fauour and tafte thereof, although many miflike it.

\section{Cн А P. I I I.}

\section{Vva Crifpa fiue Groffularia. Goofeberries or Feaberries.}

W Ee haue diuers forts of Goofeberries, befides the common kinde, which is of three forts, fmall, great, and long. For wee have three red Goofeberries, a blew and a greene.

The common Goofeberrie, or Feaberrie bufh, as it is called in diuers Countries of England, hath oftentimes a great ftemme, couered with a fmooth darke coloured bark, without anie thorne thereon, but the elder branches have here and there fome on them, and the younger are whitifh, armed with verie fharpe and cruell crooked thorns, which no mans hand can well auoide that doth handle them, whereon are fet verie greene and fmall cornered leaues cut in, of the fafhion almoft of Smallage, or Hawthorne leaues, but broad at the ftalke : the flowers come forth fingle, at euerie ioynt of the leafe one or two, of a purplifh greene colour, hollow and turning vp the brims a little: the berries follow, bearing the flowers on the heads of them, which are of a pale greene at the firft, and of a greenifh yellow colour when they are ripe, ftriped in diuers places, and cleare, almoft tranf parent, in which the feede lyeth. In fome thefe berries are fmall and round; in others much greater; a third is great, but longer then the other: all of them haue a pleafant winie tafte, acceptable to the ftomacke of anie (but the long kinde hath both the thicker skin, and the worfer tafte of the other) and none haue been diftempered by the eating of them, that euer I could heare of.

The firft of the red Goofeberries is better knowne I thinke then the reft, and by reafon of the fmall bearing not much regarded; the ftemme is fomewhat bigge, and couered with a fmooth darke coloured barke, the younger branches are whiter, and without anie thorne or pricke at all, fo long, weake, fmall, and flender, that they lye vpon the ground, and will there roote againe: the leaues are like vnto the former Goofeberries, but larger: the flowers and berries ftand fingle, and not manie to bee found anie yeare vpon them, but are fomewhat long, and are as great as the ordinarie Goofeberry, of a darke brownifh red colour, almoft blackifh when they are ripe, and of a fweetin tafte, but without any great delight.

The fecond red Goofeberry rifeth vp with a more ftraight ftemme, couered with a brownifh barke; the young branches are ftraight likewife, and whitifh, and grow not fo thicke vpon it as the former red kinde, and without any thorne alfo vpon them : the leaues are like vnto the former red, but fmaller: the berries ftand fingly at the leaues as Goofeberries doe, and are of a fine red colour when they are ripe, but change with ftanding to be of a darker red colour, of the bigneffe of the fmall ordinary Goofeberry, of a pretty tart tafte, and fomewhat fweete withall.

The third red Goofeberry which is the greateft, and knowne but vnto few, is fo like vnto the common great Goofeberry, that it is hardly diftinguifhed: the fruit or berries grow as plentifully on the branches as the ordinary, and are as great \& round as the great ordinary kinde, but reddifh, and fome of them paler, with red Atripes.

The blew Goofeberry rifeth vp to bee a bufh like vnto the red Curran, and of the fame bigneffe and height, with broader and redder leaues at the firf fhooting out, then the fecond red Goofeberry: the berries are more fparingly fet on the branches, then on the fmall red, and much about the fame bigneffe, or rather leffer, of the colour of a Damfon; with an ouerfhadowing of a blewifh colour vpon them, as the Damfon hath, before it be handled or wiped away. 
The greene prickly Goofeberry is very like vnto the ordinary Goofeberry in ftemme and branches, but that they are not ftored with fo many fharpe prickles; but the young thootes are more plentifull in fmall prickles about, and the greene leafe is a little fmaller: the flowers are alike, and fo are the berries, being of a middle fize, and not very great, greene when they are thorough ripe as well as before, but mellower, and hauing a few fmall fhort prickles, like fmall fhort haires vpon them, which are harmleffe, and without danger to anie the moft dainty and tender palate that is, and of a verie good pleafant tafte. The feede hereof hath produced bufhes bearing berries, hauing few or no prickles vpon them.

\section{The Vfe of Goofeberries.}

The berries of the ordinary Goofeberries, while they are fmall, greene, and hard, are much vfed to bee boyled or fcalded to make fawce, both for filh and flefh of diuers forts, for the ficke fometimes as well as the found, as alfo before they bee neere ripe, to bake into tarts, or otherwife, after manie fafhions, as the cunning of the Cooke, or the pleafure of his commanders will appoint. They are a fit difh for women with childe to ftay their longings, and to procure an appetite vnto meate.

The other forts are not vfed in Cookery that I know, but ferue to bee eaten at pleafure; but in regard they are not fo tart before maturity as the former, they are not put to thofe vfes they be.

\section{Сна P. I I I I.}

\section{Oxyacantha, fed potius Berberis. Barberries.}

$\mathrm{T}$

He Barberry bufh groweth oftentimes with very high ftemmes, almoft two mens height, but vfually fomewhat lower, with manie fhootes from the roote, couered with a whitifh rinde or barke, and yellow vnderneath, the wood being white and pithy in the middle: the leaues are fmall, long, and very greene, nicked or finely dented about the edges, with three fmall white fharpe thornes, for the moft part fet together at the fetting on of the leaues: the flowers doe growe vpon long cluftering ftalkes, fmall, round, and yellow, fweete in fmell while they are frefh, which turne into fmall, long, and round berries, white at the firft, and very red when they are ripe, of a fharpe fowre tafte, fit to fet their teeth on edge that eate them: the roote is yellow, fpreading far vnder the vpper part of the ground, but not very deepe.

There is (as it is thought) another kinde, whofe berries are thrice as bigge as the former, which I confeffe I haue not feene, and know not whether it be true or no: for it may peraduenture be but the fame, the goodneffe of the ground and ayre where they growe, and the youngneffe of the bufhes caufing that largeneffe, as I haue obferued in the fame kinde, to yeeld greater berries.

There is faid to be alfo another kinde, whofe berries thould be without ftones or feede within them, not differing elfe in anie thing from the former : but becaufe I haue long heard of it, and cannot vnderftand by all the inquirie I haue made, that any hath feene fuch a fruit, I reft doubtfull of it.

\section{The Vfe of Barberries.}

Some doe vfe the leaues of Barberries in the ftead of Sorrell, to make fawce for meate, and by reafon of their fowreneffe are of the fame quality.

The berries are vfed to be pickled, to ferue to trimme or fet out difhes of fifh and flefh in broth, or otherwife, as alfo fometime to bee boyled in the broth, to giue it a fharpe rellifh, and many other wayes, as a Mafter Cooke can better tell then my felfe. 
The berries are preferued and conferued to give to ficke bodies, to helpe to coole any heate in the ftomacke or mouth, and quicken the appetite.

The depurate iuyce is a fine menftrue to diffolue many things, and to verie good purpofe, if it be cunningly handled by an Artift.

The yellow inner barke of the branches, or of the rootes, are vfed to be boyled in Ale, or other drinkes, to be given to thofe that have the yellow iaundife: As alfo for them that haue anie fluxes of choller, to helpe to ftay and binde.

Clufius fetteth downe a fecret that hee had of a friend, of a cleane differing propertie, which was, that if the yellow barke were laid in fteepe in white wine for the fpace of three houres, and afterwards drunke, it would purge one very wonderfully.

C н А P. V.

Nux Auellana. The Filberd.

T He Filberd tree that is planted in Orchards, is very like vnto the Hafell nut tree that groweth wilde in the woods, growing vpright, parted into many boughes and tough plyable twigges, without knots, couered with a brownifh, fpeckled, fmooth, thinne rinde, and greene vnderneath: the leaues are broad, large, wrinkled, and full of veines, cut in on the edges into deepe dents, but not into any garhes, of a darke greene colour on the vpperfide, and of a grayifh afh colour vnderneath: it hath fmall and long catkins in ftead of flowers, that come forth in the Winter, when as they are firme and clofe, and in the Spring open themfelues fomewhat more, growing longer, and of a brownifh yellow colour : the nuts come not vpon thofe ftalkes that bore thofe catkins, but by themfelues, and are wholly inclofed in long, thicke, rough huskes, bearded as it were at the vpper ends, or cut into diuers long iagges, much more then the wood nut : the nut hath a thinne and fomewhat hard fhell, but not fo thicke and hard as the wood nut, in fome longer then in other, and in the long kinde, one hath the skinne white that couereth the kernels, and another red.

There is another fort of the round kinde that came from Conftantinople, whofe huske is more cut, torne, or iagged, both aboue and belowe, then any of our country; the barke alfo is whiter, and more rugged then ours, and the leaues fomewhat larger.

We haue had from Virginia Hafell nuts, that haue beene fmaller, rounder, browner, thinner fheld, and more pointed at the end then ours: I know not if any hath planted of them, or if they differ in leafe or any thing elfe.

\section{The Vfe of Filberds.}

Filberds are eaten as the beft kinde of Hafell nuts, at bankets among other dainty fruits, according to the feafon of the yeare, or otherwife, as euery one pleafe: But Macer hath a Verfe, expreffing prettily the nature of thefe nuts, which is,

\section{Ex minimis nucibus nulli datur efca falubris.}

that is, There is no wholfome food or nourifhment had from thefe fmall kinde of nuts.

Yet they are vfed fometime phyfically to be rofted, and made into a Lohoc or Electuary, that is vfed for the cough or cold. And it is thought of fome, that Mithridates meant the kernels of thefe nuts, to be vfed with Figs and Rue for his Antidote, and not of Walnuts. 


\section{Cи A P. VI.}

Vitis. The Vine.

$T$ Here is fo great diuerfities of Grapes, and fo confequently of Vines that bear them, that I cannot giue you names to all that here grow with vs: for Iohn Tradefcante iny verie good friend, fo often before remembred, hath affured me, that he hath twentie forts growing with him, that hee neuer knew how or by what name to call them. One defcription therefore fhall ferue (as I vfe to doe in fuch varicties) for all the reft, with the names afterwards, of as many as we can giue, and the feuerall formes, colours and proportions of the grapes.

The manured Vine, in the places where it hath abiden long time, groweth to haue a great bodie, ftemme or trunke, fometimes of the bigneffe of a mans arme, lleeue and all, fpreading branches if it bee fuffered without end or meafure, but vfually ftored with many armes or branches, both old and new, but weake, and therefore muft bee fuftained; whereof the old are couered with a thin fcaly rinde, which will often chap and peele off of it felfe; the youngeft being of a reddifh colour, fmooth and firme, with a hollowneffe or pith in the middle: from the ioints of the young branches, and fometimes from the bodie of the elder, breake out on euerie fide broade greene leaues, cut on the edges into fiue diuifions for the moft part, and befides notched or dented about : right againt the leafe, and likewife at other ioynts of the branches, come forth long twining or clafping tendrels, winding themfelues about any thing ftandeth next vnto them : at the bottome of thefe leaues come forth clufters of $f$ mall greenifh yellow bloomes or flowers, and after them the berries, growing in the fame manner in clufters, but of divers formes, colours, taftes and greatneffe. For fome grapes are great, others leffe, fome very fmall (as the Currans that the Grocers fell) fome white, fome red, blew, blacke, or partie-coloured, fome are as it were fquare, others round : fome the clufters are clofe, others open, fome are fweete, others fower or harfh, or of fome other mixed tafte; euerie one differing from others, verie notably either in tafte, colour or forme; within euerie one of which grapes, (and yet there is a grape without ftones) are contained one, two, or more kernels or ftones, fome of them being fmal, others greater: the rootes fpread far and deepe. They that keepe their Vines in the beft order, doe cut them low, not fuffering them to grow high, or with too many branches, whereby they grow the better, take vp the leffer roome, and bring their grapes fairer and fweeter.

\section{The kindes of Vines and Grapes.}

Our ordinarie Grape both white and red, which excelleth Crabs for veriuice, and is not fit for wine with vs.

The white Mufcadine Grape is a verie great Grape, fweete and firme, fome of the bunches haue weighed fixe pound, and fome of the grapes halfe an ounce.

The redde Mufcadine is as great as the white, and chiefly differeth in colour.

The Burlet is a very great white Grape, but fitter for veriuice then wine for the moft part ; yet when a hot yeare happeneth fit for it, the Grape is pleafant.

The little blacke Grape that is ripe very early.

The Raifin of the Sunne Grape is a very great Grape, and very great clufters, of a reddifh colour when it is ripe with vs, yet in an extraordinarie hot yeare, it hath got a little blewneffe caft ouer by the heat: but naturally verie blew.

The Curran Grape (or the Grape of Corinth) is the leaft Grape of all, and beareth both few, and verie feldome with vs, but in reafonable great clufters, and of a blackifh blew colour, when they are ripe with vs, and very 
fweete. There is another fort of them that are red or browne, and of a fower tafte, nothing fo fweete.

The Greeke wine Grape is a blackifh Grape, and very fweete.

The Frontignack is a white Grape, of a verie fweete and delicate tafte, as the wine declareth, that fmelleth as it were of Muske.

The fquare Grape is reported to bear a Grape not fully round, but fided, or as it were fquare, whereby it became fo called.

The Damafco Grape is a great white grape, very fweete, and is the true Vva Zibeba, that the Apothecaries fhould vfe in the Trochifci Ciphi: and fuch wee haue had in former times come ouer vnto vs in great, long and round white boxes, containing halfe an hundred weight a peece.

The Ruffet Grape is a reafonable faire grape, exceeding fweet and whitifh, with a thicke skinne, crufted ouer with a thew of afh colour.

The white long Grape is like vnto a Pigeons egge, or as it were pointed pendent like a Pearle.

The partie-coloured Grape is a reafonable great Grape, and difcoloured when it is ripe, fometimes the whole bunches, and fometimes but fome of the grapes being parted whitifh, and blacke halfe through, verie variably.

The Rhenifh wine Grape is a white Grape, and endureth the cold of winter when it commeth earely, more then the Mufcadine before fet downe, and is nothing fo fweete.

The White wine Grape is verie like vnto the Rhine Grape, the foile only and climate adding more fweetneffe vnto the one then to the other.

The Claret wine Grape is altogether like the white Grape, but that it is not white, but of a reddifh colour, which lying bruifed vpon the skins before they are preffed, give that Claret tincture to the wine.

The Teint is a Grape of a deeper or darker colour, whofe iuice is of fo deepe a colour, that it ferueth to colour other wine.

The Burfarobe is a faire fweete white Grape of much efteeme about Paris.

The Alligant is a verie fweete Grape, giuing fo deep and liuely a coloured red wine, that no other whatfoeuer is comparable to it, and therefore vfually called Spaniards blood.

The blew or blacke Grape of Orleans is another blacke Grape, giuing a darke coloured fweete wine much commended in thofe parts.

The Grape without ftones is alio a kinde by it felfe, and groweth naturally neere Afcalon, as Brochard affirmeth, the wine whereof is redde, and of a good tafte.

The Virginia Vine, whereof I muft needes make mention among other Vines, beareth fmall Grapes without any great ftore of iuice therein, and the ftone within it bigger then in any other Grape: naturally it runneth on the ground, and beareth little.

The Vfe of Vines, Grapes, and other parts that come of them.

The greene leaues of the Vine are cooling and binding, and therefore good to put among other herbes that make gargles and lotions for fore mouthes.

And alfo to put into the broths and drinke of thofe that have hot burning feauers, or any other inflammation.

They ftay (as it is held for true) womens longings, if they be either taken inwardly, or applyed outwardly.

Wine is vfually taken both for drinke and medicine, and is often put into fawces, broths, cawdles, and gellies that are giuen to the ficke. As alfo into diuers Phyficall drinkes, to be as a vehiculum for the properties of the ingredients.

It is diftilled likewife after diuers manners, with diuers things, for diuers $\&$ fundry waters to drinke, \& for diuers purpofes both inward and outward. 


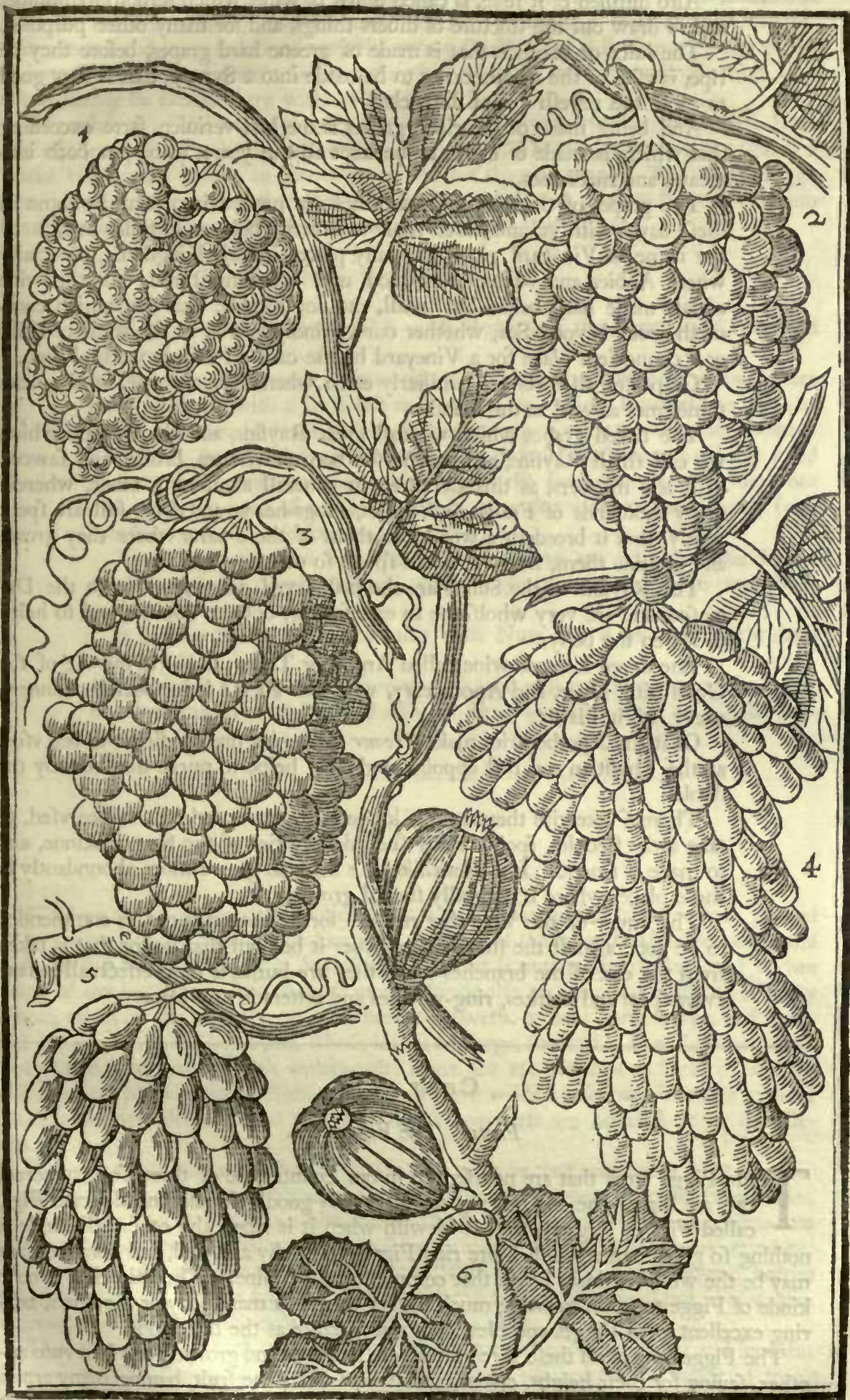

1. Vwa wigre minores. The fmall blackejGrape. 2 Vua earulea maiores. The great blew Grape. 3 Vwa Mofichatellina. The Mufadine Grape. + Vua Burletenfes. The Burlet Grape. 5 Vwa infolata. The Rayfins of the funne Grape.
Ficus. The Figge Tree. 
Alfo diftilled of it felfe, is called Spirit of wine, which ferueth to diffolue, and to draw out the tincture of diuers things, and for many other purpofes.

The iuice or veriuice that is made of greene hard grapes, before they be ripe, is vfed of the Apothecaries to be made into a Syrupe, that is very good to coole and refrefh a faint ftomacke.

And being made of the riper grapes is the beft veriuice, farre exceeding that which is made of crabs, to be kept all the yeare, to be put both into meates and medicines.

The grapes of the beft forts of Vines are preffed into wine by fome in thefe dayes with vs, and much more as I verily beleeue in times paft, as by the name of Vineyard giuen to many places in this Kingdome, efpecially where Abbies and Monafteries ftood, may bee coniectured: but the wine of late made hath beene but Imall, and not durable, like that which commeth from beyond Sea, whether our vnkindly yeares, or the want of skill, or a conuenient place for a Vineyard be the caufe, I cannot well tell you.

Grapes of all forts are familiarly eaten when they are ripe, of the ficke fometimes as well as the found.

The dryed grapes which we call great Rayfins, and the Currans which we call fmall Rayfins, are much vfed both for meates, broths, and fawces, in diuers manners, as this Countrey in generall aboue any other, wherein many thoufands of Frailes full, Pipes, Hogs-heads, and Buts full are fpent yearly, that it breedeth a wonder in them of thofe parts where they growe and prouide them, how we could fpend fo many.

The Rayfins of the Sunne are the beft dryed grapes, next vnto the $\mathrm{Da}$ mafco, and are very wholfome to eate fafting, both to nourifh, and to helpe to loofen the belly.

The dryed Lees of wine called Argoll or Tartar, is put to the vfe of the Goldfmith, Dyer, and Apothecary, who doe all vfe it in feuerall manners, euery one in his art.

Of it the Apothecaries make Cremor Tartari, a fine medicine to bee vfed, as the Phyfitian can beft appoint, and doth helpe to purge humours by the ftoole.

Thereof likewife they make a kinde of water or oyle, fit to bee vfed, to take away freckles, fpots, or any fuch deformities of the face or skinne, and to make it fmooth. It caufeth likewife haire to growe more aboundantly in thofe places where it naturally fhould growe.

The liquor of the Vine that runneth forth when it is cut, is commended to be good againft the ftone wherefoeuer it be; but that liquor that is taken from the end of the branches when they are burnt, is moft effectuall to take away fpots and markes, ring-wormes and tetters in any place.

\section{CнA P. VII.}

\section{Ficus. The Figge tree.}

$\mathrm{T}$ He Figge trees that are nourfed vp in our country are of three forts, whereof two are high; the one bearing againft a wall goodly fweete and delicate Figs, called Figs of Algarua, and is blewilh when it is ripe: the other tall kinde is nothing fo good, neither doth beare ripe Figges fo kindly and well, and peraduenture may be the white ordinary kinde that commeth from Spaine. The third is a dwarfe kinde of Figge tree, not growing much higher then to a mans body or fhoulders, bearing excellent good Figges and blew, but not fo large as the firft kinde.

The Figge trees of all thefe three kindes are in leaues and growing one like vnto another, fauing for their height, colour, and fweetneffe of the fruit, hauing many armes or branches, hollow or pithy in the middle, bearing very large leaues, and fomewhat thicke, diuided fometimes into three, but vfually into fiue feetions, of a darke greene cclour on the vpperfide, and whitifh vnderneath, yeelding a milkie iuyce when it is 
broken, as the branches alfo or the figges when they are greene: the fruit breaketh out from the branches without anie blofiome, contrary to all other trees of our Orchard, being round and long, fafhioned very like vnto a fmall Peare, full of fmall white grains or kernels within it, of a very fweete tafte when it is ripe, and very mellow or foft, that it can hardly be carried farre without bruifing.

The other two forts you may eafily know and vnderftand, by fo much as hath been faid of them. Take only this more of the Figge tree, That if you plant it not againft a bricke wall, or the wall of an houfe, \&cc. it will not ripen fo kindly. The dwarfe Figge tree is more tender, and is therefore planted in great fquare tubs, to be remoued into the funne in the Summer time, and into the houfe in Winter.

\section{The Vfe of Figges.}

Figges are ferued to the table with Rayfins of the Sunne, and blanched Almonds, for a Lenten dih.

The Figs that growe with vs when they are ripe, and frefh gathered, are eaten of diuers with a little falt and pepper, as a dainty banquet to entertaine a friend, which feldome paffeth without a cup of wine to wafh them downe.

In Italy (as I haue beene enformed by diuers Gentlemen that haue liued there to ftudy phyficke) they eate them in the fame manner, but dare not eate many for feare of a feuer to follow, they doe account them to be fuch breeders of bloud, and heaters of it likewife.

The Figges that are brought vs from Spaine, are vfed to make Ptifan drinkes, and diuers other things, that are giuen them that haue coughes or colds.

It is one of the ingredients alfo with Nuts and Rice, into Mithridates counterpoifon.

The fmall Figges that growe with vs, and will not ripen, are preferued by the Comfitmakers, and candid alfo, to ferue as other moift or candid banquetting ftuffe.

\section{Ch A P. VIII.}

Sorbus. The Seruice tree.

7 Here are two kindes of Seruice trees that are planted in Orchards with vs, and there is alfo a wilde kinde like vnto the later of them, with Afhen leaues, found in the woods growing of it felfe, whofe fruit is not gathered, nor vfed to bee eaten of any but birds. And there is another kinde alfo growing wilde abroad in many places, taken by the Country people where it groweth, to be a Seruice tree, and is called in Latine, Aria Theophrasit, whofe leaues are large, fomewhat like Nut tree leaues, but greene abouc, and grayinh vnderneath: fome doe vfe the fruit as Seruices, and for the fame purpofes to good effect, yet both of thefe wilde kindes wee leaue for another worke, and here declare vnto you onely thofe two forts are nourfed vp in our Orchards.

The more common or ordinary Seruice tree with vs, is a reafonable great trce, couered with a fmooth barke, fpread into many great armes, whereon are fet large leaues, very much cut in on the edges, almoft like vnto a Vine leafe, or rather like vnto that kinde of Maple, that is vfually called the Sycomore tree with vs: the flowers are white, and growe many cluftering together, which after bring forth fmall browne berries when they are ripe, of the bigneffe almoft of Hafell nuts, with a fmall tuft, as if it were a crowne on the head, wherein are fmall blacke kernels.

The other kinde, which is more rare with vs, and brought into this Land by Iohn Tradefcante, heretofore often remembred, hath diuers winged leaues, many fet together like vnto an Afhen leafe, but fmaller, and euery one endented about the edges: the flowers growe in long clufters, but nothing fo many, or fo clofe fet as the wilde kinde: the fruit of this tree is in fomc round like an Apple, and in others a little longer 
like a Peare, but of a more pleafant tafte then the ordinarie kinde, when they are ripe and mellowed, as they vfe to doe with both thefe kindes, and with Medlars.

The Vfe of Seruices.

They are gathered when they growe to be neare ripe (and that is neuer before they haue felt fome frofts) and being tyed together, are either hung $\mathrm{vp}$ in fome warme roome, to ripen them thoroughly, that they may bee eaten, or (as fome vfe to doe) lay them in ftrawe, chaffe, or branne, to ripen them.

They are binding, fit to be taken of them that have any fcouring or laske, to helpe to ftay the fluxe; but take heed, left if you binde too much, morè paine and danger may come thereof then of the fcouring.

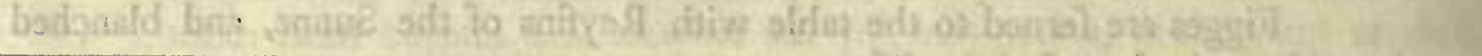

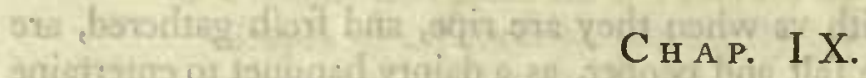

\section{Mefpilus. The Medlar tree.}

7 Here are three forts of Medlars: The greater and the leffer Englifh, and the Neapolitan.

The great and the Imall Englifh Medlar differ not one from the other in any thing, but in the fize of the fruit, except that the fmall kinde hath fome prickes or thornes vpon it, which the great one hath not, bearing diuers boughes or armes, from whence breake forth diuers branches, whereon are fet long and fomewhat narrow leaues, many ftanding together; in the middle whereof, at the end of the branch, commeth the flower, which is great and white, made of fiue leaues, broad at the ends, with a nicke in the middle of euery one; after which commeth the fruit, being round, and of a pale brownifh colour, bearing a crowne of thofe fmall leaues at the toppe, which were the huske of the flower before, the middle thereof being fomewhat hollow, and is harh, able to choake any that thall eate it before it be made mellow, wherein there are certaine flat and hard kernels.

The Medlar of Naples groweth likewife to bee a reafonable great tree, fpreading forth armes and branches, whereon are fet many gafhed leaues, fomewhat like vnto Hawthorne leaues, but greater, and likewife diuers thornes in many places: the flowers are of an herbie greene colour, and fmall, which turne into fmaller fruit then the former, and rounder alfo, but with a fmall head or crowne at the toppe like vnto it, and is of a more fweete and pleafant tafte then the other, with three feeds only therein ordinarily.

\section{The Vfe of Medlars.}

Medlars are vfed in the fame manner that Seruices are, that is, to be eaten when they are mellowed, and are for the fame purpofes to binde the body when there is a caufe: yet they as well as the Seruices, are often eaten by them that have no neede of binding, and but onely for the pleafant fweetneffe of them when they are made mellow, and fometimes come as a difh of ripe fruit at their fit feafon, to be ferued with other forts to the table.

\section{CHAP. X.}

\section{Lotus. The Lote or Nettle tree.}

T He firf kinde of Lote tree, whereof Diof corides maketh mention, is but of one kinde; but there are fome other trees fpoken of by Theophraftus, that may be referred thereunto, which may bee accounted as baftard kindes thereof, of which I meane to entreate in this Chapter, hauing giuen you before the defcription 


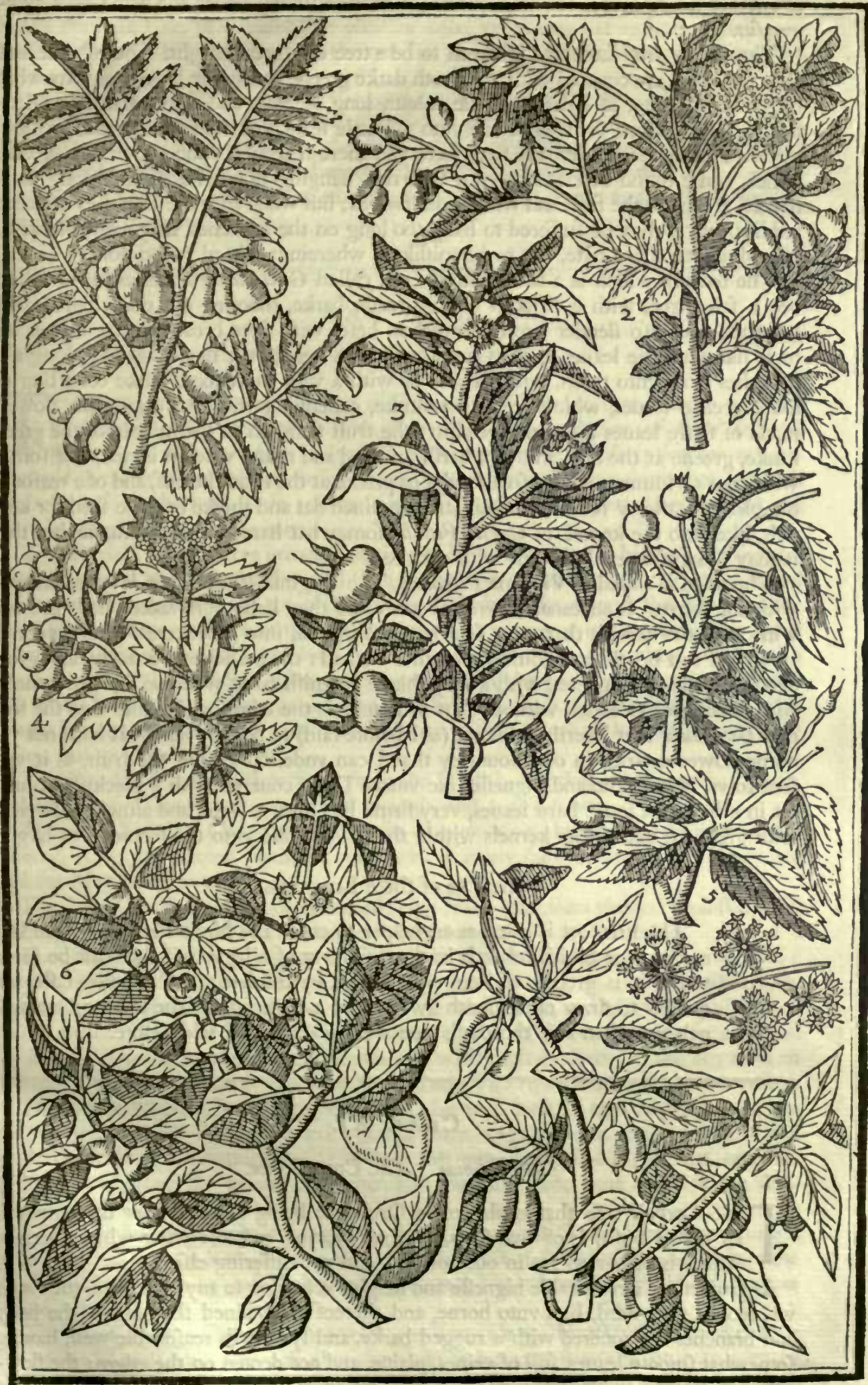

I Sorbus legitima. The true Seruice tree. 2 Sorbus vulgaris five Terminalis. The ordinary Seruice tree. 3 Mefpilus vulgaris. The common Medlar tree. 4 Mefpilus Aronia. The Medlar of Naples. 5 Lalus arbor. The Nettle tree. 6 Lolus Virginiana. The Pithamin or Virginia Plumme. 7 Cornus mas. The Cornell Cherry tree. 
of another kinde hereof (by the opinion of good Authors) vnder the name of Laurocerafus.

The firt or true Lote tree groweth to be a tree of a great height, whofe bodie and elder branches are couered with a fmooth darke greene barke, the leaues are fomewhat rough in handling, of a darke greene colour, long pointed, and fomewhat deepe dented about the edges, fomewhat like vnto a Nettle leafe, and oftentimes growe yellow toward Autumne: the flowers ftand here and there fcattered vpon the branches, after which come round berries like vnto Cherries, hanging downewards vpon long footftalkes, greene at the firft, and whitifh afterwards; but when they are ripe they become reddifh, and if they be fuffered to hang too long on the branches, they grow blackifh, of a pleafant auftere tafte, not to be milliked, wherein is a hard round ftone.

The fecond, which is a baftard kinde, and called Guaiacum Patauinum, groweth to bee a faire tree, with a fmooth darke greene barke, fhooting out many faire great boughes, and alfo flender greene branches, befet with faire broad greene leaues, almoft like vnto the leaues of the Cornell tree, but larger: the flowers growe along the branches clofe vnto them, without any or with a very fhort foote-ftalke confifting of foure greene leaues, which are as the huske, containing within it a purplifh flower, made of foure leaues fomewhat reddifh: the fruit ftandeth in the middle of the green huske, greene at the firft, and very harfh, but red and round when it is ripe, and fomewhat like a Plumme, with a fmall point or pricke at the head thereof, and of a reafonable pleafant tafte or rellifh, wherein are contained flat and thicke browne feeds or kernels, like vnto the kernels of Cafsia Fifula, fomewhat hard, and not fo ftonie, but that it may fomewhat eafily be cut with a knife.

The third is called in Virginia Pißbamin, The Virginia Plumme (if it be not all one with the former Guaiacana, whereof I am more then halfe perfwaded) hath growne with vs of the kernels that were fent out of Virginia, into great trees, whofe wood is very hard and brittle, and fomewhat white withall: the branches are many, and grow flender to the end, couered with a very thinne greenifh bark, whereon doe grow many faire broad greene leaues, without dent or notch on the edges, and fo like vnto the former Guaiacum, that I verily thinke it (as I before faid) to bee the fame. It hath not yet borne flower or fruit in our Countrey that I can vnderftand: but the fruit, as it was fent to vs, is in forme and bigneffe like vnto a Date, couered with a blackifh skinne, fet in a huske of foure hard leaues, very firme like vnto a Date, and almoft as fweete, with great flat and thicke kernels within them, very like vnto the former, but larger.

\section{The Vfe of thefe Lote trees.}

The firft fort is eaten as an helper to coole and binde the body : the laft, as Captaine Smith relateth in the difcouery of Virginia, if the fruit be eaten while it is greene, and not ripe, is able by the harfh and binding tafte and quality to draw ones mouth awry (euen as it is faid of the former Guaiacana) but when it is thorough ripe it is pleafant, as I faid before.

\section{C н A P. XI.}

\section{Cornus mas. The Cornell tree.}

$\mathrm{T}$ He Cornell tree that is planted in Orchards, being the male (for the female is an hedge burh) is of two forts, the one bearing red, the other whiter berries, which is very rare yet in our country, and not differing elfe.

It groweth to a reafonable bigneffe and height, yet neuer to any great tree, the wood whereof is very hard, like vnto horne, and thereof it obtained the name : the body and branches are couered with a rugged barke, and fpreadeth reafonable well, hauing fomewhat fmooth leaues, full of veines, plaine, and not dented on the edges: the flowers are many fmall yellow tufts, as it were of fhort haires or threads fet together, which come forth before any leafe, and fall away likewife before any leafe bee much open : the fruit are long and round berries, of the bigneffe of fmall Oliues, with an 
hard round Atone within them, like vnto an Oliue ftone, and are of a yellowifh red when they are ripe, of a reafonable pleafant tafte, yet fomewhat auftere withall.

The white (as I faid) is like vnto the red, but onely that his fruit is more white when it is ripe.

The Vfe of the Cornelles.

They helpe to binde the body, and to ftay laskes, and by reafon of the pleafantneffe in them when they are ripe, they are much defired.

They are alfo preferued and eaten, both for rarity and delight, and for the purpofe aforefaid.

\section{Си а P. XII.}

\section{Cerafus. The Cherry tree.}

$\mathrm{T}$

Here are fo many varieties and differences of Cherries, that I know not well how to expreffe them vnto you, without a large relation of their feuerall formes. I will therefore endeauour after one generall defcription (as my cuftome is in many other the like variable fruits) to giue as briefe and fhort notes vpon all the reft, as I can both for leafe and fruit, that fo you may the better know what the fruit is, when you haue the name.

The Englifl Cherrie tree groweth in time to be of a reafonable bigneffe and height, fpreading great armes, and alfo fmall twiggy branches plentifully; the leaues whereof are not verie large or long, but nicked or dented about the edges: the flowers come forth two or three or foure at the molt together, at a knot or ioynt, euerie one by it felfe, vpon his owne fmall and long footeftalke, confifting of fiue white leaues, with fome threds in the middle; after which come round berries, greene at the firft, and red when they are through ripe, of a meane bigneffe, and of a pleafant fweete tafte, fomewhat tart withall, with a hard white ftone within it, whofe kernell is fomewhat bitter, but not vnpleafant.

The Flanders Cherrie differeth not from the Englin, but that it is fomewhat larger, and the Cherry fomewhat greater and fweeter, and not fo fower.

The early Flanders Cherry is more rathe or early ripe, almoft as foone as the May Cherry, efpecially planted againt a wall, and of many falfe knaues or Gardiners are fold for May Cherrie trees.'

The May Cherrie in a ftandard beareth ripe fruite later then planted againft a wall, where the berries will be red in the verie beginning of May fometimes.

The Arch-Dukes Cherrie is one of the faireft and beft cherries wee haue, being of a very red colour when it is ripe, and a little long more then round, and fomewhat pointed at the end, of the beft rellifh of any Cherrie whatfoeuer, and of a firme fubftance; fcarce one of twentie of our Nurferie men doe fell the right, but giue one for another: for it is an inherent qualitie almoft hereditarie with moft of them, to fell any man an ordinary fruit for whatfoeuer rare fruit he fhall aske for: fo little they are to be trufted.

The ounce Cherrie hath the greateft and broadeft leafe of any other cherrie, but beareth the fmalleft ftore of cherries euerie yeare that any doth, and yet bloffometh well: the fruit alfo is nothing anfwerable to the name being not verie great, of a pale yellowith red, neere the colour of Amber, and therefore fome haue called it, the Amber Cherrie.

The great leafed Cherrie is thought of diuers to bee the Ounce Cherrie, becaufe it hath almoft as great a leafe as the former : but the fruit of this alfo doth not anfwer the expectation of fo great a leafe, being but of a meane bigneffe, and a fmall bearer, yet of a pale reddifh colour.

The true Gafcoign Cherry is known but to a few; for our Nurfery men do fo change the names of moft fruits they fell, that they deliuer but very few true names to any: In former times before our wilde blacke Cherrie was found to grow plentifully in our owne woods in many places of this Land, the French continually ftored vs with wilde ftockes to graft vpon, which then were called Gafcoigne ftocks, but fince they haue fo

termed 
termed another red Cherrie, and obtruded it vpon their cuftomers : but the true is one of our late ripe white Cherries, euen as Gerard faith, it is a great cherrie and fpotted: and this is that Cherrie I fo commend to be a fit ftocke to graft May cherries vpon.

The Morello Cherrie is of a reafonable bigneffe, of a darke red colour when they are full ripe, and hang long on, of a fweetifh fower tafte, the pulpe or fubftance is red, and fomewhat firme: if they be dryed they will have a fine harpe or fower tafte very delectable.

The Hartlippe Cherrie is fo called of the place where the beft of this kinde is nourfed vp, being betweene Sittingbourne and Chattam in Kent, and is the biggeft of our Englifh kindes.

The fmaller Lacure or Hart Cherrie is a reafonable faire Cherrie, full aboue, and a little pointing downward, after the farhion of an heart, as it is vfually painted, blackifh when it is full ripe, and leffer then the next.

The great Lacure or Hart Cherrie differeth not in forme, but in greatneffe, being vfually twice as great as the former, and of a reddifh blacke colour alfo: both of them are of a firme fubftance, and reafonable fweete. Some doe call the white cherrie, the White hart cherrie.

The Luke Wardes Cherrie hath a reafonable large leafe, and a larger flower then many other: the cherries grow with long ftalkes, and a ftone of a meane fize within them, of a darke reddifh colour when they are full ripe, of a reafonable good rellifh, and beareth well.

The Corone Cherrie hath a leafe little differing from the Luke Wardes cherrie; the fruit when it is ripe, is of a faire deepe red colour, of a good bigneffe, and of a verie good tafte, neither verie fweete or fower: the pulpe or iuice will ftaine the hands.

The Vrinall Cherrie in a moft fruitfull yeare is a fmall bearer, hauing many yeares none, and the beft but a few; yet doth bloffome plentifully euery yeare for the moft part: the cherrie is long and round, like vnto an Vrinall, from whence it tooke his name; reddifh when it is full ripe, and of an indifferent fweete rellifh.

The Agriot Cherrie is but a fmall Cherrie, of a deepe redde colour when it is ripe, which is late; of a fine tharpe tafte, moft pleafant and wholfome to the ftomacke of all other cherries, as well while they are frefh as being dryed, which manner they much vfe in France, and keepe them for the vfe both of the ficke and found at all times.

The Biguarre Cherrie is a fair cherrie, much fpotted with white fpots vpon the pale red berry, and fometimes difcoloured halfe white and halfe reddifh, of a reafonable good rellifh.

The Morocco Cherrie hath a large white bloflome, and an indifferent big berrie, long and round, with a long ftalke of a darke reddifh purple colour, a little tending to a blew when it is full ripe, of a firme fubftance: the iuice is of a blackilh red, difcolouring the hands or lips, and of a pleafant tafte: Some doe thinke that this and the Morello be both one.

The Naples Cherrie is alfo thought to bee all one with the Morello or Morocco.

The white Spanifh Cherrie is an indifferent good bearer, the leafe and bloffome fomewhat large, and like the Luke Wardes cherrie: the cherries are reafonable faire berries, with long ftalkes and great ftones, white on the outfide, with fome redneffe, on the one fide of a firme fubftance, and reafonable fweet, but with a little aciditie, and is one of the late ripe ones: But there is another late ripe white Cherry, which fome call the Gafcoigne, before remembred.

The Flanders clufter Cherrie is of two forts, one greater then another: the greater kinde hath an indifferent large leafe; the bloffomes haue many threds within them, thewing as it were many parts, which after turne into clufters of berries, foure, fiue or fixe together, and but with one ftalke vnder them, as if they grew one out of another, and fometimes they will beare but two or three, and moft of them but one cherry on a Italke, which are red when they are ripe, very tender, and waterifh fweete in eating.

The leffer is in all things like the greater, but fmaller, which maketh the difference.

The wilde clufter or birds clufter Cherry beareth many bloffomes fet all along the ftalkes, and cherries after them in the fame maner, like a long thinne bunch of grapes, and therefore called of fome the Grape cherry: there are of them both red and
blacke. 


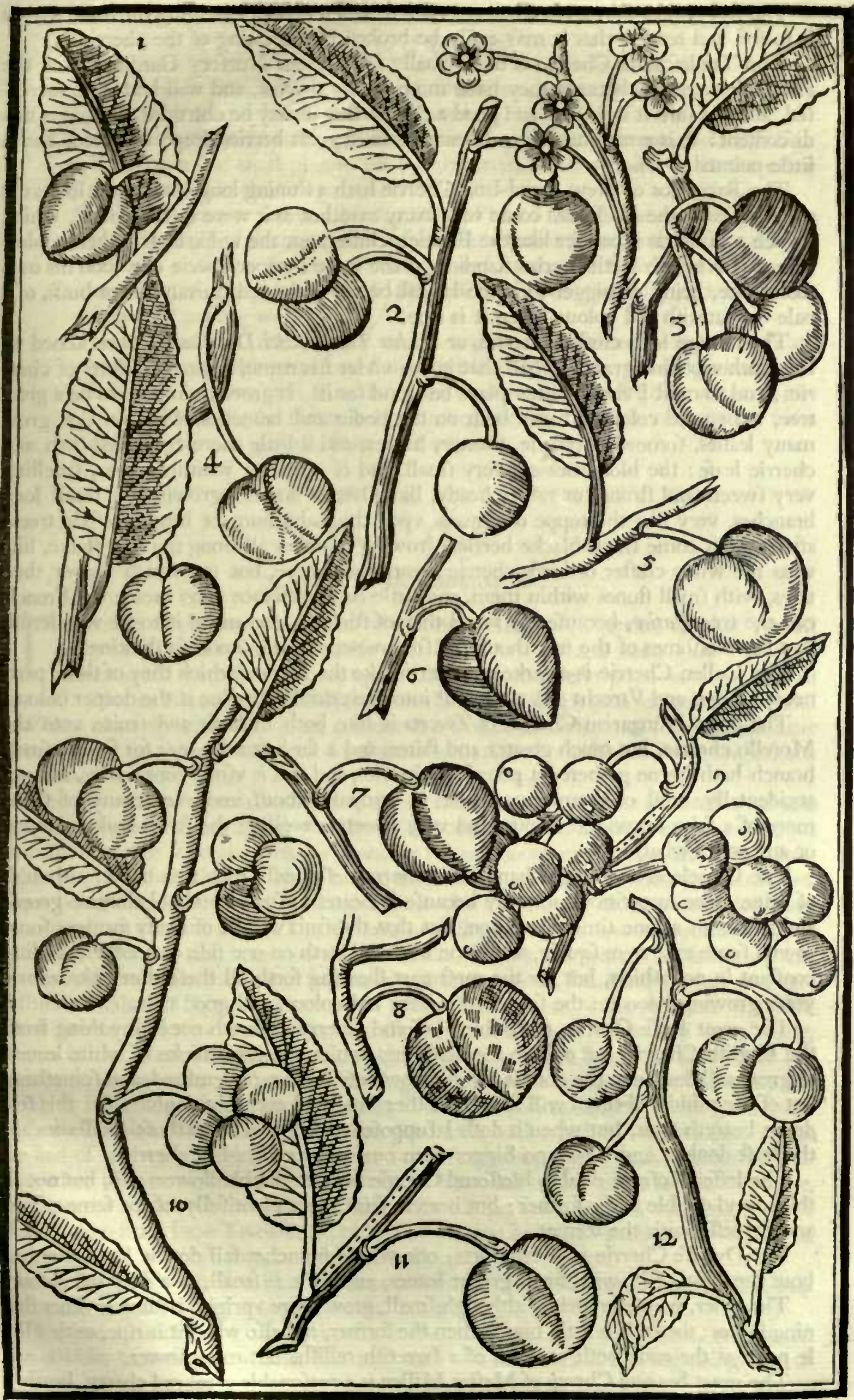

I Cerafus pracox. The May Chersy. 2 Cerafus Batauica. The Flanders Cherry. 3 Cerafus Hifpanica fiue alba. The white Cherry. 4 Cerafus platophyllos. The great leafed Cherry. 5 Cerafus Luca Wardi. Louke Wards Cherry. 6 Cerajus Neapolitana. The Naples Cherry. 7 Cerafus Cordala. The Heart Cherry. 8 Cerafus maculata. The bicnarre or fpotted Cherry. 9 Cerafus auium racemofa. The wilde clufter Cherry. Io Cerafus Carymbifera. The Flanders clufter Cherry. It Cerafus Arehiducis. The Arehdukes Cherry, 12 Chamacrafus. The dwarfe Cherry. 
The foft theld Cherrie is a fmall red cherrie when it is ripe, hauing the ftone within it fo foft and tender, that it may eafily be broken in the eating of the cherrie.

Iohn Tradefcantes Cherrie is moft vfually fold by our Nurfery Gardiners, for the Archdukes cherrie, becaufe they haue more plenty thereof, and will better be increafed, and becaufe it is fo faire and good a cherrie that it may be obtruded without much difcontent: it is a reafonable good bearer, a faire great berrie, deepe coloured, and a little pointed.

The Baccalaos or New-found-land Cherrie hath a fhining long leafe, moft like vnto a Peach leafe, the bloffomes come very many together as it were in an vmbell, which is fuch a clufter as is neither like the Flanders clufter, nor the wilde clufter cherrie bloffome: it bringeth forth berries ftanding in the fame manner euerie one vpon his own footeftalke, being no bigger then the largeft berrie of the red Curran tree or bufh, of a pale or waterifh red colour when it is ripe.

The ftrange long clufter Cherrie, or Padus Theophrasti Dalechampio is reckoned by the Author of that great Herball that goeth vnder his name, among the forts of cherries; and fo muft I vntill a fitter place be found for it. It groweth in time to be a great tree, with a fad coloured barke both on the bodie and branches, whereon doe grow many leaues, fomewhat broade, fhorter, harder, and a little more crumpled then any cherrie leafe: the bloffomes are very fmall, and of a pale or whitifh colour, fmelling very fweete and ftrong, or rather heady, like Orenge flowers, growing on fmall long branches, very like the toppe of flowers vpon the Laburnum or Beane trefoile trees: after which come fmall blacke berries, growing together all along the long ftalke, like vnto the wilde clufter or birds cherrie mentioned before, but not much bigger then tares, with fmall ftones within them, and little or no fuftance vpon them: the French call the tree Putier, becaufe the wood thereof ftinketh, and make it to be wonderfull that the bloffomes of the tree fhould be fo fweete, and the wood fo ftinking.

The Cullen Cherrie is a darke red cherrie like the Agriot, which they of thofe parts neere Cullen and Vtrecht \&c. vfe to put into their drinke, to giue it the deeper colour.

The great Hungarian Cherrie of Zwerts is like both in leafe and fruite vnto the Morello cherrie, but much greater and fairer, and a far better bearer : for from a fmall branch hath beene gathered a pound of cherries, and this is vfuall continually, and not accidentally, moft of them foure inches in compaffe about, and very many of them more of a faire deepe red colour, and very fweete, excelling the Arch-Dukes cherry, or any other whatfoeuer.

The Cameleon or ftrange changeable Cherry deferuedly hath this name, although of mine owne impofition, not only becaufe it beareth vfually both bloffomes, greene and ripe fruit at one time thereupon, but that the fruit will be of many formes; fome round, fome as it were fquare, and fome bunched forth on one fide or another, abiding conftant in no fafhion, but for the moft part thewing forth all thefe diuerfities euerie yeare growing vpon it: the fruit is of a very red colour, and good tafte.

The great Rofe Cherry, or double bloffomd Cherry differeth not in any thing from the Englifh Cherrie, but only in the bloffomes, which are very thicke of white leaues, as great and double as the double white Crowfoote, before remembred, and fometimes out of the middle of them will fpring another fmaller flower, but double alfo; this feldome beareth fruit, but when it doth I fuppofe it commeth from thofe bloffomes are the leaft double, and is red, no bigger then our ordinary Englifh cherrie.

The leffer Rofe or double bloffomd Cherrie beareth double flowers alfo, but not fo thicke and double as the former; but beareth fruit more plentifully, of the fame colour and bigneffe with the former.

The Dwarfe Cherrie is of two forts; one whofe branches fall downe low, round about the body of it, with fmall greene leaues, and fruit as fmall, of a deep red colour.

The other, whofe branches, although fmall, grow more vpright, hauing greener thining leaues: the fruit is little bigger then the former, red alfo when it is ripe, with a litle point at the end : both of them of a fweetifh rellifh, but more fower.

The great bearing Cherry of Mafter Millen is a reafonable great red cherry, bearing very plentifully, although it bee planted againft a North wall, yet it will bee late ripe, but of an indifferent fweet and good rellifh.

The long finger Cherry is another fmall long red one, being long \& round like a finger, wherof it took the name : this is not the Vrinall cherry before, but differing from it. 
The Vfe of Cherries.

All thefe forts of Cherries ferue wholly to pleafe the palate, and are eaten at all times, both before and after ineales.

All Cherries are cold, yet the fower more then the fweete; and although the fiveete doe molt pleafe, yet the fower are more wholfome, if there bee regard taken in the vfing.

The Agriot or fower Cherries are in France much vfed to bee dryed (as is faid before) as Pruines are, and fo ferue to be miniftred to the fick in all hot difeafes, as feuers Eec. being both boyled in their drinkes, and taken now and then of themfelues, which by reafon of their tartneffe, doe pleafe the ftomacke paffing well.

The Gum of the Cherrie tree is commended to bee good for thofe are troubled with the grauell or ftone. It is allo good for the cough being diffolued in liquour, and ftirreth vp an appetite. The diftilled water of the blacke Cherries, the ftones being broken among them, is vfed for the fame purpofe, for the grauell, ftone, and winde.

\section{I A P. X I I I.}

\section{Prunus. The Plumme tree.}

$T$ Here are many more varieties of Plummes then of Cherries, fo that I muft follow the fame order with thefe that I did with them, euen giue you their names apart, with briefe notes vpon them, and one defcription to ferue for all the reft. And in this recitall I thall leaue out the Apricockes which are certainly a kind of Plum, of an efpeciall difference, and not of a Peach, as Galen and forne others haue thought, and fet them in a chapter by themfelues, and only in this fet down thofe fruits are vfually called Plums.

The Plum tree (efpecially diuers of them) rifeth in time to bee a reafonable tall and great tree, whofe bodie and greater armes are couered with a more rugged barke, yet in fome more or leffe, the younger branches being fmooth in all, the leaues are fomewhat rounder then thofe of the Cherrie tree, and much differing among themfelues, fome being longer, or larger, or rounder then others, and many that are exercifed herein, can tell by the leafe what Plum the tree beareth (I fpeake this of many, not of all) as in many Cherries they can doe the like: the flowers are white, confifting of fiue leaues: the fruit is as variable in forme, as in tafte or colour, fome being ovall or Peare fafhion or Almond like, or fphericall or round, fome firme, fome foft and waterifh, fome fweete, fome fower or harfh, or differing from all thefe taftes: and fome white, others blacke, fome red, others yellow, fome purple, others blew, as they fhall bee briefly fet downe vnto you in the following lines, where I meane not to infert any the wilde or hedge fruit, but thofe only are fit for an Orchard, to be ftored with good fruit : and of all which forts, the choyfert for goodneffe, and rareft for knowledge, are to be had of my very good friend Mafter Iohn Tradefcante, who hath wonderfully laboured to obtaine all the rareft fruits hee can heare off in any place of Chriftendome, Turky, yea or the whole world; as alfo with Mafter Iohn Millen, dwelling in Olde freete, who from Iohn Tradefcante and all others that haue had good fruit, hath ftored himfelfe with the beft only, and he can fufficiently furnith any.

The Amber Primordian Plumme is an indifferent faire Plumnse, early ripe, of a pale yellowifh colour, and of a waterifh tafte, not pleafing.

The red Primordian Plumme is of a reafonable fize, long and round, reddifh on the outfide, of a more dry tafte, and ripe with the firft forts in the beginning of Auguft.

The blew Primordian is a fmall plumme, almoft like the Damafcene, and is fubiect to drop off from the tree before it be ripe.

The white Date Plum is no very good plum. 
The red Date plumme is a great long red pointed plumme, and late ripe, little better then the white.

The blacke Muffell plumme is a good plumme, reafonable drye, and tafteth well.

The red Muffell Plumme is fomewhat flat as well as round, of a very good tafte, and is ripe about the middle of Auguft.

The white Muffell plumme is like the redde, but fomewhat fmaller, and of a whitifh greene colour, but not fo well tafted.

The Imperiall plum is a great long reddih plum, very waterifh, and ripeneth fomewhat late.

The Gaunt plum is a great round reddifh plum, ripe fomewhat late, and eateth waterifh.

The red Pefcod plum is a reafonable good plum.

The white Pefcod plum is a reafonable good rellifhed plumme, but fomewhat waterifh.

The greene Pefcod plum is a reafonable big and long pointed plum, and ripe in the beginning of September.

The Orenge plum is a yellowifh plum, moift, and fomewhat fweetifh.

The Morocco plumme is blacke like a Damfon, well tafted, and fomewhat drye in eating.

The Dine plum is a late ripe plum, great and whitifh, fpeckled all ouer.

The Turkie plum is a large long blackifh plum, and fomewhat flat like the Muffell plum, a well rellifhed dry plum.

The Nutmeg plumme is no bigger then a Damfon, and is of a greenifh yellow colour when it is ripe, which is with vs about Bartholmew tide, and is a good plum.

The Perdigon plumme is a dainty good plumme, early blackin, and well rellifhed.

The Verdoch plum is a great fine greene fhining plum fit to preferue.

The Ienua plum is the white Date plum, before remembred.

The Barberry plum is a great early blacke plum, and well tafted.

The Pruneola plum is a fmall white plum, of a fine tart tafte: it was wont to bee vfually brought ouer in fmall round boxes, and fold moft commonly at the Comfitmakers, (cut in twaine, the ftone caft away) at a very deere rate: the tree groweth and beareth well with vs.

The Shepway Bulleis is of a darke blewifh brown colour, of a larger fize then the ordinary, and of a tharpe tafte, but not fo good as the common.

The white and the blacke Bulleis are common in moft Countries, being fmall round plums, leffer then Damfons, tharper in tafte, and later ripe.

The Flufhing Bulleis groweth with his fruite thicke cluftring together like grapes.

The Winter Creke is the latert ripe plum of all forts, it groweth plentifully about Bifhops Hatfield.

The white Peare plum early ripe, is of a pale yellowifh greene colour.

The late ripe white Peare plum is a greater and longer plum, greenifh white, and is not ripe vntill it be neere the end of September, both waterih plums.

The blacke Peare plum is like vnto the white Peare plumme, but that the colour is blackifh when it is ripe, and is of a very good rellifh, more firme and drye then the other. three.

The red Peare plumme is of the fame fafhion and goodneffe, but is the wort of the

The white Wheate plum is a waterifh fulfome plum.

The red. Wheate plum is like the other for tafte.

The Bowle plum is flat and round, yet flatter on the one fide then on the other, which caufed the name, and is a very good rellifhed blacke plum.

The Friars plumme is a very good plum, well tafted, and comming cleane from the Atone, being blacke when it is ripe, and fome whitifh fpots vpon it.

The Catalonia plum is a very good plum.

The Don Alteza is allo a very good plum.

The Mufcadine pluin, fome call the Queene mother plumme, and fome the Cherry plum, is a faire red plum, of a reafonable bigneffe, and ripe about Bartholmew tide.

The Chriftian plum, called alfo the Nutmeg plum; the tree groweth very fhrubby, 


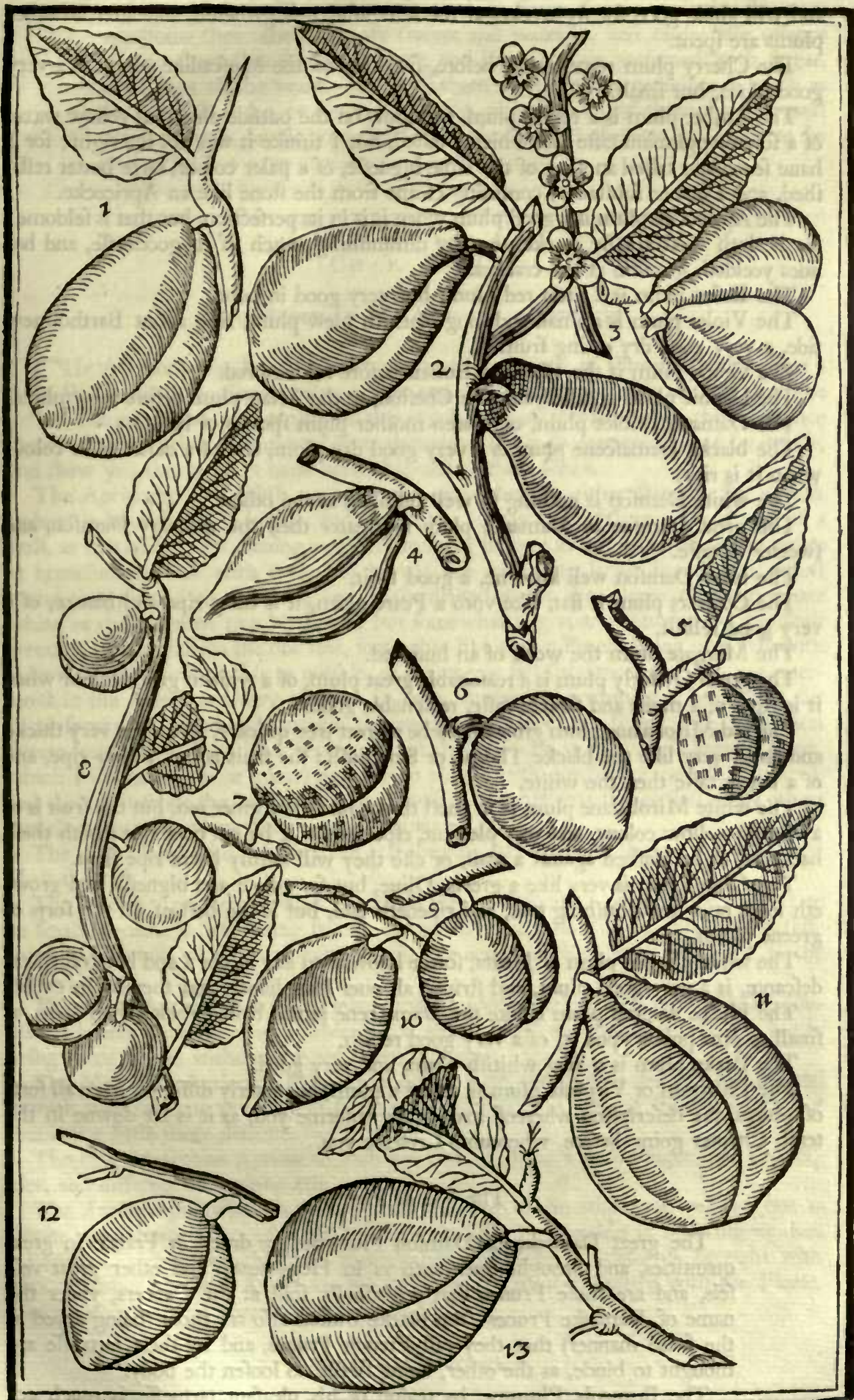

2 Prunum Imperiale. The Imperiall Plum. 2 Prwnum Turcicum. The Turkey Plum. 3 Prunum pracox rubrum. The red Primordian Plum. 4 Prurum Mrelllinum. The Muftell Plum. 5 Prunum Ambarikum. The Amber Plum. 6 Prunum Regincum The Queen gincum. Trum Myriflicum. The Nutmeg Plum. Io Prwnsm Siliquof sm. The Pefcod Plum. II Prunum Gandauenfe. The Gaunt Plum. 22 Prumum Dafylites. The Date Plum. 13 Prunum Pyrinum pracox. The early Peare Plum. 
and will abide good for fix weekes at the leaft after it is gathered, and after all other plums are fpent.

The Cherry plum remembred before, fpeaking of the Mufcadine plum, is a very good plum, but fmall.

The Amber plum is a round plum, as yellow on the outfide almoft as yellow waxe, of a fowre vnpleafant tafte that which I tafted, but I thinke it was not the right; for I have feene and tafted another of the fame bigneffe, of a paler colour, farre better rellithed, and a firmer fubftance, comming cleane from the ftone like an Apricocke.

The Apricocke plum is a good plum when it is in its perfection, but that is feldome; for it doth moft vfually cracke, thereby diminifhing much of its goodneffe, and befides yeeldeth gumme at the crackes.

The Eafon plum is a little red plum, but very good in tafte.

The Violet plum is a fmall and long blackifh blew plum, ripe about Bartholmew tide, a very good dry eating fruit.

The Grape plum is the Flufhing Bulleis before remembred.

The Dennie plum is called alfo the Cherton, or the Friars plum before remembred.

The Damaske Violet plum, or Queen mother plum fpoken of before.

The blacke Damafcene plum is a very good dry plum, and of a darke blew colour when it is ripe.

The white Damfon is nothing fo well rellifhed as the other.

The great Damfon or Damaske plum is greater then the ordinary Damfon, and fweeter in tafte.

The blew Damfon well knowne, a good fruit.

The Coferers plum is flat, like vnto a Peare plum, it is early ripe and blacke, of a very good rellifh.

The Margate plum the worft of an hundred.

The green Oyfterly plum is a reafonable great plum, of a whitifh green colour when it is ripe, of a moift and fweete tafte, reafonable good.

The red Mirobalane plum groweth to be a great tree quickly, ppreading very thicke and farre, very like the blacke Thorne or Sloe bufh: the fruit is red, earlier ripe, and of a better tafte then the white.

The white Mirobalane plum is in moft things like the former red, but the fruit is of a whitifh yellow colour, and very pleafant, efpecially if it be not ouer ripe: both thefe had need to be plafhed againft a wall, or elfe they will hardly beare ripe fruit.

The Oliue plum is very like a greene Oliue, but for colour and bigneffe, and groweth lowe on a fmall bufhing tree, and ripeneth late, but is the beft of all the forts of greene plums.

The white diapred plum of Malta, fcarce knowne to any in our Land but Iohn Tradefcante, is a very good plum, and ftriped all ouer like diaper, and thereby fo called.

The blacke diapred plum is like the Damafcene plum, being blacke with fpots, as fmall as pins points vpon it, of a very good rellifh.

The Peake plum is a long whitifh plum, and very good.

The Pifhamin or Virginia plum is called a plum, but vtterly differeth from all forts of plums, the defcription whereof may truely enforme you, as it is fet downe in the tenth Chapter going before, whereunto I referre you.

\section{The Vfe of Plums.}

The great Damaske or Damfon Plummes are dryed in France in great quantities, and brought ouer vnto vs in Hogs-heads, and other great veffels, and are thofe Prunes that are vfually fold at the Grocers, vnder the name of Damaske Prunes: the blacke Bulleis alfo are thofe (being dryed in the fame manner) that they call French Prunes, and by their tartneffe are thought to binde, as the other, being fweet, to loofen the body.

The Bruneola Plumme, by reafon of his pleafant tartneffe, is much accounted of, and being dryed, the ftones taken from them, are brought ouer to vs in fmall boxes, and fold deere at the Comfitmakers, where they very often accompany all forts of banquetting ftuffes. 
Some of thefe Plums, becaufe of their firmneffe, are vndoubtedly more wholfome then others that are fweete and waterilh, and caufe leffe offence in their ftomackes that eate them; and therefore are preferued with Sugar, to be kept all the yeare. None of them all is vfed in medicines fo much as the great Damfon or Damaske Prune, although all of them for the moft part doe coole, lenifie, and draw forth choller, and thereby are fitteft to be vfed of fuch as haue chollericke Agues.

\section{Cи A P. X I I I I.}

\section{Mala Armeniaca fue Pracocia. Apricockes.}

$\mathrm{T}$ He Apricocke (as I faid) is without queftion a kinde of Plumme, rather then a Peach, both the flower being white, and the ftone of the fruit fmooth alfo, like a Plumme, and yet becaufe of the excellencie of the fruit, and the difference therein from all other Plummes, I have thought it meete to entreate thereof by it felfe, and thew you the varieties haue been obferued in thefe times.

The Apricocke tree rifeth vp to a very great height, either ftanding by it felfe (where it beareth not fo kindly, and very little in our country) or planted againft a wall, as it is moft vfuall, hauing a great ftemme or body, and likewife many great armes or branches, couered with a fmooth barke: the leaues are large, broad, and almoft round, but pointed at the ends, and finely dented about the edges: the flowers are white, as the Plumme tree bloffomes, but fomewhat larger, and rounder fet: the fruit is round, with a cleft on the one fide, fomewhat like vnto a Peach, being of a yellowifh colour as well on the infide as outfide, of a firme or faft fubftance, and dry, not ouermoift in the eating, and very pleafant in tafte, containing within it a broad and flat ftone, fomewhat round and fmooth, not rugged as the Peach ftone, with a pleafant fweete kernell (yet fome haue reported, that there is fuch as haue their kernels bitter, which I did neuer fee or know) and is ripe almoft with our firft or earlieft Plummes, and thereof it tooke the name of Precox; and it may bee was the earlieft of all others was then knowne, when that name was given.

The great Apricocke, which fome call the long Apricocke, is the greateft and faireft of all the reft.

The fmaller Apricocke, which fome call the fmall round Apricocke, is thought to be fmall, becaufe it firt fprang from a ftone: but that is not fo; for the kinde it felfe being inoculated, will bee alwaies fmall, and neuer halfe fo faire and great as the former.

The white Apricocke hath his leaues more folded together, as if it were halfe double: it beareth but feldome, and very few, which differ not from the ordinary, but in being more white, without any red when it is ripe.

The Mafcoline Apricocke hath a finer greene leafe, and thinner then the former, and beareth very feldome any ftore of fruit, which differeth in nothing from the firft, but that it is a little more delicate.

The long Mafcoline Apricocke hath his fruit growing a little longer then the former, and differeth in nothing elfe.

The Argier Apricocke is a maller fruit then any of the other, and yellow, but as fweete and delicate as any of them, hauing a blackilh ftone within it, little bigger then a Lacure Cherry ftone: this with many other forts Iohn Tradefcante brought with him returning from the Argier voyage, whither hee went voluntary with the Fleete, that went againft the Pyrates in the yeare 1620.

\section{The Vfe of Apricockes.}

Apricockes are eaten oftentimes in the fame manner that other dainty Plummes are, betweene meales of themfelues, or among other fruit at banquets. 
They are alfo preferued and candid, as it pleafeth Gentlewomen to befowe their time and charge, or the Comfitmaker to fort among other candid fruits.

Some likewife dry them, like vnto Peares, Apples, Damfons, and other Plummes.

Matthiolus doth wonderfully commend the oyle drawne from the kernels of the ftones, to annoint the inflamed hamorrhoides or piles, the fwellings of vlcers, the roughneffe of the tongue and throate, and likewife the paines of the eares.

\section{Cн а Р. X V.}

Mala Perfica. Peaches.

A S I ordered the Cherries and Plummes, fo I intend to deale with Peaches, becaufe their varieties are many, and more knowne in thefe dayes then in former times: but becaufe the Nectorin is a differing kinde of Peach, I muft deale with it as I did with the Apricocke among the Plummes, that is, place it in a Chapter by it felfe.

The Peach tree of it felfe groweth not vfually altogether fo great, or high as the Apricocke, becaufe it is leffe durable, but yet fpreadeth with faire great branches, from whence fpring fmaller and Alenderer reddifh twigges, whereon are fet long narrow greene leaues, dented about the edges: the bloffomes are greater then of any Plumme, of a deepe blufh or light purple colour : after which commeth the fruit, which is round, and fometimes as great as a reafonable Apple or Pippin (I fpeake of fome forts; for there be fome kindes that are much fmaller) with a furrow or cleft on the one fide, and couered with a freefe or cotton on the outfide, of colour either ruffet, or red, or yellow, or of a blackifh red colour; of differing fubftances and taftes alfo, fome being firme, others waterifh, fome cleauing faft to the ftone on the infide, others parting from it more or leffe eafily, one excelling another very farre, wherein is contained a rugged ftone, with many chinkes or clefts in it, the kernell whereof is bitter : the roots growe neither deepe nor farre; and therefore are fubiect to the winds, ftanding alone, and not againft a wall. It fooner waxeth old and decayeth, being fprung of a ftone, then being inoculated on a Plumme ftocke, whereby it is more durable.

The great white Peach is white on the outfide as the meate is alfo, and is a good well rellifhed fruit.

The fmall white Peach is all one with the greater, but differeth in fize.

The Carnation Peach is of three forts, two are round, and the third long; they are all of a whitifh colour, fhadowed ouer with red, and more red on the fide is next the funne : the leffer round is the more common, and the later ripe.

The grand Carnation Peach is like the former round Peach, but greater, and is as late ripe, that is, in the beginning of September.

The red Peach is an exceeding well rellifhed fruit.

The ruffet Peach is one of the moft ordinary Peaches in the Kingdome, being of a ruffet colour on the outfide, and but of a reafonable rellifh, farre meaner then many other.

The Ifland Peach is a faire Peach, and of a very good rellifh.

The Newington Peach is a very good Peach, and of an excellent good rellifh, being of a whitifh greene colour on the outfide, yet halfe reddifh, and is ripe about Bartholmew tide.

The yellow Peach is of a deepe yellow colour; there be hereof diuers forts, fome good and fome bad.

The St. Iames Peach is the fame with the Queenes Peach, here belowe fet downe, although fome would make them differing.

The Melocotone Peach is a yellow faire Peach, but differing from the former yellow both in forme and tafte, in that this hath a fmall crooked end or point for the moft part, it is ripe before them, and better rellifhed then any of them. 


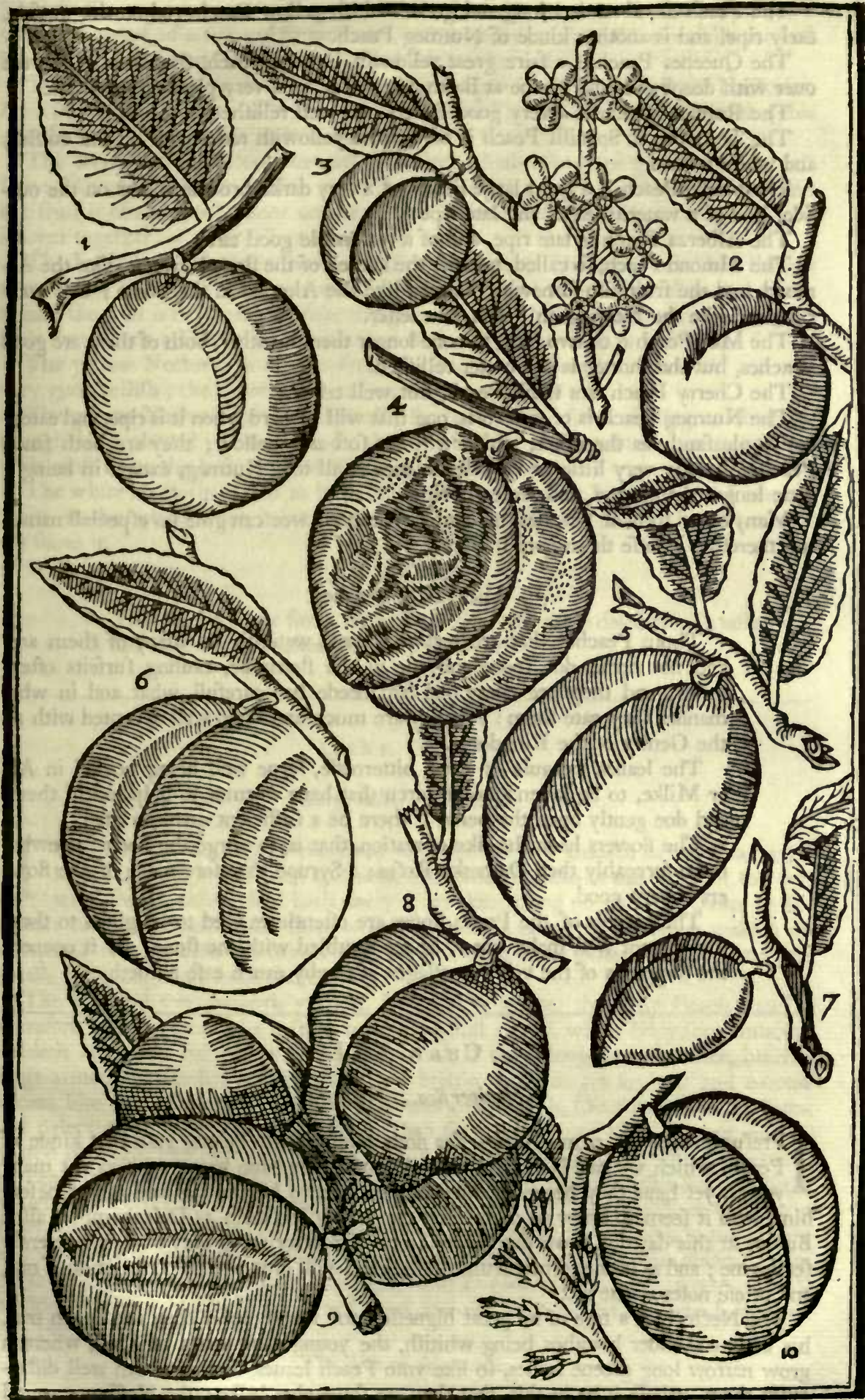

I Malus Amexiaca fixe Pracocia. The Apricocke. 2 Malus Perfica Melocolonea. The Melocotone Peach. 3 Perfica Mofchatellira. The Nutmeg Peach. 4 Porfica nigra. The blacke Peach. 5 Perfica Carnca longa. The long Carnation Peach. 6 Perfica Regixea. The Queenes Peach. 7 Amygdalus. The Almond. 8 Perfica du Troas. The Peach du Troas. 9 ing blofiome. 
The Peach $d u$ Troas is a long and great whitifh yellow Peach, red on the outfide, early ripe, and is another kinde of Nutmeg Peach.

The Queenes Peach is a faire great yellowifh browne Peach, fhadowed as it were ouer with deepe red, and is ripe at Bartholmew tide, of a very pleafant good tafte.

The Romane Peach is a very good Peach, and well rellifhed.

The Durafme or Spanith Peach is of a darke yellowifh red colour on the outfide, and white within.

The blacke Peach is a great large Peach, of a very darke browne colour on the outfide, it is of a waterifh tafte, and late ripe.

The Alberza Peach is late ripe, and of a reafonable good tafte.

The Almond Peach, fo called, becaufe the kernell of the ftone is fweete, like the Almond, and the fruit alfo fomewhat pointed like the Almond in the huske; it is early ripe, and like the Newington Peach, but leffer.

The Man Peach is of two forts, the one longer then the other, both of them are good Peaches, but the fhorter is the better rellifhed.

The Cherry Peach is a fmall Peach, but well tafted.

The Nutmeg Peach is of two forts, one that will be hard when it is ripe, and eateth not fo pleafantly as the other, which will bee foft and mellow; they are both fmall Peaches, hauing very little or no refemblance at all to a Nutmeg, except in being a little longer then round, and are early ripe.

Many other forts of Peaches there are, whereunto wee can giue no efpeciall name; and therefore I paffe them ouer in filence.

\section{The Vfe of Peaches.}

Thofe Peaches that are very moift and waterifh (as many of them are) and not firme, doe foone putrefie in the ftomacke, caufing furfeits oftentimes; and therefore euery one had neede bee carefull, what and in what manner they eate them: yet they are much and often well accepted with all the Gentry of the Kingdome.

The leaues, becaufe of their bitterneffe, ferue well being boyled in Ale or Milke, to be giuen vnto children that haue wormes, to help to kill them, and doe gently open the belly, if there be a fufficient quantity vfed.

The flowers haue the like operation, that is, to purge the body fomewhat more forceably then Damaske Rofes; a Syrupe therefore made of the flowers is very good.

The kernels of the Peach ftones are oftentimes vfed to be giuen to them that cannot well make water, or are troubled with the ftone; for it openeth the ftoppings of the vritory paffages, whereby much eafe enfueth.

\section{CHA P. XVI.}

\section{Nuciperfica. Nectorins.}

Prefume that the name Nuciperfica doth moft rightly belong vnto that kinde of Peach, which we call Nectorins, and although they haue beene with vs not many yeares, yet haue they beene knowne both in Italy to Matthiolus, and others before him, who it feemeth knew no other then the yellow Nectorin, as Dalechampius alfo: But we at this day doe know fiue feuerall forts of Nectorins, as they thall be prefently fet downe; and as in the former fruits, fo in this, I will giue you the defcription of one, and briefe notes of the reft.

The Nectorin is a tree of no great bigneffe, molt vfually leffer then the Peach tree, his body and elder boughes being whitifh, the younger branches very red, whereon grow narrow long greene leaues, fo like vnto Peach leaues, that none can well diftinguifh them, vnleffe it be in this, that they are fomewhat leffer : the bloffomes are all reddirh, as the Peach, but one of a differing fafhion from all the other, as I thall thew you by and by : the fruit that followeth is fmaller, rounder, and fmoother then Peaches, without any cleft on the fide, and without any douny cotton or freeze at all; and 
herein is like vnto the outer greene rinde of the Wallnut, whereof as I am perfwaded it tooke the name, of a faft and firme meate, and very delicate in tafte, efpecially the beft kindes, with a rugged ftone within it, and a bitter kernell.

The Muske Nectorin, fo called, becaufe it being a kinde of the beft red Nectorins, both fmelleth and eateth as if the fruit were fteeped in Muske: fome thinke that this and the next Romane Nectorin are all one.

The Romane red Nectorin, or clufter Nectorin, hath a large or great purplinh bloffome, like vnto a Peach, reddifh at the bottome on the outfide, and greenifh within: the fruit is of a fine red colour on the outfide, and groweth in clufters, two or three at a ioynt together, of an excellent good tafte.

The baftard red Nectorin hath a fmaller or pincking bloffome, more like threads then leaues, neither fo large nor open as the former, and yellowinh within at the bottome : the fruit is red on the outfide, and groweth neuer but one at a ioynt ; it is a good fruit, but eateth a little more rawifh then the other, euen when it is full ripe.

The yellow Nectorin is of two forts, the one an excellent fruit, mellow, and of a very good rellifh; the other hard, and no way comparable to it.

The greene Nectorin, great and fmall ; for fuch I haue feene abiding conftant, although both planted in one ground: they are both of one goodneffe, and accounted with moft to be the beft rellifhed Nectorin of all others.

The white Nectorin is faid to bee differing from the other, in that it will bee more white on the outride when it is ripe, then either the yellow or greene: but I haue not yet feene it.

\section{The Vfe of Nectorins.}

The fruit is more firme then the Peach, and more delectable in tafte; and is therefore of more efteeme, and that worthily.

\section{CHAP. XVII.}

\section{Amygdala. Almonds.}

7 He Almond alfo may be reckoned vnto the ftock or kindred of the Peaches, it is fo like both in leafe, and bloffome, and fomewhat alfo in the fruit, for the outward forme, although it hath onely a dry skinne, and no pulpe or meate to bee eaten : but the kernell of the ftone or fhell, which is called the Almond, maketh recompenfe of that defect, whereof fome are fweete, fome bitter, fome great, fome fmall, forne long, and fome thort.

The Almond tree groweth vpright, higher and greater then any Peach; and is therefore vfually planted by it felfe, and not againft a wall, whofe body fometime exceedeth any mans fadome, whereby it heweth to be of longer continuance, bearing large armes, and fmaller branches alfo, but brittle, whereon are fet long and narrow leaues, like vnto the Peach tree: the bloffomes are purplifh, like vnto Peach bloffoms, but paler: the fruit is fomewhat like a Peach for the forme of the skinne or outfide, which is rough, but not with any fuch cleft therein, or with any pulpe or meate fit to bee eaten, but is a thicke dry skinne when it is ripe, couering the ftone or fhell, which is fmooth and not rugged, and is either long and great, or fmall, or thicke and fhort, according as the nut or kernell within it is, which is fweete both in the greater and fmaller, and onely one fmaller kinde which is bitter : yet this I haue obferued, that all the Almond trees that I haue feene growe in England, both of the fweete and bitter kindes, beare Almonds thicke and thort, and not long, as that fort which is called the Iorden Almond.

\section{The Vfe of Almonds.}

They are vfed many wayes, and for many purpofes, either eaten alone with Figges, or Rayfins of the Sunne, or made into pafte with Sugar and Rofewater for Marchpanes, or put among Floure, Egges, and Sugar, to 
make Mackerons, or crufted ouer with Sugar, to make Comfits, or mixed with Rofewater and Sugar, to make Butter, or with Barley water, to make Milke, and many other waies, as euery one lift, that hath skill in fuch things.

The oyle alfo of Almonds is vfed many waies, both inwardly and outwardly, for many purpofes; as the oyle of fweete Almonds mixt with poudered white Sugar Candy, for coughes and hoarfeneffe, and to be drunk alone, or with fome other thing (as the Syrupe of Marn Mallowes) for the ftone, to open and lenifie the paffages, and make them flipperie, that the ftone may paffe the eafier. And alfo for women in Child bed after their fore trauell. And outwardly either by it felfe, or with oyle of Tartar to make a creame, to lenifie the skin, parched with the winde or otherwife, or to annoint the ftomacke either alone, or with other things to helpe a cold.

The oyle of bitter Almonds is much vfed to be dropped into their eares that are hard of hearing, to helpe to open them. And as it is thought, doth more fcoure and cleanfe the skin then the fweet oyle doth, and is therefore more vfed of many for that purpofe, as the Almonds themfelues are.

\section{CH A P. X V I I I.}

\section{Mala Arantia. Orenges.}

Tring here to your confideration, as you fee, the Orenge tree alone, without mentioning the Citron or Lemmon trees, in regard of the experience we haue feen made of them in diuers places: For the Orenge tree hath abiden with fome extraordinary looking and tending of it, when as neither of the other would by any meanes be preferued any long time. If therefore any be defirous to keepe this tree, he muft fo prouide for it, that it be preferued from any cold, either in the winter or fpring, and expofed to the comfort of the funne in fummer. And for that purpore fome keepe them in great fquare boxes, and lift them to and fro by iron hooks on the fides, or caufe them to be rowled by trundels, or fmall wheels vnder them, to place them in an houfe, or clofe gallerie for the winter time: others plant them againft a bricke wall in the ground, and defend them by a Thed of boardes, couered ouer with feare-cloth in the winter, and by the warmth of a ftoue, or other fuch thing, giue them fome comfort in the colder times: but no tent or meane prouifion will preferue them.

The Orenge tree in the warme Countries groweth very high, but with vs (or elfe it is a dwarfe kinde thereof) rifeth not very high : the barke of the elder ftemmes being of a darke colour, and the young branches very greene, whereon grow here and there fome few thornes: the leaues are faire, large, and very greene, in forme almoft like a Bay leafe, but that it hath a fmall eare, or peece of a leafe, fafhioned like vnto an heart vnder euery one of them, with many fmall holes to be feene in them, if you hold them $\mathrm{vp}$ betweene you and the light, of a fweet but ftrong fmell, naturally not falling away, but alwaies abiding on, or vntill new be come vp, bearing greene leaues continually: the flowers are whitilh, of a very ftrong and heady fent; after which come fmall round fruit, greene at the firft, while they are fmall, and not neere maturitie, but being grown and ripe, are (as all men know) red on the out fide, fome more pale then others, and fome kindes of a deeper yellowifh red, according to the climate, and as it receiueth the heate of the funne, wherein is contained fower or fweete iuice, and thicke white kernels among it: it beareth in the warme Countries both bloffomes and greene fruit continually vpon it, and ripe fruit alfo with them for the beft part of the yeare, but eSpecially in Autumne and Winter.

\section{The Vfe of Orenges.}

Orenges are vfed as fawce for many forts of meates, in refpect of their fweete fowerneffe, giuing a rellifh of delight, whereinfoeuer they are vfed.

The inner pulpe or iuice doth ferue in agues and hot difeafes, and in Summer to coole the heate of deiected ftomackes, or fainting fpirits. 


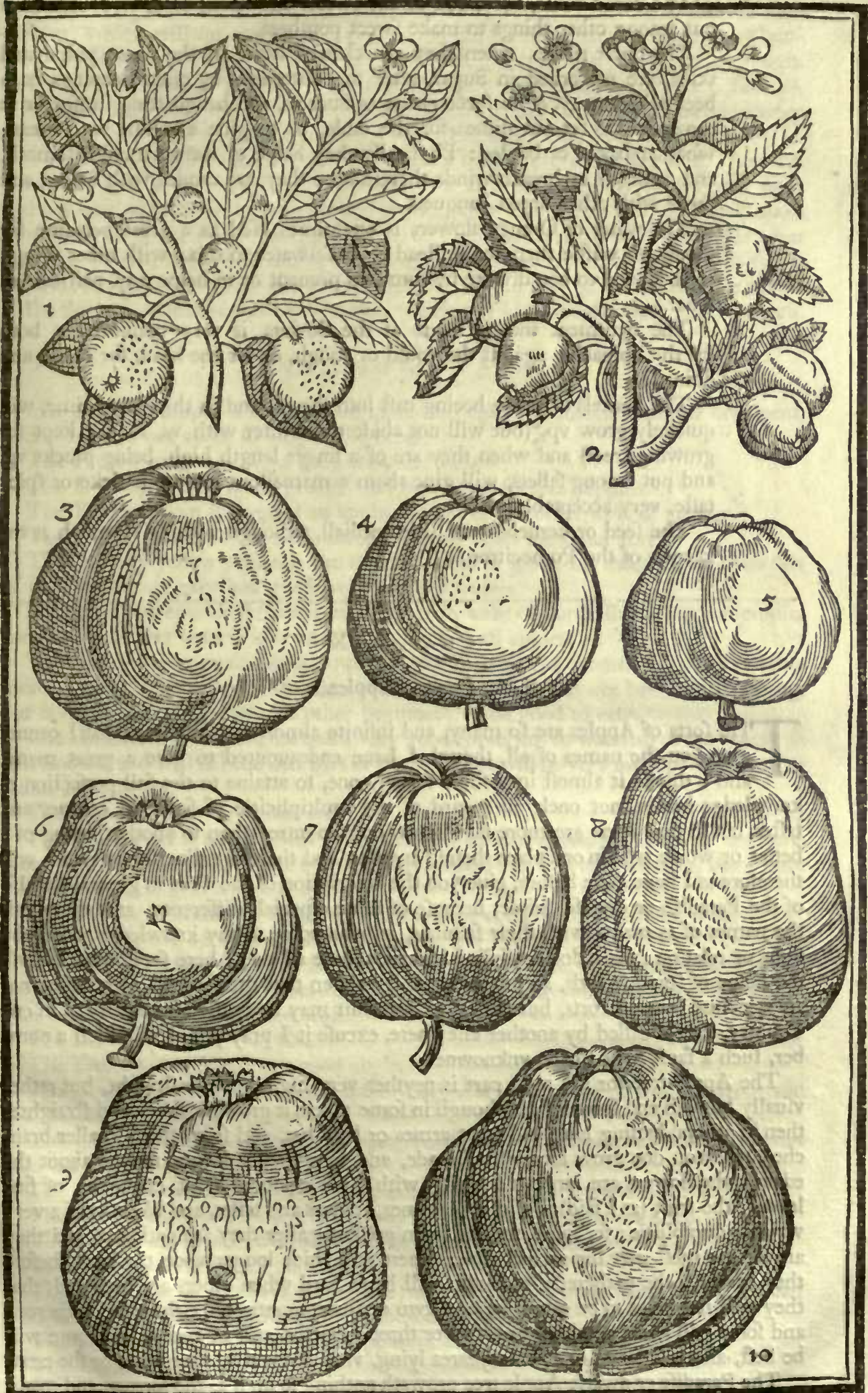

I Malus Aroutia. The Orenge tree. 2 Malus. The Apple uce. 3 Malum Carbonarium. The Pomewaler. 4 Malwm Curtipesdulum. The gulden Pippin. The Pearmaine. 6 Malwm Reginewn. The Queene Apple. 7 Malwm primis maturum. The Gennecing. \& Malum Regale. The pound Royall. g Malum Kentij ad ferucfocnduml. The Kentifh Codin. 10 Malmm Regincum ffurium. The Bardfield Quining. 
The dryed rinde, by reafon of the fweete and ftrong fent, ferueth to bee put among other things to make fweet pouthers.

The outer rindes, when they are clenfed from all the inner pulpe and skins, are preferued in Sugar, after the bitterneffe by often fteepings hath been taken away, \& do ferue either as Succots, and banquetting ftuffes, or as ornaments to fet out difhes for the table, or to giuc a rellifh vnto meats, whether baked or boyled: Phyfically they helpe to warme a cold ftomack, and to digeft or breake winde therein : or they are candid with Sugar, and ferue with other dryed Iunquets.

The water of Orange flowers is oftentimes vfed as a great perfume for gloues, to wafhe them, or in ftead of Rofe-water to mixe with other things.

It is vfed to bee drunke by fome, to preuent or to helpe any peftilentiall feuer.

The oyntment that is made of the flowers, is very comfortable both for the ftomache, againft the could or cough, or for the head, for paines and difineffe.

The kernels or feede beeing caft into the ground in the fpring time, will quickely grow vp, (but will not abide the winter with vs, to bee kept for growing trees) and when they are of a finger length high, being pluckt vp, and put among fallets, will giue them a maruellous fine aromaticke or fpicy tafte, very acceptable.

The feed or kernels are a little cordiall, although nothing fo much as the kernels of the Pomecitron.

\section{CHA P. XIX.}

\section{Poma. Apples.}

$\mathrm{T}$ He forts of Apples are fo many, and infinite almoft as I may fay, that I cannot giue you the names of all, though I haue endeauoured to giue a great many, and I thinke it almoft impoffible for any one, to attaine to the full perfection of knowledge herein, not onely in regard of the multiplicitie of fafhions, colours and taftes, but in that fome are more familiar to one Countrey then to another, being of a better or worfe tafte in one place then in another, and therefore diuerly called: I will therefore as I haue done before, giue you the defcription of the Tree in generall, as alfo of the Paradife or dwarfe Apple, becaufe of fome efpeciall difference, and afterwards the names of as many, with their fafhions, as haue come to my knowledge, either by fight or relation : for I doe confeffe I haue not feene all that I here fet downe, but vfe the helpe of fome friends, and therefore if it happen that the feuerall names doe not anfwer vnto feuerall forts, but that the fame fruit may bee called by one name in one Country, that is called by another elfewhere, excufe it I pray you; for in fuch a number, fuch a fault may efcape vnknowne.

The Apple tree for the moft part is neyther very high, great or ftraight, but rather vfually boweth and fpreadeth (although in fome places it groweth fairer and ftraighter then in others) hauing long and great armes or boughes, and from them fmaller branches, whereon doe grow fomewhat broade, and long greene leaues, nicked about the edges: the flowers are large and white, with blufh coloured fides, confifting of fiue leaues: the fruit (as I faid) is of diuers formes, colours and taftes, and likewife of a very variable durabilitie; for fome muft be eaten prefently after they are gathered, and they are for the moft part the earlieft ripe; others will abide longer vpon the trees, before they bee fit to be gathered; fome alfo will be fo hard when others are gathered, that they will not be fit to be eaten, for one, two or three months after they bee gathered; and fome will abide good but one, two or three moneths, and no more; and fome will be beft, after a quarter or halfe a yeares lying, vnto the end of that yeare or the next.

The Paradife or dwarfe Apple tree groweth nothing fo high as the former, and many times not much higher then a man may reach, hauing leaues and flowers altogether like the other, the fruit is a faire yellow Apple, and reafonable great, but very light and fpongy or loofe, and of a bitterifh fweet tafte, nothing pleafant. And thefe faults al- 
fo are incident vnto this tree, that both bodie and branches are much fubiect vnto cancker, which will quickely eate it round, and kill it; befides it will haue many bunches, or tuberous fwellings in many places, which grow as it were fcabby or rough, and will foone caufe it to perifh : the roote fendeth forth many thootes and fuckers, whereby it may be much increafed. But this benefit may be had of it, to recompence the former faults, That being a dwarfe Tree, whatfoeuer fruit thall be grafted on it, will keepe the graft low like vnto it felfe, and yet beare fruit reafonable well. And this is a pretty way to haue Pippins, Pomewaters, or any other fort of Apples (as I haue had my felfe, and alfo feene with others) growing low, that if any will, they may make a hedge rowve of thefe low fruits, planted in an Orchard all along by a walke fide: but take this Caueat, if you will auoide the danger of the cancker and knots, which fpoile the tree, to graft it hard vnto the ground, that therby you may giue as little of the nature of the ftock thereunto as poffibly you can, which wil vndoubtedly help it very much.

\section{The kindes or forts of Apples.}

The Summer pippin is a very good apple firf ripe, and therefore to bee firft fpent, becaufe it will not abide fo long as the other.

The French pippin is alfo a good fruit and yellow.

The Golding pippin is the greateft and beft of all forts of pippins.

The Ruffet pippin is as good an apple as moft of the other forts of pippins.

The fpotted pippin is the moft durable pippin of all the other forts.

The ordinary yellow pippin is like the other, and as good; for indeed I know no fort of pippins but are excellent good well rellifhed fruites.

The great pearemaine differeth little either in tafte or durabilitie from the pippin, and therefore next vnto it is accounted the beft of all apples.

The fummer pearemaine is of equall goodneffe with the former, or rather a little more pleafing, efpecially for the time of its eating, which will not bee fo long lafting, but is fpent and gone when the other beginneth to be good to eate.

The Ruffetting is alfo a firme and a very good apple, not fo waterifh as the pippin or pearemaine, and will laft the beft part of the year, but will be very mellow at the laft, or rather halfe dryed.

The Broading is a very good apple.

The Pomervater is an excellent good and great whitifh apple, full of fap or moifture, fomewhat pleafant tharpe, but a little bitter withall: it will not laft long, the winter frofts foone caufing it to rot, and perifh.

The Flower of Kent is a faire yellowinh greene apple both good and great.

The Gilloflower apple is a fine apple, and finely rpotted.

The Marligo is the fame, that is called the Marigold apple, it is a middle fized apple, very yellow on the outfide, fhadowed ouer as it were with red, and more red on one fide, a reafonable well rellifhed fruit.

The Blandrill is a good apple.

The Dauie Gentle is a very good apple.

The Gruntlin is fomewhat a long apple, fmaller at the crowne then at the ftalke, and is a reafonable good apple.

The gray Cofterd is a good great apple, fomewhat whitifl on the outfide, and abideth the winter.

The greene Cofterd is like the other, but greener on the outfide continually.

The Haruy apple is a faire great goodly apple, and very well rellifhed.

The Dowfe apple is a fweetifh apple not much accounted of.

The Pome-paris is a very good apple.

The Belle boon of two forts winter and fummer, both of them good apples, and fair fruit to look on, being yellow and of a meane bigneffe.

The pound Royall is a very great apple, of a very good and tharpe tafte.

The Doues Bill a fmall apple.

The Deufan or apple Iohn is a delicate fine fruit, well rellifhed when it beginneth to be fit to be eaten, and endureth good longer then any other apple.

The Mafter William is greater then a pippin, but of no very good rellifh.

The Mafter Iohn is a better tafted apple then the other by much. 
The Spicing is a well tafted fruite.

Pome de Rambures

Pome de Capanda all faire and good apples brought from France.

Pome de Galual )

The Queene apple is of two forts, both of them great faire red apples, and well rellifhed, but the greater is the beft.

The Baftard Queene apple is like the other for forme and colour, but not fo good in tafte : fome call this the bardfield Queening.

The Boughton or greening is a very good and well tafted apple.

The Leather coate apple is a good winter apple, of no great bigneffe, but of a very good and fharpe tafte.

The Pot apple is a plaine Country apple.

The Cowfnout is no very good fruit.

The Gildiling apple is a yellow one, not much accounted.

The Cats head apple tooke the name of the likeneffe, and is a reafonable good apple and great.

The Kentifh Codlin is a faire great greenifh apple, very good to eate when it is ripe; but the beft to coddle of all other apples.

The Stoken apple is a reafonable good apple.

The Geneting apple is a very pleafant and good apple.

The Worcefter apple is a very good apple, as bigge as a Pomewater.

Donime Couadis is a French apple, and of a good rellin.

The French Goodwin is a very good apple.

The old wife is a very good, and well rellifhed apple.

The towne Crab is an hard apple, not fo good to be eaten rawe as roafted, but excellent to make Cider.

The Virgilling apple is a reafonable good apple.

The Crowes egge is no good rellifhed fruit, but nourfed vp in fome places of the common people.

The Sugar apple is fo called of the fweetneffe.

Sops in wine is fo named both of the pleafantneffe of the fruit, and beautie of the apple.

The womans breaft apple is a great apple.

The blacke apple or pippin is a very good eating apple, and very like a Pearemaine, both for forme and bigneffe, but of a blacke footy colour.

Tweenty forts of Sweetings and none good.

The Peare apple is a fmall fruit, but well rellifhed being ripe, and is for thape very like vnto a fmall hort Peare, and greene.

The Paradife apple is a faire goodly yellow apple, but light and fpongy, and of a bitterinh fweet tafte, not to be commended.

The apple without bloffome, fo called becaufe although it haue a fmall thew of a bloffome, yet they are but fmall threds rather then leaues, neuer fhewing to bee like a flower, and therefore termed without bloffome: the apple is neyther good eating nor baking fruit.

Wildings and Crabs are without number or vfe in our Orchard, being to be had out of the woods, fields and hedges rather then any where elfe.

\section{The Vfe of Apples.}

The beft forts of Apples ferue at the laft courfe for the table, in moft mens houfes of account, where, if there grow any rare or excellent fruit, it is then fet forth to be feene and tafted.

Diuers other forts ferue to bake, either for the Mafters Table, or the meynes fuftenance, either in pyes or pans, or elfe ftewed in difhes. with Rofewater and Sugar, and Cinamon or Ginger cait vpon.

Some kinds are fitteft to roaft in the winter time, to warme a cup of wine, ale or beere; or to be eaten alone, for the nature of fome fruit is neuer fo good, or worth the eating, as when they are roafted. 
Some forts are fittelt to fcald for Codlins, and are taken to coole the ftomacke, as well as to pleafe the tafte, hauing Rofewater and Sugar put to them.

Some forts are beft to make Cider of, as in the Weft Countrey of England great quantities, yea many Hogheads and Tunnes full are made, efpecially to bee carried to the Sea in long voyages, and is found by experience to bee of excellent vie, to mixe with water for beuerage. It is vfually feene that thofe fruits that are neither fit to eate raw, roafted, nor baked, are fitteft for Cider, and make the beft.

The iuice of Apples likewife, as of pippins, and pearemaines, is of very good vfe in Melancholicke difeafes, helping to procure mirth, and to expell heauineffe.

The diftilled water of the fame Apples is of the like effect.

There is a fine fweet oyntment made of Apples called Pomatum, which is much vfed to helpe chapt lips, or hands, or for the face, or any other part of the skinne that is rough with winde, or any other accident, to fupple them, and make them fmooth.

\section{CHAP. XX.}

\section{Cydonia. Quinces.}

W

Ee haue fome diuerfities of Quinces, although not many, yet more then our elder times were acquainted with, which thall be here expreffed.

The Quince tree groweth oftentimes to the height and bigneffe of a good Apple tree, but more vfually lower, with crooked and fpreading armes and branches farre abroad, the leaues are fomewhat round, and like the leaues of the Apple tree, but thicker, harder, fuller of veines, and white on the vnderficle : the bloffomes or flowers are white, now and then dafht ouer with blufh, being large and open, like vnto a fingle Rofe: the fruit followeth, which when it is ripe is yellow, and couered with a white cotton or freeze, which in the younger is thicker and more plentifull, but waxeth leffe and leffe, as the fruit ripeneth, being bunched out many times in feuerall places, and round, efpecially about the head, fome greater, others fmaller, fome round like an Apple; others long like a Peare, of a ftrong heady fent, accounted not wholfome or long to be endured, and of no durabilitie to keepe, in the middle whereof is a core, with many blackifh feedes or kernels therein, lying clofe together in cels, and compaffed with a kinde of cleare gelly, which is eafier feene in the fcalded fruit, then in the raw.

The Englin Quince is the ordinarie Apple Quince, fet downe before, and is of fo harth a tafte being greene, that no man can endure to eate it rawe, but eyther boyled, ftewed, roafted or baked; all which waies it is very good.

The Portingall Apple Quince is a great yellow Quince, feldome comming to bee whole and faire without chapping; this is fo pleafant being frefl gathered, that it may be eaten like vnto an Apple witbout offence.

The Portingall Peare Quince is not fit to be eaten rawe like the former, but inuf be vfed after fome of the waies the Englifh Quince is appointed, and fo it will make more dainty difhes then the Englifh, becaufe it is leffe harlh, will bee more tender, and take leffe fugar for the ordering then the Englifh kinde.

The Barbary Quince is like in goodneffe vnto the Portingall Quince laft fpoken of, but leffer in bigneffe.

The Lyons Quince.

The Brunfwicke Quince.

The Vfe of Quinces.

There is no fruit growing in this Land that is of fo many excellent vfes as this, feruing as well to make many dithes of meate for the table, as for 
banquets, and much more for the Phyficall vertues, whereof to write at large is neither conuenient for mee, nor for this worke: I will onely briefly recite fome, as it were to giue you a tafte of that plenty remaineth therein, to bee converted into fundry formes: as firt for the table, while they are frefh (and all the yeare long after being pickled vp) to be baked, as a dainty difh, being well and orderly cookt. And being preferued whole in Sugar, either white or red, ferue likewife, not onely as an after difh to clofe vp the ftomacke, but is placed among other Preferues by Ladies and Gentlewomen, and beftowed on their friends to entertaine them, and among other forts of Preferues at Banquets. Codimacke alfo and Marmilade, Ielly and Pafte, are all made of Quinces, chiefly for delight and pleafure, although they haue alfo with them fome phyficall properties.

We haue for the vfe of phyficke, both Iuyce and Syrupe, both Conferue and Condite, both binding and loofening medicines, both inward and outward, and all made of Quinces.

The Ielly or Muccilage of the feedes, is often vfed to be laid vpon womens breafts, to heale them being fore or rawe, by their childrens default giuing them fucke.

Athenæus reciteth in his third booke, that one Philarchus found, that the fmell of Quinces tooke away the ftrength of a certaine poifon, called Phariacum. And the Spaniards haue alfo found, that the ftrength of the iuyce of white Ellebor (which the Hunters vfe as a poyfon to dippe their arrow heads in, that they fhoote at wilde beafts to kill them) is quite taken away, if it ftand within the compaffe of the fmell of Quinces. And alfo that Grapes, being hung vp to bee kept, and fpent in Winter, doe quickly rot with the fmell of a Quince.

Снар. XXI.

\section{Pyra. Peares.}

T He variety of peares is as much or more then of apples, and 1 thinke it is as hard in this, as before in apples, for any to be fo exquifite, as that hee could number vp all the forts that are to be had: for wee haue in our country fo manie, as I thall giue you the names of by and by, and are hitherto come to our knowledge: but I verily beleeue that there be many, both in our country, and in others, that we haue not yet knowne or heard of; for euery yeare almoft wee attaine to the knowledge of fome, we knew not of before. Take therefore, according to the manner before held, the defcription of one, with the feuerall names of the reft, vntill a more exact difcourfe be had of them, euery one apart.

The Peare tree groweth more flowly, but higher, and more vpright then the apple tree, and not leffe in the bulke of the body: his branches fpread not fo farre or wide, but growe vprighter and clofer: the leaues are fomewhat broader and rounder, greene aboue, and whiter vnderneath then thofe of the apple tree : the flowers are whiter and greater: the fruit is longer then round for the moft part, fmaller at the ftalke, and greater at the head, of fo many differing formes, colours, and taftes, that hardly can one diftinguifh rightly between them, the times alfo being as variable in the gathering and fpending of them, as in apples: the roote groweth deeper then the apple tree, and therefore abideth longer, and giueth a fafter, clofer, \& fmoother gentle wood, eafie to be wrought vpon.

\section{The kindes of Peares.}

The Summer bon Chretien is fomewhat a long peare, with a greene and yellow ruffetifh coate, and will haue fometimes red fides; it is ripe at Michaelmas: fome vfe to dry them as they doe Prunes, and keepe them all the yeare after. I haue not feene or heard any more Summer kindes hereof then this one, and needeth no wall to nourfe it as the other. 


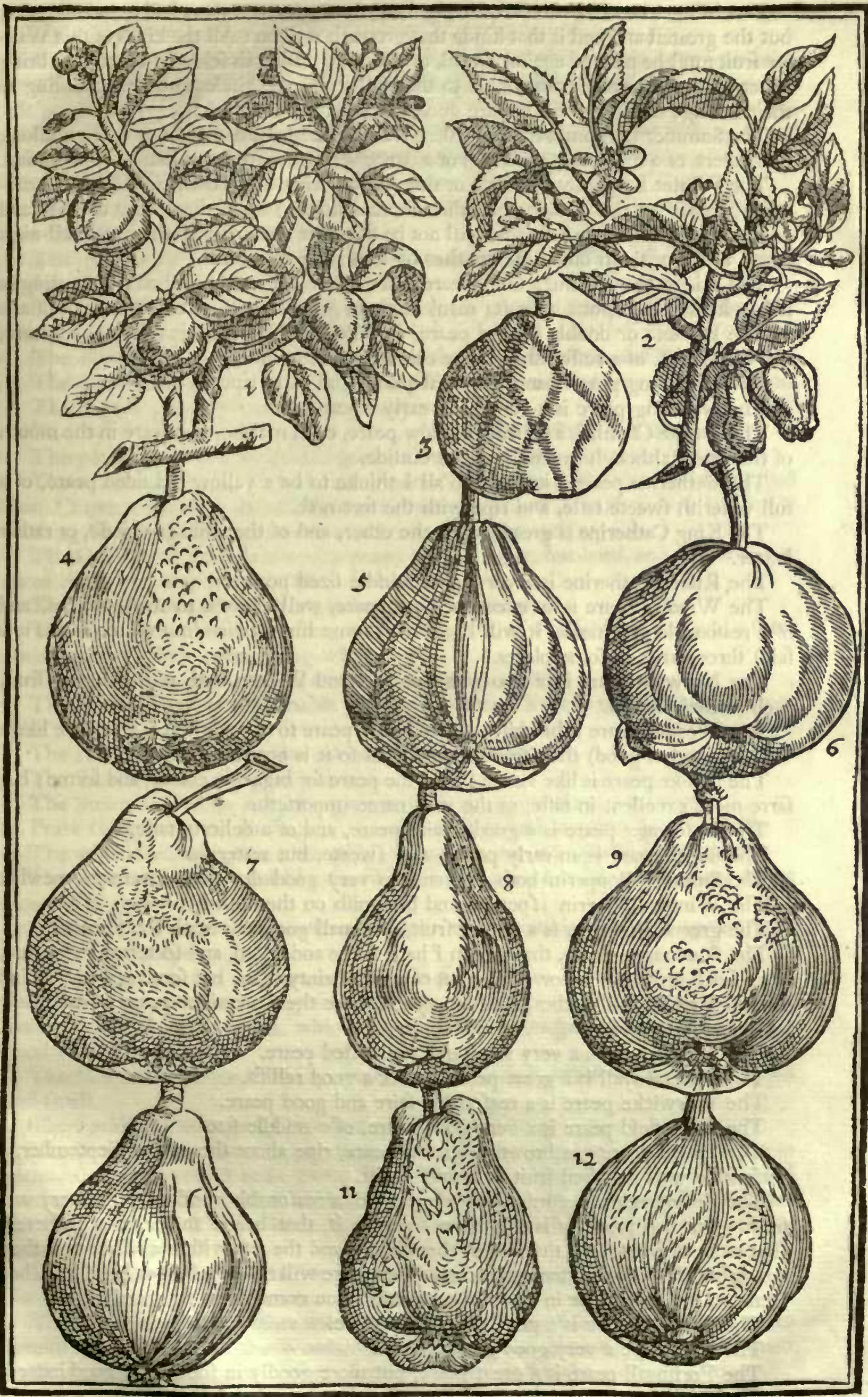

I Malus Cotonea. The Quince tree. 2 Cydonium Lusilnaicum. The Portingall Quince. 3 Pyrus, The Peare tree. 4 Pyrum Pomprianum, fuse Cucumerinum hycmale. The Winter Bon Chretien. 5 Pyrum pinnm vol frialum. The painted ot friped Peare

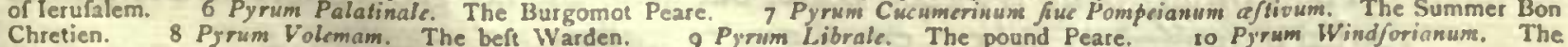
Windfor Peare. 11 Pyruox Cucumerinum. The Gratiola Peare 12 Pyrum Caryophyllatum. The Gilloflower Peare. 
The Winter bon Chretien is of many forts, fome greater, others leffer, and all good; but the greateft and beft is that kinde that groweth at Syon: All the kinds of this Winter fruit muft be planted againft a wall, or elfe they will both feldome beare, and bring. fewer alfo to ripeneffe, comparable to the wall fruit: the kindes alfo are according to their lafting; for fome will endure good much longer then others.

The Summer Bergomot is an excellent well rellifhed peare, flattifh, \& fhort, not long like others, of a meane bigneffe, and of a darke yellowifh greene colour on the outfide.

The Winter Bergomot is of two or three forts, being all of them fmall fruit, fomewhat greener on the outfide then the Summer kindes; all of them very delicate and good in their due time: for fome will not be fit to bee eaten when others are well-nigh fpent, euery of them outlafting another by a moneth or more.

The Diego peare is but a fmall peare, but an excellent well rellifhed fruit, tafting as if Muske had been put among it ; many of them growe together, as it were in clufters.

The Duetete or double headed peare, fo called of the forme, is a very good peare, not very great, of a ruffettifh browne colour on the outfide.

The Primating peare is a good moift peare, and early ripe.

The Geneting peare is a very good early ripe peare.

The greene Chefill is a delicate mellow peare, euen melting as it were in the mouth of the eater, although greenifh on the outfide.

The Catherine peare is knowne to all I thinke to be a yellow red fided peare, of a full waterifh fweete tafte, and ripe with the foremoft. better.

The King Catherine is greater then the other, and of the fame goodneffe, or rather

The Ruffet Catherine is a very good middle fized peare.

The Windfor peare is an excellent good peare, well knowne to molt perfons, and of a reafonable greatneffe: it will beare fruit fome times twice in a yeare (and as it is faid) three times in fome places.

The Norwich peare is of two forts, Summer and Winter, both of them good fruit, each in their feafon.

The Worfter peare is blackifh, a farre better peare to bake (when as it will be like a Warden, and as good) then to eate rawe; yet fo it is not to be milliked.

The Muske peare is like vnto a Catherine peare for bigneffe, colour, and forme; but farre more excellent in tafte, as the very name importeth.

The Rolewater peare is a goodly faire peare, and of a delicate tafte.

The Sugar peare is an early peare, very fweete, but waterifh.

The Summer Popperin) both of them are very good dry firme peares, fomewhat

The Winter Popperin $/$ fpotted, and brownifh on the outfide.

The greene Popperin is a winter fruit, of equall goodneffe with the former.

The Soueraigne peare, that which $I$ haue feene and tafted, and fo termed vnto me, was a fmall brownifh yellow peare, but of a moft dainty tafte; but fome doe take a kind of Bon Chretien, called the Elizabeth peare, to be the Soueraigne peare; how truely let others iudge.

The Kings peare is a very good and well tafted peare.

The peare Royall is a great peare, and of a good rellifh.

The Warwicke peare is a reafonable faire and good peare.

The Greenfield peare is a very good peare, of a middle fize.

The Lewes peare is a brownilh greene peare, ripe about the end of September, a reafonable well rellifhed fruit, and very moift.

The Bifhop peare is a middle fized peare, of a reafonable good tafte, not very waterifh ; but this property is oftentimes feene in it, that before the fruit is gathered, (but more vfually thore that fall of themfelues, and the reft within a while after they are gathered) will be rotten at the core, when there will not be a f pot or blemifh to bee feene on the outfide, or in all the peare, vntill you come neare the core.

The Wilford peare is a good and a faire peare.

The Bell peare a very good greene peare.

The Portingall peare is a great peare, but more goodly in thew then good indeed.

The Gratiola peare is a kinde of Bon Chretien, called the Cowcumber peare, or Spinola's peare.

The Rowling peare is a good peare, but hard, and not good before it bee a little rowled or bruifed, to make it eate the more mellow. 
The Pimpe peare is as great as the Windfor peare, but rounder, and of a very good rellifh.

The Turnep peare is a hard winter peare, not:fo good to eate rawe, as it is to bake.

The Arundell peare is moft plentifull in Suffolke, and there commended to be a verie good peare.

The Berry peare is a Summer peare, reafonable faire and great, and of fo good and wholfome a tafte, that few or none take harme by eating neuer fo many of them.

The Sand peare is a reafonable good peare, but frmall.

The Morley peare is a very good peare, like in forme and colour vnto the Windror, but fomewhat grayer.

The peare pricke is very like vnto the Greenfield peare, being both faire, great, and good.

The good Rewell is a reafonable great peare, as good to bake as to eate rawe, and both wayes it is a good fruit.

The Hawkes bill peare is of a middle fize, fomewhat like vnto the Rowling peare.

The Petworth peare is a winter peare, and is great, fomewhat long, faire, and good.

The Slipper peare is a reafonable good peare.

The Robert peare is a very good peare, plentifull in Suffolke and Norfolke.

The pound peare is a reafonable good peare, both to eate rawe, and to bake.

The ten pound peare, or the bundred pound peare, the trueft and beft, is the beft Bon Chretien of Syon, fo called, becaufe the grafts cont the Mafter fo much the fetching by the meffengers expences, when he brought nothing elfe.

The Gilloflower peare is a winter peare, faire in thew, but hard, and not fit to bee eaten rawe, but very good to bake.

The peare Couteau is neither good one way nor other.

The Binfce peare is a reafonable good winter peare, of a ruffetifh colour, and a fmall fruit : but will abide good a long while.

The Pucell is a greene peare, of an indifferent good tafte. fide.

The blacke Sorrell is a reafonable great long peare, of a darke red colour on the out-

The red Sorrell is of a redder calour, elfe like the other.

The Surrine is no very good peare.

The Summer Haftirg is a little greene peare, of an, indifferent good rellifh.

Peare Gergonell is an early peare, fomewhat long, and of a very pleafant tafte.

The white Genneting is a reafonable good peare, yet not equall to the other.

The Sweater is fomewhat like the Windfor for colour and bigneffe, but nothing neare of fo good a tafte.

The bloud red peare is of a darke red colour on the outfide, but piercing very little into the inner pulpe.

The Hony peare is a long greene Summer peare.

The Winter peare is of many forts, but this is onely fo called, to bee diftinguifhed from all other Winter peares, which haue feuerall names giuen them, and is a very good peare.

The Warden or Luke Wards peare of two forts, both white and red, both great and fmall.

The Spanifh Warden is greater then either of both the former, and better,alfo.

The peare of Ierufalem, or the ftript peare, whofe barke, while it is young, is as plainly feene to be ftript with greene, red, and yellow, as the fruit it felfe is alfo, and is of a very good tafte: being baked alfo, it is as red as the beft Warden, whereof Mafter William Ward of Effex hath affured mee, who is the chiefe keeper of the Kings Granary at Whitehall.

Hereof likewife there is a wilde kinde no bigger then ones thumbe, and ftriped in the like manner, but much more.

The Choke peares, and other wilde peares, both great and fmall, as they are not to furnifh our Orchard, but the Woods, Forrefts, Fields, and Hedges, fo wee leaue them to their naturall places, and to them that keep tbem, and make good vfe of them.

The Vre of Peares.

The moft excellent forts of Peares, ferue (as I faid before of Apples) to 
make an after-courfe for their mafters table, where the goodneffe of his Orchard is tryed. They are dryed alfo, and fo are an excellent repafte, if they be of the beft kindes, fit for the purpofe.

They are eaten familiarly of all forts of people, of fome for delight, and of others for nourifhment, being baked, ftewed, or fcalded.

The red Warden and the Spanifh Warden are reckoned among the moft excellent of Peares, either to bake or to roaft, for the ficke or for the found: And indeede, the Quince and the Warden are the two onely fruits are permitted to the ficke, to eate at any time.

Perry, which is the iuyce of Peares preffed out, is a drinke much efteemed as well as Cyder, to be both drunke at home, and carried to the Sea, and found to be of good vfe in long voyages.

The Perry made of Choke Peares, notwithftanding the harfhneffe, and euill tafte, both of the fruit when it is greene, as alfo of the iuyce when it is new made, doth yet after a few moneths become as milde and pleafant as wine, and will hardly bee knowne by the fight or tafte from it: this hath beene found true by often experience; and therefore wee may admire the goodneffe of God, that hath giuen fuch facility to fo wilde fruits, altogether thought vfeleffe, to become vfefull, and apply the benefit thereof both to the comfort of our foules and bodies.

For the Phyficall properties, if we doe as Galen teacheth vs, in Jecundo Alimentorum, referre the qualities of Peares to their feuerall taftes, as before he had done in Apples, we fhall not neede to make a new worke; thofe that are harh and fowre doe coole and binde, fweet do nourifh and warme, and thofe betweene thefe, to haue middle vertues, anfwerable to their temperatures, \&c.

Much more might be faid, both of this and the other kinds of fruits; but let this fuffice for this place and worke, vntill a more exact be accomplifhed.

\section{CH A P. XXII.}

\section{Nux Iuglans. The Wallnut.}

$A$ Lthough the Wallnut tree bee often planted in the middle of great Courtyards, where by reafon of his great fpreading armes it taketh vp a great deale of roome, his thadow reaching farre, fo that fcarce any thing can well grow neare it; yet becaufe it is likewife planted in fit places or corners of Orchards, and that it beareth fruit or nuts, often brought to the table, efpecially while they are frefhert, fweeteft, and fitteft to be eaten, let not my Orchard want his company, or you the knowledge of it. Some doe thinke that there are many forts of them, becaufe fome are much greater then others, and fome longer then others, and fome haue a more frangible thell then others; but I am certainly perfwaded, that the foyle and climate where they grow, are the whole and onely caufe of the varieties and differences. Indeed Virginia hath fent vnto vs two forts of Wallnuts, the one blacke, the other white, whereof as yet wee haue no further knowledge. And I know that Clufius reporteth, he tooke vp at a banquet a long Wallnut, differing in forme and tenderneffe of fhell from others, which being fet, grew and bore farre tenderer leaues then the other, and a little fnipt about the edges, which (as I faid) might alter with the foyle and climate : and befides you may obferue, that many of Clufius differences are very nice, and fo I leaue it.

The Wallnut tree groweth very high and great, with a large and thicke body or trunke, couered with a thicke clouen whitifh greene barke, tending to an afh-colour; the armes are great, and fpread farre, breaking out into fmaller branches, whereon doe grow long \& large leaues, fiue or feuen fet together one againft another, with an odde one at the end, fomewhat like vnto Afhen leaues, but farre larger, and not fo many on a ftalke, fmooth, and fomewhat reddifh at the firt fpringing, and tender alfo, of a reafonable good fent, but more ftrong and headie when they growe old: the fruit or nut is great and round, growing clofe to the ftalkes of the leaues, either by couples or by 
three fet together, couered with a double fhell, that is to fay, with a greene thicke and foft outer rinde, and an inner hard Ahell, within which the white kernell is contained, couered with a thinne yellow rinde or peeling, which is more cafily peeled away while it is greene then afterwards, and is as it were parted into foure quarters, with a thinne wooddy peece parting it at the head, very fweete and pleafant while it is frefh, and for a while after the gathering; but the elder they growe, the harder and more oily: the catkins or blowings are long and yellow, made of many fcaly leaues fet clofe together, which coine forth early in the Spring, and when they open and fall away, vpon their ftalkes arife certaine fmall flowers, which turne into fo many nuts.

The Vfe of Wallnuts.

They are often ferued to the table with other fruits while they abide frefh and fweete; and therefore many to keepe them frefh a long time haue deuifed many wayes, as to put them into great pots, and bury them in the ground, and fo take them out as they fpend them, which is a very good way, and will keepe them long.

The fmall young nuts while they are tender, being preferued or candid, are vfed among other forts of candid fruits, that ferue at banquets.

The iuyce of the outer greene huskes are held to be a foueraigne remedy againf either poyfon, or plague, or peftilentiall feuer.

The diftilled water of the buskes drunke with a little vinegar, if the fits growe hot and tedious, is an approued remedy for the fame.

The water diftilled from the leaues, is effectuall to be applyed to fluent or running vlcers, to dry and binde the humours.

Some haue vfed the pouder of the catkins in white wine, for the fuffocation or ftrangling of the mother.

The oyle of Wallnuts is vfed to varnifh Ioyners workes. As alfo is accounted farre to excell Linfeede oyle, to mixe a white colour withall, that the colour bee not dimmed. It is of excellent vfe for the coldneffe, hardneffe and contracting of the finewes and ioynts, to warme, fupple, and to extend them.

\section{Ch A P. X X I I I.}

\section{Cafanea Equina. The Horfe Chefnut.}

A Lthough the ordinary Chefnut is not a tree planted in Orchards, but left to Woods, Parkes, and other fuch like places; yet wee haue another fort which wee haue nourfed vp from the nuts fent vs from Turky, of a greater and more pleafant afpect for the faire leaues, and of as good vfe for the fruit. It groweth in time to be a great tree, fpreading with great armes and branches, whereon are fet at feuerall diftances goodly faire great greene leaues, diuided into fix, feuen, or nine parts or leaues, euery one of them nicked about the edges, very like vnto the leaues of Ricinus, or Palma Chrifit, and almoft as great: it beareth at the ends of the branches many flowers fet together vpon a long ftalke, confifting of foure white leaues a peece, with many threads in the middle, which afterwards turne into nuts, like vnto the ordinary Chefnuts, but fet in rougher and more prickly huskes: the nuts themfelues being rounder and blacker, with a white fpot at the head of each, formed fomewhat like an heart, and of a little fweeter tafte.

The Vfe of this Chefnut.

It ferueth to binde and ftop any maner of fluxe, be it of bloud or humours, either of the belly or ftomacke; as alfo the much fpitting of bloud. They are roafted and eaten as the ordinary fort, to make them tafte the better.

They are vfually in Turkie giuen to horfes in their prouender, to cure them of coughes, and helpe them being broken winded. 


\section{CH A P. XXIIIII.}

Morus. The Mulberrie.

T Here are two forts of Mulberries fufficiently known to moft, the blackifh and the white: but wee haue had brought vs from Virginia another fort, which is of greater refpect then eyther of the other two, not onely in regard of the raritie, but of the vfe, as you thall prefently vnderftand.

1. Morus nigra. The blacke Mulberrie.

The blacke: Mulberrie tree groweth oftentimes tall and great, and oftentimes alfo crooked; and fpreading abroade, rather then high; for it is fubiect to abide what forme you will conforme it vnto: if by fuffering it to grow, it will mount vp, and if you will binde it, or plafh the boughes, they will fo abide, and be carried ouer arbours, or other things as you will haue it. The bodie groweth in time to bee very great, couered with a rugged or thicke barke; the armes or branches being fmoother, whereon doe grow round thicke leaues pointed at the ends, and nicked about the edges, and in fome there are to be feene deep garhes, making it feeme fomewhat like the Vine leafe : the flowers are certaine fhort doutie catkings, which turne into greene berries at the firft, afterwards red, and when they are full ripe blacke, made of many graines fet together, like vnto the blacke berrie, but longer and greater: before they are ripe, they haue an auftere and harfh tafte, but when they are full ripe; they are more fweete and pleafant; the iuice whereof is fo red, that it will ftaine the hands of them that handle and eate them.

\section{Morus alba. The white Mulberrie.}

The white Mulberrie tree groweth not with vs to that greatneffe or bulke of bodie that the blacke doth, but runneth vp higher, flenderer, more knotty, hard and brittle, with thinner fpreade armes and branches: the leaues are like the former, but not fo thicke fet on the branches, nor fo hard in handling, a little paler alfo, hauing fomewhat longer ftalkes: the fruit is fmaller and clofer fet together, greene, and fomewhat harfh before they be ripe, but of a wonderfull fweetneffe, almoft ready to procure loathing when they are thorough ripe, and white, with fuch like feede in them as in the former, but fmaller.

\section{Morus Virginiana. The Virginia Mulberrie.}

The Virginia Mulberry tree groweth quickely with vs to be a very great tree, fpreading many armes and branches, whereon grow faire great leaues; very like vnto the leaues of the white Mulberrie tree : the berry or fruit is longer and redder then either of the other, and of a very pleafant tafte.

\section{The Vfe of Mulberries.}

The greateft and moft efpeciall vfe of the planting of white Mulberries, is for the feeding of Silke wormes, for which purpofe all the Eafterne Countries, as Perfia, Syria, Armenia, Arabia \&c. and alfo the hither part of Turkie, Spaine alfo and Italie, and many other hot Countries doe nourifh them, becaufe it is beft for that purpofe, the wormes feeding thereon, giuing the fineft and beft filke; yet fome are confident that the leaues of the blacke.will doe as much good as the white: but that refpect muft be had to change your feede, becaufe therein lyeth the greateft mysterie. But there is a Booke or Tractate printed, declaring the whole vfe of whatfoeuer can belong vito them: I will therefore referre them thereunto, that 


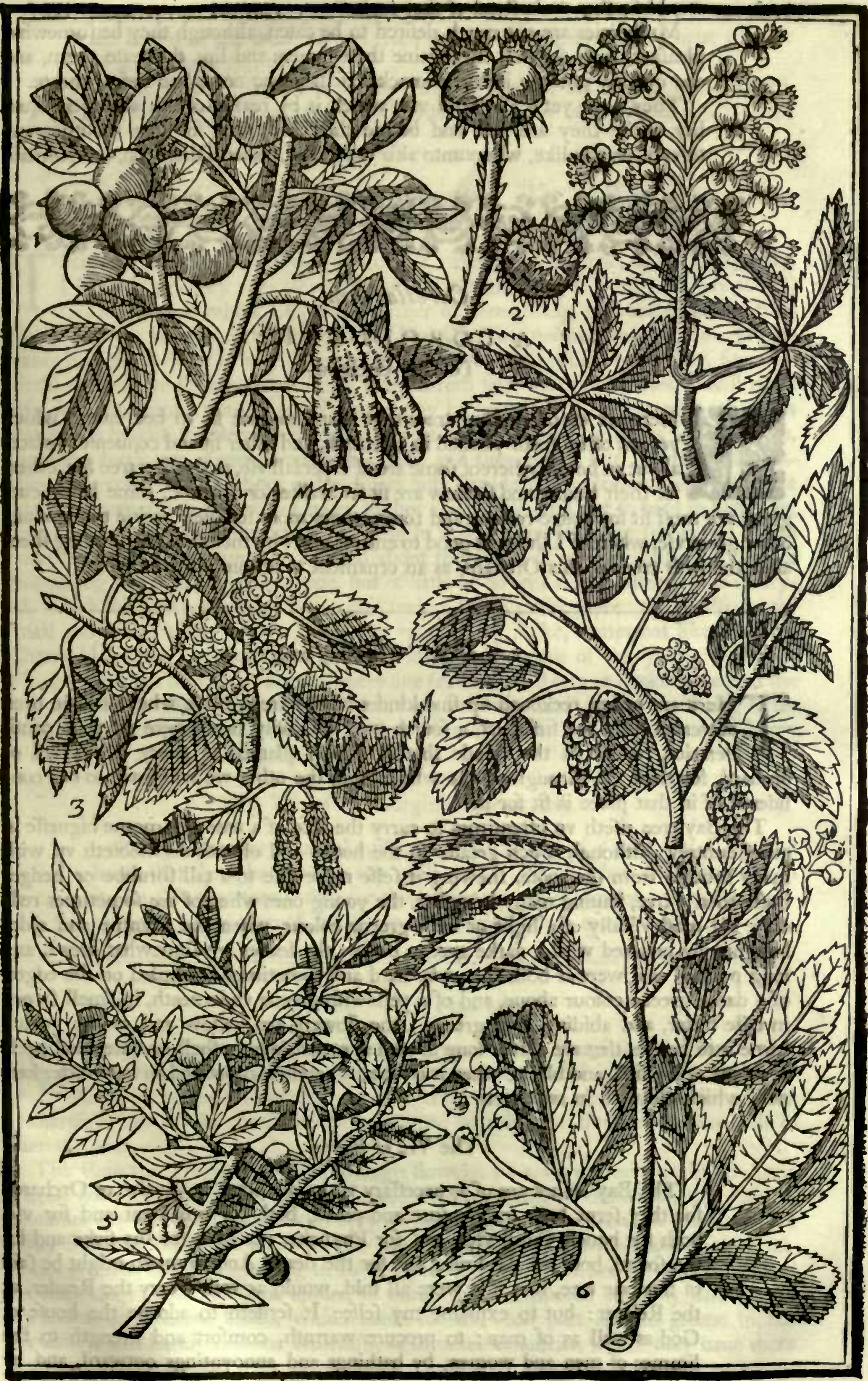

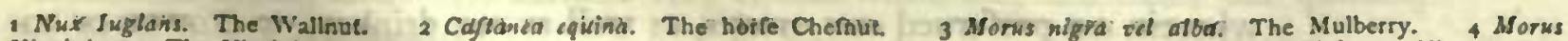
Virginiana. The Virginia Mulberry. 5 Laurus vulgaris. The ordinary Bay tree. 6 Laurea Cerafus Virginiana. The Virginia Chenty. Bay. 
would further vnderftand of that matter.

Mulberries are not much defired to be eaten, although they be fomewhat pleafant, both for that they ftaine their fingers and lips that eate them, and doe quickly putrefie in the ftomacke, if they bee not taken before meate.

They haue yet a Phyficall vfe, which is by reafon of the aftringent quality while they are red, and before they bee ripe, for fore mouthes and throats, or the like, whereunto alfo the Syrup, called Diamoron, is effectuall.

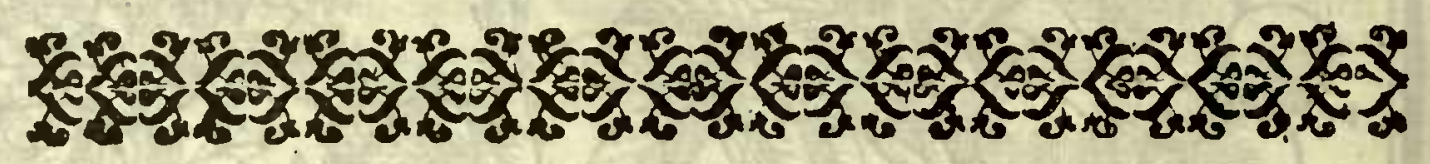

\section{Corollarium.}

A COROLLAR I E

To this Orchard.

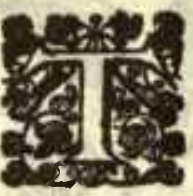

Here are certaine other trees that beare no fruit fit to bee eaten, which yet are often feene planted in Orchards, and other fit and conuenient places about an houfe, whereof fome are of efpeciall vfe, as the Bay tree \& cc. others for their beauty and fhadow are fit for walkes or arbours; fome being euer green are moft fit for hedge-rowes; and fome others more for their raritie then for any other great vfe, whereof I thought good to entreat apart by themfelues, and bring them after the fruit trees of this Orchard, as an ornament to accomplifh the fame.

\section{Laurus. The Bay tree.}

$\mathrm{T}$ Here are to bee reckoned vp fiue kindes of Bay trees, three whereof haue been entreated of in the firft part, a fourth wee will only bring here to your confideration, which is that kinde that is vfually planted in euery mans yard or orchard, for their vfe throughout the whole land, the other we will leaue to bee confidered of in that place is fit for it.

The Bay tree rifeth vp oftentimes to carry the face of a tree of a meane bigneffe in our Countrey (although much greater in the hoter) and oftentimes fhooteth vp with many fuckers from the roote, fhewing it felfe more like to a tall thrubbe or hedgebufh, then a tree, hauing many branches, the young ones whereof are fometimes reddifh, but moft vfually of a light or frefh greene colour, when the ftemme and elder boughes are couered with a darke greene barke: the leaues are fomewhat broad, and long pointed as it were at both the ends, hard and fometimes crumpled on the edges, of a darke greene colour aboue, and of a yellowinh greene vnderneath, in fmell fweet, in tafte bitter, and abiding euer greene: the flowers are yellow and moflie, which turne into berries that are a little long as well as round, whofe fhell or outermoft peele is greene at the firft, and blacke when it is ripe; wherein is contained an hard bitter kernell, which cleaueth in two parts.

The Vfe of Bayes.

The Bay leaues are of as neceffary vfe as any other in Garden or Orchard; for they ferue both for pleafure and profit, both for ornament and for vfe, both for honeft Ciuill vies, and for Phyficke, yea both for the ficke and for the found, both for the liuing and for the dead: And fo much might be faid of this one tree, that if it were all told, would as well weary the Reader, as the Relater: but to explaine my felfe; It ferueth to adorne the houfe of God as well as of man: to procure warmth, comfort and ftrength to the limmes of men and women, by bathings and annoyntings outward, and by drinkes \&c. inward to the ftomacke, and other parts: to feafon veffels \&c. wherein are preferued our meates, as well as our drinkese to crowne or en- 
circle as with a garland, the heads of the liuing, and to fticke and decke forth the bodies of the dead: fo that from the cradle to the graue we haue ftill vfe of it, we haue ftill neede of it.

The berries likewife ferue for ftitches inward, and for paines outward, that come of cold eyther in the ioynts, finewes, or other places.

\section{Laurea Cerafus, fuue Laurus Virginiana. The Virginian Bay, or Cherry Baye.}

7 His Virginian (whether you will call it a Baye, or a Cherrie, or a Cherrie Bay, I leaue it to euery ones free will and iudgement, but yet I thinke I may as well call it a Bay as others a Cherrie, neither of them being anfwerable to the tree, which neyther beareth fuch berries as are like Cherries, neither beareth euer greene leaues like the Bay: if it may therefore bee called the Virginia Cherry Bay, for a diftinction from the former Bay Cherry that beareth faire blacke Cherries, it will more fitly agree thereunto, vntill a more proper may be impofed) rifeth vp to be a tree of a reafonable height, the ftemme or bodie thereof being almoft as great as a mans legge, preading forth into diuers armes or boughes, and they againe into diuers fmall branches, whereon are fet without order diuers faire broade greene leaues, fomewhat like vnto the former Bay leaues, but more limber and gentle, and not fo hard in handling, broader alfo, and for the moft part ending in a point, but in many fomewhat round pointed, very finely notched or toothed about the edges, of a bitter tafte, very neere refembling the tafte of the Bay leafe, but of little or no fent at all, either greene or dryed, which fall away euery autumne, and fpring afrefh euery yeare: the bloffomes are fmall and white, many growing together vpon a long ftalke, fomewhat like the Bird Cherry bloffomes, but fmaller, and come forth at the ends of the young branches, which after turne into fmall berries, euery one fet in a fmall cup or huske, greene at the firft, and blacke when they are ripe, of the bigneffe of a fmall peafe, of a ftrong bitter tafte, and fomewhat aromaticall withall, but without any flefhy fubftance like a Cherry at all vpon it ; for it is altogether like a berry.

\section{- The Vfe of this Virginia Cherry Bay.}

Being a ftranger in our Land, and poffeffed but of a very few, I doe not heare that there hath beene any triall made thereof what properties are in it : let this therefore fuffice for this prefent, to haue thewed you the defcription and forme thereof, vntill we can learne further of his vfes.

\section{Pinus. The Pine tree.}

$\mathrm{M}$ $\mathrm{Y}$ purpore in this place is not to thew you all the diverfities of Pine trees, or of the reft that follow, but of that one kinde is planted in many places of our Land for ornament and delight, and there doth reafonably well abide: take it therefore into this Orchard, for the raritie and beautie of it, though we haue little other vfe of it.

The Pine tree groweth with vs, though flowely, to a very great height in many places, with a great ftraight bodie, couered with a grayifh greene barke, the younger branches are fet round about, with very narrow long whitinh greene leaues, which fall away from the elder, but abide on the younger, being both winter and fummer alwaies greene. It hath growing in fundry places on the branches, certaine great hard wooddy clogs (called of fome apples, of others nuts) compofed of many hard wooddy fcales, or tuberous knobs, which abide for the moft part alwaies greene in our Countrey, and hardly become brownifh, as in other Countries, where they haue more heat and comfort of the Sun, and where the fcales open themfelues; wherein are contained white long and round kernels, very fweete while they are frefh, but quickely growing oylely and rancide. 


\section{The Vfe of the Pine apples and kernels.}

The Cones or Apples are vfed of diuers Vintners in this City, being painted, to expreffe a bunch of grapes, whereunto they are very like, and are hung vp in their bufhes, as alfo to faften keyes vnto them, as is feene in many places.

The kernels within the hard thels, while they are frefh or newly taken out, are vfed many waies, both with Apothecaries, Comfit-makers, and Cookes: for of them are made medicines, good to lenifie the pipes and paffages of the lungs and throate, when it is hoarfe. Of them are made Comfits, Paftes, Marchpanes, and diuers other fuch like: And with them a cunning Cooke can make diuers. Keck thofes for his Mafters table.

Matthiolus.commendeth the water of the greene apples diftilled, to take away the wrinkles in the face, to abate the ouer-fwelling breafts of Maidens, by fomenting them after with linnen clothes, wet in the water; and to reftore fuch as are rauifht into better termes.

\section{Abies. The Firre tree.}

T He Firre tree groweth naturally, higher then any other tree in thefe parts of Chriftendome where no Cedars grow, and euen equalling or ouer-topping the Pine : the ftemme or bodie is bare without branches for a great height, if they bee elder trees, and then branching forth at one place of the bodie foure wayes in manner of a croffe, thofe boughes againe hauing two branches at euery ioynt, on which are fet on all, fides very thicke together, many fmall narrow, long, hard whitifh greene leaues, and while they are young tending to yellowneffe, but nothing fo long or hard or Marpe pointed as the Pine tree leaues, growing fmaller and thorter to the end of the branches: the bloomings are certaine fmall long fcaly catkins, of a yellowirh colour, comming forth at the ioynts of the branches, which fall away: the cones are fmaller and longer then of the Pine tree, wherein are fmall three fquare feede contained, not halfe fo big as the Pine kernels.

\section{The 'Vfe of the Firre tree.}

The vfe of this tree is growne with vs of late daies to bee more frequent for the building of houfes then euer before: for hereof (namely of Deale timber and Deale boords) are framed many houfes, and their floores, without the helpe of any other timber or boord of any other tree almoft; as alfo for many other workes and purpofes. The yellow Roffen that is vfed as well to make falues as for many other common vfes, is taken from this tree, as the Pitch is both from the Pitch and Pine trees, and is boyled ito make it to bee hard, but was at the firft a yellow thin cleere Turpentine, and is that beft fort of common Turpentine is altogether in vfe with $\mathrm{vs}$, as alfo another more thicke, whitifh, and troubled, both which are vfed in falues, both for man and beaft (but not inwardly as the cleere white Venice T.urpentine is) and ferueth both to draw, cleanfe and heale. Dodonæus feemeth to fay, that the cleere white Turpentine, called Venice Turpentine, is drawn from the Firre : but Matthiolus confuteth that opinion, which Fulfius alfo held before him.

\section{Ilex arbor. The euer-greene Oake.}

T He Ilex or euer-greene Oake rifeth in time to be a very great tree, but very long and flow in growing (as is to be feene in the Kings priuy Garden at Whitehall, growing iuft:againft the backe gate that openeth into the way going to Weftminfter, and in fome other places) fpreading many fair large great armes and branches, whereon are fet fmall and hard greene leaues, fomewhat endented or cornered, and 


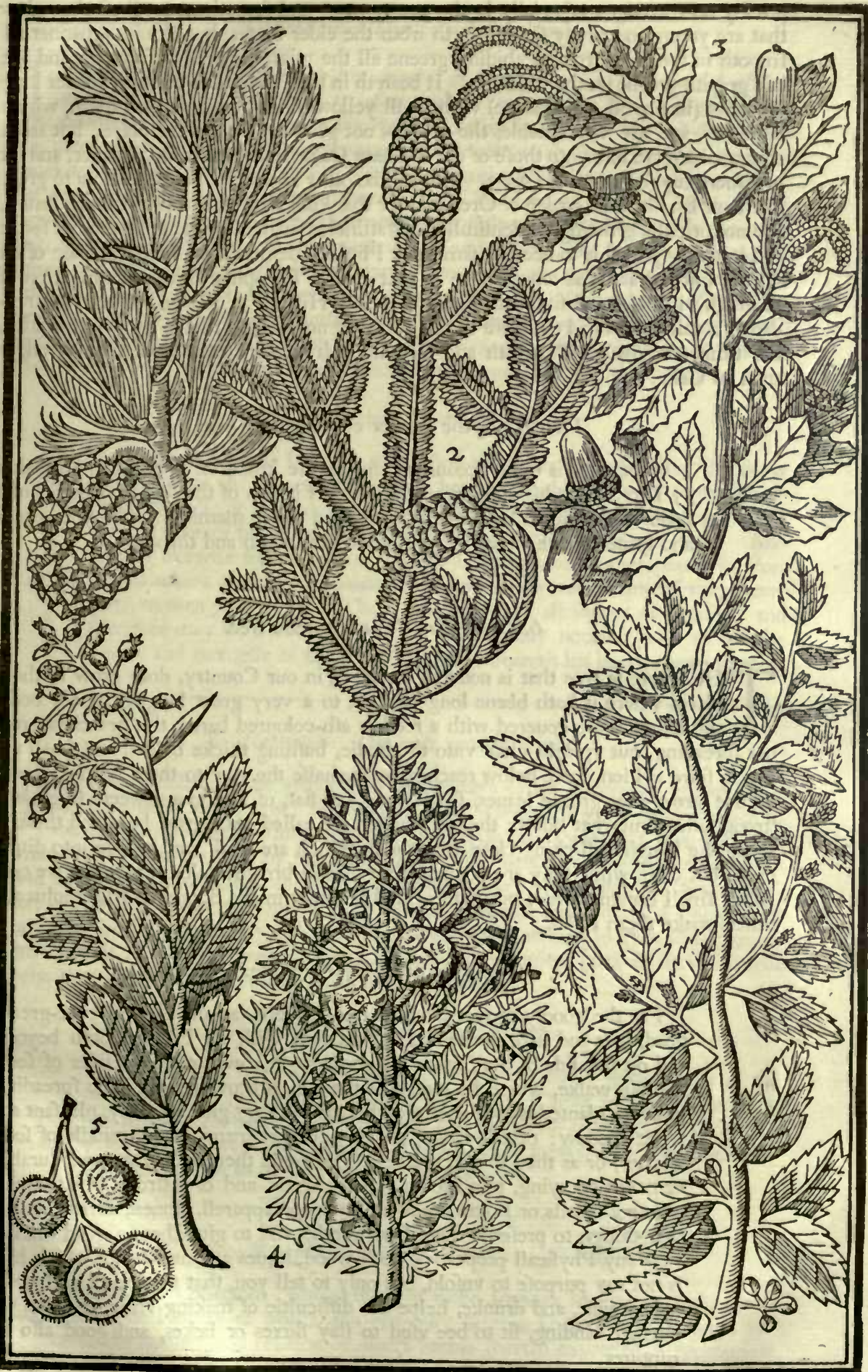

I Pinus. The Pine tree. 2 Abies. The Firre tree. 3 Ilex. The euer greene Oake. 4 Cupreffus. The Cipreffe tree. $\mathrm{G}_{4}$ 
prickly on the edges, efpecially in the young trees, and fometimes on thofe branches that are young and newly fprung forth from the elder rootes, but elfe in a manner all fmooth in the elder growne, abiding greene all the winter as well as fummer, and are of a grayifh greene on the vnderfide. It beareth in the fpring time certaine flender long branches (like as other Okes doe) with fmall yellowifh moflie flowers on them, which fall away, and are vnprofitable, the acornes not growing from thofe places, but from others which are like vnto thofe of our ordinary Oake, but fmaller and blacker, and fet in a more rugged huske or cuppe. This and no other kinde of Ilex doe I know to grow in all our land in any Garden or Orchard : for that kind with long and narrower leaues, and not prickly, growing fo plentifully as Matthiolus faith in Tufcane, I haue not feen: and it is very probable to bee the fame that Plinie remembreth to haue the leafe of an Oliue; but not as fome would haue it, that Smilax Theophraftus maketh mention of in his third Booke and fixteenth Chapter of his Hiftorie of Plants, which the Arcadians fo called, and had the leafe of the Ilex, but not prickly: for Theophraftus faith, the timber of Smilax is fmooth and foft, and this of the Ilex is harder, and ftronger then an Oake.

The Vfe of the Ilex or euer-greene Oake.

Seeing this is to be accounted among the kindes of Oake (and all Oakes by Diofcorides his opinion are binding) it is alfo of the fame qualitie, but a little weaker, and may ferue to ftrengthen weake members. The young tops and leaues are alfo vfed in gargles for the mouth and throate.

\section{Cuprefus. The Cypreffe tree.}

$\mathrm{T}$ He Cypreffe tree that is nourfed vp by vs, in our Country, doth grow in thore places where it hath beene long planted, to a very great height, whofe bodie and boughes are couered with a reddifh afh-coloured bark; the branches grow not fpreading, but vpright clofe vnto the bodie, bufhing thicke below, and fmall vpwards, fpire farhion, thofe below reaching neere halfe the way to them aboue, whereon doe grow euer greene leaues, fmall, long and flat, of a refinous fweete fmell, and ftrong tafte, fomewhat bitter: the fruit, which are called nuts, grow here and there among the boughes, fticking clofe vnto them, which are fmall, and clouen into diuers parts, but clofe while they are young, of a ruffetifh browne colour; wherein are contained fmall browne feede, but not fo fmall as motes in the Sunne, as Matthiolus and others make them to be.

The Vfe of the Cypreffe tree.

For the goodly proportion this tree beareth, as alfo for his euer-greene head, it is and hath beene of great account with all Princes, both beyond, and on this fide of the Sea, to plant them in rowes on both fides of fome fpatious walke, which by reafon of their high growing, and little fpreading, muft be planted the thicker together, and fo they giue a goodly, pleafant and fweet fhadow: or elfe alone, if they haue not many, in the middle of fome quarter, or as they thinke meete. The wood thereof is firme and durable, or neuer decaying, of a brown yellow colour, and of a ftrong fweete fmell, whereof Cheits or Boxes are made to keepe apparell, linnen, furres, and other things, to preferue them from moths, and to giue them a good fmell.

Many Phyficall properties, both wood, leaues and nuts haue, which here is not my purpore to vnfold, but only to tell you, that the leaues being boyled in wine, and drunke, helpe the difficultie of making vrine, and that the nuts are binding, fit to bee vfed to ftay fluxes or laskes, and good alfo for ruptures. 


\section{Arbutus. The Strawberry tree.}

T He Strawberry tree groweth but Mlowly, and rifeth not to the height of any great tree, no not in France, Italy, or Spaine: and with vs the coldneffe of our country doth the more abate his vigour, fo that it feldome rifeth to the height of a man: the barke of the body is rough, and fmooth in the younger branches: the leaues are faire and greene, very like vnto Baye leaues, finely dented or fnipped about the edges, abiding alwayes greene thereon both Winter and Summer: the flowers come forth at the end of the branches vpon long ftalkes, not cluftering thicke together, but in long bunches, and are fmall, white, and hollow, like a little bottle, or the flower of Lilly Conually, which after turne into rough or rugged berries, moft like vnto Strawberries (which hath giuen the name to the tree) fornewhat reddin when they are ripe, of a harfh tafte, nothing pleafant, whercin are contained many fmall feedes: It hardly bringeth his fruit to ripeneffe in our countrey; for in their naturall places they ripen not vntill Winter, which there is much milder then with vs.

The Vfe of the Strawberry tree.

Amatus Lufitanus I thinke is the firf that euer recorded, that the water diftilled from the leaues and flowers hereof, thould bee very powerfull againft the plague and poyfons: for all the ancient Writers doe report, that the fruit hereof being eaten, is an enemy to the Ptomacke and head. And Clufius likewife fetteth downe, that at Lifhbone, and other places in Portingall where they are frequent, they are chiefly eaten, but of the poorer fort, women and boyes. They are comewhat aftringent or binding, and therefore may well ferue for fluxes. It is chiefly nourfed with vs for the beauty and rareneffe of the tree; for that it beareth his leaues alwayes green.

\section{Alaternus. The euer greene Priuet.}

$\mathrm{T}$ He tree which we haue growing in our country called Alaternus, groweth not to be a tree of any height; but abiding lowe, fpreadeth forth many branches, whereon are fet diuers fmall and hard greene leaues, fomewhat round for the forme, and endented a little by the edges: it beareth many fmall whitifh greene flowers at the ioynts of the ftalkes, and fetting on of the lower leaues cluftering thicke together, which after turne into Imall blacke berries, wherein are contained many fmall graines or feedes: the beauty and verdure of thefe leaues abiding fo frefh all the yeare, doth caufe it to be of the greater refpect ; and therefore findeth place in their Gardens onely, that are curious conferuers of all natures beauties.

The Vfe of the euer greene Priuet.

It is feldome vfed for any Phyficall property, neither with vs, nor in the places where it is naturall and plentifull : but as Clufius reporteth, hee learned that the Portingall Fifhermen do dye their nets red with the decoction of the barke hereof, and that the Dyers in thofe parts doe vfe the finall peeces of the wood to ftrike a blackifh blew colour.

\section{Celaftrus Theophrafii Clufio. Clufius his Celaftrus.}

Lthough the Collectour (who is thought to be Ioannes Molineus of the great Herball or Hiftory of plants, and generally bearing Dalefchampius name, becaufe the finding and relation of diuers herbes therein expreffed, is appropriate to him, and printed at Lyons) of all our moderne Writers doth firft of all others appoint the Celaftrus, whereof Theophraftus onely among all the ancient Writers of 
plants maketh mention, to be the firft Alaternus that Clufius hath fet forth in his Hiftory of rarer plants: yet I finde, that Clufius himfelfe before his death doth appropriate that Celaftrus of Theophraftus to another plant, growing in the Garden at Leyden, which formerly of diuers had beene taken to be a kinde of Laurus Tinus, or the wilde Baye; but he impugning that opinion for diuers refpects, decyphreth out that Leyden tree in the fame manner that I doe : and becaufe it is not onely faire, in bearing his leaues alwayes greene, but rare alfo, being nourfed vp in our Land in very few places, but principally with a good old Lady, the widow of Sir Iohn Leufon, dwelling neere Rochefter in Kent; I thought it fit to commend it for an ornament, to adorne this our Garden and Orchard. It groweth vp to the height of a reafonable tree, the body whereof is couered with a darke coloured barke, as the elder branches are in like manner; the younger branches being greene, whereon are fet diuers leaues thicke together, two alwayes at a ioynt, one againft another, of a fad but faire greene colour on the vpperfide, and paler vnderneath, which are little or nothing at all fnipped about the edges, as large as the leaues of the Laurus Tinus, or wilde Baye tree: at the end of the young branches breake forth between the leaues diuers fmall ftalkes, with foure or fiue flowers on each of them, of a yellowifh greene colour, which turne into fmall berries, of the bigneffe of blacke Cherries, greene at the firft, and red when they begin to be ripe, but growing blacke if they hang too long vpon the branches, wherein is contained a hard fhell, and a white hard kernell within it, couered with a yellowifh skin. This abideth (as I faid before) with greene leaues as well Winter as Summer; and therefore fitteft to be planted among other of the fame nature, to make an euer greene hedge.

The Vfe of Clufius his Celaftrus.

Being fo great a ftranger in this part of the Chriftian world, I know none hath made tryall of what property it is, but that the tafte of the leaues is fomewhat bitter.

Io. Pyracantha. The euer greene Hawthorne, or prickly Corall tree.

$\mathrm{T}$ His euer greene fhrubbe is fo fine an ornament to a Garden or Orchard, either to be nourfed vp into a fmall tree by it felfe, by pruining and taking away the fuckers and vnder branches, or by fuffering it to grow with fuckers, thicke and plafhing the branches into a hedge, for that it is plyable to be ordered either way; that I could not but giue you the knowledge thereof, with the defcription in this manner. The younger branches are couered with a fmooth darke blewifh greene barke, and the elder with a more afh coloured, thicke fet with leaues without order, fome greater and others fmaller, fomewhat like both in forme and bigneffe vnto the leaues of the Barberry tree, but fomewhat larger, and more fnipt about the edges, of a deeper green colour alfo, and with fmall long thornes fcattered here $\&$ there vpon the branches: the flowers come forth as well at the ends of the branches, as at diuers places at the ioynts of the leaues, ftanding thicke together, of a pale whitifh colour, a little dafht ouer with a thew of blufh, confifting of fiue leaues a peece, with fome fmall threads in the middle, which turne into berries, very like vnto Hawthorne berries, but much redder and dryer, almoft like polifhed Corall, wherein are contained foure or fiue fmall yellowifh white three fquare feede, formewhat fhining. It is thought to be the Oxyacantha of Diof corides; but feeing Diofcorides doth explaine the forme of the leafe in his Chapter of Medlars, which he concealed in the Chapter of Oxyacantha, it cannot be the fame: for Mespilus Anthedon of Theophraftus, or Aronia of Diofcorides, hath the leafe of Oxyacantha, as Diofcorides faith, or of Smalladge, as Theophraftus, which cannot agree to this Thorne; but doth moft liuely delineate out our white Thorne or Hawthorne, that now there is no doubt, but that Oxyacantha of Diofcorides is the Hawthorne tree or buh.

The Vfe of this Corall tree.

Although Lobel maketh mention of this tree to grow both in Italy, and Prouince 


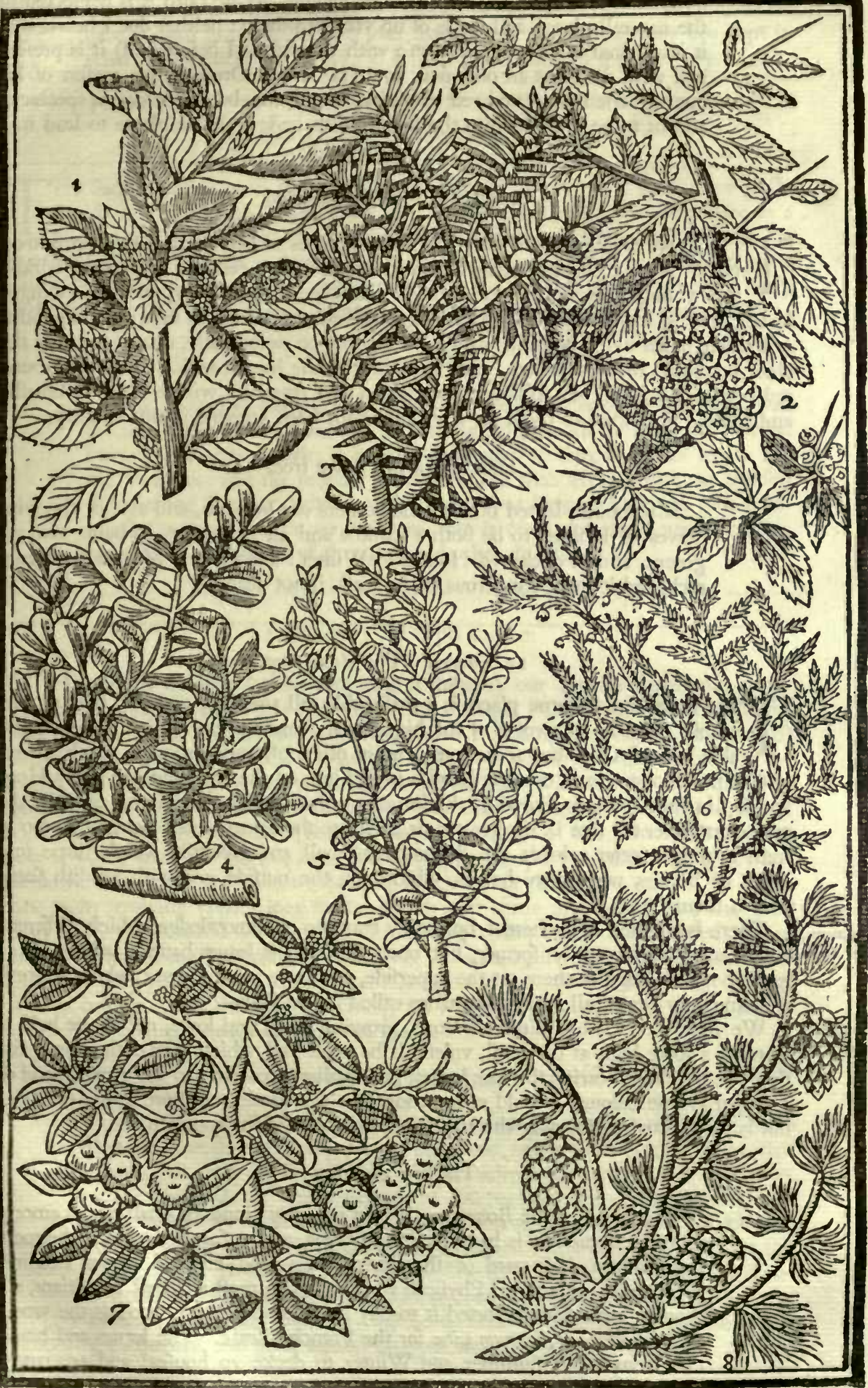

Cilaftrus Theophrafli Clufio. Clulius his Celårus, 2 Pyracaulha. The euer green prickly Corall tree. 3 Tasws. The Yewe tree. 4 Buxws arbor. The Boxe tree. 
Prouence in France, in fome of their hedges, yet he faith it is neglected in the naturall places, and to be of no vfe with them: neither doe I heare, that it is applyed to any Phyficall vfe with vs, but (as I before faid) it is preferued with diuers as an ornament to a Garden or Orchard, by reafon of his euer greene leaues, and red berries among them, being a pleafant fpectacle, and fit to be brought into the forme of an hedge, as one pleafe to lead it.

\section{I. Taxus. The Yewe tree.}

$7 \mathrm{He}$ Yewe tree groweth with vs in many places to bee a reafonable great tree, but in hoter countries much bigger, couered with a reddifh gray fcaly barke; the younger branches are reddifh likewife, whereon grow many winged leaues, that is, many narrow long darke greene leaues, fet on both fides of a long ftalke or branch, neuer dying or falling away, but abiding on perpetually, except it be on the elder boughes: the flowers are fmall, growing by the leaues, which turne into round red berries, like vnto red Afparagus berries, in tafte fweetifh, with a little bitterneffe, and caufing no harme to them for any thing hath been knowne in our country.

\section{The Vfe of the Yewe tree.}

It is found planted both in the corners of Orchards, and againft the windowes of Houfes, to be both a fhadow and an ornament, in being alwayes greene, and to decke vp Houfes in Winter : but ancient Writers have euer reckoned it to be dangerous at the leaft, if not deadly.

\section{I2. Buxus. The Boxe tree.}

T He Boxe tree in fome places is a reafonable tall tree, yet growing flowly; the trunke or body whereof is of the bigneffe of a mans thigh, which is the biggeft that euer I faw: but fometimes, and in other places it groweth much lower, vfually not aboue a yard, or a yard and a halfe high, on the backe fides of many Houfes, and in the Orchards likewife: the leaues are fmall, thicke and hard, and ftill the greater or leffer the tree is, the greater or leffer are the leaues, round pointed, and of a frefh thining greene colour: the flowers are fmall and greenifh, which turne into heads or berries, with foure hornes, whitifh on the outfide, and with reddifh feede within them.

Buxus aureus. There is another kinde hereof but lately come to our knowledge, which differeth Gilded Boxe. not in any thing from the former, but onely that all the leaues haue a yellow lift or gard about the edge of them on the vpperfide, and none on the lower, which maketh it feeme very beautifull; and is therefore called gilded Boxe.

Buxus humilis. We haue yet another kinde of Boxe, growing fmall and lowe, not aboue halfe a Dwarfe Boxe. foote, or a foote high at the moft, vnleffe it be neglected, which then doth grow a little more (hrubby, bearing the like leaues, but fmaller, according to the growth, and of a deeper greene colour: I could neuer know that this kinde euer bore flower or feede, but is propagated by lipping the roote, which encreafeth very much.

\section{The Vfe of Boxe.}

The wood of the Boxe tree is vfed in many kindes of fmall works among Turners, becaufe it is hard, clofe, and firme, and as fome haue faid, the roots much more, in regard of the diuers waues and crooked veines running through it. It hath no Phyficall vfe among the moft and beft Phyfitians, although fome haue reported it to ftay fluxes, and to be as good as the wood of Guaiacum, or Lignum vite for the French difeafe. The leaues and branches ferue both Summer and Winter to decke vp houfes; and are many times giuen to horfes for the bots.

The lowe or dwarfe Boxe is of excellent vfe to border vp a knot, or the 
long beds in a Garden, being a maruailous fine ornament thereunto, in regard it both groweth lowe, is euer greene, and by cutting may bee kept in what maner euery one pleafe, as I haue before fpoken more largely.

\section{Sabina. The Sauine tree or bufh.}

$\mathrm{T}$ He Sauine tree or bufh that is moft vfuall in our country, is a fmall lowe bufh, not fo high as a man in any place, nor fo bigge in the ftemme or trunke as a mans arme, with many crooked bending boughes and branches, whereon are fet many fmall, fhort, hard, and prickly leaues, of a darke green colour, frefh and green both Winter and Summer: it is reported, that in the naturall places it beareth fmall blacke berries, like vnto Iuniper, but with vs it was neuer knowne to beare any.

The Vfe of Sauine.

It is planted in out-yards, backfides, or voide places of Orchards, as well to caft clothes thereon to dry, as for medicines both for men and horfes: being made into an oyle, it is good to annoint childrens bellies for to kill the Wormes: and the powder thereof mixed with Hogs greafe, to annoint the running fores or fcabs in their heads; but beware how you giue it inwardly to men, women, or children. It is often put into horfes drenches, to helpe to cure them of the bots, and other difeafes.

\section{Paliurus. Chrifts thorne.}

7 His thorny fhrubbe (wherewith as it is thought, our Sauiour Chrift was crowned, becaufe as thofe that haue trauelled through Paleftina and Iudæa, doe report no other thorne doth grow therein fo frequent, or fo apt to be writhed) rifeth in fome places to a reafonable height, but in our country feldome exceedeth the height of a man, bearing many flender branches, full of leaues, fet on either fide thereof one by one, which are fomewhat broad and round, yet pointed, and full of veines, thicke fet alfo with fmall thornes, euen at the foote of euery branch, and at the foote of euery leafe one or two, fome ftanding vpright, others a little bending downe: the flowers are fmall and yellow, ftanding for the moft part at the end of the branches, many growing vpon a long ftalke, which after turne into round, flat, and hard fhelly fruit, yet couered with a foft flefhy skinne, within which are included two or three hard, fmall, and browne flat feeds, lying in feuerall partitions. The leaues hereof fall away euery yeare, and fpring forth afrefh againe the next May following. The rarity and beauty of this thrubbe, but chiefly (as I thinke) the name hath caufed this to be much accounted of with all louers of plants.

\section{The Vfe of Chrifts thorne.}

Wee haue fo few of thefe fhrubbes growing in our country, and thofe that are, doe, for any thing I can vnderftand, neuer beare fruit with vs; that there is no other vfe made hereof then to delight the owners: but this is certainly receiued for the Paliurus of Diofcorides and Theophraftus, and thought alfo by Matthiolus to be the very true Rhamnus tertius of Diofcorides. Matthiolus alfo feemeth to contradict the opinion is held by the Phyfitians of Mompelier, and others, that it cannot be the Paliurus of Theophraftus. It is held to be effectuall to helpe to breake the ftone, both in the bladder, reines, and kidneyes: the leaues and young branches haue an aftringent quality, and good againft poyfons and the bitings of ferpents. 
15. Larix. The Larch tree.

$7 \mathrm{He}$ Larch tree, where it naturally groweth, rifeth vp to be as tall as the Pine or Firre tree, but in our Land being rare, and nourfed vp but with a few, and thofe onely louers of rarities, it groweth both flowly, and becommeth not high: the barke hereof is very rugged and thicke, the boughes and branches grow one aboue another in a very comely order, hauing diuers fmall yellowifh knobs or bunches fet thereon at feuerall diftances; from whence doe yearely thoote forth many fmall, long, and narrow fmooth leaues together, both fhorter and fmaller, and not fo hard or fharpe pointed as either the Pine or Firre tree leaues, which doe not abide the Winter as they doe, but fall away euery yeare, as other trees which thed their leaues, and gaine frefh euery Spring: the bloffomes are very beautifull and delectable, being of an excellent fine crimfon colour, which ftanding among the greene leaues, allure the eyes of the beholders to regard it with the more defire : it alfo beareth in the naturall places (but not in our Land that I could heare) fmall foft cones or fruit, fomewhat like vnto Cypreffe nuts, when they are greene and clofe.

The Vfe of the Larch tree.

The coles of the wood hereof (becaufe it is fo hard and durable as none more) is held to be of mort force being fired, to caufe the Iron oare to melt, which none other would doe fo well. Matthiolus contefteth againft Fuchfius, for deeming the Venice Turpentine to be the liquid Roffen of the Firre tree, which he affureth vpon his owne experience and certaine knowledge, to be drawne from this Larch tree, and none other ; which cleere Turpintine is altogether vfed inwardly, and no other, except that of the true Turpintine tree, and is very effectuall to cleanfe the reines, kidneyes, and bladder, both of grauell and the ftone, and to prouoke vrine: it is alfo of efpeciall property for the gonorrhaa, or running of the reines, as it is called, with fome powder of white Amber mixed therewith, taken for certaine dayes together. Taken alfo in an Electuary, it is fingular good for to expectorate rotten flegme, and to helpe the confumption of the lungs. It is vfed in plaifters and falues, as the beft fort of Turpintine. The Agaricke that is vfed in phyficke, is taken from the bodies and armes of this tree. And Matthiolus doth much infift againft Brafauolus, that thought other trees had produced Agaricke, affirming them to be hard Fungi, or Mufhroms (fuch as wee call Touch-wood) wherwith many vfe to take fire, Atrooke thereinto from fteele.

\section{Tilia. The Line or Linden tree.}

T Here are two forts of Line trees, the male and the female; but becaufe the male is rare to be feene, and the female is more familiar, I will onely giue you the defcription of the female, and leaue the other.

The female Line tree groweth exceeding high and great, like vnto an Elme, with many large fpreading boughes, couered with a fmooth barke, the innermoft being very plyant and bending from whence come fmaller branches, all of them fo plyable, that they may bee led or carried into any forme you pleafe : the leaues thereon are very faire, broad, and round, fomewhat like vnto Elme leaues, but fairer, fmoother, and of a frefher greene colour, dented finely about the edges, and ending in a tharpe point : the flowers are white, and of a good fmell, many ftanding together at the top of a talke, which runneth all along the middle ribbe of a fmall long whitifh leafe; after which come fmall round berries, wherein is contained fmall blackifh feede: this tree is wholly neglected by thofe that have them, or dwell neere them, becaufe they fuppofe it to be fruitleffe, in regard it beareth chaffie huskes, which in many places fall away, without giuing ripe feede. 


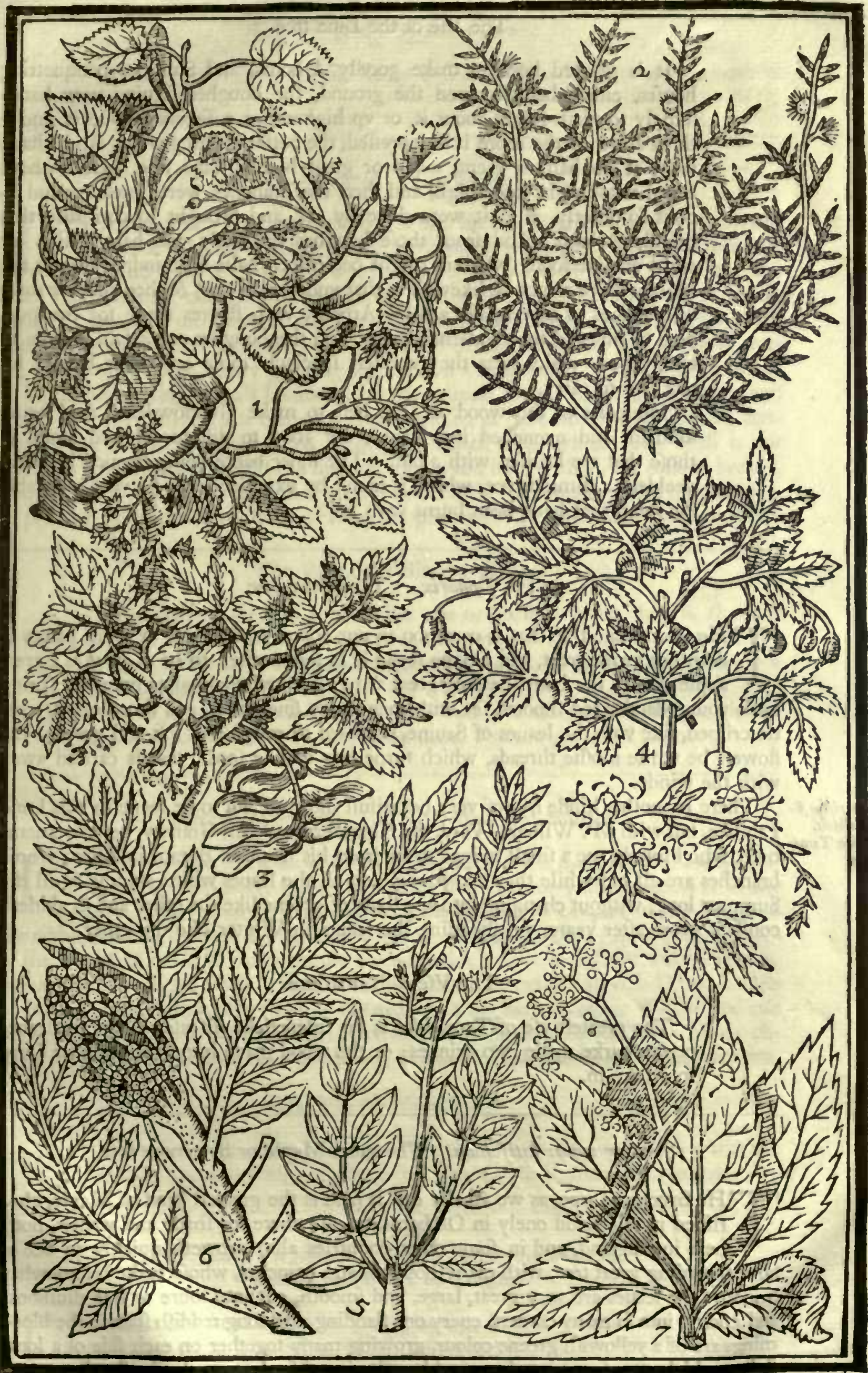

1 Tilia famina. The Line or Linden tree. 
The Vfe of the Line tree.

It is planted both to make goodly Arbours, and Summer banquetting houfes, either belowe vpon the ground, the boughes feruing very handfomely to plafh round about it, or vp higher, for a fecond aboue it, and a third alfo: for the more it is depreffed, the better it will grow. And I haue feene at Cobham in Kent, a tall or great bodied Line tree, bare without boughes for eight foote high, and then the branches were fpread round about fo orderly, as if it were done by art, and brought to compaffe that middle Arbour: And from thofe boughes the body was bare againe for eight or nine foote (wherein might bee placed halfe an hundred men at the leaft, as there might be likewife in that vnderneath this) \& then another rowe of branches to encompaffe a third Arbour, with ftayres made for the purpofe to this and that vnderneath it: vpon the boughes were laid boards to tread vpon, which was the goodlieft fpectacle mine eyes euer beheld for one tree to carry.

The coles of the wood are the beft to make Gunpowder. And being kindled, and quenched in vinegar, are good to diffolue clotted bloud in thofe that are bruifed with a fall. The inner barke being fteeped in water yeeldeth a flimie iuyce, which is found by experience, to be very profitable for them that haue been burnt with fire:

\section{Tamarix. Tamariske tree.}

\section{T}

He Tamariske tree that is common in our country, although in fome places it doth not grow great, yet I haue feene it in fome other, to be as great as a great apple tree in the body, bearing great arms; from whofe fmaller branches fpring forth young flender red fhootes, fet with many very fine, fmall, and hort leaues, a little crifped, like vnto the leaues of Sauine, not hard or rough, but foft and greene: the flowers be white moffie threads, which turne into dounie feede, that is carried away with the winde.

There is another kinde hereof very beautifull and rare, not to be feene in this Land I thinke, but with $\mathrm{M}^{\mathrm{r}}$. William Ward, the Kings feruant in his Granary, before remembred, who brought me a fmall twigge to fee from his houfe at Boram in Effex, whofe branches are all red while they are young, and all the leaues white, abiding fo all the Summer long, without changing into any thew of greene like the other and fo abideth conftant yeare after yeare, yet fhedding the leaues in Winter like the other.

\section{The Vfe of Tamariske.}

The greateft vfe of Tamariske is for fpleneticke difeafes, either the leaues or the barke made into drinkes; or the wood made into fmall Cans or Cups to drinke in.

\section{Acer maius latifolium. The great Maple or Sycomore tree.}

T He Sycomore tree, as we vfually call it (and is the greateft kind of Maple, cherifhed in our Land onely in Orchards, or elfewhere for thade and walkes, both here in England, and in fome other countries alfo) groweth quickly to bee a faire fpreading great tree, with many boughes and branches, whofe barke is fomewhat fmooth: the leaues are very great, large, and fmooth, cut into foure or fiue diuifions, and ending into fo many corners, euery one ftanding on a long reddifh ftalke: the bloomings are of a yellowifh greene colour, growing many together on each fide of a long ftalke, which after turne into long and broad winged feede, two alwaies ftanding together on a ftalke, and bunched out in the middle, where the feed or kernell lyeth, very like vinto the common Maple growing wilde abroad, but many more together, and larger. 
The Vfe of the Sycomore tree.

It is altogether planted for fhady walkes, and hath no other vfe with vs that I know.

19. Nux Veficaria. The bladder Nut.

His tree groweth not very high, but is of a meane ftature, when it is preferued and pruined to grow vpright, or elfe it fhooteth forth many twigges from the rootes, and fo is fit to plant in a hedge rowe, as it is vfed in fome places : the body and armes are couered with a whitifh greene barke: the branches and leaues on them are like vnto the Elder, hauing three or fiue leaues fet one againft another, with one of them at the end, each whereof is nicked or dented about the edges: the flowers are fweete and white, many growing together on a long ftalke, hanging downeward, in forme refembling a fmall Daffodill, hauing a fmall round cup in the middle, and leaues about it : after which come the fruit, inclofed in ruffetifh greene bladders, containing one or two brownifh nuts, leffer then Hafell nuts, whofe outer thell is not hard and woody, like the fhell of a nut, but tough, and hard withall, not eafie to breake, within which is a greene kernell, fweetifh at the firft, but lothfome afterwards, ready to procure cafting, and yet liked of fome people, who can well endure to eate them.

\section{The Vfe of the Bladder Nut.}

The greateft vfe that I know the tree or his fruit is put vnto, is, that it is receiued into an Orchard, either for the rarity of the kinde, being fuffered to grow into a tree, or (as I faid before) to make an hedge, being let grow into fuckers.

Some Quackfaluers haue vfed thefe nuts as a medicine of rare vertue for the ftone, but what good they haue done, I neuer yet could learne.

\section{Rhus Myrtifolia. The Mirtle leafed Sumach.}

$T$

His lowe fhrubbe groweth feldome to the height of a man, hauing many flender branches, and long winged leaues fet thereon, euery one whereof is of the bigneffe of the broad or large Mirtle leafe, and fet by couples all the length of the ribbe, running through the middle of them. It beareth diuers flowers at the tops of the branches, made of many purple threads, which turne into fmall blacke berries, wherein are contained fmall, white, and rough feed, fomewhat like vnto Grape kernels or ftones. This vfeth to dye down to the ground in my Garden euery Winter, and rife vp again euery Spring, whether the nature thereof were fo, or the coldneffe of our climate the caufe thereof, Iam not well affured. It is alfo rare, and to be feen but with a few.

The Vfe of this Sumach.

It is vfed to thicken or tanne leather or hides, in the fame manner that the ordinary Sumach doth; as alfo to ftay fluxes both in men and women.

21. Rhus Virginiana. The Virginia Sumach, or Buckes horne tree of Virginia.

This ftrange tree becommeth in fome places to bee of a reafonable height and bigneffe, the wood whereof is white, foft, and pithy in the middle, like vnto an Elder, couered with a darke coloured barke, fomewhat fmooth: the young branches that are of the laft yeares growth are fomewhat reddifh or browne, very foft 
and fmooth in handling, and fo like vnto the Veluet head of a Deere, that if one were cut off from the tree, and thewed by it felfe, it might foone deceiue a right good Woodman, and as they grow feeme moft like thereunto, yeelding a yellowifh milke when it is broken, which in a fmall time becommeth thicke like a gumme: the leaues grow without order on the branches, but are themfelues fet in a feemly order on each fide of a middle ribbe, feuen, nine, ten, or more on a fide, and one at the end, each whereof are fomewhat broad and long, of a darke greene colour on the vpperfide, and paler greene vnderneath, finely fnipped or toothed round about the edges: at the ends of the branches come forth long and thicke browne tufts, very foft, and as it were woolly in handling, made all of thort threads or thrums; from among which appeare many fmall flowers, much more red or crimfon then the tufts, which turne into a very fmall feede: the roote thooteth forth young fuckers farre away, and round about, whereby it is mightily encreafed.

The Vfe of this Sumach.

It is onely kept as a rarity and ornament to a Garden or Orchard, no bodie, that I can heare of, hauing made any tryall of the Phyficall properties.

\section{Vitis, feu potius Hedera Virginenfis. The Virginia Vine, or rather Iuie.}

$\mathrm{T}$

His flender, but tall climing Virginia Vine (as it was firft called; but Iuie, as it doth better refemble) rifeth out of the ground with diuers items, none much bigger then a mans thumbe, many leffe; from whence fhoote forth many long weake branches, not able to ftand vpright, vnleffe they be fuftained: yet planted neere vnto a wall or pale, the branches at feuerall diftances of the leaues will fhoote forth fmall fhort tendrels, not twining themfelues about any thing, but ending into foure, fiue, or fix, or more fmall thort and fomewhat broad clawes, which will faften like a hand with fingers fo clofe thereunto, that it will bring part of the wall, morter, or board away with it, if it be pulled from it, and thereby ftay it felfe, to climbe vp to the toppe of the higheft chimney of a houfe, being planted thereat : the leaues are crumpled, or rather folded together at the firft comming forth, and very red, which after growing forth, are very faire, large, and greene, diuided into foure, fiue, fix, or feuen leaues, ftanding together vpon a fmall foote-ftalke, fet without order on the branches, at the ends whereof, as alfo at other places fometime, come forth diuers fhort tufts of buds for flowers; but we could neuer fee them open themfelues, to fhew what manner of flower it would be, or what fruit would follow in our country : the roote fpreadeth here and there, and not very deepe.

The Vfe of this Virginian.

We know of no other vfe, but to furnifh a Garden, and to encreafe the number of rarities.

And thus haue I finifhed this worke, and furnifhed it with whatfoeuer Art and Nature concurring, could effect to bring delight to thofe that liue in our Climate, and take pleafure in fuch things; which how well or ill done, I muft abide euery ones cenfure : the iudicious and courteous I onely refpect, let Momus bite his lips, and eate his heart; and fo Farewell. 


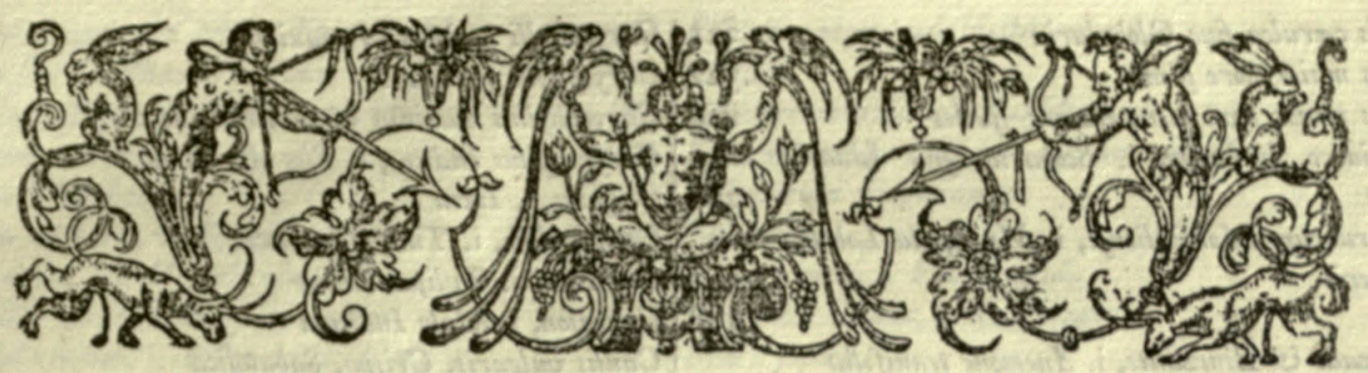

\section{Index omnium ftirpium}

\section{qux in hoc opere continentur.}

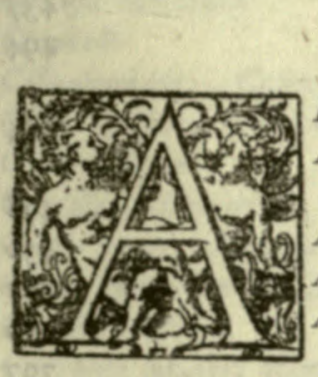

\section{A.}

\section{Acetoja}

Aconitum bacciferum, i.e. Cbriftophoriana

Aconitum fore albido

Aconitum hyemale

Aconitum luteum Ponticum

Aconitum falutiferum

Admirabilis pervana

Ethiopis

Agluophotis, i.e. Paconia

Alaternus

Albucum

Alcea Egyptia fuce Bamia

Alcea Americana

Alcea frutico/a pentaphyllea

Alcea peregrina fiue veficaria

Alifma Dodonai, i.e. Saponaria

Alifma Diofcoridis Fab. Columna, i.e. Auricula $V r / i$

Alifma fyluarum, i.e. Paralyfis

Allium

Althea frutex

Amaracus, i.e. Maiorana

Amarella, i.e. Matricaria

Amaranthus panniculis Jparfis

Amaranthus purpureus

Amaranthus tricolor

Amaranthus luteus, i.e. Heliocryfum

Ambreboi, i,e. Cyanus Orientalis

Amellus Virgilij, i.e. After Atticus Italorum

Amomum Plinij, i.e. Pfeudocap/icum Dodone:

Amygdalus

Anagyris altera, i.e. Laburnum

Anchufa

Anemone ciufque fpecies

Anethum

Angelica

Anthemis flore luteo

Anthemis Leucanthemis, i.e. Chamemelum

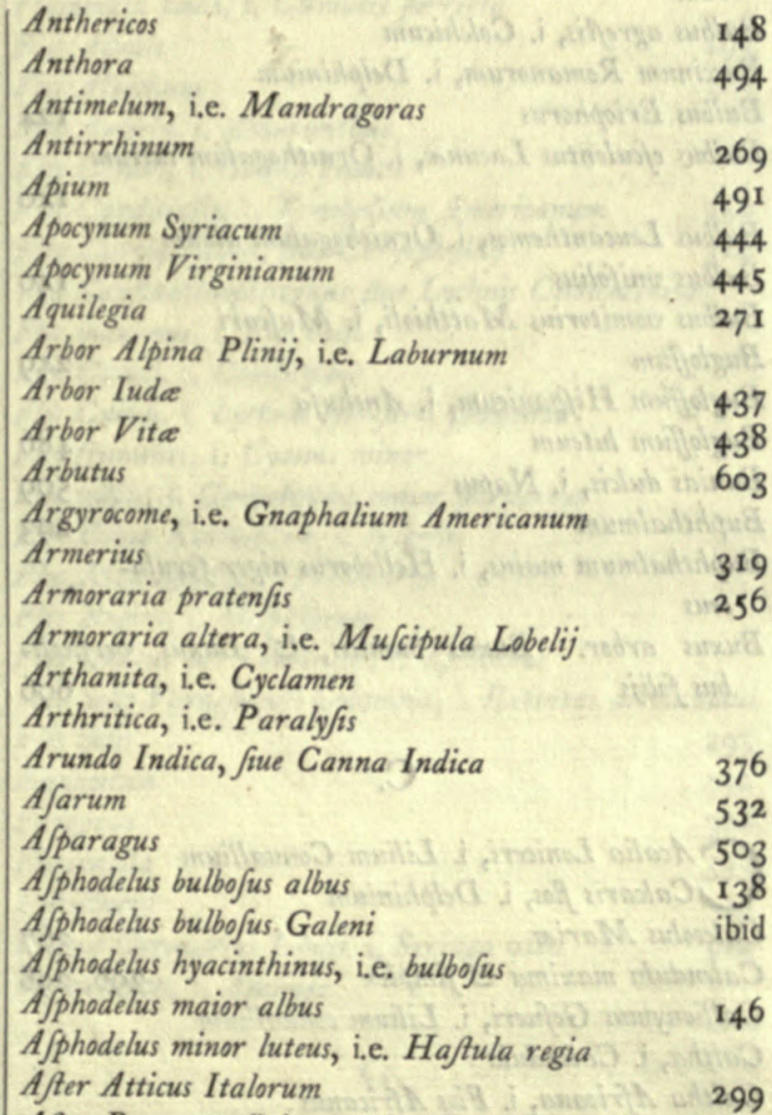

After Pervanus Columna, i.e. Battatas de Canada Attamufco, i.e. Narcifus Virginianus

Atriplex, i.e. Olus aureum

Avellana, E' Byzantina

Aurelia, i.e. Chryfocome

Auricula muris maior, i.e. Pulmonaria Gallorum

Auricula Vrfi eiufque fpecies

B.

$\mathrm{B}^{\text {Alauftium }} 430$

B Balfamina famina \&ै Balfamella $\quad 278$

Balfamita mas Es famina 482

Balfamum alpinum, i.e. Ledum Alpinum liniur 424

Bamia, i.e. Alcea Egyptia

Baptifecula, i.e. Cyanus.

Barba hirci, i.e. Tragopogon

Battatas Hifpanorum, Virginianum, \& Canadenfe

Behen rubrum, i,e. Valeriana rubra Dodonat 518 
I N D E X.

Bellis cerulea fiue Globularia

Bellis naior fore pleno

Bellis minor fore pleno ciufque species

Belvidere Italorum, i. Scoparia, fiue Linaria na

Ben rubrum Monfpelienfe, i. Mufcipula Lobelij

Berberis

Beta

Binizade E Binizante, i. Anemone tenuifolia

Blattaria

Blito de tre colori

Blitum

Bolbonach, i. Viola lunaris EO latifolice

Borrago, Borrago femtper virens

Botanaria, i. Globularia

Branca vrfina, i. Acanthus fativus

Brafjaca ciufque fpecies

Bubonium fiue Inguinalis, i. After Atticus Italorum

Bulbus agreftis, i. Colchicum

Buccinum Romanorum, i. Delphinium

Bulbus Eriophorus

Bulbus efculentus Lacuna, i. Ornithogalum luteum

Bulbus Leucanthemos, i. Ornithogalum album

Bulbus vnifolius

Bulbus vomitorius Matthioli, i. Mufcari

Buglofum

BuglofJum Hifpanicum, i. Anchufa

Buglofum luteum

Bunias dulcis, i. Napus

Buphthalmum

Buphthalmum maius, i. Helleborus niger ferulaceus

Buxus arbor. Buxus humilis, \& Buxus verficolibus falijs

\section{C.}

Acalia Loniceri, i. Lilium Conuallium Calcaris flos, i. Delphinium

Calceolus Maria

Calendula maxima Eo fimplex

Callionymus Gefneri, i. Lilium conuallium

Caltha, i. Calendula

Caltha Africana, i. Flos Africanus

Caltha paluftris fore pleno.

Camomilla vulgaris, छo fore pleno

Campanula maior pyramidalis

Campana lazura, i. Convolvulus caruleus maior

Campanula perficifolia alba E carulea

Canicida, i. Aconitum luteum Ponticum

Canis cerebrum, i. Antirrhinum

Cannacorus, i. Canna Indica

Canna Indica fore luteo punctato

Canna Indica fore rubro

Cantabrica Plinij, i. Caryophyllu

Cápnos fabacea radice, i. Radix caus minor

Caprifolium perfoliatum fiue Italicum

Cardamine fore pleno, E trifolia

Carduus benedietus

Carduus Eriocephalus, i. tomentofus

Carduus mollis

Carlina humilis

Carthamus fiue Cnicus fativus

Carum

321 Caryophylli maiores \&o maximi 316

322 Caryophylli fylueftres 314

ibid Caryoplyyllus marinus \& mediterraneus $\quad 317$

mag- Caryophyllus Indicus, i. Flos Africanus

268 Caffaua, i. Iucca

Cavala lale, i. Tulipa pracoces

561 Caffalale, i. Tulipa media

488 Cauca fon, i. Moly Indicum

Caulis vulgaris, Crippa, Sabaudica $\quad 504$

ibid

Caulo rapum ibid

Cedrus Lycia . $\quad 436$

Celaftrus 603

Cepa alba, rubra Eंc. 510

Cerafa Indiana $\quad 432$

Cerafus fore pleno 402

Ceraforum diuerfitas 571

Cerafus Trapezuntina, i. Laurocerafus

Cercis

437

Cerefolium maius E' vulgare $\quad 494$

Cervicaria, i. Trachelium

Chamaciftus Frificus

Chamacyparifus, i. Santolina

140 Chamadaphne

498

Chamedrys 456

140 Chamairis angufifolia 187

Chameiris latifolia $\quad 186$

249 Chamalea Alpina 397

Chamalaea Germanica, i. Mefereon 397

486 Chamalea tricoccos ibid

509 Chameleo, vide Carlina

293 Chamemalus, i. Malus Paradifeus

Chameemelum, i. Camomilla

Chamanerium fore Delphinij 270

Chamapauce Cordi, i. Ledum Silefacunt

606 Chamarhododendros Chamelacefolio Lobelij, i. Ledum Alpidum

Charantia formina, i. Balfamina famina

Cheiri frue Keiri, i. Leucoium luteum

Chondrilla aurea, i. Pilofella maior

Chryfanthemum odoratum, i. Chamamelum nudum

Chryfanthemum Peruvianum, i. Flos Solis

Chryfanthemum Creticum $\quad 295$

Chryfocome frue Stochas citrina $\quad 374$

Cichorium 495

Cinara alba, rubra, mofchata Eंc. $\quad 518$

224

290

354

359
Circea, i. Mandragoras

Ciftus annuus $\quad 422$

Ciftus mas $\quad 421$

Ciftus famina

Ciftus Ledon 0 ibid

Claues fanti Petri, i. Paralyfis

Clematis Daphnoides, i. Vinca peruinca 391

Clematis altera fue vrens fore albo ibid

Clematis peregrina fore rubro 392

Clematis peregrina fore purpureo ibid

Clematis peregrina fore purpureo pleno ibid

Clematis peregrina fore carneo pleno 393

Clematis carulea Pannonica ibid

Clematis furrecta fiue Flammula Iouis ibid

Clematis flore albo pleno, vel furrecta flore duplici

Clamatis Virginiana, i. Maracac

Glymenum Matthioli, i. Lathyrus latifolius fiue Pi-

fum perenne

Cneorum Matthioli . 397

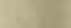

.

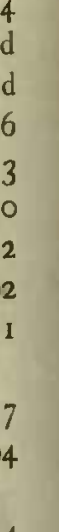

(1)

(2)

7

id

70


I N D E X.

Cneorum nigrum \& album Theophrafti

Cricus fue Carthamus fativus

Colchicum Anglicum Byzantinum E'c.

Colchicum vernum

Colytea Theophrafti

Colutea vulgaris, \&f Scorpioides

Coma aurea frue Heliochryfum

Condrilla aurea, i. Pilofella maior

Confolida minor, i, Bellis minor vulgaris

Confolida regalis, i, Delphinium

Convolvulus Americanus

Convolvulus ceruleus maior

Convolvulus caruleus minor

Convolvulus purpureus maior

Convolvulus purpureus minor picafolijs

Colchorus Dalechampij, i. Pilofella maior

Cornus mas fructu albo, rubro

Corona Imperialis

Cortufa Matthioli

Corydalis

Cofmofandalos, i. Calceolus Maria

Coftus hortorum maior छ" minor

Cotonea malus

Cotyledon altera minor, छ flore rubro

Crocus vernus albus, purpureus $\xi^{\circ}$.

Crocus Hifpanicus, i. Carthami fores

Cucumis hortenfis

Cuminum fylueftre alterum Diofcoridis Matthiolo,

$$
\text { i. Delphinium }
$$

Cupreffus

Cyanus Batitus fupinus

Cyanus floridus Turcicus

Cyanus minor variorum colorum -

Cyanus Orientalis, i. floridus Turcicus

Cyclamen Antiochenum

Cyclamen autumnale hederafolio

Cyclamen vernum. Veronenfe - \&cc.

Cyclaminus idem

Cydonia malus

Cyprus Plinij, i. Liguftrum Orientale

Cytifus vulgaris. Marantha $\xi^{\circ}$.

\section{D.}

$\mathrm{D}_{1}$ Actylus Trapeztuntinus, i. Laurocerafus Daphnoides, i. Laureola

Datura Turcarum, i, Stramonium

Delphinium

Delphinium buccinum, i. Chamenerium

Delphinium Hifpanicum parvum

Dens caninus

Dentali, i, Dens caninus

Devebohini, i. Narcif]us medio purpureus

Dictamus albus \&o Diptamus albus, i. Fraxinella

Digitalis

Diofanthos Theophrafti Dalechampio, i. Aquilegia

Diofanthos, frue Iouis flos, i. Caryophyllus

Dipcadi, i. Mufcari

Dracoherba, feu Tarchon

Draba fue Arabis Dodonai, i. Thlajpi Creticum

Dracunculus maior

E.

E Leborine flore albo Ecc.

Elleborus albus vulgaris Es pracox

426 Elleborus niger, vel Helleborus niger

329 Endinia $\quad 495$

154 Eंc. Ephemerum lethale, i. Colchicum

158 Ephemerum non lethale, i. Lilium conuallium

$43^{8}$ Ephemerum Virginianum 152

440

Epimedium $\quad 283$

Eranthemum, i. Flos Adonidis

Eriphium Galens, i. Radix caua

Eruca fatiua

Eryngium Montanum frue Pannonicum $\quad 330$

358

357

358

ibid

359

3

Gentianella autumnalis fue Pneumonanthe ibid

Giul catamer lale, i. Anemone latifolia multiplex

Gladiolus Byzantinus, Italicus 8 c. $\quad 189$

Globularia carulea $\quad 322$

347 Globularia lutea montana 323

346 Glycyrrhiza fue Liqueritia ? 533

521

Flos Caryophylleus, fue Caryophyllus

Flos Cuculi, i. Lychnis fylueftris plumaria

Flos noctis, i. Convolvulus maior purpureus

Diuce Katharina, i, Nigella

Flos Regius, i. Delphinium

Flos Solis Farnefianus Columna, i. Battatas de Canada

295 


\section{N D E X.}

Gnaphalium Americanum

374

Gnaphalium Montanum, fiue Pes Cati vel Pilofella minor Montana

Gnaphalium Rofeum

Gramen friatum vel pitzum

Gramen marinum, i. Caryophyllus marinus minor

Gramen plumarium vel plumojum

Grofularia fue Vva crifta vulgaris, boccis $45^{\circ}$ caruleis, aculeatis Ẽc.

Guaiacana fue Guaiacum Patauinum idem eft cum Pigamin Virginianorum, Loti Species

\section{H.}

T Afula regia, i. Afpliodelus luteus minor Hedera Virginiana

Hedyfarum clypeatum

Heliotropium Indicum Pelleterij, i. Battatas de Canada

Heliocry/um

Helleborafter fiue Pfeudohelleborus

Helleborus albus Ev vernus pracox

Helleborus niger verus

Helleborus niger ferulaceus, i. Buphthalmum maius

\section{Helleborine}

Hemerocallis, i. Martagon

Hemerocallis Valentina Clufij, i. Pfeudonarciffus marinus, vel Pancratium vulgo

Hepatica nobilis fue trifolia

Herba clauellata, i. Viola tricolor

Herba fancti Petri, i, Paraly/ss

Herba Sancta Catharina, i. Balfamina famina

Herba Margarita, i. Bellis minor

Herba Regina, i. Tabacca

Herba Tunica, i. Caryophyllus \& Armerius

Herba Trinitatis, i. Hepatica trifolia

Hermodaczylus Matthioli

Gefneri

Hermodactylum Colchicum

Hesperis

Hippolapathum, i. Patientia fiue Lapathum fativum, \& Rhabarbarum Manachorum

Hippolapathum rotundifolium

Hippofelinum fiue Olus atrum

Hirculus Frificus, i. Chameciftus Fricifcus

Horminum fativum

Hyacinthus E० eius genera

Hyacynthus Poctarum, i. Iris bulbofa Anglicana

Hyjopus folijs aureis

Hyjopus vulgaris

Hypecoum Matthioli, i. Alcea veficaria

\section{I.}

Tcea Betica

Iacea marina Batica

Iafminum Americanum

Iafminum Arabicum

Iafminum album

Iafminum Catalonicum

Idaus dattylus, i. Paonia

Ilex arbor

Intubum,i. Endiuia E Cichorium

louis flos, i. Caryophyllus

Iphium Theophrafi, i. Caryophyllus

600
Iris bulbofa \& eius varietas

171 ad 179

Iris Chalcedonica 179

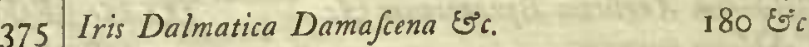

ibid Iris Perfica 172

458 Iris Tripolitana 182

Iris tuberofa $\quad 188$

58 Iucce

Ixine Theophraft, i. Carlina

K.

Eiri, fiue Leucoium luteum 256

Keiri albo flore

L.

Aburnum

39 LaEtuca agnina. Capitata Eंc. 498 Lamium Pannonicum, i. Galeopfis Pannonica $\quad 385$ Lapathum fanguineum $\quad 484$

Lathyrus latifolius, i. Pifum perenne $\quad 338$

Lathyrus fliquis orobi - ib

Lauendula mas E famina 447

Lauendula fyluefris, i. Stachas

Laurus $\quad 598$

Laurus regia, i. Laurocerafus 401

Laurus Rofea, i. Oleander
Laurus Tinus

Laurea Cerafus 599

curo cerafus

401

Ledum Alpinum. Silefiacum $\quad+24$

Ledum id eft Ciftus Ledon

Leimonia Theophrafti Clufio, i. Anemone fylueftris

Leontoftomium, i. Aquilegia

Leucoium bulbafum IOg

Leucoium hortenfe fimplex \& multiplex 258

Leucoium luteum multiplex $\quad 257$

188 Leucoium marinum Syriacum 260

I94 Leucoium melancholicum ibid

160 Leuconacifjolirion, i. Leucoium bulbofun

262 Libanotis Coronaria, i. Rofmarinus

Liguftrum 445

Ligu/trum Orientale, i. Cyprus Plinij 410

484 Lilac, i. Syringa carulea 407

490 Lilac flore argenteo 408

Liliago, i. Phalangium : vel alijs Lilium non bulbofum fiue Liliafphodelus

Lilinfphodelus

Lilionarcifus, i. Tulipa

Lilium Alexandrinum, i. Ornitlogalum Arabicum

Lilium album

Lilium aurcum, rubrum E'c. $\quad 39$

Lilium conuallium 340

Lilium Macedonicum $\quad 36$

Lilium Montanum $\quad 33$

Lilium non bulbofum, i. Liliafphodelus

Lilium Perficum vel Sufianum

Lilium fylueftre, i. Montanum

Lilium variegatum, i. Fritillaria

ibid Limonium peregrinum Rauwolfij

Linaria magna fue Belvidere Italorum $\quad 268$

495

Linaria carulea purpurea odorata

Linaria carulea purpurea odorata $\quad 486$

Linum fyluepre album, luteum $\quad 266$

Lotus 


\section{N DEX.}

Lotus Africana Dalechampij, i. Laurocerafus Lotus Arbor 568

Lotus tetragonolobus fiue filiquofus flore rubello, i. Pifum quadratum

Lunaria Arthritica, i. Paralyjis, etiamque \& $A u-$ ricula $V r f i$

Lunaria Graca $\left\{\begin{array}{l}\text { maior } \\ \text { odorata }\end{array}\right\}$ i. Bolbonach, feu Viola

Lunaria carulea, i, Soldanella Alpina, fiue Montana

\section{Lupinus}

Lychnis Chalcedonica flore fimplici, \&o flore pleno

Lychnis Coronaria

Lychnis plumaria fylueftris multiplex

Lychnis fylueftris flore albo pleno, छ flore rubro pleno

Lycoperficum Galeni, i. Flos Africanus, pomum ${ }^{254}$ moris Anguillara

\section{M.}

$\mathrm{M}$

Aiorana aurea

Maiorana tenuifolia

Maiorana vulgaris

Maiorana latifolia vulgaris

Mala Ethyopica ?

Mala Arantia

Mala Armeniaca Jiue pracocia

Malus Cotonea vel Cydonia

Malus Granata feu Punica

Malorum Perficorum diuerfitas

Malorum varia genera

Malus Punica fatiua

Malus Punica fylueftris, i, Balouftium

Malua crifpa

Malua Hifpanica flore carneo amplo

Malta horaria, i. Alcea peregrina

Malua hortenfis fimplex E" multiplex

Malua Rofea, i. hortenfis

Mandragoras mas \& famina

Maracoc fiue Clematis Virginiana

Marguerites \&o Margueritons, i. Bellis minor multiplex

Martagon album, flore carneo

Martagon Chymiftarum, i. Lilium aureum fiue rubrum

Martagon Byzantinum feu Conftantinopolitanü

Martagon Pannonicum flore fpadiceo

Martagon Imperiale

Martagon Pomponeum

Martagon Phaeniceo flore

artagon rariflimum, i. Narciffus tertius Matthioli

\section{Matricaria flore pleno}

Medica Cochleata. Spinofa

Medium Diofcoridis, i. Viola Mariana

Melampodium, i. Helleborus niger

Melanthium, i. Nigella

Melifja

Melo Mojcatus E̋c.

Mentha

Mespilus Aronia. Vulgaris

Mezereon, i. Chamalea Germanica

Mirabilia Peruviana

Moly alterum genus Plinij Dodonee, i. Phalangium
Moly varia genera

141 ad 146

Morion, i. Mandragoras

Morus vulgaris, alba, Virginiana

Mufchoromi, i. Mufcari

Mofchatella, i. Hefperis

Mufcipula Lobelij, i. Benrubrum Mon/P. $\quad 254$

Myrobalanus prunus

Myrrhis, i. Cerefolium maius

Myrtus maior \&' minor

N.

Apellus 215

Napellus Moifis, i. Anthora 216

Napus maior छீ minor $\quad 509$

Narciffus Caperonius, i. Fritillaria
Narcifforum varia genera 67 ad 108

Narciffus marinus, i. tertius Matthioli

Narciffus Iacobaeus flore rubro

169

Narciffus Mattbioli, i. Ornithogalum Neapolitanum

Narciffus Trapezunticus

Narciffus Virgineus

Nardus Italica, i. Lauendula

30

Nardus montana

Nafturtium Indicum $\quad 280$

Nafturtium hortenfe $\quad 500$

$\begin{array}{ll}\text { Nepeta } & 479\end{array}$

Nerium, i, Oleander

Nerium Alpinum, i, Ledum Alpinum

Nicotiana, i. Tabacco

Nigella flore albo duplici

Nigella flore caruleo multiplici

Nigella Hifpanica ibid

Nil Auicenna, i. Convolvulus caruleus maior

Nozelha, i. Crocus Clufio, Syfirinchium Boelis

Nuciperfica E० eius varietas $\quad 583$

Nux Auellana, Byzantina $\quad 562$

Nux Iuglans $\quad 595$

Nux Metel, i, Stramonium maius

Nux veficaria feu Staphylodendron 6 II

O.

Cellus Barbaricus, छ Damafcenus, i. Caryophyllus

Ocimaftrum Valerianthon, i. Valeriana rubra Dodonai

Ocimoides Jemper virens

254

Ocimum citratum, Indicum 450

Odontitis, i. Lychnis plumaria

Oenanthe Myconi, i. Ranunculus thaliztri folio minor

Olus album, i. Lactuca agnina

Olus atrum, i. Hippofelinum

Olus aureum, i. Atriplex

Olus hifpanicum, i. Spinachia

Opuntia, i. Lychen marinum $\quad 433$

Opuntia feu Ficus Indica $\quad$ ibid

Orchis Melitias feu Apifera 192

Orchis hermaphroditica Eंc.

Ornithogalum Ethiopicum $\quad 13^{8}$

Ornithogalum Arabicum $\quad 134$

Ornithogalum luteum $\quad$ I40

Ornithogalum Neapolitanum 138

Ornithogalum Pannonicum $\quad 136$ है $13^{8}$

Orobus Venetus $\quad 33^{8}$

Orontium 
I N D E X.

Orontium, i. Antirrhinum

Portulaca

Os Leonis, i. Antirrhinum

Oftrys Theophrafti

Ofyris, i. Scoparia vel Linaria magna

Oxalis fiue Acetofa

Oxyacantha fiue Berberis E fue acinis

\section{P.}

$\mathrm{P}$ Adus Theophrafit, i. Cerifier blanc Gallorum fiue Cerafus racemofus

Pconia mas E๐ famina fimplex E multiplex Paliurus

Palma Chrifti, i. Ricinus

Palma Chrifli, i. Orchis fiue Satyrium Bafilicum

Pancratium, i. Scilla rubra, छ non Pfeudonarciffus marinus, vide pag.

108 है 153

Panis porcinus, i. Cyclamen

Papaver fativum flore pleno

Papaver fylueftre flore pleno

Pappas fue Battatas Hifpanorum Canadenfe Virginianum

Paralyfis diuerfarum specierum 242 E

Paralytica alpina maior $\xi^{\circ}$ minor, i. Auricula $V r \sqrt{\imath}$ E Paralyfis minor

Parthenium, i. Matricaria

Parthenium Galeni, i. Amaracus

Paftinaca latifolia

Paftinaca tenuifolia

Pedua Penorum, i. Flos Africanus

Pennachio Perfiano, i. Lilium Perficum

Pepo

Peruinca fue Vinca peruinca

Periclymenum perfoliatum

Periclymenum rectum

Periploca Virginiana

Pes cati, i. Gnaphalium Montanum

Petrofelinum

Petum E Picielt, i. Tabacco

Perebecenuc, i. Tabacco

Phalangium Allobrogicum

Phalangium ephemerum Virginianum

Phalangium Italicum maius

Phalangium ramofum Eo non ramofum

Phafcolus vulgaris

Phillyrea

Phlomitis, i. Ethiopis

Phlox fiue flamma Theophrafi, i. Viola flammea fiue tricolor

Pilofella maior fue Chondrilla aurea

Pilofella minor montana, i. Gnophalium montanum

Pimpinella frue Sanguiforba

Pinus

Piper montanum, i. Chamelace frutex vel femen

Pißhamin Virginianorum, i. Guaiacum Patauinum

Pifum perenne, Lathyrus latifolius

Pifum quadratum rubrum

$P_{i f u m}$ vulgare, rofeum maculatum $\xi_{c}$.

Planta Cardinalis, i. Trachelium Americanum

Planta maxima, i. Flos Solis

Plantago rojea

Pneumonanthe, i. Gentiana autumnalis

Poma amoris maiora E minora

Pomorum varietas

Pomum fpinofum, i. Stramonium

Porrum

(4)

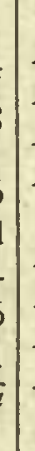

506 508

526

$R$

\section{Pothos Theophrafti, i. Aquilegia}

Primula veris fimplex Eo multiplex

Prunorum magna varietas

$242 \xi \xi^{\circ}$.

Peudocapficum, i. Amomum Plinij laceus

Pfeudohermodactylus Matthioli, i. Dens Caninus

Pfeudonarciffus Anglicus, Germanicus, Hifpanicus, Eंc.

$99 \xi^{\circ} c$.

Pfeudolotus Matthioli, i. Laurocerafus, eft Eं Guaiacum Patavinum छ Pi/hamin Virginianorum

Pfeudorhabarbarum eft Rhabarbarum Monachorum

Pfidium, i. Cortex Granatorum

Ptarmica flore pleno $\quad 288$

Pulegium

Pulmonaria Tragi छ Gallorum, i. Pilofella maior

Pulmonaria maculofa Eo non maculofa 300

$\begin{array}{ll}\text { Pulfatilla } & 200 \\ \text { Pyracantha } & 604\end{array}$

Pyracantha 604

Pyramidalis Lutetiana, i. Campanula maior fiue laEtefcens

Pyretrum officinarum

Pyretrum Sylueftre

354

288

Pyrus E eius varietas $\quad 590$

Q.

Vamoclit Indorum, i. Convolvulus America-

2uinúa Indorum, i. Amaranthus maior fue panniculis jparfis

\section{R.}

$\mathrm{R}$ Adix Caua maior, Es minor 275 Ranunculus Anglicus, Afiaticus, Creticus $\xi^{\circ} c$.

Ranunculus monophyllos, i. Aconitum hyemale 216 ad 223

Ranunculus nemorum Eo Jyluarum, i. Anemones fylueftres

Raphanus vulgaris E" nigra radice $\quad 509$

Rapum hortenfe, luteum, rubrum ibid

Rapuniculus hortenfis $\quad 514$

Rhabarbarum Monachorum E P $\int$ eudorhabarbarum

$\begin{array}{ll}\text { Rhabarbarum } \text { E Rhaponticum verum } & 483\end{array}$

$\begin{array}{ll}R \text { hododendron, i. Oleander } & \\ \text { Rhus Virginiana } & \text { II }\end{array}$

$\begin{array}{ll}\text { Rhus Virginiana } & 6 \text { II } \\ \text { Rhus Myrtifolia } & \text { ibid }\end{array}$

Ribes fructu albo, nigro, rubro $\quad 558$

Rofa Alpina, i. Ledum alpidum $\quad 424$

Rofa Iunonis, i. Lilium album

Rofa fatuina, i. Paconia

Rofa montana, i. Alpina

Rofa vltramarina, i. Malua rofea

Rofa Anglica, Cinamomea, Damafcena, Eंc. $\quad 4^{12}$

Rofmarinum vulgare $\quad 425$

Rofmarinum aureum $\quad$ ibid

Rofmarinum latifolium $\quad 426$

Rofmarinum fylueftre Matthioli, i. Ledum Alpinum

Rubus Idceus 557

Rubus Idaeus non fpinofus a ibid 
Ruta hortenfis

Ruta paluftris vel pratenfis, i. Thalietrum

\section{S.}

SAdarifa, i. Alcea Americana Sabina

Salmaris, i, Pyretrum

Saluia maior Eै minor

Saluia variegata

Sambach Arabum, i, Syringa Arabica flore duplici

Sambacus Rofea

Sampfuchum, i. Maiorana

Sana fancta E Sancta herba, i. Tabacco

Sandalida Cretica, i, Pifum quadratum

Sanicula Alpina vel montana, i. Cortufa Matthioli

Sanicula trifolia, i. Cardamine trifolia

Sanicula guttata

Sanguiforba vel Pimpinella

Sanguis Herculis, i, Elleborus albus

Santolina, i. Abrotanum famina

Saponaria fore duplici

Saponaria altera, i. Trachelium minus, E๐ Valeriana rubra Dodon.

Sarahug, i. Hyacinthus Lillifolius

Satureia vel Thymbra

Satyrium Erythronium \& Triphyllum Diofcoridis

$$
\text { i. Tulipa }
$$

Satyrium Orchidis Species

Scabiofa rubra Auftriaca

Scabiofa rubra Indica

Scarlatea, i. Armerius

Scoparia, i. Linaria magna

Scorpioides maius छo minus

Scorfonera

Scylla alba, rubra

Sedum ferratum

Segetalis, i. Gladiolus

Selinum dulce

Serincade, i. Narciffus medio purpureus

Serincade catamer lale, i. Narcifus flore pleno

Serpentaria, i. Dracunculus

Serpentina, i. Scorfonera

Serpillum aureum, Citratum $\xi^{\circ} c$.

Sefamoides minus, aliquibus eft Helleborus niger ferulaceus

Sicla छீ Sicula, i. Beta

Sidium idem quod Pfidium

Siliqua fylueftris, i. Arbor Iudee

Simboline idem quod Zumbul Indicum, Hyacinthi Orientalis jpecies

Sinapi

Sifarum

Sifyrinchium alterum, i. Cardamine altera

Sifyrinchium Mauritanicum $\Xi^{\circ} c$.

Sifyrinchium Cordi, i. Ornithogalum

Solanum arborefcens, i. Amomum Plinij

Solanum fatidum fpinofum Bauhini, i. Stramonium

Solanum Mexicanum Bauhini, i. Mirabilia

Solanum pomiferum Gefneri \& Bauhini, i. Pomum amoris

Solanum veficarium, i. Alkakengi

Solanum efculentum Bauhini, i. Battatas de Virginia

Sol Indianus, i. Flos folis

Soldanella alpina

530

I 71
Spartum Auftriacum, i, Gramen plumofum

Spartum Hifpanicum frutex, i, Genifta Hifpanica

\section{Spinachia}

Staphylodendron, i. Nux veficaria

Sternutamentoria, i. Ptarmica

Stoechas

Stoechas Citrina, i, Chryfocome

Struthium non eft Saponaria $\quad 353$

Stramonium maius E' minus $\quad 360$

$\begin{array}{ll}\text { Sumach Virginenfe } & 612\end{array}$

Sufamgiul, i. Lilium Perficum, \& Hyacinthus ftellatus, Byzantinus alter

Sycomorus, fue Acer maius latifolium 610

Symphitum maculofum, i. Pulmonaria wis
Syringa alba, carulea

Syringa Arabica flore albo duplici $\quad 408$

Syringa Italica Lobelij, i, Syringa flore albo fimplici

Syringa Italica flore albo pleno Beferi

T.

TAbacco

Tamarix vel Tamarifcus

363

Tanacetum vulgare

Tarchon herba $\quad 500$

Taxus arbor $\quad 606$

Thaliatrum vel Thalietrum Hifpanicum $\quad 274$

Thefium Theophrafti, i. Radix caua

Thlajpi Baticum marinum rofea

Thridacias, i. Mandragoras

Thuya, i. Arbor vita $\quad 436$

Thymbra, i. Satureia $\quad 476$

Thymum legitimum capitatum $\quad 454$

Thymum durius \& latifolium $\quad 474$

Tilia famina $\quad 608$

Trachelium maius छ' minus $\quad 354$

Trachelium Americanum 356

Tragium Diofcoridis, i. Fraxinella
Tragopogon caruleum, purpureum
Tragopogon

$\begin{array}{ll}\text { Tragopogon caruleum, purpureum } & 302 \\ \text { Tragopogon luteum } & 514\end{array}$

Tragoriganum Matthioli $\quad 453$

Trifolium fruticans, i. Iafminum luteum

Trifolium $\left\{\begin{array}{l}\text { aureum } \\ \text { nobile }\end{array}\right\}$ i. Hepatica

Trinitas, feu herba trinitatis, i. Hepatica

Tulipa Armeniaca Bolonienfis, Bombycina, Byzantina, Cretica छc. $\quad 52 \mathrm{E}^{\circ} \mathrm{c}$.

Tulipa media

Tulipa pracoces $\quad 48$

Tulipa ferotina

Tufai \& Turfana, i. Corona Imperialis

V.

VAcinium Virgilij

Valeriana rubra Dodonai

Valeriana Graca

Valerianthon, i. Valeriana rubra Dodonai

$\left.\begin{array}{l}\text { Verbafcum odoratum E० } \\ \text { Verbafculum odoratum }\end{array}\right\}$ i. Paralyfis 


\section{N D EX.}

Veratrum album छீ nigrum, i. Hclleborus albus छे niger

Vernilago, i. Chameloco albus

Vetonica altera, vel altilis, aut Coronaria, i. Caryophyllus hortenfis

Vetonica agreftis, i. Armerius

ViEtorialis rotunda, i. Gladiolus

Vinca peruinca

Viola alba, i. Leucoium

Viola alba bulbofa, i. Leucoium bulbofum

Viola Damafcena, i. Hejperis

Viola flammea, i. Tricolor

Viola hyemalis, i. Hesperis

Viola latifolia $\xi^{\circ}$

Viola Lunaris Bolbonach

Viola lutea, i. Leucoium luteum fiue Keiri

Viola peregrina, i. Bolbonach

Viola mariana

Viola martia

Viola Matronalis, i. Hesperis
Viola tricolor fimplex \&o duplex

Viperaria E Viperina, i. Scorfonera

Vitis Corinthiaca, Damafcena $\xi^{\circ} c$.

Vitis Virginiana

Vitis Virginen Je Jeu potius Hedera Virginiana

$V m b i l i c u s$ Veneris, i. Cotiledon

Vva crifpa, i. Grofularia

Vuularia, i. Trachelium, eft E० HippoglofJum

Y.

YVcca, fue Iucca

\section{$\mathrm{Z}$.}

7 Ambach Arabi, i. Iafminum Arabicum Zufiniare, i. Martagon Conftantinopolitanum Zumbul Arabi, i. Ornithogalum Arabicum Zumbul Indi, i. Orientalis maior pracox

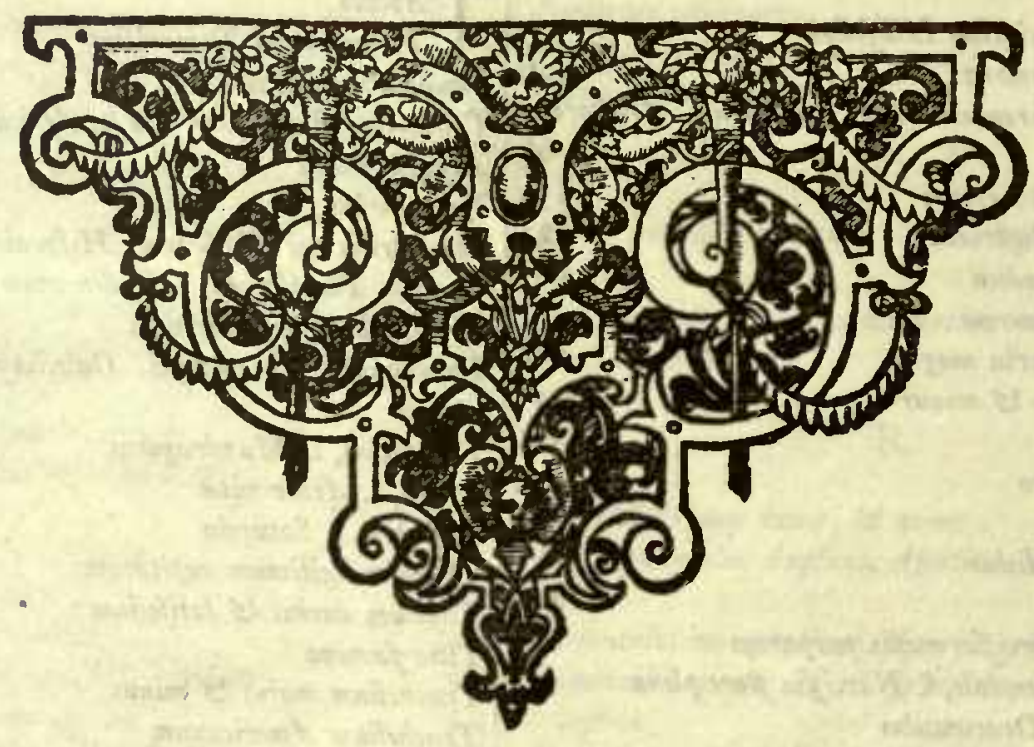




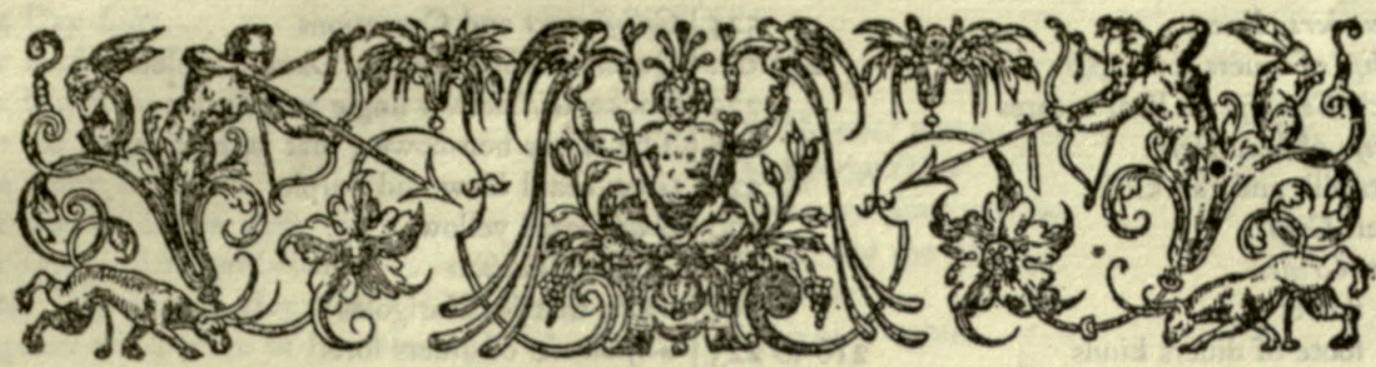

\section{$A$ Table of the Englifh names of fuch Plants as are contained in this Booke.}

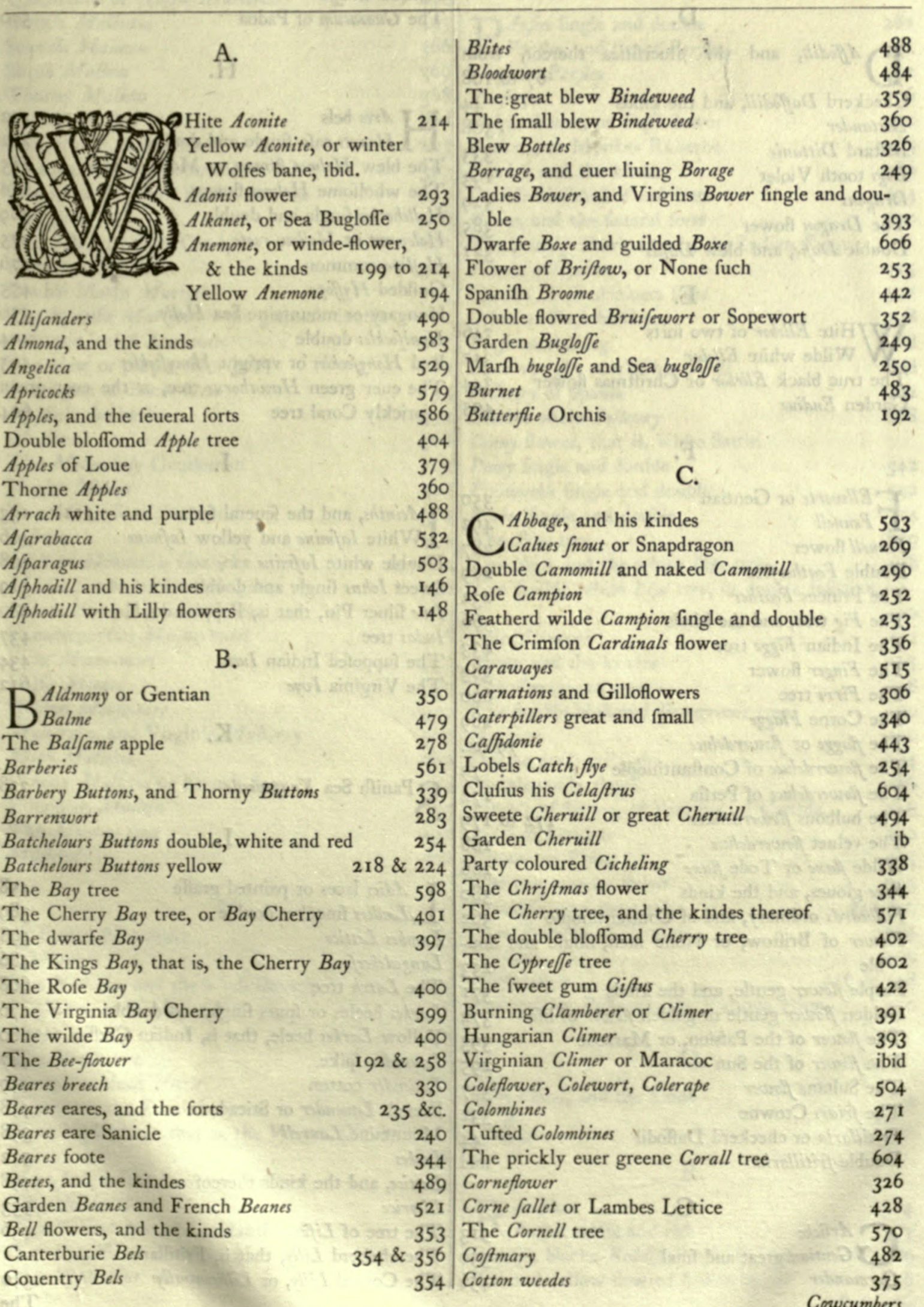


Cowcumbers, diuers

Cowflips of diuers forts

French Cowjlips or Beares eares

Cowflips of Ierufalem

Cranes bill, and the kinds

Garden CrefJes

Indian Creffes

Crow flower

Crow foote of diuers kinds

Crown Imperial

The double Cuckow flower

Currans, white, red and blacke

The true Curran Vine and Grape

\section{D.}

D Afrodils, and the di Affodits

Checkerd Daffodill, and the kinds

Dittander

Baftard Dittanie

Dogs tooth Violet

Dragons

The Dragon flower

Double Dafie, and blew Dafies

E.

WHite Ellebor of two forts Wilde white Ellebor

The true black Ellebor or Chriftmas flower Garden Endiue

\section{F.}

E Ellwarte or Gentian

Fennell flower

Double Featherfew

The Princes Feather

The Fig tree, and the kinds

The Indian Figge tree

The Finger flower

The Firre tree

The Corne Flagge

The flagge or flowerdeluce

The flowerdeluce of Conftantinople

The fowerdeluce of Perfia

The bulbous flowerdeluces

The veluet fowerdeluce

Wilde flaxe or Tode flaxe

Foxe gloues, and the kinds

Fillbeards ordinary, and of Conftantinople

Flower of Briftow, or None fuch fingle 562 ble

Purple flower gentle, and the kinds

Golden fower gentle or golden flower of life

The flower of the Pafsion, or Maracoc

The flower of the Sun

The Sultans flower

The friars Crowne

Fritillaria or checkerd Daffodil

Double fritillaria

G.

Arlicke

Gention great and $\mathrm{mal}$

Germander

67 to 108

524 Gilloflowers and Carnations

242 Eंc. Queenes Gilloflowers or Dames Violets

306

262

235 Stocke Gillofowers fingle and double 258

248 The Ginny hen-flower, that is, Fritillaria 44

228 Goats beard blew and purple 302

500 Goats beard yellow $\quad 514$

280 Candy Goldilocks 372

253 Golds, that is, Marigolds 296

216 to 223 Goofeberries of diuers forts 560

28 Herbe Grace or Rue $\quad 530$

253 and 389 Grape flower 3 I 4

558 Vipers Grafe 301

$5^{6} 3$ Feather Grafle 458

Painted Grafle ib

The Guaiacum of Padoa $\quad 570$

H.

\section{Ares bels $\quad 122$}

The blew Helmet flower or Monkes hood 282

The wholfome Helmet flower ibid

Hollihockes fingle and double $\quad 369$

$\begin{array}{ll}\text { Holewort or Hollow-roote } & 275\end{array}$

HyJope common $\quad 476$

Guilded $H_{y}$ /Jope $\quad 455$

Hungary or mountaine Sea Holly 330

Honifockles double $\quad 404$

Red Honyfockles or vpright Honyfockles 405

344 The euer green Hawthorne tree, or the euer green prickly Coral tree

604

\section{I.}

Acinths, and the feueral forts II I to I 33

White Iafmine and yellow Iafmine $\quad 406$

Double white Iafmine $\quad 408$

$\begin{array}{ll}\text { Sweet Iohns fingle and double } & 319\end{array}$

Ione filuer Pin, that is, Poppies double 286

Iudas tree $\quad 437$

The fuppofed Indian Iucca $\quad 434$

The Virginia Ivye
612

$79 \& c$

189

$98 \mathrm{c}$.

172

179

I 88

266

dou-
K.

Sanifh Sea Knapweede 328

\section{L.}

Adies laces or painted graffe $45^{8}$

LLedies fmockes double $\quad 389$

Lambes Lettice $\quad 498$

Langedebeefe $\quad 486$

The Larch tree $\quad 608$

Larkes heeles or fpurs fingle and double $\quad 276$

Yellow-Larkes heele, that is, Indian Creffes 280

Lauender fpike $\quad 447$

Lauender cotton $\quad 449$

French Lauender or Sticadoue $\quad 448$

Mountaine Laurell $\quad 398$

Leekes $\quad 512$

Lettice, and the kinds thereof $\quad 498$

Licorice $\quad 533$

The tree of Life $\quad 436$

The chekerd Lilly, that is, Fritillaria 
The Day Lilly

The Perfian Lilly

The Mountaine Lilly

The red or gold Lilly

The white Lilly

The Line or Linden tree

Liue-long, or Life cuerlafting

Noble Liuerwort or Hepatica

Lungwort or Cowflips of Ierufalem

Lupines white, blew and yellow

CWeet Marierome

M.

Guilded or yellow Marierome

French Mallowes

Spanifh Mallowe

Shrub Mallow

Thorny Mallow

Venice Mallow

Red Maiths, and white

Mandrake male and female

The great Maple or Sycomore tree

Marigolds

Corne Marigolds of Candy

French Marigolds

Double Marfh Marigolds

The Spanifh Marigold is the greateft double broade leafed Anemone

The blew or purple Marigold

Martagons of diuers forts

Mafticke the herbe

Medlars

The Melancholy Gentleman

Muske Melons

The Meruaile of the world

Mirtles

Moly or Mountaine Garlicke

Monkes hoode, or Larkes fpurs

Monkes hood or helmet flower

Counterpoyfon Monkes hood

Blew Moone-wort

Halfe Moones

Golden Moufe-eare

Mulberries, and Virginia Mulberry

Moth-Mulleine

Woody Mulleine or French Sage

Ethiopian Mullein

The Mumme tree

Muftard

\section{N.}

Potted Nauelwort

SNavew

The Nectorin, and the kinds thereof

Neefewort, or Neefing roote

Neppe

The Nettle tree

Hungarian dead Nettle

Nigella, or the Fenel-flower

Tree Night Jode, that is, the Winter Cherry tree

None-fuch, or the flower of Briftow

The bladder $N u t$

The Filberd Nut of Conftantinople

The Spanifh or Barberry Nut

The Wall $N u t$
148
28,30

33

39

40
608
375

225

248

325

5

452

446

495

366

369

368

ibid

293

377

$6 \mathrm{II}$

296

295

303

\begin{tabular}{l}
2.24 \\
\hline
\end{tabular}

207

299

33

452

568

260

525

364

427

144 \&c.

276

215

216

234

339

330

599

$3^{8} 3$

$3^{8} 4$

385

432

502

a

232

509

582

346

479

568

385

287

$43^{2}$

253

611

562

I 71

594
O.

THe euer greene Oake $\quad 600$

$\begin{array}{ll}\text { Spurge Oliue } & 397\end{array}$

Mountaine Spurge Oliue ibid

Onions, and the kinds $\quad 510$

Sea Onion $\quad \mathbf{1 3 3}$

$\begin{array}{lr}\text { Orchis of Virginia } & 194\end{array}$

Orenges $\quad 584$

Oxe eye

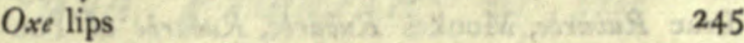

P.

Anfies fingle and double $\quad 282$

Parfey, and fweet Parfley 49I

Virginia Parfley $\quad 492$

Parfneps $\quad 506$

$\mathrm{Pa}$ fque flower, or Pafe flower $\quad 200$

Patience, or Monkes Rubarbe $\quad 483$

Peaches, and the kinds $\quad 586$

Double bloffomd Peach tree $\quad 404$

Peares, and the feueral forts 590

The prickly Peare, that is, the Indian Figge

Pearles of Spaine 35 th 15

Garden Peafe of diuers forts $\quad 522$

Crimfon Peafe bloffome $\quad 33^{8}$

Peafe euerlafting ibid

Blew vpright euerlafting Peafe $\quad$ ibid

Pelletory of Spaine $\quad 292$

Double wilde Pelletory 288

Penny flower, that is, white Sattin
Peony fingle and double

Periwinkle fingle and double $\quad 392$

Pinkes fingle and double $\quad 314$

The Pine tree $\quad 599$

The blew and the white Pipe tree 408

The double white Pipe tree, or double Iafmine

Rofe Plantane $\quad 352$

Plums, and the kindes $\quad 575$

The Pomegranet tree $\quad 428$

The double bloffomd Pomegranet tree $\quad 430$

Pompions $\quad 526$

Double garden Poppies $\quad 284$

Double wilde Poppy 286

Potato's of Spaine, of Virginia, of Canada $\quad 516$

Pride of London 310

Primme or Priuet

The euer-greene Priuet 603

Primrofes, and the kinds $\quad 242$ \&c.

Tree Primrofe of Virginia $\quad 264$

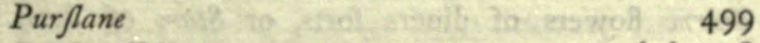

Purfe taffels $\quad$ I16 \& 118

Pufhamin or Pifhamin, the Virginia Plum 570

Vinces, and the kinds $\quad 589$

Q.

R.

P Ampions

Rappis, white and red

Reddifh, blacke Reddifh, horfe Reddif

Red and yellow flowred Indian Reede $\quad 376$

Rofarubie 
Rofarubie, that is, Adonis flower $R o f e$ tree, and the feuerall kinds Iuno's Rofe, that is, the white Lilly

The Elder or Guelder Rofe

The Holly Rofe or Sage Roje

The Mountaine Rofe

Rocke Rojes

Rofemarie common and gilded $8 \mathrm{c}$.

The Marie Rofe or Rofemary of Silefia

Rocket

Garden Rue or Herbe grace

True Rubarbe, Monkes Rubarbe, Rubarbe of Pontus

\section{S.}

Age great and fmall

Guilded Sage

Sage of Ierufalem

French Sage

Saffron flowers of diuers forts of the fpring time and of the fall

160 to 170

Medow Saffrons or Colchicum, that is, the Sonne before the Father, and the kindes

Spotted Sanicle

Beares eare Sanicle

Satyrion

The Savine tree

Summer Saurie and winter Sauory

White Sattin flower

Red Sattin flower

Scabious white and red

Scorfonera or Vipers graffe

Baftard Sena tree

The true and the ordinary Seruice

Mountaine Setwall

Virginia Silke

Skirrets

Our Ladies Slipper

Smallage

Ladies Smocks double

Snayles

Snapdragons

Mountaine Soldanella

Double flowred Sopewort

Sorrell

Sowbread, and the kindes

The Kings Speare or yellow Afphodill

Sperage or Afparagus

Spiderworte, and the kindes

Spinach

Starre flowers of diuers forts, or Stars of Bethlehem

The greene Starre flower or bulbed Afphodill of Galen

Starwort or Sharewort, and Italian Starwort

Sticadoue or Caffidonie

Stocke gilloflowers fingle and double

Storkes bils of diuers forts

Strawberries of many forts

The Strawberry tree

Succory

The Sultans flower, or Turkie Corne flower

The Sun flower or flower of the Sun

The Virginia Sumach

4 I 2 to 425

401

421

397

425

424

192

607

476

526

603

495

327

295
293 The Myrtle leafed Sumach

ibid

502

483

Throatwort, and Giants Throatewort fingle and
double

Beane 354

Beane Trefoyle $\quad 43^{8}$

Shrub Trefoile $\quad 407$

Tree Trefoile $\quad 439$

Candie Tufts 390

Golden Tufts $\quad 375$

Spaninh Tufts $\quad 274 \& 340$

The early flowring Tulipa $\quad 46$

The meane flowring Tulipa $\quad 54$

The dwarfe Tulipa 52

The Perfian Tulipa ibid

The Turkes Cap, that is, the Tulipa

The true Time 454

Guilded Time, Moske and Lemmon Time ibid

Garden Time, and Mafticke Time $\quad 474$

V.

R Ed Valerian of Dodonæus $\quad 386$

Violets 386

The bulbous Violet

The Dogs tooth Violet 193

$\begin{array}{ll}\text { Dames Violets } & 262\end{array}$

Mercuries Violets $\quad 357$

$V$ ines, and the feuerall kinds of grapes $\quad 564$

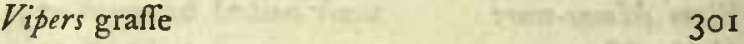

Virginia Vine $\quad 564$

Virginia Vine, or Virginia Ivie $\quad 612$

$\begin{array}{ll}\text { The Willow-flower } & 270\end{array}$

The Wind-flower or Anemone, fingle and double of many forts

I 99 to 214

Wild Wind-flower fingle and double 202

Sweet Williams, and the kinds 3 I9

IVinter Gilloflowers $\quad 258$

WVinter IVolfes bane, and yellow IVolfes bane 214

IVinter Cherries $53^{2}$

The IVinter Cherrie tree 431

Double $I$ ood-bine or Honifuckle $\quad 404$

6 II
Y.

$\Gamma \mathrm{He}$ Yew tree 


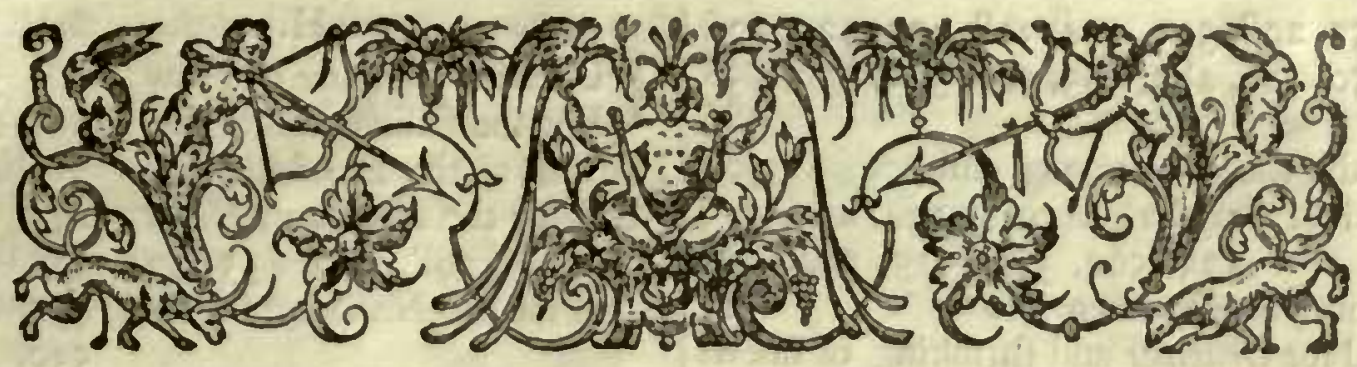

\section{A Table of the Vertues and Properties of the Hearbes contained in this Booke.}

A.

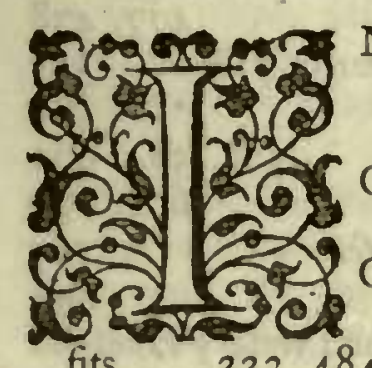

$\mathrm{N}$ feare of Abor Jment, or mif-carrying in women Good againft Aches Good in hot Agues and to drive away their fits $223,484,532,536,53^{8}, 564$ $575,579,584,595$

From whence Agaricke is taken A Syrupe of Angelica Good for deiected appetites 484,486 $499,56 \mathrm{r}, 562,578,575,584$ To perfume Apparell, Leather, \&cc. 421

For the Apoplexie Afringent or to binde 448,586 428,43 I

\section{B.}

FOr weake Backes and reines

A Balfame for green wounds To caufe Barrenne fe

Good for Bathing 294, 376, 42 1, 449 $474,477,478,479,480$ Good for Bees 440,480 Good to take away the fting of Bees and wafpes $476,479,480,482$

Good to open and mollifie the Belly, and make it foluble $333,370,421,488$ $489,490,495,566,578,582$

To clenfe the Blood

To diffolue clotted Blood

To encreafe Blood

To helpe the fpitting of Blood

To ftay Bleeding

Hurtfull for a hort Breath

Good for the fhortneffe of Breath 364

For a ftinking Breath $436,502,506,513,533$

To make a fweet Breath 610 595 290 608 529

For cold and moif Braines $335,427,448$ 481,482

To abate the ouer-fwelling of Maidens

\section{Breafis}

600

To helpe paines in the Breaft $\quad 500$

To heale womens fore Breafts $\quad 590$

To draw out broken Bones \&c. out of the fle?h

190

For Bruifes by fals \&c. $479,608,6$ ro Good for Burnings or fcaldings 362,512 610

C.

TO clenfe Cankers 364 To procure Caffings or vomitings $189,434,442,489,532$ To ftay Cafting or vomiting 477,480 To feede or make Cattell fat 348,440 Caufficke or burning plants $\quad 396$ The beft Coales for Gunpowder 610 The beft Coales for lafting $\quad 608$ For the Winde Collicke 216, 293, 453 $455,476,504,508,515,530$ To Clen/e, purge and dry 276 To fet an orient red Colour on the cheeke of a woman 241 To make a deepe blew Colour 179,603 To make a red Colour ibid To give a luftre to a white Colour 595 To make a yellow Colour 42 I For the Colts euill, or immoderate luft To warme and comfort Cold griefes 2 I 4 $37^{6}, 434,477,478,480,49$ I 567 Cooling and drying $323,353,378,421$ $43^{8}, 486,499,528,562,557,564,576$ $562,568,576,57^{8}, 590,594,598,602$ 603,607 Cooling and moiftning $234,283,380,432$ For a Con amption For a Confumption $\quad 519,608$ Cordiall to comfort the heart 170,216 252 
$252,298,30 \mathrm{I}, 3 \mathrm{I} 4,328,42 \mathrm{I}, 427,436$ $450,480,482,483,526,528,530,55^{8}$ 586

For the Cough in young children 502 Good for Coughes and colds I 34, 295, 5 I 3 $533,562,567,575,584,586$

Mithridates Counterpoy fon

Good for Crampes and thrinking of finews

D.

425

TO procure an eafie and fpeedy Deliuery to women in trauell $40,199,274$

To ftay rheumaticke Difillations $376,3^{86}, 427$ 288

To cure the biting of a mad Dogge 300 353,482

To helpe the Dropfie $235,290,353$ To caufe Drowfine fle like vnto drunkennes

\section{E.}

362

FOr paines in the Eares

Good for fore and weake $580,5^{84}$ $421,427,479,530$ Hurtfull to the head and Eyes 489 For the Epilepfre or falling fickneffe I 94 $335,344,456,477,502$

\section{F.}

$O$ cleanfe the Face, and other parts of the skinne and make it frem 40,189 $247,336,396,500,502,521,528,566$ $584,589,600$ For the Falling fickneffe $194,335,344$ $456,477,502$

Farfing or fafeting herbes $474,476,478$ To heale Felons on the ioynts of the fingers

To procure the Feminine courfes 492

\section{To procure the Feminine courfes 289} $335,453,456,477,47.9,491$

To itay the Feminine or mentruall courfes $372,396,480,486,608,6$ I I

To cleanfe Fiftula's

To expell thin Flegme

To extenuate \& expectorate tough Flegme I $34,264,436,448,456,477,500,529$ $530,533,608$

For the bloody Flixe and all other Fluxes

$193,231,372,425,431,446,483,486$ $568,595,602,605,608,6$ I I

To take away Freckles, fpots, \&cc. $\quad 500$

For the French difeafe $283,353,606$

\section{$\mathrm{G}$.}

TO ftay the Gonorrhae or running of Good for the Gout
H.

TO caufe the haire to grow $\quad 566$ For the falling of the Haire $\quad 425$ Hurtfull to the Head and eyes 489 Good for the Head and Heart I 34, I70 $298,426,455,47.4,530,586$ Good for the Head and ftomack 455,474 530,586

For paines in the Head $\quad 288,292,426$ 448,499

For the fwimming and diffineffe of the Head 24I, 247, 586

For the paffion of the Heart, and to make it merry $\quad 480,528,529,589$

To expell venemous vapours from the Heart I70, 301, 529, 530, 586 To procure Health 477,478 To eafe the Hemorrhodes or piles $5^{13}$ For an Hoar fenefle For the bots in Horjes $\quad 606,607$ For the cough in Horfes $\quad 595$ To ftay the Hickock 494 To purge flegmaticke and watery Humours - 329 FOr the yellow Iaundife $132,134,150$ $170,275,290,5.31,562$ To make excellent Inke $43 \mathrm{I}$

To affwage hot Inflammations $\quad 362,37^{8}$ 380 To helpe the Itching of the Head 477 To cure the Itch 380 $\mathrm{K}$.

TO heale exulcerated Kidneyes $\quad 533$

\section{L.}

g. Otay a Laske or loofeneffe 32 I, 323 $421,425,446,483,562,568,570,57$ I $57^{8, .595}$ For the Lepry and deformity of the skin 0820306 For chapt Lips and hands \&cc. $\quad 589$ To tanne or thicken Leather $6 \mathrm{II}$ To clenfe the Liuer 484,532 To coole and ftrengthen the Liuer 226 ary 448,486 Good for the Lunges and old coughes i $34,249,300,353,364,436,448,456$ $477,502,506,513,529,530,533,600$ To ftay immoderate luft $\quad 499,529$

\section{M.}

TO take away blew Markes 427,500 502,566 608 For the Meafels and fmall pocks 170,216 349 To ftraw on Meate $\quad 474,476$ 
For Melancholicke difeafes $345,45^{\circ}, 44^{8}$ $455,510,589$

To comfort \& ftrengthen cold and weake Members $170,290,407,427,448,449$ $453,474,477,491,598$

To Atrengthen the Memory $\quad 427,428$

To keep Milke from curdling in the ftomacke

482

To increafe Milke in womens brealts 440

504

For the Morphew and other difcolourings of the skin $\quad 336,396,427,566$

For the Mother in women 344,378

To keep garments from Moths 376, 6I I

To engender Moths

Good to warh and clenfe the Mouth 428 $431,446,528,557,564,598$

To cure Vlcers in the Mouth

For a furfet of Mufbroms

$$
\text { N. }
$$

TO wafte Nature

For a cricke in the Necke

To procure Neefing

To ftay bleeding at the Nofe

$$
\text { O. }
$$

$43 \mathrm{I}$

$5 \mathrm{I} 3$

530

66

189,289

396

TO open Objtructions

$448,484,492$

532

To take away the offence of the fmell of Onions, Garlicke, Leekes \&c.

512

A reniedie for them that haue taken Opium too liberally

P.

289

\section{TO eafe Paines}

For the Palfie

290, 370

241,247

For the Plague or peftilentiall feuers 160 $170,216,275,298,328,333,335,353$ $483,495,513,529,530,586,595,603$

From whence Pitch is made

For the fmall Pocks

600

An efpeciall Antidote againft Poy fon

170,216

I $34,339,353$

Againt the Poyfon of the Helmet flower and other venemous herbes, and againit all other infectious difeafes 216,333 $335,353,483,529$

Againft the Poyfon of the Spider Phalangium, Scorpions, Serpents, and other venemous beafts $152,301,328,333$ $335,402,453,477,607$

To take away the ftrength of certaine Poyfons

Poyfon to all fourefooted beafts

590 For fweet Pouthers and fweet bags 189

To Purge gently $421,450,453,586$ $284,421,566$

To Purge vehemently, and ftubborne difeafes $189,346,360,400,562$ To fatten Pullen 440,442

\section{R.}

TO reftore Rauifment $\quad 600$

To hinder young perfons from growing Ripe too foone

132

Fences of Reedes as good as wals 5 ro

To draw Rheume $214,288,292$

To ftay Rheumaticke diftillations $\quad 287$ $288,376,427,482$

From whence Rogen is made 60

Good for Ruptures $\quad 1602$

$\mathrm{S}$.

O put into Saw fages \&cc. $476,477,478$
480,482

For Scaldings and burnings $362, .512$

To take away Scars and markes 223, 247

$336,521,568$

For the Sciatica or paine in the hippes and ioynts 160,442

To clenfe the head of Scurfe $\quad 134,396$

For the Scurvie

389,510

To increafe Seede $\quad 524$

To eafe paines in the Sides 532,599

To cleare the Sight I $34,427,479,530$

To comfort the Sinewes and ioynts 426 $427,477,478,480,595,599$

To procure Sleepe 286, 362, 378, 499

To keep the body Soluble $333,376,421$ $480,488,495,566,578, .582$

To clenfe the head of running Sores 134

For the fhrinking of Sinewes $\quad 425,426$

To breake plague Sores

Good for Sores and wounds

303,446 600

Good for the Spleene I $98,288,455,45^{6}$ $474,490,502,510,530,610$

To draw out Splinters \&cc. out of the fle?h

190

Good for Stitches 599

Good for the Stomacke and Liuer I 34

$353,455,473,483,491,532$

Hurtfull to the head and Stomacke 489

607

For cold and windy Stomacks 301, 455 $476,49 \mathrm{I}, 495,586$

To coole an hot Stomacke 380,486 $499,525,526,528,55^{8}, 560,562,566$ $575,584,589$ To warme a cold Stomacke $474,477,480$ $482,495,500,515,529,586,598$

For the Stone in the reynes and kidneyes $230,274,293,335,370,425,492,503$ $504,510,521,526,532,533,566,575$ $582,584,607,608,6$ I I

For the Strangury

49 I 


\section{$A$ Table of the Vertues $\Xi^{2} c$.}

To caufe Surfets

To prouoke Sweating

To helpe Srounings

$T$.
364,595

I $89,439,44.2$

274, 301,529

To fay Vomiting
532

477,480

TO draw out Thornes \&c. out of the flefh

To cure the biting of a Viper or Adder 302

I90 To caufe the Vrine to feeme blood 433

Good for fwollen Throats

To warh the mouth and Throate 357,478

For the ftopping of Vrine I 32, 264, 353 $376,453,456,483,491,492,502,503$ $528,598 \quad 506,508,515,525,530,532,533,582$

For the Tooth-ach

The poore mans Treakle

I 34,292

5I 4

For Trageas or dredges

W.

602,608

573

Common Turpentine from whence it is taken

600

Venice Turpentine from whence it is taken 600,608 V.

TO helpe Venery $\begin{array}{r}66, \text { I } 90,193,194 \\ 502,506,524\end{array}$

TO purge watery humours 329

To make fweete $W$ aters 42 I , 450, 453

To breake Winde $301,455,476,49$ $494,508,5$ I $5,529,530,575,586$

To ftay the longing of Women with childe 561,564

For the Wormes I 34,2 I $6,336,345,449$ $482,483,500,502,532,582,607$ Good to cure Wounds 241, 252, 364, 389 $445,446,456,480,483,492$ Good Wound herbes 230, 231, 235, 24 I $323,383,3^{89}, 406$

\section{Faults efcaped in Some Copies.}

FOlio 8. line 14. for own reade home. f. 12. 1.27. for trouble reade treble. f. 42. 1. 5. reade, like vnto that of a Lilly. Ff. 66. 1. 42. for xipou read kpivov or $\lambda$ eipıov. f. 73. 1. 37. for top of the flower, read cup. f. 134. 1. 36. for compofed reade compaffed, f. 150.1 . 4. for hath, reade haue, and line 5 for is are. f. 173.1.12. put out thefe Wordes, the infide, in the beginning of the line. f. $18 \mathrm{~g}$. l. 38 . reade Binis florum ordinibus. f. 218 . 1. 19. reade goulons, and 1. 28. pratenfis. f. 272.1 .36 . read Pothos. f. 276. 1. 12. Chelidonia. f. 281. 1. 37. for hath. haue, and 1. 28. Maftuerzo. f. 284. 1. 15. Vicenza. f. 287. 1. 39. Citrina. f. 290. 1. 39. reade prouoke, and, helpe. f. 329 . 1. 37. for Melancholicke, reade Flegmaticke. f. 330.331 .333 . reade Eryngium in all places. f. 336.1 .8 . reade, and not very flat. f. 356.1 . 31 . Americanum. f. 357.1 . 26. Cervicaria. f. 358.1 .45 . reade, before it can haue. f. 372 . 1. 9. blot out, cxcept it. f. 389 . for fpockes, reade fmockes. f. 393. 1. 3. in the margent for cæruleo, read pleno. f. 397. l. ro. reade dwarfe. f. 424.1.45. Hirculus. f. 428.1. 20. Tarentina. f. 431.1. 10. Cyprium. 1. 19. Amomum. f. 438.1. 17. for Diofcorides, reade Theophraftus. f. 442.1. 3. for caftings reade purgings. f. 509. 1. 35. reade

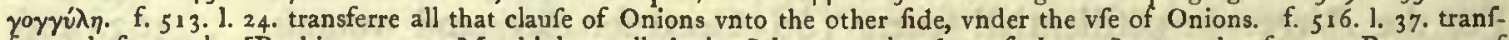
ferre: thefe words, [Bauhinus vpon Matthiolus calleth it Solanum tuberofum efculentum] vnto the former Potatoes of Virginia. f. 520 . 1. 13. for fwelleth, read fmelleth. f. 54 I. 1. 5 I. reade, after your ftockes rayfed from ftones. f. 566.1 .20 . for as, read and. and 1. 29. euery one. f. 567. l. 24. for Rice, read Rue. f. 575.1 . 8. reade ferue to be miniftred to the ficke. f. 588. 1. 3. Capandu. f. 594. 1. 18. for facility, read faculty. f. 595. 1. 39. reade Ricinus. f. 60o. 1. 4. Fuchfius.

\section{LONDON,}

Printed by Hvmfrey Lownes and Robert Yovng at the figne of the Starre on Bread-ftreet hill,

I 629 . 


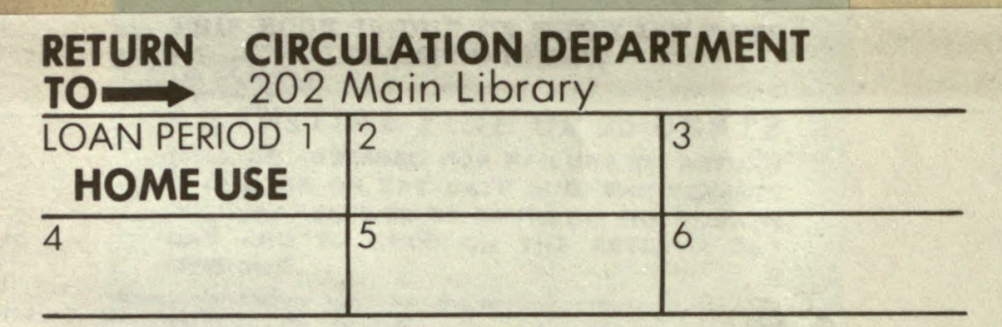

ALL BOOKS MAY BE RECALLED AFTER 7 DAYS

Renewals and Recharges may be made 4 days prior to the due date.

Books may be Renewed by calling 642-3405.

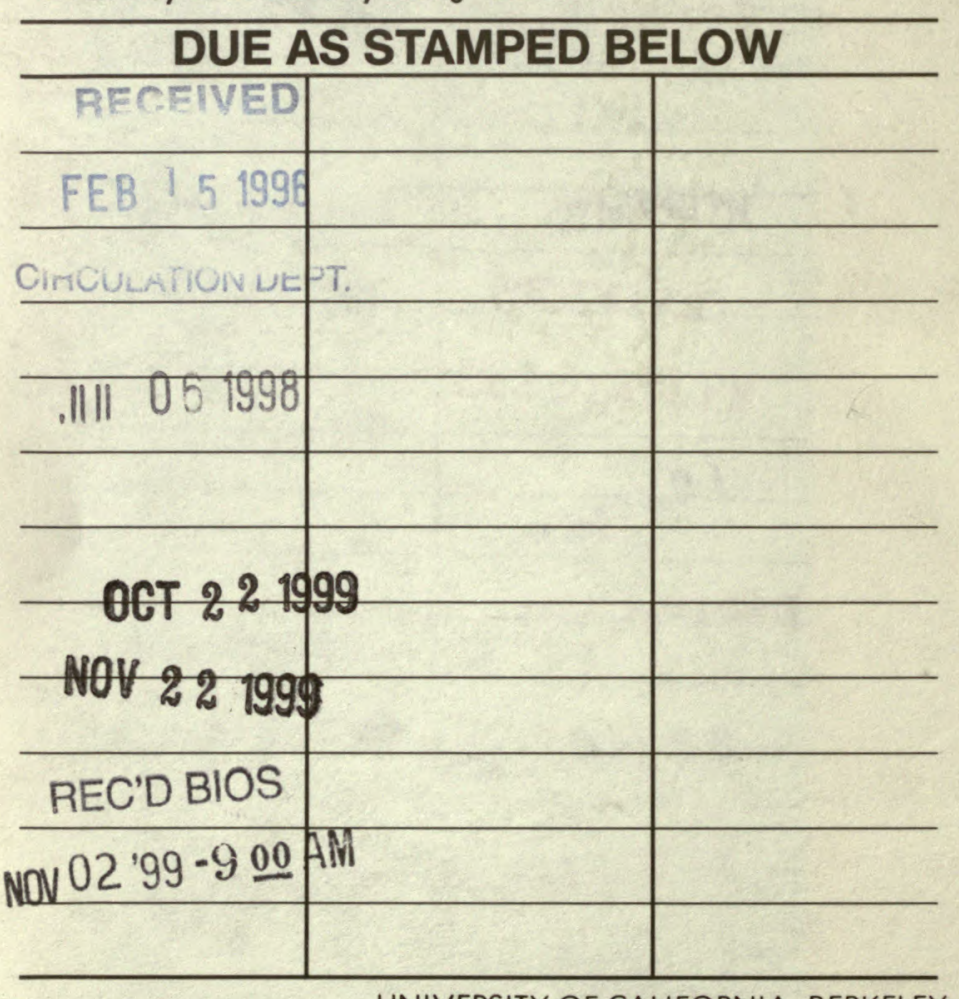

UNIVERSITY OF CALIFORNIA, BERKELEY BERKELEY, CA 94720 
17020

$\gamma^{H}$

U. C. BERKELEY LIBRARIES

|||| || || || || || || || ||

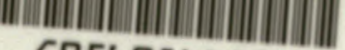

C056084482

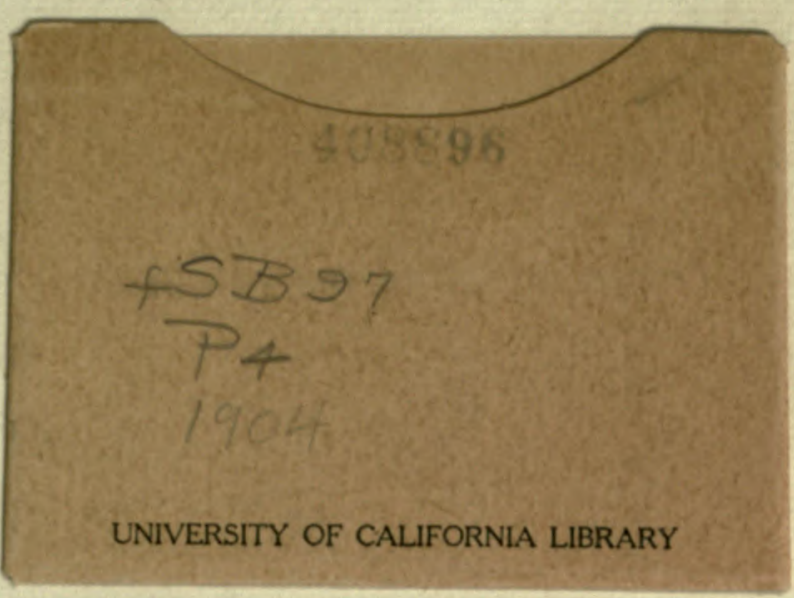

$\sqrt{7}$ 


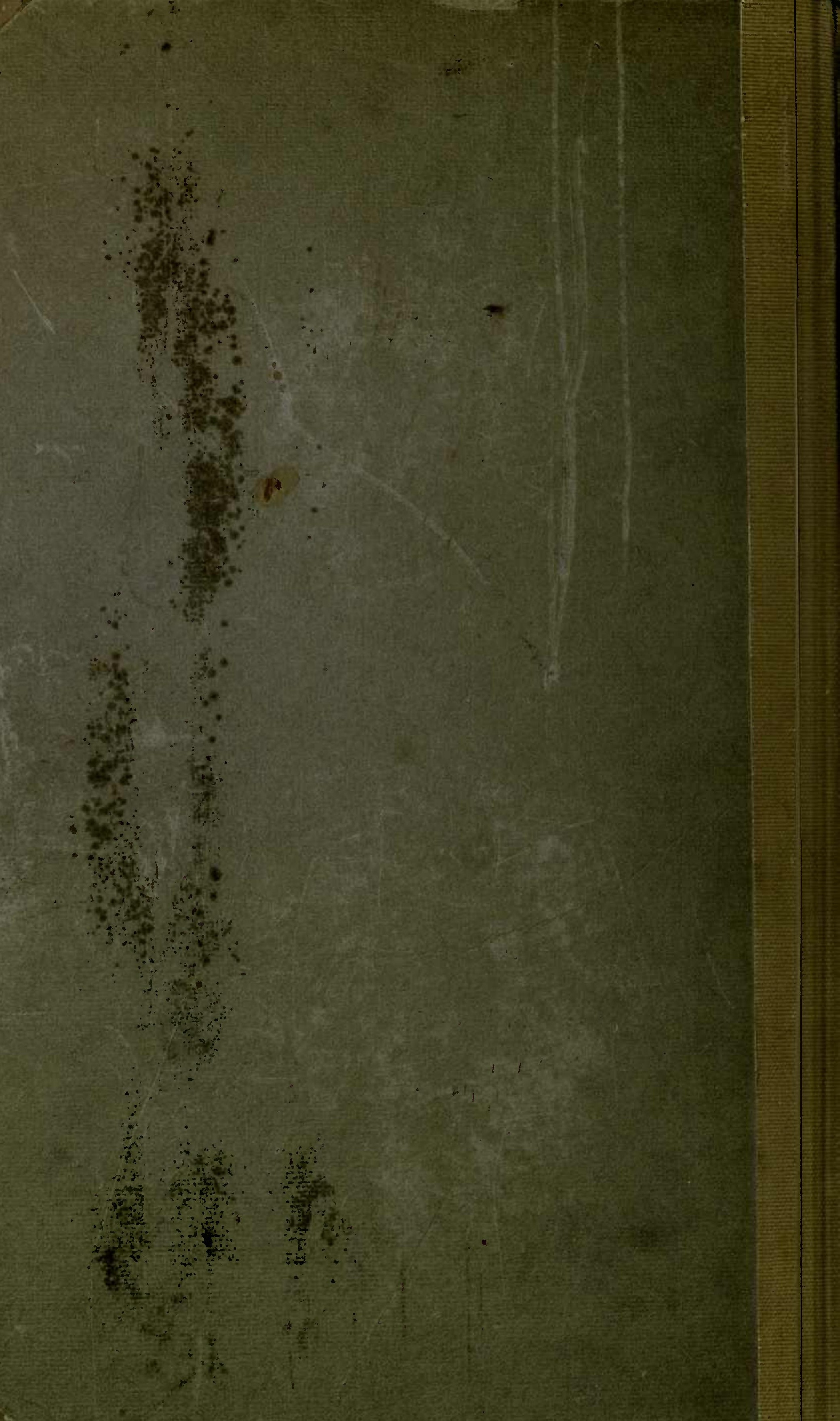

